\title{
A HISTORY OF
}

\section{LUMINESCENCE}

From the Earliest Times

Until 1900

E. NEWTON HARVEY 

Far thw Lilerary of tTo

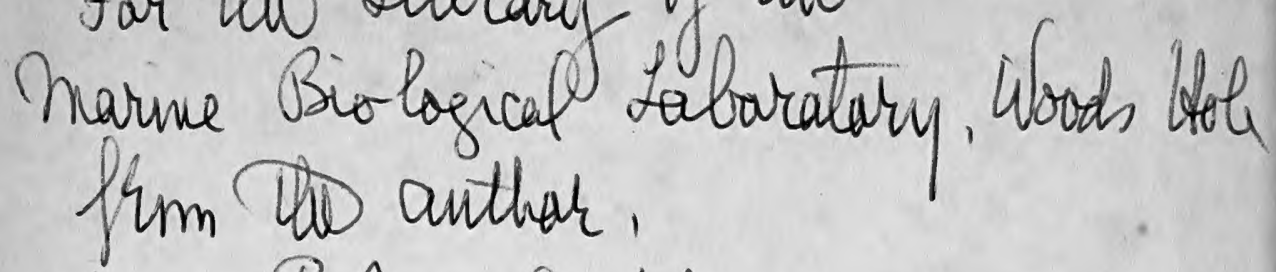

E. nututu bairey 



\section{A HISTORY OF LUMINESCENCE}




\section{Memoirs OF THE AMERICAN PHILOSOPHICAL SOCIETY \\ Held at Philadelphia \\ for Promoting Useful Knowledge \\ Volume 44}




\title{
A HISTORY OF
}

\section{LUMINESCENCE}

From the Earliest Times

Until 1900

\author{
E. NEWTON HARVEY \\ Henry Fairfield Osborn Professor of Biology, \\ Princeton University
}

THE AMERICAN PHILOSOPHICAL SOCIETY INDEPENDENCE SQUARE PHILADELPHIA

1957 
Copyright 1957 By the American Philosophical Society

\section{Library of Congress Catalog}

Card Number: $57-8124$

PRINTED IN THE UNITED STATES OF AMERICA

BY J. H. FURST COMPANY, BALTIMORE, MARYLAND 
"It is a noble employment to rescue from oblivion those who deserve to be remembered."

Punn the Younger. Letters, V. 



\section{Preface}

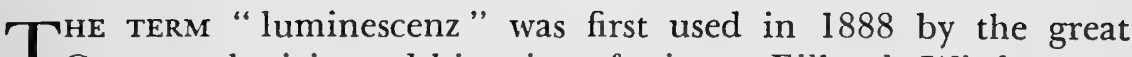
German physicist and historian of science, Eilhardt Wiedemann, for "all those phenomena of light which are not solely conditioned by the rise in temperature." By the rise in temperature, Wiedemann referred to the fact that all liquids and solids emit more and more radiation of shorter and shorter wave-lengths as their temperature is continuously raised above absolute zero. Finally wave-lengths appear which can be perceived by the eye and the material becomes red hot and then white hot. This condition is incandescence or " hot light," in contrast to luminescence or "cold light." For many centuries incandescence has been the universal method of practical illumination; the sun, the torch, candle, oil lamp, gas or tungsten filament have served both to heat and to light.

Examples of luminescence are such dim lights as the glow of phosphorus, a chemiluminescence; the phosphorescence of certain solids (phosphors) after exposure to sunlight, or to X-rays or to electron beams; the transitory fluorescence of many substances, excited by exposure to various kinds of radiation, visible or invisible; the aurora borealis and the electroluminescence of gases when carrying an electric current; the triboluminescence of crystals which are rubbed or broken; or the bioluminescence of many living organisms-the firefly and glowworm, the "burning of the sea," always due to living, mostly microscopic forms, the fungus light of decaying tree trunks, and the bacterial light of dead flesh or fish.

The purpose of this book is to trace the discovery and the ideas regarding these weak lights without heat from the earliest times until the end of the nineteenth century. As far as possible, the attempt has been made to present the views of the authors in their own words, like a source book of information on the subject. By such quotation a better idea of contemporary beliefs can be obtained, not only regarding luminescence, but also regarding fire, heat, and light in general. These were perplexing problems, and evoked continual discussion among the learned during the entire development of scientific thought.

The book is divided into three parts. Part I presents a general survey of the increasing knowledge of luminescences, divided into 
six periods and including chapters dealing with (1) Far Eastern and Classical antiquity, (2) the Middle Ages, (3) the scientific renaissance of the fifteenth and sixteenth centuries, (4) the seventeenth century, (5) the eighteenth century, and (6) the nineteenth century. These first six chapters are concerned with the general development of knowledge concerning various luminescences and the writers who may be said to have had a special interest in luminescence study.

Parts II and III deal with special types of luminescence associated, respectively, with the non-living and the living world. They contain the detailed history of observations and experiments on luminescence, beginning about 1600 , the approximate time of the new rational approach to learning, inaugurated by Francis Bacon, and the period when science became divorced from magic. Part II includes chapters on electroluminescence, phosphorescence, thermoluminescence, triboluminescence, fluorescence, radioluminescence, and chemiluminescence; Part III deals with shining fish, flesh and wood, the phosphorescence of the sea, and animal luminescence. Each chapter of Parts II and III is complete in itself, and may be read without reference to other chapters. Much of the popular and some scientific speculation regarding the aurora borealis has been omitted, and the wealth of folklore and opinion concerning the glowworm and the firefly in both prose and poetry is being prepared for a later volume.

There is ample justification for including the history of inorganic luminescences and light production by plants and animals in one volume. During the long period of observation on the subject, the origin of many weak lights remained unknown until fairly recent times. For example, the light of wood and flesh was not finally connected with fungi and bacteria until 1823 to 1853 , and hence was a subject for research by physicist and chemist as well as biologist. Indeed, every textbook of physics or chemistry which discussed the inorganic "Bolognian phosphor" also included the "spontaneous light" which appeared on wood and meat.

The attempt has been made in the special sections to indicate the first discovery of an important fact or principle, although the author realizes how dangerous such a pronouncement is. Not only is the literature of science so vast that no one person can hope to master it, but frequently a number of men are approaching a discovery simultaneously. It is often difficult or impossible to decide on the actual discoverer. The qualifying expression "appears to have been discovered by so and so " is a more realistic attitude.

Throughout the book, special attention has been paid to the views 
on luminescence of the famous men in science, but less well-known authors have not been neglected, as they frequently reflect the thought of their day in clear and unmistakable terms. The writings of Kenelm Digby and William Simpson have a definite interest for the historian, although they may not carry the weight of a Galileo, a Newton, a Franklin, or a Davy, all of whom expressed opinions on luminescence which have been recorded in the text.

It is indeed surprising how frequently luminescences have aroused interest in every branch of science and among the learned (especially the astronomers) of every nation. The history of luminescence is a guide to the history of science in general. Members of the American Philosophical Society have not neglected this important subject. While most of the American advance in knowledge has been connected with the twentieth century, and outside the scope of this history, many of the nineteenth-century pioneers in Europe have been foreign members of the society. In addition to Franklin, the American members, John William Draper and Joseph Henry, took a special interest in luminescence.

The importance of luminescence at the present time stems from the fact that it is fast becoming the universal method of commercial illumination, and also of communication, through the television screen. Moreover, it has played an all important part in the discovery of electrons, X-rays, and radioactivity. What better justification than this for the history of a subject which is destined to play a still greater role in everyday life as we progress further and further into the atomic age.

Part of the expenses of acquisition and translation of microfilm and photostat have been defrayed by a grant from the Penrose Fund of the American Philosophical Society and the University Research Fund of Princeton University. The author is particularly grateful for this support.

Much of the Latin translation has been done by Mrs. Annemarie Holborn of Hamden, Conn., in a most satisfactory manner. It is a pleasure to acknowledge the help and advice given me by colleagues and friends in connection with sources of information, for references and for interpretation of obscure pages in foreign languagesProfessors Gilbert Chinard, P. K. Hitti, and the late Alan C. Johnson of Princeton University, Professor W. Norman Brown of the University of Pennsylvania, Professor John F. Fulton of Yale University, the late Dr. E. W. Gudger of the American Museum of Natural History, and many others mentioned in the text. Sincere thanks are also expressed to Mrs. Gertrude Hess, Assistant Librarian of the American Philosophical Society, to Mrs. V. T. Phillips of the 
Library of the Academy of Natural Sciences, Philadelphia, and to the staff of the many libraries which I have used for assistance in tracing source material. My wife, Dr. Ethel Browne Harvey, has aided in translation, has read parts of the manuscript, and advised in many ways.

E. N. H. 


\section{Contents}

PAGE

INTRODUCTION

Part I. Luminescence through the Centuries . . . . 9

Chapter I. Far Eastern and Classical Antiquity . . . 11

Mythology . . . . . . . . . . . . . 11

The Near East . . . . . . . . . . . . 13

China and Japan . . . . . . . . . . . . 16

India . . . . . . . . . . . . . . 20

Greece . . . . . . . . . . . . . . 22

Aristotle . . . . . . . . . . . . . 23

Strabo . . . . . . . . . . . . . . . . 26

Rome . . . . . . . . . . . . . . 27

Pliny . . . . . . . . . . . . . . 27

Aelian . . . . . . . . . . . . . 32

Luminous Gems . . . . . . . . . . . 33

The Torches of the Bacchae . . . . . . . . 35

Electroluminescence in Ancient Times . . . . . 35

Sea Phosphorescence in Classical Literature . . . . 40

Summary . . . . . . . . . . . . 43

Chapter II. The Middle Ages . . . . . . . . 44

Introduction . . . . . . . . . . . . 44

Isidorus, Rabanus, Hildegard . . . . . . . . . 45

Arab Writers . . . . . . . . . . . . 47

Albertus Magnus and the Encyclopedists . . . . 49

Miscellaneous References to Luminescence . . . . 53

Comment . . . . . . . . . . . . . 54

Chapter III. The Fifteenth and Sixteenth Centuries . $\quad 56$

Introduction . . . . . . . . . . . . 56

Early Explorers . . . . . . . . . . . . 56

Oviedo, Martyr, and New World Discoveries . . . 57

Luminous Centipedes and Worms . . . . . 58

Phosphorescent Wood . . . . . . . . 59

The West Indian Firefly or the Cucujo . . . . 60 
PAGE

Paracelsus and Sixteenth-Century Alchemists . . . 63

Conrad Gesner and the First Book on Luminescence . 64

Luminous Stones . . . . . . . . . . . 70

Rondelet, Aldrovandi, and Other Natural Historians . 72

Sixteenth-Century Entomology . . . . . . . 74

Ulysses Aldrovandi and Others . . . . . . . 74

Thomas Muffet . . . . . . . . . . . 77

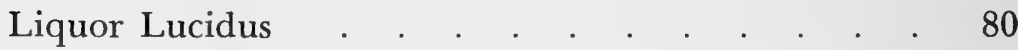

Perpetual Lamps . . . . . . . . . . . 82

Strange Lights . . . . . . . . . . . . 83

Shining Flesh . . . . . . . . . . . . . . . 86

Summary . . . . . . . . . . . . . . . 88

Chapter IV. The Seventeenth Century . . . . . 90

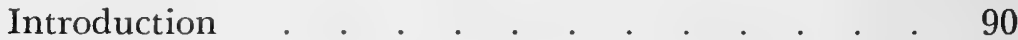

Francis Bacon . . . . . . . . . . . . 91

The Bolognian Stone and Phosphorescence . . . . 94

René Descartes and the French Point of View . . . 95

Scientific Societies and Luminescence . . . . . 98

Scientific Museums and Luminescence . . . . . 100

Athanasius Kircher and Kaspar Schott . . . . . 103

Lignum Nephriticum and Fluorescence of Solutions . 107

Thomas Bartholin. . . . . . . . . . . 107

Naturalists and New Luminous Animals . . . . 116

New Phosphors . . . . . . . . . . . . 119

Textbooks of Chemistry and Physics . . . . . . 121

Theses on Things that Shine at Night . . . . . 122

Robert Boyle . . . . . . . . . . . . 124

Robert Hooke . . . . . . . . . . . 127

Fermentation and Luminescence . . . . . . . 131

Miscellaneous Writers . . . . . . . . . . 134

Robert Plot . . . . . . . . . . . . 134

Paolo Casati . . . . . . . . . . . . 135

Domenico Bottoni . . . . . . . . . . 137

Jacques Rohault . . . . . . . . . . . 138

Antoine Le Grand . . . . . . . . . . 141

Nicolas Lémery . . . . . . . . . . . 143

Isaac Newton . . . . . . . . . . . 147

Summary . . . . . . . . . . . . . 148 
Chapter V. The Eighteenth Century . . . . . . 149

Introduction + . . . . . . . . . . . 149

Francis Hauksbee and Electroluminescence . . . . 149

Prize Essays . . . . . . . . . . . . . 151

Jean Jacques Dortous de Mairan . . . . . . 151

Johann Heinrich Cohausen . . . . . . . 154

Dufay and Réaumur . . . . . . . . . 155

Beccari and the Bolognian Institute . . . . . . 156

Bioluminescence Discoveries . . . . . . . . 158

Encyclopedias . . . . . . . . . . . . 159

Furetière's Dictionnaire . . . . . . . . . . 159

Harris's Lexicon Technicum . . . . . . . . 160

Jablonski's Lexicon . . . . . . . . . . 161

Ephraim Chamber's Cyclopedia . . . . . . 161

Zedler's Universal Lexicon . . . . . . . . 164

The French Encyclopédie . . . . . . . . 165

Encyclopedia Britannica . . . . . . . . 166

Textbooks of Physics and Chemistry . . . . . . 166

Hermann Boerhaave . . . . . . . . . 167

Neumann, Wiegleb, and Others . . . . . . 168

Van's Gravesande, Van Musschenbroek, and Contemporaries . . . . . . . . . . . . 170

Jacques Ozanam . . . . . . . . . . . 174

Benjamin Martin . . . . . . . . . 174

Abbé Nollet . . . . . . . . . . . . 175

Leonard Euler . . . . . . . . . . . 177

George Adams . . . . . . . . . . . 177

Tracts and Theses on Luminescence . . . . . 178

Priestley and his Contemporaries . . . . . . . 181

The Phlogiston Doctrine and Luminescence . . . 186

Crystalloluminescence . . . . . . . . . . . . 189

Luminescence in Literature . . . . . . . . 189

Summary . . . . . . . . . . . . 192

Chapter VI. The Nineteenth Century . . . . . . 194

Introduction . . . . . . . . . . . . 194

Theories of Light . . . . . . . . . . . . . . . . 195

Luigi Brugnatelli . . . . . . . . . . 195

Humphry Davy . . . . . . . . . . . 196

Thomas Young . . . . . . . . . . . 198

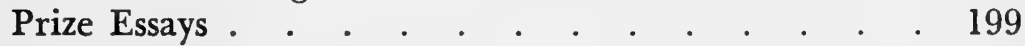


Christoph Bernoulli . . . . . . . . . 199

Heinrich Friedrich Link . . . . . . . . 201

Placidus. Heinrich . . . . . . . . . . 202

Jean Philibert Dessaignes . . . . . . . . 205

Inorganic Luminescences . . . . . . . . . 206

Introduction . . . . . . . . . . . . 206

The Rise of Spectroscopy . . . . . . . . . 207

Fluorescence . . . . . . . . . . . . 210

Radioluminescence . . . . . . . . . . 211

Chemiluminescence . . . . . . . . . . 211

Early Textbooks of Chemistry and Physics . . . 212

The Becquerel Family . . . . . . . . . 216

Luminescence after 1870 . $\quad . \quad$. . . . . . . 219

Books on Inorganic Luminescence . . . . . . 220

In Review . . . . . . . . . . . . 221

The Light of Living Things . . . . . . . . 222

James Macartney . . . . . . . . . . 222

Gottfried Reinhold Treviranus . . . . . . . 223

Christian Gottfried Ehrenberg . . . . . . . . . 224

Harting, Quatrefages, and Heller . . . . . . 225

The Nature of Animal Light . . . . . . . 228

Textbooks and Reference Works . . . . . . 229

Evolution and Bioluminescence . . . . . . 233

The Popularization of Science . . . . . . . 237

Deep-sea Exploration . . . . . . . . . 239

Paolo Panceri and the Italians . . . . . . . 241

Raphaël Dubois . . . . . . . . . . . 242

W. C. M'Intosh . . . . . . . . . . . 244

Krukenberg and Dittrich . . . . . . . . 244

In Review . . . . . . . . . . . . 245

Survey . . . . . . . . . . . . . . . . 246

Part II. Luminescence of Non-Living Material . . 249

Chapter VII. Electroluminescence . . . . . . . 251

Introduction . . . . . . . . . . . . 251

Meteors . . . . . . . . . . . . 252

The Aurora Borealis or Polaris . . . . . . . 255

Seventeenth and Eighteenth-Century Views . . . 255

Edmund Halley . . . . . . . . . . . 257

J. J. Dortous de Mairan . . . . . . . . . 258

The Aurora and the Electric Light . . . . 259 
The Aurora and the Magnetic Needle . . . . 261

Miscellaneous Theories of the Aurora . . . . . 261

Ignis Lambens and Ignis Fatuus . . . . . . . 263

Nature of the phenomenon . . . . . . . . . 263

Records of Ignis Lambens . . . . . . . . . . 266

Relation to Electricity . . . . . . . . . . 268

The "Electric Light" and "Electric Fire" . . . . 269

Virtues and Effluvia . . . . . . . . . . . 269

Otto von Guericke . . . . . . . . . . 270

The Barometer Light or the Mercurial Phosphor . 271

Francis Hauksbee and Evacuated Globes . . . . 276

The Rise of Electrical Knowledge . . . . . . 281

William Watson and Electricity in Vacuo . . . . 287

Wilson, Smeaton, and Canton . . . . . . . 289

The Relation of the "Electric Light" to other Luminescences . . . . . . . . . . . . 290

From Joseph Priestley to Michael Faraday . . . 293

Julius Plücker and Later Research . . . . . 296

Afterglow in Gases . . . . . . . . . . 301

Electrodeless Discharges . . . . . . . . 302

New Types of Rays . . . . . . . . . . . 303

Survey . . . . . . . . . . . . . 304

Chapter VIII. Phosphorescence . . . . . . . 305

Introduction . . . . . . . . . . . . 305

Early Records . . . . . . . . . . . . 305

The Bolognian Phosphor . . . . . . . . 306

Cascariolo, Galileo, and LaGalla . . . . . . 306

Pierre Potier . . . . . . . . . . . . 308

Ovidio Montalbani . . . . . . . . . . . 309

Fortunio Liceti . . . . . . . . . . . 311

Athanasius Kircher . . . . . . . . . . 312

Nicolai Zucchi and Mid-Seventeenth-Century Observations . . . . . . . . . 313

Count Marsigli and Other Italians . . . . . . 315

German Interest . . . . . . . . . . . 316

Nicolas Lémery and French Opinion . . . . 317

Phosphorus Hermeticus (Baldewein and Mentzel) . . 321

Friedrich Hoffman and Calcium Sulphide phosphor . 323

De Mairan and Cohausen . . . . . . . . . 323

Bartholomeo Beccari and Co-workers . . . . 324 
PAGE

Charles François de C. Dufay . . . . . . . 327

Andreas Siegmund Marggraf . . . . . . . $\quad$. 328

John Canton and Benjamin Wilson . . . . . . 329

Camillo Galvani . . . . . . . . . . 333

Excitation of Phosphorescence by Spectral Colors . . 333

Phosphorescence and Electric Sparks . . . . . 334

Phosphors and Combustion . . . . . . . . 337

The Effect of Ultraviolet and Infrared Rays . . . . 340

Dessaignes, Heinrich, and von Grotthus . . . . . 342

New Phosphors. The Effect of Traces of Metals . . 345

Edmond Becquerel and the Recent Period . . . . 349

Wave-lengths for Excitation . . . . . . . 352

Duration of Phosphorescence . . . . . . . 354

Intensity of Phosphorescence and the Law of Decay . 356

Spectrum of Phosphorescence . . . . . . 357

Temperature Effects . . . . . . . . . 358

Polarization of Phosphorescent Light . . . . . 359

The Photoelectric Effect and Phosphorescence . . 360

Theories of Phosphorescence (and Fluorescence). A

Review . . . . . . . . . . . 361

Chapter IX. Thermoluminescence . . . . . . 366

Introduction . . . . . . . . . . . . . 366

Seventeenth-Century Observations . . . . . . 366

Eighteenth-Century Experiments . . . . . . . 368

Relation of Thermoluminescence to Triboluminescence 370

Nineteenth-Century Contributions . . . . . . 371

Candoluminescence . . . . . . . . . . 377

Chapter X. Triboluminescence, Piezoluminescence, Crystalloluminescence, and Lyoluminescence . . . 378

Introduction . . . . . . . . . . . . . 378

Triboluminescence and Piezoluminescence . . . . $\quad 379$

Early Observations . . . . . . . . . . 379

Relation to Electricity . . . . . . . . . 381

Eighteenth-Century Observations on Minerals . . 382

Nineteenth-Century Research . . . . . . . 385

Crystalloluminescence . . . . . . . . . . 387

Lyoluminescence . . . . . . . . . . . . . $\quad$. 389 
Chapter XI. Fluorescence

Introduction . . . . . . . . . . . . . 390

Lignum Nephriticum and Athanius Kircher . . . 391

Grimaldi, Boyle, and Newton . . . . . . . . 392

Eighteenth-Century Observations . . . . . . 394

Brewster, Herschel, and Stokes . . . . . . . 394

Research after Stokes . . . . . . . . . . 398

Methods of Excitation . . . . . . . . . . . . 398

Fluorescence Distribution and Fluorescence Analysis 400

Chemical Constitution and Fluorescence. . . . 401

Properties of Fluorescent Light . . . . . . 402

Quenching of Fluorescence . . . . . . . . 405

Vapor Fluorescence and Resonance Radiation; Sensi-

tization . . . . . . . . . . . . 406

Books on Fluorescence . . . . . . . . . . 407

Chapter XII. Radioluminescence . . . . . . . 410

Introduction . . . . . . . . . . . . 410

Cathodoluminescence . . . . . . . . . . 410

Anodoluminescence . . . . . . . . . . 415

Radioluminescence Proper . . . . . . . . . 416

From Roentgen Rays . . . . . . . . . 416

From Radium Rays . . . . . . . . . . 417

Scintillation Counters and New Particles . . . . 420

Chapter XIII. Chemiluminescence . . . . . . . 423

Introduction . . . . . . . . . . . . 423

The Gaseous Chemiluminescence of Phosphorus . . 424

Discovery of Phosphorus . . . . . . . . 424

Robert Boyle and Colleagues . . . . . . . 427

Eighteenth-Century Experiments . . . . . . 433

Relation to Oxygen . . . . . . . . . . 436

Relation to Water Vapor . . . . . . . . 440

Quenching of Luminescence . . . . . . . 441

Periodic Phenomena . . . . . . . . . 442

Relation to Ozone . . . . . . . . . . . . 442

Commercial Use . . . . . . . . . . . 445

Medical Use . . . . . . . . . . . 446

Miscellaneous Chemiluminescent Phenomena in Gases 448 
Chemiluminescence in Solution . . . . . . . 452 Inorganic Compounds . . . . . . . . . . 452 Organic Compounds . . . . . . . . . . . 453

Part III. Luminescence of Living Organisms. BioluminesCENCE . . . . . . . . . . . . 457

General Statement _ . . . . . . . . . . . 459

Chapter XIV. Shining Fish, Flesh, and Wood . . . . 461

Introduction . . . . . . . . . . . . 461

Francis Bacon and Shining Wood . . . . . . 461

The Luminous Mutton of Montpellier . . . . . 462

Pierre Borel . . . . . . . . . . . . 463

Thomas Bartholin . . . . . . . . . . 463

Daniel Puerarius . . . . . . . . . . 465

Luminous Fish and Invertebrates . . . . . . . 469

Robert Boyle . . . . . . . . . . . . 470

John Beal . . . . . . . . . . . . . 474

Luminous Eggs and Other Unusual Things . . . . 476

Eighteenth-Century Views . . . . . . . . 479

J. J. Dortous de Mairan . . . . . . . . . 479

Henry Baker . . . . . . . . . . . . 479

Anton Martin . . . . . . . . . . . 480

John Canton . . . . . . . . . . . . 481

Johann Sebastian Albrecht . . . . . . . . 482

Baron von Meidinger . . . . . . . . . 483

Luminous Mushrooms and Rhizomorphs . . . . 484

Luminous Potatoes, Roots, Leaves, Fruit, and Cheese . 485

Effect of Gases on Shining Wood and Flesh . . . . 487

Frederic Achard . . . . . . . . . . . 487

Spallanzani and Carradori . . . . . . . . . 488

Nicholai Tychsen . . . . . . . . . . . . 489

Von Humboldt, Gaertner, and Boeckmann . . . 490

Nathaniel Hulme . . . . . . . . . . 491

Early Nineteenth-Century Views . . . . . . . 493

Fermentation and Putrefaction by Microorganisms . . 498

The Light of Wood a Fungus Growth . . . . . 499

Shining Flesh and Animalcules . . . . . . . 501

Johann Florian Heller and Luminous Bacteria . . . 503

From Heller to Pflüger . . . . . . . . . 504 
Chapter XV. Phosphorescence of the Sea

Sea Light as a Spectacle . . . . . . . . . 508

René Descartes and Jacques Rohault . . . . . . 510

Other Early Explanations . . . . . . . . . 512

Status of Sea Light in the Late Seventeenth Century . 513

Father Bourzes and French Observations . . . . 516

Luminous Worms and Crustacea in the Sea . . . 519

Benjamin Franklin . . . . . . . . . . 519

Henry Baker and the History of Noctiluca . . . . 521

Eighteenth-Century Theories of Sea Light . . . . 524

Electrical . . . . . . . . . . . 524

Mechanical . . . . . . . . . . 525

Insolation . . . . . . . . . . . . 525

Phosphorus . . . . . . . . . . . . 526

Putrefaction . . . . . . . . . . . . 527

Combination of Causes . . . . . . . . . . . 528

Early Nineteenth-Century Views . . . . . . . 529

François Péron . . . . . . . . . . . 529

Christoph Bernoulli and the Prize Essays . . . . 530

Humboldt, Macartney, and Tilesius . . . . 531

Sea Light and the Weather . . . . . . . 533

Discovery of Luminous Dinoflagellates . . . . . 534

Pioneers . . . . . . . . . . . . 534

Michaelis and Ehrenberg . . . . . . . 535

Chapter XVI. Animal Luminescence . . . . . 538

I. Luminous Terrestrial and Fresh-water Forms . . . 538

Fireflies and Glowworms . . . . . . . . . 538

Early Seventeenth-Century Views . . . . . 538

The Glowworm of England . . . . . . . 542

Marcello Malpighi and the Italian Firefly . . . . 543

Synchronous Flashing . . . . . . . . . 544

Eighteenth-Century Research . . . . . . . 545

Relation to Oxygen . . . . . . . . . . 547

Early Nineteenth-Century Physiological Work . . 549

Physical Nature of the Light . . . . . . . 551

Histology . . . . . . . . . . . . 552 
The Railroad Worm

Phengodes and Starworms . . . . . . . . 554

The Cucujo or Pyrophorus . . . . . . . . 554

Myriapoda . . . . . . . . . . . . 556

Earthworms . . . . . . . . . . . . . 557

The Lantern Fly, Fulgora . . . . . . . . . 559

Miscellaneous Insects . . . . . . . . . . 561

Land and Fresh-water Snails . . . . . . . . 563

II. Luminous Marine Animals . . . . . . . . 563

Protozoa . . . . . . . . . . . . . . 563

Flagellates . . . . . . . . . . . . . . 563

Radiolaria . . . . . . . . . . . . 566

Jellyfish or Medusae . . . . . . . . . . 566

Ctenophores or Comb jellies . . . . . . . . 570

Sea Pens. . . . . . . . . . . . . . 571

Siphonophores . . . . . . . . . . . . 573

Hydroids . . . . . . . . . . . . . 574

Marine Worms (and Oysters) . . . . . . . 575

The Piddock or Dail (Pholas dactylus) . . . . . 577

Nudibranchs . . . . . . . . . . . . 581

Squid and Octopi . . . . . . . . . . . . . . . 582

Crustacea . . . . . . . . . . . . . 583

Ostracods . . . . . . . . . . . . . 583

Copepods . . . . . . . . . . . . . 584

Amphipods . . . . . . . . . . . . 584

Shrimp . . . . . . . . . . . . . 585

Brittle Stars or Snake Stars . . . . . . . . 587

Pyrosoma and Salpa . . . . . . . . . . 588

Miscellaneous Marine Organisms . . . . . . . $\quad 589$

Living Fish . . . . . . . . . . . . . 590

Summary . . . . . . . . . . . . . 592

Bibliography . . . . . . . . . . . . . 599

Indices . . . . . . . . . . . . . . . . 671

Subject Index . . . . . . . . . . . . . 673

Author Index . . . . . . . . . . . . . 677 


\section{List of Illustrations}

Following page

FIg. 1. Title page of Gesner's De Lunariis, 1555 . . . 74

2. Rondelet's luminous marine invertebrates, 1555 . 74

3. Aldrovandi's jellyfish, 1606 . . . . . . . 74

4. Early drawings of creeping and flying glowworms . 74

5. Early drawings of the cucujo, a luminous beetle . . 74

6. Frontispiece of Kircher's Ars Magna Lucis et Umbrae, 1671 . . . . . . . . . . . . 106

7. Title page of Bartholin's De Luce Animalium, $1647 \quad 106$

8. Title page of Baldewein's book, Aurum Superius, etc. (1675) on the hermetic phosphor . . . . 106

9. Title page of Vogel's thesis, De Avibus Noctu Lucentibus, 1669 . . . . . . . . . . . 106

10. Title page of Rivinus and Böhme's De Noctu Lucentibus, 1673

11. Title page of Kletwich's medical thesis, De Phosphoro Liquido et Solido, 1688 . . . . . . . 138

12. Title page of Casati's book, De Igne, 1688 . . . 138

13. Plate showing experiments on firefly from Bottoni's Pyrologia Topographica, 1692

14. Title page of Harris translation of Lémery's Cours de Chymie, 1686 . . . . . . . . . .

15. Title page of Mairan's prize essay, Sur la Cause de la Lumière des Phosphores et des Noctiluques (1717)

16. Title page of Cohausen's prize essay, Lumen Novem Phosphoris Accensum, 1717.

17. Title page of Priestley's History of Vision, Light and Colours, 1772 .

18. Title page of C. Bernoulli's essay, Über das Leuchten des Meeres, 1803 . . . . . . . . . .

19. Title page of Heinrich's book, Die Phosphorescenz der Körper, 1811-1820 • . . . . . . .

20. Title pages of two books of E. Becquerel, on Divers Effets Lumineux (1859), and La Lumière (1867) 
FIG. 21. Title page of a thesis by Vulpius on Ignis Lambens, 1686

22. Title page of Heusinger's thesis, De Noctiluca Mercuriali, 1716

23. Title page of Hauksbee's book, Physico-mechanical Experiments (1709) on electroluminescence . . 250

24. Hauksbee's electrical machine and evacuated vessels 250

25. Abbé Nollet's experiments on light in glass vessels . 250

26. Large electrical machine used for experiments at the Pantheon

27. Luminescence in vacuum tubes (De la Rue and Müller, 1883)

28. Various types of Geissler tubes

29. Title page of La Galla's book, De Phenomenis, etc., 1612

30. Title page of Liceti's Litheosphorus, 1640

31. Frontispiece of Cellio's book on Pietra Bolognese, 1680

32. Title page of Marsigli's pamphlet, Del Phosphoro Minerale, 1698

33. Marsigli's drawings of the Bononian stone

34. Title page of Mentzel's book comparing Bononian and hermetic phosphor, 1676

35. Luminescent effects obtained with phosphorus by Elscholtz (1681)

36. Title page of Kirchmaier's pamphlet, De Phosphoris et Natura Lucis nec non de Igne, 1680 .

37. Title pages of Boyle's books on Colours (1664) and The Aerial Noctiluca (1680)

38. Adler's (1752) luminous worm

39. Early drawings of the luminous protozoan, Noctiluca miliaris

40. Ehrenberg's (1834) figure of luminous dinoflagellates

41. Waller's (1685) flying glowworm .

42. De Greer's (1755) plate, showing development of the glowworm 
FIG. 43. Haase's (1888) drawing of the "railroad worm," Phrixothrix . . . . . . . . . . 538

44. Grew's (1681) drawing of the lantern fly, Fulgora . 538 45. Quatrefages' (1850) figure of Noctiluca miliaris . 538 46. Godeheu de Riville's (1760) figures of the luminous ostracod crustacean, Cypridina . . . . . . 538

47. Macartney's (1810) figure of luminous jellyfish and shrimp . . . . . . . . . . . 586

48. Ellis' (1763) plate of luminous pennatulids . . . 586 49. Réaumur's (1712) plate of the "dail" (Pholas) and brittle stars . . . . . . . . . . . 586

50. Verany's (1851) plate of a luminous squid . . . 586 



\section{A HISTORY OF LUMINESCENCE}





\section{INTRODUCTION}

NE OF THE PROBLEMS of the historian of luminescence is to sift the true from the false report. Stories of luminous jewels and luminous stones have been handed down from earliest times, but in most cases the light has been due to reflection rather than light emission. The instances of luminous human beings are fascinating to read of, but it is quite certain that man has never acquired the ability to produce a light like that of the firefly.

Of the many types of reflection ${ }^{1}$ which have been confused with true light emission the most common is the glow of the eye. The glowing eyes of cats are well known, and glowing eyes have also been observed in human beings. They were particularly mentioned by classic writers as characteristic of warriors during the heat of battle. The Greeks and Romans thought the ability to see at night was connected with this glowing of the eye. Another phenomenon and a purely subjective one, the phosphene or apparent light that appears when the eyeball is pressed or struck, was known to Aristotle $^{2}$ and has frequently been confused with real luminescent phenomena.

Among the true luminescences recognized by the ancients may be placed the aurora borealis, the light of the sea, luminous animals of various kinds, phosphorescent wood and flesh, and ignis lambens, a silent electrical discharge in air. Discovery of the Bolognian stone in 1603, a true phosphor which glows after exposure to light, and isolation of the element phosphorus in 1669 added two more important examples to those already known. Much later, passage of electricity through "vacuum tubes" reproduced the silent electric discharge in the laboratory. It is interesting to note that the term " electric light" did not originally refer to the electric incandescent bulb or arc light but to a luminescent glow in partially evacuated vessels when brought near an electrical machine. These "globes" were very thoroughly studied at the beginning of the eighteenth century by Francis Hauksbee. Despite the manifold examples of luminescence available to anyone who troubles to make the search, the remarkable brightness of firefly light with no perceptible rise in temperature has always stood as a symbol of light without heat

1 An animal (Sapphirina), an alga (Chromophyton), and a moss (Schistostega) reflect the light from cells or surfaces in such a way as to appear luminous and irridescent; see "General Statement" of Part III.

${ }^{2}$ See De sensu, in Parva naturalia, trans. by J. I. Beare, 437a, Oxford Univ. Press, 1908. 
and its duplication has long been the goal of the illuminating engineer.

When Wiedemann (1888) recognized luminescence as the antithesis to incandescence, he also classified luminescences into six kinds according to the method of excitation. No better basis of classification is available today. He recognized photoluminescence, thermoluminescence, electroluminescence, crystalloluminescence, triboluminescence, and chemiluminescence. The designations are obvious, characterized by the prefix. Photoluminescence of solids is excited by light itself and is subdivided into fluorescence and phosphorescence. Thermoluminescence is light from gentle heating. Electroluminescence appears from gases in electrical fields; crystalloluminescence and triboluminescence occur when solutions crystallize or when crystals are crushed or broken, and chemiluminescence may appear during chemical reaction. All bioluminescences are examples of chemiluminescence.

Although present ideas of the mechanism by which light is emitted have changed and many more types of luminescence have been recognized, the new varieties all belong in the six categories of Wiedemann. In order to clarify the historical treatment and to orient the reader in modern terminology, a list of the present recognized types of luminescence, with definitions, follows:

Fluorescence, the emission of light from substances only during the time they are exposed to radiation of various kinds-visible light, ultraviolet light, X-rays, gamma rays, cathode rays (electrons), and other types of particles. The terms PHOTOLUMINESGENCE, CATHODOLUMINESCENCE, ANODOLUMINESCENCE, RADIOLUMINESCENCE ${ }^{3}$ are SOMEtimes used to indicate the type of exciting radiation, whether light, cathode rays (electrons) , ${ }^{4}$ anode rays, X-rays, or $\gamma$ rays. The modern fluorescent lamp makes use of a special powder excited by ultraviolet light in the glass tube.

If the light emission persists ${ }^{5}$ after the exciting radiation is cut

${ }^{3}$ The word "radioluminescence" has often been used as a general term for any luminescence resulting from bombardment by various particles other than light, such as electrons, alpha particles (ions), etc., including $\mathrm{X}$-rays and $\gamma$ rays. Various radioactive disintegrations may cause luminescence by virtue of the particles formed. Chapter XII deals with the history of radioluminescence used in this sense, and includes cathodoluminescence (or electroluminescence), anodoluminescence (or ionoluminescence), and radioluminescence proper, sometimes called roentgenoluminescence.

* When electrons strike molecules, the resulting luminescence may be called an electroluminescence.

${ }^{5}$ Persistence can only be detected by the eye, if the time is around 0.1 second. The duration of the excited state of non-metastable atoms or ions is around $10^{-8}$ second, and some workers designate as fluorescence, luminescence emissions with a persistence not longer than this. 
off, it is called PHOSPHORESCENCE, ${ }^{6}$ a persistent luminescence resulting from the above methods of excitation. Materials which exhibit phosphorescence are often called phosphors, the most famous one, historically, being the calcined Bolognian stone, an impure barium sulphide.

Thermoluminescence, the emission of light on slight heating of substances. It is characteristic of some samples of fluorspar and has been found to be dependent on a previous storage of energy, usually from light radiation; hence is a delayed phosphorescence. ThermoSTIMULATION is a more correct term.

Electroluminescence, a light accompanying an electric discharge, whether this occurs in rarified gas in a vacuum tube, or in the air, as when silk or fur is rubbed or tape is stripped from a roll. It is due to electron bombardment of gas molecules. In more recent terminology the word has been used for light emitted when electrons strike solids or liquids. The aurora borealis may for convenience be placed in this category, even though some modern theories regard it as a radioluminescence.

Galvanoluminescence, a luminous phenomenon accompanying the passage of electric currents through aqueous solutions, due to chemical reactions of chemiluminescent substances produced during electrolysis, frequently by the formation of "active oxygen."

Sonoluminescence, light accompanying the passage of intense sound waves through a liquid, owing to electrical discharges in the residual gas of cavities formed by the sound waves in the liquid.

Triboluminescence or Piezoluminescence, the emission of light on rubbing or crushing crystals of various kinds, organic or inorganic. It may be an electron bombardment of crystal surfaces or an electroluminescence from separation of surfaces.

Crystalloluminescence, the light that sometimes appears during crystallization of solutions, thought by some to be due to cleavage during the growth of individual crystals, hence a type of triboluminescence. LyOLUminescence designates the light which appears when crystals dissolve.

Chemiluminescence, the light accompanying a chemical reaction, whether in a gas or vapor (the various types of flames or PYROLUMINESCENCES) $^{7}$ or in solution. The best known chemilumines-

"The word "luminescence" is a general term; the word "phosphorescence" is often used as a general term, but strictly applies to luminescence excited by radiation or streams of particles.

${ }^{7}$ E. L. Nichols and Snow (1892) referred to the excess of short wave-lengths in certain heated incandescent oxides (e. g. thorium or magnesium), as a luminescence. 
cence is connected with the element phosphorus. Many organic compounds are chemiluminescent when oxidized in aqueous solution. Living organisms have manufactured some such chemiluminescent substance which is utilized in

Bioluminescence, the chemiluminescent emission of light by living animals and plants.

Many luminescent phenomena involve a combination of the above types. For example, if chemiluminescent substances are dissolved in a liquid through which intense sound waves are passing, the formation of active oxygen may result in a soNIC-CHEMILUMINESCENCE.

Since the formulation of the quantum theory by Max Planck in 1900, and the later developments of quantum mechanics, together with the modern conception of the atom as a highly complex entity, so many new terms have been introduced into the subject of luminescence that a physicist of the eighteen-nineties would be quite unable to comprehend the phraseology or follow the theory. He would be immediately involved with photons, excitation potentials, ionization potentials, secondary electrons, electron shells, permitted transitions, rotational quantum numbers, the lifetime of an excited state, metastable states, and the cross-section of quenching. Even an electron-volt and a molecular lattice would present novelties requiring precise definition. This "History of Luminescence" does not pretend to cover the newer field. For all practical purposes, it stops with the discovery of the electron.

However, the essentials of the present view regarding mechanism of light emission can be obtained from the following brief and simplified statement. In every type of luminescence, modern theory postulates that some atom or molecule acquires excess energy (spoken of as an "excited " atom or molecule), with displacement of an electron to a higher energy level. The energy for this displacement may come from exciting radiation (light, X-rays, various particles) or from electrical energy (electrons) or mechanical energy or chemical energy. In this way the various types of luminescence are excited. When the electron returns to the lower level, a quantum of light is emitted, the sum total of these quanta constituting the luminescence. As contrasted with the very broad spectra of incandescence or temperature radiation, the spectra of luminescences are narrow bands or lines in one or another spectral region, thus giving a definite color to the light.

The emission is quite different from the expected black body radiation for the temperature and later became known as a CANDOLUMINESCENCE, but the word is rarely used at the present time. 
In the case of fluorescence, the displaced electrons return to their original level within $10^{-8}$ or $10^{-9}$ seconds. If they fail to return in this time, they may be constrained, with the delay lasting from fractions of a second to several hours, as in phosphorescence. Sometimes they may become actually trapped, and only return to their original position after release by application of additional energy. This energy may be heat in the case of thermoluminescence, more properly called thermostimulation, or light in the case of photostimulation, when a phosphor which has ceased to luminesce may again emit if exposed to infrared radiation.

With recent improvement in light-detecting photocells and electronic circuits, the individual flash induced in various substances by a single quantum of light (a photon) can be detected, and the incident radiation measured with a scintillation counter. This device is a modern and more sensitive development of the old spinthariscope of Crookes (1903) which made use of the flash of light from a zinc sulphide phosphor to render visible the alpha particles (charged helium atoms) from radium, which struck the phosphor.

The completely dark-adapted eye is a very sensitive instrument, but the scintillation-counter can now detect and measure lights in the visible region of the spectrum which are completely invisible to the most sensitive human eye. The historian of the future will have a wholly new world of unseen luminescences with which to contend. 



\section{PART I}

\section{Luminescence Through the Centuries}





\section{FAR EASTERN AND CLASSICAL ANTIQUITY}

\section{Mythology}

$\mathrm{T}^{\mathrm{T}}$ Is UNFORTUNATE that primitive man has left no written record of $\mathcal{I}$ his observations but only crude pictographs of the more striking objects of his environment. We cannot but believe that the Neanderthaler knew of many luminescences-the aurora borealis, glowworms, or luminous wood. Perhaps he had seen the glow of luminous bacteria growing on meat or fish. Ever on the alert, a new sight at night must inevitably have caught his attention and directed all faculties into further exploration of the phenomenon. In the daytime a sudden movement arouses interest; at night, a spot of light, no matter how small.

Light has always occupied an important place in superstition among all peoples. The contrast of light and darkness is so striking that many races have adopted some story of the origin of light in the history of creation. Usually there is chaos to begin with and darkness came first, while light appeared later, as in the Biblical story. It is natural that ideas regarding the beginning of the world should follow the series of events which occur at daybreak. This type of cosmogony is well seen among some groups of Polynesians, who believed that,

In the beginning there was nothing but Po, a void or chaos, without light, heat, or sound, without form or motion. Gradually vague stirrings began within the darkness, moanings and whisperings arose and then at first, faint as early dawn, the light appeared and grew until full day had come. Heat and moisture next developed and from the interaction of these elements came substance and form, ever becoming more and more concrete, until the solid earth and over-arching sky took shape and were personified as Heaven Father and Earth Mother. ${ }^{1}$

The rest of the Polynesian universe followed as the offspring of Heaven and Earth.

Among some cultures, living beings came before daylight in the sequence of events and it is interesting to note that they were thought of as luminous. The Altaic race of Siberia believed that before the sun and moon appeared," " people who then flew in the

${ }^{2}$ From The mythology of all races, ed. by J. A. MacCulloch and G. F. Moore. 9: $5,1932$.

Ibid. 4: 419. 
air gave out light and warmed their surroundings themselves, so they did not even miss the heat of the sun. . . ." Light and heat are almost universally associated in the minds of all peoples. Only rarely is a light without heat recognized as an actuality and incorporated into folklore, as in another Siberian belief, of the Yenisei Ostiaks. This has to do with conditions after death and might definitely be attributed to observation of the luminescence of decayed wood. The Ostiaks believe that " under the earth there is a great grotto, or seven grottoes under one another, in which the souls of the dead dwell, and where in place of the sun and moon, only rotted trees give out a dim light." ${ }^{3}$

One might expect to find a myth concerning the origin of fire from phosphorescent wood but there appears to be no such connection, although the idea of fire residing in wood is a common belief. By rubbing dry sticks together the fire could be liberated. However, the Jicarilla Apaches of northern New Mexico did believe that when they first arrived on earth the trees could talk but would not burn because there was no fire. In a complicated tale ${ }^{4}$ they relate how fire was distributed throughout the world by a fox who obtained it from a great campfire which had been ignited by fireflies.

Many other primitive people have alleged that fire was brought by some animal, usually a land animal, but sometimes by a marine form such as the cuttlefish, some of which are luminous. The Gilbert and the Lord Howe islanders believe that fire came originally from the sea, a natural conclusion in regions where brilliant sea phosphorescence occurs. However, a myth of the origin of fire from "burning of the sea" is anything but common. Most races trace the origin of fire to lightning or to sparks from iron and flint.

Light and fire have been deified by most ancient peoples. A fire god and particularly a sun god, as symbol of the greatest source of heat and light, always occupied important places in the heavenly hierarchy. The ancient Greek sun god was Helios, later associated by the Romans with Phoebus Apollo.

Although no true god or goddess of luminescence can be recognized, faint cold lights were often associated with moonlight, whose goddess was Selene, later identified as Artemis, and called Luna ${ }^{5}$ and Diana in Rome. It is significant that the first book on lumines-

${ }^{3}$ Ibid. 4: 486-487.

"See J. G. Frazer, Myths of the origin of fire, 140-141, London, 1930.

${ }^{5}$ In The paradoxical discoveries of J. B. Van Helmont concerning the macrocosm and microcosm (English version, London, 1685), the lights of heaven were the sun, warm and male, and the moon, cool and female. Van Helmont pointed out that part of the moon's light proceeded from the sun, as woman was formed from man (Genesis 2: 22). 
cence, De Lunariis . . . , written by Conrad Gesner, bore the complete title, $A$ short treatise on rare and marvellous plants that are called lunar because they shine at night and incidentally on other things which shine in darkness. It was published in 1555, just before the era of real scientific approach to natural phenomena which began with the seventeenth century. Selene or Luna as the goddess of luminescence would represent those cold dim lights well known to classical antiquity although there has been no general recognition of her function in this category.

Alexander von Humboldt (Cosmos, trans. by F. C. Otté, 2: 374, footnote, London 1900) has suggested that the Nereid, Mera or Meira, one of the fifty daughters of Nereus, may represent the " phosphoric light seen on the surface of the sea, in the same manner as the word "maira ' designated the sparkling dog-star Sirius." If this is true Meira might be considered the goddess of luminescence.

The appearance of light without fire or without heat is immediately imbued with a supernatural significance. Since the start of the Christian era, many miracles have involved a light shining under mysterious circumstances or a luminous region of the human body, the hand or the face of a saint. ${ }^{6}$ The folklore and superstition of every people, especially those from mountainous regions, is full of mysterious lights, ignes fatui, corposants, feux follets, corpse candles, glowing hands, glowing tree trunks and shining animals, many of which undoubtedly had their origin in observation of true luminescences-electrical discharges or phosphorescent wood. Schertel (1902) has called attention to certain presumed cases of glowing wood in sagas and fairy tales.

The word "light" has often been used figuratively, as in Scandinavian mythology. Balder, the second son of Odin, was said to be a very fine and good man, and so beautiful and fair that light shines from him. ${ }^{7}$ The New Testament statement that, when Jesus was transfigured, 8 "His face did shine as the sun and his raiment was white as the light," is clearly a figure of speech. The student of luminescence is too frequently confronted with the many meanings of the word "light."

\section{The Near East}

No doubt the history of any branch of science should begin with the regions bordering the Tigris and Euphrates and the Nile. In Mesopotamia, civilizations of the Neolithic age but of high artistic

- See E. C. Brewer, $A$ dictionary of miracles, 39, 216-217, 421, Philadelphia, 1895.

${ }^{7}$ Balder is often designated the Apollo of the North, a god of beauty and light.

${ }^{8}$ Matthew 17: 2. 
talent appear to have lived some five thousand years before Christ, spreading southward into Egypt. Unfortunately, the facts most important for the history of luminescence are lacking. Inquiry among scholars concerning ancient Egyptian, ${ }^{9}$ and Sumero-Babylonian ${ }^{10}$ writings has failed to disclose any certain mention of luminous phenomena by these peoples. The subject no doubt suffers from lack of record rather than lack of observation.

It is among animals that a knowledge of luminescence is most likely to be found. The firefly, recorded in sacred books of India and China, seems to have been overlooked by religious writers of the Near East. Neither the firefly nor the glowworm is mentioned in the Bible or the Talmud ${ }^{11}$ or the Koran. Perhaps this can be understood in view of the rarity ${ }^{12}$ of these luminous beetles in the generally desert regions of the Middle East. The firefly is fundamentally a moisture loving insect, abundant in the tropics and lush meadowlands of the temperate zone. There is an old English proverb having to do with weather lore, "When the glowworm lights her lamp the weather is always damp " that well expresses the habit of these luminous beetles. Another saying, "To see many glowworms is a sign of a storm," expresses essentially the same idea. Indeed, such observations as these were no doubt part of the folklore of many ancient peoples before any thought of the meaning of the light or how a light could be produced by a living insect became a subject for discussion.

Possible references to luminescence in the Old Testament are all subject to highly speculative interpretation. A case in point is the shining face of Moses, an incident described as follows in the King James version $(1611):{ }^{13}$

And it came to pass, when Moses came down from Mount Sinai with the two tables of testimony in his hand.... Moses wist not that the

\footnotetext{
- Professor Hermann Ranke of the University Museum, University of Pennsylvania, has written me that he is unaware of Egyptian words for firefly or glowworm or any representations of these insects.

${ }^{10}$ Dr. S. N. Kramer of the University Museum, University of Pennsylvania, has found nothing on luminescence in Sumerian culture. No mention of fireflies or glowworms is to be found in Die Fauna der alten Mesopotamien, etc. by B. Landsberger assisted by I. Krumbiegel (Abh.d. Sächsischen Acad. d. Wiss. Philologisch-Histor. Kl. 42, No. 6, 1934), and Dr. Landsberger, of the Oriental Institute, University of Chicago, has written me in 1951 that no ideogram in the Sumero-Akkadian writing known so far suggests the occurrence of a word for luminous insects of any kind. No luminous animals are mentioned in "The fauna of Ancient Mesopotamia as represented in art," by E. D. Van Buren, Analecta orientalia 18, 1940.

${ }^{11}$ See L. Lewysohn, Die Zoologie des Talmuds, Frankfurt a M., 1858.

${ }^{12}$ Fireflies are found in certain parts of Turkey, Syria and Egypt, but they are not common (Coleopterorum catalogus of W. Junk, Lampyridae by E. Olivier, 1910.) See also discussion under "Arab Writers" Chapter II.

${ }^{13}$ Exodus 34: 29-30.
} 
skin of his face shone while he talked.... And when Aaron and all the children of Israel saw Moses, behold the skin of his face shone; and they were afraid to come nigh him.

Thomas Bartholin, in the most important early work on luminescence, De Luce Animalium (1647), discussed ${ }^{14}$ the shining face of Moses at length and suggested that the effect was due to sunlight or moonlight. It is highly probable that the word "shining" 15 implies a sign of godliness rather than any type of luminescence. In most religions, light is a symbol of knowledge, truth, and holiness as contrasted with darkness, which signifies ignorance and sin.

Perhaps the story of the burning bush ${ }^{16}$ that was not consumed ${ }^{17}$ had its origin in electrical discharges akin to St. Elmo's fire, and the "pillar of cloud " by day, that became a "pillar of fire" by night and accompanied the children of Israel in their exodus from Egypt, ${ }^{18}$ owed its light to electrical discharges also. Luminous clouds have been frequently reported ${ }^{19}$ but nothing would be gained by discussing this Biblical story, which leads too far into the realm of conjecture.

There is also the rabbinical tradition that Noah had a luminous stone in the Ark which shone more brightly by night than by day, thus serving to distinguish day and night when the sun and moon were shrouded by dense clouds. Such a legend may have been based on the well-known phosphorescence of certain diamonds or of fluorspar, but this view is unlikely. Later stories of the miraculous shining of jewels in churches are common but are probably to be explained by reflection rather than emission of light. Thus, the possible records of luminescence from Biblical lands and neighboring regions appear all too indefinite to be listed with the more certain examples from other cultures.

14 Book I, Chap. 12, "De facie Moysis lucente."

${ }^{15}$ In the Vulgate translation into Latin, made by St. Jerome in A. D. 385-405, the Hebrew verb Käran, "to shine," is connected with Keren, a "horn," and was rendered, "sent forth horns," rather than "sent forth beams of light," an interpretation retained in the English translation from the Latin, made at Douay in 1609. More modern translations refer to Moses face as "irradiated with glory" or " radiant."

${ }^{16}$ There are three common explanations of the "burning bush." (1) A mistletoe, Loranthus acaciae, which grows on low shrubs and is covered with fiery, flame-colored flowers at certain seasons; (2) a shrub with prickly spines like Acacia seyal; (3) the gasplant, Dictamus albus, with numerous oil glands on the foliage exuding so much oily vapor, that a match brought near will cause a flash of flame. See H. N. Moldenke and A. J. Moldenke, Plants of the Bible, Waltham, Massachusetts, 1953.

${ }^{17}$ Exodus 3: 2.

${ }^{18}$ Exodus 13: 21-22.

${ }^{19}$ Luminous clouds due to reflection of sunlight from volcanic dust have been observed in recent times by C. Störmer (Nature 135: 103, 1935) and J. Paton (Nature 164: 192, 1949). Older instances will be found in Phipson (1862: 52-55). 


\section{China and Japan}

Where little ancient science writing exists, as in the Far East, it is necessary to quote literature and poetry for recognition of and opinion on luminescence. Probably the first written reference to a luminous animal is to be found among the Thirteen Classics of China. $^{20}$ In one of these, the Shih Ching or Book of Odes, which dates from around 1500-1000 B. C., the line "i-yao hsiao-hsing" occurs. This has been translated ${ }^{21}$ as, "The fitful light of the glowworms would be all about," and "Glowing intermittently are the fireflies." 22

The firefly appears in another classic, the Li-Chi or Notes on Ancient Rites (ca. 400-100 в. c.) in a verse of Book IV, the Yüeh Ling ("The Orders of the Months"), which deals with what happens in the third month of summer. This has been translated by J. Legge ${ }^{23}$ as "Gentle winds begin to blow. The cricket takes its place in the walls. [Young] hawks learn to practice [the ways of their parents.] Decaying grass becomes fire-flies." This belief concerning the origin of fireflies from decaying grass has been current in China for at least two thousand years, reminiscent of Aristotle's opinion that fleas and mosquitoes arise from putrefying matter.

The firefly is also included in the Erh-ya (ca. 400-100 в. c.), a classified glossary giving the correct use of many terms, including names of animals and plants. In this book it is called the Ying-huo or Chi-chao, names still used for firefly today. The insect had wings and its abdomen produced fire. It appeared during the late summer but in autumn flew away.

Somewhat later there arose the story concerning the Chinese scholar and government official, Ch'e Yin or Hsien Yin, who lived in the Tsin Dynasty (A. D. 264-419) and died about A. D. 399. His

${ }^{20} \mathrm{I}$ am indebted to Professor Lien-sheng Yang of Harvard University for calling my attention to these references in Chinese literature, and to $\mathrm{Dr}$. $\mathrm{Hu}$ Shih of Princeton University for comments on them.

${ }^{21}$ James Legge, The Chinese classics 4:237, 1893. The Odes of Pin, III, verse 2. See also the comment of B. Karlgren, Glosses on the Kuo-Feng odes, in Bull. Museum Far Eastern Antiquities 14: 240-24I, 1942.

${ }^{22} \mathrm{Dr}$. Hu Shih informs me that the line "i-yao hsiao-hsing" has two interpretations. (A) Because hsiao means "night" and hsing means "moving " or "traveling," one school regards $i$-yao (literally "glowing or shining intermittently") as the glowworms. The line would then read: "The glowworms (i-yao) are moving about at night." But this reading is contradicted by verse 4 of the same poem, wherein occur the lines: "Ch'ang-keng yü fei $\mathbf{i}$ yao ch'i yü." (" The oriole is flying about, Its wings $c h^{\prime} i$ y $\ddot{u}$ are seen now here, now there.") Therefore the (B) interpretation makes hsiaohsing ("night-travelers") stand for the ancient local name for the glowworm. The line then reads: "Glowing intermittently are the fireflies."

${ }^{23}$ James Legge, The sacred books of China; the $\mathrm{Li} \mathrm{Ki}$, in Sacred books of the East, ed. by F. Max Muller, 27: 277, 1885. 
biography in the History of Tsin Dynasty (Tsin Shih, Chap. 83) describes him as a poor but diligent student who could not afford to buy oil, and, because of his poverty collected fireflies and used them to pursue his studies in the evening. A painting ${ }^{24}$ of this quaint scene has been made by the Japanese artist, Ka-no Tan-yu (1602$1650)$.

In Japan firefly collecting very early became a popular pastime, like the observation of autumn coloring. The firefly festival on the Ugi River was an important event in the neighborhood of Kyoto. Many references to fireflies are to be found in Japanese literature, some of them with a Chinese origin like the various accounts of mysterious lights, which arose in China and were later transferred to Japanese writing. For example, in the Wa-Kan-Sansai-Zue, an encyclopedia of China and Japan, written in classical Chinese and published in 1712 by the Japanese, Ryoan Terajima, it is stated that the firefly belongs among the kasei-rui, insects transformed from decaying grasses. The encyclopedia described several kinds of fireflies in Japan-the glowworm, arising from bamboo roots, the aquatic glowworm, and large and small fireflies, some of them coming from decayed miscanthus roots. Other luminous animals are not mentioned but a fungus which emits light is described..$^{25}$

However, the author has been unable to find early Chinese accounts of other luminous animals described as specific sources of light, comparable to the luminous organisms of Pliny's Natural History. The phosphorescence of the sea was naturally noticed by the Chinese and is referred to in oriental writings, but, without a microscope, the true cause of the light could hardly have been understood.

Professor Joseph Needham ${ }^{26}$ has informed me that a phenomenon called by the Chinese, "devil lights of the outer wilderness" (yeh wai chih kuei lin) has been associated with old blood and might be the result of luminous bacteria growing on human bodies left unburied on a battlefield. In European history, the bacterial luminescence of meat from slaughterhouses and of luminous cadavers has caused consternation on several occasions.

Both in China and in Japan there are many ancient stories of mysterious lights or fires seen over water, fields, or mountains, ascribed to dragons or caused by the gods. Sacred trees often emitted light. Usually it is only possible to guess at the cause of these ap-

${ }^{24}$ In Ko-Ji Ho-Ten. Dictionnaire a l'usage des amateurs et collectionneurs d'objects d'art japonais et chinois, by V. F. Weber, 2 v., Paris. 1923.

${ }^{25}$ From a translation of Wa-Kan-Sansai-Zue, kindly made by Dr. Yata Haneda.

${ }^{28}$ Private communication, based on material to appear in Vol. 4 of Science and civilization in China, by J. Needham assisted by L. Wang, Cambridge Univ. Press. 
pearances, which might be attributed to St. Elmo's fire or other types of electric discharge, to clumps of luminous fungi, or to phosphorescent wood containing the mycelium of the fungus. These phenomena are the equivalent of the ignes fatui of European folklore, whose explanation is likewise difficult. In some cases luminescences may also have been involved (see Chap. VII on Electroluminescence). The accounts of ignes fatui in China and Japan, together with a detailed discussion of them will be found in Needham's History of Science in China, in de Groot (1901) ${ }^{27}$ and in de Visser $(1913,1914) .{ }^{28}$ It seems quite certain that in ancient China philosophers were aware of most types of luminescence with the possible exception of the light from artificial phosphors.

It has been claimed that the Chinese knew of artificial phosphors, although the evidence is not very convincing. The following story concerning a painting of the Emperor Tsi Tsung (976-998), of the Sung dynasty, was related by a Mr. Macgowen ${ }^{29}$ in a communication to the North China Herald and has been included by $\mathrm{H}$. Rupp $^{30}$ in her book Die Leuchtmassen und ihre Verwendung (Berlin, 1937).

The story has been traced by Professor Lien-Sheng Yang, of Harvard University, to old Chinese records. I quote from a letter of Professor Yang to Mr. Langdon Warner, ${ }^{31}$ of the Fogg Museum of Art of Harvard University:

First, in the miscellaneous notes by a Sung monk, of which the title is Hsiang-shan yeh-lu (eleventh century A. D.), there is a story concerning an interesting painting which was presented to the second emperor of the Sung dynasty. On the painting was a cow which appeared during the day as eating grass outside a pen but at night as resting in it. When it was shown to the court, none of the officials could offer an interpretation. The monk Tsan-ning, however, said that the ink [or color] which was shown only in the night was mixed with drops from a [special kind of] pearl shell and the ink [or color] which was shown only during the day was made by grinding a rock which had fallen from a volcano to the seashore. He claimed that the information came from a book by Chang Ch'ien, the famous envoy sent to the Western Regions by Han Wu-ti [reigned 140-88 B. c.]. A scholar who consulted the imperial col-

${ }^{27}$ J. J. M. de Groot, Religious system of China 4: 80-81, 1901.

${ }^{28} \mathrm{M}$. W. de Visser, The dragon in China and Japan, Verhand. Kon. Akad. v. Wetens. Amsterdam. Letterkunde N. R. 13, 242 pp., 1913; Fire and ignes fatui in China and Japan, Mitteil. d. Seminars für Orient. Sprach. Kön. Univ. Berlin 17: 162-295, 1914.

${ }^{20}$ MacGowen, Science 2: 698, 1883.

${ }^{30}$ Rupp (1937: 147) attributed the painting to the Japanese.

${ }^{31}$ I express my appreciation to Mr. Warner and Mr. Yang for their efforts in tracing this story. 
lections found the reference in a work dated from the Six Dynasties. (The above is a summary of the story in the Hsiang-shan yeh-lu.)

In 1768 John Canton described a phosphor made from oyster shells and it is possible (although improbable) that the Chinese prepared a luminous paint from the pearl oyster. However, Dr. $\mathrm{Hu}$ Shih, of the Gest Oriental Library at Princeton University, informs me that nothing is known of any book left by the explorer Chang Ch'ien and that Wen-ying, the author of the Hsiang-shan yeh-lu, who lived in the eleventh century, was not noted for his veracity. He was a poet and literary monk and his book contains so many fantastic yarns that the story of the luminous cow should be given little serious consideration.

Although Chinese knowledge of phosphors is doubtful, almost all the early historical sources of information mention the "night shining jewel " or "yeh kuang pi," which seems to have particularly appealed to the imagination of the Chinese, ${ }^{32}$ possibly because of a religious significance. The Buddhist sacred jewel, one of the seven treasures, called "hashi-no-tama" in Japan, is alleged to be selfluminous and to shed a brilliant light on its surroundings, a symbol of the enlightenment of Buddha's teaching. W. H. Riddell ${ }^{33}$ has suggested that Buddhist monks may have obtained the idea of a shining jewel from a legend in Ceylon and India concerning the cobra and brought it to China via Tibet and thence to Japan. This belief in a luminous cobra-stone, used by the snake to attract fireflies, will be found in the section on India. On the other hand, knowledge of luminous gems may have come to China by way of Asia Minor in classic times. The possible interpretation of Greek and Roman stories of luminous jewels will be found in a later section, and an exhaustive study of phosphorescence of precious stones in B. Laufer's The Diamond in Chinese and Hellenistic Folk-lore (1915)..$^{34}$

Like the stories from the Near East, the legends of China are subject to difficulties of interpretation. We can only guess what techniques were involved in magic painting but electroluminescences were undoubtedly seen, on the body as well as in the sky. The earliest true astronomical observations were made by the Chinese, who naturally recorded the aurora borealis. It was described in the encyclopedia of Ma-tuan-lin (fourteenth century) under

${ }^{32}$ See F. Hirth, China and the Roman Orient, 242, Leipsic and Munich, Shanghai and Hong Kong, 1885; reprinted 1939; J. Needham, Science and civilization in China, vol. 1: 199, Cambridge, 1954.

${ }^{33}$ W. H. Riddell, Hashi-no-Tama, Buddhist Sacred Jewel, Antiquity 20: 113-121, 1946. 1915 
various designations-red vapor, red fire, sunshine at night, horizon glow, snaky arrows, and white arcs. ${ }^{35}$ Such expressions recall the Greek and Roman names for the various types of auroral display.

\section{India}

Occasional references ${ }^{36}$ to the firefly and glowworm are to be found in the holy writings ${ }^{37}$ of ancient India, the Vedas, ${ }^{38}$ and in the Indian epic poems. In the Upanishads, part of the Brahmanas or the priestly dicta of the Hindus, probably recorded at some time before the sixth century B. C., we find: ${ }^{39}$

Fog, smoke, sun, fire, wind,

Fire-flies, lightning, a crystal, a moon-

These are the preliminary appearances,

Which produce the manifestation of Brahma in Yoga.

The Mahabharata, of date and author unknown (200 B. C.-A. D. 200 ?), is probably the longest poem in existence, consisting of 18 books and 220,000 lines. It contains many episodes describing the great story of the Bharatas, people descended from the mythical king and hero, Bharata. The Sanskrit word, khadyota, meaning firefly or glowworm, occurs a number of times.

In one of the books, the Anugita, ${ }^{40}$ we find, "As those who have eyes see a glow-worm disappear here and there in darkness, so likewise do those who have eyes of knowledge. Such a soul the Siddhas see with a divine eye, departing [from the body] or coming to the birth or entering into a womb."

In another book of the Mahabharata, the Vana Parva ${ }^{41}$ there is the story of Saryāti and Sukanyā, who mistook Cyavana's eyes for glowworms and a description of "the Lord, like a fire-fly at night time during the rainy season. . .." In the As̄wamedha-Parva, ${ }^{42}$

${ }^{35}$ See D. J. Schove, Sunspots, aurorae and blood rain: the spectrum of time, Isis 42: 133-138, 1951 .

${ }^{36} \mathrm{I}$ am indebted to Professor W. Norman Brown of the University of Pennsylvania for calling my attention to these references.

${ }^{37} \mathrm{~A}$ tentative dating of Indian writings has been adopted by the National Institute of Sciences of India (see S. L. Hora in Nature 168: 1048, 1951).

${ }^{38}$ Vedas include the (1) Sanhitas, a collection of mantras or hymns, (2) the Brahmanas, priestly doctrines, including the Aranyakas and the Upanishads, and (3) the Sutras or rules. They date from 2000 to perhaps 500 B. C.

${ }^{39}$ Svetasvatara Upanishad (2:11) translated from the Sanskrit by R. E. Hume in The thirteen principal Upanishads, 398, Oxford Univ. Press, 1921.

${ }^{40} \mathrm{~K}$. T. Telang. The Anugita in Sacred books of the East 8: 239, 1882.

${ }^{41}$ See the translation of the Vana Parva by P. C. Roy, part 2, p. 375 and 801 (Mbh. 3: 10336 and 15827).

${ }^{2}$ See translation by Roy, p. 40 (Mbh. 14: 485). 
"the fire-fly appearing and disappearing amid darkness" is again described.

Finally at a later period, in the Sarvadarśana Sangraha, a treatise dealing with various schools of philosophy in India, by the celebrated scholar of the fourteenth century A. D., Mādhava Āchārya, we find the expression " many firefly-like pleasures." This is apparently a comparison of pleasures to fireflies, both of which are transient. ${ }^{43}$

In the Buddhist scriptures, the Dhammapada, the Pali word, khajjopakana, is used for firefly and the following statement ${ }^{44}$ occurs: "Disciples of the Possessor of the Ten Forces multiplied and gods and men innumerable descended upon Holy Ground. . . . But as for the heretics, lost to them were gain and honor alike, even as fire-flies lose their brilliance before the coming of the sun. . .."

The position of firefly light in a scale of brightness is indicated in Further Dialogues of the Buddha translated by Lord Chalmers from the Pali of Majjhima Nikāya. ${ }^{45}$ This excerpt ${ }^{46}$ contains a series of comparisons in which a heretic's perfection is likened to a gem. But the gem is admitted to shine and sparkle less than "the firefly of the night," the firefly less than a lamp, the lamp less than a conflagration in the night, the conflagration less than the morning stars at dawn in a cloudless sky, these less than the full moon in a clear sky at midnight, this less than the sun at his zenith at the end of the rains, and this last less than many, very many, deities, "so luminous in themselves that they draw no light from sun or moon." At the end of the series it is repeated that the heretic's perfection is "less than, and inferior to, a firefly."

These extracts will illustrate the place which the commonest and most striking luminous animal has occupied in ancient Indian literature. It is interesting to note two points. The first is emphasis on the ephemeral nature of the firefly, which appears at certain seasons for a few weeks and then disappears, to live out its life cycle as a

4 See the E. B. Cowell and A. E. Gough translation, 171, London, 1882. Dhammahada 3: 178 .

${ }^{44}$ See Burlingame, E. W., Buddhist legends 3 (Harvard Oriental Series 30: 19, 1921). Gautama Budda lived ca. 562-482 B. C., the same general period as Pythagoras (582500 в. с.) in Greece, Confucius (550-478 в. с.) in China, and Zoroaster (before 500 в. с.) in Persia.

45 2: 18 (Majjhima Nikāya II, 40).

${ }^{4}$ Another version of the story is given by H. C. Warren in Buddhism in translation, Harvard Oriental Series 3, 1900. In Chapter XIII of the "Visuddhi Magga" of the Pali Scriptures, dealing with Meditation and Nirvana, occurs the statement: "Now the power possessed by members of other sects to perceive former states of existence resembles the light of a glow-worm; that of the ordinary disciples, the light of a lamp; that of the great disciples, the light of a torch; that of the chief disciples, the light of the morning star; that of the Private Buddhas, the light of the moon; that of the Buddhas resembles the thousand-rayed disk of the autumnal sun." 
wingless larva on the ground. The second is the low opinion of the brightness of a firefly flash. Far from amazement at the ability of a tiny creature to produce a light without accompanying heat, the firefly was rated in Buddhist scriptures near the bottom of the list of luminous objects. In this respect the attitude is similar to that of the Arabs, whose name for a firefly is derived from that of a man so stingy that he always kindled a fire too small to be of any value to anyone (see Chapter II) .

Knowledge of luminescence in ancient India must not be concluded without mention of the luminous cobra-stone of India and Ceylon, although the date of the legend is unknown, and the story sounds highly improbable but completely fascinating. The best account has been related by Professor $\mathrm{H}$. Hensoldt, ${ }^{47}$ who obtained one of the stones, called "Naja-Kallu," during a stay at Point de Galle, Ceylon. It is said that about one cobra in twenty carries around in its mouth a small luminous stone that it places in the grass at night to attract fireflies, which the cobra then proceeds to eat. Hensoldt caught fifty cobras without finding a stone but one night in the field with a Tamil coolie he saw a cobra resting by what he thought was a luminous spot. He wished to kill the cobra at once but the Tamil implored him not to because the snake is alleged to be particularly dangerous when watching the Naja-Kallu. However, on the next night the Tamil saw the cobra in the same place and obtained the stone by climbing a tree and throwing ashes over it. The ashes were collected and sifted after the snake had left. The stone was " a semitransparent water worn pebble of yellowish color, about the size of a small pea, which in the dark, especially when previously warmed, emitted a greenish phosphorescent light." Chemically it was a fluorite, some varieties of which (chlorophane) are said to be sufficiently phosphorescent to shine all night long after exposure to the sun's rays. The pebble no doubt existed but the part played by the cobra is reminiscent of another more recent story regarding the Indian baya-bird or bottle-bird (Ploceus baya), which is alleged ${ }^{48}$ to stick fireflies in the mud-pellets of its bottle-shaped nest in order to scare marauding animals from the eggs and young birds.

\section{Greece}

Among the ancient Greek philosophers from Thales of Miletus (ca. 640-ca. 546 в. c.) and his pupil Anaximander (ca. 611-547 в. c.)

${ }^{47}$ H. Hensoldt, The Naja-Kallu, or cobra stone, Harpers Monthly Magazine, 80: 546540, March, 1890.

${ }^{48}$ H. A. Severn, Nature 24: 165, 1881. 
to Plato $(428-347$ в. C.), the fragments of literature and quotation which have survived contain no certain reference to luminous things. Homer (date uncertain, $c a .1000$ B. c.) cited a few invertebrates in the Iliad and the Odyssey but not luminous ones. ${ }^{49}$ The story of a luminous plant described by Democritus (ca. 475-ca. 375 в. c.) has been retold by Pliny (see that section) and it should be noted that Theophrastus (ca. 374-ca. 286 B. c.) in his treatise on stones specifically stated that the semiprecious carbuncle, literally a little coal, received its name from the fact that it shines when seen against the light, rather than from self-luminosity, as held by many later writers. Knowledge of luminous gems in classic times will be discussed in a later section.

The early Greeks observed the aurora borealis and there is somewhat uncertain indication of knowledge of inorganic luminescence. A passage of Euripides (480-406 в. с.) in his tragedy Bacchae described how the Bacchantes "carried fire on their hair without being hurt." The "fire" has been interpreted by J. P. Jorrissen (1948) as a phosphorescent material, but the evidence is far from convincing. These inorganic luminescences will be discussed in separate sections.

\section{ARISTOTLE}

It is with Aristotle (384-322 B. C.) that a fairly wide knowledge of cold light begins. He not only listed some well-known luminescenses but realized that they were different from other bodies which had color and could be seen by day. There is little doubt that Aristotle knew of the luminescence of dead fish and flesh and also of fungi. The evidence on which this is based comes from a discussion of light and color in De Anima (Book II, Chap. 7, Sec. 4). In R. D. Hicks' translation the statement is as follows:

Some things, indeed, are not seen in daylight, though they produce sensation in the dark: as for example the things of fiery and glittering appearance for which there is no distinguishing name, like fungus (mukes) horn (keras) and the head scales and eyes of fishes. But in no one of these cases is the proper color seen. Why these objects are seen must be discussed elsewhere. ${ }^{50}$

\footnotetext{
${ }^{49}$ See L. Moule, Etudes zoologique et zootechniques dans la littérature et dans l'Art. La faune d'Homère, Mem. Soc. Zool, de France 22: 183-233, 1909.

${ }^{50} \mathrm{~A}$ similar idea is expressed in Aristotle's De coloribus of the Opuscula: "some things though they are not in their nature fire nor any species of fire, yet seem to produce light." Further discussion of such phosphorescent objects was not made by Aristotle but his commentators have presented their views. Sosigenes (fl. second century A. D.), teacher of Alexander of Aphrodisias, held (in De visu 3) that luminescences gently illuminate the air around them, not enough to render objects clearly
} 
The word "fungus" must refer to the mushroom or fruiting body, many species of which are luminous. It is possible that Aristotle also realized that the mycelium of the fungus, growing on rotten wood, was responsible for the luminescence of the latter.

The head, scales and eyes of fishes are in a different category. They could refer to bacterial luminescence of these substances, although Aristotle may have noted only light reflection from the head scales and eyes of fishes.

The word "horn" is somewhat in doubt. Placidus Heinrich in his Die Phosphorescenz der Körper, 1815 (p. 415), believed that keras (meaning horn) should have been "kreas" (meaning flesh), in which case Aristotle would have referred to luminescent meat. Ehrenberg in Das Leuchten des Meeres (1834) is inclined to follow this interpretation which is also adopted in the J. A. Smith translation of De Anima. It is highly probable that the ancients, living near the sea, must have observed the luminescence of dead fish resulting from luminous bacteria, and probably observed the luminescence of flesh, also due to luminous bacteria.

That there is light in the eyes of fishes, ${ }^{51}$ and in eyes in general, has been noted by many subsequent writers. Such a light could be merely reflection of external light, as from the eye of a cat or the eye of a man. Homer, in describing Achilles rushing into battle, wrote:

Grief and revenge his furious heart inspire

His glowing eyeballs roll with living fire.

Human experience also shows that pressure on the eyeball or a blow to the eye gives the sensation of light. Theophrastus (374286 в. с.) quoted Alcmaeon (sixth century в. c.) as stating that "the eye obviously has fire within, for when one is struck (the fire) flashes out." As already pointed out, Aristotle wrote: ${ }^{52}$

But they [inquirers] hold the organ of sight to consist of fire, being

visible but only enough to free them from darkness. "Their small light perishes, as it were, during the day, and is swallowed up by a large one" (Gesner, De lunariis, 1555). Ammonius (fifth century A. D.) distinguished two kinds of visible objects. The first can be seen in daylight and are called colors while the second lack a common name and might be called shining. Aristotle thought of light as an activity (energeia) in a medium called the pellucid or the transparent (diaphanes).

${ }^{51}$ See the discussion in Chapter IV under Thomas Bartholin. A recent account is given by R. Dubois in the Com. Rend. Ac. Sci. 178: 1030-1033, 1924.

${ }^{62}$ De sensu in Parva naturalia, 437, translated by J. I. Beare, 1908. This phenomenon, the phosphene, is due to mechanical stimulation of the visual reception. David Brewster (1831) referred it to "a singular property [in the retina] of being phosphorescent by pressure," but the light is purely subjective, like the colors seen during bilious attacks or fever, or the after images of the eye, which were once called "ocular spectra" or " accidental colors." 
prompted to this view by a certain sensory affection of whose true cause they are ignorant. This is that, when the eye is pressed or moved, fire appears to flash from it. This naturally takes place in darkness, or when the eyelids are closed, for then too, darkness is produced.

The various subjective light phenomena connected with the human eye must have greatly influenced Greek theories of vision, some of which regarded emanation from the eyes as responsible for seeing.

Another possible reference to luminous bacteria on fish is found in Aristotle's discussion of sensation, De Sensu. In the second chapter, which deals specifically with light and vision, we find, ${ }^{53}$ "It is the nature of smooth things to shine in the dark as e. g. the heads of certain fishes and the juice of the cuttle-fish." The "juice" of the cuttlefish is particularly interesting. In addition to luminous bacteria, which often grow on the surface of dead squid, some forms (Sepiola and Rondeletia) have open luminous glands and frequently harbor luminous bacteria, while one remarkable deepwater species (Heteroteuthis dispar) actually discharges a brilliant luminous secretion that could be referred to as a "juice." The word tholos which is translated by "juice," really means the dark ink, or sepia, of the cuttlefish, from which the Greek verb tholo, " to make turbid," is derived. The luminous secretion of the deep-sea squid, Heteroteuthis, practically takes the place of the inky juice of other squid and the word tholos might be applied to it. It seems highly probable that Aristotle knew of Heteroteuthis, which is caught even today by the fishermen of Sicily near Messina, in the neighborhood of Charybdis, the whirlpool so fatal to the fleet of Ulysses. In this region they are carried upwards by currents from deeper waters and may actually swim at the surface of the sea. Other luminous marine animals (jellyfish, sea pens, Pholas) are not mentioned specifically, but Aristotle did refer to the light which appears when one strikes the sea with a rod at night, as explained in a subsequent section.

The firefly and glowworm occur in Historia Animalium. In D'Arcy Thompson's translation the following statements will be found: "Some insects are wingless ... ; some are winged ... ; and the same kind is in some cases both winged and wingless, as the ant and the glow-worm." 54 Also, "From a certain small, black and hairy caterpillar comes first a wingless glow-worm; and this creature

\footnotetext{
${ }^{53}$ The original Greek and a translation of De sensu and de memoria, 49, by G. R. T. Ross, Cambridge Univ. Press, 1906. Another translation by J. I. Beare (1908), reads: "For it is in the dark that that which is smooth, e. g., the heads of certain fishes and the sepia of the cuttle fish, naturally shines. ..."

${ }^{54}$ Historia animalium, ed. by J. A. Smith and W. D. Ross 4, Book IV, 523b 21, Clarendon Press, 1910.
} 
again suffers a metamorphosis, and transforms into a winged insect named the bostrychus" (a lock or curl of hair)..$^{55}$ This insect was called pygolampis (tail light) or pyrolampis (bright with fire) in most Greek texts but according to Muffet (1634) has also been called kusolampos (rump light) or lampyris (brilliant one) and, by way of metaphor, lampedon and spinther, both words meaning a spark.

Fireflies are also mentioned ${ }^{56}$ by the Greek lexicographer Aristophanes the grammarian of Byzantium ( $c a .257-180$ B. C.), the geographer Artemidor of Ephesus (second century B. c.), and much later by the lexicographers, Hesychius of Alexandria ( $c a$. fifth century A. D.) and Suidas of Byzantium (ca. tenth century, A. D.) . Aristophanes thought fireflies developed from worms on peas, while Hesychius believed they arose from the underbrush. Fireflies are not included among the animal remedies of Dioscorides (first century A. D.) .

Aristotle's remarks on the aurora borealis will be found in a later section of this chapter.

STRABO

After Aristotle, Strabo (63 B. c. to A. D. 24), the Greek geographer, in the last of his seventeen books, mentioned the dilyxnos (literally, double light), as a Nile fish. According to the Swiss naturalist, Conrad Gesner (1516-1565), the name referred to luminescence of eyes or gills. Ehrenberg (1834: 532-533) during a visit to Dongala on the Nile in Nubia, well away from salt water, noticed luminescence of the nearly flesh-free skeleton of the armor fish, Heterotis nilotica, ${ }^{57}$ and wondered whether this fish could be the dilyxnos of Strabo. The luminescence of Ehrenberg's fish was presumably due to luminous bacteria, which are occasionally found growing on fresh-water fish, as well as salt-water forms. However, some manuscripts of Strabo use the word lyxnos, ${ }^{58}$ and there is nothing in the text to indicate luminescence. The lyxnos is merely mentioned with a number of other fish living in the Nile. ${ }^{59}$. The most that can be said is that observation of a luminous fish could have been made,

${ }^{55}$ Idem., Book V, $551^{\mathrm{b}} 25$.

${ }^{56}$ According to Muffet (1634), Jonston (1653), and Otto Keller (Die Antike Tierwelt 2: 408,1913$)$.

${ }^{57}$ In G. A. Boulenger's Zoology of Egypt; the fishes of the Nile (1907), Heterotis nilotica is figured (pl. XV), but there is no mention of luminescence of any Nile fish.

${ }^{58}$ Lyxnos is literally a light or lamp. According to R. Strömberg, Studien zur Etymologie und Bildung der Griechischen Fischnamen (Goteborg, 1943), the Greeks used the collective name selachos for lumirous fish.

${ }^{s 0}$ See Strabo's Geography, Book 17 (2), sect. 4, trans. by H. C. Jones 8: 149, 1932. 
and it is surprising that Strabo did not make unquestionable references to luminescence. ${ }^{60}$

\section{Rome}

It is hard to understand why Roman literature of Classic times contains but few references to fireflies, ${ }^{61}$ for later travelers have emphasized the striking display of these insects in Italy. There is no mention of bioluminescence of any kind in the writings of the epic poet Virgil (70-19 B. c.), despite the marine adventures described in the Aeneid, where every opportunity for observing phosphorescence of the sea was presented. Virgil seemed to be impressed by the sparks obtained on striking flint, for this phenomenon, which can hardly be called a luminescence, is mentioned twice in the Aeneid ${ }^{62}$ and once in the Georgics. ${ }^{63}$ However, the ignis lambens and the aurora borealis, were observed and described in considerable detail by several authors and will be discussed in a later section.

\section{PLINY}

Omission of luminescence from Roman literature has been in part balanced by the writings of Caius Plinius Secundus, Pliny the Elder (A. D. 23-79). Although fundamentally a reader and compiler, Pliny's military career took him to all parts of the ancient world and his travels afforded the opportunity for observation and anecdote. He has been maligned by many writers but his descriptions of luminescence were often quite specific and complete.

In the Historia Naturalis, written in the first century A. D., there is mention of the glowworm; the luminous mollusc, Pholas dactylus; a luminous medusa (Pulmo marinus); the lantern fish (Lucerna piscis), a creature hard to identify; a luminous fungus and a plant, which on drying, becomes luminous. There are also references to luminous wood and possibly to luminous eyes of dead luminous fish (Aridi piscium oculi). Pliny also mentioned the glow in eyes of the cat, deer, wolf, seal, and hyena, a reflection of light from the eye, not a true luminescence. His story of the birds of the Hercynian Forest (Black Forest) whose feathers shine at night like fires must

${ }^{60}$ The only reference to luminescence in D'Arcy Thompson's A glossary of Greek fishes, London, 1947, has to do with the boring mollusc or piddock, a food of the Greeks and Romans, mentioned several times by Pliny.

${ }^{61}$ There is no mention of a firefly depicted on coins or cameos in Tier- und Pflanzenbilder auf Münzen und Gemmen des klassischen Altertums, by F. Imhoof-Blumer and O. Keller, Leipzig, 1889.

${ }^{2}$ Book I, line 174, and Book VI, line 7.

${ }^{\text {83 }}$ Book I, line 135 . 
also be attributed to reflection of light, as well as the light from precious stones, discussed in a later section.

The earliest English translation of Pliny is by Philemon Holland (1552-1637), Doctor in Physick, a two-volume work entitled The Historie of the World. Commonly called the Naturall Historie of C. Plinius Secundus. It was published at London in 1601. Holland's literal interpretation and his quaint phraseology make the parts dealing with luminescence well worth quoting. The statement regarding luminous eyes occurs in Book XI, chap. 37, ${ }^{64}$ which is entitled: "A discourse Anatomicall, of the nature of living creatures, part by part, according to their particular members." The section takes up horns, ears, eyes, and other organs. Pliny wrote:

Moreover, we see that those creatures which ordinarily do see by night ${ }^{65}$ (as cats doe) have such ardent and fierie eyes, that a man cannot endure to looke full upon them. The eyes also of the Roe-bucke and the Wolfe are so bright, that they shine agine, and caste a light from them. The Sea-calves or Seales, and the Hygenes, alter eftsoons their eies into a thousand colours. Over and besides, the eies of many fishes doe glitter in the night, when they be drie: like as the putrified and rotten wood of some old trunke of an oke or other wood. . . .

The fact that the eyes of fish at night are compared to luminous wood ${ }^{66}$ suggests that Pliny may have referred to the light of luminous bacteria which often grow on the eyes of dead fishes, although the lens of a dried eye might act as a reflector.

In addition to luminous wood, Pliny was familiar with luminous fungi, for he wrote (Book XVIII, Chap. 8) :

As for Agaricke, it groweth in Fraunce principally upon trees that beare mast, in manner of a white mushrom: of a sweet flavor, very effectual in Physicke, and used in many Antidotes and sovereaigne confections. It groweth upon the head and tops of trees: it shineth in the night, and by the light that it giveth in the darke, men know where and how to gather it.

Hennings (1904) believed the fungus might be Pleurotus olearius, common on olive and other trees in Mediterranean countries.

${ }^{84}$ The numbering of chapters is frequently different from that of later translators.

${ }^{65}$ The idea that glowing eyes mean ability to see at night has been repeated by many authors. Pliny wrote (Book XI, Chap. 54, Bostok and Riley translation) that: “Tiberius Caesar, like no other human being ... on awakening in the night, could for a few moments distinguish objects as well as in the clearest daylight, but that by degrees he would find his sight enveloped in darkness." Cardan, the elder Scaliger, and the French physicist, de Mairan, were reported to have the same power.

${ }^{88}$ A passage in the Pharsalia of Lucan (Marcus Annaeus Lucanus, A. D. 39-65) may refer to phosphorescent wood: "Fame, too, reported that full oft the hollow caverns roared amid the earthquake and that yews that had fallen rose again. And that flames shone from a grove that did not burn." H. T. Riley translation, 113, London, 1890. 
Since the birds of the Hercynian Forest (the Black Forest) have been widely quoted by writers ${ }^{67}$ of all periods as examples of luminescence among birds, it is only fair to Pliny to quote his statement, which will emphasize the fact that the story was hearsay and the birds were rare ("farre fetched "). He wrote (Book X, Chap. 47) :

In Hercinia, a forrest of Germanie, wee have heard that there bee straunge kinds of birds, with feathers shining like fire in the night season. In other respects, I have nothing to say of them worth the writing, save only they are of some name, for beeing ferre fetched.

Regarding the story of a luminous plant, which has likewise been repeated by many subsequent writers, we must again credit Pliny for quoting Democritus. In Book XXI, chap. 11, he wrote:

As touching Nyctygreton (or Lunaria) Democritus held it to be a wonderful hearb, and few like unto it; saying that it resembleth the colour of fire, that the leaves be prickie like a thorn, that it creepeth along the ground: he reporteth moreover, that the best kind thereof groweth in the land Gedrosia, that if it bee plucked out of the ground root and all after the Spring Aequinox, and be laid to dry in the moonshine for three daies together, it will give light and shine all night long; ... that some call it Chenomyche because Geese are afraid of it when they see it first; others name it Nyctalops because in the night season it shineth and glittereth a farre off.

Pliny did not mention the luminescence of another plant, Aglaophotis, so minutely described by Aelian, but merely said (Book XXIV, Chap. 17) that it was also called Marmoritis, had beautiful colors, was "magicall," and used by the wise men of Persia. ${ }^{68}$

Pliny's description of the glowworm ${ }^{69}$ has been much quoted, including his incorrect idea of the control of its light. He wrote (Book XI, chap. 28) :

The glo-wormes, are named by the Greeks, Lampyrides, because they shine in the night like a sparke of fire: and it is no more but the brightness of their sides and taile: for one while as they hold open their wings, they glitter; another while they keepe them close togithur, they

${ }^{67}$ See Chapter III and C. Vogel, De avibus noctu lucentibus (1669), reviewed in Chap. IV. It was natural that commentators on Pliny, like Caius Julius Solinus (third century A. D.?) in his Polyhistor, should repeat the story.

${ }^{88}$ None of the above plants are included in the index of the "Greek Herbal of Dioscarides" (first century A.D.), illustrated by a Byzantine (A.D. 512), englished by John Goodyer in 1665, reproduced and edited by R. T. Gunther, Oxford, 1934.

${ }^{60}$ Not to be confused with the "pyralis" or "pyrusta" a four-footed creature with wings found in Cypres, which lives only in fire and dies whenever it leaps out. Chap. 36 of Book XI (vol. 1, p. 330 of Holland's translation, 1601). 
be shadowed, and make no shew. These glowbards never appeare before hay is ripe upon the ground, ne yet after it is cut downe.

The time of year when glowworms appear is again emphasized in Book XVIII, Chap. 26, "On husbandrie." Speaking of various grains, he wrote:

Now the signe common to them both, testifying as well the ripenesse of the one [barley] as the Seednes of the other [Panicke and Millet], are the glo-birds or glo-wormes, Cicindelae, shining in the evening over the corne fields: for so the rusticall paisants and country clownes call certaine flies or wormes glowing and glittering star-like; and the Greeks name them Lampyrides: wherein we may see the wonderfull bountie and incredible goodnesse of Nature, in teaching us by that fillie creature.

Pliny used the word lampyrides, but the most common medieval Latin name, cicindelae, was applied to beetles which light during flight, although many other names have been used, without much reference to the winged or wingless condition. According to Muffet (1658: 975) - "The Latines call it [the glowworm] Cicindela, ${ }^{70}$ Nocticula, Nitedula, ${ }^{71}$ Lucio, Lucula, Luciola, Flamis, Venus, Lucernuta, Incendula, as appears out of Cicero, Pliny, Scoppa, ${ }^{72}$ Varro, ${ }^{73}$ Festus, ${ }^{74}$ Plautus, Scaliger ${ }^{75}$ Turnebus, ${ }^{76}$ Albertus, ${ }^{76}$ and Silvaticus." ${ }^{77}$ It will be noted that the list includes medieval as well as classic designations. Hesychius (fifth or sixth century A. D.) merely spoke of Cantharis.

The luminous mollusc, Pholas dactylus, called a piddock in England, is mentioned twice by Pliny in Book IX. Pliny emphasized (Chap. 61) the "wonderfull qualities" of this animal: ${ }^{78}$

${ }^{70}$ The word has been spelled in every possible way, cicindula, cicendela, etc. Many references will be found in D. du Cange, Glossarium mediae et infimae latinitatis (1883-1887) .

${ }^{71}$ Marcus Tullius Cicero (106-43 B. c.) used the word nitedula for a dormouse (Pro Sest. 72), the commonly accepted meaning, but C. Gesner and A. Kircher apply nitedula (or nitela) to the firefly.

72 Probably Scioppius (Caspar Schoppe, 1576-1649) who edited Varro's De lingua Latina.

${ }^{73} \mathrm{~T}$. Terentius Varro (116-27 B. c.). author of De lingua Latina called the firefly, lampas domestica.

${ }^{74}$ Pompeius Festus, the second century lexicographer, who revised the lexicon of Verrius Flaccus. His lexicon was epitomized by Paulus Diaconus (735-793) .

${ }^{75}$ Julius Caesar Scaliger (1485-1558), who wrote De causis linguae Latinae (1540).

${ }^{76}$ Adrianus Turnebus (1512-1565), the French classical scholar; Albertus, Albertus Magnus.

${ }^{77}$ Possibly Bernard Silvester of Tours, who lived in the twelfth century and wrote Megacosmos and Microcosmos.

${ }_{78}$ Athenaeus of Naucratis, who lived in the third century A. D. in his Deipnosophistae (Book III, sec. 35) mentions dactyli as very nutritious but with a disagreeable smell. He did not refer to their light (The Deipnosophists or banquet of the learned, trans. by C. D. Yonge, 1: 146, 1854). 
Of the shell fish kind are the Dactyli, so called of the likeness of mens nailes, which they resemble. The nature of this fish is to shine of themselves in the dark night, when all other light is taken away. The more moisture they have within them, the more light they give: insomuch as they shine in men's mouthes as they be chawing of them: they shine in their hands: upon the floore, on their garments, if any drops of their fattie liquor chaunce to fall by: so as it appeareth, that doubtlesse it is the very juice and humour of the fish which is of that nature, which we doe so wonder at in the whole bodie.

Jellyfish ${ }^{79}$ are common in the Bay of Naples, where Pliny died during the eruption of Vesuvius, A. D. 79. They were called Pulmo marinus by the Romans, and when boiled in water or taken in wine were considered good for "the gravell and the stone." One kind of jellyfish, Pelagia noctiluca, is luminescent, owing to a slime secreted from the outer surface of the bell. As Pliny observed in connection with "Remedies for fevers, etc." (Book XXXII, Chap. 10) this slime readily sticks to various surfaces: "Rub a piece of wood with the fish called Pulmo Marinus, it will seeme as though it were on a light fire; in so much as a staffe so rubbed or besmeared with it, may serve instead of a torch to give light before one." Perhaps the statement regarding the "staffe" or walking stick is somewhat exaggerated, but the animal itself is a striking object when stimulated to luminescence. ${ }^{80}$

Finally Pliny referred to a "fish called the Lanterne," Lúcerna piscis (Book IX, Chap. 27) as follows: "There is a Fish commeth ordinarily above the water, called Lucerna, for the resemblance which it hath of a light or lanterne. For it lilleth forth the tongue out of the mouth, which seemeth to flame and burne like fire, and in calme and still nights giveth light and shineth."

J. Cotte ${ }^{81}$ was inclined to believe that "lucerna" referred to the jellyfish, one of which was named "Persa lucerna" by Haeckel, while Cuvier ${ }^{82}$ took the position that the "lucerna piscis" might be the colonies of the tunicate, Pyrosoma, abundant in the Mediterranean. They often grow to large size and have the proper shape. This explanation seems fairly probable. Observed from a boat the

${ }^{79}$ In the Greek herbal of Dioscorides, englished by John Goodyer in 1655 (R. T. Gunther reprint, Oxford Univ. Press, 1933, Book II, sec. 39), the luminescence of the jellyfish, pneumon thalassios, is not mentioned, but its value in medicine is recorded: "Pulmo marinus being beaten small whilst it is new and so applied, doth help such as are troubled with kibes and chillblanes and such as have ye goute."

${ }^{80}$ Although Aristotle used the words "balanos" and "solen" for bivalve shellfish and these words were later associated with luminous molluscs, he does not refer to the luminescence.

${ }^{81} \mathrm{~J}$. Cotte, Poissons et animaux aquatiques au temps de Pline, 244, Paris, 1944.

82 G. Baron de Cuvier, notes to the Ajasson de Grandsagne translation of Pliny, 1829. 
elongated colony of Pyrosoma, if suddenly stimulated to luminesce on a dark night, might readily be mistaken for the fiery tongue of some monster of the deep.

\section{AELIAN}

Claudius Aelianus, the Roman rhetorician of the second century A. D., and author of De Animalium Natura described luminous stones and two luminous plants, ${ }^{83}$ the Aglaophotis terrestris ${ }^{84}$ and the Aglaophotis marina. He preferred to write in Greek, and the seventeen books of $\mathrm{De}$ Animalium Natura were translated into Latin and edited by Conrad Gesner in the sixteenth century. No English translation exists. Both the Aglaophotis terrestris and marina must have impressed Gesner greatly, as they were described at length in his book on luminous plants, De Lunariis (1555). Concerning the legend of Aglaophotis terrestris, also called Cynospastus, Gesner wrote: ${ }^{85}$

During the day it is indistinguishable among other plants (from which it does not differ in the least) and it cannot be recognized; but at night it shines like a star and glitters with a fiery splendor, so that it is easily seen. Therefore, men attach a marker to its roots; for they would recognize it in daytime neither by its color nor by its shape if they did not do this. Then, when the night has passed, they approach the plant and recognize it by the marker, but they take care not to pluck it up, nor even to dig around it. For they say that the first person who, unacquainted with its nature, touches it, dies. They bring, therefore, a young dog, which has not been fed for a day, and they attach a strong rope firmly to the plant and to the dog. Then they draw back as far as possible and throw pieces of roasted meat to the dog. He, aroused by the odor, charges toward the meat and pulls the plant out, roots and all. But, if the sun shines on the roots, the dog soon dies, and he is buried with certain secret rites, as having died in their service. Then, finally, they dare to touch the plant and carry it

\footnotetext{
${ }^{83}$ Flavius Josephus, in The wars of the Jews, trans. by William Whiston, London, Everyman's Lib., has described an alleged luminous plant, said by Gesner to be the Aglaophotis terrestris of Aelian, with mysterious properties as follows:

"But still in that valley, which encompasses the city on the north side, there is a certain place called Baaras, which produces a root of the same name with itself; its colour is like that of flame and towards the evenings it sends out a certain ray like lightning; it is not easily taken by such as would do it, but recedes from their hands, nor will yield itself to be taken quietly, until either the urine of a woman or the menstrual blood be poured upon it: nay, even then it is certain death to those that touch it, unless any one take and hang the root itself down from his hand and so carry it away."

${ }^{84} \mathrm{C}$. Gesner edition of De animalium natura libri XVII, Tiguri, 1556, Book 14, Chap. 27 and 24. Some writers hold that Aglaophotis terrestris, a magic herb of brilliant color, referred to the peony, Paeonia officinalis.

${ }^{85}$ De lunariis (1669 edition of Bartholin), translated by R. A. Applegate. See also under Gesner (Chap. III) .
} 
away. Its usefulness is celebrated for many things, and, among others, they recommend a remedy for epilepsy that is prepared from it. Likewise it is used for a disease of the eyes, which destroys vision by discharging too much humor into the eyes.

Concerning the other plant described by Aelian, the Aglaophotis marina, Gesner wrote, ${ }^{85}$

When the summer heat reaches its peak . . . a certain kind of seaweed [alga or fucus] is born on deep rocks. It resembles the tamarisk in size and the poppy in fruit. ... The outer part of the fruit, which is a certain crust or covering like an oyster shell and very yellow in appearance, encloses and protects the inner part like a wall. The inner part is dark blue in color, soft in substance, and transparent like inflated bladders. A noxious poison drips from this inner part and at night it emits a certain fiery light and, as it were, a sparkling glow.

The story of Aglaophotis terrestris sounds like a fable but the account of Aglaophotis marina could have been based on the apparent luminescence of marine algae, which had become covered with colonies of luminous hydroids. These growths are common and present a striking sight on late summer nights whenever they are distributed by stroking with the hand.

\section{Luminous Gems}

The evidence that the ancient knew of true luminous jewels, which would shine in complete darkness, is questionable, although many writers have mentioned shining jewels and have taken the opportunity to embellish their accounts. Chinese and Indian legends have already been described. Herodotus (ca. 484-ca. 408 B. c.) wrote in his History (II, 44) of a temple in Tyre (Phoenecia) with two pillars, one of gold, the other of emerald (Smaragdos), "which shone brightly at night." The shining may have been a reflection, although the false emerald (a type of fluorspar) is known to be phosphorescent after exposure to light. It is impossible to evaluate the story, but reflection of dim light is as plausible as light emission.

It is to the great credit of Theophrastus (ca. 374-ca. 286 в. c.), that in his History of Stones ${ }^{86}$ he made it quite clear that the name carbunculus, a little coal, was applied to this stone because of the appearance of a carbuncle (probably the garnet) when held against the sun. However, most later writers have supposed that a stone which shone at night did exist and the idea became associated with the carbuncle. In addition to fluorspar, there are certain types of diamond which become phosphorescent on warming after exposure

${ }^{80}$ Translation by Sir John Hill, London 1744, p. 74 . 
to light, but the proof of this property is of much later date. ${ }^{87}$ Carbuncles do not exhibit this property.

Pliny also mentioned shining precious stones in the Historia Naturalis (Book 37, Chap. 7, "Of Carbuncles or Rubies and their sundrie kinds: "), "whose colour is fierie" and these rubies "being cast into the fire, they seeme dead and doe loose their lustre: contrariwise, if they bee well sprinkled and drenched with water they seeme to glow, yea and to flame out againe." This statement was copied by Solinus ( $c a$. third century A. D.) and has been frequently used to claim a knowledge of luminous gems by the Romans.

Speaking of carbuncles Pliny also wrote: "They have their name of the likenesse unto fire, and yet fire hath no power of them, which is the reason that some call them Apyroti." He continued: some kinds "doe glitter and shine of their owne nature: by reason whereof, they are discovered soone wheresoever they lie, by the reverberation of the Sun-beams." Note in this (as in other passages) that the shining and glowing occur in the light and not in the dark.

Another of Pliny's stories ${ }^{88}$ concerned a marble lion on the tomb of King Hermios in the Island of Cyprus, whose eyes were set with emeralds which shone so brilliantly on the surrounding sea that the tunny fish were frightened away, so that the fishermen replaced the emeralds with stones which did not shine. However, in speaking of the smaragdus of Cyprus, Pliny said the stone had " a rich and humid transparency resembling the tints of the sea. Hence it is that these stones are at once diaphanous and shining, or, in other words, reflect their colors and allow the vision to penetrate within." This statement does not imply self-luminosity.

Aelian, like Pliny, was prone to relate marvelous stories without too much regard for the truth. A much quoted anecdote concerned ${ }^{89}$ " a small stone which shone at night like a flame. A stork dropped it into the lap of Heracleis, a woman of Taranto, by way of recompense, because she had cared for the stork when its leg had been broken in a fall the preceding year." Although the classic names of precious stones-carbunculus, a little coal, or lychnis, a lamp-suggest luminosity and there are innumerable stories of their marvelous power, no unequivocal proof of the actual emission of light from the various varieties described by ancient writers has been forthcoming. Nevertheless, the belief in luminous gems is found among most nations, particularly the Chinese, and plays an important part in their literature.

\footnotetext{
${ }^{87}$ See B. Cellini in Chap. III and R. Boyle in Chap. IX and X.

${ }^{88}$ Book XXXVII, Chap. 17. Bostock and Riley translation 6: 410, 1857.

${ }^{80}$ Aelian, De natura animalium, Book 8, Chap. 21. Translated from Gesner, De lunariis, 1555.
} 


\section{The Torches of the Bacchae}

Mention has already been made of Euripides' (480-406 B. c.) tragedy Bacchae, in which the Bacchantes "carried fire on their hair without being hurt. They also drew milk from the Tiber." 90 The festivals called Bacchanalia were also held at night every three years in Rome in honor of Bacchus, god of wine, whose Greek counterpart was Dionysus. There is a passage in Livy (Titus Livius, 59 B. C.-A. D. 17) dealing with the History of the Romans (Book XXXIX, Chap. 13) which describes the Bacchanalia held in 186 B. C. as follows: ${ }^{91}$ "Matrons in the dress of Bacchantes, with dishevelled hair and carrying blazing torches, would run down to the Tiber, and plunging their torches in the water (because they contained live sulphur mixed with calcium) would bring them out burning."

These torches have usually been explained as made of quicklime, sulphur, and a volatile petroleum ${ }^{92}$ or of sulphur and gypsum which allegedly would not be extinguished by water, but J. P. Jorrissen (1948) has suggested that the Romans may have prepared a calcium sulphide phosphor by heating natural sulphur with chalk, lime or oyster shells (vivum sulphur cum calce) as was done by John Canton in 1768. Since impure calcium sulfides are very bright phosphors, they could easily explain the behavior of the torches of Livy and the "fire on their hair " in Euripides' Bacchae. Like other phosphors the calcium sulfide phosphor will phosphoresce under water, and might disintegrate into fine particles responsible for the "milk" mentioned in the quotation of Euripides. Unfortunately the evidence to settle this question is lacking. ${ }^{93}$

\section{Electroluminescence in Ancient Times}

The daily life of the Greeks and especially that of the Romans was guided and their future determined by signs or portents, many of which were instances of electroluminescence. One of these came to be known as ignis lambens, a silent electric discharge observed

${ }^{90}$ Euripides. Verses $80 \mathrm{ff}$., $142 \mathrm{ff}$., $707 \mathrm{ff}$. and $757 \mathrm{ff}$. See also Nonius Marcellus, Compendiosa doctrina, who quotes from Homina annalium, liber IV, "ex Tiberi lacte haurire."

${ }^{91}$ From the E. T. Sage translation in the Loeb Library of Classics, 9: 255, 1936.

${ }^{92}$ See E. O. von Lippmann, Entstehung und Ausbreitung der Alchemie, 479, Berlin, 1919.

${ }^{98}$ It has been claimed by Eusebe Salverte (translated in 1846 as The philosophy of magic, prodigies and apparent miracles, by A. T. Thomson) that the ancients possessed phosphorus because of the many stories of spontaneous ignitions. See this book for examples. 
under certain atmospheric conditions. A good example is the miraculous omen described by Virgil in the Aeneid concerning the young Julus, ${ }^{94}$ when:

Lo! a light tongue of fire appeared on the head of Iulus,

Glowing with a lambent light, and a flame, quite gentle and harmless,

Flickered about his hair, and crowned his brows with a halo. ${ }^{95}$

A similar prodigy, mentioned by Livy ${ }^{96}$ (59 B. C.-A. D. 17), and by Ovid (43 B. C.-A. D. 18) in the Fasti ${ }^{97}$ occurred when the head of young Servius Tullius ${ }^{98}$ "burned amidst his hair." These electrical phenomena were well known to the Romans, and there are many accounts of ignis lambens, as well as "Castor and Pollux" or St. Elmo's fire at the ends of javelins and on the masts of ships. ${ }^{99}$

Pliny also, speaking ${ }^{100}$ of the "Wonders of fires by themselves," wrote:

Over and besides, there be fires seene suddainely to arise, both in waters and about the bodies of men. Valerias Antias reporteth, that the Lake Thrasymenus once burned all over: also that Servius Tullius in his childhood, as hee lay asleepe, had a light fire shone out of his head: likewise as $L$. Marius made an oration in open audience to the armie, after the two Scipios were slaine in Spain, and exhorted his souldiors to revenge their death, his head was on a flaming fire in the same sort. ...

The fire about the bodies of men were undoubtedly electrolumi-

${ }^{94}$ Son of Anaeas, sometimes called Ascanius.

${ }^{95}$ Virgil, Aeneid, Book II, 11, lines 682-684 (trans. by H. H. Ballard). An earlier version of the lines from a translation (1657) of J. Jonston's Traumatographia naturalis (1632) reads as follows:

"Behold a shining Crest, was from Julus head

Seen to give light, and so the harmlesse flame

Did feel full soft, and on his temples fed."

${ }^{80}$ According to Livy, in Book I, Chap. 39, of the History of the Romans, which is entitled From the founding of the city, this event occurred about 600 B. C.

${ }^{87}$ Roman poetical calendar, Fasti, Book 6.

${ }^{98}$ The sixth king of Rome, whose reign began 578 B. C.

${ }^{89}$ Pliny, Natural history, Book II, Chap. 37 and Livy, History, Book XXXIII, Chap. 32, and Seneca, Questiones naturales, Book I, Chap. 1. See T. H. Martin, La Foudre. L'électricité et le magnétisme chez les anciens, 222-413, Paris, 1866, on "Le feu Saint Elme dans l'antiquité."

J. Jonston (Thaumatographia naturalis, 1632) quoted Pliny as having said that "these lights are dangerous, if they come alone, and sink the ships, and burn them if they fall to the bottoms of the Vessels; but two are successful, and signs of a prosperous Voyage; for they by their approach drive away, say they, that unhappy and threatning Helena. Wherefore they assign that diety to Castor and Pollux, and call upon them at Sea, making them the tutelar Captains for their Ships." (English translation, $76,1657$.

${ }_{100}$ P. Holland's translation (1601) of the Natural historie, Book II, Chap. 107. 
nescences. Pliny and many others after him repeated the story of Servious Tullius, which made a lasting impression on the writers of that day.

The aurora borealis ${ }^{101}$ is a grand example of electroluminescence referred to in the Meteorologia of Aristotle as burning flames, "torches" and "goats." He wrote: ${ }^{102}$

Sometimes on a fine night we see a variety of appearances that form in the sky: "chasms" for instance and "trenches" and blood red colours. These too have the same cause [as shooting stars]. For we have seen that the upper air condenses into an inflammable condition and that the combustion sometimes takes on the appearance of a burning flame, sometimes that of moving torches and stars.

This explanation is based on Aristotle's view that

the world surrounding the earth is ordered as follows: First below the circular motion comes the warm and dry element which we call fire. ... Below this comes air. We must think of what we just called fire as being spread round the terrestrial sphere on the outside like a kind of fuel, so that a little motion makes it burst into flame just as smoke does: for flame is the ebullition of a dry exhalation. So whenever the circular motion stirs this stuff up in any way, it catches fire at the point at which it is most inflammable. The result differs according to the disposition and quantity of the combustible material.

Hence the various forms of aurora borealis, and also shooting stars and comets.

Among the Romans the aurora borealis was also a recognized phenomenon, ${ }^{103}$ considered an omen of war or disaster. The displays were called celestial beams or gulfs of heaven or blood colored flames. Marcus Tullius Cicero ${ }^{104}$ (106-43 в. C.) spoke of torches, and Pliny mentioned ${ }^{105}$ openings in the sky and " a flame of bloody appearance (and nothing is more dreaded by mortals) which falls down upon the earth, such as was seen in the third year of the 103rd olympiad, when King Philip was disturbing Greece." Pliny

${ }^{101} \mathrm{~A}$ good discussion of possible early observations of the aurora borealis will be found in S. Gunther's Das Polarlicht im Altertum (Beiträge z. Geophysik 6: 98-107, 1904). Gunther believed, as did G. Gerland (Beiträge z. Geophysik 2: 185-196, 1895) that certain descriptions of Pytheas of Massilia (fl. fourth century B. C.) must refer to the aurora. He was a Greek navigator who sailed to Northern Europe and described Thule, a place where earth, sea and air mix together. None of his writings remain, but his descriptions are to be found in Strabo's (60 B. C.-A.D. 24) geography.

${ }^{102}$ Meteorologia, Book I, Sec. 4, of E. W. Webster trans. Aristotle's works, Oxford, 1923.

${ }^{103}$ See Otto Gilbert, Meterologischen Theorien des Griechischen Altertums, 594. Leipzig, 1907, and Alfred Angot, The aurora borealis, 1-11, London, 1896.

${ }_{104}$ Cicero, De natura deorum, II, 5.

${ }^{105}$ Natural history, Book II, chap. 26, 27, 33, 57. 
recorded other later displays, one of which, in the third consulate of Marius had the sound of rattling arms and later was compared to two armies rushing against each other from east and west. The last army was defeated. This idea of armies fighting in the sky has persisted and became a common interpretation of the aurora throughout Europe. ${ }^{106}$

By far the most detailed account of auroral phenomena is to be found in the Questiones Naturales, by Lucius Annaeus Seneca (A.D. 3-65), son of the orator, Seneca the Elder. This work in seven books, written about A.D. 63, presents what was known to the ancient world concerning meteorological phenomena, halos, rainbows, thunder and lightning, rain, winds, earthquakes and comets. After discussing meteors, rainbows and mock suns, Seneca wrote: ${ }^{107}$

It is now high time that I ran over the other varieties of celestial fires, whose forms are diverse one from the other. Sometimes there is a shooting star, sometimes there are glowing lights, which are occasionally stationary, sticking to one spot, and at times able to rush through the air. Several species of these may be observed. There are, for example, Bothynae (cave-like meteors) when within an outer circle there is a blazing gulf in the sky like a circular grotto excavated in it. Then there are Pithiae (barrel-shaped meteors) when a vast circular mass of fire like a cask either rushes through the sky, or blazes away in one spot. There are Chasmata (chasms), too, when there is a subsidence of some portion of the heavens, which sends out hissing flame, as it were, from its hidden recesses. There are also a great number of colours in all these. Some are of brightest red, some of light insubstantial flame, some of white light, some glittering, some with a uniform glow or orange without sparks or rays.

Such appearances are the various forms of the aurora borealis. Seneca held the streaks of light were like stars moving so rapidly they could not be individually seen and asked how the light could be emitted:

The answer is, the fire is kindled by the friction of the atmosphere and is urged headlong by the wind. Still, it does not always arise from wind or friction. Sometimes its origin is due to certain peculiar conditions in the atmosphere; for on high there are many elements, dry

${ }^{108}$ Other references are to be found in Livy's (59 B.C.-A.D. 17), History of the Romans (III, cap. 5, 10; XII, 1; XXXI, 12; XLIII, 15), in Dion Cassius (ca. 155-? A.D.), History of Rome (XLVII, 40; LVI, 24; LXXV, 7), and in Tacitus (55-? A.D.), De situ, moribus ac populis Germanorum, cap. 45.

${ }^{107}$ Questiones naturales, Book I. Chap. 14 and 15. The Thomas Lodge translation (London, 1614) is essentially similar, although Lodge speaks of "burning flame" rather than "hissing flame," which implies that a sound might be heard (see Chapter VIII). Translated as Science in the time of Nero by John Clarke, London, 1910. 
and hot and earthy, among which fire is generated. It then streams down in pursuit of fuel to sustain it, and therefore is hurried rapidly along. The reason for the differences of colour it presents lies in the nature of the material set on fire and in the degree of violence of the conflagration. ...

How, some one further inquires, are those bright gleams of light which the Greeks call Sela (luminosities) produced? In many ways, people say. They may arise from the violence of the winds, or from the fervent heat of the upper heavens. Fire is a very widely diffused element there, and sometimes catches the lower regions if they are combustible. The mere motion of the stars in their courses may kindle fire, and convey it to all that lies beneath them. Nay, is it not quite possible that the atmosphere should drive up even to the ether the germs of fire, from which may arise a glow or burning or darting resembling a star?

Seneca was not certain whether beams (trabes) and barrel-meteors (pithiae) should be placed among the sela but was certain that,

Among these [luminosities] should certainly be placed a phenomenon of which we often read in the chronicles-the heavens appeared to be on fire. The blaze of it is occasionally so high as to mount to the very stars; occasionally it is so low as to present the appearance of a distant fire. In the reign of Tiberius Caesar the fire brigade hurried off to the relief of the colony at Ostia, supposing it to be in flames; during the greater part of the night there had been a dull glow in the sky, which appeared to proceed from a thick smoky fire. No one has any doubt that these burnings in the heavens contain flame as really as they display it: they have a certain substance in them.

Seneca then pointed out that the above luminescences were real fires, very different from rainbows, halos, and mock-suns, which involved reflection rather than emission of light.

Perhaps it is fitting that the poet Lucan (Marcus Annaeus Lucanus, A. D. 38-65), nephew of Seneca the philosopher, appointed quaestor and augur by Nero, should have included the description of an aurora in his Pharsalia (Book I, lines 582-91) : ${ }^{108}$

The angry gods filled earth and air and sea

With frequent prodigies; in darkest nights

Strange constellations sparkled through the gloom;

The pole was all afire, and torches flew

Across the depths of heaven; with horrid hair

A blazing comet stretched from east to west

And threatened change to kingdoms. From the blue

Pale lightning flashed, and in the murky air

The fire took divers shapes; a lance afar

Would seem to quiver or a misty torch;

${ }^{108}$ From the translation of Sir Edward Ridley (1896), 2nd ed., 1905. 
It is very natural that the aurora borealis should be regarded as an omen. Famous occurrences will be found in the writings of the Roman, Julius Obsequens (fl. end fourth century?), whose De Prodigiis Liber ${ }^{109}$ has been published and annotated by a number of later writers such as Conrad Lycosthenes (1552, and subsequent editions up to 1772) and J. Schaffer (1679). Obsequens' account of the heavens seen on fire (Chap. 13), nights that shine (Chap. 43), and burning torches in the sky (Chap. 88) are clearly displays of the aurora. These omens were always accompanied by disaster or followed by pestilence.

\section{Sea Phosphorescence in Classical Literature}

The earliest reference to the light of the sea ${ }^{110}$ appears to come from one of the Greek philosophers, Anaximenes (fl. 500 B. c.), a casual statement with no attempt to investigate the phenomenon. In a chapter of his Natural Philosophy (London, 1807) dealing with the "History of Terrestrial Physics," Thomas Young has written that Anaximander (610-546 в. с.) explained thunder and lightning as the violent bursting of clouds, which he thought were like bags filled with a mixture of wind and water. Young continued: "The same mistaken notion was entertained by Anaximenes, who compared the light attending the explosion to that which is frequently exhibited by the sea, when struck with an oar."

Almost an identical statement was made by Aristotle. In his discussion of lightning in the Meteorologia, the following passage occurs: ${ }^{111}$

Some-Cleidemus is one-say that lightning is nothing objective but merely an appearance. They compare it to what happens when you strike the sea with a rod by night and the water is seen to shine. They say that the moisture in the cloud is beaten about in the same way, and that lightning is the appearance of brightness that ensues.

${ }^{100}$ According to de Mairan (L'Aurore boreale, 162, 1733), Chapters 1 to 55 and a few others are by J. Obsequens, the remainder in the style of Conrad Lycosthenes. For example, Chapter 43 reads: "Two suns were seen, and light throughout the night. At Setia, a torch seemed to be stretched from east to west. A door at Tarracina, and in fact both a door and a wall at Anagnia, were struck by lightening. From the temple of Juno, a frightful crashing noise came out." In practically all the descriptions, the last events recorded have to do with war, in this case, devastations in Africa involving Scipio and Hannibal.

${ }^{110}$ It has been claimed (G. Hartig, 1861) that a reference to phosphorescence of the sea occurs in the fifth century B. C. voyage (Periplus) of the Carthaginian king, Hanno, to the Libyan regions south of the Pillars of Hercules. Hanno's "fiery torrents " probbably referred to burning grass on the hills of Sierra Leone.

111 The E. W. Webster translation of Meteorologia (Book II, Sec. 9), 370a, Oxford Univ. Press, 1923. 
This theory is due to ignorance of the theory of reflection, which is the real cause of the phenomenon. The water appears to shine when struck because our sight is reflected from it to some bright object: hence the phenomenon occurs mainly at night: the appearance is not seen by day because the daylight is too intense and obscures it.

There is also a passage in De Mundo which might refer to sea phosphorescence. Speaking of the characteristics of the ocean, Aristotle wrote: "Often too, there are exhalations of fire from the sea." No further explanation is offered, but previously he had described fire coming from the earth, as observed in Mount Ætna, and declared analogous phenomena occurred in the sea. The "exhalations of fire from the sea " probably applies to volcanic fire, but the interpretation is not certain in view of the general reference of explorers to seas on fire. It is very extraordinary that neither Aristotle nor Pliny discuss in detail that homogeneous phosphorescence of the sea, due to microscopic organisms, which aroused so much interest in later centuries and was called the " burning of the sea."

The only possible reference in Pliny is a phrase from the Natural History ${ }^{112}$ - "there are sudden fires both in waters and even in the human body; that the whole of Lake Thrasymenus was on fire." Since microscopic luminous organisms are not found in fresh water, and Lake Thrasymenus is the Lago di Perugia (Lago di Trasimeno) of modern Italy, a fresh-water lake, it seems more likely that the "sudden fires" were volcanic light or burning oil rather than bioluminescence.

However, the Romans, always on the watch for portents, did occasionally observe and record sea phosphorescence, regarding it as an omen. In 215 B. C., when Quintus Fabius Maximus was substituted for Marcellus as consul for the third time, Livy (Titus Livius 59 B. C.-A. D. 17) reported, among other peculiar happenings, that "The sea was aflame in the course of that year." 113 Again after remarking that " the spears of some soldiers in Siciliy, and a walking stick, which a horseman in Sardinia was holding in his hand, seemed to be on fire," evidently a reference to St. Elmo's fire, Livy continued: ${ }^{113}$ "The shores were also luminous with frequent fires." The "sea aflame" and the "shores with fires" are undoubted descriptions of the phosphorescence of the sea. The wonder is that so little notice was taken of the phenomenon by other writers.

A possible but dubious mention of sea light occurs in Roman

112 Pliny, Natural history (Book II, Chap. 3), translated by J. Bostock and H. T. Riley I: 143, 1855.

${ }^{113}$ Livy, Historiarum Romanarum, Book XXIII, Chap. 31 and 32, translated by F. G. Moore, Loeb Library of Classics, 6: 109. 
poetry. Martialis (A. D. 43-104), the Latin author of fourteen books of epigrams, refers to a woman named Cleopatra, who shone when immersed in the shining light of sea baths. The translation ${ }^{114}$ reads: "New to the marriage-bed, and yet unreconciled to her husband, Cleopatra had plunged into the gleaming pool, seeking to escape embrace. But the wave betrayed the lurking dame: brightly she showed, though covered by the overlapping water. ..." If the plunge was at night into sea water, there can be little doubt that a luminous wave would have revealed her whereabouts. Today, the suits of sea bathers at night become covered with the various species of sparkling dinoflagellates that are mainly responsible for marine luminescence. ${ }^{115}$

Neither Athenaeus of Naucratis (ca. A. D. 200), in whose Deipnosophistae there are references to fish and also to the luminous mollusc, Pholas, as food, nor in Oppian's (ca. 172-210) Haliutica, ${ }^{116}$ which deals with fishes and fishing, is there any mention of luminescence. Perhaps the phenomenon was so common as to be taken for granted.

It is sometimes said that the words "lampe" and "lamperos," which the Greeks used for sea foam and which in derivation imply a torch, lamp, light, lustre, brilliance, etc., could refer to the luminosity of breaking and foaming waves. Although attractive, this origin seems unlikely. "Lampe" also refers to the scum or coating that gathers on liquors left to stand and probably contrasts the light surface with the dark interior of the liquid. However, we find the word in Lampyris, the glowworm, and Lampadioteuthis, a luminous squid.

Many other classic derivations appear in the nomenclature of luminescence or of luminous animals-Pyrophorus, fire-bearing, from the Greek "pyr," fire, and " phero," to bear; also from the Greek " phos," light, there is phosphor, light giving; from the Latin, "lux, lucis," light, comes lucifer, light bearing. Greeks called the morning star, "Phosphoros," Romans called it "Lucifer." There is satisfaction in the fact that the words " phosphorescence" and "luciferin" have such poetic connotations.

114 Book 4, epigram 22, translated by W. C. A. Ker, 1919.

${ }_{115}$ Ovid's (43 B. C.-A.D. 17) statement in Tristia (Book I, Sec. 8, line 4), "unda dabit flammas, et dabit ignis aquas" (water shall produce flame and flame, water) is merely an example of what might happen if nature's laws were reversed.

${ }_{116}$ Oppian's Haliuticks. Of the nature of fishes and fishing of the ancients in five books. Trans. from the Greek by John Jones, 232, Oxford, 1722, contains a list of fishes known to Oppian. 


\section{Summary}

Thus, in the field of luminescence, our heritage from classical times has been knowledge of the firefly and the glowworm; the lantern fish (Lucerna piscis); possibly a Nile fish (Dilyxnos); dead fish and meat, luminous from the growth of bacteria; rotten wood, luminous from the growth of a fungal mycellium; a remarkable and unidentifiable plant (Nyctegreton), whose light might also be due to fungal mycelium; luminous mushrooms; phosphorescence of the sea and of growths along the seashore (Aglaophotis marina); a squid; the mollusc, Pholas, (Unguis), and the medusa, Pelagia (Pulmo marinus). In addition, the ancients had noted luminescences connected with electrical phenomena, the aurora borealis and ignis lambens. St. Elmo's fire, called Castor and Pollux, had been seen many times. The wings of the Hercynian birds and shining precious stones, probably reflected light, and the glow in the eyes of various animals, without doubt a reflection of external light, were confused with true luminescences. The above examples of luminescences and false manifestations of light emission have been copied by subsequent commentators and appear again and again in early European writing. 


\section{THE MIDDLE AGES}

\section{Introduction}

$A$ FTER the period of advanced knowledge of the Greeks and the A Romans, which may be considered to end with Galen ${ }^{1}$ (A. D. 131-200), comes the long gap of the Dark Ages and Middle Ages (A. D. 200-1400) with little original scientific observation, despite the growth of Alexandrian and Byzantine centers of learning, and the Carolingian renaissance. The intellectual mind was centered on heaven rather than on nature and the influence of classical interpreters was paramount. No new luminous phenomena were observed during the period, and mention of luminescence occurs chiefly in connection with the sea, the aurora borealis, with luminous jewels, and fireflies or glowworms (cicindelae). St. Augustine (354-430) and Gregory of Tours (544-595) both mention cicindelae, and Gregory gave a minute description of the northern lights.

The aurora borealis was without doubt the most spectacular example of luminescence, although of infrequent appearance in central and southern Europe. In Dortous de Mairan's great work on this subject, L'A urore Boreale (1733), records of the aurora begin with a statement of Nicephorus Callistus (fl. fourteenth century), a Byzantine monk, who reported in his Ecclesiastical History (Book XII, Chap. 37) that a great number of "lances" or "jets of light" were seen in the sky at night before the death of the Roman emperor, Theodosius the Great (A. D. 346-395). A second record, with the return of similar celestial phenomena, is from the "History of the Goths" of Isidore of Seville (ca. 570-636) around 447 A. D., before the entrance of Attila (406?-453) into Italy and Gaul. A third account, about 502, is to found in the Edessan Chronicles, and a fourth, in 585, was described at great length in the Historia Francorum (VIII, 7) by Gregory of Tours (Georgius Floretinus Gregorius, 544-594). He spoke of "brilliant rays of light in the north, which seemed to come into collision and to cross the one with the other, after which they separated and vanished." One great display "took possession of part of the heavens and seemed to traverse it ... there was in the midst of the sky a luminous cloud, to which all the rays combined in the form of a tent from which many

${ }^{1}$ Perhaps the fall of Rome (A.D. 476) or of Alexandria (A. D. 642) might be taken as the beginning of the Dark Ages. 
bands, larger toward the base, were narrowed at the summit, where they terminated as a kind of monk's hood." 2

The number of displays recorded increased during the seventh to tenth centuries, with the usual interpretation of bloody battles and dire portents of public catastrophes. De Mairan (1733: 163) regretted that it was necessary to resort to the work of astrologers to obtain the old records, rather than the writings of astronomers, and asked how much attention would have been paid to the aurora by Isidore of Seville, had not Attila taken Europe by fire and blood immediately afterwards. During the tenth to thirteenth centuries, especially in Russia, the aurora borealis was regarded as a "struggle of celestial armies coming to help and sustain those fighting on earth," but during the fourteenth century, when the Russian government wished to colonize the northern regions of tundra, particularly beautiful displays were interpreted as divine commands to erect churches or monasteries. ${ }^{3}$

\section{Isidorus, Rabanus, and Hildegard}

An important source of knowledge during the Middle Ages was the Etymologiae of Saint Isidore, Archbishop of Seville (ca. 560636), an encyclopedia in twenty books, compiled from various sources. It was quoted by Vincent de Beauvais (died 1264) and others. Isidore gave nearly the same account of luminous stones as did Pliny, referring to the carbuncle and also to a blue stone which, " exposed in the day time becomes impregnated with rays of light." The wording is such as to suggest phosphorescence but reflection of light is just as probable. Among insects the cicindela ${ }^{4}$ (firefly or glowworm) is described as "a genus of beetles, which is said to shine, either walking or flying."

The glowworm was noticed by a number of subsequent writers. During the Renaissance of Charlemagne (742-814), Rabanus Maurus (ca. 776-856), the Praeceptor Germaniae, a monk educated at Fulda and Alkwin and later Archbishop of Mainz, described cicindela, a lighting beetle, in his scientific reference book, De Universo. ${ }^{5}$

${ }^{2}$ Quoted from de Mairan (1733: 128).

${ }^{3}$ See G. Sarton, Introduction to the history of science 3, 709-711, 1948, and the review of the aurora borealis in Russian literature from an article by D. O. Sviatskii (1934), Isis 24: 282, 1936.

${ }^{4}$ Spelled in different ways by different authors. In modern times, the name Cicindela is used for a genus of tiger beetles, with brilliantly colored wing covers but not luminous.

${ }^{5}$ Printed in 1617 (Coloniae Agrippinae) and in 1852 (Paris). De universo was a forerunner of the Speculum of Vincent de Beauvais. 
Another Middle Ages reference to the glowworm was by the Holy Hildegard ( $c a$. 1099-1179), the German nun of Bingen, best known for her miraculous visions. Among other contributions she prepared a book, Physica, written between 1150 and 1160 and published at Strassburg in 1533, which described some insects and included the "glimus" or glowworm.

Physica was a sort of natural history, giving an account of animals, birds, insects, etc., with a statement of their healing power. Concerning the glowworm, "De glimo," included as Chapter 52 at the end of the book on birds, Hildegard wrote: 6 " The glow-worm is more cold than warm. If a person suffers from a wasting disease and is prostrated, one should gather as many living glow-worms as possible and tie them in a cloth over the navel of the affected one, who will immediately regain strength." This remedy is among the first of a number of glowworm cures, recommended during the Middle Ages. Bees, wasps, flies, locusts, and other insects had healing value. Even gnats, according to Hildegard, would cure a scaly head, or ringworm, if mixed with straw, burnt to an ash, and applied as a lixivium to the affected place.

Reference to fireflies in literature by Occidental nations, as compared with the Oriental, appears to be of relatively recent origin. According to Sarton (Introduction to the History of Science 3: 236, $487-488,1947)$, the first mention of luminous insects in Western belles-lettres occurs in Dante's (1265-1321) Inferno (XXVI, 29), where a peasant, looking down at dusk from a hillside, saw:

Fireflies innumerous spangling o'er the vale.

Sarton attributes the scarcity of mention to the fact that "references to such eerie creatures were tabooed." This opinion is substantiated by John Murray (1826: 40), who wrote: "The Italians have a superstitious dread of these beautifully adorned insects; believing them to be the spirits of their departed ancestors."

Somewhat later, the glowworm was noticed in literature, but often referred to with derision because of its small light, or as "a dirty beast." However, by Shakespeare's day, the insect had become quite respectable, and glowworm is mentioned a number of times in his plays. Probably the most famous quotation is from Hamlet (1604, I, 5, lines 89-90).

The glow-worm shows the matin to be near, And 'gins to pale his ineffectual fire.

\footnotetext{
${ }^{6}$ From Physica, Der Aebtissin St. Hildegardis myst. Tier-u. Artzneyen-Buch, 91,
} 1927. Translation by A. Huber. 
In modern times the glowworm and the firefly have become increasingly popular in poetry and song.

The various bestiaries, outgrowths of the Physiologus, were usually concerned with larger animals than glowworms and fireflies. One of them, a twelfth-century compilation (No. II, 4.26) in the library of Cambridge University has been translated by $\mathrm{T}$. H. White as The Book of Beasts (New York, 1954). The only reference to luminescence which it contains is to the "Ercinee birds" of Pliny, which are described in much more definite terms than were ever used by Pliny himself (see Chapter I). It was stated in the Bestiary that: "Their feathers shine so brightly in the darkness that, however densely the night may be overcast, their wings shed a phosphorescence. They shine on the ground so as to make safe the route which has to be flown, and the bird's journey can be followed by the tell tale glow of its shining feathers."

\section{Arab Writers}

Not only European but Arab writers, who preserved and pursued knowledge during the Middle Ages, also neglected the great variety of luminescences, despite their access to works of Aristotle and other classic writers, which they translated into Arabic around A. D. 800 . However, references to fireflies do occur in the works of Ibn-alBaithar (1197-1248) and of Isa Kamal-al-Din al-Damiri (ca. 13441405), theologian and naturalist. ${ }^{7}$

Al Baithar was a Persian botanist, born in Malaga, who became inspector general of physicians in Egypt and died in Damascus. He published Tractatus de Simplicibus, mainly dealing with plants but describing some animals, among them "Hobaheb," a "beetle with wings that lights during the night. Ground in rose oil and dropped into the ear, it will heal purulent discharges."

It is not surprising that Al Damiri, the great Arab zoologist of Cairo, should mention the firefly. In his zoological dictionary, Hayatal-Hayazuan, or Life of the Animal, completed in 1372, we find "Hubāhib" explained ${ }^{8}$ as "a certain insect [animal] like the fly, having two wings, that emits light at night as if it were fire." The Arabs employ the term in a proverbial sense, saying, "Weaker than

${ }^{7}$ I am indebted to Professor P. K. Hitti and Mr. Farhat Ziadeh, of Princeton University, for many of the references to Arab writers. Others have been taken from F. S. Bodenheimer, Materialen zur Geschichte der Entomologie bis zum Linne, 2 v. Berlin, 1928-1929. Muffet (1634) gives "allachatichi" as Arabic for glowworm.

${ }^{8}$ Translation of the Hayat-al-Hayawan by A. S. G. Jayakar, 1: 504, London and Bombay, 1906. This book gives philological derivations, description and habits, laws and proverbs regarding animals, as well as their medicinal virtues and their meaning in dreams. 
the fire of al-Hubāhib." It is said that al-Hubāhib was the name of a man belonging to the tribe of Muhārib b. Khasafah, well known for his niggardliness; he used to kindle a faint or weak fire out of fear of guests being drawn to it, and on that account he became proverbial for his fire. Therefore, a little fire which is of no use to anybody and also the fly that flies at night are called "abû-hubāhib."

The story is very old. The name "hubăhib" is also used by an Arab prose writer and theologian, Al-Jāhiz, who lived in the second half of the ninth century. In his al-Hayawann, published at Cairo in 1324 he tells anecdotes of animals, and wrote:

Every fire that the eye can see but that has no reality when it is touched is called the fire of Abu Hubāhib ... and another fire similar to the fire of Abu Hubāhib is the fire of the Yarā'ah; the Yarā'ah is a small thing that flies, which, if it flies by day it appears as other things that fly, and if it flies by night it appears as a shooting star or a flying lamp.

These two words "Hubāhib" and "Jara'a " or "Yarā'ah" are found in Arab lexicons as words for the firefly. In older Arab literature there was no fine distinction between different kinds of insects and "yara-'ah" was sometimes defined" as "a moth that, when it flies by night, no person not knowing it would doubt to be a spark of fire." The verb, "yari'a," means to be cowardly and it is possible that an attribute of cowardliness was implied in the name, as was stinginess in the derivation of hubāhib. In the fifteenth and sixteenth centuries in England and France the glowworm was a contemptuous term applied to persons as an epithet of disdain.

Arab voyagers to India and China are said to have recorded particularly brilliant displays of phosphorescent seas. According to G. Sarton, ${ }^{10}$ one of these was an unknown author who traveled to India and China in 851. He wrote: " "That sea-I mean the sea of Harkand ${ }^{12}$-when its waves have become bigger, appears like a lighted fire." Another was the Persian sea captain, Buzurg ibn Shabriyar al-Ramhurmuzi. In a book of sailor's tales, Kitab a ja ib al-Hind, composed about 953, he said: ${ }^{13}$ "Among the marvelous things of the sea of Fars ${ }^{14}$ [we might mention] what the people sometimes see at night when the waves are agitated and knock against each

-Arabic-English Lexicon of E. W. Lane, 1: 497.

${ }^{10}$ See G. Sarton. Isis 39: 235, 1948, and 41: 198, 1950.

11 Translated by M. Jean Sauvaget.

${ }^{12}$ Eastern portion of the Bay of Bengal.

${ }^{13}$ The quotation is from the Arabic-French edition (p. 4I) by P. A. Van der Lith and L. Marcel Devic.

1s The Persian Gulf or perhaps the Arabian Sea. 
other, fire sparkles from the water and the sailor imagines he is proceeding through a sea of fire."

According to E. Wiedemann (1909), the geographical Lexicon of Jâqût mentions a place in Persia where rubies are found which luminesce in the dark and $\mathrm{Al}$ Muquaddasi recorded stones which luminesced at night. Wiedemann is inclined to think that triboluminescent materials were known to the Arabs and that Arabic alchemists must surely have run across calcium sulphide phosphors in the course of their many chemical procedures. However, no references are given by Wiedemann, although such things play a part in Arab legends.

Arabic science in Persia, Egypt, and other parts of the Middle East began to wane in the latter part of the tenth century, but continued to flourish in Spain and spread to western Europe. Much of the knowledge was recorded by Adelard of Bath (ca. 1090-1150), the English natural philosopher, who lived for a time in Spain and traveled widely in southern Europe. His book, Quaestiones Naturales Perdifficiles, was published at Venice in 1472 and an English translation made by H. Gollancz (Oxford, 1920). It unfortunately contains nothing on luminescence, although questions on such matters as "XII. Why some animals see more clearly by night than by day," or "XX. Why men go bald in front," were answered in a manner that can best be described as nonsense.

\section{Albertus Magnus and the Encyclopedists}

During the thirteenth century revival of art and learning, again with the exception of fireflies and glowworms, practically nothing of special interest for the history of luminescence is to be found..$^{15}$ Learning of the time was recorded in the great books of knowledge. These enormous encyclopedic compilations had grandiose titles, such as De Proprietatibus Rerum (written in 1230-1240 and published in 1470) by the Franciscan monk, Bartholomaeus (Bartholomew Glanvil, ca. 1190-1260) ; ${ }^{16}$ or De Natura Rerum (written in 1228-1244)

\footnotetext{
${ }^{15}$ In the generation following Adelard of Bath (ca. 1090-1150), the best-known English scientist and the first English writer on zoology was Alexander Neckam (11571217), the author of $D e$ naturis rerum libri duo (ca. 1190), whose natural history was taken from Aristotle, Pliny, Solinus, Cassiodorus, and Isidore. The text has been edited by T. Wright, No. 34 of the Chronicles and memorials of Great Britain and Ireland during the Middle Ages, London, 1863. The glowworm, cicindela, does not occur in the index.

${ }^{28}$ The English translation of 1397 or 1398, Properties of All Thynges by John of Trevisa (1326-1412), chaplain to Sir Thomas lorde of Berkeley, was printed by Wynken de Worde in 1494. A later version by S. Bateman or Batman in 1582 was " newly corrected, enlarged and amended." It was the first encyclopedia in the English language and a source of natural history knowledge in the Middle Ages and later.
} 
by the Dominican monk, Thomas of Cantimpre or Th. Cantipratanus (fl. mid-1200); or the vast Speculum Naturale (written about 1250 and published in 1473) by the Dominican, Vincent of Beauvais ${ }^{17}$ (ca. 1190-1264); or the Opus Naturarum of another Dominican, Albertus Magnus, teacher of Thomas Aquinas (12251274). The works of Roger Bacon (ca. 1214-1294), despite his consideration of chemical matters and his adoption of the methods of experimental science, appear to contain but few passages that might be interpreted as a reference to luminescence. ${ }^{18}$ These passages are discussed in footnotes, leaving the contributions of Albertus Magnus to serve as a sample of the thought of this period.

Albertus Magnus (Albrecht von Bollstadt), chiefly responsible for reconciling Aristotelian teaching with the laws of the church, may be taken as an example of the group. He was the foremost naturalist of the Middle Ages, with interests that covered every field. His scientific work, much of it a commentary on Aristotle, was written between 1245 and 1260 and appeared in book form early in the history of printing. De Mirabilis Mundi was published at Venice in 1472, De Mineralibus at Padua (1474), De Animalibus at Rome (1478), De Anima at Venice (1481), De Meteoris and Physica at Venice (1488). Albertus (1193 or 1206-1280) carried out most of his scholarly work at Cologne.

His remarks on luminescence are scattered in various writings but deal mostly with the light of animals. In the chief zoological

The glowworm was included (Book XVIII, Sec. 77), with the following description taken from H. W. Seager, Natural history in Shakespeare's time, 1896:

"The Glowworm is a little beast, with feet and with wings, and is therefore sometime accounted among volatiles, and he shineth in darkness as a candle, and namely about the hinder parts, and is foul and dark in full light. And infecteth and smiteth his hand that him toucheth. And though he be unseen in light, yet he fleëth light, and hateth it, and goeth only by night."

${ }^{17}$ Ehrenberg (1834: 416) could find nothing on sea luminescence in the Speculum, despite its encyclopedic character. However, Vincent did describe the firefly in Liber 21 of Speculum naturale (Argentorati, 1472), Section 126, "De cincendela et cimice et castro," as follows: "Isodorus. Cicendela is a genus of beetles, said to shine walking or flying. From the book concerning the things of nature, cicendela is a worm, in Italy flying by night: in darkness of night emitting gleams, so that if you see it at night you think it is a bright vapor." Vincent's account, like that of Albertus, gives only the most elementary facts concerning luminous beetles.

${ }^{18}$ In The Myrrour of Alchimy, composed by the thrice famous and learned Fryer, Roger Bacon etc., London, 1597, there is a description of a stone which by working often changes color-black, red citrine, green, and "afterwards true whiteness followeth. Whereof one sayeth: When it hath bin decocted pure and clean, that it shineth like the eyes of fishes, then are wee to expect his utilities and by that time the stone is congealed rounde" (Chap VI, p. 12). The shining probably refers to reflection of light although the description might apply to the Bolognian stone, discovered in 1603 . 
work, De Animalibus, thirty-three insects are described. ${ }^{19}$ Concerning the firefly, Albertus wrote: ${ }^{20}$

The cicendula is a worm, one of the noctilucas. It has two hard wing covers like a beetle but is small like a fly, and when it flies it shines more with wings extended. When breathed upon it becomes brighter like a spark born by the wind. Shining by day, however, the color is extinguished and it becomes white. It is found more in Italy than in other places.

Here we have the barest description of the insect. He also devoted considerable space to "liquor lucidus," a mysterious glowing liquid, prepared from fireflies, which will be considered in Chapter III.

Albertus (in De Sensu et Sensato, a commentary on Aristotle) discoursed on the light of various luminous things as follows: ${ }^{21}$

For their light cannot be said to be of a coelestiall body, because a coelestiall nature comes not into composition of bodies generative and corruptible: But the determination of this question and the like, is fetched from what we determined in our second de Anima; where we shew, that the nature of perspiculity [transparency] is not proper to any Element, but it is common to many, and is participated by them per prius et posterius, which is the more pure, the farther it is from darknesse; and this is so, by how much it is more like to the nature of superiour bodies; and the proper act of this is light, which hath to do in that nature. Now this falls out in it, as often as the parts of it are very noble and clear: and therefore, all such things do shine. Now this composition sometimes is in the whole body; sometimes not in the whole, but in some externall parts: the cause whereof is, that when such a nature is from the Elements that are light; it proceeds more from the internall parts to the external, because such things will swim. And so it is found in the heads, and fins, and bones of some Fish, and in the shells of some eggs, because such parts are lesse rosted, and heat hath wrought in them much nature of perspicuous bodied condensed: Sometimes this heat acts in the externall parts of some things, when it exhales from them, and that which is subtile brings with it much perspicuity; so the parts of Okes [oak wood] corrupted do shine. But all those things that have but a weak light, are hid when a clearer light appears.

${ }^{10}$ In a critical study of the relation of the animal histories of Albertus Magnus and Thomas of Cantimpre, Pauline Aiken (Speculum 22: 205-225, 1947) has concluded that Thomas was the source of 400 of the 476 specific creatures described by Albertus. ${ }^{20}$ A translation of Book 26, Sec. 9 of De animalibus libri XXVI ed. by Herman Stadler nach der Cölner Urschrift, Münster, 1916.

${ }^{21}$ Quoted from J. Jonstonus, A history of the wonderful things of nature, 248-250, London, 1657, an English translation of Thaumatographia naturalis, Amstelodamae, 1632. Jonston also mentioned that Adrianus Junius, "when he was in the country of Bononia, drew the liquor of them [fireflies] upon Papers that shined like stars: what is writ with that in the day, may be read in the night." 
Albertus is evidently atempting to explain why parts of fish emit light, a point left unclarified by Aristotle (see Chap. I). However, luminescence of the shells of eggs is a novel observation.

Albertus also mentioned ${ }^{22}$ Pliny's birds of the Hercynian Forest with luminous wings, and, described the liquid ink of the squid, Sepia piscis ${ }^{23}$ which, "as is said, placed in a lantern and ignited makes the bystanders appear like Ethiopians." Although some squid eject a luminous secretion, the fact that the liquid was set on fire suggests a combustible oil rather than a luminescence.

Among questionable creatures Albertus included ${ }^{24}$ the "Stella figura," a fabulous animal which is so cold that like ice, it puts out fire.

It is never seen except during heavy rains and its appearance foretells fair weather to come. If it should touch a man's flesh, all his hair would fall out. This animal does not breed. Neither male or female occur; hence it must arise from putrefaction. At night it lights like a star.

Whether he referred in the above passage to luminous earthworms or to luminous centipedes is uncertain..$^{25}$

These passages will give an idea of the attention paid to luminous animals in the thirteenth century. In later compilations on natural history, such as the Liber de Natura Rerum, based on the works of Thomas, Vincent, and Albert, the cicindela and stella figura were again mentioned. One of the best known of these was Aleman, Conrad von Megenberg's (1309-1378) Das Buch der Natur (1475), written about 1349-1350, probably a translation from the Latin Liber de Natura Rerum. The glowworm appeared in this book, ${ }^{26}$ as well as luminous stones, the chrysopasion and carbuncle. During the Middle Ages the glowworm was believed to have great medicinal value and was mentioned by a number of writers as a cure for various ills (see Chapter III under T. Muffet).

Albertus devoted considerable attention to precious stones in his De Minerabilis, frequently referring to the ability of the carbuncle and the diamond to light in darkness. It has been held by both Dufay (1735) and Heinrich (1811: 9) that Albertus knew that the

${ }^{22}$ Book 23, trac. 1, cap. 24, sec. 67 of De animalibus.

${ }^{23}$ Book 24, Sec. 113 of $\mathrm{De}$ animalibus.

${ }^{24}$ Book 26, Sec. 34 of De animalibus.

${ }^{25}$ Muffet (1658: 979) recounted the story of the "Stella figura" in connection with his description of luminous centipedes but believed this creature was confused with a salamander. According to S. Killerman (1914) the "Stella figura" of Petrus Candidus was a firefly, Luciola.

${ }^{28}$ See the Old German text published by F. I'feiffer (Stuttgart, 1861), and the modern German of J. H. Schulz (Griefswald, 1897). Das Buch der Natur, is the first natural history in the German language. 
diamond would glow when warmed in water. The statement seems possible, as certain varieties of diamond are thermoluminescent. However, E. Becquerel (1867: 12) has pointed out that Albertus did not speak of placing the diamond in hot water but in "clear and limpid water"-" emicat in tenebris superfusa aqua clara et limpida in vase nigro mundo et polito." Like other early reports of luminous stones, the actual emission of light is doubtful.

\section{Miscellaneous References to Luminescence}

Knowledge of luminous phenomena ${ }^{27}$ during the Middle Ages was sketchy and the beliefs fantastic. The marvel was characteristic of the age. Marcellin Berthelot ${ }^{2 s}$ (1829-1907) has found manuscripts, transcribed in the thirteenth and fifteenth centuries, containing an old Greek description of a method of making a carbuncle glow at night by coloring it with the "bile" of marine animals, whose entrails, scales, and bones luminesce. Among the directions in the book of marvels, De Mirabilis Mundi, ${ }^{29}$ which might imply a knowledge of luminescence were: "How to write letters that can be seen only at Night," and "How to make oneself seem on fire from head to foot." The book also contained receipts for Greek fire ${ }^{30}$ and many other things.

${ }^{27}$ The only mention of luminescence or phosphorescence in the index to George Sarton's (1931) great work, An introduction to the history of science, in which the first two volumes treat knowledge of nature before 1300, has to do with Mark the Greek (second half of the thirteenth century). In addition to Greek fire, pyrotechnic and explosive recipes in his Liber ignium, phosphorescent substances, also described by $M$. Berthelot, are mentioned as Mark the Greek's invention. In the third volume (1947: 531) which covers the fourteenth century, there is a statement regarding the Gascon Franciscan theologian, Vital du Four (or Dufour, died 1327), living at Montpelier in 1295-1296, who, "In his commentary on the Sentences [a dictionary of Biblical ethics, written about 1305] showed an interest in such natural phenomena as magnetic attraction and phosphorescence." The phosphorescence was a "liquor liquidus" prepared from fireflies (see Chapter III). The six-volume History of magic and experimental science of Lynn Thorndike, covering the first sixteen centuries A.D., contains practically nothing on luminescence. Vol. 1 and 2 appeared in 1923, vols. 3 and 4 in 1934 and vols. 5 and 6 in 1941 .

${ }^{28} \mathrm{M}$. Berthelot, Collection des anciens alchemists grec 3: 336-338, Paris, 1887-1888, and Ann. de Chem. et Physique (6th Ser.) 14: 429-32, 1888.

${ }^{28}$ Usually attributed to Albertus Magnus. See Lynn Thorndike History of magic and experimental science 2: 737, 1923.

${ }^{30} \mathrm{Greek}$ fire was not a luminescence. The origin is explained by Guido Panciroli (1523-1599), whose book, Rerum memorabilium, etc. (Ambergae, 1590), was translated into English as The History of many memorable things lost, which were in use among the ancients: etc. (London, 1715). Chapter XIX is devoted to "Greek Fire commonly call'd Wild-Fire." In the reign of Constantinus Pogonatus (the bearded Constantine) the "Art to Kindle Fire under Water" was discovered and called Greek Fire because the inventor was Callinicus, a Greek, in A.D. 680. Constantine defended himself against this fire in a battle with the Saracens.

Others say Marcus Graecus invented Greek Fire, a mixture alleged to be made up 
Many of the receipts were for "a light which does not go out in a house, whether closed or open, or in water," essentially for a continually luminous liquid. One of these (no. 18), translated from the Liber Ignium of Mark the Greek, who flourished in the second half of the thirteenth century, reads as follows: ${ }^{31}$

R. Bile of tortoise, bile of mollusc or of a fish [loup d'eau], with which one colors leather purple. Mix them with four times the amount of luminous insects deprived of heads and wings. Place all in a vase of lead or glass and surround with horse-dung. Collect the oil ... [or]

Mix equal parts of the above mentioned biles and luminous insects and place in horse manure for 15 days. Collect and make a paste with the root of the herb called "cyrogaleo," which also shines at night, and soak with this licquor. Take a vase of stone or iron, wash with water extracted from this herb and pour a little of the preceeding liquor in it. Or, if you prefer, place all in a vase of glass and continue as above mentioned. On placing the vase anywhere, it will furnish a continuous light.

Some of the receipts called for mixing glowworms with oil of "Zambac," infusing in horse manure, then placing the oil in a lamp and lighting it, when a flame of long duration would be obtained. Such wonders, taken from the writings of Hermes and Ptolemy, undoubtedly furnish the basis for the "liquor lucidus" of Porta and others, described in Chapter III.

The idea that water contains light was expressed by Perscrutator or Robert of York, who flourished or died around 1348. In writing about "stars that appear in the air," the word "comet" is not used but Perscrutator said that "some had tails and others not"; and also that "they are made of earthly vapor mixed with water so that it can glow. He asserts that all water has light in it which may be proved by stirring water placed in a dark vase at night, whereupon light will appear." 32 It is possible that the statement on water referred to sea water containing phosphorescent organisms, but it was made in regard to water in general.

\section{Comment}

It will thus be seen that during the Dark and Middle Ages no new discovery or new phenomenon important for the history of luminescence had been made. A few mysterious and miraculous stories appeared, which were to be later refuted, but the end of

of willow charcoal, salt, aqua vitae, sulphur, pitch and camphor. Another formula is quicklime and a volatile petroleum, which took fire because of the heat generated in contact with water.

${ }^{31}$ M. Berthelot, La chemie au moyen âge 1: 112-113, Paris, 1893.

${ }^{32}$ See Lynn Thorndike, History of magic and experimental science 3: 115-116, 1934. 
the Middle Ages left luminescence information in the same condition as during classic times. In the fifteenth and sixteenth centuries, noted for reawakening in all branches of learning and for voyages of discovery, a number of new luminous animals were to be added to the known list. The great naturalists were to describe and classify all living things, but knowledge of inorganic luminescence of solid bodies was to remain barren until 1603. 


\section{THE FIFTEENTH AND SIXTEENTH CENTURIES}

\section{Introduction}

W ITH THE renaissance of science which followed the Middle Ages, a significant change in the profession of men who wrote about nature is to be noted. Except for Arab writers, all the names mentioned in the last chapter are of scientists connected with the church; bishops, monks, or nuns. In the Middle Ages, learning and religion were almost synonymous. In the sixteenth century, with the exception of the great explorers, twenty-one of the twenty-six prominent writers on luminous phenomena were physicians or had studied medicine, an extraordinary tribute to the scholarship of the group. In the seventeenth century medical men were still prominent in scientific affairs but had largely given way to the professional scientist.

In the fifteenth and sixteenth centuries, attention was directed to the grand sweep of the heavens and the striking phenomena of the earth. With the exception of a few electroluminescences, like the aurora borealis and the ignis lambens, the only known common types of luminescence were due to living organisms, the glowworm, phosphorescent wood, or the "burning" of the sea. The latter, especially, aroused the interest of navigators, although they did little to determine the origin of the light, and its connection with animalcules was unsuspected.

\section{Early Explorers}

Columbus (1446?-1506) referred to mysterious lights in the water the night before he landed on San Salvador in 1492, which may have been the luminous worm, Odontosyllis. ${ }^{1}$ Don João de Castro (1500-1548), Portuguese naval commander and Governor of India, recorded luminescence in the Red Sea in 1541 near Massaua. ${ }^{2}$ De Castro described the luminescence as "great dazzling white patches that lighted and glittered like the stars." The officers were so astonished they slackened sail to take soundings, for the white

${ }^{1}$ L. R. Crawshay, Possible bearing of a luminous syllid on the question of the landfall of Columbus, Nature 136: 559-560, 1935.

${ }^{2}$ Histoire general des voyages, 177. Quoted from Krukenberg, 1887: 120. 
water looked like a reef, but they found twenty-six fathoms and proceeded on their way.

John Davis (1550-1603) had a similar experience during his second voyage to the East Indies, near Ascension Island, in $7^{\circ} 5^{\prime}$ south latitude. He wrote: ${ }^{3}$ " in which place at night, I thinke I saw the strangest Sea, that euer was seene: Which was, That the burning or glittering light of the Sea did shew to us, as though all the Sea ouer had beene burning flames of fire; and all the night long, the Moone being downe, you might see to read in any booke by the light thereof." All other navigators must have noticed a sea afire but did not take the trouble to record it.

The sea was not the only luminescent phenomenon encountered. Tropical fireflies of the East Indies were seen by Sir Francis Drake (1540-1596) during the circumnavigation of the earth. ${ }^{4}$ The expedition started from "Plimmouth" on December 13, 1577. The observation was made next year on a certain little island south of Celebes, covered with trees having leaves not much different from broom. Drake wrote: "Amongst these Trees, night by night, through the whole Land, did shew themselues an infinite swarme of fierie Wormes flying in the Ayre, whose bodies being no bigger than our common English Flyes, make such a shew and light, as if euery Twigge or Tree had beene a burning Candle." Nevertheless, this casual statement is mild compared to the accounts of luminous insects brought back by explorers of the New World.

\section{Oviedo, Martyr, and New World Discoveries}

The most important record of the natural history of the New World was made by Gonzalo Fernandez de Oviedo (1478-1557), official chronicler of Indian affairs, who witnessed the return of Columbus from his first voyage. He later visited the New World, was an officer at Darien (Panama), Governor of Cartagena, and Alcaide of the fort at Santo Domingo. Oviedo's first short work, De Summario de la Natural y General Istoria de las Indias was published at Toledo in 1526. It has been translated into English by Richard Eden (died 1577), together with the writings of Peter Martyr d'Anghera and others as The Decades of the Newe Worlde, etc. published in London in 1555. These works are also included in Purchas his Pilgrimes. The first twenty volumes of the fiftyvolume complete Historia General y Natural de las Indias of Oviedo

${ }^{3}$ From Samuel Purchas, Hakluytus posthumus or Purchas his pilgrimes 1, Lib. III, cap. 6 , p. $132,1625$.

${ }^{*}$ From Purchas his pilgrimes 1, Lib. II, cap. 3, p. 56, 1625. 
appeared in 1535 and the remainder were published by the Royal Academy of History at Madrid in four volumes between 1851 and 1855. So many editions and translations of Oviedo's writings have been made that it seems best to present a translation of the official Spanish version published in 1851 .

In the Historia, four kinds of luminous things are mentioned, centipedes, worms, the light of tree trunks, and the Cucuyo, an elaterid bettle. The most interesting account of centipedes and worms is given in full because of some doubt regarding the animal referred to.

\section{LUMINOUS CENTIPEDES AND WORMS}

\section{Oviedo wrote: ${ }^{5}$}

There exist in this island of Hispaniola many kinds of centipedes. Some are thin and of the length of a finger, and like those in Spain, they bite and cause severe pain. ... There is another type, thin and about half a finger length, with many legs, that glow at night, illuminating the path they travel and can be seen from fifty to a hundred paces away. The entire body does not glow but only at the base or joints where the legs come out of the body and the glow is very bright. There are still other worms, very similar in shape, size and luminosity to these which have been just described, but they have one marked distinction, and that is, that their heads also glow, but the light is very vivid and red, like the glow of a live coal.

Oviedo spoke of luminous "worms" ${ }^{6}$ immediately after his treatment of centipedes and also said they have "many legs," but the last sentence, concerning a worm with a head that glows red like a live coal, can only refer to the "railroad worm" of South America. This "worm " is a larva or female of the beetle genus, Phrixothrix, allied to the fireflies, an insect and not a centipede. It is one of the most spectacular luminous animals. The first published illustration of the "worm," reproduced as figure 43, does not do justice to its beauty when observed at night.

The "worm" without a red light which glows "at the base or joints where the legs come out of the body," and is "seen from fifty or a hundred paces," was probably a luminous centipede, one of the Myriapoda which are world wide in distribution. This interpreta-

\footnotetext{
${ }^{5}$ Book XV Chap. II, Historia general y natural de las Indias, by Gonzálo Fernández de Oviedo, published in Madrid 1851, by the Royal Academy of History, kindly translated by Mr. Gabriel de la Haba, a lawyer of San Juan, Puerto Rico.

"The word "worm" was used by Muffet and "caterpillar" by Purchas in translation: "There are Caterpillars, which shine in the night fiftie or a hundred paces off, only from that part of the bodie whence the legges issue: others have only their head shining. I have seene some a spanne long very fearefull, but for anything I have heard, harmelesse." (Purchas his pilgrimes 15: 228, 1906 ed., from Oviedo, 1525.)
} 
tion is given by the great English entomologist, Muffet (1553-1604) . He called Oviedo's "worms" centipedes similar to those observed in England. Thus Oviedo's account may be taken as adding these two species to the growing list of recognized luminous creatures.

\section{PHOSPHORESCENT WOOD}

Another interesting luminescence reported by Oviedo (1526) was "Putrified woodde shynyng in the nyght." The description is as follows: ${ }^{7}$

I haue also thought good here to speake sumwhat of such thynges as coomme to my rememberaunce of certeyne trees which are founde in this lande [West Indies in general], and sumetyme also the lyke haue bynne seene in Spayne. These are certeyne putrifyed troonkes which haue lyne so longe rottyng on the earth that they are verye whyte and shyne in the nyght lyke burnynge fyre brandes. And when the Spanyardes fynde any of this woodde, and intende priuily in the nyght to make warre and inuade any prouince when case so requyreth that it shalbe necessary to go in the nyght in such places where they knowe not the way, the formost Christian man whiche guydethe the waye, associate with an Indian to directe hym therein, taketh a lyttle starre of the sayde woodde, which he putteth in his cappe hangynge behynde on his shoulders, by the lyght wherof he that foloweth nexte to him, directeth his iourney, who also in lyke maner beareth an other starre behynde hym, by the shynynge whereof the thyrde foloweth the same waye, and in lyke maner do al the rest, so that by this meanes none are loste or stragle owte of the way. And forasmuche as this lyght is not seene very farre, it is the better pollicie for the Chrystians bycause they are not thereby disclosed before they inuade theyr enemies.

Oviedo remarked that the wood would be more valuable if the glow lasted a longer time instead of two or three days.

This statement is the earliest scientific record of luminous wood in America but can hardly be considered new or unusual, as luminous wood was known to Aristotle, and Oviedo himself mentioned its occurrence in Spain. There are many other early accounts by travelers and in literature of the existence of phosphorescent wood and its use for illumination. Olaus Magnus (1490-1555), the Archbishop of Upsala, in his history of northern nations (De Gentibus Septentrionalium Variis Conditionibus, etc., 1567), mentioned rotten oak bark carried by people of the far north to light their way through the forest.

'Richard Eden's translation of the Summario, taken from The first three English books on America, edited by E. Arber, 227, Birmingham, 1885. This translation agrees well with later ones. 
Actually every country has a name for the light of decaying wood, which always contains a luminous fungus mycelium growing among the wood fibers.

The word "fox-fire" which is frequently used, especially in the United States, for the light of decaying wood due to growth of a luminous fungus, is included in the Catholicum Anglicum, ${ }^{8}$ an English-Latin word book published in 1483. The Latin equivalent is "glos, ${ }^{9}$ glossis." According to Herrtage ${ }^{8}$ " fox-fire" may be a corruption of the old French "fifollets," fox coming from "fol " or "fols," false. The modern French is "feux-follets" or false fires.

On the other hand, the word "fox" may be used in a sense that means to become discolored, applied to wood or paper when it turns a reddish color like a fox. ${ }^{10}$ The growth of the luminous fungus is usually associated with rotten discolored wood. Another possible derivation is fire (i. e. a glow) in the eyes of foxes.

\section{THE WEST INDIAN FIREFLY OR THE CUCUJO}

In addition to ordinary fireflies, discovery of the New World also introduced to science a brilliant and striking luminous insect, the "cocujo" or "cucujo" an elaterid beetle of the genus Pyrophorus, common in Central and South America and the West Indies. It was seen and described by Oviedo and also mentioned by the Italian historian of Spain's American conquests, Pietro Martire d'Anghiera (1455-1526) in his De Rebus Oceanis et Orbe Novo Decades VIII, and by many other writers. Better known as Peter Martyr, he never visited the "Orbe Novo." His account is second hand, from reports of Columbus, Cortes, S. Cabot, and Vespucci. Oviedo actually lived in the New World and may be considered a more accurate source of information. The two men give somewhat different information regarding the "cucuyo."

The original account of Oviedo is as follows: ${ }^{11}$

There are many flies, butterflies and beetles in these islands [Antilles] that are luminous when they fly at night. Like those that are called "luciérnagas" in Castille and fly during the summer, ... there are many here but small. But there is one kind called "cocuyo" which is notable. This is an insect well known in this [Santo Domingo] and the neigh-

\footnotetext{
${ }^{8}$ Edited by S. J. H. Herrtage in 1881 and published by the Early English Text Society (p. 140).

"Glos is defined as "Lo ligno putrido" in Domino DuCange's Glossarium mediae et infimae Latinitatis, new ed. of L. Favre, 1885.

${ }^{10}$ This derivation has been adopted in the Century Dictionary (1891).

${ }^{11}$ Historia general y natural de las Indias by Gonzalo Fernandez de Oviedo, Book XV Chap. VIII, published in Madrid, 1851, by the Royal Academy of History, translated by Mr. Gabriel de la Haba.
} 
boring islands. It is a type of beetle about the size of the first joint of the thumb, or slightly smaller. It has two hard wings, and below these, two fine ones which are kept beneath the others when not in flight. It has luminous eyes like fire and when flying the air becomes light as when lighted by fire. If one should carry one of these in the hand on a dark night people seeing it from afar and needing to make fire would think that it was a fire from which they could gather light. If placed in a dark chamber its glow is so great that one can see well to read or write a letter and if four or five are tied together they glow as much in a dark night as a lantern would in the fields or in the forest. When warring in Hispaniola and other islands the Christians and the Indians use these lights in order not to get lost; and particularly the Indians, as they have greater dexterity to capture these insects, use them to make collars when they wish to be seen a league away. So that in the country and in homes at night, men do whatever they see fit with these cocuyos as neither water nor strong winds will affect their luminosity nor hide their light to find their way. When on an assault party at night, their leader wears a "cocuyo" on his head as a guide to those following. The light that these insects have in their eyes is also present in their body and when opening their wings for flight it gives forth more light from under its wings, as well as from its eyes, joining one light with the other, thus giving forth greater luminosity when on flight. They keep these insects caged for the services of homes for use at night without the need of other lights. The Christians did the same in the past to save money on the oil they had to buy for their lamps, which was either lacking or expensive, at that time. When they saw that the "cocuyo" was getting thin, or because of the imprisonment their faculty of producing light was weakening, they turned them loose and got others for the following days. The Indians also stained their hands and faces with a paste made from these "cocuyos" and when in their celebrations they wanted to have fun, they scare others that were not watching and knew not what it was, by the great light given by the matter stained by these "cocuyos." As this insect loses weight or dies, thus its light diminishes and finally disappears.

The De Orbe Novo of Peter Martyr was first published as Decades Tres at Alcala de Henares in 1516. Later, additional decades were added. The first edition with eight decades appeared in 1530 . Several pages of Decade VII are devoted to the cucuyos, laying special emphasis on their ability to catch gnats (mosquitoes), which were a great nuisance to the natives of Hispaniola, forcing them to build houses without windows and with very narrow doors to prevent the gnats from entering. Martire continued: ${ }^{12}$

\footnotetext{
${ }^{12}$ From De orbe novo; the eight decades of Peter Martyr d'Anghera, translated from the Latin with notes and introduction by F. A. MacNutt 2: 310-313, New York, 1912. G. P. Putnam's Sons.
} 
While Nature has bestowed this pest on the islanders, she has at the same time supplied a remedy, just as we have the cat to rid us of the filthy nuisance of rats. The gnat chasers, which likewise serve other purposes, are called cucurios and are winged worms, inoffensive, a little smaller than butterflies, and resembling rather a scarabaeus, since their wings are protected by a tough outer covering, into which they are drawn when the insect stops flying. These insects, like the fireflies we see shining at night or certain luminous worms found in hedgerows have been supplied by provident nature with four luminous points, two of which occupy the place of the eyes, and the other two are hidden inside the body under the shell, and are only visible when they put out their little wings like the scarabs, and begin to fly. Each cucurio thus carries four lanterns, and it is pleasing to learn how people protect themselves against the pestiferous gnats, which sting every one and in some places are a trifle smaller than bees. . . . To catch cucurios one must go out at nightfall, carrying a burning coal, mount upon a neighbouring hut in sight of the cucurios, and then call in a loud voice, "cucurios, cucurios!"

Simple people imagine that the cucurios are charmed by this noise and answer the call. As a matter of fact they quickly appear in masses. We believe they are attracted by the light, as clouds of gnats also rush towards it, just as the martins and swallows do, only to be devoured by the cucurios. When a sufficient number of cucurios have assembled, the hunter throws down the coal, and the cucurios, following the direction of the fire, fall to the earth, where it is as easy to catch them as for the traveller to catch a scarabaeus creeping along with its wings under its shell. ... As soon as the hunter has got his supply of these cucurios, he takes them home, and closely shutting his house, he lets them loose. The cucurio immediately flies about the room seeking the gnats. He acts as though he mounted guard over the hammocks and the faces of the sleepers, which the gnats attack, assuming the duty of ensuring them a night's rest. ...

By the light shed by this insect, as long as his hunger is not satisfied, it is possible to read or write. When the cucurio's hunger is appeased by the gnats he has caught and swallowed, his light grows dim; and when the natives perceive this, they open the door and let the insect regain his liberty and search for food elsewhere. As a joke, and to scare people who are afraid of spectres, the facetious sometimes rub their faces with a dead cucurio, and show themselves, with flaming countenances, to their neighbours at night, asking them where they are going. . . .

There is another extraordinary advantage derived from the cucurio; the natives, whom the Spaniards sent on errands, prefer to go at night; attaching two cucurios to their toes, they walk as easily as though they carried as many lanterns as the cucurios have lights. They also carry others in their hands, which help them to catch utias. These utias are a sort of rabbit, a little larger than a rat, and before the arrival of the Spaniards, the natives knew of no other and ate no other quadruped. 
They also fish by means of cucurios, this being a sport of which they are passionately fond and which they follow from their cradles.

Martyr's account is far more detailed and fanciful, but actually incorrect. There is no evidence that the cucuyo catches gnats, in fact it lives on the juice of sugar cane. Nevertheless, the idea that the cucuyo kills mosquitoes has been copied by many subsequent writers. It occurs in the account of Francisco Lopez de Gomara (ca. 1510-ca. 1560), the priest and popular Spanish historian, whose Historia General de las Indias y Conquista de Méjico was published at Zaragoza in 1552. His account of the cucuyo is good but contains nothing new.

The cucujo became so famous as a source of light that its praises were sung by Guillaume de Salluste du Bartas, Seigneur (1544-1590) in La Creation du Monde, which first appeared in 1578. Some early drawings of the insect are still extant. One of these has been published by Stephan Lorant in The New World, the first pictures of America made by John White and Jacques Le Moyne and engraved by Theodore De Bry (New York, 1946). The drawing dates from ca. 1585. Woodcuts of the cucujo, said to have been copied from John White's drawings, were also included in the book on insects published by Muffet (1634), to be considered in a later section.

\section{Paracelsus and Sixteenth-Century Alchemists}

Despite the innumerable and fantastic procedures to which various materials were subjected in the alchemists' search for gold, little knowledge of inorganic luminescences appears to have been obtained. Such a discovery might have come from men with a medical interest, for example, Theophrastus Bombast of Hohenheim (ca. 1493-1541) or Paracelsus, the radical Swiss physician and founder of the iatrochemical school, a contemporary of Georg Agricola (1490-1555). Paracelsus' principal interest was in preparation of medicines. He was mostly concerned with inorganic reactions and recommended mineral remedies for illness rather than the "virtues" of plants, regularly used at that period.

It has been held that one passage from the third book of the Archidoxies, the Theophrastia, indicates that Paracelsus anticipated the discovery of phosphorus, over one hundred years before Hennig Brand of Hamburg prepared his sample in 1669. The particular statement is as follows: ${ }^{13}$

\footnotetext{
${ }^{13}$ The hermetic and alchemical writings of Aureolus Phillipus Theophrastus Bombast of Hohenheim, called Paracelsus the Great, trans. by A. E. Waite, 2: 19, 1894. There is a German translation by Berhard Aschner. Paracelsus Sämtliche Werke, 4 v., Jena, 1926-1932.
} 
Take urine and thoroughly distill it, water, air and earth will ascend together, but the fire remains at the bottom. Afterwards mix all together and distill again four times after this manner; and at the fourth distillation the water will ascend first, then the air and the fire, but the earth remains at the bottom. Then take the air and the fire in a separate vessel, which put in a cold place, and there will be congealed certain icicles, which are the element of fire. Although this congelation will take place in the course of distillation, still it will do so more readily in the cold.

The "icicles" which are "elements of fire" might refer to the element phosphorus, and it is interesting to note that Robert Boyle used the term "Icy Noctiluca" for solid phosphorus, as distinguished from the "Aerial Noctiluca" or luminescence of phosphorus vapor. However, if Paracelsus really did discover the element phosphorus, it is surprising that no greater interest was taken in the find.

Paracelsus repeated the old formula ${ }^{14}$ for "liquor lucidus," made from glowworms, described in a subsequent section, but apparently paid attention to no other bioluminescences. Like alchemists of the period, Paracelsus engaged in the transmutation of metals but his chief claim to fame is attached to his three principles-salt, sulphur, and mercury-which greatly influenced the thinking of early chemists, and were used by a number of later writers in attempting to explain the properties of various phosphors.

Andreas Libavius (died 1616), the German physician and chemist, and Rector of the Gymnasium at Coburg, who wrote what is often considered the first textbook of chemistry, Alchemia (1595), combatted the school of Paracelsus, but his writings contain nothing important on luminescence.

\section{Conrad Gesner and the First Book on Luminescence}

During the fifteenth and sixteenth centuries knowledge of luminous animals was often taken from the older works which appeared during the Middle Ages. For example, a modification of the early encyclopedia of Bartholomaeus Angelicus (ca. 1190-1260) was prepared by Stephen Batman (1537-1587), "Professour in Divinitie," and printed in old English type. The title was Batman uppon Bartholome his Booke De Proprietatibus Rerum, newly corrected enlarged and amended: etc. Profitable for all Estates, as well as for the benefite of the Mind as the Bodie, London, 1582. The added material in the field of natural history came from the works of

1. Waite translation, 2: 316, 1894. 
Gesner, Fuchsius, ${ }^{15}$ Mathiolus, Theophrastus, Paracelsus, and Dodoneus. ${ }^{16}$ The glowworm is considered in liber 18, De Noctiluca, cap. 77. Batman wrote:

Noctiluca is a little beast with feete and with wings, and is therefore sometimes accounted among Volatiles, and he shineth in darkness as a candle, and namely about ye hinder parts, and is foule and darke in full light, and infecteth and smiteth his hande that him toucheth: and though he be unseene in light, yet he flieth light and hateth it and goeth by night, and is contrary to another little one that is called Lucipeta, that riseth gladly on light, as I sid saith, lib. 12. cap. de minutis volatilibus, etc.

According to S. Killermann, ${ }^{17}$ lampyrids are included in the beautifully illustrated Codex of Animals (1460, folio 193, 201) by Petrus Candidus Decembrus (1399-1477), but William Caxton's (ca. 1422-1491) Mirrour of the World (ca. 1490) does not appear to treat of luminous animals. Another fifteenth-century compilation which might be expected to include luminous insects is the Hortus Sanitatis (1495), attributed to Joannes de Cuba (Cube or Caub, fl. late fifteenth century). The 1536 (Argentorati) edition contains quaint woodcuts of real and imagined living creatures, including the Pyralis of Cypris, which lives in fire and dies whenever it flies out, and the birds of the forests of Hercinia with shining wings, both described by Pliny, but the firefly and glowworm are not included, nor is there mention of the luminous dactyli (Pholas) so vividly described by Pliny.

In contrast to this meagre description, the middle of the sixteenth century is famous not only for the classics of Copernicus and Versalius but also for writings of the really great naturalists. At this time a resurgence of interest in animals and plants led not only to the collection of specimens, but to the accurate description of characteristics and the recording of behavior, as well as beliefs concerning the various species. The names of Wotton, Rondelet, Salviani, Gesner, Belon, and Aldrovandi, in order of birth, have become well known to the zoologist.

The youngest of these men, Edward Wotton (1492-1555), was an English physician who corresponded with Conrad Gesner, and introduced zoology to medical students. He wrote De Differentiis Animalium, libri decem (Lutetiae Parisiorum, 1552), which described a number of luminous animals, for example Cicindela and Dactylus

${ }^{15}$ Leonard Fuchs (1501-1565), German physician and botanist.

${ }^{18}$ Reinbert Dodoens (1518-1585), botanist and professor of medicine at Leiden.

${ }^{17}$ S. Killermann, Ztschr. für Geschichte der Zool. 6: 113-221, 1914. 
(or Unguie), the luminous mollusc. However, Wotton mostly repeated the statements of Aristotle and Pliny, without adding new material. There were no illustrations, and the work was not as comprehensive as that of the continental writers whose fame is acknowledged by all.

Among the above-mentioned men, Conrad Gesner (1516-1565) took most interest in luminescence, describing not only luminous animals and plants but luminous stones. To Gesner belongs the honor of preparing the first book wholly devoted to luminescence. It was a short treatise entitled, De raris \& admirandis Herbis quae sive quod noctu lucenat, sive alias ob causas LUNARIAE nominantur \& obiter de aliis etiam rebus, quae in tenebris lucent, commentariolus, published at Tiguri (Zurich) in 1555. The title page is reproduced as figure 1. A second edition was published by $T$. Bartholin at Copenhagen in 1669. An excellent idea of the contents is given by the title: A short commentary on rare and marvelous plants that are called lunar either because they shine at night or for other reasons; and also on other things that shine in darkness. The book was primarily written to call attention to allegedly luminous plants mentioned by Aelian and already described in Chapter I. However, Gesner, who had translated Aelian's complete work from Greek into Latin, discoursed on many other types of luminescence. Needless to say, he leaned heavily on classical writers but expressed his own opinions freely. Gesner's book is frequently referred to as $D e$ Lunariis.

For example he was definitely skeptical concerning the stories of luminous plants and wrote: ${ }^{18}$ "the lunar plants to which recent authors assign preternatural powers and which they say shine in darkness seem fictitious" but "it is possible that plants as yet unknown to us shine throughout the night just as among other natural phenomena certain things are known to shine." After quoting Aristotle on the distinction between those things that depend on light for visibility, and those which in light are invisible, in darkness stimulate the sense; that is "things that appear fiery or shining" Gesner concluded:

If any plants shine at night, they will shine either because the rays of the moon are reflected by something in them that is smooth and bright and like a mirror,... . or else they will shine as do the eyes and scales of fish or as decaying wood and things of that sort, which are very dry, and as the pygolampides [glowworms], that is, by some light proper to themselves, not however, of the nature of fire nor burning.

${ }^{18} \mathrm{De}$ lunariis (1669 edition), translation by R. A. Applegate. 
In addition to plants, Gesner also mentioned as luminous small animals that are called noctilucae; ${ }^{19}$ the sea fish lucerna or milvus; a fish the "Greeks call selache ${ }^{20}$ which shines clearly at night"; the firefly (pygolampis), although Gesner did not recall seeing one himself; a small worm similar to a caterpillar (eruca) "21 "which emits such a clear light at night that letters can be read "; the eyes of many animals including fish, and the feathers of a rare bird of the Hercynian Forest, described by Pliny.

Practically all the great naturalists, and others who wrote in lighter vein, believed in luminous birds. In addition to Johannes de Cuba (1536), John Maplet (died 1592), Vicar of Northolt Church in Middlesex, published from London in 1567, A Greene Forest, or a Natural Historie, wherein may bee seene the most sufferaigne vertues in all the whole kinde of stones and mettals; of brute beates, fowles, fishes, etc. Concerning the "Hercynie Birdes" which "breede [in] a Wood in Germanie," he wrote that their "feathers shine so by night, and when as the Ayre is shut in, that although the night be never so darcke and close, yet they give them their best light: so that to a man journeying they are to his great sunderance, being cast before him in the way whereas he goeth."

The Hercynian birds were also described in the Hortus Sanitatus, ${ }^{22}$ probably written by Johann von Caub (Cuba or Cube), who fluorished in the latter part of the fifteenth century. Unfortunately there is no woodcut in the 1536 edition, but later authors have identified the Hercynian birds as Bohemian waxwings (Garrulus bohemicus or Bombycilla garrulus), whose red-tipped feathers reflect light. ${ }^{23}$

Other examples of luminescence mentioned in Gesner's book were the fiery vapors around damp places, especially temples and cemeteries, what are commonly called ignes fatui, and various types of electric discharges. Gesner wrote: ${ }^{18}$

\footnotetext{
${ }^{19}$ These might be any small luminous organism.

${ }^{20}$ Possibly a luminous shark but more likely apparent luminosity due to disturbance of luminous dinoflagellates as the fish swims through the water.

${ }^{21}$ Possibly caterpillars living on Cole-Wort, Brassica eruca, which have in modern times been described as luminous from infection by bacteria. Eruca applies to either the worm or the plant.

${ }^{23}$ The first edition of the Ortus sanitatis appeared at Mainz in 1495. There were many later editions. Like most natural histories of that time, the divisions of the book were (1) animals and reptiles (2) birds and flying things (3) fish and swimming things (4) gems and other materials born of the earth. The glowworm (cicendula) is mentioned in the 1517 edition under "Avibus" (cap. XXXI), with a description taken from the Liber de naturis rerum.

${ }^{23}$ See Cuvier's commentary on Pliny in the Agasson de Grandsage edition (Paris, 1829), L. Denise (1910), and W. L. McAtee, Luminosity in birds (American Midland Naturalist 38: 207-213, 1947). None of the reported luminescent birds are known to be self-luminous.
} 
Among us it happens to many when they use the sweat-chamber that, after they have become rather warm in the chamber and have then entered a cold room, they see flame and hear it crackling when they remove their undergarment, or move it, or strike it after it has been removed. No doubt undergarments absorb the rich fumes and exhalaof bodies, which are easily retained (especially by the many thick clothes used in winter) and are combustible. These fumes, when they have become warm and have been moved into a cold place, since they do not want to be dispersed in the cold air, are rather greatly compressed; and, having been kindled by the motion, burn. For motion brings very many things from potentiality into actuality. Thus the hair of horses in stables sometimes give off a fiery glow when it is scraped with a strigil, ${ }^{24}$ and the hair of cats, which are warming themselves before a stove or fire, give off a similar glow when they are stroked the wrong way.

Like many other observers, Gesner incorrectly believed that the eyes of man and other animals emitted light.

The aurora borealis is described by Gesner in the words of Aristotle as clefts in the sky, and a great deal of space is devoted to St. Elmo's fire, referred to as "stellae castores," which appeared on the ends of javelins and yard arms of ships. Sometimes this fire took the form of ignis lambens and appeared on the heads of persons. Livy's (Book I, Chap. 39) prodigy concerning a flame about the head of Servius Tullus and Virgil's gentle and harmless (Aeneid, Book II, 1 1, 680-684) flame that flickered about the hair of Iulus is described, as well as many other instances of silent electric discharges, quoted from the Meteorologia of Marcus Frytschius Labanius and the De Prodigiis Liber of Julius Obsequens. ${ }^{25}$

Gesner's Commentariolus is a good example of the approach to the subject of luminescence in the sixteenth century. The time was not yet ripe for experiment. This first book on luminescence is a disappointment from the scientific point of view, but it did serve to bring together and direct attention to a number of phenomena which were later to receive careful attention. It is unfortunate that there was so much repetition of the statements of others, and so little original observation.

Nevertheless, it is fitting that the "German Pliny," as Cuvier called Gesner, should have turned his attention to luminescent phenomena, among his varied and universal interests. Born in Zurich, son of a poor furrier, he studied medicine in Basel and then traveled widely in Europe, but finally settled in his native town, becoming

24 A Roman instrument for scraping the skin after a bath.

${ }_{25}$ Obsequens was a Roman writer about whom little is known. He recorded all the wonderful occurrences from the founding of Rome to the time of Augustus. See Chapter I. 
professor of natural history and medicine in the University in 1555 and also city physician. He was a great lover of high mountains. Despite professional duties that finally led to his death from plague, he translated and edited the Natural History of Aelian and wrote the Bibliotheca Universalis (1545), a catalogue with titles of all known writings in Greek, Latin, and Hebrew, and his own Historia Animalium (1551-1558), a natural history in five parts.

The fourth volume of the Historia Animalium appeared in 1556. A reprint, Liber IIII, qui est de piscium et aquatilium animantium natura, appeared from Zurich in 1558. It describes chiefly fish but contains many invertebrates among the fish proper, all arranged alphabetically and based largely on Rondelet, whose books on "fishes" were published in 1554 and 1555. The "pulmo marinus," the "penna marina," the "pholade concha," the " ungue seu dacylo" and the "ungue seu solene" are mentioned as luminous and figured as woodcuts. Concerning the sea pen, Gesner wrote: "Noctu maxime splendet, stellae modo, ob candorum et laeuorum, haec ille."

Concerning the "solene mare," the statement is: "His natura in tenebris remoto lumina, alio fugore, clarere, et quanto magnis humorem habeant." The figure shows a razor clam, Solen, which, together with Pholas, was considered to be luminous by Rondelet and by all the sixteenth-century writers. The mistake is a curious one, possibly based on observation of dead Solen shining from luminous bacteria, or possibly based on Pliny, who described Pholas dactylus under several names, including Solen. Nearly two centuries later, Réaumur $(1712,1723)$ emphasized the fact that Solen did not luminesce, whereas Pholas did, and that Pholas light was brighter the fresher the animals.

At the time of his death, Gesner was working on a companion volume to the animal book, dealing with plants, but only scattered botanical writings appeared (1541). They were finally collected, together with 1,000 drawings, as the Opera Conradi Gesneri, etc., published at Nuremberg in 1751-1772.

Most of Gesner's Latin writings have appeared in second editions and some have been translated in German. His book on luminescent phenomena, generally referred to as De Lunariis, was reissued at Hafnia (Copenhagen) in 1669, bound together with a second edition of Bartholin's De Luce Animalium, first published in 1647, but with the title changed to De Luce Hominum et Brutorum. With the exception of essays on the phosphorescent Bolognian stone, Bartholin's book (1647) was the second publication wholly devoted to luminescence and the works of Gesner and Bartholin remained the 
chief books on this subject until near the end of the seventeenth century.

\section{Luminous Stones}

In his book on luminous things, De Lunariis, Gesner first cited Aelian on the luminous stone brought by a stork to Heracleis, and then wrote: "The solaris is a stone, which is called the eye of the sun. It has a shape like the pupil of the eye, from which light shines. The carbuncle likewise shines at night with a ruddy glow, as Marsilio Ficino ${ }^{26}$ writes."

This belief in luminous jewels seems to have become universal in medieval times. ${ }^{27}$ Hildegard, wife of Theodoric, Count of Holland, presented to the Abbey of Egmund a "chrysolampis," which shone so greatly at night that the monks were alleged to be able to read without any other light. In Sir John Mandeville's (1300?1377) travels there is an account of an emperor of Cathay who " hathe in his chambre, in on of the pyleres of gold, a Rubye and a Charboncle of half a fote long, that in the nyghte semethe so grete, clartee, and shynynge, that it is als light as day." Like other Mandeville stories this is no doubt a fable, although it has been frequently repeated.

More credible is the story of Gesner regarding Catharine of Aragon (1485-1536), Queen of England, who wore a ring set with a stone which luminesced at night. Gesner thought it was a ruby, but a diamond seems more probable, as certain varieties are phosphorescent. Benvenuto Cellini (1500-1571), sculptor and worker in gold, in his treatise on jewelry (Due Trattati dell' Orificera, 1568) told of a diamond which shone after exposure to light, and the experiments of Robert Boyle (see Chap. X) leave no doubt of the truth of Cellini's statement.

Another story of the same period concerning a luminous stone that could not be touched without danger was related by the French historian, J. A. de Thou (1553-1617). This stone was brought from the East Indies and presented to Henry II, King of France, on the occasion of his entry into the town of Bologna in 1550. John Jonston (1632) stated that it had a "wonderful shape and nature, for it shown with light and clearness exceedingly, and it seemed as if it were all on fire, and turn it which way you would, the lustre of it so enlightened the ayre with its beams, that they could hardly endure to look upon it."

${ }^{20}$ The Italian philosopher and scholar (1433-1499), president of the Platonic Academy in Florence.

${ }^{27}$ See C. W. King, The natural history of precious stones, $237 \mathrm{ff}$., London, 1870, and G. F. Kunz, The curious lore of precious stones, Chap. V, Philadelphia, 1913. 
The carbuncle was still regarded as luminous in the sixteenth century. In The Dialogues of Creatures Moralised, probably written anonymously around 1550 , edited (with an introduction) by Joseph Haslewood in 1816, we find the following statement on page 37. "Carbunculus is a Precyous stone, as sayth Brito, and so namyd, for it is brinnynge lyk a cole of fyre, and the brightnes of hitte shewith in the nyght tyme. Hitte shynyth in derknesse so greatly that the flamys of hitte smytythe the iye sight. A myrowre of Glasse went to this Carbunculus uppon a tyme and sayde: he was bright like Carbunculus and so if we two were one we would be of more excellence." To which Carbunculus replied "No" because glass was of "frayle stocke."

John Maplet in his Natural Historie (London, 1567) wrote that the carbuncle, "so called for that (like a fierie cole) it giveth light, but especially in the night season. ..." E. Fenton was another who referred in his book, Certaine Secrete Wonders of Nature (London, 1569), to a story of Luigi Varthema (Ludovicus Vartomanus, born about 1480). Varthema had seen carbuncles of the King of Pege in India of "so great a shining, that who behelde them in any darke or shaded place, seemed to have his boddy distempered . . . suche was the light and piercing glimmers of these stones...." This type of statement was typical of sixteenth-century authors.

A change in attitude toward these stories of luminous gems, tales handed down from the Middle Ages, was to come in the seventeenth century. The subject was discussed and a much more cautious opinion expressed by Sir Thomas Browne (1605-1681), famous physician and writer, in his Pseudodoxia Epidemica or Inquiries into Vulgar Errors. In Book 2, Chapter 5, of the second edition (1650), he wrote: ${ }^{28}$

Whether a carbuncle (which is esteemed the best and biggest of rubies) doth flame in the dark, or shine like a coal in the night, though generally agreed on by common believers, is very much questioned by many. By Milius, who accounts it a vulgar error: by the learned Boëtius, ${ }^{29}$ who could not find it verified in that famous one of Rodolphus, which was as big as an egg, and esteemed the best in Europe. Wherefore, although we dispute not the possibility (and the like is said to have been observed in some diamonds), yet, whether herein there be not too high an apprehension, and above its natural radiancy, is not without just doubt: however it be granted a very splendid gem, and whose sparks may somewhat resemble the glances of fire, and metaphorically deserve that name.

${ }^{28}$ From T. Browne's Works, edited by Simon Wilkins, 2: 354-355, 1835.

${ }^{29}$ Anselmus Boëtius or de Boot, who wrote Gemmarium et lapidum historia (Lugd. Bat., 1636). 
As for that Indian stone that shined so brightly in the night, and pretended to have been shewn to many in the court of France, as Andreus Chioccus ${ }^{30}$ hath declared out of Thuanus, ${ }^{31}$ it proved but an imposture, as that eminent philosopher, Licetus, ${ }^{32}$ hath discovered; and, therefore, in the revised editions of Thuanus it is not to be found.

Thus, erroneous beliefs of the fifteenth and sixteenth centuries were to be corrected in the seventeenth.

Despite the extravagant and unbelievable claims of brightness and of hazard connected with the fifteenth and sixteenth century stories of luminous stones, these do exist. In addition to diamonds, certain varieties of fluorspar ${ }^{33}$ remain luminescent after exposure to light for many hours, and the luminescence is increased on warming. There is at least a basis for the legends.

\section{Rondelet, Aldrovandi, and Other Natural Historians}

Of the four great students ${ }^{34}$ of natural history who lived in the same period as Gesner, two were French, Belon and Rondelet, and two were Italian, Salviani and Aldrovandi. Pierre Belon (15171564) in 1551 and 1553 (in Latin, or 1555 in French) wrote two small books on " poissons," by which he meant not only vertebrate fish but also shells, starfish, crabs and other aquatic invertebrates. He was no mere compiler but an original observer, who traveled extensively. However, he paid scant attention to luminescence, as nothing of value concerning luminous species is contained in his works.

His countryman, Guillaume Rondelet (1507-1566), professor of anatomy at Montpellier, can be classed as one of the greatest original

${ }^{30}$ Andrea Chiocco (died 1624), Italian physician and naturalist.

${ }^{31}$ Jacques Augustus de Thou (1553-1617), the French historian.

${ }^{32}$ Fortunio Liceti (1577-1657), Italian physician and philosopher in De quaesitis per epistolas a claris viris responsa (Bononiae, 1640).

${ }^{33}$ H. E. Millson has reported (Jour. Opt. Soc. Amer. 40: 430-435, 1950) that a variety of fluorite from Trumbull, Conn., was visibly luminous to thoroughly dark adapted eyes $4 \frac{1}{2}$ years after exposure to short ultraviolet light. The initial intensity was much brighter.

${ }^{34}$ Another scholar, less well known as a naturalist, was Julius Caesar Scaliger (14841558): He wrote Exotericarum exercitationum liber XV (Lutitiae, 1557) and mentioned a luminous rooster and the glowworm. Ferrante Imperato (1550-1625), Fabius Colonna or Columna (1567-1650), G. J. Vossius (1577-1649) and Leo Allacci or Allatius (1586-1669), span the sixteenth and seventeenth centuries. All these men included the glowworm or other luminous species in their writings. Olaus Magnus (ca. 14901568), Archbishop of Upsala, who traveled widely in Europe and lived in Rome, wrote of the light of Pholas and said that some fish and whales off the coast of Norway were visible at night by the light of their eyes, which were 8 to 10 cubits (12-15 feet) in circumference while the pupil was one cubit ( $1.5 \mathrm{feet})$. The whale story is characteristic of Magnus and of the time. 
naturalists of the century, judging by the authority attributed to him in later writings. He published two Latin works with excellent figures (De Piscibus Marinis, Lugduni, 1554, and Universae Aquatilium Historiae, Lugduni, 1555), which were issued together in French at Lyons in 1558 as L'Histoire Entière des Poissons. As was the custom of the time, many "testacea" and other invertebrates were included. Luminous species were the "pulmon marine" (jellyfish), the "pennache" (sea pen), the "solen " and the "pholade." The book contains the first published figures of luminous organisms. There is an excellent woodcut of Pholas in rock, and reproductions of the other luminous animals, reproduced as figure 2, but no extended discussion of light emission in any of these forms. $\mathrm{He}$ also described the "luna" or "orthogoriscus," ${ }^{35}$ a fish that shines brightly at night from certain parts of its body, probably an observation of luminous bacteria growing on the fish.

Rondelet's work was publicized by another writer, Franciscus Boussvetus (Boussuet) (1520-1572), in two books of poetry, published at Ludguni (Lyons) in 1558, De Natura Aquatilium Carmen in Universam Gulielmi Rondeletii, quam de piscibus marinis scripsit historiam; cum vivis eorum imaginibus. The poems were non-scientific epigrammatic Latin verses describing the "fish" of Rondelet, illustrated with his figures. Luminescence of jellyfish, Pholas, Solen and the sea pen was mentioned. Boussuet followed Rondelet, who had incorrectly described Solen, the razor clam, as luminous, despite the fact that Rondelet lived at Montpellier, not far from the sea. The excellent illustration leaves no doubt of identification. In his poem on De Solene Mare et Foemina Boussuet wrote:

The male Solen moves the urine

But they call the female sweeter (dulcior) than the male.

Strange, because at night, they shine with remote splendor,

What, one asks, can be the cause of so much light.

The other poems are similar in character, often stressing some medical use or characteristic of the animal, and mentioning the light production.

Hippolyto Salviani (1514-1572) was a physician of Rome. His book, Aquatilium Animalium Historia (1554-1558), dealt only with vertebrate fishes, squid and octopi, giving Latin, Greek, and vulgar names of the animals, but no special information on luminescence.

The last natural historian of the period, Ulysses Aldrovandi (15221605 or 1607), a physician of Bologna, was a great encyclopedist

${ }^{35} \mathrm{G}$. Rondelet. De piscibus, lib. XV, cap. 7, fol. 427. Perhaps the pig-fish or Crthopristis. 
like Gesner and a collector whose museum went to his native city. His Opera were issued in thirteen large volumes between 1599 and 1668, at Bologna, mostly by students and friends. Aldrovandi considered true fishes in a special volume De Piscibus libri $V$ et De Cetus liber unus (1613). In his De Reliquis Animalibus Exanguibus. De Mollibus, Crustaceis, Testaceis et Zoophytis (1606), dealing with invertebrates, there are many excellent woodcut figures, mostly taken from Rondelet. "De Pholade" (pp. 525-526), "De Solene" (p. 527-529), "De Pulmone Marina" (pp. 575-578), and "De Penna Marina" (p. 591) are separate chapters, describing the morphology and giving synonyms and uses as food or for other purposes of pholads, solens (razor clams), jellyfish, and sea pens. His figure of a jellyfish is reproduced as figure 3 .

Aldrovandi was much influenced by both Pliny and Rondelet. Pliny's account of the luminous appearance of the mouths of those eating dactyli (Pholas) is described in the chapter "De Solene," the razor clam, and the story of walking sticks made luminous from juice of jellyfish is also recounted. Regarding the sea pen, Aldrovandi wrote: "It shines greatly at night like a star on account of its whiteness and smoothness." Aristotle's opinion can be recognized in the idea that smooth things shine.

In his book on insects, De Animalibus Insectis (Bologna, 1602), which will be discussed in the next section, Aldrovandi hinted that he had a real interest in luminescence. After describing the views of various authors concerning the light of fireflies, he wrote: "We, too, have drafted a book on things that shine at night, and will publish it if we live long enough, for we must first finish the ones that are more necessary." Unfortunately he died about 1606 and the material, if it exists, has never been published.

\section{Sixteenth-Century Entomology \\ ULYSSES ALDROVANDI AND OTHERS}

Insects have always been a group of animals set apart from others by special features, one of which is their wide geographical distributio and a second their enormous variety. More species of insects have been described than all other animal species taken together. Perhaps the vast array of small and lowly creatures delayed their study, as compared with larger and more noticeable animals. Rondelet did not consider them; neither did Gesner, although he asked Thomas Penny to complete a history of insects begun by Edward Wotton (1492-1555). Penny died before completion, and the book 


\title{
CONRADI GES: NERI MEDICI. DE RARIS ET ADMIRANDIS HERBIS, QVAE SIVE QVOD NOCTV luceant, fiue alias ob caufas, LVNARIAE nominan. tur, Commentariolus: \& obiter de alijs etiam rebus qu $z$ in tene- brislucent.
}

\section{Inferuntur of Icones quedam her. barum nous.}

\begin{abstract}
EIVSDEM DESCRIPTIO MONTIS FRACTI, Gue Moatis Pilati,iuxta Lucernam in Heluetia.

10. Rbellicari STOCKHORNIAS, que STOCK hornses mons alsysims in Bernenfium Helisetioruns agro, verfibu Heroicis defcribisur.
\end{abstract}

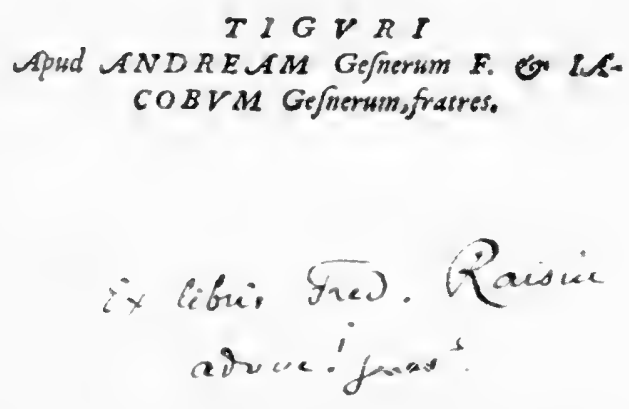

$T \perp G \vee R T$

Apud ANDREAM Gefnersm F. ON LA. COBVM Gefnerum, fratres.

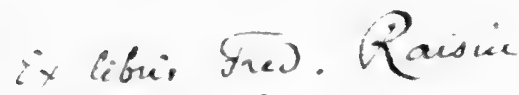

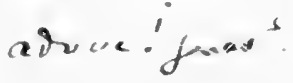

Fif; I. Title page of the first book on luminescence, by Conrad ciesner, published at Zurich in 1555. 
Pholades Rondelerij.

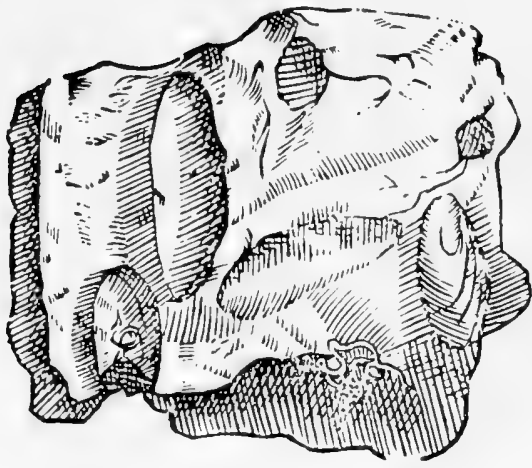

Pholades authoris in fax is hoofpirantes.

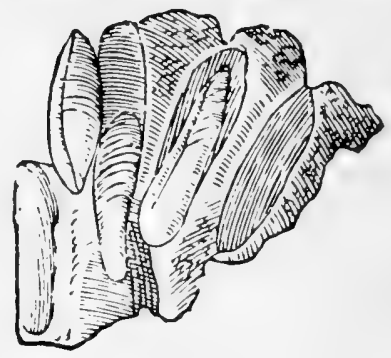

Pennacuariaa Rondeletij.

Б

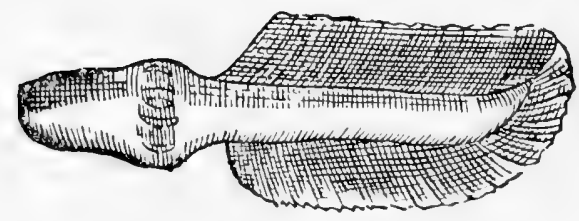

Pennamarina fanguinei coloris.

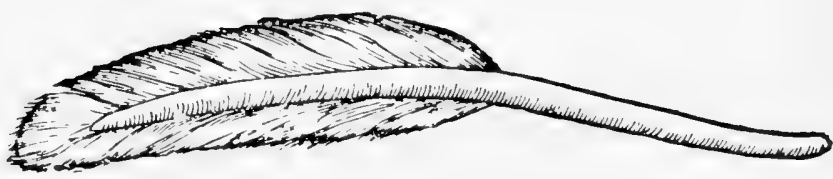

Solenmas Rondel. nu.I.

Solen foemina Rondel aw zh
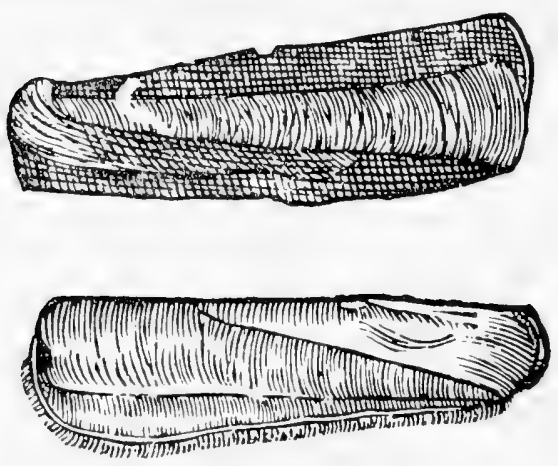

dedaiี

FIr. 2. The first figures of luminous marine invertebrates, originally published by Rondelet in Lniversae Aquatilium Historiae (Lugduni, 1555), and copied by Aldrovandi in his De Reliquis Animalibus Exsanguibus, libri IV (Bologna, 1606). Alove, the piddock or dail burrowing in rock; middle, the sea pen; below, the razor clam, incorrectly called luminous. 


\section{De Zoophytis : Lib.IV. \\ Pulmo marinus Marth.}

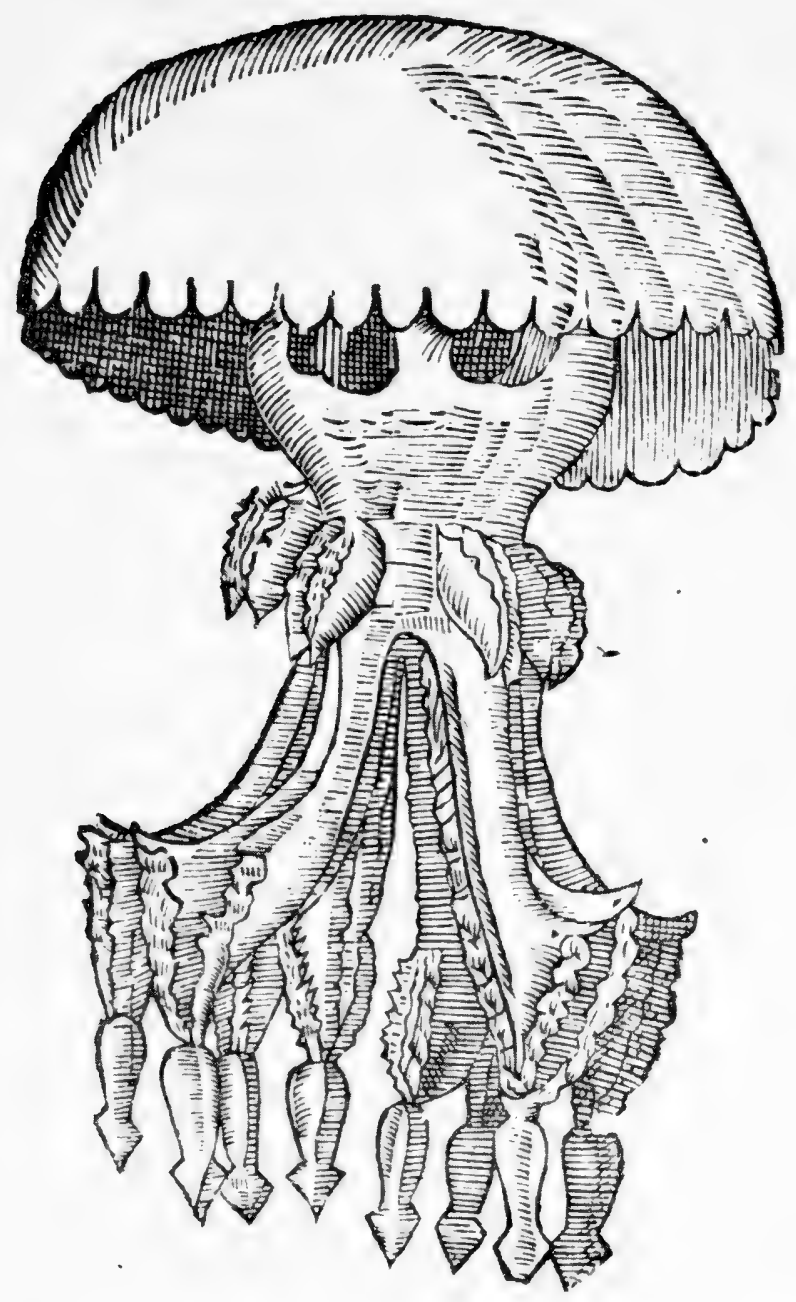

Fir. 3. A jellyfish, many of which are luminous, as ligured h! Alloorandi $(1606)$ 


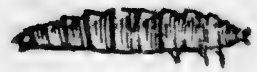

$\mathbf{Z}$
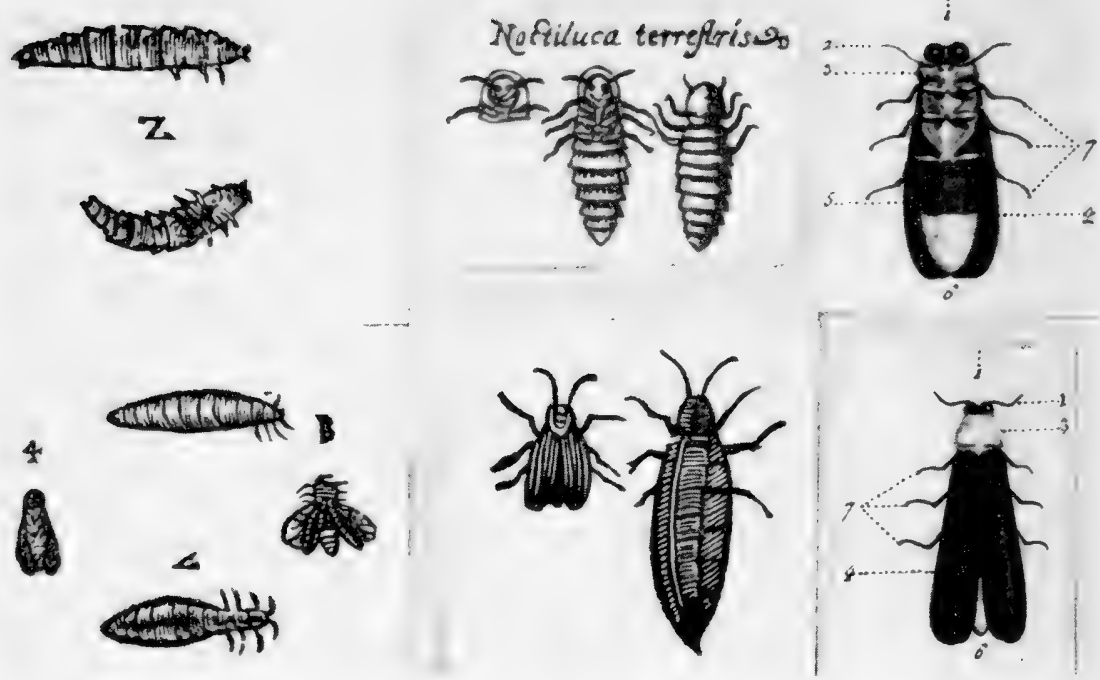

Fic. 4. Early drawings of creeping and flying glowrorms. Left, by Aldrovandi in De Animalibus Insectis, Libri JII (Bologna, 1602). Upper middle, by F. Columna in Aquatilium et Terrestrium Aliquot Animalium, atc. (Rome. 1616); lower middle, by Muffet in Insectormm sine Minimonum Animalium Thealrum (London, 1634). Upper right, the lucciole (ventral view); lower right, the same (dorsal view), both from Fougeroux de Bondaroy (1769).
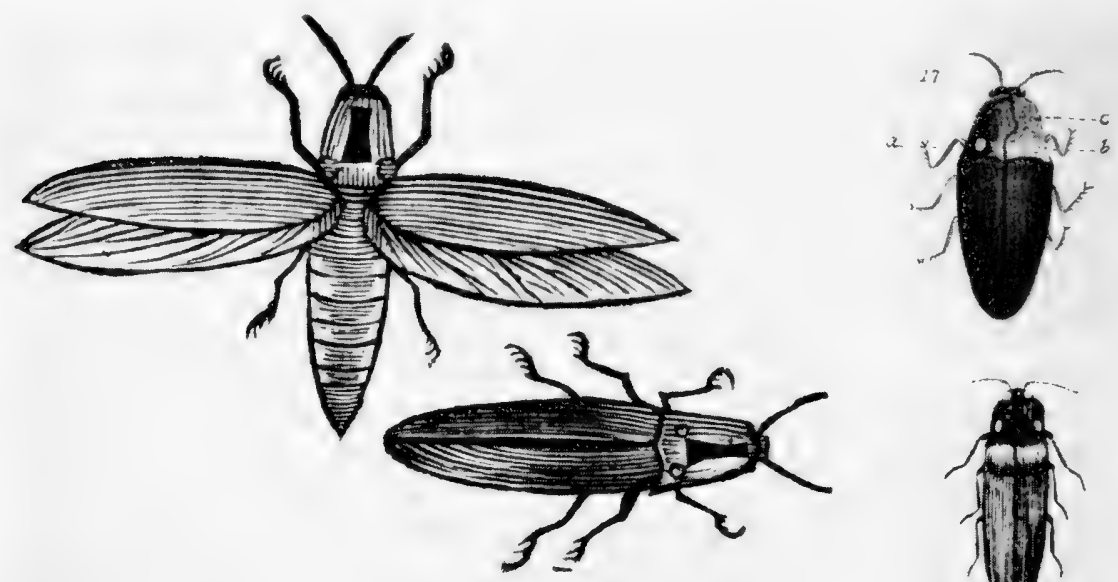

Fis. 5. Left, the first drawing of the cucuyo (the elaterid beetle, Pyrophorus) by Muftet (1634), said to have been copied from a water color brought from America by John White. Right bottom, the same insect, as illustrated by Hans Sloane in A Voyge to Jamaica (London, 1707). Right top. the reproduction of Macartner (1810). 
finally appeared in 1634 as Insectorum sive Minimorum Animalium Theatrum, by Thomas Muffet and others (see the next section).

The first important separate treatise on insects ${ }^{36}$ was Aldrovandi's De Animalibus Insectis, libri VII (Bologna 1602), with later editions in 1618, 1620, 1623, and 1638. Luminous forms are included in Chapters seven and eight of the fourth book, entitled "De Coccoio" and "De Cicindela," occupying eight pages (491-499) of the 1602 edition. All known facts regarding the firefly and glowworm are given, together with the statements of many different authors. The names by which these insects are designated in different countries, minute descriptions of various species, how they arise, their habits and nature, what they presage, riddles and epigrams concerning them, and uses of the insects for lighting, in medicine, and for fishing are included.

Indeed, the history of luminous insects revolves around the firefly and the glowworm. These small animals were discussed not merely by the scientist but frequently appeared in literature, prose and poetry, and also played a prominent part in the folklore and medicinal remedies of the time. The sixteenth century marks the beginning of rational inquiry concerning luminous beetles and for convenience in treatment considerable space will be devoted to the ideas regarding them, even though some earlier and some later quotations are included.

In addition to Aldrovandi and Muffet, the names of earlier writers, Georg Reisch (died 1525) and J. C. Scaliger (1485-1558) should be particularly mentioned, as giving important information. Scaliger was apparently the first to observe the copulation of fireflies and to see the young larvae which hatched from the egg (see the section on Muffet), while Reisch, as indicated below, discussed the origin of the light.

The most common Latin name for a lampyrid was "cicindela" (with various spellings) but "cantharis" was also used. It is interesting to note that these names now stand for non-luminous genera among the coleoptera, designating widely separated and wholly unrelated families, the tiger-beetles and blister-beetles.

In connection with the habits of the cicindelae, Aldrovandi wrote: ${ }^{37}$

This kind of insect has been endowed by a wondrous kindness of nature. For it does not harm man when touched or held in his hand.

${ }^{30}$ As part of the animal kingdom insects were included in all the general natural histories. See F. S. Bodenheimer (1928-1929) for much material on the history of insects.

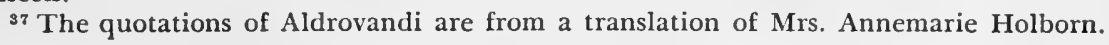


It does not attack him with its bite nor irritate or molest him by its sting when it encounters him. Frequently and avidly it flies towards candles and lights, the way the moths (papilio) do which we have treated above.

In a section on the nature of the light, he quoted Aristotle on smooth things that shine and Albertus Magnus on why the light is not extinguished by water, although the reasoning of Albertus is quite obscure. Aldrovandi favored the explanation of Georg Reisch, the German philosopher and Prior of Freiburg, who died in 1525. In a section on "Noctilucae" of his Margarita Philosophica (1st ed., 1496), Reisch had written as quoted by Aldrovandi: ${ }^{37}$

Glow-worms [noctilucae] are said to be visible at night, because they have an internal and inborn light by which they can be seen even in the darkness, the same way as putrid wood, little worms [vermiculi], ${ }^{38}$ or fish scales, and they have this light implanted from fire. For since such worms are without blood and are cold, fiery parts congregate around the place of digestion and shine there.

If this statement may be taken as a crude way of saying that glowworms, like other luminous organisms emit light as a result of an oxidation (a fire) taking place internally it is not far from the truth. Aldrovandi concluded: "Nature has given this light to the cicindelae on their hind part so that they can see in their nightly flight. To us, I admit, it seems very small, but it is sufficient for them to show them their way over the fields in their flight at night." 37

Under the heading "Varied Uses," Aldrovandi stated that one could write on paper with firefly juice, as had been done by Hadrianus Junius, "for whatever is written with this liquid in daytime, can easily be read at night." He apparently believed in the "liquor lucidus," to be described in a later section, and mentioned particularly the methods of Vitalis ${ }^{39}$ (Ad diver. morb. rem. cap 85), Gaudentius Merula (Memor, lib. 3, cap. 61) Baptista Porta and Mizaldus (Memora. Cent. 6) for making the luminous liquid. $\mathrm{He}$ also quoted Wecxerus (De Secre. lib. 3) as stating that "lampyrides that are boiled with a slow fire in a cupping glass produce a water suitable for catching fish." 37

The same general approach was adopted by Aldrovandi in his treatment of insects, as in his other works. The glowworm is illustrated by an original woodcut with six figures, the earliest scientific reproduction (1602) the author has been able to find of this historic insect (see fig. 4), although it appeared in an emblem of J. Camer-

${ }^{38}$ It is possible that luminous earthworms or centipedes are referred to (See Margarita philosophica, Lib. 10, trac. 2, C 10). This book was a small encyclopedia.

${ }^{89}$ Probably Vital du Four, who died in 1327. 
arius in 1597. Later writers, particularly Muffet and also Jonston, have made good use of Aldrovandi. Although Muffet cannot be accused (see fig. 4) of reproducing Aldrovandi's drawing of the glowworm in toto, much of the material is the same, and an excellent idea of what was known concerning this insect and other luminous "insects" (centipedes) in the sixteenth century can be obtained from his Theatre of Insects (1658).

Other writers of this period who mentioned fireflies in Europe were Bishop Simon Majolus (ca. 1520-1597) born in Piedmont, who wrote Dies Caniculares (Tomi VII 1 ed. Mogunt. 1600) with descriptions of insects (including the coccojo) and Adam Lonicer or Adamus Lonicerus (1528-1586), a German physician, who wrote Naturaliae Historiae Opus Novum, etc. published at Frankfort in 1551. He mentioned Cicindelae or "Joannes Kafer" among twelve other insects, spoken of as flying worms and described under "volatilibus" as was customary at that time.

Johann Thomas Freigius (died 1583), a Basel author, who published Questiones Physicae in 1579, also described cicindelae as "wingless Pygolampides which light from their hind parts and the winged, which blind the eyes at night with their splendor." Finally, Caspar Schwenckfeld (1563-1609), a Hirschberg physician, described the local fauna of Silesia in Theriotropheum Silesiae in quo Animalium, etc." Ligniciae, 1603. Among other insects he described a Cicindela, evidently a species of Phausis, as " a flying insect similar to Cantharides, with two luminous spots that light at night or in darkness. It appears on summer evenings in paths and meadows." The insect was called Pygolampis aquatica, Nitedula palustris, Cantharis aquatica, or Wasser Käferlin.

\section{THOMAS MUFFET}

The London physician, Thomas Muffet, Moffet, Mouffet, or Moufetus (1553-1604) was much younger than Aldrovandi and his interests in nature were more restricted. Muffet was closely associated in later years with Thomas Penny (ca. 1530-1588), also a physician, botanist, and entomologist, who had been asked by Gesner to complete a history of insects started by Edward Wotton (1492-1555). Both Muffet and Penny traveled extensively although independently in Europe. Using the collections of Penny and the notes of Wotton and Gesner, Muffet ${ }^{40}$ prepared a manuscript, first

\footnotetext{
${ }^{10}$ Muffet also wrote a book on diet, corrected and enlarged by Christopher Bennett and published in 1655 as Health's improvement, or rules comprizing and discovering the nature, method and manner of preparing all sorts of food used in this nation,
} 
finished about 1589 but later revised, which was not published until well after his death. Some of the final information came from Aldrovandi (1602), although he is not mentioned. The book appeared under four (Wotton, Gesner, Penny, Muffet) names in 1634 as Insectorum sive Minimorum Animalium Theatrum, and was translated by John Rowland as The Theatre of Insects in 1658, appearing at the end of E. Topsell's History of Four-footed Beasts and Serpents, the latter an adaptation of Gesner.

The Theatre has a definite medical slant throughout, with a special section on fireflies as remedies. It is poorly written but of value because Muffet collected and recorded all knowledge of the time concerning luminous insects, adding to the treatise of Aldrovandi. In the six pages of Chapter XV, "Of the Glow-worm," the Cucuyo (including the first drawing ${ }^{41}$ of the insect, reproduced as figure 5) and also centipedes (called Scolopenders or Juli) are described from the accounts of the early Spanish explorers (see Chapter II) . Compared with the meager description of Oviedo, Muffet left no doubt of luminescence in centipedes from the Old World. The accounts came from Gaudentius Merula ${ }^{42}$ (1500-1555) and from his friend, William Brewer. The latter twice found luminous Scolopendrae in England, once " in summer nights, of a shining fiery appearance, in heath and mossie grounds. The whole body shines something more darkly than a glow-worm," and again,

It once hapned that I came sweating home to my house at night, that I wiped my head in the dark with a napkin, the napkin seemed to me all over of a flaming fire; whereupon I wondered a while at this new miracle, all the lustre seemed to draw to one place, then folding the Napkin together, I called for a candle, and opening the cloth, I found such a Scolopendra, which I had rubbed against my head, and had caused this strange light like fire. ${ }^{43}$

Muffet paid the greatest attention to fireflies of various kinds. Like Aldrovandi, he faithfully recorded the names by which these insects were known in different countries, ${ }^{44}$ the opinion of various

London. He also wrote three books on medicine, and a poem, The silkworms and their flies; lively described in verse by T. M. a countrie farmar (1599), is ascribed to him.

${ }^{41}$ According to C. E. Raven, English naturalists from Neckam to Ray (Cambridge, 1947: 182) Muffet's figure of Pyrophorus came from a water color drawing of John White, who sailed with Sir Richard Grenville for Virginia in 1585. Muffet (1658: 978) mentioned no name but reported that the figure was by "a most skillful painter, who had taken strict observation of it both in the lesser Spain and in Virginia."

${ }^{42}$ Lib. 3, Memor. c. 61. Merula wrote on Italy, for example De Gallorum Cisal. pinorum antiquitate ac origine, Ludguni, 1538.

${ }^{43}$ The theatre of insects, $979,1658$.

44 A long list of local French names will be found in Eugène Rolland, Faune populaire de la France 3: 181-183, 1881. 
writers regarding them, their habits, their structure (with illustrations), whether they light after death, their uses as medicine and the superstitions and poetry regarding them.

Concerning European glowworms Muffet, after giving the name in various languages, wrote:

In English, Glow-worm, Shine-worm, i.e. a glissening or shining worm. For here, as also in Gasconia, the male or flying Glow-worm shines not, but the females which are meer worms. On the other side in Italy, and in the County of Heidelberg, the females shine not at all, and the males do. I leave the reason to be discussed by Philosophers.

His drawing is reproduced in figure 4.

Then follows a detailed description of both male and female in which Mouffet disagreed with Pliny that the light always appeared during flight. He also emphasized the fact that dead glowworms do not light.

Those parts [of the abdomen] that are white do glitter in the dark with a wonderful splendor, representing terrestrial stars: insomuch that they may seem to contend with candle or moon light. This is worthy observation, that that so bright lustre expires with the life; where then is that perpetual light which some foolish naturalists so foolishly and impudently prate of? ... They feed upon herbs, they continue long in copulation, as Julius Scaliger 45 (a great Philosopher of our times, not behinde any of the Ancients) hath diligently observed.

Muffet also took exception to Cardanus' statement that the Cicindeles come from the Crabrones (wasps) and held that "Baptista Porta ${ }^{46}$ and Hesychius ${ }^{47}$ were grossly mistaken who ascribe their origin to the dew or tow." J. Scaliger had seen a female lay eggs "which within the space of twenty hours went away alive."

However, it is in relation to medical use that Muffet related much of interest. He wrote:

Neither do they only please the eye, and instruct the minde, but they are good for the body in divers diseases, for the female Cicindele being put into the matrix of the mule, causeth the woman that bears childe with much danger, to be barren; saith Kiranides. ${ }^{48}$ Cicindeles being

${ }^{45}$ Julius Caesar Scaliger (1485-1558), the physician, scholar and poet, who wrote De causis linguae Latinae (1540) and Exotericarum exercitationum, etc. (Paris, 1557), in which the mating of fireflies is described in exercise 191, sec. 2.

${ }^{48}$ Giambattista della Porta (ca. 1541-1615), the natural philosopher of Naples.

${ }^{47}$ Author of a Greek lexicon of uncertain date, but written since the Christian era began, first printed in 1514. Aristotle had written in Historia animalium (V, 551A): "Other insects are not derived from living parentage, but are generated spontaneously, some out of dew falling on leaves. ..."

${ }^{48}$ A work of doubtful date and authorship on the medicinal virtues of plants and animals, supposed to be a Greek translation of an Arab manuscript. 
drank in wine make the use of lust not only irksome but loathsome, as Benedictus $^{49}$ saith; the same also Gilbertus ${ }^{50}$ an English Physician, Albertus, ${ }^{51}$ Nicolaus, ${ }^{52}$ Florentinus, ${ }^{52}$ and Rhasis ${ }^{53}$ do confidently affirm. It were worthily wisht therefore that that unclean sort of Letchers were with the frequent taking of these in Potion disabled, who spare neither wife, widow nor maid, but defile themselves with lust not fit to be mentioned. Rhasis saith that the Glow-worms are very good for the stone, if beaten with oil, and therewith the place having the hair clipt off, be anointed, which will never suffer it to grow afterwards. Bairus. If they be beaten and put behinde the ears, they will divert and evacuate all Rhumes ${ }^{54}$ falling into the eyes and teeth. Anonymus.

\section{Liquor Lucidus}

Beliefs concerning the firefly before 1600 should not be dismissed without an account of a miraculous liquid, "liquor lucidus," or "liquor cicindelarum," allegedly prepared from flying or creeping glowworms. The story of its existence and preparation goes back at least to Albertus Magnus (1193-1280) and undoubtedly had its origin in the alchemy of the Dark Ages (see Chap. II). It was believed in by Paracelsus (?1493-1541), Cardanus (1501-1576), Levinus Lemnius (1505-1560), ,55 Gaudentius Merula (1500-1555) ${ }^{56}$ and many others. Giambattista della Porta (1541-1615) actually boasted of lighting houses with the liquid in his Magia Naturalis, libri IV (1558).

A large number of receipts, differing in detail were published. The two commonest methods of preparation involved burying the luminous organs in manure, or mixing them with quicksilver, with or without distillation. Again Muffet has recorded the procedures in his Theatre of Insects (1658). He wrote:

Some there are which take a great many Glow-worms, beat them together, put them into a vial of glass and bury them fifteen daies in

49 Possibly John Benedictus, a Polish physician, who wrote in 1530.

${ }^{50}$ William Gilbert (1540-1603) who wrote De magnete (1600).

51 Albertus Magnus. Theodosius (1553) also considered the matter.

${ }^{52}$ Although there is a comma between Nicolaus and Florentinus in Muffet's Theatre of insects (1658), he probably referred to Nicolaus Florentinus (Nicolo Falcucci, died 1412) who wrote Sermones medecinales (1484).

${ }^{53}$ Ar-Rãzi or Rasis or Razes (died 930), an Arab physician, physicist, and alchemist, who practiced at Bagdad, and traveled extensively.

5s Rhumes, watery matter secreted by mucous membranes and supposed to cause disease, now archaic.

${ }^{55} \mathrm{De}$ miraculis occultis naturae, libri IIII. Coloniae Agrippinae, 1581 (lst ed. Antverpiae, 1559). Lemnius was a physician of Zeeland, who wrote on occult matters.

${ }^{56}$ Merula said, "Of these glow-worms being putrified there is made a water, or a liquor rather, in a vessel which will wonderfully shine in the dark" (Muffet, 1658: 979). Merula is best known as a writer on Cisalpine Gaul. 
horse dung. Afterwards they distil them through an Alembick, and keep the water in a clear glass. ... Others ... together with Glow-worms, digest the gall of Tortoises, of a Weasel, and Sea-dog, puting them in dung, and afterwards they distill them. This water they say far excels all other whatsoever in lustre. Others put whole Glow-worms in dung for nine daies to digest, others for three weeks, then throwing away the Glow-worms, they take the fat of them and keep it in a clean glass for to use. Some yet more fondly take Glow-worms, and casting away their heads, they put to them the scales of fishes, and rotten shining wood, such as glistens in the dark, with the gals of Sea-dogs, and so distill them through an Alembick. Others promise confidently to make letters to shine in the dark, by pricking out the yellow moisture of the Glow-worm, and anointing therewith the paper, or painting it with the same liquor in form of a star, some rub them with the oyl of Linseed upon marble, and whatsoever you shall paint or write, they perswade us, may easily read in the night, be it never so dark; but let them believe them that have made the trial. Others after they have digested in horse-dung nine daies, take the liquor that is left in the bottome of the glass and write with it, and so think confidently to obtain their desire. John Arden, ${ }^{57}$ a skilful Chirurgeon, an English man, walking after their steps, above thirty years ago left such a description of this perpetual light in writing: He gathered a great number of Glow-worms, and shuts them in a glassen vessel well stopt, laies them in dung fifteen daies, then puts the water he findes in the bottome of the glass into a clean glass; to which he adds as much of Quicksilver, the dross being purged from it, and then he saith you must shut the glass mouth very close, and hang it where you will, and then for certain (as he affirms) it will produce the wished effect. Some have told me that this is very true, whom notwithstanding I will not believe untill such time as the experiment be made before mine eyes. These and many the like you may finde by reading, but what credit may be given to them is easily conjectured out of what went before. Hence then we may plainly understand how foolishly and vainly mans wisdome doth many times vaunt it self, and whither our wits may be carried, if not founded upon right Reason, the mistress of all Arts and Sciences, shunning with all diligence the uncooth rocks of opinion and self conceit.

It is to the great credit of Muffet, and later of Athanasius Kircher (1601-1680), Sir Thomas Browne (1605-1682), and Robert Boyle (1624-1691) that they regarded ${ }^{58}$ the story of a glowworm liquor as a myth, which it certainly was, for the light of these insects disappears quickly when the luminous organs are macerated with water. ${ }^{59}$ As Muffet pointed out, if glowworms

57 Probably John of Arderne (1306-1390), who practiced at Newark and London. He is regarded as the first English army surgeon.

${ }^{58}$ See Chapter IV for Kircher and Boyle's views.

${ }^{50} \mathrm{~J}$. C. Scaliger was another who scorned the stories. In his polemic of 1557 against 
be but put into a clear Crystal glass, so that the air may freely come at them, with a little grass, they may perchance give light for the space of some 12 dayes, if every day fresh grass be put to them; but at the length as they languish and faint away, so the light by little and little is remitted and slackned, and in the end they dying (as before is said) it is totally extinguished.

\section{Perpetual Lamps}

The idea of a liquor liquidus prepared from fireflies is possibly the outgrowth of one of the unfulfilled goals of the alchemists, a perpetual lamp. ${ }^{60}$ Such lamps ${ }^{61}$ were mentioned in prose and poetry and widely believed in during the fifteenth and sixteenth centuries. The ancients were said to have the secret of such lamps, used in tombs, and that they burned until someone opened the tomb and let in the air, when they went out. Fortunio Liceti (1577-1657) published a whole book on the subject, De Lucernis Antiquorum Reconditis (Venice, 1621; Utini, 1652).

As late as 1684, Robert Plot (1640-1689) published ${ }^{62} A$ Discourse Concerning the Sepulchral Lamps of the Ancients, showing the possibility of their being made divers Waies. His paper is of interest because he invoked luminescence as a possible source of the light. One of the "waies" was a "weik" of asbestos (" linum asbestinum, earth flax or salamander's wooll") and crude petroleum (" naphta or liquid bitumen"), but Plot also suggested that phosphorus might have been used in a way he had observed during experiments of his "worthy Friend, Frederick Slare, M. D." All sepulchral lamps were not described as going out when a tomb was opened, and Plot consequently thought the lamps might not be "inkindled" in the tomb but begin to light when exposed to the air, just as phosphorus in an evacuated glass phial glows when the air is let in. Phosphorus was regarded as such a miraculous substance in the late seventeenth century that Plot's explanation may have seemed plausible at that time.

Shining wood is another possibility. A light in any tomb or grave constructed of wooden parts might come from luminous fungi

Cardan (Exotericarum exercitationum, 194) he wrote: "If you use the cicindelae as an example that a liquid can be artifically devised and prepared that shines in the dark, it seems you can impose the light that has been brought down from heaven into matter, like a captive rower into a trireme, and hold it in chains."

${ }^{\circ 0}$ The perpetual fires of the temple of Attush Kudda, near Baku on the Caspian Sea, were undoubtedly due to the abundant petroleum of this region. Petroleum or natural gas were fuels for many "eternal fires."

${ }^{61}$ See B. H. Carrington, Legends of sepulchral and perpetual lamps. Monthly (Quarterly) Journal of Science 1: 715-123, 1879.

${ }^{82}$ R. Plot, Phil. Trans. 14: 806-811, 1684. 
growing on the wood. Such growths would dry up when exposed to the air and the light would disappear. One such case has actually been described by DuPuget, ${ }^{63}$ who saw in the catacombs of Rome that " the dust [Staub] in a rectangle about a decayed human body was so phosphorescent that it produced a noticeable light in the upper part of the grave. The phosphorescence lasted some months." However, shining wood as a sepulchral lamp seems rather far fetched, and many authors began to question the existence of perpetual light.

\section{Strange Lights}

The belief in a luminous liquid or a perpetual lamp merely reflects the much more general tendency to accept any strange tale as true. Many of these tales had to do with what were commonly known as meteors, well described in a book of William Fulke (15381589), a Doctor in Divinitie, in 1563. The first edition was entited, $A$ Goodly Gallerye with a most pleasaunt Prospect, into the garden of Naturall Contemplation, io behold the naturall causes of all kynde of Meteors, as wel fyery and ayery, as watry and earthly, etc. (London, 1563). The following excerpts are taken from a 1640 edition, called Meteors, etc. by W. F.

Fulke first explained that:

The meteors are divided after three manner of wayes: First, into bodies perfectly and imperfectly mixed: Secondly into moist impressions and drie: Thirdly into fiery, airy, watery and earthy. ... [The first three] are called imperfectly mixed because they are very soon changed into another thing, and resolved into their proper elements of which they doe most consist ... as snow into water, clouds into waters, etc. ... earthy meteors are called perfectly mixed, because they will not easily be changed and resolved from that form they are in, as be stones, metalls, and other minerals.

The Aristotelian influence appears in Fulke's explanation of the cause of the various phenomena. Concerning the material cause of meteors,

The matter whereof for the most part meteors doth consist, is either water or earth: for out of the water proceed vapors, and out of the earth come exhalations.

Exhalations ... because they be thinne and lighter than Vapours, passe the lowest and middle Region of the aire, and are carried up even to the highest Region, where for the excessive heat, by neerness of the fire, they are kindled and cause many kinds of impressions: They are

${ }^{\text {e3 }}$ Cited without a reference by J. L. M. Poiret in a footnote to p. 501 of "Uber den pyrituosen Torf" (Ann. der Physik 14: 469-510, 1803). 
also sometimes viscose, that is to say, clammy, by reason whereof, they cleaving together and not being dispersed, are after divers sorts set on fire, and appear sometimes like Dragons, sometimes like Goats, sometimes like Candles, sometimes like Spears.

The goats, candles and spears are manifestations of the aurora borealis.

Continuing, Fulke wrote:

The efficient cause of all Meteors is that cause which maketh them; even as the carpenter is the efficient cause of a house... . The first and efficient cause is God the worker of all wonders ... [for] fire, haile, snow, ice, wind and storms, doe his will and commandment; ... The second cause efficient, is double, either remote, that is to say, farre off or next of all.

Fulke then proceeded to explain that the sun is a far-off cause but that " the next cause efficient as the first qualities are heat and cold, which cause divers effects in Vapors and Exhalations."

There were also "lights that goe before men, and follow them abroad in the fields, in the night season." They are called "ignis fatuus " if observed on land, and "Helena," or, when two together, "Castor and Pollux," when observed at sea, i. e. examples of St. Elmo's Fire.

Like the alleged supernatural feats of magicians and sorcerers, all strange lights such as ignis fatuus or ignis lambens were grouped together as works of the devil. Few men of the sixteenth century had the conviction or the courage to explain such phenomena by natural means. Johann Wier (1515-1588) was an exception. Born in Brabant and physician to the Duc de Cleues, he wrote several books on sorcery, one of which ${ }^{64}$ was finished in 1577 and published in a French tranlsation in 1579 as Histoires Disputes et Discourse des Illusions et Impostures des Diables, des Magiciens Infames, Sorcieres et Empoisonneurs, des Ensorcelez et Demoniaques et de la Guerison d'Iceus; etc.

Wier made the attempt to explain supernatural things by activities of " mother nature." As a physician, Wier laid stress on influences at work on the mind and body of man, but in a section, Book I, Chap. 18) entitled "On estime quelquefois que les choses naturelles et artificielles soyent ouures des diables," he attempted to show that the ignis fatuus (feu folet) and ignis lambens (feu lechant), as well as other natural luminescences had a physical explanation. He wrote:

${ }^{04} \mathrm{~A}$ reprint was issued in 1885 by the Bureaux du Progrès Médical, as part of the Bibliotheqque Diabolique. The translator is not mentioned. Wier's works appeared as Opera omnia at Amsterdam in 1660. 
Many things present themselves to our eyes which, appearing to be more than natural are considered illusions or works of the devil, although for certain very evident causes and reasons, nature, mother of all things, has produced them; among these is the "feu folet," called "un ardant," which is an exhalation emanating from the earth into the lower regions of the air, where it is ignited by "antiperistase," because in rising it is repelled by the cold of the middle region. ...

Of the same kind is the "feu lechant" which licks the mane and hair of animals and the garments of persons, because it is an exhalation diffused from the body, which, coming to meet and strike a similar one in the air, it ignites. Such fires, burning without damage, are perceived the more often in humid, clammy, decaying, marshy and fuming places, as in the neighborhood of kitchens, valleys, cemeteries, under gibbots and where one lets dead bodies decay: because these places exhale fatty fumes thick and viscous, but not warm enough to ascend to the higher regions of the air: but in ascending continuously they [the effluvia] ignite in meeting like fire issuing from two pebbles struck one against the other.

Wier continued with a discourse on luminous plants, quoting Gesner, and he referred to the glowworm as producing the same kind of light. The word " antiperistasis," used to explain the "feu folet" and the "feu lechant," refers to the meeting of two contrary qualities as a result of which one is intensified. The warm emanation of the earth or of an animal body coming in contact with the colder air above actually kindles the two, giving rise to visible light. Many other observations of ignis fatuus and lambens were recorded during the fifteenth and sixteenth centuries but the state of knowledge was such that no electrical origin could have been proposed.

Allied to ignis fatuus in the minds of the people were lights in the heavens. The fifteenth and sixteenth centuries had their regular displays of the aurora borealis. It is interesting to note that Gesner recognized the aurora as a luminescence, and included it in his book on that subject, De Lunariis (1555). Conrad Lycosthenes (Wolffhart) (1518-1561) has listed many in his Prodigiorum ac Ostentorum Chronicon (Basel, 1557), a large book profusely illustrated with woodcuts of double-headed human beings and animals of monstrous and bizarre form. It was translated as The Doome Warning all Men to the Judgements (1581) by S. Batman, Professor in Divinitie.

The English edition is a remarkable compilation, "Wherein are contayned for the most parte all the straunge Prodigies, hapned in the Worlde with diuers secrete figures of Reuelations tending to mannes stayed conuersion towards GoD: In manner of a generale Chronicle gathered out of sundrie approued Authors." The wood- 
cuts of strange animals and double-headed human monsters of all kinds have been retained. Many of the omens appeared simultaneously-a comet and a "boy with two legges" or "At London in Englande trees seemed to be a fire. At Yorke fountaines ranne bloude. In Kent a Boye laughed in hys mothers belly." Earthquakes, plague, cloudes of grasshoppers, streams of bloude and rayned stones are all recorded, together with the occasions when "the skie was seene to burne" or "the Elemente seemed to burne" or "a burning torch was seene in the Elemente." Such prodigies were displays of the aurora, many of them taken from the records of Julius Obsequens (see Chap. I). Lycosthenes apparently believed the bands of the luminous arc of an aurora were the tails of comets, whose heads were below the horizon.

Another chronicler of the period and a particularly trustworthy one, according to de Mairan (1733), was Cornelius Gemma the Frisian (1535-1577), an astronomer and a famous M. D. of Louvain, son of Reinier Gemma (1508-1555), also a physician. In his two books, De Divinis Naturae Characterismis (Antwerp, 1575) and De Prodigiosa Specie utraque Cometae anni 1577 cum adjuncta explicatione duorum chasmatum anni 1575 (Antwerp, 1578), he recorded the important displays of the sixteenth century in great detail, ${ }^{65}$ describing one as like "a great eagle suspended in air by balancing its extended wings directed from east to west," and another as resembling balls of fire (ignium globas ... nubium ... specie rotundos).

\section{Shining Flesh}

Another of the remarkable phenomena which excited the interest of the learned in the sixteenth century was the light which occasionally appeared on fish or flesh, now known to result from the growth of luminous bacteria. It is possible that these bacteria were responsible for the luminous fish, Orthogoriscus, mentioned by Rondelet. George Reisch (second half fifteenth century), the German savant, wrote in Margarita Philosophica (1496) that "Fish in their scales comprehend some fiery parts, and by that they shine." This statement is probably a repetition of Aristotle, but it seems quite certain that at least two other writers saw colonies of luminous bacteria growing on fish or meat.

In 1557 Cardanus (Girolamo Cardano, Jerome Cardan, 15011576) reported in De Rerum Varietate (1557:26) that he had seen the light of dead sea fish during a visit to Scotland in 1552 to attend John Hamilton, Archbishop of St. Andrews, who was ill with tuber-

${ }^{65}$ See de Mairan, 1733: 181-186. 
culosis. Cardan, professor of mathematics at Milan, a physician, astrologer, and philosopher, was one of the most unusual men of the Renaissance, and it is unfortunate he did not pay more attention to luminescence. There is little on this subject in his two most important publications. De Subtilitate Rerum (1551) and De Rerum Varietate (1557), which contain his philosophical writings.

Luminous fish are also mentioned in an early work of Giambattista della Porta (1538-1616), the Magia Naturalis libri IIII, published at Naples in 1558 when he was only twenty years old. However the observation was not original with Porta, who was merely eager to extol "the things which plentiful and lavish nature lends so liberally to human usage, even the secret and hidden ones ... that impress our senses at night," ${ }^{66}$ and show their benefit to mankind. He listed the various luminescences known to the ancients, such as glowworms, fungi, scales of fishes, pholads, the milvas (gurnard, a species of Trigla, "called lucerna ${ }^{67}$ because its eyes shine at night"), trunks of rotten oaks, etc., as well as "sea water, gleaming with fiery sparks, which has been stirred by hands." Porta then gave as an example of the use of such things his famous formula for the preparation of a luminous liquid from the firefly and declared that a similar liquid, "which we have often seen being separated," could be made from the scales of fishes.

In 1589 Magia Naturalis libri IIII was expanded to libri XX and wholly changed, with less occult and superstitious matter. The twenty books appeared in many later editions and languages, including an English Natural Magick in Twenty Bookes (London, 1658). There is no mention of luminescences in this edition.

The other famous reference to luminous flesh is contained in the writings ${ }^{68}$ of Girolamo Fabrizia (Hieronymus Fabricius ab Aquapendente, 1565-1619), pupil of Vesalius and teacher of William Harvey (1578-1657). An account taken from Fabricius is given by Joseph Priestley in The History and Present State of Discoveries Relating to Vision, Light and Colours (1772: 563). Priestley wrote:

When three Roman youths, residing at Padua, had bought a lamb, and had eaten part of it on Easterday 1592, several pieces of the remainder, which they kept till the day following, shone like so many candles, when they were casually viewed in the dark. Part of this luminous flesh was immediately sent to Aquapendente, who was pro-

${ }^{68}$ The quotations are from a translation by Mrs. A. Holborn.

${ }^{67}$ The "lucerna piscis" of Pliny (see Chap. I) may have been the gurnard. $R$. Dubois has called attention to the "pseudoluminescence" of this fish, a reflection of light from the tapetum of the eye (Com. Rend. Ac. Sci., Paris, 178: 1030-1032, 1924). ${ }^{68} \mathrm{De}$ visione sive de oculto visus organo bound with $\mathrm{De}$ voce and $\mathrm{De}$ auditu, Chap. 4, pp. 43-45, Venetiis, 1600. 
fessor of anatomy in that city. He observed that both the lean and the fat of this meat shone with a whitish kind of light, and also took notice that some pieces of kid's flesh, which had happened to have lain in contact with it, was luminous, as well as the fingers, and other parts of the bodies of those persons who touch it. Those parts, he observed, shone the most which were soft to the touch, and seemed to be transparent in candle light; but where the flesh was thick and solid, or where a bone was near the outside, it did not shine.

Fabricius also quoted Aristotle, mentioning the heads, scales, and eyes of fishes, fungi and Sepia, which "shine at night, sometimes to no purpose, as though crushed and stifled by the aforesaid light of day." He regarded them as lights similar to the innate light of the eye (lumine insito) observed in animals which see at night, i. e. the cat, whose eyes appear to glow in the dark, and stated that those creatures which lacked the glowing eye were unable to detect objects in darkness.

The story of the luminous mutton has been repeated many times by various authors but in the writings of William Harvey (15781657) who arrived in Padua as a pupil of Fabricius about 1597, some time after the event, there appears to be no reference to luminous meat or any kind of luminescence. Other examples of shining flesh were to receive much attention and comment in the next century.

Superficially allied to shining meat was the luminous medusa or "Pulmone marino," included in an Italian book of marvels, $L a$ Miniera del Mondo, by Gio M. Bonardo and published at Venice in 1585. The statement is similar to that of Pliny that " the jelly-fish rubbed on a stick renders it luminous, like a lighted torch."

\section{Summary}

Progress in the study of luminescence in the fifteenth and sixteenth centuries may be summed up in a few words. From the death of Pliny to 1400 , no new luminous phenomena were discovered. During the fifteenth and sixteenth centuries, knowledge of the ancients was still copied but became much better known and many of the statements were confirmed by actual observation. Little progress was made in rectifying mistakes or in interpretation. A number of new luminous animals were discovered. The existence of the railroad worm, luminous centipedes, and the luminous elaterid beetles of the New World became well established, and the sparkling of the sea pen recognized. Knowledge was collected in the works of the great naturalists. The diffuse phosphorescence of the sea, often referred to as a "white sea" at night, was frequently described, 
but its explanation remained wholly obscure. Among inorganic luminescences the stories chiefly concerned luminous gems. The Bolognian phosphor had not yet been discovered, and nearly a century must elapse before the element phosphorus would become available to those who could afford it. Nevertheless, many facts had been accumulated. The scene was set for the great investigators of the seventeenth century and the start of Science as known today.

The end of the sixteenth century, the time of Shakespeare (15641616) and Queen Elizabeth (1558-1603), of Sir Walter Raleigh (1552-1618) and the Spanish Armada, is also famous for the names of William Gilbert of Colchester (1540-1603), physician to Queen Elizabeth, Francis Bacon, Baron Verulam (1561-1626), and Galileo Galilei (1564-1652). All three men adopted the scientific method. Neither Galileo nor Gilbert studied luminescence although each became leaders in their field. Gilbert's De Magnete (1600) marks the beginning of research in magnetism and electrical attraction, and Galileo's studies cover many fields.

Of the three men, Bacon paid most attention to luminescence. Like Galileo, Bacon actually bridges the two centuries. Although born in the sixteenth and endowed with a spirit of intellectual revolt, his early life was so unstable that only in the seventeenth century did he have the leisure to set down his ideas in writing. Bacon's many remarks on luminescence will make a fitting beginning for the seventeenth century which was to see the investigation of luminescences carried on in an extensive and logical manner. 


\section{THE SEVENTEENTH CENTURY}

\section{Introduction}

$\mathrm{T}$ THE SEVENTEENTH CENTURY is sometimes called the Insurgent Century or the Century of Genius; certainly it was an Age of Inquiry. At this time actual search for the causes of luminescence, as contrasted with mere record of the existence of the phenomena, made a valiant start, largely as a result of Francis Bacon's influence. No better evidence of the success of the new approach in science can be found than a statement of John Dryden (1631-1700), made in 1668 during the height of the change:

Is it not evident, in these last hundred Years (when the Study of Philosophy has been the business of all the Virtuosi in Christendom) that almost a New Nature has been revealed to us? that more Errors of the School have been detected, more useful Experiments in Philosophy have been made, more noble Secrets in Optics, Medicine, Anatomy, Astronomy, discovered, than in all those doting Ages, from Aristotle to us? So true it is, that nothing spreads more fast than Science, when rightly and generally cultivated."1

Despite the boasting of John Dryden, a few authors continued the obscure phraseology and mystical philosophy of the previous centuries. One of them was Robert Fludd or Flud (Robertus de Fluctibus, 1574-1637) the physician, whose many works contain a remarkable combination of scientific observation and religious interpretation. A second was Eugenius Philalethes (Thomas Vaughan, 1622-1666), another English mystic who continued the secret tradition of the alchemists. His last work was $A$ Brief Natural History, intermixed with variety of Philosophical Discourses ... with Refutation of such Modern Errours as our Modern Authors have omitted (London, 1669). Vaughan's book contains many references to the Bible and quotes from Aristotle and Pliny. There is no mention of luminescence, but his general attitude is exemplified by a remark concerning light, to which he attributed " a Masculine vertue, it quickens all kinds of Seeds, it makes them vegetate, blossom and fructifie. ..."

It is fortunate that many men, imbued with a philosophical attitude and a rational and experimental approach were to follow, and

${ }^{1}$ John Dryden, An essay of dramatic poesy, 1668. Works 1: 22, London, 1717. 
that their interests should turn to such subjects as heat, fire, light, and color. Well-known students of optical phenomena, like Gassendi (1592-1655), Descartes (1596-1650), Kircher (1602-1680), Grimaldi (1618-1663), Boyle (1627-1690), Huygens (1629-1695), Hooke (1635-1703), and Newton (1642-1727), lived the productive part of their lives in the seventeenth century, and most of them were familiar with luminescences of all kind. The phraseology and terminology of these men was sufficiently modern for ready comprehension. Symbolism and mysticism were rapidly disappearing. It is, therefore, appropriate to begin the history of luminescence during this century with the man most responsible for the change, Francis Bacon (1561-1626).

\section{Francis Bacon}

At the beginning of the seventeenth century the distinction between organic and inorganic luminescences was not clearly drawn, but a surprising number of luminous bodies were recognized. The first adequate enumeration of low temperature light emissions is to be found in Francis Bacon's discussion ${ }^{2}$ of light, in a manuscript which deals with that subject alone, "Topica Inquisitionis de Luce et Lumine," written before 1612. The first section, which is an excellent example of his approach to natural phenomena, discusses sources of light:

We have first to note which are the substances, of whatever kind, that generate light; as stars, fiery meteors, flame, wood, metals, and other burning bodies, sugar in scraping or breaking it, the glowworm, the dews [drops] of salt water when it is agitated or scattered, the eyes of certain animals, some sorts of rotten wood, large quantities of snow; perhaps the air itself may possess a weak light adapted to the vision of the animals which see by night; iron and tin, when put into aqua fortis to be dissolved, boil, and without any fire produce intense heat, but

\footnotetext{
${ }^{2}$ Bacon's sources of information were largely Aristotle, Pliny, Albertus Magnus, Jerome Cardan, and Arab writers. His estimation of them in The advancement of learning (1605) is quite frank: ". . . in natural history, we see there hath not been that choice and judgment used as ought to have been; as may appear in the writings of Plinius, Cardanus, Albertus and divers of the Arabians; being fraught with much fabulous matter, a great part not only untried, but notoriously untrue, to the great derogation of the credit of natural philosophy with the grave and sober kind of wits. Wherein the wisdom and integrity of Aristotle is worthy to be observed; that having made so diligent and exquisite a history of living creatures, hath mingled it sparingly with any vain or feigned matter; and yet on the other side hath cast all prodigious narrations which he thought worthy the recording into one book; excellently discerning that matter of manifest truth, such whereupon observation and rule was to be built, was not to be mingled or weakened with matter of doubtful credit; and yet again that rarities and reports that seem uncredible are not to be suppressed or denied to the memory of men."
} 
whether or not they give out any light demands inquiry; the oil of lamps sparkles in very cold weather; a kind of faint light is sometimes observed in a clear night around a horse that is sweating; around the hair of certain persons, there is seen, though rarely, also a faint light, like a lambent flamule, as occurred to Lucius Martius in Spain; there was lately found an apron of a certain woman which was said to shine, yet only when rubbed; but it had been dyed in green, of which dye alum is an ingredient, and it rustled somewhat when shining. Whether alum shines or not when scraped or broken is matter of inquiry; but, I suppose, it requires more violent breaking, because it is firmer than sugar. In like manner, some stockings shine whilst you are pulling them off, whether from sweat or the dye of alum. ${ }^{3}$

In discussing the "Colours of Light" (section 4), Bacon wrote: "No green flames are observed: what most inclines to greenness, is that of the glow-worm."

Regarding "Cognations [resemblances] and Hostilities [antagonisms] of Light" (Section 12) Bacon wrote:

Light, as far as regards its production, has most of all cognation with three things, heat, tenuity, and motion. ... The flame of spirit of wine or of an ignis fatuus, has a much feebler heat than red-hot iron, but a stronger light. Glow-worms and the dews of salt water, and many of the things which we mentioned throw out light, yet are not hot to the touch. ...

But hostilities of light, or privations, if any like the term better, occur not. However, as is exceedingly probable, the torpor of bodies, in their parts, is very inimical to light. For almost nothing gives light that is not in its own nature remarkably mobile, or excited by heat, or motion, or vital spirit.

In the Advancement of Learning (1605), luminescences were again mentioned, in connection with a discussion of light and the human soul and sensation. Bacon wrote: ${ }^{4}$

And men ought to lower their contemplations a little, and inquire into the properties common to all lucid bodies, as this relates to the form of light; how immensely soever the bodies concerned may differ in dignity, as the sun does from rotten wood, or putrefied fish. We should likewise inquire the cause why some things take fire, and when heated throw out light, and others not. Iron, metal, stones, glass, wood, oil, tallow, by fire yield either a flame, or grow red-hot. But water and air, exposed to the most intense heat they are capable of, afford no light, nor so much as shine. That it is not the property of fire alone to give light; and that

\footnotetext{
${ }^{3}$ Topics of inquiry concerning light and the matter of light. In Basil Montague, Esq., The works of Francis Bacon 15: 82-87, London, 1834.

- Book IV, Chap. 3, p. 131, Edition of J. E. Creighton, London and New York, The Colonial Press, 1900.
} 
water and air are not utter enemies thereto, appears from the dashing of salt-water in a dark night, and a hot season, when the small drops of the water, struck off by the motion of the oars in rowing, seem sparkling and luminous. We have the same appearance in the agitated froth of the sea, called sea-lungs. ${ }^{5}$ And, indeed, it should be inquired what affinity flame and ignited bodies have with glow-worms, the Luciola, the Indian fly [Pyrophorus], which casts a light over a whole room; the eyes of certain creatures in the dark; loaf-sugar in scraping or breaking; the sweat of a horse hard ridden, etc. Men have understood so little of this matter, that most imagine the sparke, struck betwixt a flint and steel, to be air in attrition. But since the air ignites not with heat, yet apparently conceives light, whence owls, cats, and many other creatures see in the night (for there is no vision without light), there must be a native light in air; which, though weak and feeble, is proportioned to the visual organs of such creatures, so as to suffice them for sight.

The relation between light, heat, and flame must have presented many perplexities, for it is again discussed in the Novum Organum ${ }^{6}$ (1620) without adding new ideas. The best example of Bacon's deductive approach to the study of phenomena is to be found in the Sylva Sylvarum or A Natural History in Ten Centuries, published in 1627. In Century I, section 30 deals with " the commixture of flame and air and the great force thereof." Bacon wrote: "As for living creatures, it is certain their vital spirits are a substance compounded of an air and flamy matter." Like oil and water they "will not well mingle of themselves; but in the bodies of plants, and living creatures, they will."

This statement is apparently a recognition of the intimate relation between combustion, light, and living things, because in a later section ${ }^{7}$ entitled, "Experiment solitary touching wood shining in the dark," Bacon described sixteen trials with this material, which are quoted in Chapter XIV on Shining Wood, Fish and Flesh. He also explained his reason for the inquiry:

The experiment of wood that shineth in the dark, we have diligently driven and pursued; the rather, for that of all things that give light here below, it is the most durable, and hath least apparent motion. Fire and flame are in continual expense; sugar shineth only while it is in scraping; and salt-water while it is in dashing; glow-worms have their shining while they live, or a little after; only scales of fishes putrified

\footnotetext{
${ }^{5}$ In Latin, pulmo marinus, in Greek, pneumon thallasios, a medusa or jellyfish, many of which are luminous. Bacon appears to have suggested that jellyfish come from sea foam. Since jellyfish are luminous and the sea is often luminous when it foams or is agitated, the two were associated.

" "The New Instrument." Second book. Aphorisms. Sec. 12.

${ }^{7}$ Century IV, Sec. 352.
} 
seem to be of the same nature with shining wood: and it is true, that all putrefaction hath with it an inward motion, as well as fire or light.

Bacon showed great intuition by recognizing the essential similarity of the light from shining wood, due to fungal mycelia, and the scales of fish, now known to be due to luminous bacteria. He paid scant attention to the nature of light itself and in fact complained "that the form and origin of light had been but little inquired into," that rays of light had been considered only mathematically with little attention paid to them physically. "This therefore he placed among the desiderata of his time, and desires that inquiry may be made into it." 8

\section{The Bolognian Stone and Phosphorescence}

Another great scientist at the beginning of the seventeenth century, Galileo Galilei (1564-1642), was also interested in light, but was concerned more with that from heavenly bodies than with the variety found on earth. There appears to be no discussion of the firefly or of shining wood in Galileo's writings, but he was one of the first to become acquainted with the Bolognian stone or Bolognian phosphor, perhaps the greatest discovery in the entire history of inorganic luminescence. Galileo demonstrated to La Galla (1612), who first published the account, how the material after exposure to daylight would light in the dark. This phosphor exemplified a new method of light production, now specifically spoken of as phosphorescence. Since phosphorescence is merely a delayed fluorescence, it is no exaggeration to claim that the Bolognian phosphor, after more than three hundred years, through invention of the fluorescent lamp, finally revolutionized the lighting industry and made the development of television possible.

The Bolognian or Bononian phosphor or phosphorus was first prepared by an Italian shoemaker of Bologna, Vincenzo Cascariolo, a dabbler in alchemy. In 1603 he found that a local stone, now known as heavy spar, a native barium sulphate, after special treatment by calcination, would "imbibe" the light of day and emit it later in the dark. The material aroused the greatest interest among the learned of the time, and led to a famous controversy between Galileo and Liceti concerning the light of the moon. A detailed history of the discovery of the stone and an account of the work of many subsequent investigators who studied the Bolognian and similar phosphors, will be described in Chapter VIII on Phosphorescence. It is sufficient to emphasize here that the storage of light, an entirely

${ }^{8}$ Quotations from Priestley (1772: 43-44). 
new phenomenon, had been discovered. This property of matter was not mentioned by Bacon and not fully discussed ${ }^{9}$ by any previous philosophers. As far as the history of luminescence is concerned, the seventeenth century became the Age of Phosphori or Light Bearers.

Derived from the Greek word for the morning star, phosphor or phosphorus ${ }^{10}$ came to mean any one of the various types of luminous compounds now so commonplace in everyday life. The words " phosphoric, phosphorical, phosphorescent, phosphoresce, phosphorescence," etc., are associated in a very general way with any light devoid of heat, for example the "phosphorescence of the sea." Strictly speaking, however, the modern scientific usage restricts phosphorus to the element, as applied by Elsholz in 1677, while phosphor and phosphorescence apply to any compound, such as the Bononian phosphor, which absorbs light and emits it for some time afterwards in the dark.

By the end of the seventeenth century, many kinds of phosphorescent substances were known. The word phosphorescent appeared in prose or poetry, most frequently in connection with the sea (see Chap. V and Chap. XV of this book).

\section{René Descartes and the French Point of View}

Descartes did not discuss luminescence in any detail but his views on the subject are of special interest, because he has been regarded as the first philosopher since Aristotle to develop a new and unified system of cosmology, and he exerted a tremendous influence on contemporary thought. The Greeks had already exhausted the possibilities regarding the nature of light. Although the various points of view differed in detail, their theories may be placed in four categories. Light was considered to be (1) a stream of particles given off by a visible object (Pythagoras); (2) material films or images from the object, flowing to the eye (Democritus and Epicurus); (3) particles (Empedocles and Plato) or "emanations" (Euclid) from the eye falling on an object, which is then seen; (4) a quality, i. e. an activity (energeia) of a transparent medium (diaphenes), not material in nature. Light is not fire, but the presence of a fiery

\footnotetext{
- See Chapters I and II for luminous jewels and Chapter VIII for the story (1600) of van Helmont's stone which retained the light of the sun, when placed in the dark.

${ }^{10}$ At first the Bolognian stone was referred to as lapis solaris, lapis lunaris, lapis lucifer, lapis illuminabilis, lapis phengis (from the Greek, pheggo, to shine or make bright), later as spongia solis or luna terrestris. In $1640 \mathrm{~F}$. Liceti entitled his great monograph on the Bolognian stone Litheophosphorus or stony light bearer, and the word phosphorus became more and more popular as a designation.
} 
quality in "the transparent" (Aristotle). These views were discussed over the succeeding ages and were still a matter of argument in the early seventeenth century.

About the time of Descartes' greatest activity, the famous conferences ${ }^{11}$ of Theophraste Renaudot (1586-1653) were being held at the Bureau d'Addresse in Paris. They give an excellent idea of contemporary opinion. In one of these conferences, on January 2, 1635, six opinions on the nature of light were expressed, and luminescences were used to support two of these opinions. It was argued that light is a form connected with rarity or transparence (the view of Aristotle) by the fact that

we find light in sundry animated bodies, as in the Eyes of Cats, and of those Indian Snailes [perhaps Pyrophorus] which shine like torches, and in our Gloe-worms, whose light proceeds from their Spirits; which being a middle nature between the Body and the Soul, are the least material thing in the world. ... Whence it follows that Light is a form with the most of essence among sensible formes, as obscurity hath the least.

Another opinion, that of the Florentine philosopher, Marsiglio Ficino (1433-1499), held that rarity alone could not be a cause of light, since the fact that

burning mirrors made of steel, the hardest of all metals . . make the Sun-beams do more than their own nature empowers them to, shews sufficiently that their Light cannot arise from a rare and diaphanous cause. Nor may the light of rotten wood be assign'd to its rarity alone, since many other bodies of greater rarity shine not at all; nor that of Gloe-worms and Cats-eyes to their spirits, since the flesh of some animals shines after their death; as 'tis affirm'd of Oxen, that have frequently eaten a sort of Moon-wort; and not onely the scales of divers fishes shine after separation from their bodies, but sparkles of fire issue from the hair of some persons in great droughts, whereunto the spirits contribute nothing.

Such were the arguments in 1635 .

Descartes' views on light were announced in his Discours de la Methode...plus la Dioptrique, les Meteores et la Geometrie, published anonymously at Leyden in 1637 as Essais Philosophiques. The Méditations appeared in 1641. The theory was amplified in the Principia Philosophiae (Amsterdam, 1644), which contains his ideas on the constitution of matter and the universe. Briefly, Descartes

11 These were talks over the years 1633-1642 on matters of social and scientific interest, published as Feuilles du Bureau d'Addresse (Paris, 1636) with an English translation by G. Havers, Gent., A general collection of discourses of the virtuosi of France, upon questions of all sorts of philosophy, and other natural knowledge, 1664. The quotations are from this book. 
regarded light as rapid motion in a subtle (elastic) fluid (the æther), made up of particles (the first element) invading all space, even the pores of solid bodies like glass. Space was a plenum, with no vacuum anywhere. Its particles moved in vortices, not in straight lines. Light was not a transmission of particles but was communicated by the push or pressure of one particle to another, as the motion of one end of a stick is felt at the other. The sun's particles were in agitation and transmitted this agitation instantaneously ${ }^{12}$ throughout the Universe.

It will be noted that Descartes' point of view clearly distinguished between the manner in which light was generated, by agitation and friction of particles, and the manner in which it was transmitted, by the motion of a subtle liquid communicated by the pressure of the moving body.

Descartes took it for granted that the eyes of cats had the power of emitting light, and, like others of his time, thought some men might see better because of the light in their eyes. He presented views on phosphorescence of the sea in 1637 in Les Meteores (see Chap. XV) and later in his Philosophia, including also luminous wood and fish. His explanation is best given by quoting the paragraph in Principia Philosophia (Amsterdam, 1644; Part IV, Sec. 91) which answers the question, "What is the light of the sea, rotten wood, etc.?"

But about what concerns sea water-the nature of which I have explained above, it is easy to see that the light which appears around the drops [of sea water] when they are distrubed by storms comes only from the fact that this stirring up, while leaving the parts that are soft and pliant joined together, makes the little points of the others which are stiff and straight, like little darts, stand out and push with impetuosity into the parts of the second element which they encounter. I believe also that rotten wood, salt fish and other such bodies do not light except at a time when an alteration in them restricts many of their pores so that they contain only matter of the first element: whether this alteration comes when some of their parts approach each other, while others separate, as appears to occur in rotten wood; or when some other bodies mix with them, as occurs with salt fish, which do not light except during the times that the particles of salt enter their pores.

In either case Descartes held that the friction between the parts results in the appearance of light.

Descartes had many followers, who expounded and elaborated his views. Among such men as François Bayle (1622-1709), Père Nicholas Malebranche (1638-1715), and Antoine LeGrand (fl. 1650-

12 Ole Roemer demonstrated a finite velocity of light in 1675. 
1680), the Cartesian doctrines were well defended, but only LeGrand among the three discoursed at any length on luminescences, expressing opinions which will be considered in a subsequent section of this chapter. Descartes's son-in-law, the physicist Jacques Rohault (1620-1675), and the chemist Nicolas Lémery (1645-1715) were likewise Cartesians. Their views on luminescence will be presented in final sections of this chapter.

In later years of the seventeenth century, theories of light were chiefly two, the wave ${ }^{13}$ theory of Robert Hooke (1635-1703) and of Christian Huygens (1629-1695), opposed by the corpuscular ${ }^{14}$ theory associated with Isaac Newton. It should be pointed out that even those scientists who compared the propagation of light to a wave motion, nevertheless regarded the generation of light as connected with movement of particles. Newton's influence and authority were so great that, despite the contrary views of Descartes, of Hooke and Huygens, the conception of light as a material substance persisted throughout the eighteenth century. Although Leonard Euler (17071783) supported the wave theory in his Nova Theoria Lucis et Colorum, etc. (Berlin, 1746), his views were not generally accepted, ${ }^{15}$ and it was the work of Thomas Young (1773-1829), supported by that of Augustin Fresnel (1788-1827) which finally led to abandonment of the corpuscular theory during the nineteenth century.

\section{Scientific Societies and Luminescence}

With increasing interest in physical phenomena of all kinds, it was natural for those concerned to meet togther for mutual discussion. The trend began in the sixteenth century in Italy. ${ }^{16}$ The earliest of such gatherings and the forerunner of stable societies was

\footnotetext{
13 Franchesco Maria Grimaldi (1618-1663) of Bologna, the discoverer of diffraction, thought of light as a wave. He did not study luminescence except to explain the blue color of "lignum nephriticum" extract (actually a fluorescence) as a reflection of light (see Chapter XI) .

${ }^{14}$ In discussing sight, Thomas Willis (1621-1675), in his Exercitatione duae de anima brutorum (London, 1672, Chap. XV) leaned toward the view that light consists "of most thin little bodies," but had difficulty in understanding how they could move so rapidly, "for when a candle being lighted, immediately the whole chamber is illuminated, it can scarse be conceived, that the fiery little Bodies of that flame, should break forth so suddenly or so thick, that they should fill, in the twink of an Eye, so vast a space. ... Besides, when from a glow-worm, a certain Kind of Light or fire shines in the dark, and is perceived at a distance, if this apparition should be made by reason of the fiery little Bodies streaming from this little Creature, whence I pray is so much fiery Tinder supplied? ..." (from the translation, Two discourses concerning the soul of brutes, London, 1683, p. 75).

${ }^{15}$ See chapter VIII on Phosphorescence for Euler's views on phosphors, on color, and on reflection of light.

${ }^{10}$ See Martha Ornstein, The role of scientific societies in the 17th century, Univ. of Chicago Press, 1928.
} 
"I Segreti," the Accademia Secretorum Naturae, held in Naples in 1560 at the house of Giambattista della Porta (1538-1615) of "liquor lucidus" fame (see Chapter III of this book).

At about the same time as the discovery of the Bolognian phosphor, the first Accademia dei Lincei was formed in Rome. It lasted from 1600 to 1630 . In reorganized condition the society still exists. Another society, the Accademia del Cimento, i. e., the Academy of Experiments, was started in Florence a little later, in 1657, and continued for ten years. Its publications, representing the work of its members as a group, appeared together in 1667 and were called "Saggi," or trials. They were translated into English by Richard Waller of London in 1684, and into Latin, with commentaries and new experiments, by van Musschenbroek in 1731. The "Saggi" deal with many physical matters, such as measuring instruments, atmospheric pressure and light, and include triboluminescent phenomena, described in Chapter X. In this respect the "Saggi " differ from the "Gesta Lynceorum" (1603-1630), proceedings of the first Accademia dei Lincei, which included nothing on luminescence.

Another Italian scientific group, the Philosophi Inquieti met at the house of Conte di Marsigli, a collector and patron of science at Bologna, who donated his collections to the University of Bologna in 1690. With his nucleus of books and apparatus, the Bolognian Institute of Science was formerly established in 1711, and became closely associated with luminescence studies through the work of Beccari and his associates on phosphors, and on luminous animals, the dactyli. Marsigli himself published on the Bolognian phosphor in 1698.

In England the Royal Society of London was an outgrowth of informal meetings begun in London in 1645, at Oxford in 1649, and then London in 1658, and was chartered in 1662 by Charles II, who took considerable interest in scientific affairs. Its journal, the Philosophical Transactions, containing everything of importance in English science and many papers on luminescence, began publication in 1665 .

The French Académie des Sciences in Paris also started with an informal group of men meeting at various private houses. It was incorporated in 1666 under Louis XIV, and reorganized in 1699. The transient Journal des Sçavans, which contained most of the early proceedings, was first issued in Paris in 1665. The Histoire covered years 1666-1699 and the Mémoires of the French Academy followed. It is interesting to note that the first article on luminescence in the Journal des Sçavans (April 12, 1666), on luminous worms in oysters by Auzout and de la Voie, was also the first article 
on luminescence in the Philosophical Translations, a translation in the May 7, 1666 issue (No. 12, page 208). The second article on luminescence in the Phil. Trans., observations on shining fish by Dr. Beal, appeared shortly after (p. 226).

In Germany, the Collegium Naturae Curiosorum, of physicians, with no fixed home, was founded in 1652 and later (1687) became the Academia Caesarea-Leopoldina. Its publications, the Miscellanea Curiosa or Ephémérides started publication in 1670. This series contains many references to luminescent phenomena.

It is hardly possible to overestimate the importance of these groups in the history of scientific thought. Thus the Atti, the Commen. Bonon., the Phil. Trans., the Mémoires, and the Ephémérides have become precious records of early work on luminescence. Much was published in the seventeenth century, only to be rediscovered in modern times. When the various academies or societies had become firmly established, they offered prizes for the best paper on particular subjects. Many prizes were announced for essays on the subject of luminescence early in the eighteenth (see Chap. V) and early in the nineteenth (Chap. VI) centuries.

\section{Scientific Museums and Luminescence}

Just as scientific societies began in the sixteenth century with private gathering of friends to discuss scientific subjects, so the scientific museum, ${ }^{17}$ a collection of various objects of natural or philosophical interest, can be traced to the same period. The material was assembled in a special room by important learned individuals, and became a permanent display. One of these remarkable collections belonged to Olaf Worm (1588-1654), the physician and professor at Copenhagen. The contents of his collection was described in Museum Wormianum, seu Historia Rerum Rariorum (Lugduni Batavorum, 1655). This book, published posthumously by his son, Willum Worm, was no mere catalogue of specimens, but a summary of the scientific opinion of his day, a real contribution to knowledge. It included an essay on the Bolognian phosphor.

One of the earliest museums in Italy was started by Francesco Calceolari in the sixteenth century and continued by his son. The book, Museum Francisci Calceolari Junioris, etc. (Veronae, 1622) gave a detailed description of the contents, which included dactyli but no lapis Bononiensis. The contents of the museum passed into

\footnotetext{
${ }^{17}$ See the remarkably complete and erudite three-volume work of David Murray, Museums, their history and their use (Glasgow, 1904). The Latin word Museum and the French Cabinet literally refer to a place of study, and later became a "repository of learned curiosities" or a "chamber of rarities," in Ben Jonson's time.
} 
the hands of several persons, chiefly Conte Lodovico Moscardo, a Veronese nobleman.

Samples of the Bolognian phosphor, called a "miracle of nature," were contained in the collection of Moscardo, and described in Ovvero Memorie del Museo Moscardo (Padua, 1656, and Verona, 1672). The 1672 edition was made up of three books, one dealing with antiques, another with stones, minerals, and earths, and a third with corals, shells, animals, fruits, and other things. The phosphor was also displayed in the Museum Kircherianum at Rome.

The "Pietra luminare di Bologna, et sua storia" was the title of a section in Lorenzo Legati's Museo Cospiano (Bologna, 1677), describing the collection of Senator Ferdinando Cospi of Bologna, which has been annexed to that of the famous Ulisse Aldrovandi (1522-1605.) The other great naturalists of the sixteenth and seventeenth centuries also left collections. Remains of insects and shells may be expected to last for several centuries but so far as the author can learn, no specimens of glowworms, fireflies, or pholads survive from those early times.

The various learned societies had their own collections of rarities. That of the Royal Society of London included a green stone (fluorspar), which luminesced on heating, and the "Lanthorne Flie" (Fulgora lanternaria) both described by Neremiah Grew in $M u$ seum Regalis Societatis (London, 1681). C. A. Baldewein presented a sample of his "phosphorus hermeticus" to King Charles II of England in 1676, who in turn presented it to the Royal Society. The Royal Society collection finally went to the British Museum in 1781, but mineral specimens cannot be traced today and nothing remains of the "Lanthorne Flie," described by Neremiah Grew. ${ }^{18}$

If the flowering of museums began in the seventeenth century, they came to fruition in the eighteenth. National collections were started in most countries, such as that of the British Museum in England, when Parliament passed an Act to purchase the Sir Hans Sloane (1660-1753) library and collections in 1759 for $£ 20,000$.

The director of the Natural History section of the British Museum, Sir Gavin de Beer, informs me that some of Sloane's insects are now in the Petiver collection, one of them a North American firefly, Photinus pyralis, but that no example of the Jamaican firefly, Elater (Pyrophorus) noctilucus ${ }^{19}$ remains. The Photinus specimen

\footnotetext{
${ }^{18}$ Information kindly supplied me by Sir Gavin de Beer, Director of the Natural History Museum, London.

${ }^{19}$ Professor L. Chopard of the Museum National d'Histoire Naturelle in Paris writes me that three specimens of Elater noctilucus labeled "Amerique meridional " are contained in the collection of E. L. Geoffroy (1727-1810). They must date from the second half of the eighteenth century. One of them might be "le marechal," described
} 
dates from around 1700 and must be one of the oldest examples of a luminous insect in existence. There is also a shell of Pholas dactylus, the luminous mollusc, from the collection of Thomas Pennant, about 1777 .

One of the most remarkable books on various collections of curiosities was the Museum Museorum oder Vollstandige SchauBühne (complete display-stage), published at Frankfort-on-the Main in 1704 by Michael Bernhart Valentini (1657-1729), a professor at Giessen and a F. R. S. The folio volume of 520 pages in German dealt with minerals and metals in Book I, with seeds, roots, plants and fruits in Book II, and with animals in Book III. It contained not only a list of objects in various museums but a detailed account of what was known concerning these things, with references to the literature, really a cyclopedia of natural history.

The first edition (1704) contained only a short description (p. 52) of the Lapis Bononiensis, calling it " einen anderen frembden Risselstein," and referring to the Miscellanea Curiosa (Dec II, An VII) for further details. However, the greatly enlarged second edition (1714, 1136 pages) devoted considerable space to luminous earth, luminous eggs, luminous linen, and luminous stones. The earth came from Stockholm and gave off a light when rubbed in the dark. The story of luminous hen's eggs described by Paullin in 1687 (see Chap. XIV) was repeated and elicited considerable comment by Valentini. After stating that Albertus Magnus (Lib. II in anim. tr. $3 \mathrm{C} \mathrm{12)} \mathrm{had} \mathrm{already} \mathrm{paid} \mathrm{attention} \mathrm{to} \mathrm{luminous} \mathrm{eggs} \mathrm{in}$ his time, and that Scaliger (Exercit, 174) had mentioned white hens which glowed when roosting on a tree at night, Valentini wrote:

luminous eggs can perhaps arise if dogs or cats, whose vapor [Dünste] also luminescences, lie on them, or if a young woman seeks to incubate an egg under her breasts, and sweat and Lebens-Balsam (in which there is much Lebens-Geister) attaches to it, in the same manner as the linen of honorable [erlicher] men is accustomed to luminesce when removed in darkness.

In Chapter IV, "Von denen leuchtenden Blitz und brennenden Steinen," all kinds of phosphori are described, including those considered in a later section of this chapter-phosphorus ignius or fulgurans, or merely the " pyropus," which had been discovered by the German, Brand, the Lapis Bononiensis, the Balduini Phosphorus and the Phosphorus Smaragdinus or Thermophosphorus, with a few remarks on the mercurial phosphorus of Picard and Bernoulli. In

by Fougeroux de Bonderoy (1769), which appeared in St. Antoine near Paris in September, 1766, and startled the ladies living there (see Chapter XVI on Pyrophorus). 
all, four folio pages were devoted to phosphors and the account was accompanied with a woodcut of the Bononian stone.

Museums may thus be considered as important as societies in the dissemination of luminescence knowledge. One of the best known was that of A. Kircher, whose interest in luminescence was both extensive and detailed. This was the Museum Kircherianum, to be considered in the next section.

\section{Athanasius Kircher and Kaspar Schott}

The first of the seventeenth-century scientists to pay particular attention to all kinds of luminescences was a German Jesuit priest, Athanasius Kircher (1602-1680), born at Geisa near Fulda about the time Cascariolo made his famous discovery of the Bolonian phosphor. His interests ranged from the great to the small, from geology to microscopy, and included mathematics, optics and other physical subjects, biology, medicine, and miracles. He was also musician, orientalist, and a great traveler, having taught at Münster, Cöln, Coblentz, Mainz, and Würzburg, and having lived in Avignon, Rome, and Vienna.

Among Kircher's important works in science were the Ars Magnetica (1641) and the Ars Magna Lucis et Umbrae (1646). The latter book was first issued at Rome, and another edition appeared at Amsterdam in 1671. The frontispiece is reproduced as figure 6. Both editions, folio works of some eight hundred pages, give the same discussion of luminescence. Priestley (1772: 99) called the work " a very capital performance." Chapters VI, VII, and VIII of Book I dealt respectively with "The light inherent in animals," "The marvelous light of certain things that are born in the sea," and "On the luminescence of stones." Chapter VIII describes the Bolognian stone in practically the same words as used in Ars Magnetica in 1641. Another publication was Mundus Subterraneus (1664), in which luminescence is again discussed by Kircher.

Kircher described the light of fireflies (Nitedulae, Lampades, or Cicindelae) in detail, quoting Pliny but adding many observations and opinions of his own. He wrote: ${ }^{20}$

I spent some time at Malta, where I found a great multitude of them [fireflies] shining at night, and I collected a large number in order that I might both observe their nature and investigate rather deeply the origin of this kind of living light; and I noted that the animalcule voluntarily, as I might say, at one time drew back and at another put

${ }^{20}$ The quotations are from Ars magna lucis et umbrae, Amsterdam, 1671, translated by R. A. Applegate. 
forth that shining matter, as it sensed the presence of a friend or foe; for when it was pinched or moved, it drew back the matter and, after a little while, it brought it forth again. But especially when rather many cincindelae or lampades were put together, then most of all did it display the proud ornament of its shining liquid, as if it were exulting in the ostentatious glory of light. You would say that it was walking around in order to be seen.

Kircher then asked, "What is this light?" and referred to Aristotle's statement that "it is of the nature of smooth things to glow." This explanation was rejected, for Kircher wrote:

We, putting aside such opinions as these, say that the noctilucent Nitedula has this intrinsic and innate light, whereby it both sees and is seen, by the providence of nature, for definite ends, just as decaying wood and the scales of fish; and it has that inborn light from fire. For animalcules of this sort, without blood, when the fiery parts and the heat concentrated by nature around the place of digestion are very cold, then they acquire the power necessary to make them shine. We see the same thing in fish. Nature has provided for them, since they live in a cold element, very hard and sticky scales and earthy parts endowed with a certain fiery power to strengthen and conserve the heat of nature. But in decaying wood the fiery warmth is collected at the extremities with humid air. ${ }^{21}$

Experiments prove that very many fish, but especially the Lucius, Gabio (gudgeon), Rana piscatrix, [Lophius], shell-fish, crustacea, and other offspring of the sea, have the power of shining in the darkness; and decaying oysters, put in a dark place, pour forth so much light that, because of the unknown causes of things, they can reasonably seem prodigies. And there is the dactylus of the mussel family [Pholas], which when rubbed with the hands scatters from itself light like sparks, as I remember observing, not without wonder, under the guidance of fishers and sailors, in Malta, Calabria, Sicily, and along the coasts of the Gulf of Genoa.

Kircher then discussed the possibility of making a luminous liquor from the firefly to light houses as had been claimed by Porta, who

prepared the separated liquid of the Nitedula rubbed in porphyritic stone and confined under a glass for fifteen days; then he added some mercury and distilled out the essence with an alembic. He [Porta] thought that this when put in a glass saucer would illuminate the whole house. Nonsense of nonsense. For I do not see how that liquid could preserve its original purity when it had been completely changed, coagulated, fixed, encompassed, putrified, and mixed with destructive mer-

${ }^{21}$ In Mundus subterraneous (1664, 12: S 2, C 5, F 366), Kircher held that cincindelae are luminous because they come from rotten wood which is itself luminous (Quoted from Sachs, Gammerologia 209, 1665. 
cury. These are the vain notions of Agyrtae and strolling quacks. I, indeed, in order that I might find the truth, made test of everything and tested each point individually, but I could not extract one drop of liquid even from fifty animals; nay, rather this very little bit of liquid, when it is separated from the animal, perishes along with it, and I discovered that scarcely any trace of its light remains: I observed thus that the liquid offered no traces of light except in that place in which nature had implanted it for definite purposes, but outside of the place that was natural to it, it perished completely.

There is no doubt of Kircher's views on a liquor lucidus but perhaps the most interesting aspect of his presentations is the revolt from authority. Kircher, as contrasted with Gesner, is definitely skeptical of the statements of the ancients and also of Porta, only a generation before him. Moreover, he used the experimental method to refute extravagant statements while at the same time introducing teleological ideas of his own. Kircher was always searching for a purpose for the light.

In a section on the light of marine animals, Kircher described the luminous humors of the Dactyli and the Medusae which he believed to have been "implanted for no other reason than for enabling the animals to acquire the necessities of life." He noted that "nature has endowed these animals [pholades] with a liquid so luminous that in darkness it shines no differently than fire." $\mathrm{He}$ then continued:

Mention should be made here of another marvel of the sea, which, although it is nearly the lowliest and most despised of blood-containinganimals, yet has not a little nobility by virtue of its innate light. Some call it the Pulmo marinus [sea lung], others Urtica [sea nettle], because its private parts in some marvelous way affect the hands with a burning itch. I have found the humor of this animal, or zoophyte, so similar to the liquid implanted in the Dactylus that there is scarcely any effect produced by the latter that cannot be produced also by the former. But it is a marvel that the liquid of this Pulmo when rubbed on black sticks and certain other things causes them to shine in darkness no differently than fire: I discovered this by experiment, first at Aquae Martiae near Marseilles, and then again I remember having observed it at Bellonium. Twigs and sticks, when smeared, glowed at night like torches. After this, I discovered that traces of this liquid that is luminous by its own light are implanted in nearly all "fish," but especially in soft crustacea and testacea. I think that this is the reason why nature wanted to imbue these animals with light: namely, that they should not live in perpetual darkness and seem to have been provided with eyes by nature in vain, since they live in the depths of the sea and cling to sticks, but the depths of the sea are dark and are not reached by the rays of the 
sun, as divers inform us. Thus, nature gave to these animals this viscous liquid imbued with counterfeit light, that by its help, as it were by a lamp born with them, they might both seek food and also easily elude the snares of foes by the voluntary emission of light and darkness, and thus they might not be destitute of those things that are necessary for their own life.

In this manner Kircher attempted to answer the question, what is the use of light to a mollusc or jellyfish?

In the chapter on the luminescence of stones Kircher dealt exclusively with the Bononian phosphor which "so absorbed and incorporated the light that when it was removed from its box and put in a dark place it poured forth the light that it had absorbed, just like live coals, to the great admiration of spectators." He pointed out that the mineral was not restricted to the region of Bologna, as he had found it near Tolpha, "where men are accustomed to dig up lumps of alum." His methods of preparation and his views on the cause of the light will be found in Chapter VIII on Phosphorescence.

During his travels and after, Kircher acquired sufficient " rarities" to form a museum, established in Rome. Its contents were first described by G. Sepi in 1678, later by Filippo Buonanni (16381725). In Buonanni's book, Museum Kicheranum .... in Collegio Romano Societatis Jesu etc. (Rome, 1709), a whole page is devoted to the stone which was called Bononian. The account was largely taken from Kircher himself, from Licetus (1640), and from Marsilius (1698).

Most of the luminescences mentioned by Kircher were also described by Kaspar Schott (1608-1666), a Jesuit priest, professor of mathematics at Würzburg and friend and companion both of von Guericke and of Kircher. Indeed, details of the vacuum pump invented by von Guericke ${ }^{22}$ were first published in Schott's $M e$ chanica Hydraulica-Pneumatica (1657). He was especially interested in phenomena of light. However, the subject was well covered by Kircher, and Schott added nothing new to knowledge of luminous human beings, or of luminous fish, meat, oysters, sugar when scraped, etc. The material was collected in his Thaumaturgus Physicus sive Magia Universalis Naturae et Artis, Pars IV, Herbipoli, 1657. A later version, Physica Curiosa (1662) is an extraordinary mixture of angels, spectres, monsters, portents, and meteorological phenomena, such as the aurora borealis, St. Elmo's fire, ignis fatuus, and ignis lambens, together with additional accounts of the lumines-

${ }^{22}$ Otto von Guericke (1602-1686) did not publish Experimenta nova Magdeburgica until 1672. Schott's account inspired Boyle to set Hooke the task of constructing an improved pump. 


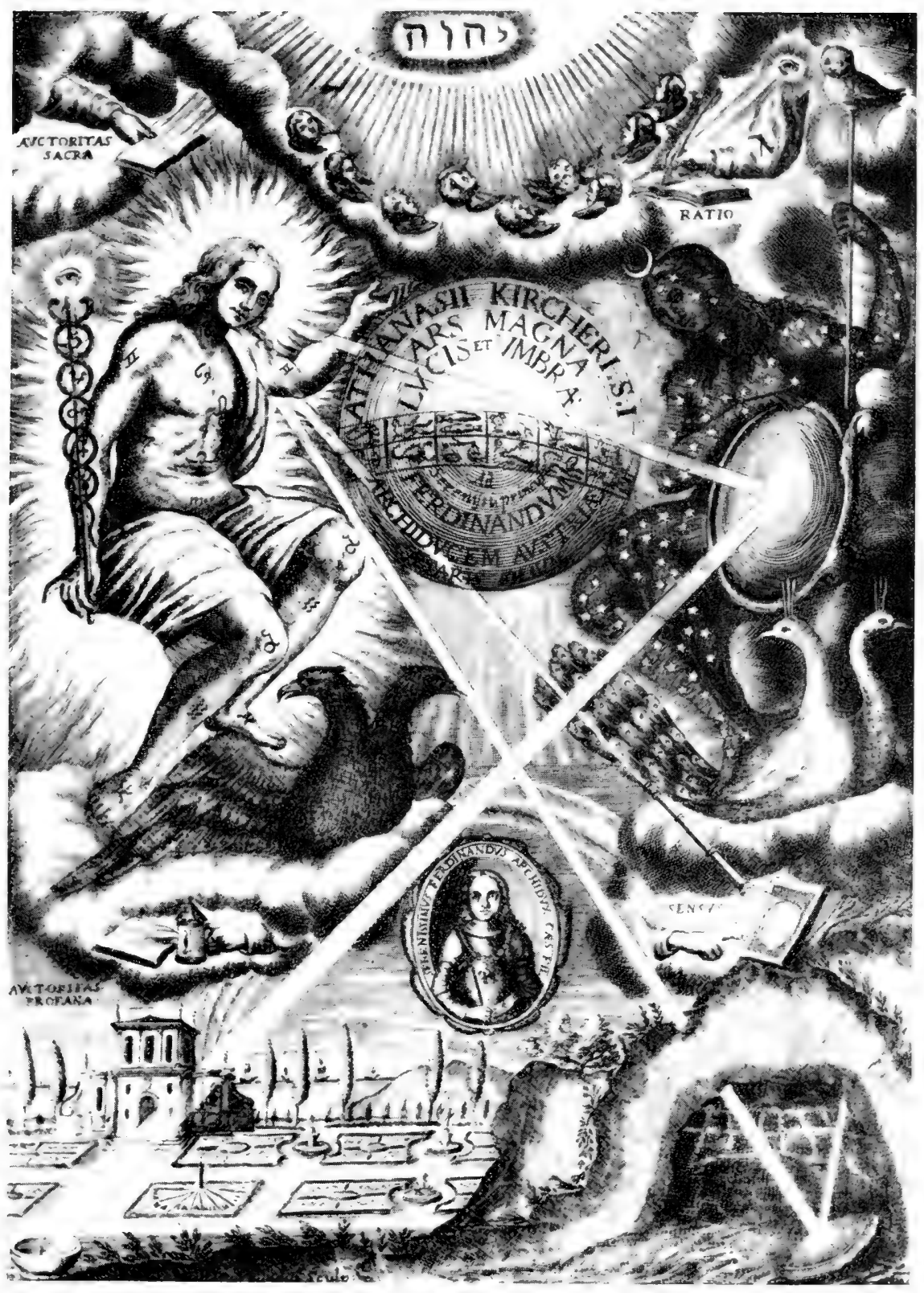

Fis. 6. Frontispiece to one of the important boohs on light of the seventeenth

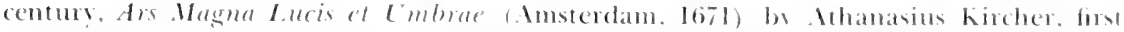
published at Rome in 1640 . Kircher devoted much space to rarious luminescences. 


\title{
THOMA BARTHOLINI
}

\author{
CAs F. FILII
}

$D E$

L VCE ANIMALIVM

I. I B R I III.

Admirandis hiftoriis rationibufquc novis referti.

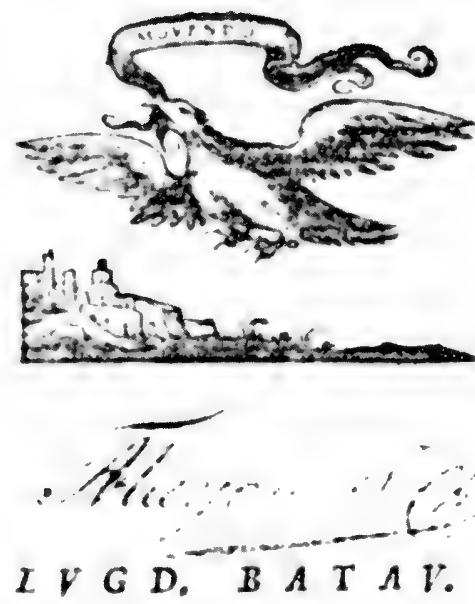

Ex Officina Francifci Hackii. Anno cIJIJ c xivil. 


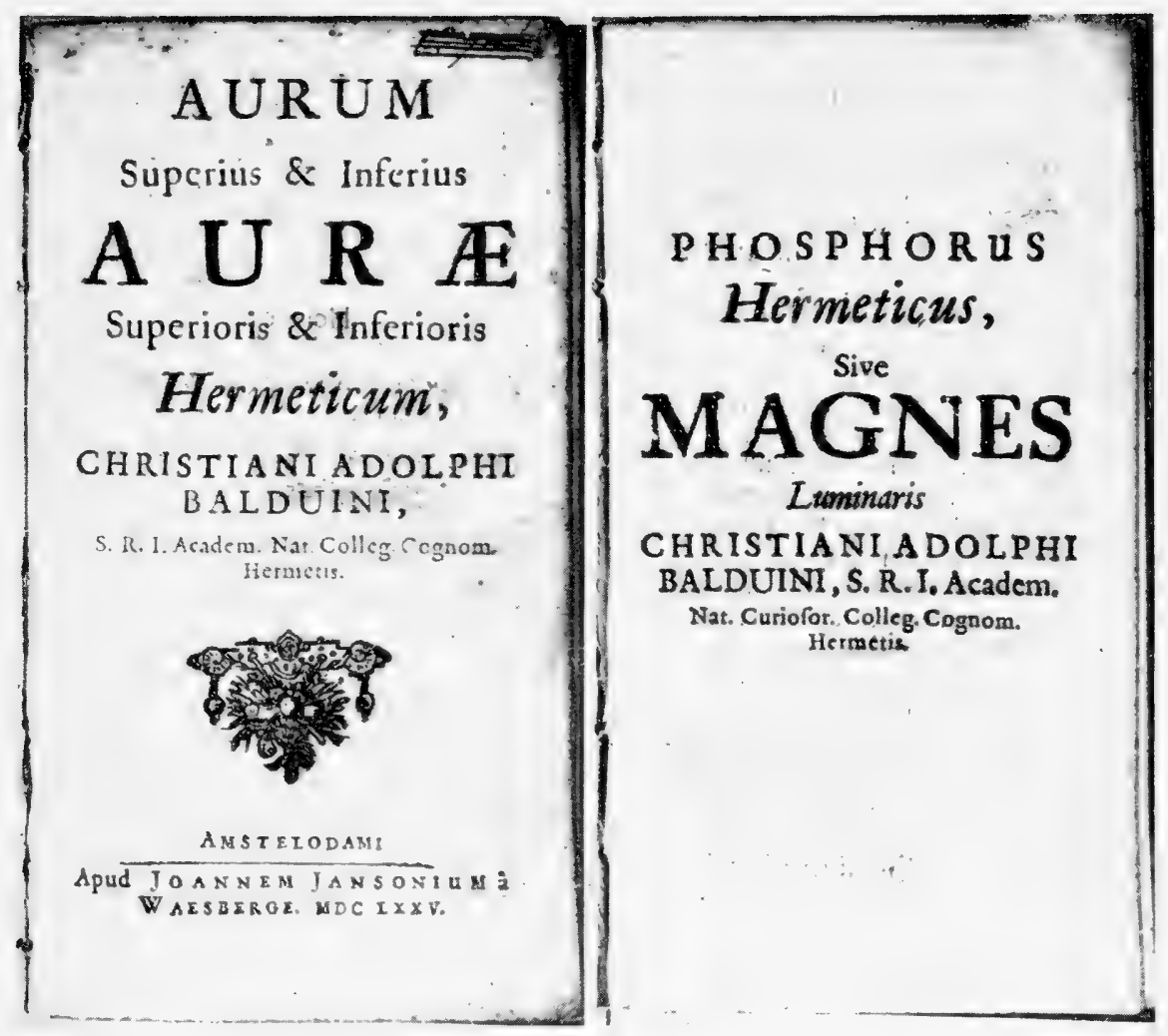

Fic. 8. Title page of the book (Amsterdam, 1675) concerning the second light adsorbing phosphor, discovered by C. A. Baldewein, and the title of the section which describes his hermetic phosphor or light magnet. 


\section{JESU CHR ISTO \\ Lumine GentiumPrælucente,}

E

Amplifimo Senatu Philofophico in Academia Lipfienfium indulgente

\section{SCHEDIASMA De}

AVIBUS NOCTU LUCENTIBUS,

fub Prafidio

Viri Claxisfimi

Dn. M. JOACHIMI FELLERI,

P. L. C.

Fautoris ac Sympatriote fui omnibonoris cultu profegpendi

Publico Eruditorum Examini fubmittit

Cornelills Bogel/ Cygn.

Die 2\%. Famarii amsto M.DC. LX7X. 1664

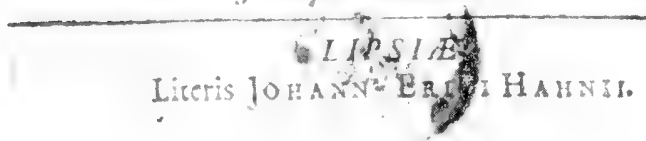

fix: $x: 57$

Fu, 9. Title patge of one of the oldest theses on luminescence, dealing mostly with Pliny's luminous binds of the Hercunian forest. but in addition listing all kinds of luminescences, by Comelius Vogel (Leiprig, 1669). 
cences well known in his day. Like Kircher, Schott engaged in a great deal of theological speculation, which detracted from the value of his work.

\section{Lignum Nephriticum and Fluorescence of Solutions}

A particularly interesting observation of Kircher recorded in his book on light (1846), had to do with the extract of "Lignum nephriticum," so called because it was recommended for kidney complaints by Nicolas Monardes (1493-1588) in 1565, and Francisco Hernandes (sixteenth century) in 1577. The phenomenon is one of the most important in the history of luminescence. An aqueous infusion of this wood exhibited different colors, which depended, according to Kircher, on the light intensity in which the extract was observed. His exact words will be found in Chapter XI on Fluorescence, but the statement is not correct, as was later pointed out by Newton, Boyle, and others. The color depended on whether the solution was observed by transmitted light, when it was yellow, or by reflected light, when it was blue. Actually the blue light is a type of light emission which has come to be called fluorescence, exhibited by many substances in solution. Kircher appears to have been the first to emphasize the peculiar optical properties of a fluorescent liquid, and has frequently been called the discoverer of fluorescence.

\section{Thomas Bartholin}

The outstanding book of luminescence of the seventeenth century, the second special treatise on the subject, and one from which many later writers copied, was De Luce Animalium of Thomas Bartholin (1616-1680). Bartholin was a Danish physician, born in Copenhagen, the son of Caspar Bartholin (1585-1629), a professor of medicine at the University of Copenhagen. The family was a distinguished one. A brother, Erasmus Bartholin (1625-1698), professor of mathematics at the University of Copenhagen, discovered the double refraction of Iceland spar in 1669.

Thomas started traveling when twenty years old, studying at Leyden, Pavia, Naples, Montpellier, and Basel, later returning to Copenhagen to become professor of anatomy at the University. He corresponded with most of the savants of his time. Although best known for his work on anatomy, especially the lacteals and the lymphatic system, we may guess that his extended travels brought him in contact with various luminous phenomena.

The first edition of De Luce Animalium was published in 1647 
at Lugduni Batavorum (Leyden).$^{23}$ The title page is reproduced as figure 7. Another edition appeared in 1669 with practically no change in text, although the title was new, De Luce Hominum et Brutorum. It was bound with Gesner's De Lunariis (1555), which Bartholin had emended. All editions are divided into three books, I "De luce hominum," II " De luce brutorum," and III "De causis lucis animantium." The whole compilation contains more than four hundred pages (1647 edition), with the first and third books of about equal size but the second book on the light of animals occupying only seventy pages. There is an excellent index.

Considerable attention will be paid to Bartholin's book, for it describes every luminescent phenomenon known at that time whether real or imagined, organic or inorganic. It reveals particularly well the approach to a scientific subject characteristic of the early part of the seventeenth century. Bartholin tells in his introduction how

I was first thrown into those reflections on rich light by the lamb's meat at Montpellier that was shining in the market [see Chapter XIV]. While the minds of the inhabitants were wavering between several conjectures, it made me take my pen and urged me on by the novelty of the case once I had started my wanderings. Then I decided to extend this 'splendid' subject through all the living species and illustrate them either by their own examples or those found in our authors.

A key to his ideas is also given in the introduction:

I have claimed the innate light as a fifth principle or element, which either shines brightly from itself or by an added movement, like sparks elicited from the rubbing of steel or silex, from eyes pounded with a fist and fire from teeth, for which Hornungus cites an example. That they are kindled by the appropriate matter is shown on the twelve year old boy in Rome who brought forth sparks from his hair by friction and whose head smelled of sulphur. ... Such and similar things occupied my youthful pen.

His interest in the subject persisted through his life, as evidenced by remarks in the 1669 edition, revised twenty-six years ${ }^{24}$ after the first: ${ }^{25}$

${ }^{23}$ There are 1643, 1647, 1663, and 1669 editions given in L. Agassiz, Bibliographica zoologica (1848), but the Bibliotheca danica (1877) mentions only 1647 and 1669, and I have been unable to find a 1643 edition in the catalogue of the British Museum, the national libraries of France, Germany, and Denmark, or in Leiden, or any library of the United States.

${ }_{24}$ This is Bartholin's statement. Twenty-six years before 1669 would be 1643 , but there is no record of an edition in that year.

${ }^{25}$ All quotations are from the 1669 edition, from translations kindly made for me by Mrs. Annemarie Holborn. 
Now I can better than before, when I was thrown on my own resources, explain those sections on light which I had undertaken, where so many learned men have shown before me, with whose help the work can be completed more easily. For after my first outlines of the first edition, others have successfully wrestled with this light, Hermannus Conringius, ${ }^{26}$ the embellishment of his age, in his De Igne Animali, the famous Jacobus Holstius in De Flammula Cordis, Daniel Puerarius of mature judgment in De Carne Lucente [see Chap. XIV], and many others who, in their writings, either followed my footsteps or opened up new paths to be followed from the accurate observations of the more recent scholars.

It is not surprising to find that Bartholin's treatment of the light of men in Book $I$ is full of mysticism. There are many references to the Bible and to writers of antiquity. One can judge of this from the titles to the first nine chapters:

I. True light is assigned to man by his perfection.

II. It is demonstrated from stones that light is in us.

III. The light of man is proved by luminous minerals and vegetables.

IV. It is proved also by the internal mixture and temperature.

V. Light is given to man by [internal] actions (operationes) .

VI. We infer light in man from the condition and sufferings of the sick.

VII. The same light is produced by his natural desire.

VIII. Human light is proved from the quick action of [natural] causes.

IX. It is shown by examples that men shine.

The remaining chapters (10 to 24 ) of Book I deal with light from the various anatomical regions of the human body, including "the shining face of Moses" (Chap. 12) and "the light of the human soul" (Chap. 23).

Bartholin used (precious) stones, minerals, and vegetables to prove that light is in all things. In dealing with precious stones (Book I, Chap. 2), the usual stories are recounted of shining carbuncles, sapphires, rubies, etc., whose light is actually due to transmitted or reflected color. Among stones in Book I, Chap. 3, sulphur is mentioned as "not only shining with an external brightness, but possesses a great amount of an inner light, by whose benefit, once its structure has been loosened, it is lighted very quickly by heat and consumed by its own light."

Concerning the newly discovered Bolognian stone, Bartholin wrote:

Quite similar to it [sulphur] is the other mineral that began to be brought forth in 1602 in the vicinity of Bologna at the time of our fathers,

${ }^{28}$ Hermann Conring (1606-1681), professor of philosophy and medicine at the University of Helmstadt and physician to Queen Christiana of Sweden. 
first by the chemist Vincentius Casciorolus. It soon emits the light which it has imbibed from the surrounding illuminated air wonderfully in a dark place with the brightness of lighted coal and retains the same faculty of conceiving light of several years. With a renewed calcination it is impregnated again. ...

Among plants (Book I, Chap. 3), rotten wood, the luminous barras of Josephus and the nyctegretos or nyctilops of Pliny were discussed, as well as " the indian reed [Canna indica] from which it has been common knowledge that sparks can be produced, and trees the same, about which Thucydides and Lucretius write that they conceive fire through mutual collision when the wind blows."

Among the examples of shining men are many undoubted electroluminescences described in Chapter VII. Bartholin cited the sparks which leaped from the body of Theodoric, King of the Goths, or "What rumor says about Carolus Gonzaga, the Duke of Mantua: after slight friction applied to his entire skin burning appearances used to come forth."

Mixed with these accounts are others of purely figurative connotation. Bartholin wrote (Book I, Chap. 9),

Athenaeus (Deipn. Book 13) introduces a prostitute by the name of Lampyris [shining like a lamp], perhaps on account of the similar splendor of her whole body, by which she was endowed by nature or which she had acquired with red dye by way of her meretricious art. However, Martialis, (Ep. IX, 3) pronounced the old woman resplendent only from the shimmer of clothes and jewels: "The dazzling adulteress is resplendent with Erythrean stones."

The lights observed from parts of the human body were also electrical phenomena. For example:

On the manifest light of the limbs. [Book I, Chap. 19.]

We have reported on the arms of the Pisan Antonius Gianfius. ... A similar thing is reported about those of Franciscus Guidus: he was lying naked in his bed and casually stroking his arms with his hand when be elicited considerable sparks.... A rare example is that of a matron in Verona, whose skin (on arms and feet) even if only superficially touched shot forth sparks....

Another noble matron was so marked by the Creator that whenever she touched her body slightly with a cloth sparks would shoot forth from her limbs in profusion, visible to all in the house, as if cast out from silex, with the accompaniment of a hiss audible to all. . .

... The Cardinal Count Conrad of Urach, famous for his holy life ... [is reported] to have seen a very bright light emanate by night from three fingers. ...

Of Gothofredus Antonius it is told that whenever after a severe 
paroxysm of arthritis he dropped off to sleep he sent out licking little flames from his legs.

Bartholin does not appear to have observed the luminescence of human cadavers due to luminous bacteria, but in Book II a number of cases of bacterial light are described on the flesh of animals and fish. Book II, entitled "The light that is in animals," takes up luminescences of the lion, horses, bulls, wolves, sheep, the dog and fox, the cat and hyena, mice, snakes, insects, birds and fish. In many cases the light is electrical, such as is observed on combing horses hair; likewise the horse of Tiberius which " disgorged flames from its mouth."

The light of snakes referred mostly to light reflected from their scales. There is a long discussion of the Biblical statement: "The Lord sent fiery serpents among the people, and they bit the people" (Numbers 21:6). Bartholin pointed out that fiery may have meant burning and referred to the bite, or it may have referred to the shape and movement of serpents which are like flames of fire. ${ }^{27}$ In the chapter on birds, Pliny's luminous birds of the Hercynian forest are fully discussed.

In Bartholin's chapter, "On the light of lambs," a true bioluminescence is described-light due to the growth of luminous bacteria. He tells the story of luminous mutton observed by Fabricius at Padua in 1592, which has already been quoted (Chap. III) and his own observations on the meat of lamb at Montpellier which impressed him so much. Details of the account are given in Chapter XIV of this book.

The above examples of light connected with larger animals illustrate Bartholin's ability to collect material that, superficially at least, supported his thesis that light was a fifth principle (in addition to fire, earth, air, and water) and that it was present in all things.

By "shining fish" Bartholin meant not only fish proper, of which he cited many instances, but also almost any invertebrate that lives in the sea. In the chapter on fish, the light of dactyli (Pholas), ${ }^{28}$ pulmo marinus (jellyfish), oysters (possibly containing luminous worms), river lobsters (with luminous bacteria) and the "lucerna piscis" of Pliny is described. True deep-sea fishes and surface forms that shine from photophores with their own light were unrecorded

${ }^{27}$ It is surprising how frequently the idea is expressed in the seventeenth century that a snake's tongue is fiery. Lémery (Keill translation 1698: 695) included in his discussion of luminescence, "The Viper being irritated, darts forth its tongue with so much quickness, that it appears all on fire."

${ }^{28}$ Apparently Bartholin never saw the light of Pholas and was inclined to believe the Pliny story a myth (Rivinus and Boehme, 1673). 
in both the seventeenth and eighteenth centuries. Many of Bartholin's instances of shining fish resulted from luminous bacteria, such as described by Cardanus from Scotland in 1557 (Chap. III) .

Many accounts of vertebrate fish luminescence would appear to be very dubious. Bartholin described the "Luna," which, "by its curved form and heavenly light and silvery color, reminds one of the moon above the firmament and which has been observed to shine at night by Gesnerus (De Lunariis, 1555) and Rondeletus (De Piscibus, 1554: XV, 7)." He noted that Jonstonus (Thaumatographia Piscum, 1632) wrote concerning herring that: " with their stomachs turned toward the surface of the sea they shine in the water and emanate such splendor that not only does the sea seem to be brilliant but the neighboring air is illuminated . . . clear indication of a good haul." Such examples of shining by day are clearly reflections of light from silvery skin or scales. The shining of live fish at night, so often recounted by early observers, must result from disturbance by the swimming fish of myriads of luminous dinoflagellates in the water, an effect well known to fishermen today and used by them to locate schools of fish. Only if the fish were dead, might their luminescence be due to luminous bacteria.

A third false account of light has to do with the eyes of fish. Olaus Magnus (Hist. XX, 29) is quoted by Bartholin ${ }^{29}$ in connection "with fishing for halex [herring] in our native country. "The eyes of the halex shine like a light at night on the sea; and, what is more, by the great motion of this fish and the reflection of a large school it appears as if flashes and tremulous gleams were stirred up on the sea, commonly called the lightning flashes of the halex!.' " 30 Again these lightning flashes are probably " phosphorescence of the sea," stimulated by schools of fish.

A number of other instances of light from the eyes of marine animals were recorded by Bartholin. Oppianus (Halieutika, Book II) spoke of the radiant eyes of the dolphin, Olaus Magnus (Hist. Sept. XXI, 5) and Thevetus ${ }^{31}$ (Cosm. vol. II, Book 20) of the burning eye of the "Limax" and Blefkenius ${ }^{32}$ of the sea monster, "Balena," of Iceland, with fiery eyes.

${ }^{20}$ Bartholin, De luce animalium, Book II, Chap. 15.

${ }^{30}$ That the eyes of herring are luminous is an old belief, to be found in the Hortus sanitatus of Cube (Mainz, 1484). In Book IV, Sec. 3, there is the statement: "The Herring's eyes shine by night in the sea like a light, but their virtue dies with the fish." However, a later writer on herring, Paul Neucrantz (1605-1671) declared in De harengo (1654, Chap. III, p. 20) that the brilliance of their shining eyes continues several days after they are dead.

${ }^{31} \mathrm{~F}$. André Thevet $(1502-1590)$, the French explorer, who wrote on Antarctica in 1558 and a Universal Cosmography in 1571.

${ }^{32}$ Dithmar Blefken, a German traveler who visited Iceland in 1563 and wrote a description of the country in Latin. 
Several reasons can be presented to account for these shining eyes of fish. One derives from authority, Aristotle's mention of "the head, scales and eyes of fish"; another from the fact that eyes in general appear to glow from the reflection of external light. The belief was general that men whose eyes glowed could see well in the dark. There is also the fact that pressure on the eyeball gives rise to the sensation of light, what is now called a phosphene, described by Aristotle. If light exists in human eyes, why not in the eyes of animals? Coupled with the fact that luminous bacteria growing on dead fish find the outer surface of the eyeball an excellent medium for growth, there is every reason why Bartholin should stress luminescence of the eyes of fish.

Bioluminescences were again discussed by Bartholin in the chapters on European insects that shine, called by the collective term, "noctilucae." Four kinds were mentioned, two have wings and two others are wingless, crawling on the ground. The relation between the crawling and the flying glowworm, the use of the light and the fact that the egg of the glowworm is also luminous were taken up in detail and have been quoted in Chapter XVI on fireflies and glowworms.

Bartholin was also aware of the three luminous " insects" mentioned by Oviedo from the New World, the railroad worm Phrixothrix, whose "light shines forth from the joints of their arms, and their head is aglow with no less gleam than that of a burning coal," luminous centipedes, and the cucuyo.

The third book of De Luce Animalium deals with the cause of the light of living things. It treats of material causes, efficient causes, and final causes in the Aristotelian sense. The material cause is the nature of the matter itself, the efficient cause is what is now understood as the cause of physical phenomena, how they arise, and the final cause is the purpose of the light.

Under material cause Bartholin discussed the differences and qualities of light of living things. Under final cause, it is not surprising to find the statement that (Book III, Chap. 9) "Light has been created by God for the perfection of the universe with such beauty and form emulating divinity as he deemed necessary for a perfect example of his glory amidst the mortal and frail. . . . In his primary intention he looked toward its usefulness for man. . .."

The efficient cause, i. e., the origin of the light, is presented in the form of ten problems:

I: Is God the immediate author of animal light?

II: Does animal light depend on the sky and stars? 
III: Is animal light generated by putrefaction?

IV: Does animal light come from transparency?

V: Whether from the blue sky?

VI: Do animal sparks came from the rubbing of bodies?

VII: Are our humors the causa efficiens?

VIII: Does our light come from fire?

IX: Do animals shine from water?

$\mathrm{X}$ : Does animal light come from whiteness?

Under each problem, Bartholin gave some prevailing views and usually refuted them by introducing his own conception of light as a fifth element pervading all things and called into being under special conditions. Much of the discussion is meaningless from our present point of view.

The type of argument used by Bartholin can best be understood from his discussion of problem IX, the origin of animal light from water. He first recalled that moisture is characteristic of animals, for example sweat, or the aqueous humor of the eyes; then cited the general belief that little luminous worms come from dew. ${ }^{33}$ "Some think that in the meat at Montpellier, dew, conceived by putrefaction brought forth splendor." He then went on to say that

Observation teaches that light inheres in water. Flames, the companions and offspring of light often broke out on the sea. Some think the salt ${ }^{34}$ in the sea to be responsible ... but also rivers, lakes and fountains shine ${ }^{35}$ and salt has also the quality of extinguishing fire. Others suppose fattiness of the water to be the cause. Closer to the truth are those who see the origin of fire of the sea in some fiery exhalations and vapors.

Bartholin's own observations are expressed as follows:

The light resides not only in the foam but in the water itself, as I have often observed in the upper and lower sea. For the floods stirred by the circular motion of the oars show a very clear splendor, which in bright daylight becomes white. Yes, even without any motion I have extracted from the sea glittering seaweed and, by throwing in some linen [which becomes] tinged with splendor, I have communicated light to neighboring things, emulating the stars.

The question as to whether the sea and water in general shine because of smoothness (laevitas) as Aristotle postulated, was con-

${ }^{33}$ Note that Hesychius made this statement, as quoted by Muffet in Chapter III.

${ }^{34}$ Probably an early recognition that phosphorescence is not observed in fresh-water seas or lakes. Descartes attributed the "burning of the sea" to friction between salt molecules (see Chap. XV of this book).

${ }^{35}$ Perhaps a reference to reflection of light. 
sidered, and Bartholin concluded that smoothness does contribute to the "external light of waters," apparently a reference to reflection of light which he called "fulgor" as distinct from the emission of light. "But back to the animate beings, which are believed to shine from water and dew. ... Dew has no color nor shiny effect." It cannot produce splendor in animals by itself, because it is lacking in light, as is easily observed when taken up by the body. If it illuminates brightly it does so by the benefit of the enclosed light. "And I gladly admit that light, the companion of air, is taken up by dew as an appropriate subject. ..."

"But shining animate beings do not shine with some whitishness or brilliance with which they could have been endowed by dew, but manifest themselves with real light which communicates itself also to the surroundings," that is, with the inherent light, characteristic of all things.

Even the obvious connection between putrefaction and luminous fish, flesh, and wood was not considered a direct one. Bartholin (in Problema III) held that the light was not "begotten by putrefaction but only laid open," that putrefaction only "liberates the latent seeds of light which had been suppressed in the mixture of the elements." These quotations will suffice as examples of the reasoning current in the mid-seventeenth century.

Although Bartholin's explanation of the widespread distribution of luminescence was by the simple assumption that light is a principle associated with matter in general, this point of view is by no means entirely new. Gregor Reisch (fl. end of fifteenth century) attributed an inborn light to all living things in his encyclopedic work, Margarita Philosophica (Heidelberg, 1496). The belief was widespread in medical circles that the heart was like a flame, as expressed in the title, De Flammula Cordis (1667) of T. Bartholin and Jacob Holst.

It is not possible to say that Thomas Bartholin introduced any fresh point of view for the interpretation of luminescence, or other wonders which he observed on his travels. De Luce Animalium is full of Biblical references. Bartholin believed implicitly in the conversion of Lot's wife to salt, citing instances of people turned to stone in more recent times. He believed in many strange things, including spells and charms for sickness-part of the widespread credulity of his day-an attitude which shows only too clearly in the previously quoted statements on the origin of the light of animals. Nevertheless, as author of the first comprehensive book on luminescence, he deserves a prominent position in our history. 


\section{Naturalists and New Luminous Animals}

It is probable that Bartholin's book in its various editions greatly stimulated ${ }^{36}$ the study of luminescence. He is quoted at length in Gammerologia (Frankfurt and Zurich, 1665), a large monograph on every aspect of crustacean knowledge considered from a "physical, physiological, historical, medical and chemical " point of view, by Philipp Jacob Sachs von Lewenhaimb (1627-1672), M. D., of Breslau, a member of the Collegium Naturae Curiosorum. One section dealt with the innate light of crustacea, repeating Bartholin's account of the river lobsters seen by Leo Allatius, but describing many other luminous invertebrates and discussing particularly whether there was such a thing as inborn light, a point of view denied by the van Helmont school.

Sachs mentioned practically all the apparent luminescences known at the time, including fireflies, balani or dactyli, oysters, fish, crabs, flesh, eyes, and Hercynian birds. He recognized in connection with the light of oysters that marine rather than fresh-water animals were more apt to luminesce and wondered whether the light might not be connected with saltiness, as held by N. Papin in his treatise in La Mer Lumineuse (1647). The observation of luminous oysters is an old one, referred to by Licetus in his Litheosphorus (1640), and some have thought that the word oyster referred to shellfish in general, including Pholas dactylus. However, it is quite clear from Sachs's description, copied from a letter written to Sachs on December 6, 1644, by an eye-witness, Johann Daniel Major (16341693), that the oyster and not Pholas is under discussion. Major, who is described as "the brightest Evening Star of the Collegium Curiosum,"

had sometimes observed in the oysters in Murano near Venice, if they were still alive, juicy, and well-preserved, especially at the time of waxing moon, and were lying in the dark, that at times in one of their shells, where they are widest, a little drop, the size of a small pearl, shone up with a tiny, though readily discernible, light. This light had the color of that on the belly of the glow-worm at the time of the Johannes feast. Oysters handled by human hands sometimes drew back this little drop, which shone by night, through a hidden passage of their shell, but after they were left alone for a while, they brought it back into the open. ${ }^{37}$

${ }^{36}$ Among important naturalists of the seventeenth century, John Ray (1627-1705), J. J. Swammerdam (1637-1680), F. Redi (1626-1698), J. Jonston (1603-1675), R. Plot (1641-1696), P. J. Sachs (1627-1672), and J. D. Major (1634-1693), mention luminous organisms briefly, whereas F. Willoughby (1635-1672), Martin Lister (1638-1712), W. Charleton (1619-1707), and C. Merret (1614-1695) hardly noticed them.

${ }^{37}$ Translated by Mrs. Annemarie Holborn, from Sachs's Gammerologia, p. 210. 
Major did not realize that his little drop like a pearl which shone so brightly was really a worm. The proof was to come later with publication of the true situation by De la Voye and Auzout (1666) in the Mémoires of the French Academy.

Sachs realized that the mere statement that all things contain light is not entirely satisfactory and took considerable pains to point out (p. 948),

in regard to the light of crabs shining at night, it is certain that the shells of what are generally known as crabs, have no inborn light, and do not spread it in the dark unless they have previously advanced to a very definite stage of putrefaction. Once they have gone beyond that, they immediately lose the light; not even the shells of lobsters give forth such light, whereas most living beings and plants in a certain stage of putrefaction do shine. From various experiments which I have collected, it can be shown that the heads, bones, scales, humors, and the flesh of most marine fish shine when thrown out in the dark, once they have reached a certain degree of putrefaction.

Sachs mentioned Bacon's experiments with rotten wood and then indicated that there was another side to the story, for "Kircher tells miraculous things about the humor of the pholades and the plumones marini [jellyfish], but he seems to assume that the light in their humors is there by virtue of an innate principle without previous putrefaction."

It was indeed a difficult thing to distinguish between flesh covered with the growth of luminous bacteria, wood containing luminous fungi, the jellyfish or Pholas shining with their own light, and the electrical discharge, ignis lambens, that frequently appeared on the hair of animals or skin and clothes of humans. The resolution of such diverse luminous phenomena was to require a vast amount of further study.

Bartholin's influence is also well shown in a rather interesting book by Filippo Buonanni (1638-1725), a Jesuit and inspector of the Museum Kircherianum in Rome. It was entitled Ricreazione dell'Occhio et della Mente nell'Osservazione delle Chiocciole, Roma, 1681. A Latin edition appeared in 1684. This type of book might be considered the forerunner of the popular natural history of today, for the author described luminous fish and various luminous invertebrates, and also proposed problems. The material was taken from previous writers, particularly Bartholin. Problema XXXIV took up the question, "Why does Balanus ${ }^{38}$ [i. e., Pholas dactylus, the lumi-

${ }^{38}$ Balanus means an acorn or some fruit of the same shape, or a date. Buonanni used the word for the Italian, datti, a local name for Pholas dactylus. The same account is to be found in Buonanni's later book, Museum kircherianum (Rome, 1709). 
nous mollusc] shine like lightning?" Buonanni quoted Kircher's "Mundus subterraneus" in which he observed a "fiery rain, sparkling in the darkness and a shining light similar to that of glowworms," and then stated that this light was not present merely on balani but was to be found in many marine and land animals, in shellfish, worms, crustacea, sea lungs (medusae), dead fish, the tongue of the lantern fish, mushrooms, eyes, hair, etc.

Buonanni was particularly impressed with putrefaction as the cause of light, a theory originally attributed to Aristotle "who thought there was no marine light without putrefaction." 39 In addition Galenus ${ }^{40}$ had seen a light from rotten pigeon excrement and Esichius [Hesychius] held that glowworms were born in tows and thickets after a previous putrefaction. Buonanni repeated Bartholin's argument against the view, that "if putrefaction were really the cause of the light we should expect to see light arising from the skin of hogs covered by dirt, and furthermore how could such a noble thing as light be produced by such a low and vulgar thing as putrefaction?" Putrefaction could not be thought of as producing the light, but might liberate the various principles which make up the organisms, thus freeing the light particles previously combined in complex substances.

However, Buonanni pointed out that the light of balani could not be explained in this way as they lighted before putrefaction. He also disposed of the idea that the light was similar to the sparkles observed when a horse is curried, since they lighted without rubbing. He concluded that balani are able to produce nitrous and sulfurous vapors because they generate a mineral odor similar to burning horn. When taken from the cold water of the sea into the heat of the air, these vapors burn and shine in a manner quite similar to the vapors over buried corpses in cemetaries, called will-o-thewisp. Certainly such speculations were well suited to arouse the interest of the general reader.

${ }^{39}$ The author has been unable to find a statement to this effect in Aristotle's works. There is considerable discussion of the sea and of putrefaction in Metereologia, but only the statement (Book II, Sec. 1): "the sea putrefies quickly when broken into parts but not as a whole; and all other waters likewise. Animals too are generated in putrefying bodies, because the heat that has been secreted, being natural, organizes the particles secreted with it." Many later writers took pains to emphasize that luminescence of fish occurs before putrefaction sets in.

${ }^{40}$ In David Brewster's (1787-1868) Letters on natural magic addressed to Sir Walter Scott, Bart (1831, letter 13), discussing heat and combustion produced by fermentation in moist hay stacks, we find: "Galen informs us that the dung of a pigeon is sufficient to set fire to a house, and he assures us that he has often seen it take fire when it had become rotten. Casati likewise relates, on good authority, that the fire which consumed the great Church of Pisa was occasioned by the dung of pigeons that for centuries built their nests under its roof." 
Other writers of the time also paid some attention to luminescences. Paolo Boccone (1633-1704), the distinguished Sicilian naturalist, included the Bolognian phosphor, electrical phenomena in man, and many "animal phosphors" in his book, Osservazioni Naturali, ove si contengono materie medico-fisiche, $e$ di botanica, published at Bologna in 1684 (p. 224-248). He recorded as luminous, balani in the harbor of Ancona, fish, sea anemonies, the "Satyrus marinus" of Antonio Donati, ${ }^{41}$ and various luminous beetles and worms, all of which required a certain amount of dampness in order to light. He noticed small animals in the sea near England that luminesced like the firefly and mentioned the observations of Count Marsigli on light from lizards' eggs. This phenomenon was attributed to egg-white combined with slime, thus forming an animal phosphor.

During the latter part of the seventeenth century three new luminous animals were discovered. In 1666 de la Voye and Auzout showed that the light of living oysters was actually due to luminous marine worms living in them, Grimm (1670) discovered luminous earthworms along the Coromandel coast, and Meriam recorded the light of the lantern-fly, Fulgora, from Surinam in 1699, although publication of the account was delayed until 1705. The cucuyo continued to be an object of wonder to travelers, and the firefly and glowworm a subject for speculation, but there was no real progress in understanding the way in which the light was produced. The details of all these discoveries will be found in the chapter on Bioluminescence.

\section{New Phosphors}

Modern chemistry really started at the end of the seventeenth century, arising from two main early endeavors, (1) the search for a philosopher's stone-some method of transforming base metals to gold-and (2) the search for an elixir of life and panacea-some means of prolonging youth and curing all the ills of mankind. With this close connection between medicine and chemistry it might be supposed that the luminescence of wood, flesh, and fish, or animals of the sea would attract the attention of the late iatrochemists. However, no important discussions of these phenomena are to be found in the writings of Johann Baptista van Helmont (1577-1644) or Johann Rudolf Glauber ${ }^{42}$ (1604-1668). Van Helmont particu-

${ }^{41}$ A. Donati was a Venetian naturalist (1603-1659), who wrote Frattato de semplici, pietri e pesci marini, etc. (Venezia, 1631).

${ }^{42}$ The English translation of Glauber's Works by Christopher Packe, a 756-page folio volume issued at London in 1689, contains nothing on phosphors or bioluminescent phenomena in the index. 
larly, who looked on water as the chief constituent of matter, might be expected to notice bioluminescences because of experiments on juices of the body, or from the study of gases, but such is not the case. His description of the flint stone, which might be a natural phosphor, will be described in Chapter VIII.

During the last third of the seventeenth century, several new luminescent materials were recognized, three of them the result of chemical experiments. In 1669 a substance was prepared which played an all important part in the theories of animal luminescence until after the middle of the nineteenth century. This was the element phosphorus, isolated by Hennig Brand (or Brandt). The announcement caused great excitement in the intellectual world. Such men as Kunkel, Krafft, Leibnitz, and Boyle were stimulated to rediscover the original secret. Details of its history are given in Chapter XII on Chemiluminescence.

Another chemical discovery of the same period was the second substance capable of storing light, a preparation of Christolph Adolph Baldewein (1632-1682), the phosphorus balduinus or hermeticus, probably an impure calcium nitrate. Prepared in 1675, Baldewein's phosphor created a renewed interest in luminescence and started the search for additional examples. The title page of his book is reproduced as figure 8 .

As a result, three more types of luminescence, all considered in separate chapters, were to be recognized before the end of the century. Knowledge of artificial electroluminescence in tubes may be said to have started when Jean Picard (1620-1682), in 1675, noticed the greenish light emitted from the vacuum of a mercury barometer when shaken. It was later studied by many savants, including Johann Bernoulli (1667-1748) in 1700 and by Francis Hauksbee (died 1713) in 1704 to 1708 . Often referred to as the mercurial phosphor, its connection with electricity became apparent early in the eighteenth century.

Thermoluminescence was recognized as an entity in 1676 by Johann Sigismund Elsholtz's (1623-1688) observation that certain varieties of fluorspar would luminesce on warming slightly. The material, an impure calcium fluoride, was called phosphorus smaragdinus or the thermal phosphor. Thus by 1676 , the principal phosphori were the Bolonian phosphor, the Baldeweinian phosphor, phosphorus mirabilis, and phosphorus smaragdinus. This circumstance led to the publication of De Phosphoris Quatuor (1676) by Elscholtz, and an account in the Phil. Trans. (1676) by Heinrich Oldenburg (1626-1678) entitled, "Four Sorts of Factitious Shining Substances." 
One more phosphorus was soon to be added. Although the light which appears on rubbing or breaking sugar was a common observation, the first material with this property to be prepared artificially was Homberg's phosphorus, an impure calcium chloride discovered by Wilhelm Homberg (1652-1715) in 1693. The material luminesced on scratching and striking and helped to found the subject of triboluminescence.

These discoveries emphasize the many ways in which light can be produced and quite naturally became the basis for later classification of luminescences. Together with the existence of shining flesh, fish, and wood, the burning of the sea and the many examples of animal light, they served to confuse and complicate all attempts to explain the cause of the light in universal terms. Indeed Bartholin's idea of light as a fifth principle or element, equivalent to earth, water, air, and fire, was becoming a more and more logical concept. Light did appear to be present in all things and to manifest itself in various ways.

\section{Textbooks of Chemistry and Physics}

It is rather surprising to find practically no mention of luminescence in the early books on chemistry, even in those published after the Bolognian phosphor was discovered in 1603. The Tyrocinium Chymicum of Jean Beguin (fl. seventeenth century) first appeared in 1608 and passed through many editions and translations, but there is nothing on phosphors in the 1625 edition, although calcination is discussed.

The more detailed chemistries, Oswald Croll's ${ }^{43}$ Bazilica Chymica (1608), Nicolas le Fèbure's (died 1674) Traicté de la Chymie (Paris, 1660), P. Thibaut's Cours de Chymie (Paris, 1667), and Christolphe Glaser's Traité de la Chymie (Paris, 1673) to mention a few, were all published before the first edition of Nicolas Lémery's (1645-1715) Cours de Chymie (Paris, 1675). Again, none of these books discuss luminescences, and in fact a treatment does not appear in the first or subsequent editions of Lémery until the fifth, which was translated into English in 1686 by Walter Harris. Lémery's later views on luminescence are extensive and will be found near the end of this chapter.

The first textbook of physics in the modern sense is more difficult

${ }^{43}$ Oswald Croll (ca. 1580-1609) wrote the original Basilica chymica in 1609. Some eighteen editions of Croll's book appeared before 1658. The English edition, Bazilica chymica et praxis chymiatricae or royal and practical chymistry englished by a lover of chymistry (London, 1670), deals mostly with drugs and also contains nothing on luminescence. 
to name. The subject was the equivalent of cosmology and so broad that physical compilations were of encyclopedic proportions, including mathematics, astronomy, meteorology, etc. The classical divisions of physics-mechanics, properties of matter, sound, heat, light, electricity, and magnetism-under the designation "Natural Philosophy" appeared in textbooks of physics in the eighteenth century.

Perhaps Jacques Rohault's (1620-1675) Traité de Physique (1671), which adopted Cartesian principles, and contained a good deal of chemistry, was the best of the seventeenth-century books on general physics. It was translated into Latin in 1671 and into English in 1723. Rohault's views on luminescence, essentially like those of Lémery, are best presented at the end of this chapter. With the exception of these two authors, seventeenth-century textbooks of chemistry and physics were definitely disappointing in their consideration of luminescence.

\section{Theses on Things that Shine at Night}

Compared with early textbooks of chemistry and physics, the treatment of luminescence in dissertations ${ }^{44}$ was quite adequate. One of the earliest was a Schediasma de Avibus Noctu Lucentibus by Cornelius Vogel, with M. Joachim Feller presiding, presented to the Leipzig Academy, and published at Leipzig in 1669 (see title page as figure 9). The ten-page pamphlet includes much more than Pliny's luminous birds of the Hercynian Forest.

Vogel spoke of light as one of the ornaments of the world and distinguished three groups or orders of light emissions. In the highest category is the sky with its heavenly bodies; in the second, fire and fiery meteors; while in the third are the gleaming things (fulgentia), either animate or inanimate, endowed with light visible only in the dark.

The luminescences mentioned in the first half of the thesis include luminous jewels, the Bononian stone, fungi, fish scales, shining wood and flesh, glowworms, the cucujo, worms in oysters, cat's eyes, and fur, etc.-all the luminous phenomena recognized at the time. However, there is no more information than a listing of the person who reported the luminescence. The author's remarks are merely preliminary to his main topic in which the views of various commentators on luminous birds are given, with a final conclusion similar to Michovius that "the birds which shine at

\footnotetext{
${ }^{44}$ In addition to dissertations, a number of books on fire include many kinds of luminescence, for example Ezechele di Castro's Ignis lambens (Verona, 1642), discussed in Chapter VII, and De igne (Frankfurt and Zurich, 1688) by Paolo Casati, discussed in a later section of this chapter.
} 
night cannot be found in the north and not in other parts of the world."

A far more important and complete Schediasma is that of Quintus Septimus Florens Rivinus and Johannes Godofredus Boehme, written for the degree of Bachelor and Master of Philosophy at Leipzig in 1673. The thesis was in Latin, a nine-page pamphlet entitled, De Noctu Lucentibus. The title page is reproduced as figure 10. No original observations were made but the compilation is remarkable for the complete roster of luminescences known to classic and later writers, chiefly Gesner and Bartholin. Despite its brevity, this pamphlet is a mine of information concerning both real and false luminescences recognized in 1673.

The authors begin:

There are, principally, two kinds of bodies that shine at night: one that throws off light and small sparks when an external motion strikes it, and another that of itself gives off light without flame. The light of the former is almost instantaneous and sometimes is seen even in shady places; the light of the latter lasts longer and is seen only at night.

In the former class, the first place rightly belongs to man, from whose body exhalations sometimes proceed, which resolve themselves into light and flame....

Rivinus and Boehme then stated that the phenomena were usually observed on prominent persons, and repeated the list of luminous humans given by Bartholin, and the animals mentioned by him.

Also included in the first category were "flames visible in darkness with a clean odor of sulphur produced by the mutual collision of Indian reeds, just as from steel and flint," and Bacon's little drops of salt water that leap forth from the blow of oars and shine and gleam," as well as " the gleaming sparks of sugar scraped or broken." With the exception of sea water, these lights are instances of triboluminescence.

In the second group, Rivinus and Boehme mention a "giant's tooth, which is visible by its own light in dark places and which Petrus Charisius brought with him from Sicily." This phenomenon is a mystery, perhaps reflected light. The eyes of men, particularly men reputed to see in darkness, and likewise the eyes of animals and of fishes were also classed in the second group.

Regarding other animals, Rivinus and Boehme state: "Experience proves that there is light in shell-fish and marine testacea." They included the much quoted crawfish luminescence of Allatius and the sea lung (pulmo marinus), the sea feather (penna marina), the dactyli (also called cappae longae, solenes or pholades), and the worms in oysters seen by Auzutus. 
Among terrestrial animals the luminous leg of lamb of Fabricius, the luminous meat of cattle, sheep, and hens mentioned by Bartholin and Borellus are described. Considerable space was devoted to Pliny's birds of the Hercynian Forest "which Aldrovandus and Gesner took pains to refute," and finally the cincindela or lampyris and the "coyouyou" of the Antilles were mentioned as examples of shining insects. There is no reference to luminous scolopendrae.

"Among plants also you will find those that display visible flames during the hours of night. Famous in this respect is the root of Baaras, mentioned by Josephus, and the plant, Nyctegreton of Pliny, which shines at night when dried by the light of the moon for thirty days." However, Rivinus and Boehme seemed skeptical of decaying wood for they "will pass by in silence" the experiments of Bacon and Boyle on this material.

The article ends with a consideration of mineral luminescences, which were confined to the diamond, carbuncle, and ruby, and "a certain shining fossil which first began to be unearthed by the chemist, Vincentius Casciorolus at Boulais in 1602 and was later discovered at Topha by Kircher."

Another thesis, presented to the medical faculty and published at Frankfurt am Oder, appeared thirteen years later by Johann Christolph Kletwich, with Bernhard Albinus presiding. It was a pamphlet of fifty-four pages entitled Dissertatio de Phosphoro Liquido et Solido (1686). The title page is reproduced as figure 11 . The subject matter is mostly the element phosphorus, with special mention of Brandt, Krafft, Boyle, and Slare but with only passing reference to the other phosphors known at the time.

In addition to the theses, which represent the work of younger writers and were frequently mere compilations of the observations of others, a number of the learned men of the latter part of the century paid especial attention to luminescences in various of their writings. Some reported experiments designed to help understand cold light, while others presented explanations which they argued were of universal applicability. All made interesting statements, which reflect the diverse thinking of the age. Among them, the man who deserves most to be mentioned is undoubtedly Robert Boyle.

\section{Robert Boyle}

Of all the distinguished group on the roster of the Royal Society of London, the only member to make an extended study of luminous phenomena was Robert Boyle (1627-169l), a founder of the Society and a prolific contributor to its publications. Although Boyle never wrote a general account of luminescences, he became 
one of the outstanding experimentalists in this field during the seventeenth century. Light, heat, fire, and flame represent only a few of his interests, which were universal, indeed truly remarkable, and his conclusions were sound and far ahead of others of his time. It is no wonder that cold light particularly intrigued him. The title pages of two of his books are reproduced in figure 37.

Boyle lived in Oxford from 1654 to 1668 , and Gunther ${ }^{45}$ has quoted a contemporary opinion:

His greatest delight is chymistrey. He haz at his sister's a noble laboratory, and severall servants (prentices to him) to looke to it. He is charitable to ingeniose men that are in want, and foreigne chymists have had large proofs of his bountie, for he will not spare for cost to gett any rare secret. Experiment, he declared, is the interrogation of Nature.

Boyle's interest in acquiring knowledge was so great that he prepared a small pamphlet ${ }^{46}$ for the use of explorers. It was published after his death, and began as follows:

And the great Disadvantage many Ingenious Men are at in their Travels, by reason they know not beforehand, what things they are to inform themselves of in every Country they come to, or by what Method they may make Enquiries about things to be known there, I thought it would not be unacceptable to such to have directions in General, relating to all, and also in Particular, relating to Particular Countries, in as little Bounds as possible, presented to their View . . . as they were some Years ago given to the Publick by the worthy and never to be forgotten Mr. Boyle. ...

One of the questions which he suggested might be answered by those who visit Virginia and the Bermudas was: "Where the shining Flees, called Cucuyes, hide almost all their Light when taken, but when at Liberty, afford it plentifully." Another concerned "the shining of the sea in the night."

Although not fortunate enough to obtain specimens of the cucuyo, which would surely have astounded members of the Royal Society, Boyle did find a glowworm, and in Tracts Touching the Relation betwixt Flame and Air (1671) related how its light disappeared in a vacuum and returned on admitting the air (see Chapter XVI, Fireflies).

Moreover, he particularly used the belief in a "liquor lucidus" prepared from glowworms as an example of the absurd things

${ }^{45}$ R. T. Gunther, Early science in Oxford 1: 10, 1923.

${ }^{46}$ Boyle, R., General heads for the natural history of a country, London, 1691. This was an outgrowth of questions published in the Phil. Trans. 1: 186-189, 315-316, 330$343,1666$. 
claimed by the alchemists, especially that fire was the great "opener of bodies" and "improves their vertues." In The Sceptical Chymist (1661), his plea for concise definition of chemical terms, with argument against both the "Hermetick philosophers" and the "vulgar spagyrists," Boyle wrote (1680 ed.: 344) :

The shyning property of the tayles of glowworms does survive but so short a time the little animal made conspicuous by it, that inquisitive men have not scrupled publickly to divide Baptista Porta and others; who, deluded perhaps with some Chymical surmises, have ventured to describe the distillation of a Water from the tayles of Glowwormes, as a sure way to obtain a liquor shining in the Dark.

Boyle's principal luminescence studies began with diamonds, extended to shining wood, fish, and flesh, and ended with the element phosphorus. All these luminous materials are dealt with more fully in later chapters, but it will not be amiss to point out some of his more unusual observations. Boyle was probably the first to describe phosphorescence, thermoluminescence, electroluminescence, and triboluminescence in a single substance, a diamond. He had noted in 1662 that certain varieties had not only the properties of a phosphor when exposed to candle light, but that if heated slightly or if made electrical by rubbing on woolen cloths, they would shine for a little while in the dark. He knew that diamonds glowed when broken, and recorded (1663) that one of the King's diamonds would shine after "one brisk stroke of a bodkin." 47

His studies on the influence of a vacuum on various phenomena led to the testing of "shining fish" and "shining wood" in vacua and the famous comparison of shining wood with a glowing coal. These experiments, described in Chapter XIV, are truly classical and have been quoted by the great majority of subsequent writers.

There is evidence that Boyle observed meat and fish to be luminous at least five years before publication in the Royal Society Transactions (1667). His interest in the preservation of anatomical material led to the suggestion of spirit of wine for the purpose to a Mr. Croune, who exhibited two dog embryos preserved in this liquid at a Royal Society meeting on May 28, 1662. In June, 1663, Boyle expressed his ideas on the advantages of alcohol:

For this Liquor being very limpid, and not greasy, leaves a clear prospect of the Bodies immers'd in it; and though it do not fret them, as Brine and other sharp things commonly employ'd to preserve Flesh are wont to do, yet it hath a notable Balsamick Faculty, and powerfully resists Putrefaction, not onely in living Bodies ... but also in dead

${ }^{47}$ Works of Boyle, 2nd ed., 5: 29, 1772. 
ones ... we have for curiosity sake, with this Spirit, preserv'd from further stinking, a portion of Fish, so stale, that it shin'd very vividly in the dark.

It is unfortunate that alcohol did not also preserve the luminescence of the fish.

Boyle's studies on shining fish and shining wood placed in a vacuum may be considered the first important experiments on the chemistry of a bioluminescence.

His second major contribution to knowledge of luminescence was the preparation of phosphorus independently of Brandt, and his continued study of the properties of this element. This work, described in Chapter XIII, occupied much of his time in later years, and led to publication of The Aerial Noctiluca (1680) and The Icy Noctiluca (1681).

Boyle lived most of his life too far from the seashore for direct experimentation, but his interest in and ideas on phosphorescence of the sea are expressed in the following quotation:

When I remember how many questions I have asked navigators about the luminousness of the sea; and how in some places the sea is wont to shine in the night as far as the eye can reach; at other times and places, only when the waves dash against the vessel, or the oars strike and cleave the water; how some seas shine often, and others have not been observed to shine; how in some places the sea has been taken notice of, to shine when such and such winds blow, whereas in other seas the observation holds not; and in the same tract of sea, within a narrow compass, one part of the water will be luminous, whilst the other shines not at all: when, I say, I remember how many of these odd phaenomena, belonging to those great masses of liquor, I have been told of by very credible eye-witnesses, I am tempted to suspect, that some cosmical law or custom of the terrestrial globe, or, at least, of the planetary vortex, may have a considerable agency in the production of these effects. ${ }^{48}$

Surely the guiding spirit of so versatile a genius can best be expressed by quoting ${ }^{49}$ a reflection of this great investigator, "For sometimes I think a naturalist's pen ought to be like a merchant ship, that comes from time to time into port to rest, but not always to stay there, but to take in new ladings, and refit itself for a new voyage to the same or other parts."

\section{Robert Hooke}

Next to Boyle, Robert Hooke (1635-1702) probably referred to luminescences more often than any of the other philosophers of his

${ }^{48}$ Works of Boyle, by T. Birch, Ist ed., 3: 91, 1744; 2nd ed., 4: 381, 1772.

${ }^{19}$ Icy noctiluca, 88, 1681. 
group. At first an intimate laboratory assistant to Boyle (from 16551662), and the man who built his air pump (in 1658), Hooke was responsible for many of Boyle's experiments. He later became professor of geometry in Gresham College and city surveyor of London, curator and then secretary of the Royal Society. He was a versatile and highly accomplished scientist in his own right-his theory of combustion approached that of Lavoisier-a man occupied with an extraordinary number of varied interests.

From the very beginning of the Royal Society it was the custom to suggest subjects and experiments for the next meeting. After Boyle had presented his observations on shining wood and fish it was ordered that these finds be recorded, and Robert Hooke, as Curator in charge of experiments, was directed to perform Boyle's experiments before the Society as soon as luminescent wood or fish could be obtained. ${ }^{50}$ Apparently none was found, for other experiments were shown at subsequent meetings.

We might expect that Hooke, as the author of Micrographia: or some physiological descriptions of minute bodies made by magnifying glasses, ${ }^{51}$ with observations and inquiries therupon (London, 1665), would have discovered that the light of shining wood was due to a fungus growth ${ }^{52}$ on the wood or the phosphorescence of sea water to minute animals, but such was not the case. However, Hooke used various luminescences to support his idea that light is a vibratory motion. In "Observ. IX. Of fantastical colours," dealing with the colors of muscovy glass and thin plates, Hooke made some revealing statements:

First, that all kind of fiery burning Bodies have their parts in motion, I think will be very easily granted me. That the spark struck from a Flint and Steel is in a rapid agitation, I have elsewhere made probable. And that the Parts of rotten Wood, rotten Fish, and the like are also in motion, I think, will as easily be conceded by those, who consider, that those parts never begin to Shine till the Bodies be in a State of putre-

${ }^{50}$ Thomas Birch (1705-1766), History of the Royal Society of London. 4 v. 2: 225 and 235,1756 .

${ }^{51}$ Henry Power (1623-1668), a Doctor of Physik, had observed with a microscope many of the same things as Hooke, and at about the same time. He had examined the minute spherules left from sparks when steel strikes flint (he referred to Hooke's observation of these globules), as well as "a small atom of quicksilver" (which reflected objects on every side), and the glowworm or glasworm (minutely described; see Chapter XVI). Power's work was entitled Experimental philosophy in three books: containing new experiments microscopical, mercurial, magnetical . . . illustration of the now famous atomical hypothesis, London, published in 1664, although the fiftyone microscopical observations were written up in August, 1661.

${ }^{52}$ Hooke gave an excellent figure of blue mould, and realized moss or mould " to be a more simple and uncompounded type of vegetation, which is set a moving by the putrefactive and fermentative heat, joyn'd with that of the ambient aerial, ..." 
faction; and that is now generally granted by all, to be caused by the motion of the parts of putrifying bodies. That the Bononian stone shines no longer than it is either warmed by the Sun-beams, or by the flame of a Fire or of a Candle, is the general report of those that write of it, and of others that have seen it. And that heat argues a motion of the internal parts, is (as I said before) generally granted.

But there is one Instance more, which was first shewn to the Royal Society by Mr. Clayton a worthy Member thereof, which does make this Assertion more evident then all the rest: And that is, That a Diamond being $r u b^{\prime} d$, Struck, or heated in the dark, Shines for a pretty while after, so long as that motion, which is imparted by any of those Agents, remains. ... That the shining of sea-water proceeds from the same cause, may be argued from this, That it shines not till either it be beaten against a Rock, or be some other wayes broken or agitated by Storms, or Oars, or other percussing bodies. And that the Animal Energyes or Spirituous agil parts are very active in Cats eyes when they shine, seems evident enough, because their eyes never shine but when they look very intently either to find their prey, or being hunted in a dark room, when they seek after their adversary, or to find a way to escape. And the like may be said of the shining Bellies of Gloworms, since 'tis evident they can at pleasure either increase or extinguish that Radiation.

It seems probable that Hooke regarded the vibration of hot incandescent bodies as self-evident and consequently devoted his argument to proving that light without heat was also the result of vibratory motions. His continued interest in luminescence can be inferred from a number of quotations.

In a letter to Boyle, August $15,1665,,^{53}$ concerning various matters, Hooke ends by saying, "I made last night also a pretty odd discovery of a new kind of shining animals, whose blood, or juices, did shine more bright than the tail of a glow-worm, when the candle was put out." It is possible that this new animal was a luminous centipede but no further reference was made to it.

In The Posthumous Works of Robert Hooke, M. D., S. R. S., by Richard Waller, published in 1705, Hooke expressed his ideas on the light of fish (p. 48) :

Fish when fresh or newly dead shine not or afford no Light, when they begin a little to taint and ferment as 'twere, they begin to shine or glare, but as they grow more putrid and rot, so again the Light decreases and at last goes quite out. So that it seems for the production of Light in such a Body there is requisite a determinate Degree of Fermentation or Corruption.

${ }^{53}$ From R. T. Gunther, Early science in Oxford. The life and work of Robert Hooke, 6: 250, 1930. 
In Hooke's Cutler Lectures ${ }^{54}$ there is a tract entitled Cometa, published in 1678, which dealt not only with the Comet of April 1677 , but also with "Mr. Boyle's Observation made on two new Phosphori of Mr. Baldwin and Mr. Craft." This section is an eyewitness account by Boyle of Mr. Craft's exhibit of his "Artificial Substance, that shines without any precedent illustration." The demonstration took place after supper September 15, 1677, and Mr. Craft is continually referred to as "the Artist." These observations on the element phosphorus describe various phenomena, especially writing on paper in self-luminous letters. They were introduced by Hooke apropos of a discussion of the light of the comet's tail. He took the position that one could not argue that the light of the tail was like "a sulphureous vapor exhaled from the earth and kindled above," because there were "very many and these very differing" ways of producing light, which he then proceeded to enumerate.

These various methods were restated, together with some new ones, in Hooke's "Lectures on light, explicating its nature, properties and effects," read about the beginning of 1680 , and published in Posthumous Works (pp. 71-148). The luminescences were divided into three categories (p. 112):

(1) Bodies shining without Heat, by an inward Fermentation [as] Glow-worms, Scolopendra, several kinds of Flies, decaying Fish, as Whitings, Oysters, and many others, sometimes Flesh, as Veal, also rotten Wood, and some sorts of Putrifying Vegetables, also some putrifying Urines; also the Phosphorus made out of the Caput mortuum, or the Rob ${ }^{55}$ of Urine found out by Dr. Kunkell, and many others. (2) "such as shine by Impression of Light made upon them, by being exposed only to the Light of the Sun or Day" as Bononian and Balduinian Phosphorus. (3) such as shine by Motion, Diamants, Sea water, some sort of Dews, Sugar, Black Silk, the Back of a Cat, and clean warmed Linnen, and several other Substances which will shine with a degree of Motion or a little rubbing.

He included here iron hammered till red hot or flints struck against each other.

Hooke also experimented with Baldwin's phosphorus given him by Dr. Slare, which "was found to be very receptive of light" 56

\footnotetext{
${ }^{54}$ Reprinted in facsimile as vol. 8 of R. T. Gunther, Early science in Oxford, 270, Oxford, 1931. Lectiones Cutlerianae, 1674-1679.

${ }^{55}$ A syrup of fruit juices. The word "rob" was apparently applied to concentrated wine. Caput mortuum refers to the worthless residue of a distillatum, in this case not so worthless.

${ }^{56}$ R. T. Gunther, Early science in Oxford, 7:517 and 540, 1930. Part II of Life and work of $R$. Hooke.
} 
although the light of the full moon, even when concentrated by a large reflecting glass was unable to excite it.

However, despite his interest in light, and despite his manysided ability-anatomist, microscopist, physicist, chemist, mechanical genius, and architect-Hooke made no comprehensive study of luminescence, although he saw and commented on every conceivable variety.

\section{Fermentation and Luminescence}

It will be observed that the word "fermentation" is frequently used by Hooke in connection with organic luminescences. Other writers, also, relied on the word in attempting to explain obscure processes. From the Latin, "fervere," to boil, the designation has indicated any kind of commotion resulting in chemical change or in solution. There was usually bubble formation, either carbon dioxide bubbles from the activity of yeast or vapor bubbles on heating a liquid. Chaucer spoke of "fermentacioun," and alchemists have used the word, together with putrefaction ${ }^{57}$ and digestion, to indicate almost any kind of chemical change accompanied with motion. The philosopher's stone was visualized as setting up a fermentation in common metals by which they were transformed into gold or silver, thus purifying and elevating them.

The remark of Gregory Ripley (died 1490), the English alchemist and poet, in A Compound of Alchymie (1471) that, "Trew Fermentacyon few Workers do understand," was particularly applicable in the seventeenth century. Not only Hooke, but Thomas Willis (1621-1675) in De Fermentatione (1659) considered fermentation a vibration or commotion of the particles of the fermentable substance ${ }^{58}$ and Neremiah Grew (1628-1711) in the Anatomy of Plants (1682) declared "The general cause of the growth of a . . . seed is Fermentation." These quotations will serve to indicate the importance which has been attached to the word.

Fermentation was included in textbooks of chemistry and physics, and indeed whole volumes were devoted to the subject. The $D e$ Fermentatione of Thomas Willis (1659) was done into English by S. P. Esq under the title $A$ Medico-Philosophical Discourse of Fermentation, or the Intestine Motion of Particles in every Body, and

${ }^{67}$ Aristotle in De generatione animalium (Oxford edition, ed. by W. D. Ross, 762 a) wrote: "All those which do not bud off or 'spawn' are spontaneously generated. Now all things formed in this way, whether in earth or water, manifestly come into being in connection with putrefaction and an admixture of rain-water. . . Nothing comes into being by putrefying but by concocting; putrefaction and the thing putrefied is only a residue of what is concocted."

${ }^{58}$ Justus Liebig's views in 1839 were similar. 
published as the first part of Willis's Practice of Physick (London, 1681). For Willis, fermentation, involving motion of particles, was responsible for practically all phenomena, the dissolution of materials in solvents, as well as fire, heat, and light, even life itself. Combustion was no more than fermentation.

An explanation of luminescences by fermentation was undertaken in the Zymologia Physica, or a Brief Philosophical Discourse of Fermentation, from a New Hypothesis of Acidum and Sulphur (London, 1675), by a London physician, William Simpson. The book, a pamphlet of 149 pages, was dedicated "To the Right Honorable the President and Fellows of the Royal Society." It deals not only with chemical matters of medical interest, but also discusses such things as hot baths, generation of minerals, and development of heat in haystacks and manure piles, as well as fire and light in general. Its interest lies in Simpson's obscure explanations.

Simpson listed a large number of luminous phenomena recognized at the time in connection with his treatment of

... Light as it is communicable to us from the great Fountain thereof, the Sun, which, as we suppose, consists in an illumination of Air by a perpetual emanation or eradiation of solar beams, springing from an incessant, but peculiar Fermentation in the body of the Sun, and fostered by an unwearied circulation of Ethereal matter, Light and Heat....

Our design at present is, onely to discourse of the nature and manner of such sort of Lights, which we find amongst bodies we usually converse with upon the Earth, and within the verge of our Atmosphere: which are as followeth, viz. the Light of culinary Fire, I mean, of most usual combustable concretes, the Light of all Sulphurous matters, whether in the form of mineral Sulphurs, Gumms, Rosins, Turpentine, Axungia's, \&c. or in liquids of Bitumen, Oyles, vinous Spirits, \&c. The Light of rotten Wood, long dry'd Fish, as Codds, \&c. who have an incipient putrefaction; the Light of Glow-worms, Cats-eyes, Light from attrition of Wood green or dry, which have thereby taken Fire, from the attrition or percussion of Steel and Flint, or any Pyrites, from the frication or pectation of animals: such as are Light from the Combing a Womans head (as sometimes hath been known) Light struck in the currying of a Horse; and that Light I have seen from a sudden frication upon a Catts-Back; of some Liquors, the Light of subterraneal Lamps; the perpetual Light preparable by the exuberate Mercury of the Philosophers, graduated by circulation and cohobation, according to our English Anonymus, who had seen it done.

The Light of some precious Stones, as Carbuncles; some sort of Diamonds, magnetical of Light, as the Bononian-stone, prepared by an artificial calcination. Lastly, The Light of meteors, amongst which may be reckoned Lightening, flashes of Fire, or Light seen in Storms upon the 
Sea, also those luminous meteors which in great Storms at Sea are seen to cleave to the tops of Maine Masts, and at the Sterns of Ships, by the Ancients call'd Castor and Pollux, by our English-men corpus-Ants, and very probably is the same with that meteor we call ignis fatuus, of which, as also concerning the Light seen upon the impressions of footings on the Sand upon Sea-shores: we shall shortly speak more.

Simpson's explanation of the light from all the above phenomena was the same, fermentation involving acid and sulphur. The glow of a cat's eye or

... the striking Flame or Light from a Cats back by frication in the dark ... may (for ought we know) be done naturally by a brisk, but slender woven Fermentation, perform'd either in the texture of their eyes, or rather in the very fabrick of their animal Spirits. . . .

In the next place we come to give the reasons of Light in rotten Wood, and dry'd Fish, \&c. where we are to observe, that as in the causes of Light aforesaid, from the principles of Acid and Sulphur, variously put into motion, being excited into a Fermentation divers ways: So amongst the rest, this by putrefaction is not the least; for Wood shines not till its principles of Acid and Sulphur, by a retrograde motion, fall into a new sort of Fermentation. . . .

The like account may be given of Light, from some sorts of Fish, hung up till they undergo an incipient putrefaction: For while their principles of Acid and Sulphur, do by the moisture in the Air, undergo a putefactive Fermentation, the Sulphur by those retrograde motions, becomes more volatiz'd, and by gentle touches from its inbred Acid, winds off in a luminous flame: ...

As to the Light from Glo-worms, its probable that sort of insect takes its original from the putrid juice or excrements of some animal or other insect, wherein the principles are winding off in a slender texture of an eradiating brightness, while juice that insect yet retains: For I look upon the slender woven flame inherent in Glo-worms, and other foresaid putrid juices to proceed from a mutual, but gentle vibration of the principles in their retrograde motion: . . .

Simpson continued with the same meaningless explanation of luminous meteors, subterraneal lamps, precious stones and "those which by a foregoing calcinatory preparation, become magnetical of Light, of which sort is the Bonian stone. ..." In all cases the cause was fermentation involving acid and sulphur, three magic words not one of which could be accurately defined.

In view of the original broad meaning of fermentation and its application to combustion processes, it is not surprising to find that George Ernst Stahl (1660-1734) announced the principle of phlogiston in his Zymotechnia Fundamentalis (Halae, 1697). Later, fermentation came to have a more restricted application, to bio- 
logical processes, involving decompositions of various kinds, more specifically to the activity of yeast and other microorganisms (see Chapter XIV). The late cighteenth-century view, which still attributed the process of fermentation to movement of the particles of one substance affecting another, lasted well into the eighteenth century, and indeed, traces of the idea in chemical thought persisted after ferments became definite chemical entities. With the discovery in 1887 of an enzyme, luciferase, responsible for light emission of plants and animals, perhaps we should not criticize too strongly the early use of the word "fermentation" to explain the light of rotten wood, long dead fish, and glowworms.

\section{Miscellaneous Writers}

Since no comprehensive book on luminescence appeared at the end of the seventeenth century, ideas regarding luminescence must be obtained from the writings of various well-known men, chiefly members of the Royal Society or the French Academy. Plot, Casati, Bottone, Lémery, Rohault, and Newton have all presented their views more or less casually in memoirs or in books dealing with other subjects. These men represent quite different approaches to the subject and their theories are correspondingly diverse, but representative of late seventeenth-century thought. Their statements illustrate a point made earlier in this chapter-the value of the scientific society in stimulating the acquisition of knowledge.

\section{ROBERT PLOT}

Robert Plot, L.L.D. (1640-1696), keeper of the Ashmolean Museum and professor of chemistry in the University of Oxford, was a contemporary of Boyle and Hooke. His interest in luminescence apparently arose from an account of luminous turf, recorded in his Natural History of Staffordshire (London, 1686, Chap. III, p. 115) . He wrote a vivid description of horses' hooves, which "fling up so much fire" from the peaty ground of a moor near Berefford over which they passed. The display of luminescence, as pointed out in Chapter XVI, was undoubtedly due to luminous earthworms living in the peat, but it stimulated Plot to discourse on "the things there are beside fire ... that give any light" and "whether the shining of the earths and mud above mentioned, may not be reduced to some one, or more of them," He divided "luciferous bodies, that send forth a light and yet have nothing of the nature of fire" into " animate, and others inanimate": 
As to the animate, 'tis evident that our English Glow-wormes, as well as the American, or flaming flyes, have a luminous juice in their tailes which shines in the dark: And 'tis as certain if we may believe the learned Monsieur Auzout, that the clammy moisture of Oysters that shines in the dark of a violet colour, comes from luciferous wormes that have their holes in the shells, whereof he distinguishes no less than three sorts [Phil. Trans. 12: 204, 1666].

It is true also, as 'tis a common experiment, that a cat rub'd upon the back in the dark against the hair sends forth luminous sparks. And there is a Master of Arts in this University that when He shifts Himself, emits such sparks so violently that they have been heard to crackle like the sparks of fire: all of which (with other instances that might be brought) seem mightily to confirme that there are such accensions, or Platonic flames in the juices of Animals, which shine only, and doe not burn, as were hinted and proved, from the Aerial Noctiluca, and solid Phosphorus.... And as for the inanimate luciferous bodies, beside the Bononian and Balduinian stones; the Phosphori, Smagdarinus and Fulgurans, and of Dr. Kunkelius. Everybody knows that rotten wood and loaf sugar scraped, shine in the dark, and that the salt water of the Sea, more especially when the wind is South East, ... gives so great a light, that being dashed with Oars, it seem to run off them, just like liquidfire; ...

Now though it be possible indeed that there may be small subterranean Animals, such as Oyster worms etc that may be bred and live in such black, bituminous, moist, rotten earths, or the mud of ditches, and upon sudden commotions may send forth such lights as were at large above mention'd; Yet me thinks they may rather proceed from some salinosulphurous mixtures that may be in those Earths and $M u d$, which being smartly moved as in the ditch, or violently striken with the Horses feet, as the Sea-water with Oars ... may more likely occasion such lights from the same principles (howsoever they operate) as in the salt-water of the Sea, though others may more probably think ... that they may become luciferous by the same means that rotten-wood and stinking fish are so: which yet shine not so much upon account of their rottenness as they doe of their moisture.

Plot was initially correct in suggesting that the light of the moor might be due to "worms." It is unfortunate that he finally changed his view in favor of "moisture," but the idea that there is light in water was very strong at the time.

\section{PAOLO CASATI}

Another learned writer on luminescence was the Italian Jesuit, Paolo Casati (1617-1707), teacher of mathematics and theology at Rome, who later became rector of the College in Parma. He wrote a number of works on physics, dealing with mechanics, hydrostatics, 
light, and fire. The book on fire, Dissertationes Physicae de Igne (Francofurti et Lipsiae, 1688), is best known (see title page in figure 12). In dissertatio 12 of De Igne, entitled, "De Luce Ignis," some seven pages are devoted to glowing eyes of cats, the light of the sea, luminous wood, mushrooms, the Nyctegretus of Pliny, luminous insects, the carbuncle, and the four kinds of phosphorus, viz., Bononiensis, hermeticus, smaragdinus, and fulgurans. He was one of those who had a single explanation for all the luminescences-salt.

Casati discussed these luminescences in the form of a conversation between three persons, one of whom was Dandulus. Each contributed some statement from previous writers or an opinion of his own. It was generally agreed that the glow of the eye was a real light emission. Dandulus, however, held that some light might be subjective (from the spirits), as the "sparks" observed when a person coughs hard, ${ }^{59}$ but sometimes light must be attributed to salts (salibus) : ${ }^{60}$

If you cut in the dark a gourd seasoned with much sugar and covered with a hard crust, you will see sparks flashing. When I saw this unexpectedly at an early age, I was quite overcome. But this is nothing spectacular, for the sea water itself when stroked by oars at night sometimes sends forth sparks, as I have heard from trustworthy persons who have sailed in triremes.

Dandulus held that the sea is saltier and more luminous in the tropics (Brazil for example) than toward the poles, and continued: ${ }^{60}$

I note the combination of a great amount of salt and much light in the same water. And it seems that this argument cannot be easily dismissed, since the wood of rotten oaks shines at night. For oakwood is of extraordinary weight, not so much from the admixture of earth but also from its abundance of salt. ... On the other hand, light wood, such as the poplar tree, which contains but little salt, does not shine at night. Agaricus, the luminous fungus, also contains salt, for did not Pliny say that Chiefly the acorn-producing trees of the Gauls carry agaricus ... [which] shines at night.

The close relationship between light and salt was also proved by the Bononian stone, for when the sulphur is removed by calcination (p. 351), "what is left is a very strong and biting salt . . . and with this salt light combines easily and, imbued with it, it shines in a dark place." Not so much was known of the other phosphors, particularly of the element phosphorus, which in the liquid form (dissolved in oil) could be rubbed on bodies and (p. 354),

${ }^{50}$ These "sparks" are actually a phenomenon connected with light refracted by white blood corpuscles moving in blood vessels over the retina.

${ }^{\circ 0} \mathrm{P}$. Casati, De igne, 349-350, 1688. 
because what is coated with this liquid burns with a harmless flame, the liquid is called by some ignis frigidus. If we knew by which method this type of phosphorus is prepared, this would shed considerable light on this our disputation, but in the meantime we must content ourselves with mere names; thought what is told about it indicates that this lastmentioned liquid consists mostly of swiftly moving salts. The scientists, so resourceful and diligent, through whose study the physical science makes such wonderful progress, certainly deserve highest praise.

\section{DOMENICO BOTTONI}

Another Italian who devoted considerable space to cold light was Domenico Bottoni (1641-1731), a physician of Messina and later of Naples, who wrote on various physical phenomena. His book, Pyrologia Topographica, etc. (Naples, 1692) was divided into three parts. The first, "De Igne in Genere," gave a philosophical account of the views held by various men, ancient and modern, on fire. The second section, "De Ignibus Coelestibus," was devoted to "fires" which produce light without being hot ("de ignibus lucidis non ardentibus"). Bottone discussed the difference between Lucem, Lumen, and Ignem with special reference to the firefly (Nitedula). The third section was entitled, "De Ignibus Terrestribus," taking up subterranean fires, especially the eruptions of Mount Aetna and Mount Vesuvius.

In the second part (pages 61 to 118 ) practically every type of luminescence was mentioned-marine scintillations, fish, rotten wood, glowworm, firefly and "cuciyo," Grimm's earthworms of Coromandel, dactyli, various inorganic phosphors, luminescence of skin and hair, and the aurora borealis. Bottoni held that motion was the basis of these luminescences. He wrote: ${ }^{61}$

A fiery nature is inherent in everything shining . . . for, although heat is not perceived on account of the fineness and looseness of some bodies, it will be sufficient for producing fiery effects and for causing motion in the air, as we have learned from many observations. ... When the wings [of a firefly] were tied together abandoning their constant movement, the light faded. Likewise we have noticed that when the eyelids of cats are sewn together so that they cannot move their eyes, their paths which are illuminated at night are obscured. In the same way, the glitter of the sea, of fish and putrid wood depends on motion.

Bottoni believed that motion

is the reason why fire-flies shine in the summertime, for the air is moved more continually in the neighborhood of the sun. It is also the reason

${ }^{\text {11 }}$ The translations have been made by Mrs. Annemarie Holborn. 
why fire-flies, having been exposed to the sun and then tightly shut in a glass, shine with greater brilliance at night as long as the air which is contained in the tubes and bladder of the fire-fly is set into quick vibration by the motion of the sun and is thus preserved.

A drawing depicting his firefly experiments is reproduced as figure 13.

Bottoni was particularly critical of Kircher, who had stated that

the nitedulae [fireflies] have obtained this innate light as something intrinsic by the providence of nature in order that they may see and be seen. But how could an ignorant overseer [of an estate] have expressed anything more clumsy? And why should a just nature have endowed these worms with this privilege of light while refusing it to other little animals, thus being liberal towards the first and stingy towards the others? The explanation for this phenomenon is simple because in difficult things we often take refuge in the occult. What eludes the vision of the human mind in the natural world, we try in vain to attribute to mysterious, especially divine, forces. Rather we should explain those phenomena by natural reasons, resorting to the world of senses as much as we can.

His own explanation of luminescence, that " when there is motion induced, fiery sparks come forth," seemed particularly applicable to sugar and to the light of the sea. Bottoni wrote:

Sugar, which is rich in fiery particles, when kneaded with more solid substances, emits sparks. In the same way particles of salt from the sea shimmer after they have been deposited when the sea becomes calm again, and they shine forth from the violent motion of the flood beating against the rocks, or breaking after the rising of a storm. When the air has been stirred up into whirlwinds, when the waves are impetuous and excited winds are blowing, it strangely looks as though flames were hanging on the masts of ships [St. Elmo's fire].

If we recall how quickly air in motion will rekindle a smouldering fire and produce a bright light, Bottoni's argument does not seem so ridiculous.

\section{JACQUES ROHAULT}

As pointed out in a previous section, Descartes was mostly concerned with the universe and man, practically neglecting luminescence, but some of his followers treated the subject in some detail.

One of these was Jacques Rohault (1620-1675), the eminent French mathematician and physicist of the Cartesian School, who wrote a Traité de Physique ${ }^{62}$ (1671), which was translated into

\footnotetext{
62 See G. Sarton, Isis 38: 137-148, 1947-1948, for the various editions of Rohault's famous textbook.
} 


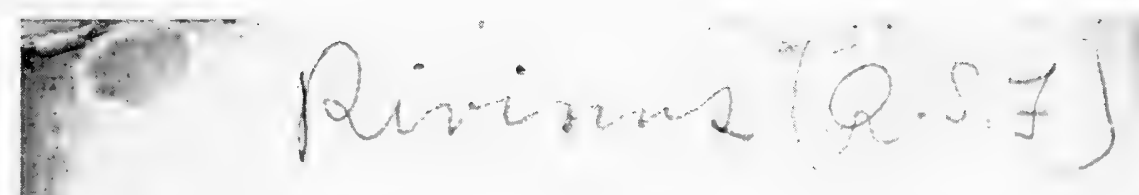

\author{
DE I \\ SUPERIORUMQVE GRATIA \\ SCHEDIASMA \\ NOCTU LÜCENTIBUS
}

Publica Erudizorum Difquifitioni

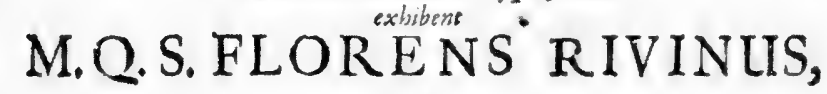

JOHANN-GODOّFR Feras :

Schrebezenfis, Philor. Baccalrandigifter.

Candid.

ALUMNI ELECTORALES:

Ad d.6. Decembr. 1673 .

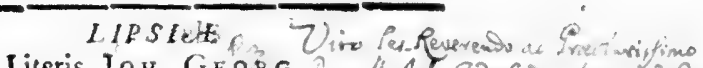

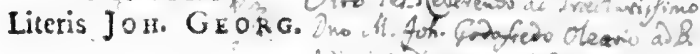

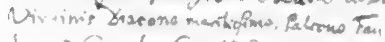

tow as apmate fis cotew.

Fig. 10. Title page of a second thesis on luminescence by Q. S. F. Rivinus and I. (.. Böhme (Leipzig, 1673), with an inscription by the author, M. Rivinus. 
DISSERTATIO

DE

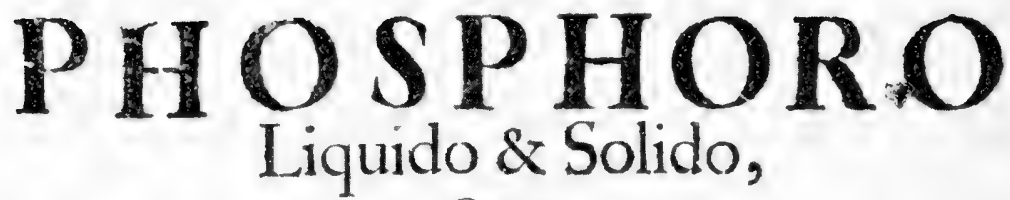

Quam

Gratiofe Facultatis Medice

CONSENSU

P R $\mathbb{E} S$ I D E

DN.BERNHARDO ALBINO,

PHIL. \& MED. DOCTORE, hujusq́; PROFESSORE ORDINARIO CELEBERRIMO,

PATRONO AC PR.ECEPTORE SUO ATERNUM

DEVENERANDO.

Publico Eruditorum Examini

Die IX. Nobembris Anno MDC LXXXIIX.

exponet

JOH. CHRISTOPH. KLETWICH, Laub. LUS. AUTHOR.

Francofurti ad Oderam, Typis ZEITLERIANIS.

Fic. 11. Title page of a medical thesis on phosphorus by J. C. Kletwich (Frankfurt-on-the-Oder, 1688). 

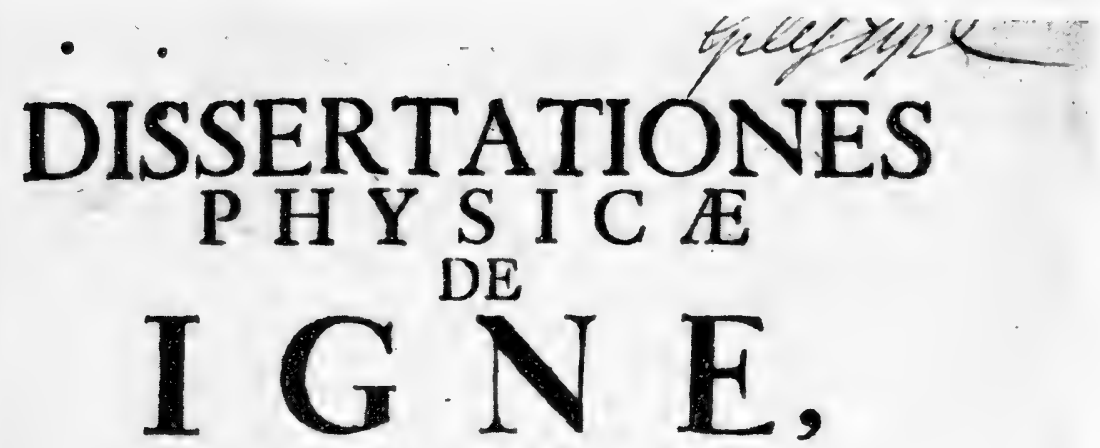

AUCTORE

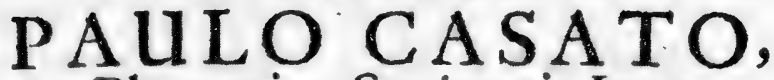

Placentino Societatis JESu.

In qvibus non tantum plura ad Ignis naturam ßpectantia Pbyfice explicantur;

Sed etiam folida totius fcientiæ Phyficx fundamenta traduntur.

juxia Exemplar Venerianusn revife atgre curatus edisai

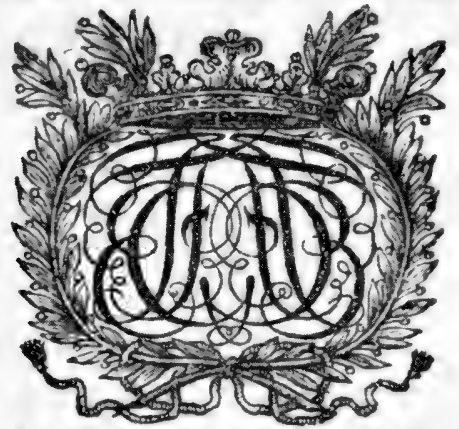

FRANCOFURTI E LIPSIAE,

SUMTIBUS JOH. FRIEDERICI GLEDITSCH.

ANNO N. DC. LXXXVIIL,

Fig. 12. Title page of the book on fire (Frankfurt and Leipzig. 1688), by the Jesuit. Paolo Casati. Like many other works on fire, such as that of another Jesuit, Joseph Herbert (Vicmna, 1773) it contains a full discussion of luminescences. 


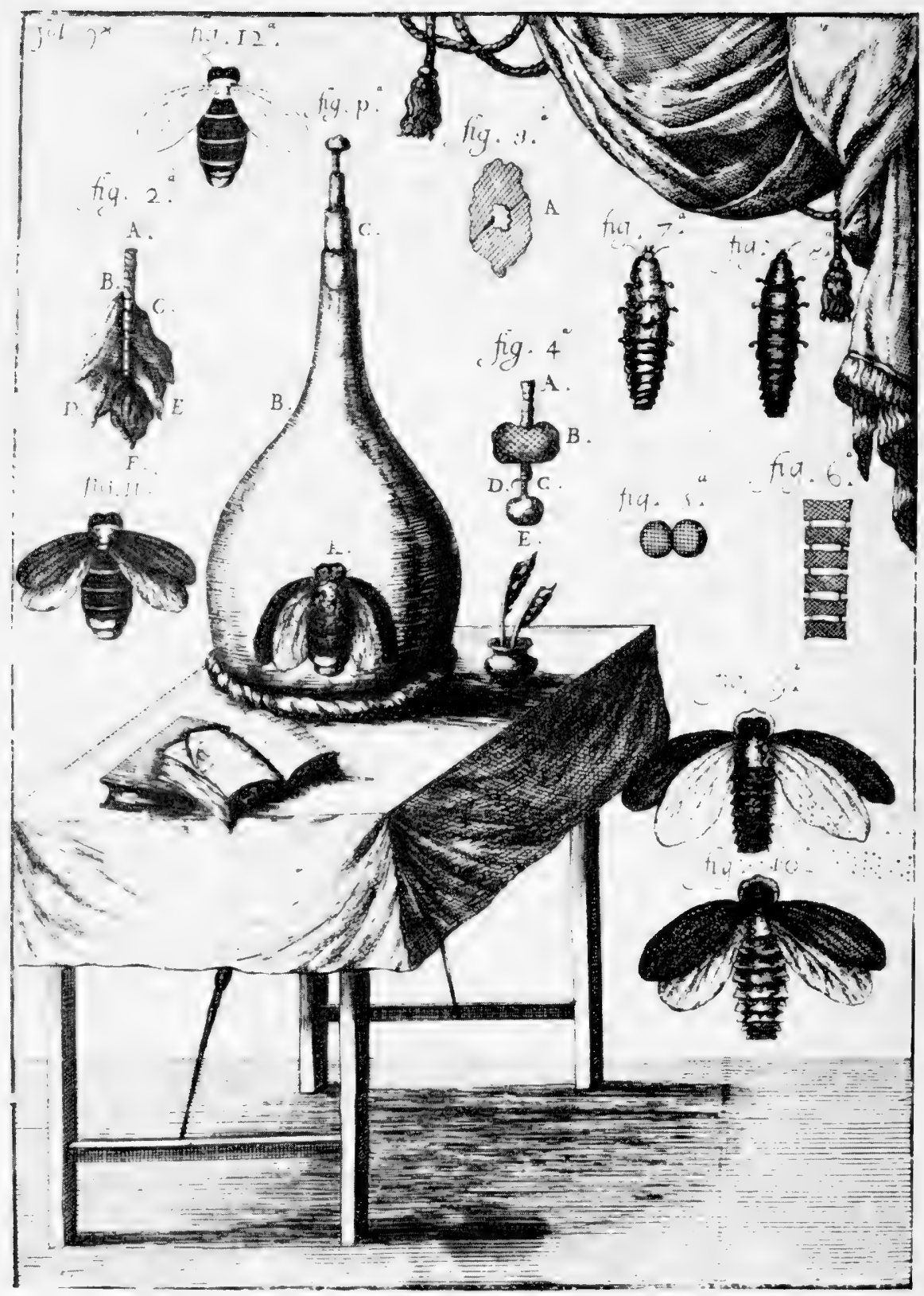

Fic. 13. Plate showing experiments on the firefly carried out by Domenico Bottoni. published in his book. Pyrologin Topographica (Naples, 1692). 
Latin by Samuel Clark in 1697 (later editions in 1701 and 1718) and into English by John Clarke D. D., Dean of Sarum, in 1723. Rohault discussed the question of light and colors in Part I, Chapter 27. He stated in his preface that he would follow Aristotle when he fully agreed with him but not otherwise, warned against a too experimental or too theoretical approach, and deplored the fact that mathematics was not used more frequently by physicists. John Clarke sought to modernize the work, for his translation carries the title, Rohault's System of Natural Philosophy illustrated with Dr. Samuel Clarke's Notes taken mostly out of Sir Isaac Newton's Philosophy. The copious footnotes bring the treatise up to date, but Rohault's ideas are left intact.

Like Descartes, Rohault held "That there is such a Thing as subtile Matter which penetrates the Pores of transparent Bodies." Then he proceeded (Sec. 19) to "examine all the luminous bodies that we know" and to show that they

do actually push this Matter every Way; which they will be found to do if it be true that the Parts are very small and very much agitated. . . . And to begin with Flame. It has been already so plainly demonstrated that it [flame] is composed of Parts very small, and which move with the greatest Celerity, that it is superfluous to say any more about it.

Rohault then proceeded to bring all other light sources in line with the Cartesian view. He wrote (Sec. 20-26):

We see also, that there arises very bright Sparks upon striking a Flint against Steel, or two Flints against each other, or an Indian Cane, against a common one, or by stroking the Back of a Cat in the Dark, when the Weather is dry and cold, and in a Multitude of other Things. The Cause of all which, is only this, that some of the Particles of these Bodies being entangled between others, when they are struck, acquire in flying off, a Motion like that of Flame, by which they in like manner push forward the small Globules of the second Element. ${ }^{63}$

There is some sort of rotten Wood, and of Fishes, when they begin to be corrupted, which shine very bright. Now a Body cannot putrify or be corrupted, but by the Motion of its Parts, some of which fly off (as is evident in rotten Wood, from the Largeness of its Pores, and from its Lightness, which render it different from what it was before; as a Coal, and the Wood out of which it is made differ from each other.)

${ }^{63}$ According to Descartes, light consisted of particles of the first element (materia subtilis or coelestis) invading all space, even solid bodies. The push or pressure of one particle on another was transmitted instantaneously as light from the sun throughout the universe. The second element was made up of globules of matter between stars and earth, and the globuli of the third element formed terrestrial bodies. Every natural phenomenon was the result of conduction of motion from one element to another, and every kind of material was determined by the relative amount and motion of the three elements. 
We must own therefore, that the Motion of the Parts which we suppose in luminous Bodies, is to be found here also.

It is not so easy to tell certainly, what sort of Motion that is, which makes some Worms and Flies to shine in the Dark: However it is very probable, that some sort of Matter is exhaled out of these Insects, like the Sweat of other Animals, and that this pushes the Matter of the second Element; and this is confirmed from hence, that they cease to shine as soon as they are dead.

The luminosity of precious stones gave some difficulty because it was not easy to visualize the particles of such hard bodies in motion and Rohault was inclined to doubt that they emitted light. He wrote:

If it were true, what they say of a Carbuncle and a Diamond, viz. that they shine in the Dark; I should freely own, that I am mistaken in all that I have said about Light; for there is no Probability, that Bodies so hard, should be composed of Parts which separately are in any Sort of Agitation. But it is certain, that these are only idle Stories, told without any Proof, and received by credulous Persons, for I have often times experienced the contrary my self.

'Tis true indeed, that a Diamond shines very bright in a darkish Place; but the Reason of this is, because it is so cut that the Sides reflect all the Light which they receive towards the same Part, as shall be more fully explained afterwards, when we come to treat of the Refraction of Light.

We have lately had an Account from England, ${ }^{64}$ that some Diamonds rubbed in the Dark, have shined so bright for a short time, that a Word or two might be read by Light of them. I have not observed this in any Diamonds that I have tried; however it may be true, without contradicting any Thing that I have hitherto wrote. For the Rubbing may raise some Agitation, if not in the Parts of the Diamond, yet at least in some Matter contained in the Pores of it, which continuing in Motion in the same manner as the Flame in the Pores of a burning Coal, may for some time push the second Element which is all round it, and dispose it to raise a small Sensation of Light.

After explaining how the Bononian stone imbibes light and then emits it in the dark (see Chap. VIII), Rohault discussed the properties of salt, its abundance in the sea, the flow and ebb of the tide, and other matters pertaining to the ocean. He had no conception of the animal origin of the light of the sea, but, like Descartes, attributed the sparks seen on violent agitation of sea vater to particles of salt. These salt particles become disengaged from the water and "dart themselves into the Air with their Points forward" and thus communicate a force "sufficient to impel the second Element,

os The work of Robert Boyle. 
and so produce the light." The details of his ingenious arguments will be found in Chapter XV on Phosphorescence of the Sea.

\section{ANTOINE LE GRAND}

Another Cartesian, who devoted considerable space to luminescences, was Antoine Le Grand (fl. 1650-1680), Le Père Antoine of Douay. In his book, Institutio Philosophiae (London, 1675), his discourse followed Descartes closely in explaining luminous fish and phosphorescence of the sea. He then elaborated on other luminous effects, presenting a typical Cartesian explanation. Le Grand wrote: ${ }^{65}$

Some kinds of Fire do shine, and yet are destitute of all heat. For they who use the Sea, observe that at sometimes when the Waves are dasht against Rocks, they appear as if flames of Fire rebounded from them. And thus also Rays of Light proceed from Rotten-wood, and Saltfish, but without any sensible heat.

The Reason is, because the Matter of the 1st Element, which is shut up in the Pores of such Bodies as these, tho' they be of force enough to push the Globuli of the 2nd Element, and to move the Retina, as much as is sufficient to produce the perception of Light; yet it is too weak, to separate the Earthly parts from one another, and to excite that agitation in them, which is strong enough to produce heat. Fire, therefore only shines when the Pores of the Terrestrial Particles are so narrow, that they can only admit the first Element, and shut out every thick Body. Thus when the pointed Needles, as it were of Salt do enter the strait Pores of Fishes, and drive thence the Globuli of the 2 nd Element, so as to be open only for the admission of the matter of the 1st Element, they do by this means make the Fishes Scales to shine like Glow-worms. Historians tell us of a certain Fly in New Spain, of the bigness of a Beetle, called Cocujus, whose Eyes do enlighten the Night, like a Wax Candle, so that it serves for a Lanthorn to those that walk by Night, and for a Lamp to burn in ones Chamber; and by the Light whereof one may read and write; and have the same effect when the Insect is dead, as when yet alive.

Some Bodies afford great Heat, but are destitute of all manner of Light: As the Blood of Live Animals, Horsdung tending to putrefaction, Quicklime sprinkled with water, in which things there is a hidden Fire that burns and scorcheth, without the appearance of any Flame.

The Reason is, because in such Bodies as these, the parts that surround the 1st Element and that are agitated by it, are too soft and limber to transmit the Action of Light. For tho' some of them swim on the top of the matter of the 1st Element; and comply with its motion;

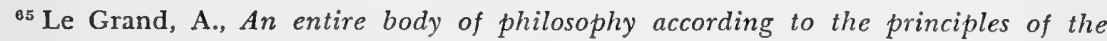
famous Renate des Cartes, etc. Trans. from Latin of the learned A. Le G. by Richard Blome 1: 99 ff., London, 1694. 
yet because some Watry and Aiery plyable parts, are mingled with them, they have the power to kindle heat and fire, but not of receiving the action of Light. Hence it is that when the Spirit of Vitriol and $O y l$ of Tartar are poured together, an effervescence or boyling is caused, because the free passage of the subtil matter being hindered in them, doth produce a wrestling or contest betwixt these two liquors which is the cause of a vehement heat....

Quick lime sprinkled with water waxeth hot because its parts are so suited and disposed as to admit the water surrounded only with the matter of the 1st Element; so that the Globuli, being expelled, the matter of the 1st Element only bears sway. For those Bodies are said to have the form of Fire whose particles do separately comply with the motion of the 1st Element and imitate the agitation thereof. . . .

When a Cats Back is strongly rubb'd with ones hand, sparks of Fire seem to proceed from them.

The Reason whereof seems to be this, because this Rubbing drives out some Particles of Moisture and causes them to be dissipated into the Air whereupon the particles of the fire, or if you will, the Sulphureus, greasy Particles, wherewith the Hair and Skins of Animals do abound; and those of Cats more than any other, croud and meet together, whence proceeds fire, and from the fire, light. Now this fiery Stream, or Exhalation, is easily retained or kept close in this Thicket of Hair, which consisting wholly of Sulphureous filaments, becomes easily entangled amongst the said Hairs. Which is the true Reason, why a Garment lin'd with Fur doth so obstinately retain the heat committed to it, and keep off the Cold. But it is to be noted, that these sparks of Light, which by stroaking are forc'd from the Back of a Cat, do only appear in the Dark, because a greater Light obscures and swallows them, as the Light of the Sun does that of the Stars.

Here we have the observations and the explanation of many kinds of luminescence according to a system of philosophy which Le Grand was ready to defend at all costs. This method of presentation is very characteristic of French science ${ }^{66}$ of that day and is particularly rell shown in the next section by the ingenious explanations of the chemist, Lémery. Quite naturally, he devoted considerably more

${ }^{66}$ Another Frenchman, Edme Mariotte (ca. 1620-1684) of Dijon, treated luminescence briefly in his book, Traité de la nature des couleurs (Paris, 1688). He noted that the flame of wood may be white, yellow, red, or blue, that of charcoal is red, and that of molten copper appears either blue or green, while the flame of sulphur and that of spirit of wine are blue. Rotten wood, the glowworm, and scales of some marine fish emit a light which also approaches blue. In this category, Mariotte also placed the artificial phosphors, "the blue light of sea water when agitated, and the light which appears when certain parts of the flesh of some animals begins to spoil." The light of these luminescences is blue "because of the fineness (subtilité) of some exhalations of volatile salt or of sulphureous material which give off no sensible heat whatever. It is true they resemble but are not like a flaming material, as water does not put out their light and they are not consumed." 
space to inorganic phosphors than did Le Grand, and his views on this particular subject will be found in Chapter VIII. It will be noted that both Rohault and Le Grand discussed a variety of luminescences, whereas Descartes mentioned chiefly sea water, luminous wood, and salt fish. Rohault and Le Grand were not only interpreting the views of the master, but also expanding his system to include all known phenomena.

\section{NICOLAS LÉMERY}

Probably few men have had more influence on the early development of chemistry than Nicolas Lémery (1645-1715). A court apothecary to Louis XIV and son of an apothecary, Lémery became disgusted with the alchemistic doctrines of the day and spent his life first in teaching the newer chemistry by simple experiments in his own room, and later to large classes under the auspices of the French Academy of Science, to which he was elected a member in 1699. He was one of the first to popularize science in any country. We may hazard a guess that luminescence experiments played a very considerable part in promoting the popularization.

He wrote a much used textbook ${ }^{67}$ which passed through thirteen editions during his lifetime and a total of twenty-two French editions. The first, Cours de Chymie Contenant la Manière de Faire les Operations qui sont en usage dans le Médecine (Paris, 1675), was translated as $A$ Course of Chemistry by Walter Harris, London, 1677. It contained nothing on luminescence. The second edition of Harris' translation (1686) from the fifth French edition (see title page in figure 14) devoted fifteen pages to the element, phosphorus, and four pages to the Hermetick phosphorus of Balduinus. However, the third English edition (and succeeding editions) edited by James Keill in 1698, gave a really extensive account (pp. 684-732) of phosphorus, as well as Homberg's, the Bolognian and the Balduinian phosphors. This edition was entitled $A$ Course of Chymistry containing an easie Method of Preparing those Chymical Medicins which are used in Physick.

Lémery was greatly influenced by Descartes's (1644) idea of matter as made up of particles in motion, and fire as resulting from terrestrial particles agitated by the "materia coelestis" i. e., fire is violent motion of minute bodies (corpuscles ignées) about their common center. Descartes held that flame was directed upward because it contains a large amount of "materia coelestis" lighter than air.

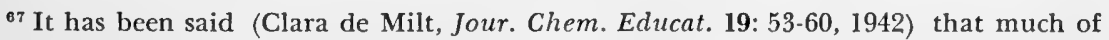
Lémery's material came from the Traité de la chymie (1663) of Christolphe Glaser (died ca. 1670).
} 
Lémery regarded light as "fire, which, coming tempestuously from the sun in great rays, divide themselves into an infinite number of small rays, which cover the Universe, and turn weaker and weaker in proportion as they go from their Center. . . ." As he represents the chemist's point of view, considerable space will be devoted to his knowledge of and ideas on various luminescences. His association with Wilhelm Homberg (1652-1715), the German chemist, who worked in Rome and London as well as Paris, and prepared a phosphorus of his own, may have aroused his special interest in cold light. As we shall see, Lémery had an explanation for everything.

Phosphorus is called ${ }^{68}$ by Lémery (p. 684), "A luminous matter distilled from Urine that has been fermented." The history of its discovery and detailed directions for making it are given, together with the following observation:

It is observed, That those who commonly drink Wine, their Urine doth scarce afford any Phosphorus, probably because the Wine being spirituous, its luminous matter doth very easily evaporate; for a viscous substance is necessary to retain it, like that of Ale or Beer: Hence it is, That they succeed in this Operation in England, Flanders and Germany much better than in France.

Various properties are described, such as solubility in turpentine, or better in oil of cloves, which " corrects its offensive smell," its ability to set fire to paper or to bedclothes, and its luminosity. The phosphorus itself can be used for writing when "the letters do seem to be a perfect fire" or "you may also mix carefully a little Phosphorus with a good quantity of Pomatum, and anoint such parts of the body with it, as you would have to appear luminous, without any danger; for the burning particles of the Phosphorus are tempered by the Pomatum" (p. 691).

Detailed descriptions (p. 701) are given by Lémery for making the "New Phosphorus of Monsieur Homberg" from fusion of " exactly one part Sal Armoniack powdered, and two parts of Quicklime quenched by the Air. ... If you strike this matter [a fused gray glass] with a Hammer or Pestle, you shall presently see it on fire."

The history of discovery of the Bolonian Stone and preparation of the Bolonian phosphor are told in detail, together with various observations and conjectures regarding it (see Chapter VIII). The article ends with a short account (p. 729) of "The Hermetick Phosphorus of Balduinus" which results from fusion of " a mixture of Chalk, and the acid Spirits of Aqua fortis, which makes it lucid. ... This Phosphorus is in its effects very like to the Bolonian Stone,

${ }^{68}$ All quotations are from the Keill translation (1698). 
but that takes the Air much sooner than this Stone, because it contains abundantly more salt; its light does not endure so long as that of the Phosphorus which I described before" (p. 732).

Lémery's great interest lies not in original experiments but in his attempts to explain the origin of the light of various luminescent bodies. His style was conversational; moreover he anticipated objections to his ideas, and always had a ready answer. Some of these explanations follow (p. 695):

From considering all the kinds of Phosphorus both Natural and Artificial, and the Experiments that have been made upon them, I cannot but conclude that the general cause of the light they give does proceed from a very great agitation of insensible parts; and whereas it is very probable that fire is only a very violent motion of little bodies round their center, the parts of our Phosphorus may be said to have received the same determination by the fermentations it hath undergone; for Wood never shines in the dark until it becomes rotten, that is to say, until it has undergone a sufficient fermentation to make its most subtile parts move nimbly round their center. The Bolonian Stone is not luminous until it has been calcined a certain time, in order to excite a motion of its parts. A Cat is not luminous throughout the whole body, but if you rub its back roughly against the hair, in the night, it will shine, because this irritates the Animal, and determines the Spirits to move much more strongly than otherwise they would do. We may also say, That the Eyes of a Cat are a kind of Phosphorus.

The Viper being irritated darts forth its Tongue with so much quickness, that it appears all on fire. Many little creatures, such as some kinds of Caterpillars, and Woodlice do shine in the night, because they have a matter so exceeding subtile towards their Tail, that it produces a sort of fire; and it is for the same reason of the motion of parts that Urine does become luminous.

That which gave occasion to the working upon Urine for the making of the Phosphorus was, That in some little holes of the earth wherein there had been standing puddles of Urine, a light had been observed to be seen at nights.

This statement appears to have been neglected by writers on the discovery of phosphorus, but Lémery referred to the light of standing urine several times.

Lémery's explanation of luminous meat is very interesting. He wrote (p. 698):

Sometimes there have been found in the Shambles pieces of Veal, Mutton, Beef, which do shine in the dark, though they have been but newly killed, and yet other pieces of the same kind killed at the same time, shall not shine at all. Nay, this very year was seen at Orleans, in a very temperate season, a great quantity of meat of this sort, some of it 
would shine all over, and others of it would shine only in some certain places, in form of Stars. It was likewise observed that with some Butchers almost all their meat was found to be luminous, and with other Butchers there was not a bit to be seen of that kind. Men concluded presently that such flesh as this was altogether unwholesome to eat of, they therefore flung away a great deal of it into the river, and several Butchers there were like to be ruin'd by this accident; but at last perceiving that there was such quantities of it, some people ventur'd to eat of it, and at length it was found to be as good meat as any other.

I conceive that this Phenomenon may be imputed to two causes.

First, To the Pasturage of the Beasts; for it is certain that in some Countries the Herbs are more spirituous than in others, and those do give such an active impression to the humors of those Beasts who feed on them, that they may have a disposition to the making this Phosphorus.

Secondly, To these Beasts having been heated more than others in their driving upon the road, or else to their having been killed before they had sufficiently rested after their journey; for the spirits being put into a great motion thereby, do not every where lose it after the Beast is killed, and so long as the spirits do continue their rapid motion, so long the Phosphorus is to be seen, but when the flesh begins to stink, there appears no more light in it because these vigorous spirits are then spent, or else they come to be confused in the meat by the means of another fermntation.

But you will not fail to make me this Objection: If the Phosphorus does consist in a violent motion of the insensible parts, then stinking meat should be more luminous than that which was newly killed, because the smell proceeds from the separation of the principles of a mixt body by fermentation, which as they rise from it do strike the Nerve of Smelling, wherefore there must needs be a great motion of parts in stinking meat than in that which is fresh.

I answer, That that which makes the Phosphorus in meat newly killed is a matter much more active and more subtile than that which gives the ill smell to stinking meat; it is a remainder of the spirits which do run with a prodigious swiftness through the body of a living creature in all its parts, and unless the matter be in this degree of motion, it will never become lucid, no more than if the insensible parts of inflammable matters be not put into a very rapid motion, they will not take fire.

Perhaps also it may be that the meat in the corrupting might receive a sufficient agitation of parts to produce light, as it happens sometimes in the standing puddles of Urine.

In considering the light which appears upon the surface; of standing Urines, I have been led to think that there are oftentimes ferosities that settle in the bodies of sick persons which might be in a condition to make kinds of Phosphorus, if they had but air enough to illuminate them; at least they do produce the effects of fire, as in Gouts, in Rheumatisms, in the Erysipelas, and in abundance of other Inflammations. 
Here we have excellent examples of the point of view of one chemist at the end of the seventeenth century.

\section{ISAAC NEWTON}

As Francis Bacon bridged the sixteenth and seventeenth centuries, Sir Isaac Newton (1642-1727) may be said to have connected the seventeenth and eighteenth. The experiments and thought which went into his work were largely products of the seventeenth century. Newton first obtained a prism in 1666. He delivered a course of lectures ${ }^{69}$ on optics at Cambridge University in 1669-1671 and communicated his discourse to the Royal Society as a "New Theory about Light and Colours" in 1672. It contained the germ of the corpuscle theory, and described the supposed properties of an aether pervading all space. This paper led to publication of the Opticks in 1704 , followed by later editions in 1717, 1721, and 1730 .

The first edition of Opticks contained only sixteen queries and practically nothing on luminescence. In the second edition (1717) Newton omitted some mathematical tracts, and enlarged some of the sixteen queries of the first edition and added fifteen more, making thirty-one in all. It is among the "Questions" in the 1717 edition that Newton listed many different ways of producing light. After speaking of incandescence as due to vibratory motions within bodies he referred (Opticks, 2nd ed., 361-318, 1718), to other light emissions as the result of similar vibratory motions:

Qu. 8. Do not all fix'd Bodies, when heated beyond a certain degree, emit Light and shine; and is not this Emission perform'd by the vibrating motions of their parts? And do not all Bodies which abound with terrestrial parts, and especially with sulphureous ones, emit Light as often as those parts are sufficiently agitated; whether that agitation be made by Heat, or by Friction, or Percussion, or Putrefaction, or by any vital Motion, or any other Cause? As for instance; Sea-Water in a raging Storm; Quicksilver agitated in vacuo; the Back of a Cat, or Neck of a Horse, obliquely struck or rubbed in a dark place; Wood, Flesh and Fish while they putrefy; Vapours arising from putrefy'd Waters, usually call'd Ignes Fatui; Stacks of moist Hay or Corn growing hot by fermentation; Glow-worms and the Eyes of some Animals by vital Motions; the vulgar Phosphorus agitated by the attrition of any Body, or by the Acid Particles of the Air; Amber and some Diamonds by striking, pressing or rubbing them; Scrapings of Steel struck off a Flint; Iron hammer'd very nimbly till it become so hot as to kindle. Sulphur thrown upon it; the Axletrees of Chariots taking fire by the rapid rotation of the Wheels; and some Liquors mix'd with one another whose Particles come together

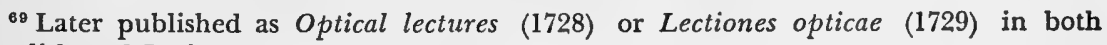
English and Latin.
} 
with an Impetus, as Oil of Vitriol distilled from its weight of Nitre, and then mix'd with twice its weight of Oil of Anniseeds. ...

Qu. 9. Is not Fire a Body heated so hot as to emit Light copiously? For what else is a red hot Iron than Fire? And what else is a burning Coal than red hot Wood?

Qu. 10. Is not Flame a Vapour, Fume or Exhalation heated red hot, that is, so hot as to shine? For Bodies do not flame without emitting a copious Fume, and this Fume burns in the Flame. This Iqnis Fatuus is a Vapour shining without heat, and is there not the same difference between this Vapour and Flame, as between rotten Wood shining without heat and burning Coals of Fire?

Newton was thus fully aware of the various kinds of luminescences, and, like others of his time endeavored to explain them by reference to a common cause, in his opinion the "vibratory motion of their parts," applicable to all luminous bodies both hot and cold. It is not in the origin of light but in his view of the propagation of light, as a stream of particles, that Newton differed from Descartes, and also from his contemporaries, Hooke and Huygens, the supporters of a wave-like propagation.

\section{Summary}

Thus, before 1700, all the main types of luminescence save one (crystalloluminescence) were recognized, and a very considerable body of facts regarding their properties had been accumulated. Some new luminous animals had been recognized. With the growing disuse of Latin as a scientific language, and the rapid spread of knowledge in every country, the stage was set for the many detailed studies of luminescent phenomena characteristic of the coming years. New examples of all types of luminescence were to be discovered and new facts assembled. The great goal ahead was explanation of the cause of the light emission, a fitting aim for scientists who followed the pioneers of the seventeenth century. 


\section{THE EIGHTEENTH CENTURY}

\section{Introduction}

$A^{\mathrm{S}}$ JOHN DRYDEN extolled the remarkable advances of science in the A seventeenth century, so Joseph Priestley heralded the state of knowledge during the eighteenth. Speaking of conditions since the revival of letters in Europe, Priestley (1772: 30) wrote that there were "those who consider the world as having now arrived at the state of perfect manhood with respect to science," and that whoever "shall reflect upon the astonishing improvements that have been made ... in all branches of real knowledge, in little more than two centuries that have elapsed [since] the expiration of that long period of darkness, cannot help forming the most glorious expectations."

The eighteenth century has been called the "Age of Reason" or the "Age of Enlightenment," Knowledge did increase at a rapid pace. Many science academies, both national and local, were started-the Russian Academy at St. Petersburg (1725), the Swedish Academy at Stockholm (1739), the Royal Academy of Denmark at Copenhagen (1742), the American Philosophical Society at Philadelphia (1743). Local Institutes appeared in various cities, Bordeaux in 1703, Montpellier in 1706, etc. Journals, textbooks, and encyclopedias made knowledge available to all.

The first book of the eighteenth century to treat a luminescence in some detail was Francis Hauksbee's Physico-mechanical Experiments (1709). Among other things, it described the light produced by rubbing evacuated " bottles." It will serve as a proper historical beginning to focus attention on a new type of luminescence, now all important to modern living. Moreover, this new light was associated with electricity, and the eighteenth century deserves, above all, to be remembered as the century when interest in electricity was paramount. The names of Franklin, Beccaria, Nollet, Gray, Dufay, Desaguliers, van Musschenbroek, and many others come to mind, but the first important experiments were those of Hauksbee.

\section{Francis Hauksbee and Electroluminescence}

Although Jean Picard had noted the light of a mercury barometer when shaken in the dark in 1675, and much discussion of the phenomenon appeared around 1700 after Johann Bernoulli described 
his perpetual phosphor (mercury shaken in a glass phial), a real understanding of the source of the light was to come from electrical experiments. William Gilbert's book, De Magnete (1600), may be considered the first dealing with the new science of electricity and both von Guericke and Boyle made electrical experiments in the seventeenth century, but Francis Hauksbee (died 1713), deserves special acclaim as the inventor of a glass electrical machine used for half a century, and as the first man to study electroluminescence intensively in the laboratory. His interests also included capillarity, density, and the cause of barometric changes, but his observations on the light of rarified air in glass globes have had as great an effect on modern illuminating art as the discovery of the Bolognian phosphor one hundred years before.

Hauksbee succeeded Hooke as Curator of Experiments of the Royal Society. Little is known of his life except that his education was slight and he had an inquiring mind, combined with a great admiration for the learned. These characteristics appear in the title, the dedication and the preface of his book, Physico-Mechanical Experiments on Various Subjects, published in London in 1709, with a second edition in 1719 . The complete title is reproduced as figure 23.

In the preface, Hauksbee stated his credo as follows: "The Learned World is now almost generally convinc'd, that instead of amusing themselves with Vain Hypotheses, which seem to differ little from Romances, there's no other way of Improving NATURAL PHILosophy, but by Demonstrations and Conclusions founded upon Experiments judiciously and accurately made." He then launched into a description of his device for rotating and rubbing various materials, particularly the glass vessels which could be evacuated and in which he observed such striking luminous effects. The details of his experiments are presented in Chapter VII on electroluminescence.

Hauksbee's Physico-Mechanical Experiments evidently exerted a very considerable influence on the popular interest in natural phenomena. In the 1720's a pamphlet appeared advertising "A Course in Experimental Philosophy. To be perform'd by Benj. Worster ${ }^{1}$ A. M. and Tho. Watts, at the Academy or Accomplant's Office, for qualifying young Gentlemen for Business, in Little Tower Street. ..." The course was to be divided into (1) Mechanicks, (2) Hydrostaticks, (3) Pneumaticks, and (4) Opticks. The demonstrators had a good supply of apparatus. Among such matters as electrical

${ }^{1}$ Benjamin Worster (f. 1720), later wrote a book, $A$ compendium and methodical account of the principles of experimental philosophy (London, 1730). 
attraction and repulsion, a dissection of the eye, and the working of microscopes and telescopes, there were to be shown-" The Electrical Phosphorus, The Mercurial Phosphorus, The Liquid Phosphorus, The Solid Phosphorus, and The Light of Phosphorus augmented in Vacuo."

\section{Prize Essays}

It has been pointed out that when the first societies were formed in the seventeenth century, the custom was to carry out experiments at the meetings. The Royal Society allotted particular inquiries to members or groups of members who were to report on them after special study. At the beginning of the eighteenth century a change occurred. Prizes were bestowed for the solution of general problems, treated in the form of an essay.

\section{JEAN JACQUES DORTOUS DE MAIRAN}

One of the first of these prizes was offered in the field of luminescence by the Bordeaux Academy of Science, established in 1703. It was won by de Mairan (1678-1771), later a member of the French Academy, physicist and mathematician, who succeeded Fontenelle as perpetual secretary in Paris. His essay ${ }^{2}$ was entitled Dissertation sur la Cause de la Lumière des Phosphores et des Noctiluques, a 54-page booklet, published at Paris in 1715 and at Bordeaux in 1717. The title page is reproduced as figure 15. The preface stated that this was the third prize won by de Mairan and added new glory to his triumphs. Later he was to become famous as the creator of a new theory of the aurora borealis (see Chapter VII).

De Mairan's prize essay is of particular interest because it gives an excellent insight into the explanations current at the beginning of the eighteenth century. The first twenty-four pages were devoted to a discussion of the two theories of light-that it consisted either of waves propagated in the ether or was an effusion of corpuscles. De Mairan upheld the latter view. He believed that the light substance (matière lumineuse) consisted of sulphur, "very subtile and very restless (agité). It alone of the five principles (sulphur, salt, earth, water, and mercury) known to chemists has the property of acting on and transmitting its action to other substances." De Mairan stated that the words "Phosphores" and "Noctiluques" would be used synonomously. He divided them into the natural and the artificial.

The natural phosphores were glowworms, flies, caterpillars, other

${ }^{2}$ A disappointing work, according to both Heinrich (1815) and Ehrenberg (1834). 
insects in hot countries, and worms in oysters; also rotten wood, hair, scales, feathers, blood, and flesh of animals at certain times and certain circumstances. Eyes, such as those of Alexander the Great which shone like fire, and the tongue of the viper "which seems on fire when the animal is irritated," were also classed as natural phosphores; likewise, the diamond, rubbed on gold; gold, silver, and copper rubbed on glass, as observed at the French Academy of Sciences in 1707; sulphur and sugar when crushed, water of the sea in tempests and in the wake of ships.

De Mairan remarked that some explained the light of the sea as reflection of moonlight or starlight but he declared that the sea actually had a light of its own. The only other marine luminescent body mentioned was the "poulmon marine" (jellyfish) which some thought to be a fish and others claimed to be a "viscous excrement of the sea hardened by the sun." 3

Finally, among the "phosphores naturelles" were those phenomena which consist of sulphurous exhalations and inflame in the air, the "Ardens" or "feux folets" on the hair of horses or on infants, or on trees. They were called St. Elmo's fire by sailors. In addition, the occasional displays of "feux aeriens" (the aurora borealis), especially bright in 1683, were grouped as natural phosphores. This list has a strong resemblance to one published by Francis Bacon.

Among artificial phosphores, de Mairan mentioned the burning phosphorus of Kunkel, the Bolognian Stone, the hermetic phosphorus of Baudouin, the phosphorus of Homberg, and the light of mercury in a barometer or in a pneumatic machine, i. e., a vacuum. According to de Mairan, the explanation of all these luminescences lay in movement of the sulphur which they contained. The ordinary cause of this movement was fermentation, external agitation, rubbing or fire. The movement had to be great enough to disengage the sulphur from material which hampered it. The density and cohesion of this material was regarded as an impediment to the movement until the sulphur transmitted some of its motion to its surroundings and "broke from its prison," when light appeared. Matter that contained much sulphur luminesced by fermentation alone, such as flesh, the skin of "testaceous fishes" and exhalations in the air. The luminescence of animal material after death and of wood that luminesces when it is rotten, were regarded as the best examples of light from fermentation.

The glowworm and other living animals could not become luminous unless circulation of a nourishing fluid, agitation of the spirits

${ }^{8} \mathrm{~F}$. Bacon apparently held this view. 
and transpiration produced an effect similar to fermentation. Part of the light-giving sulphur which they contain thereby collected in vesicles or was filtered in purifying glands, from which it escaped because of its abundance and extreme agitation.

Mercury was regarded as a material in which the light substance was already present but so rare and weak that it did not appear unless the air was removed from it (as in a barometric vacuum) and it was gently agitated. The diamond was a material in which the sulphur had need of excitation by violent rubbing.

All artificial phosphores had passed through fire and their sulphur had consequently received various modifications, i. e., their sulphur had been released and augmented. Fire itself was thought to be made up of foreign corpuscles with a great quantity of sulphur, all luminous. In preparation of phosphores, fire moulded the pores of the material into a "figure" convenient to receive the corpuscles of light.

De Mairan explained why the "phosphore brulant" of Kunkel could not be made as readily from urine after wine drinking as after beer drinking. Like Lémery, he held it was owing to the fact that the sulphur of wine was "beaucoup plus exaltez" than that of beer and dissipated itself more during fermentation or in the fire necessary for preparation. Kunkel's phosphorus contained, in addition to sulphur, much saline principle to ignite the material, which required air or humidity, and should be sprinkled with some "licqueur" which causes a subtle and violent fermentation called an effervescence. The light of burning phosphorus was said to be as bright as sunlight gathered into focus by a silver mirror.

These explanations certainly represent a valiant attempt to bring together a number of diverse (unfortunately too diverse) phenomena and to explain them by a common principle. It will be noted that de Mairan was greatly influenced by Lémery and his phrase, "agitation of insensible parts," as the mechanism of light production. He spoke of sulphur as the particles which become agitated and the material which explains everything. Although Lémery is not mentioned in the essay, in fact there are no references, certain passages very clearly indicate that Lémery's work had been carefully read. The essay ended with a quotation from Pliny: "Often contemplating the nature of things, I am persuaded to think nothing is incredible."

De Mairan was born at Beziers, near Montpellier, but removed to Paris in 1718, when he was elected a member of the French Academy. He was not only a scientist interested in many subjects, especially in celestial and meterological phenomena, but a littéra- 
teur as well. He wrote Letters on China and was an intimate of Voltaire (1694-1778), who mentioned him in the satirical poem, Le Temple du Goût (1733).`

It is probable that de Mairan's early interest in luminescence led him to prepare another work, Traité Physique et Historique de l'Aurore Boréale, first published in 1733. His views on this celestial luminescence, attributed to the atmosphere of the sun descending at times to the earth, were radically different from those expressed in Des Phosphores et des Noctiluques. Details of his remarks on the aurora borealis will be found in Chapter VII on electroluminescence.

\section{JOHANN HEINRICH COHAUSEN}

A longer essay, ${ }^{5}$ and possibly a competitor for the prize, was published by the official physician of the episcopal bishopric of Münster, Johann Heinrich Cohausen (1665-1750). It was entitled Lumen Novum Phosphoris Accensum, sive de causa lucis in phosphoris tam naturalibus, quam artificialibus, Amstelodami, 1717 (see title page in figure 16). This extensive monograph of 342 pages considered most of the known luminescences and marshalled a considerable array of facts. Cohausen's idea of classification is revealed in the table of contents. The book is divided into three parts. The first part, dealing with natural phosphors, has two sections, one treating phosphors of the air ("De Meteoris Lucidus et Igneis"), the sea ("De Lumine Maris") and of the land ("De Phosphoris Mineralium, Lapidium et Gemmarum "), the second with luminescence of animals (including man and brutes, animals which see at night, i. e., whose eyes are phosphori, and insects) and plants (including herbs, roots, and rotten wood).

The second part is also divided into two sections. The first section takes up phosphors made artificially, like the Bononian stone, the

${ }^{4}$ The poem poked fun at French literature, especially at the poet, Jean Baptiste Rousseau (1670-1741), who had criticized Voltaire. Concerning the gifted Bernard de Bovier de Fontanelle (1657-1757), who preceded de Mairan as perpetual secretary of the Academy of Sciences and was also a member of the French Academy of Inscriptions, Voltaire wrote:

\footnotetext{
" He from a planet came post-haste

Back to the sacred shrine of Taste;

Reasoned with Mairan, with Quinault

Trifeled away an hour or so;

And managed with an equal skill

The lyre, the compass and the quill."
}

From the translation of Voltaire's Works 36:53, Paris, London, New York, Chicago, E. R. DuMont, 1901 .

${ }^{5}$ Regarded as better than de Mairan's essay by Ehrenberg (1834) but valueless according to Kayser (1908). 
noctiluca aeria and fulgurante (from urine) and the phosphorus Balduinus. The second section deals with pyrophori fecali, the pyrophoro sacro machabaeorum, pyrophori and phosphori of vegetable origin and the mercurial phosphor, together with their uses.

In the third part of the book a great deal of attention is devoted to the hermetic phosphorus of Baldouin, which was the pride of the Germans. There is an excellent index.

Throughout the work, Cohausen attempted not only to describe the luminescence but to explain the light itself. However, there is little but metaphysical speculation, based on the chemistry of the day. A few excerpts will illustrate the treatment of the subject:

There is in all things a certain salt, which is nothing other than potential fire or, as the philosophers say, earthly water impregnated with fire.

Therefore, just as light concentrated and rather vigorously set in motion produces fire, so fire, rarified, produces light. Particles of light, however, confined at least, though not compressed, generate heat or invisible fire.

For indeed this stone [the Bononian], by calcination, and especially by being freed from heavier sulphur, takes on such a texture that it gives off a peculiarly modified air (aether), which easily acquires from the luminous air circumfused around it such an impulse and motion as this air acquires from light itself, or from material of the primary ${ }^{6}$ element, even when that extraneous source shall have been removed. ${ }^{7}$

It would be futile to continue the presentation of such ideas, which seem far more obscure than those of Lémery. The Lumen Novum Phosphoris Accensum was Cohausen's only work on luminescence, but he was a learned man of wide reading and reflection, who published a number of medical works. He ridiculed the use of snuff in a book in 1716 and held that the secret of attaining a vigorous old age was the company of young people, whose insensible perspiration was important, particularly the breath of virgins. His views on this subject will be found in Hermippus Redivivus, etc. (Frankfurt, 1742). It was translated into English and issued as a privately printed limited edition from Edinburgh in 1885 .

\section{Dufay and Réaumur}

Charles François de Cisternay Dufay (1698-1739) was another important investigator of the early seventeen-hundreds. He not only wrote a paper giving the history of the luminescence of the barometer in 1723 but also carried out many other experiments on luminescent substances, particularly minerals and precious stones, which

"Probably the "materia coelestis" of Descartes.

${ }^{7}$ From Cohansen, Lumen novum, etc. (1717), translated by Dr. Hannah Croasdale. 
were published in the memoirs of the French Academy of Sciences in 1726,1732 , and 1738 . He is perhaps best known for his interest in electricity, but he also wrote on chemistry and many other sciences. In 1732 Dufay was appointed Director of the Jardin des Plantes in Paris, but despite this contact with living things, he made no real study of bioluminescences and never collected his researches on inorganic luminescences into a book. This was no doubt due to the fact that Dufay's death occurred when he was only forty-one years old, thus cutting off a brilliant career. His ideas, as expressed in his published papers, will be found in Chapters VII, VIII, and IX, devoted to electroluminescence, phosphorescence, and thermoluminescence, respectively.

Another eminent Frenchman of independent means, René Antoine Ferchault de Réaumur (1683-1757), admitted to the Academy in 1708 , is best known for studies in the mechanical arts (conversion of iron to steel, 1722), as a physicist (introduction of a particular thermometer scale, 1731), and as an entomologist (Mémoires pour Servir à l'Histoire des Insectes, 6 v., Paris, 1734-1742). However, his interest in luminescence is attested by the monograph on the light of the mollusc, Pholas, dactylus, Des Merveilles des Dails (1723). This work was apparently inspired by the hope of preserving indefinitely the luminous secretion of the mollusc. Although no liquid preservative was found, Réaumur did notice that dried Pholas would again light when moistened. He thus gave the tirst proof that water was necessary for bioluminescence, a finding not tested on other luminous forms until the work of Spallanzani on medusae in 1794. Réaumur's experiments are described in Chapter XVI.

It is unfortunate that Réaumur did not complete the history of insects. The volume on beetles remained unfinished. Had he studied the glowworm with the care he lavished on the silkworm, science would have had the first accurate knowledge of its life history, habits, and fine structure. This gap was to be filled by Baron Carl De Geer (1720-1778) of Stockholm, in 1755, and by the Frenchman, Philibert Gueneau de Montbeillard (1720-1785), in 1782.

\section{Beccari and the Bolognian Institute}

In Italy a group of workers, chief of whom was Jacopo Bartolomeo Beccari (1682-1766), carried out experiments on luminescent materials, both organic and inorganic, and published a series of papers (1731-1747) in the Commentarii de Bononensi, official organ of the Bologna Institute of the Sciences and Arts, founded by Count Marsigli in 1711. Soon after the foundation, Beccari was appointed pro- 
fessor of physics, medicine, anatomy, and chemistry and later became its president. He was associated with Domenico Maria Gusmano Galeati (1686-1775), Giuseppe Monti (1682-1760), and Francesco Zanotti (1692-1777). The experiments of these men were similar to those of Dufay, and greatly extended the materials known to be phosphors. They included such organic substances as paper, natural plant products, and dried animal parts, although the luminescence might not last longer than a second or two after exposure to sunlight. The work was quite new and fascinating; details will be found in Chapter VIII on phosphorescence.

Apart from the discovery that so many common substances are luminescent, a chief interest in Beccari derives from the classification of luminescences which he adopted in the two papers which appeared in 1744 and 1747 . His views are well expressed in the opening paragraph of a translation by B. Wilson (1776), entitled: An Account of a Great Number of Phosphori Discovered by J. B. Beccari.

1. Of bodies that give light in the dark there are several kinds. For some bodies throw out light spontaneously, and others upon being excited. And of the former kind some shine with a natural light as glow-worms, dates [i.e., Pholas], and a good many aquaticks: others enjoy an adventitious light, as rotten woods and the flesh of some quadrupeds and birds. These are not naturally phosphori, but owe that property to some particular cause; which generally is putrefaction, and sometimes an insensible change introduced into the natural constitution of the parts.

2. The other kind of bodies which become phosphori upon being excited, or are at least assisted by that means, may be distributed into different species, according to the different modes of excitation. These modes are attrition, heat, the free admission of the air, and lastly, being exposed to the external light.

Here we have practically a modern classification of luminescence by method of excitation, as if the words triboluminescence, thermoluminescence, chemiluminescence and photoluminescence were used.

Beccari's monograph deals entirely with the latter, excitation by exposure to light. He related that there were not sufficient samples of the Bolognian stone to supply the demand since the secret of preparation was mostly kept in a few prominent families, and philosophers were glad when Baldwyn prepared his phosphor from chalk and spirit of nitre. ${ }^{8}$

\footnotetext{
${ }^{8}$ The work of Beccari and others of the early eighteenth century had focused atten. tion on the extraordinarily large number of luminous materials. At the same time there was a growing interest in electricity. It seemed logical to regard "phosphores"
} 
Beccari's (1747) interest in bioluminescences ${ }^{\circ}$ is shown by the study (with Monti and Galeati) in 1724 of Pholas dactylus, the boring mollusc, brought to Bologna by Marsigli. Their goal was the same as that of Réaumur, preservation of the luminescence. However, they attained greater success. The luminous material could be kept for over a year by mixing it with flour or adding honey, thereby forming a paste that would luminesce when added to water. ${ }^{10}$

\section{Bioluminescence Discoveries}

Throughout the eighteenth century knowledge of animal light increased by the slow process of accretion; facts were added from time to time. Biological textbooks in the modern sense were unknown, and no general monograph on the subject appeared. Natural histories merely mentioned that an animal was luminous.

Some progress was made in proving that most phosphorescence of the sea is due to living organisms, but the light of wood and flesh was generally regarded merely as a natural phosphor to be contrasted with the artificial variety, made by man. There was no certain knowledge of luminous bacteria or fungal mycelium, although "animalcules" were occasionally suspected as the cause of the light.

The work of Réaumer and of Beccari and associates on the luminescence of Pholas, mentioned previously, that of Spallanzani on luminous jellyfish (1794), and the various studies of the effect of gases on the firefly and on luminous wood and flesh, made toward the end of the century, represent the experimental approach to the bioluminescence problem. The belief was gaining that the light of organisms was due to phosphorus or something like phosphorus, and resulted from a slow combustion.

Descriptions of new luminous animals continued, but the number reported was small, compared with the new species to be described in the nineteenth century. The published list begins with Meriam's (1705) observation of light from the lantern fly, Fulgora. Swimming worms ("Insects") in the canals of Venice were seen by

as electric bodies. This opinion was expressed by an anonymous writer, actually Antoine-Joseph Dezallier d'Argenville, a member of the Royal Society of Sciences of Montpellier. He sometimes wrote under the pseudonym, Alexandre le Blond. His book, L'Histoire naturelles éclaircie dans deux de ses parties principales, la lithologie et la conchylologie dont l'une traité des pierres et l'autre des coquillages, appeared at Paris in 1742. The section on "Phosphores" contains nothing new, except the author's identification of phosphors with electricity, but a rather complete list of the known luminescences is presented.

${ }^{\circ}$ For details, see Chapter XVI of this book.

${ }^{10}$ When the author started work on luminescence in 1916, Professor Raphael Dubois kindly shipped him a jar of the siphons of Pholas, preserved in sugar, from Tamarissur-Mer, France. 
Vianelli in 1749. Noctiluca was described by Baker (1753) from a letter of Sparshall; then ostracods (Godeheu de Riville, 1754) and shrimp ${ }^{11}$ (Banks and Solander, 1768) were observed to be luminous and, finally, ctenophores were recognized as contributing to the light of the sea by Bosc (1800). Details of all this new knowledge will be found in Chapters XIV, XV, and XVI, dealing with "Burning of the Sea," "Shining Wood, Fish and Flesh" and "Animal Luminescence," respectively.

\section{Encyclopedias}

Following the great books of knowledge of the Middle Ages, the compilation of facts was for a time published in more compact and concise works. A number of these, both dictionaries and cyclopedias, appeared during the late seventeenth century, by Furetière, Corneille, Moreri, Coignard, Bayle, and others, but not all dealt with science. Often called dictionaries or lexicons, they were really cyclopedias, with a detailed treatment of the subjects discussed. Some of them, for example Le Grand Dictionnaire Historique of Louis Moreri (1643-1680), were greatly enlarged in the eighteenth-century editions and contained articles on phosphors.

\section{FURETIÈRE'S DICTIONNAIRE}

The best of the early compilations was the Dictionnaire Universel (1690) of Antoine Furetière (1620-1688), sponsored by the French Academy. It was quite up to date in treatment of luminescence and will serve as a reference point with which to compare the larger works of the eighteenth century.

Furetière's dictionary as well as his Essais (1684) places science first. He proposed to explain "les termes de toutes les Sciences et des Arts" rather than the Arts and Sciences, a subtitle used in practically all other compilations.

Furetière gave nine senses in which the word "lumière" is used, many of them figurative. The physical meaning is defined as

a very subtile body, rapid [prompt] and fine [deslie], which causes brightness, which brightens, which gives color to all things and which renders objects visible. ... "Lumière" also applies to all other gleaming things [clartez sublunaires] such as those which come from fire, flame, candles, torches and other natural or artificial bodies like the glow-worm, rotten

${ }^{11}$ Marine shrimp are self-luminous. Probably the first example of a Iuminous bacterial infection of a fresh-water shrimp, the "crevette de rivière," was observed by Thulis and Bernard (1786), without knowing that the light must have been due to luminous bacteria. Among land animals, the first case of luminous bacterial infection was observed by Hablitzl among the midges of the Bay of Astrabad, Persia, in 1782. 
wood, decayed [gaste] fish, eyes of the cat, etc. The Bolognian stone imbibes the light of day and emits it in darkness.... It is a necessary condition for a light to appear blue that it be discontinuous, such as the flame of sulphur or spirit of wine, as contrasted with a bright strong light which appears white. Rotten wood, glow-worms, scales of certain marine fish emit light that borders on blue on account of the subtlety of their emanations, from some volatile salts or some sulphureus material which is abundant in them. They are not inflammable materials because they are not extinguished by water, nor consumed nor sensibly hot.

Under the word "Phosphore," Furetière mentioned particularly "Pierre de Boulogne or ardoise de Boulogne or aimant de la lumière." He then wrote that Jean Elhoz in 1676 distinguished four kinds of phosphors, the Bolognian, the Balduinian, the Phosphorus smaragdinus, and the phosphorus of Kunckel, also known as "feu perpetuel " and "feu froid." The words "luminescence" or "phosphorescence" do not appear, but the treatment in this early dictionary is extraordinarily comprehensive. No wonder that Furetière placed "Sciences" before "Arts" in his title.

\section{HARRIS'S LEXICON TECHNICUM}

The first English technical dictionary, the Lexicon Technicum, a Universal English Dictionary of Arts and Sciences Explaining not only the Terms of Art but the Arts Themselves, was published in London (1704) by John Harris ${ }^{12}$ (ca. 1667-1719), a clergyman. In a later edition (1736), the subjects were arranged in alphabetical order. It was more than a dictionary. "Phosphorus" was defined as a "Chymical Preparation, which being exposed to the Light or Air, will shine in the Dark." He told how to prepare the phosphorus of human urine, the Bolognian phosphorus and Balduin's phosphorus and quoted Mr. Boyle and Dr. Slare's experiments.

The word "Light" was used to signify three things (1) sensation, (2) cause of that sensation, (3) medium between light source and object. Harris wrote:

Light is undoubtedly produced by Motion; but yet 'tis not every Motion that will produce Light. The Learned Dr. $H$ [R. Hooke] in his Micrography p. 55 judges the Motion that produces Light ought to have these Requisites: 1. That it be exceeding quick, like the Motions of Fermentation and Putrefaction; (as you see in Shining Pickels and Rotten Wood) . (2) It must be a Vibrative Motion, and also have its vibrations exceeding short. This he concludes from the shining of Diamonds, when chafed or rubbed. ...

\footnotetext{
${ }^{12}$ Harris delivered the Boyle lectures in 1698, and became Secretary of the Royal Society in 1709.
} 


\section{JABLONSKI'S LEXICON}

A rather complete compendium was the Allgemeines Lexicon der Kunste und Wissenschaften, published in 1721 by Johann Theodore Jablonski (1654-1731). This work ${ }^{13}$ is full of science and devotes considerable space to luminescence, not as a general subject but under special headings such as Johannis-würmlein (the glowworm), where the claims for preparation of a "liquor lucidus" are described and rejected. Ignis fatuus is called "Irrlicht" or "Irrwisch," an apparent light or flame seen near the earth in damp places, akin to the ignis lambens which appears when the fur of animals is rubbed. It is explained as " entzünden von schwefligen Ausdampfungen." Under "Licht," all the known luminescences are cited and under "Phosphorus," there is a short paragraph defining the word as light from other than the usual sources (i. e. fire, sun, etc.), with a division into the natural and artificial variety. ${ }^{14}$

\section{EPHRAIM CHAMBER'S CYCLOPEDIA}

The first popular cyclopedia that divided knowledge into rather broad subjects in a modern manner was the two volume work of Ephraim Chambers, ${ }^{15}$ F. R. S. (died 1740), which first appeared in 1728 (2nd ed., 1738), entitled, Cyclopedia or An Universal Dictionary of Arts and Sciences. Its popularity is attested by the fact that it passed through five editions between 1728 and 1743 and stimulated production of the great French Encyclopèdie.

${ }^{13}$ Second edition, 1748, by J. H. Hartung. A third edition appeared in 1767.

${ }^{14}$ In Germany also the Gazophylacium medico-physicum or Treasury of medical ana natural things, was published at Leipzig in 1709 by Johan Jacob Woyt, a cyclopedia in which German explanations of Latin words are given. There are nearly two pages devoted to phosphorus or noctiluca, which is defined as a body lighting in the dark either natural, like shining worms, rotten wood and other things, or artificial, when made from the Bononian stone, chalk, blood, or urine. Then follows a description of the discovery of phosphorus by Brandt in 1669 and the method of preparation. The Handlungs Lexikon (1712) of Johann Hübner (1668-1731) contains nothing of importance on luminescence, but Felix Maurer in Observationes curioso-physicae (1713) devoted about fifty pages to perpetual fires and lights in chapter VIII, entitled "Unauslöschliche Liechter zu machen-wie auch von denen Kunst-Feuer." The discussion included fireflies and other luminous animals as well as phosphors and phosphorus. The book is a collection of wonders, not alphabetically arranged.

${ }^{15}$ Not to be confused with Chambers' Encyclopedia of 1860-1868, published by William (1800-1883) and Robert Chambers (1802-1891) and based on the tenth edition of Broeckhaus' Konversationslexikon. Another cyclopedia, less well known, was that of Chevalier Dennis de Coetlogen, Knight of St. Lazare, M. D., and member of the Royal Academy of Angiers. It was titled, An universal history of arts and sciences, in two volumes, published in London in 1745. The excellent nine-page article on "Phosphorus," which includes all types of luminescence, is an appendix to the subject, "Opticks." The author has been unable to inspect the ten-volume Nuovo dizionario scientifico e curioso sacroprofano of Gianfrancesco Privati (1689-1764), published in Venice from 1746 to 1751 . 
The second (1738) edition contains an excellent article on phosphorus, using this word to designate any type of body emitting light at a low temperature, rather than for the element phosphorus specifically. The word "phosphorescence" is a more modern term not found in Chambers.

The two-page article on "Phosphorus" divided them into the natural and artificial variety. (1) Natural phosphori luminesce without any preparation such as glowworms, lantern-flies, rotten wood, the eyes, the blood, scales of fish, flesh, sweat, feathers of certain animals; diamonds when rubbed, sugar and sulphur when pounded; "sea water and some mineral waters, when briskly agitated," cat's fur or horse's backs when rubbed. Dr. Croon tells us that

upon rubbing his own body briskly with a well-warmed shirt, he has frequently made both to shine; . . . all natural phosphori have this in common, that they do not shine always; and that they never give any heat. But that, which, of all natural phosphori, has occasioned the most speculation, is the Barometrical or mercurial phosphorus.

A considerable account is given of this, referring to Picard, Bernoulli, Homberg and Hauksbee.

(2) Artificial phosphori require some sort of preparation. Such are $(a)$ the burning phosphorus (also called Kunkel's phosphorus and phosphorus fulgurans), $(b)$ the Bononian phosphorus, and (c) the Balduinian or hermetic ${ }^{16}$ phosphorus.

Chambers described the preparation of the Bononian and Balduinian phosphors and gave the following

Rationale of the effects of PHOSPHORus. It may be observed that in most of the natural phosphori, there is a brisk attrition or friction concerned; which we may suppose either to give the minute parts of the substance the proper motion and agitation necessary to convert them into fire, if fire be so producible, (as Bacon, Boyle, Newton, and the generality of the English philosophers have supposed it is) or to expel and emit the particles of fire naturally contained in them. See FIRE, FLAME, FRICTION, ATtRition, \&c.

In the factitious sorts, we may note, that a long process by fire is usually required wherein the matter undergoes divers coctions, torrefactions, calcinations, distillations, \&c. in the course whereof a considerable quantity of fire must necessarily be imbibed, and may possibly be retained therein.

The word "Noctiluca," as defined by Chambers, applied to "a

\footnotetext{
${ }^{16}$ So called because the German chemist Baldouin was referred to as Hermes in the Society of the Naturae Curiosum.
} 
species of phosphorus, so called because it shines in the night, without any light being thrown on it: such is the phosphorus made of urine. ... Mr. Boyle ... gives an account of three NoctilucaeThe first, invented by Krafft, he calls the consistent, or gummous Noctiluca, as being of a texture not unlike that of cherry-gum." It was also called the constant Noctiluca or solid Phosphorus.

The second is liquid, invented by the said Krafft, being only a dissolution of the former in a convenient liquor [oil]. The third kind was prepared by Mr. Boyle himself, and of a different nature from both the other; for it would not shine of itself, like either of them, but required the contact of the air (though not any external rays or heat) . . . it was not the body that shown, but an exhalation or effluvium mixed with the air; on which accounts, the inventor gives it the denomination of the aerial Noctiluca. The same Mr. Boyle, afterwards, prepared another sort; which from the little pellucid fragments, or crystals therein, he denominated the icy Noctiluca.

The word "luminescence" does not appear except in fairly recent dictionaries. However, much discussion of luminescence is to be found in the older encyclopedias under the heading "Luminosity" or "Light." The word "Fire" may also contain data on luminescence but Chambers merely gave an interesting discussion as to whether fire is to be considered a body or a motion.

Under the heading "Light," Chambers devoted two large pages to the subject, quoting Newton on different ways of producing light and referring to the experiments of Hauksbee on light from attriticn and rubbing and those of Boyle on shining wood and its behavior in a vacuum. Chambers also quoted M. Bernoulli who "found by experiment that mercury amalgamated with tin and rubbed on glass produced a considerable amount of light in the air; that gold rubbed on glass did it still in a greater degree: but that, of all others, the most exquisite light was that produced by the attrition of a diamond."

In a two-volume supplement ${ }^{17}$ to the Cyclopedia, published in 1753 there is an additional three-page article on phosphori, bringing the subject up to date. Data on light from rotten wood and the experiments of Beccari are given. In the Chambers' treatment of the subject bioluminescences occupy a subordinate place. In some of the nineteenth-century encyclopedias this position is reversed and a great deal of space is devoted to the "Luminosity of Animals and Vegetables." However, we must conclude that the subject of luminescence was quite extensively considered in this Universal Dictionary of Arts and Sciences.

${ }^{17}$ Abraham Rees (1743-1825) brought out an enlarged edition of Ephraim Chambers' Cyclopedia in 1778-1788. 


\section{ZEDLER'S UNIVERSAL LEXICON}

The next great work is the truly remarkable sixty-four volume Grosses vollständiges Universal Lexicon aller Wissenschaften und Künste welche bisher durch menschlichen Verstand und Witz erfunden worden, published by Johann Heinrich Zedler (17061760) between 1732 and 1750. Each volume contains something like 1,000 pages. It differs from previous compilations in that it is a cooperative work of many authors. The articles on "Licht" (1738) makes no mention of luminescence but the subject is rather exhaustively treated under "Phosphorus" (1741) which is defined as a substance which shines in the dark without burning.

Many kinds of phosphori were listed, again divided into the natural and the artificial. Among the natural phosphori Zedler included (1) the worms and beetles found among grasses and bushes in summer, (2) damp rotten wood, (3) luminous fish, (4) luminous flesh, (5) the luminous dust (Staubwesen) of hair when rubbed against the grain. All of these have neither heat nor fire. The list of artificial phosphors is especially interesting because of the terminology used. They are of two kinds, (1) those that must first be exposed to the light of day such as $(a)$ the Phosphorus Bononiensis, also called P. italicus or P. mineralis, sometimes Lapis luminosus or Ignis frigidus, ${ }^{18}$ prepared from the Lapis Bononiensis and (b) the Phosphorus Baldeweinus or P. Hermeticus; (2) those which will light day or night but previously require some movement such as shaking, striking or pumping away the air. Of this sort are (a) the Phosphorus mercuralis, when mercury is shaken in a vacuum; (b) P. aethericus, when an evacuated tube is rubbed and light appears; (c) P. scintillans, when a warmed silk handkerchief is stroked between the fingers; $(d)$ P. Hombergii made from sal ammoniac; (e) P. liquidus, prepared from Phosphorus urinae dissolved, together with camphor, in clove oil; $(f)$ various other varieties of the element phosphorus.

There is no attempt by Zedler to explain the origins of the light, and the bioluminescences are merely mentioned by name, but every possible variety of inorganic luminescence is considered and five columns are devoted to Phosphorus urinae. The reader is referred to the monographs of both Cohausen (1717) and Dortous de Mairan (1717), described as a learned nobleman of France, for additional information.

${ }^{18}$ Note our modern term, "cold light," rather than "cold fire." 


\section{THE FRENCH ENCYCLOPÉDIE}

The great French Encyclopédie of the eighteenth century originated in a French translation (1745) of Ephraim Chambers' Cyclopedia. However, a much more ambitious compilation was soon planned which, over a period of years, passed through a remarkable history of delay and censorship. It finally appeared as thirty-nine huge volumes in 1777-1779 under the editorship of Denis Diderot (1712-1784) and Jean Baptiste le Rond D'Alembert (1717-1783), both eminent scholars and scientists. In this work, entitled Encyclopédie, ou Dictionnaire raisonné des Sciences, des Arts et des Métiers, par un Société de Gens de Lettres, ${ }^{19}$ luminescences are mostly considered under the heading "Phosphore," although the article "Feu electrique" by M. le Monnier is comprehensive, describing the electroluminescence observed by von Guericke, Boyle, Dufay, Hauksbee, and others. The article on "Lumière" merely mentions the light of phosphors, diamonds, and feu electrique.

Although the basis of the Encyclopédie was Ephraim Chambers' compilation, it is difficult to recognize this origin for the article, "Phosphore." The idea that luminescence and electricity are closely related is the main theme of the presentation. The existence of phlogiston is also assumed, for the text had been completed before Lavoisier's discoveries. Phosphores are divided into six categories: (1) Animal bodies "which the electric fluid has penetrated and rendered luminous," such as the glowworm, the lucciole, insects of the Canals of Venice, flies of the Antilles, the tongue of the irritated viper, eyes of some living animals, the flesh of those recently killed, certain fish, some shellfish, the coats and hair of many animals when rubbed vigorously. "These bodies are not all organized to exhibit the electric phosphorescence constantly, as the electric torpedo or electric eel, but they become so under certain circumstances during love, irritability and anger, among many others. The identity of the nervous fluid and the electric fluid is well known." (2) Inanimate electric phosphores, excited by friction such as the globe of Hauxbee. (3) A group of substances rendered luminous by brisk striking or friction which electrifies or puts into movement their innate light or inflames the phlogiston which they contain. Such are sugar, diamonds, or quartz pebbles. (4) The solar phosphori that must be first exposed to light in order to shine. (5) Phosphores produced by putrid fermentations, distillation of inflammable sub-

${ }^{19}$ The Encyclopédie methodique of the bookseller, C. J. Panckoucke, started appearing in 1781 and was not complete in 1832, after 166 volumes had appeared. One part, the Dictionnaire de physique (1793) contains an excellent article on "L'aurore boreale." 
stances, deflagration of sulphur, solution in acids of metals, abundant with phlogiston. Included in this category are the fires that arise from heat of fermentation,,$^{20}$ luminous vapors of fish, or meats cooked or spoiled, vapors of stagnant waters, ${ }^{20}$ feux follets, defined as little fires that play in the air, "étoiles filantes" and other "pareils meteores," perhaps also the pyrophore of Hoffman. (6) Phosphores produced by the union of a strong acid with pure phlogiston, which results in a true sulphur, although all sulphurs or all unions of acid and phlogiston are not phosphores. The Phosphore de Kunkel, known also as "phosphore d'urine" or "le soufre phosphorique," is " un soufre parfait," composed of phlogiston and a particular acid.

\section{ENCYCLOPEDIA BRITANNICA}

The first edition of the Encyclopedia Britannica (1768-1771), in three volumes, contains practically nothing on luminescence but the second edition of ten volumes (1777-1784) makes up for the previous deficiency. The long article on electricity contains much on the "electric light" or electroluminescence, while the article on "light" is full of various luminescences. The discussion was taken almost entirely from Priestley's book, Vision, Light and Colours (1772), to be considered in a later section on Priestley and his contemporaries.

This general survey of encyclopedias of the eighteenth century reveals that the authors had excellent knowledge of the recognized luminescences of their time. The different varieties are all mentioned but the explanations are understandably influenced by the nationality and the period of the writer. Public instruction on "cold light" was by no means neglected in the "Age of Enlightenment."

\section{Textbooks of Chemistry and Physics}

The various textbooks of chemistry and physics must rank in importance with encyclopedias for the diffusion of luminescence knowledge. Since light is primarily a physical subject and fire a chemical problem, in treating luminescences the distinction between chemistry and physics breaks down. Since luminous phenomena were sometimes thought of as fire and sometimes as light, they are to be found in both chemical and physical treatises.

It will be recalled that throughout the eighteenth century Newton's views became predominant, replacing the Cartesian conception of the universe. Light was almost universally accepted as a cor-

${ }^{20}$ Possibly a reference to the mist observed over manure piles and marshes. 
puscular material body. Heat and fire were also usually regarded as corporeal bodies, although not necessarily the same, and heat came to be spoken of quite generally as a material fluid, "caloric." The times were definitely materialistic in conception. There was the electric fluid, the magnetic fluid, and the phosphoric principle. The change of view, light as a wave and heat as a mode of motion and a form of energy, was to come at the beginning of the nineteenth century with the work of Thomas Young and Count Rumford, respectively.

Space does not permit a detailed survey of the views presented in various textbooks, but a few selected quotations from the best-known authors will serve to present the thinking of the day. In chemistry, the importance of Lémery's Traité of the previous century cannot be overemphasized. Its influence in later editions lasted well into the eighteenth century, particularly in medicine. The 1756 edition contains 35 pages on phosphorus and on the Bononian and Baldeweinian phosphors.

\section{HERMANN BOERHAAVE}

After Lémery, one of the best known textbooks was Elementa Chemiae, Paris (1724), by the famous Dutch physician, Hermann Boerhaave (1668-1738), professor of chemistry at the University of Leyden. It was translated in 1735 by Timothy Dallowe and in 1727 as $A$ New Method of Chemistry by Peter Shaw and E. Chambers of Encyclopedia fame. Shaw was the English physician who edited Bacon's Works. A section (pp. 353-357) of the second (1741) edition (by P. Shaw alone) was entitled, "Of producing true Fire in a cold body, by the sole access of the Air." It dealt with what are called phosphori and also included pyrophori. Boerhaave described Krafft's phosphorus made from animal juices by distillation, and the Homberg pyrophore, made from charcoal of plant parts or animal excrement and alum. Both ignite when exposed to air.

The emphasis in the book is very definitely on the nature of fire, regarded as an infinite number of little corporeal bodies. In a footnote it is pointed out that no body " attracts [fire] by any peculiar virtue " except possibly the Bononian and Baldwinian stones, which seem "peculiarly disposed to imbibe and retain fire," i. e., they are a "magnet with respect to fire ... . having imbibed a stock of fire, and lodged it in their spongeous substance, to be dispensed again by degrees." On the other hand the phosphori from human urine "retain it [fire] so well in their unctuous substance, that it shall keep there in water for 20 years," to " exhale in lucid fumes" when exposed to the air. Boerhaave also wrote: 
Something like this is observed in shining wood; for some wood having rotted in the ground, shall shine very briskly when taken out, the fire having been kept in the contiguous earth: but in a day or two's continuance in the air it spends all its light and ceases to shine. T'is hard to say how fire should thus be confined by ambient, loose, porous bodies; or by what action such bodies should produce this effect.

\section{NEUMANN, WIEGLEB, AND OTHERS}

Considerable attention was paid to luminescence in later textbooks ${ }^{21}$ on chemistry. Some of the best known were written by Kasper Neumann (1683-1737), Royal Pharmacist and professor of chemistry in the Collegium Medico-Chiurgicum of Berlin, in 1740 and 1759; by Johann Friedrich Cartheuser (1704-1777), the German physician and professor of chemistry at Frankfort on the Oder, in 1736 to 1766 ; and by Jakob Reinhold Spielmann (1722-1783), professor of medicine, later of chemistry at Strassburg, in 1763 and 1766.

In France, the earlier works of the chemist-physician, Pierre Joseph Macquer (1718-1784), the Elemens de Chymie Théoretique (1749) and Elemens de Chymie Practique (1756), were quite popular but contain little on luminescence. Phosphors were considered to be a weak sort of burning in his Dictionnaire de Chymie (1766; 2nd ed., 1778).

The great German chemist, Andreas Sigismund Marggraf (17091782) wrote no textbooks but his papers, brought together in Chemische Schriften (1761 and 1767), contain his analyses of and views on phosphorescent substances, considered in Chapter VIII.

A later chemistry which contained considerable on luminescence was the Handbuch der Allgemeinen Chemie (Berlin, 1781; 2nd ed., 1796) of Johann Christian Wiegleb (1732-1800), a pharmacist of Langensalza, and also a senator. The first edition (1787) was translated into English as A System of Chemistry by C. R. Hopson, M. D., in 1789. Although Wiegleb carried out no original researches on luminescence, his book contains a very full account of every type, both inorganic and organic, and includes such unusual things as the observation that corrosive sublimate $\left(\mathrm{HgCl}_{2}\right)$ will light for some days after sublimation whenever broken in the dark. He was a strong believer in phlogiston, which is invoked to explain the luminescences.

${ }^{21}$ Practically nothing on luminescence is to be found in George Wilson, chymistA compleat course of chymistry, London, 1709; J. J. Becher-Grosse chymische Concordance, Halle, 1726; A. Baumé-Manual de chymie, Paris, 1765; L. B. Guyton de Morveau-Elemens de chymie, Dijon, 1776-1777; Wm. Nicholson-First principles of chemistry, London, 1792. F. A. C. Gren's Systematische Handbuch der gesammte Chemie (Halle, 1794; in English, 1800) contains a brief account of inorganic phosphors. 
Wiegleb began his chapter on "Phosphori" in a section dealing with "Philosophical Chemistry," as follows: ${ }^{22}$

Fire is divisible into Light and Heat, which are two real chemical, and therefore physical, elements quite distinct from each other. . . Some bodies attract the light and give it off afterwards (light magnets)... . Other bodies in which the light is fixed in the form of phlogiston, give it out only in certain degrees of heat, and in consequence of being exposed to the air ... properly termed Phosphori, or bearers of light.

Each of these Classes of Bodies may be distinguished into natural and artificial.

The diamond was classified among the natural and the best known artificial light magnet was the prepared Bolognian Stone. Wiegleb then gave a considerable account of the Bolognian phosphor and other varieties, such as Baldouin's and Canton's phosphorus, and finally remarked, "No one has ever been able to explain the real cause of the power of attracting light in a satisfactory manner."

Among the "Phosphori, properly so called,... the natural abound in different parts of the animal creation" (glowworm, elaters, Fulgora, sea pens, worms, medusae, Pholas dactylus and various bodies when in a state of decomposition-veal, fish and wood). "With respect to genuine artificial Phosphori, there is but one species known at present, viz. the Phosphorus of Urine." Then followed a long account of phosphorus and methods of preparing it, with special mention of the work of Marggraf. Wiegleb continued:

Instances of imperfect phosphori are Homberg's Phosphorus and lump sugar, which light when struck, and fluor spar and Scharfenburg blend " which can emit a phosphoric light merely on the application of heat.

Having admitted that an explanation of the attraction of light is difficult to explain, neverthless Wiegleb made an attempt. Applying his own view that there are ten classes of substances-heat, light, water, earth, salts, metals, combustibles, mephitic gas, and magnetic fluid-and that phlogiston is light and heat plus a substance combined with them, while fire is light and heat combined but without a substance, he wrote:

It should seem indeed that the state of privation of air, into which the ponderous or calcareous earth [i.e., the Bolognian stone before calcination] is put, by being treated in fire by the substances that are added to it, must make it fit to attract the light $a b$ extra; the added substances however must necessarily contribute something to this, as pure calcareous earth deprived of air does not posses this property. . . . It is probably

${ }^{22}$ Quotations from the English translation (1789), pp. 612-620. 
phlogiston that renders the de-aerated calcareous earth fit to attract the light with certain degrees of affinity.

\section{VAN'S GRAVESANDE, VAN MUSSCHENBROEK, AND CONTEMPORARIES}

Just as Lémery's chemistry influenced the early chemical thought of the eighteenth century, so the Traité de Physique of Rohault influenced physical views (see Chap. IV). Sarton ${ }^{23}$ has pointed out how the Cartesian gradually gave way to the Newtonian philosophy in the various translations and later editions of this famous book.

The Dutch textbook of physics, contemporary with Boerhaave's Chemistry, was the Physices Elementa Mathematia, etc. (1720-1721) of Willem Jakob van's Gravesande (1688-1742), professor of mathematics at the University of Leyden. It was translated into English by J. T. Desaguliers (1683-1744). ${ }^{24}$ 'sGravesande was an upholder of the Newtonian philosophy. The first edition was mostly mechanics and properties of liquids and gases, but later editions (1747) included the Bononian stone, phosphorus of urine, and electroluminescence.

Holland was a country very active in natural philosophy in the early eighteenth century. Nicolas Hartsoeker (1656-1725), a native of Holland and professor at Utrecht, who spent much of his seventeenth-century years in Paris and published largely in French, wrote a series of books Conjectures Physiques (Amsterdam, 1706), including the Suites de Conjectures Physiques and the Eclaircissements, which followed. He was largely anti-Newton in point of view. In the 1706 volume, Book I treated the system of the world, Book II the earth and its properties, Book III the principles of physics, and Book IV various meteors. Book III contained discourses on fire, light, and colors but it was only in connection with fire that Hartsoeker explained luminescence. He told why many kinds of phosphors (rotten wood, insects, and fish, or water of the sea) give light without heat (clarté sans chaleur sensible) when exposed to the air, while other bodies heat themselves considerably without giving light. The reason lay in Cartesian doctrine. The matter of the first element was held in the pores of bodies and in the case of luminous substances able to push the " parcelles" of the material aside, appearing as rays of light. In coal or heated metals, the first element cannot escape, despite the large amount present, and consequently coal retains its heat for a long time without giving much light.

${ }^{23} \mathrm{G}$. Sarton, The study of early scientific textbooks, Isis 38: 137-148, 1947-1948.

${ }^{24}$ In addition to translating 'sGravesande, Desaguliers wrote $A$ course of experimental philosophy. The first edition appeared in 1725 and many others followed. In the 1734-1744 edition, luminescence is referred to but nothing of any value is included. 


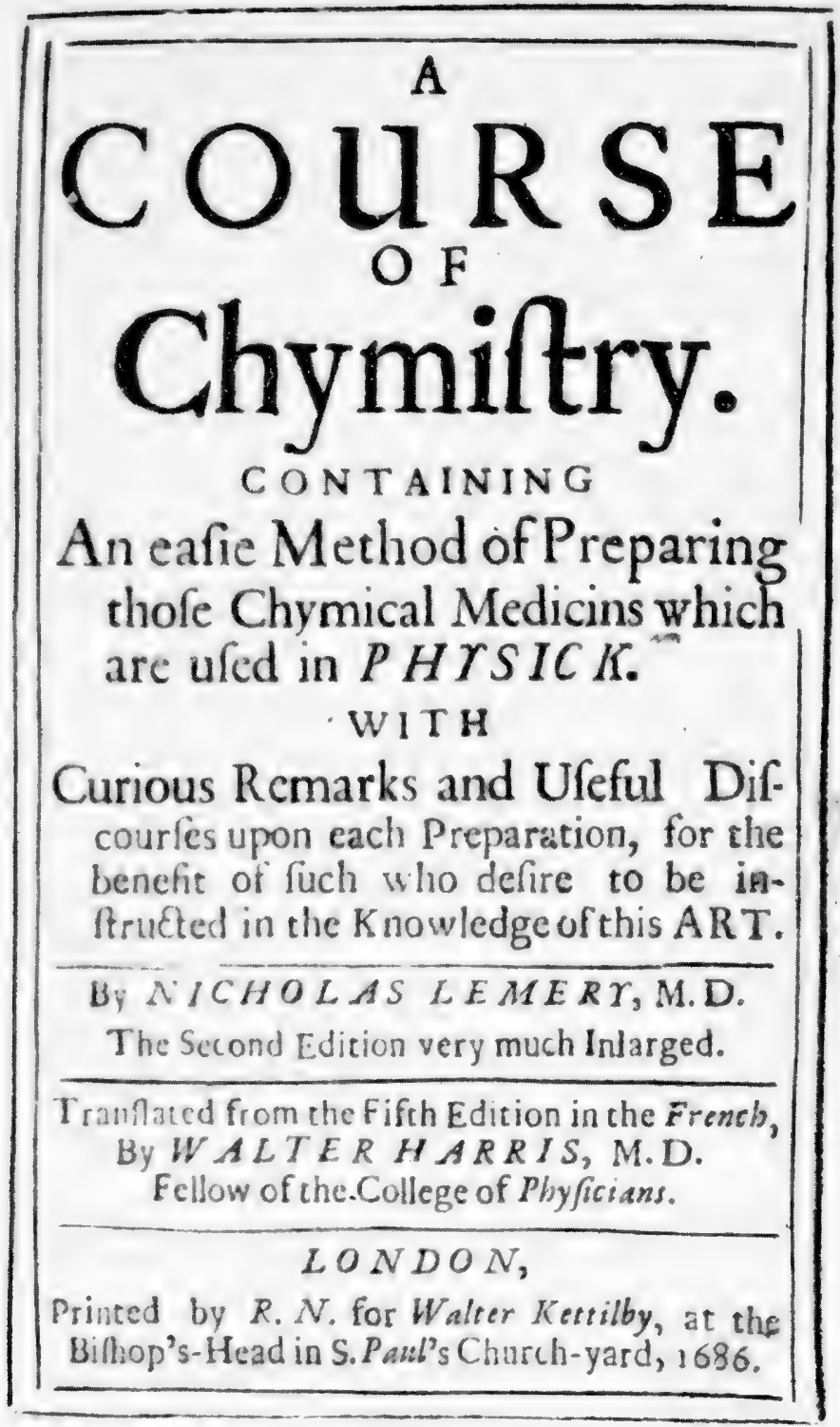

Fif. 14. Titie page of the English translation (London, 1686) of Nicolas lémery's Cours de Chymie, by Walter Harris. This edition contains facts concerning the element. phosphorus, but the 1698 translation (from the sth French edition) by James keill treats exhatsivels of all types of luminescence. 


\section{DISSERTATION}

\section{SUR-LA CAUSE}

DE LA LUMIERE 2

\section{DES PHOSPHORES}

\section{* ET}

DES NOCTILUQUES.

Qui a renporté le Pris à 2 Academie Royale. des Bolles Lettres., Sciences Arts de Bordeaux, pour lannée 1717 .

Par M: Dorious de May a a:

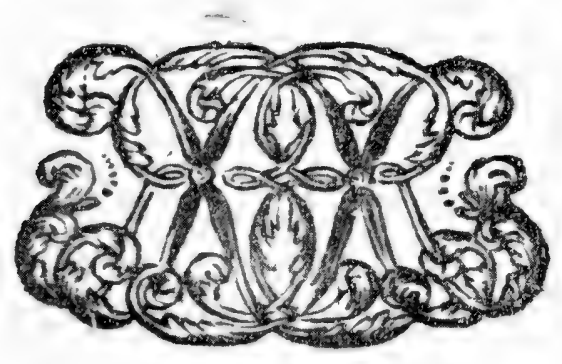

\section{A BORDEAUX;}

ChezR. B R U N, Inprimeur de l'Academie: Royale, ruë Saint James.

M. D. C C. XVII.
Avec Permifion.




\title{
Alexanori Kelleri. 1750 \\ LUMEN NOVUM PHOSPHORIS ACCENSUM,
}

\author{
S I V E
}

E X E R C I T A T I O

PH Y S I C O-CHY MICA,

De caufa lucis in Phofphoris tam naturalibus quàm artificialibus,

\section{pirste}

Ad provocationem celeberrimæ

Regiæ in Galliis Burdegalenfium Academix

à

JOANNE HENR:COHAUSEN, A.D.

Recercudit. E Celfaf? Principis \& Epif-

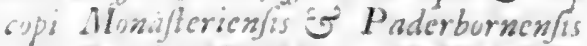

D. D. FRANCISCI ARNOLD!

Archiatro Horfarario-Abufano.

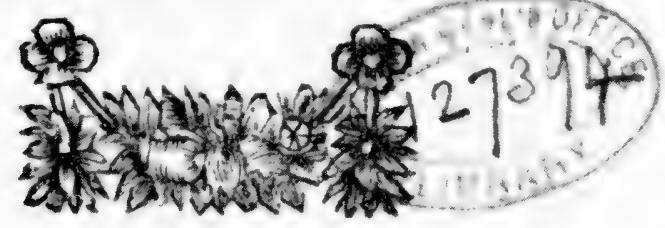

A MSTELO D A M I,

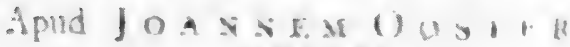

$M D C C \times \vee I I$. 


$$
\text { T II E }
$$

$\begin{array}{lllllll}H & I & S & T & O & R & \text { I }\end{array}$

A N $\mathrm{D}^{\circ}$

PRESEN T S TA T E

OF D ISCOVERIES relating to

V I S I O N, L I G H T,

$A N D$

C O L $\quad \mathrm{O} U \mathrm{U}$ S.

By JOSEPH PRIESTLEY, LL.D R.R.S.

Fariat of inmone copia mundi.

Orin.

L O N D O N,

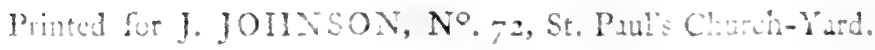

MIDCCLXXI.

tiris

Fin. 17. Title page of Joseph Priestley's book on Light, which contains all knowledge of luminescence up to the time of publication (London. 1772). Priestley was a foreign member of the American Philosophical Societs. elected in 178.5. 
Several other early eighteenth-century writers on physics paid particular attention to various luminescences. One of them was Hermann Fredrick Teichmeyer (1685-1744), a German doctor of medicine, who became successively professor of experimental physics, medicine, botany, surgery, and anatomy at the University of Jena. His Elementa Philosophiae Naturalis Experimentalis first appeared at Jena in 1717. Teichmeyer was a Cartesian and took pains to explain in pars I, caput XVIII, "De Luce," how " Light is pure fire or the material of the first element of Descartes which moves violently the unsteady material of the second element or the aetherial globules." In the 1733 edition Teichmeyer explained how light might be liberated from either liquid or solid bodies and mentioned a surprising number of luminescences, including the mercurial barometer, glass tubes on rubbing, the various experiments of Hauksbee, the Baldewinian, Bononian, and Hombergian phosphors, as well as English phosphorus in solid and liquid form (phosphorus dissolved in oil of cloves). Bioluminescences were not discussed. Bartholin's De Luce Animalium was mentioned in connection with ignes fatui, and the various manifestations of the aurora borealis were described in a chapter, "De Meteoris." Teichmeyer also wrote a pharmacology, Institutiones Materiae Medicae (1737), in which he recommended "English phosphorus" in kidney troubles, particularly for dissolving renal concretions.

Another writer on physics, Georg Erhard Hamberger (1697-1755), at various times professor of medicine, physik, botany, anatomy, and surgery at the University of Jena, published his Elementa Physices (Jena, 1727), a popular volume on a wide variety of physical phenomena, which passed through many editions, the fifth in 1761 . Hamberger paid particular attention to the light of the barometer and luminescences which appear from rubbing materials. He described the various experiments of Bernoulli and others published by the French Academy, regarding the phenomena as a kind of fire. He thought that an air current moved toward the vacuum because the surrounding glass of the barometer attracted light bodies to it while the luminescence appeared..$^{25}$

Practically the same material is contained in the book of Johann Melchior Verdries (1679-1735), a professor of physics and medicine at the University of Giessen. His Physica, sive in Naturae Scientiam Introductio (Gissae, 1728) contained a chapter "De Qualitatibus Visibilibus," in which a large number of luminescences were discussed. 
Probably the most famous of the books on physics ${ }^{26}$ in the early eighteenth century was Pieter van Musschenbroek's (1692-1761) Elementa Physicae. Van Musschenbroek visited England in 1717 and, like 'sGravesande, was much influenced by Newton's work. Later he also became professor of mathematics and natural philosophy at the University of Leyden and famous for association with the discovery of the Leyden jar. The first edition of his text appeared in Latin in 1734 and a two volume translation, Elements of Natural Philosophy, was made by John Colson in 1744, from which the following extracts are taken. French editions of his works appeared in 1751 and 1769 .

A considerable amount of chemistry is included, for van Musschenbroek was greatly concerned with the nature of "fire," a word he used in a very broad sense. His thesis appears to have been that if enough "fire" were present in a body, and if the fire were in motion, the body would shine. This reasoning was applied to luminescences as well as to incandescent matter. Van Musschenbroek cited the experience of himself and of others which indicated that many metals increase in weight when burned and hence "Fire which thus copiously insinuates itself into bodies, and adheres to them, is found to increase their weight, and therefore like all other bodies is itself endued with gravity."

He then continued:

A large quantity of fire, when pent up within the parts of bodies, very often shines, as may be seen in the Helvetian androdamas, in the Bononian stone, and almost in all other stones, whether calcined, or first dissolved in acid spirits, and afterwards calcined; as also in boles [treetrunks], earths, the bones of animals, the ashes of plants. For all these things, being something illuminated by the sun, and then carried into an obscure place, will shine and retain the light for some time; nay, if they lose it, being again exposed to the sun, they will recover it again. The Bononian stone, being preserved in cotton, keeps it's shining virtue above five years. The calcined belemnites and the topaz do the same.... Bodies endued with the property of imbibing light may lose the same by frequent ignitions, as is observed in crystals, the phosphorus stone of Bern, and emeralds. There are others which acquire that faculty by ignition, as the Bononian stone, the belemnites, gypse, the phosphorus of Balduin.

Fire is susceptible of very different degrees of velocity, continually decreasing before it passes from that most rapid motion, which it enjoyed

${ }^{26}$ Additional early texts on natural philosophy were those of John Keill (1720), Benjamin Worster (1730), Richard Helsham (1739), and John Rowning (1737-1744), but they contained nothing on luminescence except for a rather extended account of the aurora borealis by Rowning. 
before, to a lesser and lesser degree, and finally almost to a state of rest. Therefore there may be sometimes much fire in a body with but little motion, or with but small effects of it; and sometimes but little fire with a great effect. Perhaps phosphori prepared from the parts of animals are of that nature, that whereas they are cold under water, and not shining, but only shine out of water, they may possibly contain a great deal of fire, but which is chiefly at rest.

The relation of fire and light to air were discussed as follows:

Hot water sooner loses it's fire in Boyle's vacuum, than in the open air. Rotten and shining wood, surrounded by air, retains it's fire for some days, of which it will be soon bereaved if put into Boyle's vacuum. This wood, when once deprived of it's fire, does not recover it again by being restored to the air. Lampyris shines in the air, in the vacuum ceases to shine, and admitting the air it shines again. Yet iron keeps it's fire longer in vacuo than in the air; and perhaps many other bodies are subject to the like irregularities. . . . Fire therefore is present every where, and in every body, and that which before was almost at rest, or but little moved, by rubbing being again swiftly agitated from such parts, as by a vibratory motion tremble very briskly, then shews it's presence and efficacy.

Regarding light, van Musschenbroek wrote: "Light is a most fluid matter, and therefore like other fluids consists of particles not cohering with one another," and then asked:

First, how do light and fire differ? Is it in substance, or only in the magnitude of their parts, or in the direction of their motions? Perhaps not in substance, nor in the magnitude of their parts, since a great quantity of light collected together has always the characters of fire. But fire does not shine, unless when determined to the eye in right lines. A silver spoon heated does not shine in the dark; but if you put diamonds or crystals into it, though they did not shine before, yet they soon begin to shine, expelling the fire they had received under the form of light. They do the same thing, if thrown into hot water. . . .

Lastly, do not those bodies shine most easily, which abound with oily and sulphureous parts, as soon as they begin to move by friction, percussion, putrefaction, vital motion, or by any other cause? For what reason does the sea shine, when tossed by the winds? or the back of a cat, the neck of a horse, when rubbed contrary to the natural situation of the hair? or wood, flesh, fish, when rotten? the eyes of animals and glow-worms? Also a glass ball in violent rotation, and rubbed by the hand, why does it emit a blue light sticking to the hand?

The influence of Newton is marked. It is apparent that van Musschenbroek was familiar with the most diverse luminous phenomena and tried, without too great success, to fit this knowledge into a general theory of fire and light. 


\section{JACQUES OZANAM}

One of the less well-known writers on physics was the eminent French mathematician, Jacques Ozanam (1640-1717), whose Récréations Mathematiques et Physiques, first published in 1694, went through a number of editions, after his death. The later editions, contained considerable on luminescence. For example Vol. 4 of the Paris (1735) edition, entitled Des Phosphores et des Lampes Perpetuelles contains 270 pages devoted to natural and artificial phosphors, including both the organic and inorganic types. It constitutes a really comprehensive monograph on the subject. Among the natural phosphors were fiery meteors, luminous diamonds, various kinds of fireflies and glowworms, rotten wood and fish, some birds (of Hercinia) and men (electroluminescence), while the artificial types of phosphorus included the Bolognian and the Baldewinian; also phosphorus of Kunkel, Homberg, Lyonet, Nuguet (called " phosphore de verre," mercury shaken in an evaculated glass vessel) and du Tal (the luminous barometer). These types were all described in great detail. A third section on "perpetual lamps" followed the "phosphores." The 1735 and 1791 editions, "lately recomposed and greatly enlarged ... by the celebrated M. Montucla," were translated by Charles Hutton, L. L. D. and F. R. S., and appeared in 1803, but the section dealing with natural and artificial phosphors was reduced to 35 pages. Another edition is dated 1844 .

\section{BENJAMIN MARTIN}

The Newtonian point of view was widely publicized during the eighteenth century by Benjamin Martyn or Martin (1704-1782), whose interests involved instrumentation, mathematics, and all branches of physics. He was a prolific popular writer on natural philosophy (Philosophical Grammar, 1735; Philosophia Britannica, 1747), including optical and electrical essays, natural history, and biography. Some of his books on physics passed through many editions, and were used at Harvard College. ${ }^{27}$

Martin's explanation of various luminescences is given in a chapter of the Philosophia Britannica dealing with fire and flame. $\mathrm{He}$ wrote: ${ }^{28}$

That Heat, Fire, Flame, etc. are only the different Effects and Modifications of the Particles of Light, is, I think, very evident; and the Particles of Light themselves depend entirely on Velocity for their lucific Quality;

\footnotetext{
${ }^{27}$ See T. Hornberger, Scientific thought in American colleges, $107 \mathrm{pp}$. Univ, of Texas Press, 1945.

${ }^{28}$ B. Martin, Philosophia Britannica, 3rd ed., 2: 279-281, London, 1771.
} 
... Heat is a Motion in the Particles of a Body with a lesser Degree of Velocity; and Fire a Motion with a greater Degree of Velocity, viz. such as is sufficient to make the Particles shine, though we often call such a Degree of Heat as will burn, Fire, though it does not actually shine; and we seldom call those lucid Bodies Fires which only shine and do not burn. These are a Sort of Phosphori, which though they have no Heat yet seem to owe their Lucidity to the Motion of the Parts.

This I think will appear for the following Reasons; (1) We observe several of those Phosphori are owing to Putrefaction, as rotten Wood, very stale Meat, especially Veal, some Sort of Fish long kept, as Oysters, Lobsters, Flounders, Whitings, etc. which Putrefaction is the Effect of a slow and gentle Fermentation, and that consists in the Intestine Motion of the Parts, as we have formerly shewn. (2) Most of those Phosphori have their Light so very weak as to shine only in the Dark, which seems to indicate a lesser Degree of Velocity in the Parts than what is necessary to Produce Heat; for such a Degree of Velocity will cause Bodies to shine in open Day-light. (3) Some of those Noctilucae, or Bodies which shine in the dark, are the Parts of animated Bodies, as in the Glow-Worm, a small Sort of Centipede, etc. but all the Parts of an Animal are undoubtedly in Motion. (4) Other Phosphori put on the Appearance of Flame, as the Ignis Fatuus, the Writing of common Phosphorus made from Urine, Flashes of Lightning, etc. but all Flame is nothing but a kindled Vapour, whose Parts are all in Motion, but may be too weak to cause Burning. (5) Several of those innocent lambent Flames may have their Matter so agitated, or the Velocity of their Motion so increased, as to produce Heat and burn; thus the Writing of Phosphorus on blue paper, sufficiently rubbed, will immediately kindle into an ardent Flame, and burn the Paper. (6) Those Phosphori seem to have the essential Nature of Fire, because they are so easily susceptible of a burning Quality from Fire; thus common Phosphorus is immediately kindled into a most ardent and inextinguishable Flame by common Fire. (7) In stroking the Back of a black Horse, or Cat, in the Dark, we produce innumerous Scintillae, or lucid Sparks; in the same manner as rubbing a black Piece of Cloth, which has hung in the Sun to dry, will cause it to throw out the Particles of Light which it had imbibed from the Sun; whereas a white Piece of Cloth, which reflects most of the Sun's Rays, emits no such lucid Sparks in the Dark. Many other Reasons might be urged to show that Light of every kind is owing to one and the same cause in a greater or lesser Degree, viz. to the Velocity of the Parts of the lucid Body.

\section{ABBÉ NOLLET}

One of the colorful physicists of the mid-eighteenth century was Jean Antoine, Abbé Nollet (1700-1770), a member of most learned societies, a teacher of physics to Monseigneur Le Dauphin, and Professeur Royal de Physique Experimentale of the College of Navarre. Abbé Nollet is perhaps best known to biologists as an early observer 
of osmotic pressure and to physicists as an electrical experimenter who engaged in a famous controversy with Franklin. One of his earliest luminescence contributions in 1750, was concerned with observations on small annelids, designated as the cause of the sea phosphorescence in the lagoons of Venice. When in Italy, he experimented with fireflies.

Nollet's interests were indeed broad, for he published a fourvolume work, Leçons de Physique Experimentale, in 1745, and a six-volume edition in 1753-1764. Volume IV (1753) is largely concerned with the nature and properties of fire and contains a section dealing with the Phosphore of Kunckel (the element phosphorus), with an experiment to demonstrate its ability to set fire to paper. The fifth volume (1755) is devoted entirely to light. After describing the ideas of Descartes and Newton on this subject, Nollet cited the behavior of the element phosphorus to show that light comes from a material which is present both within and without bodies, and he used the Bolognian phosphore to prove that the light material which resides at the surface of bodies can be set into action by the light of day alone.

A section of volume V contains the "Histoire des phosphores tant naturels qu'artificiels." Nollet defined a phosphore or porte-lumière as a substance, either natural or artificial, which glows in the dark without taking fire. The natural phosphores, such as the glowworm, animals of the Venice canals, meat observed at Orleans, luminous fish, cat's or horse's hair when stroked, luminous wood, esprits folets or the ignis lambens, were substances glowing in the dark without any special preparation. The artificial phosphores, such as the Bolognian or Balduinian variety, required some treatment known to the arts. Nollet described the various bioluminescences mentioned above without being able to explain them. It is interesting to note that certain electroluminescences, classed as ignis lambens, were included among the natural phosphores. Nollet had ample opportunity to observe artificial electroluminescences from electrical discharges in evacuated tubes, described in his books on electricity. ${ }^{29}$ The studies on these phenomena, so obviously similar to ignis lambens, were collected in volume VI (1764) of the Leçons.

\footnotetext{
${ }^{20}$ Nollet also wrote short treatises on electricity (Essai, 1747; Recherches, 1749, 1754; Recueil des lettres, 1753) in which electroluminescences were mentioned but no special emphasis laid on this subject. Many other textbooks on electricity appeared in the eighteenth century, by F. U. T. Aepinus (1759), G. B. Beccaria (1753, 1769, 1772, 1775), G. M. Bose $(1738,1743,1744,1745,1746)$, T. Cavallo $(1777,1795)$, J. Ferguson (1770), J. Jallabert (1748), J. Lyon (1780), C. Stanhope (Lord Mahon) (1779), J. P. Marat (1782) , J. B. Secondat $(1746,1748)$, and W. Watson (1745), but none of these authors went into such details regarding the electric light as in the History and present state of electricity (1769), by Joseph Priestley, reviewed in Chapter VII on Electroluminescence.
} 


\section{LEONARD EULER}

Leonard Euler's Letters to a German Princess published in French in 1768-1772, and in English in 1795, is practically a textbook of physics. It contains an excellent account of his earlier (1746) theory of light as a wave motion, and reflection of light as an actual emission of light, when the impinging beam sets up sympathetic vibrations in the opaque body. The different colors of the object represented different frequencies of vibration. The book contains his explanation of phosphorescence, depending on vibrations in the phosphor, set up by light (more fully described in Chapter VIII), and remarks on the electric light, which he regarded as an indication of the "electric atmosphere" around a charged body.

Euler did not undertake an explanation of the luminescence of animals, or shining wood, but he did consider the aurora borealis. This light he attributed to particles in the earth's atmosphere rather than particles from the sun (see Chapter VII).

\section{GEORGE ADAMS}

Even toward the end of the century there was little change in the conceptions regarding "phosphoric bodies," as indicated in the treatise on physics by George Adams (1750-1795), an optician and instrument maker of London, with a broad interest in natural phenomena. His book, Lectures on Natural and Experimental Philosophy, considered in it's present state of improvement, describing in a familiar and easy manner, the principal phenomena of nature; and showing, that they all cooperate in displaying the Goodness, Wisdom, and Power of God, was published at London in 1794.

It is quite apparent where Adams obtained his information. In Vol. II, the various types of luminescence are grouped according to the classification of Beccari, which Adams quoted almost verbatim. There were the (1) spontaneous luminescences and (2) the excited luminescences, of which the mode of excitation might be

attrition, agitation, heat, the free admission of air, and being exposed to the external light.

Bodies of every kind become phosphori by attrition, provided they can bear that force of friction which is sufficent to produce the reluctant light that is hid in their substances; agitation agrees mostly with liquid substances, as sea-water

The emerald phosphorus, and many gems, and amongst these not a few diamonds, the lapis lazuli, and a great part of the mountain crystals, become phosphoric by the application of heat. 
The free admission of air not only produces light in using the phosphorus of Konkel, but even a blaze of fire where friction is used. The phosphorus of Homberg [really a pyrophore] burns also furiously upon the approach of air.

The last class, those which act after being exposed to the external light, are exceedingly numerous; there seem but two substances which do not emit light when tried in this way, water, in it's fluid state, and metals. All bodies then, whatever, except water and metals, have a power of imbibing light, and when placed in proper circumstances of emitting it again.

Adams was a firm believer in phlogiston and in the corpuscular theory of light, treating it as a kind of matter. He wrote:

Phosphoretic and phlogistic bodies agree in containing a quantity of light, which is not in any perceived state of heat.

Although phlogistic and phosphoretic bodies emit light upon the same principles, so far as this depends upon luminous matter contained in the bodies, which is set at liberty during the operation, by which it is rendered luminous; yet the manner in which the luminous matter is set at liberty, is very different, as is that also by which the luminous matter is retained. The exposure to the atmosphere is essential to the emission of light from phlogistic bodies; but this is a circumstance indifferent or unnecessary for the same operation in those that are phosphoretic. In phosphoretic bodies there is no difference perceived after they have lost their shining qualities; but this is not the case with phlogistic bodies, where the greatest difference is perceived on the abstraction of their luminous matter.

Phosphoretic bodies furnish us with a strong additional proof of a principle already noticed, that light is matter which may continue for some time therein without exciting heat, and may be again separated therefrom, and resume it's character of light, ...

Such are the views on luminescence of selected writers of the eighteenth century, views expressed in the hope of unifying ideas of light, heat, fire, and flame in their various manifestations.

\section{Tracts and Theses on Luminescence}

During the middle of the eighteenth century many observations were made on sea luminescence, on electroluminescences in evacuated vessels, and on phosphorescences, but few papers appeared of a general nature, comparable to the earlier essays of de Mairan, Cohausen, Dufay, or Beccari. This statement is particularly true in the field of bioluminescence and contrasts strongly with the situation in the next century, when many general works on the light of plants and animals were published. The eighteenth-century student 
was forced to use the great encyclopedias discussed in a previous section, or special cyclopedias such as the Dictionnaire d'Histoire Naturelle (1769). A later work, the Dictionnaire Raisonné Universel d'Histoire Naturelle (1791) of J. C. Valmont-Bomare (17311807) contained excellent information on "Mer lumineuse," "Portelumière," or " Mouches luisantes."

The nearest approach to a general work on luminescence in the middle of the century was a doctor's thesis entitled, De Noctilucis, a Dissertatio Philosophica Inauguralis, by Johannes Albertus Melchior, Franequerae (Franeker), 1742, under the direction of W. G. Muys. Melchior followed the classification used at the start of the century and divided his thesis into two sections, "De Noctilucis Artificialibus" (36 pages) and "De Noctilucis Naturalibus" (25 pages). In connection with the artificial phosphors, the ideas of Desaguliers, Newton, 'sGravesande, Hauksbee, Boyle, Boerhaave, Descartes, Bernoulli, Dufay, Hamelio, ${ }^{30}$ Homberg, and Lémery were presented, while views on natural phosphors, i. e., living organisms and precious stones, came from Boyle, Clark, Lémery, Beale, Waller, de la Voie and Auzout, Vossio (on the cucuyo), Dufay, Josephus (on the Baaras), Pliny, and Aelian.

Another thesis, a Dissertatio Inauguralis Chymico-medica, of forty pages, was by Nicholas Ludolphus Marheinecken, entitled, De Phosphoris (Jena, 1744). Although rotten wood and insects were mentioned, the chief interest of the author was inorganic luminescence, with most of the classical work reviewed and nothing new added.

Finally, the thirty-six-page pamphlet of Johann Gottlob Lehmann (died 1767), Abhandlung von Phosphoris, etc. (Dresden und Leipzig, 1750), gives a short account of a wide variety of luminescences. Lehmann was a Bergrath in Berlin until 1761 and later a professor of chemistry and director of the Royal Museum in St. Petersburg. This work on various phosphors was one of his earliest publications. It professed to give the preparation and uses of phosphors as well as remarks on fire and light and his theory of the origin of the luminescence. Lehmann's later writing had to do mostly with minerals but his treatment of luminescences was not very good. They were divided into the natural and the artificial, the latter either prepared chemically, or lighting by mechanical manipulation, which Lehmann realized was electrical in nature in the case of mercury shaken in a glass tube.

${ }^{30}$ Jean Baptiste Duhamel (1624-1705), French astronomer and secretary of the Académie des Sciences, who wrote a history of the Academy (1698) and a treatise on the old and new philosophy (1678), in Latin. 
The cause of all light was acid. In the case of the glowworm, an acid emanation or exhalation (Ausdünstung) appeared, and "one can easily think that the sweat pores must be incomprehensibly tiny and delicate in such a small insect. The pores of [luminous] decomposing flesh [and fish] must be narrow also. In wood it is especially oak-wood [which becomes luminous] where dampness makes the canals through which the parts mix with the outer air, thin." Lehmann believed that "oak-wood contains 'Vitriol-Saure' with a metallic earth [iron] in so disintegrated [aufgeschlossenen] a form that it must necessarily light."

The green stone (fluorspar) of Saxony lights on heating because it "contains a vitriolic acid salt which is decomposed by the warming and manifests itself as a true phosphorus." Lehmann devoted several pages to preparation of phosphorus and also spoke of pyrophores. It is well known that chemically prepared phosphorus "consist in great part of entirely disintegrated [volkommen aufgeschlossenen] acid." The acid nature can be noted by the smell of urine from which phosphorus is prepared.

During the last half of the eighteenth century a number of tracts appeared dealing with various types of luminescence, for example the Dissertatio de Igne, etc. (1773) by Joseph Edler von Herbert (1725-1794), a Jesuit who became professor of experimental physics at the University of Vienna and Canon of St. Stephan. Herbert took the position that light and fire were the same thing and devoted eighteen pages to the proposition: "Fire is liberated in the form of light in phosphors and flame."

The Phosphorescentia Adamantum, etc. (Viennae, 1777) by Michaele de Grosser, A Series of Experiments Relating to Phosphori and the Prismatic Colours they are Found to Exhibit in the Dark (London, 1777) by Benjamin Wilson (born 1708) and Della Pïetra Fosforica Bolognese (Bologna, 1780) by Camillo Galvani also consider luminescences. All these contributions are discussed in Chapter VIII on phosphorescence, since they deal entirely with this field.

No books or general contributions appeared in the latter part of the century which can be regarded as general treatises on luminescence although papers on special luminous animals, on shining wood and flesh, and burning of the sea were numerous. Two eminent scientists, John Canton and Lazzaro Spallanzani, published special papers. The writings of John Canton (1718-1772) include the discovery of a bright new phosphor (Canton's phosphorus) in 1768 , interesting observations on shining fish in relation to phosphorescence of the sea (1769), and new observations on electro- 
luminescence $(1753,1754)$. The most important student of bioluminescence was Lazzaro Spallanzani (1729-1799), who carried out experiments on medusae (1794), and on the glowworm and luminous wood (1796), designed to determine the nature of the light.

\section{Priestley and his Contemporaries}

It is disappointing to find that Joseph Priestley (1733-1804), foreign member of the American Philosophical Society since 1785, whose studies on the gaseous exchange of plants and animals were so important, carried out practically no original experiments on luminescence, although he mentioned the subject many times. $\mathrm{He}$ did write two very readable scientific books, histories or summaries of what was then known concerning electricity, in 1769, and concerning light, in 1772. They are both full of facts regarding luminescence. His third scientific book, on Different Kinds of Air (London, 3 v., 1774, 1776, 1777) contains most of his experimental work, but little on luminescence.

The book, History and Present State of Electricity (London, 1767), went into many editions, a fifth appearing in 1794. Priestley describes most of the many experiments of various investigators on the "electric light," a subject which will be fully considered in Chapter VII on electroluminescence.

The second book, History and Present State of Discoveries relating to Vision, Light and Colours (London, 1772), is the nearest approach to a general treatise on luminescence written during the latter part of the century. It is exactly what its title (see fig. 17) implies and contains a long section (p. 360-382) on "The property of some substances to imbibe and emit light, especially the Bolognian Phosphorus " and another (pp. 563-588) on "Light proceeding from Putrescent Substances, etc. and Phosphorus." The two would make up a pamphlet of forty-eight pages. No mention is made of the firefly or glowworm but studies on Pholas dactylus and luminous worms are considered, as well as the phosphorescence of the sea, shining flesh fish and wood, corposants and ignes fatui, luminous sweat, and the luminous woman of Milan.

Priestley's approach is mostly descriptive. As far as luminescence is concerned he is a narrator rather than a theorist, presenting the hypotheses of the authors whose observations he describes. The nearest recital of his own views is to be found in a paragraph interposed between discussion of the light of putrescent substances and that of phosphorus. Priestley wrote:

A light in some respects similar to that of putrescent matter has been 
found to proceed from that celebrated chymical production called phosphorus, which is, in fact, an imperfect sulphur, tending to decompose itself, and so as to take fire by the access of air only. Phosphorus, therefore, when it emits light is properly a body ignited; though when a very small quantity of it is used, as what is left after drawing it over paper, or what may be dissolved in essential oil, the heat is not sensible. But perhaps the matter which emits the light in what we call putrescent substances may be familiar to it though it be generated by a different process, and burn with a less degree of heat. Putrescence does not seem to be necessary to the light of glow-worms, or of the pholades: and yet their light is sufficientily familiar to that of shining wood or flesh. Electric light is unquestionably similar to that of phosphorus, though the source of it is apparently very different.

It is apparent that, in Vision, Light and Colours, Priestley was greatly influenced by Newton. In his summary he remarked that the observations made in his book "will authorize us to take it for granted that light consists of very minute particles of matter, emitted from luminous bodies." In the "Hints of some Desiderata," a chapter proposing new subjects of inquiry, the Queries of Newton are quoted and discussed in detail.

Priestley is undoubtedly best known for his study of oxygen and other gases. In Section VIII, at the end of the first volume of Experiments and Observations on Different Kinds of Air (London, 1774), in a section entitled "Queries, Speculations and Hints," Priestley speculated on a number of puzzling phenomena. He stated that electric matter directed through the body of any muscle forces it to contract and held:

that the source of muscular motion is phlogiston [the fire principle] is still more probable, from the consideration of the well known effects of vinous and spirituous liquors, which consist very much of phlogiston, and which instantly brace and strengthen the whole nervous and muscular system. ...

As to the manner in which the electric matter makes a muscle contract I do not pretend to have any conjecture worth mentioning. . . Possibly, the light which is said to proceed from some animals, as from cats and wild beasts, when they are in pursuit of their prey in the night, may not only arise, as it has hitherto been supposed to do, from the mere friction of their hairs and bristles; etc. but that violent muscular exertion may contribute to it. This may assist them occasionally to catch their prey; as glow-worms, and other insects, are provided with a constant light for that purpose, to the supply of which light their nutriment may also contribute.

Priestley then went on to apply this statement to human beings: 
I would not even say that the light which is said to have proceeded from some human bodies, of a particular temperament, and especially on some extraordinary occasions, may not have been of the electrical kind, that is, produced independently of friction, or with less friction than would have produced it in other persons; ... The electric matter in passing through non-conducting substances always emits light. ... It is probable, therefore, that electric light comes from the electric matter itself; and this being a modification of phlogiston, it is probable that all light is a modification of phlogiston. . . .

Priestley expressed his views on heat as follows: "It appears to me that heat has no more proper connection with phlogiston than it has with water, or any other constituent part of bodies ... the heated state of bodies may consist of a subtle vibratory motion of their parts." The speculations continue with a defense of phlogiston, which received his ardent support throughout his life, even after the theory had been abandoned by many of his contemporaries.

Priestley's study of Airs also included observations on electric behavior in different gases. He found that no kind of gas would conduct electricity but that a spark would pass and the color was white in " fixed air" and red or purple in " inflammable air." However, a Mr. Walsh and Mr. DeLuc had boiled the mercury in a double barometer and hence obtained a more perfect vacuum, so that the "electric spark or shock would no more pass through it than through a stick of solid glass." Priestley had previously found that sparks " diminished common air and make it noxious, making it deposit its fixed air exactly like any phlogistic process; from whence I concluded that the electric matter either is or contains phlogiston." It is evident that the word "phlogiston" had made such a lasting impression on Priestley that he found it impossible to renounce the doctrine.

The names of four contemporary men, Joseph Black (1728-1799), Henry Cavendish (1731-1810), Karl Wilhelm Scheele (1742-1786), and Antoine-Laurent Lavoisier (1743-1794), are associated with that of Priestley. They all had much to do with the early history of oxygen and combustion, but none of them carried out extensive research on luminescence. ${ }^{31}$ Each played an important part in separating the different kinds of gases, one of the great advances of eighteenth-century chemistry. They thus paved the way for studies on the effect of various gases on luminescence, experiments which were so important in the later history of the subject.

${ }^{31}$ A fore-runner of these men, Stephen Hales (1677-1761), best known for his work on Haemastaticks (1727), and Vegetable staticks (1733) apparently overlooked the phosphorescence of the sea and the light of wood and flesh. 
Like Priestley, Joseph Black also summarized the views of his predecessors in a book of Lectures on the Elements of Chemistry (1803) edited from his manuscripts by John Robinson, L. L. D. and published posthumously. In an appendix headed "Pyrophore," Black gave very good descriptions of the known phosphors and pyrophors, including the work of John Canton and Benjamin Wilson, but with only casual mention of bioluminescences. He admitted that the phenomena differed from ordinary combustion and wrote:

But it were worth while to examine by some proper train of experiments, whether this shining is effected by the absorption of vital air [oxygen], and a subsequent decomposition by the action of fresh light.... To us [the chemists] they are important, being nearly connected with the whole doctrine of combustion, - a doctrine still full of difficulties, notwithstanding the very great discoveries which have been made. The separability of light and heat by a plate of glass, in the valuable observation of Scheele, and their seeming separability in the present instances, are undoubtedly facts of great moment in philosophical chemistry, especially when considered along with Herschel's observations. ${ }^{32}$ The observation also of $\mathrm{Mr}$. Goettling, that phosphorus shines bright in azote and in volatile alkali, and the shining of vegetable and animal substances, (particularly sea fish) in a certain stage of putrescence, and their shining in vacuo and other situations incompatible with combustion, merit a much more careful attention than has yet been given.

\section{As a friend of Lavoisier, Black found the new theory}

incomparably more agreeable to our general knowledge of chemical facts than the ingenious [phlogiston] doctrine of Dr. Stahl, and is really supported by proofs which seem incontrovertible. Even though imperfect, this new doctrine furnishes us with a fact, formerly unnoticed, which accompanies all combustion, namely, the combination of the body called combustible with vital air.

Had Black actually studied the luminescence of animal and vegetable substances he would have found the proof for his idea that these luminescences are in fact connected with a type of combustion.

Even before Priestley, Henry Cavendish had called attention to various gases in his Experiments on Factitious Air (1766), including inflammable air (hydrogen) and fixed air $\left(\mathrm{CO}_{2}\right)$, and in later studies on the composition of the atmosphere (1783). However he paid scant attention to luminescence.

Karl Scheele shares with Priestley and Lavoisier the honor of " discovering " oxygen, ${ }^{33}$ which he called " empyreal air" or "Feuer

${ }^{32}$ On the infrared region of the spectrum.

${ }^{33}$ Perhaps John Mayow (1645-1679) should be included among the discoverers of oxygen because of the "spiritus nitro-aereus," described in his tract De respiratione 
Luft," and also contributing to knowledge of combustion. Scheele's observations on luminescence come from another more general chemical interest, the composition of fluorspar, whose thermoluminescence he had observed. His experiments and views on the light emitted by this compound are highly specific, and will be found in the chapters devoted to thermoluminescence and phosphorescence.

Antoine-Laurent Lavoisier also paid little attention to luminescence of any kind, despite his recognition of the analogy between animal respiration and combustion and despite the similarity of luminescence to combustion processes. He did make a suggestion regarding the luminescence of fish, which appealed to many later writers, an idea expressed in his Traité Elémentaire de Chimie (1789). In speaking of putrefaction, Lavoisier wrote: ${ }^{34}$

In putrefaction of animal substances sometimes the ammoniac predominates, which is easily perceived by its sharpness upon the eyes; sometimes as in feculent matters, the sulphurated gas is most prevalent, and sometimes as in putrid herrings, the phosphorated hydrogen gas is most abundant.

It was natural to suppose that phosphoretted hydrogen, often called phosphine or hydrogen phosphide, a self-inflammable gas, was the cause of the light of fish. Like all plant and animal material, fish are especially rich in phosphorus but unfortunately for Lavoisier's theory, later work has indicated that hydrogen phosphide, unlike hydrogen sulphide, is not a naturally occurring decomposition product or organic material. Phosphoretted hydrogen is usually prepared by boiling phosphorus in caustic alkali and is actually a mixture of $\mathrm{PH}_{3}$ and $\left(\mathrm{PH}_{2}\right)_{2}$, the latter gas only being the self-inflammatory one.

Lavoisier's idea that phosphine is responsible for the light of shining fish, flesh, and wood has been espoused by many workers and has been suggested in explanation of the light of the glowworm and other luminous animals. Phosphine also is a ready explanation of the ignes fatui or feux follets, alleged to appear over swamps and damp boggy ground, where decomposition of vegetation might give rise to this gas. However, no actual formation of self-inflammable phosphine has ever been observed in decaying plant or animal tissue and the ignis fatuus must have another explanation. Marsh gas $\left(\mathrm{CH}_{4}\right)$ and sulphuretted hydrogen $\left(\mathrm{H}_{2} \mathrm{~S}\right)$ are the gases of anaerobic

(Oxford, 1669). Lavoisier's claim to discovery comes from demonstration of the elemental nature of oxygen. 1793.

${ }^{34}$ Elements of chemistry by Mr. Lavoisier, trans. by Robert Kerr, 201, Edinburgh, 
decomposition of dead animal and plant remains. They both burn in air but neither of them are self-inflammable.

\section{The Phlogiston Doctrine and Luminescence}

The closing years of the eighteenth century were notable for the passing of the phlogiston doctrine ${ }^{35}$ of Johann Joachim Becher (1635-1682) and his pupil, George Ernst Stahl (1660-1734). Although Becher and Stahl were both chemists and physicians they contributed nothing to the history of luminescence, but they did influence later thinking on the subject because of the attractive idea that fire resulted from the escape of a material substance, phlogiston. Becher thought that bodies were made up of air, water, and three earths, one of which was "terra pinguis," a fatty or inflammable earth, ${ }^{36}$ really a fire-principle, corresponding to the sulphur of Paracelsus.

Stahl's views ${ }^{37}$ were more definite and his name is more generally and rightly associated with the phlogiston theory of combustion. He held that the fire-principle, which he called "phlogiston," 38 later thought of as a definite chemical compound, escaped when a substance was burned or oxidized. Phlogiston thus accounted for the flame and heat. The element sulphur was almost pure phlogiston since it left no residue on burning. Wood or carbon was believed to be made up of phlogiston and ash, phosphorus of phlogiston and white ash $\left(\mathrm{P}_{2} \mathrm{O}_{5}\right)$, metals of phlogiston and a calx (a metal oxide). When the calces of metals were heated with carbon (rich in phlogiston) the carbon gave up its phlogiston to the calx and the metal containing the phlogiston was formed.

While it was perfectly apparent that wood or carbon or a candle became lighter on burning, it had been recognized very early that calces were heavier than the corresponding metals. How then could additions of phlogiston to a calx make a metal which weighed less? Such discrepancies led to the suggestion of levity or negative weight, ${ }^{39}$ finally to abandonment of the phlogiston doctrine, pri-

${ }^{35}$ See J. H. White, The history of the phlogiston theory, London, 1932.

${ }^{36}$ Geber (died A. D. 765) had spoken of sulphur as "pingucodo terrae," fatness of the earth. Becher's other two earths were the vitreous and the mercurial earth, described in Physica subterranea (1669).

${ }^{37}$ G. E. Stahl, Zymotechnia fundamentalis (1697); Fundamenta chymiae dogmaticae et experimentalis (1723), translated by P. Shaw (1730). "Phlogiston" comes from the Greek phlogistos, meaning burnt.

${ }^{38}$ Boerhaave spoke of "oil" rather than "phlogiston" or "fatty earth," but the three words all stood for the quality of combustibility.

${ }^{39}$ An idea of Johann Juncker, Conspectus chemiae theoretico-practicae, etc., $2 \mathrm{v}$., Halle, 1730. 
marily from Lavoisier's studies ${ }^{40}$ in 1774 on the change of weight when phosphorus, sulphur, and metals burned in air. $\mathrm{He}$ also demonstrated that part of the air, the "air vital" or "air pur," which he called "principe oxygine" in 1777, later changed to oxygène, combined with the phosphorus, the sulphur or the metal, when these materials burned. There was left behind, the noxious or unvital air, hence called azote ${ }^{41}$ (without life).

The phlogiston theory was accepted by most chemists of the eighteenth century-K. Neumann, J. H. Pott, A. S. Marggraf in Germany; S. F. Geoffroy Duhamel de Monceau and P. J. Macquer in France; and the group of men whose names have come to be intimately associated with gases and combustion, H. Cavendish, J. Black, and J. Priestley in England, and K. W. Scheele in Sweden. They were all phlogistonists at first, as was T. O. Bergman, Scheele's contemporary. Marggraf, Macquer, Priestley, and Scheele remained so during their lifetime, but the others were gradually converted to the point of view of Lavoisier, whose terminology was adopted almost from the start by such men as Berthollet, Fourcroy, and Guyton de Morveau.

Phlogiston doctrine postulated that in the vital processes of combustion in the body, phlogiston was constantly removed. To Lavoisier also is due the credit of demonstrating ${ }^{42}$ in 1777 , again by quantitative methods, the essential similarity of chemical processes in the burning candle and in the animal-taking up of oxygen and formation of carbon dioxide. Thus the older terms of fire-air or vital air or dephlogisticated air ${ }^{43}$ (for oxygen), spent air or phlogisticated air (for nitrogen) and fixed or mephitic air (carbonic acid)

${ }^{40}$ Opuscules physiques et chimiques, Paris, 1774.

${ }^{41}$ Some hold azote comes from the alchemistic term "azoth," meaning " mercury of wisdom." Isolation of noxious or injurious air was carried out by Daniel Rutherford (1749-1819) in 1772 at the instigation of J. Black. According to Black, the name "nitrogène" was suggested by J. A. C. Chaptal de Chanteloup (Elemens de chimie 1: 128, Paris, 1790), producing nitre (saltpeter).

${ }^{42}$ A. L. Lavoisier, Expériences sur la respiration des animaux, et sur les changements qui arrivent à l'air en passant par leur pulmon. Hist. Acad. Roy. des Sciences 1777, 185-194, Paris, 1780.

${ }^{43}$ Priestley noted that oxygen (from heating mercury oxide) caused rapid and intense burning and must therefore be able to take up much phlogiston. Hence it originally contained little phlogiston and was called dephlogisticated air. An air left after a substance had stopped burning was phlogisticated air, for example, nitrogen. Priestley's actual words in a letter to the Royal Society read May 25, 1775 were: "the purest air [oxygen] is that which contains the least phlogiston: that air [nitrogen] is impure (by which I mean that it is unfit for respiration, and for the purpose of supporting flame) in proportion as it contains more of that principle." Later (1775) he wrote: "I think I have sufficiently proved that the fitness of air for respiration depends on the capacity to receive the phlogiston exhaled from the lungs, this species of air may not improperly be called, dephlogisticated air." 
were finally replaced by Lavoisier's terminology. The new theory of combustion represented a true revolution in thought and may be regarded as the beginning of the modern era of chemistry.

During the middle and latter part of the eighteenth century, even after Lavoisier's discoveries phlogiston was invoked to explain many types of luminescence. Wiegleb's views have already been given. Benjamin Wilson in 1777 thought that oyster shells, which become phosphors on calcination, received phlogiston from bodies they touched in the crucible. The article on "phosphores" (1778) of the French Encyclopédie called Kunkel's phosphorus a " perfect sulphur composed of phlogiston and acid," and Scheele declared: "heat . . . made very elastic by the addition of phlogiston, penetrates likewise into them [phosphors].'

Bryan Higgins, M. D., wrote A Philosophical Essay Concerning Light (London, 1776), in which he attempted to show that "A motion of light is necessary toward illumination and vision" by observations of the element, phosphorus. He wrote:

The phosphorus of Kunkel causes no illumination whilst it is kept in the Torricellian void, and whilst it is by any means prevented from emitting its phlogiston. The same phosphorus illuminates, more or less, as the quantity of phlogiston which escapes from it, in a given time, is greater or less; and the illumination ceases when the phlogiston is departed from the residual incombustible saline matter, with which the fresh phlogiston of any phlogistic body is capable of forming phosphorus again. And since the phosphorus is luminous only whilst matter is manifestly moved from it; we clearly perceive that Light at rest, whether in the phosphorus or diffused in the chamber, is not sensible to us; and that the illumination caused by phosphorus consists in the motion of Light emitted from the phosphorus or in the motion which diffused or quiescent Light receives from the moved phlogiston of the phosphorus.

George Adams in Lectures on Natural and Experimental Philosophy (1794) believed that "phosphoretic and phlogistic bodies agree in containing a quantity of light," the latter necessitating " an exposure to the atmosphere" and being greatly changed "on abstraction of their luminous matter," the former not requiring air and remaining unchanged after their light (regarded as a material substance) had disappeared.

Lavoisier's studies on combustion and animal respiration stimulated a host of later workers to try the effect of gases on luminescent materials-phosphorus, phosphors, luminous wood and fish, fireflies, and glowworms, etc. The papers appeared between 1782 and 1800 . Among the dozen men carrying out this work, only two, G. Forster (1782) and F. Achard (1783), used the word "dephlogisticated air" 
for oxygen, while C. P. D. Beckerhinn (1789) spoke of "reiner Luft." The remainder adopted modern terminology. Their results will be found in the chapters dealing with the appropriate luminescence.

Thus the eighteenth century was to see the final passing of the Greek elements-earth, air, fire, and water-as simple principles. Earth was obviously of complex composition. The studies outlined above indicated that air could no longer be regarded as a simple gas. Lavoisier's views on combustion placed fire in proper perspective, although heat was regarded as a material substance until Count Rumford's experiments in 1798. Water had been formed by combustion of inflammable gas (hydrogen) with air in the experiments of Cavendish (1784), but his explanation was a strained application of the phlogiston theory. It remained for Lavoisier (1784) to set the matter straight and to show that "hydrogène" and "oxygène" (his own names) formed water by combustion. The last of the Greek elements was proven to be a compound. All this work prepared the way for a much more rational approach to the explanation of luminescences.

\section{Crystalloluminescence}

At the beginning of the eighteenth century every type of luminescence had been recognized except crystalloluminescence, the light which appears when certain solutions crystallize, and radioluminescence, the light from bombardment of matter with particles, with $\mathrm{X}$-rays, or with gamma rays. Radioluminescence was a discovery of the next century but crystalloluminescence became known from the simultaneous observations of J. G. Pickel (1751-1838) and of Schönwald, in 1786. Both these men saw the striking greenish light which appears when solutions of potassium sulphate crystallize rapidly. The phenomenon is fairly widespread, but has not been too extensively studied and is not well understood, even at the present time. Details of the early and later experiments must be left for Chapter X.

\section{Luminescence in Literature}

Many passages from non-scientific literature might be quoted to illustrate the early interest in glowworm and firefly light, as well as folklore concerning these insects. From Dante's, "Fire-flies innumerous spangling o'er the vale" (Inferno, XXVI, 29, 1300), to Du Bartas' verses on the cucuyo in La Creation du Mond (1578), and Shakespeare's lines in Pericles (II, 3, lines 43-44, 1609),

... like a glow-worm in the night,

The which hath fire in darkness, none in light, 
luminous insects have inspired the poet and intrigued the prose writer up to the present day. At first regarded as a dirty worm or an insignificant source of illumination, the glowworm of eighteenthcentury poets had ceased to be a foul creature. Instead, the poems stress the light that guides as dusk gives way to night, or compares the glow to light in lovers' eyes.

The beauties of a phosphorescent sea were also extolled by such eighteenth-century writers as William Falconer (1735-1769), George Crabbe (1754-1832), S. T. Coleridge (1772-1834), and many others (see Chapter XV), but far less attention was paid to the many more unusual types of luminescence known to the eighteenth-century chemist and physicist.

An early notice of phosphorescence in prose literature was made by Joseph Addison (1672-1719), who wrote: "Of lambent flame you have whole sheets in a handful of phosphor." In poetry, the allusion is mostly to dark places, as in Edmund (1700), an epic poem by Bishop Thomas Ken (1637-1711): "No light was there but what the phosphors raise." The personal touch was introduced by John Keats (1795-1821) in Lamia (1819), when he wrote:

Her eyes in torture fix'd, and anguish drear . . .

Flashed phosphor and sharp sparks.

Because of Goethe's (1749-1832) early interest in light and colorhe published Beträge zur Optik (2 parts) in 1791-1792, and Zur Farbenlehre in 1810-one might expect references to luminescence in his poetry and prose, at least frequent mention of phosphors, with which he was concerned in the 1780's and 1790's (see Chapter VIII). However, a check in various word indices to Goethe's works has revealed no Johanniswürmer and very little on luminescence. "Leuchtamiesen," translated as "firefly-emmets," is used in Faust in describing (Part II, Act I) the gnomes: ${ }^{44}$

In massy garb with lantern bright,

They move commingling, brisk and light,

Each working on his separate ground,

Like firefly-emmets swarming round.

A few luminous ants have been reported, probably infected with luminous bacteria, but Goethe undoubtedly wished to imply a combination of luminescence and industrious behavior.

The word "phosphor" occurs only once in Faust. In the second part, Act V (not finished until 1831), Mephistopheles remarks to the "Stout devils, with short straight horns": ${ }^{44}$

${ }^{44}$ From the English translation of Bayard Taylor (1870). Lines 5845 and 11659 of the Weimar edition of Goethe's Werke (1888). 
Watch here below, if phosphor-light be shed:

It is the Soul, the wingéd Psyche is it;

Pluck off the wings, ' $t$ is but a hideous worm:

This description of the soul is no doubt a reflection of the old custom of representing the spiritual aspect of human beings as luminous, departing at death from the body, which is left a repugnant thing.

It is perhaps fitting to conclude the eighteenth century by mention of one writer who did do justice to various phosphors. He was the English physician, scientist, and poet, Erasmus Darwin (17311802), grandfather of Charles Darwin. His published scientific observations on luminescence were slight, but he managed to include a surprising number of references to this subject and to scientific phenomena in general in his poem, The Botanic Gardan, first published in 1791. Part II of the poem, "The Loves of the Plants," which had appeared anonomously in 1789, contains the following:

So shines the glow-fly, when the sun retires,

And gems the night-air with phosphoric fires;

Thus o'er the marsh aerial lights betray,

And charm the unwary wanderer from his way.

In Part I, " The Economy of Vegetables," Darwin referred to the northern lights which:

Dart from the North on pale electric streams,

Fringing Night's sable robe with transient beams.

Then he spoke of the faint lights seen after the sun sets, personified as nymphs, "Effulgent Maids," which:

O'er Eve's pale forms diffuse phosphoric light,

And deck with lambent flames the shrine of Night.

So, warm'd and kindled by meridian skies,

And view'd in darkness with dilated eyes,

Bologna's chalks with faint ignition blaze,

BECCARI's shells emit prismatic rays. ...

Or mark with shining letters KunkeL's name

In the pale Phosphor's self-consuming flame.

The ignis fatuus, believed to come from "inflammable air" near the surface of a morass, the "flashing" of Calendula flowers, at first thought to be a luminescent phenomenon, the glowworm, and other animal lights were ascribed to these same Nymphs:

You with light Gas the lamps nocturnal feed, Which dance and glimmer o'er the marshy mead;

Shine round Calendula at twilight hours, 
And tip with silver all her saffron flowers; Warm on her mossy couch the radiant Worm, Guard from cold dews her love-illumin'd form, From leaf to leaf conduct the virgin light, Star of the earth, and diamond of the night. You bid in air the tropic Beetle burn, And fill with golden flame his winged urn:

Or gild the surge with insect-sparks, that swarm Round the bright oar, the kindling prow alarm; Or arm in waves, electric in his ire, The dread Gymnotus ${ }^{45}$ with ethereal fire. . . .

\section{Summary}

The eighteenth century may be characterized by the acquisition of a vast collection of facts regarding luminescences of all kinds, as befits an "Age of Enlightenment." The greatest attention was paid to inorganic phosphors, particularly to the preparation of new lightemitting materials. Although the light might last but a short time, the conclusion was reached that nearly everything, inorganic and organic, was a potential phosphor. If the material did not respond to illumination, slight heating, or friction, or attrition was effective in exciting the luminescence. Particular attention was paid to the interrelation between phosphorescence, thermoluminescence, and triboluminescence.

During a century concerned with the phenomena of electricity, many investigators turned their attention to the "electric light," little realizing how important electroluminescences were to become in practical illumination. The phosphorescence of the sea was regarded more and more as due to the light of living organisms, but convincing proof that all sea light could be ascribed to animaculae was still lacking. The light of dead flesh and rotten wood was still a problem for the physicist and chemist, with incorrect ideas of the cause. Bioluminescences were neglected as a group, compared with the very great interest in the inorganic field, and compared with the great revival of interest in luminous animals and plants characteristic of the nineteenth century.

A start was made to discover important details concerning the light emitted, such as its spectrum, or by what new methods a luminescence might be excited, for example, the action of the electric spark. The chemical composition of various luminescent materials was studied, as well as the effect of the newly isolated gases, both on living luminous organisms and on inorganic luminous material.

${ }^{45}$ Gymnotus, an electric fish, is not luminous. 
However, research was hampered by inadequate instruments and crude methods, as well as by the general level of scientific knowledge. The eighteenth century was mainly important in outlining the problems, in anticipation of the intense attack of better equipped workers during the next century. As far as luminescence is concerned, the eighteenth century may be looked upon as effecting the transition from a point of view rather mysterious and obscure, to one which may justly be described as rational and enlightened. 


\section{THE NINETEENTH CENTURY}

\section{Introduction}

SCIENCE of the eighteenth century merged imperceptively into that $S$ of the nineteenth. Perhaps the century is best characterized as one of specialization. An important new development was the founding of periodicals devoted to particular branches of science, in contrast to the publications of societies and academies, which embraced a great variety of knowledge. Beginning in the seventeennineties and early eighteen-hundreds, many new chemical and physical journals were started. They contained articles on all types of luminescence. These periodicals were usually known by the name of their editor-Voigt's or Tilloch's Magazines, Schweigger's or Scherer's or Delamétherie's Journals, Crell's or Lavoisier's or Gilbert's Annals, Karsten's or Kastner's Archives, etc. Their policy was determined by the editor. For example, Ludwig Wilhelm Gilbert (1769-1824), professor of physics, first at Halle and then at Leipzig, who edited the Annalen der Physik for twenty-seven years, took special interest in luminous phenomena. He translated Macartney's (1810) article on luminous animals and reproduced Macartney's plate in Vol. 61 (1819). This volume was practically devoted to phosphorescence of the sea and contained the observations of Tilesius and many other world explorers. Although it had been recognized since 1750 that many small luminous animals which lived in the sea were at times responsible for its phosphorescence, and several observers had expressed the opinion that diffuse sea-light was due to minute organisms, in 1800 there was still considerable doubt as to whether every display could be traced to animalcules. Moreover, the light of dead fish, meat, and wood had not yet been correctly explained and was not thought of as due to living organisms. Such phenomena were still a subject of particular interest to physicist and chemist rather than biologist. Biological journals began to appear in the second half of the century.

With the advent of exploration for science rather than for conquest, expeditions brought back great collections of animals, together with accounts of new luminous species from the sea. The first book on luminescence published during the nineteenth century, Über das Leuchten des Meeres (1803), by Christoph Ber- 
noulli, dealt almost exclusively with marine luminous organisms. Biology as a science was rapidly becoming a reality. In contrast to the publications of the previous century, an increasing number of books and general articles were devoted solely to bioluminescences.

Division into the organic and the inorganic is particularly noticeable after the publication of the prize essays on the nature of light by Link, Heinrich, and Dessaignes, and after the appearance of Biologie oder Philosophie der lebenden Natur, by G. R. Treviranus. The fifth volume (1818) of this great work contained a long section on "Phosphorische Erscheinungen der organische Natur."

Such a change in outlook justifies the arrangement adopted in this chapter following the consideration of Heinrich's book, Die Phosphorescenz der Körper (1811-1820). Discoveries concerning the light of luminous organisms and the light of inorganic luminescences will be treated in separate sections. The study of luminescences became so popular in the nineteenth century that only the more general works and the trends of thought can be considered. Publication was substantial, but an attempt will be made to relate luminescence discoveries to the advancing front of knowledge in chemistry, in physics, and in biology, and to present the views of the leaders in these fields.

\section{Theories of Light}

During the previous century the corpuscular theory of light, suggested by Pythagoras and championed by Newton, made a far more lasting impression on science than did the wave theory of Hooke, Huygens, and Euler. The particle emission hypothesis held almost uncontested sway until the early part of the nineteenth century, when Thomas Young (1773-1829) and Augustin Fresnel (17881827) reestablished faith in the wave theory through logical explanations of interference and diffraction. At this time, light, together with heat and electricity, was regarded as a material substance. In no field was the corpuscular hypothesis more popular than in that of luminescence. What more simple explanation than to suppose that a phosphor retained the light particles within its pores, to emit them slowly in the dark. The ideas on luminescence of two eminent scientists will illustrate this trend.

\section{LUIGI BRUGNATELLI}

That light is a material thing, a light substance, was particularly appealing to many chemists at the beginning of the century. For example, the celebrated Luigi Gasparo Brugnatelli (1761-1818), 
professor of chemistry at the University of Pavia, held (1797) that light existed in three forms in bodies. First, there was chemically bound light which is freed on heating because of "its affinity for caloric," as in fluorspar, various calyces, corrosive sublimate, sugar, camphor, turpentine, oils, and fats. All these substances shine with great vivacity on a hot plate, either as a solid or in the form of vapor and Brugnatelli held that air was not necessary for the light. Second, there was mechanically held but invisible light, freed by approximation of the parts of materials, thereby pressing out the light, as in the mercurial phosphor, "vitriolated tartar" on crystallization, in the phosphorescence of sea water, pounding or scraping sugar, striking cream of tartar, alum or borax, knocking quartz pebbles together, the eye when struck, and in certain plants. Third, there was mechanically held but visible light, as with the Bolognian and Baldeweinian phosphors, diamonds and other precious stones, the eyes of the cat and hyena, putrified fish, rotten wood, the body of the glowworm and other phosphorescent animals. Apart from the fact that many of the above luminescences are not true light emissions, a more illogical scheme is hard to imagine, but it may serve to emphasize the advance destined to take place later in the century.

\section{HUMPHRY DAVY}

Another distinguished scientist of the early nineteenth century, Humphry Davy (1778-1829), also thought of light as a substance capable of combination. Despite his broad interest in chemistry and physics and his eminence as an electrochemist, Davy never made any concerted study of luminescences. However, in the Syllabus of a Course of Lectures, delivered at the Royal Institution in 1802, when he was only twenty-four years old, Davy (1799, 1803) mentioned $^{1}$ methods for the artificial production of light, which very clearly indicate that he recognized phosphorescence, thermoluminescence, triboluminescence, chemiluminescence, and bioluminescence as distinct categories. He later (1822) studied electroluminescence in some detail.

Davy spoke "Of Phosphorescent Bodies" as follows:

Certain bodies, (solar phosphori) after being for some time exposed at a high temperature to light, continue luminous for a considerable length of time after this exposure. Such are many preparations of lime, the bolognian stone, \&c. This phaenomenon is in some measure analogous to the ignition of incombustible bodies.

Light, it appears, is only susceptible of combining, and of remaining

1 Opera 2. Early miscellaneous papers, 1799-1805, 33-35, London, 1839. 
in combination with those bodies at a higher temperature than that of our atmosphere; at the common temperature it is liberated. . . .

Other bodies exist, which become luminous when their repulsive motion is increased by communication of it from some bodies of a higher temperature. Light remains in combination with these bodies only at a low temperature. When their repulsive motion is increased, the light is liberated. This decomposition appears to arise from the diminution of the chemical attraction between light and the body, by the repulsive motion, and from the supply of a quantity of it sufficient to enable light to fly off in the repulsive projectile form. Amongst these bodies are the different combinations of lime, and particularly the fluate, ${ }^{2}$ (the colours of which appear to depend upon combined light,) different combinations of barytes, the sulphate of potash, some of the metallic oxyds, cotton, wool, oils, wax, alcohol, \&:c. . . .

There is a class of phosphorescent bodies, which give out their combined light on attrition. Amongst these are borate of soda, sulphate of $\operatorname{argil}^{3}{ }^{3}$ tartrite of potash, and all the silicious class of stones. This phosphorescence may be accounted for in the same manner as the last species.

Certain substances give out their combined light on immersion into the mineral acids. When magnesia is thrown into the sulphuric acid, a light is liberated which produces a sensation similar to that known by the name of red heat. The same effect is produced when the nitric acid is used.

During the combination of lime with the mineral acids, a flash of white light is uniformly perceived; the same effect is not produced during the combination of strontian and barytes with these acids.

This phaenomenon appears to be owing both to the attraction of the acids, and to the repulsive motion generated during the combination, a motion sufficient to give to the combined light repulsive projection; for lime and magnesia become luminous when heated, which is not the case with strontian and barytes.

Finally in Elements of Chemical Philosophy (1812) (Opera 4: 163), in speaking of "Radiant or Etherial Matter" Davy wrote:

Many phenomena which have been attributed to combined light, appear to be electrical, or to be merely the effect of the ignition of the substances, for whenever heat rises beyond a certain degree, bodies become luminous; pieces of quartz rubbed together are rendered electrical; and by percussion or friction any hard bodies may be intensely heated.

During the putrefaction of certain animal and vegetable substances, light is emitted; and this is no more difficult to account for, than the heat produced during similar operations.

The light emitted by certain living insects, appears to depend upon the secretion of a substance very easy of decomposition: and any chemical change may be supposed adequate to the production of light.

${ }^{2}$ Fluorspar or calcium fluoride.

${ }^{8}$ Argil is a term for potter's clay, but may also refer to aluminium. 
Inorganic phosphors and luminous organisms thus came within the sphere of Davy's interest but it must be emphasized that the above quotations represent his early views. The material nature of light, which assumed the ability to combine with matter, was a generally accepted belief at that time, a continuation of eighteenthcentury thought.

\section{THOMAS YOUNG}

In $1804^{4}$ the material theory of light was seriously questioned by Thomas Young, M. D. (1773-1829), whose studies on diffraction and interference completely supported a wave theory. Young was a man of unusual talents and broad interests, not only a physician and physicist, a student of both physical and physiological optics, and a mathematician, but also a linguist and Egyptologist. He was Foreign Secretary of the Royal Society and Professor at the Royal Institution. In his two-volume Course of Lectures on Natural Philosophy and the Mechanical Arts (1807), Young elaborated on his interference theory and touched on luminescences. He used Lavoisier's word "oxygen," stating that light and heat from terrestrial sources mostly came from combustion, which

is not capable of a very correct definition: in general it requires an absorption, or at least a transfer, of a portion of oxygen; but there appear to be some exceptions to the universality of this distinction; and it has been observed that both heat and light are often produced where no transfer of oxygen takes place, and sometimes by the effect of a mixture which cannot be called combustion.

Light is also afforded, without any sensible heat, by a number of vegetable and animal substances, which appear to be undergoing a slow decomposition, not wholly unlike combustion. Thus decayed wood, and animal substances slightly salted, often afford spontaneously a faint light, without any elevation of temperature; and it is not improbable that the light of the ignis fatuus may proceed from a vapour of a similar nature.

He also described the solar phosphori and luminous phenomena, "attributed to the motions of the electrical fluid," but he merely mentioned the general facts without interpretation. In a section entitled, "Catalogue of Works Relating to Natural Philosophy," there is a surprisingly complete subject bibliography ${ }^{5}$ with some

"See the Bakerian Lecture of T. Young, "Experiments and calculations relative to physical optics," Phil. Trans. 94: 1-16, 1804.

${ }^{5}$ Special subject bibliographies on luminescence started at the end of the eighteenth century with Joseph Banks (1743-1820), Catalogus bibliothecae historico-naturalis, which appeared from 1796-1799 in four volumes-I Scriptores generales, II Zoologi, III Botanici, IV Mineralogi. In the zoology volume a section on Phosphorescentia animalium and Phosphorescentia maris contains thirty-eight references. In the volume 
annotation, on the aurora borealis, on spontaneous light, on solar phosphori, and on light from friction. The "spontaneous light" section contains most of the early work on phosphorescence of the sea and "phosphoric animals."

The Natural Philosophy of Thomas Young was a truly valuable compilation, containing not only the facts themselves, but the early history of natural science, presented in a readable yet comprehensive manner, made possible by Young's wide interests and ability as a linguist. The wave theory of light held sway during most of the nineteenth century as a result of the labors of Young and of Augustin Jean Fresnel (1788-1827), whose diffraction formulas were completely verified by experiment. Only after 1900 were corpuscular theories revived, following Max Planck's concept of quanta and Albert Einstein's explanation of the photoelectric effect by the quantum principle. At the present time both views appear to be acceptable.

\section{Prize Essays}

Like the first part of the eighteenth, the early nineteenth century was characterized by the offer of numerous prizes for essays on various physical, chemical, industrial, biological, and medical subjects. They ranged from a reward of 3000 francs $(\$ 600)$, offered by the Society for the Encouragement of National Industry in France for discovery of a metal which is not corroded by animal and vegetable juices, to one of 300 francs for an essay on the results of too rapid growth, offered by the Royal Medical Society of Bordeaux. Among the prizes, several were offered for essays on light and luminescence, and at least three awards (to Link, Heinrich, and Dessaignes) were made, and probably a fourth (to Bernoulli) .

\section{CHRISTOPH BERNOULLI}

The first essay, devoted entirely to bioluminescence, was by Christoph Bernoulli (born 1782) entitled, Ueber das Leuchten des

on mineralogy, Phosphorescentia mineralium and Lapis bononiensis include fourteen authors. This would appear to be the first bibliography on luminescence not contained in a publication specifically devoted to that subject. Many author bibliographies of both eighteenth and nineteenth centuries, such as those of W. Englemann, the Bibliotheca historico-naturalis, 1740-1846 (Leipzig, 1846), continued as Bibliotheca zoologicae by J. V. Carus and W. Englemann (1861), or the Select bibliography of chemistry by H. C. Bolton (Smithsonian Misc. Collec. No. 850, 1893 and No. 1170, 1899), or the Index to literature on spectroscopy, by Alfred Tuckermann (Smithsonian Misc. Collec. No. 658, 1888), all contain luminescence subjects grouped in the index.

Extended literature references on bioluminescence are included in Ehrenberg's Das Leuchten des Meeres (1834), with 436 titles, and Dittrich's Ueber das Leuchten der Tiere (1888), with 250 titles. The really comprehensive subject bibliography on luminescence is a growth of the twentieth century. H. Kayser (1908) is excellent for inorganic luminescences and E. N. Harvey (1952) for bioluminescences. 
Meeres mit besonderer Hinsicht auf das Leuchten tierischer Körper, a pamphlet of 182 pages published at Göttingen in 1803. The title page is reproduced as figure 18. According to Heinrich (1815, p. $387)$, this was presumably an answer to a prize question and was quite superior to other papers of the time, but the author has been unable to locate the donor of the prize. It is divided into six parts, with Parts I to V devoted to sea light, leaving Part VI to take up the origin of light in animal bodies.

Bernoulli's ideas on diffuse sea light will be considered in Ghapter $\mathrm{XV}$, and his ideas on luminous fish in Chapter XIV. His views on the origin of light in the larger animals sound quite modern. He recognized that many sea animals possessed light organs producing a "Leuchtstoff" that could be separated without harming the animal and that the light intensity could be controlled by muscular movement, which he thought regulated the admission of air. He held that the light arose during slow burning of an oxidizable material which in many cases appeared to be actually phosphorus. This material was produced by a living process as the result of a vital force, ${ }^{6}$ and the oxidation came from a supply of air, by respiration or by a similar process. However, the light was not visible during complete but only during incomplete oxidation, and a transparent skin was necessary for detection of internally produced light-no doubt a reference to the transparency of many luminous marine forms such as medusae and ctenophores. Bernoulli actually considered it possible that many animals, frogs for example, might be found to produce light, if they were opened by vivisection. He called attention to the fact that in some forms luminous material could be secreted into a reservoir and then expelled by the contraction of muscles. Such secretions were not necessary for the life of the animal but their purpose was unknown. In contrast to these definite statements his views on the light of dead animal tissues (fish and flesh) were highly imaginative.

Christoph Bernoulli was one of the famous Bernoulli family, whose scientific contributions started with the brothers Jacob I (1654-1705) and Johann I (1667-1748), the great mathematicians of Basel. Johann II (1710-1790), youngest son of Johann I, professor of rhetoric and also mathematician at Basel, had a son Daniel II (1751-1834), an M. D. and a professor of rhetoric at Basel, who was the father of Christoph. His thesis, Ueber das Leuchten des Meeres (Göttingen, 1803), was his only work concerned with luminescence. Later publications dealt with anthropology, mineralogy,

${ }^{6}$ Wöhler's synthesis of urea, which shattered the idea that biological substances were synthesized by vital force, was made in 1828 . 
and engineering. Christoph Bernoulli had been a Lehrer at the Paedagogium at Halle and since 1817 professor of natural history at the University of Basel.

\section{HEINRICH FRIEDRICH LINK}

In 1804 the Imperial Academy of Sciences at St. Petersburg announced a prize of 500 rubles for

a series of new and instructive experiments on light, considered as matter, also on the properties which may in part be attributed to it; on the affinities which it may appear to have, either to organized or unorganized bodies, and upon the modifications and phenomena of these substances, by their combinations with the matter of light.

The conditions and handling of the prize essays are rather interesting. ${ }^{\text {? }}$

The manuscripts, unsigned except by a motto, were to be deposited with the Academy in 1806, together with a sealed note marked with the motto and containing the name of the author. Six manuscripts were received, with the following mottoes.

No. 1 in Russian, by “A philosopher who has learn'd to doubt, knows more than all the learned."

No. 2 in Russian, by " Time is the earliest thing in nature, etc."

No. 3 in Latin, by "Is the color true or do reflections of light deceive the eye?"

No. 4 in French, by "Night is gone, nevertheless day has not yet arisen."

No. 5 in German, by "As you may know, things lack their fresh splendor, etc.”

No. 6 in German, by "Physics will not be truly a science until all natural actions can be deduced from one and the same principle demonstrated with certainty."

The Committee which awarded the prize decided that the first three essays contained no new experiments and only well-known or ill-expressed hypotheses. The fourth, although " not without merit" also contained no new experiments and all four were rejected. The fifth and six essays were accepted and given a joint prize, which went to Dr. Heinrich Friedrich Link, professor of physic at the University of Rostock, and Mr. Placidus Heinrich, professor of physics and mathematics at the Abbey of St. Emeran at Ratisbon. The first four notes containing the names of the unsuccessful authors were burned without being opened. This was the method of eliminating

${ }^{7}$ From Phil. Mag. 28: 184-185, 1807. 
undue influence and personal prejudice at the beginning of the nineteenth century.

The essays of Link and Heinrich were published together in book form in 1908 by the Royal Academy of Sciences at St. Petersburg under the title Ueber die Natur des Lichts. Link's essay, "Ueber die chemischen Eigenschaften des Lichts," of 92 pages, appears first in the book. It was divided into four parts as follows: I. Effects of light; II. Effects of colored light; III. The development of light and IV. The relation of light to other bodies, matter, heat, and electricity. As winner of a prize, the essay is distinctly disappointing.

A very short section dealt with phosphors (Lichtsaugende Körper), including as luminescences the light of phosphorus (also the light of burning sulphur and arsenic) and the "lifeless but not necessarily foul" luminescent organic bodies (wood or fish). Link considered the latter to be light magnets, i. e., the luminescence was believed to result from insolation, chiefly because of the effect of heat, which increased both the light of inorganic phosphors and of the dead organic material. Link emphasized that the consistency of the material was an important attribute of luminous bodies but hesitated to propose a theory as to why one substance would luminesce and another not. Sea light along the north sea, channel, and Atlantic coasts he attributed to small transparent jelly-like spheres, $\frac{1}{2}$ line $(1 / 12$ inch $)$ in diameter, which looked like eggs and which he thought to be eggs of medusae. They were undoubtedly Noctiluca.

Heinrich Friedrich Link (1767-1851) was a physician and a professor, first of natural history, chemistry, and botany at the University of Rostock, since 1811 professor of chemistry and botany at the University of Breslau, and later (1815) professor of botany and director of the botanical gardens at the University of Berlin. Link was a voluminous writer on many diverse subjects, but it is as a botanist that he is best known.

\section{PLACIDUS HEINRICH}

Heinrich's prize essay of 287 pages, Von der Natur und Eigenschaften des Lichts; Eine physisch-chemische Abhandlung (1808), was divided into six parts, the first three dealing with the effects of light on animals, plants, and chemical processes, respectively. The fourth part was on luminescence and burning, sixty-six pages devoted entirely to various luminous phenomena. A fifth part was concerned with the analysis of light by the prism, with "electric light" and "galvanic light," and a sixth part with the properties of light. In the latter Heinrich held that light was something that 


\title{
Ueber dás
}

\section{Leuchten des Meeres,}

mit besondrer Hinsicht

\author{
a uf das
}

Leuchten thierischer Körper.

Von

Christoph B Bernoulli,

Doctor der Philosophie, und Mirglied der physikal.

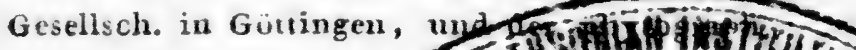

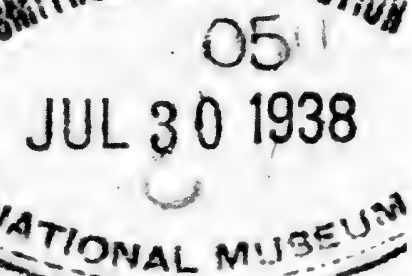
$\left\{\begin{array}{c}05 \\ \text { JUL } 301938 \\ N_{A} \text { TIONAL MUSEU }\end{array}\right.$

Göttingen,

bey Heinxich Dieterich. 1803. 
Dic

Phos phorescenz d e r $\quad k \ddot{o} r$ p e $r$

oder

dic im Dunkeln bemerkbaren Lichtphänomene der anorganischen Natur,

Anch eine Reihe cigener Beobachtungen und Versuche geprüf und bestimmt ron

Placidus Heinrich, der Gothergelehutheit und Weltweisheit Doctor, konigl. Baier. geistl. Rath, der Physik, Meteorolugie, und Astronomic Protessor und melnerer gelehren Gesellschafon Mitglicd.

Erste $\Lambda$ b hand lung von der

durch Licht bewirkten Phosphorescenz der Kïrper.

Vi $\mathrm{r} n$ b e $r$ is,

im Vorlage der Juhan Jeonhad Schragehen Buchlanallung.

1811.

Fu, 19. Title page of the first part of the most comprehensive book on luminescence of the ninetenth century, by Placidus (Joseph) Heinrich. The five parts were published at Nimberg in $1811,1812,1815$ and 1820 . 


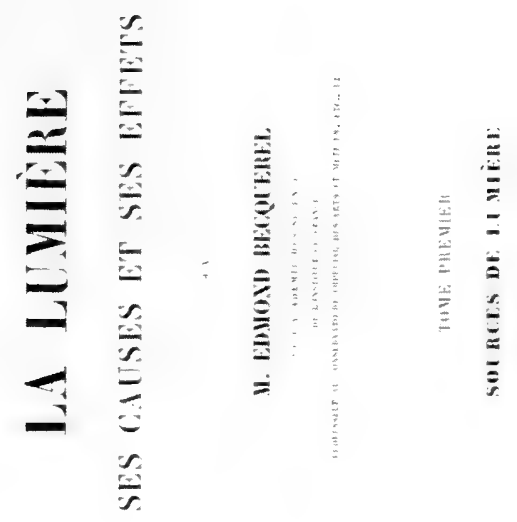


DISPUTA I I O PHYSICA De

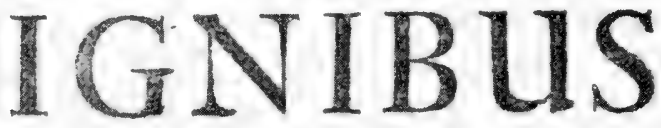

LAMBENTIBUS, Q2v.3m

Aupiciis Dei Opt. Maxumi

IN ILLUSTRI SALANA

$S$ U B P RAES I D I O

DN. CASPARIS POSNERI,

NATURAL. PROF. PUBL. AC ORdiNAR.

\author{
CELEBERRIM!
}

PRAECEPTORISAC PATRONISUT

DEEITA OBSETVANTIA COLENDI,

publico ERuditorum cxamini;

fubmition

JOII CHRISTOPHORLIS VLILPIUS,

Regiononte Borlussus. ann? an"? AD DIEM XXII. SEPTEMBR.

Am Chr. M DC LAXXVI.
Horis locógré folitis.

J E N AE,

Liecris JOHASN. ZACH. N1ST.

Fig. 21. Title page of a thesis (Jena, 1686) by J. C. Vulpius on ignis lambens. 
existed, but was not material in the sense that terrestrial bodies were material. He thought that the "light substance" and "heat substance" were different.

The sections on the "Phosphoren" were particularly full, giving an excellent résumé of the important work on light-absorbing phosphors, luminous wood and flesh, luminous animals, the sea, light from rubbing, heating, etc. Here is to be found the beginning of Heinrich's interest in luminescence phenomena which was to lead him to compete for another prize offered by the French Academy, and finally to the publication of his great work, Die Phosphorescenz der Körper, in 1811-1820.

In 1807, the French National Institute, Class of Mathematical and Physical Sciences, offered a prize of 3,000 francs, to be adjudged at the meeting on the first Monday in January, 1809, for the following subject: "To establish, by experiments, what are the relations which exist between the different modes of phosphorescence, and to what cause is each owing; excluding the examination of the phoenomena of this kind observed in living animals." The prize was instigated by Abbé René Just Haüy (1743-1822), the famous professor of mineralogy at the Museum d'Histoire Naturelle and honorary canon of Notre-Dame, whose Traité de Minéralogie (1801) contained a list of thermoluminescent minerals. The memoirs had to be delivered to the Academy before October 1, 1808. Anyone not a member of the Institute might be a candidate and like the St. Petersburgh prizes, the essays had to bear only a sentence, with the author's name in a sealed note.

Among others, Placidus Heinrich (1758-1825) and a Frenchman, Jean-Philibert Dessaignes, submitted essays and Dessaignes won the prize. ${ }^{8}$ However, Heinrich was too much interested in the subject to be deterred by this disappointment. He collected his experiments and notes, which were published as the first large work on all types of luminescence to appear in the nineteenth century, a huge collection of miscellaneous knowledge. The book, Die Phosphorescenz der Körper, was a real monograph of 596 pages (see title page in fig. 19). It is divided into five sections, appearing separately between 1811 and 1820. They represent the ideas of that day on the classification of luminescences and it is interesting to note that all the bioluminescences were grouped together in the third section (1815) entitled, "Vom Leuchten vegetabilischer und thierischer

${ }^{8}$ Another contemporary student of luminescence, Theodor von Grotthuss (17851822), did not compete for a prize. His papers are considered in Chapters VIII and IX. David Brewster (1781-1868) also worked on luminescence during the same period (see Chapter IX and XI). 
Substanzen, wenn sie sich verwesung nähern mit Rücksich auf das Leuchten lebender Geschopfe." The other sections dealt with (I) phosphorescence of natural and artificial preparations, inorganic and organic, after exposure to light (i. e., phosphors) ; (II) the phosphorescence of bodies as a result of rise in temperature, including both phosphorus and heated oils; (IV) luminescence by mechanical means such as fracture and friction, and (V) luminescence from chemical mixtures of various kinds. Heinrich included not only the work of his predecessors, but his own experiments, and in a final series of papers (1820) answered the criticisms leveled against his book.

Space does not permit a detailed résumé of Heinrich's views. His classification of luminescences is quite modern, generally corresponding to the divisions of his book, except that he grouped luminescences from rise in temperature, according as the heating came from the outside, as in thermoluminescence, or from internal heat due to chemical mixture, solution, fermentation, etc. Heinrich attempted to show that all bodies which luminesced contained acid. By irradiation, warming, or friction, the material was to a certain extent decomposed, some acid separated out, and since the acid contained " light substance," part of the light was freed. For example, he held that because many diamonds phosphoresce they must contain carbonic acid, and since ice is phosphorescent it "has more acid principle than water." Indeed, one might think that Heinrich had taken over almost completely the acid theory of J. G. Lehmann, who argued so vigorously in 1750 that all light resulted from acid (see Chapter V under Tracts and Theses on Luminescence).

A great deal of attention was paid to phosphorescent wood, shining fish and flesh, the general light of the sea, the luminescence of marine animals, insects and men, both dead and living, classed together as spontaneous decompositions.

Heinrich grouped larger sea animals into three classes-naked worms, crustaceans, and fish. The first luminesce only when alive, the second both alive and dead, and the third only when dead. He inquired how this could be, since they live in the same element and eat the same material on which the formation of a light-substance must depend, for Heinrich declared emphatically there must be a "Leuchtstoff." He made a detailed comparison of animal and vegetable phosphorescence and came to the conclusion that both are fundamentally alike and due to combustion of a luminous material-the plant combustion weak but more noticeable than the animal. He held that phosphorus in combination with hydrogen and nitrogen was concerned in the burning, since phosphorus was 
thought to be the most combustible of all known substances, and is widespread in the animal world. Moreover, in burning it produces an acid.

Placidus Heinrich, whose real name was Joseph Heinrich, was a Benedictine monk at the Royal Monastery of St. Emmeran near Regensburg. With the exception of the years 1791 to 1798 as professor of natural science, mineralogy and meteorology at the University of Ingolstadt, Heinrich spent most of his life at the monastery. He was teacher of philosophy and physics at the Lyceum and also head ("Capitular") of the high cathedral. In addition to his work on luminescence he published in the fields of pyrometry, thermometry, and meteorology.

The introduction to his book tells how he had always been interested in the nature and properties of light. In 1776 he began a study of mathematics, physics, and chemistry, noting that the newer knowledge of the latter two subjects would be particularly important for an understanding of the nature of light. He studied Newton's Principia and Priestley's History and Present State of Discoveries Relating to Vision, Light and Colours, reading the book through " more than once." Luminescences intrigued him most of all. He remarked that "it is unbelievable what a well prepared eye can see in the dark ... quite new phenomena show themselves; complete darkness and a sensitive eye are for us a microscope to discern the smallest atoms of light."

\section{JEAN PHILIBERT DESSAIGNES}

The winner of the French Institute prize, Jean-Philibert Dessaignes was at that time Director of the school (Pensionat) of Vendome. His essay was published serially in the Journal de Physique, beginning in 1809 under the title "Mémoire sur la Phosphorescence," and was followed by a number of papers in 1810 to 1812 dealing with additional aspects of the subject, such as luminescence from compression of gases. There are five chapters, the first outlining the field and classifying the various types of luminescences, the second, third, and fourth dealing with phosphorescence by rise of temperature, by insolation, and by collision, respectively, while the fifth was reserved for spontaneous phosphorescence, including luminous wood and fish, because their light was not then known to be biological in origin.

Dessaignes divided spontaneous luminescences into two kinds: (1) a transient one as when lime is mixed with water and (2) a lasting one such as luminous wood or fish. His experiments and conclusions 
led him to the view that wood and fish luminescence is an oxidation resulting in the formation of water and $\mathrm{CO}_{2}$ (see Chapter XIV).

Although the light of luminous animals was specifically excluded from the prize essay, Dessaignes did discuss light of the sea, and spoke of two kinds, "discrète et continue," the first from small living animals (molluscs or fishes) which secrete a luminous slime, the second resulting from such disintegrated slime in the water. Living luminous forms were thought to contain a sap (suc albumino-muqueux) in transparent receptacles. The sap absorbed oxygen in bound but not combined form and the resulting oxidation produced the light, dependent on the movement and will of the animals. In all cases of "spontaneous phosphorescence" the principle of light production was the same, whether in dead or in living creatures.

Dessaignes' greatest contributions had to do with inorganic phosphorescence excited by insolation, warming, compression, and collision. He occupied a place in France comparable to that of Heinrich in Germany, but was more active and a better experimenter. As the prize announcement required, Dessaignes did his best to establish the relations between the different types of luminescence and to explain them by a common cause. As Heinrich's principle was acid, Dessaignes' was water. He believed the light substance adhered strongly to water and that all substances containing bound water would luminesce. Dessaignes' greatest difficulty lay in explaining the ability to luminesce of substances which apparently contained no water. How he endeavored to apply the water principle to his various observations on inorganic phosphors will be described in Chapter VIII on Phosphorescence.

\section{Inorganic Luminescences}

\section{INTRODUGTION}

After the last installment of Heinrich's book appeared in 1820 , no outstanding contributions ${ }^{9}$ were made to knowledge of nonliving luminescences until the work of David Brewster and the Becquerel family in the eighteen-thirties and forties. Brewster's early research (1819-1823) had to do with thermoluminescence of minerals and his later studies (1833-1838) with what came to be known as fluorescences. His twenty-page article, "Phosphorescence," in the Edinburgh Encyclopedia (1832) is particularly comprehensive.

The middle of the century will always be noted for the brilliant

- A general paper on all kinds of luminescence was published by J. J. Virey in 1819. 
research of Edmond Becquerel on phosphorescence of solids and the equally comprehensive investigation of G. G. Stokes on fluorescence of solutions, while electroluminescence of gases was studied by J. Plücker, Wm. Crookes, and many others.

During the century, three new types of luminescence were identified, fluorescence in 1852 by G. G. Stokes, radioluminescence from bombardment with new kinds of rays in 1858 by J. Plücker, and chemiluminescence of organic solutions in 1877 by B. Radziszewski. Only a brief statement on these new luminescences, and on important monographs and textbooks can be given in subsequent sections. Details of the research on various luminescences will be found in corresponding chapters.

\section{THE - RISE OF SPECTROSCOPY}

The trend of luminescence study at the beginning of the eighteenth-century had been concerned with the discovery of new phosphors and the realization that almost all bodies (except metals and water) could be excited to luminesce in some way. Electrical knowledge had brought the ability to produce high voltages and powerful electrical discharges. At the beginning of the nineteenth century, the most important factor in the advance of luminescence knowledge was the extension of the solar spectrum into the infrared and ultraviolet regions, coupled with the rise of spectroscopy ${ }^{10}$ as a tool for the study of matter.

Spectral study during the nineteenth century was made possible by the construction of a real spectroscope. The first necessity was the introduction of a slit in front of the light source, a procedure standardized by Wollaston in 1802. Previously, in 1752, the Scotsman, Thomas Melvill (1726-1753), had examined (1756) a spirit flame containing nitre and sea salt, using a pinhole diaphragm and prism. He remarked that "the bright yellow which prevails so much over other colours, must be of one determined degree of refrangibility." However, the pinhole was soon forgotten, and it was the slit which brought out the dark lines in sunlight for Wollaston ${ }^{11}$ in 1802. They were later rediscovered by Fraunhofer (1814), who had added the collimating tube and a telescope for observing the

\footnotetext{
${ }^{10}$ See H. Kayser, Handbuch der Spectroscopie 1: 3-130, Chap. I, Geschichte der Spectroscopie, Leipzig, 1900.

${ }^{11} \mathrm{Wm}$. Hyde Wollaston first saw dark (Fraunhofer) lines in the sun's spectrum (Phil. Trans. 92: 378, 1802), but merely pictured the dark lines as separating the various colors. They were overlooked by Newton because of a poor prism and because his light came from a round hole instead of a very narrow slit. Joseph Fraunhofer's (1787-1826) description was published in 1814. He determined their wave-lengths in 1821 and 1823.
} 
image of the slit. These additions completed a usable instrument, and the Fraunhofer lines served as points of reference in comparing one spectrum with another. Fraunhofer continued his studies in 1821 and 1823 and investigated the electric spark in 1824.

In 1822-1823, John Herschel (1792-1871) had regularly used a prism for studying colored flames ${ }^{12}$ and colored media and suggested that such spectra might serve for detection of extremely minute quantities of compounds. William Henry Fox Talbot (18001877) emphasized the idea in 1826, and C. Wheatstone (1835) studied the spectra of sparks between different metals. Spectroscopy was employed more and more for examining light sources, and as a means of analysis, by David Brewster ${ }^{13}$ (1781-1868) and others, culminating in the investigations of Gustav Robert Kirchoff ${ }^{14}$ (1824-1887) and Robert William Bunsen (1811-1899), whose classic papers, Chemische Analyze durch Spectralbeobachtung, were published in 1860 and 1861.

The earliest observations of the spectrum of inorganic phosphorescences were made in 1713 with a prism by Zanotti (1748). He noted the dim monochromatic light of phosphors, but without a slit and with low light intensity no true idea of spectral distribution could be obtained. Priestley (1767) had no better success with electroluminescence. When he examined the diffuse electric light in a vacuum tube with a prism, it "made no sensible alteration in the appearance of it." Dessaignes (1811) reported that the prism revealed different colors when used to examine various phosphors, but an accurate spectrum of inorganic luminescences could not be obtained without the proper equipment.

The first published drawings of the spectra of phosphors appear to be figures 8 and 9 of plate VIII in the second volume of A. C. Becquerel's Traité de Physique (Paris, 1844). Becquerel referred to the fact that he and Biot had studied the "phosphorogenic rays" of the electric spark and found them different from the "luminous rays "; also that $\mathrm{E}$. Becquerel had studied the phosphorogenic rays of the solar spectrum, which were identical with those of the electric spark. The method of study was to cover paper with the powdered phosphor held on with a gum, and when dry, to place the paper under a solar spectrum from a slit in a dark room. His figure 8

\footnotetext{
12 Marggraf had used flame color tests, observed visually, to identify various salts in 1760. J. Herschel's work appeared in the Trans. Roy. Soc. Edinburgh 9 (II) : 445-460, 1823. He drew diagrams of emission spectra.

${ }^{13}$ Brewster in 1832 studied absorption spectra and noted the dark absorption bands of nitrogen peroxide (Trans. Roy. Soc. Edinburgh 12 (III): 519, 1834).

14 See G. Kirchoff, Zur Geschichte der Spectralanalyse, etc., Ann. der Physik 118: 94$111,1863$.
} 
shows that calcium sulphide has two separate luminescent bands, one in the violet and one in the ultraviolet, whereas the barium sulphide of figure 9 has a single wider band extending into both violet and ultraviolet. For comparison, a solar spectrum, with the Fraunhofer lines was also reproduced..$^{15}$

Later advance in knowledge of spectral composition of the light of phosphors is due to the systematic researches of Edmond Becquerel. It is true that fluorescence spectra ${ }^{16}$ had been observed previously, and Stokes had examined the various fluorescences carefully, noting the series of emission bands of uranium compounds and other substances. In fact he announced in 1852 what came to be known as Stokes' law that the emitted light is always of longer wavelength than the exciting light, but published no adequate plates of fluorescent spectra.

E. Becquerel's earlier papers $(1843,1848,1858)$ were mostly concerned with the composition of the exciting light, but in his 1859 contribution, he used a spectroscope of the modern type. The paper is illustrated by a plate showing the phosphorescence emission bands in fifteen different solids. His wave-length scale was in relation to Fraunhofer lines. Accurate investigation of the spectral characteristic of the luminescent light of solids had begun.

Although colored lines had been noted in the spark spectra of mercury vapor and other metals as early as 1835 by C. Wheatstone, and David Alter, an American M. D., had described the line spectrum of hydrogen and other gases in 1855, nevertheless, accurate electroluminescent spectra of gases will always be associated with the name of Julius Plücker (1801-1868), whose dumbbell-shaped tubes containing gases at low pressure are still used for spectroscopic observation. The glass capillary connecting the two bulbs with sealed-in platinium electrodes allow an intensity of electroluminescence quite adequate for spectral examination. Plücker's observations were published in 1859, about the same time Becquerel's discoveries were announced to the scientific world, but plates ${ }^{17}$ of his gas spectra did not appear until the Plücker and Hittorf paper in 1865. The work of these men not only paved the way for detection of new methods of exciting luminescence, by electrons, by beams of

\footnotetext{
${ }^{15}$ Although Fraunhofer had determined the wave-lengths of his lines in 1821 and 1823, the wave-length scale was not generally adopted until after the independent measurements of J. Muller, of E. Mascart, and of $\AA$. J. Angström, all in 1863. Comparison of spectra was made by Fraunhofer lines.

${ }^{10}$ Brewster $(1833,1846)$ merely described the color of fluorescent light and Herschel (1845) noted that in the blue light of fluorspar when examined with a prism, red, orange, and yellow were absent or deficient but some green was present.

${ }^{1 \tau}$ V. S. M. van der Willigen (1858) published a rather poor plate of gas spectra in his Durch paper.
} 
ions and X-rays, but finally led to discovery of mathematical formulae, which applied to the series of lines observed in the gas spectra (see Chapter VII).

\section{FLUORESCENCE}

As explained in previous chapters, the peculiar bichromatic appearance of certain solutions, depending on whether they were observed from the side or by transmitted light, has been known since the description of an extract of "lignum nephriticum " by Kircher in 1646. There continued to be considerable interest in the phenomenon during the late seventeenth century, a period noted for inquiry into the nature of colors, but during the eighteenth century almost no research was carried out except for an occasional description of new liquids with the peculiar property of "lignum nephriticum " extract.

At the beginning of the nineteenth century, interest again revived, chiefly because a number of crystalline minerals, for example fluorspar, were found to behave as did the solutions. David Brewster (1838, 1846, 1848) and John Herschel (1845) both attempted to explain the color of a beam of light passing through a crystal or a liquid by "scattering" or by what they called " epibolic dispersion" or "internal dispersion." However, their interpretation was incorrect, and it remained for G. G. Stokes (1852) to characterize the light as a true emission, actually a phosphorescence of very short duration. At first Stokes spoke of "true internal dispersion" in contrast with scattering or "false internal dispersion," then used the word "dispersive reflection," and finally hit on the term "fluorescence," from fluorspar, analogous to the term " opalescence," used to describe the play of colors in another mineral, the opal. During the study, Stokes noticed that in producing fluorescence, light is always "degraded," i. e., the shorter wave-lengths excite the fluorescent emission of longer wave-lengths. This characteristic, now known as Stokes' law, is one of the important generalizations of luminescent study during the nineteenth century.

Stokes' papers started a wave of investigations on fluorescence. During the last half of the century, many workers studied fluorescence of all states of matter-gases, liquids and solids-especially in relation to Stokes' law, and attempted to classify the various types observed. Spectroscopic and phosphoroscopic observations were the order of the day. The best known worker in the field was E. Lommel (1837-1899), whose research on luminescence extended from 1862 to 1895. A generalization (1875) often associated with his name is the pronouncement that a body only fluoresces by virtue of those 
rays which it absorbs, just as a photochemical reaction is only possible as a result of absorption of certain wave-lengths. The effect is obvious, inherent in Stokes' law. It might, perhaps, be designated Lommel's law, although that name does not actually appear to have been applied. The more detailed history of fluorescence will be found in Chapter XI.

\section{RADIOLUMINESCENCE}

Earlier in this chapter, attention was called to the fact that one direction of phosphorescence study during the nineteenth century embraced new methods of excitation. It was established that spark discharges were especially active in producing phosphorescence of minerals, and the effect was traced to the ultraviolet light in the spark. Another course of inquiry concerned the peculiar luminescence of the glass which appears when electric discharges pass through rarified gases. From the early observations (1858) of J. Plücker and E. Becquerel, the effect was traced to cathode rays, later found to be made up of a beam of electrons. Cathodoluminescence was thus recognized as a form of light emission. Somewhat later, anode rays of positive particles were discovered (1886) by E. Goldstein (1850-1931) and their effect was called anodoluminescence.

The production of higher and higher vacua in glass tubes through which an electric current is passed led to discovery of the X-rays of Wilhelm Konrad Röntgen (1845-1923) in 1895, immediately followed by experiments of Henri Becquerel (1852-1908) with uranium (1896) and those of the Curies, Pierre (1859-1906) and Marie (1867-1934) with radium (1898). The two elements proved capable of emitting various types of rays, including gamma rays, which also excite luminescence in appropriate substances. In general the effects of $\mathrm{X}$-rays, gamma rays, cathode and anode rays are referred to as radioluminescences, thereby adding additional types of luminescence to the classification based on the nature of the excitation. The details of these discoveries will be considered in Chapter XII.

\section{CHEMILUMINESCENCE}

The light of the element phosphorus is usually thought of as the prime example of chemiluminescence. Although the first to be prepared artificially, every living luminous organism produces light by chemiluminescent reactions proceeding within its living cells or in a liquid secreted to the exterior. The luminescence of organisms always comes from some organic compound in solution. 
A number of other apparent chemiluminescences of inorganic material have been reported-from mixing lime and water, observed in the eighteenth century; also a light on new-cut surfaces of the metal potassium, reported by $W$. Petrie in 1850 . The potassium luminescence in air is presumably analogous to that of phosphorus, although little studied. Many types of luminescence in flames were reported in the nineteenth century and a consideration of some of these will be found in Chapter XIII.

The nineteenth century is chiefly notable for the first instance of a similar light emitting reaction in solution from a known organic chemical, which was actually demonstrated in the laboratory. The discovery was made by Bronislaus Radziszewski (born 1838), professor of chemistry at Lemberg (Galicia). He found that compounds containing the triphenylglyoxaline ring, such as amarin and lophin, would, when dissolved in alcohol and shaken with air in alkaline solution, oxidize with light emission.

The observation was published in 1877 , over two hundred years after the discovery of phosphorus. It was followed in 1880 with a list of many additional organic compounds which were also chemiluminescent and Radziszewski himself pointed out the importance of the find for the explanation of bioluminescences. Later workers soon added more compounds to the list, but Radziszewski may be credited with founding the science of chemiluminescence in solution. Luminescence of phosphorus takes place in the vapor phase. A more detailed history of the subject is related in Chapter XIII on chemiluminescence.

\section{EARLY TEXTBOOKS OF CHEMISTRY AND PHYSICS}

It is not possible to discuss luminescence as expounded in the various textbooks of chemistry and physics, or in the encyclopedias of the nineteenth century, in any detail. They usually gave excellent accounts under various headings and the treatment by some authors was outstanding. The subject was very much in the public eye and a few representative texts will be mentioned. The views of Brugnatelli, who wrote a two-volume text, Elementi di Chimica in 1795-1797, and of Davy, whose Elements of Chemical Philosophy appeared in 1812, have already been quoted.

Another popular chemistry, that of William Henry (1799), was brought out in an American edition (1808), sponsored by John Maclean, professor of natural philosophy and chemistry in the College of New Jersey (later Princeton University) and by Benjamin Silliman, professor of chemistry in Yale College, New Haven, Conn., 
both members of the American Philosophical Society. The book merely told how to make phosphors and described some luminescence experiments with phosphorus dissolved in oils ("liquid phosphorus "). However, the two-volume Elements of Chemistry (New Haven, 1830), written by Benjamin Silliman himself, contained an adequate section devoted to all kinds of luminescence under the heading: "Light is Emitted as well as Absorbed by Bodies." The section dealt with (a) solar phosphori (diamonds); (b) artificial solar phosphor (Canton's preparation and the Bolognian and Baldewinian phosphorus; (c) phosphorescence by heat (fluorspar); $(d)$ light by percussion, friction or pressure (quartz, borax, bonnet cane); (e) phosphorescence is seen in some animals (glowworm, firefly, sea water); $(f)$ phosphorescence is produced by chemical action (slaking lime, potassium and sulphur, iodine and phosphorus, etc.). Silliman was particularly interested in minerals and described a number of places near New Haven where thermoluminescent or triboluminescent varieties could be obtained.

Perhaps the best known chemistry ${ }^{18}$ text which dealt adequately with luminescence was that of Leopold Gmelin (1788-1853), professor of medicine and chemistry at the University of Heidelberg and an associate of Tiedemann. The Gmelin family have been famous as physicians, pharmacists, and chemists since the beginning of the eighteenth century. The first edition of his Handbuch der theoretorische Chemie appeared in 1817-1819, and was followed by three other editions, the last in 1843-1855.19 Gmelin's works were translated under the auspices of the Cavendish Society by Henry Watts (eighteen volumes between 1848-1871) as a Handbook of Chemistry. In volume one (1848) of Watts' translation, pages 181208 were devoted to "Development of Light by Ponderable Substances." They contain a surprisingly complete account of the known types of luminescence, based largely on the general work of Heinrich and Dessaignes, and the later book of F. Tiedemann (1830).

Luminescence of living animals and plants and putrefying animals and wood is classified under the head of "Development of Light as a Consequence of Probable Chemical Combination" and contrasted with " The Development of Light Unaccompanied by any

\footnotetext{
${ }^{18}$ Among other textbooks of chemistry, considerable discussion of luminescences will be found in the ones written by John Murray (1819), and J. F. Daniell (1839), while those of T. Thomson (1802), F. Accum (1803), A. F. Fourcroy (1804), L. J. Thenard (1816), E. Turner (1827), J. B. Dumas (1828-1846, 8 v.), F. A. C. Gren and C. F. Bucholz (1839), J. W. Draper (1847) and J. Troost (1865) make no mention or present only trifling facts on the subject.

${ }^{10}$ Later editions have appeared and even today the revised Gmelin-Kraut Handbuch der Anorganische Chemie is a standard reference book on the subject.
} 
Alteration in the Ponderable Matter of Bodies," which included phosphorescence, thermoluminescence, triboluminescence, and crystalloluminescence. As a chemist, Gmelin was not particularly concerned with luminescences in which no chemical changes occurred.

The only reference to light development at a low temperature as a result of "actual chemical combination" was the following (p. 181):

Hydrate of potash or soda produces light in combining with sulphuric, nitric, or concentrated acetic acid dropt upon it; baryta or lime with water or one of the acids just mentioned; magnesia with sulphuric or nitric acid. . . .

The light must either have existed ready formed in one or both of the combining bodies, and be merely separated by the act of combination, or it must be evolved during the combination of the ponderable bodies out of imponderable elements contained in them.

\section{Gmelin attributed animal light to the fact (pp. 181-182),}

that they eliminate a peculiar and in most cases liquid substance, containing phosphorus or some other element, which combines, at common temperatures, with the oxygen of the air or of water containing air, producing a faint luminous appearance. Not only does the separation of this fluid appear to depend upon the life of the animal, but its will seems likewise to determine whether the fluid shall-partly by means of the respiratory process-come in contact with the oxygen of the air, and thus produce a development of light, or not.

Regarding putrefying animal and plant material, Gmelin stated (p. 189):

At a certain temperature, and in contact with moisture and oxygen gas, a decomposition appears to arise in many dead animals, especially in sea-fish, before the commencement of actual putrefaction,--producing a glutinous substance, whose constituents are capable of burning in the smallest quantity of oxygen, with a feeble light and scarcely perceptible development of heat:-or may it not be supposed that the decomposition is attended by the production of luminous infusoria?

The suggestion of animalcules as the cause of light in meat and fish comes very near the truth. Gmelin was presenting the work of others, but the extraordinarily complete tabulation of luminous organisms and luminous phenomena makes his article outstanding.

Most of the nineteenth century textbooks on natural philosophy, the present day physics, contain some references to luminescence. One of these was the Course of Lectures on Philosophy and the Mechanical Arts (1807) of Thomas Young, already mentioned in 
connection with the wave theory of light and most useful because of its bibliography. Another was the Elements of Natural or Experimental Philosophy (2 v., Philadelphia, 1813), by Tiberius Cavallo (1749-1809), best known for his work on electricity. The book contains a section dealing with "Phosphorescent Bodies," which are divided into five types: (1) Animals like glowworms; (2) Phosphors which imbibe light and give it off in the dark; (3) Bodies which light when heated slightly; (4) Bodies which light as a result of attrition; (5) Bodies in a state of decomposition such as fish and flesh, also the ignis fatuus.

In the middle of the century, in the various textbooks of the Becquerels, father and son, particular attention was paid to luminescence. These texts exerted such an influence on subsequent study that they will be considered in a special section.

The Cours de Physique (1856) of Adolphe Ganot, famous as a college textbook in the English translation (1861, 1876) of E. Atkinson, mentioned luminous wood, flesh, and the sea, without much detail.

Bioluminescence was included as late as 1879 in the Traité Elémentaire de Physique Théoretique et Expérimental (4 v., Paris) of P. A. Daguin, which devoted five pages to phosphorescence of animals and inorganic substances, and mentioned the bacteria of Nuesch (1877) as the cause of phosphorescence of meat.

An important physics text, Cours de Physique, by J. E. Jamin, appeared as a first edition ( 3 v.) in 1858-1866 and was used in the École Polytechnique, Paris for many years. The third edition (of four volumes, 1878-1883) with the name of E. M. L. Bouty added as co-author, contained one of the best accounts of phosphorescence and fluorescence to appear at that time. The thirty-page treatment included all the pertinent facts concerning emission spectra, color changes in the phosphorescence depending on temperature or type of impurity, duration of the phosphorescence, etc. In addition it was well illustrated with graphs and figures.

The end of the century is noted not only for great increase in volume of journal papers, but for the massive German compilations on physics, which were to run to many volumes in the twentieth century. One of these, which appeared in several editions was the Lehrbuch der Experimental Physik of Adolf Wüllner (1835-1908), who carried out important research on fluorescence. The first edition was published in 1870 and contained little on luminescence, but the fourth edition in 1883 devoted considerable space to the subject, and the fifth edition (vol. 4), appearing in 1899, contains sixtythree pages on electroluminescence, fluorescence, and phosphores- 
cence. This special treatment has been covered in the chapters dealing with these three subjects.

\section{THE BECQUEREL FAMILY}

Because of their notable interest in luminescences, the various texts of the Becquerel family, father and son, deserve special mention. These began to appear about the same time as Gmelin's chemistry, and may serve to clarify the point of view of the physicist. One fact was becoming clear, that less and less attention would be paid by physicists to the luminescence of " organized bodies," although this type of light was still included in physics textbooks.

Study of inorganic luminescences during the mid-century may be considered the specialty of Edmond Becquerel (1820-1891), professor of physics at the Conservatoire des Arts et Métiers in Paris, working in the fields of electricity and optics. Edmond Becquerel was a real leader who made innumerable contributions to knowledge of phosphorescence and fluorescence. He is perhaps best known for spectral studies of the exciting and the emitted light, and as the inventor of the phosphorescope by which short-lived phosphorescences can be detected and their duration measured. His father, Antoine Cesar Becquerel (1788-1878), was an engineer and physicist, who also studied $(1826,1839)$ phosphorescence, but is better known for books on electricity and magnetism. Edmond's son, Henri Becquerel (1852-1908), was the discoverer of the radioactivity of uranium compounds (1896), and a student of phosphors and infrared light.

One of the important works of the father, A. C. Becquerel (17881878), was the Traité Expérimental de l'Electricité et du Magnétisme, a seven-volume work published in 1834-1840. In Volume 4, Book 8 (54 pages) is entitled “De la Phosphorescence." The subject is divided into I " Principes généraux "; II " Les different modes de phosphorescence"; III "Les causes qui influent sur la phosphorescence en general"; IV “De la phosphorescence des corps organisés et de la mer." Practically the same material is presented in his two-volume Traité de Physique Considérée dans ses Rapports avec la Chimie et les Sciences Naturelles (1842-1844). The first eight pages of the section, "De la Phosphorescence," are devoted to bioluminescences under the headings "Phosphorescence spontanée" (fish, meat, wood, and molluscs), "De la phosphorescence de les lampyres" and "Phosphorescence de la mer"; the remainder deal with luminescence from rubbing, percussion, light exposure, heat and chemical action.

In connection with sea luminescence, Becquerel thought the light 
could be due to animalcules and to " an organic material intimately combined or mixed with the water, analogous to that which covers herring and other fish." A proof of this idea came from the fact that the luminous material on fish only appears in a certain state of decomposition preceding putrefaction, when it disappears, and the sea water also loses its phosphorescence on standing for some time. Becquerel believed that in lampyrids

phosphorescence is the result of a chemical action under the control of the animal but in certain inferior animals (infusories et annelides) the production of light so resembled a discharge of electricity that Ehrenberg did not hesitate to establish their identity and he is certain that the light does not come from a secretion but is a spontaneous act of the animal, manifest on irritation by chemical or mechanical means.

Just as an electric torpedo requires a certain time for recovery after several discharges, so also do these small organisms after they have been agitated for some time. Becquerel considered it remarkable that the light should be so great when the organisms that produce it are so small.

As a student of electricity, it is not surprising to find that A. C. Becquerel's explanation of inorganic luminous phenomena relied on the ultimate units of electricity in matter. It is quite possible to read into his statements the modern concept of an electron displaced from its position of equilibrium by absorption of energy, with the emission of light upon its return. His point of view is expressed in the conclusions of the section "De la Phosphorescence" in the Traité de Physique, etc. (1844). Becquerel believed that any type of luminescence might appear

whenever the particles of bodies (particules des corps) lose their natural position of equilibrium from any cause whatever. Under these circumstances, the equilibrium of electricities which are associated with bodies is likewise disturbed and their recomposition can give rise to visible light if a certain amount of time is taken to effect the change.

If the "recomposition" is too rapid, no light appears. Such is the case in metals which are never phosphorescent. Becquerel held that light causes phosphorescence by acting on the electricities associated with the particles, again changing their position of equilibrium, rather than by acting directly on the particles themselves. As a visible example of the displacement, he cited the fact that when fluorspar is subject to the electric light (a spark discharge), certain parts of the crystal become colored, and these colored regions are also the parts which are luminous on sight heating. He continued: 
Naturalists know of a large number of substances, particularly varieties of fluorspar and $\mathrm{Ca}$ phosphate, which possess for some time their luminous faculty after being taken from the earth, but they finally lose it. It is infinitely probable that the loss of this property is to be attributed to a change in the grouping of the particles produced by the action of solar light or perhaps by variation in temperature.... One sees then that the phenomena of phosphorescence can bind together the relations between all the imponderable agents which very probably derive from one and the same cause diversely modified.

By the time the next great work (3 v.) appeared, Traité d'Electricité et Magnétisme, by A. C. Becquerel and his son, Edmond Becquerel, in 1855-1856, the idea that the light of marine organisms was electrical in origin is not mentioned. There is merely a thirtypage section on "Effets Lumineux" of electricity.

The interest in luminescence of Becquerel senior was magnified many times in the work of his son, Edmond Becquerel (1820-1891), who published several papers and two books (see titles in fig. 20) on luminescences of various kinds. One was a reprinting of three monographs, Recherches sur divers Effets Lumineux qui Résultent de l'Action de la Lumière sur les Corps (Paris, 1859), which had been presented as three ${ }^{20}$ Mémoires to the French Academy of Sciences in 1857-1858, and printed in the Annales de Chimie et de Physique in 1859. The second book was the monumental La Lumière, ses Causes et ses Effects (Paris, 1867) in two volumes. The first volume of 426 pages deals entirely with light emission, the second with photochemical action. Although incandescences are considered, the first volume is so largely concerned with phosphorescence resulting from the action of light, electric sparks, gentle heating, and mechanical means that it is fundamentally a book on luminescence. A final section of thirteen pages treats briefly of the "Effets Lumineux Produits pars les Corps Organisés," both vegetable and animal. The older work on luminous wood, fish, and flesh was mentioned and the remark made that (p. 415) " these effects cannot be explained except by a sort of decomposition, by virtue of which organic matter is burned with oxygen in a slow combustion that is the cause of the light emitted." Becquerel rightly attributed the phosphorescence of the sea to the minute forms living therein, but it is surprising to find that as late as 1867 , the true origin of the light from phosphorescent wood or luminous fish and flesh was unknown to him.

Becquerel's work on inorganic phosphorescence dealt with every

${ }^{20}$ A fourth monograph was published in the Ann. de Chim. et de Physique (ser. 3) 62: $5-100,1861$. 
phase of the subject and is considered in appropriate chapters, chiefly in Chapter VIII. His book is illustrated with four beautiful colored plates of spectra, one of the sun, a second of various flames, and two more of various phosphorescences and fluorescences. The wavelength scale is calibrated by Fraunhofer lines rather than micra. In contrast to his father, E. Becquerel presented no universal theory to account for the light emission but contented himself with the collection of new quantitative data regarding the light.

\section{LUMINESCENCE AFTER 1870}

The book of E. Becquerel, La Lumière, published in 1867, marks the end of an epoch in study of phosphorescence. The work of Stokes (1852) on fluorescence and that of Julius Plücker (18011868) on electroluminescence (1858) were to lead to the rapid development of these branches of luminescence study and to the all important phenomena of radioluminescence. Among the many men who followed and made luminescence a major interest, the names of Wm. Crookes of England, P. E. Lecoq de Boisbaudran (1838-1912) of France, and Eugene Lommel (1837-1899), Eilhardt Wiedemann (1852-1928), and Philipp Lenard (1862-1947) of Germany take precedence. In the United States during this period Joseph Henry (1799-1878) and John William Draper (1811-1882), both members of the American Philosophical Society, did more to foster experiment than others, but the great surge of luminescence research in America was to come in the next century with $\mathrm{E}$. L. Nichols (1854-1937), E. Merritt (1865-1948) and R. W. Wood (1868-1955) leading the way.

In devoted study of luminescences of all kinds, the Wiedemann family of Germany is the counterpart of the Becquerel family of France. The father of Eilhardt Wiedemann, Gustav Heinrich Wiedemann (1826-1899), professor of physics at the University of Leipzig since 1871, was interested in electricity and magnetism and published only a few papers on luminescence (1876). He edited the Annalen der Physik und Chemie from 1877 until his death in 1899. During the last six years he was aided by his son. His wife, Clara Laura Wiedemann, one of the Mitscherlich family and also a physicist, translated the works of Tyndall and wrote on light and sound. The son, Eilhardt (Ernst Gustav) Wiedemann, obtained his Ph.D. at Leipzig in 1872, became a professor there and then (1886) was appointed professor of physics at the University of Erlangen. His early work had to do with polarization and refraction of light, later with the specific heat of gases, finally with their spectra in electrical 
discharge tubes, beginning in 1878 . He then became interested in phosphorescence and other types of inorganic luminescence which took up a major part of his research time, but his only book on physics, a Physikalische Practicum with H. Ebert (4th ed., 1899), hardly mentions luminescence. An early student of the history of science, Wiedemann specialized in Arab knowledge, concerning which he published many papers, and a booklet, Die Naturwissenschaften bei den Araben (Hamburg, 1890, 32 pp.).

\section{BOOKS ON INORGANIC LUMINESCENCE}

After Heinrich's compilation in 1811-1820, Die Phosphorescenz der Körper, most of the papers on luminescence were published in various journals. One little known thesis, De Phosphorescentia per Irradiationem, designated a "Dissertatio Historica Physica" by Petrus Adrianus Bergsma, appeared in Dutch at Utrecht in 1854. As the title indicates, the essay was a comprehensive historical account of phosphors. There were three sections: (1) From discovery of the Bolognian phosphor in 1604 until the work of Beccaria in 1771; (2) From Beccaria to Becquerel, 1771-1839; (3) From Becquerel until 1854. Thus the history ended in the midst of the great labors of Edmond Becquerel, even before his description of the famous phosphoroscope, but the divisions of the book indicate the influence which E. Becquerel's work was exerting throughout Europe at this time.

Another work of interest on a special subject was Die Fluorescenz des Lichtes of 115 pages, published at Vienna by F. J. Pisco in 1861. The volume was based on Stokes' research and covered quite completely the facts concerning fluorescence known at the time (see Chapter XI).

The only other book on luminescences which appeared during the Becquerel period was Phosphorescence, by T. L. Phipson, published in London (1862). This semi-popular account used the word "phosphorescence" in a broad sense, to include all kinds of light emission at a low temperature. Somewhat less space is devoted in Part I to "Phosphorescence of Minerals" than to " Phosphorescence of Vegetables" (Part II) or "Phosphorescence of Animals" (Part III), but every aspect of inorganic luminescence knowledge is included-light after insolation; light by heat, cleavage, friction, percussion, crystallization, and molecular or chemical change; also " phosphorescences of gases," " metereological phosphorescence," and "invisible phosphorescence." By the latter, Phipson referred to "some curious phenomena discovered by my ingenious friend $\mathbf{M}$. Niepce de St. Victor." The effect was the rapid formation of a 
latent image on silver chloride photographic paper, when an engraving previously exposed to sunlight was laid on the paper. Phipson believed the effect was "owing to the action of light alone; no chemical agent whatever, to which such a phenomenon might be attributed, entered into these experiments." However, later experiments ${ }^{21}$ have indicated that chemical action rather than invisible radiation is usually responsible for photographic effects.

It is surprising to find that after the treatise of $\mathrm{E}$. Becquerel in 1867, if the lists of fluorescent compounds are excepted, no general book on phosphorescence or fluorescence appeared in any language until the next century. ${ }^{22}$ This lack was finally filled by one of the huge German compilations in physics, the great Handbuch der Spectroscopie of Heinrich Kayser (1853-1940), for many years professor of physics at the University of Bonn. The five volumes were published between 1900 and 1912, and covered most phenomena connected with light. Volume 4 (1908) contained 289 pages on phosphorescence by Kayser himself and 373 pages on fluorescence by $\mathrm{H}$. Konen, a really comprehensive historical and factual survey which served to summarize the knowledge of all inorganic luminescences in the pre-quantum period.

\section{IN REVIEW}

The principal advances in knowledge of inorganic luminescence, or better, luminescence not connected with living organisms, may be stated briefly as (1) recognition of fluorescence as a true light emission; (2) discovery of radioluminescence excited by elementary particles and X-rays; (3) recognition of many chemiluminescences of organic compounds in solution; (4) invention of the phosphoroscope; (5) accurate measurement of the spectral distribution of luminescence emission, and (6) clarification of the relation between the emitted and the exciting light in the case of fluorescence and phosphorescence; (7) collection of accurate information on various factors (temperature, pressure, impurities, etc.) which affect various luminescences; (8) development of theories of luminescence based on energy changes and well established thermodynamic principles. More specific observations might have been considered, for

${ }^{21}$ See W. J. Russell, Proc. Roy. Soc. 61: 424-433, 1897, and G. L. Keenan, Chem. Rev. 3: $95-111,1926$.

${ }^{22}$ Many articles were of book length, for example E. Wiedemann's Zur Mechanik des Leuchtens, Ann. d. Physik 37: 177-148, 1889, and the series by E. Lommel, Uber Fluorescenz, in the Annalen der Physik (1871-1880). The principal work on chemiluminescence, triboluminescence, and crystalloluminescence was the 112-page article of Max Trautz, Studien über Chemilumineszenz, published in the Zeitschrift für physikalische Chemie for 1905. 
example, the quenching action of infrared rays on phosphorescence and the phenomena of quenching in general, but these discoveries are best left to the chapters on special types of luminescence.

\section{The Light of Living Things}

During the century, naturalists greatly extended the list of known luminous species of animals. The luminous fire-cylinder (Pyrosoma) of F. Péron (1804), the brittle stars and sandfleas of D. Viviani (1805), the radiolaria of W. G. Tilesius (1819) and the siphonophores of F. J. F. Meyen (1834) were described. Luminescence came to be recognized as a phenomenon well scattered among the simpler organisms of the animal kingdom.

\section{JAMES MACARTNEY}

Important monographs ${ }^{23}$ also appeared; for example, the much quoted "Observations on Luminous Animals" (1810) by J. Macartney. The Macartney paper of thirty-five pages in the Phil. Trans. contained his own results and also observations of Sir Joseph Banks, a member of Capt. Cook's voyage in 1768-1771. Medusae, shrimp, ctenophores, fireflies, Pyrophorus, and Noctiluca were figured. From the facts regarding marine phosphorescence, Macartney also took the definite stand that it was always due to living animals. He regarded the light as appearing "only at certain periods, and in particular states of the animal's body" and "is commonly produced or increased by a muscular effort; and is sometimes absolutely dependent upon the will of the animal. ... The power of shewing light resides in a peculiar substance or fluid," which is sometimes situated in a particular organ, and sometimes diffused throughout the animal's body. Macartney wrote:

The luminous matter, in all situations, so far from possessing phosphoric properties, is incombustible, and loses the quality of emitting light by being dried, or much heated. The exhibition of light, however long it may be continued, causes no diminution of the bulk of the luminous matter. It does not require the presence of pure air, and is not extinguished by other gases. . . The luminous property does not appear to have any connection with the oeconomy of the animals which possess it,

\footnotetext{
${ }^{23}$ In 1821 the last of the Latin theses on luminescence appeared, an octavo tract of 85 pages, entitled $D e$ animalibus phosphorescentibus by Johan Marcus Baart de la Faille. The work is divided into three chapters, the first dealing with luminous living terrestrial animals, the second with marine forms and the third with dead animals. Baart de la Faille gave no original observations but compiled his facts from many authors, particularly Cohausen (1717), Macartney (1810), and Treverinus (1818). D. Viviani's Phosphorescentia maris (Genoa, 1805, 15 pp.), was an earlier thesis in Latin.
} 
except in flying insects, which by that means discover each other at night, for the purpose of sexual congress.

Macartney's facts regarding the necessity of air were incorrect, based on experiments using impure gases, but most of his statements were true and he was one of the first to emphasize the part played by a stimulus in light production. Although Alexander von Humboldt (1769-1859) was actually the first to stimulate a luminous animal electrically (a medusa in 1799), Macartney was the second to carry out the experiment and particularly to note the importance of electricity as a method of excitation.

\section{GOTTFRIED REINHOLD TREVIRANUS}

One of the first scientists to take a really broad view of biological phenomena, as contrasted with those who classified animals, was Gottfried Reinhold Treviranus ${ }^{24}$ (1776-1837) professor of medicine and mathematics at the Bremen Lyceum, a man of broad biological interests. He wrote a sixty-eight-page article on the general subject, "Phosphorische Erscheinungen der Organische Natur" (1818), for his Biologie oder Philosophie der lebenden Natur für Naturforscher und Aertze, a six-volume work which appeared between 1802 and 1822. A similar section, "Phosphorescence der Organische Wesen," appeared in his two-volume work, Die Erscheinungen und Gesetze des Organischen Leben (1831, 1833). The treatise on luminescence in the Biologie was divided into four sections: (1) Phosphorescence of living organisms; (2) Phosphorescence of dead plants and animals; (3) Development of fire (Feuer) in men's bodies; (4) General results of the investigations. The second book, Die Erscheinungen, 1: 432-447) devotes less space to luminescence but in both, Treviranus described most of the classic bioluminescences - sponges, medusae, Beroë, pennatulids, alcyonarians and gorgonians, Pyrosoma, branchiopods, Pholas, Cyclops brevicornis of O. F. Müller, Cancer fulgens of Banks and Cancer pulex of Thulis and Bernard, Scolopendra electrica, marine worms, earthworms, Elater, lampyrids, Scarabaeus phosphoricus of Luce, Paussus sphaerocerus of Afzelius, Bupestris ocellata of Latreille, Gryllus gryllotalpa of Kirby and Spence, Fulgora of Merian, and Culex pipiens of Hablizl.

Among luminous plants he mentioned Aristotle's fungus; Humboldt's Byssus phosphorea, an example of the subterranean rhizomorphs; Schistostega osmundacea; Confervae described by Duc-

\footnotetext{
${ }^{24}$ Not to be confused with L. C. Treverinus of Breslau, who also wrote on luminescence (1829).
} 
luzeau; the fiery yellow flowers of Tropaeolum, Calendula, etc. Treviranus realized that most of the plant phosphorescences involved light reflections and that only the subterranean rhizomorphs luminesced when living. Among vertebrates such luminous phenomena as the eggs of lizards, the breast of an American heron, ${ }^{25}$ the urine of skunks, sweat, and the eyes of various animals were classed as true luminescences, although Treviranus (1832) cited Prevost (1810) and Esser (1826), who thought the glow of vertebrate eyes to be a reflection. The luminescence of wood, roots, and flesh were considered in the section on dead animals and plants.

In 1818 Treviranus concluded that light production had no direct relation to life. Although higher animals can produce heat, it is only the lower animals (and a few plants) that produce light. In some insects the light appears to have a use in mating but not among zoophytes. The luminous material is mostly excreted, like urine or comes from skin glands. By movement and the access of air the phosphorescent material is increased, an act dependent on the will of the animal. "There is always some material, sometimes local, sometimes over the whole body, from which the light comes, that has the property of a true phosphorus," i. e., the element phosphorus, which luminesces in the air.

In his second book (1832), Treviranus again restated his opinion that the luminescence came from phosphorus or a material containing phosphorus, but was under the control of vital processes. Luminescence required the respiration of the animal, especially in fireflies, and also secretion, both of which are life processes. He considered the fact that sea fish and wood produce luminous material by a sort of decomposition to be evidence for the secretory origin of animal light and suggested that the human cases of spontaneous combustion might be due to phosphoretted hydrogen.

\section{CHRISTIAN GOTTFRIED EHRENBERG}

By far the most complete record of bioluminescence is to be found in C. G. Ehrenberg's (1795-1876) monumental work of 161 pages, "Das Leuchten des Meeres," published in the Abhandlungen der Königlichen Akademie der Wissenschaften at Berlin in 1834. The monograph includes much more than phosphoresence of the sea. In addition to his own observations, Ehrenberg mentioned every known writer (435 names and many more references) on luminescence of plants and animals from Aristotle to Johannes Müller (1834), and gave a table of all known luminous forms with the

\footnotetext{
${ }^{25}$ Loudon's Mag. Nat. Hist. 2: 64, 1829, a letter from Philadelphia, confirmed by Mr. Franklin Peale, proprietor of the Philadelphia Museum.
} 
probable date of discovery. Space does not permit a reprinting of Ehrenberg's table. Many of the early observations on particular species will be found in the subsequent chapters of this book dealing with luminescence in various phyla of animals. It must suffice to say that Ehrenberg's compilation will always be of great value to every serious student of light production by living things. His original observations occupy forty pages of the book and are largely devoted to the story of the discovery and descriptions of those microscopic forms, the dinoflagellates, responsible for the diffuse luminescence of the sea. Although Ehrenberg suspected that the light of dead fish and flesh came from living things, the proof was not certain in 1834 .

Ehrenberg was fundamentally a student of protozoa and other small forms. His interest in marine luminescence arose from the suspicion that these organisms might cause the light of the sea, observed during his travels. Born at Delitzsch, near Leipzig, Ehrenberg first studied theology at Leipzig, then medicine and science at Berlin. A six-years' voyage of exploration to Egypt and the east in 1820-1826 directed his interest to biology. He brought back important collections and in 1829 accompanied Gustav Rose and Alexander von Humboldt on their Asiatic expedition.

Ehrenberg's most productive years came before 1838, when his Infusionsthierchen als Vollkommenden Organismen appeared. This work greatly advanced the knowledge and classification of protozoa, but he adopted the idea that these forms were complete organisms, with digestive systems, reproductive organs and other structures found in higher multicellular animals. When the theory fell into disrepute, Ehrenberg largely ceased active research. He was made professor of medicine at the University of Berlin in 1839, and became Permanent Secretary of the Berlin Academy of Sciences in 1842. The completeness of Das Leuchten des Meeres is a tribute to Ehrenberg's historical talents, which developed quite early in life.

\section{HARTING, QUATREFAGES AND HELLER}

The middle of the century saw the publication of several general papers on animal light, by Quatrefages in France, by the naturalist, P. Harting in Holland, and by Heller in Germany. The Quatrefages and Heller publications were of real importance. The Pieter Harting (1812-1885) contribution, ${ }^{26}$ " Het Lichten von Dieren" was a twenty-five-page review in Album der Natur (1852), a semipopular journal published at Haarlem. It contained figures of well-known luminous or allegedly luminous animals such as the

${ }^{26}$ A German translation, Das Leuchten der Thiere, by J. E. A. Martin appeared in Skizzen aus der Natur in 1854. 
"glimworm," the elaterid beetle, Pyrophorus, the lantern fly, Fulgora laternaria, Pyrosoma, Physalia, and Noctiluca, the latter as depicted by Quatrefages in 1850 .

Jean Louis Armand de Quatrefages (1810-1892) was a man of extraordinarily wide interests in the field of natural history. A professor of anatomy and ethnology in the Natural History Museum at Paris, he is perhaps best known as an anthropologist for his studies on the origin of man. Nevertheless, much of his earlier work had to do with invertebrates, a great deal of which dealt with luminous forms. In 1850 he published a comprehensive monograph on Noctiluca and also a general paper of forty-five pages, Mémoire sur la Phosphorescence de Quelques Invertébrés Marins, which considers not only the mechanism but also the history of bioluminescence. This paper was translated in the American Journal of Science for 1853 and later (1862) as a more popular version, " The Phosphorescence of the Sea," in the Popular Science Review.

Quatrefages mentioned the observations of his predecessors in the field and then listed the known luminous animals of his time, with additional ones from his own experience. He believed that the work of Matteucci (1847) and others indicated that firefly light was due to a slow combustion of oxidizable material, but raised the question as to whether this view could be applied to "invertebrated animals living in water."

Quatrefages quoted ${ }^{27}$ Ehrenberg (1834) as declaring all light of the sea to be due to organized beings and mentioned also the various theories itemized by Dr. Coldstream in 1847. He, himself, was inclined to believe,

that under the general name of phosphorescence, phenomena essentially distinct have been confounded, and which have really nothing in common but the production of light. . . . Without speaking of the phosphorescence arising from animal decomposition nor that which results from mucus in a state of solution, I believe that light is produced in animals in two ways:

lst by the secretion of a peculiar substance exuding either from the entire body, or from a special organ. It is probable that in this first mode of phosphorescence, the light always arises from a slow combustion.... 2nd by a vital action whence results the production of a pure light independent of all material secretion.

Quatrefages went on to say that he agreed mostly with Ehrenberg's (1834) views but did not believe that the luminescence was always connected with reproductive activity. He also pointed out that although some animals appear to have definite luminous organs,

\footnotetext{
${ }^{27}$ Quotations from Quatrefages (1853), p. 202.
} 
such is not the case in the Noctilucae which he studied so thoroughly. In Noctiluca, Quatrefages believed he had shown that the luminescence was not a combustion and came to the conclusion that the light emission was independent of all material secretion and due to " contraction of the interior mass of the body," the rapid scintillations being the result of " rupture and rapid contraction of the filaments of the interior and that the fixed light which these animals emit before dying, proceeds from the permanent contraction of the contractile tissues adhering to the inner surface of the general envelope."

The idea that light emission was connected with muscle contraction may possibly have originated with Macartney $(1810)$; it was expressed by a surprising number of later students of bioluminescence. The connection is undoubtedly due to the fact that stimulation of a luminous animal results both in light production and in muscle contraction. The two processes have no more in common than that they are both responses to stimulation.

Quatrefages was reluctant to express an opinion on the cause of the light of dead animals or of rotten wood. In fact no one had ventured to state categorically that the light was due to bacteria and fungi, although from time to time suggestions had been made that "animalculae" were responsible.

Actual proof that the light of rotten wood and shining meat came from a "Pilz" is due to Johann Florian Heller (1813-1871), a professor in the General Hospital, docent, and later a professor at the University of Vienna; he named the organisms. His paper, "Ueber das Leuchten im Pflanzen und Tierreiche," appeared in 1853. It was a serial of six intallments, totalling seventy pages, in the Archiv für physiologische und pathologische Chemie und Microscopie. The choice of this journal is evidence of the well-established chemical approach to luminescence problems. Heller's work actually dealt with all aspects of bioluminescence, but is best known for his categorical statement that the light of decaying wood was due to a fungus, called "Rhizomorpha noctiluca," and the light of shining fish and meat to a bacillus, "Sarcina noctiluca."

Despite his preoccupation with luminescences due to bacteria and fungi, Heller thought that the spontaneous light of living animals might result from a special secreted substance, in such forms as Lampyris, Scolopendra, or Medusa, and attributed the light of the sea to myriads of microscopic plants as well as to animals. He suggested that Rhizomorpha and Sarcina light might be useful in gunpowder mills or magazines or in coal mines, where a weak continuous, heatless light is desirable. The discovery was fundamental 
one but received little attention for over two decades, not until Eduard Pflüger's extensive papers on respiration and phosphorescent organisms appeared in 1875.

\section{THE NATURE OF ANIMAL LIGHT}

Just as the middle of the nineteenth century was characterized by a rapid accumulation of knowledge concerning all types of inorganic luminescence, so the production of light by living things was subject to investigation of all kinds-its physical characteristics, the source of light in luminous animals, i. e., the histology of luminous regions, and somewhat later the chemistry of the process. Details of these findings must be left for Chapter XVI on bioluminescence. It will suffice to say that the first adequate studies on the spectrum of animal light were made by Dr. Lehman (1862) and by J. Schnauss (1862), using the glowworm, and that light intensity and heat studies were initiated by R. Dubois in 1886, using the elaterid beetle, Pyrophorus. Many later workers established that animal light was unpolarized as produced, and no different from any other kind of light, except in spectral composition. The spectrum is always a short band in various regions of the visible, either red, yellow, green, or blue, depending on the animal. It is quite similar to the spectra of phosphors and also to the spectrum of lophin. Lophin is an organic compound which can be oxidized in solution with the emission of light, a discovery of B. Radziszewski (1877), who also studied its chemiluminescent spectrum in 1880 (see Chapter XIII on chemiluminescence). Important biochemical studies were begun by $\mathbf{R}$. Dubois, whose work is considered in a subsequent section.

It was also realized during the mid-century that bioluminescence might result either from material secreted to the outside of the animal (extracellular luminescence) or the light might arise within cells themselves (intracellular luminescence). The first studies on the fine structure of a complicated luminous organ, such as that of the glowworm, were made by R. A. von Kölliker (1817-1905) and by F. Leydig (1821-1905), both in 1857, to be followed by Max Schultze (1825-1874) in 1863, and a host of later workers.

The physiological aspects of light production and the relation between luminescence and excitation became clarified after the middle of the century. It was proved that special nerves existed, whose stimulation carried nerve impulses to luminous cells but the details of all these discoveries must be sought in Chapter XVI. 


\section{TEXTBOOKS AND REFERENCE WORKS}

The great breadth of biology and the various avenues of approach have led to a more complex literature dealing with the properties of living things than the literature on the properties of inanimate matter. Textbooks of chemistry and physics will adequately cover inanimate subjects but the living world requires textbooks of zoology, botany, anatomy, physiology (including biophysics and biochemistry), histology, perhaps entomology for special luminous groups. The luminescence of living things has been treated in many textbooks of various kinds, in some cases with outstanding articles, but it is obvious that space will allow only a brief résumé of the most important texts.

One of the earliest textbooks of biology in a broad sense was the Biologie oder Philosophie der lebenden Natur (1802-1822), the five-volume work of G. H. Treviranus, already discussed. No subsequent " biology" during the century devoted as much space to luminous organisms although almost all such texts contained short chapters or sections on bioluminescence. These frequently did little more than mention that certain groups of animals were luminous.

The authors did not inquire into the chemical mechanism of light production. Such considerations were left for the various physiologies, which contained what was then known concerning the biophysics and biochemistry ${ }^{28}$ of animal light. Most textbooks of physiology during the first half of the nineteenth century were quite broad in outlook. They often dealt with comparative physiology, even though their title might indicate the subject to be physiology of man. They were more or less patterned on the eight-volume Elementa Physiologiae Corporis Humani (Lausanne, 1759-1766), of Albrecht von Haller (1708-1777) the great Bernese physiologist, anatomist, botanist, and poet. The Elementa was translated into German, and also in English as First Lines in Physiology (Edinburgh, 1786). Haller's writings contained nothing on luminescence but his followers frequently devoted considerable space to this subject.

If Haller was the physiologist of the eighteenth century with widest interests, Johannes Müller (1801-1858) must be considered

${ }^{28}$ It is unfortunate that the great Justus Liebig (1803-1873) did not discuss luminescence in an early animal biochemistry, Die Tierchemie oder der organische Chemie in ihren Anwendung auf Physiologie und Pathologie (Braunschweig, 1842). Liebig did state (see the English translation, Animal chemistry, 190-191, edited by Wm. Gregory, 1842), that Walchner had observed phosphoretted hydrogen bubbles spontaneously inflame "from the trough of a spring in Karlsruhe on the bottom of which fish have putrified," and he is quoted (Heller, 1853: 45) as saying that the light of dead fish was due to a phosphorus compound like $\mathrm{PH}_{3}$. 
a comparable figure in the nineteenth. His investigations ranged over the whole animal kingdom, from anatomy to pathology. Müller included a section of seven pages on "Lichtentwicklung" in his Handbuch der Physiologie des Menschen für Verlesungen (Coblentz, 1834, with many later editions). The account of bioluminescence was remarkably complete. It was based largely on the monographs of Ehrenberg (1834) and Meyen (1834) and included all groups of luminous animals, even the newly discovered dinoflagellates.

Light production by animals was also treated in the medical physiologies of K. A. Rudolphi (1821), F. Tiedemann (1830), D. de Blainville (1833), A. A. Berthold (1837), A. Duges (1838), C. Matteucci (1844-1847), W. B. Carpenter (1854, 1st ed., 1844), H. Milne-Edwards (1863), J. Marshall (1868), and in many later texts. ${ }^{29}$

Among the authors mentioned, the thirty-page treatment in the Physiologie des Menschen (1830) by Friedrich Tiedemann (17811861), professor of physiology, anatomy, and zoology at the University of Heidelberg, and the twenty-eight-page chapter in Leçons sur la Physiologie et l'Anatomie Comparée de l'Homme et des Animaux (1863), by Henri Milne-Edwards (1800-1885), professor of zoology and physiology in the Faculty of Sciences, Paris, are the best. $^{30}$

Tiedemann followed Treviranus closely and attributed the light of living animals to material containing phosphorus or some similar chemical, elaborated in living cells and secreted by special organs. The secretion was considered to be a vital act but not the light emission itself. Tiedemann's statements are thoroughly supported by numerous references and his article must be regarded as a quite remarkable contribution to the literature of luminescence, especially since it appeared in a physiology devoted to man.

Milne Edwards' Leçons was a work of many volumes. One chap-

${ }^{29}$ No mention of luminescence is to be found in the physiologies of C. L. Dumas (1806), La C. Richerand (1825), F. Hildebrand (1828), De la S. Lapelletier (1831), F. Magendie (1834), K. A. Burdach (1835-1840), R. Wagner (1842-1853), A. P. Gunther (1848), G. Valentin (1850), K. Ludwig (1852-1856), C. Bernard (1855), O. Funke (1858), J. Beclard (1866), W. Wundt (1868), K. Vierardt (1871), and some later books for medical students.

${ }^{30}$ One of the first books on biophysics was published by Carlo Matteucci (18111868), first a professor of physics at the University of Bologna, then professor at Ravenna, and then at Pisa, later a Senator. His Lezioni sui fenomeni fisco-chimici dei corpi viventi (Pisa, 1844) was very popular, dealing with electrophysiology and related subjects. It was translated into French (1845) and English (1847). One lecture of twenty-four pages in the English edition was entitled "Phosphorescence of organized beings." Although a few other bioluminescences are mentioned, the firefly received most attention and Matteucci became a much quoted authority on the light of this insect (see Chapter XVI on fireflies). 
ter of Volume 8 (1863) is devoted to "Production de lumière par les animaux," with approximately 130 references to all the known studies on luminous animals of the time. Milne-Edwards divided the work into " Phosphorescence dûe à la putrefaction," "Phosphorescence physiologique" -the latter observed in Insectes, Myriapodes, Crustacés, Les Vers, Mollusques, Zoophytes-and "Phosphorescence de la mer" which is correctly attributed to Noctiluques and other small organisms. Regarding the phosphorescence of putrefaction (dead fish and meat), Milne-Edwards believed it to be due to the formation of small quantities of hydrogen phosphide, from the action of nascent hydrogen on decomposing organic phosphorus compounds, which burned in the air. The light which appeared at night from wet sandy beaches might also be due to putrefaction but Milne-Edwards admitted that in the present state of science there was not a satisfactory explanation of light emission by living animals. In some cases it was thought to be due to the secretion of a material susceptible of becoming luminous in contact with oxygen, whereas in other cases the luminescence did not appear to arise in the same manner.

Toward the end of the century the medical physiologies ${ }^{31}$ omitted any account of bioluminescence but the subject was taken up in the general physiologies, ${ }^{32}$ of which Max Verworn's (1863-1921) Allgemeine Physiologie became widely known. It appeared in 1894, with a second edition in 1897, translated into English by F. S. Lee in 1899. The section dealing with "Die Production von Licht" was completely modern and compared the emission of light by living things to the chemiluminescences discovered by Radziszewski in 1877 to 1883 .

Among the many plant physiologies of the nineteenth century, some of the older works discussed " The Development of Light," but only Wilhelm Pfeffer (1845-1920) in his great Handbuch der Pflanzenphysiologie, which first appeared in 1880 , has adequately treated plant luminescence in a special section. In Vol. 3 of A. J. Ewart's translation (1900), six pages are devoted to "The Production of Light" with a considerable number of bibliographical references. The account is excellent, with modern treatment of both bacteria and fungi, and reference to the luciferin and luciferase of R. Dubois (see a later section), as well as to inorganic luminescences. In the

${ }^{31}$ These include such famous works as those of L. Hermann (1879-1883), John C. Dalton (1882), M. Foster (1877), E. A. Schäfer (1898), and the American text-book of physiology (1896), by several authors.

${ }^{32}$ One of the earliest of these was the Principles of general and comparative physiology (1839) of W. B. Carpenter (1812-1885), who also wrote on the microscope in 1856. The Principles (1854 ed.) contains a good section on "Evolution of light." 
next century the appearance of Hans Molisch's book, Leuchtenden Pflanzen (1904), completely filled the need for a treatise on light production by plants.

Because of the wide distribution, spectacular display, and popular appeal of fireflies and glowworms, entomologists have paid particular attention to luminescence. The first modern English entomology was that of William Kirby (1759-1850) and William Spence (17831860), a four-volume work which appeared between 1815 and 1826 . In one section, "On Luminous Insects," twenty-one pages are devoted to luminous beetles, molecrickets, lanternflies (Fulgora) and the centipede, Scolopendra-a quite adequate treatment.

In Germany, the first volume of the great Handbuch der Entomologie of Herman Conrad Carl Burmeister (1807-1892) came out in Berlin in 1832, and many additional volumes were added. It was translated into English by W. E. Shuckard in 1836. Nine pages of the translation were devoted to "The Luminousness of Insects," with special reference to lampyrids and elaterids.

In France also, the two-volume Introduction à l'Entomologie (1834, 1838) of Jean Théodore Lacordaire (1801-1870), part of the Suites à Buffon, devoted ten pages to "Matière Phosphorique," a fairly good account of luminous insects.

No special attention was devoted to luminosity of insects in the American treatise of Alpheus Spring Packard (1839-1905), Guide to the Study of Insects (New York, 1869), or in his later textbooks. There is merely a brief description of luminous lampyrids and elaterids. Later entomologies of every nationality suffer from the same defect. The only comprehensive treatment of insect light during the nineteenth century is Les Insects Phosphorescents by Henri Gadeau de Kerville, which appeared at Rouen in 1881, with "Notes Compleméntaires et Bibliographie Général " added in 1887. making a book of 188 pages.

Throughout the century, dictionaries and encyclopedias in various languages gave excellent accounts of the light of living organisms but nothing would be gained by analyzing the articles ${ }^{33}$ which merely reflected the views expressed by authors already considered. Since the Encyclopedia Britannica was started in 1768, every edition

\footnotetext{
${ }^{33}$ Among the works dealing specifically with biological subjects, comprehensive accounts of luminescence are to be found in the Dictionnaire de sciences médical (Paris, 1830), the article on "Phosphorescence" by DeLens; in the Popular cyclopedia of natural history (London, 1843), Chap. IX, "On the evolution of light, heat and electricity" by W. B. Carpenter; and in R. B. Todd's The cyclopedia of anatomy and physiology (London, 1836-1859), the article on "Animal luminousness" (1847) by Dr. Coldstream. General articles of the same period by medical writers were published by R. J. Graves $(1835,1863)$ and W. P. Hort $(1848,1849)$. A mediocre review was written by $G$, von Hayek (1869).
} 
except the first has had considerable to say on luminescence, although the articles were scattered under such subjects as light, electricity, chemistry, phosphorus, etc. This treatment was continued until the seventh edition (1830-1842) when the article on "Light," written by T.S. T., contained sections on "Evolution of Light without Appreciable Heat" and "Light Emanating from Living Animals."

In the ninth and tenth editions (1875-1889) there is a special article on "Phosphorescence" by W. E. Hoyle of the Challenger Expedition Office, which treats of both inorganic luminescences and bioluminescence. The latter word does not occur in the article, nor can the words "luminescence" and "fluorescence" be found in the index. Separate articles on these subjects only appeared in the later editions of the twentieth century.

\section{EVOLUTION AND BIOLUMINESCENCE}

The great revolution in biological thought which followed Charles Darwin's (1809-1882) publication of The Origin of Species by Means of Natural Selection (1859) had certain repercussions among students of bioluminescence. It emphasized the use or value of an organ to the animal, and turned attention to the purpose of light emission. Post-Darwinian writers have regarded the light of animals as of use to attract the sexes or for species recognition marks, to lure food where it could be easily caught, warn or confuse predators, and for actual illumination of the surroundings.

Some of these categories are by no means recent. Thomas Bartholin (1647) related the suggestion of Carolus Vintimillia that " nature had endowed them [the female fireflies] with a more vigorous light in order that they could call the males at night with their shine," and M. de Flaugergues (1780) thought the light of earthworms might be involved in sex attraction. Later, nineteenth-century pre-Darwinian writers also realized that some use must be found for light production. J. MacCulloch (1821) said there could be no light in the depths of the ocean and held that the luminousness of organisms living there might be a means of seeing each other. This view was upheld by Coldstream (1847) and others, but objected to by McIntosh (1872). Carpenter, Jeffries, and Thomson (1869: 432) also, in their preliminary report on the "Porcupine" exploration of the depths, remarked on the large number of luminous species obtained, and held that it is "scarcely possible that the sun's light can penetrate beyond 200 fathoms at most. . . I It seems to us probable that the abyssal regions might depend for their light solely upon the phosphorescence of their inhabitants." This sup- 
position became known as the "Theory of Abyssal Light" and occasioned a considerable amount of discussion in books on ecology such as the Animal Life (1881) of Karl Semper (1832-1893), professor of zoology at the University of Würzberg. It was more or less upheld by Wyville Thompson, Alexander Agassiz, and others, and particularly supported by C. C. Nutting (1859-1927), who had previously written on The Color of Deep-sea Animals (1898) and Phosphorescence in Deep-sea Animals (1899). Nutting revived the "Theory of Abyssal Light" as late as 1907. While a very high proportion of deep-sea organisms can produce light, the number of these forms is certainly not sufficient to give a general illumination. The purpose of the complicated lanterns of deep-sea crustacea, squid, and fish can be reasonably assumed to be attraction, recognition, warning, etc., but the use of light by large numbers of organisms, and particularly unicellular forms, merely floating at the surface of the sea, is still problematical.

Of all naturalists, Charles Darwin (1809-1882) might be expected to devote considerable space to luminous animals. In the Journal of Researches (1839) compiled during the voyage of the "Beagle," Darwin did record observations of luminous animals encountered on his travels, for example a (dead?) cuttlefish, fireflies, and sea phosphorescence near La Plata off the coast of South America. The five years (1831-1836) of world wide travel on the "Beagle," together with observations on the English glowworm, supplied the material for later remarks on luminescence, as Darwin never left England after his return from the voyage in 1836.

However, the Origin of Species is disappointingly brief in discus. sions of luminous animals. Under the heading "Special Difficulties of the Theory of Natural Selection," there is merely a statement that the evolution of luminous organs is to be placed in the same category as the evolution of electric organs. ${ }^{34}$ Darwin apparently had great difficulty in explaining why electric organs appeared to have arisen in diverse groups of fishes and in diverse regions of the body. An even more diverse distribution of luminous organs is found among various luminous animals, and the number of species possessing luminous structures is far greater than those with electric organs. Concerning the latter, Darwin wrote: "It is impossible to conceive by what steps these wondrous organs have been produced."

The best description of Darwin's views on bioluminescence is

${ }^{34}$ See pp. 150-151 of the Origin of species, London, John Murray, 1872. This is the sixth edition. In the fourth (1866), Darwin wrote that evolution of luminous organs offered an exact parallel to electric organs but the statement does not occur in the first edition (1859) or the second (1860) or the third (1861). 
contained in a letter dated August 7, 1868, to G. H. Lewes (18171878 ), the author of a history of philosophy. ${ }^{35}$ No doubt Darwin was at this time preparing the material for his third book on evolution, The Descent of Man and Selection in Relation to Sex (1871). In the letter Darwin wrote:

I should just like to add, that we may understand each other, how I suppose the luminous organs of insects, for instance, to have been developed; but I depend on conjectures, for so few luminous insects exist that we have no means of judging, by the preservation to the present day of slightly modified forms, of the probable gradations through which the organs have passed. Moreover, we do not know of what use these organs are. We see that the tissues of many animals, [as] certain centipedes in England, are liable, under unknown conditions of food, temperature, etc., to become occasionally luminous; just like the [illegible]: such luminosity having been advantageous to certain insects, the tissues, I suppose, became specialised for this purpose in an intensified degree; in certain insects in one part, in other insects in other parts of the body. Hence I believe that if all extinct insect-forms could be collected, we should have gradations from the Elateridae, with their highly and constantly luminous thoraxes, and from the Lampyridae, with their highly luminous abdomens, to some ancient insects occasionally luminous like the centipede.

I do not know, but suppose that the microscopical structure of the luminous organs in the most different insects is nearly the same; and I should attribute to inheritance from a common progenitor, the similarity of the tissues, which under similar conditions, allowed them to vary in the same manner, and thus, through Natural Selection for the same general purpose, to arrive at the same result. Mutatis mutandis, I should apply the same doctrine to the electric organs of fishes; but here I have to make, in my own mind, the violent assumption that some ancient fish was slightly electrical without having any special organs for the purpose.

In the Descent of Man and Selection in Relation to Sex (1874), Darwin wrote on the differences between the male and female glowworm as follows:

The use of the bright light of the female glow-worm has been subject to much discussion. The male is feebly luminous, as are the larvae and even the eggs. It has been supposed by some that the light serves to frighten away enemies, and by others to guide the male to the female. At last, Mr. Belt ${ }^{36}$ appears to have solved the difficulty: he finds that all the Lampyridae which he has tried are highly distasteful to insec-

${ }^{85}$ More letters of Charles Darwin, edited by Francis Darwin 1:306-307, letter to G. H. Lewes, London, John Murray, 1903.

${ }^{38}$ T. Belt, who wrote, The naturalist in Nicaragua, 1874. See p. 320. 
tivorous mammals and birds. Hence it is in accordance with Mr. Bates' view, hereafter to be explained, that many insects mimic the Lampyridae closely, in order to be mistaken for them, and thus to escape destruction. He further believes that the luminous species profit by being at once recognised as unpalatable. It is probable that the same explanation may be extended to the Elaters, both sexes of which are highly luminous. It is not known why the wings of the female glow-worm have not been developed; but in her present state she closely resembles a larva, and as larvae are so largely preyed on by many animals, we can understand why she has been rendered so much more luminous and conspicuous than the male; and why the larvae themselves are likewise luminous. ${ }^{37}$

It is indeed surprising that Darwin rejected the undoubted use of lampyrid light as a sex attraction.

Later advocates of evolution have been little more successful in visualizing the evolution of luminous organs, which must be of use if natural selection is to operate. The subject was discussed by A. R. Wallace in Tropical Nature and Other Essays (London, 1878), using practically the same argument as Darwin, by E. B. Poulton in The Colours of Animals (1890), by J. T. Cunningham in Sexual Dimorphism in the Animal Kingdom (1900) and by A. Weismann in his Decendenztheorie (1902).

Poulton held that the bright red of the tentacles of the worm, Polycirrus, was a warning color, since Garstang had observed that the worms were eaten by fish only if the tentacles had been cut off. As the tentacles are luminous at night, Poulton suggested that the light may also be a warning to predators, and hence of selection value.

Cunningham was concerned with the wingless glowworm. In discussing wingless females and winged males among the lampyrids, he held that "it would be difficult to prove that the wings became a positive disadvantage to the female. On the view that disuse of the wings in the female only has led directly to their degeneration, the evolution becomes intelligible" since nocturnal species "are naturally apt to develop to the extreme their retiring and inactive habits ... and the wings are therefore only required [by males] in seeking the females." He added: "I do not profess to be able to explain the origin of the property of phosphorescence in Lampyris."

Finally, in August Weismann's Vorträge über Descendenztheorie (Jena, 1902), attention was directed to the large numbers of deepsea animals with complicated lantern-like photophores, which Chun held must be used to allure small animals, which were then eaten. The fact that these lanterns had developed in such diverse groups

${ }^{37}$ C. Darwin, The descent of man, Part II: 277, New York, 1889. Not in 1871 ed. 
(shrimp, squid, and fish) as " adaptations to the darkness of great depths," left " no possibility of referring them to sudden mutations which have arisen all at once in these groups with no relation to utility, and yet have not occurred in any animals living in the light. Only 'variations' progressing and combining in the direction of utility can give us the key to an explanation of the origin of such structure." 38 These quotations are of historic interest as a sample of the reasoning current during and after the great debate on evolution.

\section{THE POPULARIZATION OF SCIENCE}

During the seventies, eighties, and nineties in the United States and in other countries, science became popularized to an extraordinary ${ }^{39}$ degree. The trend affected both the exact sciences and the natural sciences. The latter owe a particular debt to Darwin and other writers on evolution and to the public lectures of Louis Agassiz (1807-1873).

Agassiz's own contributions ${ }^{40}$ to luminescence were small. $\mathrm{He}$ merely mentioned that many transparent forms like medusae and also the sea kidney, Renilla, were luminous, in lectures delivered before the Lowell Institute, ${ }^{41}$ in December and January, 1848-1849. Nevertheless, he created a demand in the United States for popular zoological information. Series of books appeared dealing not only with every phase of natural history, but with science in general. ${ }^{42}$

One of the examples of popular writing is Les Phénomènes de la Physique (Paris, 1868), by Amedée Victor Guillemin (1826-1893), a French mathematician, whose profusely illustrated works on the sun, comets, and the heavens were highly regarded at the time. His work on Physique (translated by Mrs. Norman Lockyer as The Forces of Nature, 1873) contained a six-page section on "Phosphorescence," treating of animal and vegetable light, phosphors, etc.

${ }^{38}$ From the J. A. Thomson translation of Weismann, The evolution theory 2: 322 , London, 1904.

${ }^{38}$ Popular science writing actually started before the 1870 's. A good example is The poetry of science, by Robert Hunt, first American from the second English edition, Boston, 1850. The book contains many quaint interpretations of luminescence.

${ }^{40}$ The son, Alexander Agassiz (1835-1910), first noted that ctenophore embryos were luminous in 1874 (Mem. Amer. Acad. Arts and Sci. 10 (2), Supp.: 357-398).

${ }^{41}$ Published as Twelve lectures on comparative embryology delivered before the Lowell Institute in Boston, New York, 1849. This was the first "phonographic report" (shorthand) ever made and printed. There is nothing on luminescence in Agassiz and Gould's Principles of zoology, Boston, 1854, nor in Agassiz's Methods of study of natural history, Boston, 1863.

${ }^{22}$ The International Scientific Series (New York) and the Modern Science Series (London), edited by Sir John Lubbock, are examples. One of this series was The fauna of the deep sea by S. J. Hickson (1893) containing a chapter dealing with the characteristics, including luminescence, of deep sea forms. 
The first book on luminescence during the "popular period" was Phosphorescence or the Emission of Light by Minerals, Plants and Animals, by T. L. Phipson (1833-1908), published in London in 1862 and in New York in 1869. Phipson remarked in his preface that the original sketch for the book appeared in $1858^{43}$ in Brussels and was translated into German and Italian, thus revealing a widespread interest in the subject. Phipson's book of 210 pages is definitely popular in character. It is divided into four parts-the first dealing with mineral phosphorescence and meteorological manifestations of light, the second with phosphorescence of plants and decaying wood, the third with phosphorescence of animals, including dead animal matter and phosphoric phenomena in man, and the fourth with historical, theoretical, and practical considerations.

It is interesting to note that the light from decayed wood was correctly attributed to a fungus. Regarding luminous fish Phipson was uncertain. He studied a dead luminous ray himself (1860) and showed (p. 103) "by direct chemical experiment that no phosphorus can be found in the luminous grease which shines upon fish." He wrote (p. 103) : "I was at first inclined to attribute their phosphorescence to the presence of some microscopic fungi, but at present I am more inclined to believe it is owing to some peculiar organic matter which possesses the property of shining in the dark like phosphorus itself."

Of even more popular appeal was the Living Lights, by Charles Frederick Holder (1851-1915), a Pasadena, California, writer on zoological subjects. It was published in London and in New York in 1887, and later became one of the "Marvels of Animal Life" series. As Holder wrote in his preface, "The object of the present work is to interest young people in natural history by the presentation of an attractive-indeed, marvellous-phase of nature, and to encourage healthful outdoor observation, as well as habits of investigation." Pointing out that "In the United States there are ten thousand enrolled young naturalists, comprising the Agassiz Association ...., it is to these young scientists, their unscientific elders and the boys and girls in general who have not yet had their interest arused in Nature's works, that this volume is addressed."

Basing his statements on the work of previous scientists-for a bibliography of 114 references accompanied the book-Holder succeeded very well in presenting, with excellent, if somewhat extravagant illustrations, the varied examples of light-producing animals and plants. Many of the classic and sensational instances of luminous phenomena are discussed-the luminous meat of Fabricius ab

${ }^{48}$ T. L. Phipson, Jour. de Méd. et de Pharm. de Bruxelles, 1855 and 1858. 
Aquapendente and Bartholin's luminous Italian lady, as well as the potatoes that seem to be on fire. The incorrect accounts of luminous birds and flowers are repeated, but a large number of true luminous organisms are described.

In France, Henri Gadeau de Kerville, an entomologist, published a popular book on Les Animaux et les Végétaux Lumineux (Paris, 1890 ) with short descriptions of luminous forms and scientific rather than artistic illustrations. The book was translated into German in 1893. It was the outcome of previous study of invertebrates, especially insects, for de Kerville had published, Les Insects Phosphorescents (Rouen, 1881), with an enlarged edition in 1887. The 1881 edition contained a general bibliography of luminous insects of 346 titles, going back to the earliest times, a really comprehensive historical list of references. On the other hand Les Animaux et les Végétaux Lumineux contained references to only five general works-Ehrenberg (1834), Milne-Edwards (1863), Holder (1887), Gadeau de Kerville (1887) and Dittrich 1888. Gadeau de Kerville evidently regarded these five as the best of the period.

\section{DEEP-SEA EXPLORATION}

The controversy over evolution was a great boon to the study of natural history. Every zoologist and botanist was eager to discover new species of animals and plants. Exploration was stimulated, particularly exploration of the deep sea, which was to reveal the existence of so many remarkable luminous creatures. Despite an occasional find of living zoophytes on a sounding line ${ }^{44}$ most zoologists doubted the existence of life at great depths. There were no facilities for deep-sea collecting during the voyage of the "Beagle" (1831-1836). The Manx naturalist, Edward Forbes (1815-1854), obtained specimens at 230 fathoms in 1841, but thought 300 fathoms about the limit for life. Little did he realize the vast amount of living material to be later obtained by numerous expeditions of all nations. ${ }^{45}$

In the meantime the Erebus and Terror (1839-1843) explored the Antarctic under command of Sir James Ross (1800-1862) and

14 Probably the first indication of deep sea life came with the discovery of a pennatulid, Umbellularia groenlandica, which happened to be a luminous form, caught by the ship "Brittania" when entangled on a sounding line at 236 fathoms off the coast of Greenland in 1753. This specimen, which looks like a crinoid, was described by Ellis in the Phil. Trans. (1754) and later rediscovered by M. Lindahl in 1874 in the Arctic Ocean (see Voyage of the Challenger, Narrative by C. W. Thomson 1: 49), and called Umbellula. Many samples of luminous Umbellula were obtained by the "Challenger."

${ }^{45} \mathrm{~A}$ brief but excellent history of oceanographic investigation will be found in J. Murray and J. Hjort, The depths of the ocean, London, 1912. 
found abundant life by sounding at 400 fathoms. Michael Sars (1805-1869) in 1850 and his son, G. O. Sars (1837-1927) in 1864, also described organisms at 400 fathoms.

However, Charles Wyville Thomson (1830-1882) must be credited with really extensive exploration of the ocean bottom. In his book, The Depths of the Sea (1872), the collections of the British Admiralty ships, "Lightning" and "Porcupine" are described. During the summers of 1868 to 1870 , the "Lightning" found life at 600 fathoms and the "Porcupine" at 2,435 fathoms in the Bay of Biscay, thus completely revising the older ideas regarding the floor of the ocean. Moreover, a surprisingly large number of deep sea forms turned out to be luminous. Speaking of depths from 557 to 584 fathoms west of Ireland, Thomson (2nd ed., p. 98 and 149) wrote: "In some places nearly everything brought up seems to emit light and the mud was perfectly full of luminous spaces. ... It is difficult to doubt that in a sea swarming with predaceous crustaceans ... phosphorescence must be a fatal gift."

Thompson also described the singular sea pen, Pavonaria quadrangularis found at 100 fathoms in the Sound of Skye near Loch Torridon. They

were resplendent with a pale lilac phosphorescence like the flame of cyanogen gas; not scintillating like the green light of Ophiacantha, but almost constant, sometimes flashing out at one point more brightly and then dying gradually into comparative dimness. ... The stems were a metre long, fringed with hundreds of polyps.

The seventies, eighties, and nineties were marked by many expeditions of different nationalities to study the ocean depths in various parts of the world. The British "Challenger" (1872-1876), the U. S. "Tuscarora" (1872-1876), "Blake" (1877-1880) and "Albatross" (1891, 1899-1900), the French "Travailleur" and "Talisman" (1880-1883), the Italian "Washington" and "Vettor Pisani " (1881-1885), the "Hirondelle" and "Princess Alice" (1885) of the Prince of Monaco, the German Plankton expedition of Viktor Hensen in the "National" (1889) and the German "Valdivia" (1898-1899) under the direction of Carl Chun, The Danish "Ingolf" (1895-1896) and the Dutch "Siboga" (1899-1900) of Max Weber.

Of these, the "Challenger" expedition, with a staff of six naturalists under C. Wyville Thomson, was the most noted. Its collections were worked over by a group of specialists under John Murray (1841-1914) and the results published in fifty thick folio volumes. In Thompson's Voyage of the Challenger (London, 2 v., 1877), and 
in the "Narrative" (Vol. 1 of the Challenger Reports), Thomson and Murray again described the abundant and beautiful luminescence of living forms, not only at great depths but also at the ocean surface in such passages as the one previously quoted.

Such expeditions helped to found and maintain the new science of oceanography and resulted in a series of books, both scientific and popular, all of them with a section devoted to bioluminescence. Such works as those of H. Filhol (1885), La Vie au Fond des Mers; E. Perrier (1886), Les Exploration Sous-Marins; Le Marquis De Folin (1887), Sous le Mer; L. Figuier-E. P. Wright (1891), The Ocean World; S. J. Hickson (1893), The Fauna of the Deep Sea; and C. Chun (1900), Aus den Tiefen des Tiefen des Weltmeeres, will serve to indicate the trend

Before the voyage of the "Challenger," hardly thirty species of deep-sea fish were known. A. Günther $(1880,1887)$, who worked up the "Challenger" fishes described 370 deep-sea (below 100 fathoms) species, many of which possessed luminous organs. However, not all deep-sea animals possess a pattern of photophores or other types of luminous organs. Among free-swimming forms, light production is most marked in fish and squid

\section{PAOLO PANCERI AND THE ITALIANS}

During the period 1870-1890, the principal writers of general scientific articles on animal light were Giglioni, Panceri, and Della Valle in Italy, M'Intosh in Great Britain, Krukenberg and Dittrich in Germany, and Dubois in France. The more popular books of Phipson, Gadeau de Kerville, and Holder have already been mentioned. In 1870, E. H. Giglioni published a twenty-page essay, $L a$ Phosphorescenze del Mare, listing the luminous animals he observed during a voyage around the world in the "Magenta " in 1865-1868. However, there was no attempt to interpret what he found.

Perhaps the greatest Italian student of bioluminescence was Paolo Panceri (1833-1877), professor of comparative anatomy at the University of Naples, a region noted for its variety of luminous animals. His major works were never collected in book form but appeared in the Atti of the Royal Academy of Science of Naples. Panceri's papers on luminescence dealt (in order) with pennatulids (1871), including also observations on siphonophores; Pyrosoma and Pholas (1872) ; Phyllirrhoeë (1872) ; ctenophores (1872) ; annelids, including also Balanoglossus and brittle stars (1875); and hydroids (1876) . All these articles are accompanied by beautiful colored plates illustrating the antomy and the histology of the various luminous forms. $\mathrm{He}$ also dealt with their physiology. An excellent sixty-eight-page 
summary of much of his work, written by Panceri himself, appeared in French in the Annales des Sciences Naturelles for 1872. Unfortunately his life was short. He died in 1877 at the height of his career, when only forty-four years old.

The work of Panceri and others was summarized by his pupil, Antonia Della Valle who published in 1875 a "Libera dissertazion" of 69 pages, dedicated to his maestro, Paolo Panceri. This thesis, entitled La Luce negli Animali, is divided into two parts, dealing with the luminescence of (I) Dead and (II) Living animals. It included human bodies, wounds, sweat, and urine; animal eyes, eggs, flesh, etc., with a full list of luminous living forms and their characteristic methods of emitting light, but no mention of luminous bacteria. Della Valle considered the phosphorescent material to be fat, as suggested by Panceri (1871), or noctilucine, as suggested by Phipson (1872). No new facts were announced and the work of Heller (1853) on living organisms as the cause of light of dead fish and meat was completely overlooked.

\section{RAPHAËL DUBOIS}

In 1884, the distinguished French physiologist, Raphaël Dubois (1849-1929), began his studies on the West Indian elaterid beetle, Pyrophorus, which led to publication of his first monograph, Les Élatérides Lumineux (1886), a comprehensive treatise of 275 pages and 9 plates. ${ }^{46}$

A second monograph by Dubois appeared in 1892, 167 pages and 15 plates, on Anatomie et Physiologie Comparées de la Pholade Dactyle. ${ }^{47}$ A third followed in Leçons de Physiologie Générale et Comparée (Paris, 1898) of which the second part (pp. 301 to 527) is entirely devoted to luminous organisms. The next large publication appeared in the form of a more or less popular book, La Vie et La Lumière (Paris, 1914). Dubois's final comprehensive work was another monograph in the Dictionnaire de Physiologie of Charles Richet, vol. 10, the article on "Lumière." The first part of the contribution (pages 277-394) had to do with "Biophotogenese" and the second part with action of light on organisms. Although Richet's great Dictionnaire was begun in 1895 , the volume containing Dubois' article was not finished until 1928. It must have been written earlier for the latest reference in the bibliography is dated 1922. Dubois died January 21, 1929. In addition to these general

${ }^{46}$ In the Bull. de la Soc. Zool. de France 11:275, 1886. Also published by Meulan, Paris, 1886.

${ }^{47}$ Ann. de l'Univ. de Lyon 2; also published by G. Masson, Paris, 1892. 
works, Dubois published over fifty papers on bioluminescence, several of which are of a general nature.

The second part of Dubois's Leçons was entitled "Production de la Lumière et des Radiations Chemiques par les Etres Vivants." After describing luminescence in each group of organisms, Dubois emphasized his belief in the importance of "granulides" as fundamental structures for light production and described his experiments to demonstrate the luminous materials, luciferin and luciferase, in both Pyrophorus and Pholas. He gave the methods of purifying these substances and stated that the "Chemical nature of luciferin should be easy to establish. It is only a question of time and quantity from where we stand today" (p. 524). Luciferin was regarded as "certainly not living as it withstands temperatures incompatible with life." On the other hand the nature of luciferase presented greater difficulties. It existed only in the luminous regions of animals in the form of "bioplastes, plastidules, microzymes, etc., which one can consider as made up of infinitely small granulations, actually alive [a l'état vivant]."

Raphael Dubois was professor of general physiology at the University of Lyons and Director of the Marine Laboratory at Tamarissur-mer, where much of the bioluminescence study was made. His interests were indeed broad, covering every field of comparative physiology and biochemistry, ranging from narcosis to animal pigments and animal behavior.

His great contribution was to place the chemical investigations of bioluminescence on a firm foundation. By demonstrating the existence of luciferin and luciferase he brought the production of light by animals and plants in line with other biological processes which are enzyme controlled.

With the work of Dubois, the history of bioluminescence has arrived at the modern period. The chemical structure of all the luciferins and the luciferases are not yet completely known and details of the mechanism of light emission remain to be filled in, but the broad outlines are understood. The phosphorescence of the sea and the shining of wood, fish, and flesh are no longer mysterious, but due to the light of living microorganisms. Like the larger marine and terrestrial animals, their light production is also a chemiluminescence, in which a compound manufactured within living cells and given the general name of luciferin, oxidizes in the presence of an enzyme, luciferase. In some cases accessory substances are also necessary. 


\section{W. C. M'INTOSH}

In 1885 , for the first time, a presidential address of the British Association for the Advancement of Science dealt with luminous animals. This was delivered before the biology section, by Dr. W. C. M'Intosh, at the meeting held at Aberdeen in 1885, fifty-four years after the Association was founded in 1831. It was a general survey and mentioned all groups known to be luminous, as well as some whose luminescence was doubtful. M'Intosh did not go into the problem of the origin of the light but restricted his subject to biological aspects. The address was printed not only in the report of the British Association for the Advancement of Science but also in Nature (1885) and in the Revue Scientifique of Paris (1885). M'Intosh had always been interested in bioluminescence, having contributed general articles in 1872 and later in 1906. He was a professor of biology at the United College at St. Andrews until his retirement in 1917, the immediate predecessor of D'Arcy Thompson. His paper is one of the few from the British Isles in which knowledge of animal light is treated in a general review.

\section{KRUKENBERG AND DITTRICH}

In Germany two large papers on bioluminescence appeared at about the same time. The first was by C. F. W. Krukenberg (18521889), "Neue Thatsachen für eine vergleichende Physiologie des Phosphorescenzerscheinungen bei Tieren und bei Pflanzen," part of his Vergleichende Physiologische Studien, published at Heidelberg in 1887. Krukenberg reported on bioluminescence in general and also recorded his observations on a pennatulid, Pteroides griseum, a fungus, Agaricus olearius, and the phosphorescence of the Red Sea during a trip from Marseilles via Trieste to Suakim and Massua.

The second German contribution, by Rudolf Dittrich, " Über das Leuchte der Tiere" in 1888, was a much more general account, listing species, giving the structure of luminous organs, the physiological chemistry, the possible use to the animal and other matters of interest. A bibliography of 250 titles accompanied the paper. It was unfortunately published in a rather obscure journal and has not been read by many investigators. No later general account of bioluminescence came from German writers until the next century, when the gap was filled by Hans Molisch's Leuchtenden Pflanzen (1904), by August Pütter's “ Leuchtenden Organismen (1905), and by Ernst Mangold's “Die Production von Licht" (1910). 


\section{IN REVIEW}

From the purely biological point of view, the most important discoveries of the nineteenth century may be stated as follows: (1) realization that all light of the sea is due to living organisms, (2) demonstration that the light of flesh and dead fish comes from luminous bacteria, (3) proof that the light of shining wood is of fungal origin and (4) the discovery of life at great depths in the ocean with a very high proportion of luminous species. In addition a considerable array of new luminous surface forms was added. These belonged to some fifteen groups in which luminosity had not previously been described. In order of discovery it was established that luminosity occurred in the following groups: ctenophores (Bosc, 1800); hydroids (Stewart, 1802); Pyrosoma (Péron, 1804); brittle stars (Viviani, 1805) ; Radiolaria (Tilesius, 1819); teleosts (Cocco, 1838); sharks (Bennett, 1840); a fly larva, Ceroplatus (Wahlberg, 1849); collembolids (Allman, 1851); squid (Verany, 1851); siphonophores (Meyen, 1834); Sagitta (Giglioni, 1870); Phyllirrhoë (Panceri, 1873) ; Balanoglossus (Panceri, 1875); and the fresh-water limpet, Latia (Suter, 1890).

In addition, the fine structure of luminous tissues, was fully worked out and the complicated lantern-like structure of some luminous organs established. It was realized that sometimes the light is of intracellular origin and sometimes appears from extracellular secreted material.

The physiology, biochemistry, and biophysics of light production made great strides during the nineteenth century, keeping pace with the advancing knowledge of other functional activities of animals. Although details of all these investigations will be found in Chapter XVI, together with the more purely biological discoveries, the following fundamental ideas may be regarded as nineteenth-century contributions to the study of bioluminescence: (1) Realization of the part played by stimulation in exciting light production, and discovery of the existence of special luminescence-effector nerves, (2) demonstration of inhibition of the bioluminescence of some forms by light, (3) establishment of the basic facts regarding action of drugs, salts, and other chemicals, temperature, etc., on light production, (4) disproof of the early view that phosphorus played a part in bioluminescence, and demonstration that in some forms the light is a chemiluminescence connected with enzymic oxidation of a definite organic compound, luciferin.

Some light intensity and heat measurements of "living light" were made, but the continuous recording of rapid flashes of light 
had to await the development of electronic techniques of the next century. The spectra of luminous animals were fully investigated and the absence of sharp lines established.

\section{Survey}

It is hardly possible to summarize the truly overwhelming mass of information collected during the nineteenth century concerning every conceivable type of luminescence. Even the chapters of Parts II and III of this book, on the history of specific types of luminescence, can do little more than summarize. It will suffice to say that many important facts were known, but that integration and explanation were lacking.

Rather than attempting to summarize the advances covered in this chapter, it is more valuable to look ahead and note how the nineteenth century influenced later luminescence research. Perhaps the discoveries which had the greatest effect in changing the interpretation of luminescence and setting a trend for present luminescence theory came at the end of the nineteenth or the beginning of the twentieth century. They were, in order of publication: (1) The final identification of the electron in the paper on "Cathode Rays" by J. J. Thompson in 1897, (2) the quantum theory of light of Max Planck ${ }^{48}(1900)$ as modified by Einstein ${ }^{49}$ (1905) and (3) the new theory of the structure of the atom ${ }^{50}$ with electronic energy levels as the basis of spectral lines, advanced by Niels Bohr in 1913.

This new physics led to the conception of energy levels in atoms and molecules and the mechanism of emission of light quanta of definite energy, connected with a particular frequency. Incandescence played less of a role in the new conceptions of atomic structure, than did the luminescence of gases, with their spectra of sharp discrete lines arranged in mathematically predictable order. The theories derived from study of electroluminescence were applied to other luminescences with a broader distribution of spectral energies, even to the chemiluminescences, and hence to bioluminescence.

From energy changes of matter in bulk, attention turned to energy changes in atoms and molecules. The Einstein (1905, ${ }^{49}$ 1912) ${ }^{51}$-Stark ${ }^{52}$ (1908) photochemical equivalence law taught that

${ }^{48}$ M. Planck, Verhandl. deut. physik. Gesell. 2: 202-204, 1900. The theory was developed to account for the radiation from heated black bodies, spoken of as temperature radiation or incandescence.

${ }^{40}$ A. Einstein, Ann. d. Physik 17: 132-148, 1905.

${ }^{50}$ N. Bohr, On the constitution of atoms and molecules, Phil. Mag. 26: 1-25, 676-502, 857-875, 1913.

${ }^{51}$ A Einstein, Ann. d. Physik (4) 37: 832-838; 38, 881-884, 1912.

${ }^{52}$ J. Stark, Physikalische Ztschr, 9: 889-894, 1908. 
each quantum of light absorbed may cause one molecule to react in a primary photochemical reaction. Conversely, chemiluminescence can only occur if the free energy of the reaction is sufficiently high to account for the quantum energy of the frequency emitted when one molecule undergoes change. ${ }^{53}$ Based on a mole of material undergoing chemical change, the energy necessary (a quantum, $\mathrm{h}_{\nu}$, multiplied by the number of molecules in a gram-mol, called an einstein) is rather high. A blue luminescence requires a free energy change of some 60,000 calories. Thus the modern student of bioluminescence, concerned with the mechanism of light production in any organism, must answer this fundamental question-what reaction produces sufficient energy to result in frequencies observed in the bioluminescence spectrum? Only then can the emission of light be understood. Such a question was unheard of before 1900. With this new outlook, research on all types of luminescence progressed rapidly during the twentieth century, adding new names and new theories to history.

${ }^{53}$ The relation of quantum energy in the light emitted to the heat of reaction was first considered by F. Haber and W. Zisch (Ztschr. fur Physik. 1: 302-326, 1922) in the case of the yellow luminescence observed when chlorine and sodium vapor are mixed. Free energy of reaction $\Delta F$ is a more correct designation, related to heat of reaction $\Delta H$ by the expression, $\Delta F=\Delta H-T \Delta S$, where $T$ is absolute temperature and $\Delta S$ the entropy of activation. 



\section{PART II}

\section{Luminescence of Non-living Material}





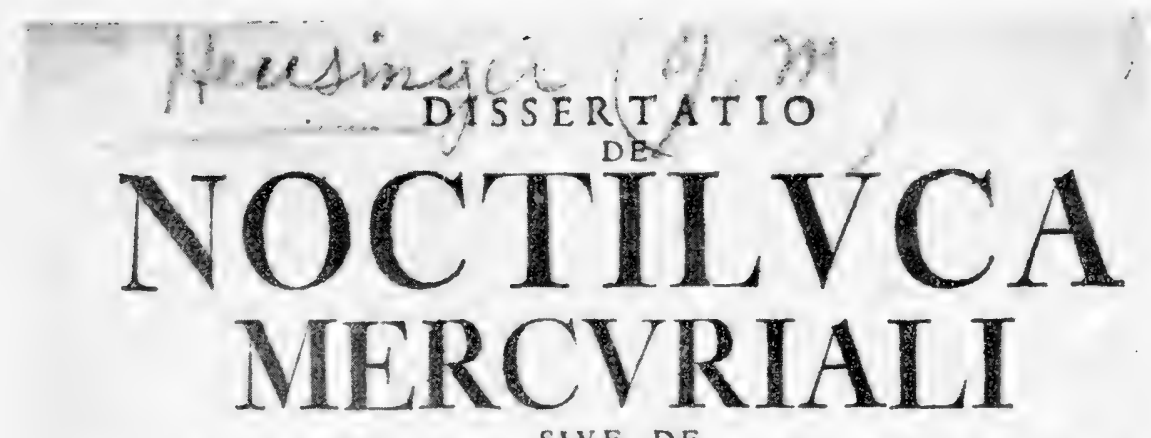

SIVE DE

LVCE QVAM ARGENTVM VIVVM IN TENEBRIS

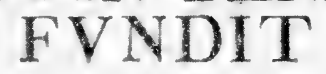

CVAM

IN ACADEMIA LVDOVICIANA

PRAESIDE

IARO EXCELLENTISSIMO ATRTE ANPSISSIMO

IO. GEORGIO LIEBKNECHT MATHEM. PROE. P. ET ORD IT ET ACAD. LEOPOLDINO CAROL. CAESAR. COLlEGa PATRONO AC PRAECEPTORE SVO ONANA.PIET:ATE
COLENDO

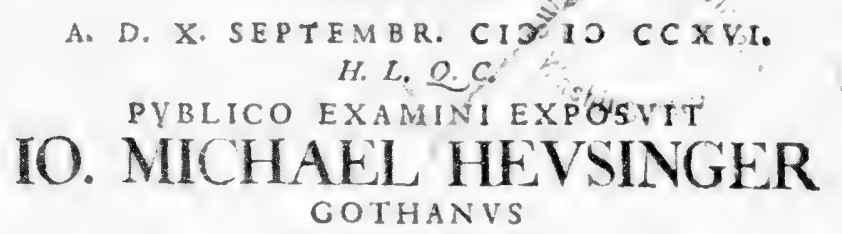

A V T O R.

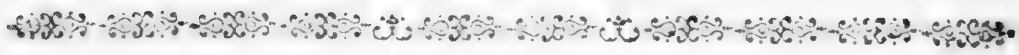
$G$ IS SAE

LITTERIS IOANNIS MVLLERI.

Fir. 29. Title page of a thesis (Giessen, 1716) on the mercurial phosphor. by J. M. Heusinger. 


\section{Pbyfico-Mecbanical \\ EXPERIMENTS \\ On Various Subjects.}

CONTAINING

An Account of feveral Surprizing Pbenomena

$T \bigcirc U$ CH IN G

\section{Light and Electricity,}

- Producible on the Attrition of BO D I Es.

With many other Remarkable Appearances, not before obferv'd.

Together with

The Explanations of all the MACHINEs, ( the Figures of which are Curioully Engrav'd on Copper) and other A P A R A T U S Us'd in making the EXPERIMENTS.

BY. F. HA U K $S$ B E E, F. R.S.

$$
\text { L } O N D D O N \text {, }
$$

Printed by R. Brugis, for the A u T H O R; and Sold only at his Houfe in Wine-Office-Court in Fleet-freet. 170y. 


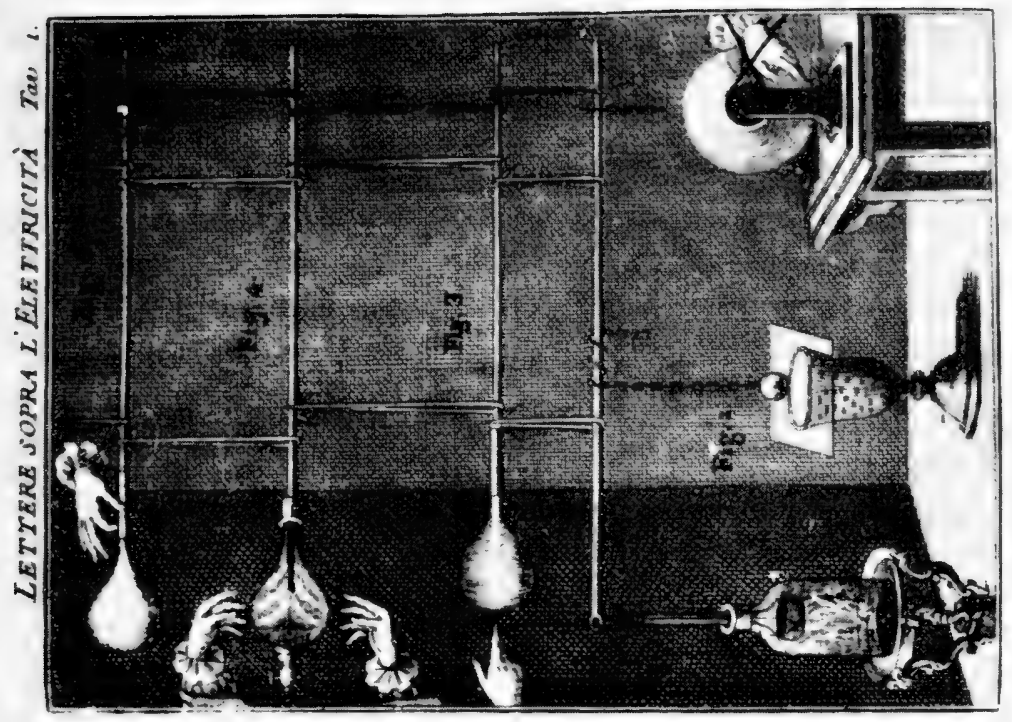

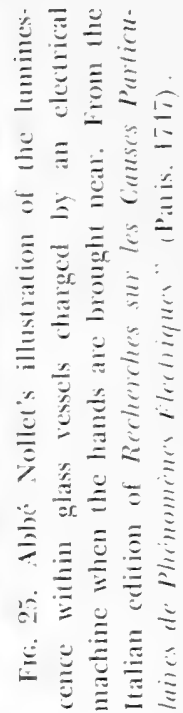

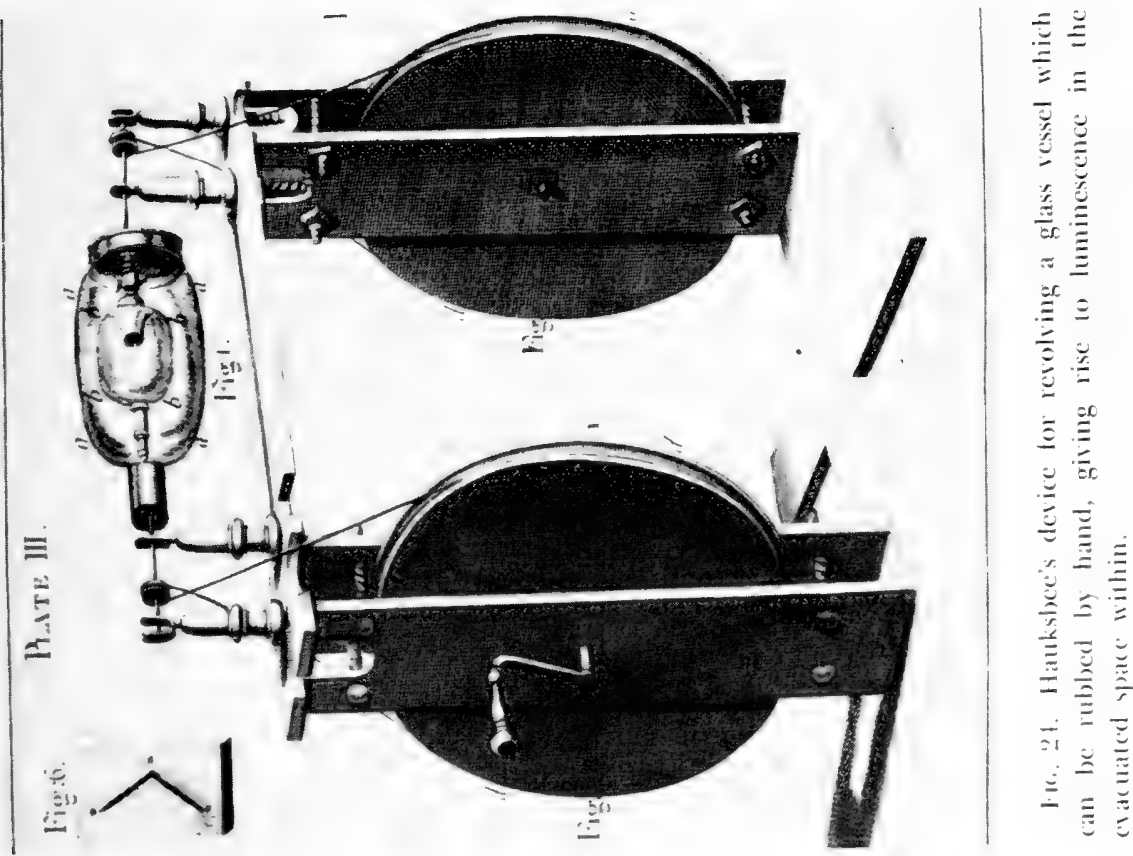




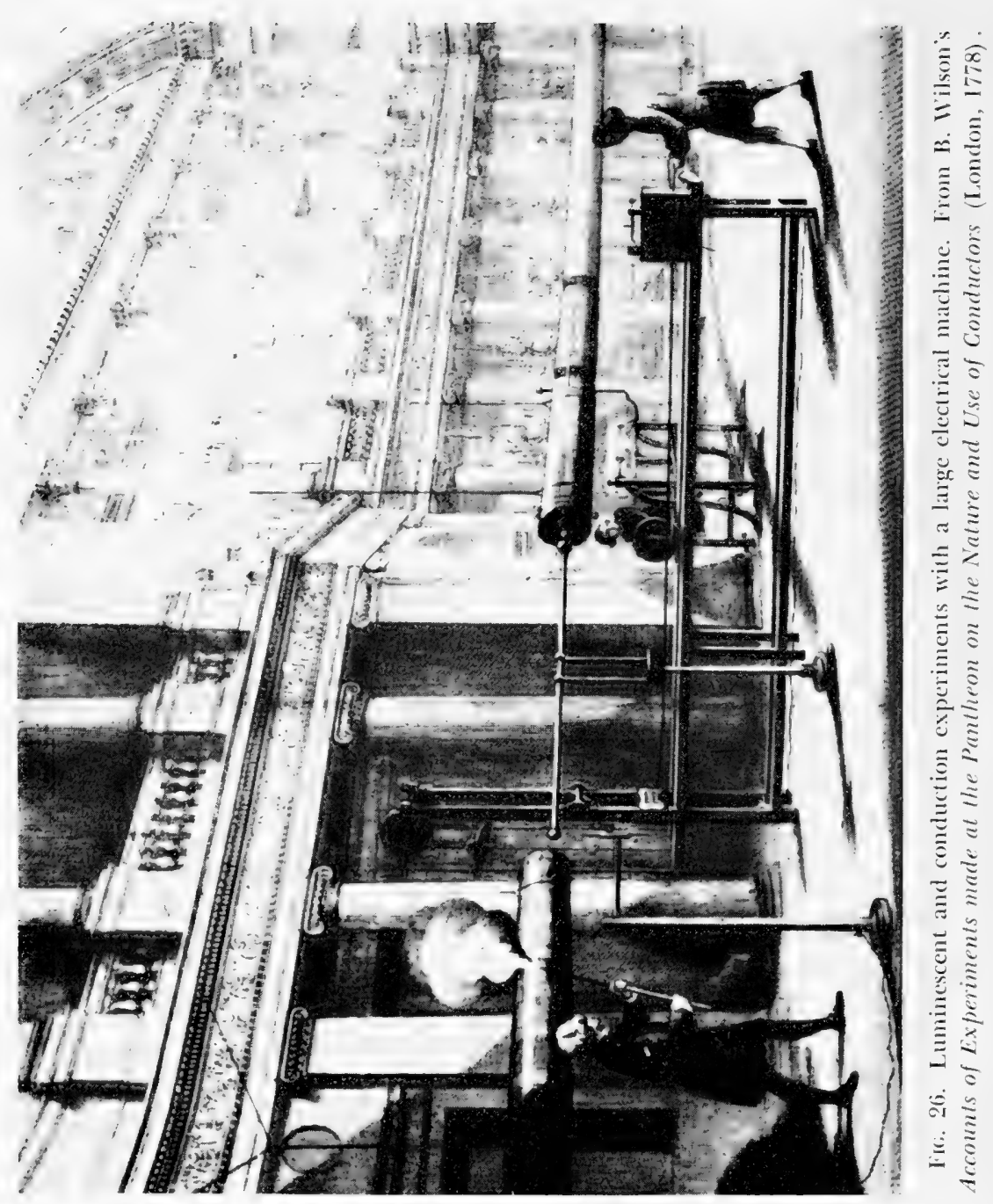




\section{ELECTROLUMINESCENCE}

\section{Introduction}

THE wORD "electroluminescence" is usually applied to the light 1 resulting from flow of current through partially evacuated tubes of gas-neon, argon, nitrogen, mercury vapor, etc.-which glow in various colors. ${ }^{1}$ This phenomenon is commonplace today. Indeed, the present widespread use of neon lights as advertising signs gives little clue to the chance discovery and many steps which led to practical application. ${ }^{2}$

Sometimes light appears when electric currents are passed through certain solutions, mostly from changes occurring at the electrodes, such as the "electrolytic flames" when halides (especially sodium bromide solutions) are electrolyzed at mercury anodes, ${ }^{3}$ or the light from the aluminium anode of a carbon-aluminium rectifier. ${ }^{4}$ Such light emissions are more properly called galvanoluminescences rather than electroluminescences and actually belong in the category of chemiluminescence. Light may also be observed at electrodes in a solution of certain chemiluminescent compounds, the result of hydrogen peroxide or oxygen formation. ${ }^{5}$

Electroluminescence as used in this history, that is, light in gases due to an electric discharge, requires no vacuum tube. It is very common and occurs in the air when clothing or fur or other insula-

${ }^{2}$ When a beam of electrons (cathode rays) strikes a solid or liquid, the light emitted is sometimes called an electroluminescence rather than a cathodoluminescence.

"Within the last few years, the word "electroluminescence" has been used for a new method of exciting specially prepared phosphors, by which the luminescent material forms a sheet of dielectric, between a metallic and a transparent conductor in the form of three thin plates. The whole acts as a condenser and a brief flash of light appears whenever a potential is applied to or discharged from the conducting plates. If an alternating current field is used for excitation the light appears continuous to the eye and large areas may be rendered light-emitting. Such a device has been called a panelescent lamp.

${ }^{3}$ See Bancroft, W. D. and H. B. Weiser, Flame reactions. Jour. Physical Chem. 18: 213, 281, 762; 19: 310, 1913-1915.

- Discovered by Ferdinand Braun (1898). A luminous phenomenon accompanying electrolysis of acid water with platinum electrodes at high current densities has been described by N. P. Sluginov (1880) in Russian, translated in the Jour. de Physique Théor. et Appl. (Series 2) 3: 465-466, 1884. The light is practically an arc, with a continuous spectrum containing some lines of hydrogen and of platinum. See also $S$. Anderson, Jour. App. Phys. 14: 601-609, 1943, for explanation of anode light.

'See E. N. Harvey on luminol (Jour. Phys. Chem. 33: 1456-1459, 1929) and on luciferin (Jour. Gen. Physiol. 23: 275-284, 1923). 
tors are rubbed, or by a more simple procedure. Whenever two closely applied surfaces are separated, light may appear, called "Trennungsleucht" in Germany. This light can be observed with thoroughly dark-adapted eyes if mica sheets are split in two, or collodion films are stripped from a glass surface. Another example is the transient greenish luminescence which occurs at the point where electrician's or surgeon's or "Scotch" tape is unrolled. With some samples this luminescence may be so bright that it is visible with only partially dark-adapted eyes. Finally, certain types of "triboluminescence" are undoubtedly due to electric discharges (see Chapter X).

The explanation of such luminescences appears to be this: whenever two surfaces are separated from each other the electrical capacity diminishes and the voltage rises until a discharge takes place, exciting the surrounding gas to luminesce. That a discharge does actually take place can be readily shown by stripping surgeon's tape or Scotch tape in an atmosphere of low pressure neon gas. ${ }^{6}$ Then the luminescence is reddish instead of greenish. Red luminescence also occurs when two strips of mica are pulled apart or when collodion is stripped from glass in a low-pressure neon atmosphere. The light which appears when ultrasonic waves cause cavitation of liquid appears to be due to electric discharges also. This remarkable example of cold light, sonoluminescence, was first described by J. Frenzel and H. Schultes (1934).

Electroluminescences are not only among the oldest natural light phenomena to be observed by man, for example the aurora borealis, ${ }^{7}$ but in the laboratory controlled electroluminescences have been intimately connected with the rise of modern physics. Since a gas represents the simplest state of matter, study of the conditions for light emission from a gas have supplied the basis for theories of light emission in general, concepts based on present ideas regarding the structure of matter (see Introduction).

\section{Meteors}

The word "electroluminescence" is also used in a broad sense to include light from a natural electrical discharge which does not involve the sudden complete surges of electricity, such as occur in lightning flashes or condenser sparks. The silent or glow discharge describes a very diverse group of natural luminous phenomena,

\footnotetext{
1939.

- See E. N. Harvey, The luminescence of adhesive tape, Science 89:406-461,
}

${ }^{7}$ Perhaps the aurora borealis should be considered a radioluminescence. 
often on a grand scale, knowledge of which goes back to ancient times. In addition to the aurora borealis, there are St. Elmo's fires at the tips of masts or church steeples and glow or brush discharges from objects near the ground in high mountain regions. The glow on rubbing the fur of a cat or on removing silk clothing are examples of electroluminescence, all dependent on certain atmospheric conditions. This glow is often called ignis lambens to distinguish it from ignis fatuus, a light hard to explain.

The above phenomena, when of cosmic origin, were formerly described as " meteors," since the word meteor was originally used for any atmospheric appearance, although it has a more restricted meaning today. Reference has already been made to Chinese and to classic Greek and Roman knowledge of the aurora borealis, called chasmata by Aristotle, and bolides or trabes by Seneca and Pliny. In addition, Roman soldiers saw "fires" at the end of their pikes and "stars" settle on the masts of ships. These "stella castores" or "Castor and Pollux" of the Romans, "polydeuces" of the Greeks, together with more gentle displays, the ignis lambens, were observed and recorded by Pliny, Plutarch, Seneca, Caesar, and Livy.

Every race has had its name for the English St. Elmo's fire or the German St. Elmsfeuer, which appears to be a corruption (through Sant' Ermo) of St. Erasmus, a bishop who was killed in A. D. 304, and became the patron saint of Mediterranean sailors. The French speak of St. Helene's or St. Telme's fire, the Spaniards of St. Helme's fire. On the other hand, Italians refer to the fires of St. Peter and St. Nicholas. ${ }^{8}$ Called corposants or comazants by sailors, a name which came from the belief of early Portuguese and Spanish voyagers that the body of the Saint (Cuerpo santo in Spanish) could be seen in the electrical display; a more common term is Corpus Christi lights.

Space does not permit an extended discussion ${ }^{9}$ of the beliefs concerning the various phenomena classed as meteors or things of the air, the occasional appearances of the sky, as distinguished from the permanent fixtures-the moon, stars, and planets. Comets were meteors which gave rise to endless discussion, especially concerning the tail which streamed away from the sun. One of the best seventeenth-century statements on meteors will be found in the Speculum

If three lights appear, the third may be called St. Anna or St. Barbara.

- See Joanne Stierio, Praecepta doctrinae, logicae, ethicae, physicae, metaphysicae, etc., London, 1641, p. 24 of Physicae, dealing with "De meteoris ignis puris"; also Thomas Willsford's Nature's secrets; or the admirable and wonderful history of the generation of meteores (London, 1658) and the Thirteen books of natural philosophy (London, 1661) by Danniel Sennert, Nicholas Culpepper and Abdiah Cole. Book IV, Chap. 1 deals with "Meteors in general " and Chap. 2 with "Fiery meteors." 
Mundi (Cambridge, 1635, Chap. V, Sec. 2) by John Swan (fl. 1635). Swan pointed out that

meteors consist of Exhalations, and Exhalations are of two kindes. 1. There is Fumus (a kinde of Smoke) and 2. Vapor (from the water or some watry place)....

And in coming to particulars, it may be found that those kinde of Meteors concerning which I speak, are of three sorts; either Fierie, Waterie, or Aierie.

Fierie are of two sorts: either such as are in very deed fired; or else such as onely seem to burn, which are therefore called Phasmata: In which regard it may be said that these Fierie ones are either Flames or Apparations. ...

Furthermore, these Fiery impressions, according to the diverse disposing of their matter, are of severall fashions; and thereupon they have severall appellations, being called according unto the names of those things unto which they seem to be like. As 1. Torches. 2. Burning Beams. 3. Round Pillars. 4. Pyramidal pillars. 5. Burning Spears, Streams, or Darts. 6. Dancing or Leaping goats. 7. Flying sparks. 8. Shooting Starres. 9. Flying Launces. 10. Fires, either scattered, or else as if the aire burned. 11. Flying Dragons or Fire-drakes. 12. Wandering Lights. 13. And also licking or cleaving fire, sticking on the hairs of men or beasts.

Now all these kindes (of which I have mentioned thirteen) I take to be such fierie Meteors as are said to be pure and not mixt.

Then again have you those which are said to be mixt and lesse pure: As 1. Comets of all sortes. 2. All kindes of lightening. 3. Unto which must be joyned thunder, as an adjunct. ...

It will be noted that the list and the explanation of meteors differ little from the classification of William Fulke (1538-1589) written in the last century (1563), as indicated in Chapter III. Fulke's book of 1563 was reissued in 1640 under a new name, Meteors, or a Plain Description of all Kinds of Meteors, as well Fiery and Ayrie as Watry and Earthy, etc. by $W . F$. (London, 1640). In fact no change in point of view occurred until the eighteenth century. A number of the categories describe the various manifestations of the aurora borealis; others can hardly be called luminescences. Among the electrical phenomena included among meteors, the northern lights, and ignis lambens may be considered true luminescences, although it is often difficult to draw a sharp distinction between the brush and glow discharge of electricity. As one of the earliest luminescences to be observed by mankind, and as a cold light which has been compared to that of luminous wood by Jules de Viano (1788), the aurora borealis will be treated first in a brief account, which does not pretend to cover completely the various theories regarding 
this fascinating type of light; then ignis lambens and ignis fatuus will be considered.

\section{The Aurora Borealis or Polaris}

\section{SEVENTEENTH AND EIGHTEENTH GENTURY VIEWS}

Although observation of flames in the sky, popularly called the northern lights, ${ }^{10}$ has been made throughout recorded history, and they have regularly been considered omens of war, death, pestilence, or famine-signs of the wrath of God-few of the early reports contain more than records ${ }^{11}$ of particularly brilliant displays. They might have the appearance of a monk's hood or an eagle with extended wings. A number of such ancient and medieval examples has already been given in Chapters I, II, and III.

The name "aurora borealis" is usually attributed to Pierre Gassendi (1592-1655), used in his Diogenes Laërcë (1649), while aurora australis designates the similar phenomena at the south pole. These aurorae may exhibit every possible luminous effect, from a mere glow in the sky, or columns and shafts of light pointing upward, or a crown, to waving curtains of a brilliant red color.

Most early treatises on cosmic phenomena mention the aurora. Francis Bacon thought they were signs of heat and René Descartes intimated that they might result from the light of the sun below the horizon, but a more common view regarded them as vapors from the earth set on fire, as suggested in the previously quoted book on meteors (1560) by William Fulke (see Chapter III) .

The seventeenth-century view of the northern lights is well expressed by John Swan in Speculum Mundi (Cambridge, 1635), at a time when the phrase "aurora borealis" had not been coined, and many of the types of meteors were not known to be essentially the same. After the listing of various meteors, Swan proceeded to explain how all these kinds of fiery meteors might arise. For example:

Burning Streams, Spears, or Darts, is that Meteor which is called Bolis or Jaculum, and is an Exhalation hot and drie, meanly long, whose thick and thinner parts are equally mixt: and thereupon being fired in the highest Region, it flameth on the thin or subtil part; which nevertheless, because the matter is well mixed, doth also send fire to the other parts, insomuch that it seems to run like a dart from the one unto the other.

${ }^{10}$ Nororljós (northern lights), is said to have been applied to the aurora borealis by the Icelandic settlers of Greenland.

${ }^{11}$ A list of records from 503 B.c. to 1873 will be found in H. Fritz, Verzeichniss beobachteter Polarlichten, Wien, 1873. 
Or, if you will this Meteor (or one very like it) is thus generated, viz. when a great quantitie of hot and drie Exhalation (which indeed may fitly be called a drie cloud) is set on fire in the midst, and because the cloud is not so compact that it should suddenly rend, as when thunder is caused, the fire breaks out at the edges of it, kindling the thin Exhalations which shoot out in great number like to fiery spears or darts, the streaming or flashing being so much the whiter by how much the Exhalation is the thinner. Such like coruscations as these we use to see many nights in the North and North-east parts of the skie.

One of the first eighteenth-century theories to account for an aurora was presented by Harald Vallerius (1646-1716), professor of mathematics at the University of Upsala, in a small tract Exercitium Philosophicum de Chasmatibus (Upsala, 1708). He listed eighteen characteristics of the aurora of 1707, which he explained as due to the reflection of the rays of the sun (below the horizon) by thin, light, six-sided ice plates, floating in the upper atmosphere, a view also supported (1724) by J. C. Spidberg (1684-1762), the Bishop of Christiansand in Norway.

The paper of Vallerius was little known in Europe, but the auroras of 1716 and 1717 were seen over a vast area, and gave rise to many publications and much speculation in all countries. ${ }^{12}$ One of the most extensive series of observations was by William Whiston (1667-1752), a divine who followed Newton as Lucasian Professor of Mathematics at Cambridge in 1703, and was expelled in 1710 . His booklet (1716) of seventy-eight pages was entitled, An Account of a Surprising Meteor Seen in the Air, March the sixth, 1715-16 at Night.

Whiston recognized the similarity of the aurora to other luminescences and in fact referred to it as "an aerial phosphorus." The phenomenon was believed to result from

no other than such Exhalations are arose out of the Earth some Time before; and which at this time got together, as Vapours do before they compose dense Clouds for Rain, or Matter for great Storms ... as for the Nature of these Exhalations, it seems plainly to be like that of the Ingredients of Gunpowder, Nitre and Sulphur, especially the latter: Which as they are proper in Fermentation to cause Light, and if that Fermentation be very violent, Thunder and Lightning also ... properly exhibiting such a thin Light in the Northern cold Countries, as they do Thunder and Lightning when they are more ripened in the Southern hot Ones.

\footnotetext{
${ }^{12}$ Christian Wolf (1679-1754), professor of physics at Halle, explained (1716) the appearance as "a thunder and lightning storm [Gewitter] which has not attained full strength," a pronouncement which has been repeated and over-emphasized because of the great authority of Wolf.
} 
In brief Whiston considered the auroral display as " a kind of imperfect unripe Lightning."

In general the idea of a "thin Nitro-sulphureous Vapor," which "by Fermentation takes fire" was the current opinion well into the eighteenth century, as expressed by John Rowning in "A Compendious System of Natural Philosophy" (1735). Rowning held that the great arch of an aurora was the center of burning exhalations, the streamers of light were "Streams of Fire," the trembling was due to "the Quickness wherewith the Flashes succeed one another," the great height to " the exceeding Lightness of the Effluvia," and the various spatial configurations to "motions of the air and to perspective." "When the matter of the aurora is so far spent, as to emit no more Streams, it appears only as a bright steady Light in the North, which gradually dies away, for want of fresh Fuel to support it."

\section{EDMUND HALLEY}

A quite different and a novel point of view from the above was taken by Edmund Halley (1656-1724), the great English astronomer and mathematician, popularly known for his prediction of the return of "Halley's comet" of 1680. Stimulated by a request of the Royal Society to look into the "Etiology" of the "lights in the air," the great auroral display of March 6, 1716, Halley (1716) rejected as the "Material Cause" the then current idea that they were " the Vapour of Water rarified exceedingly by subterranean Fire, and tinged with sulphureous Streams. ..." He proposed that they resulted from "Effluvia of a much more subtile Nature ... the Magnetical Effluvia, because the distribution of light was along the lines of magnetic force from a spherical magnet," a " Terrella," such as the earth. ${ }^{13}$ These magnetic effluvia might "be capable of producing a small Degree of Light ... a after the same manner as we see the Effluvia of Electrick Bodies by a strong and quick Friction emit Light in the Dark: to which sort of Light this seems to have a great Affinity."

Halley's view is remarkably modern. Although he compared the corona to the field of a spherical magnet, he did not emphasize in his 1716 paper the fact that the center of the corona corresponded in direction to the dipping needle, a point later stressed by Halley in $1726^{14}$ and by de Mairan in $1747 . .^{15}$ His most important contribution is the comparison of the aurora to magnetic and electric effluvia.

\footnotetext{
${ }^{13}$ Halley had previously postulated that the earth was a double terella, a globemagnet inside an outer magnet "as the Shell includes the Kernel."

14 In the Journal of the Royal Society, Nov. 10, 1726.

${ }^{15}$ In an article in the Mémoires of the French Academy for 1747.
} 


\section{J. J. DORTOUS DE MAIRAN}

One of the most interesting early books, and the first comprehensive treatise devoted entirely to the aurora, was by Jean Jacques Dortous de Mairan (1678-1771), entitled Traité Physique de l'Aurore Boréale. The first edition, based on reports in the Mémoires of the French Academy (1731), appeared in 1733 and recorded 229 displays of the aurora, dating from A. D. 502 until 1731 . The second edition (1754) recorded 2,137 displays gathered from all records, although duplicate observations reduce the individual number to 1,441 . De Mairan must be credited with recognizing the recurrent appearances of aurorae, as indicated in his memoires.

The first edition of the Traité was reviewed in the Phil. Trans. for 1734 by John Eames, who pointed out that most hypotheses proposed by the learned

suppose these Phosphorus like appearances to proceed from certain Effuvia, either perspired out of our Earth, or at least passing through it. But our ingenious Author has thought of a Cause very distant, as well as very different from all these, viz., the Atmosphere of the Sun, which at some time shows itself under the appearance of a Light, which he calls the Zodiacal Light, but at other times produces an Aurora Borealis. The Zodiacal light is the purer unmixed Atmosphere of the Sun: But an Aurora Borealis is the effect of the Solar Atmosphere, consequent upon its making a Descent into and blending itself with the Atmosphere of our Earth, at certain Times and Seasons of the Year. . . .

Attention had been called to the zodiacal light in the spring of 1683 by its discoverer, G. D. Cassini (1625-1712), who published an account in the Journal des Sçavans, May 10, 1683.

In the second edition (1754), de Mairan answered those who had disagreed with his hypothesis in a series of 21 " Eclaircissements." He paid particular attention to the electrical theory which had become popular since the first edition of his book (1733) but he took a dim view of the theory, pointing out that electrical manifestations (lightning) were known in the lower atmosphere but not in the upper regions, and inquired how electricity could manifest itself a whole night long in so different a form; why should electricity appear so infrequently, even after years, to suddenly manifest itself as an aurora; what is the relation of this material (electricity) to the annual revolution of the earth that it should affect the frequency of aurorae; by what mechanism or impulsion or attraction is the earth inundated by electricity at the poles rather than in the torrid zone where electricity is known to exist; finally how can one explain by electric matter all the peculiar and varied manifestations of aurorae? 
De Mairan held that he had a right to demand an explanation of these difficulties from those who believed electricity to be the cause of the aurora and asked "Can the sun produce the effects of electricity here on earth?"

De Mairan was pleased that the hypotheses of Eusebia Sguario (1738), of R. J. Boscovich (1738) and C. Noceti (1747) in a poem differed little from his own, but spent much time in refuting that of Leonard Euler (1746), who believed the aurora was made up of subtile parts of the earth's atmosphere rather than the sun's atmosphere, for he could not conceive of the sun's atmosphere extending to the earth. The aurora was much like the tails of comets, made up of "opaque particles [from the earth] receiving the light of the sun and perhaps emitting their own light, as they may vibrate in the new medium and may be ignited."

\section{THE AURORA AND THE ELECTRIC LIGHT}

De Mairan and others had overlooked the most important development of his century. Francis Hauksbee's (1709) observations of the "electric light" in evacuated tubes and the general use of electrical machines had given a great impetus to the study of electricity. Just as electric discharges in air resemble thunder and lightning, so under certain conditions the discharge in vacuo greatly resembles an aurora. Halley called attention to the similarity, and another early comparison was made by G. M. Bose (1744), after observing the light which "flowed and turned and wandered and flashed "in evacuated glass vessels as a result of electric discharges.

It is not surprising to find that Benjamin Franklin (1706-1790), independently, had definite views on the aurora, nor that he regarded the display as an example of electric fire which is diffuse rather than concentrated as in a lightning flash. In a long letter (V), addressed to Dr. John Mitchel, F. R. S. London, dated Philadelphia, April 29, 1749, Franklin stated his "Observations and suppositions toward forming a new Hypothesis for explaining the several Phenomena of Thunder-Gusts." Among other things he wrote:

When the air, with its vapours raised from the ocean between the tropics, comes to descend in the polar regions, and to be in contact with the vapours arising there, the electrical fire they brought begins to be communicated, and is seen in clear nights, being first visible where 'tis first in motion, that is, where the contact begins, or in the most northern part; from thence the streams of light seem to shoot southerly, even up to the zenith of northern countries. But though the light seems to shoot from the north southerly, the progress of the fire is really from the south northerly, its motion beginning in the north, being the reason that 'tis there seen first.... This is supposed to account for the Aurora borealis. 
At several later times Franklin expressed the same idea and in April 14, 1779 addressed the French Academy on the subject.

The relation between aurorae and electricity was generally recognized after the middle of the century. Wm. Watson in 1752 remarked how electric discharges in evacuated tubes " resembled very much the lively coruscations of the aurora borealis." John Canton (1753) also wrote: "Is not the aurora borealis the flashing of electrical fire from positive toward negative clouds at a great distance through the upper part of the atmosphere where the resistance is least?" Later he declared (1754) that he had never seen the air outdoors at night to be electrical " except when there has appeared an aurora borealis, and then to but a small degree." He gave as additional proof of electrical origin the fact that

electricity is now known to be the cause of thunder and lightening; that it has been extracted from the air at the time of an aurora borealis, that the inhabitants of northern countries observe the aurora to be remarkably strong when a sudden thaw happens after severe cold weather; and that the curious in these matters are now acquainted with a substance that will without friction, both emit and absorb the electric fluid, only by the increase or diminution of its heat. ...

This substance was tourmalin, whose thermoelectric or pyroelectric properties were discovered by Aepinus (1724-1802) in 1756. G. B. Beccaria (1758) also considered the aurorae electric in origin. Finally, Joseph Priestley (1769:353) disposed of the relation of aurorae and electricity by writing: "That the Aurora Borealis is an electrical phenomenon was I believe never disputed from the time that lightning was proved to be one." ${ }^{16}$

An alleged connection between aurorae and the weather has been noted by almost everyone, and became so fixed in the minds of observers that a Mr. J. W. Winn in 1774, in a letter to Benjamin Franklin, published in the Phil. Trans. of that year, cited twentythree cases in which an auroral display in England had invariably been followed by a southwest gale. The kind of weather predicted was by no means uniform, varying from hot to cold, and from hurricanes and stormy weather to " beau temps" depending on the experience of the person making the prediction.

${ }^{10}$ The Abbé Bertholon de Saint Nazaire (died 1799), who wrote the excellent article, "Aurore boréale," for the Dictionnaire de physique of the Encyclopedie méthodique in 1793, expressed the same generally accepted view at the end of the century, that the aurora was a "lumière phosphorico-électrique." He assembled eight principles characteristic of electricity or the "electric fluid" in support of this view. 
THE AURORA AND THE MAGNETIG NEEDLE

Edmund Halley called attention to the relation between auroral streamers and the magnetic field of the earth in 1716. The influence of the aurora in causing irregular movement of the magnetic needle during displays appears to have been first observed in 1741 by Olav Peter Hjörter ${ }^{17}$ (1696-1750), an assistant of Anders Celsius (1701-1744), professor of astronomy at Upsala. The observations were continued by Celsius and additions made in 1750 by Peter Wilhelm Wargetin ${ }^{18}$ (1717-1783), an astronomer and secretary of the Swedish Academy of Sciences.

In 1759 Canton confirmed the Swedish observations and remarked that Wargetin was "silent as to the cause." He then proceeded to give his own explanation. Canton believed that the well-known diurnal variation of the needle is connected with the daily temperature change on the earth and applied the same explanation to the aurora. Since the aurora is "electricity of the heated air above (the earth)," it would also affect the needle and would "appear chiefly in the northern regions as the alterations of the heat of the air in those parts will be greatest."

Actually the magnetic variations on the earth are primarily related to the appearance of magnetic storms on the sun, visible as the sunspots, described by Johann Fabricius (1611), and by Galilei. Cassini, in his work on the zodiacal light, had related this phenomen to sunspots and said that after the year 1688, when the zodiacal light began to decline, the sunspots also disappeared.

In later years the relation of aurorae to magnetic fields on the earth was particularly studied by John Dalton (1766-1844), the distinguished English chemist and author of Meteorological Observations and Essays (London, 1793: 153-194), who paid much attention to the disturbance of the magnetic needle during a display and also emphasized that the luminous beams were always parallel to the dipping needle and the arches bore definite relations to the magnetic meridian. The effect on the compass was also studied by Dominique François Jean Arago (1786-1853), the famous French astronomer, during the years 1818 to 1835 .

\section{MISCELLANEOUS THEORIES OF THE AURORA}

After the publication of Different Kinds of Air by Joseph Priestley (1774), Richard Kirwan (1733-1812), Irish chemist and meteorologist, published An Essay on the Variations of the Barometer

17 Vetensk. Acad. Handl., 1747.

${ }^{28}$ P. W. Wargetin, Phil. Trans. 47: 126-131, 1752, in Latin. 
(1788), in which he attributed the aurora to hydrogen, generated by putrefaction of animal and vegetable substances in the tropics, and from volcanoes. The gas was presumably kindled by electricity, as Kirwin indicated that the northern lights, highest of all meteors, were regarded by meteorologists as electrical, following Dr. Franklin's conjecture.

About the same time another gas theory was advanced by Antoine Libes (1752-1832), who suggested that the aurora was due to vapors of nitric acid which had been formed by electrical discharges through nitrogen and oxygen, when illuminated by the sun. He was led to this theory by observing the play of reddish colors in a flask of nitric oxide in sunlight in 1790 .

In the late 1700's and early 1800's auroral theories returned to the view of $\mathrm{J}$. H. Vallerius (1708), that the aurora was a reflection of the sun below the horizon. The reflecting particles might be ice crystals or clouds, a theory favored by Julius Ludwig Ideler (18091842), a meteorologist, Privatdocent at the University of Berlin and son of Christian Ludwig Ideler (1766-1846), the Royal Astronomer and Professor at the same university. J. L. Ideler took this view in his book Ueber den Ursprung des Feuerkugeln und des Nordlicht (Berlin, 1822). He held that cloud-like precipitates became attracted to the magnetic poles and arranged themselves in a stable series of forms which are recognized on the earth as northern lights by reflected light.

However, more modern views were to prevail, well expressed by Thomas Young in A Course of Lectures in Natural Philosophy and the Mechanical Arts (1807: 716):

It is doubtful whether the light of the aurora borealis may not be of an electrical nature; the phenomenon is certainly connected with the general cause of magnetism; the primary beams of light are supposed to be at an elevation of at least 50 to 100 miles above the earth, and everywhere in a direction parallel to that of the dipping needle; but perhaps, although the substance is magnetical, the illumination, which renders it visible, may still be derived from passage of electricity, at too great a distance to be discovered by any other test.

This statement represents the general opinion throughout the nineteenth century up to the time when discovery of new types of particles again raised questions as to the exact mechanism of light emission. A good example of the electro-magnetic theory of the aurora, with a model of the various effects observed, is to be found in the papers of A. De la Rive $(1862,1872)$. As indicated in a later section, De la Rive was apparently the first (1849) to observe 
how a magnet could affect the luminous phenomena in a gas at low pressure, when electric discharges were passing through the tube.

Spectral investigations of the aurora appear to have been first made by Ånders Jöns Ångström (1814-1874), astronomer at Upsala, who discovered (in 1869) the green line, whose origin subsequently aroused so much discussion. He also found three weak lines in the blue region.

\section{Ignis Lambens and Ignis Fatuus}

\section{NATURE OF THE PHENOMENON}

The ignis lambens or licking fire has excited as much superstition as the aurora but of a more personal kind, since the silent electrical discharge is often associated with human beings. Ignis lambens is without doubt an electroluminescence, but is sometimes confused with ignis fatuus or foolish fire, a phenomenon much less definite, which may have a variety of origins, as indicated below.

Practically every early writer on "meteores" and the nature of things included ignis lambens and ignis fatuus in the discussion, for example J. Jonston, in Thaumatologia Naturalis $(1632,1657)$. Like their celestial counterparts, these appearances were attributed to "exhalations." The point of view is well expressed in the account from the Speculum Mundi (Cambridge, 1635), written by John Swan (fl. 1630), as follows:

Ignis lambens is a cleaving and licking fire or light; and is so called because it useth to cleave and stick to the hairs of men or beasts, not hurting them, but rather (as it were) gently licking them. These flames may be caused two wayes, as the learned write.

First, when clammie Exhalations are scattered abroad in the aire in small parts, and in the night are set on fire by an Antiperistasis; ${ }^{19}$ so that when any shall either ride or walk in such places as are apt to breed them, it is no wonder that they stick either on their horses, or on themselves.

Secondly, they may be caused another way, vis. when the bodies of men or beasts, being chafed, do send out a fat and clammie sweat; which (according to the working of nature in things of this kinde) is kindled and appeareth like a flame.

Ignis fatuus, or foolish Fire (so called, not that it hurteth, but feareth or scareth fools) is a fat and oily Exhalation hot and drie (as all Exhalations are which are apt to be fired) and also heavie in regard of the

${ }^{18}$ Antiperistasis-“Antagonism of natural qualities, as of light and darkness, heat and cold; specifically, opposition of contrary qualities by which one or both are intensified, or the intensification so produced." Century Dictionary, 1891. 
glutinous matter whereof it consisteth: in which regard the cold of the night beats it back again when it striveth to ascend, through which strife and tossing it is fired, (for in this encounter it suffereth an Antiperistasis) and being fired it goeth to and fro according to the motion of the Aire in the silent night by gentle gales, not going alwayes directly upon one point, ...

These kindes of lights are often seen in Fennes and Moores, because there is alwayes great store of unctuous matter fit for such purposes; as also where bloudie battells have been fought; and in church-yards or places of common buriall, because the carcases have both fatted and fitted the place for such kinde of oyly Exhalations. Wherefore the much terrified, igncrant, and superstitious people may see their own errours in that they have deemed these lights to be walking spirits; or (as the silly ones amongst the Papists beleeve) they can be nothing else but the souls of such as go to Purgatorie, and the like. In all which they are much deluded: For souls departed (Eccles. 9.5,6.) cannot appeare again: ...

There can be no doubt of the religious affiliation of the author.

Not all the explanations relied on an exhalation set on fire by antiperistasis. Christopher Merret (1614-1695), curator of Wm. Harvey's library and museum, published a museum catalogue in 1660 in which (under "Meteora") he defined "Ignis fatuus, the Walking Fire or Jack of the Lantern" as "a white and glutinous substance seen in many places which our people call 'star faln'; they believe it owes its origin to a falling star and is its stuff. But to the Royal Society I openly demonstrated that it merely arises from the intestine of frogs ${ }^{20}$ piled up in one place by crows."

Willoughby and Ray, ${ }^{21}$ according to Dr. Derham ${ }^{22}$ (1657-1735), both thought the phenomenon was due to "shining insects." Wm. Derham himself, however, who saw an ignis fatuus on a calm dark night, wrote: "with gentle Approaches I got up by Degrees within two or three yards of it . . f found it frisking about a dead Thistle growing in the Field, until a small motion of the Air ... made it skip to another Place, and thence to another, and another." Derham related that he saw this fifty-five years ago but "I am of the same Opinion now, that it was a fired Vapour," not glowworms, as he never saw glowworms in such large numbers.

\footnotetext{
${ }^{20}$ According to J. L. Wolff (1733), Robert Fludd (1574-1637), is alleged to have caught an ignis fatuus and found in his hand a sticky matter similar to the sperm of frogs.

${ }^{21} \mathrm{~J}$. Ray made the suggestion that an ignis fatuus was "nothing else than swarms of these flying glow-worms," in his Travels through the Low Countries, etc. (1673). during a stay near Bologna in 1664 .

${ }^{22}$ W. Derham in Phil. Trans. 36: 204-214, 1729. See Priestley (1772, 580 ff.) for other records of ignis fatuus.
} 
We have seen (Chap. III) how John Wier (1579) made a plea for a rational explanation of such appearances, rather than to accept the popular belief that they were apparitions or specters, spirits of unrighteous men or ghosts of unbaptized children, generally works of the devil and sometimes omens of death. However, many writers since his time have applied the supernatural explanation.

It is interesting to note that 150 years later the question was still alive. Johann Leonard Wolff wrote an Exercitatio Physica entitled, An Ignes Fatui Sint Spectra in 1733 in which he also took the position that they were not apparitions (even though they did appear in cemeteries and near gallows) because they were material and corporeal and could be explained by physical means. The evidence was

that putrid wood, the putrid viscera of fish, and the exhalations of certain animals and insects shine at night and emit a splendor very much like that of fire or sparks. ... But nothing is found in these shining things that could produce the light and splendor except sulphuric, bituminous, oily and viscous effluvia.... Hence ignes fatui produced out of these ... effluvia, which are material, must themselves be material. . . .

Wolff had to admit that some strange things had been reported in addition to the fact that they follow a person who flees and recede from those who approach at full speed. He wrote: "It has been observed that these ignes fatui recede farther from the vicinity whenever a man swears recklessly in a loud voice; but when a scrupulous person takes a deep breath out of a pious heart or sends prayers to God, to him they come closer."

Thus an ignis fatuus was quite generally regarded as "a kind of slight exhalation set on fire in the night-time, which oftimes causes men to wander out of their way," ${ }^{23}$ a point nicely expressed by Samuel Butler (1612-1680) in Hudibras (I, 1: 509, 1660):

An Ignis Fatuus that bewitches and leads Men into Pools and Ditches.

In more recent times ignis fatuus has been attributed to masses of phosphorescent wood or fungi, to stray light reflected from wisps of vapor, which frequently condense near low ground and damp places in the early evening, or to marsh gas set afire, ${ }^{24}$ or to self inflammable

${ }^{23}$ Edward Phillips (1630-1696), in the New worlde of English words (1658).

${ }^{24}$ In a letter (Dec. 10, 1776) to Priestley (published in Experiments and observations on different kinds of air, 3: appendix, pp. 381-382, 1777) on "Inflammable Air from Putrefaction of Vegetable substances," A. Volta explained "ignes fatui " over marshy ground by inflammable air set on fire "by the help of the electricity of fogs, and by falling stars which are very probably thought to have an electrical origin." 
phosphine, ${ }^{25}$ or to electrical discharges. ${ }^{26}$ The English names applied have been as numerous as the explanations-Kitty-with-a-wisp or Kit-with-the-Candle-Stick, fetch lights, dead men's candles, corpse candles or elf candles, etc., when seen near grave yards. To the French they were "feux follets" and to the Germans, "Irrwisch" or "Irrlicht." The author has never seen one, unless an ignis fatuus is no fire at all but a whisp of vapor condensing over a marsh and seen in a dim light.

\section{RECORDS OF IGNIS LAMBENS}

Examples of ignis lambens in classic times have already been given in Chapter I, the most quoted being the flames that appeared about the heads of Julus (Ascanius), of Servius Tullius, and of L. Marius; flame from the unbridled horse of Tiberius; and the legend of Alexander the Great of whom it was said he emitted sparks in battle. Thomas Bartholin (1647) collected many records from the nobility, cited in Chapter IV of this book.

Other examples of ignis lambens were reported in a treatise $D e$ Igne Lambente (Verona, 1642), by Ezechiel (later Petrus) di Castro, a physician of Verona; in De Ignis Lambentibus (Jena, 1686), a Disputatio Physica, by J. C. Vulpius; and in a paper in the Ephemerides Naturae Curiosum for 1733-" De Rariore Ignis Lambentis Specie "-written by "Eugenianus I."

The Ignis Lambens of di Castro, an octavo book of 198 pages, dealt with more than the "licking fires" its author had observed in medical practice. He began with a general discussion of the three kinds of fire, recounted the famous historical cases of ignis lambens, and referred to the various luminescences of animals and plants. However, di Castro is most quoted for his luminous matron of Verona, who appeared not only in Bartholin's famous book (1647) but in most later accounts of strange light connected with human beings.

The "Disputatio Physica" of Vulpius, De Ignis Lambentibus (1686) was a really comprehensive compilation (32 pages) of the records of ignis lambens, going back to classic times. Its title is reproduced as figure 21 . The observations and opinions of over sixty eminent commentators on the subject are given, including writers up to the latter part of the seventeenth century.

The light from combing human hair was often recorded. Light from the hair of horses, cats, dogs, and other animals, when stroked

${ }^{25}$ Phosphine is not known as a decomposition product of organic matter.

${ }^{28}$ An account related by J. Priestley in his book on Electricity (I769: 294), quoted in the next section. 
or rubbed, was known to all observers and usually mentioned when luminous phenomena were listed, as appears in the writings of $\mathrm{J}$. C. Scaliger, J. Cardan, F. Bacon, T. Bartolin, P. Borel, R. Boyle, W. Simpson, Newton, and others.

Many accounts have to do with ignis lambens connected with bed clothes or wearing apparel rather than the human body. In the Speculum Mundi (1635) of John Swan, it is reported that persons "testify how they have been scared in their beds by a kinde of light sticking to their coverings, like dew upon the nap of a frieze coat: which must needs be this Ignis Lambens, caused by some kinde of clammie sweat proceeding from among them."

Rudolph Jacob Camerarius (1665-1721), professor of botany at the University of Tubingen, and his brother, Elias Camerarius (1672-1734), professor of medicine at Tubingen, both described linen shining at night in 1690 and $1691 .^{27}$ The subjects were young men of good "temperament," whose physical characteristics were described in some detail, as possibly bearing on the origin of the light, which struck terror in the men, and in friends who observed it. A peculiarity of one subject was that he sweated a great deal and was the only person in his family with this characteristic.

The phenomenon appeared especially when the linen was rubbed and it made no difference whether the material was hot or cold, had been washed in different ways at different times, or whether the man changed his dwelling to a place many miles away. There was no heat, no smoke, no odor, good or bad, and the linen was not burnt. Although minute sparks were seen, the electrical origin of the light was not suspected at that time. The appearance was compared by E. Camerarius to various phosphors-the glowworm and rotten wood and fish-in fact the light of the linen was classed as a natural phosphorus.

There are too many old accounts of luminous clothes and luminous hair to warrant tabulation, but they always excited interest, and were supposed to be connected with some peculiarity or act of the individual. Sir Hans Sloane (1660-1753), famous physician and naturalist, successor to Newton as president of the Royal Society, knew "a Bristol gentleman and his son, both whose stockings will shine after much walking, like glow-worms or shining beetles." $27^{\mathrm{a}}$ Robert Symmer (1759) also observed the shining of silk stockings. Johann Friedrich Henkel (1679-1744), a physician in Freiburg interested in plants and minerals, in 1740, and Sigismund Friedrich

${ }^{27}$ Translations of the original Latin articles in the Ephémérides will be found in the Collection Académique Etranger 6: 316, 320, and 336.

${ }^{27 a}$ From T. Knight, 1749: 56. 
Hermbstädt (1760-1833), a physician and royal apothecary in Berlin, in 1808 , both described men whose sweat was luminous, especially when rubbed or on removing clothing. Although the light was attributed to the sweat, and was thought to be due to salts eaten by the men, the accounts suggest that electric discharges were responsible for the light at the time their clothes were removed.

Such "lucid effluvia in animals" were supposed to be a kind of burning or were explained by the principles of fermentation. Only as a result of the growing interest in electricity was the true origin of the light generally accepted, a connection which will be traced in the next section.

\section{RELATION TO ELECTRICITY}

Although Stephen Gray (1720) noted the light when silk wool was pulled through the fingers, and knew the effect was electrical, he made no mention of ignis lambens. One of the first cases to which an electrical origin was applied (by H. Miles in 1745), was an old one, that of Mrs. Suzanna Sewall, wife of Major Sewall and daughter of Lord Baltimore, described in a letter from William Digges to the Reverend John Clayton at James City, Virginia, and sent by him to Robert Boyle under date of June 23, 1684:

There happened about the Month of November to one Mrs. Susanna Sewall: ... a strange Flashing of Sparks (seem'd to be of Fire) in all the wearing Apparel she put on, and so continued until Candlemas.... . The said Susanna did send several of her wearing Apparel; and, when they were shaken, it would fly out in sparks, and make a noise much like unto Bay-leaves when flung into the fire; and one spark litt on Major Sewall's Thumb-nail, and there continued at least a Minute before it went out, without any Heat: All which happend in the Company of Wm. Digges, my Lady Baltimore, etc. . . .

They caused Mrs. Susanna Sewall one Day to put on her sister Digges's Petticoat, which they had tried beforehand, and would not sparkle, but at Night when Madam Sewall put it off, it would sparkle as the rest of her own Garments did. ${ }^{28}$

The letter was read before the Royal Society in 1745 by the Reverend Henry Miles, F. R. S., parson at Touting in Surrey and a writer on electrical matters. He proceeded to explain the effect as due to electricity rather than "fermentation." He wrote: "I humbly apprehend, the Properties of the Effluvia in animal Bodies are many of them common with those produced from Glass, etc.; such as their being lucid, their Snapping and their not being excited without some Degree of Friction, and I presume, I may add Elec-

${ }^{28}$ From H. Miles, Phil. Trans. 43: 441-446, 1745. 
tricity; for I have by repeated trials, found a Cat's Back to be strongly electrical, when stroak'd." Miles went on to point out that "electrical effluvia" and "luminous effluvia" are the same.

Electricity as a cause of ignis lambens was also adopted by Bonifaz Heinrich Ehrenberger (1681-1759), a professor of mathematics and metaphysics at Coburg. Ehrenberger's tract (1745) is in the form of a memorial to B. G. H. Hoffman, with the title: Concerning the Mistress Shedding Light and Sparks. In this case the persons involved were of humble origin, and the story one of illicit love. When the couple met, the girl was observed "shining and scattering sparks." The high magistrate of the town saw this as proof that the pair was incurring its doom, and forbade their marriage.

Ehrenberger, however, had his own explanation. He wrote:

... For she was so filled with the ardor of love that her limbs were far from being stiff with cold, rather the excessive heat stirred up a greater and more intense motion of her blood and also sweat, which adhering to the passages of the skin or the fibers of her clothing partly diffused light, and, separated from them by the motion of the air, partly spread sparks. This makes it evident that there is something similar to what happens in electricity. For the latter originates from swift and intense motion. . . By that motion light is generated in the electric. ${ }^{29}$

After the middle of the century, the electrical explanation of ignis lambens became universal, as had the electrical nature of the aurora borealis.

\section{The "Electric Light" and "Electric Fire"}

\section{VIRTUES AND EFFLUVIA}

Although William Gilbert (1540-1603) introduced the words "electricks" and "anelectricks" for substances which would or would not attract light bodies, there is no mention of any luminous phenomena in his famous book, De Magnete (1600). Apparently van Helmont ${ }^{30}$ used a word, translated as " electricity," in connection with the cure of wounds by magnetism. Thomas Browne ${ }^{31}$ (1605-1682) also spoke of electricity in Pseudodoxica Epidemica, and Boyle used the term regularly in Experiments and Notes about the Mechanical Origine or Production of divers particular Quali-

\footnotetext{
${ }^{29}$ Translated by Mrs. A. Holborn from De amatrice lumen scintillas spargente, Coburg, 1745.

${ }^{30} \mathrm{~W}$. Charleton, $\boldsymbol{A}$ ternery of paradoxes of the magnetic cure of wounds, etc. translated, illustrated and ampliated by W. Carleton, 77, London, 1650, a translation of van Helmont.

${ }^{31}$ Pseudodoxia epidemica, Book II, Chap. 4.
} 
ties, often referred to as Tracts on Magnetism; and Electricity (1675).

The term "electric virtue," universally used to describe the new properties of electrified bodies, stems from Gilbert's idea of the orb of virtue about a magnet, within which magnetic effects are detectable. There was also the orb of coition, within which small bodies actually move toward the magnet. These orbs were spoken of as " effused" and to have "effluent strengths." The electric effluvium of amber was regarded as corporeal like a vapor given off from a liquid. ${ }^{32}$ Later, all sorts of properties and characteristics were referred to as virtues, especially by von Guericke, who spoke of the "lighting virtue" and "coloring virtue" of the sun, of "sounding virtue" when a sound was heard. It is no wonder that the electric virtue and the lighting virtue or electric light and fire should be regarded as the same thing by $\mathrm{Wm}$. Watson as late as 1752 .

\section{OTTO VON GUERICKE}

The invention about 1660 by Otto von Guericke (1602-1686) of a device to generate electrical charges first called attention to the "electric light," and indicated a connection between the electric virtue and the lightning virtue. Von Guericke's machine was a ball of sulphur which could be rotated on a shaft. It was charged by holding the hand on it during rotation, and von Guericke (1672) himself noticed that "if you take the globe with you into a dark room and rub it, especially at night, light will result, as when sugar is beaten."

The review of von Guericke's book, Experimenta Nova Magdeburgica (1672), for the Royal Society ${ }^{33}$ emphasized the philosophical aspects of his discoveries rather than the electrical phenomena. Von Guericke

thinks may be represented the chief Vertues he enumerates of our Earth, perform'd by a Globe of Sulphur melted and cooled again, and then perforated to traject an Iron axis through it for circumvolution; whereby attrition being used withall, he affirms that the Impulsive, Attractive, Expulsive and other vertues of the Earth, as he calls them, may be ocularly exhibited.

Von Guericke's globe possessed not only the virtue of light but also a virtue of sound, "for when it is carried in the hand or is held in a warm hand and thus brought to the ear, roarings and cracking are heard in it." It was in fact an electric terella instead of

${ }^{32}$ See R. Boyle, Essays of effluviums, etc., London, 1673.

${ }^{s 3}$ Phil. Trans. (No. 88), 5103-5105, 1672. 
a magnetic terella, such as had been previously studied by Gilbert. These experiments were made in the early sixteen sixties and observed by the physician, Adviser to the King, and Lieutenant of Police from Lyons, Balthasar de Monconys, ${ }^{34}$ but not published by von Guericke until $1672 .{ }^{35}$

Von Guericke not only heard the electric noise and saw the electric light but discovered most of the fundamental phenomena of static electricity in so simple a form that later workers are usually thought of in connection with the concepts. Conduction and induction were clearly observed by von Guericke although the former is usually credited to Gray in 1729 and the latter to Dufay in 1733 .

Luminescence from rubbing the well-known electric, amber, must have been noticed by many persons, although the effect appears not to have been recorded until the paper of W. Wall (1708). One of the important early observations of electroluminescence was that of Robert Boyle (1663) on a diamond which "being rubbed upon my clothes as is usual for the exciting of amber, wax and other electrical bodies, it did in the dark manifestly shine." Some of the light in this case was undoubtedly due to electrical discharge but complicated by phosphorescence and thermoluminescence, characteristics of certain kinds of diamonds (see Chapter X).

After the sulphur ball and the diamond, the next instance of artificial electric light to be described was the luminous barometer, which came to be known as the mercurial phosphor, although it was not recognized that the phenomenon was connected with electricity until some years later.

\section{THE BAROMETER LIGHT OR THE MERCURIAL PHOSPHOR}

Two pupils of Galileo, Evangelista Toricelli (1608-1647) and Vincenzo Viviani (1622-1703), constructed the mercury barometer in 1643 , thereby contributing to science an instrument of universal importance in research. During the latter part of the seventeenth century, every laboratory had its barometer. Some thirty years after its invention, in 1675, Jean Picard (1620-1682), a French priest and one of the famous group of astronomers at the newly established Paris observatory, noticed a glow above the mercury in his barometer when carried about in a dark room, and duly reported this observation in a note in the second volume of the Mémoires de l'Académie

${ }^{34} \mathrm{~B}$. de Monconys, Journal des voyages, 3 parts, Lyons, 1665.

${ }^{35}$ Experimenta nova (ut vocantur) magdeburgica de vacuo spatio, Amsterdam, 1672. German translation in Ostwald's Klassiker, No. 59. Kaspar Schott (1608-1666) repeated many of von Guericke's experiments and published them as Mechanica hydraulico-pneumatica in 1657. 
Royale des Sciences covering 1666-1691, published in 1730. The discovery was reported in the publications of other societies, and the public exhorted to carry out research on so singular a phenomenon. One of the remarkable characteristics of the light was its appearance when the mercury moved downward but not when it was moving upwards. A number of barometers behaved like the one of Picard but others did not. After the first enthusiastic report the eerie light was neglected for some years.

In 1700 Johan Bernoulli the first (1667-1748), Swiss mathematician and son of Nicolas, founder of the famous family, again called attention to the barometer light and considerable discussion ensued in the French Academy at that time. The argument, in which Cassini and de la Hire joined, chiefly centered around the precautions necessary to produce the effect. Bernoulli's three letters (17001701) were published by the French Academy and translated by Martyn and Chambers (1742). In the first letter, June 19, 1700 , he suggested that pure mercury and complete absence of air were essential, because in passing through air, the mercury became covered with an ash gray pellicle which prevented the material of "the first element" from passing out of the mercury into the vacuum. ${ }^{36}$ Consequently, Bernoulli devised some ingenious methods of filling the barometer without allowing the mercury to come in contact with air, but the French Academy was not always successful in obtaining a luminous barometer by following his methods. Bernoulli reasoned that light appears when the mercury descends because a subtle material must go out of it (call it matter of the first element) and meet another matter that enters through the pores of the glass (matter of the second element or celestial globules).

He went on to say that while particles of the first element are in the mercury they cannot make light, because they are "oppressed" by the mercury but when they get out by descent of the mercury, they

take that rapid course [out of the mercury] ... and by the effect which they make on the celestial globules which meet them, they produce this light; from whence the reason is seen why this light is only observed in the descent of the quicksilver; for when it reascends the matter of the first element is so far from going out, that there rather enters again, a part of that which went out in the preceeding fall; and the rest is driven away with the celestial globules, out of the tube through the pores of the glass.

\footnotetext{
${ }^{36}$ Bernoulli accepted the Cartesian conception of light, "making it consist in the inost rapid motion of the matter of the first element, assembled only in some space, and in the effort which it makes on the celestial globules."
} 
New matter of the first element must keep coming from the mercury to make the light visible and hence the light only lasts while the mercury descends.

Repetition of Bernoulli's new methods by the French Academy also gave trouble, but in September, 1706, M. Du Tal, in an article published in the Nouvelles de la Republic des Lettres in 1716 confirmed Bernoulli's results using well purified mercury, and suggested that the Academy members had not carried out his directions exactly. This was undoubtedly true, for Bernoulli's reasoning and experiments were all that could be desired. It is probable that the reason some barometers did not luminesce was the presence of quenchers as impurities and the experiments may be taken as the first to demonstrate quenching of electroluminescence, but it is difficult to assign a name to the discovery.

However, Bernoulli's chief claim to luminescence fame lies not in his barometer experiments but in demonstrations which followed from them, described in his second letter to the French Academy, November 6,1700 . He placed clean mercury in a clean phial well exhausted of air and found that a brilliant light appeared whenever he shook the phial. This was called the "perpetual phosphorus," which would last forever. Bernoulli wrote: "The curious to whom I have shown them [the exhausted phials containing mercury] have declared, that they have seen nothing more wonderful, in short, the whole phial is in a flame, and the quicksilver like a burning liquor."

When air was let in, the light no longer appeared on shaking and the mercury surface was found to be covered with a pellicle. In a third letter, July 5, 1701, Bernoulli described preparing some particularly pure mercury, which he placed in a scrupulously clean phial and found that it gave light by shaking when the vial was full of air. The light

appeared only like separate sparks, which arose successively and perished almost at the same time; whereas the light in the vacuum is like a continual flame which lasts incessantly while the quicksilver is in agitation. I conclude from these experiments, that the quicksilver, if it be perfectly purified, may let the subtile matter (which I call with M. Descartes, by the name of the first element) go out of its pores in such a quantity at once, that for all the resistance of the air, it has still motion enough to produce some light.

The visual evidence for an electrical origin of the light was thus described by Bernoulli, but at that time electrical knowledge was confined to attraction and repulsion, with no inkling of the spectacular development to come.

The experiments of Bernoulli aroused the interest of the English 
experimenter, Francis Hauksbee, whose studies of the light from mercury and other materials in a vacuum during the first decade of the eighteenth century are so important that they will be considered in a separate (the next) section.

During the years 1710-1719 a number of publications on the barometer light appeared; by N. Hartsoeker (1710), who denied Bernoulli's facts and theory without adding anything himself; by T. Negotius (1715), an inconsequential pamphlet of eight pages; by J. F. Weidler (1715), who also combatted Bernoulli's views, holding that the pellicle on the mercury does not interfere with the light, which comes from rebounding of the rays of luminous material; by J. M. Heusinger (1716), an excellent forty-eight-page dissertation (see title page in figure 22) under the auspices of J. G. Liebknecht (1679-1749) professor of mathematics and theology at the University of Giessen; then the views of J. J. D. de Mairan (1678-1771), expressed in his prize essay on phosphores (1717); finally another dissertation of seventy-four pages by W. B. Nebel (1719), under the auspices of J. Bernoulli ${ }^{37}$ at Basel. The Nebel thesis gave Bernoulli an opportunity to sum up the knowledge and to answer his critics. The pamphlet ends with a discussion of the uses of the light and dedicatory poems.

It is not worth while to recount the detailed experiments of all these men. The most surprising result of the extended investigations is the totally opposite conclusions drawn from the experiments. For example, Bernoulli stressed removal of air, while Heusinger (1716) found luminous barometers in which he could observe bubbles of air, and pointed out that small air pockets sometimes observed along the sides of a barometer tubes could emit flashes of light. Nevertheless, he agreed that air should be removed and that water was particularly harmful, if light were to be observed. Pure mercury did not appear to be necessary, as he had made a luminescent barometer with an amalgam in which five parts of lead were added to twenty-three parts of mercury. Heusinger called attention to the ready divisibility of mercury into the finest globules and, like Bernoulli, held that a subtile luminous material must be present in the interstices between the minute globules, a material which is expressed when the mercury is agitated and produces the light.

De Mairan (1717) had an ingenious explanation for the fact that

${ }^{3 r}$ This thesis was included in the Opera omnia of J. Bernoulli, 2: 319-392, Lausanne and Geneva, 1742. Bernoulli's work and the experiments of others excited considerable general interest and were discussed in Elementa physices (Jena, 1727) of Georg Erhardt Hamburger (1697-1755) in Chapter X, dealing with fire. 
light appears only when the mercury is falling. He held that luminescence was due to the "sulphur" of the mercury in movement, but that a material, different from common air, remained in the vacuum and arrested the movement of the "sulphur" and consequently the light. When the mercury descends this "sulphur-arresting material cannot follow the mercury rapidly enough and the "sulphur" can escape, with luminescence, but when the mercury rises the material prevents escape of "sulphur" and no light appears.

In 1723 a final paper on the mercury barometer was published in the Mémoires of the French Academy by C. F. Dufay (1698-1739), whose later researches in electricity (1733-1734) were to make him famous. Dufay also studied the luminescence of minerals and precious stones in three later papers $(1726,1732,1738)$, again published in the Mémoires of the French Academy. It would seem that an interest in luminescence and electricity would be a happy combination and the explanation of the barometer light might naturally follow. However, such was not the case. Les Baromètres Lumineux (1723), after an historical introduction, is largely concerned with Dufay's attempts to find a fool-proof method of making a luminous barometer. He came to the conclusion that an excess of air prevented luminescence and that water was absolutely prohibitive. He suspected that something in the mercury must be involved in luminescence or non-luminescence and postulated two principles-one was common air which he proved to be present, "as it is in all liquids," and the second a "matière subtile," responsible for the light. He believed that ordinarily the air in the mercury enveloped and prevented the subtile matter from getting out, but if there was not much air present, on shaking in a vacuum the subtile material could escape.

It is squeezed out particularly as the column of mercury of a barometer moves downward. When the mercury moves up, the pores of the mercury are so dispersed as to receive the subtile material and no light appears. The subtile material is thus not lost or gained during a long rest of the barometer, but appears again whenever it is agitated. Dufay's theory is little more than a restatement of previous views.

Despite the many observations of Hauksbee from 1705 to 1711 , and despite Dufay's later interest in electricity, there is no mention in Dufay's Mémoire of a possible electrical origin of the light and no identification of the subtile material with electrical effluvia. Dufay did mention Hauksbee's experiment of 1708 in which light appeared when he brought his hand near a rotating globe from which the air had been exhausted and also Hauksbee's belief that the barometer 
light was due to the friction of the mercury against the glass, but did not profit by the suggestion.

Discussion of the barometer light had actually stimulated Haukebee (1705) to undertake his own experiments on the light from mercury in motion and from friction on surfaces, together with his observation on light in vacuo. However, he worked with large vessels rather than barometer tubes. Hauksbee discussed and for all practical purposes demonstrated the electrical origin of the mercurial phosphor, although it remained for Christian Ludolff (17101763) actually to test a barometer in 1745 and find by the movement of silk threads that the glass became electrified in the region where the mercury had passed. The manner in which light and electricity came to be closely associated will be explained in the following sections.

\section{FRANCIS HAUKSBEE AND EVACUATED GLOBES}

In the meantime a worthy successor to Robert Hooke was appointed to prepare experiments for the Royal Society, Francis Hauksbee (died 1713), about whose life little is known except that he had no formal education. One of his many interests was the mercurial phosphor, which he imitated ${ }^{38}$ with a mass of mercury in an evacuated bottle. The demonstration led him to publish several papers in the Phil. Trans. between 1705 and 1711 , having to do with the light which appears when bodies are rubbed or abraded in a vacuum. This work, with additional material, which was collected in a book, Physico-mechanical Experiments, London, 1709, entitles Hauksbee to be called the founder of the science of electroluminescence, even though von Guericke had noticed the "lighting virtue" of his sulphur sphere when rubbed. A second edition (1719) contains two additional experiments on light, but nothing new was added to his previous discoveries. The title page of the first edition is reproduced as figure 23.

Hauksbee first described what happens when air is passed through mercury into a vacuum, "blowing up with Violence against the sides of the glass that held it, appearing all-round as a body of Fire, made up of abundance of glowing Globules, Descending again into its self. The Phenomenon continuing till the Receiver was half Repleat with Air."

In another experiment mercury forced into an evacuated vessel by the pressure of the air appeared "like a Shower of Fire in a

${ }^{38}$ F. Hauksbee, Phil. Trans. 24: 2129-2135, 1704-1705. Most laboratory workers have seen the greenish glow at the region where mercury vapor condenses in a mercury vacuum pump. 
very surprising manner." Some of the mercury globules rolled down the sides of the glass and others fell directly and Hauksbee observed that only the former, with a rotary motion produced light. Using his mercury gage, he determined that only when the mercury was sinking in the gage did light appear and only if the pressure was about half an atmosphere or less. By allowing mercury to fall into a vacuum and strike a rounded glass surface, Hauksbee noticed that " the mercury did not only appear as a shower of Fire, but from the Crown of the included glass were darted frequently Flashes resembling Lightning of a very pale Colour, very distinguishable from the rest of the Light produc'd." The two essentials for the appearance of light from mercury appeared to be a rolling motion of the mercury and a partially evacuated space.

The latter requirement, however, was only necessary for the brightest light. When the mercury was violently shaken in a globe containing air at atmospheric pressure " Particles of Light appear'd plentifully, about the bigness of small pin beads, very vivid, resembling bright twinkling stars. ..." When the same vessel was exhausted, "the mercury then did appear Luminous all round, not as before, like little bright sparks, but as a Continued Circle of Light during that motion."

In a more modern version of the mercurial phosphor, a tube containing mercury is filled with neon at low pressure. Because of the low excitation potential and red luminescence of neon, it is easy to observe that as the mercury is made to roll over the glass surface a bright red glow appears at the rear end of the mercury drop as it separates from the glass. By shaking the tube violently a beautiful red glow can be obtained. These tubes are sometimes made in the form of annuli and worn as earrings, which luminesce with every turn of the head.

Hauksbee's researches on light from mercury in glass vessels, which he attributed to friction on the glass walls, led him to investigate the effects of rubbing other materials. His first paper on the subject in 1706 was entitled: "An experiment touching the production of a considerable light upon a slight attrition of the hands on a glass globe exhausted of its air; with other remarkable occurrences."

This contribution presents the first experiments on electroluminescence following observation of the barometer light. The exhausted glass globe was about nine inches in diameter, fixed on his device for rotation:

and then applying my naked Hand (expanded) to the surface of it, the result was, That in a very little time a considerable Light was produc'd. And as I mov'd my hand from one place to another (that the 
moist effluvia, which very readily condense on the Glass, might, as near as I could, be thrown off from every part of it,) by this means the Light improv'd; and so continued to increase, till words in Capital Letters became legible by it: (as has been observed by Spectators.) Nay, I have found the Light produc'd to be so great, that a large Print might without much difficulty be read by it: and at the same time, the Room, which was large and wide, became sensibly enlightned, and the Wall was visible at the remotest distance, which was at least 10 Foot. The Light was of a curious Purple Colour, and was produc'd by a very slender touch of the Hand; the Globe at the same time being scarce sensibly warm: neither could I ever find, that a more violent Attrition did contribute any thing to the increase of the Light.

He then let in the air and noticed that when the globe was revolved no inner light appeared on touching, but that:

For if a Man touch'd the Globe with his Fingers, there were specks of Light (tho' without any great Lustre) seen to adhere to them. Nay, while my Hand continued upon the Glass, (the Glass being in motion) if any Person approach'd his Fingers towards any part of it in the same Horizontal Plane with my Hand, a Light would be seen to stick to 'em, at the distance of an inch or thereabouts, without their touching the Glass at all; as was confirm'd by several then present.

Hauksbee next studied the appearances with different amounts of air present in the globe and compared these effects with the difference in behaviour of mercury shaken in vacuo and in different amounts of air. His globe experiments confirmed his view that the mercurial light came not from any peculiarity of mercury but from the rubbing of the mercury on the glass walls.

Hauksbee then showed that attrition of a number of substances in vacuo would result in a light. His device fos doing this is illustrated in figure 24. When amber beads were rubbed against woolen in vacuo a light appeared which " is not a meer lambent Fire, but such as is accompanied by great Heat." He noted "That this Light depends so immediately on the Attrition, as to disappear where it ceases. That it requires a very thin and rare Medium, in order to its Appearance: And the thinner the Medium, the greater the Appearance." The light was much greater in vacuo and was due of course to an electric discharge at reduced pressure.

Hauksbee also studied the light from attrition of various combinations in vacuo, flint and steel, glass on oyster shells (" a fierce flaming of spark"), oyster shells on woolen ("a dim one, and, at best like a faint Halo"), woolen on woolen (" a small glimmering Light"), glass on glass ("a considerable Light," the color "of melted Glass"). 
The glass on glass experiment was even tested under water when "A pretty brisk Light was produc'd," red in color, but the most important observations came from the attrition of glass and woolen. In vacuo this "quickly produc'd a beautiful Phenomenon, viz, a fine purple Light, and vivid to that degree, that all the included Apparatus was easily and distinctly discernable by the help of it. And thus it continued while the friction lasted."

If the woolen cloth was soaked in spirit of wine or impregnated with saltpetre "I observ'd the Light to break from the agitated Glass in a very odd form, resembling that of Lightning. This is manifestly different from the last Phenomenon: For there indeed we had a delicate Purple-colour'd Light; but here, a brisk fulgurating Light, scattering itself about in Flashes, and darting with a force from the surface of the revolving Glass."

Hauksbee realized that rubbing the glass electrified it so that brass foil and threads were attracted, and that both noise and light were apparent. In one experiment a bright light appeared inside an exhausted glass globe which was arranged within a rotating glass globe filled with air (see fig. 24). When rotation stopped the light disappeared but returned when rotation was again started. If both globes were rotated the light was much brighter. If the hand was brought " near the surface of the outer Glass, there would be Flashes of Light (like Lightning) produc'd in the inward Glass; just as if the Effluvia from the outer glass, had been push'd with more force upon it by means of the approaching Hand."

Hauksbee was particularly interested in the relation between electrical and luminous effluvia and cited a number of cases which finally led him to declare that there was " a real difference... (at least in some Cases)" between the two. "For these Qualities require different Circumstances with respect to the Circumjacent Medium, in order to their discovering themselves." His researches on electrical discharge in vacuo were so varied and so significant as to establish him as the true discoverer of electroluminescence in the laboratory; nor should it be forgotten that he was the inventor of an electrical machine in use for half a century.

Hauksbee's experiments may be said to have set the scientific world to rubbing and it soon became evident that rubbing various materials would quite regularly result in a luminescence, whether in a vacuum or in the air. A statement in the Histoire of the French Academy (see Martyn and Chambers 3: 3-5, 1742) for 1707 referred to the new "perpetual phosphorus" of Johann Bernoulli, "which could not fail of raising the curiosity of philosophers, and especially those of the academy, who had a sort of right to a discovery made 
by one of its members. Among other experiments on this head they came at length to the light that certain bodies yield, by rubbing in the dark," like cat's fur, or sugar, or sulphur pounded.

The French Academy held that certain conditions had to be observed in order to obtain light by friction: (1) one of the bodies "must be transparent that the light may be seen through while it lasts"; (2) "the surface of the bodies must be plain, smooth and clean that the contact may be the more immediate"; (3) the "two bodies must both be hard "; (4) "a great density without a great degree of hardness will also have its effect"; (5) "one of the two bodies must be as thin as possible that it may be the easier heated by friction "; (6) "Gold rubbed upon glass, appeared the fittest of all metals to afford light; but no body yields so exquisite a light as a diamond, which comes nothing behind a live coal, briskly blown by the bellows, nor is it any matter how thick the diamond is."

The luminous qualities of amber, diamonds, and gum lac were also studied by a Dr. Wm. Wall (1708), with a somewhat different approach. He explained in a letter to Dr. Hans Sloane, Secretary of the Royal Society, that he came to the idea that amber might be a "Natural Phosphorus or Noctiluca " by reflecting that the "Artifical Phosphorus," the element, is made from dung or urine which contains

an Oleosum and Common Salt, so I take it the Artificial Phosphorus to be nothing else but that Animal Oleosum, coagulated with Mineral Acid of Spirit of Salt, which Coagulum is preserv'd and not dissolv'd in Water, but accended by Air. ... These considerations made me conjecture that Amber, which I take to be a Mineral Oleosum coagulated with a Mineral Volatile Acid, might be a Natural Phosphorus.

Although the reasoning may sound faulty today, nevertheless Dr. Wall did find that a piece of amber rubbed with his hand or a woolen cloth became luminous, as did gum lac and particularly a yellow diamond, which luminesced for some little time. He realized that the light was connected with electricity, as a crackling sound was often heard, but noted that the yellow diamond would become luminous when exposed to the sky without rubbing. Wall wrote "I'm well assur'd that all or most of the Bodies which have an Electricity yield Light; for in my Opinion, 'tis the Light that is in em which is the cause of their being Electral, yet this Electricity never shows itself without Friction." He also noted that "This light and crackling seems in some degree to represent thunder and lightning," a similarity made strikingly certain by the kite experiment, suggested by Franklin in 1749, and carried out so successfully in 1752 
by Dalibard and Delor in France and by Franklin himself in America.

\section{THE RISE OF ELECTRICAL KNOWLEDGE}

After Hauksbee's experiments, striking as they were, little inquiry into electricity occurred until the late seventeen-twenties. The observations were chiefly concerned with attraction and repulsion but the fact that bodies which were rubbed emitted sparks and showed luminosity drew more and more attention to the electric light and electric fire, which became accepted accompaniments of electrical effects. ${ }^{39}$ The principal investigators of the early eighteenth-century were three: Stephen Gray (died 1736), a pensioner at the Charter House, who rediscovered ${ }^{40}$ conduction in 1729 and showed that metals could be electrified if insulated, otherwise they conduct away the " electric virtue" as fast as excited; Charles François de Cisternay Dufay (1698-1739), who rediscovered induction and declared (1733) that there two kinds of electricity, vitreous and resinous; and Jean Theophile Desaguliers (1683-1744), who continued the study of metals, calling them conductors. Desaguliers won many medals and prizes between 1734 and 1742 but added nothing to luminescence knowledge. The idea of "electric effluvia" about the electrified body changed to an "electric fluid" which might move, and Gilbert's idea of electrics and anelectrics changed to that of insulators and conductors.

All these men worked before the discovery of the electric phial or Leyden jar in 1745. The electrical machine was still Hauksbee's globe, or a tube, usually of glass, ${ }^{41}$ revolved and rubbed by hand. It was found that all substances could be made electric (i. e., electrified), if insulated, especially when heated, and a number of experiments involved the electrification of chunks of beef, chickens or small boys suspended on silk cords. Gray's and Dufay's demonstration of the possibility of conducting the "electric virtue" to some very distant place by wet threads or metal connections was of great practical advantage. The fact that Dufay's discovery of vitreous and resinous electricity was by Franklin to be identified respectively with an excess (plus) and a deficiency (minus) of electricity and referred to as positive (vitreous) and negative (resinous), did not detract from its importance.

\footnotetext{
${ }^{39}$ See P. T. Riess, Die Lehre von der Reibungselectricitat 2: 124-170, Berlin, 1853, for a detailed history of light phenomena.

${ }^{40}$ Von Guericke had observed conduction along a linen cord six feet long in the sixteen sixties.

${ }^{41}$ The glass disk was used by Martin Planta in 1755 and by Jesse Ramsden (17351800) of London in 1768.
} 
Stephen Gray's first paper on electricity, which appeared in 1720, had to do with the light observed when electric bodies (feathers, hair, linen, wool, etc.) are drawn through the fingers. Later (1735) with an electrical machine, Gray repeated some experiments of Dufay and described ${ }^{42}$ corona and brush discharges. He observed at night,

suspending the Iron Rod on the Silk Lines; then applying one end of the tube to one End of the Rod, not only that End had a Light upon it, but there proceeded a Light at the same Time from the other, extending in the Form of a Cone, whose Vertex was the End of the Rod, and we could plainly see that it consisted of Threads, or Rays of Light, diverging from the Point of the Rod, and the exterior rays being incurvated. This light is attended by a small hissing Noise; every stroke we give the Tube, causes the light to appear.

He obtained the same effects with wood and other material. Like Dr. Wall, Gray concluded "this Electrick Fire . . seems to be of the same Nature with that of Thunder and Lightning."

Dufay had long been a student of the phosphorescence of minerals and precious stones, after exposure to light or on warming (see Chap. VIII and IX). He used the electroluminescence of amber rubbed with a cloth as a standard light to tell if his eyes were dark adapted. Since Dufay did not work with vacua, he contributed little to the subject of electroluminescence, but he stated ${ }^{43}$ that the writings of Hauksbee and Gray " put him upon the subject and furnish'd me with the Hints" that led to discoveries. Dufay was highly solicitous of Gray's feelings concerning his entry in the field of electricity.

Dufay's (1723) early work on the barometer light contains no mention of electric phenomena. Later experiments on electrification of various objects and living animals, including himself, helped to identify the light observed on living things, the ignis lambens, with electricity, although Dufay made no special point of the resemblance. In these experiments he noticed the crackling noise and the minute sparks and added: ${ }^{43}$ "But it is otherwise if the Experiment be made with the Carkass of an Animal, for then one perceives only, if it be in the Dark, a still uniform Light, without Snappings or Sparks." The fancied difference between living and dead was of course only a reflection of certain conditions of the experiment. Dufay repeated many of Gray's experiments, increasing the distance to which electric effects could be conducted, and had as a willing assistant the Abbé Nollet, who later greatly extended electrical

42 S. Gray, Phil. Trans. 39: 16-24, 166-170, 1735.

${ }^{43}$ Dufay, Phil. Trans. 38: 258-266, 1733, a letter containing a good résumé of the French experiments. See J. G. Doppelmayr (1744) in German. 
knowledge by his own experiments and became an opponent of Franklin's theories.

The ideas of the time are well expressed in Petrus van Musschenbroek's (1692-1761) Elementa Physicae, published in 1734. In Chapter XVII, "On electrical bodies," he took the position ${ }^{44}$ that electricity " depends on some subtile exhalations, emitted by cold or hot bodies, but chiefly by hot ones, after they have been rubbed violently for a good while... . These effluvia are discoverable even by our senses ... they even shine in the dark. ... The electrical virtue continues in vacuo and can run along a string 1256 feet long."

Like Dufay, Desaguliers was also solicitous of Gray's feelings, and did not publish until after Gray's death in 1736. His many experiments between 1739 and 1742 were not concerned with vacua and hence contributed little to knowledge of the electric light. He pointed out the ability of water films to conduct and the necessity of dryness for success in electrical experiments, a condition which made many of the striking luminous effects possible.

After the period of Gray, Dufay, and Desaguliers, many isolated experiments kept the " electric fire" and the "electric light" in the public eye. The names of Ludolff, Winckler, Allemand, Wilke, Bose, Hausen, Grummert, Franklin, van Musschenbroek, Nollet, Beccaria, Watson, and Jallabert are associated with this electric era, characterized by public demonstrations of striking effects and a belief in the therapeutic value of electrical treatment. Even John Wesley ${ }^{45}$ (1702-1791), founder of the Methodist Church, advocated electrical cures.

Among the interesting discoveries of the 1740's was the ability of electric fire to inflame the ethereal liquor or "phlogiston of Frobenius" ${ }_{46}$ (ether), the vapor of spirits of wine, and hydrogen, prepared by the action of acid on iron. Credit for these observations goes to Dr. Christian Friedrich Ludolff (1707-1763) of Berlin in 1744 and to Dr. Johann Heinrich Winckler (1703-1770) of Leipzig, also noted for introducing a cushion of leather for rubbing the globe, instead of the hand, thereby greatly improving the electrical machine. Dr. Watson later (1745) confirmed them and Mr. Bose (1744) even fired gunpowder and described the feat in latin verse. ${ }^{47}$

"From the translation by John Colson, Elements of natural philosophy, London, 1744.

${ }^{45}$ John Wesley, The desideratum, or electricity made plain and useful, London, 1760.

${ }^{10}$ Sigismund August Frobenius (died 1741), a German living in London, prepared ether and published on it in the Phil. Trans. for 1730. Valerius Cordus is said to have discovered ether in 1535.

${ }^{47}$ Die Elektrizität, nach ihre Entdeckung und Fortgang mit poetischer Feder entworffen, Wittenberg, 1744. Also W. Watson, Phil. Trans. 43: 483, 1745. 
The growing interest in electricity again focussed attention on the barometer light. Although Hauksbee demonstrated for all practical purposes that the mercurial phosphor was similar to his light in rubbed globes and electrical in nature, perhaps the final proof may be said to have come from Christian Friedrich Ludolff, an M. D. of Berlin. He showed in 1745 that a barometer, when shaken to produce light, actually became charged and would attract threads. In the same year, a letter from a Mr. Abraham Trembly, F. R. S., to the President of the Royal Society, Martin Folkes, Esq., was published in the Phil. Trans. (1745), "Concerning the light caused by Quicksilver shaken in a glass Tube, proceeding from Electricity." In this letter from The Hague, February 4, 1745, Trembly said that "Mr. Allamand ${ }^{48}$ continues here very successfully his Experiments upon Electricity" and had empowered him to report that the light of mercury is due to friction as it runs on the glass and electrifies it. A bit of feather down in the tube is attracted to the mercury. Hence the barometer light should not properly be called a phosphorus. Trembly also saw Mr. Musschenbroek at Leyden with " an exhausted Globe of Glass, which, when rubbed with the Hand, seemed all fill'd with a very bright Fire."

In addition to the electric fire and the electric light, there was also the "electric wind," which had been observed by Hauksbee. This effect is due to electrified air (ions) repelled by the charge on a point. They set the air in motion with sufficient velocity to move a candle flame. It was well shown in a striking experiment of Johann Carl Wilcke ${ }^{49}$ (1732-1796), reported by Priestley (1769: 292) in his book on Electricity.

Mr. Wilcke put English phosphorous upon a pointed body, which in the dark, rendered the whole visible; and when he suspended this pointed body perpendicularly, the phosphoreal vapours were seen to ascend; but upon electrifying it, as it hung in the same direction, the vapours were carried downwards, and formed a very long cone, extending out of the middle of the cone of electric light, which was seen perfectly distinct from it. When the electrification was discontinued, the phosphoreal vapour ascended as at first.

It is apparent that an electrical age of wonderful luminous effects had arrived. Priestley related that by the use of several simultaneously rotating glass globes or tubes and good insulation, it became

${ }^{48} \mathrm{~J}$. N. S. Allamand (1713-1787), a professor of philosophy and natural history in the University of Leyden.

${ }^{49}$ Wilcke's experiments were published in the Svenska Vetenskapakademiens Handlingar, and in the book De electricitatibus contrariis, a Disputatio inauguralis physica, Rostok, 1757. 
possible to draw such powerful sparks from human beings that they " nearly fell down with giddiness." A letter in the Phil. Trans. for 1745 by Georg Mathias Bose (1710-1761), professor of experimental philosophy at the Academy of Wittemberg and the man who added the metal prime conductor to the electrical machine around 1733, alleged "the Motions of the Heart are very sensibly increased" when a man is electrified in a chair suspended by silk ropes. "In the dark a continual Radiance or Corona of light appears incircling his Head, in the manner Saints are painted." This was spoken of as beatification. If a vein were opened while electrified the blood that flowed out appears "lucid like phosphorus, and runs out faster than when the man is not electrify'd." It was also observed that water spouting from an artificial fountain "scatters itself in little luminous drops; and a larger quantity of water is thrown out in any given time, than when the fountain is not made electric." 50

According to Priestley (1769: 149), Bose's experiment on beatification set the electricians of all Europe to work but none were able to repeat the experiment and observe the luminous halo, and Bose later ${ }^{51}$ admitted that he had used a suit of armor rather than a man, and that when the electrification was very vigorous the edges of the helmet shot forth rays such as are painted on the heads of saints. Many other marvellous virtues of electricity, the passing of odors through glass by J. H. Winkler and effects of a medical nature were announced at this time but later shown by W. Watson to be without foundation. ${ }^{52}$

Bose also ignited ether and other inflammable vapors, and observed the discharge in exhausted glass vessels, a light which "flowed and turned and wandered and flashed," so that he compared it with the aurora borealis. He was perhaps the first " electrical wizard," who delighted in theatrical display of electric effects and helped to start the vast popular interest in lectures and exhibition of electrical phenomena which lasted for years.

A contemporary of Bose, Christian August Hausen (1693-1743), a professor of mathematics at the University of Leipzig, in 1743 distinguished three kinds of electric light, the spark, the brush, and the glow. He regarded the ether of Newton and electric matter to be the same because both can glow and argued that this matter must be present in the blood, because electric fire can be drawn from human beings. Hence the blood may be the seat of the soul.

\footnotetext{
${ }^{50}$ Francis Arago collected many instances of luminous rain drops, mentioned in T. L. Phipson, Phosphorescence, 45-46, 1862.

${ }^{51}$ In a letter published by W. Watson (1750).

${ }^{52}$ See W. Watson, Phil. Trans. 46:348-356, 1750 on Bose and 47:231-241, 1751, on Winkler.
} 
Cromwell Mortimer, M. D., Secretary of the Royal Society, was much impressed by the electrical experiments shown at the Royal Society meetings and by the accounts of spontaneous human combustion recently reported by Paul Rolli (1745) in the Phil. Trans. Imbued with the idea that there are "Elements of Fire and of Air lying dormant in all Bodies," particularly "animal Sulphur, commonly called by our modern Chemists, Phosphorus," Dr. Mortimer (1745) cited fireflies, luminous fish, light from friction of the hair of animals as examples. He also sounded a word of caution:

Animals appearing more susceptible of electric Fire than other Bodies, greatly confirms my Conjectures of the phosphoreal Principles; and I should think, that being render'd electric to any high Degree might prove a dangerous Experiment to a Person habituated to a plentiful Use of spirituous Liquors, or to Embrocations with camphorated Spirit of Wine; on the contrary, in some languid, cold, or wornout Constitutions, possibly, future Experiments may evince, that Electricity may be used medically in order to renew and regenerate a proper Quantity of vital Fire, such as is necessary for the conveniently carrying on, and performing the animal Functions.

Sporadic observations on the true electric light were made in various places. Gottfried Heinrich Grummert (1719-1776) of Biala, Poland, later of Dresden, discovered (1745) that an exhaused glass tube did not need to be rubbed to show the electric light but would glow if touched to or merely brought near an electrified conductor. He also observed that for some time afterwards light might appear spontaneously in the tube at a distance from an electrified body. Grummert suggested the use of such a tube in mines, where a light from fire cannot be used because of the danger of explosions.

Discovery of a condenser, the Leyden phial, independently by Bishop G. von Kleist in 1745 and P. van Musschenbroek in 1746, gave a great impetus to electrical study, although attention was diverted for the moment from electroluminescence to spark discharges. The shocks which could be transmitted to subjects became terrific and really dangerous. All students of electrical history are familiar with the famous statement of Professor Musschenbroek in a letter to M. Réaumur of the French Academy, that he would not take a second shock from the electric phial for the Kingdom of France.

The Abbé Jean Antoine Nollet (1700-1770) was one of the first to be informed of the Leyden discovery, and was especially active in charging and shocking animals and persons. Most of the work was carried out in the air and the value of points for brush discharges became well recognized. Franklin, in a letter to Peter Col- 
linson dated July 11,1747 , spoke of the " wonderful effect of pointed bodies in drawing off the electrical fire ... in the dark you will see, sometimes at a foot distance and more, a light gather upon it (electrified point) like that of a fire-fly or glow-worm." The expression "electric fire" was highly descriptive, not merely from the appearance but because the discharges actually burnt the flesh.

In France, the study of electricity was quite the vogue, carried on chiefly by Nollet and Jallabert. Abbé Nollet, friend of Dufay and instructor of the royal family, carried out experiments of many kinds, among them observations on the appearance of the electric light in vacuo. Like others he noticed that the light was much more diffuse and unbroken in the absence of air. If the end of a conductor from the electrical machine was inserted in an exhausted glass vessel, the vessel became full of light whenever his hand was brought near and much brighter when his hand was spread over the glass, an effect due to the conduction of electricity through the residual gas toward the body of the investigator, as shown in figure 25, from the Italian edition (1755) of Recueil des Letters sur l'Electricité des Corps (Paris, 1753) by Nollet.

Nollet included in his studies the effects of electricity on plants and animals. He also helped to refute the extravagent claims of electrical cures, which had been reported by Dr. Privati in Italy in 1747. His early ideas on electricity are summarized in two books, Essai sur Électricité des Corps (Paris, 1747) and Recherches sur les Causes Particulières des Phénomènes Électriques (Paris, 1749). Later studies are contained in his Leçons de Physique Expérimentale, vol. 6 (Paris, 1764).

The second French worker was Jean Louis Jallabert (1712-1768), professor of philosophy and mathematics at Geneva. In his Expériences sur Électricité, published at Geneva in 1748, he devoted seventy pages to the electric light, summing up all knowledge of the subject available in his time.

\section{WILLIAM WATSON AND ELECTRICITY IN VAGUO}

Fortunately there were physicians in the mid-eighteenth century with true scientific interest, unwilling to be carried away by speculation on electricity and the human body. One of these was Dr. William Watson (1715-1787), also a botanist, whose electrical experiments became so famous they were observed by royalty at his home in Aldersgate. He had studied electrical discharges in air in 1747 and their behavior in a vacuum was described in a paper entitled, "An Account of the Phenomena of Electricity in Vacuo with some Observations thereupon," published in the Philosophical Transac- 
tions of the Royal Society for 1752, a contribution full of observations on electroluminescence. The experiments were on a grand scale. Watson first used a glass cylinder three inches in diameter and three feet long, containing a movable and a fixed brass plate, the two connected with an electrical machine. The cylinder could be evacuated and the brass plates brought near or far from each other for different experiments. Watson (1752) wrote:

It was a most delightful spectacle when the room was darkened to see the electricity in its passage; to be able to observe, not, as in the open air, its brushes or pencils of rays an inch or two in length, but here the coruscations were of the whole length of the tube between the plates... and of a bright silver hue. These did not immediately diverge, as in the open air, but frequently from a base apparently flat, divided themselves into less and less ramifications, and resembled very much the most lively coruscations of the aurora borealis.

Watson also discharged a Leyden phial through the evacuated tube and "at the instant of the explosion you saw a mass of very bright embodied fire, jumping from one of the brass plates in the tube to the other."

To produce the vacuum, Watson had used the air pump of Mr. John Smeaton (1724-1792), " by which we are empowered to make Boyle's vacuum much more perfect than heretofore" but this was not good enough, and Watson proposed to use the best vacuum known, that of the barometer. He wrote:

The difficulty however of applying the Torricellian vacuum to these experiments has been happily got over by the right honorable Lord Charles Cavendish, ${ }^{53}$ our worthy vice-president. This noble lord, who to a very complete knowledge of the sciences joins that of the arts, and whose zeal for the promotion of true philosophy is exceeded by none, has applied it in the following manner, and his lordship has had the goodness to put his apparatus into my hands.

The Cavendish device was a double barometer, consisting of a long glass tube bent in the middle, filled with mercury, and then inverted, with the two ends dipping into two cups of mercury. The Torricellian vacuum in the bend and the two mercury cups which could be connected with an electrical machine, made a perfect discharge tube. Watson wrote "while the [electrical] machine was in motion the electricity pervaded the vacuum, in a continued arch of lambent flame, and as far as the eye could follow it, without the least divergency." Many experiments were performed with this tube and

${ }^{\text {Bs }}$ Father of Henry Cavendish (1731-1810), whose notable researches on gases and on electricity did not include a study of luminescence. 
changes in the light effects noted when the hand was brought near the glass.

Watson was so imbued with the connection of electricity and fire that he asked $(1746,1747)$ the question whether electricity was not elementary fire which merely appeared in different forms, and whether an electrical machine is not a "fire-pump," as Guericke's or Boyle's machine is an "air pump." He related that he inclined to the opinion of Homberg, Lémery the Younger, s'Gravesande, and Boerhaave, "who held fire to be an original, a distinct principle, formed by the Creator himself, than to those of our illustrious Countrymen, Bacon, Boyle and Newton, who conceived it to be mechanically producible from other bodies. Must we not be very cautious how we connect the elementary fire, which we see issue from a man, with the vital flame and calidum innatum of the Ancients; when we find that as much of this fire is producible from a dead animal as from a living one, if both are especially replete with fluids?" The Copley Medal of the Royal Society was awarded Watson in 1745 for his earlier discoveries incorporated in his book (1746).

\section{WILSON, SMEATON, AND CANTON}

The next study of the electric light was similar to that of Hauksbee and had to do with evacuated vessels revolved on a lathe and rubbed by hand. The experiments were made by Mr. Smeaton ${ }^{54}$ at the request of Benjamin Wilson (1708-1788), Secretary of the Royal Society, later a student of phosphors. If the air within was rarified five hundred times, " a considerable quantity of lambent flame, variegated with all the coulours of the rainbow, appeared within the glass, under the hand." This light was steady but "when a little air was let in it appeared more vivid and in greater quantity; but was not so steady." With more air "streams of bluish light seemed to issue from under his hand," sometimes in the form of trees or moss. ${ }^{55}$ With more air the coruscations within became less and then vanished and when full of air no light appeared inside but only a dim light on the outside of the glass where rubbed by the hand.

The effects of different gas pressures were clearly recognized in the Smeaton-Wilson experiments, and the attempt to obtain higher and higher vacua, as exemplified by Watson's use of the double barometer of Lord Charles Cavendish, has continued until the present day. The reward came in the next century with the dis-

\footnotetext{
${ }^{54}$ See Priestley, History of electricity, 301, 1767.

${ }^{55}$ The Abbé Nollet referred to "aigrettes lumineuses."
} 
covery of cathode rays and Roentgen rays, radioactivity, and the many luminescent effects connected with them, described in Chapter XII on radioluminescence.

Other experiments of the same type were made by John Canton (1718-1772), whose interest in luminescence also extended to dead fish and phosphors. Like Grummert (1745), he noticed (1753) the light which appeared spontaneously in a sealed evacuated tube which was brought near and then removed from the neighborhood of a charged Leyden phial. The glow darted from one end of the tube to the other at uncertain intervals for nearly a quarter of an hour and imitated the appearance of an auroral display. In fact Canton (1753) asked, "Is not the aurora borealis the flashing of electrical fire from positive toward negative clouds at a great distance through the upper part of the atmosphere where the resistance is least?"

Benjamin Wilson (1759) continued the studies on electricity in a vacuum, calling attention to differences in appearance of electric light at the two poles. Using the double barometer of Cavendish, Wilson broke the column of mercury on one side by letting in a little air, thus separating the column into separate cylinders of mercury, and he connected the other cup of the barometer to the earth. When electrified by a rotating cylinder of glass, light appeared in the vacuum of the tube but was always brighter in the upper surfaces of the mercury, whereas when electrified by a rotating cylinder of rosin, the bright regions were on the lower surfaces of mercury column. Wilson inferred from this that glass electrified positively and rosin negatively, "depriving them of part of the electric fluid which they naturally had."

THE RELATION OF THE “ ELECTRIC LIGHT" TO OTHER LUMINESCENCES

In later years, both Canton (1768) and Wilson; (1775) became students of luminescence in general. For example, Canton noted that electric sparks were particularly good exciters of his newly prepared phosphor and Wilson wrote a book on phosphors (see Chapter VIII), but neither attempted to relate the electric light to other types of luminescence, except by comparison with the aurora borealis.

A somewhat different attitude was taken by Father Giovanni Battista (Giambattista) Beccaria (1716-1781) of Turin, a member of the religious order of the Pious Schools, an astronomer and ingenious experimenter, who had supported Franklin in his controversy with Nollet. He was especially interested in atmospheric electricity, and like many others, compared the electric light in vacuo to the northern lights. He published a number of papers in the Phil. Trans. 
and two books, Dell'Elettricismo Artificiale e Naturale (Turin, 1853) and Lettere dell'Elettricismo (Bologna, 1758). An English edition appeared in 1776, A Treatise upon Artificial Electricity. One of Beccaria's goals was to discover the relation between common fire and electric fire; another was to find out what part electricity played in various luminescences. He made the statement that " common fire propagates itself with most difficulty, through such bodies as refuse to conduct the electric fire, and most easily through those which can conduct it." Beccaria proposed to prove this by such arguments as "The common as well as the electric fire, are speedily dissipated in dilated air," etc.

He first studied the barometer light, noting that a little air must be present and, like Hauksbee, that a ring of light appears at the mercury surface when the mercury moves downward. An electric discharge through the Cavendish double barometer gave splendid effects and bubbles of air rising in the mercury looked like the lighting globes seen during an auroral display. The color of the light depended on the "dilation" of the air and was often reddish, as in an aurora borealis.

He noted the flashes of light in evacuated glass globes when rubbed, but was particularly interested in the cause of the light in evacuated glass vessels when broken. Priestley (1769: 191) has described the latter experiments' as follows:

Signor Beccaria observed that hollow glass vessels, of a certain thinness, exhausted of air, gave a light when they were broken in the dark. ${ }^{56}$ By a beautiful train of experiments, he found, at length, that the luminous appearance was not occasioned by the breaking of the glass, but by the dashing of the external air against the inside, when it was broke. He covered one of these exhausted vessels with a receiver, and letting the air suddenly on the outside of it, observed the very same light. This he calls his new invented phosphorus. (Lettere dell'Elettricismo, 354 etc., 1758.)

The light comes from electrification of the glass as the air rushes over the surface and is a true electroluminesce. Beccaria found that solid glass spheres like "Batavic drops " ${ }^{57}$ or "Bologna bottles" do not luminesce when broken, either in air or in vacuum.

${ }^{88} \mathrm{~J}$. Burke (1895), at the suggestion of J. J. Thomson, repeated Beccaria's experiments and confirmed his results but could not explain all the phenomena observed, especially the fact that luminescence appeared to be associated with the broken fragments of glass.

${ }^{57}$ Presumably " Prince Rupert drops," allegedly discovered by Prince Robert Rupert of Bavaria, but probably known since glass blowing began. They were mentioned by Samuel Pepys in his Diary, January 13, 1662, as "chymicall glasses, which break all to dust by breaking off a small end; which is a great mystery to me." Knolgläser were 
Beccaria also studied the excitation of phosphors by electric sparks and pointed out that those bodies which retained the solar light to the greatest degree also retained the electric light best, for example phosphors given him by Beccari, sugar and paper. He endeavored to find out if sugar when pounded in a mortar became electrified but could observe no attraction of fine threads, despite the fact that the triboluminescent light of sugar looked exactly like electric sparks.

Another worker of this period was Johann Karl Wilcke (17321796) of Stockholm, Sweden, who studied the production of "spontaneous electricity" by melting electrics, a discovery of Stephen Gray. He made a few observations on luminescence, described by Priestley (1769: 290) as follows:

Some curious observations relating to electric light were made by $\mathrm{Mr}$. Wilcke. Rubbing two pieces of glass together in the dark, he observed a vivid phosphoreal light: which, however, threw out no rays, but adhered to the place where it was excited. It was attended with a strong phosphoreal smell, but with no attraction, or repulsion. From this experiment he inferred, that friction alone would not excite electricity, so as to be accumulated upon any body; and that to produce this effect, the bodies rubbed together must be of different natures, with respect to their attracting the electric fluid. He, moreover, imagined, that all examples of phosphoreal light, without attraction, were owing to the same excitation of electricity, without the accumulation of it. Such he imagined to be the case of light emitted by the Bolognian stone, cadmea fornacum, rotten wood, pounded sugar, and glass of all kinds.

Both Beccaria and Wilcke thus endeavored to explain the triboluminescence of sugar by the electric light, a reflection of the logical desire to unify the causes of phenomena and bring all luminescences into a common category.

It is recognized today that many luminescence phenomena, which are ordinarily spoken of as triboluminescences, actually result from electric discharges. T. Wedgwood (1792) described the light from

also mentioned by Hooke in Micrographia (1665). Contrary to Beccaria's experience, Sir David Brewster (1781-1868) observed light when the unannealed glass drops were broken, either in air or under water. Helvig (1815) also reported light from the breaking of "lacrymae Batavae" and that "Knallbomben" (gas filled explosion bombs), dropped on the floor, gave a pale white light. De Parcieux (1797) observed the same, "a brisk flame like an electric spark," with air-filled glass spheres which burst in a vacuum, and a note in the Philosophical Magazine (14:363, 1803) states that Professor Pictet of Paris wrote to Mr. Tillock (editor of the Magazine) that $\mathbf{M}$. Mollet of Lyons saw light when an air gun was discharged into the air. Dessaignes (1814) also discussed the matter, and Heinrich's monograph is full of references to this type of luminescence. In more recent times, H. F. Newell (1896) reported on similar phenomena during compression of certain gas mixtures which would exhibit phosphorescence after electrical excitation. 
mica when two pieces were rubbed together as triboluminescence but this light can actually be shown to be (in part at least) an electroluminescence. Some years ago (Harvey, Science 89, 461, 1939) the author split mica plates in an atmosphere of low pressure neon gas and noted that the light was definitely red, the color of electrical discharges passing through neon.

Another example was described by Dumas (1826) - a flash of light when fused boric acid cools in a crucible. The luminescence occurs at the time the melt separates from the container. Dumas said the light was electrical and compared it to the flash observed when mica sheets separate.

\section{FROM JOSEPH PRIESTLEY TO MICHAEL FARADAY}

It was in 1767 that the first edition of Joseph Priestley's (17331804) book, The History and Present State of Electricity, with Original Experiments, London, was published. A second edition followed in 1769 and a third of two volumes in 1775. As the name indicates, his treatise is a chronological account of all electrical experiments and ideas up to the date of publication. In describing a few experiments of his own, Priestley (1767) stated that several previous writers had alleged that the electric light contained no prismatic colors. He decided to test this for himself by observing electric sparks taken from the prime conductor through a prism, and found the colors as distinct as those from the sun. He also noted that the spark in inflammable air (hydrogen) is red in color, and that "when the light was a little diffused, as in those red or purple parts of a long spark, as it is called, the colours were not so vivid, and less easily distinguished from one another; and when the light was still more diffused, through a vacuum, the prism made no sensible alteration in the appearance of it." Priestley then remarked that "the flames of different bodies yield very different proportions of prismatic colours, I have often thought of attempting to ascertain the proportion of these colours in the electric light ... but have had no leisure to pursue the inquiry." This was in 1766, before it was realized that a slit is necessary for proper spectroscopic observation. Priestley emphasized that " the greatest quantity of electric light is produced in vacuo," and cited Mr. Canton's aurora borealis experiment as an example of "entertaining philosophical experiments made by a combination of philosophical instruments," i. e. by an evacuated glass tube, three feet long, which will glow and flash when held in the hand and presented to the conductor from the electrical machine.

It is rather surprising that there should be a general belief that 
prismatic colors are not present in the electric light. As early as 1748, Stephen Hales (1677-1761), better known for his Vegetable Staticks (1727) and Hemastaticks (1733), published a short paper, "Concerning some Electrical Experiments," in which he related when he was in London he saw green, yellow and white electric sparks depending on the material from which they arose:

The active electric Fluid seems to be a great Agent in conjunction with the Air, in the Production of Fire. . . . A warm thick Piece of Iron being suspended by two silk Lines, had a warm very thick Piece of Brass laid on it, on which was placed a common Hen's Egg: When electrified, the Flashes from the Iron were of a bright silver light colour; from the Brass (especially near it) the Flashes were green; and from the Egg of a yellowish flame colour; which seemed to argue, that some Particles of those different Bodies were carried off in the Flashes, whence these different colours were exhibited.

Hales was quite correct in his conclusions.

One whole section of Priestley's book is specifically devoted to "Experiments and Observations concerning Electric Light" in vacuo. The observations of Hauksbee, Watson, Smeaton (transmitted to Wilson), Canton, Beccaria, Wilke, and others are described in detail. Priestley noted particularly the effect of the electric light in exciting the luminescence of such substances as Canton's phosphor, or the surface of marble as described by Mr. Lane (see Chap. VIII), a phenomenon indicating " that electric light is more subtle and penetrating, if one may say so, than light produced in any other way. ..." Here we see the realization that electric discharges are quite different from ordinary light, a difference now known to be due to the ultraviolet light they contain, so important in modern methods of illumination by the fluorescent lamp. The electrical machine of Priestley's day had grown greatly in size, as illustrated in figure 26, taken from B. Wilson's (1778) book on conductors.

Toward the end of the century, a number of papers appeared on the electric light in a vacuum, but little was added to general knowledge. Edward Nairne (1726-1806), one of the first foreign members of the American Philosophical Society, noticed that the electric light is very faint in a moist vacuum, and he also described (1777) the striae which often appear when electricity is conducted through evacuated tubes. These striae are particularly marked if mixed gases are present. They attracted much attention in the middle of the next century when the conduction of electricity was a popular and rewarding field of experimentation. Starting at the negative pole (cathode) there is a thin layer of luminosity, the cathode glow, then a dark region, the "Crookes dark space" or "Hittorf's 
dark space" then a longer luminous region "the negative glow," then the "Faraday dark space," and finally a long "positive column " of luminosity with striations made up of dark and luminous regions, which extend to the anode. Occasionally another dark space appears near the glowing anode. Details of the above phenomena change with the length of tube, the current density, and the pressure and kind of gas, and have been studied by many workers.

The experiments of Wm. Morgan (died 1833), an insurance actuary who experimented with electricity in 1785 are of considerable interest, since he stressed the different colors of the electric light, depending on the gas pressure. He stated that a Mr. Walsh, using a double barometer, had demonstrated " the impermeability of the electric light through a vacuum." Morgan repeated the experiment and showed that if small amounts of air are admitted the color changes progressively from green to blue, to indigo, to violet, to purple, " till the medium has at last become so dense as no longer to be a conductor of electricity." He especially noticed that "the degree of the air's rarifactions may be nearly determined by this means," an observation which is still useful in judging the perfection of a vacuum.

During the early nineteenth century few observations on electroluminescence were made. With the discovery of the voltaic pile (A. Volta, 1792), attention turned to low voltage high current electrical phenomena, the passage of electricity through solids and liquids rather than gases. The trend was accelerated by Humphry Davy's isolation of potassium and sodium metals in 1807. The chemical experiments of Davy have eclipsed the fact that he was particularly interested in the relation between electricity and matter and endeavored to determine whether any electrical discharge could occur in a " perfect vacuum." Morgan (1785) had previously held that the electric light became less, the more perfect the vacuum, or did not appear at all. In 1822 Davy prepared a short U-shaped tube with a platinum wire fused in one end, filled with mercury (or tin, which could be melted) and another platinum wire fused in the glass near a stop-cock, so that the tube could be evacuated. When the tube was pumped out, the mercury fell, leaving an evacuated space and sealing the cock. Davy found that when the

mercurial vacuum was perfect it was permeable to electricity, and was rendered luminous by either the common spark, or the shock from a Leyden jar, and the coated glass surrounding it became charged; but the degree of intensity of these phenomena depended upon the temperature; when the tube was very hot, the electric light appeared in the tube 
of a bright green colour, and of great density; as the temperature diminished, it lost its vividness; and when it was artificially cooled to $20^{\circ}$ below zero of Fahrenheit, it was so faint as to require considerable darkness to be perceptible.

When air was let in the color of the light changed. Davy also obtained a light above tin, coming to the conclusion that the heat of the discharge volatilized the metals and that some vapor must be present. There appeared to be conduction of current in the best vacua obtainable at the time.

Ever since Bose (1743) distinguished the spark, the brush (a multitude of minute sparks) and the glow discharge, the relation of the three forms had been a subject for speculation. A great deal of attention was paid to the type of discharge by Michael Faraday (1791-1867), successor to Davy at the Royal Institution, in 1838 and 1839. After pointing out that: "Rarefactions of the air wonderfully favors the glow discharge" and that "To obtain a negative glow in air at common pressures is difficult" but "In rarified air the negative glow is easily obtained," Faraday showed that the spark passes to the brush sooner when the surface of the electrode is negative, but a positive brush passes to a glow sooner than a negative brush. The glow, which could never be analyzed as minute sparks like the brush, occurred in all gases tried (air, $\mathrm{N}_{2}, \mathrm{O}_{2}, \mathrm{H}_{2}$, coal gas, $\mathrm{CO}_{2}$, $\mathrm{HCl}, \mathrm{SO}_{2}$, and $\mathrm{NH}_{3}$ ) but differences in color were to be observed. Faraday was of the opinion that in the highest vacua obtainable, the surface of the glass might conduct the current.

An important observation was the "dark discharge," which referred to a dark space in rarified gas between the positive and negative glow, which was later to bear his name, the Faraday dark space. The electric light thus becomes a complicated phenomenon, dependent on many factors-different conditions of temperature and pressure and different materials. New tools were obviously necessary for new advances. These turned out to be the perfection of glass blowing techniques and the rise of spectroscopy.

\section{JULIUS PLÜCKER AND LATER RESEARCH}

With increasing interest in spectra of all kinds, together with the perfection of the spectroscope, it was natural to continue the study which Priestley had hoped to undertake years ago, the spectrum of electroluminescent glow. ${ }^{58}$ However, the varying colors which appear during the discharge of electricity through vacuum tubes were not adequately analysed for spectral composition until the late fifties.

\footnotetext{
${ }^{58}$ See Chapter VI for the history of spectral investigation.
} 
One of the leaders in this field was Julius Plücker (1801-1868), professor of mathematics and physics at the University of Bonn. His early work, beginning in 1826 , was purely mathematical, but later, in 1847, he turned to the study of magnetism and particularly (1851) the magnetic relations of gases at atmospheric pressure. No interest could have been better chosen for discovery of the extraordinary phenomena which turned out to be connected with the emission of cathode rays. His paper of 1858 had to do with the action of the magnet on electrical discharges in Torricellian vacua (1858) and continued with the stratifications and dark bands and the spectra (1859-1863) emitted. The first investigations were observational, but the Plücker and Hittorf (1865) paper contains plates of the spectra of various gases.

The influence of a magnet ${ }^{59}$ on luminescence of a gas in vacuum tubes appears to have been first (1849) observed by August Arthur de la Rive (1801-1873), a professor at the Academy in Geneva, in connection with his theory of the aurora borealis, although the discovery of magnetic effects in a rarefied gas is usually attributed to Plücker (1858). Certainly the results of Plücker's experiments were far reaching and led to the important research on cathode rays described in Chapter XII. When Plücker's papers appeared, de la Rive (1858) called attention to his earlier work and very actively continued (1858-1872) the study of luminous phenomena in rarefied gases. J. W. Hittorff's series of papers on electrical conductivity of gases began in 1869 and lasted until 1884. It was entitled, Ueber Elektricitatsleitung der Gase, but contained much more than the title would indicate. E. Becquerel $(1859,1869)$ carried out many experiments with solids sealed in glass tubes containing rarefied gas through which electric discharges were passed, although he was principally engaged in mapping the spectra of phosphorescent and fluorescent substances in his phosphorescope. For phosphors, E. Becquerel, and for gases, J. Plücker may be considered the pioneers in spectral research on luminescence. V. S. M. Van der Willigen (1858, 1859) was another early worker, whose original paper in Dutch contained a plate of gas spectra.

At about the same time John Peter Gassiot (1797-1878), a merchant in London, was investigating (during the years 1858 to 1862) the form of the electric discharge in partial vacua, particularly the dark spaces and stratification. De la Rive and Gassiot wrote a joint

${ }^{59}$ Others who studied the effect of a magnet on electroluminescence in a rarefied gas are W. Hittorf (1869), A. Treve (1870), A. J. Angström (1871), L. Daniel (1870), A. Secci (1870), de la Rive and E. Sarasin (1872), J. Chautard (1874-1876), and E. Van Aubel (1898). 
paper in 1863. Later, between 1878 and 1883 Warren de la Rue (1815-1889), a wealthy London physicist, published (with H. Müller) some beautiful plates (see fig. 27) of the various effects in rarefied gases excited by his famous silver chloride battery of 25,400 cells, while the papers (1879) of Wm. Crookes (1832-1919) on molecular discharge in high vacua contained a colored plate of cathode ray effects. These contributions all appeared in the Phil. Trans. of the Royal Society, together with the paper (1879) of William Spottiswood (1825-188Z3), another wealthy Londoner. The unusual luminescent effects in vacuum tubes seemed to attract men of independent means.

Other early observers of electroluminescence not primarily interested in spectra were E. Reitlinger (1862) and Quet et Sequin (1862) on stratification, J. F. A. Morren (1861-1869) on the afterglow, A. Wüllner (1874) on stratification, E. Goldstein (1874 to $1899)$ on cathode rays, and B. Hasselberg $(1879,1880)$ on low temperature effects.

The research on rarified gases required special tubes, many of which were made by Heinrich Geissler, ${ }^{60}$ a glass blower of Bonn, engaged by Plücker to make vacuum tubes with sealed-in platinum electrodes. The light, of all colors depending on the gas, could be concentrated in capillary spaces and made to follow the tortuous curves imparted to the glassware. Figure 28 is a plate of the various shapes, taken from the book of O. Lehmann (1898: 485). By the use of uranium glass in parts of the apparatus, really striking and beautiful effects were obtained. These were the Geissler or Plücker tubes, which fascinated audiences in the sixties and seventies, and played so important a role in understanding the nature of matter.

Gassiot's "cascade" (1860) was obtained by means of a large goblet of uranium glass, the inner surface lined with tin foil and the base resting on a metal plate. When covered with a bell jar and evacuated to the proper degree, with the tin foil and plate connected to an "influence machine," spectacular electroluminescent effects appeared in the gas which seemed to flow over the edge of the goblet itself, glowing with uranium glass fluorescence of a beautiful greenish yellow.

In the last third of the nineteenth century, noted for the development of spectroscopy and its application in every branch of science, particularly chemistry and astronomy, the study of electroluminescence in vacuum tubes was pursued in minutest detail by a host of

\footnotetext{
${ }^{80}$ Geissler published a short paper in 1868 on tubes which would luminesce when rubbed.
} 


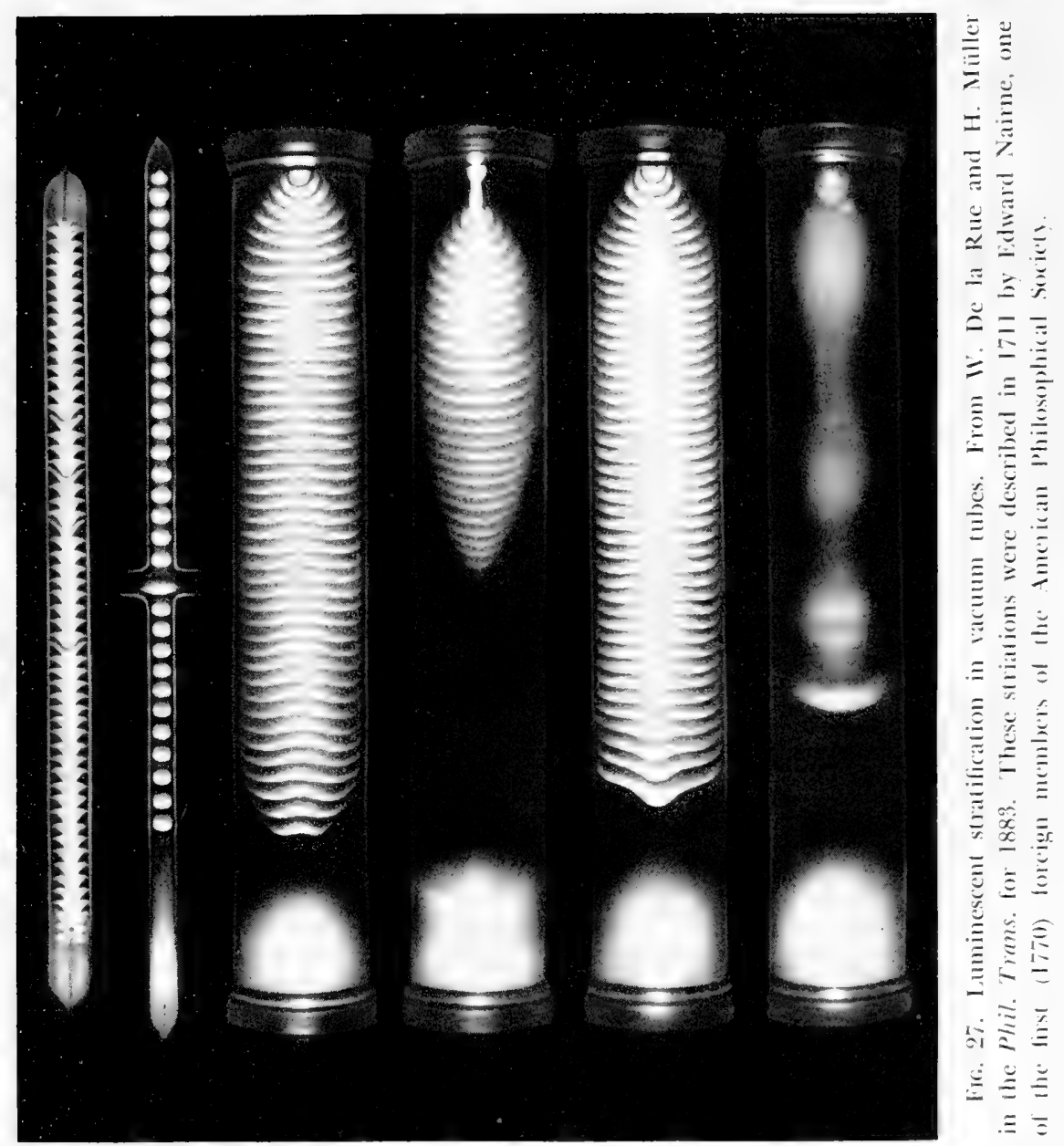



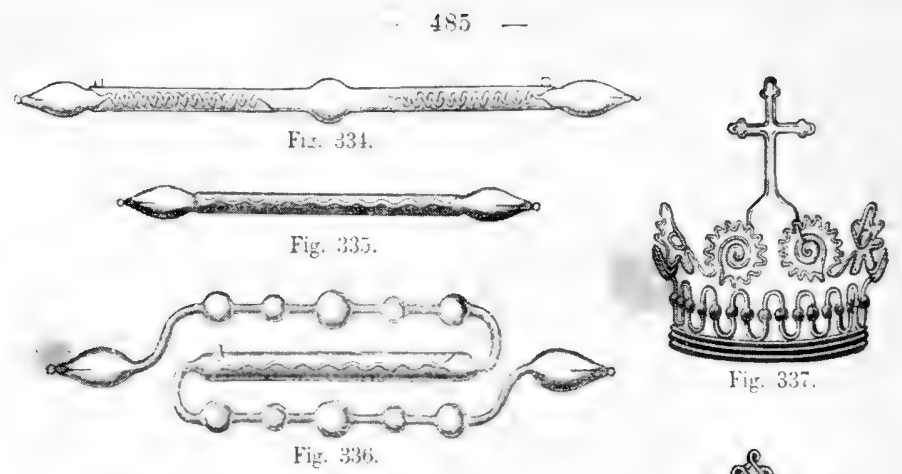

Fiv. 337.

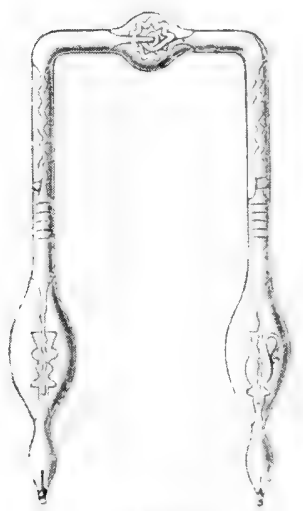

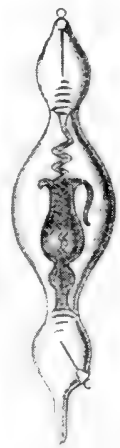

Fig. 310 .

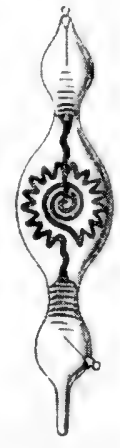

Fig. 341 .

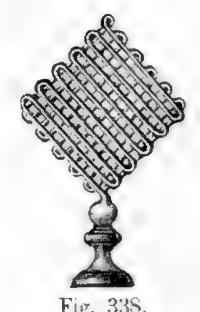

Fig. 33S.
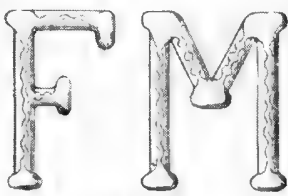

Fig. 34".
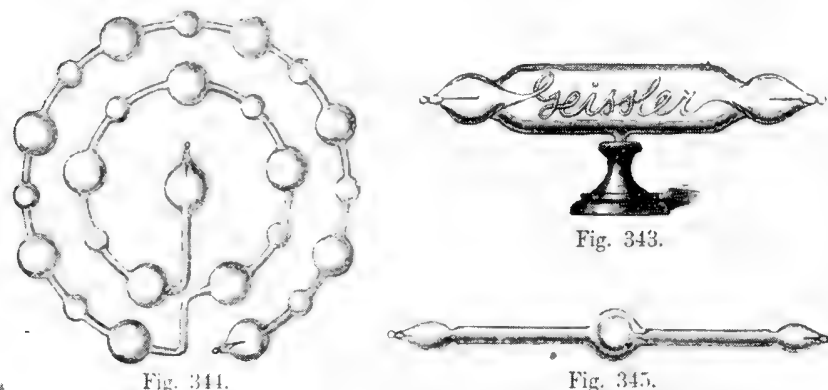

Fig. 343 .

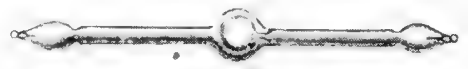

Fig. 34.

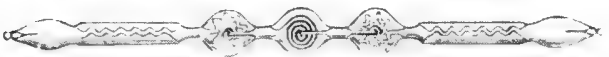

Fig. 346 .

Fis. 28. Types of cieissler tubes, filled with gas at low pressure. They luminesce in various colors when electric current from an inlluence machine or induction coil is passed through the tubes. From O. Lehman Die Elektrische Lishterscheinungen oder Entladungen (Halle a. S., 1898). 


\section{E}

\section{P HOE NOMENIS IN ORBE LVN NOVI TELESCOPII VSV A D. GALLILEO GALLILEO}

NVNC ITERVM SVSCITATIS Phylica difputatio,

\section{A D IVLIO CAESARE I A G A L L A}

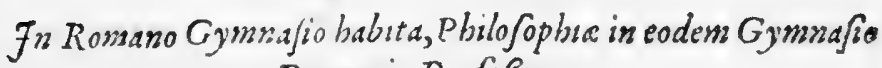
Primario Profeßore.

NECNON DE LVCE, ET LVMINE Altera difputatio.

SVPERIORVM PERMISSV, ET TRIEILEGIO.

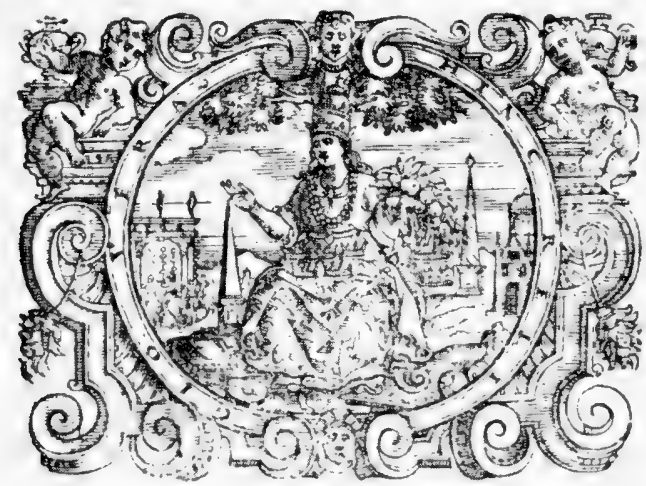

VENETI I S, M D C X I I Apud Thomam Balionum.

Fis. 29. Title page of the first written account of the Bolognian phosphor, by J. C. La Galla (Venice, 1612). 


\section{LITHEOSPHORVS,}

$S \perp \mathrm{V}$ :

DE LAPIDE BONONIENSI

Lucem in fe conceptam ab ambiente claro mox in tenebris mire conferuante

$\angle I B E R$

\section{FOR T V N I L ICETI}

G E N V E N S I S

Pridem in Pifann, nuper in Patauino, nunc in Bononien $\sqrt{8}$ Aribigymnafro Philofophi Eminentis

Eminentifs. ac Reuerendifs. D.D.

ALOYSIO CARDINALI

C A P P O N I O

RAVENNAE ARCHIEPISCOPO

D I C A I V S.

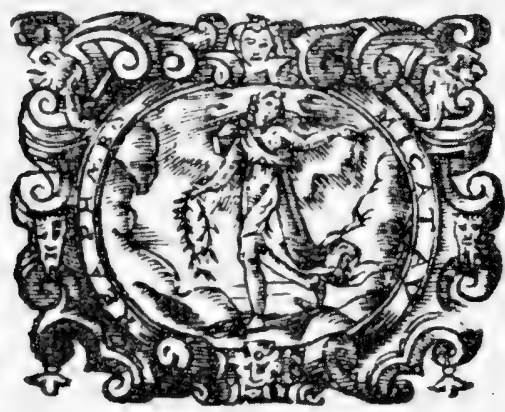

VtinI, Ex Typographia Nicolai Schiratti. MDCXL.

ANNVENTIBVS SVPERIORIBVS:

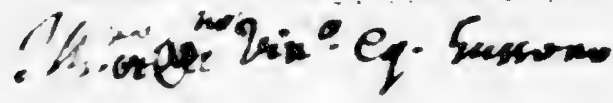

Fic. 30. Title page of the most extensive seventeenth-century book on the Bolognian phosphor, by Fortunio Liceti (Ltini, 1640). 
workers. $^{61}$ Research was of two kinds: (1) on the spectroscopic composition of the light ${ }^{62}$ and (2) on the physics of the discharge itself. One of the early workers (1869-1873) on spectroscopy was Paul Emile Lecoq de Boisbaudran (1838-1912), a private chemist in Cognac and in Paris, who received the Bordin prize in 1872 for his study of spectra. He later became known, together with Wm. Crookes of England, for investigation of the cathodoluminescent spectra of the rare earths, described in Chapter XII.

At this time spectra were recorded under "normal " conditions, but it was early recognized that changing the pressure, temperature and the electrical conditions of the discharge would greatly change the character of the spectra, leading to intensity differences, to broadening and to actual reversion of lines. A. Schuster (1877) was particularly impressed with the totally different spectral composition of light from a gas when a Leyden jar was incorporated in the electrical circuit.

These studies received a great impetus when Gustav Robert Kirchoff (1824-1887), in 1859 explained the Fraunhofer lines of the sun's spectrum as due to absorption by vapors of metals in the sun's atmosphere. The new science of astrophysics made excellent use of the laboratory finding on gases in vacuum tubes for interpretation of the materials and the physical condition in stars, nebulae, comets, and the aurora borealis. As early as 1869, E. Frankland and J. N. Lockyer contributed a paper, "Researches on Gaseous Spectra in Relation to the Physical Constitution of the Sun, Stars and Nebulae," in which they studied the effect of low temperatures and pressure on the hydrogen spectrum. Space will permit an account of only one of the many lines of spectral inquiry.

\footnotetext{
${ }^{61}$ See the account in Vols. I (Chap. 2) and II (Chap. 3, 4, 5 and 6) of Kayser's Handbuch der Spectroscopie (1900 and 1902). Also J. J. Thomson. Recent researches in electricity and magnetism (Oxford, 1893) and Conduction of electricity through gases (Cambridge, 1903; 2nd ed., 1906; 3rd ed. with G. P. Thomson (2 v.), 1928 and 1933); O. Lehmann, Molecularphysik, etc. (Halle a S., 1888, 1889) and Die elektrische Lichterscheinungen oder Entladungen, etc. (Halle a S., 1898) and J. Stark, Die Elektrizität in Gasen (Leipzig, 1902).

${ }^{62}$ In addition to Plücker, Plücker and Hittorf, Van der Willigen, Lecoq de Boisbaudran, and others to be mentioned, the following men have studied the spectral composition of the electroluminescence of gases: J. S. Ames, 1890; §. J. Angström, 1871, 1893; M. Berthelot, 1897; T. W. Best, 1887; J. R. Capron, 1880; J. Chautard, 1864; G. Ciamician, 1878; J. N. Collie and W. Ramsay, 1896; A. Cornu, 1886; H. Deslandres, 1888; H. Ebert, 1888; J. M. Eder and E. Valenta, 1896; S. Friedlaner, 1896; E. Goldstein, 1874, 1881; B. Hasselberg, 1879-1885; A. Kalähne, 1898; H. Kayser, 1896; K. R. Koch, 1889; H. Lagarde, 1885; B. Lengyel, 1878; P. Lewis, 1899; H. F. Newall, 1895; A. Paalzow and H. W. Vogel, 1881; C. Runge and F. Paschen, 1897; G. Salet, 1871-1876; J. Scheiner, 1898; O. Schenk, 1873; A. Schuster, 1877-1884; C. P. Smythe, 1882; C. P. Smythe and A. S. Herschel, 1883; D. Van Monckhoven, 1877, 1882; H.W. Vogel, 1879; A. von Waltenhoften, 1865; E. Wiedemann, 1878-1883; G. Wiedemann, 1872, 1876; A. Wüllner, 1869-1889; E. Zöllner, 1871.
} 
The spectra of gases, excited electrically at low pressure are made up of a series of lines, a condition now known to be characteristic of relative simple atoms. These lines exhibit a certain regularity and have given important information regarding the constitution of matter. In 1869, E. Mascart suggested that the regular distribution of lines in sodium or magnesium spectra might be as important as the fact that such lines were characteristic of these metals. Lecoq de Boisbaudran (1869-1873) also, called attention to regularities in potassium and rubidium lines, and in 1870 G. J. Stoney studied hydrogen, and showed that the distribution of the line frequencies were such that they might be considered overtones of a fundamental frequency. On discovery of additional hydrogen lines in the stars, Stoney (1880) extended his findings and later $(1891,1892)$ added to the general knowledge of regularity. In 1871, J. L. Soret wrote a paper, "On Harmonic Ratios in Spectra," dealing with magnesium, while A. Schuster (1881) applied the harmonic ratio concept to other elements.

These papers represent the start of a field of spectroscopy in which gas spectra have played an important part. Probably the most satisfactory relationship was that noted in 1885 by Johan Jakob Balmer (1825-1898) for hydrogen, now known as the Balmer series. An enormous amount of research has been carried out since then, and many other series observed. Such spectral lines are now regarded as light of definite frequencies emitted as a result of sudden corresponding energy changes in the atoms (or molecules) of a substance, connected with shift in position of electrons from one orbit of revolution to another-what has come to be called a transition. In this way electroluminescent spectra can be interpreted in a logical manner, although it would be presumptuous to say that the last word has been written on spectral analysis.

In addition to the colors of gases in a discharge tube, the changing forms of luminescence, dark spaces and striations, also required explanation. ${ }^{63}$ They presented some baffling problems to the physicists of the last century. These rapidly changing visual phenomena depend on temperature, pressure, and electrical characteristics of the discharge, just as in the case of spectral structure. They have also been studied in minutest detail, ${ }^{64}$ and their character related

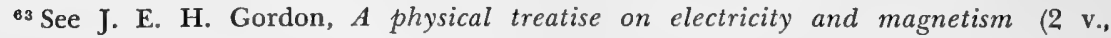
London, 1880), for a general account of luminescent effects in vacuum tubes.

${ }^{64}$ In addition to Becquerel, Crookes, de la Rive, de la Rue, Goldstein, Hittorf, Wiedemann, Gassiot, Plücker, Spottiswoode, and others previously mentioned, the following men, working in the latter part of the century, have contributed to knowledge of conditions during electroluminescence in gases: E. C. C. Baly, 1893; C. Chree, 1891; H. Ebert, 1899; H. Ebert and E. Wiedemann, 1893; E. S. Ferry, 1898; W. P. Graham, 
to the temperature gradient, potential drop, kind and pressure of gas, etc., in the tube. Since Plücker had presumed that the light of Geissler tubes was the result of temperature rise, rather than a purely electrical effect, the temperature of different regions of the tube assumed particular importance. It was studied by both the father, G. Wiedemann (1876), and the son, E. Wiedemann (18781880 ), in one of the latter's first investigations of luminescence.

The phrase, "conduction of electricity through gases," has become almost synonymous with the name of J. J. Thomson (18561940), whose book (1903) of that title has summed up knowledge of the many complex phenomena to be observed. It has served to obscure an earlier work, Recent Researches in Electricity and Magnetism (Oxford, 1893), which was intended as a sequel to ClerkMaxwell's treatise (1873) on these subjects. In Thomson's book (1893), Chapter II (pp. 53-207) deals with the "Passage of Electricity Through Gases," a general account of the many luminescent and other phenomena which occupied the principal attention of physicists of the period. A similar work Elektrische Lichterscheinungen, was published by Otto Lehmann (1855-1922) in Germany in 1898, to be followed by Die Elektrizatät in Gasen (1902) of Johannes Stark, a Nobel prize winner in 1919. Knowledge of electroluminescence before the more modern approach made possible by quantum theory is well covered in these works.

\section{AFTERGLOW IN GASES}

In some of Becquerel's tubes containing only rarified gas, it was noticed that a persistent light ${ }^{65}$ was visible, not due to phosphorescence or electrification of the glass. ${ }^{66}$ It was later determined by

1898; G. Granquist, 1898; H. Hertz, 1883; A. Herz, 1895; W. Hittorf, 1869-1884; M. Hoffmann, 1897; C. Kirn, 1894; O. Lehman, 1895; C. A. Mebius, 1896; B. Nebel, 1885; A. Paalzow and F. Neesen, 1895; J. Puluj, 1880-1882; A. Schuster, 1884, 1890; G. Seguy, 1898; C. A. Skinner, 1899, 1900; W. Spottiswoode and J. E. Moulton, 1880; F. Stenger, 1885; J. J. Thomson, 1886-1895; J. Trowbridge and T. W. Richards, 1897; E. Wiedemann and H. Ebert, 1888; E. Wiedemann and G. C. Schmidt, 1898; G. Wiedemann, 1876; G. Wiedemann and R. Rühlmann, 1872; R. W. Wood, 1896.

${ }^{65}$ It is interesting to note that Michael Faraday (1857) described "the persistent appearance of a lightning flash" which appeared as a $\mathrm{Y}$ in the clouds and lasted a second or more. The form was not an impression on the eye, as it did not move with the eye but remained fixed in the cloud. Faraday asked, "What is the cause of this effect? The most probable guess seems to me to be, that it is due to a highly exalted phosphorescent condition of the particles of cloud, along or through which, the electric discharge has passed; and perhaps an experiment might find means of realizing it in some degree. I believe that like luminous traces have been observed upon sugar and some other bodies when the electric discharge has been made over them." Perhaps this is the first record of a persistent luminescence of gases.

${ }^{80}$ See E. Becquerel, Ann. Chim. et Phys., ser. 3, 57:40-124, 1859; also P. Riess, 
E. Becquerel (1861) and particularly by A. Morren (1861-1869) that the effect was most marked with mixtures of gases and that oxygen played an important part in the phenomenon. In his book (1867: 1: 196) , E. Becquerel closed his discussion by writing: “ Thus this persistent temporary luminescence, that is to say this phosphorescence which is produced by oxygen or by its mixture or by its combination with other bodies, is as curious as the luminous effect given by the slow combustion of phosphorus." It was these observations which called attention to the afterglow of gases, ${ }^{67}$ a field that has played so important a part in theories of light emission.

One of the most quoted cases was described by E. P. Lewis (1900), who noticed that nitrogen gas under a few millimeters pressure could be "stimulated" by the electric discharge to emit a bright yellow glow which continued for some time after the discharge ceased. The phenomenon was further studied by Lord Rayleigh

(R. J. Strutt) in a series of papers beginning in 1911, who called the gas " active nitrogen." The conditions for the phenomenon and the spectral emission received much attention in the early twentieth century. Additional knowledge of the afterglow will be found in Chapter XIII on chemiluminescence.

\section{ELECTRODELESS DISCHARGES}

Later research led to a great variety of "vacuum tubes" for various studies, including glass vessels without electrodes. Although Hauksbee (1706) used electrodeless glass vessels for light effects, J. J. Thomson (1891) described a special electrodeless vessel giving a bright luminescence in the form of a ring when placed in a solenoid through which rapid alternating currents were passing. In $1893 \mathrm{H}$. Ebert and E. Wiedemann and others ${ }^{68}$ investigated luminous phenomena in "electrodeless" tubes containing gas at low pressure under the influence of rapidly changing electric fields between condenser plates. They also enclosed luminescent substances in the tubes and observed the brilliant blue of Balmain's paint $(\mathrm{CaS})$, the bright red of burnt magnesia, the intense blue of aesculin, the green of anthracene, etc. In describing the method of electrical excitation, H. Ebert (1894) particularly emphasized the

Pogg. Ann. der Physik 110: 123-124, 1860, who described one of Geissler's tubes with this property.

${ }^{87}$ Later work was carried out by E. Sarasin (1869) , A. de la Rive (1870) , E. Warburg (1884), J. J. Thomson (1891), C. Kirn (1894), G. Seguey (1895), and H. F. Newall (1896).

${ }^{68}$ Light from electrodeless discharge tubes was also described by J. P. Gassiot (1858), J. Plücker (1862), Alvergniat (1871), E. C. Remington (1893), and O. Lehmann (1892). 
brilliant luminescence of gases and "Leuchtfarbe" and the small amount of energy used, suggesting that such devices might be the "Luminescenzlampe" of the future.

The experiments are reminiscent of the fluorescent lamp and of the newest light, the "panelescent lamp," in which special phosphors are excited by the rapidly changing potentials of condenser plates (see Introduction). In 1896 Wiedemann and Schmidt, who had discovered the green fluorescence of sodium and the red of potassium vapor in the light from an arc lamp, noted the same colors when electrodeless tubes containing these vapors were subjected to oscillating discharges. Thus the fundamental discoveries had been made, and the twentieth century was to see the gas discharge tube undergo rapid commercial development.

\section{NEW TYPES OF RAYS}

The attempts of the older investigators to obtain more perfect vacua bore fruit in the middle of the nineteenth century. As the pressure in a vacuum tube decreased, new types of rays were found to appear, revealed by the nature of the luminescence they produced. The names of Plücker, Hittorf, Goldstein, Crookes, Lecoq de Boisbaudran, Lenard, Thomson, and E. Wiedemann are associated with cathode ray discoveries, while Goldstein, W. Wien and G. C. Schmidt investigated anode ray phenomena.

Among these men, Sir Wm. Crookes (1832-1919) paid particular attention to luminescence. Beginning in 1874 , he carried out his series of studies on the discharge of electricity in vacuum tubes containing different pressures of gas. He paid particular attention to the cathode glow, the dark spaces in the tube, and the streams of "radiant matter" (cathode rays or electrons) which he thought were molecules of the residual gas repelled from the cathode. Crookes' name was applied not only to the tubes but to one of the characteristic regions of the tube, the Crookes dark space, called the Hittorf dark space in Germany. As we have seen, another region, the Faraday dark space, honored a second early investigator of electrical discharges in vacuum tubes, Michael Faraday (1791-1867), who later became more noted for discovery of the laws of electrical induction. Perhaps the name of J. J. Thomson, who did so much to elucidate the nature of the electron, should be applied to a third region of the tube.

After cathode rays were established as a definite new phenomenon of vacuum tubes, the part they played in the luminescence of the tube became a matter of discussion, leading H. Hertz (1883) to remark that "The light of gases in the glow-discharge is no phos- 
phorescence under the direct influence of the [electric] stream, but a phosphorescence from the stream induced cathode rays."

When the pressure in an evacuated tube reaches $0.01 \mathrm{~mm} \mathrm{Hg}$ or less, the Crookes dark space practically fills the tube. Faint bluish cathode ray streamers can be detected and a brilliant fluorescence of the glass walls of the tube where the cathode rays strike. The conditions are now ripe for the emission of X-rays, discovered by W. K. Roentgen in 1895.

The many luminescence effects resulting from cathode rays, anode rays and $\mathrm{X}$-rays are described in the chapter on radioluminescence, while phosphorescence and fluorescence from ultraviolet light produced by electroluminescence are considered in corresponding chapters on these subjects.

\section{SURVEY}

Nearly three hundred years have elapsed since von Guericke observed light on a sulphur ball, and nearly 250 years since the light in Hauksbee's evacuated glass globes astonished the members of the Royal Society. From so humble a beginning has come a highly popular method of advertising, the neon sign, and in combination with fluorescence, the predominant means of illumination at the present day. The so-called "electric light" of the eighteenth century was not the "electric light" of Edison and the late nineteenth century. It was in fact more literally an electric light than the high temperature incandescence of a filament, and it is interesting to note that gas discharge lamps represent a return to the original meaning of the words.

Electrical discharge lamps for illumination are associated with the names of D. McFarlane Moore in the eighteen-nineties, and Georges Claude around 1900. The earliest practical suggestion the author can find for use as an illuminant appeared as a short note by J. P. Gassiot (1860) in the Proceedings of the Royal Society. The paper contains a figure of a flat glass coil with enlarged electrodes at the end which could be connected with a Ruhmkorff coil. When filled with carbon dioxide at low pressure and the current from the coil passed through, "the spiral becomes intensely luminous exhibiting a brilliant white light." It was demonstrated at one of the meetings. Thus over forty years passed before commercial development became practical. 


\section{PHOSPHORESCENCE}

\section{Introduction}

LThough the popular use of the word "phosphorescence" implies $A$ any kind of cold light, this term will be restricted here to the lasting luminescence which results from exposure of a substance to visible or ultraviolet radiation-what is more properly designated photoluminescence. When the luminescence is of very short duration-a fluorescence-the history will be given in Chapter XI, since fluorescence has been recognized as a light emission only in fairly recent times.

When light strikes a body, a number of well-known changes may occur, the most apparent being a chemical change, the photochemical effect. A second effect may be a production of light which is not a reflection, fluorescence, or phosphorescence. In addition there are changes in electrical properties of substances, the photoconductive effect, as when light changes the conductivity of selenium metal, discovered by W. Smith in 1873, and the photoemissive or Hallwachs ${ }^{1}$ effect, the fact that negative charges (electrons) leave a metal when irradiated by light. The question as to whether phosphorescence may be the result of reversible photochemical or other changes in the phosphorescent body will be considered in subsequent sections, but it is an important characteristic of phosphorescence, distinguishing it from chemiluminescence, that no permanent chemical change need result from the exposure to light.

\section{Early Records}

The light from Chinese paintings and the "torches" of the bacchantes, described in Chapter I, are possible but questionable cases of phosphorescence. The evidence seems to indicate that the "luminous jewels" of ancient and medieval writers excited the admiration of observers by the light which they reflected or transmitted,

\footnotetext{
${ }^{1}$ W. Hallwachs (Ann. der Phys. 33: 301-312, 1888). H. Hertz had noticed the phenomenon at spark gaps (Ann. der Phys. 31: 383-421-448, 983-1000, 1887), as well as E. Wiedemann and H. Ebert (Ann. der Phys. 33: 241-264, 1888). The fact that light can give rise to a current when it strikes sensitive material in a circuit is called the photovoltaic effect (E. Becquerel, Com. Rend. Acad. Sci. 9: 145-149, 1839). An E. M. F. is actually produced, whereas the photoemissive and photo-conductive effects require that an E. M. F. be applied in order that current may flow.
} 
thus giving merely the appearance of a glowing coal. ${ }^{2}$ However, the diamond described by Cellini in Due Trattati dell'Orificera (1568), which would shine after exposure to light must be authentic, since certain varieties of diamonds do possess this property, a fact established beyond question by Robert Boyle in 1662. Cellini's diamond is perhaps the first recognized natural phosphor.

In addition to jewels, certain natural phosphorescent minerals may have been known before the discovery of prepared phosphors. About 1600, Jan Baptista van Helmont (1577-1644) had in his possession a stone or a flint (silicem) which would receive the light, and preserve it, visible in the dark for some time, but no one knew how it was prepared and " almost the memory of it has died with the inventor," according to B. Wilson (1775). A translation from the Latin of van Helmont's statement from Magnum Oportet ${ }^{3}$ is as follows:

Indeed I observe that if I expose a stone (silicem) to the air, when the sun is high on the horizon, at least during two or three hours (and it does not matter if the day is clear or if it is cloudy), when after I move this stone in a dark place, the stone retains the light of the sun, during about the same period of time. This happened every time I repeated the exposure to light above mentioned. ...

This account is certainly a straightforward description of phosphorescence. In addition to Wilson, Beccaria (1744) and Priestley (1772) both mentioned van Helmont's flint stone. Heinrich (1811: 13) thought it might be a diamond or fluorspar, while Kayser (1908: 604) believed it to be fluorspar. The suggestion is most probable, as certain varieties of this flint-like stone are phosphorescent, especially if warmed slightly by the heat of the hand (see Chapter IX).

\section{The Bolognian Phosphor}

\section{CASCARIOLO, GALILEO, AND LA GALLA}

Despite the undoubted observations of natural phosphorescence previously mentioned, the importance of the discovery of methods for preparing artificial phosphors cannot be overestimated. This technique was perfected between $\mathrm{I} 602$ and $1604^{4}$ by Vincenzo

\footnotetext{
${ }^{2}$ One of the best known books on jewels of the seventeenth century was Boecius de Boot's (?1550-1632), Gemmarum et lapidum historia (Ludguni Batavorum, 1647), to which was added the De gemmis et lapidibus libri II, by Jean de Laët (1593-1649), a translator of Theophrastus. They repeated the story of carbuncles, etc., that "shine" at night. See also John Hill $(\mathbf{1 7 4 6}, \mathbf{1 7 7 4})$.

${ }^{3}$ Section 35 , bearing the date 1600 . Translated by B. Wilson (1775).

1 Priestley's (1772: 361) date, 1630, is undoubtedly a misprint.
} 
Cascariolo or Casciorolo), the cobbler of Bologna, who dabbled in alchemy. He found, apparently by chance, that a mineral obtained from Monte Paterno near Bologna, would, after calcining, glow in the dark. The mineral was heavy spar, a native barium sulphate, rich in sulphur. Properly prepared, it would attract the "golden light of the sun" and seemed to be the appropriate material to convert ignoble metals into gold, whose alchemistic symbol was the sun $(s o l)$. In later years many prominent men ${ }^{5}$ were to tread the slopes of Monte Paterno near Bologna, searching for the small (size of a walnut or orange) heavy silvery stones which they thought promised so much.

Cascariolo showed his "lapis solaris" to Scipio Bagatello (or Begatello), well known at the time in the art of gold making, and also to Giovanni Antonio Magini (1555-1617), the astronomer and professor of mathematics at Bologna, who spread the news quickly among their friends. Although the hope of preparing a philosopher's stone failed, the discovery of a material which would imbibe the light of day aroused the interest of learned men throughout Italy. Many knew of the Bolognian stone, a name often used indiscriminately for heavy spar itself or for the material prepared from the stone, more properly called the Bolognian phosphorus. For some time the method of preparation was kept more or less a secret.

Galileo (1564-1642) joined in the general discussion ${ }^{6}$ of the "stone" although he never wrote a special treatise on the subject. He presented samples to the eminent Gulio Cesare La Galla (15761624), a professor of philosophy at the Collegio Romano in Rome, the first to mention its properties in writing. In the book, De phenomenis in Orbe Lunae, etc., Venetis, 1612, whose title page is reproduced as figure 29, La Galla made it clear that the original stone did not luminesce but attained that property only after it had been heated into a calx. Exposure to twilight as well as sunlight made the calx appear like a glowing coal. The ability to luminesce was lost after a time, owing, as is now known, to the absorption of moisture. La Galla's explanation of the behavior was that a certain amount of the fire and light substance to which it had been exposed became confined in the stone and later passed out slowly. Light must be absorbed, as a sponge absorbs water, and the behavior was taken to indicate that light is a material substance.

\footnotetext{
${ }^{5}$ Goethe was one of them, in 1786, although he was not looking for the philosopher's stone. See Winderlich (1936) .

${ }^{\circ}$ According to Olschki's (1927) Galilei und seine Zeit (p. 454), the letters are in ed. naz. XI 136, 140, 371, 505, 513, 515, and XIII 339, 340 of Galileo's works.
} 
PIERRE POTIER

The first detailed description of the method of preparing the stone was published by Pierre Potier or Poterius (died 1640), physician to the kings of France, in a section of his Pharmacopoea Spagirica (1625), dealing with inorganic remedies based on the teachings of Paracelsus. The account ${ }^{7}$ first appeared at Bologna in 1622 and as Potier lived in that city for some time, he was able to give a reliable version of the discovery. He began with acclamation of the marvels discovered in his time: 8

Daily there emerge new things in nature, in which its great miracles are appearing. $\mathrm{O}$ you idle haters of truth who are ashamed of learning more. Wrongly we believe that everything was known to the ancients. How many plants, how many fossils not seen by our ancestors have come to light! Among other phenomena unknown to them there appears to us something special in the class of stones which is quite new and unheard of. ... It is wonderful how a dark body receives its light from the sun or moon and reflects it in the dark. Which makes us wonder whether light is a body and what kind of a body; or a substance or an accident, and other questions on light which perhaps it is not difficult to elucidate.

There then follows a minute description of the appearance and properties of the stone itself and the parts of Monte Paterno where it is found, with the receipt for preparation:

According to the light-bearing quality sought for it is calcined in two ways: the first is to reduce the stone to very fine meal, then to calcine it in a crucible with a very strong fire. The second to reduce it to meal and, in the place of thalerum (?), work it into cakes either with plain water or the white of an egg. After they have dried out they are put in layers with coal in a blast furnace and, after a very hot fire has been made, they are calcined four or five hours. When the oven has cooled off the cakes are taken out. If not cooked sufficiently the performance is repeated as before. Sometimes this is done three times. The best calcination is the one made from choice stones, shining, pure, and diaphanous.... From this powder various animals are formed in little boxes (pyxidiculum) which shine wonderfully in the dark. The lixivium is prepared in the same way and once it is dry it produces a sulphurous, fetid, sharp, and biting salt.

Potier did not attempt an explanation of the light. On the contrary he said, " Those who like to settle disputes over minute points may, concerning the uncommon things told about its light, speculate

${ }^{7}$ Translated into German by L. Vanino, Die Künstlichen Leuchtsteine, 10-14, 1906, and Die Leuchtfarben, 2-5, 1935.

${ }^{8}$ Translated from the Latin by Mrs. Annemarie Holborn. 
to their heart's desire whether this splendor was stolen or received from the sun and moon." He did, however, possibly as an excuse for including the stone in his Pharmacopea, ${ }^{9}$ state: ${ }^{8}$

So far the known use of this stone has been only external. From it is made the lixivium for the psilothrum (a depilatory), which could be profitably applied to the beard and for removing hair if it did not have such offensive smell, but this, I think, could easily be corrected with moschus or some sweet smell. The very quality which is the most wonderful feature of the stone does not have any practical use, except that it delights the eyes, as usually happens to be the case with newly found things.

\section{OVIDIO MONTALBANI}

The Bolognian phosphor stimulated many illustrious persons to write, and Ovidio Montalbani (1601-1671), professor of astronomy and mathematics at Bologna, published a short account in $1634, D e$ Illuminabili Lapide Bononiensi Epistola. Montalbani's ideas were expressed in reply to a letter dated Verona, October 23, 1633, from Count Majolino Bisaccioni (1582-1633) an Italian soldier, diplomat, and author of Astronomia Microcosmica, who stated that thirty years ago he had been shown the stone by Vincento Cascariolo himself and begged an explanation of its marvels. Bisaccioni wrote: ${ }^{8}$

I want to trace this stone and its operations. My mind soars to higher things and rejoices to have found a body which is a receptacle of the heavenly light. Therefore I call your Lordship to work, to help, for I know that you have left behind the ordinary paths and are searching earnestly into the inner chambers of science. I know how illuminated your intellect is, therefore I call you into the ring, search for the stone and once you have found it, pass it on to me. And not enough, explore its anatomy and disclose your findings. ...

${ }^{\circ}$ Despite the rather striking properties of the Bononian phosphor, the material found no great use in medicine at any time. All accounts mention its ability to remove hair. In $A$ compleat history of drugs, written in French by Monsieur Pomet, chief druggist to the late French King Lewis XIV, to which is added what is further obserable from Mess. Lémery and Tournefort, etc., by John Hill (third ed., London, 1737), the only phosphor mentioned is the Bolognian variety, which is again described as “Depilatory; and being powder'd and mix'd with Water to the Consistance of a Paste, may be apply'd to any Part of the Skin where there is Hair to be taken off." C. Mentzel (Ephem. Dec I, An. 4 and 5) reported that, taken internally, it caused vomiting and quoted Licetus that it relieved gout.

Johann Friedrich Cartheuser (1704-1777) the German physician and pharmacologist at the University of Frankfort-on-the Oder, wrote a text book of chemistry in 1736 and Fundamenta materiae medicae in 1749 , introducing many new drugs. He gave a detailed description of the preparation of the Bononian and Balduinian phosphors as a footnote to a chapter dealing with quick-lime. Lime water was recommended for cachexia, scurvy, dropsy and many other conditions but the phosphors were not specifically prescribed. A French translation, Materie médicale, appeared at Paris in 1755. 


\section{Montalbani ${ }^{8}$ replied from Bologna, January 1, 1634:}

Since you ask me for the details of its characteristics and qualities, and especially the way of illumination, not described by any pen before, by way of an analysis, and since I have always complied with your wishes, I believe I should start this obscure thing with a discussion of light.

Then follows a rather obscure discussion of solar light or ethereal fire, earthly fire, color, the noctiluca [glowworm] and eyes of cats. Montalbani continued: ${ }^{s}$

But I am convinced that the light of our stone that has been processed has a different origin besides color, which it has in common with other things that are mixed. In a definite, though hard to recognize measureon account of the arrangement of its parts-the light of the sun or fire directly or reflected ... ignites certain parts of this stone, be it calcined or left intact. . . . These ignited parts are separated from the others by calcination and ready to take up light or some inflammation and become luminous. But we see this splendor, which shines in the dark, being extinguished by what surrounds it, sometimes sooner, sometimes later, depending on whether more or fewer of the dissoluble particles in the whole of the mixed body have been ignited. ... As to the composition of the stone, I am inclined to consider it, if not totally, at least predominantly arsenic with some admixture of sulphur and chalk. For, exposed to great heat this stone, the pigment of gold, at once has a foul smell, from a pale leaden color it turns yellowish, reddish, whitish, finally blackish, while formerly it resembled the appearance of a crude simple silex or a mostly roundish gypsum. Taken internally it causes very bad vomiting; externally applied it has a depilating effect.

Montalbani then described the external appearance of the stone, which existed in three varieties, and closed his letter as follows: ${ }^{8}$

I send you various fragments of the genuine stone, which show a dark red vivid light, [or] slightly indicated, the blue smooth flame of sulphur, [or] something like rare fiery embers. ...

He then continued:

I leave you the road free for deeper speculation, since you know how to sustain any light in a purer state by virtue of your sharp intellect. Be sure that I was more concerned with your wishes than my own reputation and also that I live more for my friends than for myself. May God give you all you deserve. Farewell.

Apart from the flowery compliments with which these correspondents greeted each other, the letter of Montalbani is of special interest as indicating the different colors of luminescence which were obtained and the first suggestion that the light was a kind of burning. 
The most impressive book on the subject, and at the same time with the least scientific approach, was the Litheosphorus sive De Lapide Bononiensi, of Fortunio Liceti (1577-1657), published in 1640 while professor of philosophy at Bologna. ${ }^{10}$ The title page is reproduced as figure 30 . In the 55 chapters and 280 pages there is a detailed account of the various names by which the Bolognian stone was known, its discovery, the places where it occurred, and an attempt at explanation. The statements are characteristics of much of the scientific thought of the time. No original experiments were performed but many philosophical and absurd questions were discussed, with citations from the Bible, from Aristotle, and from contemporary writers. The belief was presented that stones in general arose not only in the ground but also from fully developed animals, although not from plants or imperfect animals like oysters or mussels.

Liceti's language is hard to understand but he apparently believed that the cause of the light was fire, a kind of burning due to the absorption of sunlight. He held that exposure to the sun "impregnated" the phosphor with light and that it took some time before the luminescence was "born," an idea probably based on the lightadaption of his eyes. On going into a dark room from sunlight, the phosphorescence could not at first be seen but only as the eyes grow dark-adapted would the slow birth of the luminescence become visible. Impregnation and birth was compared to reproduction among humans and the glow was believed to have the property of repelling all unclean things and bringing pure parts to the surface.

Liceti went so far in his enthusiasm as to declare that the faint light of the new moon's disk was due to a phosphorescence like that of the Bolognian stone and was not, as Galileo believed, a reflection of sunlight from the earth to the moon. Liceti's statement (Chap. 50) led to correspondence ${ }^{11}$ between Prince Leopoldo de Medici (1617-1675), a founder of the Accademia del Cimento in 1657, and Galileo in 1640, and between Galileo and Liceti in 1640-1641, in which Galileo rather forcibly adhered to his own explanation. These letters were the last that Galileo, already blind, wrote. He died in 1642. His corrected reply to Count Leopoldo, fifty pages in length,

${ }^{10}$ The Bolognian stone and a number of other luminescences were mentioned by Liceti in his De lucernis antiquorum reconditis, etc., Book IV, Chap. 7, Utini (1653). There is nothing in De luminis natura et efficientia, 244 pp., Utini, 1640, or in De lucidis in sublimingenuarum exercitationum, 120 pp., Patavii, 1641.

${ }^{11}$ See C. G. Venturi, Memorie e lettere inedite finora o disperse di Galileo Galilei, Part II, Articolo VI, p. 293, Modena, 1821. An account of the controversy will be found in The private life of Galileo (London, 1870), by Sister M. Celeste. 
was printed in another book of Liceti, entitled De Lunae Subobscura Luce Prope Conjunctiones etc. (Utini, 1642).

\section{ATHANASIUS KIRCHER}

Knowledge of the Bolognian stone spread throughout Europe. Athanasius Kircher of Fulda (1601-1680), who was in Rome in 1635, devoted four pages to it in his book on magnetism, Magnes, sive de Arte Magnetica, published in Rome, 1641, and gave the same account in his book on light, Ars Magna Lucis et Umbrae, Rome, 1646. His interest lay in the comparison of a phosphor which attracts light to a magnet which attracts iron.

Speaking of the variety of the stone which he found at Tolpha, Kircher said:

This fossil is a certain selenitic mass of sulphuric gypsum much mixed with arsenic, antimony and copperas water [chalcantium], and easily resolved to a gypsum calx. The smell proves more than sufficiently the presence of sulphur, the transparency indicates the presence of selenite, the burning and depilatory power arsenic, the ability to cause vomiting, antimony and finally the caustic action, copperas water. ${ }^{12}$

Kircher described the methods of preparing the phosphor from the stone (called "lapis phengis") and discoursed on the cause of the light:

Just as the marvels of this prodigious stone have excited admiration among philosophers, so also has it by its miraculous light stimulated many to enquire with all zeal as to the cause of this so rare effect. Therefore, as usually happens with respect to things that are new and rare, various opinions have been expounded by various men. Some indeed, when they saw this stone shut up in a box and carried into a dark place and at the same time preserve its light without any dependence on a luminous body, thought that light was a substance, against the universal opinion of philosophers, and that the stone carried the light in the same way that naphtha attracts fire and a magnet iron. Some thought that the light was a property of some fiery and celestial substance and that the stones shone in the darkness in the same way as all other noctilucent bodies; others that the stone is kindled by the light surrounding it depending on the atomic particles, into which they think it is resolved. Others have proposed different theories. ${ }^{12}$

Kircher branded all these explanations as "frivolous, falacious and with no foundation in truth." He denied that the "light is a celestial quality inherent in the stone." Its light is quite different from the light "in Noctiluca, a decaying oak, the cincindela, the eyes of

${ }^{12}$ Translated by R. A. Applegate. 
cats, the heads of certain fish, the mold of ships, and similar things " which are not produced by a luminous body but have their own light implanted by nature for certain definite ends.

He held that the Bolognian stone

by the calcination and baking is purified of the admixture of earthly dirt so that, when its crasser and denser substance has been purified and attenuated, it becomes a body most fitted to receive through the opening of its pores the vapors of which the air is full in the presence of a luminous body, whether from a fire or the full sun. If these suggestions are accepted, then our stone, with its pores open because of the calcination, thirsty on account of its dryness, naturally desires that vapor, which is pregnant with its conception of light. And, just as a sponge draws the neighboring water to itself, the white magnet draws slag, and the similar bodies of the nature of gypsum attract wet lips, flesh, and other things of humid nature; so it happens that the vapor now imbued with light is attracted by the thirsty stone and is received into its pores. ${ }^{12}$

In short, Kircher's study of the Bolognian phosphor led him to the belief that the material was made porous by the calcination necessary for its preparation, thereby holding the subtile vapors of air suffused with light in its pores as a sponge holds water. This position was also taken in 1659 by his friend, Kaspar Schott (16081666), a fellow member of the Jesuits and a teacher at Palermo and at Würzburg. Schott added nothing new to the study of the Bolognian phosphor but, like Kircher, took a great interest in unusual physical phenomena.

\section{NICOLAI ZUCCHI AND MID-SEVENTEENTH-CENTURY OBSERVATIONS}

The stone was mentioned by Thomas Bartholin (1616-1680) of Copenhagen, but only casually, in his De Luce Animalium (1647), by Pierre Borel (1620-1689) in connection with his explanation of the light of lamb's flesh at Montpellier, and by Oläus Worm (15881654), also of Copenhagen, in his Museum Wormianum seu Historia Rerum Rariorum (1655). As the century progressed, "explanations" of the light are more clearly expressed. After describing the appearance of the Bolognian Stone, the method of preparing the phosphor from it and how the phosphor behaves, Worm discussed the various theories regarding it, but added nothing new to general knowledge.

Apparently John Evelyn (1620-1706) was one of the first Englishmen to learn of the marvel, as indicated by an entry in his diary. During a visit to Bologna in late May 1645 he wrote: ${ }^{13}$

${ }^{13}$ Diary and correspondence of John Evelyn, ed. by Wm. Bray, v. 1, London, 1819. 
After dinner, I enquired of a priest and Dr. Montalbano, to whom I brought recom'endations from Rome ... the composition of the lapis illuminabilis, or phosphorus. He shew'd me their property (for he had several), being to retain ye light of the sun for some competent time, by a kind of imbibition, by a particular way of calcination. Some of these presented a blew colour like the flame of brimstone, others like coals of a kitchen fire.

Evelyn's statement thus confirms the fact that the luminescence was of different colors.

The light of the stone was accepted as a fact by Sir Thomas Browne (1605-1682) in the second edition of his Pseudodoxia Epidemica (1650), although he regarded the stories of luminous gems as vulgar errors. John Ray (1628-1705) in 1663, when at Bologna, actually visited Signor Gioseppi Bucemi, a chymist, who prepared the Bononian stone or "Lapis phosphorus," which, " if exposed a while to the illuminated air, will imbibe the light, so that withdrawn into a dark room, and there look'd upon, it will appear like a burning coal; but in a short time gradually loses its shining, till again exposed to the light." ${ }^{14}$ No samples were taken to England, as an anonymous note ${ }^{15}$ appeared in the Philosophical Transactions of the Royal Society (No. 21) in 1666, regretting the fact that preparation of the Bononian stone had apparently been lost.

The most important discovery of the mid-century came from one of the Italian workers, Nicolai Zucchi (1586-1670), a teacher of mathematics at the Collegio Romano in Rome. His large book, Optica Philosophia, from Lugduni in 1652, included pages on the Bolognian phosphor, as well as many experiments on light in general. He not only showed that the Bolognian stone luminesced more intensely the stronger the light to which it was exposed, but also that the color of the luminescence was the same whether exposed to white light or whether the white light had passed through glasses of red, yellow, or green color. From this he concluded that the light is not merely absorbed as such, but " rather it excites and unites with a spiritous substance contained in the stone, and when the illumination has ceased, this substance gradually dissipates and becomes unsuitable for exhibiting a visible glow." 16 Although Zucchi's explanation is a little difficult to understand, it has the germ of truth in it as indicating that the light absorbed is not the same as the light emitted. His experiment was a very important one, not repeated

14 Travels through the Low Countries, by John Ray, 1673.

${ }^{15}$ Possibly by $\mathrm{R}$. Boyle, as he wished to study the effects of a vacuum on the light. See Phil. Trans. 2: 581-600, 1668.

${ }^{16}$ Modified from a translation of Mrs. Annemarie Holborn. 
for nearly a century, until Zanotti (1748), with a group of Italian scientists in Bologna, started reinvestigation of phosphors.

About the same time another Italian, Father Benedictus Mazzotta of Bologna, devoted a short paragraph to the Bolognian phosphor in his book De Triplici Philosophia, Naturali Astrologica et Minerali (Bononiae, 1653), often referred to as Philosophia Triplex.

\section{COUNT MARSIGLI AND OTHER ITALIANS}

The first paper on the Bolognian stone in Italian, entitled Il Fosforo O'vero la Pietra Bolognese, Rome, 1680, was written by Marc Antonio Cellio, professor of astronomy in the Physico-Mathematical Academy of Rome. Cellio ${ }^{17}$ described the places where the Bononian stone was found, chiefly on Monte Paterno, and said they were usually the size of oranges, but there was one in Aldrovandi's $\mathrm{Mu}$ seum weighing two and a half pounds, and he had one weighing five pounds. The color of the stones varied, but white ones were best for preparing a sensitive phosphor by a method which he described. As a result of such preparation, even the light of a candle or moonlight would be absorbed. Cellio told how to make luminous pictures by mixing the powdered phosphor with egg white and drawing on any surface desired. Figure 31 is the frontispiece to his book. Note that the pictures and the preparation of the phosphor are shown.

The second paper in Italian, containing many figures of the mineral, entitled, Dissertatione epistolare del fosforo minerale $e$ sia della pietro bolognese, etc., appeared in 1698. It was written by Count Luigi Fernando de Marsigli (1658-1730), the distinguished naturalist, mathematician and soldier, who founded the Bolognian Institute of Sciences and Arts. Marsigli had planned to write the booklet (see title page as fig. 32) as a present for Boyle but it was laid aside after Boyle's death in 1691, and only published in 1698. A presentation copy was abstracted in the Philosophical Transaction $^{18}$ for 1698 . A point emphasized in the abstract was that "The Stone shines in Water and receives the Light in Oyle of Nuts, but will not emit it till it be out of it." This last statement is hard to understand, as most phosphors will shine in any liquid medium which does not distintegrate them.

Count Marsigli and others had thought that the Bolognian stone imbibed less light from the direct rays of the sun than from reflected beams, but this opinion was probably connected with light adapta-

${ }^{17}$ A review of the book is given in the Hutton, Shaw and Pearson abridgment of the Phil. Trans. 2: 215 f., taken from the Philosophical Collections, No. 3: 77-79, 1680.

${ }^{18}$ Phil. Trans. 20: 306, 1698. 
tion of the eyes and was, in fact, later retracted. He also analysed the Bolognian stone which he regarded as a kind of talc and found sulphur as an alkaline salt, and what he thought was mercury. His drawings of the stone are shown in figure 33. Marsigli's language was decidedly flowery. In the introduction to his book, there is a passage which expresses his dissatisfaction with current explanations of the light emission.

Many have already written on my phosphorus, and perhaps they have not done anything but give birth to so many little serpents of Egypt, ${ }^{19}$ to which may also be added mine; which is perhaps of a redder nature than the others. Therefore I pray to Heaven that a destroying serpent may appear as soon as possible; that is a great mind, which will further illuminate [i. e., explain] the light of my phosphorus, a light as dark to the mind's eye as it is clear to the eye of vision, despite all that which has been written in the past.

As we have seen in Chapter IV, the Bolognian stone was preserved in muscums in Italy and considerable space devoted to its history in the books of Lodovico Moscardo (1656, 1672), Lorenzo Legati (1677), and Paolo Boccone (1684). Paolo Casati (1617. 1707) in De Igne (1688) discoursed on phosphors of various kinds, but in Domenico Bottoni's Pyrologia Typographia (1692) they are merely mentioned in connection with fires that light but are not hot.

\section{GERMAN INTEREST}

In Germany, interest centered on the German phosphors, the Baldeweinian and the phosphorus of urine, but an account of the Bononian stone was published by Friedrich Hoffman, senior (died 1675), a physician in Halle, father of the Friedrich Hoffman (16601742) who was physician to Frederick I of Prussia and who discovered the calcium sulphide phosphor in 1700. In Clavis Pharmaceutica Schröderiana (Halle, 1675), Hoffman, senior, devoted over a page to Lapis Bononiensis, "sponge of the sun, sponge of the moon, holder of the heavenly light, luminous stone, lucifer, phosphorus, etc.," citing Potier, Liceti, Kircher, and Mazotta as authorities for his account of the appearance, composition and methods of preparation. Hoffmann stated that "although this stone [after processing] is of external use in medicine-a lixivium for a depillatory is made from it-its outstanding quality is the delight presented to the eye." In contrast to the early use of the element phosphorus as pills for the ailing, the Bononian phosphor gained no reputation as an internal medicine, at least this use is not stressed

${ }^{19}$ Little serpents of ignorance. 
by any of the writers of the seventeenth or eighteenth century. They were carried away by the novelty of something which could capture and hold the light of heavenly bodies.

\section{NICOLAS LÉMERY AND FRENCH OPINION}

In France as in England, little was known of the Bononian stone in the 1660's and 1670's and the secret of preparation was also supposed to have been lost. This statement is made in the fifth edition of Lémery's Cours de Chymie in 1686, which contains methods of preparing the phosphorus of urine and the Baldeweinian phosphorus, but no details regarding the Bononian phosphorus. In the meantime Wilhelm Homberg (1652-1715), the physician and chemist, born in Batavia of German parents, whose later life was spent in Paris, journeyed to Italy expressly to inquire about the stone. Although many in Bologna toward the end of the century were also unaware of the methods of preparation, Homberg was successful in his quest. He imparted the information to Lémery and showed him many experiments, recorded in detail in the eighth edition ${ }^{20}$ of Cours de Chymie. Like Cellio, he drew figures on wood or paper with white of egg, dusted the moist egg-white with the powdered phosphor and allowed the material to dry. By exposure to light, luminescent pictures could be made, similar to those prepared today. ${ }^{21}$

It is important to note that Lémery held that the crushing of the Bononian stone must be done in a brazen mortar in order to have success in preparing the phosphor. An iron mortar was particularly bad, as grinding in iron led to products which did not shine at all. Marble, porphyry or crystal mortars were also not good. These observations were actually made by Homberg, whose many experiments dealing with preparation of phosphors were not well known to his contemporaries. ${ }^{22}$ Although presented to the French Academy of Science in 1673, the volume for the years 1686-1699 did not appear until 1730. Homberg also found that too long grinding of the Bononian stone in a bronze mortar also gave poor results. To Homberg, therefore, must be attributed the observation that traces of impurities (from the bronze) greatly affect the light-emitting

${ }^{20}$ The English translation by James Keill appeared in 1698.

${ }^{21}$ The use for phosphorescent paintings was described by Marsigli (1698) and Homberg may have learned of it from him.

${ }^{22}$ In Homberg's (1730) article, "Nouveau phosphore," presented in 1693, two kinds of phosphors were recognized-one, made from blood or urine, luminesced day and night, without being kindled (the element phosphorus), the other kind needed to be exposed "au grand jour," such as the Bolognian and Baldewinian phosphors. 
ability of the phosphor, ${ }^{23}$ and that too much impurity (too long grinding) is also detrimental. The effect of a trace of copper and just the right amount of copper in modern preparation of phosphors is well known, but the variation of results of the early experimentors must have been very discouraging.

Lémery can be regarded as in large part expressing Homberg's views. He appears to have been a born expounder, for he had an explanation for any peculiarity. Regarding the action of the iron and brass mortars, Lémery wrote: ${ }^{24}$

So it seems there is something in Iron prejudicial to this quality [of phosphorescence 7 and that on the contrary Brass is agreeable to the Nature of the Stone. As to the Marble, Porphyry and Crystal, without doubt they want the agreeable quality of the Brass, but they do not make such a prejudicial impression as Iron. This bad quality of the Iron, it may be, proceeds from the Vitriolick acid of this metal which unites with the exalted Sulphur of the Stone, thereby fixing it, so that it hinders the light from kindling it to make it shine, as I shall shew afterwards.

Regarding the composition of the stone and the effect of calcination, Lémery wrote:

The Bolonian Stone is full of Sulphur, but this Sulphur before its calcination, is so well united with the other principles, which compose the Stone, that it appears not at all: and it is no more luminous than any other stone. The fire in which it is put opens its pores, and exalts the Sulphur, of which a great part is lost in the Air, but there still remains a great deal, which is stopped by the powder which is about the Stone.

If too much calcined the sulphur evaporates away and if too little calcined the pores are not sufficiently opened.

It is therefore certain by all Experiments, that the calcined Stone, which gives light, contains a very exalted Sulphur, whose insensible particles are in motion upon the surface.

These things being granted, which to me appear indisputable, I say, That the calcined Bolognian Stone becomes luminous, when exposed to light, because the light which is a fire, lightens the Sulphur which is upon the surface, and makes it appear burning, the same way as the fire lights Charcoal.

Lémery then proceeded to explain in terms of the above theory all the peculiarities observed. He held that the fire of the Bolognian

\footnotetext{
${ }^{23}$ Marheinecken (1744) and Neumann (1740) both advised using no iron in the preparation.

${ }^{24}$ Quotations from the James Keill translation of the eighth French edition. $A$ course of chymistry, 711-725, London, 1698.
} 
Stone did not burn the skin "because being so fine, it has not the strength to make the impression upon the nerves." The reason the stone could imbibe and emit light for years was because " this little fire rarifies and exalts other Sulphurs in the inside of the Stone, which take the place of those that are lost."

"The Stone takes the light of the colour of the fire which was used in the calcination, because its Sulphur is tinctured with this colour,... when the stone has lost its properties a new calcination rarifies and exalts the sulphur which remains."

Lémery held that the luminescence appeared in a vacuum because

the sulphureous parts of the Stone being of a fineness proportioned to the fire of light, there is no need of Air to light them, nor to preserve them burning: For if the light pass and preserve itself in a vacuum, it can also set on fire a very subtile Sulphur, and preserve it burning. But if this reason does not please, and that you think Air absolutely necessary for burning the Bolognian Stone, you may find as much as is needful in that which we call a vacuum, since it is impossible entirely to pump the air out of a vessel of glass or crystal, but there will always remain a little, do what you can: and this little quantity of air is sufficient for lighting so fine a Sulphur.

Lémery then compared the Bolognian stone with the phosphorus of urine which does require air to luminesce and also burns the fingers and decided that the latter "cannot be set on fire by light alone, because its Sulphur is too gross to be burnt by so fine a fire as it [light] is: There must be a pair of Bellows such as the Air is, to put the saline and sulphureous parts of the Phosphorus in motion that by rubbing violently upon one another, they may take fire . . . for this there must be a great disposition to motion in the parts of the matter." On the other hand the Bolognian stone has such exalted sulphur " and so well purified from the grosser parts that it has no need of any other motion than that of the light to set it on fire; its Sulphur will not take fire at night, because then there is nothing which can light it: All the Air in the world is not capable to move its parts so swiftly as is necessary to inflame it; they are too subtile to receive any impression from it." Such statements give an excellent idea of the thought of a French chemist at the time.

The views of French physicists are also of interest. Although Descartes did not mention the Bolognian phosphor, both Jacques Rohault (1671) and Antoine Le Grand (1680) wrote concerning it. Rohault gave the following explanation in his Traité de Physique, the English edition of John Clark (1723). 
The Reason hereof very probably is, that the Fire has made this Stone extremely porous, so that among the Parts which are almost wholly disjoined from each other, there may be some so easy to be put in Motion, that the Light of the Air alone is capable of agitating them; and they may be so disposed to retain this Motion, that they may keep it after they are removed from amongst the luminous Bodies, which put them in Motion; and this is confirmed from hence, that when this Experiment is often repeated, these Parts exhale, and the Stone quite loses its shining Quality; which Quality cannot be preserved above four or five Years, though the Stone be carefully shut up in a Box, where no Light can come at it.

For a farther Confirmation of what has been said, we may observe, that if this Stone be kept too long in the Fire, or though it be kept in it but six Hours, yet if the Fire be very hot, all the Parts of it which cannot resist the Fire, may be carried off, and then the remaining Parts may be so heavy, as not to be shaked by the Light; in which case the Stone ought not to shine, and so we find by Experience.

Antoine Le Grand presented a typical Cartesian point of view in detail. In his Body of Philosophy (London, 1694), translated from the Latin of 1680 , in speaking of stones which shine in the night (Part II, p. 44) Le Grand wrote:

We must not imagine, with some, as if the Light of the Sun were preserved in the foresaid Stone [Bononian phosphor]; forasmuch as that Light, upon the withdrawing of the Sun, doth altogether vanish, as not being able to subsist a moment without its presence; but rather conclude, that within the Pores, made by the Fire in the said Stone, there be some Fibres, so very moveable, as that upon the presence of the Light they are put into a great agitation, and upon the withdrawing thereof do still continue the motion imprest upon them; and consequently move the surrounding Globuli of the Second Element. And therefore, when either in process of Time, or by the strength of Fire, such Fibres are taken away, that Luminous Virtue immediately vanisheth. The Light of this Stone, as was said, can only be perceived in a Dark Room, because it is very weak, and therefore easily overcome of a stronger Light. As is evident in Rotten-wood, Crickets, and other things that shine in the Night, which by Day give no Light at all.

The Reason why a Diamond shines in the Dark, seems to be this, because in the Pores thereof the particles of the $3 d$ Element are so comprest, that those of the $2 d$ Element being push'd out, some of them are surrounded only with the 1st Element, by which they are carried away, and the Globuli are driven or push'd forwards. 


\section{Phosphorus Hermeticus (Baldewein and Mentzel)}

Despite many attempts, particularly by Christian Mentzel (16221701), physician of the Elector, Friedrich Wilhelm of Brandenburg, to prepare phosphors similar to the Bolognian variety, no success was attained until the last quarter of the century. In 1673 Christolph Adolph Baldouin or Baldewein (Balduinus), a magistrate of the town of Grossenhayn in Saxony and devoted to the fashionable pursuit of alchemy, prepared the second artificial phosphor, the phosphorus Balduinus or phosphorus hermeticus. ${ }^{25}$ It was made from chalk and nitric acid, believed to be the alkahest or universal solvent, and was presumably an impure calcium nitrate. The method of preparation was not accurately described and there is a possibility that some sulphur was present. Baldouin entitled his paper, "Phosphorus hermeticus sive magnes luminaris." It appeared in the Miscellanea Curiosa" for 1673-1674 and was also published as an appendix to a pamphlet entitled, Aurum Superius et Inferius Aurae Superioris et Inferioris Hermeticum, Amstelodami, 1675. Baldewein's translators have all complained of his enigmatic language, known only to those initiated in the mysteries of alchemy.

A sample of Baldewein's phosphor was sent in a gilded silver box to Henry Oldenburg, Secretary of the Royal Society

as a small present to his Majesty as founder and patron of your Society; and to the illustrious President, Council and Members thereof. This phosphorus contains the real spark, yea the most secret soul of the fire and light of nature, consequently the invisible fire of philosophers; attracting magnetically the visible fire of the sun, and afterwards emitting and diffusing in the dark the splendour of the same. ${ }^{26}$

Oldenburg expressed the thanks of the Society, whose members had witnessed the ability of Baldewein's gift to absorb and shine not only by "Daylight, even when the weather was gloomy and misty, but also by the Flame of a Candle. And 'tis hoped, that the said Presenter will so far extend his generosity ... as to impart to them the way of preparing the same; to be Recorded in their Register books, as a perpetual monument of his ingeniosity and frankness."

${ }^{25}$ In the articles by R. Lentilius (1685) and O. Jacobaeus (1677-1679), translated in the Collection academique étranger (vol. 6) of the French Academy (twelve volumes of abstracted translations of foreign publications) the "phosphor hermétique" is the element phosphorus.

${ }^{26}$ From a translation of Balduinus' letter in Phil. Trans. abbreviated by Hutton, Shaw and Pearson, 2: 386, 1809. Original in Latin in Phil. Trans. 10: 788-789, 1676, with Oldenburg's statement. In the Phil. Trans. (No. 134: 842) a letter from Malpighi, dated March 9, 1677, told of Zagonius, who prepared the material and made pictures with the Bolognian phosphor, but the secret died with him. 
The discovery resulted by chance, from Baldewein's attempt to collect the universal world spirit (Weltgeist) by setting hygroscopic substances in the air, where they collected the moisture, and then distilling them to concentrate the spirit. One of these substances was calcium nitrate formed by treating chalk with nitric acid. On one occasion the $\mathrm{CaNO}_{3}$ was distilled under too hot a fire by mistake, and there remained behind in the retort a dry yellow material. The retort was broken and about to be discarded when Baldewein noticed that the encrusted surface gleamed at night. The designation, phosphorus hermeticus, came from Hermes, God of Science and Art, the name by which Baldewein was known in the Society of the Naturae Curiosum. A madrigal was composed in praise of the discovery. In this poem, the fiery magnet stone was compared to a sparkling star that ruled the destiny of Jason's ship and proclaimed the progress of discovery as so clear and rapid that already afar off could be seen the golden fleece.

At first, preparation of the material was kept a secret and it was sold for a high price, but the secret was soon learned by Johann Kunkel von Löwenstern (1638-1703), the great chemist of Wittenberg, and others. The Baldewinian phosphor was apparently responsible for Kunkel's knowledge of the element phosphorus, the new luminous material of Brandt. During a trip to Hamburg with the Baldewinian phosphor, he was told of the Brandt discovery and learned Brandt's secret also. A little later the new thermophosphorus was described by Elsholtz, in 1676, thus bringing to four the number of shining bodies available for experimentation.

In an extensive paper (see title page in fig. 34) published in 1675, Christian Mentzel (1622-1701) compared the Baldewinian and Bolognian phosphors, coming to the conclusion that the former absorbed light more easily, and emitted a brighter luminescence. Explanations of the light were still couched in alchemistic language and had no rational meaning. Baldewein's ideas are expressed in his letter of gift to Oldenburg, and his enthusiasm was so great that he, like Liceti, regarded the light of the moon itself to be similar to that of his phosphor drawn from the sun in daytime and then emitted at night. Like Montalbani and Liceti, Mentzel believed the color ${ }^{27}$ of the luminescence of phosphors to indicate their constituents, yellow from gold, whose symbol was the sun, a bluish light from the sulphur and the vitriol of Venus, the symbol for copper,

\footnotetext{
${ }^{27}$ Color naturally played an important part in alchemistic belief. The philosopher's stone, if red or yellow, was thought to impart qualities of gold to a base metal, if white, then the qualities of silver. Hence the excitement at discovery of something which would absorb the light of the sun, the symbol of gold.
} 
while the whitish sparks indicated silver, whose symbol is the moon. The argument was that a phosphor like the Bolognian stone must contain silver because of its whiteness, for was not the moon goddess, Diana, with her swan the whitest of all the goddesses.

\section{Friedrich Hoffmann and Calcium Sulphide Phosphor}

The next century was to show that the ability to shine after illumination was a very general property of many substances and not the rare and unique phenomenon previously supposed. It was ushered in with a discovery of Friedrich Hoffmann the younger (1660-1742), the noted German physician and professor of medicine at Halle, who made mineral waters popular. He found (1700) that gypsum (singularis species Talci) could be made into a phosphor. The statement is very brief and the method not given, although presumably similar to that used for the Bononian phosphor. The untreated Bononian stone is a $\mathrm{BaSO}_{4}$, while gypsum is a $\mathrm{CaSO}_{4}$, and Hoffmann's phosphor a calcium sulphide. Although barium and calcium were not recognized as separate elements at the time, the discovery of the calcium sulphide phosphor may legitimately be attributed to Hoffmann, who named the material "phosphorus lucens germanicus." He adopted the sponge theory of light absorption in explanation of its behavior. The phosphorescence of a strontium sulphide was first observed by J. F. John in 1817.

\section{De Mairan and Cohausen}

In the prize essays of de Mairan (1717) and Cohausen (1717) the Bononian and Balduinian stones were both discussed. As we have seen (Chapter V), de Mairan believed that luminescence in general was due to the "movement" of sulphur. This movement had to be great enough to set the sulphur free from the surrounding material with which it was bound. Only then would light appear. He regarded fire itself, which was accompanied by light, as composed of foreign corpuscles with a great quantity of sulphur and that in the calcination of the stones to be made into phosphors, fire was important in determining the character of the pores in which the light was held.

De Mairan's essay ends with an explanation of the varying colors of the light of phosphors, in which this point of view is clarified. He based his ideas on Newton's theory of colors, that white represents all colors in proper proportions and black absence of color; that the varying colors can be separated by a prism, but they cannot be converted one into another; and that fundamentally different colors 
are corpuscles of different sizes (red large and violet small) thrown off by the light source. For example, a phosphor calcined in a fire with considerable green light receives the green sized corpuscles in its pores, which thereby take and conserve exactly the size characteristic of green. Thus the phosphor is comparable to a sieve that allows only certain sized grains to pass. When the phosphor is exposed to the light of day, it is only the green corpuscles, of the proper size to fit its pores, which are absorbed. Or, if one supposes that daylight merely sets in movement the sulphurs of the phosphor and they ignite, these sulphurs directly represent in their conformation (moules) the figure, the size, and the degree of movement which the fire of calcination has communicated to them and which is partly conserved. That is why, if one transports this stone or rather this sponge of light from daylight to obscurity, it appears like a green coal for some minutes.

Cohausen also looked upon the calcination of the natural stone as producing a certain texture, but instead of referring the luminescence to movement of sulphur, he regarded the emitted light as something connected with the air or the aether. The calcined material was able to hold the air (aether) in such a way that it could vibrate in the same manner that light in air itself was believed to vibrate.

\section{Bartholomeo Beccari and Co-workers}

Work on the Bolognian phosphor was continued by the Italians, Jacopo Bartholomeo Beccari ${ }^{28}$ (1682-1766), a physician and professor of physics at the Institute of Sciences and Arts at Bologna, and Francesco Maria Zanotti (1692-1777), ${ }^{29}$ later president of the University of Bologna. This work had the support of Count Marsigli, whose book (1698) has already been mentioned, and Domenico Maria Gusmano Galeati (1686-1775), a physician and also professor of physics at the Institute of Bologna. The study was started in 1711 but not published until much later (Zanotti, 1748).

Many of their experiments at the Bolognian Institute were quantitative, designed to determine the relation between the intensity, duration, and color of the exciting light and corresponding qualities of the emitted light. Only a very short exposure, one second, was sufficient to excite a luminescence which lasted thirty minutes.

${ }^{28} \mathrm{~J}$. B. Beccari, De adamente aliisque rebus in phosphororum numerum referendis, Comment. Bonon. II, 1: 274-303, 1745. Comment. Bonon. XII, 2 (2): 136-179, 1746; 2 (3) : 498-519, 1747. See the English translation in Phil. Trans. 44: 81-91, 1746, and the appendix to B. Wilson's book (1775). A French translation will be found in the Collection académique étranger 10:525-545 and 594-600, 1775.

${ }^{20}$ F. M. Zanottus, De lapide bononiensi, Comment. Bonon. 1: 181-205, 1748. 
The brighter the exciting light the brighter the luminescence, the longer it lasted, and the more noticeably reddish it became. Very weak exciting light resulted in a whitish luminescence. Although these men took all precautions to dark-adapt their eyes, it was not realized at that time that the color change was a peculiarity of the eye, that all dim lights appear whitish, no matter what their spectral distribution may be.

The group observed that if one part of the phosphor was illuminated only that part luminesced, without propagation of light to other regions, and they decided that phosphors which had been most used imbibed the light better than when first tested and better than others not much used.

In 1713 Zanotti (1748), together with Count Francesco Algarotti (1712-1764), the Italian writer and connoisseur, repeated and confirmed Zucchi's experiment on colored light, using sunlight and a prism instead of colored filters, and found that their sample emitted the same whitish luminescence after exposure to either blue or red light. This showed that the phosphor "shines by its own natural light, which is only kindled by foreign light." When the phosphorescence was observed through a prism, no spectrum appeared but the luminescence was monochromatic, like that of dim coals, undoubtedly because too faint for the eye to perceive colors. Despite poor apparatus, Zanotti appears to have been the first to investigate the spectrum. The Italian group in 1719 also found that the Bononian phosphor appeared to be less bright in a vacuum but this effect may have been due to poor glass of the receiver.

Somewhat later, Beccari observed that many other substances, both organic and inorganic, were phosphors. According to Priestley $(1772 ; 368)$, as a physician he "was visiting a lady after her lying-in, when the room being pretty dark, she casually observed that a diamond which he wore in a ring appeared exceedingly bright." Beccari soon discovered that his own diamond was truly phosphorescent and decided to test a large number of substances. He had built for himself a special light-tight box, large enough to enclose a man and equipped with a window into which fitted a special rotating cylinder. The material to be examined was placed in this cylinder and by a quick rotary movement could be first exposed to sunlight and then examined in complete darkness. After using this improved device, Beccari wrote: ${ }^{30}$ "It followed from this accuracy that some things were observed which had before escaped not only me, who am a pretty diligent observer, but likewise other persons of great sagacity and discernment."

${ }^{30}$ Quotation from the B. Wilson (I775) translation. 
Beccari then described his experiments in detail, dividing the materials tested into natural and artificial phosphori and each of them into "fossils, vegetables and animals." He observed that the time of excitation need not be long and that sunlight was better than the sky and that the excitation was less if the sunlight had passed through a glass window. He likewise noted that the duration of phosphorescent light was frequently very short.

Among inorganic materials tested and found to luminesce were certain gems, earths of various kinds, marble, gypsum, limestone and Iceland spar. Among products of plants and animals, wood, seeds, sugar, bones, teeth, egg shells, shells of molluscs and many other materials were observed to be natural phosphors, but no metallic substance could be made to luminesce.

Beccari considered that any manufacturing treatment of a natural product made it an artificial phosphor and classed such materials as linen and paper in this category. He became particularly interested in the effect of heat and noted that before illumination, heating or roasting (toasting but not actual browning) of material increased its ability to phosphoresce, but that heating an already phosphorescing material decreased the light. He found, for example, that paper is " a considerable phosphorus" but on heating becomes "so splendid as to be in a manner a new phosphorus." The action of gentle heat, not sufficient to fuse bodies, produced phosphors of the white meat of poultry, nerves, glue, bread, nuts, oats, cheese, and resins but not feathers, hoofs, or the white of eggs. However, the dried yolks of eggs were good phosphors and Beccari recalled that Lémery tried to make Homberg's phosphorus from eggs and succeeded with the yolk but not with the white. Beccari concluded " in truth, the phosphorus in bodies roasted or newly burnt, seems to be fixed in its oily, or as the chymists call it, its sulphureous principle."

Another kind of artificial phosphor was prepared by strong heating of various materials, as in calcination. The ashes of plants were found to be good phosphors especially when mixed with sulphur and the " tutty" from furnaces of blacksmiths. These artificial phosphors usually emitted a yellowish or reddish long lasting light, while the light of natural phosphorus was short and white. Beccari thought there might be " two species of phosphoric quality ... one of them the phosphorism of earthy bodies or limestone; and the other the oleaginous or sulphureous phosphorism: following in this respect the example of electricity, one species of which is for a like reason called vitreous and the other resinous."

In a second paper (1746) Beccari reinvestigated materials in which 
he had previously noted no "phosphorism." He often concentrated the sunlight by means of a lens and came to the conclusion that all plant and animal parts were phosphors if they were well dried, even milk ${ }^{31}$ and fat "if hardened by cold." The flesh of animals was least phosphoric but became so when well dried. Beccari was interested to know whether living material was phosphoric and investigated his own hand: "I saw, to my apprehension, some faint traces of light upon my fingers especially at the sides and ends." He thought the effect might be due to dust or dirt, but subsequent observations after his hand had been thoroughly cleaned also revealed phosphorescence. One January during a severe frost his newly washed hand shone particularly bright and Beccari concluded that " the human skin proved upon good grounds to be phosphoric."

Again the only substances that showed no trace of phosphorism under any conditions were metals. "Indeed I have never desisted from trying every means I could devise to make them phosphoric, but never with success." He came to the conclusion that a metal was "surely a hard and stubborn kind of body, since it rejects light and electricity and even dew."

\section{Charles François de C. Dufay}

The next investigation of real importance was by the French savant, Charles François de Cisternay Dufay (1698-1739) who in 1724 had tested a number of minerals, precious, and semiprecious stones (see Chapter IX), finding that they would luminesce on warming, but if cooled and then heated again there was no light. These stones exhibited a thermophosphorescence and their luminescence with rise in temperature depended on a previous exposure to light. His complete paper was published in 1726 .

In a second paper in 1730 Dufay (1732) demonstrated that many calcium-containing materials such as belemnite, gypsum from Montmartre, marble, ivory, bones, egg shells, and oyster shells treated with nitric acid and then calcined, were converted into phosphorescent material. Topaz (aluminum silicate) also became a phosphor when treated in this manner. The color of the emitted light was different with different stones.

In a third paper in 1735 , Dufay (1738) made an exhaustive study of the diamond and other precious stones, giving the history of luminous gems and summing up his ideas on luminescence in general. He established the fact that two yellow diamonds would luminesce visibly for at least twelve minutes after exposure to daylight

${ }^{31}$ Beccari may have tested his milk frozen. 
without being appreciably warmed, a striking experiment, which Boyle overlooked, as his diamonds were merely exposed to candlelight. All the rubies, spinels, topazes, sapphires, and true emeralds were not luminescent. Dufay determined that the yellow diamonds would luminesce under water and suggested that if the light was prevented from escaping it might persist for some time. He cited results with a diamond exposed to light and then dipped in ink, which was luminescent on removal after five hours. This result is hard to understand.

Like the Italian workers, Dufay was particularly careful about the dark adaptation of his eyes and tested his dark adaptation with a standard weak light, a piece of amber which he rubbed from time to time, to make it electroluminescent. He discovered that by keeping one eye shut, that eye could be dark-adapted, while the other eye was exposed to light. This independent dark adaptation of the eyes turned out to be a great convenience in working with weak luminescences.

Many other natural minerals were found to be luminous after exposure to sunlight, an effect attributed to absorption of the light particles. In speaking of the ability to prepare artificial phosphors from calcareous matter, Dufay had said, "We know that chalk impregnates itself with the substance of light with great ease, conserves it for sometime and then loses it."

His general conclusion was that materials became phosphors by three methods of excitation, by heating, by illumination and by rubbing. Some, for example rubies, only responded to rubbing; others, like quartz, to rubbing and heating; while others, such as diamonds, to all three methods. In explanation of the luminescence, Dufay at times spoke of a metallic sulphur which burns, and at other times of the absorption of light.

After Dufay, in the middle of the century, phosphors were discussed in the dissertations of Melchior (1742) and Markheinecken (1744) and the Mineralogia (1747) of J. G. Wallerius, the professor of chemical mineralogy at Uppsala; and also in an article on luminous stones by H. E. von Delius (1748, 1785), but little new was added to previous knowledge. The most important work came from the German chemist Marggraf.

\section{Andreas Siegmund Marggraf}

Although the chemical composition of phosphors had intrigued the earlier workers, chemistry had not advanced to the point where reliable analyses could be made. As we have seen, the presence of silver was inferred from whiteness and weight, and the word sul- 
phur was used for a material that burned or appeared to burn. After the original disappointment in finding no gold or silver in the Bolognian stone, the Italians designated an alkali and sulphur as important constituents of phosphors. This conclusion was quite correct.

In 1749 the great German chemist, Andreas Siegmund Marggraf (1709-1782) of Berlin, famous as the discoverer of sugar in beets in 1747 , endeavored to analyze the phosphor which he had prepared from the heavy spar of Monte Paterno itself. He found that hydrogen sulphide was given off on addition of acids, leading him to the conclusion that the material was a compound of a sulphur acid and an alkaline earth, which he thought was calcium. ${ }^{32}$ Marggraf made clear the purpose of calcination. Like Hoffmann (1700) he was able to prepare phosphors from gypsum $\left(\mathrm{CaSO}_{4}\right)$, as well as from the heavy spar of Germany, from limestone, marble, oyster shells, calcite and chalk, but not from every sample. The materials were dissolved in nitric acid, precipitated with sulphuric acid and the precipitate calcined. Like Lémery, he emphasized that iron mortars should not be used for pulverizing the stone but held the material should touch the coals during calcination. Marggraf also stressed the fact that the mineral to be calcined must come from a special locality, in this respect differing from the Swede, Johann Gottskalt Wallerius (1709-1785), who believed all limestones could be made into phosphors by calcination. In Wallerius' experiments the acid used may have contained the impurities important for success.

\section{John Canton and Benjamin Wilson}

One of the last of the eighteenth-century phosphors to bear the maker's name was Canton's phosphorus, an impure CaS, prepared in 1768 by John Canton (1718-1772), a school teacher of London. His method was simple, as follows: ${ }^{33}$

Calcine some common oyster shells, by keeping them in a good coal fire for half an hour; let the purest part of the calx be pulverized, and sifted; mix with three parts of this powder one part of the flowers of sulphur; let this mixture be rammed into a crucible of about an inch and a half in depth, till it be almost full; and let it be placed in the middle of the fire, where it must be kept red hot for one hour at least, and then set

32 The metal was actually barium, discovered as baryta in 1774 by C. W. Scheele.

${ }^{33} \mathrm{~J}$. Canton in Phil. Trans. 58: 337-344, 1768. According to Hulme (1801), who studied temperature effects, Canton's method was later modified by Bryan Higgins, Operator to the Society for Philosophical Experiments and Communications, who recommended calcining the whole oyster shells in layers with sulphur in the crucible. (See Ann. der Physik 12: 224, 1802.) 
by to cool: when cold, turn it out of the crucible, and cutting, or breaking it to pieces, scrape off, upon trial, the brightest parts; which, if good phosphorus, will be a white powder; and may be preserved by keeping it in a dry phial with a ground stopple.

Canton did not mention the color of the luminescence. $\mathrm{He}$ studied the effect of prolonged illumination, of electric sparks, ${ }^{34}$ which were as good exciters as daylight, of heat (increases light), of water (slowly destroys), alcohol (slight effect) and ether (no effect) on the behavior of his phosphor. In another paper he also carried out a few observations on shining fish, which he believed might explain the "burning of the sea." The heat experiments are of special interest as indicating that moderate rise in temperature increases the light intensity but decreases the duration. Canton came to the above conclusion by comparing two luminescent samples in glass containers at room temperature and at the temperature of boiling water. The material merely parted with the light more quickly at the higher temperature. Canton also observed that two days later, when no light could be observed in either sample, a quite bright luminescence appeared in the phosphor not previously heated when placed in boiling water. Six months later the phosphor which had previously lost its light in boiling water would luminesce again if placed on a hot iron plate. The experiment was confirmed by Nathaniel Hulme (1732-1807) in 1801. This phenomenon is none other than thermoluminescence (see Chapter IX) and again illustrates the close connection between phosphorescence and thermoluminescence (see Chapter IX). Canton argued that his experiment was definitely contrary to the wave theory and in favor of the corpuscular theory of light:

That a substance should either give light or not, when its parts are agitated by the same degree of heat, according as it has, or has not been exposed to light, for a few seconds of time more than six months before: seems plainly to indicate a strong attraction between that substance and the particles of light:

Canton was no newcomer in study of luminescences for he had previously carried out experiments on electroluminescence in 1753 .

The same statement is true of Benjamin Wilson (1708-1788), a Secretary of the Royal Society, perhaps best known for his electrical experiments, which included a study of the electric discharge in different pressures of gas (see Chapter VII). Wilson's investigation of phosphors began with a repetition of the experiments made by Beccari some thirty years before, and then continued with the be-

34 Beccaria (1776) also studied the exciting action of electric sparks on phosphors. 
havior of oyster-shell phosphors prepared by his own method. Wilson not only translated Beccari's articles but wrote a treatise of his own, A Series of New Experiments Relating to Phosphori and the Prismatic Colours they Exhibit in the Dark (London, 1775). This treatise dealt entirely with phosphors excited by sunlight; no bioluminescences were mentioned. Using the same experimental procedure, Wilson confirmed much of Beccari's work. He observed the bright phosphorescence of paper, especially when hot or slightly browned (but not when charred), toasted bread, linen, cotton, gum arabic, gum copal, sugar, joiners glue, some kinds of bone and hair, feathers, and shells. He noted that paper wet with hot water and hot oil would phosphoresce and the oil itself gave off light, but the most interesting observation had to do with sugar pressed into paper by a hot iron, which Wilson found to phosphoresce with a green color.

Many minerals and gems would also phosphoresce, as Dufay had shown, but Wilson was disappointed that the 200-grain diamond of Lord Pigot showed no phosphorescence, although a smaller yellow diamond was very bright. He was particularly interested in the discovery that oyster shells previously dissolved in nitric acid and calcined in a crucible with copper, gave all the colors of the rainbow when exposed to sunlight and examined in a dark room. Wilson tried many such experiments, calcining oyster shells with various metals, alkaline salts, neutral salts, inflammable bodies like oils, and phosphorus, in some cases obtaining material that phosphoresced with light of many colors, in other cases only red or only green phosphorescence.

He observed that steel added to the shells gave better results (i. e., more prismatic phosphorescent colors) than iron, and concluded that steel, since it was made from iron by heating over charcoal, which abounds in phlogiston, must have imparted that phlogiston to the oyster shells. He in fact believed that "prismatic colours ... depend upon that inflammable principle [phlogiston] which the shells received in consequence of its being disengaged by the force of the fire, from the bodies they were in contact with in the crucible." Later Wilson discovered that mere heating of oyster shells over a "sea-coal" fire without adding anything would result in material exhibiting beautiful prismatic phosphorescent colors and had to admit that chance played a considerable part in his experiments.

Wilson's idea of light emission was connected with his study of excitation by different colored lights and was strongly influenced by the phlogiston theory, which was still in vogue at that time. Since every luminescence color appeared under red (or green, blue, 
etc.) glasses, which transmit only " red making rays" some other principle than light must be involved in producing the various colors and

that principle must have been the phlogiston which was previously lodged within the shell (during calcination).... After they have been phlogisticated they can emit no other colored light than what corresponds with the thickness and densities of their parts: for example the densest parts ... cannot emit any other colour than red, no more than those which are next in degree of density can emit any other color than yellow and so on.

The future importance of phosphors emitting light of various colors was suggested in a statement at the end of Wilson's account: "Why may not chance hereafter, by some lucky combination of circumstances, again produce some discovery, in consequence of those extraordinary appearances, that may turn out to be of far greater importance? Attention and industry seldom fail of producing something worthy the notice of philosophers." Detailed knowledge of the effect of traces of various heavy metals, which do determine the color of phosphorescence, was to come later and resulted in the controlled production of phosphors, indispensable for modern living.

Wilson's (1775) publication led to a number of comments and theories, based largely on the generally accepted fact that blue light has a particularly strong effect in exciting phosphorescence. Leonhard Euler (1707-1783), the famous mathematician, who revived the wave theory of light ${ }^{35}$ in 1746 , published a paper in $1777^{36}$ in which Wilson's views were rejected and a vibration theory substituted. Euler held that when white light strikes the surface of an opaque or colored body, the light is not reflected, but characteristic vibrations are set up in the material particles of the surface, practically resonance vibrations, which are transmitted to the ether as the color of the object. In a similar manner the phosphor particles exposed to light were believed to vibrate after the exciting light is cut off, like the continued vibrations of a plucked violin string, with a frequency depending on the phosphor. Blue light can excite an orange phosphorescence because the natural period of the phosphor vibrators corresponds to orange. This point of view was a new one, unique at the time, just as Euler's support of the wave theory was a departure from the thought of the eighteenth century.

\footnotetext{
${ }^{35}$ Nova theoria lucis et colorum in opuscula 1, art. 3, 1746.

${ }^{36}$ The essential idea was outlined in letter 27 of Euler's Lettres à une princesse d'Allemagne (1770), written July 12, 1760. This book contains a good account of Euler's ideas on light and other physical subjects.
} 


\section{Camillo Galvani}

Shortly after Wilson's (1775) book appeared, a general account of the Bolognian stone was published at Bologna by Camillo Galvani, Della Pietra Fosforica Bolognese (Bologna, 1780), dedicated to six "Agl' Illustrissimi ed Eccelsi Signori Senatori Assunti dello Studio Di Bologna," mostly counts and marquises.

In the twelve chapters of the ninety-one-page book, the history, color, shape, internal structure, and analysis, etc., of the Bolognian stone are described in considerable detail, and a comparison made with other phosphors. Beccari and his co-workers are particularly referred to and ten pages of experiments reported. Galvani ended with various reflections on the subjects presented. On the whole the book is a good résumé of contemporary knowledge, although John Canton and Benjamin Wilson are not mentioned.

\section{Excitation of Phosphorescence by Spectral Colors}

The discovery of the new phosphor of John Canton in 1768, and the ease with which it could be prepared from oyster shells, started a wave of research on these substances which revolved about three principal questions: (1) the color of phosphorescence after exposure to different colored lights; (2) excitation by electric discharges; (3) whether the light was the result of combustion. Study of the relation between the color of the exciting light and that of the phosphor was largely initiated by an incorrect report. In 1771, Father Giovanni Battista Beccaria (1716-1781) of Turin (no relation to Jacopo Bartholomeo Beccari of Bologna) whose principal interest was electricity, wrote a letter to Canton, published in the Philosophical Transactions, in which he claimed that Canton's phosphorus, illuminated under red, yellow, and green glasses, would luminesce with red, yellow, and green light. This finding was contrary to the previous work of Zucchi (1652) and Zanotti (1748) on the Bononian phosphor, and, as we have seen, differed from the results of Benjamin Wilson (1775) on oyster shell phosphors.

Since the publication of the Beccaria note, a large number of investigators working with a variety of phosphors have mostly concluded that phosphors behave as if the light they emit depends on an inherent peculiarity of the phosphor rather than on the exciting light. However, interpretation is often difficult because of the intensity of phosphor luminescence in different colors. The Jesuit, Joseph Edler von Herbert (1725-1794), professor of physics at Vienna and canon of St. Stephan, discussed the matter in his book on fire, De Igne, etc. (1773). Herbert regarded fire and light as the 
same thing, as a material substance absorbed by the phosphor. The Bolognian variety gave off only a very faint greenish white luminescence under red light but a bright reddish luminescence under the blue light of a spectrum. The emitted light appeared to be always of a different color from the absorbed, but Herbert failed to take into account the different intensities of the emitted luminescence, which was to confuse interpretation. Herbert explained the behavior by the affinity of different particles of the phosphor for the red and blue light, whereas the true explanation would appear to depend on the inability of the human eye to detect color in weak lights. At least the color of luminescence in Herbert's experiments was not the same as the exciting light which Beccaria had claimed to be the case.

The experiments of W. L. Krafft (1777) are of special importance because he used the Canton phosphor exposed to the various colors of a solar spectrum, and found the phosphor light to be of one color. In addition to Krafft, many other writers, M. de Grosser (1777), M. de Magellan (1777), von Scherer (1795), H. C. Englefield (1802, 1803), C. E. Wünsch (1803, 1807), Goethe and Seebeck (1810), ${ }^{37}$ T. von Grotthuss (1815), and G. W. Osann (1825), have failed to confirm Beccaria's results. There can be no doubt that the spectral emission of phosphors remains essentially the same when excited with different wave-lengths, provided these wave-lengths can excite at all. Variation in results can be explained by the fact that colored glasses are not usually monochromatic, and by the inability of the eye to estimate color in the weak phosphor light which is excited by certain colors. Since Krafft's and de Grosser's (1777) time, it has been recognized that the blue end of the spectrum is far more effective in exciting phosphorescence than the red, a fact particularly emphasized by Osann (1834).

\section{Phosphorescence and Electric Sparks}

The great interest in electricity during the eighteenth century led to a study of the effect of electric sparks, usually referred to as the electric light, on many materials. Canton (1768) made a casual statement that they excited his phosphor. Apparently he was anticipated by G. B. Beccaria of Turin, who tested ${ }^{38}$ a number of sub-

\footnotetext{
${ }^{37}$ There is an extended discussion of the behavior of phosphors when excited with various colored lights in Goethe's Zur Farbenlehre (1810), because of its bearing on the Newtonian and Cartesian theories of light and Goethe's anti-Newton bias. For the effect of ultraviolet and infrared light, see a later section.

${ }^{38}$ The work was carried out before 1753, and appears in an English translation of his book, Dell elettricismo artificiale e naturale, Turin, 1753, as $A$ treatise upon artificial electricity, London, 1776; sec. 763, "On phosphoreity."
} 
stances (some of which were given him by J. B. Beccari of Bologna) in the electric light, i. e., the electric spark, before 1753. He found that those bodies which retain the solar light in greatest degree, also retain the electric light, for example the well-known phosphors and also paper and sugar. Beccaria wrote: "A full discharge of my usual coated plate, sent through powdered sugar, produced the beautiful light of a copious luminous flower, and left as it were a Glory ${ }^{39}$ of light around the place which drew the sparks. I also found that a like Glory remained imprinted on the surface of a very fine dry linen cloth."

Joseph Priestley, in his book on electricity (1769: 244), has commented on some later experiments of a Mr. Lane, as follows:

That electric light is more subtle and penetrating, if one may say so, than light produced in any other way is manifest from several experiments, particularly the remarkable one of Mr. Hawkesbee; but none prove it so clearly as some made by the ingenious Mr. Lane, who gives me leave to mention these:

When he had, for some different purpose, made the electric shock pass over the surface of a piece of marble, in the dark; he observed, that the part over which the fire had passed was luminous, and retained that appearance for some time. No such effect of the electric shock having ever been observed before, he repeated the experiment with a great variety of circumstances, and found it always answered with all calcarious substances, whether animal or mineral, and especially if they had been burnt into a lime. And, as far as he had tried, many more substances would retain this light than would not do it; among others several vegetable substances would do it, particularly white paper. Tiles, and brick were luminous, but not tobacco-pipe clay, though well burnt.

That gypseous substances, when calcined, were luminous, appeared from bits of images made of plaister of Paris; and of this class, he says, is the famous Bolognian stone. But many bodies, he found, were luminous after the electric stroke, which were not apparently so, when exposed to the rays of the sun.

He made these curious experiments by placing the chains, or wires that led from the conductor to the outward coating of his jar, within one, two, or three inches (according to the strength of the charge) from one another, on the surface of the body to be tried, and discharging a shock through them. If the stone was thin, he found, that if one chain was placed at the top, and the other at the bottom, it would appear luminous on both sides after the explosion.

Mr. Canton, to whom these experiments were communicated, clearly proved, that it was the light only that the substances retained, and nothing peculiar to electricity; and, moreover, after frequent trials, discovered God.

${ }^{39}$ A splendid luminous appearance around heads of saints or the Virgin Mary or 
a composition, which retains both common light, and that of electricity, much more strongly than either the Bolognian stone, or any other known substance whatever. With this new phosphorus he makes a great number of most beautiful experiments.

Another observer was Michaele de Grosser who published a small book in Latin ${ }^{40}$ in 1777 on phosphorescence of the diamond in which he confirmed many previous findings, observed luminescence in a vacuum, and showed that diamonds could be excited not only by warming but by electric sparks.

The most comprehensive study of phosphorescence excited by electricity was made by Karl von Kortum (1748-1808), a banker and mayor of Warsaw. In 1794 von Kortum used "fat" electric sparks from a Leyden jar, allowing the spark to pass over the surface of the material and observing the color, brightness, and duration of the phosphorescent streak. He studied 168 substances, organic and inorganic, obtaining results similar to those of Beccari and Wilson. Von Kortum found that nuts, seeds, wax, bone, egg shells, silk, wool, cotton, linen, gums, starch, potatoes, etc., all phosphoresced provided they were dry, but resin, shellac, glass, porcelain, sulfur, butter, amber, tourmaline, and all metals did not. Oxygen was not necessary for the phosphorescence.

Although pure water had never been observed to be phosphorescent or fluorescent, von Kortum reported that ice would luminesce on exposure to an electric discharge, and J. Weber (1802) found that it was triboluminescent. ${ }^{41}$

Van Kortum's success, like that of Beccaria, Mr. Lane, and Canton, was of course due to the abundant ultraviolet wave-lengths in the spark, as indicated in a later section. In the nineteenth century the study of phosphor excitation by electric sparks became an important approach through the work of Dessaignes (1809), Heinrich (1812), Pearsall $(1830,183 \mathrm{I})$, and the Becquerels (1839). When the effect of electrical discharges on material enclosed in glass tubes was studied, entirely new phenomena appeared, which led to recognition of various radioluminescences (see Chapter XII).

It was E. Becquerel (1839) who pointed out the difference between glass and quartz in allowing certain rays from an electric

${ }^{40}$ Translated in Jour. de Physique 20: 270-283, 1782. De Grosser endeavored to make non-phosphorescent diamonds luminesce by heating but mostly in vain. One diamond heated in borax became phosphorescent but heating diamonds with rocksalt was of no avail.

${ }^{11}$ P. Heinrich (1811, 1920: 83 and 482) mentioned a number of observations on luminescent ice but he could never confirm its triboluminescence as reported by Wässtrom (1798). In $1856 \mathrm{M}$. Ghaye described luminescence of fresh falling snow flakes and also of the rim of his hat, a circumstance which indicates the snow crystals were probably charged and the light an electroluminescence. 
spark to excite phosphorescence. The transparency of quartz for ultraviolet radiation has turned out to be one of the most important practical discoveries for work in this region of the spectrum. In 1845 Draper confirmed the opacity of glass for phosphorogenic rays of the electric spark but found that it was transparent for those from incandescent lime. In $1890 \mathrm{~V}$. Schumann found that quartz was opaque to very short ultraviolet wave-lengths, whereas fluorspar was quite transparent in this now designated Schumann region.

\section{Phosphors and Combustion}

In the last quarter of the century a number of publications on phosphors appeared in which the light was regarded as resulting from combustion, as this process was understood at that time. In Wilson's day, the phlogiston theory was at the zenith, with both Priestley and Scheele strong adherents. One might expect that these two men would be prejudiced in favor of a combustion theory, or at least a phlogiston theory of phosphor light, but such was not the case. Priestley advocated no views of his own, but it is clear from the opening sentence of his chapter on the Bolognian phosphorus in the History of Light and Colours (1772:360) that he accepted the light absorption (sponge) theory. He wrote:

The hypothesis of the materiality of light is peculiarly agreeable to the phenomenon of the Bolognian stone, which has the remarkable property of imbibing light, of retaining it for some time, and of emitting it again; and more especially of the emitting it more copiously, according to the degree of heat applied to it. By this hypothesis, also, it is easiest to account for some facts, by which it appears that the colour and internal texture of bodies are changed by light only, exclusive of heat, or any other circumstances.

Scheele's ideas were essentially similar to Priestley, although he did refer to phlogiston in connection with heat. His remarks will be found in his Chemical Observations and Experiments on Air and Fire (1777) translated by John Reinhold Forster in 1780 and dedicated by Forster to Priestley. Scheele wrote (p. 121):

In regard to the Phosphorus Balduini, and the Bononian Phosphorus, it is most probable, that these two substances attract the light from the sun or fire. I cannot find the cause in anything else than in a certain magnitude of the subtle pores, into which the particles of light penetrate, without being very strongly attracted by the matter of these bodies; to which the acid of nitre or sulphur existing in these bodies may contribute something. Heat which necessarily ought to be somewhat coarser than light, when made very elastic by the addition of more phlogiston, 
penetrates likewise into them; because it is attracted more powerfully because of its greater density, and therefore expels again the light: The more heat penetrates at once into the subtle pores, the quicker is the light expelled; and the brighter shines the phosphorus.-Hence I collect the cause, why these phosphori, after they are somewhat heated, do not attract the light, as long as they still remain hot; because then the particular pores are filled up with heat. Humidity has the same effect.

Most eighteenth-century combustion theories were based on the presence of sulphur (the material, not the principle) an obviously combustible body, in phosphors. Such was the attitude of Macquer $(1766,1778)$ and also de Saussure $(1792)$, who spoke of "la combustion a l'air libre du soufre ou du fois de soufre que le pierre contenant."

The same point of view is very definitely expressed in a paper (1791) of Giovanni Marchetti (died 1817) professor of medicine and chemistry at the University of Bologna. He had prepared phosphors from borax, sodium sulphate, and other compounds of sulphuric acid plus metals ( $\mathrm{Fe}, \mathrm{Pb}, \mathrm{Zn}$, etc.), as well as vegetable ash, all of which he thought contained a sulphur compound. Since many sulphur-containing compounds do not burn in air, they were believed to contain a fluid which easily burned, called "gas hepaticum " or "aer foeteus sulphuris," which smelt of rotten eggs and made many metals black, i. e., he explained the phosphorescence by the combustion of hydrogen sulphide. The phosphors were then regarded as giving off their own light rather than absorbed light.

Another writer who thought in terms of combustion was the Rev. Mr. Morgan (1785) (not to be confused with Dr. William Morgan, the student of electricity). The Rev. Morgan's paper, "Observations and Experiments on the Light of Bodies in a State of Combustion," contained a section dealing with "Observations on phosphoric light." He had noted the varied colors which salts impart to flames, often accompanied by a "dense fume of unignited particles," and thought that when light escapes from a burning body blue comes first. To him this meant " that light, as an heterogeneous body, is gradually decomposed during combustion . . . that the indigo rays escape with the least heat and the red with the greatest." Whereas Newton said "flame is a vapour heated red hot," Morgan said "flame is an instance of combustion whose colour will be determined by the degree of decomposition which takes place."

Morgan then referred to the various phosphorescent colors observed by Mr. Wilson in calcined oyster shells exposed to light and wrote: 
If with Mr. Wilson we suppose, that these shells are in a state of slow combustion, may we not conclude, that some are just beginning to burn, and therefore, agreeably to what I have observed on combustible bodies, emitting the most refrangible rays; whilst others are in a more advanced state of combustion, and therefore emitting the least refrangible. If this conclusion be right, the shells which are emitting the purple, or the green, must still retain the yellow, the orange, and the red, which will also make their appearance as soon as the combustion is sufficiently increased.

In line with this theory he reported that Wilson's oyster shells, which emitted a green phosphorescence, would become yellow to red luminescent when warmed.

However, Morgan found some objections to his own view. The most important was the fact that a phosphoric body " never fails to lose its light entirely in a certain degree of heat, without losing the power of becoming phosphoric again when it has been sufficiently cooled."

Connected with the problem of combustion, was the identification and study of gases, which received much attention in the latter part of the eighteenth century, largely owing to the paper of Cavendish on gases in the Phil. Trans. for 1766, and to Priestley's book, Experiments and Observations on Different Kinds of Air (1774). Phosphors, the element phosphorus, shining wood, and shining meat were all subjected to the action of various gases, but the impurity of eighteenth-century samples of these gases led to conflicting results and endless controversy. Compared to the numerous studies on shining wood and luminous meat, experiments on phosphors were definitely neglected. Moreover, the conclusions drawn from the most elaborate series of experiments were quite incorrect.

In 1786 Count Carlo Luigi di Morozzo (1744-1804), an Italian physicist of Turin, studied the behavior in different gases, finding that the Bolognian phosphor only luminesced well in dephlogisticated air (oxygen), like all combustible bodies, and also that the air itself was changed by its presence. In fact, he claimed that the presence of the phosphor in aria fissa $\left(\mathrm{CO}_{2}\right)$, aria nitrosa (nitrous air) and aria inflammabile (hydrogen ?) made these gases respirable for a short time. The conclusions are extraordinary and could not be explained by Count Morozzo, although he claimed that he had "collected many facts and discovered new properties concerning gases, which one day may contribute to a reasonable theory in this new branch of science."

Volta had apparently obtained similar results earlier, for he 
wrote $^{42}$ to Joseph Priestley in 1776 that the Bolognian phosphor made the air highly phlogistic (phlogisticated air = nitrogen) and effected a quick and astonishing decrease in volume, but to obtain this effect the phosphor must be a good one and the weather not too cold. Kayser (1908: 623) has suggested that Volta observed adsorption of some gas by the phosphor rather than combination with oxygen. The experiment did not succeed well with Canton's phosphor, and the phosphorus of urine " diminished the air rather slowly." It is now known that oxygen is not necessary for phosphorescence, and phosphorescence is not a burning.

\section{The Effect of Ultraviolet and Infrared Rays}

In Benjamin Wilson's time the spectrum of sunlight had not been divided into the infrared (heat), the visible and the ultraviolet (actinic) rays, nor were the differences in spectral distribution of various light sources appreciated. That waves existed beyond the violet appears to have been discovered in 1801 by Johann Wilhelm Ritter (1776-1810), a physician of Munich. He found that this ultraviolet region of the spectrum would blacken silver chloride, a phenomenon observed to occur in white light by the German physician, Johann Heinrich Schultze ${ }^{43}$ in 1727. That blackening is most marked in the blue and violet region ${ }^{44}$ was an observation of $\mathrm{K}$. W. Scheele, in 1777.

The possibility that ultraviolet rays might excite a phosphor was suggested by Humphry Davy to Sir Henry Charles Englefield (17521822), who found (1802) that Canton's phosphor was excited much more by the blue than the red end of the solar spectrum. Englefield wrote:

There was great reason to suspect that this power, like that of blackening silver nitrate, extended beyond the visible blue ray; but our apparatus was not prepared for the more delicate part of these experiments, which are only mentioned with a view to exciting further research on this very interesting subject and of giving Mr. Davy the credit due him for having thought of the experiment.

\section{Like many important discoveries, the effect of ultraviolet and}

${ }^{42}$ In Priestley, Experiments and observations on different kinds of air 3, Appendix: $381-382,1777$.

13 It is said that Schultze discovered the blackening in an attempt to prepare a phosphor by treating chalk with nitric acid. The nitric acid happened to have silver dissolved in it and the resultant silver salt blackened in sunlight.

${ }^{4}$ It was not until 1873 that $H$. W. Vogel discovered photo-sensitization, the fact that certain dyes added to silver salts would make them sensitive to green and yellow light. 
infrared wave-lengths on phosphors cannot be attributed to any one man. Apparently Johann Wolfgang von Goethe (1749-1832) in collaboration with Thomas Johann Seebeck (1770-1831), a physician, and discoverer of thermoelectric junction potentials, noticed at some time between 1786 and 1792 that the blue and violet end of the spectrum was much more effective in exciting luminescence of various phosphors than the red end. The account appeared in Goethe's Zur Farbenlehre (1810), and contains the statement, "beyond the violet, where scarsely any color can be observed, it [the phosphor] gave a vivid brilliance, as in the violet region." According to R. Winderlich (1936) the observation was made on Goethe's return to Weimar, after a visit to Bologna in October 1786, where he procured specimens of the heavy spar. Goethe wrote from Weimar of this discovery in a letter dated July 2, 1792 to S. T. von Sömmerring (1755-1830), a physician of Mainz, interested in physics and natural history.

Careful testing of phosphors in the ultraviolet region of the sun's spectrum was made by Ritter (1803) and by Christian Ernst Wunch (1744-1828), a professor of mathematics and physics at Frankfurt a. O. in 1803 and also by Dessaignes (1808), Heinrich (1811), and Grotthus (1815). Somewhat later, T. J. Pearsall (1830) noted the bright green luminescence of chlorophane excited by the ultraviolet light in electric sparks, and made an extended study of thermophosphorescence of various materials after such exposure (see Chap. IX) .

The identification of infrared radiation is usually attributed to the eminent English astronomer, Sir William Herschel, in 1800, but it was von Ritter (1803), who put the infrared region to a thorough test with phosphors, finding that these wave-lengths diminish the phosphorescence. His explanation was based on an incorrect theory. He believed that the light of phosphors came from a kind of combustion, an oxidation, and that short wavelengths had a reducing action and long wave-lengths an oxidizing effect on substances they illuminated. ${ }^{45}$ When exposed to violet or better to ultraviolet, a phosphor luminesced well because the short wave-lengths reduce and prepare the phosphor for new oxidation. Long wave-lengths like red and infrared, which have an oxidizing effect, actually decrease the light intensity.

Again the question of priority is difficult to decide. Seebeck may have noticed the quenching action of less refrangible, long-wave

${ }^{45}$ This idea arose from Ritter's studies on light and silver chloride. Similar views will be found in the work of W. Herschel, E. Becquerel and J. W. Draper on photochemical action. 
light. Goethe (Farbenlehre, 1810) published Seebeck's observations, "Wirking farbiger Beleuchtung auf verscheidene Arten von Leuchtsteine," which stressed the quenching effect of infrared radiation on both the Ba sulphide and Sr sulphide phosphors. He used the light transmitted by an orange red glass, which had practically no effect in exciting the phosphorescence of these materials, but when concentrated by a lens on an already luminous phosphor, he found that their phosphorescence, which ordinarily might last for some ten minutes in the dark, disappeared in a few seconds. The date of the experiment is not certain but the striking and wellknown quenching effect of long waves on phosphors was certainly recognized about 150 years ago. This quenching results from the increased rate of decay of phosphorescence in infrared light. The luminescence intensity may temporarily increase (Ausleuchtung in German) or may suddenly decrease (Tilgung in German). If the former occurs, the effect could be called photo-stimulation, analogous to thermostimulation, i. e., thermoluminescence (see Chapter IX) .

The rediscovery of the quenching effects of long-wave radiation appears to have been made by $\mathrm{E}$. Becquerel (1843) in 1842 in studying the constitution of the solar spectrum. In 1848 he again called attention to the momentary brighter luminescence of his phosphor where the infrared rays impinged, before the light disappeared. So marked is the quenching that dark infrared Fraunhofer lines in the solar spectrum stand out as bright phosphorescent lines against the quenched phosphor, when the sun's spectrum strikes a phosphorescent screen. Quite understandably the effects of longwave radiation on phosphorescence received considerable attention in the twentieth century, in connection with theories of phosphorescence.

\section{Dessaignes, Heinrich and von Grotthus}

In the early nineteenth century extensive investigations ${ }^{46}$ on phosphors were carried out by Jean Philibert Dessaignes, Placidus Heinrich (1758-1825), and Theodor von Grotthus (1785-1822). The principal interest of Grotthus was thermoluminescence, but it was becoming obvious that any theory involving light emission from moderate rise of temperature must necessarily explain phosphorescence as well. Some new phosphors were discovered by these men but at this time the phenomenon of phosphorescence was recognized as widespread and a new phosphor did not attract the attention that it would have at the beginning of the eighteenth century.

${ }^{40}$ A note by L. P. and J. C. Delamétherie (1802) described phosphorescence of certain diamonds and some minerals. 
Nevertheless, Heinrich (1811) described an extraordinary number of phosphors, including a particularly bright one prepared from white alabaster by mixing it with acid potassium oxalate and heating in a coal fire.

The three men are of special interest because they all proposed universal but quite different theories to account for the light production. For Dessaignes, water was all important, for Heinrich, it was acid, and for Grotthus, electricity.

As we have seen (Chapter VI), theories of light emission at the beginning of the nineteenth century assumed light to be a material but imponderable substance, and to be held in some way between the molecules of the phosphor. Dessaignes believed that the light substance was associated with water but there were also electrical undertones in his view. He cited the fact that strongly heated earths which were freed of water by high temperature failed to phosphoresce but acquired the ability if slightly dampened. Since glass and porcelain are phosphorescent and certainly contain no water, Dessaignes was forced to assume that in hard bodies there was a phosphoric fluid ("fluide de la phosphorescence"), which would luminesce if it were "concentrated" by moderate heat or other physical or mechanical forces. To explain the light that appeared from friction or collision, the fluid was believed to be of an electrical nature. In favor of this view, Dessaignes cited an experiment in which he heated glass powder until it was no longer phosphorescent and then sent electric discharges through the powder, when it again became phosphorescent. This result was of course due to the ultraviolet light in the spark but Dessaignes cited additional experiments which convinced him that the electricity of the spark and not the light was responsible. He concluded that good conductors of electricity were never phosphorescent even after the discharge of a Leyden jar; insulators were only weakly phosphorescent and required the discharge of a Leyden jar, but medium conductors were very good phosphors, luminescing after exposure to sunlight. Had Dessaignes used the word semiconductor, his phraseology would have sounded quite modern and correct.

Dessaignes also confirmed the fact that the color of the emitted light was independent of the exciting light, thus disposing (in his mind) of the idea that the light substance was absorbed on illumination. He held the light substance to be already present in the phosphor and to be set in vibration by the repulsive force of the light. But if the phosphor is heated to a high temperature, the fluid is driven out and illumination no longer excites to phosphorescence. Dessaignes distinguished two kinds of water in non-metallic bodies 
responsible for phosphorescence, (1) tightly bound water and (2) that present between the molecules. Light emission is connected with the bound water, which may be excited by strong stimulation, i. e., by high temperature (incandescence) or at low temperatures, by collision, by electricity or by illumination. This type of luminescence ceases when the excitation ceases. The more easily excited phosphorescence, also connected with bound water, which lasts for some time after the exciting light is cut off, is a proof "that the phosphoric fluid is easily concentrated and does not immediately return to the resting condition."

Naturally, Dessaignes had a difficult time fitting a theory to the mass of observed facts which came from his experiments. This led to changing ideas and inconsistencies in his statements. Briefly stated, his theory appears to be fundamentally based on the belief that only substances containing bound water can luminesce and that this water takes up the phosphoric fluid (light substance) which is nothing else than electricity. Each excitation acts like a shock and sets the light substance free. Although Dessaignes' explanations may be unacceptable, he (1810) appears to have been the first ${ }^{47}$ to expose phosphors to an electric discharge in a vacuum, the primary step in the development of a fluorescent lamp. E. Becquerel was to carry out similar but much more extensive studies in 1839 .

Heinrich relied on acid to explain phosphorescence. All luminescent substances contained an acid with which the light substance was associated. Therefore, he prepared his phosphors by treating minerals with acid and heating. The acid was supposed to be set free by decomposition as a result of illumination or warming (thermoluminescence) and some of its associated light substance became visible as luminescence. Naturally Heinrich encountered the same difficulties with acid as Dessaignes had with water, and endeavored to bolster his views with dubious chemical hypotheses. For example, because some diamonds would phosphoresce he had to assume they contained carbonic acid. Since ice phosphoresced on illumination, he alleged the ice had more acid principle than water. Heinrich also noted the marked action of the electric discharge in exciting phosphorescence of minerals but, in opposition to Dessaignes, correctly attributed it to the light and not to heat or electricity. ${ }^{48}$ His reasons were that glass between spark and phosphor had little effect in reducing the phosphorescence and that phos-

${ }^{47}$ Dessaignes, Jour. de physique 71: 67-70, 1810.

${ }^{48}$ P. Heinrich, Die Phosphorescenz der Körper, Abt. I: 85 ff., 1811. Later (Abt. II: $238 \mathrm{ff} ., 1812$ ) he wrote as if electricity were involved in restoration of the ability to luminesce of calcite, fluorite, and heavy spar, when destroyed by heat. 
phors which responded well to sunlight, also responded well to the electric spark.

Theodore von Grotthus (1785-1822), a gentleman who traveled widely in his youth and then settled on his hereditary estate at Geddutz near Wilna, is best known as the first to realize that only the light rays which are absorbed are effective in producing chemical change. This generalization is generally known as the Grotthus (1815) -Draper (1841) photochemical absorption law, since J. W. Draper emphasized the fact also. The interests ${ }^{49}$ of Grotthus in chemistry were extensive, chiefly connected with effects of light and electricity, and quite naturally involved phosphors. He was led to his theory of phosphorescence, explained in two long papers ${ }^{50}$ in 1815, from photochemical experiments and from observations on the phosphorescent and thermoluminescent mineral, chlorophane (see Chapter IX). Light, heat, and electricity were regarded by him as practicaliy identical, light appearing when positive and negative electricity combine against a resistance, while heat forms if there is no resistance. Light, then, is nothing but positive and negative charges traveling side by side. A photochemical change was thought to be similar to electrolysis, with the reaction products combining with positive and negative electricity.

Grotthus believed that sunlight on striking the outer surface of a phosphor becomes split into its electrical principles (into positive and negative charges) between the poles of the elementary parts of the material. The gradual combination of the separated light elements then results in phosphorescence. Metals and conducting fluids, including water, do not phosphoresce because the combination of the light elements goes too rapidly. This theory, also, had its difficulties, as was bound to be the case, considering the variety of facts to be reconciled and the state of knowledge at the time.

\section{New Phosphors. The Effect of Traces of Metals}

After the period of Dessaignes, Heinrich, and Grotthus, the papers on phosphorescence were mostly short communications describing new phosphors and the part played by traces of metals in determining ability of a material to phosphoresce, or they continued the experiments on excitation of phosphorescence by the electric spark.

\footnotetext{
49 See the collection of his papers in Ostwald's Klassiker, No. 152 (Leipzig, 1906), “Abhandlungen über Elektrizität und Licht," 198 pp.

${ }^{50}$ Apparently Grotthus was aware of Dessaignes' but not J. Heinrich's work, as Heinrich is not mentioned in the first paper. Both men were subject to polemical discussion in the second paper (Schweigger's Jour. für Chemie u. Physik 14: 133-192, 1915, 15: 171-199, 1915) of Grotthus.
} 
The preparation of a strontium sulphide phosphor appears to have been first made in 1817 by Johann Friedrich John (1782-1847), at one time a professor of chemistry at the University of Frankfurt a.d O., later a physician in Berlin. He found that his SrS luminesced sky blue, while the $\mathrm{BaS}$ which he also prepared luminesced reddish violet.

One of the points emphasized by the very early workers for success in obtaining a phosphor was the character of the raw material, i. e., its physical properties. The Bolognian stone to be calcined should have a certain size (that of a walnut) or surface quality (smooth and silvery) or grain (fibrous), if the phosphor was to absorb the light of the sun. Also important was the temperature of calcination or length of heating. Later Lémery held that the use of a brass mortar for grinding the mass to be heated was an absolute necessity. Wilson's experience with oyster shells indicated that traces of metals affected the color of the luminescence, but contamination of the material was too great to come to any definite conclusion, and Wilson was forced to admit that chance played a large part in the result. Neverthless, the necessity of metal impurities was correct and important. De Saussure $(f i l s)$, in 1792, in connection with his study of dolomite, made the suggestion that impurities like iron were necessary for thermoluminescence, and pointed out that the more colored a specimen of fluorspar is, the more intense thermoluminescence it will show.

Following Benjamin Wilson (1775), attempts to increase the intensity and duration of light and to control the color of the light of phosphors by adding other materials were made by Gottfried Wilhelm Osann (1797-1866), professor of physics and chemistry at the University of Wurzburg, and by G. F. Wach.

Osann (1825) obtained phosphors with blue or green luminescence from oyster shells to which arsenic, antimony, or mercury sulphide had been added.

In a second paper Osann (1834) described a quantitative photometric study of luminescence intensity after exposure to light through various colored filters. He also discussed the three recognized theories of phosphorescence-that a combustion takes place; that light is absorbed and then slowly liberated; and that light already present is set free by excitation (insolation or slight heating). He favored a combination of the absorption and excitation theory. When exposed to light phosphors absorb a certain amount and then give up a part of what they have absorbed. The remainder can be liberated by moderate heating. The combustion theory was ruled out by the fact that many non-combustible substances are 


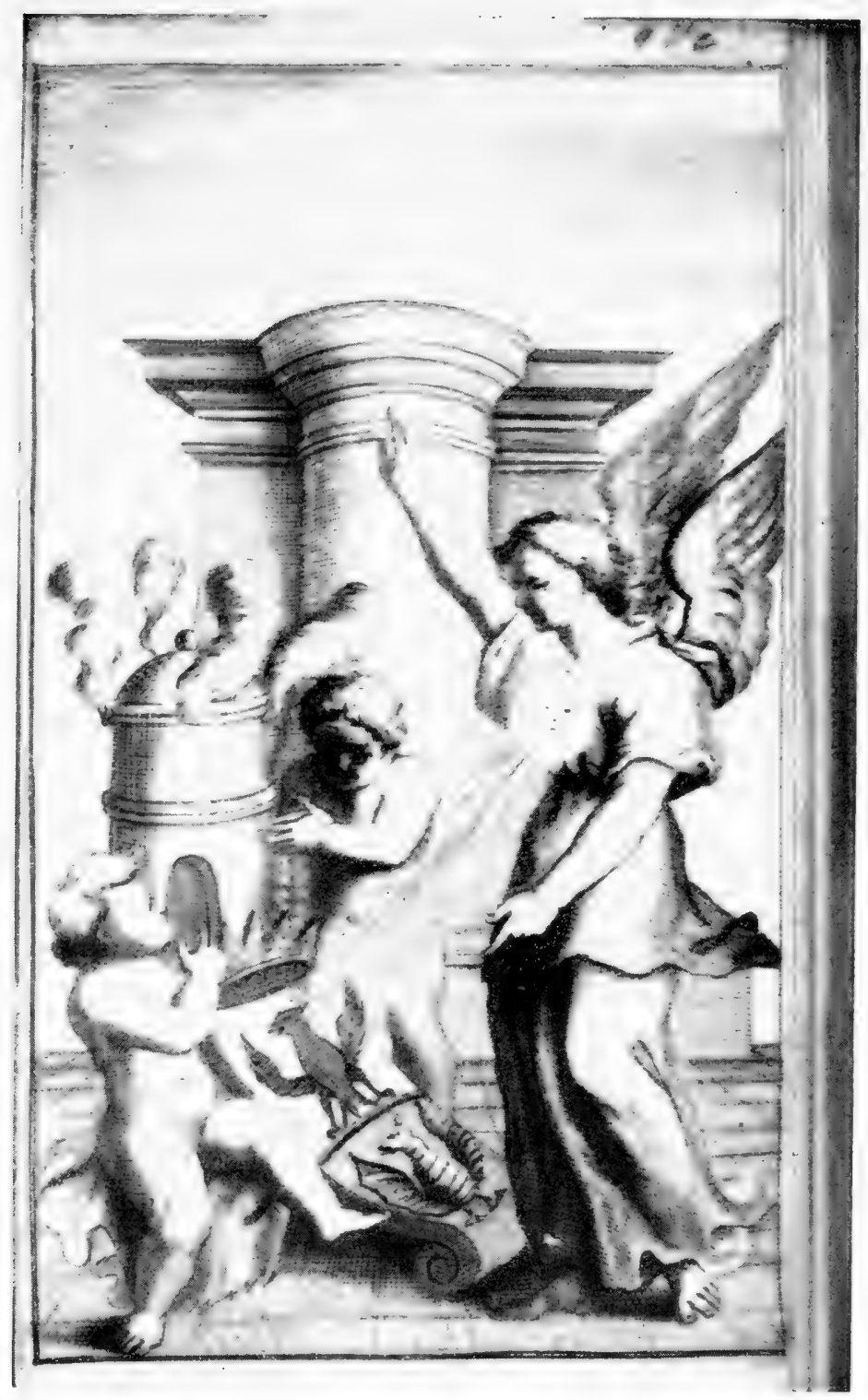

Fic. 31. Frontispiece to a book of Marco Antonio Cellio, II Fosforo O'vero la Pietra Bolognese (Rome, 1680), showing the oven for calcining the stone and sunbeams striking a picture drawn with the phosphor, which then luminesces in the dark. 


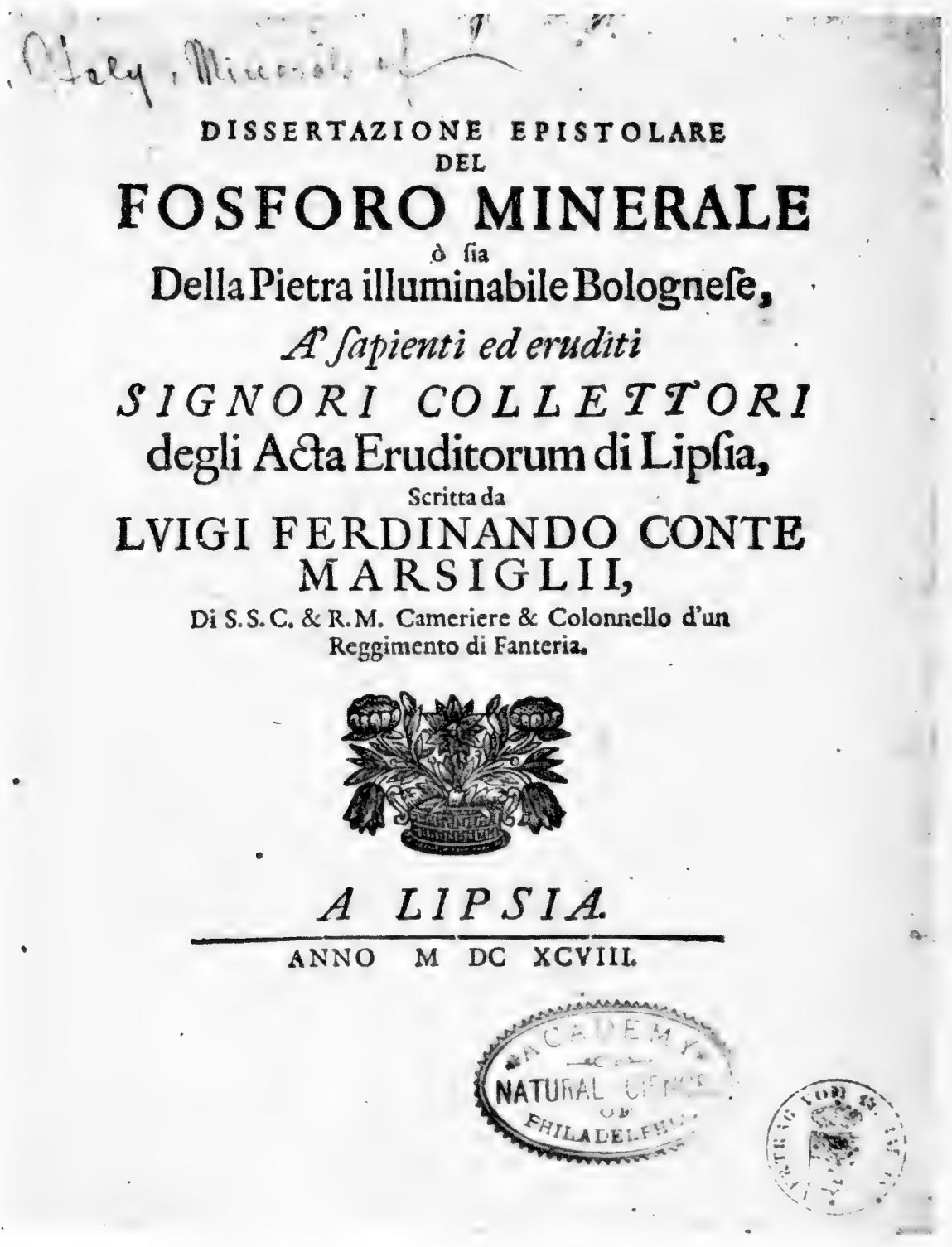

Fis. 32. Title page of the pamphlet by Conte di Marsigli, which he had prepared in 1691 to send to Robert Boyle (1627-1691). After Boyle's death he delayed publication until 1698, when it was published at Leipzig. 


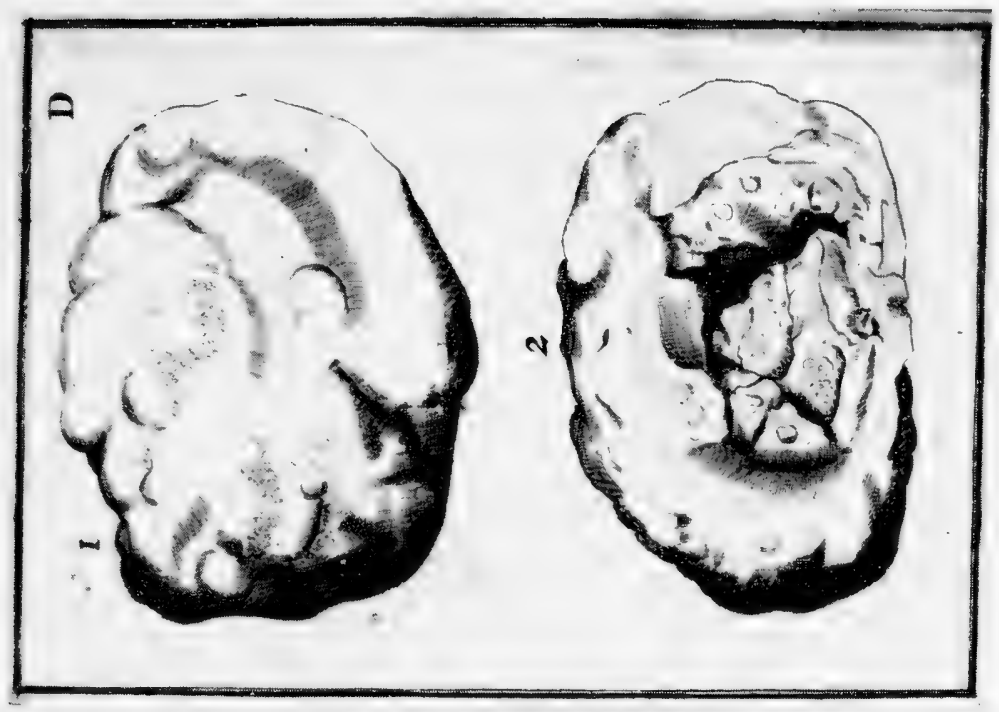

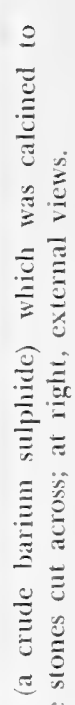

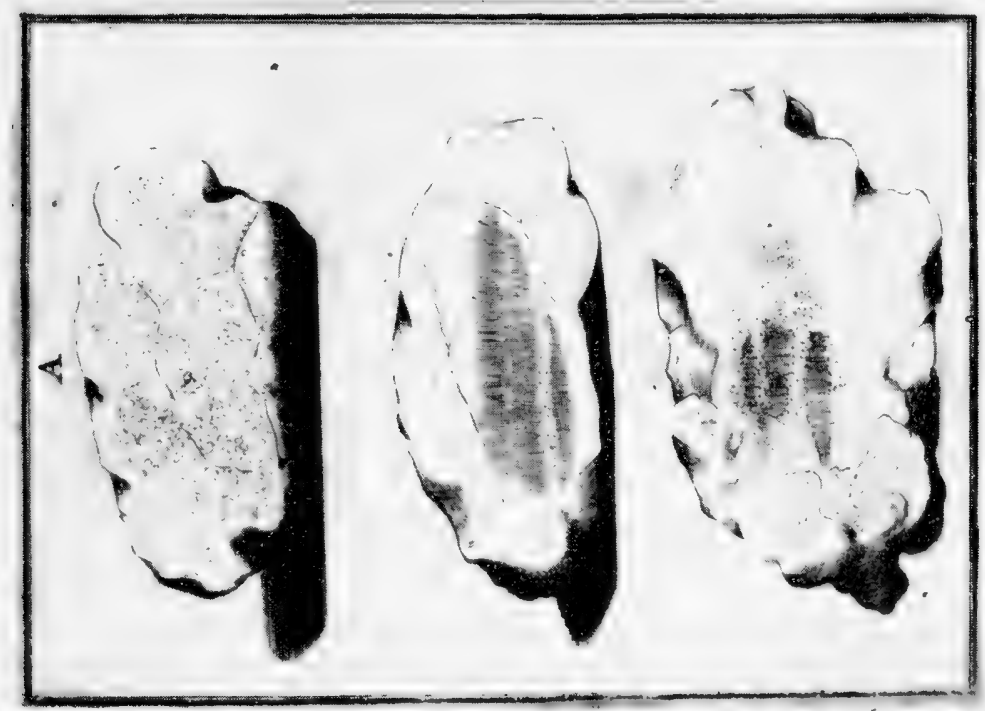

$\cong$

흘

$\Xi$

푸

ङ

$\cong \frac{2}{3}$

光

ถ⿻

흘

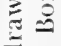

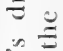

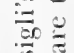

吾

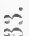

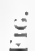




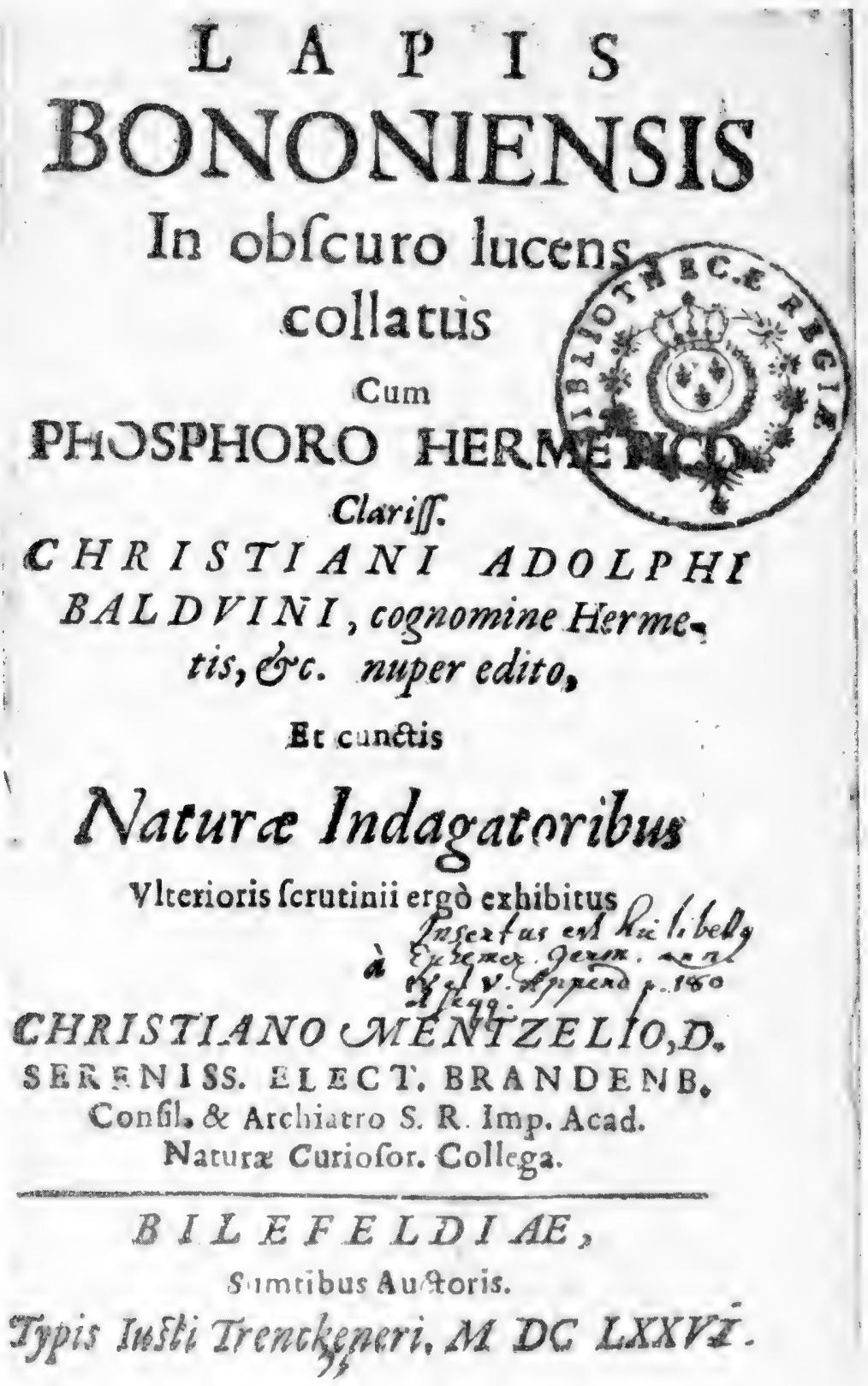

Fir. 34. Title page of the book by Christian Mentzel in which he compares the properties of the Bolognian and the Baldwinian or hermetic phosphor (Bielfels, 1676). 
phosphors and the luminescence appears in hydrogen as well as oxygen.

On the other hand, Wach (1833) made little progress with the Wilson method of calcining oyster shells with a few drops of metal salts, but succeeded with heavy spar $\left(\mathrm{BaSO}_{4}\right)$ or celestite $\left(\mathrm{SrSO}_{4}\right)$ to which oxides of $\mathrm{Mg}, \mathrm{Zn}, \mathrm{Sn}, \mathrm{Cd}$, and $\mathrm{Sb}$ were added. He obtained phosphors whose light was very bright and lasted a long time.

Osann and Wach were on the right track and pioneers in the use of trace metals. ${ }^{51}$ The presence of impurities did affect the behavior of phosphors and explained the diverse results of different observers in studying what were presumably the same minerals, but which actually contained small amounts of foreign metals. However, the all important part played by trace elements ${ }^{52}$ was not fully recognized, and the controlled preparation of phosphors with any desired color, intensity and persistance of luminescence was a somewhat later development.

Curiously enough, one of the most important present day phosphors, hexagonal blende $(\mathrm{ZnS})$, was not recognized as phosphorescent until 1866, when the mineralogist, Theodor Sidot, prepared it by heating $\mathrm{ZnO}$ in a stream of hydrogen sulphide. Previous observations of J. G. Lehmann (1749) as well as C. G. Hoffmann (1750) had indicated that samples of yellow blende $(\mathrm{ZnS})$ from Scharfenberg would luminesce on scraping and some varieties of natural $\mathrm{ZnS}$ were phosphorescent, but the hexagonal variety called Sidot blend was particularly bright.

In $1868 \mathrm{~A}$. Forster published detailed directions for making a number of phosphors and Balmain's paint, a $\mathrm{CaS}$ with $\mathrm{Bi}$ as impurity, was placed on the market in 1870, the first well-recognized luminous paint. ${ }^{53}$ Its light was blue in color.

The phosphors prepared by A. Verneuil in 1886-1887 became important commercial products a little later, especially the yellow phosphorescent $\mathrm{ZnS}$. Verneuil was probably the first to prove that

${ }^{51}$ Another who attempted to improve phosphors was Jacques Mande Daguerre (1789-1851), the collaborator with Joseph Nicephore Niepce (1765-1833) in development of the daguerreotype method of photography on metal plates. It seems that in the many attempts to obtain a method of recording images, Daguerre had turned to phosphors as a possibility. D. F. J. Arago, the French astronomer, presented Daguerre's notes on a method of preparing one from barium sulphate to the French Academy (Com. Rend. Acad. Sci. 8: 243-246, 1839).

${ }^{52}$ In 1881 and succeeding years, Lecoq de Boisbaudran (1838-1912) and also Wm. Crookes (1832-1919) became interested in spectral analysis of phosphorescent light and pointed out the connection between spectral bands and the presence of traces of various metals in phosphors, particularly the rare earths, which were undergoing study at that time.

${ }^{53}$ A patent for "Leuchtfarben" was taken out in 1879. 
traces of heavy metals control phosphorescent properties. His researches were well planned. He analyzed commercial phosphors prepared from mussel shells and found that, in addition to $\mathrm{CaS}$, traces of $\mathrm{Si}, \mathrm{Mg}, \mathrm{Bi}, \mathrm{SO}_{4}$, and $\mathrm{PO}_{4}$ were present. A pure $\mathrm{Ca}$ sulphide did not phosphoresce but gave a brilliant phosphorescence if impurities were added. Bismuth was responsible for a violet color. He found that both the color and intensity of sulphide phosphors could be controlled by traces of impurities and came to the conclusion that "all substances which are capable of vitrifying the surface of the calcium sulphide without coloring it render the product very phosphorescent."

This conclusion is not the whole truth, as two additions must be made to a sulphide to obtain a good phosphor. The trace of metal is actually an "activator," responsible by means of electron shifts for the light emission. There must also be a flux. The alkaline earth phosphors, prepared by $\mathrm{V}$. Klatt and Philipp Lenard ${ }^{54}$ in 1889 were made up of sulphide plus a flux, usually a sodium sulphate or borate, to which $\mathrm{Cu}, \mathrm{Bi}$, or $\mathrm{Mn}$ were added in traces as activators. The metals were found to be responsible for certain definite bands in the phosphorescence spectrum, which determined the color of the luminescence. Each band has its characteristic period of decay. Further details were published in three extensive later papers by Lenard and Klatt in 1903 and $1904 . .^{54}$

Thus the control of "impurity phosphors" was not fully understood until near the end of the nineteenth century. Even the great Edmund Becquerel originally thought that the characteristics of phosphor luminescence were determined by physical characteristics, but his last papers $(1886,1888)$ dealt with the importance of traces of heavy metals. Following the studies of Crookes and of Lecoq de Boisbaudran during the eighteen-eighties on cathodoluminescence, which indicated the importance of impurities, a number of new workers continued to add metal traces to prepare new phosphors. Today a phosphorescence of any color and any duration can be obtained by the proper mixture of pure materials and the metal activator.

The subject of new phosphors should not be left without mention of another type of phosphor, prepared by Wiedemann in 1887 and studied more extensively by Wiedemann and Schmidt (1895) and Schmidt (1896). It may be described as a solid solution. For example, analine dyes, which in water exhibit true fluorescence,

${ }^{54}$ These "Lenard" or "impurity" phosphors are often designated thus: Ca Mn S, with the activating impurity Mn between the alkaline earth and sulphide, without mention of the flux. Omission of the activator abolishes the ability to phosphoresce. 
become phosphorescent in such dry solids as gelatin, sugar, or phthalic acid. The solid often affects the color of the light. Fuchsin in gelatin phosphoresces yellow but in phthalic acid is green. If the gelatin is dissolved in water a short phosphorescence detectable with the phosphoroscope is to be observed. In recent times a boric acid glass containing fluorescent dyes ${ }^{55}$ has been particularly useful in developing theories of fluorescence and phosphorescence. The combination exhibits a remarkably bright and long lasting phosphorescence after exposure to light. However, the new Lenard and Klatt (1904) phosphors, ${ }^{56}$ prepared in the first years of the twentieth century, have become the more useful variety for commercial purposes.

\section{Edmond Becquerel and the Recent Period}

Far more important than the preparation of new phosphors is a quantitative study of the physical characteristics of the light which phosphors emit, in relation to various modes of excitation and under various conditions-temperature, pressure, previous treatment, etc. Such investigation requires adequate measuring instruments and brings study of phosphors to a more modern period, beginning about the middle of the nineteenth century.

In 1839 a paper appeared by A. C. Becquerel (1788-1878), J. B. Biot (1774-1862), and E. Becquerel (1820-1891), "Mémoire sur la Phosphorescence Produit par la Lumière Electrique," a summary of previous papers in the Comptes Rendus, in which an attempt was made to find out exactly which radiations in the electric spark ${ }^{57}$ were active in exciting phosphorescence. Various colored films and glasses were used for filters, as well as clear glass, quartz, calcite, and water in a quartz container. The last three allowed as much exciting light to pass as does air, but clear glass and gelatin weakened the exciting rays considerably. The sodium flame was used for the first time as an exciting light and found to be non-effective. The conclusions were very definite, the same as those of previous workers at the time the ultraviolet region of the solar spectrum was discovered. The ultraviolet plus the violet and blue regions were most active.

${ }^{55}$ Introduced by E. Tiede and P. Wulf (Ber. d. d. Chem. Ges. 55: 588-597, 1922. See also 53: 2206-2216, 1920).

${ }^{56}$ See E. N. da C. Andrade, Lenard's researches in phosphorescence, in Science Progress 8: 54-71, 1913.

${ }^{57}$ Excitation by light of the electric spark and by other light sources (flames of phosphorus, sodium, and potassium) was also studied by Carlo Matteucci (1811-1868) the Italian physicist, whose interest in biochemical and biophysical problems led to his memoir $(1844,1847)$ on luminous animals. Matteucci's work on the phosphors, published in 1842, merely confirmed that of the Becquerel-Biot group. 
The transparency of quartz was an important discovery, of great value today for experiments with ultraviolet light.

Thus began the career of Edmond Becquerel who was to lead the study of phosphorescence and related luminescences for many years. The combination of the Becquerels, father and son, and Jean Baptiste Biot could hardly have been a more celebrated one, although Edmond Becquerel was only nineteen years old at this time. Biot had been professor of physics at the College of France since 1800 and professor of astronomy of the Faculty of Sciences at Paris since 1809. He was a man of very wide interests in the natural sciences, perhaps best known for studies on polarized light, which led to a method for the analysis of sugars. A. C. Becquerel, a professor and director of the Museum of Natural History in Paris had a long and distinguished career in physics, especially in the fields of electricity, magnetism, and electrochemistry.

The outline of E. Becquerel's research presented above, and subsequent discussion of contemporary workers are not intended to detract from the importance of the huge amount of experimentation on phosphors carried out in the latter part of the century. In fact the later research is too voluminous to be reported in detail; in many respects it did fill in where Becquerel had pioneered. The names of E. Wiedemann and G. C. Schmitt of Erlangen, or P. Lenard and V. Klatt of Heidelberg on phosphorescence, of G. G. Stokes of Cambridge and E. Lommel of Munich on fluorescence, and of W. Crookes and P. Lenard on cathodoluminescence deserve the same historical acclaim as that of Becquerel, and their pioneering discoveries will be found in subsequent pages of this book.

An immediate consequence of the Becquerel publications was stimulation of research on phosphorescence in Italy by C. Matteucci (1842) and in the United States by former members of the American Philosophical Society, the famous Joseph Henry (1797-1878), professor of natural philosophy at the College of New Jersey (Princeton, N. J.) from 1832 to 1846, and J. W. Draper, professor of chemistry at New York University. Draper's work is considered in the next section.

Joseph Henry's studies on electromagnetic induction and his prestige as the first Secretary of the Smithsonian Institution have served to conceal an earlier work, "On Phosphorogenic Emanation," presented in 1841, and published in the Proceedings of the American Philosophical Society for 1843. By this term Henry referred to the discovery of Becquerel and Biot (1839) that something produced in an electric spark, which caused luminescence of phosphors in the air, was cut off by glass but would act through quartz, i. e., 
ultraviolet light. He repeated many of the French experiments and studied some forty transparent materials to determine whether they were "permeable" for the phosphorogenic emanation. He noted the phosphoresence of such materials as sulphate of potash and chalk and considered that "it is not improbable that the chalk cliffs of England are sometimes rendered phosphorescent by flashes of lightning during a thunderstorm." He later demonstrated to his students how the light from an aurora borealis would excite the fluorescence of quinine.

Henry also studied the ability of the " emanation" to be polarized, using a pile of mica plates instead of a Nicol prism, which was not very permeable to the "emanation." He found that it could be polarized, that it " is an emanation possessing the mechanical properties of light, and yet so different in other respects as to prove the want of identity. That the same 'emanation' from a spark also differs from heat is "manifest from the fact, that the lime [sulphide] becomes as luminous under a plate of alum as under a plate of rock salt. . . ." He found no excitation of phosphorescence by electromagnetic induction, and any electrical origin of the light was ruled out by the fact that the material could be covered with water and would still phosphoresce. Henry concluded that the excitation resulted from a wave motion perhaps " differing in length and amplitude, and possibly also slightly differing in the direction of vibration" from visible light. He was observing the effect of ultraviolet light.

E. Becquerel's contributions may be grouped in three series, the first between 1839 and 1848, particularly papers published in 1843 and 1848; the second, consisting of four memoirs to the French Academy, three in 1857,1858 , and 1859, collected in a booklet, Recherches sur Divers Effets Lumineux qui Resultent de l'Action de la Lumière sur les Corps (Paris, 1859) and a fourth in 1860; the third period included the occasional papers beginning after 1860 and lasting until 1888, three years before his death in 1891 . In 1867 his two-volume work, La Lumière, ses Causes et ses Effets, Paris, appeared. It recorded additional experiments carried out with more elaborate and precise techniques, and was illustrated with fine colored plates of luminescence spectra.

Becquerel's work had to do with many aspects of the light emission: (1) with the composition of the light and the nature of the agencies which cause phosphorescence, i. e. new methods of excitation; (2) the duration of phosphorescence; (3) the intensity of phosphorescence and the law of decay; (4) the spectrum of phosphorescence; (5) temperature effects. It was reviewed by M. Fara- 
day in 1859. Becquerel's results will be taken up under these headings, together with the important discoveries of some of his early contemporaries. In this way the type of research, and some of the results of the recent period can be presented.

\section{WAVE-LENGTHS FOR EXCITATION}

When Becquerel started his study of phosphors, the varying effect of different regions of the spectrum was well recognized. His ingenuity in demonstrating these relations visually is attested by his method (1843) of powdering a phosphor, spreading the powder mixed with gum arabic as an adhesive on paper, and then exposing it to the sun's spectrum. The exciting effect of ultraviolet and the quenching of infrared show beautifully under these conditions. He continued the studies in 1848, and in the first paper of 1859 investigated a large number of different phosphors, recording the wavelengths of the exciting light. After G. G. Stokes' (1852) paper, the phosphorescent sheet was replaced by a fluorescent one, and solar spectra in the ultraviolet observed by W. Eisenlohr (1856), using quinine sulphate paper, and by Stokes (1862), using uranium glass.

In 1843 Becquerel noticed a streak in the infrared quenched region which remained bright, a dark infrared line, and he later $(1873,1876)$ made this observation the basis for a method of studying the infrared spectrum. ${ }^{58} \mathrm{He}(1848)$ had also noticed that infrared quenching was preceded by an increased intensity, before the phosphorescence faded.

In 1881 John William Draper, M. D. (1811-1882), professor of chemistry and physiology in New York University, for whom the Grotthus-Draper law of photochemistry is named, refined the method by adding photography. He had obtained a photograph of the solar spectrum in 1842, showing the region to which silver iodide is sensitive. On exposing powdered phosphorescent material to the sun's spectrum in the dark, the exciting action of the blue, violet, and ultraviolet regions were visible, essentially as in his previous photograph. A second exposure in a light sufficient to cause moderate phosphorescence of this phosphor allowed the quenching effect of the red and infrared region to become effective. ${ }^{59}$ He then placed

${ }^{58}$ The modern method is the use of an infrared sensitive photographic plate.

${ }^{50}$ Extinction by infrared and excitation by blue wave-lengths were responsible for some peculiar effects when phosphor layers were exposed to various mixed light sources, phenomena investigated by Stokes (1882) about the same time as Draper's experiments (1881), and by G. LeBon (1900). In 1874 J. L. Soret described a fluorescing ocular of uranium glass. In $1883 \mathrm{E}$. Lommel introduced the phosphorescing ocular (a thin layer of Balmain's paint on glass) for the spectroscope and later (1888. 
the phosphorescent screen on a photographic plate to make the record (after development) permanent and called the print a phosphorograph. ${ }^{60}$ Draper had published a general paper "On the Phosphorescence of Bodies," in 1851, and another, "On the Production of Light by Chemical Action," in 1848. His interest in phosphors was no doubt the result of previous work on photochemical and phosphorogenic effects of the chemically active ultraviolet light, which he referred to as tithonic ${ }^{61}$ rays in papers published in 1841-1845.

In 1852 G. G. Stokes (1820-1903) published the correct interpretation of fluorescence and announced what is now called Stokes' law that the exciting light is of shorter wave-length than the emitted light. Becquerel (1859) confirmed the general truth of this law, which was so much discussed in later work on luminescence.

The testing of methods of excitation other than visible ${ }^{62}$ or ultraviolet light came with the development of vacuum techniques. In the 1839 paper, the Becquerel group had placed phosphorescent substances in a vacuum and exposed them to electrical discharges sent through the evacuated tube. A luminescence was observed but it was much weaker than the excitation from the electric discharge outside the vacuum. However, in 1857 to $1859 \mathrm{E}$. Becquerel's experiments in glass tubes with sealed-in electrodes, highly evacuated, and also containing various gases under different pressures, led to new results. He noticed that double cyanides of platinum or sulphides of calcium and barium placed in the tubes luminesced most brightly in the neighborhood of the cathode. His observation that the glass of the tube fluoresced green when a high tension current was passed through, probably indicating the generation of cathode rays, whose excitation of glass is now well known. In the same year, J. Plücker

1891) published more extended papers on "Phosphoro-photographie des ultrarothen spectrums."

${ }^{60}$ Draper's claims to priority for the phosphorograph gave rise to some acrimonious discussion. See W. de W. Abney (1881) and E. Becquerel (1882). H. Becquere] $(1883,1884)$ and E. Lommel $(1888,1889,1890)$ continued the studies.

${ }^{81}$ From Tithonus, a beautiful youth with whom Aurora fell in love.

62 A particularly potent source of light for phosphor excitation was that of lime heated by an invisible flame like burning alcohol. H. F. Talbot (1835) had spread lime on paper and then burnt the paper with an alcohol flame, finding that the lime framework gave off a very intense light. He thought the heat of the flame caused the lime molecules to vibrate, thereby causing undulations of light in the surrounding medium. If molecules were able to vibrate when cold they would also produce light, and he therefore proposed this simple explanation of the light of phosphors. The first description of the "lime light," which became a symbol of brilliancy, appears to be that of Wm. Brewster in the Edinburgh Philos. Jour. 3: 343-344, 1820. Draper (1845) called attention to the difference between lime light and electric sparks in exciting Canton's phosphor. 
(1859) had also observed the green fluorescence of the glass of vacuum tubes. These two men were apparently the first to observe cathodoluminescence. To Wm. Crookes (1879) belongs the credit for exhaustive experimentation and observation of a variety of luminescences excited by cathode rays, canal rays, X-rays, and radium rays and other kinds of radiation, as described in Chapter XII on radioluminescence.

\section{DURATION OF PHOSPHORESCENCE}

Early workers may have presumed that a phosphor emitted light during illumination, but actual proof of the emission cannot be obtained by observation in sunlight, which obscures the feeble luminescence. However, the phosphorescence can be seen during illumination if the exciting light is of a different wave-length from the emitted light. The most striking demonstration comes from excitation with completely invisible ultraviolet light, as in the previously mentioned spectral studies. Nevertheless, because a short time interval cannot be estimated by the eye, the question remains as to how quickly after excitation phosphorescence appears and how soon it ceases after the exciting light is cut off. ${ }^{63}$

This duration of phosphorescent light appears to have aroused much less interest among early observers than its color, or the methods of excitation. The very early workers noticed only the long lasting phosphorescences. However, the improved technique for observation introduced by Beccari and his associates indicated that many materials would phosphoresce for a very short time after exposure. The question as to whether a phosphor luminesced the instant it was illuminated or stopped the instant it was cut off, or how short an exposure was necessary to excite a phosphorescence could only be answered by new experimental techniques for measurement of short time intervals.

Probably the first attempt to measure the duration of a fluorescence, that of uranium glass, was made by E. Esselbach in 1856 , although his method was not published and only the result, about $1 / 2000$ second, appeared in $1863 .^{64}$ Credit for invention of the phosphoroscope ${ }^{65}$ belongs entirely to Edmond Becquerel. His in-

${ }^{63}$ The present term, fluorescence, was not applied to a phosphorescence which lasted only as long as the material was exposed to light until after 1852. At that time the word was coined by G. G. Stokes for light emission in fluorspar (hence the word) and also for material in solution (see Chapter XI) .

${ }^{84}$ Rep. Brit. Assoc. Adv. Sc. for 1862, 32:22, 1863.

${ }^{65}$ Becquerel (Com. Rend. Acad. Sci. 46: 969-975, 1858), as early as 1854, considered there was no difference between fluorescence and phosphorescence and set out to develop the phosphoroscope to test this. (See his book, 1: 320, 1867.) 
strument of 1858, which solved the problem for times as short as $10^{-4}$ seconds ${ }^{66}$ is well known. The material to be examined is mounted between two revolving disks each containing a number of staggered holes near the periphery, so arranged that light passing through a hole in the first disk and striking the material cannot be seen by looking through a hole in the second disk. A small fraction of a second later, depending on rate of revolution of the disks, the exciting light is cut off from the material and the hole in the second disk has moved into a position where observation becomes possible.

Becquerel's experiments with this instrument showed that a great many compounds phosphoresced for varying lengths of time after illumination, times measured either in ten thousands of a second or in seconds. The distinction between fluorescence and phosphorescence appears to break down. However, Becquerel was never able to measure the duration of fluorescence in solutions, ${ }^{67}$ which was later found to be of the order of a one-hundred millionths of a second. The expression "true fluorescence" is sometimes reserved for such light emissions, but the observation that fluorescence in solution becomes a phosphorescence if the solution gels (Wiedemann, 1887) or at liquid air temperatures (Dewar, 1894), makes the distinction rather arbitrary. ${ }^{68}$ In this book, phosphorescence and fluorescence have been separated as chapters, purely because, during most of the long history of the subjects, the two were not generally recognized as similar phenomena.

Becquerel was never willing to admit a difference between phosphorescence and fluorescence except one of time, although he did describe substances observed in his phosphoroscope in which the color of the light at the first moment of exposure differed from the later color. On the other hand Stokes (1852) claimed that, in addition to the fact that a phosphorescence always had duration, the phosphorescent light from material spread in a thin film and sharply illuminated actually spread sideways, whereas fluorescent light did not. He also argued that phosphorescence and fluorescence were quite distinct because different substances exhibited these types of luminescence.

${ }^{6 \theta}$ Time intervals of $10^{-\theta}$ seconds can now be measured.

${ }^{\text {e7 }}$ Becquerel was unable to observe an afterglow in quartz, sulphur, phosphorus, metals, or liquids. Even after Wiedemann (1888) improved the phosphoroscope to the point where a few millionths of a second could be measured, a phosphorescence of solutions could not be detected.

${ }^{68}$ Modern theory indicates that duration of the light is not necessarily a distinction between phosphorescence and fluorescence. A better test is to determine whether the excited state is paramagnetic, when phosphorescence is indicated. If both phosphorescence and fluorescence excited states occur in one molecule, the phosphorescence emission (observed at low temperature) is of longer wave-length and of longer duration. 
After Becquerel, a number of phosphoroscopes ${ }^{69}$ using new principles were invented, one by Crookes (1887) for observation of cathode ray phosphorescence, another by Lenard (1892) for electric spark ${ }^{70}$ excitation, and one by Levinson (1898) for excitation by scratching, a tribophosphoroscope. The Crookes and Lenard instruments contained a commutator to set off the cathode discharge or the electric spark at the proper instant before the luminescent material could be observed. Perhaps the simplest type consists of a revolving cylinder on whose surface the phosphor is cemented.' If illuminated with a sharp beam of light, all stages of decay of the phosphorescent light can be observed at various distances behind the illuminated spot as the cylinder rotates. This simple device was first used by E. Becquerel (1861), and was adopted by John Tyndall for demonstration in his famous lectures on light. It was employed for minerals by W. G. Levinson (1898), and for quantitative investigations by F. E. Kester (1899).

\section{INTENSITY OF PHOSPHORESCENCE AND THE LAW OF DECAY}

In a general way the earliest observers noted that the brighter the light, the more intense the phosphorescence. Probably Beccari (1745) was the first to consider a relation between the two. He found that one candle at a certain distance would excite the same glow as four candles twice as far away. This result merely demonstrates the inverse square law and shows that lights of equal intensity excite the same luminescence. Becquerel (1861) was the first to measure the excited light with a polarization photometer, finding that within certain limits there was a direct proportionality between intensity of exciting and that of the emitted light. He used sunlight for excitation and was surprised to find that the phosphorescent light of a uranium phosphate phosphor was only $1.5 \mathrm{mil}$ lionth the intensity of the sunlight. Uranium salts were particularly bright but there was much variation in other substances. The double phosphate of uranium and calcium was the brightest studied by him, and a wollastonite (a Ca silicate) the dimmest.

Becquerel was the first to establish a law of decay (Abklingen in German) of the emitted light, finding that the intensity decreases exponentially. Later workers like L. Darwin (1881), E. Wiedemann $(1888,1889)$, H. Becquerel (1891, 1892), C. Henry (1892,

${ }^{B}$ Wiedemann (1888) modified the Becquerel phosphoroscope for high rates of rotation and easy inspection. The various types were reviewed by Nichols and Howes (Science 43: 937-939, 1916).

${ }^{70}$ The "phosphoroscope électrique" of Labarde (Com. Rend. Acad. Sci. 68: 1576, 1859) was merely a Becquerel type using electric discharges. No mention of a commutator to trigger the sparks is made. 
1893), F. E. Kester (1899), and many others have noted deviations from any simple law over the whole period of decay, and proposed decay equations of their own. The problem is greatly complicated in some phosphors by the emission of several bands of light which decay at different rates. The decay equations have become important in testing various theories of phosphoresence.

\section{SPECTRUM OF PHOSPHORESCENCE}

Another question which was to occupy the research time of Becquerel and many later investigators, and which was to lead to important theoretical interpretations of phosphor light was the nature of the emission spectra. Although Zanotti (1748) observed the light of phosphors through a prism in 1717, the introduction of the slit (by Wollaston in 1802) was necessary before accurate studies could be made. Again, Becquerel (1843-1859) led the way. In his most important work, the second paper of 1859 , he described the bands observed when the material to be studied was mounted as a narrow rod (essentially a slit) in his phosphoroscope, followed by collimator, prism, and telescope. Sunlight, electric lights, or sparks were used for excitation. He found that the bands remained the same with different wave-lengths of exciting light although the intensity varied. The bands of the phosphorescent light occupied different spectral regions in different substances; in the uranium salts, they became a series of narrow bands, related in a definite way to the wave-lengths of exciting light.

In 1852 Stokes had published his announcement that fluorescent light is always of longer wave-length than the exciting light (Stokes' law), and the same principle was found to apply in most cases to phosphorescence. During the years 1859 and 1872 Becquerel amassed a large amount of data on spectra, some of which appeared in his book (1867) and in his 1872 paper. During this time there was practically no study of phosphorescence spectra in other laboratories, with the exception of a note by Kindt (1867) on fluorspar.

With the eighteen-eighties a new era began with a flood of papers on luminescent spectra-Ca and $\mathrm{Sr}$ sulphide phosphors exposed to light by W. de W. Abney (1882) and by E. Lommel (1886, 1887), aluminum and rare earth salts exposed to cathode rays by Crookes (1881, 1887) and Lecoq de Boisbaudran (1886-1888), calcium sulphide by Klatt and Lenard (1889), as well as many other isolated observations. The importance of spectral measurements had been demonstrated but the results are too detailed and specialized to be considered here. 


\section{TEMPERATURE EFFECTS}

The effect of temperature on phosphorescence has been noticed more or less casually since the studies of John Canton (1768), already mentioned. N. Hulme (1801) also demonstrated that Canton's phosphor would emit a brighter light on slight warming and observed no light in a freezing mixture (salt and snow), although luminescence reappeared on thawing. ${ }^{71}$ Grothus (1815) was the next to try low temperatures $\left(-25^{\circ} \mathrm{C}\right)$. His results led him to declare that cold favored the taking up of light and heat the emission of luminescence. Osann (1825) found no luminescence of phosphors at high temperatures.

These early workers did not realize how complicated the behavior of phosphors might be at different temperatures. There is not only an effect on absorption of light and on intensity of emission, but also on total light emitted, on rate of decay and on color. In addition, the whole problem is greatly complicated by delayed emission, i. e., thermoluminescence. Different phosphors behave in different ways. Some of the observations on these effects are recorded below.

Becquerel's (1839) first studies on temperature had to do with the effect of illuminating Canton's phosphor at two different temperatures, minus $20^{\circ} \mathrm{C}$ and plus $20^{\circ} \mathrm{C}$, after which samples were kept at these two temperatures. For as long as fifteen minutes they luminesced with equal intensity, but when the light disappeared, only the sample at low temperature emitted more light on warming. Becquerel came to the conclusion that a phosphor was more excitable the lower the temperature.

This conclusion is not universally true. His later (1859) work indicated that other phosphors behaved differently. Some showed an optimum temperature for greatest intensity at low temperatures and others at high temperatures. Becquerel's final conclusion was that at various temperatures phosphors absorb "a certain amount of light which is always the same for a given temperature and once placed in darkness a quantity of light is emitted corresponding to the total absorbed, more slowly under ordinary conditions and more rapidly the higher the temperature or under the influence of infrared rays." What this statement ${ }^{72}$ amounts to is that in general after irradiation the luminescent light intensity increases and the dura-

${ }^{71}$ Hulme (1801) came to the conclusion that Canton's phosphorus behaved toward temperature in the same manner as the luminescence of fish, referred to as "spontaneous light," his principal object of study.

${ }^{72}$ Becquerel's statement, quoted in the previous paragraph, has been quite generally confirmed, that the total light emitted by a phosphor after a definite exposure to light is a constant quantity whether it be emitted rapidly or slowly. 
tion decreases with rise in temperature, a relation confirmed by G. A. Bardetscher (1889). In fact E. Wiedemann (1892) later demonstrated that eosin in dry gelatin, which phosphoresces at room temperature, becomes at $140^{\circ}$ a fluorescence of so short a duration that the time could not be measured in his phosphoroscope.

After the preparation of liquid oxygen by L. Cailletet and R. P. Pictet, independently in 1877, and commercial manufacture of liquid air in sufficient quantities in the eighteen nineties, it was found that phosphorescent light in some substances may disappear at this temperature and reappear on warming, as shown by $\mathrm{R}$. Pictet and by $\mathrm{J}$. Dewar, both in 1894. The fact that exposure to any type of exciting radiation at liquid air temperatures would result in phosphorescence when the temperature of the phosphor was raised, even though no light could be seen in liquid air, appears to have been first observed by James Dewar (1894). Low temperatures were also studied by R. Cusack (1897), A. and L. Lumière (1899), C. C. Trowbridge (1899), and others during the twentieth century.

The color of the light of phosphors changes with temperature also, as noted by $\mathrm{E}$. Becquerel in 1859. He found a $\mathrm{SrS}$ phosphor to give off dark violet light at $-20^{\circ} \mathrm{C}$, blue violet at $20^{\circ}$, bright blue at $40^{\circ}$, green at $70^{\circ}$, yellow green at $90^{\circ}$, yellow at $100^{\circ}$, and orange at $200^{\circ}$ The phenomenon is a particularly striking one as certain phosphors warm up from liquid air temperatures. Similar changes were noted by G. A. Bardetscher (1889) and by E. Wiedemann and G. A. Schmidt (1895).

It is apparent that in place of a heterogeneous mass of information, Becquerel was responsible for what can be designated a planned approach, based on quantitative measurement of intensity and duration of phosphorescence and spectral emission in relation to the characteristics of the exciting light. Becquerel did not attempt to explain phosphorescence. He was content to ascribe the effects of light to an upsetting of the molecular equilibrium. His greatness lies in the collection of precise data on which a theory could be based when generalization became possible.

\section{POLARIZATION OF PHOSPHORESCENT LIGHT}

Becquerel's investigations were so thorough that he practically monopolized the study of phosphorescence during his most productive years. However, a few scattered discoveries by other workers not previously described, can be called "firsts." An early published test of polarized light in exciting phosphorescence of prepared noncrystalline phosphors was made by $\mathrm{H}$. W. Dove in 1861 . He found that polarized light was quite effective in excitation and that the 
emitted light was not polarized. This statement is generally true for isotropic substances.

The emission of polarized fluorescent or phosphorescent light appears to have been first noted for platinocyanide crystals by Stokes in 1852. It was also studied by J. L. Grailich in 1858 (see Chap. XI) . Later, Professor Maskelyne and Crookes reported polarized fluorescence in the last section of Crookes' (1879) paper on cathode effects. These men observed the polarization of the luminescence of certain precious stones (emerald, sapphire, ruby) exposed to cathode rays, but not of others (diamond, beryl).

The most extensive work came later by L. Sohncke (1896) and G. C. Schmidt (1897). Schmidt made a systematic search for polarized luminescence of matter in various states, finding no polarization in gases or liquids, but its frequent occurrence in anisotropic crystals, no matter whether the light emission is classified as a fluorescence, a phosphorescence or a thermoluminescence. An apparent polarization of the cathodoluminescence of glass under pressure was later denied by Schmidt (1899).

\section{THE PHOTOELECTRIC EFFECT AND PHOSPHORESCENGE}

Another field of inquiry which cannot be attributed to Becquerel is the relation between phosphorescence and electrical conductivity. After the discovery that ultraviolet light influenced the electrical properties of bodies, affecting their surface charge (H. Hertz, 1887; Hallwachs, 1888) as the result of emission of negative electricity, the phenomenon (called a surface photoelectric effect) was studied by J. Elster and H. Geitel in an extended research. Their first paper (1889) dealt with the fact that alkali metals and Balmain's paint ${ }^{73}$ were sensitive to visible light, and in 1891 they announced that fluorspar and certain other minerals showed the phenomenon. G. C. Schmidt (1897, 1898) studied "Die Beziehung zwischen Fluorescenz und Actinoelectrität" in solids and liquids. Much later P. Lenard and S. Saeland (1909) showed that the long wave-length limit for the photoemissive effect was also the limit for exciting luminescence.

That light can affect the electrical conductivity of material like selenium has been known since the publication of Willoughby Smith in $1873,{ }^{74}$ but the relation between phosphorescence and

${ }^{73}$ An impurity phosphor (CaBiS) of the type which exhibits the photoelectric effect. Other luminescent materials such as uranyl salts, platinum double cyanides, or organic compounds have given negative results.

${ }^{74}$ Jour. Soc. Tel. Eng. 2: 31, 1873. An extensive study was made by W. G. Adams and R. E. Day (Phil. Trans, 167: 328-349, 1876). 
photoconductivity was only definitely established by B. Gudden and R. Pohl ${ }^{75}$ in 1920. The change in electrical resistance is now recognized as an internal or volume photoelectric effect, due to emission of electrons within the substance illuminated. It has played an important part in theories of luminescence since the beginning of the century. It was in 1899 that both P. Lenard ${ }^{76}$ and J. J. Thomson ${ }^{77}$ demonstrated that the negative charges emitted from illuminated metal surfaces were the same as the particles of cathode rays, that is, they were electrons.

Quite naturally these discoveries formed the basis for theories of phosphorescence during the early twentieth century. The subject is beyond the scope of this book and it will suffice to say that after 1900 a number of workers regarded the exciting light as liberating electrons. The first of these was L. E. O. de Visser (1901), while P. Lenard and V. Klatt (1904) and de Kowalski ${ }^{78}$ (1907) emphasized the presence of emission centers represented by the trace of heavy metal present, from which light separated electrons. Later work of Lenard and Saeland ${ }^{79}$ (1909) and J. Stark (see 1911) ${ }^{80}$ gave support to the photoelectric theory. Usually luminescent emission was presumed to occur on return of the electron to the positively charged atom or molecule. The theory is particularly important in connection with thermoluminescence and cathodoluminescence and has become associated with the names of Lenard and Klatt. Philip Lenard won the Nobel Prize in physics in 1905 for work on cathode rays. Virgil Klatt was his teacher and later a collaborator in their extended work on impurity phosphors in 1904, some fifteen years after the Klatt and Lenard paper of 1889. Their work has formed the basis for present theories of phosphorescence.

\section{Theories of Phosphorescence (and Fluorescence). A Review}

Although the views of various early workers on the mechanism of phosphorescence have been presented in connection with their discoveries, it may be helpful to review the theories as a whole, now that the proper perspective has been acquired. As practically every student of phosphorescence has ventured a theory, only the principal

${ }^{75}$ Ztschr. für Physik 1: 365-375, 1920, and many later papers.

${ }^{76}$ P. Lenard, Sitzungsber d. Akad. Wiss. Wien. 108: 1649-1666, 1899; Ann. der Phys. 2: $359-375,1900$.

${ }^{77}$ J. J. Thomson, Phil. Mag. 48: 547-567, 1899.

${ }^{78}$ J. de Kowalski, Phil. Mag. 13: 622-626, 1907, and Arch. Sci. Phys. et Nat. 21: 22-24, 384-386, 1907.

${ }^{79}$ P. Lenard and S. Saeland, Ann. der Physik 28: 476-502, 1909, and P. Lenard, Ann. d. Physik 31:641-685, 1910.

${ }^{80} \mathrm{~J}$. Stark. See Prinzipien der Atomdynamik 2: 213-227, 1911. 
ones can be considered. The older opinions are of special interest in contrast with those of the present day.

Previous to the electron concept, the explanations of phosphorescence passed through a series of beliefs, evolving as rapidly as the general advance in knowledge of material phenomena would permit. One of the oldest views was the sponge theory, that phosphorescence is connected with the absorption of light in a porous material, to be later released, a conception introduced by La Galla (1612), held also by Liceti (1640), Kircher (1641), Schott (1656), Hoffmann (1700), Dufay (1735), Scheele (1771), Herbert (1773), and Osann (1834).

Another view, due to Montalbani (1634) regarded phosphorescence as akin to burning, because of the "sulphur" contained in the phosphor, a view adopted by Homberg and in part by Lémery (1698), by de Mairan (1717), at one time by Dufay (1726), by Zanotti (1748), Volta (1776), Macquer (1778), Morozzo (1786), Marchetti (1791), de Saussure (1792) in connection with thermoluminescence, and by Ritter (1803). Dufay's views were somewhat variable, as he appeared to rely at times on one and at times on the other theory, while Beccari presented no special theory. Ideas of combustion and chemical processes were not sufficiently clear to classify certain beliefs, for example that of J. A. Le Duc (1787) .

According to the light absorption theory, calcination made the stone more porous; according to the burning theory, calcination brought the sulphur to the surface or freed it or " exalted " it, or removed impurities. The observations of Zucchi (1652), that a phosphor emitted the same color of luminescence no matter what the color of the light to which it was exposed, was definitely against the light absorption theory but apparently had little effect on the popularity of the absorption idea or the belief that light was a material substance.

Conceptions regarding the nature of light naturally influenced the explanations of phosphorescence. A number of physicists proposed vibration theories. Lémery (1698) spoke of vibrations of small parts and Cohausen (1717) held that calcination modified the Bolognian stone in such a way that it would hold the air (ether) in a special modification which allowed it to vibrate, as when there is light in the air around us. L. Euler (1777), a proponent of the wave theory of light, also suggested the vibration theory previously mentioned, based on his concept of surface color, that when light strikes a body, it sets up characteristic vibrations in the material particles, practically resonance vibrations, which are transmitted to the ether as the color of the object. A phosphor exposed to light 
vibrates after the exciting light has ceased. Thus, blue light can excite an orange phosphorescence because the natural period of the phosphor vibrators corresponds to orange.

In the early nineteenth century, theories of phosphorescence became more specifically chemical. Ritter (1803), who observed the exciting action of blue light and the quenching action of red light, explained the effects in terms of combustion. The blue light reduces material in the phosphor, thereby allowing subsequent oxidation and phosphorescence to proceed, while red light, by oxidation of the material, quickly suppresses luminescence. Heinrich (1811) looked on light as setting free an acid with which light was bound, while Dessaignes (1809) believed bound water contained the phosphoric fluid which is essentially electricty. A complex electrical theory was also proposed by Grotthus (1815), and applied to photochemical effects in general. In some ways, he may be regarded as the pioneer in formulating a theory which bears some resemblance to the modern concept of interaction between light quanta and electrons.

After the publication of G. G. Stokes (1852) and the recognition (see Chapter XI) that certain luminous phenomena in fluorspar and in solutions were not due to light scattering but to a light emission which he called fluorescence, theories of phosphorescence and fluorescence were frequently combined. The vibration theories came back into favor together with the vibratory theory of light itself. It was easier to picture light setting molecules in vibration for a short time than for a long time. As no chemical changes could be observed in a fluorescent body, Stokes himself regarded fluorescent light as arising from resonance-vibration of molecules, while the continuous character of fluorescent spectra represented damped vibrations as given by a Fourier series analysis.

W. Eisenlohr $(1854,1856)$ was one of the first (after Stokes) to present an explanation of the way in which fluorescent light might be excited by interference, comparable to combination tones. In this way ultraviolet light plus another wave length might produce blue fluorescence, and red light plus a second color result in infrared fluorescence.

The most important suggestions came from E. Lommel, whose theories of fluorescence in various modifications extended over a considerable period (1862-1895), with important papers in 1878 and 1885. He made use of the laws of vibrating bodies applicable in the theory of sound. According to his latest version, the atoms of an illuminated body were set in vibration, both natural and forced; they were also subject to a damping proportional to their velocity 
as a result of friction, and were acted on by a restoring force proportional to the square of their displacement. Stokes' law and the broad fluorescence bands might be explained by these assumptions, but the original theory was not satisfactory in detail and subject to criticism by many workers, which led to changes over the years $(1882,1885,1895) .{ }^{81}$

It might be supposed that E. Becquerel, who recognized no distinction between phosphorescence and fluorescence, would develop a theory, but he was satisfied to speak of changes in molecular equilibrium, in orientation or constitution of molecules, giving rise to electricity, which appeared as heat or light when the molecules returned to their former state.

The last statement begins to have a modern look. Toward the end of the century, E. Wiedemann (1889) assumed that a phosphor could exist in two modifications, $A$ and $B$. When light struck the surface the stable modification $A$ absorbed certain wave-lengths and was converted into the unstable modification $B$, which then returned to $A$ with emission of light. The logarithmic decay of phosphorescence, observed in some cases, gave direct support to the theory. Infrared rays had a quenching action because they were absorbed by $B$, converting $B$ quickly to $A$. Phosphorescence was thus regarded as a true chemical process, actually a chemiluminescence. Weidemann and Schmitt (1895a) cited in its favor the very long afterglow of some phosphors and facts connected with color changes in phosphors and with thermophosphorescence, tribophosphorescence, and lyophosphorescence.

In a second paper Wiedemann and Schmidt (1895b) modified and enlarged the hypothesis to include not only luminescence emitted when $A$ and $B$ recombine but when $B$ is converted into $C$, and also luminescence from undecomposed molecules in which atoms or valency charges are set to vibrating by the exciting light. Ionization was regarded as one of the chemical changes which might occur.

Although E. Becquerel pioneered in discovering facts concerning luminescence, Eilhardt Wiedemann (1852-1928) was his most distinguished contemporary and successor (see Chapter VI). Wiedemann's research in the field of phosphorescence and fluorescence did much to place the newer knowledge on a quantitative and theoretical basis. His papers on all kinds of luminescence and those

${ }^{81}$ Among those who discussed Lommel's theory or developed general opinions regarding a theory of fluorescence were J. J. Obermann (1871), A. Wiillner $(1878,1883$, 1899), E. Ketteler (1882), E. Linhardt (1882), K. Wesendonck (1884), F. Stenger (1886), O. Knoblauch (1895), G. Jaumann (1894, 1895), and B. Galitzin (1895). 
of his colleague at Erlangen, Gerhart C. Schmidt appeared over the years 1878 to 1907 . In 1901, Wiedemann prepared a pamphlet of twenty-eight pages, Ueber Luminescence, which was published by the University of Erlangen in a Festschrift seiner Königlichen Hoheit des Prinzregenten Luipold von Bayern zum achtzigsten Geburtstage. This more or less popular presentation was a rare departure from his usually technical publications.

With the turn of the century, the electron and the quantum became the most important concepts in the theory of light and views on luminescence changed completely, taking the direction discussed in the previous section on the photoelectric effect and phosphorescence.

It must not be supposed that the hypothesis of Wiedemann and Schmidt contained the last word on phosphorescence. In the first decade of the twentieth century, approach to the scientific study of phosphorescence (and fluorescence) was pioneered by Robert Wood (1868-1955), Edward L. Nichols (1854-1937) and Ernest Merritt (1865-1948) in the United States, and by J. Stark (born 1874) and Peter Pringsheim in Germany, while P. Lenard (1862-1947) and V. Klatt continued their important work. These men introduced new theories, in which the electron played an all important role, and a host of later workers continued phosphorescence study until, by 1955 , at least sixty books (including published symposia) have dealt with this fascinating subject. 


\section{THERMOLUMINESCENCE}

\section{Introduction}

$\mathrm{B}^{\mathrm{ECAUSE}}$ of its early discovery and long usage, the term "thermo$\mathrm{B}$ luminescence" has been retained for the emission of light on heating a substance to relative low temperatures-far below the point at which incandescence begins. The word implies that heat energy excites the luminescence, but actually heat merely liberates energy in the form of luminescence, energy from absorbed light, cathode rays, etc., which has previously been stored in the material. The more appropriate term thermostimulation might be applied, to conform with the modern explanation of thermoluminescence as the liberation by rise in temperature of trapped electrons, whose transitions result in the emission of light.

Thermoluminescence is strikingly exhibited by minerals, which have been previously exposed to light or to cathode rays at liquid air temperatures, where no luminescence is visible, but as the mineral is warmed, a bright light emission occurs, often changing color as the temperature rises. Historically, the term " thermal phosphor" was first applied to solids which luminesce on slight heating above room temperature, without any reference to previous treatment of the material. It is because of this historical connotation that thermoluminescence is rated a chapter heading rather than a section of the chapters on phosphorescence or radioluminescence.

\section{Seventeenth-Century Observations}

Robert Boyle undoubtedly noted ${ }^{1}$ the thermoluminescence of diamonds in October, 1663, when he held a particular one near a hot but non-luminous piece of iron and saw the diamond glow. The discovery of a similar property in the mineral fluorspar, some varieties of which are remarkably thermoluminescent, must be ascribed to Johann Sigismund Elsholtz (1623-1688) of Berlin, physician to the Elector, Friedrich Wilhelm. He published a book, De Phosphoris Observationes, etc., in 1681 of which the first part, "De Phosphoris Quatuor" appeared separately in 1676 and contained the account of fluorspar. When the finely ground mineral was dusted as letters and figures on a plate, slight heating would result

\footnotetext{
${ }^{1}$ Works of Boyle, ed. by T. Birch, 797, 2nd ed., 1772, and his book on Colours (1664); see figure 37.
} 
in luminescence, a spectacle which must have aroused considerable interest. The mineral was shown to Duke Frederick Johann of Braunschweig and was brought to the attention of the Royal Society and the French Academy. G. B. von Leibnitz (1710) in his paper on the discovery of phosphors referred to it as the thermophosphorus.

Henry Oldenburg, Secretary of the Royal Society and publisher of its Philosophical Transactions made a statement (1676) concerning the new phosphor in 1676: "An account of four sorts of factitious ${ }^{2}$ Shining Substances communicated to the Publisher from very good hands, both in Printed Papers and in Letters not printed." In addition to the "Factitious Paste" of Dr. Baldwin, the Bononian Stone, and the Phosphorus Fulgurans (i. e., the element phosphorus), there was the thermal phosphorus, which was called by the Germans, "Phosphorus Smaragdinus, said to be of this nature that it collects its light not so much from the Sun-beams, or the illuminated air, as from the Fire it self; Seeing that if some of it be laid upon a Silver or Copper-plate, under which are put some live coals or a lighted taper, it will presently Shine. ..."

In the dissertation on phosphors of George Kaspar Kirchmaier (1635-1700), De Phosphoris et Natura Lucis nec non de Igne (1680) the material is referred to as a green stone powdered and mixed with water which when heated will glow in the dark without smoke or smell.

Nathaniel Grew, in classifying the gems of the collection belonging to Gresham College, described in his Museum Regalis (1681), mentioned

A Clear and Green Stone, (a kind of Smaragdus) which being heated red hot, shineth in the Dark for a considerable time, sc about $1 / 16$ th of an Hour ... I tried the experiment myself also. And at the same time observ'd That as it grew hot in the fire its Green colour was changed into a Sky-blew; ${ }^{3}$ which it likewise retained so long as it continu'd to shine: But after that, recover'd its native green again.

The material was also described by R. Southwell in 1698 under the name of Phosphorus metallorum:

Take Lapis Smaragadi Mineralis (such as is found in the mines of Saxony) and beat it into a very fine Powder. If you strew this very fine on any Metal, and in any Figure, and set the Plate on any hot Coals, in a short time you will perceive in the Dark, a Light to Shine, which will (saith my Author) last as long as you continue the hot Coals, and if you beat out the Fire, it may do again for once or twice, but then the Vertue will fade.

\footnotetext{
${ }^{2}$ Factitious means artificial, i.e., prepared.

${ }^{3}$ The blue thermoluminescence of the green colored stone.
} 
These quotations indicate the widespread interest in thermoluminescence.

\section{Eighteenth-Century Experiments}

Since the earliest observations, the mineral chlorophane, a green fluorescing variety of fluorspar, has been the most celebrated thermophosphorescent substance. It was known as false emerald," "émeraude brute," and a particular variety, the " pierre de Berne," was described by L. Bourguet (1724) and by Dufay (1726) as "Phosphore de Berne." This material had been sent to the French Academy from Bern, Switzerland. It was very luminous on the first slight heating but Dufay found it would not become phosphorescent again on a second heating. He therefore thought the stone contained a sulphur which burned.

Dufay also established that certain precious or semiprecious stones -a false emerald from Auverne (a green fluorspar), some rubies (aluminum oxide), amethyst (violet quartz), oriental topaz (aluminum fluorosilicate) and hyacinth (zirconium silicate) -would luminesce on slight heating, but not oriental emerald (aluminum and beryllium silicate with a trace of chromium) yellow jasper (quartz with iron) sapphire (aluminum oxide) or opal (silica). He thought that, if the coloring of a stone was due to sulphur, it would luminesce, otherwise not. In line with his idea that the light was a kind of burning, Dufay wrote: "It must be acknowledged that the pierre de Berne and all the others which have no light except that imparted to them from the fire of calcination, scarcely differ from a glowing coal, which is a very strong phosphor and a durable one which lights in plain daylight."

In 1735 Dufay (1738) studied other thermoluminescent materials, rock crystal (quartz) for example, and showed that once exhausted, exposure of this mineral to light would revive the ability to luminesce again on heating. This experiment established the fact that thermoluminescence is really a delayed phosphorescence, excited by slight heating, a thermophosphorescence. However, too great heating was found to destroy permanently this property. Dufay repeated the experiments of Boyle on diamonds, contributing a monograph on this gem in 1738. The Italian group at Bologna, especially Monti, also knew of thermoluminescence and made some scattered observations.

In the middle of the century relatively few experiments were

- Also called smaragdine or Bohemian emerald; Kirchmaier (1680) wrote of the mineral as "hesperus" or "vesperugo." Ornaments of the material became fashionable in England after 1765; they were manufactured in Derbyshire. 
carried out but a number of new minerals were found to be thermoluminescent. In $1746 \mathrm{~J}$. H. Pott (1692-1777) an M. D. and professor of chemistry at the Collegium Medico-Chiurgicum at Berlin, reported the phenomenon in fluorite, calcite, opal, and quartz. Sven Rinman (1747) noted that the Lysspat (shining spar) of Garpenberg occurred in five different colors, all of which glowed on heating with a pale blue light, whereas other varieties of spar used in glass-making did not. On too great heating the material became white. During the luminescence there was no smell, no loss of weight, and no sign of electrical charge.

That chalk, various minerals and precious stones were luminescent on heating was mentioned in most eighteenth-century chemistries and by Delius (1785). Nicolas (1784) reported the luminescence on heating of " spath phosphorique calcaire d'Apremont " and Pallas (1787) described a fluorite from Russia which would luminesce from the heat of the hand. Crell (1795) also studied thermoluminescence of minerals without adding much to general knowledge.

In 1771 Carl Wilhelm Scheele (1742-1786) of Köping, who initiated research on fluorine chemistry, concluded that fluor mineral was a calcareous earth of an (at that time) unknown acid (hydrofluoric acid), produced by treating fluor with vitriolic acid. ${ }^{5} \mathrm{He}$ was able to make an artificial fluorspar by adding lime water to the unknown acid, obtaining a precipitate which phosphoresced when heated in the dark. He realized that the green variety from Garpenberg contained iron whereas the white variety from Gislof in Scania did not. He tried without success to find some change in composition of fluorspar after phosphorescence had been abolished by strong heating. Since fluor phosphoresced in a vacuum and under water, Scheele concluded " that its phosphorescence does not depend on a subtile inflammable material." He believed that because of a special structure, the light was taken into the pores of the fluorspar but not firmly bound. On warming, the heat was more firmly bound and displaced the light.

Toward the end of the eighteenth century considerable interest was again aroused in the relation between phosphorescence and thermoluminescence. In 1768 Canton demonstrated a similar behavior in prepared phosphors, that his phosphorus (CaS) would luminesce a second time, if heated slightly, after all previous luminescence had disappeared. He also found that when this thermoluminescent light had faded, raising the phosphor to a still higher temperature would bring another return of light. Herbert (1773)

${ }^{5}$ The chemical essays of Charles-William Scheele, translated from the Swedish by Thomas Beddoes, 1-7, London, 1786. 
noted a similar phenomenon, using the Bolognian phosphor, as did the Rev. Morgan (1785) with oyster shell phosphors prepared by Wilson's (1775) method. Canton thus discovered thermoluminescence of artificial phosphors. It was quite obvious that thermoluminescence and phosphorescence must be closely related.

\section{Relation of Thermoluminescence to Triboluminescence}

Although Dufay had pointed out that scratching was one method of exciting certain minerals to luminesce, a rather close relation between thermoluminescence and triboluminescence was demonstrated in the 1790's. In 1791, de Dolomieu discovered a calcite-like mineral in Tyrol, later called dolomite (a CaMg carbonate), which hardly dissolved in acids, and which luminesced on rubbing, scratching, or hitting. In 1792 de Saussure noted the thermoluminescence of certain samples of the mineral. The color of the light of dolomite on heating is orange and it will not luminesce on a second heating even after exposure to sunlight. De Saussure analyzed the mineral and suggested that impurities like iron might have something to do with the luminescence, but never followed up the idea. He recognized three types of stones which luminesced on heating(1) those containing sulphur or a hepar (fois), a compound of sulphur, which burned in the free air, (2) those which absorb the light and then emit it, like the diamond, and (3) those which do not require air and will luminesce under hot water, like dolomite and fluorspar. He noted that the more colored the fluorspar, the more thermoluminescent it was and that on heating the color disappeared at the time the ability to thermoluminesce was lost.

A little later, J. Thomson (1798) pointed out that the connection between thermo- and triboluminescence is not universal. A marble from Castellammare, near Vesuvius, luminesced on heating but not when rubbed, whereas Dolomieu's (1791) "calcite" (really dolomite) would luminesce on rubbing but not on heating. The two phenomena appeared to be distinct.

In one of the last comprehensive papers of the century (1792), Thomas Wedgwood (1771-1805), son of the famous potter, Josiah Wedgwood (1730-1795), and a potter himself, made a special study of thermo- and triboluminescence. He compared the ability of a great variety of substances, inorganic and organic, to luminesce when placed on an iron plate heated to below the temperature of a red glow, and also tested their response to attrition by rubbing two pieces together. On heating he found blue fluorspar to be brightest, giving a green light changing to lilac. Then came red feldspar, vari- 
ous marbles, chalk, and ruby powder with a red to orange luminescence, diamond and sea shells with a white luminescence. Quartz, iceland spar, and white porcelain also showed a white luminescence.

Some of these materials were luminescent "by attrition" but the order of brightness was not the same. The duration of the thermoluminescence was very variable. In general, the experiments indicated a certain parallel between thermoluminescence and triboluminescence but it was far from exact.

Wedgwood also found salts of various kinds and some organic materials-paper, linen, wool, wood, waxes, and oils-to be luminescent on heating. ${ }^{6}$ This effect was no doubt in some cases an actual combustion, as M. van Marum (1776, 1782) had observed the luminescence of oils when heated. At a time when combustion was not thoroughly understood, the similarity of diverse phenomena made interpretation difficult. Wedgwood himself called the light "some sort of inflammation," and Dessaignes $(1809,1810)$ and C. B. J. Williams (1835) showed that no light appears in absence of air (see Chapter XIII).

\section{Nineteenth-Century Contributions}

It will be noted that the previous work had been mostly descriptions of new thermophosphors, with some experimentation. The trend continued in the early nineteenth century. René Just Haüy (1743-1822), the eminent French mineralogist and discoverer of piezoelectricity (in 1782), tested systematically a large number of minerals on a hot plate. Among them about a dozen showed marked thermoluminescence. The list is contained in his Traité de Minéralogie (1801). Dessaignes (1809, 1810), Heinrich (1812), and Grotthus (1815) added more examples.

By far the most important contributions were made by the last three men, who used their findings as a basis for the theories of phosphorescence which have been described in Chapter VIII. Like others, Dessaignes held that almost all organic and inorganic bodies would luminesce when scattered as powder on a hot plate at $256^{\circ} \mathrm{C}$. The nature of the plate made no difference. However, most of the organic substances which he tested required air and the light was actually a burning. His study of heat and light excitation led him to the idea that in the material there was a phosphoric fluid of an electrical nature, which was set into vibration by moderate heating but destroyed by strong heating.

\footnotetext{
- Brugnatelli (1800; in Italian, 1797) noticed that ground sugar, cotton, feathers, wool, and camphor would "luminesce" on a hot plate.
} 
Heinrich's studies on thermoluminescence were even more extensive than those of Dessaignes. He also declared that almost all substances emitted light in powder form on moderate heating. Again, many of his compounds were organic (meal, paper, etc.), others were calcareous plus organic matter (egg shells, bone), and others mineralized carbon (coal, graphite), and burning must have occurred. Of the non-combustible minerals, all fifty-one of his calcium-containing compounds, most barium combinations, and some precious stones were thermoluminescent. Even some metals gave a momentary bright light, followed by a permanent resting luminescence. The tables in Heinrich's book give the relative intensity and color of the thermoluminescence. Both Dessaignes (1808) and Heinrich (and later Grotthus) knew that exposure to an electric spark discharge would very effectively revive the ability of an exhausted thermoluminescent material to luminesce again on warming, but they interpreted the action of the spark in different ways. Dessaignes held that the effect was due to the electricity, Heinrich (correctly) to the light in the discharge.

Of all thermoluminescent substances, fluorspar excited the most interest. The different varieties emitted light of different colors, and at surprisingly low temperatures. One of the important contributions of the early nineteenth century, two papers by Theodor von Grotthus (1785-1822) dealt exhaustively with this mineral. They appeared in Schweigger's Journal für Chemie und Physik in 1815 and contained his complicated theory of phosphorescence (see Chapter VIII) and thermoluminescence, based on his view that light is essentially the same as electricity, made up of positive and negative parts. He had obtained specimens of red-violet colored fluorspar from Nertschinsk known as fire emerald (pyrosmaragd) or chlorophane. When the chlorophane was heated in the light, its color changed to green, an indication that an intense green luminescence was emitted, as could be observed in the dark. After the light had disappeared, a later heating in the dark gave no greenlight emission unless the chlorophane had been previously exposed to sunlight. Then it would retain for months the ability to luminesce whenever it was heated slightly to $50^{\circ} \mathrm{C}$ ). If illuminated at $-25^{\circ} \mathrm{C}$, the luminescence on heating to $50^{\circ} \mathrm{C}$ was much more intense than if illuminated at $25^{\circ} \mathrm{C}$. Grotthus naturally came to the conclusion that cold favored the absorption of light while heat favored the luminescence emission.

Grotthus particularly emphasized the fact that no light was already present in a thermoluminescent phosphor, but that it had to be taken up by a previous exposure to light. There was also his obser- 
vation that the color of the thermoluminescence was always the same after exposure to different colored lights. Hence one color was apparently transformed to another color, which was contrary to Newton's views that colors could not be interconverted. Grotthus therefore abandoned the Newtonian concept and held that color must depend on a greater or less difficulty of movement which light (regarded as a combination of plus and minus electricity) encounters at the surface of bodies. He postulated that when light strikes a phosphor surface, it is split into its plus and minus principles, and may be again emitted when the plus and minus principles recombine, provided there is some resistance to the recombination. If the plus and minus principles encounter no resistance in recombination the surface is merely heated.

The result of heating a thermoluminescent body is to cause the elementary parts of the mineral to expand. Thereby the polar forces, by means of which light is decomposed and absorbed, become weakened and the combination of the plus and minus electrical charges of which light consists can take place at the proper speed. Grotthus' reasoning was logical, although the theory was difficult to test experimentally.

Attempts to find some general rule by which the thermoluminescence of a substance could be predicted were continued without too great success. David Brewster (1781-1868), whose later studies of "internal dispersion" were so important in establishing the concept of fluorescence in solutions, made an exhaustive study of luminescent minerals in 1819 and 1820 , noting especially the color of the light which appears on heating, and recording the color in his tables. ${ }^{7}$ The 1820 paper described one sample of fluorspar showing a layered structure, with each layer exhibiting thermoluminescence of a different color. The sample was useful in his study of fluorescence (see Chap. XI) .

In general Brewster found that thermoluminescence is most characteristic of colored minerals but the color of the light is not related to the color of the mineral. The property is destroyed by intense heat and contrary to the finding of Grotthus, not always regained on exposing the minerals to light. The phosphoric light has the same properties as sunlight. It is not necessarily related to luminescence from attrition, as minerals which give no light on heating may emit on attrition. Brewster (1823) also noticed that the $\mathrm{CaCO}_{3}$ framework of Chara plants is luminous when laid on a hot plate.

We have seen that many of the older observations on light emis-

\footnotetext{
${ }^{7}$ Reprinted in the Edinburgh Encyclopedia 12, 1832, of which David Brewster was editor.
} 
sion when powdered organic materials are placed on a hot plate are not to be classed as luminescences, but probably result from actual combustion, with glowing of the powder. Such an explanation cannot be applied to an observaton of M. Callaud, a pharmacist of Annecy, reported by P. J. Pelletier (1821). This was the luminescence of quinine sulphate, on slight heating. Callaud found that the light would last for some time, and believed that only pure quinine behaved in this way. He suggested that the luminescence could be used as a test for purity. Pelletier himself confirmed the report, and found that quinidine sulphate would behave in the same way. He wished to test other alkaloids, but had no opportunity, and it was not until 1840 that R. Böttger (1840) obtained negative results. It was later claimed by $\mathrm{A}$. Kälahne (1905) that dehydration of the crystals is responsible for the light. Hence, if the crystals crack on heating the phenomenon could be a triboluminescence. More modern studies should be undertaken.

Sporadic interest in thermoluminescence continued. In 1830 Thomas J. Pearsall, chemical assistant at the Laboratory of the Royal Institution, published an important paper on the effects of electricity in exciting thermoluminescence. He studied the behavior of a number of thermoluminescent minerals and calcareous organic material, exposed to the light of the electric spark, repeating some of the earlier work. Usually a luminescence was found to occur during the discharge, after which, on heating slightly, the brightness of the thermoluminescence was very considerably greater than during the discharge. If heated to the point where no more thermoluminescence appeared, a single spark discharge would make the material thermoluminescent again. Moreover certain colorless fluorspars and diamonds, not normally thermoluminescent, could be made so by exposure to the spark discharges, although an amethyst, sapphires, rubies, and garnets gave no indication of such thermoluminescent behavior.

Mother of pearl, scallop shells, cuttlefish bone and egg shells, exposed to the spark and then heated, luminesced with colors from yellow to purple. A colorless fluorspar became colored after exposure to the spark discharge. These effects of the spark are largely due to the ultraviolet light in the spark, as had been pointed out by Heinrich, but Pearsall did not appear to realize this fact and thought that voltage of the spark was responsible, rather than the light or the amount of electricity.

Pearsall's observation that spark discharges make a colorless fluorspar blue, together with the fact that natural thermoluminescent samples of fluorspar are colored and lose their color when heated 
as the thermoluminescent light appears (Saussure, 1792), indicates a definite relation between color and thermoluminescence. The relation was again noted with a zirconium compound. W. Henneburg (1846) showed that colored zircon loses its color on heating and thermoluminescence appears, but G. Specia (1876) held that the color change had nothing to do with light emission. It was later shown that cathode rays and $\mathrm{X}$-rays color inorganic compounds and they then become thermoluminescent (see Chap. XII).

Although many authors regarded thermoluminescence as a thermophosphorescence in which the light previously absorbed was merely set free by heating, cases were known in which great blocks of opaque rocks had been split open in the dark and the inner pieces never in contact with light found to be thermoluminescent. However, it could be held that light was absorbed at the time of formation of the rock.

In this connection an interesting experiment was carried out by James Napier (1810-1884) in 1851. It had been observed by Lavoisier in 1776 that chalk and many other calcareous compounds emit light when moderately heated. Napier drew lines with chalk on an iron plate. These lines glowed like phosphorus for a few seconds when the plate was heated. The glow had usually been explained by a theory of J. W. Draper (1851). Draper held that during a previous exposure to light, the undulations "became fixed by the cohesions of the molecules of chalk ... and the light thus fixed within or amongst the molecules is set at liberty by the high temperature ... and by completing its undulations (the chalk) becomes visible for a time." Napier showed that such an explanation would not hold. He precipitated chalk by the action of carbon dioxide on lime water in complete darkness and found that the precipitate, used to mark lines on the iron plate would luminesce on warming exactly like the natural chalk previously exposed to light.

Edmond Becquerel reviewed the knowledge of thermoluminescence rather scantily in his book, La Lumière, ses Causes et ses Effets (1867), and carried out little experimental work of his own. In fact few papers ${ }^{8}$ on thermoluminescence after exposure to light were published toward the end of the century. At that time the various luminescent phenomena in vacuum tubes were claiming the attention of physicists.

After the discovery of cathode rays, X-rays, and radium rays,

${ }^{8}$ The contribution to knowledge of fluorspar thermoluminescence by C. Bohn (1867), G. C. Kindt (1867), G. Wyrouboff (1867), A. Forster (1871), E. Hagenbach (1877), Cossa (1877), and G. D. Liveling (1878) are inconsequential. 
together with their effects in exciting fluorescence of various materials, it was noted that bombardment by any of these radiations would make the material highly thermoluminescent. In fact the extraordinary ability of discharges in a vacuum tube to render fluorite and other substances thermoluminescent led Wiedemann (1895) and Wiedemann and Schmitt (1895) to deny that light in the discharge was responsible, and they attributed the effect to "Entladungsstrahlen" (cathode rays), whose nature was at the time somewhat uncertain. They published a long list of compounds rendered thermoluminescent by cathode rays. Some of these retained their ability to thermoluminesce after exposure to the discharge for months, others lost the ability fairly quickly. Wiedemann and Schmitt noted the change in color of alkali halide crystals after radiation and believed that chemical changes resulted from the exposure.

M. W. Hoffmann (1897) found that no thermoluminescence could be excited by "Entladungsstrahlen" if solid bodies, even transparent quartz or fluorite, were placed in their path, again indicating that more than ultraviolet light was present. Thus the electric discharge in a vacuum turned out to be a complex phenomenon, requiring considerable controversy and much research before all of its effects were cleared up and the electron designated the exciting agent.

In $1898 \mathrm{~J}$. Trowbridge and J. E. Burbank exposed fluorite, whose thermoluminescence had been destroyed by heating, to X-rays in a dark metal box and found that after exposure the fluorite would again luminesce momentarily on warming. The paper was entitled "Phosphorescence Produced by Electrification." Since it was known at the time that X-rays electrify bodies, Trowbridge and Burbank suggested that the electric energy gained from charging fluorite by $\mathrm{X}$-rays was dissipated as light.

At the end of the nineteenth century it was recognized that energy from some source must be stored in some way in a thermoluminescent body, to be released by rise of temperature. The suggestion has been made that thermoluminescence of fragments from the interior of opaque rocks, never exposed to sunlight in recent times, might be the result of energy accumulated from radioactive substances in the crust of the earth. ${ }^{9}$ Recent research ${ }^{10}$ has fully born out this prediction.

- A. S. Herschel (1899) showed that material from the inside of the Middlesborough aërolite was thermoluminescent and held that this indicated the interior could never have been heated.

${ }^{10}$ See F. Daniels, C. A. Boyd, and D. F. Saunders, Thermoluminescence as a research tool, Science 117: 343-349, 1953. 
In present terminology, the storage of energy in solid phosphors is expressed in terms of electron traps, F-centers, phonons, positive holes, polarons, etc. The history of these terms is beyond the scope of this book, but they have been coined largely from a consideration of thermoluminescence resulting from the action of streams of electrons or radiation other than light.

Some of the most beautiful luminescent effects can be obtained from artificial phosphors, from minerals and other inorganic materials exposed to light, cathode rays, X-rays, or gamma rays at liquid air temperatures and then warmed. Dewar (1894) appears to have been the first to try this experiment, using calcium sulphide and light. With certain substances, as the temperature rises, a succession of thermoluminescences of various colors appears, giving a spectrum in time rather than in space.

This display might seem to have no practical value, but in recent years thermoluminescence, even without the color display, is now used $^{10}$ in a number of ways- to identify minerals, to detect differences in surface structure of catalysts, to assess radiation damage, to estimate geological age, possibly in the future to determine the dates at which rocks and ceramic material were heated to high temperatures.

\section{Candoluminescence}

No history of luminescence would be complete without mention of certain phenomena which occur as a result of heating, which appear different from incandescence, and have been given the name of candoluminescence. It has been well known that lime and certain other oxides become exceedingly bright when heated to a high temperature. The same is true with such minerals as gadolinite, containing rare earths, studied by T. Scheerer (1840) and H. Rose (1858). On heating, at a certain temperature these earths rather suddenly emit an intense light connected with a molecular change, far brighter than would correspond to their temperature. According to E. L. Nichols and B. W. Snow (1892), zinc oxide, as well as lime (Nichols and M. L. Crehore, 1894) " possesses the remarkable property, long since known to exist in case of other oxides, of luminescence by heat." The phenomenon was later called the "blue glow," or candoluminescence, and regarded as fundamentally due to fluorescence excited by the incandescent radiation. C. Swinton (1899) has shown that certain rare earths (thoria) become brilliant on bombardment with cathode rays, while others (ceria) do not, although both earths are equally brilliant when heated to the same temperature. Candoluminescence is now regarded as selective thermal radiation rather than luminescence. 


\section{TRIBOLUMINESCENCE, PIEZOLUMINESCENCE, CRYSTALLOLUMINESCENCE, AND LYOLUMINESGENCE}

\section{Introduction}

ITERALly interpreted triboluminescence should refer to a low1 temperature light which results from rubbing a material ( Greek tribo, to rub), whereas piezoluminescence should infer that pressing (Greek, piezo, to press) has excited the light. Rubbing and scratching from local pressure often involve fracture of the material and in many cases breaking or separation appears to be necessary for such luminescences. Hence the name "Trennungsleuchten," first applied by Heinrich (1820), and often used in Germany. Light resulting from collision, friction, fracture, or attrition is also considered in this chapter. Triboluminescence and piezoluminescence are synonymous and the former word will be used as the preferred term.

Actually radiation described under these headings may be due to three different activities. ${ }^{1}$ It may result (1) from frictional electricity, from the building up of a potential which discharges through the air, an electroluminescence. It may be (2) a light emission from unstable molecules (centers, electron traps) which have previously been excited by exposure to radiation of some kind, a delayed phosphorescence like thermoluminescence, or what might be called tribophosphorescence. Certainly not all triboluminescences are due to previous radiation, and the word "tribostimulation" cannot be applied. Finally (3) there may be emission from molecules excited by the unbalanced charges on the two faces of the separated crystal planes, what has been called true triboluminescence. Without attempting to distinguish which process or combination of processes is involved in any one case, the experience of a long list of investigators has indicated that many minerals (amorphous or crystalline) and many organic crystals exhibit the phenomenon of triboluminescence.

Allied to triboluminescence is crystalloluminescence, the light which appears when solutions crystallize, whereas lyoluminescence

${ }^{1}$ See F. G. Wick, Uber Triboluminescence, Sitzungsber. Akad. Wiss. Wien, Math-Nat. Klasse IIa, 145: 689-705, 1936, and Jour. Opt. Soc. Amer. 27: 275-285, 1937. 
refers to light emission during solution of crystals. Crystalloluminescence has been attributed by Trautz and Schorigin (1905) to fracture of the newly formed crystals as they crowd each other during growth. However, not all cases of crystalloluminescence appear to be capable of the above explanation, notably $\mathrm{NaCl}, \mathrm{KCl}$ or $\mathrm{AsCl}_{3}$, as explained later. The interpretation of lyoluminescence is more obscure.

\section{Triboluminescence and Piezoluminescence}

\section{EARLY OBSERVATIONS}

The first knowledge of triboluminescence appears to be connected with sugar. Many early writers have mentioned the light which appears when lump sugar is scraped. One of the oldest records, already referred to, comes from Francis Bacon (1561-1626) in the Advancement of Learning (1605), but triboluminescence of sugar must have been observed before Bacon, as cane sugar was prepared since earliest times in India and Persia and introduced into Europe ${ }^{2}$ in the twelfth century. The original use of sugar was in medicine and it did not become plentiful until sugar cane was disseminated by the Spaniards in the fifteenth and sixteenth centuries. The early sugar often formed a very hard mass which had to be chipped from the container and any person attempting this at night would be certain to observe the luminescence.

Members of the Accademia del Cimento of Florence during the decade 1657-1667 noted triboluminescence, judging from the following statement, taken from Richard Waller's (1684: 158) translation.

Of Bodies affording Light. . . B Besides Firestones there are other Bodies that seem to be greater Conservatories of Light; for by striking them together or by breaking them in the Dark, they Sparkle. Such are White Sugar, Loaf Sugar and Sal Gemme [rock salt] in the Stone; all which being broken in a Mortar, give forth so great a Light as distinctly to discern the sides of the Mortar and the shape of the Pestle thereby: but we have not succeeded to see the same appearance in pounding Common Stone salt, Alumn, or Nitre; nor in Coral, the Yellow or Black Amber; Granats, or Marchasites: But Rock-Chrystal, and Agate, and Oriental Jasper, either struck together, or broken, give a clear Light.

The Italian scientists thus recognized a number of luminescences from breaking materials and it is significant that they use the expression " hold the light which they receive." The complexity of triboluminescence is well illustrated in certain kinds of diamonds, as

${ }^{2}$ See Dissertation on the history of sugar, by Prof. Beckmann, in Phil. Mag. 11: $1-7,1802$. Beckmann believed that sugar from sugar cane was unknown to the Greeks and Romans. 
evidenced by the careful experiments of Robert Boyle, made on October 27, 1663, and reported to a meeting of the Royal Society next day. ${ }^{3}$ Boyle's particular diamond "that shines in the dark" belonged to a Mr. Clayton, whereas most of his own diamonds as well as rubies, sapphires, and emeralds did not exhibit this property. The stone was hard and would write on quartz but was dull in appearance and blemished with a whitish cloud in the middle. ${ }^{4}$ Boyle found "this to have like other diamonds an electrical faculty," as indicated by the attraction of light objects. "Being rubbed upon my clothes as is usual for the exciting of amber, wax and other electrical bodies, it did in the dark manifestly shine like rotten wood, or the scales of whitings or other putrified fish." Holding the diamond near a candle made it shine in the dark, although less intensely, and it did not then become electrified, whereas holding it over a well heated but not glowing piece of iron made it glow only slightly.

The last experiment would seem to indicate Mr. Clayton's diamond was weakly thermoluminescent, and the candle experiment would indicate phosphorescence. ${ }^{5}$ Boyle showed that the diamond, previously excited by rubbing on cloth, would luminesce under water and other liquids, but it could not be excited if rubbed while under water or with a damp cloth. Evidently electrification of the diamond played some part in its glowing. It seems probable that the light of electroluminescence, as well as the light of the candle excited the phosphorescence of the diamond, which then lasted some time.

Boyle went on to demonstrate that "incalescence" had little to do with the glow in rubbing but that "compression of its parts" was an important factor. By pressing on one spot (without rubbing) with a well-glazed white tile or with a steel bodkin, there was disclosed " a very vivid but exceedingly short lived splendor, not to call it a little coruscation." This last experiment would appear to demonstrate true triboluminescence, i. e., piezoluminescence, of the crystal. Even though Boyle did not separate the various types of luminescence, his communication is a model of experimental procedure, and deserves to be read by all interested in the history of science. Boyle's observations on the diamond were repeated by

\footnotetext{
${ }^{3}$ T. Birch, Works of Boyle 1: 796-799, 2nd ed., 1772. Publication of the Phil. Trans. did not begin until March 6, 1665. The account was annexed to Experiments and considerations touching colours (London, 1664), see figure 37.

* Boyle later showed that some clear diamonds would also glow after rubbing. He tried to buy Clayton's diamond, but Clayton would not sell.

${ }^{5} \mathrm{Had}$ the diamond been exposed to sunlight and then warmed in the dark, thermoluminescence might have been marked, but Boyle did not perform this experiment.
} 
many later workers, the most important being Dufay, whose Recherches were published in 1738.

Boyle, like Bacon, was also aware that " hard sugar being nimbly scraped with a knife would afford a sparkling light," and he showed that the light still appeared when sugar was scraped in a vacuum.

It is possible that Christian Mentzel (1675) whose teacher was Liceti and who knew Montalbani, discovered triboluminescence of the Bolognian stone, for he compared the sparkles of white light which sometimes appeared from specimens to the sparks observed on stroking cat's fur or on scratching sugar. He endeavored to prepare phosphors in many different ways and it seems quite certain that triboluminescence of a mixture of antimony and saltpeter, calcined in a crucible, was observed by him.

Another artificial preparation which showed the phenomenon of triboluminescence was made by Wilhelm Homberg (1652-1715), in 1693, published in the Histoire of the French Academy (1733). This was an impure fused $\mathrm{CaCl}_{2}$ which resulted on heating "one part of sel armoniak and two parts of chaux vive," to form a grey vitreous substance. It luminesced on rubbing or striking when freshly crystallized, but the experiment did not always succeed.

\section{RELATION TO ELECTRICITY}

It was evidently in Boyle's mind that electricity had something to do with the glow of his diamond. Discovery of the mercurial phosphor (an electroluminescence) led Bernoulli and Cassini (1707) to try rubbing sugar, sulphur, copper, gold, and diamonds on glass and diamonds on silver. Light appeared in all cases. Some of these effects (sugar) may have been true triboluminescences but most were probably due to discharge from frictional electricity, a relation not recognized at that time.

Hauksbee's (1709) experiments, which involved rubbing materials against each other in a vacuum and obtaining light, were mostly electroluminescences (amber and wool, glass and wool, etc.), but a disk of steel revolving against flint, which gave off sparks in the air, in a vacuum showed only a diffuse luminescence, which may have been in part a triboluminescence. Hauksbee's work is of greatest importance in connection with electroluminescences and further details will be found in Chapter VII.

In 1735 the problem of diamond luminescence was minutely reinvestigated by Dufay (1738), better known for his studies on electricity. Dufay quoted from Boyle's experiments and wondered that Boyle had not exposed Mr. Clayton's diamond to sunlight before observation. He also referred to Bernoulli's and Cassini's observa- 
tions (1707) on diamonds which luminesced when rubbed on glass, metals or faience (glazed pottery). In Dufay's experience many diamonds turned out to be both phosphorescent and thermoluminescent. He proved rather conclusively that electrification of the diamond and luminescence had no immediate connection. Some diamonds became electric on rubbing and did not luminesce, whereas others would luminesce and not become electrified. Moreover, an electrified and luminescent diamond on being moistened would lose its charge without disappearance of the light. Dufay also found no relation between the color of the diamond and its luminescent and electric properties.

It is not surprising that later students of electricity should turn to the study of triboluminescent substances. Rubbing was the easiest way to produce electricity and a characteristic of electrification was the "electric light." Father Giambattista Beccaria (1716-1781) endeavored ${ }^{6}$ to discover a relationship between the two, using the best known triboluminescent substance, sugar. Concerning this he wrote: "You may, when in the dark frighten simple people only by chewing lumps of sugar, and, in the meantime, keeping your mouth open, which will appear to them as if full of fire; to this add, that the light from sugar is the more copious in proportion as the sugar is purer." On pounding sugar in a mortar Beccaria described the light as exactly like electric sparks, but could observe no attraction of fine threads, which would have indicated that electrification had occurred. Sugar, like diamond, shows "true triboluminescence," and the various sugar experiments confirmed those made with diamonds. There is no connection between electrification and triboluminescence of sugar.

\section{EIGHTEENTH-CENTURY OBSERVATIONS ON MINERALS}

Another common material which exhibits triboluminescence is quartz. Anyone can confirm the observation that quartz pebbles when knocked together, especially if hit a glancing blow, exhibit a yellowish flash of light. Except for Hauksbee's experiment with flint, there is no special mention of this property in the early literature $^{7}$ but in 1748 , H. F. Delius $(1720-1791)$, a physician and professor of medicine at the University of Erlangen, called attention to

- Reported in a translation of his book, Dell' elettricismo artificiale e naturale (Turin, 1753), which appeared as $A$ treatise on artificial electricity, 324, London, 1776. J. K. Wilcke, according to Priestley (1769: 290) was another who endeavored to explain triboluminescence of sugar by the "electric light."

${ }^{7}$ Boyle (On colours, 1664) stated that he could see no light when two white pebbles were "hard rubbed" against each other. Possibly they were not quartz but marble. 
the fact that two pieces of quartz or of flint rubbed against each other would emit light and give off a smell of sulphur. $\mathrm{He}$ also found that emerald, hyacinth, amethyst, topaz, and carneol would luminesce when rubbed in a hot oven. These experiments were confirmed by J. H. Pott, who observed flint, quartz crystals, and porcelain triboluminescence in 1757, while Robert de Paul de Lamanon (1752-1787), the French naturalist, in 1785 again mentioned the sparks which appeared on striking flint and other minerals. He suggested that the sparks indicated an actual burning of the material, since diamonds will burn. Although such sparks from flint cannot come from burning (oxidation) as do sparks from iron, they undoubtedly represent incandescent particles and must not be confused with the triboluminescent phenomena of quartz or flint. G. G. Schmidt (1795) noted "phosphorescence" of quartz when rubbed with precious stones.

Many other natural minerals are triboluminescent. Of special interest are zinc ores, because of the present importance of various zinc sulphide phosphors. The physician, Samuel Theodor Quellmalz (1696-1758), at various times a professor of anatomy, surgery, physiology, pathology, and therapy at the University of Leipzig, observed in 1735 that calamine (a native hydrous zinc silicate) and also "Cadmia fornacum," the zinc oxide encrustaced on furnaces, luminesced on touching or handling. A little later, in 1744, the councillor of mines, Johann Friedrich Henckel (1679-1744), observed luminescence on scraping these compounds with a knife, as did Johann Gottlob Lehmann, (died 1767), a physician in Berlin who became professor of chemistry and director of the Royal $\mathrm{Mu}$ seum of St. Petersburg, in 1749.

A Dr. C. G. Hofmann, writing for the Hamburgische Magazin in 1750 , reported that zinc blend $(\mathrm{ZnS})$ from Scharfenberg ${ }^{8}$ would become strongly luminescent on rubbing and endeavored, without success, to remove the property by treatment with various chemicals.

Tobern Olof Bergmann (1735-1784) also, the great Swedish chemist and naturalist, knew of these phenomena. In 1772, Joseph Marie François Lassone (1717-1788), French physician to royalty and a student of chemistry, saw the luminescence of zinc oxide, obtained by burning zinc, shaken in a flask. When stirred, the light was said to last for an hour.

Thomas Wedgwood's (1792) experiments on triboluminescence were made by what he called attrition, by striking or rubbing two pieces of the material together. Rock crystal (quartz) was the brightest, then diamond, both giving a whitish light, then white

${ }^{8}$ See also Sven Rinman (1747) on thermoluminescence of fluorspar. 
quartz, with a faint orange luminescence, then chert (rock flint), and then rubies, both with a red luminescence. Hard alum did not luminesce. Often a peculiar smell, described as "fetid," could be detected. The light appeared only when the minerals were rubbed, not afterwards. Simple pressure was ineffective but there was luminescence if the material was broken. This luminescence occurred under water and in an inert gas like fixed air (carbon dioxide).

Wedgwood thought the effect was due to local heating ${ }^{9}$ and argued that heating could take place under water because it was so local, but he admitted that the triboluminescence of sugar, which is soft, yet gives light on gentle rubbing, could not be explained in that way. In favor of the local heating hypothesis he demonstrated that the sparks which came from stones on hitting were hot because they would ignite gunpowder, and also because many of his triboluminescent substances would also light on heating.

Other observers of triboluminescence were de Dolomieu (1791) and Gillet-Laumont (1791) on dolomite from Tirol and de Saussure (1792), who observed an orange luminescence on rubbing, scratching, and hitting the mineral, as well as on slight heating. These men emphasized the fact that not all samples showed the property. As indicated in Chapter IX they endeavored to connect tribo- and thermoluminescence, without too great success. ${ }^{10}$ In 1798 Count C. L. Morozzo noted the triboluminescence of certain minerals when brushed with " une plume," and Accum (1799) described the luminescence of borax.

In 1799 and 1800 Humphry Davy (1778-1829), later to become knighted and famous as professor at the Royal Institution and president of the Royal Society, discovered that many plant parts which contain silicic acid, particularly bonnet cane, would luminesce on rubbing. ${ }^{11} \mathrm{He}$ also experimented with sugar, fluorspar, calcium phosphate, and many other salts, finding that they would luminesce when struck in an atmosphere of carbon dioxide. Since they were transparent non-conductors which could be electrified by friction, Davy at that time was inclined to regard the luminescence as electrical in nature.

- In 1785 de Lamanon had believed the sparks which come from striking quartz and other minerals indicated a burning of these bodies, just as diamond will burn.

${ }^{10}$ Nearly one hundred years later similar observations were being made. At the Academy of Natural Sciences at Philadelphia, H. C. Lewis (1884) exhibited a limestone from Utah, which gave " a lurid red light when struck, scratched or heated. The glow lasted from half a second when lightly struck, to a much longer time as the result of a blow." The same sample emitted a deep red light when heated, but a specimen from Kaghberry, India, "glowed with a strong yellow phosphorescence when heated, although no such effect was produced by scratching or striking."

${ }^{11}$ Many writers on luminescence have mentioned the Indian reed (Canna indica) as giving light when the stalks are struck together. 
Thus the century came to a close ${ }^{12}$ with a large amount of information on triboluminescence, but no generalization and no theory to account for the heterogeneous collection of facts. It was not even certain what part electrification might play. Indeed, even today the phenomena of triboluminescence cannot be explained by any one theory, since they represent diverse effects gathered together under one name.

\section{NINETEENTH-CENTURY RESEARCH}

One of the important and comprehensive studies was made by Dessaignes $(1809,1811,1812)$ who endeavored to bring the triboluminescences which he observed in line with his theory of a phosphorescent fluid, which is fundamentally electricity, bound with water. As reported in his first paper (1809), he ground his materials (glass, moonstone and pumice) in a mortar and held that the triboluminescence was brighter in a metal mortar than a porcelain one and brighter in dry weather than in damp weather. The material previously ground in the metal mortar would not luminesce if strewn on a hot plate because the electric fluid had escaped through the metal, but the same material powdered in a porcelain mortar did luminesce on a hot plate, because some of its phosphorescent (electric) fluid was retained. It is hard to understand on what change this finding is based.

In the second paper, Dessaignes (1811), tried other methods of crushing. Many powders hammered on an anvil gave a scintillating light without being appreciably warmed. He found that water will luminesce if compressed and that certain powdered materials when added to water, also lighted on compression.

Dessaignes' third paper (1812) contained a list of minerals which would luminesce " on collision." The organic materials, sugar and resin, behaved in a similar way. Other minerals, metals, sulphur, and most metal salts were not triboluminescent. He observed that the light arose at particular points where the material was fractured and held that a certain diamond, not previously luminescent after exposure to light, or on rubbing, would show both phosphorescence and triboluminescence after it was struck in such a way that one of its edges was damaged.

Triboluminescent light is usually of very short duration, but Dessaignes observed that sometimes the light near a fracture would last 4-5 minutes (moonstone), depending on the material, what

${ }^{12}$ Other observers, who contributed no new facts, were Dr. Juch (1799) on sugar, William Hamilton (1800) and L. von Buch (1800) on calcite from Vesuvius. Compte de Bournon (Phil. Trans. 92: 248, 1802) noticed that the corundum stone would luminesce when struck, if the stone was of a red color. 
might be called a tribophosphorescence. No temperature rise accompanies triboluminescence, but the light emission is favored if the material is warmed and the harder the substance the more likely it is to luminesce.

Grotthus (1815) had also observed light from percussion but made no extensive study, merely attributed it to light "which the body had absorbed and preserved between its elementary parts."

Heinrich's treatment of triboluminescence in the fourth section (1820) of his book is quite thorough. He included the light phenomena accompanying the compression of gases and the rapid rush of gas into a vacuum (see Chapter VII), as well as luminescence on compression of solids. He held that all substances which emit under compression were also thermoluminescent. His list of triboluminescent materials is large. In general silicious substances are best, followed by clayey (Thon), calcareous and talc-like material. Heinrich did not endeavor to connect triboluminescence with acid but held that it was due either to: (1) separation of parts (Abspringen der Unebenheiten) through friction, or to (2) electricity generated by friction, or to (3) the chemical decomposition of the material.

In $1855 \mathrm{~J}$. Schneider took the position that triboluminescence had nothing to do with rise of temperature or electrification, as he was able to select diamonds easily electrified but not triboluminescent and minerals triboluminescent on such slight rubbing that no rise in temperature was possible.

During the rest of the century the subject of triboluminescence was somewhat neglected. It was hardly considered by $\mathrm{E}$. Becquerel. The communications merely recorded new triboluminescent material, but with the important discovery that many organic compounds are triboluminescent. E. Becquerel (1859) and T. L. Phipson (1860) described the scintillations of milk sugar and uranyl nitrate ${ }^{13}$ when crushed, while J. Noggerath (1823) and H. C. Lewis (1884) discovered new triboluminescent minerals among organic compounds. F. Krafft (1888) added high molecular weight benzol derivitives like pentadecylparatolylketone; ${ }^{14} \mathrm{~J}$. Reuland (1889), tetramethyldiphenylin; P. Gucci and G. Grassi-Cristaldi (1892) and others, santonin compounds; Arnold (1897), hippuric acid; W. J.

\footnotetext{
${ }^{13}$ E. Becquerel (Ann. Chim. et Phys. (3rd ser.) 55: 86, 1859) first described the short (3-4 milliseconds) phosphorescence of uranyl nitrate. J. Dewar (1901) and $\mathbf{H}$. Becquerel (1901) reported that light appeared when the crystals were placed in liquid air during cooling and then during rewarming. Presumably the effect is a triboluminescence connected with cracking or breaking of crystals from contraction and expansion. Ice shows the same phenomenon.

${ }^{14}$ E. Wiedemann (Ann. d. Physik 37:229, 1889) demonstrated a short phosphorescence of this compound after exposure to light in his new phosphoroscope.
} 
Pope (1899), saccharin; F. Richarz (1899), salophen; all with crystals which are triboluminescent on breaking. For several centuries sugar had been the one well recognized organic triboluminescent compound, but the greater advances in organic chemistry in the latter half of the nineteenth century revealed these additional examples and led the way for the extensive studies of M. Trautz in 1905. No comprehensive theory to account for triboluminescence was proposed and the principal advance was discovery of the large number of organic crystals, which emit light on crushing.

As in the study of other types of luminescence, so in the case of triboluminescence there have been conflicting results of various investigators and inconsistent observations noticed by the same observer. The explanation of this variation may be due to the fact that (I) triboluminescence of certain substances only appears in impure material, and that (2) triboluminescence disappears some days after a crystal has been formed. At the time of his study of saccharin, Pope (1899) noticed that not every crystal would sparkle on crushing. He also emphasized that it was "commercial" saccharin which showed marked triboluminescence and not the purified material. Moreover his crystals lost the property after a few weeks. This phenomenon of "temporary triboluminescence" is fairly widespread. Homberg (1693) found that his phosphor must be freshly crystallized in order to luminesce and not every trial was successful, while Heinrich (1820) remarked that a previous bright glowing destroyed the ability to triboluminesce.

\section{Crystalloluminescence}

In 1786 a novel kind of luminescence was described, to which the name crystalloluminescence ${ }^{15}$ has been given. Johan George Pickel (1751-1838), who published in 1787, and Schöenwald (1786) were the first, and later G. A. Giobert (1790) and J. M. Schiller ${ }^{16}$ (1791) also noticed the greenish points of light when vitriolated tartar $\left(\mathrm{K}_{2} \mathrm{SO}_{4}\right)$ crystallized rapidly. Since the light is much brighter if the crystallizing liquor has been stirred, most observers attribute the light to breaking of crystals rather than the formation of crystals, and hence consider it a triboluminescence. The discoverers noted especially that light appeared when the crystals were scraped with a fingernail.

${ }^{15}$ Crystalloluminescence is of interest in bioluminescence history because $R$. Dubois (1893) once thought the light of centipedes was a crystalloluminescence but later reversed this opinion. These forms secrete a material full of granules which he described as transforming into crystals.

${ }^{18}$ Schiller (1791) noted that crystals of $\mathrm{K}_{2} \mathrm{SO}_{4}$ also lighted when scraped off the side of the vessel, a triboluminescence. 
Later observations on crystalloluminescence were made by Jons Jacob Berzelius (1779-1848) and Friedrich Wöhler (1800-1882) in 1823 , and F. Penny in 1855. They noticed the sparkling light during the crystallization of $\mathrm{K}_{2} \mathrm{SO}_{4}$, and that the newly formed crystals would leave a streak of light if they were stroked, i. e., a long-lasting triboluminescence. The phenomenon was lost if the crystals were redissolved and again crystallized. C. H. Pfaff (1815) added $\mathrm{Sr}\left(\mathrm{NO}_{3}\right)_{2}$, K. S. L. Hermann (1824) added cobalt sulphate and potash and A. M. Pleischl (1835) added $\mathrm{KHSO}_{4}$ to the list of crystalloluminescent substances. Most of these papers appeared in J. S. C. Schweigger's Journal für Chemie und Physik, and led Schweigger (1823-1825) to comment on the crystalloluminescences, classifying them as electrical phenomena and referring to "Krystallelectricität" as a general natural principle. He was particularly interested in Döbereiner's new "Feuerprincip" (platinum sponge) and discussed the glow of finely divided platinum under certain circumstances. This led J. W. Döbereiner (1780-1849) to publish an account of Büchner (1824) of " the wonderful spectacle of continuous spray of sparks" when benzoic acid is sublimed in a tall glass tube. Döbereiner declared that the benzoic acid luminescence was a crystalloelectric phenomenon, similar to that observed when manganese dioxide and potassium chlorate are heated for preparation of oxygen.

It is possible that electrical discharges accompany some types of crystallization. Professor Pontus (1833) described a bright spark which appeared at the end of a small glass ampule containing water a moment before solidification. The water was frozen rapidly by covering the glass ampule with ether-soaked cotton and placing in a vacuum. The experiment was repeated and confirmed by J. S. E. Julia-Fontenelle (1780-1842). Fontenelle discussed the effect with A. C. Becquerel, who merely mentioned that a similar scintillation occurred during the formation of other crystals. ${ }^{17}$

A quite new compound was discovered and studied in 1835 by Heinrich Rose (1795-1864), professor of chemistry at the University of Berlin. This was arsenious acid, whose luminescence on crystal formation Rose described as bright enough to light up the whole room. The ability to emit light would last for two or three days, if the solution was stirred. He determined the conditions

\footnotetext{
${ }^{17}$ What appears to be triboluminescence of ice was described by Wässtrom (Crell's Chem. Ann., 392, 1799, translated from Neues Schwedischen Abhand., 1798), who explained the light of the sea in cold regions by the light from ice crystals rubbing against each other. In recent times, both J. Dewar (1901) and H. Becquerel (1901) have observed light from ice cooled to liquid air temperatures, presumably a triboluminescence connected with fracture of crystals.
} 
necessary for light production, namely, solution of the $\mathrm{As}_{2} \mathrm{O}_{3}$ in $\mathrm{HCl}$, and slow cooling so that the $\mathrm{As}_{2} \mathrm{O}_{3}$ would crystallize in the vitreous modification.

In 1841 Rose was unable to observe crystalloluminescence from pure $\mathrm{K}_{2} \mathrm{SO}_{4}$ but found that light accompanied the crystallization of the double salt $\mathrm{NaKSO}_{4}$ or double $\mathrm{NaK}$ chromates and selenates. They were also triboluminescent. He held that the light emission was connected with formation of an isomeric modification. Von Reichenbach described crystalloluminescence of $\mathrm{Na}_{2} \mathrm{SO}_{4}$ in 1861 .

No further important studies of crystalloluminescence were made until E. Bandrowski reinvestigated the above cases in 1894 and 1895. In the meantime the Arrhenius theory of ionic dissociation had been formulated and was in the height of popularity, leading Bandrowski to the conclusion that light emission is connected with the formation of molecules from charged dissociated ions, whose union before crystallization produces sparks on discharge. In favor of this view he found that addition of concentrated hydrochloric acid or alcohol to saturated $\mathrm{NaCl}$ or $\mathrm{KCl}$ solutions, would result in luminescence, although the light was sometimes homogeneous rather than in spark-like flashes. Both these procedures were supposed to result in recombination of ions in solution preceding crystal formation. Thus the subject was left at the end of the century, to be continued by M. Trautz (1904), M. Trautz and P. Schorigin (1905), J. Guinchant (1905), and D. Gernetz (1905). Despite the research of these men and others who followed them, the understanding of crystalloluminescence is not too satisfactory at the present time.

\section{Lyoluminescence}

This term was applied by E. Wiedemann and G. C. Schmidt ${ }^{18}$ (1895) to light which appeared when chlorides of lithium, sodium, and potassium which had become colored from exposure to cathode rays, dissolved in water. "One can observe the phenomenon when the strongly colored substances are thrown into a small amount of water or when water is slowly poured over them in a mortar, or finally if the powder is poured in a test-tube, covered with water and shaken." Later, G. Schwarz ${ }^{19}$ (1903) observed light from sugar on solution, brighter the higher the temperature. Kayser (1908: 683) was inclined to believe the phenomenon a triboluminescence from contact of crystals, but reinvestigation of all aspects of lyoluminescence is much to be desired.

${ }^{18}$ Ann. der Physik 56:210-254, 1895.

${ }^{19}$ Oesterr. Chem. Ztg., 1903. Abstract in Fortsch. d. Phys. 59 (2) : 452, 1903. 


\section{FLUORESCENCE}

\section{Introduction}

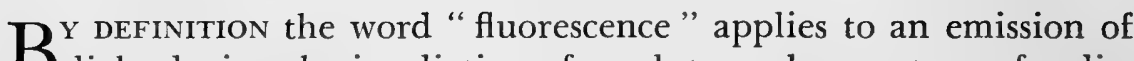
$B$ light during the irradiation of a substance by any type of radiation, provided the emission ceases immediately when the exciting radiation is cut off. If the luminescence persists, the word " phosphorescence" is used to describe it. Obviously the words "immediately" and "persists" are relative terms, depending on the sensitivity of the instrument used to measure them. Beccari's (1744) box and device for exposing a material to sunlight and rapidly examining it in the dark revealed substances whose phosphorescence lasted seconds or tenths of a second, while Becquerel's phosphoroscope (1858) decreased the time between irradiation and examination to $10^{-4}$ second. Since then the ability of phosphoroscopes to detect a rapid decay of phosphorescence has increased. Time intervals of the order of $10^{-9}$ second can now be measured. Thus the distinction between fluorescence and phosphorescence seems rather arbitrary and the two are usually treated together.

The term "true fluorescence" has sometimes been applied for light emissions lasting of the order of $10^{-8}$ seconds. Such effects are observed only with gases, ${ }^{1}$ liquids, or materials in solution, and the very short decay of light in fluids contrasts with the longer decay in solids. However, an organic compound (eosin or fluorescein) in solution in water or alcohol at room temperature, may exhibit " true fluorescence," but at very low temperatures or when dissolved in a boric acid glass (see Tiede and Wulff, 1922) or a water poor gelatin gel (Wiedemann, 1888) or when absorbed on surfaces at room temperature, the material will phosphoresce for minutes after irradiation.

It is significant that E. Becquerel never recognized a distinction between phosphorescence and fluorescence and did not use the latter word, although he did discuss the work of Stokes. Immediately after Stokes' introduction of the term "fluorescence" in 1853, attempts were made to find criteria other than duration of light emission, which would distinguish between fluorescence and phosphorescence.

\footnotetext{
${ }^{1}$ Fluorescence has been applied to the luminescence of gases in vacuum tubes excited by electrical charges or emitted rays, a phenomenon also spoken of as electroluminescence.
} 
Stokes himself held that a phosphorescence increased in light intensity on heating, whereas a fluorescence did not. Phosphorescence is usually associated with impurities while fluorescence depends on fluorophore groups in the molecule, but this is not always true; pure substances may show phosphorescence. Fluorescence obeys Stokes' law while phosphorescence occasionally does not, but again there are exceptions. Modern theory does recognize certain fundamental differences between fluorescence and phosphorescence, but the terms will be retained as convenient expressions to indicate time of light decay rather than to designate strictly separate phenomena ${ }^{2}$ Despite the difficulties of definition, it is particularly the fluorescence of liquids and solutions, with a few solids of very short duration which will be considered in this chapter.

\section{Lignum Nephriticum and Athanius Kircher}

Observation of fluorescence ${ }^{3}$ in solution is very old, although the phenomenon was not understod, merely regarded as a rather remarkable example of varied colors. The first recorded instance of a fluorescent solution appears to have been made by Nicolas Monardes (died 1578) a Spanish physician and botanist who wrote on medicines of the New World. He described a wood, called "lignum nephriticum," because of its supposed value in treating kidney diseases. When made into cups, and filled with water, a peculiar blue tinge can be observed. In the seventeenth century such cups were highly esteemed gifts, fit for royalty and very important persons. The physician Francisco Hernandes (sixteenth century) also described the wood in his book on the natural history ${ }^{4}$ of New Spain (1615).

Monardes' statement concerning the wood ${ }^{5}$ is rather brief. It will be found in "Joyfull Newes out of the Newe Founde Worlde" (1577), an English translation ${ }^{6}$ by John Frampton of the first three

\footnotetext{
${ }^{2}$ Modern theory indicates that duration of the light is not necessarily a distinction between phosphorescence and fluorescence. A better test is to determine whether the excited state is paramagnetic, when phosphorescence is indicated. If both phosphorescence and fluorescence excited states occur in one molecule, the phosphorescence emission (observed at low temperature) is of longer wave-length and of longer duration.

${ }^{3}$ See the historical account by H. Konen in H. Kayser's Handbuch der Spectroscopie 4: 843-909, Leipsig, 1908.

"Francisco Hernandez, Quatro libros de la naturaleza y virtudes de las plantas y animales que están recevidos en el uso de medecina en la Nueva España, etc., Mexico, 1615.

${ }^{5}$ The tree is Eysenhardtia polystacha, the palo dulce of Mexico. Cups were also made from Pterocarpus indica wood, from the Philippines. See W. E. Safford, Ann. Rep. Smithsonian Inst., 272-298, Washington, 1916, for an excellent account of the history of lignum nephriticum.

'The book was reprinted in 1925 (2 v., New York, A. A. Knopf). See 1: 46-47.
} 
parts of La Historia Medicinal de las Cosas que se traen de nuestras Indias Occidentales que sirven en Medecina (Seville, 1574). In a chapter entitled "Of the Woode for the Evilles of the Raines and of the Urine," Monardes merely wrote of a "white woodde which gives a blewe color" when placed in water that was good "for them that doeth not pisse liberally and for the paines of the Raines of the stone...." No mention of other colors noticed by later writers is to be found in this account.

A solution of this wood aroused the interest of Kircher (1646), who received a cup from the Procurator of the Society of Jesuits in Mexico, and presented it to the Emperor. He said: ${ }^{?}$

If one pours this water [of lignum nephriticum] into a glass globe and exposes it to light, not the slightest trace of blue will appear, but, like the pure water of a transparent fountain, it will show itself transparent and clear to the beholder. When the glass vial is moved to a shadier place the whole liquid will reflect the most pleasing of colors; in still darker places it will become a reddish color and thus, according to the conditions of the surroundings, it will miraculously change. But in the dark or put in an opaque vase, it will resume its blue color. As far as I know, I am the first to observe this spectacle of its chameleon-like nature....

A similar play of colors, like an opal, was also described by Johan Bauhin ${ }^{8}$ (1541-1631).

\section{Grimaldi, Boyle, and Newton}

This account of many colors is not quite correct and was clarified by Robert Boyle (1626-1691) in his treatise on Colours in 1664 (see fig. 37), by Francesco Maria Grimaldi (1618-1663) in his book Physico-Mathesis de Lumine, Coloribus et Iride (Bologna, 1665) and by Isaac Newton (1642-1727) in 1672. All these men, and also Robert Hooke, recognized that the tincture was blue by reflected light and yellow by transmitted light.

Boyle gave the best account. He noticed that after many infusions, the wood lost its power to color water and concluded there must be an "essential salt" in the wood responsible for the effect. He found that this salt was not volatile and could not be distilled, since a distillate was as clear as pure water. He found the blue color to be abolished by the acid salts of vinegar and to return when a "sul-

${ }^{7}$ Ars magna lucis et umbrae, Book I, part III, p. 77, 1646. Translated by Mrs. A. Holborn.

${ }^{8}$ See his posthumous work, Historia universalis plantarum nova (1650). Bauhin's infusion was made from a wood called "Palum Indianum." 
phureus salt of a contrary nature" (oil of tartar per deliquium), an alkali, was added; also that a concentrated infusion of the wood did not exhibit the phenomena too well.

Although Kircher is often regarded as the discoverer of fluorescence in solution, Boyle really established two main chemical facts regarding fluorescence of organic compounds-that the phenomenon is most apparent in dilute solutions and is greatly affected by acicls and alkalies. The latter change results from the fact that an organic compound is usually fluorescent when present as a salt, rather than as either the free organic acid or base. These transformations can be brought about by addition of acid or alkali.

Boyle also observed that other materials exhibited different colors by reflected and transmitted light, for example gold foil, which is the color of gold by reflected and green by transmitted light. He also called attention to the colors of thin films, soap bubbles and glass, but of course these phenomena have nothing to do with fluorescence.

L. Nuguet (1705) claimed that he could detect the yellow but not the blue color of an extract of "lignum nephriticum " and that such behavior was of no special interest anyway, since the phenomenon can be observed with " certain little pots of glass in which jam is kept."

Newton's observations were published in the famous "Letter containing his New Theory about Light and Colors" in the Philosophical Transactions (No. 80) for 1672. He wrote: ${ }^{9}$

The odd Phaenomena of an infusion of Lignum Nephriticum, Leaf Gold, Fragments of coloured glass, and some other transparently coloured bodies, appearing in one position of one colour, and of another in another, are on these grounds no longer riddles. For, those are substances apt to reflect one sort of light and transmit another; as may be seen in a dark room, by illuminating them with similar or uncompounded light. For, then they appear of that colour only, with which they are illuminated, but yet in one position more vivid and luminous than in another, according as they are disposed more or less to reflect or transmit the incident colour.

The subject was again alluded to in the first edition of the Opticks (1705, Book I, part 2, proposition 11), where he used Lignum Nephriticum infusion, among other tests, to make sure a beam of white light reconstituted by a second prism from the many colors produced on passing through a first prism, was really the same as the original white light. Had Newton used the word "emit"

${ }^{8}$ I. Newton, Phil. Trans. 6: 3084, 1672. 
instead of "reflect," he would have solved the fluorescence problem nearly two hundred years before the classic work of Stokes. For that whole period the emission and the reflection of light from surfaces was to remain in confusion.

Edme Mariotte (ca.1620-1684), the mathematician and physicist of Dijon, was another who compared the blue color of "lignum nephriticum " to that of air containing smoke, thus continuing the confusion between scattering and emission of light. His discussion will be found in De la Nature des Couleurs, published in Euvres de Mariotte (Leiden, 1717).

\section{Eighteenth-Century Observations}

The phenomena exhibited by lignum nephriticum were also observed by a few other early workers like Christian Wolf (1679-1754) in Experimenta Physica (1721-23), and new liquids were found to behave in a similar way, petroleum by Peter van Musschenbroek (1734), blue and red sandalwood, Quassia wood (bitter wood) tincture and horse-chestnut bark tincture (aesculin) by K. W. Nose (1780). However, there was little progress in explanation, although another experimental attempt was made by Christian Ernst Wünsch (1744-1828), recorded in his book, Versuche und Beobachtung über die Farben des Licht (Leipsig, 1792). He studied the transmitted and reflected light of lingnum nephriticum solution when illuminated by light of different spectral tints, but his colors were so impure that little can be concluded from the work. The term "fluorescence" had not yet been coined and the whole subject lay dormant during the eighteenth century.

\section{Brewster, Herschel, and Stokes}

At the beginning of the nineteenth century, a material in the solid state, fluorspar, was to play an important part in the explanation of bicolored solutions, and was in fact to supply the name "fluorescence" to the phenomenon. Fluorspar was known to exhibit thermoluminescence and phosphorescence, even triboluminescence, and many mineralogists, particularly the celebrated Abbé René Just Haüy (1743-1822), professor of mineralogy in the Musée d'Histoire Naturel in Paris, observed and commented (1801) on the fact that the color of the mineral was different by reflected and transmitted light. Haüy attempted to explain the effect as an example of the color of thin films. Somewhat later, John Herschel (17921871), the famous astronomer, in his Treatise on Light (1828) at first adopted the same point of view, but in 1845 introduced a new 
conception, although it turned out to be incorrect and will be considered later.

In the meantime, David Brewster (1781-1868), a Scottish preacher of many talents, editor of the Edinburgh Encyclopedia, and an experimentalist in the field of optics (polarization by reflection and double refraction), became interested in colors. He described (1833) the red color of a beam of white light passed through an alcoholic tincture of leaves (chlorophyll) when observed from the side, and compared it with the blue light coming from a light beam passing through the interior of a crystal of fluorspar. Brewster had been previously interested in the phosphorescence of minerals, especially on heating $(1819,1821)$ and had discovered (1820) a particular specimen of fluorspar with material arranged in layers or strata, which gave different colored luminescences on heating. He noted exactly the same colors when this specimen was traversed by a beam of white light, but at that time did not realize that the effect was an actual light emission. He spoke of the blue color of ordinary fluorspar as a diffusion or scattering of light which " must be produced by extraneous matter of a different refractive power from the spar, introduced between the molecules of the crystal during its formation." At that time (1838) the red light of chlorophyll and the green light of a Stramonium seed extract were also spoken of by Brewster as dispersion.

In the meantime, Herschel had continued his studies of fluorspar and also of quinine and lignum nephriticum solution in a glass vessel exposed to a beam of white light. In two consecutive papers in 1845, he expressed the view that the bright blue color at the surface, especially noticeable with quinine and lignum nephriticum solutions, was "a case of superficial colour presented by a homogeneous liquid, internally colourless " and called the phenomenon "epipolic dispersion," from the Greek, epipole, a surface. Had Herschel used a more intense beam or a less concentrated quinine solution, he would have seen that the blue color actually did appear in the path of the beam in the interior of the liquid. With concentrated solutions, absorption of light is so marked where the beam enters that all the fluorescence appears to be at the surface.

Using a prism, Herschel also determined that only the blue end of the spectrum, not the red end, gave rise to the "epipolic dispersion," whose spectral analysis showed blue, green, and a slight amount of yellow, without dark or bright lines. No polarization could be detected.

Herschel's papers stimulated Brewster $(1846,1848)$ to emphasize anew the fact that a concentrated beam of white light is blue within 
the fluorspar and quinine sulphate solutions, and red within a chlorophyll solution, undoubtedly similar phenomena. He used the term "internal dispersion" in order to contrast these effects with the "superficial reflexion" of Herschel. Brewster also noted that the internally dispersed beam became fainter the farther it penetrated into the solution and hence behaved as if absorption were occurring. In fact, that was true, the only difference between Herschel's blue light at the surface and Brewster's blue in the interior was one of absorption. Light absorbed near the surface becomes extinguished and hence more and more invisible in the interior.

Brewster again referred to the sample of fluorspar in which different layers emitted different colored thermoluminescences on heating, and showed corresponding colors when traversed by a beam of light, and pointed out that aesculin solutions showed blue dispersion and uranium glass gave a green " dispersion." He had previously (1815) found that light reflected from a surface at a certain angle is polarized. There was some polarization of the whitish beam of light in quinine and aesculin solutions, but the blue light was unpolarized, and the green beam in uranium glass was also unpolarized. He concluded that the small amount of polarization must have come from scattering, i. e., from reflection by colloidal particles ${ }^{10}$ in the solutions, since such scattered light is always polarized. Although these observations were not in accord with the view that the absorbed and dispersed light were of the same wave-length, nevertheless Brewster still had this idea in mind rather than an emission of light from within the liquid.

The subject was reconsidered four years later by George Gabriel Stokes (1820-1903), professor of mathematics at Cambridge, a physicist and a recipient of many honors during his life. Stokes' (1852) paper in the Phil. Trans. was one hundred pages in length, entitled "On the Change of Refrangibility of Light," and was followed by a postscript in $1853 .{ }^{11}$ It is one of the most thorough in the history

${ }^{10}$ Later observers (Lallemand, 1869, 1870), who claimed polarized fluorescence in solution, were led astray by polarization from reflection; see Soret (1869).

${ }^{11}$ It should be noted that $\AA$. J. Angström published similar views in his "Optische Untersuchungen" in the Swedish Academy Transactions for February 16, 1853, a paper dealing with dispersion, absorption, and diffusion of light in relation to vibration of molecules, written in Swedish. He later submitted the article to the Annalen der Physik for 1855, which was translated in the Philosophical Magazine (1855:341) and contains the following statement by Angstrom: "I have only recently had an opportunity of becoming fully acquainted with the interesting memoir of Stokes 'On the change of refrangibility of light,' I see with satisfaction that Stokes' explanation of the remarkable phenomena of dispersion in the green colours of plants, in sulphate of quinine, and in an infusion of horse-chestnut bark, namely, that the medium, when illuminated by the sun, becomes itself luminous, is exactly the same as that which I have given in the foregoing pages of the same phenomenon." 
of physics. The phenomena studied by Herschel and Brewster were reinvestigated in detail, leading Stokes to the conclusion that the light beam in fluorspar was actually emitted, and he spoke of " true internal dispersion" to distinguish it from "false internal dispersion" or scattering, such as makes the smoke particles in air appear blue. He also used the term "dispersive reflection." In a footnote (p. 479) to the first paper, Stokes wrote "I confess I do not like the term. I am inclined to coin a term and call it fluorescence, from fluor-spar, as the analogous term opalescence is derived from the name of a mineral." In the second paper (p. 387) he definitely resolved to use the word "fluorescence" and referred to "those cases in which the fluorescent light is yellow."

Thus "fluorescence" came to be used in connection with the study of both solid (fluorspar) and liquid material, although the duration of light is of the order of seconds in the case of fluorspar and $10^{-8}$ second in the case of quinine or fluorescein solutions. Stokes also held that phosphorescence and fluorescence had much in common, in that short waves are the best exciters for both, and that the two phenomena were often found in the same material. For example, fluorspar, which was blue by "internal dispersion," also became blue phosphorescent on heating slightly. The two were not always linked, however, as Iceland spar (calcite), which was thermophosphorescent, exhibited no fluorescence.

Another difference pointed out by Stokes had to do with the spread of the excitation as shown by Canton's phosphorus: "When one part of a phosphorus is excited, the phosphorescence is found gradually to extend itself to the neighboring parts. In this respect a substance which exhibits internal dispersion presents a striking contrast. The finest fixed lines of the spectrum are seen sharply defined, whether in a solution or in a clear solid, or on a washed paper."

Stokes emphasized two methods of detecting fluorescence. First the method of complementary absorption by which a substance was illuminated through a filter by one kind of light (say blue) and observed through a filter (say yellow), opaque to the blue light but which might allow any yellow fluorescent light to pass. Second, the method of spectral illumination by which light from a prism illuminates the material in such a way that emission of the fluorescent body by any wave-length of exciting light can be observed.

By the second method Stokes' law was proclaimed, that the fluorescent light is of longer wave-length than the exciting light, or that the light is always "degraded" in exciting fluorescence, as Stokes expressed it. One of the most spectacular observations of Stokes came in connection with a test tube of quinine solution, which 
glowed with a blue light when held in the ultraviolet region of a solar spectrum. He wrote: "It was certainly a curious sight to see the tube instantaneously light up when plunged into the invisible rays; it was literally 'darkness visible." "12 Since the great majority of fluorescent substances are excited by ultraviolet light the best method of detection is to examine them in so called "dark light" or "black light," an intense beam of ultraviolet wave-lengths transmitted by a filter which absorbs the visible. Such filters are a product of the twentieth century. The workers of Stokes' epoch hardly dreamed of the striking fluorescent effects now obtained with ultraviolet light.

Stokes' researches were remarkably complete, including a study of various light sources which might excite fluorescence. He found that spark discharges were particularly effective and noted the bright fluorescence of quinine during a lighting flash. He added greatly to the list of fluorescent substances, using not only uranium salts and aesculin, but also the red pigment of seaweeds, madder and tumeric dyes, and guaiac in alcohol. He studied the bands of fluorescence spectra, worked out the relation between concentration and intensity of fluorescence, and called attention to phenomena of quenching, not only by addition of foreign substances but also in concentrated solutions. Like Brewster, Stokes found that the fluorescent light of solutions was unpolarized, whether the exciting light was polarized or not, but that one group of substances, the platinum cyanide double salts, did emit polarized light when in the form of crystals, although their solutions were not even fluorescent. Through his efforts fluorescence was established as a major field of inquiry.

\section{Research after Stokes}

\section{METHODS OF EXCITATION}

Soon after Stokes' papers appeared, the scientific world began confirming and applying his ideas in related fields of inquiry. The term fluorescence was a happy one, adopted immediately by most workers. Osann (1854) confirmed the fact that blue rays which excited fluorescence also excited phosphorescence and likewise (1857) confirmed the ability of electric sparks to excite quinine and cumarin solutions. The excitation of fluorescence by flames, an inquiry of Stokes, was taken up anew. Babo and J. Müller (1856) called attention to the marked ability of the weak flame of carbon bisulphide

12 This remarkable effect was a great stimulus to the study of the ultraviolet region of the spectrum. It led E. Becquerel to a "Reclamation de priorité " in Cosmos 4:509$510,1854$. 
burning in nitrous oxide not only to affect a photographic plate but also to excite fluorescence. Like the electric spark, the bisulphide flame is rich in ultraviolet light. T. R. Robinson (1858) thought it of sufficient interest to record that a particularly intense display of the aurora borealis on March 14, 1858, would make a drop of quinine sulphate solution as well as potassium platinocyanide, luminesce. G. Seelhorst (1869) studied fluorescing liquids in Geissler tubes.

When it was realized around 1860 that something from the cathode of an electric discharge tube was causing a green luminescence of the glass of the tube, the word "fluorescence" was soon applied to the light, which lasted only while the cathode was active, i. e., while the electrode emitted what came to be known as cathode rays. Similarly, the excitation of various substances by anode rays, $\mathrm{X}$-rays, and radium rays was also designated fluorescence at the time these new radiations were discovered (see Chapter XII).

The term "fluorescence" was almost too widely used. It was applied to the luminescence of solids, liquids, ${ }^{13}$ and gases, even to the light from residual gas in a vacuum tube, by which the path of cathode rays can be observed. In the enthusiasm of a new discovery the question arose whether all substances might not be fluorescent, whether when illuminated by visible light they might not emit in the infrared. F. Salm-Horstmar (1861) and Dammer (1862) thought they had observed such effects but the phenomenon turned out to be no more than the warming of the irradiated material by absorbed sunlight.

In addition to positive fluorescence, which was now recognized as of common occurrence, a more remarkable claim was made for the existence of negative fluorescence, described by H. Emsmann (1861), by C. K. Akin ${ }^{14}$ (1865) and by John Tyndall (1865). The designation itself is not a good term and the above writers studied different phenomena having nothing to do with fluorescence. Since Stokes had observed ultraviolet converted to visible radiation and called this change a fluorescence, the converse change of infrared to visible light might be called negative fluorescence, i. e. negative fluorescence would be excited by "heat rays" as positive fluorescence is the result of " chemical rays."

Emsmann gave as examples of negative fluorescence the change

\footnotetext{
${ }^{13}$ Substances fluorescent as solids may not be fluorescent in solution. This point led to a discussion between Stokes (1855) and R. Böttger $(1855,1856)$.

${ }_{14}$ Rep. Brit. Assoc., 33-105, 1863, and Phil. Mag. (4) 29:28-43, 1865. Akin spoke of infrared as Herschel's rays, the visible as Newton's rays and the ultraviolet as Ritter's rays.
} 
in color of tungstic acid from yellow to green and of cobalt chloride from red to blue on heating, effects which are due to loss of water and not related in any way to fluorescence.

The negative fluorescence of Tyndall and Akin, which led to a priority controversy, was no more than the demonstration that by infrared rays of high intensity, matter could be heated to the temperature where visible light is emitted. These men heated, among other things, a spiral of platinum to incandescence by the concentrated invisible rays of the sun, filtered through iodine dissolved in carbon bisulphide. ${ }^{15}$ Akin used the word "calcescence," from the Latin word for lime $($ calx $)$, since lime is especially bright on heating, while Tyndall suggested that "calorescence" be used for negative fluorescence. However, none of these words has any real significance, although they started a bitter controversy between Emsmann, Akin and Tyndall. Bohn $(1867,1868)$, pointed out the error of the conception.

\section{FLUORESCENGE DISTRIBUTION AND FLUORESCENCE ANALYSIS}

The flood of early papers describing new cases of fluorescence is too vast to be included in any history. Many were merely concerned with the fact that one or another plant or animal extract or organic compound is fluorescent, but some were extensive publications such as that of E. Hagenbach (1869) on "leaf green." There appeared to be a wide distribution of fluorescent substances in the living world. C. B. Greiss (1861, 1864) was moved to write: "All parts of all plants contain fluorescent substances." It is not surprising that $H$. von Helmholtz in 1855 should examine the retina of a human eye from a cadaver, in connection with his study of sensitivity of the eye to radiation. He found that the retina was in fact fluorescent, and pointed out that the sensation of violet in this region of the spectrum was modified by the greenish white fluorescence. Retinal fluorescence was confirmed for the living retina by M. von Bezold and G. Englehardt (1877). The cornea and lens of the eye are also fiuorescent, as all those who have been in a dark room with intense ultraviolet light will realize. The "haze" which can be observed under these conditions is quite striking. E. Brücke (1845, 1846) had noticed that lens and cornea were opaque to ultraviolet light, but he worked before Stokes' paper appeared.

Although Brewster described the red fluorescence of chlorophyll in 1833 , the red fluorescence of a derivative of the related animal pigment, hemoglobin was not observed until 1868, when J. L. W.

${ }^{15}$ Tyndall discovered this filter in 1862 . 
Thudichum published on hematoporphrin, which he called "cruentine." In a long (142 pp.) and little-known paper "On the Chemical Identification of Disease," containing beautiful plates of the absorption spectrum of various biological pigments, he wrote ( $p$. 228):

It [neutral cruentine] fluoresced with a splendid blood-red colour in the sun-cone. This is the first body which is known to fluoresce with homogeneous light, that is to say, the same kind of light or colours which it transmits. . . . Considering its beauty alone, the phenomenon may be placed by the side of those exhibited by quinine, chlorophyle, or cudbear.

The possibility of using fluorescence as a method of detecting organic compounds was certainly present in Stokes' mind, as he lectured "On the application of the optical properties to detection and discrimination of organic substances" before the Chemical Society and the Royal Institution in 1864. The same idea was presented by Victor Pierre, a professor at Prague, later at the Polytechnicum in Vienna, in a series of papers, beginning in 1862. Pierre studied solutions of single fluorescent compounds and mixtures. He satisfied himself that fluorescent band spectra were characteristic of a particular substance, if the same exciting light was used. He noted that the spectra were different in different solvents and especially stressed the effect of acidity and alkalinity. F. Goppelröder used the word "Fluoreszenzanalyse" in connection with an extract of "Kubaholz" in 1868. In the twentieth century this technique has become a most important tool. The fluorescence-microscope has been developed for examining cells and tissues, and fluorescence analysis of solutions is regularly used for quantitative determination of compounds.

\section{CHEMICAL CONSTITUTION AND FLUORESCENCE}

With the rise of organic chemistry, many new synthetic substances became available. Fluoresceine was prepared by A. von Baeyer in 1871, and eosine, a related fluoresceine dye by $\mathrm{H}$. Caro in 1874 . These are examples of a number of organic compounds with fluorophore groups, which have become legion. Such fluorescence colors are now used for special effects in the theatre, for the production of a brilliant sheen on clothing, and for advertising. The relation between fluorescence, color, and chemical constitution became a popular study in the 1880's, and in fact has continued to be until the present day. In 1880 Liebermann called attention to the fact that anthracenes were fluorescent, anthraquinones not, and thought that numerous internal linkages were connected with fluorescence 
(Liebermann's rule). J. Dewar (1880), C. Knecht (1882), H. E. Armstrong (1888-1893), and W. N. Hartley (1892) found similar relations.

Chemical groups with which fluorescence tended to be associated were called fluorophores in the extensive paper of R. Meyer (1897) on this subject. The term is analogous to chromophore, for groups whose presence in an organic molecule is associated with color, a word applied by O. N. Witt in 1876. A fluorophore is often a sixmembered heterocyclic ring, but its presence does not inevitably confer the ability to fluoresce on the molecule. Substitution groups are also important, some decreasing and others increasing the fluorescence intensity of a compound. When the substitution of a particular group in a fluorophor results in a fluorescent compound, it is called a fluorogen.

By the end of the nineteenth century the number of known fluorescent compounds had greatly increased. In 1887, a book was published by K. Noack (born 1856), professor in Giessen, containing a list of substances arranged according to the color of their fluorescent light. Some 660 compounds were described, with references to the literature, making a book of one hundred pages. No comparable list appeared during the remainder of the century.

Much of the research on chemical constitution, color, and fluorescence occurred in the 1890's, by W. N. Hartley (1892) and early 1900 's by H. Kauffmann and others. Kauffmann introduced the term "luminophore" for atom groups capable of radiating, and he designated the benzol group as the one most widely distributed. Early in the next century the book of 102 pages by Kauffmann, Die Beziehung zwischen Fluorescenz und chemische Constitution (Stuttgart, 1906), summed up the accumulated knowledge at that time. In 1908 the article on fluorescence by H. Konen in Kayser's Handbuch der Spectroscopie (vol. 4) devoted 105 pages to a list of 1,700 fluorescent compounds, arranged alphabetically, with references to the literature. Such lists have served as the basis for relating fluorescence to chemical constitution.

\section{PROPERTIES OF FLUORESGENT LIGHT}

Stokes' monograph was remarkably complete and started many new lines of investigation. Only the more important later work can be mentioned. One of the first systematic studies of fluorescence of various crystals, especially those of uranium and platinum double salts, were undertaken by W. Joseph Grailich (1829-1859), a crystallographer and Privatdocent at the University of Vienna. His prize essay, Krystallographish-optische Untersuchungen, of 226 pages, was 
published at Wien and Olmutz (1858), when he was assistant curator of the Royal Mineral Collection in Vienna. Like Stokes, Grailich noticed that the fluorescent light of certain crystals might be polarized, when excited by unpolarized light. He also described, among other things, what he called "Doppelfluorescenz" in certain crystals, analogous to but different from dichroism.

Polarized fluorescence of crystals is particularly noticeable among the platinum double salts. Magnesium platino-cyanide crystals standing upright and traversed by a beam of blue light give an orange yellow fluorescence if examined through a Nicol prism when the polarizing plane of the Nicol is perpendicular to the axis of the prism. The fluorescent light is scarlet when the plane is parallel to the axis. If the exciting light is already horizontally polarized, the fluorescent light is yellow, changing to red as the plane of polarization is rotated through $90^{\circ}$. Under certain conditions the crystals emit unpolarized light and many striking color effects can be demonstrated.

Later studies in polarized fluorescence were made by $\mathrm{E}$. Lommel (1879), R. A. Millikan (1895), L. Sohncke (1896), and G. C. Schmidt $(1897,1899)$. That the fluorescence of crystals may be polarized when excited by cathode rays was shown by Professor Maskelyne (1879) in an appendix to W. Crookes' (1879) paper, and also by E. Wiedemann (1880) .

Schmidt concluded that the fluorescent light of isotropic crystals, pure liquids, or gases is not polarized, but most if not all doubly refracting crystals emit polarized fluorescence. Phosphorescent and thermoluminescent light is also polarized in the case of those bodies which emit polarized fluorescence.

The light of solutions is never polarized although investigation of the latter gave rise to some controversy. Stokes had pointed out how turbidity in a solution might give rise to an appearance of false fluorescence, owing to polarization of light reflected from fine particles. Failure to recognize this fact and also the polarization which light undergoes at the surface of a liquid, gave rise to claims of polarized fluorescence in solution and considerable discussion by A. Lallemand $(1869,1870)$ and J. L. Soret (1869) .

In 1862 Eugene von Lommel (1837-1899), professor of physics at Munich, began his investigations on all aspects of fluorescence, which were to extend over much of the rest of the century. His work may be compared with that of Eilhard Wiedemann (18521928) on phosphorescence. An older man, Lommel's papers somewhat preceded Wiedemann's but included similar subjects. His theory of fluorescence was discussed over three decades. 
Although Stokes' law certainly implies that absorption of light is necessary for emission, Lommel $(1875,1876)$ emphasized that to excite fluorescence, light must be absorbed, just as in the case of photochemical effects the Grotthus-Draper law declares that light must be to effect a chemical change. Lommel made his observation abundantly clear, that " every dark band in the absorption spectrum corresponds to a bright band in the fluoresceing spectrum of a fluorescent solution.... The general proposition can therefore be laid down that a body capable of exhibiting fluorescence, fluoresces by virtue of those rays which it absorbs." He applied the statement to phosphors also: "Phosphorescence, like fluorescence, is an effect of absorbed light." The generalization might be called Lommel's law. It came from his study proving empirically that the amount of fluorescent light from unit volume of solution is proportional to the amount of absorbed light. In the next century, measurements of energy in the light absorbed and in the fluorescent light were to lead to such important values as fluorescence efficiency and quantum yield.

Perhaps greater attention in the post-Stokes period was paid to spectral characteristics of the exciting and of the fluorescent light, than to any other aspect of fluorescence. Lommel was only one of the investigators. Stokes' law had not only stimulated much careful study but also aroused considerable controversy. One of the principal investigators was E. Hagenbach, who undertook a study of chlorophyll fluorescence in 1869. In 1872 his monumental paper, "Versuche uber Fluorescens" appeared in Poggendorff's Annalen der Physik. This and later work included a special study of the spectra of absorbed and emitted light in relation to Stokes' law. The subject also occupied the interests of E. Lommel (1862-1895), V. Pierre (1862-1866), J. Obermann (1871), O. Lubarsch (18741881), H. C. Sorby (1875), J. Brauner (1877), A. Wüllner (1878, 1883, 1899), S. Lamansky (1879), E. Becquerel (1879), E. Linhardt (1882), E. Ketteler (1882), K. Wesendonck (1884, 1897), F. Stenger (1886, 1888) B. Walter $(1888,1892)$, W. Bohlendorff (1891), G. Salet (1892), G. Jaumann (1894), E. Buckingham (1894), O. Knoblanch (1895), B. Galitzin (1895), G. C. Schmidt (1896), J. Burke $(1897,1898)$, and others in the next century. The list is a roster of those who have studied fluorescence, although the details of experiment and theory are so great that results cannot be presented. Suffice it to say that Stokes' law has been subjected to rigid tests and found to be generally true for both fluorescence and phosphorescence, one of the basic laws of luminescence. A few anti-Stokes emissions have been logically explained by modern theory. 
During the last quarter of the century the effect of concentration of dissolved fluorescent material on color and intensity of fluorescence and the duration of fluorescent light have been minutely studied. Solids and pure liquids have also been investigated. The decay time, even though short, was important and challenged measurement. After E. Becquerel's pioneer work, E. Wiedemann (1888) developed a phosphoroscope that would measure a few millionths of a second, but found that the fluorescence of solutions was even shorter than could be detected by his instrument. Actual measurement of time intervals of the order of $10^{-9}$ seconds was a product of the twentieth century, when experimental work continued with new theories and new names. The effect of different temperatures, ${ }^{16}$ of different solvents, ${ }^{17}$ and of the state of aggregation ${ }^{18}$ of the fluorescent substances and other changing conditions were investigated in great detail during the eighties and nineties, but space prevents any extensive discussion of the results. Only one important factor in fluorescence emission can be mentioned, that of quenching.

\section{QUENCHING OF FLUORESCENCE}

Among the many observations of Stokes (1852) was the fact that addition of $\mathrm{NaCl}$ or $\mathrm{HCl}$ (and other halogens) to quinine sulphate solution reduced the intensity of fluorescence, a phenomenon now known as quenching, since the effect is reversible, and chemical changes do not occur in the solution. E. Buckingham (1894), who interpreted fluorescence in terms of Ostwald's dissociation theory, showed that quinine ions were fluorescent. The effect of $\mathrm{Cl}$ ions on quinine sulphate is not the result of optical absorption. The situation is also quite different from that where $\mathrm{pH}$ changes decrease or increase the fluorescence intensity of a compound by changing ionization. Quinine chloride is not fluorescent because the $\mathrm{Cl}$ ions completely suppress fluorescence of the quinine ion. Later, G. C. Schmidt (1900) also emphasized that the halogen ions acted by their mere presence, like a catalyst.

Most of the studies on quenching have been made in the twentieth century, but the phenomenon introduced a secondary effect into

${ }^{16}$ Stokes established the fact that fluorescent glasses were affected by temperature but that temperature change had practically no influence on solutions within the limits of temperatures then available. Later work, already mentioned in Chapter VIII has indicated how very low temperatures change a fluorescence to a phosphorescence. ${ }^{27}$ Stokes studied the effect of different solvents and the later work of V. Pierre (1862-1866), E. Hagenbach (1872), H. Morton (1872-1875), F. Stenger (1886), B. Walter (1889), and O. Knowblanch (1895) has indicated that both color and intensity of fluorescence depend on solvent.

${ }^{18}$ See especially the studies of $\mathrm{E}$. Hagenbach $(1872,1874)$. 
the older work, making interpretation difficult. In general, halogen and heavy metal ions, certain oxyacids, and some aromatic compounds have a quenching effect on fluorescence, as a result of which the fluorescence yield is changed. Quenching is also an important factor in the light intensity of chemiluminescence in solution, and of any type of luminescence in a gas.

Another kind of quenching results from too many molecules of the fluorescent substance itself, a phenomenon noticed by Boyle (1664), the so-called " concentration quenching " or "self quenching." If the fluorescence yield is constant, fluorescence intensity should increase with increasing concentration of fluorescent molecules although not proportionally, because of light absorption in the more concentrated solutions, and then remain constant. Actually the fluorescence intensity decreases above a certain concentration. This peculiarity was noticed by Stokes, and gave rise to numerous arguments and polemics during nineteenth-century study of the laws relating concentration and fluorescence intensity. It follows that fluorescence is proportionately more intense in dilute solutions of pure compounds, not only because light can penetrate further without absorption, but also because there is no self-quenching. The ability to detect minute traces of material by means of fluorescence has been commented on many times by various authors ever since this type of luminescence has been recognized.

\section{Vapor Fluorescence and Resonance Radiation; Sensitization}

A particularly important discovery of Lommel was the orangeyellow fluorescence of iodine vapor, made in 1883. This effect in a gas had been overlooked by Stokes, but was studied in some detail by its discoverer, who recorded the spectrum and the nature of the exciting rays. Lommel was impressed by the fact that iodine vapor appeared to be one material whose fluorescence is not excited by violet rays in solution; dissolved iodine is not fluorescent. Later discoveries concerning vapor fluorescence were reported by $\mathrm{E}$. Wiedemann (1890) and in Wiedemann and Schmidt's paper, "Über Lichtemission organische Substanzen im gasformigen, flüssigen, und festen Zustand," in 1895. This investigation dealt with fluorescent organic vapors like those of anthracene, and later contributions of Wiedemann and Schmidt $(1896,1897)$ reported the fluorescence of sodium and potassium vapor, with an account of their spectra and behavior under electrical excitation. These authors believed that the green fluorescence of sodium and the red of potassium, as well as similar fluorescence of other metals in the sun's atmosphere, 
might contribute very appreciably to the light of the corona, and they advised astronomers to be on the lookout for such effects.

These studies aroused an interest in light emission from atoms and molecules in their simplest condition, the vapor state, and paved the way for the concept of " resonance radiation," demonstrated by Robert Wood (1863-1955) in 1905 for sodium vapor. The study of metal vapor fluorescence was greatly expanded in later years of the twentieth century, particularly the resonance radiation of mercury vapor in the ultraviolet $(2735 \AA)$, and gave rise to the important concept of sensitized fluorescence. This was very clearly demonstrated by G. Cario and J. Franck (1922) for mercury and thallium vapor. In photosensitization of photographic plates, the sensitizer molecule (certain dyes) can initiate chemical reactions in other molecules (silver halides) which do not absorb that particular wave-length. In the case of $\mathrm{Hg}$ (sensitizer) and $\mathrm{Th}$ (emitter) vapor, illuminated by the mercury resonance wave-length $2537 \AA$, the fluorescence spectrum contains a number of thallium lines, despite the fact that thallium absorbs no $2537 \AA$ wave-lengths. The mercury atoms absorb the energy and transfer it to the thallium by collision; the thallium then emits a green fluorescence.

This phenomenon of sensitization may be as widespread in luminescence phenomena (see Chapter XIII) as it is in photochemistry. A striking example of what was called photodynamic sensitization in connection with living organisms was discovered in the winter of 1897-1898 by O. Raab (1900), a student of H. von Tappeiner of Munich. He found that the infusorian, Paramecium, was killed by the dye, acridin, when in the light but not in the dark. According to the book of $\mathrm{H}$. von Tappeiner and A. Jodlbauer, Die sensibilizierende Wirkung fluorescierender Substanzen (1907), the sensitizing substances are fluorescent, although it is not the fluorescent light which has a toxic action, but the contact of the dye with living cells plus daylight. A great deal of research has been carried out in this field in the twentieth century.

\section{Books on Fluorescence}

A survey of fluorescence study since the time of Stokes reveals an enormous collection of experimental data, practically all appearing as original articles in various journals. One exception is the 115-page booklet of F. J. Pisco, Die Fluorescence des Lichtes, published at Vienna in 1861. Pisco's contribution explains the findings of Stokes and his methods of detecting fluorescence in some detail, and also includes the new papers which had appeared in Poggen- 
dorff's Annalen between 1852 and 1861. The final section deals with uses of fluorescence, such as the detection of ultraviolet light in various spectra, and testing light which is not safe to use in a photographic dark room, since the fluorescence-exciting and the photochemically-active rays are essentially identical. He noted that invisible writing with quinine or aesculin solutions can be photographed as a result of their fluorescence, and uranium glass used in a microscope to reduce the annoyance experienced from the intense blue light of the sky. On the whole, Pisco covered the subject quite thoroughly for 1861, but he could not foresee the widespread applications of the present day.

The book of E. Becquerel, La Lumière, ses Causes et ses Effets (Paris, 1867), contains much information on fluorescence, although he used the term phosphorescence, rather than fluorescence, for the light emission. Becquerel's later work was presented as original papers.

Despite the attention to theory and to interpretation of results by Lommel, his extensive research of the last third of the century was not brought together in book form. With the exception of $\mathrm{K}$. Noack's (1887) list of fluorescent substances and a few articles in textbooks of physics ${ }^{19}$ or on light, no book devoted to fluorescence appeared between E. Becquerel's La Lumière (1867) and Konen's article, "Fluorescence" (1908), previously mentioned. Heinrich Mathias Konen (born 1874) was a professor of physics in the University of Munster i W., later at Bonn. His thesis, "Über die Spectren des Jod" (1898), as well as later publications dealt mostly with spectra and theoretical optics. His monumental review (373 pages) in H. Kayser's, Handbuch der Spectroscopie, makes a fitting companion on "Fluorescence" to Kayser's own 239-page article on "Phosphorescence" in the same volume.

With the development of "black light," using filters which pass ultraviolet light and absorb the visible, largely perfected through the efforts of Robert Wood at the time of the First World War, fluorescence may be said to have come into its own. The term became a household word as a result of fluorescent effects in the theatre and in advertising. Secret invisible writing, which fluoresced in black light, was used in World War I, and aroused great curiosity afterwards. Fluorescence became important in biological research and in medicine for detection of disease. The development of physical and chemical theories concerning the excitation of atoms and

${ }^{19}$ In Adolph Wüllner's Lehrbuch der Experimentalphysik (4th ed., 1883), the fourth volume, Die Lehre von der Strahlung, contains twenty-four pages on fluorescence and eleven pages on phosphorescence. 
molecules has led to an ever increasing interest in the subject, with the publication of a large selection of twentieth-century books, from which the latest theories on fluorescence may be obtained (see Chapter VIII for nineteenth-century theories). The early observations on lignum nephriticum extract, the later recognition of an unusual play of colors in other solutions, and the penetrating research of Stokes have led to an important topic in the physical study of light, a topic well represented in every modern textbook of physics. 


\section{RADIOLUMINESCENCE}

\section{Introduction}

THE WORD " RADioluminescence" has been used in a broad sense 1 to indicate emission of light by substances when exposed to radiation of various kinds other than light, whether streams of particles, or certain regions of the electromagnetic spectrum, X-rays, and gamma rays. A radioluminescence from streams of particles arising from cathode or anode in a vacuum tube was a middle nineteenthcentury discovery (1858). Depending on the kind of particle involved, corresponding names have been applied to the resulting light-cathodoluminescence and anodoluminescence. In modern terminology electroluminescence and ionoluminescence have been used to indicate the nature of the particles, electrons or ions.

More specifically, radioluminescence applies to the luminescence from impact of X-rays or the gamma rays given off by radioactive elements. Knowledge of such specific radioluminescence effects began with Wilhelm Konrad Roentgen's (1845-1923) demonstration of X-rays in 1895 and played an important part in the search for penetrating radiation from naturally occurring materials. This led to the discovery of uranium radioactivity and to the isolation of radium itself and the demonstration of gamma rays. Never before had observation of luminescence been followed by such momentous results.

\section{Cathodoluminescence}

Experiments on electrical discharges through a vacuum soon demonstrated that a luminescence (fluorescence) appeared when rays which were obviously not light rays, since they could be bent by a small magnet (J. Plücker, 1858), ${ }^{1}$ struck various solid substances. Peculiar luminescent effects occurred in highly exhausted tubes when something from the negative electrode or cathode struck the glass of the tube. This phenomenon had been observed as early as 1858-1859 by J. Plücker (1801-1868), by E. Becquerel (18201891) and by J. P. Gassiot (1817-1879). Becquerel noted that the light at the cathode was of a different wave-length from that at the

${ }^{1}$ De la Rive $(1849,1858)$ had noted movement of luminous discharges in gas under the influence of a magnet, and used the observation in explanation of the aurora borealis, but made no mention of luminescence of the glass. 
anode and remarked that the green light from the glass was similar to that which he had observed in his phosphoroscope when glass was illuminated by sunlight. Plücker referred to "the beautiful green light whose appearance is so enigmatical." He thought at first that the color was subjective but later realized it was a fluorescence of the glass, and stated that lead glass would fluoresce blue. Plücker used the expression "magnetic light" for the light which spreads in all directions from the negative pole and can be moved by a magnet.

Fluorescence of the glass near the cathode led Gassiot (1859: 141) to use the expression "a distinct phenomenon, having the appearance of a force or action emanating from the negative terminal." J. W. Hittorf (1824-1914) found in 1869 that a solid body in the path of the action would cast a shadow. This was confirmed and the name "cathode rays" (Kathodenstrahlen) ${ }^{2}$ was coined in 1876 by E. Goldstein ${ }^{3}$ (1859-1930), when he found the rays to be deflected in an electric field. These cathode rays were spoken of as "attenuated particles of matter" and a "molecular torrent" by C. F. Varley " in 1871 and as the "ultragaseous state of matter" by William Crookes (1832-1919) in 1879. Later they were called " radiant matter," and many of their effects were studied extensively by Crookes, who emphasized the "green fluorescent light of molecular impact."

Henrich Hertz (1857-1894) in 1892 showed that they passed through gold and aluminum foil inside the vacuum tube, and in 1893 Philip Lenard (1862-1947) had a thin aluminum window built into the walls of the tube, allowing the rays to pass into the air outside, where they were called Lenard rays. The controversy between English and German workers over their nature, whether particles or waves, lasted until 1897 when J. J. Thomson (18561940 ), by measuring the deflection ${ }^{5}$ in an electric field, accurately measured their mass and established without a doubt their material nature. He used the word "corpuscles" to designate them, and

${ }^{2}$ The "discoverer" of cathode rays has given rise to much controversy. J. J. Thomson (Conduction of electricity through gases, 1903) named Plücker (Ann. der Physik 107: 77-113, 1859), while W. Ramsay in Elements and electrons (1912) and P. Lenard in Great men of science (translated from the German by H. S. Hatfield, 1935) referred to Hittorff (Ann. der Physik 136: 1-30, 1869) as discoverer. E. Becquerel (1881) claimed observing their effects in 1858 (see Ann. de Chim. et Phys. (3), 55: 92-97, $1859)$, but he did not recognize cathode rays as distinct exciting agents. Crookes (1879) first referred to them as fast moving particles.

${ }^{3}$ E. Goldstein, Monatsber. d. Berlin Akad., 284, 1876. See also his book (1880).

${ }^{4}$ C. F. Varley, Proc. Roy. Soc. 19: 238, 1871.

${ }^{5}$ Jean Perrin (Com. Rend. Acad. Sci. 121:1130-1136, 1895) showed that cathode rays carried negative charges. 
regarded them as elementary particles of matter. As a beam of electrons, ${ }^{6}$ this radiant matter is now familiar to every user of the cathode ray oscillograph and to everyone who watches a television screen.

Electrons are highly effective exciters of luminescence. However, in the earliest work on electrical discharge in vacuo, it is doubtful whether they were responsible for the luminescence of solids. Both Dessaignes (1810) and E. Becquerel (1839) subjected phosphorescent material to discharges in a vacuum, but the luminous effects observed were mostly due to ultraviolet light. The green cathodoluminescence of glass previously mentioned would appear to be the first good example. Cathodoluminescence study of other material began in earnest in 1879 with research by Goldstein (1879), and by Crookes (1879), both of whom observed the luminescence of various salts placed in evacuated tubes and subjected to "electrical rays " or " molecular shocks." In a short paper Goldstein recorded the luminescence of double salts of platinum, alkaline earth carbonates, uranium salts, and alkali hydrates.

It was Crookes who made a really comprehensive study of cathode rays. He not only marshalled the evidence for their particle nature, but paid particular attention to the cathodoluminescence which they excited. He confirmed the fact that English glass containing lead luminesces blue, as contrasted with the green of continental glass, ${ }^{7}$ and saw the cathodoluminescence of artificial phosphors (CaS and $\mathrm{SrS})$, uranium glass, and various precious stones, particularly diamonds. The color of diamond cathodoluminescence might be blue, green, orange, yellow, or red, whereas the ruby emitted a narrow red line at $689 \AA$, which appeared to be identical with the line which E. Becquerel had observed in his phosphoroscope as a result of light excitation of rubies.

In the last section of his paper, Crookes reported on polarized cathodoluminescence. He wrote: "I have been favored by my friend Prof. Maskelyne with the following notes of results obtained on submitting to the electric discharge various crystals which he has

"According to Ramsay (1912: 51), the name "electron" was applied by G. Johnstone Stoney (1826-1911) of Dublin in 1876 to the electricity carried by a single monovalent atom, identical with Thomson's corpuscles. See Stoney in Phil. Mag. (5) 38: 418-420, 1894 and W. Ramsay, Elements and electrons, New York, 1912.

${ }^{7}$ Crookes found for example that the luminescence of glass becomes fatigued after continued exposure to cathode rays. A region of his glass tube which had been protected by an opaque object in the shape of a cross casting a "shadow" luminesced more brightly than other regions of the tube when the cross was removed. This fatigue phenomenon persisted even after the glass had been fused and allowed to cool. It is generally true that most cathodoluminescent substances cease to luminesce after long exposure to cathode rays. 
lent me for the purpose of these experiments." Then follows the statement that diamond and beryl luminescence (from cathode rays) is not polarized, but light (the extraordinary rays of higher velocity) from emerald, sapphire, ruby, and tinstone is completely polarized, with luminescence colors-crimson red, blue grey, red, and yellow, respectively. In hyacinth, luminescence of the ordinary ray depends on the variety-pink in some specimens and yellow in others, while the extraordinary ray luminescence is lavender blue in the first type and deep violet in the second type. Such observations indicate the complicated phenomena to be encountered in study of cathodoluminescence.

"Crookes tubes" or "radiant matter tubes" became famous. Crookes' earliest work in 1863-1864 and 1872 had been on the rare earths and his later experiments (1874-1879) on the mechanical effects of light, during which period he developed the radiometer. What more appropriate subject for his experimentation than the mysterious cathode rays, which did excite the most characteristic luminescence of rare-earth compounds. For completeness and pertinent observation, the 1879 papers of Crookes on cathodoluminescence are to be compared with the 1852 paper of Stokes on fluorescence.

In addition to exciting luminescence, Crookes also demonstrated that the rays heated substances they struck, and could move a rotating vane mounted in their path; also that two beams of rays moving side by side repelled and were deflected from each other. These observations supported the particle nature of cathode rays, a stand fully vindicated by later work.

Crookes continued his luminescence investigation in 1881, the year after E. Wiedemann (1880) observed polarized light from double salts of platinum when struck by cathode rays. In general Crookes (1883-1888) found that cathodoluminescence spectra were usually continuous but in some cases made up of rather narrow bands, which turned out to be connected with the presence of rare earths. "Radiant matter spectroscopy" was actively pursued during the 1880 's and 1890's by Crookes ${ }^{8}$ himself, and by E. Wiedemann (1880, 1889), E. Becquerel (1885), François Lecoq de Boisbaudran (1885-1893) and others too numerous to mention. ${ }^{9}$ These men all added new cathodoluminescent materials ${ }^{10}$ to the growing list and

\footnotetext{
${ }^{8}$ Several of Crookes' papers (1887) dealt with study of the after-glow, using a phosphoroscope of his own design. Papers on Cathode ray spectra of rare earths appeared from 1879 to 1899 , the most important in 1883 and 1885 .

${ }^{9}$ See the dissertation of W. Arnold (1897) and also E. Goldstein (1900).

${ }^{10}$ An English patent was granted to Rankin Kennedy in 1882 for a vacuum bulb with electrodes coated with phosphorescent material which glowed when hit by cathode rays.
} 
made a detailed study of the spectra emitted by the various compounds, pointing out the importance of impurities. Finally the extensive publication of Wiedemann and Schmidt (1895) indicated that exposure to cathode rays would also excite liquids and render many solid compounds thermoluminescent (see Chapter IX). Wiedemann (1895) called the rays which had this effect "Entladungsstrahlen," but the most general term was cathode rays ( $c f$. P. Villard, 1899).

One of the interesting actions of cathode rays was to cause development of color in previously clear crystals exposed to their action. E. Wiedemann (1880) noted the browning of barium-platinum cyanide with an accompanying change in the color of its cathodoluminescence and E. Goldstein $(1894,1895)$ studied corresponding changes in lithium, sodium, and potassium chloride. A great deal of research on this coloration, also induced by X-rays, was carried out at the turn of the century. Wiedemann and Schmidt (1895) showed that the colored salts ${ }^{11}$ exhibited not only thermoluminescence, but also triboluminescence, and even emitted light as they dissolved in water, a lyoluminescence (see Chap. X).

It was abundantly evident that in cathode rays man possessed perhaps the most powerful tool for exciting luminescence ${ }^{12}$ in a wide variety of materials, and in luminescence a correspondingly valuable means of following the path of cathode rays. Crookes' (1879) early experiments on deflection of cathode ray beams and C. Swinton's (1899) study of the focus of a beam both involved luminescence for detection. The invention of the "Braun tube," an early type of cathode ray oscillograph, by Ferdinand Braun (18501918 ) in 1897, opened a whole new field for investigation of rapid electrical changes, and gave the scientific world a research instrument of extraordinary value.

Of the many men connected with cathode ray research, J. J. Thomson and P. Lenard appear to have received most acclaim, Thomson for establishing the ratio of mass to charge of the electron and the general phenomena connected with gases and electricity; Lenard for investigations on cathode rays and the photoelectric effect. Lenard paid more attention to luminescence and should be particularly mentioned for application of the electron in a theory of phosphorescence, described in Chapter VIII.

${ }^{11}$ Elster and Geitel (Ann. der Physik 59: 487-514, 1896) showed that these salts were highly photoelectric, discharging negative electricity like a metal when exposed to light.

${ }^{12}$ Although the efficiency of the process is low, E. Wiedemann (1898) showed that about the same small fraction of the energy of cathode rays was converted to visible light as in the case of light exciting photoluminescence. 


\section{Anodoluminescence}

Not long after the recognition of cathode ray phenomena, it was apparent that another type of ray existed, the anode rays or canal rays or positive rays. They were discovered by E. Goldstein (18501931 ) in 1886, and first called canal rays because, arising from the anode, they can be easily separated from cathode rays by allowing them to pass through a small opening or canal in the cathode, whence they travel in a region away from the electric field between anode and cathode.

After considerable experimentation, anode rays or canal rays were identified as streams of positively charged atoms (ions) of various kinds. It was W. Wien (1898), who showed that they are positively charged and deflected in strong electric and magnetic fields, a property made use of in the mass spectrograph. A. Wehnelt (1899) discussed their relation to the glow observed in vacuum tubes. Like cathode rays they excite luminescence in a wide variety of materials, in modern terminology an ionoluminescence.

This anodoluminescence or ionoluminescence excited by positively charged canal rays did not at first arouse as much interest as cathodoluminescence. Its study has been mostly confined to the twentieth century. Wien (1901) noticed the luminescence of some metallic oxides when thoroughly dry, and both Wien (1902) and Goldstein (1902) studied luminescence of the glass. J. Tafel (1903) and G. C. Schmidt $(1902,1904)$ observed the light from oxides and salts of various metals. It was soon established that the spectra of anodo- and cathodoluminescence are not by any means alike. The same substance can be readily compared by constructing a vacuum tube in such a way that material placed in a holder may be bombarded either by anode rays or by cathode rays merely by changing the sign of the charge of the electrodes, that is by making one first an anode and later a cathode. Striking differences in the color of anodo- and cathodoluminescence are apparent. Lithium chloride, for example, luminesces bright red with canal rays, showing the red line of lithium, and a steely blue with cathode rays, giving a faint continuous spectrum but no red Li lines. A similar behavior was early observed with glass. Instead of the green cathodoluminescence, soda glass bombarded by canal rays emits the yellow lines of sodium.

In addition to the luminescence of solids which are struck by cathode and anode rays, Goldstein (1886) noticed that the path of both types of rays can be observed in highly evacuated tubes by the luminescence of the trace of residual gas through which they 
pass. Positive rays cause a yellowish luminescence of air, a rose luminescence of hydrogen, bright red with neon, and yellowish with helium. Cathode rays often excite very different colors, for example a pale blue with neon and a green with helium, thus making a sharp contrast in a tube filled with the appropriate gas, and so constructed that both types of rays can be observed at the same time. This luminescence of the residual gas in the path of cathode and anode rays is to be considered an electroluminescence, since it depends on the same mechanism of excitation of light as in any gas discharge tube through which current flows. Only when cathode and anode rays strike solids or liquids should the light be classified among the radioluminescences.

\section{Radioluminescence Proper}

FROM ROENTGEN RAYS

The well-known story of X-ray discovery began on November 8, 1895. On that date, Roentgen noticed that a barium platinocyanide screen lying near a vacuum tube with which he was working became brightly fluorescent whenever current was turned on, despite the fact that the tube was enclosed in an opaque black paper shield. Roentgen (1895, 1896) himself, who had seen the fluorescence due to cathode rays outside a tube, took pains to demonstrate that his new X-rays were not cathode rays but much more penetrating. They would pass through a book and even through metals, if not too thick. It is when cathode rays are stopped suddenly, on hitting glass or metallic plates that X-rays or Roentgen rays are generated. While anode rays pass through matter with great difficulty and cathode rays only pass through very thin sheets of metal, the great penetration of X-rays and their absorption by matter in proportion to its density aroused the profound interest of contemporary scientists. The ability to render visible bone and other structures in the human body particularly excited the medical profession and the public. News of the new sensation quickly spread throughout the world. Photographs of various parts of the body were obtained by Roentgen in 1895, and a photograph of a human hand injured by a buckshot wound was made in the United States by Michael Pupin (18581935) on February 2, 1896. This particular photograph ${ }^{13}$ is of unusual interest because Pupin then used his method of shortening the exposure for X-rays photographs, now universally adopted, of combining a fluorescent screen and a photographic plate. The lumi-

\footnotetext{
${ }^{13}$ Charles Henry (1896) reported augmentation of the photographic effect of X-rays at a meeting of the French Academy, February 10, 1896.
} 
nescence of the screen has a far greater action on the plate than that of X-rays alone and hence reduces the exposure time and helps prevent injury to tissue.

In addition to the radioluminescence of barium-platinum cyanide, Roentgen, in his first paper, noted that calcium sulphide, uranium glass, Iceland spar, and rock salt also luminesced. It was not long before a systematic study of the ability of these X-rays to excite fluorescence of various compounds was undertaken. ${ }^{14}$ An editor's article in the Electrical Review for 1896 (38: 508) on "The Roentgen Rays" stated that T. A. Edison had tested a large number of compounds and found that it was not necessarily dense substances but some relatively light ones, such as ammonium salicylate, which phosphoresce in X-rays. A. Winkelmann and R. Straubel in 1896 observed a marked fluorescence with fluorspar and zircon, while many other minerals showed little effect. W. Arnold and also J. Precht in 1897 discovered the bright fluorescence of sheelite (calcium tungstate) and of many artificial preparations (tungstates and platinum cyanides), although some common phosphors frequently showed no effect. Arnold also noticed that certain materials excited to luminesce by cathode rays were inert to $\mathrm{X}$-rays. The search for radioluminescence of minerals and other substances was continued in America by J. E. Burbank (1898) and J. Trowbridge and J. E. Burbank (1898) and in France by H. Becquerel (1899). For many years the use of barium platinocyanide and calcium tungstate screens with no phosphorescent afterglow was standard, but the development in recent years of high intensity zinc sulphide screens with practically no persistence has so reduced the exposure time that $\mathrm{X}$-ray moving pictures can be made.

\section{FROM RADIUM RAYS}

Discovery of the natural radioactivity of uranium, which led to the isolation of radium, was made in 1896. Like the discovery of $\mathrm{X}$-rays, knowledge of radio-activity is connected with luminescence ${ }^{15}$

${ }^{14}$ A book by Edward P. Thompson appeared as early as 1896, Roentgen rays and phenomena of the anode and cathode (190 pp., New York, 1896), which described in detail a large number of luminescent effects. Other popular works were Light, visible and invisible (New York, 1897) by Silvanus P. Thompson, and Radiation (London and New York, 1898) by H. H. F. Hyndman, both paying considerable attention to luminescence.

${ }^{15}$ The various luminescent phenomena connected with radioactivity greatly stimulated the general interest in cold light. In addition to a paper by W. Arnold (1897), several popular books appeared in the early twentieth century, for example, Radium and other radioactive substances, etc. (New York, 1903), by W. J. Hammer, in which chapters were devoted to phosphorescence and fluorescence. Hammer, a consulting electrical engineer, lectured before a joint meeting of the American Institute of Elec- 
and it also owes something to chance. Since cathode rays and X-rays excite luminescence, why not look for penetrating radiation which might be emitted by fluorescent and phosphorescent substances in general. In addition to the visible light of phosphorescence, it is quite possible that some other peculiar radiation ${ }^{16}$ might also be produced. Such was the reasoning of Antoine Henri Becquerel (1852-1908), who tested the hypothesis and communicated the results to the French Academy of Sciences on February 24, 1896. Becquerel exposed a number of phosphorescent substances to light and placed them on a photographic plate wrapped in black paper, which was later developed. Many samples gave negative results, but among them, fortunately, was a uranium potassium sulphate, a salt whose phosphorescence he had previously studied. When the plate exposed to this salt was developed it showed a definite blackening that was not due to vapors, which he ruled out by placing a thin sheet of glass between the salt and the plate. It was quite certain that the uranium salt emitted a penetrating ray.

Somewhat later, ${ }^{17}$ on an overcast day, Becquerel placed his uranium specimen and paper-covered plate in a drawer, awaiting a sunny day for the exposure, and then decided to develop the plate to see whether any darkening had occurred without the sunlight. To his astonishment the uranium salt affected the plate even without excitation of phosphorescence. Evidently a penetrating radiation which had nothing to do with phosphorescence came from the uranium salt and affected the plate.

Later experiments indicated that other uranium compounds also emitted penetrating radiation and that the property was characteristic of uranium itself. In fact, at that time no other known phosphor could have replaced the uranium salt, and any uranium

trical Engineers and the American Electrochemical Society in New York City, where he exhibited post-cards of the blue grotto of Capri printed with phosphorescent paint. $\mathrm{He}$ also demonstrated Edison's calcium tungstate lamp or "X-ray lamp," essentially a Crookes' tube whose interior walls were coated with calcium tungstate. The tube glowed when connected to a large induction coil, owing to cathode rays striking the tungstate crystals. Hammer quoted Langley on the firefly as the most efficient source of light and Sir Oliver Lodge as saying that if the secret of the firefly were known, a boy turning a crank could furnish sufficient energy to light an entire electric circuit.

Another popular writer with a special interest in "Intra-atomic Energy" (see Annual Report Smithsonian Institution, 263-293, 1903) was Gustave LeBon. His books were entitled: Evolution de la matière (Paris, 1905; English 1907) and Evolution of forces (New York, 1908), both of which involve discussion of luminescence and invisible light.

${ }^{16} \mathrm{H}$. Muraoka (1896) claimed that penetrating radiation accompanied firefly light, but the effect was shown to be due to chemical action on the photographic plate from the paper with which it was wrapped.

${ }^{17}$ See the series of papers by $\mathbf{H}$. Becquerel in the Comptes Rendus of the French Academy (1896-1897). 
compound, whether a phosphor or not, would have emitted the penetrating radiation. Although uranium was discovered by M. $\mathrm{H}$. Klaproth in 1789 , over one hundred years were to elapse before its radioactivity was suspected, and over one hundred and fifty years before the full significance of its potentialities was to be recognized.

A test of various uranium minerals by Madame Curie led to the discovery of some which had a much greater action than could be explained by their uranium content. Chemical purification of one of these, pitchblende, resulted in the isolation of polonium and radium in 1898 . Not only did radium isolated by the Curies, Marie (1867-1934) and Pierre (1859-1906), excite luminescence when brought near a barium platinocyanide screen, but the radium salt itself emitted blue light, a perpetual self-luminosity.

Later, radium was found to give off three sorts of invisible radiation: (1) the alpha rays which turned out to be charged helium atoms, corresponding to anode rays in a helium vacuum tube, (2) the beta rays or electrons, corresponding to the cathode rays of a vacuum tube, and (3) gamma rays of high penetrating power, which were identified as X-rays of very short wave length. All these radiations on striking certain compounds may excite a light to which the name radioluminescence has been applied. Strictly speaking, only the gamma ray excitation is a radioluminescence; the beta rays cause anodo- and the alpha rays excite cathodoluminescence.

It is not surprising to find that $\mathrm{H}$. Becquerel (1899) made an early study of "les phénomènes de phosphorescence produits par la rayonnement du radium." Soon after radium was isolated he found that some minerals (ruby and calcite) which luminesced in visible light did not luminesce in the presence of radium, but that in general those excited by ultraviolet and X-rays did respond to radium rays, with a few exceptions. Some diamonds which were not excited by $\mathrm{X}$-rays would luminesce in radium rays. A fluorspar exposed to radium luminesced for twenty-hour hours, whereas the luminescence of fluorspar after exposure to sunlight is momentary. He also found that fluorspar which exhibited thermoluminescence after exposure to visible light would likewise luminesce on heating after exposure to radium rays.

Another radioactive material was thorium, discovered independently in 1898 by Madame Curie (1898) and G. C. Schmidt (1898) . It was also noticed that the activity of thorium compounds appeared to vary greatly, a peculiarity which was traced by $R$. B. Owens (1899) to the action of air currents, and by E. Rutherford (1900) to the formation of a gas. In fact, a radioactive gas called the emanation, which excited luminescence, could be drawn from the ma- 
terial by a current of air. A similar emanation from radium was explained as a gas by E. Dorn (1900), and F. Giesel (1903) obtained it from actinium, another radioactive element, discovered in 1899 by $A$. Dieberne. Uranium does not produce an emanation.

The three emanations are actually elements, isotopes, belonging in the series of inert gases-helium, argon, etc. Radium emanation has been given various names, exradio, radeon, radon, or niton, from nitere, to shine. Some very striking luminous experiments can be carried out with radon or niton, whose rays cause a transitory luminescence of zinc sulphide when blown over a screen of this material. If drawn through a tube containing willemite (Zn silicate), there results a brilliant luminescence of the mineral, despite the infinitesimal concentration in which the gas is present. Kept in any container, the emanation causes luminescence of the walls, blue in quartz, lilac in sodium glass, and blue green in leadpotassium glass.

The fact that cathode rays will cause the development of color in certain crystals, which then emit light on gentle heating, has been mentioned previously. The same result can be obtained with ionizing radiation such as $\mathrm{X}$-rays and gamma rays. In the twentieth century it has been established that this effect is of two sorts. In some material, the ionizing radiation may bring about changes which result in luminescence after heating or exposure to light and the change is irreversible, i. e., a second heating or exposure to light will not cause a second luminescence. This effect is called thermostimulation or photostimulation. In other materials, new permanent stable centers are formed by ionizing radiation, thereby creating a material which will fluoresce when exposed to light, whereas the unradiated material is not fluorescent. This effect, which is called radiophotoluminescence is permanent, and has become important. in detecting $\mathrm{X}$-radiation and gamma radiation.

\section{Scintillation Counters and New Particles}

A trace of radium salt added to a zinc sulphide phosphor produces the luminous paint of watch dials. If this paint is examined with a low power microscope, numerous little flashes of light or scintillations may be seen, each one of which is due to an alpha particle (a charged helium atom) hitting the zinc sulphide. The effect, ${ }^{18}$ discovered independently by Wm. Crookes, by H. Becquerel, and by E. Elster and H. Geitel, all in 1903, can be used to count

${ }^{18} \mathrm{H}$. Becquerel believed that the alpha particles actually make a small fracture in the crystal, resulting in a triboluminescence. 
alpha particles. The instrument to do so was called a spinthariscope by Crookes.

In recent years the spinthariscope has been greatly improved and become a scintillation counter, ${ }^{19}$ capable of detecting a single beta particle (electron) or a gamma ray quantum. Photo-tubes and then photomultiplier tubes have been used for detecting the light flashes. A particularly practical instrument was described by $P$. J. van Heerden ${ }^{20}$ in 1945, using $\mathrm{AgCl}$ at low temperatures as detecting material. In $1947 \mathrm{H}$. Kallmann ${ }^{21}$ demonstrated that naphthalene crystals emit flashes of ultraviolet light, which can be recorded by a photomultiplier tube and amplifier system. The light flashes are well above the background "noise" of the instrument. Since then, liquids as well as crystals have been found to emit similar pulses of ultraviolet light. The technical advances in this latest field of luminescence have been extremely rapid and highly interesting. Their importance is the only excuse for mentioning them in a history which is not intended to cover the twentieth century.

Since the development of high voltage particle accelerators, cyclotrons, synchrotrons, betatrons, etc., the known phenomena of luminescence have been greatly multiplied. The many types of new particles, positrons, neutrons, protons, deuterons, etc., projected as an intense beam will excite various substances to emit a light, either directly or as a secondary effect. Such a light can be called a radioluminescence. Many of the new isotopes and the new elements which decay spontaneously also emit particles or rays which can excite luminescence, and, like radium, some of the radioactive isotopes are self-luminous.

The discoverers of various phenomena connected with radioluminescence have been amply rewarded. The first Nobel Prize (1901) went to W. Roentgen, the third to A. H. Becquerel and the Curies (1903), the fifth (1905) to P. Lenard, and the sixth (1906) to J. J. Thomson. In more recent times the discoverers of new particles, which are associated with luminescence effects, have also become Nobel prizemen. It is indeed surprising to note how frequently the award has been connected with men whose concern was in the field of radiation even though their research was not primarily connected with luminescence. From 1901 to 1950, forty-four Nobel Prizes in physics have been given to fifty-four men. The principal

${ }^{10}$ See A. T. Krebs, Early history of the scintillation counter, Science 122: 17-18, 1955.

${ }^{20}$ Van Heerden, The crystal counter. Utrecht dissertation, 1945.

${ }^{21}$ Luminescent naphthalene crystals and photomultiphers as gamma ray counters, Natur und Technik, July, 1947. 
work of all but five has been connected with radiation, using this term in its broadest sense to include both waves and particles.

Thus, radioluminescence studies have led to a most effective and an almost unbelievably sensitive method of detecting the ultimate particles of matter or units of energy which make up the universe. Simple luminescence monitors can now determine the amount of radiation to which a human being has been exposed. ${ }^{22}$ In every hospital, the action of X-rays on a photographic plate is intensified by the radioluminescence of a backing screen, and the television set would not have become a household article without cathodoluminescence to form the picture. As no laboratory is complete without its cathode ray oscillograph to make visible on a thin film of phosphor the movement of a beam of electrons, it is apparent that radioluminescence is now one of the most common phenomena in every facet of modern life.

${ }^{22}$ See J. H. Schulman and H. W. Etzel, Small volume dosimeter for X-ray and gamma-rays. Science 118: 184-186, 1953. 


\section{CHEMILUMINESCENCE}

\section{Introduction}

$\mathrm{T}$ HIS TYPE of luminescence requires no previous exposure to radiation of any kind, no gentle heating, and no mechanical excitation. The energy for light emission comes from a chemical reaction, usually involving considerable change in the composition of the chemiluminescent material. The reaction may occur in gas phase or in a liquid. The so-called "cold flames" of ether or carbon disulphide or metal vapors in contact with oxygen or halogens are examples of gaseous chemiluminescence. The various flame reactions called pyroluminescences, the yellow of sodium, green or blue of copper salts, etc., in the Bunsen flame are additional examples of gas reactions, at one time regarded as chemiluminescences connected with recombination of ions to molecules or change of monovalent to bivalent ions. They are sometimes called indirect chemiluminescences to distinguish them from the direct chemiluminescences, where actual splitting of a molecule occurs. The observation of these colors is as old as alchemy itself. ${ }^{1}$

The outstanding example of a gaseous chemiluminescence is the glow of solid phosphorus in air. When dissolved in organic liquids or as a colloidal solution in water, phosphorus does not luminesce; the light of a solution comes only from a gaseous layer near its surface or from bubbles of air in suspension. Chemiluminescence which accompanies oxidation of organic compounds dissolved in a liquid is a much later discovery, connected with the spectacular development of organic chemistry in the late nineteenth century.

${ }^{1}$ Vannuccio Biringuccio (1480-1539?) of Sienna, in his De la pirotechnia (Venice, 1540), translated by C. S. Smith and M. T. Gnudi (New York, 1942), used the color of flame to identify metals. He wrote: "on a well burning fire it [ore and lye] develops the color of the fumosities which issue from it." E. Mariotte (1688) cited a number of green flames and Thomas Melvill in 1752 called particular attention to the yellow color of sodium. His account was published in 1756. David Brewster introduced the monochromatic sodium lamp in 1822. 


\section{The Gaseous Chemiluminescence of Phosphorus}

\section{DISCOVERY OF PHOSPHORUS}

Just as phosphorescences, i. e., photoluminescences, may have been known to the ancients or during the Middle Ages, before the time of Cascariolo of Bologna, it is possible that the light of phosphorus may have been seen before the generally accepted discovery by Brand in 1669. The suggestion has been made by Raimondo di Sangro ${ }^{2}$ (1710-1771) that the "perpetual lamps" of St. Augustine (354-430) found in the sepulchers of early Christians contained phosphorus. However, in view of the marvelous but completely false tales concerning the "liquor lucidus," allegedly made from glowworms, the presence of phosphorus in perpetual lamps cannot be given too much credence (see Chap. III) .

Mention has already been made in Chapter III of the "icicles" of Paracelsus (1493-1541) which were the "element of fire," but surely had this material been phosphorus, much more would have been written concerning it and the new discovery would have played a prominent part in spagyric medicine. ${ }^{3}$

Like the discovery of the Bolognian stone, Brandt's preparation of the element phosphorus was a matter of luck, a good example of the reward which occasionally comes to those who try all procedures with sufficient persistence. If a material which would light after exposure to the sun aroused the wonder of observers, how much more extraordinary the preparation of a material that luminesced continuously in darkness. It is appropriate that the first example of artificial chemiluminescence was called "phosphorus mirabilis." Nothing like it was known except shining wood and shining flesh, and these manifestations were not only short lived, but rare and capricious. They could not be produced at will and did not have the fascination of a substance fabricated by man himself.

The history of the discovery of phosphorus has been related many times ${ }^{4}$ although the accounts differ somewhat, because of the secrecy with which the preparation of the material was shrouded. It is fair to say that the same motives and the same jealousies and greed for

${ }^{2}$ See Gino Testi in Archion 13: 67-68, 1931; also 14: 490-491, 1932.

${ }^{3}$ In J. W. Mellor's Comprehensive treatise on inorganic and theoretical chemistry 8: 730,1928 , it is suggested that Arab alchemists, who were continually distilling bones and urine must have obtained phosphorus. See especially a twelfth-century manuscript of Alchid Bechil, where the formation of "escarboucle" is described (cf. F. Hoefer, Histoire de la chemie 1: 339, 1843 and 2: 183, Paris, 1843).

4 For details see Discovery of the elements by M. E. Weeks, Easton, Pa., 1945. Also J. Ince $(1853,1858)$, and G. Gore (1861), T. E. Thorpe (1890), T. L. Davis (1927) and W. Prandtl (1948). 
wealth were involved in the discovery of phosphorus as in the preparation of the Bolognian stone some seventy years before.

All authorities agree that the discoverer was Hennig Brand or Brandt (died 1692), a physician of Hamburg, who hoped to amass a fortune through the goal of alchemy. After dry distillation of the solids of urine, Brand obtained his material, by reduction of the phosphates in this liquid, about 1669. The first knowledge of the new phosphorus came to scientific circles by way of Johann Kunckel (1630-1702), the famous chemist of Dresden, later manager of a glass-works in Berlin and finally counsellor on metals to King Charles XI of Sweden.

During one of his trips to Hamburg, Kunckel showed Baldewein's phosphor to a friend, was told of Brand's discovery and was later introduced to Brand, who showed him the phosphorus. ${ }^{5}$ According to some accounts, Kunckel wrote his friend, Johan Daniel Krafft, another chemist and commercial agent of Dresden, concerning the discovery, and Krafft immediately journeyed to Hamburg and bought Brand's secret for 200 thalers. According to Leibnitz (1710) and certain letters ${ }^{6}$ which still exist, both Kunkel and Krafft learned the secret from Brand during a visit in which they suggested that the new material might be sold to some royal person for a high price. Apparently no purchase was made at that time.

At any rate Kunckel was stimulated to experiment with urine, succeeded in making phosphorus himself, and wrote his well-known tract on the subject Offentlische Zuschrift vom Phosphoro mirabili und dessen leuchtenden Wunderpilulen (Wittenberg, 1678). The properties of phosphorus, called "noctiluca constans," had been previously described by Kunckel's friend Kirchmaier in 1676 and it was mentioned in J. S. Elsholtz's (1623-1688) De Phosphoris Quatour Observationes (Berlin, 1676). Elsholtz was physician and chemist to the Elector of Brandenburg and had seen phosphorus exhibited at court by Krafft. He was greatly intrigued by the new material and in 1677 gave an account of a liquid phosphorus in a flask, which he called "ignis frigidus." A plate of this publication reproduced as figure 35, shows " phosphorus stellatus, phosphorus nubilosus and phosphorus literatus," three varieties or rather three new ways of exhibiting the spectacle of phosphorus. His observations were summarized in a pamphlet published at Berlin in 1681, De Phosphoris Observationes, etc.

\footnotetext{
5 Brand's phosphorus is sometimes referred to as the hermetic phosphorus, for example by O. Jacobaeus (1677) and R. Lentilius (1685) .

${ }^{6}$ Collected by H. Peters, Chem. Zeitung 26: 1190-1198, 1902 and Max Speter, Chem. Zeitung 53: 1005-1006, 1929; also Chem. tech. Rundschau 44: 1049-1051, 1929.
} 
The first publication on phosphorus, written in 1676 by George Kaspar Kirchmaier (1635-1700), professor of eloquence at the University of Wittenberg, was undoubtedly at Kunckel's suggestion, designed to popularize the material. It was entitled Noctiluca Constans et per Vices Fulgurans, etc. and was followed by a longer article in 1680, De Phosphoris et Natura Lucis nec non de Igne (see title page in figure 36), giving all that was known concerning phosphorus and recounting his own ideas on fire and light.

One of Kunckel's contributions was to cast the phosphorus in little molds such as are sometimes used today. Priestley (1772: 585) wrote:

Kunckel formed his phosphorus into a kind of pills, about the size of peas, which, being moistened a little, and scraped in the dark, yielded a very considerable light, but not without smoke. The light was much more pleasing when eight or ten of these pills were put into a glass of water; for being shaken in the dark, the whole glass seemed to be filled with light. Kunckel also reduced his phosphorus into the form of larger stones, which being warmed by a person's hand, and rubbed upon paper, would describe letters that were very legible in the dark.

A complete account of Kunckel's work will be found in his Laboratorium Chymicum, which appeared in 1716, well after his death.

Advertisement of the new material was largely due to Krafft. Around 1677 he exhibited his "Kalte Feuer" or "immerwährende Feuer" to various royal persons, including Charles II of England. Robert Boyle saw ${ }^{7}$ the material but did not know its method of preparation, except that it came from some constituent of the human body. Boyle immediately set to work to prepare phosphorus and succeeded so well that on October 14, 1680, he deposited a sealed paper with the Secretary of the Royal Society giving the method of preparation. It was published (Boyle, 1692-1693) two years after his death in 1691, and gives very detailed directions. Boyle published two booklets on phosphorus, which will be discussed later.

In the meantime (1678), Gottfried Wilhelm von Leibnitz (16461716), then librarian at the Court of Hanover, drew up a contract between Duke Johann Friedrich and Brand involving payment for the secret and for any new developments concerning the cold fire. As a result Leibnitz was able to prepare phosphorus himself and sent a specimen to Christian Huygens in Paris. Later the secret of preparation was sent by Leibnitz to Count Ehrenfried Walter von

${ }^{7}$ According to Hooke's Cutler Lectures, the demonstration took place in the evening of September 15, 1677 and Mr. Krafft is referred to as "the artist." At this time it was suggested that luminescence of the material might be tested in a vacuum but Mr. Krafft did not offer to have the trial made. 


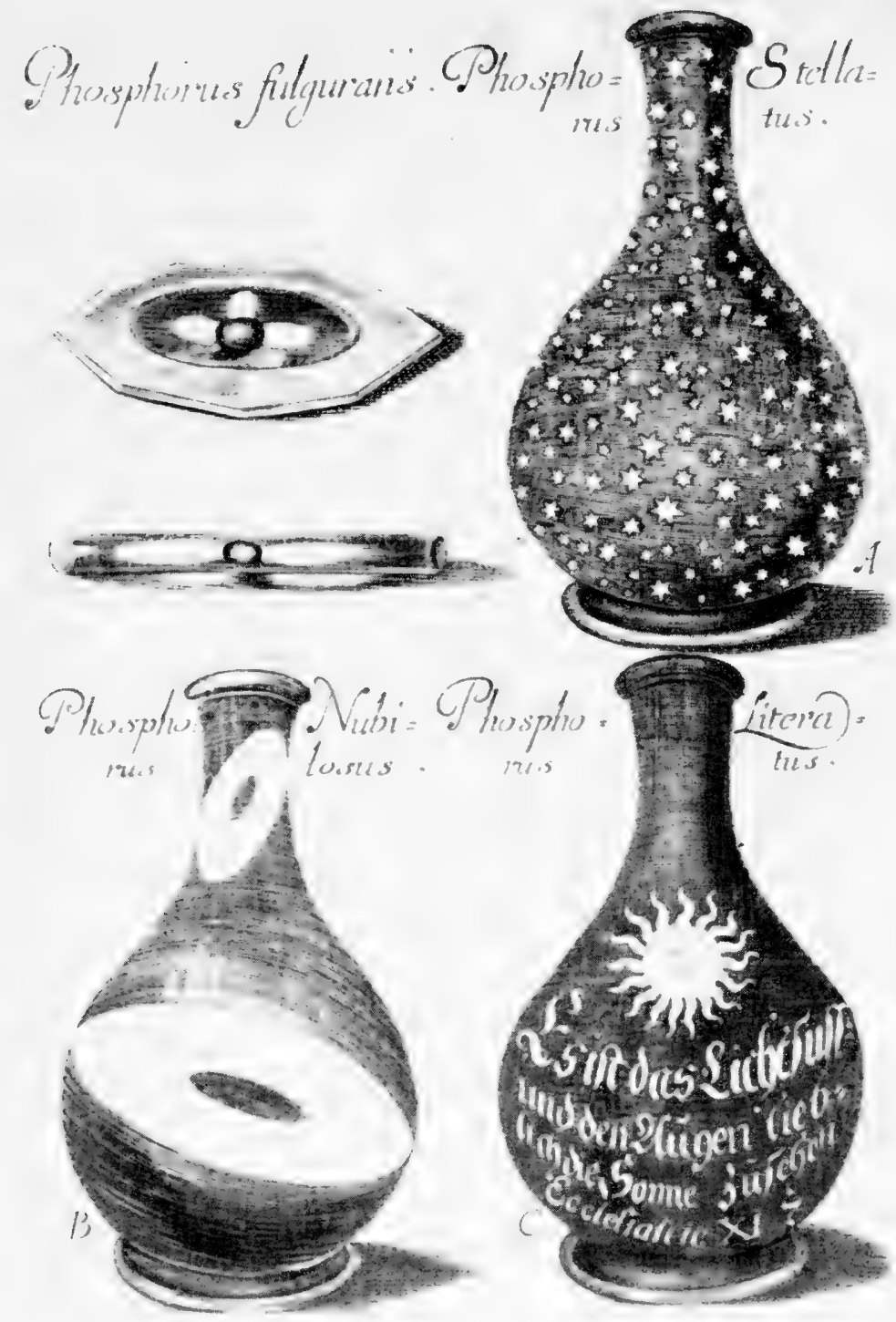

Fig. 35. A plate of the luminescent effects of phosphorus from the book of $\mathbf{J}$. S. Elscholtz, De Phosphoris Observationis (Berlin, 1681). Elscholtz described tour phosphors (Berlin, 1676), the Bolonian, the Baldewinian, the true phosphorus fulgurans or stellatus (also called "ignis frigidus") and a themophosphorus which would glow when warmed slightly. 
Giorgi Caspo Krrohatajeri, In Electorali VVitteberga P.P. Acad. C.

PHOSPHORIS NATURA LUCIS,

Nec non
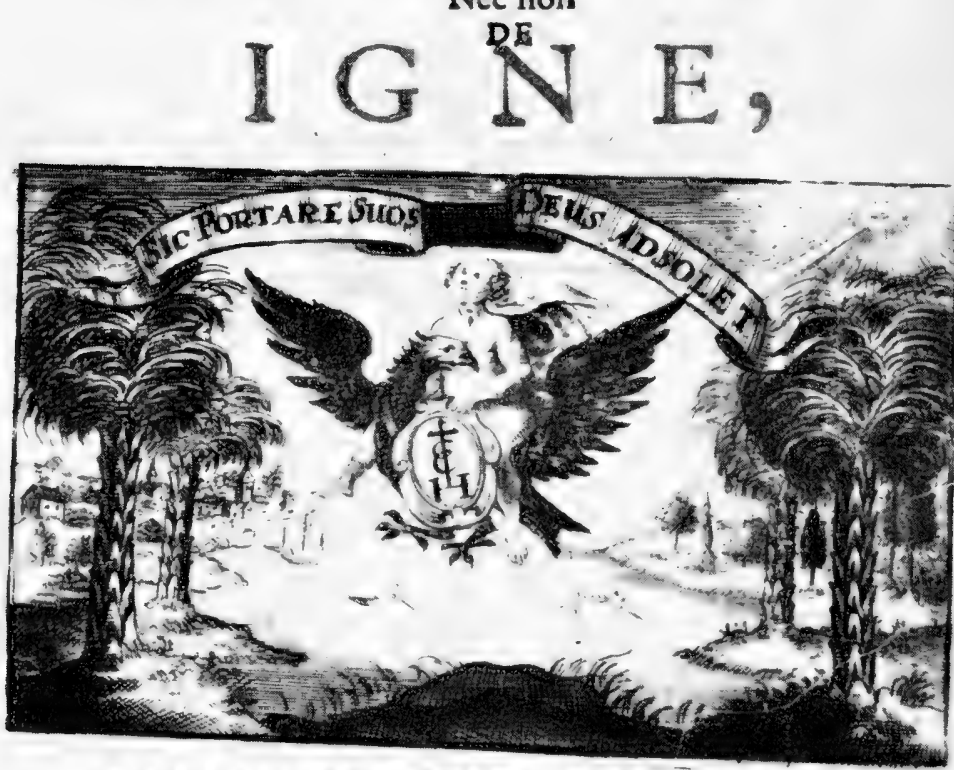

\section{COMMENTATIO PPISTOLICA.}

\section{WTT TEBERGA,}

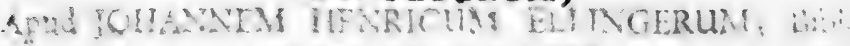

\section{Asto clo Ioc LXXX. it.}

Fic. 36. Title page of one (Wittenberg, 1680) of G. C. Kirchmaier's two pamphlets on the newly discovered phosphorus of Krafft and Kunkel von Löwenstjem. The other pamphlet was called Noctiluca Constans (1676). Kirchmaier was Professor of Eloquence at the University of Wittenberg. a friend of Kunkel. His pamphlets helped to popularize the "phosphorus mirabilis." 


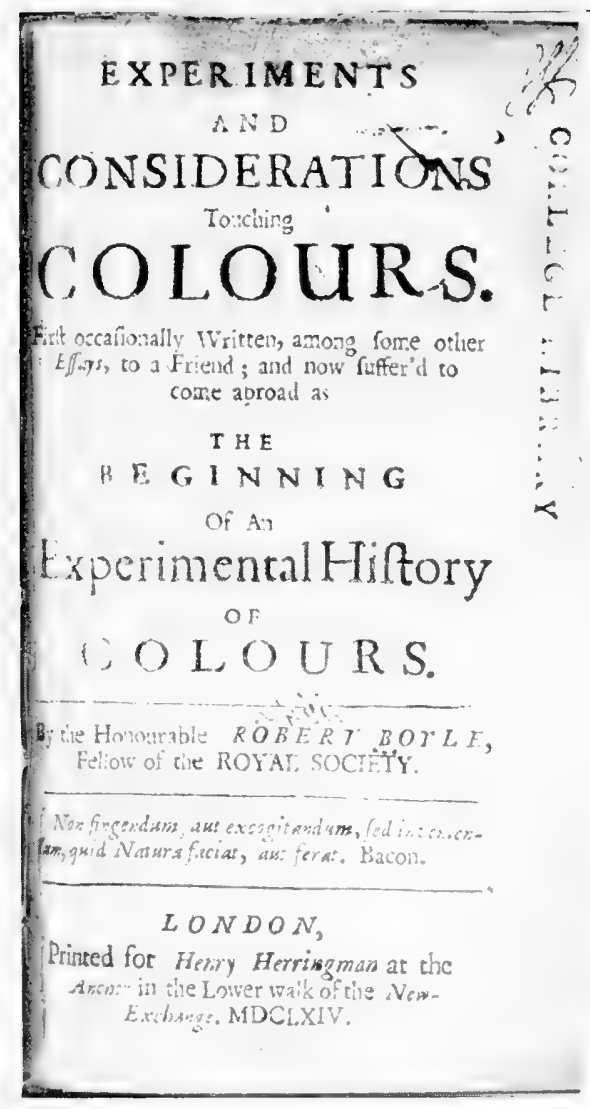

RI Y IERSF

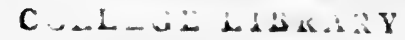

T H E

AERIAL NOCTILUCA:

OR

Some New Phonomena, ANDA

$\begin{array}{lllllll}P & \mathrm{R} & \mathrm{O} & \mathrm{C} & \mathrm{E} & \mathrm{S} & S\end{array}$

$\mathrm{OF}$

A Factitious Self-Anining Subatance.

Imparted in a Letter to a Friend, living in the Country.

By the Honourable ROBERT BOYLE, Fellow of the Roral societr.

$$
L O N D O N
$$

Printal by 7io. Shotede, and arc to be fold by Nath. Rarem. Booldfiler in St. Pauts Church-Yard a 1 S’o.

Frs. 37. Left, title page of Robert Boyles book on Colows (London, 166t) in which his experiments on "Lignum nephriticum" are described. as well as the observations on luminous diamonds. Right, title page of the first of his pamphlets on phosphorus. The derial Noctiluca tLondon. 1680). It was followed by The ley Voctiluca (Lomdon. $\left.1681-186^{\circ}\right)$. 


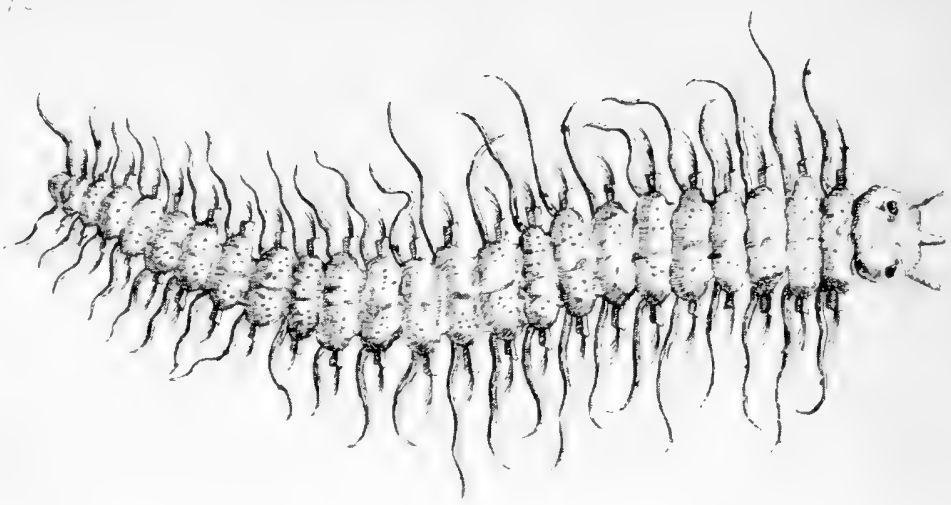

Fig. 38. A luminous worm, often responsible for sea light, reproduced from the thesis of C. F. Adler, entitled Noctilua Marina (1752), under the auspices of Carolus Limnaeus, one of the first foreign members of the American Philosophical Socicty, elected in 1770.
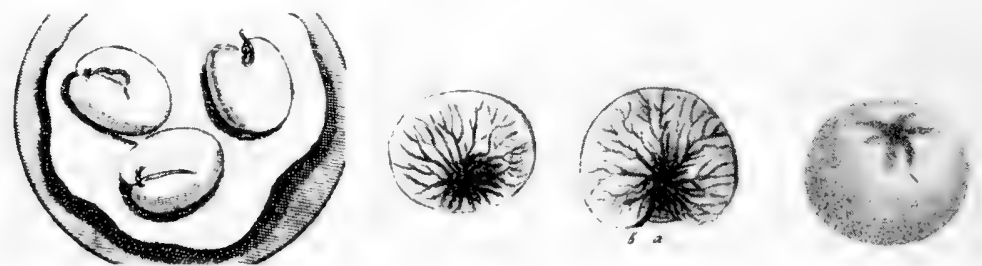

Fic. 39. Various early drawings of the famous marine protozoan, Noctiluca miliaris, responsible for much of the luminescence of the sea. The organism is visible to the naked ere, about $0.8 \mathrm{~mm}$. in diameter. The three in dish at left are after Dicquemare (1755); wo in center, after Slabber (17/8); one at right, after Macarmey (1810).
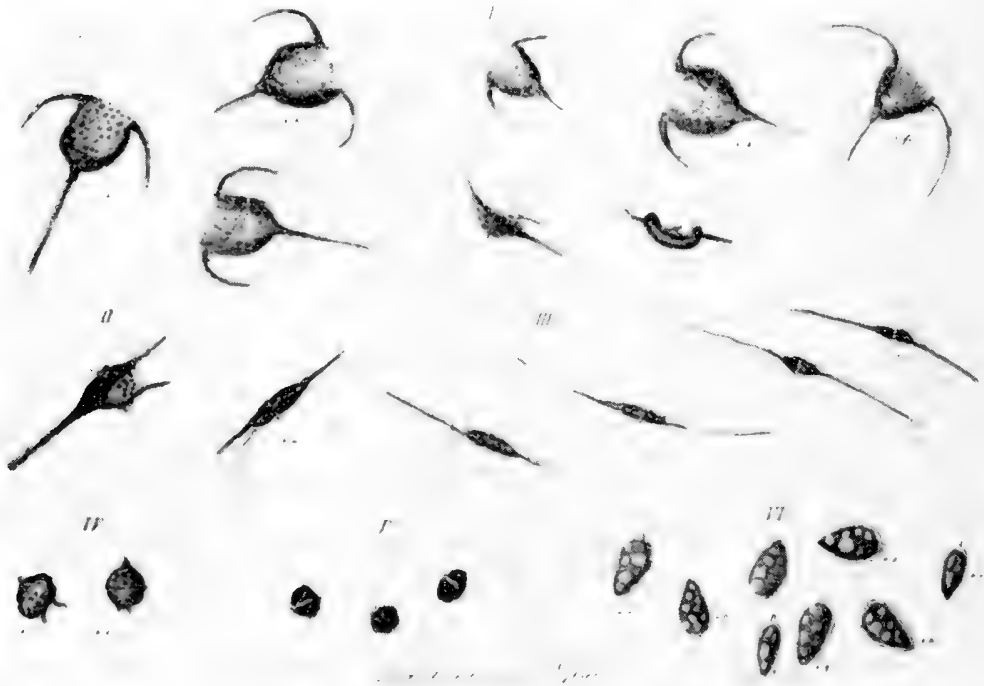

Fis. 40. Ninute dinoflagellates, microscopic in size, recognized as the source of the diffuse light of the sea about 1830. Reproduced from a plate of (:. C. Khrenberg's paper, "Das Leuchten des Meeres" (1834). 
Tschirnhaus (1651-1708) in Paris. An account was published in the Histoire of the Royal Academy and appeared in the fifth edition of Lémery's Cours de Chymie in 1683. Since that time, William Homberg, who had seen the material prepared by Boyle, described its properties in Paris. His experiments appeared in the April and May issues of the Mémoires of the Royal Academy of Sciences, 1692. He later described a "burning Phosphorus, which may be drawn from Human Excrement " and gave the receipt to the Academy in 1710. This material prepared from dried faeces and alum was a pyrophore which would spontaneously ignite when exposed to the air, rather than a phosphorus. Thus, despite the attempts at secrecy and the various underhanded dealings and accusations between the principles involved, the mode of preparation of phosphorus became a well known fact. ${ }^{8}$

It is not surprising that so remarkable a substance as phosphorus should be suggested as material for a doctor's dissertation. The first of these, a thesis of fifty-four pages, was presented in 1688 to the medical faculty of the University of Frankfurt on the Oder, Bernardo Albino presiding. The author was John Christolph Kletwich and the title Dissertatio de Phosphoro Liquido et Solido, Kletwich related the known properties of the material, included twenty observations of his own, which added nothing new, and referred to the work of Balduinus, Kirchmajerus, Elscholtzius, Lentilius, Boyleus, Menzelius, and Dr. Slare. In 1710 Leibnitz published his history of the knowledge of phosphorus in the Miscellanea Berolinensia (1710, part II, pp. 91-98).

\section{ROBERT BOYLE AND COLLEAGUES}

The earliest workers noted that phosphorus was luminous as a solid or in gaseous form or when dissolved in oils, as a liquid. These materials came to be known as the icy, the aerial, and the liquid noctiluca, largely through the work of Robert Boyle. Of all those who prepared phosphorus in the seventeenth century, the studies of Boyle were most complete. His two books appeared a few months apart and were entitled The Aerial Noctiluca (London, 1680) and The Icy Noctiluca (London, 1681) of 109 and 150 pages, respectively. Figure 37 reproduces the title page of The Aerial Noctiluca. The two (bound together) were translated into Latin in 1682 and into German in the same year. Boyle noticed all the peculiar phe-

\footnotetext{
${ }^{8}$ Rosinus Lentilius described the properties and preparation of phosphorus from England in the Ephemerides (Dec. II, An. IV, 1685 on phosphor hermétique), as related to him by a man who had obtained the method in England.
} 
nomena connected with phosphorus luminescence, and will therefore be quoted at some length.

The Aerial Noctiluca was actually a letter, written to and dedicated to J. B. " a Virtuoso living in the Countrey, who has been for many years absent from London ... to gratifie your curiosity about the Phosphorus's, as much as I can without indiscretion at present do." Boyle then explained that there were two sorts of phosphore: "Those that may be stil'd Natural, as Glow-worms, some sorts of rotten Wood and Fisches, and a few others, and those that are properly Artificial." The fact that they "without manifest heat shine in the dark," distinguished them from " common Fire and Flame." Regarding the artificial phosphori there are "Bodies as shine only by the help of External Illustration, or (if you please) such Bodies, as being expos'd to the beams of the Sun," shine, and " another sort, which needs not be previously illustrated by any external Lucid, and yet continues to shine...." The latter "by some Learned Men has been call'd, to discriminate it from the former, a Noctiluca." This division into natural and artificial luminescences is an early, if not the earliest classification of cold lights, and was adopted by all writers for many years afterwards.

Boyle did not entirely approve of the designation "noctiluca" which implied a light only at night but decided to use the word, although reserving the right to speak of " a Selfshining substance, which is more expressive of its nature: Of this substance Mr. Daniel Krafft, a German Chymist, shew'd his Majesty two sorts or degrees ... the Consistent (or Gummous) Noctiluca" or as "tis call'd by some in Germany, The Constant Noctiluca; which title it does not ill deserve, since this Phosphorus is much the noblest we have yet seen. . . ."

"Besides this Gummous Noctiluca, Mr. Krafft had a Liquid one, that perhaps was made by dissolution of the former in Water, or some convenient Liquor." Boyle described "a third kind, that we ourselves lately prepared ... not the Body of the Liquor included in the Vial, but an Exhalation or Effluvium mingled with the admitted Air ... the Aerial Noctiluca. ..."

Boyle then discussed the practical value of the new material, as follows: "The Uses that may be made of Noctilucas, especially of the Consistent, are not, in probability, all of them to be easily foreseen and declar'd ... if the lucid vertue of the Constant Noctiluca could be (as I see not, why it may not be) Considerably invigorated," in the powder rooms of ships or " of use to those that dive in deep waters; and also may very safely and conveniently be let down into the Sea ... to draw together the Fishes that are wont to resort 
to the light of a Fire or a Candle; as in divers parts of Scotland and Ireland is well known to the Fishermen, who get much profit by this resort. ..." He also pointed out that phosphorus might be used

to shew the hour of the night when one wakes [or as a] guide knowable at a good distance off in spite of tempestuous Winds and great Showers, and this in the darkest night. Divers ludicrous Experiments, very pleasing and surprising, may be made with the Noctiluca, by him that has enough of it. But these trifles, though very pretty in their Kind, I purposely pass over. ... In the mean while I shall only intimate, that probably the utilities that so Subtle and Noble a Substance may be brought to afford in Medicine, may be more considerable than any of its other particular uses; ... and [may] be found conducive to discover the nature of so Noble a Subject, as Light . . . the first Corporeal thing the great Creator of the Universe was pleased to make .... and to alot the whole first day to the Creation of Light alone, without associating with it in that Honour, any other Corporeal thing.

The next section dealt with Mr. Boyle's thirty-two “ Observations about the Aerial Noctiluca." There was also a final section on the method of preparation. An explanation of the origin or the cause of the continuous light, much the most lasting of all the phosphors known at the time, would have been most revealing, but Boyle specifically stated that he would merely describe experiments and reserve interpretation. He did incline " to think, that, to speak in a general way, the Light of our Noctiluca depends upon a peculiar and very brisk agitation of some minute particles of the shining matter, in point of bulk, shape, and contexture, peculiarly fitted to impel the contiguous aether to the bottom of our eyes. ...."

In Observations 4 to 10 , Boyle explained how he could obtain no light from the aerial noctiluca by shaking but when the vessel was unstopt a light or flame (Boyle could not tell which) appeared inside, beginning where the outer air touched the noctiluca and then progressed from top to bottom of the vessel. The various phenomena seemed "to favor the conjecture or suspicion I lately propos'd, about the interest of the air in our unburning flame." Boyle then speculated "that the admitted Air, either by some subtle Salt that it contain'd, or upon some such account excited in the fumes, it mingled with, a kind of Fermentation, or (if you please) a Commotion, by which means the matter acquired so brisk an agitation, as to propagate the motion to the eye, and there make an impression, the sense whereof we call Light. . .." The chief objection to this view was that the Constant Noctiluca remained luminous even when in a stoppered vessel, just like rotten wood or fish or "the liquor of Glow-worms, taken out after they are dead." However, Boyle 
finally decided that " contact of fresh external Air might contribute to this peculiar kind of agitation in the Gummous Noctiluca, as an helpful thing, and in the Aerial Noctiluca, as an almost necessary concurrent."

$\mathrm{He}$ also noticed that some of his noctiluca rubbed in the hands gave not uniform flames but "often seemed to tremble much, and sometimes, as it were, to blaze out with sudden flashes, that were not lasting (which put me in mind of some of the faculae solares)." A great store of whitish smoke arose and " other Effluviums ... imbued the neighboring Air with a ranck and offensive smell." 9 There was practically no heat but the appearance was like an artificial ignis lambens, reminding Boyle of Virgil's lines in the Aeneid, describing the flame on the head of Julus.

In order to test the effect of a vacuum, Boyle took " a pretty large piece of paper, which, being well moistened, and partly besmear'd with our luciferous matter" was placed in a glass in the receiver of the pneumatick pump. When " the pump was set awork," the light seemed to increase but later became palpitating, and when air was let in disappeared. This disappearance was attributed to the moist air in the pump and it was found that on taking the paper out of the receiver the light reappeared. Because of a belief that the vacuum was not as good as could be obtained, both Boyle and the spectators agreed the experiment should be repeated.

The pamphlet on The Icy Noctiluca (1681) related that a liquid noctiluca had been made since his book, The Aerial Noctiluca, had been published and then explained that the word, glacial or icy, had been chosen for the solid or consistent variety, because the small transparent grains of material in the distillate looked like ice. They did not shine under water but only in the air and smoke accompanied the luminescence. They were heavier than water, could be melted under water and would fuse together to a large piece. The water containing them had a penetrating vitriolic taste and on evaporation left a gelatinous residue. Boyle studied the liquids in which his icy noctiluca would dissolve, observing that in turpentine when air was admitted, no light appeared above the bottle and no fumes were observable. Because of the disagreeable smell of the noctiluca, making experiments " much less acceptable, than they otherwise would have been, to the delicate sort of spectators, especially to ladies," Boyle "found a way to prevent this ungrateful concomitant of our artificial light."

His method was the use of an aromatical oil like cinnamon or clove or mace, in which enough solution took place to make the

- Perhaps an early notice of ozone production. 
surface of the oil luminous, often accompanied by flashes of light in the bottle. Solution in spirit of wine led to "A way of suddenly producing light in common water, by the help of another nonluminous liquor." The alcohol solution of the noctiluca showed no light until mixed with water, when the drops were

kindled by the cold water, and afford little flashes of light, which was more vivid than the noctiluca itself, affording a splendor, that made not only the brims of the cup, but divers of the neighboring objects manifestly visible, not to say conspicuous. But these coruscations had the property of other lightning, to vanish almost as soon as they appeared, nor would the water that produced them, by being agitated, shine; . . .

It seemed not very improbable, that these sudden and vanishing flashes might, at least in great part, proceed from the quick disengagement and extrusion of the noctilucal particles, made by the water, which, diluting the vinous spirit, disabled them from retaining with them the luciferous particles.

Boyle then compared the effect to camphor dissolved in alcohol, which is separated as a white powder on mixing with water.

In "Experiments discovering a strange subtilty of parts in the glacial noctiluca," Boyle showed that "if the whole grain of icy phosphorus had been dissolved at first in the spirit of wine, it would have impregnated above six hundred thousand times its weight of water, sufficient to make it shine." He compared this dilution with the great dilution in which the red of cochineal is visible. This phosphorus experiment appears to be the first to recognize that chemiluminescence can be detected when minute amounts of material are present.

Finally Boyle experimented on the inflammability ${ }^{10}$ of the noctiluca itself and its ability to set things afire. He told of flames set in his laboratory and also how his

laborant, who was very helpful to me in varying the preparation of the phosphorus, had a worse misadventure not long after; for bringing me some newly distilled grains of our noctiluca, covered with some of the shining water, that came over with it, he unluckily broke the glass in his pocket; whereupon the heat of his body, increased by the motion his long walk had put into it, did so excite the matter, that was fallen out of the broken vial, that it burned two or three great holes in his breeches, before he could come to me to relate his misfortune, the recent effects of which I could not look upon without some wonder as well as smiles.

When phosphorus was melted under water and consequently at the higher temperature, "as soon as the air came to touch the

\footnotetext{
${ }^{10} \mathrm{Krafft}$ had fired gunpowder with his material but Boyle found that this was not easy, although he could ignite sulphur.
} 
noctilucal matter, it seemed to be kindled into an actual flame, that afforded a very vivid light; which success pleased me the better, because it shewed, that a kind of fire may be kept under water, as long as one pleases, without sensible burning, ..."

In conclusion, Boyle wrote:

Light is so noble a thing, that the matter our phosphorus affords it to reside in being endued with some uncommon qualities, and particularly with a strange, and almost incredible subtility of parts, I cannot but hope that ... [in the future] something would be produced, tending to the discovery of the nature, not only of light but divers other bodies, and perhaps also, of good use to human life. If some unwelcome circumstances did not, for the present, discourage me, I would contribute my weak endeavors toward such a design.

One of the extraordinary phenomena connected with phosphorus is a periodic luminescence of the vapor when kept in a partially confined space. This was observed by Boyle and also described by " the Ingenious Fred. Slare M. D." (1683), who tried many experiments. He referred to it as "A Parallel betwixt Lightning and a Phosphorus" and continued,

In order to the keeping my solid Phosphorus from consuming, I usually plac'd it at the bottom of a Glass of Water: having several of these Glasses disposed upon a Table in view whilst I lay upon my Bed, I could observe several flashes of Light that successively past through the Water, and made such bright, and vigorous Coruscations in the Air, as would surprise and affrighten one not used to the Phenomenon. This fiery Meteor passes something contracted through the incumbent Water, but expands itself much as soon as it gets above it.

Slare went on to point out that the above effect was pronounced in warm weather and he never noticed it in winter as "the season of the Summer is most productive of Lightning."

Slare also studied the behavior of phosphorus in absence of air in an article published in the Philosophical Collections (No. 4:81, 1681-1682). He wrote:

It being now generally agreed that the fire and flame of phosphorus have their pabulum out of the air, I was willing to try this matter in vacuo. To effect this I placed a considerable lump of this matter [phosphorus] under a glass, which I fixed to an engine for exhausting the air; then presently working the engine, I found it to grow lighter [i. e., more luminous], though a charcoal that was well kindled would be quite extinguished at the first exhaustion; and upon the third or fourth draught, which very well exhausted the glass, it much increased the light, and continued to shine with its increased light for a long time; 
on readmitting the air it returns again to its former dulness. Endeavoring to blow it up to a flame with a pair of bellows, it seemed to be quite extinguished; as it was a good while before any light appeared.

As a member of the Royal Society, John Evelyn (1641-1706) witnessed the new experiments on phosphorus. On December 13, 1685 , he wrote: ${ }^{11}$

Dining at Mr. Pepys's, Dr. Slayer shewed us an experiment of a wonderful nature, pouring first a very cold liquor into a glass, and super-fusing in it another, to appearance cold and cleare liquor also; it first produced a white cloud, then boiling, divers coruscations and actual flames of fire mingled with the liquor, which being a little shaken together, fixed divers sunns and starrs of real fire, perfectly globular, on the sides of the glasse, and which there struck like so many constellations, burning most vehemently, and resembling starrs and heavenly bodies, and that for a long space. It seemed to exhibite a theorie of the eduction of light out of chaos, and the fixing or gathering of the universal light into luminous bodys. This matter or phosphorus was made out of human blood and urine, elucidating the vital flame or heate in animal bodys. A very noble experiment.

Another colleague and an assistant to Boyle brought over from Germany, was Ambrose Godfrey Hanckewitz (1660-1741), whose observations were published at a later date and will be presented in the next section.

\section{EIGHTEENTH-CENTURY EXPERIMENTS}

Most of the phosphorus of the early eighteenth century was prepared by Ambrose Godfrey Hanckewitz, ${ }^{12}$ who sold it for three pounds sterling an ounce. He had tested practically every possible source of the material and reported some of his trials and failures in a general paper (1733). Phosphorus was usually prepared ${ }^{13}$ from the waste products of man, but could be obtained from urine and the excrement of other animals, such as "Lions, Tygers and Bears." Hanckewitz wrote:

My Curiosity led me likewise to Rats-Nests, and Mouse-Holes, and I had Phosphorus thence. I then addressed myself to the feather'd Tribe,

${ }^{11}$ John Evelyn, Diary and correspondence, ed. by Wm. Bray, 1, 2nd ed., London, 1819.

${ }^{12}$ Often referred to merely as Ambrose Godfrey or Godfry. See Joseph Ince for the life and character of Hanckewitz in the Pharmaceutical Journal 18: 126-130, 157$162,215-222,1858$.

${ }^{13}$ Hanckewitz's secret method of preparing phosphorus was revealed in letters to Johan Frederrick Henckel (1679-1744), a councillor of mines in Freiberg. They were published in 1794-1795. 
visiting the Hen-Roosts, and the pigeon-House, and got some small matters thence also; I emptied the Guts of Fish, in order to get their Excrements, and had a little Phosphorus from these, but none from the Fisches themselves.

He also tried vegetables, "Corn and other Fruit," but without success; and also coal and minerals, and wished he had a sufficient supply of glowworms "which seem to have Phosphorus lodged in their Bodies."

Hanckewitz (1733) expressed his idea of the composition of phosphorus in the peculiar phraseology of the time. He wrote:

It is my Opinion, that Phosphorus doth not naturally exist in Animals by itself; but when formed out of Urine, by Means of Putrefaction and Fire, its principle Contexture is found to consist of a subtile Acid concentrated by the Salt of Urine, and of a fat depurated Oil. . . .

The Phlogistic Part is so slightly connected with the other Principles, that the least Motion, Friction or Warmth, sets it on fire. . .

Phosphorus may be called an urinous Sapo or Soap, as it consists of the saline and oleaginous Parts of the Urine: But Phosphorus is not to be got in so great Plenty out of Urine alone, as when the Faeces Alvinae are elixerated along with it, and then brought to a Magma fit for distillation: ... .

The solubility of phosphorus in non-aqueous solvents aroused considerable interest. One of these alluded to by Hanckewitz, was "spiritus vini aethericus," or ethyl ether, prepared by Frobenius some years before. ${ }^{14}$ The demonstration was made before the Royal Society in 1731 and described by Cromwell Mortimer (1733), who wrote: "He [Frobenius] took a solution of Phosphorus in the Aetherial Spirit of Wine, which he called Liquor Luminosus, and pour'd it into a Tub of warm Water; whereupon it gave a blue Flame and Smoak, attended with so small a Degree of Heat, as not to burn the Hand, if put into it."

Frobenius also demonstrated the light which could be obtained from stick phosphorus, when burned under a bell jar, described by Mortimer as "a very pompous Machine which he calls Machina Frobeniana." The demonstration was only one of many on phosphorus performed before the Royal Society, but was apparently on a grand scale, as Hanckewitz (1733) devoted some space to it and Mortimer alluded to it again in discussing the heat of animals (1745).

The production of phosphorus in England must have been highly successful because the English preparation gained great renown on

14 See Frobenius, Phil. Trans. 36: 288, 1730. 
the continent. Although Frederick Hoffman the younger (16601742), professor of medicine at the University of Halle and a German, recognized the part played by Krafft and Kunckel in the early history of phosphorus, he attributed the perfection of the method of preparations to the illustrious Boyle. In his book, Observationum Physico-Chymicorum Selectorum, libri III (Halle, 1736; 1st ed., 1722), Hoffman described "Experimenta circa Phosphorum Anglicanum" (Lib. III, Obs. XIV), ten in number, paying particular attention to its behavior when dissolved in essential oils. It is highly significant that he should call the material "English phosphorus," despite the many other names originally used on the Continent.

Phosphorus ${ }^{15}$ was made in France by Jean Hellot (1685-1766), and the method published in the Memoirs of the French Academy for 1737, and in Macquer's Elemens de Chymie (1749), translated by Andrew Reid in 1764. The French pharmacist G. F. Rouelle (1703-1770) made phosphorus in public, during his lectures on chemistry, and the Abbé Nollet (1748) experimented with it.

In Germany in 1743, Marggraf (1709-1782) discovered a better method of preparation from urine, published in his " Chymische Schriften" (1761 and 1767). He used urine with lead chloride instead of sand, and also found phosphorus in wheat and mustard seeds. In 1785 he reported additional methods.

The preparation of phosphorus from bones is usually attributed to J. C. Gahn working with C. W. Scheele in 1769. The discovery was unnoticed until Lorenz von Crell (1744-1816) unearthed the account in an Edinburgh medical society book, repeated the procedure with success, and published it in his Chemisches Journal for for 1778. Stag antlers were said to be especially good sources of phosphorus.

Practically all the early chemists regarded phosphorus as a compound. W. Homberg termed it an acid plus phlogiston. G. E. Stahl and J. Hellot (1737) thought of it as hydrochloric acid plus phlogiston, F. Hoffman as hydrochloric and sulphuric acid plus phlogiston and $H$. Boerhaave as sulphuric acid plus phlogiston. When burned the phlogiston escaped and the acid remained.

A. S. Marggraf showed that the white phosphorus pentoxide, formed as a result of burning, was heavier than the original phosphorus, and A. L. Lavoisier found that the acid weighed more than the original phosphorus owing to something taken from the air,

${ }^{15}$ A letter of J. G. Gmelin (1674-1728) of Tubingen to J. W. Dieterich of Nürnberg indicated that Gmelin prepared phosphorus from urine and charcoal in Sweden in 1715. See H. Peters Phar. Ztg. 37: 607, 1892. 
i. e., oxygen. He later established its simple character and included it in his list of elements, together with light and caloric.

\section{RELATION TO OXYGEN}

One of the characteristics of phosphorus luminescence is its dependence on the presence of oxygen. The history of this discovery is long, involving many workers and contradictory results, and was not finally settled until the nineteenth century, but is introduced here, because srime of the earliest experiments were designed to answer the questions. It will be recalled that Boyle's experiment with phosphorus smeared on paper and placed under his air pump, gave inconclusive results, and his spectators agreed that the trials should be repeated. No more complicated test could have been undertaken, as the relation between phosphorus luminescence and oxygen pressure depends on temperature and water vapor, as well as oxygen. Moreover, the presence of small amounts of inhibitors greatly affect the results.

Nevertheless, a number of early workers repeated Boyle's experiment with phosphorus in absence of air. Dr. Slare was one of these and another was William Homberg, whose experiments were carried out in the house of M. d'Alence, and are described by Lémery. A small piece of solid phosphorus was placed in a little glass bottle containing a brass cock which was connected with a large evacuated jar. When the cock was opened a great flash of light occurred as the air from the phosphorus bottle rushed into the jar, the phosphorus became heated but the light practically disappeared. On admitting air the light returned. The experiment would seem to indicate the necessity of air for luminescence. However, a second trial gave the opposite result: ${ }^{16}$

When the air was drawn out of the bottle the Phosphorus did shine brighter; on the contrary when we let the air again into it, the Phosphorus went out: which is quite different from what hapned whilst the bottle that held the Phosphorus was hot in the former Experiment. We repeated the Experiments divers times, and saw the same thing continually happen: that is to say, that Phosphorus being heated lost much of its light, when the air was pumped out of the bottle wherein it was contained, and it recovered light again when new air was let into it: on the contrary, the Phosphorus being cold did shine when the air was pumped out of the bottle, and the light disappeared when the air was let into it.

Lémery was puzzled by the fact that " the air does sometimes make

${ }^{18}$ Quotations from W. Harris translation, A course of chymistry, 529-530, London, 1686, from fifth French edition. 
the Phosphorus shine, and sometimes not," and endeavored to "explicate this difficulty" by comparison with small (cold) fires that are snuffed out by too much air (wind), whereas great (hot) fires burn more brightly. The experiments illustrate how important it is to control conditions rigidly and how early in the history of experimental science observers were plagued by conflicting results.

The increase in brightness of phosphorus vapor with decreasing oxygen pressure was also observed by F. Hauksbee, Secretary of the Royal Society. In 1705 he wrote:

In pursuance to the Commands of this Honourable Society, Having a dark Room provided, the first Experiment was by drawing some Lines on a piece of blue Paper with the Phosphorus, which became immediately Luminous in the open Air, having a continual undulating Motion. This being plac'd under a Receiver, after some few Exsuctions, the Undulation ceas'd, but the Luminous Quality appeared to be in a great measure increas'd; the Receiver being farther exhausted, it became manifestly brighter; and so continu'd, till on the admission of Air (which was gradually done) the Light sensibly diminishing all the while. But upon the Repitition of the Experiment, it was the Opinion of those Gentlemen then present, that it did not appear altogether so brisk or so vivid as at first.

With a piece of solid phosphorus Hauksbee noticed the same thing except that this time "Upon letting in the Air the Light perfectly vanish'd; and it would have been in vain (as I have often try'd) to have awaited in expectation of its Recovery in the open Air."

After the experiments of Hauksbee, the study of phosphorus became largely a search for new sources and new methods of preparing the remarkable material. In fact, the relation of phosphorus to oxygen could not be properly investigated until the various gases had been isolated as entities and purified. Research on the behavior of phosphorus in vacuo or in gases was not carried out until the 1790 's and early years of the nineteenth century. Included in the list of workers were many prominent chemists-A. F. de Fourcroy (1788), C. L. Berthollet (1795), J. F. A. Göttling (1795), A. N. von Scherer and C. C. F. Jäger (1795), L. Spallanzani (1796), L. G. Brugnatelli (1797), J. B. van Mons (1797), N. Tychsen (1797), M. van Marum (1797), C. W. Boeckmann (1800), A. Van Bemmelen (1818), A. Bellani de Monza (1813), T. Graham (1829), J. Davy (1833), N. W. Fischer (1845), and others in more recent times. A. Schroetter (1852) was particularly emphatic that the luminescence only appeared as a result of oxidation and not from evapo- 
ration as J. J. Berzelius (1843) and R. F. Marchand (1850) had claimed.

The most important early papers were those of Göttling, Berthollet, Spallanzani, and Boeckmann. They will be discussed in some detail, as they illustrate the difficulty in interpreting results, due to impure gases or traces of volatile substances, even water vapor.

Berthollet was led to study the luminescence of phosphorus after reading about the peculiar results of Göttling (1795), who found no luminescence in pure oxygen, but claimed luminescence in nitrogen, and thought the nitrogen acted on the phosphorus. Berthollet was surprised to find that phosphorus did luminesce in nitrogen gas, but the light was weak and did not last long. He was even more surprised to note, as Göttling had claimed, that in pure oxygen at room temperature, no luminescence of phosphorus was visible, but on slight heating light appeared.

If a bubble of oxygen was allowed to enter the nonluminescent sample of phosphorus in nitrogen gas, the luminescence started again. He consequently suggested that nitrogen decomposed (dissous) the phosphorus, and that only after this change could oxygen attack it, forming white fumes of acid, accompanied by luminescence in the dark. Berthollet also attributed the weak light in "pure" nitrogen to the presence of small amounts of oxygen, as did de Mons (1797) at a later date.

Spallanzani, like Berthollet, was intrigued with Göttling's observations, and wrote a booklet, Chimico esame degli Esperimenti del Sig. Göttling sopra la Luce del Fosforo di Kunkel Osservata nell'Aria Comune (Modena, 1796), ${ }^{17}$ in which, as usual, he came to the correct conclusion. His essential findings were translated in the Annalen der Physik for 1799. Spallanzani studied luminous wood (see Chapter XIV) in addition to Kunckel's phosphorus and found that both luminescences became weaker in nitrogen or in marsh gas, and returned to the original brightness in air. He therefore concluded that both were the result of a slow combustion, and criticized Göttling's conclusions.

Of special interest is another book, Versuche über das Verhalten des Phosphors in verscheidenen Gasarten (Erlangen, 1800) of C. W. Boeckmann, who made a minute comparison of the luminescence of both phosphorus and shining wood in various gases. Boeckmann's results with respect to Kunkel's phosphorus are as follows: ${ }^{18}$

${ }_{17}$ Translated in Ann. der Physik 1: 33-63, 1799.

${ }^{18}$ From the translation in Phil. Mag. 16: 18-26, 1803. In addition to Göttling's paper the first volume (1795) of Gren's Neues Jour. der Physik contained papers on phosphorus by Lemke and Lampadius and by Hauch. After four volumes, the Journal was continued as Gilbert's Annalen der Physik. 
Ist, It becomes luminous in oxygen gas only at a temperature of about $16^{\circ}$ to $22^{\circ}$ of Reaumur.

$2 \mathrm{dly}$, Of all the non-respirable gases as pure as possible, it is luminous only in azotic gas, oxidated azotic gas, and muriatic acid gas.

3 dly, In muriatic acid gas it inflames immediately of itself, and burns with great brightness.

4thly, The light of phosphorus is stronger in rarefied air.

5 thly, It emits no light in vacuo.

6 thly, On being subjected to heat, it inflames and burns with rapidity in oxygen gas; and in the non-respirable gases, not pure, its light is stronger.

7thly, By its phosphorescence in oxygen gas no carbonic acid is formed.

8thly, When artificial phosphorus has emitted light in the nonrespirable gases not perfectly freed from oxygen gas, a fresh piece of phosphorus does not become luminous in them: azotic gas, however, is an exception, in which, after being purified, phosphorus becomes luminous for some time.

9thly, Moisture and wet are impediments to its being luminous.

10thly, Fluids are altogether contrary to the luminous property of artificial phosphorus.

In his comparison with shining wood (see Chapter XIV), Broeckman found some differences, especially in the conditions necessary for phosphorus to become luminous, and therefore held that the assertion of Spallanzani, that the greatest analogy exists between the luminous phenomena of wood and of phosphorus, must lose some of its weight.

Some of Boeckmann's statements are correct and some are wrong, owing to the use of impure gases. As indicated in the first conclusion, temperature, noticed by Lémery many years ago, is most important, and other conditions ( $c f$. conclusion 9) greatly affect the luminescence. Only through a very large number of subsequent workers was the fact established that a certain minimum pressure of oxygen is necessary for luminescence and in addition there is a " maximum luminescence pressure " of oxygen above which no luminescence occurs. The exact values for these critical pressures depend in a complicated manner on temperature, water vapor, and presence of quenching impurities. Such relations are responsible for the paradoxical fact that sometimes phosphorus appears to luminesce with greater intensity as the oxygen pressure is lowered, mentioned by Boeckmann in conclusion 4.

Perhaps the most extraordinary finding of the eighteenth century is that phosphorus does not luminesce in 100 per cent oxygen at ordinary temperatures. This observation appears to have been made as early as 1788 by A. F. de Fourcroy, and has been confirmed by 
practically all workers since then. If the oxygen pressure is lowered, luminescence reappears, and at a higher pressure, the higher the temperature. C. F. Schönbein (1853) and also W. Müller (1870) reported that phosphorus can be kept in pure oxygen for $2 \frac{1}{2}$ months at room temperature with no luminescence and no oxidation or ozone formation. This unusual relation of one of the most inflammable substances led, during the second half of the nineteenth and the first part of the twentieth century to a concerted effort to obtain quantitative values for the luminescence intensity of phosphorus at different oxygen pressures.

One of the best general contributions was by J. Joubert in 1874, a thesis on phosphorus luminescence in general. Joubert found that the maximum luminescence pressure in oxygen is a linear function of the temperature and a linear function of the volume per cent of foreign gas added to the oxygen. He gave equations to express the relationship and also held there is no doubt of the absence of luminescence in complete absence of oxygen, but found the pressure was too low to measure accurately. Joubert also noted the effect of inhibitors and the periodic flashes of light so characteristic of phosphorus luminescence. Since then additional studies have been made by T. Ewan (1894, 1895), with comment by J. H. van't Hoff (1895), by $\mathrm{M}$. Centnerszwer (1898). In fact the amount of research ${ }^{19}$ which was carried out during the nineteenth and early twentieth centuries on the conditions for luminescence of phosphorus is truly overwhelming, and no history could do justice to it without becoming a monograph on the subject. Only two of several factors which influence the luminescence can be considered, water vapor and volatile inhibitors or quenchers.

\section{RELATION TO WATER VAPOR}

It has been observed for a long time that many reactions will not proceed in absence of traces of water, which appears to act as a catalyst. In the Dissertation on Elective Attractions (1785: 213) translated from the Latin (1775), T. O. Bergman (1735-1784), noted that water is necessary for the spontaneous combustion of phosphorus, and K. W. Scheele ${ }^{20}$ reported that a pyrophore would not ignite in air which had been dried over quicklime. In 1795 Wilhelm August Lampadius (1772-1842) demonstrated that phosphorus does not luminesce in dry air.

Others who have studied the relation of phosphorus luminescence

\footnotetext{
${ }^{10}$ See the account in J. W. Mellor's Comprehensive treatise on inorganic and theoretical chemistry 8: 771-782, 1928.

${ }^{20}$ Experiments on air and fire $(1786: 112,130)$.
} 
to water vapor are L. J. Thenard (1812), C. F. Schönbein (1845), L. Gmelin's Handbuch (1849: 116), J. Davy (1833), W. Schmid (1866), H. B. Baker $(1885,1888)$, and R. H. Brembridge (1889). The Baker work was very carefully done and indicated no luminosity of phosphorus in dry oxygen at any pressure, and no burning, even if phosphorus is raised to its boiling point, a truly remarkable observation.

T. Ewan (1895) could not obtain consistent curves for oxidation of phosphorus in dry oxygen, and the subject has presented great difficulties, because of the marked effect of traces of water vapor. However, there is no doubt but that the light is dependent on oxygen, i. e., phosphorus luminescence involves oxidation, provided the conditions under which oxidation can occur, are satisfied.

\section{QUENCHING OF LUMINESCENCE}

The importance of quenching processes has already been pointed out in connection with fluorescence, where the effect of chloride on quinine sulphate was noted by Stokes (1852). This phenomenon is to be expected whenever luminescence occurs in the gas or liquid phase. The effect of foreign substances in decreasing light emission when electrical discharges occur in gases appears to have been first observed in preparing a mercury barometer that would luminesce (see Chapter VII) .

The influence of quenching substances on phosphorus luminescence is perhaps the oldest of all quenching observation. Boyle (1681) noticed the extinguishing effect of mace and aniseed oils, while Lémery (1686) mentioned camphor as putting out the light of phosphorus. Since that time many workers have turned their attention to this specialized field. The quenching effect of vapors or gases has been observed by C. L. Berthollet (1795), T. Graham (1829), J. Davy (1833), H. A. von Vogel (1840), C. F. Schönbein (1845), M. H. Deschamps (1861), J. Joubert (1874), J. Chappuis (1881), F. Molnar (1883) and M. Centnerszwer (1898). According to Graham, whose study was quite extensive, the quenching gases or vapors include $\mathrm{Cl}, \mathrm{S}, \mathrm{I}, \mathrm{H}_{2} \mathrm{~S}$, ethylene, ethyl ether, naphtha, alcohol, acetone, turpentine, camphor, and many others, while $\mathrm{H}_{2}$, $\mathrm{N}_{2}, \mathrm{NO}_{2}, \mathrm{CO}_{2}$ and $\mathrm{CO}$ may increase the luminescence. Davy stressed the quenching effect of $\mathrm{CH}_{4}$ and pointed out that lack of luminescence in pure oxygen might be due to presence of quenchers. Schönbein held that the quenchers destroyed ozone which accelerated the phosphorus oxidation, and Centnerszwer also believed that ozone was a catalyst for phosphorus oxidation, but found the explanation of quenching more complicated. 


\section{PERIODIC PHENOMENA}

One of the remarkable properties of phosphorus luminescence is the periodic appearance and disappearance of the light under certain conditions. It was noticed by the earliest observers. For example, Boyle (1680) wrote that the light from material on his hands "seemed to tremble much, and sometimes, as it were, to blaze out with sudden flashes, that were not lasting." Fred. Slare (1681), noted flashes like lightning in a jar containing phosphorus, while Hauksbee (1705) referred to the "undulating motion" of lines drawn with phosphorus on a piece of paper.

During the eighteenth and nineteenth centuries, particularly the latter part of the nineteenth, when the behavior of phosphorus in various gases and the influence of inhibiting vapors was being studied, the periodic luminescence was frequently observed. The pulsating light appears when conditions are critical for luminescence, for example near the lower or upper luminescence pressure of oxygen or when enough inhibitor is present nearly to suppress the light. Conditions may be chosen so that a wave or pulse of light will spread through phosphorus vapor.

The meaning of the periodic luminescence has baffled investigators. Most of the theories concerning the phenomenon have been suggested after 1900 and only one will be mentioned. The simplest explanation is that an impermeable film, presumably of phosphorus pentoxide, prevents the reaction of phosphorus and oxygen. Such a film would explain the lack of luminescence in pure oxygen until the temperature has been raised to the point where evaporation of phosphorus can take place through the film. Any destruction of the film would allow oxidation and luminescence to proceed. The periodic breaking of a film might occur under critical conditions of oxidation velocity determined by the presence of inhibitors. For example I. Corne (1882) held that the action of turpentine vapor was to form a solid "acide terebenthophosphoreux" film which preserved the phosphorus against the action of oxygen. Corne believed that phosphorus was not attached directly by oxygen but that vaporization must occur first; hence no light appears in pure oxygen because the high pressure of oxygen prevents vaporization. Despite the research devoted to the problem of periodic luminescence, a satisfactory explanation has not yet been achieved.

\section{RELATION TO OZONE}

The peculiar behavior of phosphorus luminescence resulted in many theories of mechanism during the twentieth century and it is 
worth while to emphasize some of the significant facts which were brought out before 1900. Schönbein's discovery of ozone (1840) and his suggestion ${ }^{21}(1845,1848)$ that the ozone found in phosphorus oxidation is associated with the luminescence process because inhibitors which suppress luminescence are the same as those which destroy ozone, ${ }^{22}$ concentrated attention on this substance. He also found (1853) that red phosphorus does not luminesce and no ozone appears on oxidation.

It was discovered by J. Chappuis (1881) that if yellow phosphorus is placed in pure oxygen, where no light appears, luminescence will begin if ozone is introduced into the vessel; i. e., ozone will raise the maximum luminescence pressure of phosphorus. Chappuis consequently thought the light was connected with decomposition of ozone. Moreover, ozone itself has been shown to luminesce during thermal decomposition (see a later section). In addition to Schönbein, N. Blondlot (1868), J. Joubert (1874), and I. Corne (1882) also emphasized the importance of ozone and it was thought to be a universal accompaniment of the luminescence.

An interesting result of the relation between ozone and phosphorus was a study by W. Moffatt (1863) of the luminescence of phosphorus in relation to atmospheric conditions. He made observations over a three-year period and found that phosphorus became luminous before storms, when ozone in the air is at a maximum, corresponding to the "south current" of the atmosphere and to magnetic disturbances; non-phosphorescence and minimum ozone occurred during the " north or polar current." Moffatt also observed that the white vapor of phosphorus was attracted to a magnet and concluded: "It appears then that there is an intimate connection between phosphorescence, atmospheric ozone, storms and negative electricity ... and terrestrial magnetism."

Most workers agree that during oxidation a trioxide $\left(\mathrm{P}_{4} \mathrm{O}_{6}\right)$ is formed first and that oxidation of trioxide to pentoxide $\left(\mathrm{P}_{2} \mathrm{O}_{5}\right)$ presents all the luminescence phenomena that oxidation of phosphorus itself presents. T. E. Thorpe and A. E. Tutton (1890) made a special study of trioxide oxidation and pointed out that oxidation of phosphorus to phosphorus pentoxide requires the formation of ozone $\left(\mathrm{P}_{2}+30_{2}=\mathrm{P}_{2} \mathrm{O}_{5}+\mathrm{O} ; \mathrm{O}+\mathrm{O}_{2}=\mathrm{O}_{3}\right)$, whereas the oxidation of phosphorus trioxide does not $\left(\mathrm{P}_{4} \mathrm{O}_{6}+2 \mathrm{O}_{2}=2 \mathrm{P}_{2} \mathrm{O}_{5}\right)$. They could

${ }^{21} \mathrm{~J}$. C. G. de Marignac (1845) presented similar ideas. He showed that pure oxygen passed over phosphorus does not result in ozone formation.

${ }^{29}$ The work of E. Gilchrist (1923) and H. J. Emelaeus (1926) has indicated that several phosphorus inhibitors are not ozone destroyers. Chappuis (1881) found that phosphorus and vapor of turpentine, a strong inhibitor for phosphorus luminescence, will light momentarily when ozone is admitted to the vessel. 
find no ozone or $\mathrm{H}_{2} \mathrm{O}_{2}$ in moist trioxide oxidation ${ }^{23}$ despite the luminescence. Therefore, it would appear that ozone is a by-product of oxidation rather than an essential factor in luminescence. Thorpe and Tutton held that the second step in oxidation resulted in light emission. The result suggests that $\mathrm{P}_{2} \mathrm{O}_{5}$ molecules are the emittors but the spectrum of phosphorescence was not studied until 1912. ${ }^{24}$

One early discovery that has had a lasting influence on later work was the observation that the air which has passed over luminescent phosphorus can discharge negative or positively charged bodies (C. Matteucci, 1850). This is a sign that the air has become a conductor of electricity such as was generally observed for gases in flames by W. Giese in 1882. In discussing the nature of ozone, R. Clausius (1858) was led to assume that oxygen was split by phosphorus into atoms with positive and negative charges. These charged atoms or ions would conduct the current.

The electrical conductivity of phosphorus vapor was investigated by Elster and Geitel (1890) and attributed to the changes resulting in ozone formation, but they found ozone itself was not responsible. That ions are formed is indicated by the fact that phosphorus vapors will condense a steam jet (Helmholtz and Richarz, 1890), which led J. H. van't Hoff (1895) to postulate the formation of oxygen atoms, one oxidizing the phosphorus and the other forming ozone with oxygen. The possibility gave rise to much discussion by many workers during the first decade of the twentieth century.

The striking discoveries connected with radioactivity of uranium and radium stimulated the claim that phosphorus produced penetrating rays ${ }^{25}$ which would affect a photographic plate and an emanation ${ }^{26}$ of phosphorus was described like that of uranium. These conclusions were later disproved, after a considerable amount of research in the twentieth century but there is no doubt of the formation of something which increases the electrical conductivity. Much of the twentieth-century discussion has dealt with the question whether this material consists of charged particles or true gaseous ions.

${ }^{23}$ E. Scharff (1907) also claimed that no ozone is formed during oxidation of $\mathrm{P}_{4} \mathrm{O}_{8}$ although luminescence appears, but W. E. Downey (1924) has detected ozone.

${ }^{24}$ By M. Centnerszwer and A. Petrikaln. Ztschr. für physik. Chemie 80: 235-240, 1912.

${ }^{25}$ A similar penetrating radiation was supposed to be emitted from fireflies by $\mathbf{H}$. Muraoka (1896). See Chap. XVI. L. Kann (1899) published preliminary experiments, claiming penetrating radiation from Balmain's paint.

${ }^{28}$ R. Schenck and E. Breuning, Ber. d. d. chem. Gesell. 47:2601-2611, 1914; see also 39: 1506-1521, 1906. 


\section{COMMERCIAL USE}

At the present time, the derivatives of phosphorus, such as phosphide in the metal industry and phosphate in fertilizer, are more valuable than the element phosphorus itself. The latter is sometimes used in rat poisons but no practical value has been found for the luminescence. A phosphorus burn is so disagreeable and the danger of fire such as hazard, that phosphorus in luminescence kits as a novelty have never taken the public fancy.

Nevertheless, ever since its discovery, phosphorus has lent itself to trickery and horseplay of all kinds. Boyle (1680) spoke of "divers ludicrous experiments," but decided to "purposly pass over . . . these trifles," which no doubt consisted in making the faces of his friends luminous. ${ }^{27}$ One instance is reported by J. L. Hanneman, professor of medicine at the University of Kiel, in the Ephémèrides ${ }^{28}$ for 1697 . He rubbed phosphorus on the face of a colleague, making it look like a multitude of glowworms. Unfortunately one bit, rubbed rather more vigorously than the rest, caught fire and burned his hair, "causing much grief."

Later the use of phosphorus was cited by Stephen Fovargue in A New Catalogue of Vulgar Errors (Cambridge, 1767) to indicate how absurd is the belief in ghosts. He described in some detail the way "these gentry [the chymists] could "frighten a whole Village" by drawing with phosphorus a figure of the devil in some dark place and you may guess the Surprise of the poor Country People, at seeing the Old Gentleman on the Wall.-They all took to their heels." Tales of such pranks could be repeated indefinitely, especially instances in which the phosphorus started serious fires or caused serious burns to would-be human ghosts.

The middle nineteenth century required large amounts of yellow phosphorus in the match industry. The yellow variety has now been discontinued in favor of safer material, the allotrophic red modification of phosphorus, which does not luminesce and does not easily take fire. However, the old designation, "phosphorus fulgurans," which served to contrast the inflammable and the Bononian or the Baldewinian phosphori, suggests the use of such material in firemaking. The earliest workers could not fail to notice that phosphorus readily ignited organic matter, and the first commercial firesetting device appears to have been the phosphoric taper or phosphoric bottle, used in France around 1781. This was a vessel containing phosphorus, placed in warm water to melt the contents. If

${ }^{27}$ Fred Slare (Philos. Collec. No. 3: 48-50, 1680) reported such an occasion.

${ }^{28}$ Translated in the Coll. Académique Etranger 6: 336. 
a frayed wax taper was then dipped in the liquid phosphorus and withdrawn from the bottle it would light spontaneously. In 1786 in Italy a sulphur-tipped splint of wood was used to dip in phosphorus instead of a taper. The wood usually ignited on withdrawal.

Friction matches (lucifers) made of potassium chlorate, antimony sulphide, and starch mixture, with gum as a binder on the tip of the wood, were made in 1826 by John Walker of England. When rubbed on sandpaper they would usually ignite, but replacement of phosphorus for the antimony sulphide by Charles Sauria in 1830 was a great improvement and marked the successful beginning of the match industry, for which phosphorus has been an important material for many years, despite its poisonous action in the human body. ${ }^{29}$

MEDICAL USE

It is not surprising to find that so remarkable a substance as phosphorus should be used in medicine. A remedy which emitted light must have had a special appeal to the patient eager for relief. A letter from J. C. Sturm in the Philosophical Collections, No. 2 (1681) stated: "This Chymist Dr. Kunkell prepares out of the same condensed Light (which by his skill he knows how to Extract out of any kind of Terrestrial Body whatsoever as if it were there naturally placed) certain Pills about the bigness of Peas (to which he ascribes very strange Conforting and Medicinal Virtues)...."

Somewhat later, in 1733, a Dr. Kramer, physician to the Elector of Saxony, employed a preparation of phosphorus with great success in epilepsies, insanity, and malignant fevers. He alleged the patients recovered miraculously and many physicians adopted phosphorus as a remedy.

One of these was Hermann Friedrich Teichmeyer (1685-1744), a physicist as well as a physician, whose extended treatment of luminescences has been referred to in Chapter V. In his Institutiones Materiae Medicae (Jena, 1737), Teichmeyer noted that now phorphorus could be prepared in quantity as a result of the labors of Hanckewitz, and recommended the material for all sorts of kidney complaints, particularly for dissolving renal calculi. Concerning phosphorus he wrote: "Nephritica autem sunt medicamenta renibus dictata."

Several theses appeared on the subject in the middle of the eighteenth century, by Mentz (Menzius, 1751), F. J. Kikinger (1759), and Hartmann (1760). Mentz held that phosphorus has

${ }^{29}$ See M. F. Cross, Jr., A history of the match industry, Jour. Chem. Educ. 18: 116$120,277-282,316-319,380-384,1941$. 
virtue in such malignant fevers as bilious fever and whenever it is necessary to revive the energy of the patient, while Hartmann's recommendation was for miliary and petechial fevers. He had observed the practical effect of the remedy in measles, pleuropneumonia, and for the pains of rheumatism, epilepsy, and opthalmia, both bloody and serous.

A French doctor, Alphonse Leroi, ${ }^{30}$ gave such heavy doses that the body of a patient who had died was found on autopsy to have luminous internal organs. Leroi himself took three grams of phosphorus in treacle and was very much disordered for a time but next day his strength was doubled and his sexual appetite greatly enhanced. This observation led to the use of phosphorus for impotence, a fact mentioned by Erasmus Darwin in Zoonomia (1794). Leroi employed phosphorus internally with great success " especially to restore and revive young persons exhausted by excesses."

De Lens in his article on "Phosphore" in the Dictionaire des Sciences Médicales (1820) devoted twenty-four pages to properties, pharmaceutical preparations, physiological and toxic action, and therapeutic applications of phosphorus. He referred to a certain case of Leroi as a successful experience, the patient, a woman affected with " une fièvre putride... et qui succomba aux suites d'une imprudence." In those days phosphorus was frequently given in cases of headache, extreme debility, paralysis, epilepsy, melancholy, gouty rheumatism, hydropsies, fevers of a bad character, and other organic maladies.

Most pharmacologies devoted a section to phosphorus. A book on the subject was published by F. Bouttatz in 1800, Ueber den Phosphor als Arzneimittel, in Göttingen. The use of phosphorus dissolved in oil rather than the raw material became more general, and a highly favorable appraisal is given in the book, Recherches et Observations sur le Phosphore (1815), by J. F. D. Lobstein, translated as Researches and Observations on the Use of Phosphorus in the Treatment of Various Diseases (Philadelphia, 1825). The book contains a letter from Lafayette, and was subscribed to by Thomas Jefferson. Lobstein concluded that phosphorus, in danger of removal from the pharmacopoeia because of its caustic nature, was actually " a remedy capable of producing extraordinary effects in various internal diseases ... extremely dangerous to administer [but] confined to judicious hands, [although] not a universal panacea ... good effects [were obtained in] asthenic diseases and chronic agues. ..."

${ }^{30}$ See the account in Phil. Mag. 2: 290-293, 1798. 
However, Dr. W. E. Horner, a Philadelphia physician, wrote in his Home Book of Health and Medicine (Philadelphia, 1834) : "It has been recommended in a variety of diseases, but must be considered as an uncertain and dangerous prescription."

The use of phosphorus in the match industry in the first half of the nineteenth century led to many serious cases of phosphorus poisoning. The history of this poison, the symptoms, the theory of action and treatment have been reviewed by P. Munk and E. Leyden in Die acute Phosphor-Vergiftung (Berlin, 1865). The element phosphorus as a physic has disappeared from the materia medica of physicians, despite its mysterious and attractive luminescence. ${ }^{31}$

\section{Miscellaneous Chemiluminescent Phenomena in Gases}

A few other phenomena that appear to involve gaseous chemiluminescence were observed in the eighteenth century. The most quoted work is that of Martin van Marum (1750-1837), a physician and director of the physical and natural history museum in Haarlem, who noticed $(1776,1782)$ that many oils (linseed, olive, butter, etc.) when heated to $100^{\circ} \mathrm{F}$ or above would luminesce. Wedgwood (1792), Brugnatelli (1797), Göttling (1800), and many others observed similar phenomena. Undoubtedly oxidation processes were proceeding, possibly below the ignition point. In 1809-1810, Dessaignes actually showed that many powdered organic bodies strewn on a hot plate required air for luminescence, indicating a combustion (see Chapter IX) Heinrich, also, included many combustible bodies in the second section (1812) of his book, Die Phosphorescenz der Körper, which dealt with thermoluminescent minerals, with phosphorus, and with heated vapors. He described the vapor that bursts into flame when fuming $\mathrm{HNO}_{3}$ is added to alcohol, turpentine, $^{32}$ citron, and other oils, and the luminous phenomena observed when oils of various kinds are heated in the dark.

Such occurrences might be considered allied to incandescence and of little interest for the history of luminescence. Many kinds of pyrophores, bodies that spontaneously take fire in the air, were known to early chemists. However, most chemiluminescences require the presence of oxygen also, and it is not possible to argue that a light accompanying the vaporization of oils necessarily indicates a local high temperature with incandescence from the heat of combustion. In fact among the substances listed by Radziszewski

${ }^{31}$ For various nineteenth-century opinions on phosphorus in medicine and phos. phorus poisoning, see J. H. Robbi (1818), A. B. Poggiale (1859), and E. R. Arnaud (1897).

${ }^{82}$ Discovered by Rouelle (1747). 
(1880), which could be oxidized with light emission in solution, were oils in alkaline solution. The luminous phenomena accompanying vaporized oils should be reinvestigated; as it is quite possible that chemiluminescence is involved.

Another luminescence, somewhat akin to that of phosphorus, may be observed with metals. After the preparation of pure alkali metals by Sir Humphry Davy (1778-1829) around 1807, it was recorded by W. Petrie (1850) and also by E. Linnemann (1858) and H. Baumhauer (1867), that fresh-cut surfaces of potassium and sodium are luminous and remain so for an hour or so until they become covered with a film of hydroxide. According to Phipson (1859), the light is especially bright at $70^{\circ} \mathrm{C}$. Petrie realized that the light was of chemical origin. At that time the light of most gases and metals in flames was attributed to increase in temperature, although $\mathrm{J}$. W. Draper (1848) had investigated hot flames and entitled his paper, " On the Production of Light by Chemical Action."

Certain types of "cold" flames involving chemiluminescence can be obtained with metals. In the vapor state sodium will luminesce, emitting the yellow D lines in contact with halogens, ${ }^{33}$ with hydrogen, or with mercuric halides at a relatively low temperature. A number of other metals behave in a similar manner. For example, mercury vapor coming in contact with chlorine, luminesces green; with bromine, a yellow, and with iodine, an orange-red light appears. These and allied chemiluminescences emitted during a reaction between simple gas molecules, have been much studied in the twentieth century.

The light which appears when "active nitrogen" or "active hydrogen" (nitrogen and hydrogen atoms) are formed after an electrical discharge and the two atoms recombine to the molecule can be considered a chemiluminescence provided the recombination explanation of mechanism is the correct one. On the other hand, if the light comes from "metastable" molecules of nitrogen of long life, formed during the electrical discharge, the after-glow should not be designated chemiluminescence.

This yellow after-glow of nitrogen is a striking phenomenon. It has been found that pure nitrogen shows a very weak after-glow; a small amount of oxygen or some other gas is necessary for an easily visible light. Although "phosphorescence" of gases after passage of electricity was noticed by E. Becquerel (1859) and received sporadic

\footnotetext{
${ }^{33}$ The relation of quantum energy in the light emitted to the heat of reaction was first considered by F. Haber and W. Zisch (Ztschr. für Physik 1: 302-326, 1922) in the case of the yellow luminescence observed when chlorine and sodium vapor are mixed.
} 
attention during the nineteenth century (see Chapter VII), it was the studies of E. P. Lewis $(1899,1900)$ on nitrogen and the new views on emission of light from "excited" atoms and molecules that again led to the twentieth-century discussion and controversy over the nature of "active nitrogen," so called because of chemical activity. The principle study of the conditions favoring formation of active nitrogen was carried out by R. J. Strutt, later Lord Rayleigh, beginning in 1910.

Another gas, hydrogen, exhibits an after-glow of much shorter duration ( 0.2 second) under conditions similar to those of nitrogen, as shown by R. W. Wood in 1920. Both active hydrogen and active nitrogen are of particular interest, not only because of their selfluminosity but because they excite luminescence of material they come in contact with-gases or metals like sodium or mercury, as well as certain phosphors and fluorescent substances. All these bodies then glow with their characteristic spectra. It has been established that this effect is not due to any ultraviolet light emitted from the active gas, but by energy transfer to the luminescent body.

Another important gaseous luminescence is that connected with ozone. ${ }^{34}$ Although a peculiar smell had been noted in the vicinity of electrical discharges in the eighteenth century, it was C. F. Schönbein in (1840) who found that "l'odeur électrique" also accompanies the electrolysis of water and appeared to be a distinct gas, which he called ozone, from the Greek ozo, to smell. Later, Schönbein (1845) noted that slow oxidations like that of phosphorus also gave rise to the smell and he rather specifically connected it with the luminescence, as indicated previously.

As a strong oxidizing agent, ozone not only causes chemiluminescence of organic compounds, but there is also evidence that gaseous ozone itself may emit light. As early as 1881 , it was demonstrated by A. Schuller that ozone heated to $200-500^{\circ} \mathrm{C}$, would decompose with luminescence, and a number of later workers have confirmed the observation. ${ }^{35}$ Again the light is less marked with pure ozone, and is much influenced by various gases, some increasing and some decreasing the light.

In $1888 \mathrm{~J}$. Dewar allowed dried air to pass through an electric discharge and then enter an evacuated space by a capillary orifice,

${ }^{34}$ See the excellent summary of ozone properties by F. Fonrobert, Das Ozone, Stuttgart, 1916).

${ }^{35}$ Trautz and Seidel (Ann. der Physik 67:527-572, 1922) find no decomposition of ozone at high temperature if it is pure and free of organic vapors. That gases do not emit light merely as a result of heating was demonstrated by Thomas Wedgwood (Phil. Trans. 82: 272, 1792) who observed no light when air was passed through a red hot tube, although a strip of gold in the tube became red hot from the heated air. 
when a luminescence like the tail of a comet appeared. Only gases containing oxygen gave the effect, which Dewar attributed to ozone because starch iodide paper was darkened near the luminescence. ${ }^{36}$ It is possible that active nitrogen was partly responsible for the light in this particular experiment. Ozone excites persistent luminescences in sulphur, iodine, sodium, and other metals.

The origin of the light which appears when gases containing ozone come in contact with liquids, reported by E. Fahrig (1890) and E. Ritsert (1890), is subject to some doubt. In $1898 \mathrm{M}$. Otto made a careful study of the luminescence of ozonized air or oxygen bubbled through tap water. He found that there was no light if the water was carefully purified. The light was particularly bright in milk or urine, and Otto came to the conclusion that oxidation of organic material was responsible. Ozone will cause luminescence of chemiluminescent substances (like pyrogallol or aminophthalichydrazid) in solution, but in the case of Otto's tap water experiments, the decomposition of gaseous ozone in contact with organic material may have been the source of the luminescence, analogous to the light from decomposition of ozone at high temperature.

Another interesting action of ozone is its ability to cause luminescence of Sidot-blend $(\mathrm{ZnS})$, observed by F. Richarz and R. Schenck (1903). Ozone also causes formation of the latent image of a photographic plate and a charged electroscope becomes discharged in its presence. In fact its behavior is so similar to that of radium that during the early part of the twentieth century a number of papers were published referring to the "emanation" from reactions involving formation of ozone (see F. Richarz and R. Schenck, 1903, 1904).

Finally, we come to the chemiluminescences which take place in the so-called "cold flames," a name used to distinguish them from the incandescence of carbon particles in hot oil or gas flames, and also from the characteristic emission of metals, which is responsible for various colors in the Bunsen flame, the pyroluminescences. It is practically impossible to state who first observed a particular cold flame, but they received considerable attention in the last half of the nineteenth century. For example, the blue flame of ether at $260^{\circ}$ was studied by W. H. Perkin (1882) who remarked that it was seen by H. Davy. ${ }^{37}$ This flame does not burn paper and the ether itself is not ignited.

${ }^{36} \mathrm{~J}$. J. Thomson (1893: 184) has called attention to the phosphorescent glow in vacuum tubes containing oxygen after electrical excitation, which he has attributed to decomposition of ozone.

${ }^{87}$ Davy (1811) noted the green light of chlormonoxyd on sudden decomposition, 
Dibbits (1864) made a comprehensive study of the spectra of various flames- $\mathrm{CO}$ and $\mathrm{CN}$ in air, oxygen, and nitrous oxide, $\mathrm{H}_{2} \mathrm{~S}$ and $\mathrm{CS}_{2}{ }^{38}$ in air and nitrous oxide, etc. These spectra are not of the continuous incandescent type, although considerable ultraviolet may be emitted, as indicated by Dibbits' observation that some of the flames, especially sulphur compounds, cause fluorescence of quinine sulphate solution..$^{39}$

The luminescent vapors of phosphorus can be arranged to burn like a flame but it is less often recognized that vapors of other nonmetals, such as sulphur and arsenic behave in the same way at a slightly higher temperature, as pointed out by J. Joubert (1874), K. Heumann (1882), and many others. All these gaseous chemiluminescences, representing relatively simple reactions, became of great interest in the twentieth century.

\section{Chemiluminescence in Solution}

\section{INORGANIC COMPOUNDS}

Observation of chemiluminescence in solution begins with inorganic compounds. Placidus Heinrich devoted the fifth section of his book to "Phosphorescenz durch chemische Mischungen" (1820). He described the luminescence which appears when water or strong acids are added to fresh burnt lime (p. 584) or when corrosive alkalies (K, Na, $\mathrm{NH}_{4}$ hydroxides) are mixed with acids (p. 573-574) or when mercurous nitrate or lead acetate is treated with $\mathrm{H}_{2} \mathrm{SO}_{4}$ (p. 576).

One of the most striking luminescences of this type is the glow which accompanies the laking of freshly prepared lime. Mixing water and calcium oxide produces not only heat but light, a discovery of Johann Friedrich Meyer (1764), who discoursed at some length on light, fire, and heat in his book ${ }^{40}$ on lime. It became the subject of much discussion in the late eighteenth century, some holding that carbonic acid was replaced by the material of heat during the roasting of limestone, while others held that lime was a simple uncombined substance. The light production was considered by Dizé (1799) in connection with the then prevalent idea that heat is a substance and responsible for the luminous effects. H. Davy

and later work indicates that explosive gases like chloroazide $\left(\mathrm{N}_{3} \mathrm{Cl}\right)$ luminesce if decomposed slowly.

${ }^{38}$ See E. Pringsheim (1893) and H. B. Dixon and E. J. Russel (1899).

${ }^{30}$ This observation is by no means new as many flames were studied by Stokes (1852) (see Chap. XI).

${ }^{40} \mathrm{~J}$. F. Meyer, Chymische Versuche zur näheren Erkenntnisse der Ungelöschten Kalchs, etc., Leipzig, 1764. 
(1803) also mentioned the whitish light when lime and the reddish light when magnesia are mixed with strong acids like $\mathrm{H}_{2} \mathrm{SO}_{4}$ and $\mathrm{HCl}$. After the discovery of hydrogen peroxide it was noticed that its decomposition in the presence of catalysts like colloidal silver and platinum, $\mathrm{PbO}_{2}$ and $\mathrm{MnO}_{2}$ will result in light production.

In $1861 \mathrm{~K}$. J. von Reichenbach gathered together many instances of dim chemiluminescence which he held were the result of vibration of molecules during such processes as crystallization, fusion, solidification, effervescence, and condensation of vapors. He mentioned the light which appears when $\mathrm{H}_{2} \mathrm{SO}_{4}$ is added to water, or $\mathrm{HCl}$ to calcite, when water drops pass into steam or water is electrolysed, and other remarkable phenomena, so unusual in fact that many of his claims may have been based on unknown impurities, or may have been subjective phenomena. ${ }^{41}$

\section{ORGANIC COMPOUNDS}

The first important study of organic chemiluminescences in solution is due to Bronislaus Radziszewski (born 1838), professor of chemistry at Lemberg in Galicia. He published two papers in 1877, one dealing with the luminescence which appears when lophin, amarin, or hydrobenzamid are shaken with air in alkaline alcohol solution, the other, a few months later, describing the light of new organic compounds, aldehydes and amides, treated in the same way. These contributions were followed (1880) by investigation of a long list of organic and biological compounds, terpene oils, cholic acids, fatty acids, etc., which luminesced when oxidized in alkaline solution. The first chemiluminescent spectrum of an organic compound in solution, that of lophin, was also studied by Radziszewski (1880) and found to have a short continuous band, brightest at the Fraunhofer line E, quite similar to the spectra of some luminous animals.

Radziszewski's observations on oils and his spectral studies led him in 1883 to extract a yellowish oil from the luminous jellyfish, Pelagia noctiluca, which luminesced, "blitzartig," on shaking with alkali, just as does the living jellyfish itself, and he held that oxidation of an oil was responsible for the light. Although the idea that the luminescence of animals was due to an oil was expressed by Phipson in 1860 and 1862 and by Panceri in 1871, Radziszewski's studies on luminescent oils greatly influenced the later ideas on the chemical nature of the luminous material of luminous animals. They were reviewed by a Dr. Kolbert in the Deutsche Medezinische

11 Among other subjects, Reichenbach wrote on Od, a hypothetical force which he thought explained mesmerism and animal magnetism. 
Wochenschrift (7: 428-430, 1881) under the title, "Das Leuchten der lebenden und todten Substanzen." They served to show that not only oils but also many other organic compounds are chemiluminescent.

The history of chemiluminescence in solution is indeed a late development, mostly during the twentieth century, and a brief outline of these important discoveries follows because of their connection with light production by plants and animals.

After Radziszewski's work, the next chemiluminescent compound ${ }^{42}$ to be discovered was pyrogallol, which is especially prone to luminesce in solution, as was first noticed by J. M. Eder (1887) and P. Lenard and M. Wolf (1888) in developing a photographic plate with pyrogallol developer. Many articles have subsequently appeared from time to time describing the luminescence of photographic plates. Later pyrogallol luminescence was studied in some detail by Trautz and Schorigin (1904-1905), who developed the well-known luminescent mixture of pyrogallol, formaldehyde, potassium carbonate, and hydrogen peroxide. Luminescence appears with many organic compounds in presence of $\mathrm{H}_{2} \mathrm{O}_{2}$.

Pyrogallol can hardly be called a biological compound although some of its relatives play important roles in cell processes, especially in the plant kingdom. With the turn of the century, in 1901, a most important chemiluminescence of the substance, aesculin, the glucoside from horse-chestnut bark, was discovered by Raphael Dubois (1849-1929). His demonstration in 1887 of luciferin and luciferase, the light-emitting constituents of luminous animals, had placed the chemistry of bioluminescence on a firm foundation. Whenever a solution of luciferin, a relatively simple oxidizable substance, and a solution of the enzyme, luciferase, were mixed in the presence of dissolved oxygen, light would appear. Dubois (1901) pointed out that aesculin is a fluorescent substance and that it is only necessary to mix it with alcoholic potash to obtain a bluish chemiluminescence, as bright as that from the mucous of the mollusc, Pholas dactylus, containing luciferin and luciferase. However, the similarity to bioluminescences was even closer. J. Ville and E. Derrien discovered in 1913 that lophin could be oxidized with luminescence in the presence of $\mathrm{H}_{2} \mathrm{O}_{2}$ and haemoglobin, the latter acting as a catalyst, and Dubois in the same year found that aesculin would also luminesce with $\mathrm{H}_{2} \mathrm{O}_{2}$ and haemoglobin. E. N. Harvey (1916) noted the light emitted when pyrogallol is mixed with peroxidase and $\mathrm{H}_{2} \mathrm{O}_{2}$. As a result of these experiments the fundamental light-

$4^{2}$ B. Lachowiez (1882) reported the luminescence of paraphenanthrenchinon when warmed in alcoholic $\mathrm{KOH}$ solution. 
producing process in animals and plants had been imitated in a test tube.

In the meantime, Trautz (1905) discovered many more biological substances to be chemiluminescent, ${ }^{43}$ Guinchant (1905) noted chemiluminescence of uric acid and asparagin, Weitlaner (1911) of substances in humus, and McDermott (1913) of substances in urine and the anaerobic alkaline hydrolysis products of glue and Witte's peptone, when oxidized by strong oxidizing agents like $\mathrm{H}_{2} \mathrm{O}_{2}$, hypochlorite, etc. Later many more organic chemiluminescent substances were discovered, among them the most brilliant and important aminophthalichydrazid (luminol), by H. O. Albrecht in 1928, and dimethyldiacridinium nitrate (lucigenin), by K. Gleu and P. Petsch in 1935. At this time, research in chemiluminescence was largely concerned with designation of the excited molecule and the mechanism of the light emission, a field without the scope of this history.

No book devoted entirely to chemiluminescence (apart from studies of animal light) appeared in the nineteenth century, and in fact even today the subject has been treated as a whole only in articles or in chapters of larger works. The early twentieth century was a period of expanding interest in the subject. A systematic search for new chemiluminescent reactions was made by Max Trautz, whose general article of 110 pages, "Studien über Chemilumineszenz" was published in the Zeitschrift für Physikalische Chemie for 1905. The relation of crystalloluminescence and triboluminescence to chemiluminescence was included and all aspects treated at length.

Since then many new chemiluminescent compounds have been discovered, of which the list includes the organic sulphur compounds of Delepine in 1910; oxidative reactions at the surface of siloxene compounds by $\mathrm{H}$. Kautsky in 1921, supplying beautiful examples of sensitized chemiluminescence (Kautsky and H. Zocher, 1922; Zocher and Kautsky, 1923); aminophthalichydrazid (luminol), by $H$. O. Albrecht in 1928; dimethyldiacridinium nitrate (lucigenin), by K. Gleu and P. Petsch in 1935; and metal phthalocyanin and metal porphyrin compounds, by J. H. Helberger in $1938 .{ }^{43}$

Spectroscopically the chemiluminescences in solution exhibit moderately narrow bands in different regions of the visible spectrum, as pointed out by Radziszewski (1880) in his early studies. Every color is represented; luminol luminescence is blue, lucigenin yellow,

\footnotetext{
${ }^{43}$ References to the many twentieth-century studies on chemiluminescence mentioned below will be found in the books of $\mathrm{E}$. N. Harvey, The nature of animal light (Philadelphia, 1920) and Living light (Princeton, 1940).
} 
and the metal porphyrins red. Photometrically the light of some compounds (luminol) can only be described as brilliant (for luminescences), and it seems certain that much future work is destined to appear on mechanism of light emission and other aspects of these fascinating organic chemiluminescences. 


\section{PART III}

Luminescence of Living Organisms. Bioluminescence 



\section{General Statement}

THE Burning of the sea and the shining of wood, dead fish, and Iflesh were well recognized phenomena in 1600 , but the biological origin of the light was completely unknown. The existence of cucujos, fireflies, glowworms, and luminous centipedes was an obvious fact. Larger luminous sea animals, such as jellyfish, piddocks, and sea pens, indicated that living marine forms were capable of emitting light, but it was over 200 years before the diffuse phosphorescence of the sea was universally ascribed to microscopic luminous organisms. A somewhat longer time was necessary to establish the fact that phosphorescence of wood came from the luminous threads of a fungus, or that glowing meat and dead fish had colonies of luminous bacteria growing on them. Apart from some incorrect cases of light production reported among higher plants, ${ }^{1}$ these fungi

${ }^{1}$ The following are the best known reports of false luminescence among plants. The statement that Jean Senebier observed luminescence from the spadix of an arum when placed in pure oxygen is incorrect. Senebier (Physiologie vegetal, 3: 315, Geneva, 1800) had found heat produced when the spadix opened in air and suggested there might be phosphorescence in pure oxygen, but he never carried out the experiment.

The phosphorescent milky latex of Euphorbia phosphorea, reported by von Martius in Reise in Brasilien (2: 726, 746, 1828) might be explained as a reflection from heat lightning, since the observations were made during a sultry evening (gewitterschwïlen Abend). Molisch (1904: 153) was unable to observe any luminescence in the various types of latex he examined. Another record of a luminous latex from Brazil, by A. F. Mornay (Phil. Trans., 106, 279, 1816) could also be due to a dim light reflected from the white liquid. The observation was made on the curious plant, "cipo de cunanam," abundant between Monte Santo and the river Bendegó, near Bahia. Mornay wrote: "When I made a cut at the bush with my hanger, in the dusk of the evening, the wounds inflicted presented a beautiful luminous line, which was not transient, but lasted for several seconds or a quarter of a minute. Having taken a piece of the plant, I bent it in the dark until the skin cracked, when every crack showed the same light which is of a phosphorescent appearance. I continued to bend the twig until the milky juice dropped out, when each drop was a drop of fire, very much like what I have seen on dropping inflamed tallow. I did not observe any particular smell." The statement is definite, but was made "in the dusk of the evening," and hence the phenomenon cannot be designated as a true luminescence with any certainty.

Much has been written on the "flashing of flowers," since the light of the Indian Cress (Tropaeolum majus) was described in 1762 by Elizabeth Christine von Linné, the daughter of Linnaeus (Kongl. Svenska Wetenscap. Acad. Handlingar, 284, 1762). This "glow" of yellow or orange flowers, observed in the early evening has been considered an electrical phenomenon by Volta in 1799 (Meterologische Briefe 1: 24), and by Richard Pulteney in 1790 (Historical and biographical sketches of the progress of botany in England 1: 346), whereas Goethe (Zur Farbenlehre 1:21, 1810) called it an illusion. Whatever the explanation of the flashing, there is no luminescence involved.

The European dittany, Dictamnus fraxinella, is said to evolve on inflammable gas 
and bacteria are the only known members of the plant kingdom which emit a light that can be classed as a bioluminescence. Therefore, the history of light emission in the plant kingdom, the discovery of luminous bacteria and fungi, will be described in Chapter XIV under the heading, "Shining Fish, Flesh, and Wood."

The history of animal luminescence is taken up under two categories-(1) Phosphorescence or "Burning" of the Sea, the sparkling luminescence due to microscopic protozoa and other small organisms (Chapter XV), and (2) "Animal Luminescence" or "Animal Luminousness," dealing with the various groups of larger forms (Chapter XVI). The last title, "Animal Luminousness," is now somewhat archaic but was a popular expression in the nineteenth century. At the present time over forty different groups in the animal kingdom are known to be luminous. Chapter XVI contains not only the earliest observation of the luminous animals of each group, but also an account of the first studies designed to describe the characteristics and explain the mechanism of light production. $^{2}$ The various groups will be discussed under two main categories, (I) Luminous terrestrial and fresh-water forms, and (II) Luminous marine animals.

(essential oil?), which can be ignited with a match, but again luminescence cannot be claimed.

Another famous instance of false luminescence in plants has to do with the moss, Schistostega osmundacea, which lives in dimly illuminated places. Its cells are almost spherical, constructed like a lens, and some of the light condensed on the chloroplasts is reflected from the cells, again giving the appearance of self-luminosity, as in one of the modern road-marking signs.

The flagellate, Chromophyton rosanoff, is a similar case, described by Molisch (Sitzb. d.k. Akad. der Wiss. Wien, 110, abt. 1, 1901), as well as a number of marine algae, which have an irridescent appearance similar to that of the copepod, Sapphirina, or insects such as Entimus imperialis; see A. Gorbasso (Mem. della real. accad. d. Sc. di Torino, ser. 2, 46:180-186, 1896). Most of the above cases of false luminescence have been fully discussed in Leuchtenden Pflanzen (1904) by Hans Molisch. A good anonymous review will be found in Science Gossip for 1871: 121-125.

${ }^{2}$ More detailed information will be found in the book, Bioluminescence (New York, 1952), by E. N. Harvey. 


\section{SHINING FISH, FLESH, AND WOOD}

\section{Introduction}

W Henever dead fish, flesh of animals of all kinds (including man), eggs, sausages, and various dead invertebrates become luminous, it is practically certain that the light results from the growth of luminous bacteria. If the luminous material is wood, leaves, leaf mould, roots, beets, potatoes or fruit, the light is usually due to growth of luminous fungi. The evidence that Aristotle and Pliny knew of these phenomena has already been given, as well as the early descriptions of luminous wood or flesh by Reisch (1496), Oviedo (1526), Cardan (1557) and Fabricius (1592).

\section{Francis Bacon and Shining Wood}

It is fitting that the first experiments on luminous organic material should have been carried out by Francis Bacon. In his Sylva Sylvarum (1627) a section was headed: " Experiment solitary touching wood shining in the dark." As he expressed it: ${ }^{3}$

The trial sorted thus: 1. The shining is in some pieces more bright, in some more dim; but the most bright of all doth not attain to the light of a glow-worm. 2. The woods that have been tried to shine, are chiefly sallow and willow; also the ash and hazel; it may be it holdeth in others. 3 . Both roots and bodies do shine, but the roots better. 4. The colour of the shining part, by daylight, is in some pieces white, in some pieces inclining to red; which in the country they call the white and red garret. 5. The part that shineth is, for the most part, somewhat soft, and moist to feel to; but some was found to be firm and hard, so as it might be figured into a cross, or into beads, \&c. But you must not look to have an image, or the like, in any thing that is lightsome: for even a face in iron red-hot will not be seen, the light confounding the small differences, of lightsome and darksome, which show the figure. 6. There was the shining part pared off, till you came to that that did not shine; but within two days the part contiguous began also to shine, being laid abroad in the dew; so as it seemeth the putrefaction spreadeth. 7. There was other dead wood of like kind that was laid abroad, which shined not at first; but after a night's lying abroad began to shine. 8. There was other wood that did first shine; and being laid dry in the house,

${ }^{3}$ The Works of Lord Bacon 1: 124 (section 352), by B. Montagu. London, 1838. 
within five or six days lost the shining; and laid abroad again, recovered the shining. 9. Shining woods being laid in a dry room, within a sevennight lost their shining; but being laid in a cellar, or dark room, kept the shining. 10. The boring of holes in that kind of wood, and then laying it abroad, seemeth to conduce to make it shine: the cause is, for that all solution of continuity doth help on putrefaction, as was touched before. 11. No wood hath been yet tried to shine, that was cut down alive, but such as was rotted both in stock and root while it grew. 12 . Part of the wood that shined was steeped in oil, and retained the shining a fortnight. 13. The like succeeded in some steeped in water, and much better. 14. How long the shining will continue, if the wood be laid abroad every night, and taken in and sprinkled with water in the day, is not yet tried. 15. Trial was made of laying it abroad in frosty weather, which hurt it not. 16. There was a great piece of a root which did shine, and the shining part was cut off till no more shined; yet after two nights, though it were kept in a dry room, it got a shining.

These sixteen statements make up the first important scientific observations and experiments on phosphorescent wood. Bacon discovered facts which were later tested and verified many times. Almost every subsequent worker has observed that the luminous quality of wood persists under oil, in water and at low temperature-experiments designed to understand the nature of the light. Of most interest is the fact that not green wood but only dead rotting wood becomes luminous, that the wood must be moist, and that the "putrefaction spreadeth." The real clue to an explanation lies in the last statement, but science had not advanced to the point where the spreading could be attributed to the growth of a luminous fungus, a microorganism.

\section{The Luminous Mutton of Montpellier}

Following Bacon, in the seventeenth century, many observations ${ }^{4}$ on shining fish, flesh, and wood were made-by Borel, Bartholin and Puerarius on lamb-flesh in 1640-1641, by Allatius on "river lobsters" (reported by Bartholin, 1647), by Marcgrave in 1648 and Worm in 1655 on fish, by Boyle in 1667 and 1672 on wood, flesh, and fish, by Beale in 1665 and 1676 on meat, by Redi in 1672 on squid and a dead snake, and by Jacobaeus in 1679 on an octopus. Finally there is Boccone's (1684) story of Count Marsigli, who saw luminous

- Descartes in Principia philosophia (1644) discussed luminous wood and salt fish in connection with light of the sea (see Chap. IV). The light of "le bois pourri" was classed with "le vers luisant" and "étoiles" as light which cannot be seen in the daytime because of bright sunlight, by René de Cerisiere, Sr. (1605-1662), a French Jesuit and writer on historical and religious subjects, in Le Philosophie François 1: 172,1651 . The views of J. Rohault have been given in Chapter IV. 
lizard eggs and of C. F. Paullin (1687), who reported luminous hen's eggs. Many of these accounts are mere observations, but in some cases the writers presented theories of the origin of the light and Boyle and Beale performed experiments designed to find out something about the phenomenon.

\section{PIERRE BOREL}

Few occasions have given rise to more wonder and speculation than the luminous mutton which appeared at Montpellier in 1640 and 1641. One of the first to notice the light of 1640 was Petrus Borellus (Pierre Borel, 1620-1689), Royal Physician and member of the French Academy. While giving the work in medicine at Montpellier in 1640, he saw "the flesh of a wether [castrated ram] shining at night like so many glow-worms." His explanation of the phenomenon presented many years later (1657) was as follows: ${ }^{5}$

Some used to think that it arose from a particular plant eaten by the wether, for plants have been found shining at night, as fungus stellatus, and the root of Baaras, others thought that it arose from a certain rottenness, as in rotten wood, shining at night, from which they would announce a future pestilence; others attribute it to a certain magic virtue. But I consider that it was able to do this by means of viscid membranes retaining for a certain time the captured light of the sun (as the stone of Bononia has been said to do, which having been exposed to the light, afterwards shines in the dark). Thus the eyes of many retain for some time the light of the sun, just as after a sight of the sun they perceive on walls figures of the sun from images taken from it.

Borel then enumerated the various luminous phenomena known at that time and elaborated his theory further by declaring that "air is kindled daily by the sun" and "that the fiery heat of a shining part kindles the denser parts of air, whence light can be emitted to a small distance; that light, however, is so much burning air, for it is changed over in turn to elements. ..."

\section{THOMAS BARTHOLIN}

In 1636 Thomas Bartholin (1616-1680) started his travels throughout Europe and some five years later, was able to give a detailed description of another display of luminous mutton at Montpellier. Indeed, this phenomenon led him to write De Luce Animalium (1647). It was in April, 1641, that ${ }^{6}$ " with some rare spectacle, all

${ }^{5} \mathrm{P}$. Borel, Historiarum, et observationum medico physicarum, Parisii, Century I, Obs. 3: 5-7, 1657. Translated by Miss Hannah T. Croasdale.

- All Bartholin quotations have been translated from De luce hominum et brutorum, Hafniae, 1669, by Mrs. Annamarie Holborn. 
the meat of the butchers in the meat market shone very brightly and illuminated the whole environment with its clear light." The phenomenon was discovered when

A woman, busy otherwise, had to put off the cooking of the meat [mutton] which she had brought and which was still warm. She hung it up in her cottage for the next day. The shadows of the night had already fallen when the woman, who for some reason could not sleep (her bed, kitchen, eating place all being in the same room), anxiously cast her eyes around, and about the middle of a dark night saw the meat she had hung up in a dark corner shining in such a way that as far as it reached, the room was filled with bright light. . . The woman was panic-stricken, she thought of the eternal fire or the spirits of a deceased person hidden in the inert matter and a thousand other things. ... Early next morning the matter was related to her neighbors and a stupendous miracle confirmed. The rumor spread around and filled everybody with the same eagerness to see it. They came in droves to buy and look, and while normally they would have been kept away by the smell of the place, now they showed up in full dress, found what they had been told, and marvelled. A shining particle was brought to the illustrious prince Henricus Borbonius Condaeus, governor of those provinces for the Christian King, and occupied his amazed observation for several hours. The light that shone forth was not fiery but white, like that of stars, it did not evenly pour out over the bulk of the meat but was unevenly distributed like jewels shining here and there. It lasted as long as putrefaction and became gradually extinct. Pious witnesses of this decline claimed that the light had the shape of the holy cross and gradually diminished its lustre and subsided. Though $I$ have not ascertained this, there is no doubt according to the nature of light that it could have been possible.

Bartholin's explanation of the spectacle was merely that the luminous meat offered another confirmation of his view that light exists in all things, even in water, for example the light of the sea, and is to be regarded as a fifth element. The most difficult problem was why, if light is universal, it only appears in the meat after a certain time, "for daily experience shows that neither wood nor fish shine before they become putrid." Bartholin asked (Book III, Chap. 7, Problem III) :

But how does splendor follow from putrefaction? Most authors agree that from the heat produced in a putrid body a flame as well as light is spontaneously kindled. ...

Some think that putrid things shine by night on account of the great looseness of their parts. ... Through putrefaction the humid is separated from the dry, because it increases the heat that is shut up in it by compression, and by this increase the humidity is taken away. This is 
followed by dryness and looseness of the parts, which is illuminated by a smooth gleam without any danger of ignition. . . .

I myself cannot conceive of a special claim of putrefaction and the ordinary qualities to bringing forth light, which neither the celestial heat before putrefaction nor the whole perfected mixture was able to kindle. The majesty of noble nature would work ignobly if the ignoble parts by themselves could kindle splendor, which the body could not achieve, though it flourished in its symmetrical mixture with the power of some higher being. ...

The light does not originate from putrefaction, nor is it begotten by it, but only laid open. Putrefaction has the effect that the compound, resolved in its principles and loosened from a strict union of its parts to a minimum, liberates the latent seeds of light which had been suppressed in the mixture of the elements. Thus in the death of living matter, putrefaction does not produce light by generation, but only by separation leads forth what before had been latent in the whole structure. Therefore also putrefaction does not arouse light from just any mixture but only the proper one which acknowledges the inner mixture of some light.

Despite Bartholin's argument, the idea that putrefaction had a causal connection with the emission of light persisted for at least 150 years. Further information on the thinking of the time can be obtained from a discussion of the luminous meat by Daniel Puerarius, since not all of Bartholin's contemporaries accepted the universal light theory.

\section{DANIEL PUERARIUS}

In the 1669 edition of his book, Bartholin mentioned three men who had attempted to explain the light of flesh-Herman Conring (1606-1681) who wrote De Calido Innato sive Igne Animali, etc. (Helmstadt, 1647), Jacob Holst, and Daniel Puerarius. The opinions of Holst and Puerarius were published under the name of T. Bartholin as De Flammula Cordis Epistola cum Jacobi Holsti Viri Clarissimi ejusdem Argumenti Dissertatione. Accessit De carnibus lucentibus Danielis Puerarii responsio (Hafniae, 1667). Puerarius, who was professor of philosophy in the Geneva Academy, and a doctor of medicine, answered questions proposed to him by letter. In the letter the statement was made that the more the writer thought about the luminous lamb " the deeper becomes the mystery and the more controversial its explanations. The scholars do not even agree what light is, a substance or an accident."

Then the following questions were proposed:

1) What has Puerarius found out about the nature of light? 
2) Why did the splendor gleam in the meat of lamb rather than in other meat?

3) Why did those shining rays stream forth from the fatty and membranous parts rather than from the fleshy or lean ones?

4) Why did the ensuing corruption extinguish those little fires comcompletely, which is different from the way it happens in other decaying things? For it is well known that they acquire light by putrefaction, e.g. putrefying wood and other things. Finally, if those are right who say that light differs from fire merely by the looseness of its parts, how is it that there are many luminous things which are not deemed to be warm, while others again have much warmth but do not show any splendor?

Those things puzzle me most, and just this shining light shows our mind immersed in deepest darkness and betrays not so much itself as our own darkness. I ask you, illustrious man, that you should pierce with your beacon through that deep darkness which envelops my mind. . . .

Puerarius replied that he might have something to say even though the book of Thomas Bartholin "which I have avidly read, [is] a perfect work, without fail worthy of its subject which he seems to have exhausted."

The answer to the first question was:

Light is a substance and corporeal; it does not actually differ from the celestial or elementary fire. It moves, rebounds, is reflected from bodies that hinder its transit, destroyed by those that do not permit free transit at all, and when its parts come together and unite it turns into that intensity of warmth which properly is called fire. Then it even becomes inflamed and burns. Therefore, light differs from fire only by the looseness of its parts, light gathered together becomes fire. . .

Puerarius held that Archimedes had proved it just as boys prove it in their play with mirrors in his day. He drew the same conclusion as Bartholin, that light is inborn in all bodies.

Since light differs from fire only by the looseness of its parts, and since the celestial light differs from the elementary one only in its purity, it follows with necessity that the rare fire which enters into the composition of mixed bodies is light. Even if we do not always see it or touch it, light is there within the minute spaces, for example, sparks elicited from stones, which were not seen before, and the inanimate metals, minerals, and stones of which Bartholin wrote. Living creatures contain more of it, even some of the most lowly creatures, e. g. cicindela [the glow-worm].

In regard to the second question, why light appeared in lamb meat rather than other kinds, Puerarius discarded one idea, that 
the constellation Aries, which the sun traverses during April, "kindled those torches by diffusing its starlight into the lambs." Rather he considered that shining things were of three types:

1) Those which on account of the polish and clean disposition of their parts contain this light which unites with the light striking it from without and gleams [for example precious stones].

2) Those living creatures, swollen with closely compressed spirits, who, once they become hot for some reason, start glowing all over their bodies or in certain parts [for example the flames of animals ${ }^{7}$ and of menAscanius in Virgil and the father of Theodoric the Goth].

3) Those which obtain their light from putrefaction, e.g. wood, fish [and] the above named little insects [glow-worms] that shine for the reason that they are generated from dung, manure and similar decaying matter ... though I am convinced that some of them shine for the reason that they easily conceive light on account of the peculiar disposition of their membranous parts and afterwards emit the light they have conceived.

It has been confirmed by many arguments that the shining lamb meat owed its light to the putrefaction that had set in.

For such is the principle of nature that the elements are contained in tight bonds and amiable concord. But when the structure of the mixture is dissolved, the elements are separated and fire, the noblest of them, having broken its fetters and torn down the prison walls which detained it, tries at once to free itself and hasten away. Breaking forth violently to the periphery of the body and taking with it its innate humor, it makes the putrefying bodies appear humid and warm from the outside and even catch fire and become inflamed, as we know best from hay and the stool of pigeons. ${ }^{8}$ Since lambs have an inner mixture of rich light, by which they are foremost in jumping, playing, butting each other with their horns and blows, it is no wonder that they are liable to putrefaction and corruption, wherefore they are often assailed by an ugly itch and easily rub it on to others.

As additional reasons why lambs' meat might shine, Puerarius remarked that it is rather white, more closely related to light. In addition, trustworthy people reported that the lambs had eaten herbs which contain fire, like thyme and rosemary. ${ }^{9}$ At Nîmes in 1628 when shining lamb meat was also observed, a terrible pestilence followed.

${ }^{7}$ Bartholin had searched the old annals and had seen it "mentioned in Julius Obsequens, among the prodigia that under the consulate of $\mathrm{C}$. Valerius and $\mathbf{M}$. Herenius a flock of wethers had been out on the pasture in Lucania and at night in the stables was surrounded by a flame that did not burn anything." This observation is no doubt another example of electrical discharges from the wool.

${ }^{8}$ A reference to Galen, who saw luminous pigeon dung.

'Evidently a reference to the essential oils of these plants. 
In answer to question 3, why fatty and membranous parts were mostly observed to shine, Puerarius believed it was not only because they were white but because fatty substances retain warmth and fire.

The fatty lumbar parts are especially warm, as the doctors know, and some, with good reason, derive from there the stimuli of desire by which the animals are driven. It was clear to everybody that the lambs were excited with this frenzy, and this explains why the other parts did not diffuse so many rays, since they do not enclose so many fiery particles nor can they prevent them from breaking forth, nor do they possess a disposition so favorable for the reflection of light.

In answer to the final question, why the fires in the meat went out during decay, Puerarius answered:

The evident reason for this being that with the elements completely broken up and severed, the shining light gradually wasted away and soon gave way to darkness. But why, then, should some things acquire light by putrefaction and retain it for a long time, e. g. wood?

The answer is to be found in the above quoted principles; only in the case of wood, putrefaction takes a slow course. Wood, as contrasted with flesh, retains its structure for a long time until finally it is resolved into ashes or earth, and it shines as long as the elements are not completely dissolved.

The reasoning of Puerarius is fully as ingenious and somewhat similar to that of Lémery (see Chapter IV), who also attributed the light of meat at Orleans to "spirituous herbs" the animals had eaten, and held that it was most bright in meat from spirited animals, which were overheated or not sufficiently rested before they were killed. Lémery wrote: "when the flesh begins to stink, there appears no more light in it because these vigorous spirits are then spent, or else they come to be confused in the meat by the means of another fermentation." 10

The light of lamb flesh at Montpellier and Padua was surprising enough, but Johann Wesling or Vesling ${ }^{11}$ (1598-1649) in 1664 had " distinctly seen the brilliance of light in the brain of freshly slaughtered cattle that had been finely dissected, and when he dissected the pericardium of a living young hyena, the heart had shone for a while with a fiery shine, to the great amazement of Aloysius Cornelius, the Venetian consul, who was present."

Wesling believed that "in the body of living beings the heavenly

${ }^{10}$ Kiell translation (1698: 698) of Lémery's Cours de chymie.

${ }^{11}$ Vesling was a German physician, professor of anatomy at Padua. See Epistolae medicae 34: 1664. The incident was reported both by Bartholin (1647:169) and by Sachs (Gammerologia, 1665: 896). 
spirit unfolds itself, starting from the heart, together with heat. From there brilliance blooms forth on the tender cheeks and appears on other parts of the body [limbs]."

\section{Luminous Fish and Invertebrates}

Many examples of luminous flesh were reported among coldblooded animals, especially fish and invertebrates. One much quoted account of a luminous dead fish came from Olaus Wormius (15881654), professor of Greek, medicine, and physics at Copenhagen and possessor of a famous museum, whose contents were described in Museum Wormianum seu Historia Rerum Rariorum (Leyden, 1655). This book described the Scorpio marinus ${ }^{12}$ (p. 267) but did not mention luminescence. However, in a letter to Bartholin, ${ }^{13}$ Worm wrote: "The other day my maid had bought in the fish market among other fish the Scorpio marinus, which is so called in Schonveld, but colloquially en Ulk. She skinned it and threw away skin and head into a place destined for waste. After several days a servant went there around twilight and saw an unusual light shining in the dark, which filled him with considerable fear," but he finally " discovered the head and skin of the fish which had been discarded." Worm wrote: "I believe that the sticky and mucous liquid on a snowy-white subject disposed toward putrefaction has much contributed to the nature of this light."

Another luminous fish was described by Georgius Marcgravius (1610-1644) in the Historia Rerum Naturalium Brasiliae, published in 1648 at Amsterdam. He spoke of a scaly and brilliant fish of Brazil, the "jurucapeba" or "itajara," whose sides became luminous at night. It has been identified from the figure as one of the Serranidae, the sea perches or sea bass, Serranus itaiara. Some of the Serranidae, for example, Apogon marginatus of Japan, are luminous when living and may contain luminous bacteria living symbiotically within them. If this is true of the "jurucapeba," Marcgrave's observation is the first report of symbiotic luminescence in any animal. His statement is: "Parieti recens appensus noctu toto corpore clare lucet," which may be translated, "When fresh, ${ }^{14}$ if

\footnotetext{
${ }^{12}$ The fishing frog (Lophius piscatorius), a fish sometimes referred to as the marine scorpion.

${ }^{13}$ Bartholin, De luce animalium, Book II, Cap. 15, 1647.

14 A Portuguese translation of Marcgrave, Historia natural do Brasil, was published at Sao Paulo in 1942. It honors the man who first made a detailed study of the plants and animals of Brazil. The account of Jurucapeba, identified by Dr. Paulo Sawaya, is on p. 147. He writes me that the Portuguese word "fresco" used for the Latin "recens" is applied to a caught fish which cannot breathe but whose gills are still bright red.
} 
hung by a wall, the whole body shines brilliantly." Whether the light was due to symbiotic bacteria or saprophytic bacteria is as yet uncertain.

Another early record of luminous bacteria, on crustacea, is reported by Bartholin (Book II, Chap. 15) :

the learned Leo Allatius ${ }^{15}$ [who] saw it in Rome, as demonstrated in his letter written to Licetus on the learned Pomarus. One night he saw lights in the corner of the museum, which he was eager to obtain, but feeling something cold and soft to his touch, he dropped them again. He then fetched a light and examined everything in this corner, where he found pieces and remnants of the river lobster (Gammarus), smaller and larger ones. He put them on a table, removed the light, and shut himself with his find in the dark, with good result: for at once those same remnants of the lobsters became luminous, more or less according to their size, and gave out a gleam somewhat like that of lighted sulphur or burning water, but a pale and not so vivid one with broken and dulled rays, which faded out when a brighter light appeared.

This account is also repeated by P. J. Sachs von Lewenhaimb (1627-1672) in his Gammerologia (1665), a treatise dealing with everything concerning crustacea, and including many other invertebrates as well, for example, dactyli and oysters (probably containing luminous worms). Crabs were also said to be luminous.

Squid and devil-fish have frequently been observed to shine when dead. A record of luminous squid, seen by Francesco Redi (16261698 ) in 1672 was published in 1687 , and a particularly brilliant octopus was recorded by Oliger Jacobaeus (1650-1701) in the Acta Hafniensia Medica et Philosphica (1677-1679), a journal edited by T. Bartholin. Every observer has been astonished at the light of fish and flesh, which is indeed a striking sight to those whose eyes are thoroughly dark adapted.

\section{Robert Boyle}

After the remarkable display of luminous meat at Montpellier, and the reports of luminous fish just enumerated, only occasional notice was taken of similar phenomena until the time of Robert Boyle (1627-1691). He made many experiments to show that the light from luminous flesh, fish, and wood is dependent upon the presence of air, and he drew an interesting comparison between the light of shining wood and that of a glowing coal. In fact his "resemblances" and "differences" between living light and combustion has become a classic comparison.

\footnotetext{
${ }^{15}$ Leoni Allacci (1586-1669), scholar and physician, librarian of the Vatican under Pope Alexander VII.
} 
Boyle's observations on luminous meat were made in 1672 when a servant found a brightly luminous neck of veal in his cellar. He wrote: "Notwithstanding the great Number of lucid Parts not the least degree of Stench was perceivable to infer any Putrefaction" and he could not "by the touch discern the least degree of heat in the parts whence it proceeded." Thinking that atmospheric conditions had something to do with the luminescence, Boyle carefully noted that "The Wind as far as we could observe it, was then at South-ivest, and blustering enough, the Air by the sealed Thermoscope, appeared hot for the season, the Moon was past its last Quarter; the Mercury in the Barometer stood at 29 3/16 inches." 16

Boyle also investigated luminous wood and fish in a paper entitled "New Experiments (to the number of 16) Concerning the Relation of Light and Air (in Shining Wood and Fish)," published in the Phil. Trans. (No. 31) for 1668. He was not well at the time of his trials but he made eleven experiments, October 29, 1667, and five more on December 6, 1667. They were about evenly divided between wood and fish and left no doubt of the fact that both lost their light in a vacuum and that it returned in the air, sometimes after a three-days stay in the vacuum. Boyle wished to test the King's shining diamond, the Bononian phosphor and a glowworm in a similar manner, but he could not obtain them, and contented himself with a red-hot piece of iron in a clay pipe placed in the vacuum chamber. Contrary to the fish and wood, the redness of the iron did not dim in absence of air and did not become brighter when air was readmitted.

He endeavored to find out whether luminosity would develop on a piece of fish kept in a vacuum at the same time as it appeared on fish in the air. His purpose was to determine "how great an interest Putrefaction hath in the shining of Fishes, and Air in the Phenomena of Putrefaction." The idea was excellent but the experiments failed, in one case because the glass receiver broke and in another because neither piece of fish developed luminosity.

The last result led Boyle to comment on his experiences with shining fish, that having

caused a competent number of them to be bought, not one of them all would shine, though they were brought by the same person I was wont to employ, and hung up in the same place where I use to have them put, and kept not only 'till they began to putrifie, but beyond the time that others used to shine; although a parcel of the same kind of Fisches [whiting], bought the week before, and another of the same kind, bought not many days after, shined according to expectation.

${ }^{16}$ T. Birch, Works of Boyle, 3: 651-655, 2nd ed., 1772; Phil. Trans., No. 89: 5108, 1672. 
The "uncertain shining of Fishes" mystified Boyle as it did many others after him.

At this time Boyle preferred not to comment on the experiments and was willing merely to remark:

That notwithstanding the Coldness (at least to sense) of Fishes and other animals, there may be in the Heart and Blood a Vital Kind of Fire, which needs $A i r$, as well as those Fires that are sensibly hot: which may lessen the wonder, that Animals should not be able to live when robbed of Air. And if I had now time, I could possibly furnish you with some other Trials, that seem much to favour the Comparison, though as to the opinion it self of a Vital Flame, I shall not now tell you my thoughts about it.

Boyle's most quoted experiments were carried out with phosphorescent wood on October 29, 1667, using his air pump: ${ }^{17}$

Exp. I: Having at length procured a Piece of shining Wood, about the bigness of a groat or less, that gave a vivid Light, (for rotten Wood) we put it into a middle size Receiver, so as it was kept from touching the Cement; and the pump being set a-work, we observed not, during the five or six first Exsuctions of the Air, that the splendor of the included Wood was manifestly lessened (though it was never at all increased;) but about the seventh Suck, it seemed to glow a little more dim, and afterwards answered our Expectation, by losing of its Light more and more, as the Air was still farther pumped out; till at length about the tenth Exsuction, (though by the removal of the Candles out of the Room, and by black Cloaths and Hats we made the place as dark as we could, yet) we could not perceive any light at all to proceed from the Wood.

Exp. II: Wherefore we let in the outward Air by Degrees and had the pleasure to see the seemingly extinguished Light revive so fast and perfectly, that it looked to us almost like a little Flash of Lightning, and the Splendor of the Wood seemed rather greater than at all less, than before it was put into the Receiver. ${ }^{17}$

If a glowing stump is chopped with an axe the chips are luminous throughout and look like so many glowing coals. Boyle was impressed with the similarity of the light-giving process in glowing coal and shining wood, as he draws a comparison between the two which brings out the fundamental similarity of combustion processes. This comparison may also serve to summarize his many experiments: ${ }^{17}$

Resemblances:

VII. The Things wherein I observed a Piece of shining Wood and a burning Coal to agree or rescmble each other are principally these five:

${ }^{17}$ Works of Boyle 3: 170-174, 2nd ed., 1772, based on Phil. Trans. 2: 605-612, 1668. 
1. Both of them are Luminaries, that is, give Light, as having it (if I may so speak) residing in them; and not like Looking-glasses, or white Bodies, which are conspicuous only by the incident Beams of the Sun, or some other luminous Body, which they reflect. . . .

2. Both shining Wood and a burning Coal need the Presence of the Air (and that too of such a Density to make them continue shining. . . .

3. Both shining Wood and a burning Coal, having been deprived, for a Time, of their Light, by the withdrawing of the contiguous Air, may presently recover it by letting in fresh Air upon them. . . .

Both a quick Coal and shining Wood will be easily quenched by Water and many other Liquors. ...

5. As a quick Coal is not to be extinguished by the Coldness of the Air, when it is greater than ordinary; so neither is a Piece of shining Wood to be deprived of its Light by the same Quality of the Air....

Differences:

1. The first Difference I observed betwixt a live Coal and a shining Wood is, that whereas the Light of the former is readily extinguishable by Compression (as is obvious in the Practice of suddenly extinguishing a piece of Coal by treading upon it), I could not find that such a Compression as I could conveniently give without losing sight of its operation, would put out, or much injure the Light, even of small Fragments of shining Wood....

2. The next Unlikeness to be taken notice of betwixt rotten Wood and a kindled Coal is, that the latter will, in a very few Minutes, be totally extinguished by the withdrawing of the Air; whereas a Piece of shining Wood, being eclipsed by the Absence of the Air, and kept so for a Time, will immediately recover its Light if the Air be let in upon it again within half an hour after it was first withdrawn. . .

3. The next Difference to be mentioned is, that a live Coal, being put into a small close Glass, will not continue to burn for very many Minutes; but a Piece of shining. Wood will continue to shine for some whole Days. ...

4. A fourth Difference may be this: that whereas a Coal, as it burns, sends forth Store of Smoke or Exhalations, luminous Wood does not so.

5. A fifth, flowing from the former, is, that whereas a Coal in shining wastes itself at a great Rate, shining Wood does not. . . .

6. The last Difference I shall take notice of betwixt the bodies hereto compared is, that a quick Coal is actually and vehemently hot; whereas I have not observed shining Wood to be so much as sensibly lukewarm.

Although Boyle did not know that luminous bacteria were responsible for the light of shining fish and flesh or that the mycelium of a luminous fungus caused the wood to shine, we may credit him with recognizing the fundamental similarity of the two luminescences and with showing the necessity of air (oxygen) to maintain the luminescence. He tested the effect of spirits and salt on the wood, and found that the light disappeared. 


\section{John Beal}

About the time of Boyle's work on shining wood and shining flesh, John Beal or Beale (1603-1683) made some observations on luminous fish and actually examined the luminous material with a microscope. Beal, a doctor of theology and Rector at Yeavel in Somersetshire, published his observations in the first volume of the Philosophical Transactions under the title "An Experiment to Examine what Figure and Celerity of Motion begetteth, or encreaseth Light and Flame" (p. 226-228). Beal actually published before Boyle. He described how, on May 5, 1665, "fresh Mackrels were boyl'd in Water, with salt and sweet herbs" and left for pickle. On the evening of May 8 the cook

found the water at first motion ${ }^{18}$ [had] become very luminous, and the Fish shining through the water, as adding much to the Light, which the water yielded.

Wherever the drops of this water (after it was stirr'd) fell on the ground, or benches, they shin'd: And the children took drops in their hands, as broad as a penny, running with them about the house, and each drop, both neer and at distance, seem'd by their shining as broad as a six pence, or a shilling or broader. . .

Beal noted that no light came from the lower side of the fish, but "from the throat and such places as seemed a little broken in the boyling."

I took a piece that shin'd most, and fitted it, as well as I could devise in the night, both to my great Microscope, and afterwards to my little one; but I could discern no light by any of these Glasses; nor from any drops of the shining water, when put into the Glasses. And May 10. in the brightst rays of the Sun, I examin'd, in my great Microscope, a small broken piece of the Fish, which shin'd most the night before. We could find nothing on the surface of the Fish very remarkable. It seem'd whitish, and in a manner dried, with deep inequalities. And others, as well as myself, thought, we saw a steam, rather darkish, than luminous, arising, like a very small dust, from the fish: And rarely here and there, a very small, and almost imperceptible sparkle in the Fish. Yet of these sparkles we are certain, we numbered them, and agreed in the number, order and place. Of the steam I am not confident, but do suspect our Eyes in the bright Sun, or that it might be some dust in the Aire.

It is hardly possible that the "dust" could have been luminous bacteria.

\footnotetext{
${ }^{18}$ Motion of the water resulted in the appearance of light because more oxygen dissolved, but Beal, and also later writers (Hulme, 1800), were not in a position to realize this.
} 
Later Beal (1676) wrote on luminous meat in Volume 11 of the Phil. Trans. "Two Instances of Something Remarkable in Shining Flesh." Beal referred to some luminous beef, previously observed in the Strand in London. He then described the experience of a "Woman of this Town " who brought a "Neck of Veal" on Friday, February 25, 1675, and hung it on a shelf in the bedroom.

Upon the following Saturday, about 9 in the night, the Neck of Veal shined so bright, that it did put the Woman into a great affrightment. She calls up her Husband; he hastens to the Light, as fearing fire and flames, and seeing the light come only from the flesh, he caught the flesh in his left hand, and beat it with his right hand, as endeavouring to extinguish the flame, but without effect. The flesh shined as much, if not more, than before, and his hand, with which he did beat the flesh, became all in a flame, as bright, and vivid, as the Flesh of the Veal was, and so it continued, whilst he went from place to place, shewing it to others. Then he thrusts his blazing hand into a pail of pure water; this could not extinguish the flame at all, but his hand shined through the water: at last he took a napkin, and wiped his hand, till he wiped off all the Light.

Beal then described a similar experience of his own with some pork which had been pickled. He emphasized the brightness of the light, yet there was no heat to be perceived even by "young children which have the tenderest touch." Beal had no explanation of the origin of the light except to compare it with other luminescences, such as Auzout's worms and Boyle's diamond. He had heard of " some Dews on Meadows shining in the early morning, before daylight," and had "read in our Chronicles, That in England, for many days together, there had been a fiery incalescence, with light, as if all the air had been in a flame. Thus we have flaming Air and flaming Water, in Seas, in.Clouds, and in Pickle; yet not so frequent as to escape always the Suspicion of being Prodigies." Beal ended by noting that at the time his pork became luminous, the stars had been brighter and larger than ordinary and the weather had been more gentle and warm than usual, " but tis above my skill to demonstrate, how this belongs to the matter in hand."

Beal and Boyle evidently had considerable correspondence. In a letter from Beal written February $1,1680,{ }^{19}$ to Boyle's secretary, thanking Boyle for a sample of the "aerial noctiluca," Beal described his experience with luminous lobster ${ }^{20}$ shells "shining

${ }^{19} \mathrm{~T}$. Birch, Works of Boyle 4: 440-441, 1772.

${ }^{20}$ Charles Dickens (1812-1870) may have heard of this kind of phosphorescence from Beal's letters; at least he alluded to luminous lobsters in $A$ Christmas carol (Chapter I, 1843). Dickens related how Scrooge, returning home one evening, saw on 
vividly from a cupboard, to which they were removed." Boyle himself remarked in a discourse ${ }^{21}$ at the Royal Society in 1681 that of all fishy substances, the eggs of lobsters which have been boiled shone the brightest.

\section{Luminous Eggs and Other Unusual Things}

In addition to wood and meat, purchased in the market, many unusual organic materials were observed to shine. Redi (1687) not only knew of the luminescence of decaying fish and squid, but he saw a putrifying serpent continue to shine in darkness for four nights. The light then disappeared little by little. ${ }^{22}$

Robert Plot's (1686) story of the turf or peat in Oxfordshire, which looked like fire when broken by horses' hoofs, might be due to a luminous fungal mycelium, but the recent observations of $\mathrm{A}$. Harker (1888), as described in Chapter XVI on Bioluminescence, indicate that the light actually came from luminous earthworms.

Perhaps the most extraordinary records are those which have to do with reptiles or hen's eggs. The reptile egg story appears to have originated in the seventeenth century. Paulo Boccone (1684), among other luminous phenomena, had recorded in his Osservazioni Naturali (1684:224) the occurrence of luminous lizard eggs seen by Count Marsigli, an observation referred to by Heinrich (1815), Ehrenberg (1834), Heller (1853), and others.

Another and a particularly convincing account was published in 1774 by Gottfried August Gruendler, a painter and etcher in Halle. Gruendler found five lizards' eggs which he took home, wishing to observe the young lizards on hatching. That night, to his surprise, he observed that three of them showed luminous patches, like a glowworm, but two were dark. Realizing that movement generated electricity, he tried shaking the dark eggs in his hand, and found that they also started to luminesce but soon ceased. The three luminous eggs continued bright throughout the night but were dark the following night. On cutting into the leathery shell he found "eine trübe und zähe Feuchtigkeit," but he does not mention whether the material was luminescent. The article was published in Der Naturforscher (Stuck 3:218-221) in the hope that others might have observed the same phenomenon and report on it.

his door, not the usual knocker but an image of Marley's face. "It was not in impenetrable shadow as the other objects in the yard were, but had a dismal light about it, like a bad lobster in a dark cellar." Lobsters were also seen to luminesce by Horne (1869) .

${ }^{21}$ T. Birch, History of the Royal Society 2: 70.

${ }^{22} \mathrm{De}$ animaculis vivis quae in corporibus animalium vivum reperiuntur observationes (Opuscularum pars tertia 3: 15, 1672) and Osservazioni di Napoli, 10-11, 1687. 
This story has also been repeated by a number of writers ${ }^{23}$ on luminescence, but Emmert and Hochstetter (1811), who made an embryological study of the developing eggs of both lizards (Lacerta) and snakes (Coluber) never saw luminescence, despite many examinations in the dark. However, a friend, Herr Lienert of Bern, saw luminous lizard eggs one evening under the sand where they were laid, but the following evening there was no light. ${ }^{24}$

The luminous hen's egg story also stems from the seventeenth century and has been recounted by Bouvier (1910). After speaking of the alleged light-giving birds of the Hercynian Forest and more recent reports of luminous birds, Bouvier asked whether the luminosity could not be due to the same cause as " oufs lumineux," which were described in the Collection Académique Etrangère 4: 174), published at Dijon in 1757 and taken from the "Ephemerides Naturae Curiosum" (Dec., II, 1687). It was reported that a certain Christian François Paullin noticed one night a light in his room. Approaching more closely, he realized "que cette clarte venoit de quelques oufs, que couvait une pole blanche, fécondée par un coq très ardent, lesquels etoient devenus lumineux." No further details are given by Bouvier, and we might possibly classify this observation, with its French touch, as a reflection of light from the white shell of the eggs, were it an isolated case.

However, there are more recent reports. J. Heller (1853: 165) himself saw hen's eggs with weak thin shells that luminesced "stellenweise" on the second day after laying, like phosphorescent wood. He also saw luminous eggs of the snake, Coluber natrix, and noted that the light came from a moist, slippery coating which could be easily wiped away.

In an attempt to check on these stories, Hans Molisch (1904) made many attempts to observe luminous hen's eggs, fresh, old and actually rotten, but without success. However, he did observe the luminescence of "soleiern," hen's eggs boiled, shelled, and preserved in salt solutions, sent him by Dr. Gerloff of Nauheim. This luminescence turned out to be bacterial in origin and brilliant cul-

\footnotetext{
${ }^{23}$ Schrank (1788) called attention to the luminous hen's eggs of Paullinus (1687), and considered the light due to decomposition, since luminescence occurred in the upper layers, full of "fäulenden Theilen." Jacob Sturm's unpaged pamphlet, published at Nürnberg in 1799, mentions that the eggs of Lacerta agilis are luminous. The account was written by a man named Wolf, evidently copied from Gruendler.

${ }^{24}$ A more modern observation on luminous eggs of a lizard has been published (Lacerta, No. 1: 87-88, 1908) by $\mathrm{H}$. Geyer, who found nine eggs in his garden in very damp soil, of which six were luminous. They contained well advanced embryoes, alive and non-luminescent, but the albumen and particularly the empty shell shone brightly. On the next night the eggs were dark. Geyer attributed the light to luminous bacteria.
} 
tures of luminous bacteria could be grown on boiled eggs. It is possible that the uncooked reptile and bird eggs also became infected with luminous bacteria.

In addition to luminous eggs of various kinds, there are many records of human corpses which became luminescent. A particularly informative example is described in a later section (Shining Flesh and Animalcules) in which the observers (Cooper and Cooper, 1838) saw light on a body in a dissecting room and almost came to the correct conclusion regarding the origin of the light. Of even greater interest are the records of luminescence of wounds, which were apparently fairly common among soldiers, according to the account of Percy and Laurent (1820). It was generally believed that a luminous wound would in most cases heal and very seldom leave a scar.

The light of luminous wounds in Baron Percy's day, when antisepsis was not practiced, undoubtedly came from luminous bacteria. It is much more difficult to ascribe a cause to luminescence of human breath (Watson, 1845), skin, sweat (Henkel, 1740, 1785; Panceri, 1871) and urine, all of which have been described. Electroluminescence from electrical discharges was in most cases probably observed, as described in Chapter VII, although this explanation is not too clearly indicated in some of the accounts (See Hermbstadt, 1808; Donoven, 1840; Sharkey, 1840; Marsh, 1842: Collier, 1842-1843; Wood, 1844; M'Cormac, 1846).

By far the most frequent records deal with luminous urine, which has been observed from time to time since the paper of S. Reisel (1625-1702) in 1688, followed by reports of Jurine (1813), GuytonMorveau (1814), Driessen (1818), Esser (1826), Kastner (1826), and Fallot (1847-1848). As late as 1872, P. Panceri reported a letter from Anton Dohrn, famous founder of the Stazione Zoologica at Naples, saying that his urine was once luminous. In Reisel's own case, it is most probable that he urinated on luminous earthworms or centipedes, which then gave off the light, but such an explanation cannot be applied to many of the reports, and it is necessary to fall back on luminous bacterial infection or the reflection of a dim light as the most likely origin. A particularly baffling case of reported luminescence is that of the blood and entrails of a newly shot porcupine, by L. Moreau. The account was published in Nature for 1897. 


\section{Eighteenth-Century Views}

\section{J. J. DORTOUS DE MAIRAN}

During the early part of the eighteenth century more or less sporadic discussion of shining wood and fish took place. William Derham, F. R.S. (1657-1735), the English divine and natural philosopher, included in his Philosophical Experiments and Observations of the Late Eminent Robert Hooke, S. R. S., and other Eminent Virtuosos in his Time (London, 1726) printed directions for finding shining wood (p. 176), as follows:

The author occasionally speaking of shining Woods, delivers this Rule for the future finding of them. That an Apple-Tree is the best wood; that it must be very dry, or rotten; that being so and lying under ground, that part under ground will partake of a shining Quality, which will not last above three Days, nor to be recover'd again when lost.

In the prize essay by de Mairan (1717), the attempt was made to explain shining wood and flesh in terms of his general belief that light of "phosphores" and "noctiluques" results from anything which puts their "sulphure" in movement. Possibly this idea is a reflection of the observation that stimulation or agitation excited the luminescence of animals. De Mairan believed that the cohesion of a substance normally prevents the movement of its sulphur, but when the natural agitation of the sulphur is sufficient to be transmitted to the surrounding material, the sulphur breaks from its prison and light appears. Matter which contains much sulphur becomes luminous by fermentation alone, like flesh and the skin of fishes. Wood is stronger and much more compact than the skin of animals and hence does not become luminous until it is thoroughly rotten. De Mairan may not have been correct in attributing the light to agitation of a fiery principle, but he did have a definite theory which he attempted to apply to all types of luminescence.

\section{HENRY BAKER}

In the middle of the century, when speculation regarding the cause of phosphorescence of the sea was at its height, interest in fish luminescence revived. It is possible that Henry Baker, whose book, The Microscope Made Easy (London, 1742: 242) had aroused popular interest in microscopic things, may have given the first hint that the light of fish, flesh and wood was due to microscopic organisms. 
Baker noted that worms were responsible for the light of oysters and wrote:

As the Bodies of Lobsters ${ }^{25}$ and some other Kinds of Fisches, tainted Flesh, rotten Wood and other Substances are sometimes found to shine with a Light resembling the foregoing, [i. e., animalcules on oysters] may it probably proceed from the same, viz. from Animalcules. . . . The curious will judge it proper to examine this matter carefully, and to them it is submitted.

\section{ANTON MARTIN}

A most important work on fish luminescence, pointing out the necessity of salt for the development of light, was published by the Swede, Antonius Martin, in 1761. Although Martin gave no evidence of accepting Baker's prophetic hint, he did study luminous fish as a means of interpreting phosphorescence of the sea. His experiments were described by Priestley (1772: 575-576) :

He thought that he had reason to conclude, from a great variety of experiments, that all sea fishes have this property; but that it is not to be found in any that are produced in fresh water. Nothing depended upon the colour of the fishes, except that he thought that the white ones, and especially those that had white scales, were a little more luminous than others. This light, he found, was increased by a small quantity of salt, and also by a small degree of warmth, though a greater degree extinguished it. This agrees with another observation of his, that it depends intirely upon a kind of moisture, which they had about them, and which a small degree of heat would expell, when an oilness remained which did not give this light, but would burn in the fire. Light from the flesh of birds or beasts is not so bright, he says, as that which proceeds from fish. Human bodies, he says, have sometimes emitted light about the time that they began to putrify, and the walls and roof of a place in which dead bodies had often been exposed, had a kind of dew or clamminess upon it, which was sometimes luminous; ${ }^{26}$ and he imagined that the lights which are said to be seen in burying grounds may be owing to this cause. ${ }^{27}$

Martin also recognized that sea fish never luminesced when alive and swimming-that any light observed near a living fish came from small "worms" in the sea water-and that freshly caught fish never luminesced the first evening but on the second the eyes of the fish

\footnotetext{
${ }^{25}$ Baker probably referred to Beal's letter, quoted previously. Luminous meat was reported from time to time, for example by $\mathbf{M}$. Marcelle, a correspondent of the French Academy at Toulouse in 1755 (Mém. de Math. Phys. Sar. Etranger 2: 613-614, 1755).

${ }^{28}$ Probably luminous mycelium of a fungus.

${ }^{27}$ Swed. Abhand. 23: 225, 1764.
} 
were most likely to luminesce, later the head, belly, and tail, but only as long as the parts remained moist.

\section{JOHN CANTON}

The next investigator of shining fish was John Canton (17181772), perhaps better known as a student of electricity and as the inventor of Canton's phosphorus, prepared in 1768 by heating oyster shells and sulphur. Canton (1769) became interested in the "Luminousness of the Sea " and endeavored to prove that this phenomenon " arises from Putrefaction of its Animal Substances." Like Martin he observed that when he put sea fish, a whiting or a herring, in sea water, the next night the fish was luminous and the luminosity spread throughout the sea water when the material was stirred, in this respect, resembling the light of the sea, which appears on agitation. However, in the case of the fish, the stirring is merely due to solution of more oxygen from the air, an absolute necessity for bacterial luminescence, whereas the agitation of sea water produces light by stimulation of luminous organisms. The resemblance is purely superficial.

Canton found that no such luminescence developed when the whiting was placed in fresh water overnight, and that fresh-water fish ${ }^{28}$ did not become luminous in salt water, with the exception of one carp. He made artificial sea water by adding salt to fresh water and found that herring became luminous in the artificial medium, thus confirming the experiments of Martin (1761).

Canton was especially interested in temperature effects on his phosphor, and was apparently the first person to report on the reversible extinction of the light of luminous bacteria by rise in temperature. He observed

that though the greatest summer heat is well known to promote putrefaction, yet twenty degrees more than that of the human blood seems to hinder it. For putting a small piece of luminous fish into a thin glass ball, I found that water of the heat of 118 degrees would destroy its luminousness in less than half a minute; which, on taking it out of the water, it would begin to recover its light in about ten seconds; but was never so bright as before. ${ }^{29}$

The effect of low temperature on the fish was not tested.

${ }^{28}$ In 1784 Delius described Iuminous material on a piece of Rhine salmon which could be rubbed off with the finger, but he had no idea what the phenomenon was due to.

${ }^{29}$ J. Canton, Phil. Trans. 59: 449, 1769. 


\section{JOHANN SEBASTIAN ALBRECHT}

In the meantime observations on luminous wood were progressing. Johann Sebastian Albrecht (1695-1774), a professor at the gymnasium of Gotha, published a work in Latin in the Acta Physica Medica of the Academia Caesaraea Leopoldina for 1740, "De Ligno non Putrido in Tenebris Lucente," in which he emphasized the fact that luminous wood need not be rotten, and might still contain half its original moisture. The logs he observed were of fir, felled by a wind storm, and stored in his cellar. On entering the storeroom, Albrecht was dumbfounded by the light and exhibited some samples to a great crowd of his students, who were much impressed. "When they returned to their houses, they illuminated the streets here and there with fragments of still shining bark."

Albrecht had evidently read a good deal on the subject of luminescence, for he referred to Pliny, Bartholin, Boyle, Réaumur, and in fact to all the well-known writers on the subject, as an introduction to his paper. His findings regarding the luminous wood and his conclusions were presented as follows:

1. The light was greatest in the bark and wood where the bark had only recently come off.

2. Not only the place which the bark had covered but also the other sides, though to a lesser degree, were illuminated.

3. When such wood was dried out, it lost this quality of shining in the dark.

4. In one way or another it regained it, though to a much lesser degree, when stored in the cellar, thus acquiring again the former proportion of wet and dry.

5. However, once the logs were dried out still more, though they were again subject to moisture in the cellar, the light would never come back.

Therefore it is evident that not exclusively decay but only certain characteristics of the wood are necessary for this phenomenon, such that an ethereal substance, freed from its shackles and fetters, pressed and put in motion by the outer encircling air and having suffered friction in its transit through narrow pores, affects our visual sense with what we describe by the name of light. But every single experiment and phenomenon in shining bodies proves that the primary and decisive cause [of light] is this friction of air rushing and pressing in....

In support of the above statement, Albrecht cited Boyle's experiment with shining wood, which does not light in a vacuum but does when the air is let in and rushes over it, as well as Réaumur's work with the "dails" (Pholas dactylus) which luminesce when rubbed, and the many cases of light from friction, especially the mercurial 
phosphor, to explain how the light of wood comes from the movement of air within it.

This also explains why dry wood loses the quality of shining, for the pores are wider and provide an easier passage for the air, without such frictions as was formerly required. A large amount of these particles of air passing from these wide pores results in a gradually weakening light, until it finally disappears altogether ... though by the addition of new moisture the pores become narrower.

Albrecht certainly had a very definite theory.

\section{BARON VON MEIDINGER}

In 1777 Baron von Meidinger wrote from Vienna on the light of damp wood and presented a theory of light, which, although based on only a few experiments, actually came very near the truth. $\mathrm{He}$ had noticed that many different kinds and samples of wood but not all samples might develop luminosity if moist. The light came from bright specks or strands and disappeared when the wood dried out, but did not reappear on again moistening the sample. ${ }^{30}$ The light was obviously similar to that of the St. Johanniswürm (Lampyris noctiluca) and von Meidinger thought it might be due to little insects on the wood, ${ }^{31}$ especially as Baker (1742) had observed the light of the sea to be due to insects. However, an examination of the wood with a good microscope revealed nothing. Therefore the Baron drew three conclusions: (1) The light must come from animalcules (Tierchen), too small to be seen with the highest powers of the microscope, with many millions together producing the light. (2) These animalcules must appear only when the wood reached a certain degree of rottenness and need not necessarily attack all samples. (3) They must light only as long as they are alive. Since drying kills them, drying also destroys the ability of the wood to luminesce. Had von Meidinger used the term "fungus mycelium" instead of " animalcule" he would have been quite correct.

${ }^{30} \mathrm{M}$. Sage (1780) also emphasized the necessity of water for phosphorescence of oak timbers in a bridge at Chaton, a village on the Seine. The light disappeared and returned on moistening.

${ }^{31}$ A similar idea was expressed in 1780 by M. Gioanetti, who investigated a reported luminous phenomenon in the water of Eglise, a hamlet in Fontanemore parish in the Duché d'Aoste. He found no light in the water but bright luminous specks in the mud, which were little animals, perhaps "nymphs of luminous flies." He remarked that perhaps luminous wood contained luminous animalcules also. The observations were published in the Journal de Physique 15: 495-496, 1780. 


\section{Luminous Mushrooms and Rhizomorphs}

The existence in wood of a luminous mycelium, and the relation of the mycelium to the fruiting body, the mushroom, was not suspected by Albrecht, von Meidinger, or others. Although Aristotle and Pliny both wrote of luminous mushrooms and a few systematic botanists had described luminous fungi from various parts of the world, much more attention was paid to luminous wood, regarded as a natural phosphor, than to the mushroom which would have given the clue to the origin of the light of wood. The relationship was only established in the first half of the nineteenth century, although the great French chemist, de Fourcroy, did state in 1801 that wood on becoming luminous developed an odor of mushrooms.

One of the early records of luminous fungi is due to Georg Everard Rumph (1637-1706), for many years the Dutch physician, merchant and consul at Amboina in Indonesia. In his "Herbarium Amboiense," which appeared in 1750, Rumph described Fungus igneus, with a bluish light like centipedes, and said that natives carry the fungus in their hands for a lantern to keep from wandering off a path at night. ${ }^{32}$

In Europe, Giovanni Antonio Battara included the common luminous agaric of olive trees (Agaricus or Pleurotus olearius) in his Fungorum Agri Arimensis Historia (Faventiae, 1755) under the name of Polymyces phosphoreus. An excellent figure is included on plate XIV. This was undoubtedly the mushroom mentioned by Pliny as luminous.

The Species Plantarum (Holmiae, 1753) of Linnaeus contains no mention of luminosity among fungi, although Byssus phosphorea, one of the rhizomorphs of Armillaria mellea, is listed under Cryptogamia algae rather than Cryptogamia fungi, and the habitat given as Europe, in rotten wood. Byssus had been previously mentioned in the thesis, Noctiluca Marina, by C. F. Adler (1752), sponsored by Linnaeus himself. Adler had referred to luminous wood containing Byssus violaceous and Linnaeus changed the name in Species Plantarum.

Rhizomorphs, variously known as Rhizomorpha fragilis, R. subterranea, and R. subcorticalis were considered for many years to be a special fungus. One variety was figured on plate 100 of James Sowerby's (1757-1822) Colored Figures of English Fungi (1, London, 1797) and called "Clavaria phosphorea," with "Rhizo-

${ }^{32} \mathrm{Dr}$. Yata Haneda has informed me that even today natives of Micronesia use luminous fungi as head ornaments for dances, or smear them on their faces to frighten people. Often they are regarded as bad omens and destroyed. 
morpha fragilis" given as a synonym. Accompanying the figure was Sowerby's description:

Found in a wine cellar in Little St. Helens, London, creeping among saw-dust and bottles in the autumn of 1796, communicated by Mr. B. M. Forster. It is remarkable for being luminous in the dark, when fresh, at the ends of the shoots. Mr. Forster has doubted whether this phosphoric appearance may not be owing to some vinous moisture imbibed, rather than a natural property of the fungus.

The work of R. Hartig (1873) proved that these growths were the mycelium of a common fungus, Armillaria mellea, whose fruiting body is nonluminous. According to A. von Humboldt ${ }^{33}$ (1799), Freyesleben, a counselor of mines, was the first to observe luminescence of rhizomorphs, which he called Lichen filamentosus, in mines at Freiburg in 1796. The terms Lichen pinnatus and Dematium violaceum were also used at that time for luminous rhizomorphs (Heller, 1853: 83). Von Humboldt was unable to separate anything which remained luminous from the wood which he studied. It was only with the observations of Derschau in 1823 that rhizomorphs and luminous wood became associated.

\section{Luminous Potatoes, Roots, Leaves, Fruit, and Cheese}

Wood is not the only vegetable material which may become phosphorescent. A most interesting and famous case of luminous potatoes occurred in the military barracks of Strassburg on January 7 , 1790. The circumstance was recorded by Valmont de Bomare in the Journal de Physique for 1790 (36: 225) as a letter from "M. d'H-Officier d'Alsace, sur un phénomène phosphorique." The account was widely quoted in German and English publications and was exaggerated to include a statement that the officer on guard thought the barracks were on fire.

Actually the officer was astonished when he entered the barracks to perceive a great light at an hour when lights were prohibited by the police. It seems that the soldiers had started to prepare potato soup but discovered that fermentation connected with germination had begun, and, after they were cut, the potatoes were discarded in a pail. As darkness fell they were seen to give off a light like glowing charcoal by which it was possible to read the characters of print. Next morning the officer examined the yellowish potato slices. They contained little starch and were covered with a multitude of tiny

${ }^{33}$ A. von Humboldt, Versuche über die chemisch Zerlegung der Luftkreises, IX, Uber die Entbinding des Lichtes, 231, 1799. 
brilliant points. The odor was strong like a sponge. On succeeding nights the light became weaker and disappeared on January 10 , but the color and odor remained. The letter concludes with this sentence: "Si je ne m'abuse pas, ce fait est très singulier, et mérite quelque attention de la part des physiciens."

Roots of the European blood root, Potentilla tormentilla (Anon., 1795 ), as well as Valeriana (K. von Kortum, 1800) and garden lettuce roots (Anon., 1832) sometimes luminesce. There are also records of luminous melons, ${ }^{34}$ and, according to Heinrich (1815: 337), of cabbages and beets, tubers, bulbs, and berries; likewise peaches, which may luminesce as they begin to rot (J. A. Deslonchamps, 1838), and dead oak leaves on the ground in damp woods (Naudin, 1846; L. R. Tulasne, 1848). The luminescence of living leaves has also been seen (G. von Szutz, 1800). ${ }^{35}$ It has even been reported by F. Goebel (1824) that luminous bubbles of carbon dioxide form during fermentation of raspberry juice and arrak. He thought the effect might be electrical, owing to rubbing of the glass surface by the gas bubbles. In later trials he never saw the light again.

Many unusual cases of luminescence were collected and discussed in an article (1808) of Sigismund Friedrich Hermbstädt (17601833), a "Sanitätsrath" in Berlin, on the light of organic bodies while alive and after death. In addition to human sweat, eggs, potatoes, roots, etc., already mentioned, Hermbstädt declared that he had seen luminous "faulendem Käse," without giving further details. The light of cheese is undoubtedly bacterial or fungal in origin, but information on the organism responsible is lacking, and no recent cases of luminous cheese appear to have been recorded.

The light of unusual vegetable materials such as potatoes and roots was so rare that practically no experiments were attempted; and little more than a record of the phenomenon is to be found. On the other hand, shining wood was common and served as material for extensive experimental research in the 1780's and 1790's, chiefly in connection with the effect of gases.

34 Casati, De igne, 349, Francofurti, 1688.

${ }^{35}$ The origin of the bluish-green "Phosphorlicht," observed between 9 and 10 P. M. one evening in September, 1800, on the leaves of a garden plant, Phytolacca decandra (Linn), by Carl von Szutz, an apothecary of Hungary, is uncertain. Szutz picked the leaves and the light continued to shine, sometimes yellowish-green, sometimes bluish, sometimes stronger, sometimes weaker, depending on whether the "Zug der Luft" was stronger or weaker. The phosphorescence lasted until after midnight and then disappeared. The light may have been an electrical phenomenon, although luminous fungi growing on living leaves is a second possibility. 


\section{Effect of Gases on Shining Wood and Flesh}

With the recognition and separation of various kinds of gas at the end of the eighteenth century, it was only natural that the action of these new substances should be tested on shining wood, fish, and flesh, i. e., on what were called "spontaneous phosphorescences," to distinguish them from the phosphors that had to be excited by a previous exposure to light. The element phosphorus was also classed as a spontaneous phosphorescence and was frequently studied at the same time as luminous wood (see Chapter XIII).

Between 1783 and 1800 , seven papers dealing with the effect of gases on luminous wood appeared, by F. C. Achard (1753-1821), L. Spallanzani (1729-1799), G. Carradori (1758-1818), N. Tychsen (1751-1804), A. von Humboldt (1769-1859), C. F. Gaertner (17851829), and C. W. Boeckmann (1773-1821). An eighth paper by N. Hulme (1732-1807) treated both wood and fish, particularly the latter. All the investigations by authors of four nationalities, were definitely experimental, published in chemical or physical journals, their purpose to elucidate the cause of the luminescence and to point out its relation to other light emitting processes, particularly that of phosphorus. They will be treated in some detail since they represent an important epoch in the history of bioluminescence.

\section{FREDERIC ACHARD}

The first article by Achard, a director of the physical section of the Berlin Academy, appeared in 1783. It was entitled "Experiences sur le Bois Pourri Luisant," and described thirty-one experiments, designed to discover the origin of the light of decaying wood, although no conclusions were drawn. Achard collected wood in different degrees of putrefaction and observed that to be luminous it must be rotten but not too rotten, that is not actually spongy-the fibers must be coherent. He discovered that the luminous wood could be dried, when the light would go out, but that it reappeared on moistening; that the luminosity would remain under water and also in a vacuum of $27 \frac{1}{4}$ inches $^{36}$ and in dephlogisticated air ${ }^{37}$ $\left(\mathrm{O}_{2}\right)$ and inflammable air $\left(\mathrm{H}_{2}\right),{ }^{36}$ but in nitrous air (from action of $\mathrm{HNO}_{3}$ on $\mathrm{Fe}$ ) the light disappeared quickly, and in fixed air $\left(\mathrm{CO}_{2}\right)$ it disappeared after one hour. Since the light of Kunkel's

\footnotetext{
${ }^{36}$ Very little oxygen is necessary to support luminescence. Enough remains in partial vacua and also in nitrogen and hydrogen unless specially purified.

${ }^{37}$ During his study of the glowworm, Forster (1782) noted that luminous wood became no brighter in dephlogisticated air $\left(\mathrm{O}_{2}\right)$, than in ordinary air.
} 
phosphorus disappeared in dephlogisticated air (oxygen), ${ }^{38}$ Achard argued that luminous wood could not be an "insensible inflammation." He also showed that previous illumination was not necessary for luminescence, since a piece of wood dried in the dark would again luminesce on moistening without exposure to light. Achard studied the effects of many chemical substances, of which the most important was spirit of wine. The luminescence did disappear in this liquid but returned again (with diminished intensity) when washed with water-an early, perhaps the first demonstration of the reversible action of a narcotic (alcohol) on a bioluminescence.

Achard appears to have been the first, also, to study the spectrum of shining wood. When the light was observed through a prism it appeared white and Achard could detect no light when the wood was observed behind blue, green, or red color filters. These results indicated to Achard the irrefrangibility ${ }^{39}$ of the light of rotten wood, a finding which he regarded as "fort singulier et très difficule à expliquer" (p. 106).

\section{SPALLANZANI AND CARRADORI}

After the experiments of Achard the scene shifts to Italy. The next observers, Spallanzani (1796) and Carradori (1797), did not agree on the interpretation of results. The material which Spallanzani used, called "fuochi matti " or " $\operatorname{mad}$ fires" by the Italians, was collected from chestnut trees near Modena in August, 1795. He was aware of Göttling's (1795) study of phosphorus in different gases and hence placed the luminous wood, together with phosphorus, in an atmosphere of nitrogen, finding that the light of both became weaker but returned to the original brightness in air. Spallanzani also obtained the same result with gas from swamps (probably mostly methane). When dried, the wood frequently became luminous if moistened. In Venice further studies with a dead luminous squid ${ }^{40}$ (Sepia officinalis) showed that this type of luminescence also disappeared in nitrogen, returned in air, and became twice as bright in oxygen. He was able to prove that the light of the firefly (lucciole) likewise disappeared in nitrogen, hydrogen, and $\mathrm{CO}_{2}$. From these experiments, Spallanzani drew a close analogy between the behavior of phosphorus, foul fish, rotten wood, and

${ }^{38}$ The Iuminescence of phosphorus does disappear in pure oxygen (see Chapter XIII) .

${ }^{30}$ The light intensity was evidently too low to pass the particular filters which Achard used.

${ }^{40}$ Light due to luminous bacteria. Spallanzani wished to study Pennatulae and Medusae also, but they were not obtainable at Venice. 
the firefly, coming to the conclusion that the light of all resulted from a slow burning quite comparable to the combustion connected with the respiration of animals. He believed that during the putrid fermentation of the wood, its hydrogen and carbon come more readily into contact with oxygen of the air. The reason that every kind of rotten wood is not luminous is because "the quantity of hyrogen and carbon necessary to make a visible light is not produced." Despite Spallanzani's demonstration in 1767 that no small organisms arose de novo in sterile culture media, he overlooked the luminous organisms on meat and wood.

At almost the same time (1798) Carradori (1758-1818), a professor at Pisa, had been studying the glowworm and had come to the conclusion that the light depended solely on the will of the insect. ${ }^{41}$ He criticized Spallanzani's work on luminous wood in a letter ${ }^{42}$ to Fabroni, saying that phosphorescent wood will luminesce under water, oil and in the vacuum of a barometer and consequently cannot be a slow combustion. He suggested that perhaps something from the phosphorus had affected the wood in Spallanzani's experiments with gases, because Spallanzani had placed both phosphorus and wood together in the same chamber. Moreover, Carradori held that glowworm luminescence occurred under water and oil, and could not be due to the use of dissolved oxygen, because if that were true, phosphorus should also light under water, which it did not.

Although some of Carradori's criticisms were reasonable and some of his arguments seem justified, Spallanzani was correct. In fact his views on "spontaneous phosphorescence" were decidedly modern.

\section{NICHOLAI TYCHSEN}

Tychsen (1751-1804), an apothecary of Kongsberg in Norway, later living in Copenhagen, used the wood of fir trees which had lain in the earth many years for experiments in 1797 . He noted that the wood luminesced under water. It lost its light when dry and would not luminesce when again moistened if dried for too long a time. The light also disappared when the wood was crushed between the fingers. Tychsen was particularly interested in comparing luminous wood and phosphorus, which had been studied by Göttling (1795). In general, the two were found to be rather simi-

${ }^{41}$ According to Brugnatelli (Gilbert's Ann. der Physik 4:442, 1800), Carradori thought the light of the firefly and rotten wood was like that of a phosphor, i. e., due to absorption of light.

${ }_{42}$ Carradori, Annales de Chemie 24: 216-225, 1797; translated in Phil. Mag. 2: 77-80, 1798, and Annalen der Physik 1: 205-213, 1799. 
lar, both using up oxygen and producing acid, but Tychsen was surprised that wood should luminesce under water while phosphorus did not, and that phosphorus would light ${ }^{43}$ in $\mathrm{H}_{2}, \mathrm{~N}_{2}$ and nitric oxide, while wood did not. Neither wood nor phosphorus would light in pure oxygen. This result is correct for phosphorus but suggests that the pure oxygen Tychsen used must have contained some harmful ingredient, for the light of fungi continues in oxygen as well as in air.

\section{VON HUMBOLDT, GAERTNER, AND BOECKMANN}

The chief interest of these three Germans was to determine whether the light of rotten wood resulted from a slow burning, as Spallanzani and others believed. Von Humboldt (1799) did find that the light would disappear in $\mathrm{CO}_{2}$ and in azotic gas $\left(\mathrm{N}_{2}\right)$ and other non-respirable gases, but that it reappeared in oxygen or air, leading to the conclusion that the luminescence was dependent on oxygen, which was apparently absorbed by the wood. He also stressed the fact that the luminescent process could be affected in many other ways, by high temperature, or acids, alcohol, etc.-even though oxygen was present.

Von Humboldt concluded that luminescence must depend on a certain equilibrium between the organic constituents in the wood, an equilibrium which was changed by temperature or by substances in the surrounding medium. For example, at low temperatures, oxygen would combine with hydrogen, forming water, a process accompanied by luminescence, but at a high temperature with carbon to form $\mathrm{CO}_{2}$, and the light would disappear, as it did in absence of oxygen. The cause of the light was sought in a delicate balance between such reactions at the time putrefaction begins.

Gaertner (1799), an apothecary at Hanau, believed that the light of rotten wood was different from that of light resulting from combustion, since oxygen appeared to be less essential for wood, and he asked, "whether the luminous appearance of wood be not produced by the union of phosphorus and carbon in a certain proportion still unknown to us?" Gaertner concluded that it was not yet possible to give a satisfactory explanation of the phenomenon.

Boeckman, a professor of physics at the Gymnasium at Carlsruhe, published two papers in 1800, one on phosphorus (see Chapter XIII) and one on luminous wood. The two luminescences were compared as regards the effect of gases, with the following conclusions: ${ }^{44}$ (1) Wood is luminous in oxygen gas at low temperatures

${ }^{43}$ Owing to impure gases containing very small amounts of oxygen.

44 From the translation in Phil. Mag. for 1803. 
whereas phosphorus is not. (2) Wood is luminous in many more non-respirable gases than phosphorus. (3) Wood luminescence disappears but phosphorus takes fire in muriatic acid gas. (4) Wood emits less, and phosphorus more light in rarefied air. (5) Wood luminesces in vacuo but phosphorus does not. (6) Wood luminescence disappears when heated in oxygen while phosphorus burns. (7) Wood produces $\mathrm{CO}_{2}$ while phosphorus does not. (8) Moisture and wet promote the luminescence of wood but are impediments to the luminescence of phosphorus, which will not light under water.

Some of the above statements are incorrect, that wood luminesces in vacuo; other differences are connected with the peculiar behavior of phosphorus luminescence at different oxygen tensions (see Chapter XIII). However, many of the differences are quite striking and Boeckmann concluded: ${ }^{44}$

"Phosphorescent wood, therefore differs essentially from artificial phosphorus by the conditions requisite for its being luminous; and therefore the assertion of Spallanzani, that the greatest analogy exists between the luminous phenomena of these two substances must lose some of its weight." He held that "The extinction of the light of rotten wood in different mediums does not so immediately arise from want of oxygen gas as from some change which the wood itself has experienced."

\section{NATHANIEL HULME}

England's contribution to the study of gases on luminous fish and wood was made by Nathaniel Hulme, a practising physician in London. His two important papers on "Light which is Spontaneously Emitted, with some Degree of Permanency, from Various Bodies," were published in 1800 and 1801. The 1800 paper, dealing with light from a concoction of fish in sea water, is divided into a number of sections with such headings as:

I. The Quantity of Light emitted by putrescent Animal Substances is not in proportion to the Degree of Putrefaction in such Substances, as is commonly supposed; but on the contrary, the greater the Putrescence, the less is the Quantity of Light emitted. II. The Light here treated of is a constituent principle of some Bodies, particularly of Marine Fishes, and may be separated from them, by a peculiar process; may be retained, and rendered permanent for some time. It seems to be incorporated with their whole substance, and to make a part thereof, in the same manner as any other constituent Principle.

After pointing out that some substances preserve and others extinguish spontaneous light, Hulme said that when extinguished "it is 
not lost but may be again revived in its former splendour and that by the most simple means "-for example, by adding excess salt, the light goes out but may be revived by diluting with fresh water.

Hulme noted, as Canton had also, that "Spontaneous Light is rendered more vivid by Motion" (a result connected with the solution of additional oxygen when the water was stirred) and that "Spontaneous Light is not accompanied by any degree of sensible Heat, to be discovered by a Thermometer." He also studied the effects of heat and cold on luminous fish, wood and the glowworm and the effect of animal fluids. Fresh milk and blood serum allowed luminescence of fishes for a long time but sour milk, urine, and bile extinguished the light quickly.

Hulme's second paper (1801) dealt with the effects of "various aerial Fluids" on spontaneous light, both of fish and of rood. He showed that neither a blast of air from bellows nor vital air (oxygen) increased the luminescence as they did a fire and that azotic gas (nitrogen, undoubtedly impure), which is incapable of supporting combustion, had no effect on the light of fishes that were already luminous, although it prevented the development of the light. Inflammable air (hydrogen) and fixed air $\left(\mathrm{CO}_{2}\right)$ prevented both the development of spontaneous light and also extinguished it when emitted, but the light again revived quickly in " atmospherical air." Sulphuretted hydrogen gas $\left(\mathrm{H}_{2} \mathrm{~S}\right)$ and "nitrous gas" (from dilute $\mathrm{HNO}_{3}$ and $\mathrm{Cu}$ ) both extinguished the light quickly and irreversibly (some reversion in $\mathrm{H}_{2} \mathrm{~S}$ ). A vacuum also put out the light but it returned quickly in the air.

Hulme came to the conclusion from these experiments that the light is a "constituent principle of marine fishes" and the "first that escapes after the death of the fish." Such a statement was quite in line with the Newtonian conception of light as made up of material particles. Humphry Davy (1778-1829) also, in 1803, after referring to the materiality of light, attributed the light of dead fish to a light substance becoming free at a certain period of decay.

The conflicting results and conclusions of all these men at the end of the eighteenth century illustrate the difficulty of reaching generalizations regarding relatively simple phenomena. The fact that they were handicapped by impure gases and other chemicals partly explains the difference in results. Although certain bioluminescences do not require oxygen, ${ }^{45}$ the luminescence of the glowworm, luminous bacteria, luminous fungi and phosphorus all depend on the presence of molecular oxygen and might be called a "slow" combustion. Boyle (1667) made the first discovery of the

${ }^{45}$ The ctenophores, a relation discovered by the author in 1926. 
necessity of air for the luminescence of "shining" wood and flesh, but at that time oxygen was not recognized as an element. Achard's gases were too impure to give the proper conclusion, so that Spallanzani must be credited with first proving the necessity of dissolved oxygen for bioluminescences in general. Carradori, Tychsen, Gaertner, Boeckmann, von Humboldt, and Hulme had the correct approach but unfortunately drew some wrong conclusions.

\section{Early Nineteenth-Century Views}

The studies of gases on spontaneous phosphorescence had the general effect, despite some dissension, of emphasizing the oxidative nature of the light-emitting process and its similarity to the glow of phosphorus. With the beginning of the nineteenth century, the "phosphorus theory" of the light of wood and flesh was the dominant one, although not by any means universally accepted. The varied opinions expressed by prominent men will illustrate how far from the truth some of the theories were.

The light from wood excited curiosity but did not lead to the philosophical speculation induced by the luminescence of flesh. It was not possible to apply to wood the view of Puerarius (De Carnis Lucentibus, 1667), regarding meat, that the fatty lumbar parts of the luminous mutton at Montpellier were brightest because they are especially warm and the stimuli of desire arise from this region, or to adopt the point of view expressed in Paullin's (1687) story of the luminous hen's eggs, that the hen had been fertilized by "un coq très ardent."

Pierre Jean George Cabanis (1747-1808), the eminent French physician and philosopher, friend of Diderot, D'Alembert, Mirabeau, and Franklin, was one early writer, who did attribute the light of flesh to phosphorus, although he could not entirely abandon the belief that activity and desire were factors in producing the light. As a member of the medical profession, he had observed the luminescence of cadavers, and as a philosopher, he interpreted what he had seen. His views were expressed in a book, Rapports $d u$ Physique et du Moral de l'Homme (1802). The sixth mémoire ${ }^{46}$ of the book was entitled, "De l'Influence des Tempéraments sur la Formation des Idées et des Affections Morales." Cabanis wrote: "in the bodies of animals which decompose, phosphorus can undergo a slow combustion without producing a true flame" or "igniting combustible bodies" and this fact "has given much credence to those visions which one dreads and which one generally finds near

${ }^{48} \mathrm{~J}$. G. Cabanis, Euvres 3: 379-381, Paris, 1824. 
tombs." Cabanis then pointed out that the brain and nervous system are particularly rich in phosphorus. Hence,

It is the commencing decomposition of cerebral tissue, to which are due those phosphoric lights which are often observed in [dissection] amphitheatres at night; and it is principally around the exposed brains or their debris on the dissecting table that one notices them. A very great number of observations have led me to believe that the quantity of phosphorus which develops after death is proportional to the activity of the nervous system during life. It appears to me that the brains of persons dead of maladies characteristic of excess of this [nervous] activity emit a light more brilliant and sparkling; those of maniacs are very luminous; those with dropsy or of the "leuco-flegmatiques" type are much less so.

\section{In a footnote Cabanis explained further that,}

The brilliance of light from (luminous) animals is related to their vital energy or to the degree of their excitation. This light is, for example, more brilliant at the time of their loves. It even appears that it is destined, in many species, to serve as a guide and lantern to the male when he searches for the female; "elle est alors à la lettre le flambeau de l'amour."

The grandfather of Charles Darwin, Erasmus Darwin (17311802), botanist and poet, was rather more specific, believing that oxygen combined with carbon or sulphur or phosphorus to give heat, as in a dung-hill, or to give light, as in rotten wood. In his Phytologia or the Philosophy of Agriculture and Gardening (Sec. X, 5. 1, London, 1800), Darwin called attention to phosphorescent wood so bright " as to alarm benighted passengers; which is undoubtedly owing to the phosphorus it contains, and which is at this time converted into phosphoric acid.'

Antoine François de Fourcroy (1755-1809), professor of chemistry at the Jardin des Plantes, in his eleven-volume System des Connaissances Chémiques (Paris, 1801), took particular pains to point out that wood often becomes luminous during the course of slow putrefaction and develops an odor of "des agarics et des bolets." This was a happy observation, but Fourcroy did not realize the causal connection between luminescence and the fungus smell, merely included these peculiarities among others characteristic of "bois pourri," such as the change in color, the light weight, the softness, and the fact that rotten wood burned quickly without much heat. Luminous wood and fungi were not definitely associated until the letter of Derschau to Nees von Essenbach in 1823.

The prize essays of Bernoulli and Link, were not primarily con- 
cerned with the luminescence of fish, flesh, and wood. Nevertheless, these men expressed their opinion on the subject. Bernoulli (1803) believed that the light of fish and flesh resulted not necessarily from an oxidation, but was an essential constituent of all organized beings, becoming visible during their decomposition, a statement much like that of Hulme $(1800,1801)$. The light was spoken of as a material body, in line with the prevalent views of his time, but was held in the body in a form spoken of as mechanically aggregated (angehäuftes) light by the elasticity of the tissues. As the elasticity of tissues disappears and they become porous (literally, bei ihrer Entweichung) after death, the light is set free. He thought it remarkable that the light of luminous animals ceased on death but that of non-luminous forms began after death; Pholas was cited as the only animal that lighted before and after death.

Link (1808:80) suggested that shining wood and fish might be a kind of light magnet, as he was unable to obtain light from herring kept in a completely dark cellar, and von Humboldt had noticed that the luminous wood in mines occurred where some light could penetrate. However, this was only a surmise and a poor one at that.

At the time of the prize essays, general interest in cold light was widespread. A short paper in the Magazin der Berliner Gesellschaft Naturforschende Freunde for 1808, by S. F. Hermbstädt, a royal apothecary in Berlin, entitled "Bemerkungen über das Leuchten organische Körper im Leben und nach dem Tode derselben," summarized the contemporary knowledge. Hermbstadt referred to luminescence of living animals but paid particular attention to unusual luminous phenomena such as the light of sweat, cheese, potatoes, wood, meat, etc. Although his only original experiments had to do with the effect of gases on fireflies (see Chap. XVI) Hermbstädt wondered whether the luminous fluid in these insects emitted light as a result of a natural phosphorus, was electrical in nature, or excited by galvanism. He refrained from taking a stand on the cause because he had been unable to experiment, but did express his opinion that " perhaps the separation of the constituent elements of rotten wood causes emission of a pure non-warming light," and that there were sufficient grounds for applying this explanation to every luminous phenomenon.

Dessaignes (1809) devoted considerable attention to wood in Chapter V of his Mémoire, entitled "De Phosphorescence Spontanées." He noted that during the period of phosphorescence the wood lost about half its weight and after the decomposition the luminescence came to an end. With an air pump, considerable gas 
could be removed from the wood, part of which was $\mathrm{CO}_{2}$. Dessaignes tried extracting pieces of phosphorescent and non-phosphorescent wood with solvents and applied various tests to the extracts to find out what changes took place. He also studied luminous fish.

During the entire period of light production by fish there was no trace of decomposition and no change in the muscle fibers. Only the outer slime changed, becoming more turbid and opaque (but always before decomposition), and could be precipitated as a grayish powder. Dessaignes studied the effects of temperature, distilled water, alcohol, ether, many salt solutions and other agents on both fish and wood, obtaining results, difficult to understand in 1809 , but easy to explain with modern knowledge that the light is due to luminescence of bacteria.

Dessaignes demonstrated the production of $\mathrm{CO}_{2}$ and showed that the time the light lasted in a vacuum depended on the amount of "bound air." In a "crucial experiment," he found that luminescent material from fish suspended in sea water entirely filling a closed vessel soon lost its luminescence but the introduction of an air bubble would call forth the luminescence again.

From such facts Dessaignes concluded that spontaneous phosphorescence was a kind of burning whereby water and $\mathrm{CO}_{2}$ were formed. The wood molecules did not appear to change but the luminous substance, "un suc glutin-extractif," responsible for the phosphorescence was connected with the slimy binding material (undoubtedly the fungus mycelium) of the wood fibers and disappeared during a process that Dessaignes described as a fermentation, something like the retting of hemp. In animals also the light substance was not the muscle fibers but appeared to be a slimy albuminous sap (suc albumino-muqueux) that absorbed oxygen and became continually more sticky and finally turbid. Dessaigne's comparison with fermentation came very near the modern conception of luminescence as an enzymic process. Most of his ideas were quite good, but he unfortunately missed the presence of luminous fungi or bacteria which would have removed the luminescence of wood and fish from consideration in his prize essay.

Placidus Heinrich, also, had the right idea in his views on luminous wood. Forty-two pages of the third Abteilung of Die Phosphorescenz der Körper (1815) are devoted to luminous stumps, logs, timbers, and roots. Like others he was somewhat mystified by the fact that the beautiful light was so infrequent, and that it lasted so short a time. Heinrich listed dampness and prevention of the free access of air as absolutely necessary conditions for luminescence and stated that the light did not arise in the fibers but in the binding 
material, which by decomposition liberates water, carbon, and phosphorus. These then burn slowly.

Like those of his predecessors, many of Heinrich's experiments had to do with the effect of various fluids and gases. He found that the light lasted longer in oxygen than in air and longer in a free than in a closed space; also that luminous wood placed in a closed vessel over water produced only a negligible change in volume. This was correctly explained as the result of the formation of as much new gas as was removed by the wood.

Heinrich's final conclusion was that this spontaneous luminescence came from "decomposition of the sap and of the fluid constituents of the wood .... an extremely weak combustion taking place in a minimum amount of air." Phosphorus was believed to play an important role since it is widespread in plants. He held that both phosphorescent wood and fish were similar and might be considered "the simplest, the most natural, and the most instructive of the pyrophors" (Luftzünder). Despite the fact that Heinrich mentioned luminous mushrooms as examples of other luminous vegetative growths, he failed to see a possible relationship between them and luminous wood.

G. R. Treverinus $(1818,1831)$ was undoubtedly influenced by Heinrich's views, for he also believed that luminous material of organized beings, which was obviously secreted by many living animals, was true phosphorus (wirklicher phosphor) or a material having all the properties of true phosphorus.

The "phosphorus origin" of luminous wood and fish appears to have been generally accepted in the first half of the nineteenth century. For example, the great Justus Liebig (1803-1873), leader in biochemical thought of the period, in his 1839 paper ${ }^{47}$ on "Gärung, Fäulniss und Verwesung," attributed the light of wood to oxidation, and the light of fish to a phosphorus compound like phosphine, set free during the decomposition of the flesh. This "chemical " point of view was quite in line with his general ideas regarding the biological processes of fermentation and putrefaction, as indicated in the next section.

Finally, as the mid-century approached, the opinion of a distinguished biophysicist is of interest, that of Carlo Matteucci (18111868) of the University of Pisa, whose luminescent studies had previously been on the firefly. Matteucci (1849) made observations on luminescent fish along the Mediterranean in 1847, finding that the light "persisted a long time without decrease" in intensity in hydrogen, nitrogen, and carbon dioxide containing " no trace of

«7 J. Liebig, Ann. der Physik (2) 18: 106-150, 1839. 
oxygen," but his gases were evidently impure. However, a seawater extract of the luminous parts in a long tube lost its luminescence quickly, but the light would return on agitation, just as is true for phosphorescence of the sea. In this case the bacteria had used up dissolved oxygen in the tube and the light on agitation was the result of additional solution of oxygen, when the surface of the water was disturbed.

Matteucci finally concluded that the fish luminescence was not due to phosphorus but " to a substance which develops on putrefaction, requiring for development the presence of oxygen, but which shines without oxygen, by an action all but physical." It was different from phosphorescence of the sea which becomes more brilliant on adding ammonia, alcohol, etc., while the fish luminescence disappears in their presence. Fish luminescence also persists at -2 to $-3^{\circ} \mathrm{C}$, while sea luminescence stops at +2 to $+3^{\circ} \mathrm{C}$. Thus, Matteucci discarded the possibility that the light might have come from microorganisms.

\section{Fermentation and Putrefaction by Microorganisms}

Realization of the important part microorganisms play in connection with changes after death was a very slow development. Although Hooke described the mycelium of bread mold in Micrographia (1665), and Leeuwenhoek wrote to the Royal Society on protozoa (1676), yeast cells (1680), and bacteria (1683), over 150 years elapsed before their activity in such common phenomena as fermentation and putrefaction was appreciated.

Yeast "globules" were again observed by Desmazieres in 1826, but it is almost unbelievable that the recognition of yeast as a living plant which reproduced by budding and was responsible for the conversion of sugar to alcohol and carbon dioxide was not recognized until the researches of Baron Charles Cagniard-Latour (17771855) in 1836-1838. His findings were confirmed independently by F. T. Schwann (1810-1882) and by F. T. Kützing (1807-1893), both in 1837 .

These discoveries were attacked by the chemists, J. J. Berzelius (1779-1848) and J. Liebig (1803-1873), two of the greatest names of the times. Berzelius in 1839 held that fermentation was an example of the "catalytic principle" which he had announced in 1836 , and Liebig in 1839 published his own theory, which regarded "ferments" as unstable molecules in a peculiar sort of vibration which they communicated to other molecules, thus causing decomposition.

Pasteur's monumental studies, beginning in 1857 and culminating 
in 1876 with his Etudes sur la Bière, completely supported the importance of microorganisms in fermentation processes. ${ }^{48}$ Nevertheless, Liebig clung to his original thesis of vibrating molecules as late as 1869. No one had succeeded in extracting anything from yeast which would convert sugar to alcohol in solution, and the whole problem of organized and unorganized ferments was not resolved until Eduard Buchner (1860-1917) prepared zymase from yeast in 1897 .

The above dates are of special interest for the history of bacterial and fungal luminescence. We shall see that in the years 1823 and 1853, clear proof was advanced in support of the view that the light of luminous wood and of luminous flesh, respectively, came from microorganisms. When it is recalled that belief in spontaneous generation was laid to rest only after the concerted efforts of Pasteur in 1860-1861 and of Tyndall in 1876-1877, and that the bacterial origin of disease was not generally accepted until the work of Pasteur and Koch in the late eighteen seventies, recognition that luminescence could come from microorganisms was in advance rather than behind the general knowledge of the time. Realization that the diffuse light of the sea was due to microscopic flagellates also came in the years, 1821 to 1834 , although luminous macroscopic forms had been known for some time.

\section{The Light of Wood a Fungus Growth}

After the publication of Heinrich's book (1815), a lull of nearly a decade occurred in the careful study of luminous wood and nearly four decades in the study of luminous flesh before the true origin of the luminescence became apparent. Discovery in the case of wood came from an observation of the director of mines (Bergrath) in Bochum, a man named Derschau, who had written a letter describing bright luminescence of the wooden supports and beams of coal mines, so bright in fact that lamps were unnecessary. Although his companions ascribed the light to the rotten part of the wood itself, Derschau noticed that the light came only from lines and streaks ${ }^{49}$ in the wood, that could be torn away by the hand, i. e., from the structures growing in the wood called Rhizomorphs, described in a previous section. Derschau's letter was included in a paper in Flora by T. F. L. Nees von Esenbeck (1823), who announced the finding to the scientific world.

${ }^{48} \mathrm{M}$. Traube also held fermentation to be due to living organisms, in Theorie der Fermentwirkung, Berlin, 1858.

${ }^{49}$ Note the previous (in section on "Luminous Mushrooms and Rhizomorphs") observation of Freyesleben in 1796, that rhizomorphs on wood are luminous. 
In the same year, C. G. and T. F. L. Nees von Esenbeck, J. J. Nöggerath and K. C. G. Bischoff (1823) published a 110-page paper on "Die unterirdische rhizomorphen, ein leuchtender Lebensprocess," which included a consideration of all plant phosphorescent phenomena. The authors stated definitely that the light of wood came from Rhizomorpha subterranea stellata, and from $\mathrm{R}$. aidela. These forms did not light in a vacuum or in irrespirable gases but did luminesce under water and in the air. The light was not dependent on previous insolation, but was a visible indication of the life process, which required absorption of oxygen, a mild burning. The important point in the work of these men is their recognition that wood luminescence comes from a living thing rather than from a process of chemical decomposition. Attention was also called to the views of Freyesleben in 1796 by Nöggerath and C. G. Nees von Esenbeck (1825).

The ideas of Derschau, Nees von Esenbeck, and others were not immediately accepted. J. von Schmitz (1843) made a special study of the growth of Rhizomorpha, both in the forest and in the laboratory under different conditions, and was impressed with the close connection between the life of the plant and its luminescence. This circumstance led Schmitz to the belief that perhaps the light of luminous wood, a non-living material, was a different sort of luminescence from that of Rhizomorpha after all. He also observed that different samples of Rhizomorpha varied greatly in the intensity of their light, depending on internal conditions.

L. R. Tulasne (1848) studied not only Rhizomorpha subterranea and a mushroom, Agaricus olearius, but also the phosphorescence of dead leaves, which Naudin had described in 1846. He emphasized the fact that the light appeared not only during life, as in Agaricus and Rhizomorpha, but also after death, for example in the case of wood, dead leaves, the pulp of fruit, such as the peaches about to decay (J. A. Deslonchamps, 1836) and other organized material. The listing of these luminescences together was a good sign, but Tulasne's remarks about light after death indicate he did not fully appreciate the significance of the observation of Derschau. Final proof of the fungus origin of the light of luminous wood came with the publication of Heller's (1853) paper, described in a later section. T. Hartig (1855), not knowing of Heller's work, was another who thought the light had nothing to do with a fungus, although he saw fungal fibers in the wood. ${ }^{50}$ In the meantime, more attention was directed to luminous mushrooms, whose light was

${ }^{50} \mathrm{R}$, Hartig (1873) later discovered the relation of rhizomorphs to Armillaria. 
obviously the result of processes occurring in a living plant. A. Raffenau-Delile (1833) examined the phosphorescence of the common luminous mushroom of olive trees, Agaricus olearius, and Tulasne (1848) wrote his long paper on the spontaneous light of rhizomorphs, dead leaves, and the olive-tree agaric.

A more modern experimental approach to determine the cause of fungal light was made by J. H. Fabre (1855). Following a suggestion of Tulasne, that it would be important to know whether more oxygen was absorbed and more $\mathrm{CO}_{2}$ and heat produced in luminous than in non-luminous parts of a fungus, Fabre measured these gases and found that the luminous pileus of Agaricus olearius did produce more $\mathrm{CO}_{2}$ than the non-luminous fungal regions. However, he could detect no rise in temperature. In the last third of the century the identity of fungus light and that of rood became universally accepted. The principal student was Friedrich Ludwig (1851-1918), Oberlehrer at the gymnasium in Greiz, whose inaugural dissertation was entitled "Ueber die Phosphorescence der Pilze und des Holzes" (Göttingen, 1874).

\section{Shining Flesh and Animalcules}

In the meantime, ideas on phosphorescence of the sea underwent a reversal. The old theory that diffuse sea light was due to decomposition of organic material gave way to the universally accepted belief that all sea light came from microscopic organisms. It was logical to hold that the light of dead fish must also be due to microorganisms, as Henry Baker had suggested in 1742.

For example, John Murray (1821) in his treatise, "on the Luminosity of the Sea," and in his book, Experimental Researches (1826: 72) referred to whiting and mackerel which "yield light in the incipient stage of decay. In this case I am of opinion that it proceeds from adhering, perhaps parasitic, luminous animalculae, the evolution of light being the effect of the slight increment of temperature produced by the commencement of animal decomposition." Michaelis (1830) and Ehrenberg (1834) quite naturally thought of animalcules as causing the luminescence of fish as well as phosphorescence of the sea.

In 1838 D. and R. Cooper published in a medical journal an important but overlooked paper on the light of human cadavers, which came very near the truth, although these observers finally interpreted the luminescence they observed to be due to "a peculiar state of decomposition."

The chief source for the Coopers' study was a human corpse, 
Boreham, "admitted to the Webb-street School of Anatomy and Medecine, Borough," which showed luminescence on the interior and exterior of the thorax. The luminosity remained for several days and gradually extended to other parts, chiefly along bones and tendons, but not to the viscera of the chest or abdomen. The luminous material could be scraped off the flesh but appeared to penetrate bone rather deeply, as considerable scraping was necessary to remove it. The authors remark that the phenomenon had never been observed before (except in a corpse, Tomkins, admitted a few days previously, whose thigh was luminous), although the attendant had served at the school since 1812. Several persons had observed luminescence on "birds when they had been hanging for some time" or on cats and dogs in ditches, or on veal. "The common opinion with these individuals with respect to the cause, is, that the meat had been struck by lightning, it having generally been observed in the summer months."

The first experiment of the Coopers was to smear some of the luminous material on other bodies, which soon became luminescent also, from which they concluded that the light of Boreham had probably come from Tomkins, whose thigh was slightly luminous. Under the microscope (900 magnification) "luminosity appeared to be emitted from an oily matter." They saw " small globules darting from one side to the other and occasionally stemming the current for a considerable distance. ... Mr. Bowerbank observed a small thread-like body dart across the field of the microscope, which he immediately recognized as one of those bodies (Vibriones) which are so abundantly seen upon macerating animal matter, such as a mouse, in water for a length of time." They were convinced that no such animal as Monas existed in the luminous matter, but there were globules or "molecules" that appeared to be one hundred thousandths of an inch in diameter and hence one thousand times smaller than the minute animals known to be responsible for the phosphoresence of the sea. Since the Coopers observed similar movements of the small globules in a gamboge suspension, ${ }^{51}$ they were not sure that anything living existed in the slime from the luminous corposes. However, the evidence indicates that they really did observe luminous bacteria under the microscope.

The Coopers also showed that the light of the material disappeared in a vacuum but returned in air, that it would last only ten to fifteen minutes under water or milk but three days in oil, that it was extinguished by heat, alcohol, acid, and other chemicals,

\footnotetext{
${ }^{51}$ Gamboge particles are in Brownian movement, whereas luminous bacteria are self-motile.
} 
although it persisted in a tube at the low temperature of a freezing mixture. Regarding the cause of the luminescence they say: "We are inclined to believe that it is the effect of a peculiar state of decomposition, totally independent of atmospheric causes, the luminosity residing (to the best of our belief) in the oily matter, which we observed upon submitting it to microscopic observation."

\section{Johann Florian Heller and Luminous Bacteria}

The final proof of the fungal origin of shining wood and the bacterial origin of shining flesh came from Johann Florian Heller, M. D. (1813-1871), professor of medicine at the University of Vienna. His views on "Leuchten gefaulter Hölzer" were first reported at the twenty-first Versammlung deutscher Naturforscher and Aerzte at Gratz in 1843. Leibig was the presiding officer. Heller's general paper, "Über das Leuchten im Pflanzen und Tierreich," was published in 1853. By microscopic observation of luminous wood he determined with certainty that it was the fungal threads alone in the wood that emitted the light and called them Rhizomorpha noctiluca. He found that the fungus would light when separated from the wood but only as long as it was in vegetative growth and not after death. The light of potatoes, beets, and roots was grouped with that of wood as due to the fungus itself.

Regarding dead fish and flesh, Heller had a similar explanationthe light came not from any decomposition products containing phosphorus but from a "Pilz" growing superficially on the material. Like the Coopers (1838), he was able to inoculate dead non-luminous fish with the luminous material and make them light, although in the case of fresh-water fish it was necessary to bathe them in sea water. He wrote: "Die verwesenden und faulenden Tiere leuchten nicht, sondern es leuchtet ein nach dem Tode sich an den Tierstoffen bildender Pilz, somit wieder eine Pflanze, fur welche ich den Namen, Sarcina noctiluca, vorgeschlagen habe." $\mathrm{He}$ also declared that the light of human corpses, sausage, and eggs came from the Sarcina noctiluca, and presumably the light of human sweat and urine, although the explanation of luminous urine was not certain. There is no uncertainty in Heller's statements and we now know that he was absolutely correct. ${ }^{52}$ This paper, despite its publication in a rather obscure medical journal, is a milestone in the knowledge of "spontaneous luminescences."

\footnotetext{
${ }^{52}$ Even after Heller's (1853) paper there were still some who doubted the organismal origin of luminous wood. Th. Hartig (1855) and also DuBary in Hofmeister's Handbuch der Botanik, 230, Leipzig, 1866, believed that the wood itself and not a mycelium luminesced.
} 
In only one respect did Heller go astray. Basing his conclusions on experiments with impure nitrogen and hydrogen in which the light of wood persisted, he came to the conclusion that the origin of the light in the fungus itself was electrical rather than a combustion or an oxidation.

\section{From Heller to Pfüger}

Although Heller's work on Sarcina noctiluca was clear cut and his ideas correct, an added proof of luminous bacteria as the cause of the luminescence of fish and meat came from the two papers of Eduard Pflüger (1839-1910) in 1875. His great reputation had much to do with convincing the scientific world. Without a knowledge of Heller's work, Pflüger had studied the older literature, particularly the monograph of Heinrich (1815), and came to the conclusion that the light must be the result of living organisms. Microscopic observations, showing great numbers of bacteria in the luminous slime of fish, and the fact that a filtrate showed no luminescence removed all his doubts. The crucial test came from the inoculation of shellfish and fresh-water fish with luminous material from a marine fish, and the demonstration that the luminous spots would increase in size. Pflüger also stressed the point that light production was a "Verbrennungsprocess."

Between Heller (1853) and Pflüger (1875) a number of observers remained completely unaware of the bacterial origin of the luminescence of flesh. Phipson $(1860,1862: 103)$ discarded the microorganism theory of fish luminescence and leaned toward the idea of a luminous grease, a "peculiar organic matter which possesses the property of shining in the dark like phosphorus itself."

E. Mulder (born 1832), professor of chemistry at Utrecht, claimed in 1860 that the luminescence of fish began when they started to decompose. He realized that the light did not come from phosphorus but thought it resulted from the action of hydrogen on phosphorus in organic combination in the fish, giving rise to phosphine. This conclusion was based largely on a study of the effect of various agents on fish luminescence, whose behavior he found to be the same as on phosphine. He also related the story of an acquaintance who had eaten shrimp that were not fresh. As a consequence the person became ill and his excrement, as well as the remains of the repast, were luminous in a dark room.

Another skeptic of the bacterial origin of the light of flesh was W. G. Hankel (1862), a professor of physics at Leipzig. Using the microscope, he was unable to find any evidence of "Infusorien oder 
Kryptogamen" in the greasy luminous mass on hog flesh or fish. He tested many substances to find out their effect on the light but added nothing new to the knowledge of the day. Under an air pump, the light of the luminous material became very weak but on readmitting air "blitze er plötzlich wieder auf." Hankel was surprised to find that in pure oxygen or in ozonized oxygen the light failed to increase in brightness. C. Horne (1869 reported a dead luminous lobster with no mention of bacteria, and even as late as 1871, P. Panceri, the great Italian student of bioluminescence, in a study of luminous fish, attributed the luminescence to the oxidation of fat.

It is fitting that for all practical purposes the history of knowledge of shining wood, fish, and flesh should end with Eduard Pflüger, a pupil of Karl Ludwig (1816-1895) and the founder of the Archiv für die gesamte Physiologie in 1868, one of the foremost physiologists of Germany. Pflüger is also a good example of a scientist who made one important contribution to bioluminescence and then became interested in other things. The study of luminous fish in his two papers (sixty-six pages in all) was a direct consequence of early interest in cell oxidation. It was Pflüger who showed in 1872 that the blood was not the place where oxidation of foodstuff took place, as had been generally supposed, but that they burned in the muscles and other cells of the body.

After Pflüger's papers, publications were largely concerned with characterizing and naming the various species of luminous bacteria. Two years later, J. Nuesh (1877) spoke of Bacterium lucens (1877) and Bacterium termo (1879), F. Cohn (1878) of Micrococcus phosphorens, and O. Lassar (1880) of Micrococci, confirming Pflüger's work. In $1884 \mathrm{~F}$. Ludwig described Micrococcus Pflugeri, and O. Katz $(1887,1891)$ a number of new species.

Other workers are too numerous to mention, but three names of the nineteenth century should be remembered as preeminent, that of B. Fischer (1852-1915), a ship's medical officer, later professor of hygiene in Kiel, who noted the world-wide distribution of luminous bacteria in 1887, 1888 and 1894, that of M. W. Beijerinck (18511931), the great Dutch bacteriologist of Delft, who greatly advanced biochemical knowledge from 1889 to 1915, and F. Ludwig, whose studies of the light of both bacteria and fungi extended from 1874 to 1904.

Investigation of luminous wood and fungi in the last half of the nineteenth century was concerned chiefly with descriptions of new luminous species and attempts to culture the mycelium from luminous wood. F. Ludwig was the pioneer in this field, ably followed 
in the early twentieth century by Hans Molisch (1856-1937), professor of botany at the University of Vienna. Like Ludwig, Molisch studied both fungi and bacteria, and summed up knowledge of luminescence in the plant kingdom in his book Leuchtenden Pflanzen (Jena, 1904, 1912).

In recent times, so much experimental work has been carried out with luminous bacteria that it is fortunate the organisms are not pathogenic to man. Although Beal (1666) had remarked that his luminous "Fish were not yet fetide, nor insipid to the best discerning palats," it is not certain whether he ate the mackerel being prepared for pickle. On the other hand, Nicolas Lémery (Harris translation 1686: 537, of Cours de Chymie, 5th ed.), in speaking of the luminous meat in the butcher shops of Orleans in 1683, did make a perfectly definite statement: " there was such quantities of it, some people ventur'd to eat of it, and at length it was found to be as good meat as any other."

However, the first experimental test of luminous bacteria themselves appears to have been made by P. Tollhausen in 1889. Having first fed the luminous bacteria to a cat, he sprinkled his own meals with a bouillon culture of Bacterium phosphorescens, and ate up to $25 \mathrm{cc}$. of the luminous broth on three successive days without any ill effects.

\section{Parasitic Luminous Bacteria}

Probably the first observation of infection of a living animal with luminous bacteria must be ascribed to Thulis and Bernard (1786), who observed a luminous "Crevette de Rivière" (shrimp) from a fresh-water stream in southern France, without knowing that the light must have been due to luminous bacteria. The next instance appears to be that of D. Viviani (1805) who figured luminous species of what he called Gammarus from the Mediterranean near Genoa. Judging from the drawings, the animals were sandfleas.

These papers have been mostly overlooked and the discovery of a luminous bacterial malady of living animals is usually attributed to A. Giard (1889) and A. Giard and A. Billet (1889, 1890), who demonstrated very clearly that sandfleas of the genera Talitrus and Orchestia become infected and luminous, live a few days, and then die. These men cultured the bacteria, which they identified as a Diplobacterium, later spoken of as Bacterium giardi, and showed that the infection could be transferred to other beach fleas and other genera of amphipods and crabs, making them luminous. H. L. Russell (1892) also inoculated the shrimp, Palaemon, with this bacillus. 
Among land animals, insects frequently become infected with luminous bacteria. The first case was described by Hablitzl in 1789 among midges of the Bay of Astrabad, Persia. They have been noticed in Russia and other parts of Europe by many persons (W. D. Alenitzin, 1875; I. D. Kusnezoff, 1890; P. Schmidt, 1894; W. Henneberg, 1899) in the last century.

Caterpillars are very prone to become infected with luminous bacteria. In the nineteenth century such luminous larvae were described by B. A. Gimmerthal (1829), J. A. Boisduval (1832) and E. C. Rye (1878) .

Other reported luminous insects, such as mole-crickets (W. Kirby and W. Spence 1817; F. Ludwig 1891), mayflies (H. A. Hagen, 1873; A. E. Eaton, 1880) and ants (F. Ludwig, 1902), have probably been infected with luminous bacteria, although actual proof from visual observation is lacking. Earthworms appear to be always selfluminous.

\section{Symbiotic Luminous Bacteria}

The idea that bacteria might be responsible for the light of other animals appears to have been first made by $\mathrm{R}$. Dubois $(1888,1889)$, who found luminous bacteria in the siphon of the mollusc, Pholas, and in the luminous slime of the jellyfish, Pelagia. However, he (1890) quickly corrected the idea in favor of self-luminosity of these animals. In $1907 \mathrm{P}$. Kuhnt suggested that firefly luminescence was due to luminous bacteria, but this view is undoubtedly incorrect.

Luminous bacterial symbiosis was proved in the twentieth century. In 1912 B. Osorio described luminous bacteria secreted from a gland in the belly of the fish, Malacocephalus, whose light has proven to be bacterial in origin. Many other fish with symbiotic luminous bacterial have been described in recent times, but Osorio's discovery was largely overlooked and H. Molisch (1912) regarded the idea of light symbiosis as defunct. However, U. Pierantoni (1914), in the case of lampyrids, and P. Buchner (1914), in the case of the tunicate, Pyrosoma, revived the conception, and both authors have been ardent supporters of symbiosis in numerous papers and books. Symbiotic bacterial luminescence does exist, and will be discussed in more detail in Chapter XVI under the two groups of animals concerned, the squid and the fish. At this point it is sufficient to state that a true symbiosis is very questionable among other groups. 


\section{PHOSPHORESCENCE OF THE SEA}

\section{Sea Light as a Spectacle}

$\mathrm{I}^{\mathrm{T}}$ is rather surprising that classic poets of the sea have not extolled $\mathbb{I}$ the magnificent luminous effects to be seen on so many occasions. There is no certain mention of sea light in Homer's Iliad or Odyssey, in Virgil's Aeneid, or in that Portuguese epic of the sea, the Lusiad (Os Luciadas) of Camoens (Luiz de Camōes, 1524 ?-1580), written in 1572. Just as surprising is lack of reference to phosphorescence of the sea in Greek and Roman prose, and by the great navigators. The casual statements of Aristotle and of Livy have already been mentioned, as well as the sea flames and sparklings of the sea observed by a few sea captains before the seventeenth century.

It is only in relatively recent times that poets and travelers became ecstatic in their description of the light of the ocean.

Lord Byron (1788-1824), speaking of Conrad in The Corsair (Canto I, 1814), wrote:

Then to his boat with haughty gesture sprung

Flashed the dipt oars, and sparkling with the stroke,

Around the waves phosphoric brightness broke.

Sir Walter Scott (1771-1832) in Lord of the Isles (i. 21, 1815), expressed the same idea:

Awak'd before the rushing prow,

The mimic fires of ocean glow,

Those lightnings of the wave;

Wild sparkles crest the broken tides,

And flashing round, the vessel's sides

With elfish lustre lave;

While far behind, their livid light

To the dark billows of the night

A blooming splendour gave.

James Montgomery's ${ }^{1}$ waves at night are:

Spangled with phosphoric fire

As though the lightnings there had spent their shafts,

And left the fragments glittering in the field.

${ }^{1}$ James Montgomery (1771-1854), Pelican Island (1827), Canto I. 
while for Wm. Falconer, ${ }^{2}$

High o'er the poop the audacious seas aspire Uproll'd in hills of fluctuating fire.

Eighteenth and nineteenth-century explorers were as ecstatic as the poets in their appreciation of the spectacle. Johann Reinhold Forster (1729-1798), naturalist for Captain Cook's voyage around the world in the "Resolution" in 1772-1775 described (1778: 636-4) the sea during a fresh gale off the Cape of Good Hope, October 30, 1772:

Scarcely had night spread its veil over the surface of the ocean, when it had the appearance of being all over on fire. Every wave that broke had a luminous margin or top; wherever the sides of the ship came in contact with the sea, there appeared a line of phosphoreal light. The eye discovered this luminous appearance every where on the ocean; nay, the very bosom of this immense element seemed to be pregnant with this shining appearance.

Charles Darwin (1809-1882), in his Journal of Researches during the Voyage of H.M.S. Beagle, made in 1839, wrote:

While sailing a little south of the Plata on one very dark night, the sea presented a wonderful and most beautiful spectacle. There was a fresh breeze, and every part of the surface, which during the day is seen as foam, now glowed with a pale light. The vessel drove before her bows two billows of liquid phosphorus, and in her wake she was followed by a milky train. As far as the eye reached, the crest of every wave was bright, and the sky above the horizon, from the reflected glare of these livid flames, was not so utterly obscure as over the vault of the heavens.

One of the officers of the "Challenger" in a highly poetic mood wrote $^{3}$ of the sea southeast of the Cape Verde Islands:

On the night of the 14th the sea was most gloriously phosphorescent to a degree unrivalled in our experience. A fresh wind was blowing and every wave and wavelet, as far as one could see from the ship on all sides to the distant horizon flashed brightly as they broke while above the horizon hung a faint but visible white light. Astern of the ship, deep down where the keel cut the water, glowed a broad band of blue, emerald green light, from which came streaming up, or floated to the syrface, myriads of yellow sparks, which glittered and sparkled against the brilliant cloud light below, until both mingled and died out astern far away in our wake. Ahead of the ship, where the old bluff bows of the "Challenger" went ploughing and churning through the sea, there

${ }^{2}$ Wm. Falconer (1735-1769), The shipwreck (1762).

${ }^{3} \mathrm{C}$. W. Thomson, Voyage of the Challenger 2: 85, 1877. 
was enough light to read the smallest print with ease. It was as if the "Milky Way" as seen through a telescope, "scattered in millions like glittering dust" had dropped down into the ocean, and we were sailing through it.

Such descriptions could be repeated indefinitely.

This phosphorescence or "burning" of the sea mystified the early scientists as completely as it fascinated the poets and travelers. ${ }^{4}$ The most superficial inspection would reveal that the larger lights of the sea were due to animals like jellyfish, but the apparently uniform brightness when viewed from the deck of a ship gave no hint of the myriads of microscopic organisms responsible for the phenomenon.

Early explanations of the light of the sea quite naturally stressed the connection with motion. As indicated in Chapter IV, Francis Bacon (1605) grouped together the "dashing of sea water on a dark night" and "the fervent froath of the sea "with other apparently luminous phenomena like the sweat of heated horses and the glow of animal eyes. He wrote: ${ }^{5}$ "Sea water violently stirred up with oars will give a light and seem to burn, which kind of light the Spaniards call the sea-lungs" (jellyfish).

\section{'René Descartes and Jacques Rohault}

Bacon merely mentioned the phenomenon. A very definite explanation of the cause of sea light came from René Descartes (15961650). In his discourse on Les Météores, published in French at Leyden in 1637 and in the Latin Principia in 1644, Descartes attempted to explain many natural phenomena. Among other things he discussed

why sea water is less suitable to extinguish fire than river water, and why it shines during the night when stirred up; for you should realize that the particles of salt, being easily set in motion because they are, so to speak, in suspension between particles of fresh water and possessing much momentum once they are stirred up because they are straight and inflexible (rigid), are capable not only of causing the flames to flare up when they are thrown into a fire, but also of emitting flames themselves when shooting out of the water in which they are. ${ }^{6}$

\footnotetext{
"The word "fire" was regularly used in connection with the sea. Wm. Dampier (1652-1715) wrote: “The Sea (near Hong Kong) seemed all of a Fire about us, for every wave that broke sparked like lightning." From Dampier's voyages, ed. by John Masefield 1: 409, London, 1906.

${ }^{5}$ Bacon, F., 1622, History of winds, trans. by R. G., 234.

- From a translation by Professor Gilbert Chinard of Princeton University of the Euvres de Descartes, published by Charles Adam and Paul Tannery, 4: 255-256, Paris, 1902.
} 
Descartes' idea was that when a wave hits an obstacle, the motion that the agitation imparted to the particles of salt caused them to separate from the particles of water and to

generate sparks rather similar to those which are emitted by pieces of flint when they are struck. In truth, to produce that effect these salt particles must be very straight and smooth so that they may more easily separate themselves from the particles of fresh water. This explains why brine or sea water which have been kept a long time in some container are not suitable for that experiment. Furthermore, the particles of fresh water must not be too closely packed (pressed) around the salt particles. This explains why these sparks are more often observed in warm than in cold weather and when the sea is somewhat rough, and also why fire does not issue from all the waves. Finally the salt particles must have a straightforward motion, like arrows and not move crosswise, this being the reason why all the drops which spurt out of the same water do not shine with the same brightness. ${ }^{6}$

It is not surprising that Jacques Rohault (1620-1675), as the foremost protagonist of Cartesian philosophy should have dealt with the light of the sea in a very detailed manner, especially interesting for comparison with Decartes' earlier phraseology. Rohault's opinions are expressed in his Traité de Physique (1671) in a chapter dealing with salt, but which also includes various phenomena connected with the sea. The quotations printed below are from the English edition, Rohault's System of Natural Philosophy "done into English by John Clarke with Samuel Clarke's notes taken mostly out of Sir Isaac Newton's philosophy, with additions," London, 1723 (Part III, Chap. 4, Sec. 14-17).

Rohault answered four questions regarding the shining of the sea, all of them quite uninfluenced by Newton's views, as follows:

Why the water of the sea shines when it is in violent Agitation.

Salt being then of such a Nature as we have described, it is not at all strange that when the Waters of the Sea are violently agitated in a very hot Season, its Waves should ${ }^{7}$ throw out an infinite Number of Sparks in the Night into the Air. For we ought to consider, that these Waves must disperse a great many Drops about in the Air, which divide themselves into still smaller Drops; and that some of the Particles of the Salt, which are the most solid and most agitated, may then disengage themselves from the Parts of the Water, and dart themselves into the Air with their Points forward in such a manner as to be surrounded only by the Matter of the first Element, which may communicate a force to them sufficient to impel the second Element, and so produce Light.

\footnotetext{
' Clarke quoted Newton on "Sea Water in a raging Storm," query 8 of Newton's Opticks (1718).
} 
Why stagnating Water does not Sparkle at all.

However, in order to produce this Effect, it is necessary that the Parts of the Salt should be very smooth and slippery, wherefore Sea Water which has been kept a long Time, and Brine whose Parts are covered with Dirt and as it were rusty, are no Ways proper to produce these Sparks.

Why this Shining is chiefly seen in Summer.

It is further necessary, that the Parts of fresh water, which are rolled about the Particles of Salt, should be extremely pliable, so as to be able to unfold themselves very easily, and give the particles of Salt liberty to disengage themselves; now this can never be but only in the greatest Heat of the Summer; and therefore we ordinarily see such sparks in that Season only.

When it is that all Sorts of Waves are not proper to produce these Sparks.

Lastly, it is evident that in order to this, the agitation must be very violent, and the Parts of the Salt must move with their Points forward, that they may the more easily disengage themselves from the Drops of Water; and this is the Reason why the Sparks do not come from all the Waves nor from every Drop of the same Wave.

It is quite obvious that Rohault had no conception of a biological explanation of sea light. His arguments are definite, if somewhat forced. Another Cartesian, Antoine LeGrand (1692, part II: 45) also attributed the phosphorescence of the sea to the

stiff particles of Salt; for by their penetrating little Bodies, the particles of the 2 nd Element they meet with in their way, may be so expelled, as that some of the particles of the $3 r d$ element, may be only surrounded with the 1 st element, and by it be carried away, and driven on to the Eye, by a continued Range of the Globuli.

\section{Other Early Explanations}

Descartes thus brought the explanation of sea light in line with his general conception of particles of matter in motion, either as vortices or vibrations, and Rohault added some details. Descartes was one of the earliest philosophers to develop a purely physical theory, which, in one form or another, usually regarded the phosphorescence as due to friction. However, it must not be supposed that Descartes' views were accepted by all the philosophers, even those in France.

Nicolas Papin, a physician and uncle of the famous Denis Papin (1647-1712), wrote a small tract, Traité de la Lumière de la Mer, as an appendage to his book, Raisonnements Philosophique touchant 
la Salure, Flux et Reflux de la Mer, etc. (Blois, 1647). The fortyfive-page tract is addressed to his cousin, M. Decahaignes Lord of Troteual, Verrières, etc., and professor at the University of Caën. It is a rambling, philosophical discussion which contains little of scientific value. Descartes was not even mentioned, but Papin took the opportunity to discuss Aristotle's views on matter and light. Like others, he was aroused to poetic description of a display which was so bright the sailors thought the ship was on fire. This sea light " entirely without heat, appears as a guide to those who voyage by the stars and who pretend to have journied to the globe of the moon, for to discourse on these marvels is to be transported to a new luminous sphere in which each atom rivals another in lighting for him who views them."

Papin spent the night considering the marvel. He was particularly impressed with the appearance of the anchor and hawsers, which "scintillate like the reflections of stars," and which he compared to the "luminous material which adheres to the skin and fur of animals and which detaches itself when they are stroked." $\mathrm{He}$ also mentioned the glowing eyes of cats and referred to true luminescences-the "vers coquin" of Italy, the glowworm, the "cucuye" of Bartas (see Chap. III), scales of fish, the flesh of cattle and wood of the oak. His conclusion was " that the light which appears from mixed bodies, particularly in the sea, is a corporeal substance, entirely different from elementary substances, endowed with a most essential luminous quality from which it cannot be deprived except by complete destruction; ..." Papin spent considerable time explaining how the light got out of the water but his views on this subject need not concern us further. He did notice the fundamental similarity of sea light and light from living organisms without realizing the direct connection between the two.

Thomas Bartholin (1647) used the light of sea water as evidence for the existence of light in all things (see Chapter IV), while others compared the scintillation to sparks produced on striking flints or when quartz pebbles are knocked together. ${ }^{8}$

\section{Status of Sea Light in the Late Seventeenth Century}

Robert Boyle's remarks on the phosphorescence of the sea and his conclusion that some cosmical law must produce the effect have already been presented in Chapter IV. On October 22, 1666, the

${ }^{8}$ Such a view of the cause of sea light was expressed by Richard Ligon (fl. midseventeenth century), who published, $A$ true and exact history of the island of Bar. bados (London, 1657). 
Royal Society proposed "The shining of the sea at night" as a subject to be investigated, and an early description was presented in 1667 by its first president, Sir Robert Moray, ${ }^{9}$ Observations made by a Curious and Learned Person, sailing from England, to the CaribIslands. He described burning of the sea at Deal the night before departure: " all the water ran off our Oars, almost like liquid fire; the wind was then South-East and the Sea men told me that at East and South winds it burned most." In the harbor of Jamaica he observed that current affected the burning.

Samuel Pepys (1633-1703), elected president in 1681, also noticed " the strange nature of the sea water on a dark night, that it seemed like fire upon every stroke of the oar."

In 1674 Paulus Biononius, ${ }^{10}$ residing in Iceland and, " given to some Philosophical Inquiries regarding that Country," wrote to the Society: "Our Sea-water, in clear nights, being struck with Oars, shineth like Fire bursting out of a Furnace."

Frederick Martens (1635-1699), a German whose Spitzergische oder Groenlandische Reise Beschreibung gethan im Jahr 1761 (Hamburg, 1675) has been translated into many languages, also mentioned the light of the sea in northern waters, showing that it is by no means in the tropics that this phenomenon is to be observed. Martens wrote: ${ }^{11}$

At night when the sea dasheth very much, it shines like fire; the seamen call it burning. This shining is a very bright glance, like unto the lustre of a diamond.

But when the sea shines vehemently in a dark night and burns, a south or west wind followeth after it.

At the stern of the ship where the water is cut through, you see at night, very deep under water, bubbles rise and break, then this shining or lustre is not there.

Christian Mentzel (1675) in his article on the Bononian stone called attention to the "shining sparks like silver," which appeared when he spit in the sea on a calm night. Like Martens, he merely observed, and added nothing to real knowledge of the origin of the phenomenon. Indeed the views of the time were so extravagant that the simplest experiment would have disproved them. Georg Rumph (1637-1706), the German botanist, in 1682 explained the phosphorescence of the sea at Amboina in the Dutch East Indies as volcanic in origin, while Pere Guy Tachard (died 1714), in 1685

${ }^{8}$ Moray, Phil. Trans. 2: 496, 1667 (No. 27).

${ }^{10}$ An account in the Phil. Trans. 9: 239, 1674 (No. 111).

${ }^{11}$ From the English account in the Hakluyt Society Publications, No. 18: 28, 1855. 
saw the southern sea during a voyage to Siam luminescent with sparkles which attached themselves to linen, resembling a glowworm, alive and bluish. He also noted larger masses of light, a foot in diameter, "which might come from fish which shine naturally."

Regarding the origin of the light, Tachard (1688) wrote: "I do not believe one errs in searching anywhere for the cause of this light than in the nature of sea water, which is salt, nitre, and all the other materials of which chemists make those phosphors which inflame immediately on being agitated and become luminous. ..." Tachard then continued,

It is not only when the sea is agitated that it becomes brilliant but we have seen more [lights] toward the equator during the calm after the sun sets. They appear to us as an infinity of little flashes, rather feeble, which go out of the sea and disappear. We attribute the cause to the heat of the sun, which has, as it were, impregnated and filled the sea during the day with an infinity of fiery and luminous spirits [d'esprits]. These spirits after dark reunite to pass out in a violent state [from the sea], where the sun has put them, attempting in its absence to be set at liberty and fashioning these little flashes in escaping under the cover of the night.

The idea that phosphorescence of the sea came from the sun persisted for many years.

Worms' (1709) speculations, as quoted by C. G. Ehrenberg (1834: 422), will serve to climax the series. After describing the entire surface of tropical seas sparkling with light, observed during a voyage to Persia and the East Indies, he suggested that the light came from the salt and saltpeter of the sea water which, by rapid movement, kindled themselves and became luminous. This was actually a combination of Papinian and Cartesian ideas, but for good measure Worms also surmised that during the day the sunlight impregnated the sea water with an infinite number of fiery ghosts which in the evening combined with each other as a great many small lightnings which vanished as they came out of the sea. The comparison with lightning indicates a very definite Aristotelian influence (see Chapter I), since Worms did rely chiefly on the opinion of others in suggesting an explanation. It is quite obvious that the light of the sea was completely unexplained in the early eighteenth century.

It is rather surprising that greater interest was not taken in the study of sea luminescence by men primarily dealing with biological matters, for example the great microscopists of the period. Marcello Malpighi (1628-1694), Jan Swammerdam (1629-1682), Antony van Leeuwenhoek (1632-1723) Robert Hooke (1635-1702), and Nehemiah Grew (1641-1712) all overlooked the many microscopic lumi- 
nous animals of the sea. Lack of observation is particularly hard to understand in the case of Leeuwenhoek, the discoverer of bacteria, a person living near the sea and one who subjected every possible object to the scrutiny of his lenses. It was reserved for another microscopist, Henry Baker, nearly a century later, in 1753, to publish the first clearly recognizable description of the luminous marine protozoan, Noctiluca.

\section{Father Bourzes and French Observations}

With the beginning of the eighteenth century, attempts to ascertain the true cause of the light of the sea became more experimental. One of the first to apply this approach was Father Bourzes (1708), a Jesuit missionary, who made a trip to the East Indies in 1704. After describing a remarkable phosphorescence observed in the Indian Ocean, July 10, 1704, bright enough to read by, he wrote ${ }^{12}$ a letter to Father Estienne Souciet, which was published in the Philosophical Transactions for 1713:

If one takes some Water out of the Sea, and stirs it never so little with his Hand in the dark, he may see in it an infinite number of bright Particles. Or if one dips a piece of Linnen in Sea Water, and twists or wrings it in a dark Place, he shall see the same thing; and if he does so, though it be half dry, yet it will produce abundance of bright Sparks. When one of the Sparkles is once formed, it remains a long time; and if it fix upon any thing that is solid, as for instance, on the side or edge of a Vessel, it will continue shining for some Hours together. It is not always that this Light appears, tho' the Sea be in great Motion; nor does it always happen when the Ship sails fastest: Neither is it the simple beating of the Waves against one another that produces this Brightness, as far as I could perceive: But I have observ'd that the beating of the Waves against the Shore, has sometimes produced it in great plenty; and on the Coast of Brazil the Shore was one Night so very bright, that it appeared as if it had been all on Fire.

The Production of this Light depends very much on the Quality of the Water. . . . And I have often observed, that when the Wake of the Ship was brightest, the Water was more fat and glutinous; and Linnen moisten'd with it produced a great deal of Light, if it were stir'd or mov'd briskly. Besides, in sailing over some Places of the Sea, we find a Matter or Substance of different Colours, sometimes red, sometimes yellow. In looking at it, one would think it was Saw-dust: Our Sailors say it is the Spawn or Seed of Whales. What it is, is not certain; but when we draw up Water in passing over these Places, it is always viscous and glutinous. Our Mariners also say, That there are a great many Heaps or Banks of

\footnotetext{
12 Bourzes, Phil. Trans. 28: 23\$-234, 1713, and Jones' Abridgment of the Phil. Trans. $5(2): 213$, translated from "Lettres edifiantes et curieuses."
} 
this Spawn in the North; and that sometimes in the Night they appear all over of a bright Light, without being put in Motion by any Vessel or Fish passing by them. But to confirm farther what I say, viz. That the Water, the more glutinous it is, the more it is disposed to become luminous, I shall add one particular which I saw my self. One Day we took in our Ship a Fish, which some thought was a Boneta. The inside of the Mouth of the Fish appeared in the Night like a burning Coal; so that without any other Light, I could read by it the same Characters that I read by the Light in the Wake of the Ship. It's Mouth being full of a viscous Humour, we rubbed a piece of Wood with it, which immediately became all over luminous; but as soon as the Moisture was dried up, the Light was extinguish'd.

I leave it to be examined whether all these particulars can be explained by the system of such as assert, that the principle of this light consists in the motion of a subtle matter, or globules, caused by a violent agitation of different kinds of salts.

Had Father Bourzes gone so far as actually to filter the sea water through his "linnen" and had found that thereby the ability of the filtrate to luminesce was lost he would have made a real contribution. However, Father Bourzes did imply that the light was organic by his reference to the glutinous material as the "Spawn or seed of Whales" and by his description of the luminous mouth of the Boneta. He was one of the first to break away from a purely physical explanation of sea luminescence.

Another organic origin of sea light, was presented by M. Deslandes (1713), Commissaire de la Marine, who thought the phosphorescence was due to the continual decomposition of oily animals like "insects and worms" that lived in the sea. He presumed that this material burned, thus giving off light, a view not too far from the truth. Deslandes' argument was that water kept in casks on ships became full of "worms" and it was reported in the Philosophical Transactions of England that sometimes the old water would burn like spirits of wine. Deslandes doubted the latter statement but remarked that occasionally when a cask was unbunged, a light was to be seen near the bunghole. He thought that possibly this effect was connected with decomposition of the "worms" in the water. ${ }^{13}$

Many of the papers on marine phosphorescence were no more than records of unusually bright displays, frequently accompanied

${ }^{13}$ Another Frenchman who particularly noticed the "mer lumineuse" near the Isle de St. Nicholas et St. Lucie et St. Vincent was M. Frezier, Ingenieur Ordinaire du Roy, in his Relation du voyages de la mer du sud aux cotes du Chilly et due Perou (Paris, 1714); English translation, London, 1717, p. 9). Frezier remarked that physicists, especially Rohault, had given an explanation of the phenomenon and seemed quite content to accept the physical point of view. 
by white water or colored water. These records, with references, have been collected by C. G. Ehrenberg (1834) and by A. Boué (1869), and will not be recounted here.

At the begining of the eighteenth century reports of phosphorescence of the sea had reached such a point that the French Academy of Sciences considered it necessary to warn the public against too sensational reports of luminescence, under the heading: ${ }^{14}$ "Another fiction of an uncommon shining of the sea." The communication was based on

a letter from Cadiz, importing, that for 15 nights together they had seen the whole sea shining with a clear light, almost like a liquid Phosphorus; and to make this comparison the more perfect, the sea water being carried away in bottles, gave the same light in the dark; that some drops of it being let fall on the ground shone like sparks of fire, and that linnen dipt in this water became also luminous. The fact having been well examined, is found to be false. At most this report, which was spread even in Spain, might be founded on some particular and lively colour, which the sea might have at sunsetting. The academy think, they do as much service to the publick, in disabusing them with regard to false wonders, as in recounting to them the true.

All the statements in the Cadiz account could have been true and it is rather surprising to find the French Academy taking the stand it did.

Despite the warning of the French Academy in Paris, so much interest in luminescence had been aroused that the Bordeaux Academy of Sciences offered a prize in 1716 for the best essay on the cause of natural and artificial phosphors. The prize was won by J. J. D. de Mairan, perhaps best known for his work on the aurora borealis. De Mairan's dissertation was Sur la Cause de la Lumière des Phosphores et des Noctiluques, Bordeaux, 1717, a fiftyfour-page essay. He maintained that sea light was not a reflection but a true light emission, although the cause was not explained. It was most apparent when the sea was oily (grasse). De Mairan also recognized the luminous "pulmon marine" (jellyfish) as a source of light, and attributed luminescence in general to movement of "sulphur," great enough to disengage the sulphur from surrounding material.

${ }^{14}$ From vol. 2, p. 13 of The philosophical history and memoirs of the Royal Academy of Sciences at Paris, Or an abridgment of all the papers relating to natural philosophy which have been published by the members of that illustrious society, from the year 1699 to 1720, a five-volume work by John Martin and Ephraim Chambers, published in London in 1742. 


\section{Luminous Worms and Crustacea in the Sea}

After the prize essays of 1717 , little speculation on the luminous appearance or burning of the sea occurred until the middle of the century. At this time a large number of papers were published describing small but easily visible luminous animals in sea water. Such observations served to focus attention on the biological origin of sea light. The majority of the papers had to do with marine annelids, the Scolopendra marina of J. Vianelli (1749), Griselini (1750), and the Abbé Nollet (1750) in the canals of Venice; also C. F. Adler (1752), Father J. Torrubia (1754), J. Baster (1760), and Fougeroux de Bondaroy (1767), described in the section on Marine worms. So much public interest was aroused in the luminous worms of Venice that the observations were printed in the Gentleman's Magazine for 1753 and 1757 under such titles as "The Cause of the Lustre or Resplendency of the Sea-water in the night time discover'd and explained" and "An account of that Species of Worms, to which the luminous appearance of the sea in the Nighttime is owing." The worm of Adler is reproduced as figure 38.

Small luminous crustacea were also recognized as a source of sea light. J. Anderson (1747) described Oniscus fulgens (probably shrimp), and Godehue de Riville (1760) figured a luminous ostracod in his paper, significantly entitled, "Mémoire sur la mer lumineuse" (see fig. 46). The time was ripe for the discovery of still smaller luminous animals usually referred to as "insects" in the sea.

\section{Benjamin Franklin}

The views on sea light of one scientist of this period, Benjamin Franklin (1706-1790), merit special attention, ${ }^{15}$ not merely because of his fame as a man of universal interests and unusual talents, but because of his willingness to change an opinion when the facts so indicated. It might be expected that Franklin would lean to the electrical theory of phosphorescence of the sea and he has been widely quoted as believing the phosphorescence to be electrical in origin but he changed his opinion as the result of two simple experiments performed in 1750. In a letter to his great friend, Peter Collinson, Esq. F. R. S. (1694-1768), a wealthy English manufacturer, naturalist, and patron of science, who sent books to the Library Company of Philadelphia, Franklin wrote in September, 1753:

In my former paper on this subject, wrote first in 1747, enlarged and

\footnotetext{
${ }^{15}$ See the paper by E. N. Harvey (1940); also I. B. Cohen. Benjamin Franklin's experiments, Cambridge, Mass., 1941.
} 
sent to England in 1749, I considered the sea as the grand source of lightening, imagining its luminous appearance to be owing to electric fire, produc'd by friction between the particles of water and those of salt. Living far from the sea, I had then no opportunity of making experiments on the sea water, and so embraced this opinion too hastily:

For in 1750 and 1751 , being occasionally on the sea coast, ${ }^{16} \mathrm{I}$ found, by experiments, that sea water in a bottle, tho' at first it would by agitation appear luminous, yet in a few hours it lost that virtue; hence, and from this, that I could not by agitating a solution of sea salt in water produce any light, I first began to doubt of my former hypothesis, and to suspect that the luminous appearance in sea water, must be owing to some other principles.

In 1753, a letter (No. VII) from J. B. Esq. (James Bowdoin (1727-1790) of Boston, Governor of Massachusetts) to B. F., published in Franklin's Experiments and Observations on Electricity made at Philadelphia in America, to which are added Letters and Papers on Philosophical Subjects (1769), pointed out that the light in sea water could be removed by filtering through a cloth and that the

said appearance might be caused by a great number of little animals, floating on the surface of the sea, which, on being disturbed, might, by expanding their finns, or otherwise moving themselves, expose such a part of their bodies as exhibits a luminous appearance, somewhat in the manner of a glow-worm, or fire-fly. . . .

\section{Franklin ${ }^{17}$ replied as follows:}

... It is indeed very possible, that an extremely small animalcule, too small to be visible even by the best glasses, may yet give a visible light. I remember to have taken notice, in a drop of kennel water, magnified by the solar microscope to the bigness of a cart-wheel, there were numbers of visible animalcules of various sizes swimming about; but I was sure there were likewise some which I could not see, even with that magnifier; for the wake they made in swimming to and fro was very visible, though the body that made it was not so. Now, if I could see the wake of an invisible animalcule, I imagine I might much more easily see its light if it were of the luminous kind. For how small is the extent of a ship's wake, compared with that of the light of her lantern.

${ }^{10}$ Possibly at Stratford, Conn., where, during the summer of 1750, Franklin visited Samuel Johnson, an Episcopalian minister and later the first president of King's College, now Columbia University. (from C. Van Doren, Benjamin Franklin, 193, 1938). It is unlikely that Noctiluca was among the organisms observed by Franklin. Franklin left for England in 1757.

${ }^{27}$ A. H. Smyth, The writing of Benjamin Franklin 3: 192, New York and London, Macmillan, 1905. 
Here we have Franklin's final and correct views on the burning of the sea, views that were definitely abreast of the advancing knowledge of his time.

\section{Henry Baker and the History of Noctiluca}

Without a good microscope the previous observers missed the part played by one-celled organisms in phosphorescence of the sea. One of the earliest, if not the earliest reference to the small luminous protozoan, Noctiluca, occurs in Henry Baker's first edition of Employment for the Microscope (1753), a companion volume to The Microscope Made Easy, the first edition of which appeared in 1742. In a chapter entitled, "Of Luminous Water Insects," Baker, after referring to luminous worms on oysters and to a marine Scolopendra sent "by a Friend whom I can depend on," stated that he received a letter from Joseph Sparshall describing in sea water little bladders that luminesced. Baker said:

A curious Enquirer into Nature [Mr. Joseph Sparshall], dwelling at Wells, upon the Coast of Norfolk, affirms, from his own Observations, that the Sparkling of Sea Water is occasioned by Insects. His Answer to a Letter wrote to him on that Subject runs thus: "In the Glass of Sea Water I send with this are some of the Animalcules which cause the Sparkling Light in Sea Water: they may be seen by holding the Phial up against the Light, resembling very small Bladders or Air Bubbles, and are in all Places of it from Top to Bottom, but mostly towards the Top, where they assemble when the Water has stood still some Time, unless they have been killed by keeping them too long in the Phial.

"Placing one of these Animalcules before a good Microscope; an exceeding minute Worm may be discovered, hanging with its Tail fixed to an opake Spot in a kind of Bladder $\ddagger(+A$ A Drawing of this came with the Account, but it was too late for the Engraver), which it has certainly a Power of contracting or distending, and thereby of being suspended at the Surface, or at any Depth it pleases in the including Water."

The organism seen by Sparshall was undoubtedly Noctiluca, which is easily visible to the naked eye and floats at the surface. The minute worm hanging by its tail to a kind of bladder was the tentacle of this protozoan. It is unfortunate that the drawing arrived too late for publication. Noctiluca was not actually figured until the paper by M. Slabber in 1771 .

Henry Baker (1698-1774), F. R. S., was a well-known microscopist, who received the Copley Medal in 1744 and established the Bakerian Lecture of the Royal Society with a grant of one hundred pounds. His books were highly popular and sold well. 
The history of Noctiluca is of special interest, since it is one of the commonest protozoa responsible for sea light, especially along the Atlantic shores of Europe, and in the Far East. In fact the history of sea phosphorescence is almost a history of Noctiluca. After Sparshall's letter to Baker (1753), Jean Baptiste LeRoy (1760), an apothecary and professor of medicine at Montpellier, probably saw Noctiluca as he examined sea water with a microscope on a trip from Naples to France. He described in 1754 luminous particles ("grains") like the head of a pin, that became sparks ("etincelles") at night and could be caught on a handkerchief. However, he thought them of an oily or bituminous nature, since they did not have the appearance of an animal. He noticed that the more they were agitated, the less light they gave, unless they were allowed to rest. Le Roy was probably the first to record this fatigue of light production, a well known characteristic of Noctiluca and other luminous organisms. He also found that the addition of alcohol or acid and many other chemicals caused the appearance of long lasting sparks of light which finally went out, the death glow, and no amount of agitation would make them luminous again. Le Roy lamented that he did not have a good microscope and could not leave Montpellier to work at the seashore.

In 1757 Job Baster (1711-1775), a Dutch botanist, who tried to prove that corallines were plants and not animals, recognized with his microscope a number of minute "infusoria" as the cause of sea light and found, as did James Bowdoin in 1753, that filtering the sea water through blotting paper would remove the organisms and the luminescence.

In 1762 Pehr Forskål (1736-1763), professor of natural history in Copenhagen, confirmed the filtering experiment and described a number of new marine luminous forms. He noted that the periphery of Noctiluca, called by him " medusa noctiluca," luminesced more markedly than the center.

In 1765 M. Rigaut, a "Physicien de la Marine" at Calais, described Noctiluca so minutely that it could be easily recognized. He had been asked by the Abbé Nollet to see whether the phosphorescence of the sea at Calais was due to animacules. In carrying out the experiment, he added small amounts of various acids ( $\mathrm{HCl}$, $\mathrm{HNO}_{3}, \mathrm{H}_{2} \mathrm{SO}_{4}$ and acetic) to the sea water and discovered, like Baster, that the small "insects" therein luminesced continuously and then the light disappeared. There was no return of luminescence on neutralization. At present most observers use ammonia rather than acid for this purpose because ammonia will excite a more lasting light, thereby allowing more time to identify the lumi- 
nous form. The acid experiment convinced Rigaut that sea light was due to "marine insects."

J. R. Forster (1729-1798), the companion and narrator of Captain Cook's voyage around the world in 1772-1775, was another who described (1778) transparent jelly-like spheres about the size of the head of a pin, probably Noctiluca, ${ }^{18}$ that were responsible for a beautiful luminescence near the Cape of Good Hope.

Four persons, M. J. Slabber in 1771, the Abbé Dicquemare (17331789) professor of physics and natural history at Le Havre, in 1775 , J. G. Bruguière ${ }^{19}$ in 1791 and J. Macartney in 1810, published the earliest drawings of Noctiluca. There can be no mistake in recognition, as can be seen from figure 39. Dicquemare sent his sketch of Noctiluca to Rigaut, who assured him that it was the same organism responsible for the luminescence he had seen in $\mathbf{1 7 6 5 .}$

Dicquemare also described and figured a luminous ctenophore in 1775 and later (1778) observed another great phosphorescence display along the shores near Le Havre, which led him to believe that navigators might make use of the kind of luminous animal near the ship to determine its position " as they now use the magnet."

The names by which Noctiluca has been designated are numerous. Forskål (1762) wrote of "Medusa noctiluca," while Martin Slabber (1741-1835), a Dutchman and friend of Baster, used the name, "Medusa marina" in his book, Naturkundige Verlustigingen, Haarlem, 1771. Macartney (1810) called it "Medusa scintillans," L. Oken ${ }^{20}$ called it "Slabberia," and Ehrenberg (1834:559) spoke of "Mammaria scintillans."

In 1816 Suriray, a physician at Le Harve, sent a manuscript to Lamarck describing a small luminous medusa which he thought was new, calling it Noctiluca miliaris. Lamarck (1816) included the organism in his System des Animaux sans Vertebres (2: 470-472) as Noctiluca miliaris Suriray, placing it near the ctenophore, Berö̈. Although the Suriray paper did not appear until 1836, the name has survived from Lamarck's classification. In 1873 the great Ger-

\footnotetext{
${ }^{18}$ Many other travelers undoubtedly saw Noctiluca, for example, Captain C. Newland (1772) in a trip from Mocha to Bombay, where spots of "white water" containing minute ammaculae were seen at night; Dombey (1780) observed "etincelles" off Peru; Labillardière (1791), on a voyage around the world in the ship "Lapérouse," near "Guinée"; possibly A. von Humboldt during his voyage to the equinoctial regions of America in the year 1799-1804. Finlayson (1826) was apparently the first to describe a luminous green Noctiluca containing flagellate parasites.

${ }^{10}$ Figures 2 and 3 of plate 89 in the Encyclopedie Méthodique plates dealing with "Helminthologie ou les vers infusoires" (1791). O. Bütschli (1880-1882: 1031) thought Brugière's figures of "Gleba" were copied from Slabber.

${ }^{20}$ L. Oken, Lehrbuch der Naturzeschichte (3rd part, abt 1) of the Lehrbuch der Zoologie, Jena, 1815.
} 
man zoologist, Ernst Haeckel (1834-1920), included the animal in a special order of the Flagellates, the Cystoflagellata. ${ }^{21}$. Thus ends the story of the discovery of a famous organism. Nineteenth-century studies on the physiology of Noctiluca will be found in the section on Flagellata in chapter XVI.

\section{Eighteenth-Century Theories of Sea Light}

Although phosphorescence of the sea came definitely to be connected with minute organisms in the 1750 's, certain physical and chemical explanations of the light still persisted, outgrowths of the earliest views of the seventeenth century. These physical or chemical theories may be divided into at least six groups: (1) Electrical; (2) Mechanical; (3) Insolation; (4) Phosphorus; (5) Putrefaction; or (6) a combination of the above.

\section{ELECTRICAL}

Electrical theories were very popular in the eighteenth century. Jacques Charles François de la Perrière de Roiffé (died 1776) supported the electrical view in his Mechanisme de l'Electricité (1: $111,1756)$, but without making personal investigations. Guillaume Hyazinthe Joseph Jean Baptiste Le Gentil de la Galaisière (17251792), the astronomer at Paris, made a journey to the Indies in 1760 to observe the transit of Venus. From observations on this trip, he (1761) was inclined to consider sea light electric in origin, although he did say that not all of it was due to electricity. $\mathrm{He}$ mentioned reflection and the fact that dwellers by the sea regard the light phenomena as due to fish spawn.

M. Bajon (died 1790), a physician at Cayenne in French Guiana and correspondent of the French Academy, also considered (1778) electricity, resulting from collision of currents, to be the source of light. He claimed to obtain more luminescence when the sea was disturbed with a metal object than with a glass one.

He also noted that with continued agitation of the sea water, the light became weaker, and if placed in a well-stoppered bottle, the light disappeared, but would return if the sea water were poured into a pail and exposed to the air. His final conclusion attributed the light to "une matérie phosphorique qui a une analogie directe avec l'électricité."

\footnotetext{
${ }^{21}$ According to C. A. Kofoid and O. Swezy (Mem. Univ. of California, 5, 1921), who removed Noctiluca from Haeckel's order of cystoflagellates, by the rules of zoological nomenclature, the correct name should be Noctiluca scintillans Macartney. There appears to be only one species, although various specific names have been applied. See this monograph for synonymy.
} 
J. Bressy (1800) also, had developed a machine for electrifying water in motion. Since the sea was always in motion and sea phosphorescence, particularly, resulted from movement, he naturally considered the light to be electrical in origin. Henry Robertson, a physician to the Duke of Kent, as late as 1819 , also considered sea luminescence electrical.

\section{MECHANICAL}

An example of the mechanical point of view was that held by M. de la Coudrénière (1775). He expressed surprise that celebrated physicists should consider sea light ("ce météore marin") due to "insects" which they have seen in seaweed. Coudrénière held that it was more like "météores phosphoriques," characteristic of the surface itself. He said that a blow on the surface would always render the sea luminous during any season or in any climate. Olaf Wässtrom ${ }^{22}$ (1798), who described light from ice when broken, suggested that light of the sea was due to small ice crystals in the sea water which flashed when broken by waves. L. Brugnatelli (1797), who had studied the luminescence of crystals when rubbed together, also thought that sea light was a similar mechanical though invisible accumulation of a light-substance by movement.

\section{INSOLATION}

We have seen that as early as the late seventeenth century, Père Tachard attributed (1688) the light of the ocean to "igneous particles with which the sun has impregnated the sea during the day, that assemble and escape, going out in a violent state at night." The idea that phosphorescence of the sea came from the sun persisted for many years. It was generally held in Siveden, according to Erich Pontoppidan (1698-1764), Bishop of Bergen, a writer on natural history. After speaking of the "unctuousness of the sea" which "has probably some connection with its effulgence and scintillations" and is called "Moorild" by sailors, he wrote: ${ }^{23}$ "Mr. Urban Hierne, the Swedish naturalist who derives sea salt from the sun judges this sea light to be a kind of phosphorus, formed from the

${ }^{22}$ Neue Schwedische Abhandlungen 1798, with a translation in Crell's Chem. Ann., 392, 1799. J. Weber (1892) described "Feuerstrahlen" from ice in the Donau, and Heinrich (1820: 482) discussed reports of triboluminescent ice. In more recent times, J. Precht (Physik. Zeit. 3: 457-459, 1902) observed luminescence of ice at liquid air temperature.

${ }^{23}$ Pontoppidan, E., The natural history of Norway, translated from the Norwegian, 73-75, London, 1775. In 1765 another Norwegian bishop, Erik Schyttes, distilled sea water which exhibited "moorild" (sea light), and found that the luminescent material did not pass over with the distillate, but was permanently quenched. 
luminous particles of the sun, and even the moon, impregnated by water; as is the case in the Lapis Bononiensis, and Baldwin's phosphorus." On the other hand, Pontoppidan himself was inclined to believe the light was due to "worms," as indicated by the studies at Venice in 1750.

The idea that the light of the sea came from the sun was expressed by Joseph Mayer (1752-1814), a professor of natural history at Prague and later at Vienna. Unlike others, Mayer (1786) carried out experiments to prove his point. He learned from the inhabitants along the Adriatic that there was not much luminescence of the sea after stormy, cloudy days, even when it is calm at night, and he himself noted during a visit to Trieste in 1783 that the sea was especially luminous on agitation after calm days with a bright sun; also that sea water from a depth of nine fathoms where the sunlight was weaker did not luminesce very well. However, if this deep sea water was kept in jars exposed to the sun all day, it luminesced markedly at night.

At the present time it is easy to explain the above results in terms of the distribution and growth of luminous dinoflagellates, but to Mayer, who could detect no living things with a strong magnifying glass, and in addition found that his sea water could be filtered without losing its ability to luminesce, the absorption of sunlight appeared to be the important factor. He proved that there was no electrical charge in sea water that could affect a sensitive electrometer at the time the light appeared, but as a zoologist, he could not overlook the many kinds of luminous marine organisms previously described, and finally suggested that the light of the sea might come from several causes, one of which was absorption of sunlight.

Even as late as 1815, Karl Gottfried von Helvig (1765-1844), a general in the army, thought the ocean to be a light magnet. His evidence for this view was similar to that of Mayer, the observation that near Constantinople, at the entrance to the Black Sea, there was a bight, well shaded by trees. Phosphorescence never occurred in this bight although it was common in open water exposed to the sun. Moreover Helvig had examined ocean water that was phosphorescent and found no animals present. Hence the light could not be due to animals.

\section{PHOSPHORUS}

Even in modern times travelers frequently explain the phosphorescence of the sea by the exclamation, "phosphorus." Among the scientists who believed that sea light is connected with this luminous element, Silberschlag ${ }^{24}$ (1770) should be mentioned, and also an

${ }^{24}$ Quoted from C. G. Ehrenberg (1834: 429). 
anonymous writer who sent an article "Sur le Phenomène des Lueurs de la Mer Baltique," to the Journal de Physique (24:56) in 1781 and declared that phosphorescence near Copenhagen was due either to phosphoric gas or acid.

Another was Conti di Borch, who noticed the light of the sea on a trip from Naples to Sicily in 1776, and when he arrived at Messina found that swordfish eaten by the Messinians were brightly luminous. In his publication "Memoria sopra il Fosforo Marino," in the Atti of the Academy of Sienna (1781), he claimed to have obtained a phosphorescent oil by collecting and distilling the oily material which dripped from the heads of these swordfishes. The oil was kept in bottles for a year and "gave a light as pleasing as Kunckel's phosphorus or at least as pleasing as those [preparations] sold under this name." However, his method of simple distillation would not produce phosphorus, nor would such an oil be phosphorescent. Borch implied that his preparation explained the light of the sea.

Reinhold Forster (1729-1798), the naturalist of Captain Cook's second world voyage in 1772-1775, considered (1778) that at least one kind of sea light, the homogeneous glow, was due to phosphorus and Christoph Bernoulli (1803) had a similar view. He held that phosphorus might be concerned in the luminescence of dead organisms, which in turn contributed to the diffuse phosphorescence of the sea.

\section{PUTREFACTION}

Other explanations considered the sea light organic but did not realize the organisms were living. It is not surprising that phosphorescence of the sea should be attributed to putrefaction of animal bodies, since that was a common explanation of the light of shining fish, flesh, and wood before the bacterial and fungal origin of the light was discovered. A. Martin (1761, 1764) and John Canton (1769) both studied dead luminous fish and concluded from their observations that sea luminescence was the result of a similar decomposition. The light was believed to arise from the greasy or oily luminous slime of the fish.

The view of Canton was quite plausible. In his paper, "Experiments to prove that the Luminousness of the Sea arises from the Putrefaction of its Animal Substances," the argument is based on the fact that salt-water fish, placed in sea water became luminous but not if placed in fresh water. However, when salt was added to fresh water, herring placed therein became luminous also. Canton was particularly struck with the light that appeared on agitation of 
the water, like that of the sea. He wrote (pp. 446-447) "I drew the end of a stick through the water, from one side of the pan to the other, and the water appeared luminous behind the stick all the way, but gave light only when it was disturbed. When all the water was stirred, the whole became luminous and appeared like milk; ..." We now know that this development of luminescence on stirring is merely the admission of more air to the milky suspension of luminous bacteria, which have used up all the oxygen in the sea water, but to Canton the milkiness and the agitation necessary for luminescence exactly resembled the description of Father Bourzes, which Canton quoted. Canton also quoted Sir John Pringle ${ }^{25}$ (1750) to the effect that salt hastens putrefaction of tissues. His evidence for the putrefactive origin of sea light did appear convincing.

Martin (1761) had previously emphasized that salt was essential for the development of the light of dead fishes, but his argument connecting luminescence of the sea was less convincing. While luminous bacteria may make salt water luminesce, they normally never grow in such numbers as to be responsible for the light of the sea.

\section{COMBINATION OF CAUSES}

There were a number of observers unwilling to attribute the light of the sea to any one cause. Usually the larger flashes of light were known to be of animal origin, and the more diffuse luminescence was considered due to other causes. L. Spallanzani (1784), who investigated so many natural things, gave an opinion on sea light during a $2 \frac{1}{2}$-months stay at Portovenere, near Genoa, in 1783 . He observed several small luminous animals in the sea water, including the worms of Vianelli (1749) and Griselini (1750) but not the ostracods of Godeheu de Riville (1754). He was inclined to believe that the more diffuse light arose from disintegrating parts of animals but did not go as far as Canton in thinking that it came from decaying fish. He saw very few fish luminesce and they were not necessarily the most oily ones. Moreover, sea light did not always appear at the surface, where oil would be found, but often came from considerable depths. Therefore, Spallanzani believed the sea had a characteristic light of its own, in addition to that from obvious living and luminous animals.

Reinhold Forster ${ }^{26}$ (1778), whose poetical description has already been quoted is a good example of an observer who believed that

${ }^{25}$ Pringle, Phil. Trans. 46: 480-488, 525-534, 550-558, 1750.

${ }^{28} \mathrm{R}$. Forster, Observations made during a voyage around the world, 61-68, London, 1778 . 
sea light or "phosphoreal light" resulted from several causes-that there were in fact three kinds of sea light. One kind was observed mostly during a fresh gale, near the ship or on nearby waves, and resulted from the ship's disturbance. It was regarded as electrical, owing to rubbing of the hull of the ship as it passes through the water. The second sort of luminescence was observed only during a calm. It extended far from the ship and deeper in the water and was due to a " real phosphoreal light" of decomposing animal parts, all of which contain phosphorus in the form of an acid. "Everyone who has seen salted fish drying must know that many of them become phosphoreal." The third type of light was due to medusae and other "live animals floating in the sea and is owing to their peculiar structure or rather the nature of their integrant parts," which Forster said should be analyzed chemically to find out the origin of the light.

Several writers at the end of the eighteenth century prepared general articles on sea light, reviewing previous observations without taking too definite a stand on the origin. Such a review is to be found in the article on "Mer Lumineuse ou Noctilucum Mare," in Valmont-Bomare's Dictionnaire Raisonné Universal d'Histoire Naturelle 8: 396-407, 1791. Another was by Johann Georg Ludolf. Blumhoff (1774-1825), professor of technology at Giessen, in 1797. A translation appeared in the Philosophical Magazine for 1800 , which indicated that Blumhoff was inclined to favor the Forster notion of three kinds of sea light. Another review was that of Tingry (1798), "De la phosphorescence des corps et particulièrement sur celles des eaux de la mer," published in Delamétherie's Journal de Physique.

\section{Early Nineteenth-Century Views}

\section{FRANÇOIS PÉRON}

At the beginning of the nineteenth century there was a growing tendency especially among naturalists, to attribute all sea light to living organisms of one kind or another. The belief is very forcibly expressed by François Péron (1775-1810), whose travels to Australia and New Zealand in 1800-1804 gave him abundant opportunity for observation. After pointing out that phosphorescence appears in the seas but is more apparent under certain conditions, Péron (1804) wrote:

All the phenomena of the phosphorescence of sea water, however multiplied and singular, are ascribable to one cause, the luminousness attached to sea animals, and most especially to molluscae, and other soft zoophytes. My numerous experiments, and the beautiful series of phosphorescent 
animals executed by M. Lesueur, will I trust empower me to remove all rational doubt of this important truth.

The active phosphorescence inherent in animals, different in every respect from the weak light, which in certain instances emanated from putrid decomposition, is so completely dependent on the organization and life of these animals, that it increases with their growth, diminishes with their decay, becomes extinct with their life, and after death is incapable of reproduction.

Luminous animals of the sea were also described by Bory de Saint Vincent (1804), and in the pamphlet of Domenico Viviani (1805), Phosphorescentia Maris.

\section{CHRISTOPH BERNOULLI AND THE PRIZE ESSAYS}

Another excellent discussion was contained in Christoph Bernoulli's Ueber das Leuchten des Meeres (Göttingen, 1803), in which the light of larger marine animals was explained as a slow burning (oxidation) of a material which appeared to be actually phosphorus. His essay considered sea light under four headings:

(1) Sea light as a result of absorption of sunlight in which $\mathrm{J}$. Mayer's ideas were expressed. (2) Sea light of possible electrical origin, based largely on Forster's views that the light along the sides of a ship came from electricity generated by the rubbing of water on the hull. (3) Sea light from living creatures, for which view Bernoulli presented many observations. (4) Sea light from decomposition of animal substances, in which Bernoulli said the entire body was filled with a luminous material which streamed out regularly in life but irregularly in death. He regarded it as especially remarkable that during the chemical changes (Ä̈flösung) of living organic material, no light should be emitted, but rather that light, which probably comes from phosphorus, should accompany dead decomposing material.

In general Bernoulli appeared to favor the animal origin of sea light. However, despite his rather rational ideas on the luminescence of marine animals, the diffuse light of the sea appeared to confuse him. Sodium chloride, a combination of acid and alkali, was looked upon as playing an important role in the general process of organic decomposition and Bernoulli, perhaps influenced by Martin (1761) and Canton (1769), believed that the sodium chloride of the sea together with oxygen, resulted in maintaining an endless succession of organisms (Organizationen), whose decomposition after death was responsible for the diffuse phosphorescence. Thus, the light was regarded as organic in origin, probably from 
phosphorus, but connected with decomposition rather than with minute living organisms.

In 1806 the Batavian Science Society of Haarlem ${ }^{27}$ offered the following prize question for an essay to be submitted before November, 1807. "What is the cause of the phosphorescence of sea water? Does this phenomenon depend on the presence of living animals; what are they and can they impart to the atmosphere properties which are injurious to man?" This question suggests a belief that maladies appearing at certain times of year might be connected with brilliant displays of phosphorescence of the sea. As there appear to have been no worthy essays submitted for the prize, a gold medal worth thirty ducats, ${ }^{28}$ was again offered in 1808 and 1809 , after which, no satisfactory answer being received, it was withdrawn. Nevertheless, the mere offer of this prize and its phrasing again indicates the interest in marine phosphorescence and the fact that the animal theory of its origin was not generally accepted at the beginning of the century. The offers of 1808 and 1809 specifically mentioned D. Viviani's (1805) paper, Phosphorescentia Maris, and suggested that his belief that the light came from living organisms be discussed. Bernouilli's contribution was not mentioned.

Prizes were also offered by the Russian Academy in 1804 for an essay on the nature of light, and by the French Institute in 1807 for an essay on phosphorescence, excluding animals. The winners of the Russian prize, Link (1808) and Heinrich (1808), and the winner of the French prize, Dessaignes (1809), hardly mentioned phosphorescence of the sea in their prize essays. For example, Dessaignes merely stated, toward the end of his Chapter $\mathrm{V}$, dealing with "Phosphorescences Spontanées," that one may observe in the sea two kinds of light, (I) "Discrete" and (2) "Continue." The first is due to living animalcules which "transsude un mucus phosphorescent"; the second depends on the same "mucus en dissolution dans l'eau."

\section{HUMBOLDT, MACARTNEY, AND TILESIUS}

It was the continuous or unceasing phosphorescence, due to microscopic organisms, that was the hardest to explain, but more and more investigators adopted the view that all light of the sea must be attributed to living organisms. Marine exploration was in vogue at the time and many expeditions brought back accounts and speci-

\footnotetext{
${ }^{27}$ See Ann. der Physik 23: 126, 1806; 29: 333, 1808; 32: 356, 1809. The essay could be written in Dutch, German, French, or Latin.

${ }^{28}$ A ducat contained 3.43 grains of fine gold, worth about $\$ 2.30$ (Century Dictionary, 1900).
} 
mens of luminous animals. The opinion of Péron has been mentioned previously. Additional important statements are due to A. von Humboldt, J. Macartney, and W. G. Tilesius von Tilenau.

Alexander von Humboldt's ideas on the phosphorescence of the sea came from his early expedition to South America in 1799-1802. In later editions of the Views of Nature (1849), which recorded the mature reflection on his observations, he discarded the idea that sea light was electrical, owing to friction along the sides of a vessel, and declared it to come from living organisms. However, von Humboldt's views were somewhat confused, as can be seen from the following quotations, ${ }^{29}$ which attempt to explain how light can be emitted by living things in general:

The luminous animals of the ocean appear, from these conjectures, to prove the existence of a magneto-electric light-generating vital process in other classes of animals besides fishes, insects, mollusca, and acalephae. Is the secretion of the luminous fluid which is effused in some animalcules, and which continues to shine for a long period without further influence of the living organism ... merely the consequence of the first electric discharge, or is it simply dependent on chemical composition? The luminosity of insects surrounded by air assuredly depends on physiological causes different from those which give rise to a luminous condition in aquatic animals, fishes, Medusae, and Infusoria. The small Infusoria of the ocean, being surrounded by strata of salt-water which constitutes a powerful conducting medium, must be capable of an enormous electric tension of their flashing organs to enable them to shine so vividly in the water. They strike like the Torpedo, the Gymnotus, and the Electric Silurus of the Nile, through the stratum of water: ...

Sometimes one cannot, even with high magnifying powers, discover any animalcules in the luminous water: and yet, wherever water is violently agitated, flashes of light become visible. The cause of this phenomenon depends probably on the decomposing fibers of dead Mollusca, which are diffused in the greatest abundance throughout the water....

James Macartney (1810) had the advantage of Sir Joseph Banks' observations on Captain Cook's expedition in 1768-1771. His contribution to the Phil. Trans. in 1810 was entitled, "Observations on Luminous Animals." After summing up the various theories previously mentioned and rejecting them all, he wrote:

I shall not trespass on the time of the Society to refute the above speculations; their authors have left them unsupported by either arguments or experiments, and they are inconsistent with all ascertained facts upon the subject. The remarkable property of emitting light during life is

${ }^{29}$ A. von Humboldt, Views of nature, trans. by E. C. Otté and H. G. Bohn, 248-249, London, George Bell \& Sons, 1875. 
only met amongst animals of the four last classes of modern naturalists, viz., mollusca, insects, worms, and zoöphytes.

Macartney recognized the true cause of the light, although he had little idea of the vast number of marine forms which are luminous and omits entirely any reference to the fishes, many of which produce a light of their own when living, apart from bacterial infection when dead. He also omitted the "infusoria."

Wilhelm Gottlieb Tilesius von Tilenau's (1769-1857) observations were published in part in volume 4 of Krusenstern's Reise and in part arranged by L. W. Gilbert in the Annalen der Physik for 1819 , a volume largely devoted to sea phosphorescence. There were two microscopes on the ship during its voyage around the world in 1803-1806. Tilesius observed animals such as mollusca, crustacea, nereidae, medusae, pyrosomae, salpae, zoophytes, and infusoria to be present in displays of phosphorescence and responsible for the bright specks, balls, fiery streaks, and chains of light. The weaker, more general luminescence he considered due to animals also, perhaps spawn, as Tilesius could not imagine what else the light might come from. There was no doubt in Tilesius's mind as to the biological origin of this phenomenon. After Macartney (1810) and Tilesius (1819), innumerable writers ascribed the light of the sea to living things and described the animals involved, largely as a result of some sea journey.

\section{Sea Light and the Weather}

It was an early observation that the sea "burned most" when the wind was from a certain direction. The relation of sea light to the weather is of course directly connected with the growth of living organisms, particularly the dinoflagellates described in the next section. The long spell of hot and calm weather which precedes a storm is particularly favorable for their growth. A number of observers have commented on this relation, among them John Murray (1826). He did not describe minute organisms, but he did observe larger animals, and wrote (1826: 84): "It seems quite certain, therefore, that the luminosity of the sea is a phenomenon dependent on the presence of luminous marine animals." He was particularly struck with the fact that unusual brilliant displays of sea light preceded gales. To quote again (1826: 78) : "I believe I may claim for myself the priority of brilliance or appearance on the coast, as connected with this new metereological feature-the coming storm."

C. Decharme (1869) also, from observations near St. Nazaire held that phosphorescence of the sea came after hot weather and before 
a storm, and could be very useful to meteorologists in predicting the weather.

The value of sea light to fishermen in making visible at night the position of schools of fish was particularly noted by D. Landsborough (1842), a student of luminous hydroids on seaweed. Another view was expressed by J. C. Wilcocks in The Sea Fishermen (London, 1865: 271), that " should the 'brine' or 'fire' show itself, the fish will not be likely to strike the nets." Phosphorescence occurs in all seas, not necessarily in the tropics but in the Arctic and Antarctic as well. Sea light has been observed under the ice at Kiel (H. A. Meyer, 1866) and along the west coast of Norway, where W. E. Koch (1882) noted flashes of light as his ship crashed through the ice of Hardangerfjord. He found that, when some of the ice was melted, the resulting water was still luminous. Koch had noticed that the luminescence was greater during atmospheric disturbances and argued that it was partly caused by electricity, although he also reported a connection with the migration of fish and thought that it might have an important bearing on their food. The light was at a maximum in spring and autumn when the waters swarm with embryonic forms.

\section{Discovery of Luminous Dinoflagellates}

\section{PIONEERS}

Although Macartney described and figured the flagellate, Noctiluca, he omitted one group of minute luminous organisms, the dinoflagellates proper, particularly responsible for sea light. Their ability to luminesce was as yet undescribed because of their small size and the inadequacy of microscope objectives of the time. ${ }^{30}$ They are classified in such genera as Ceratium, Peridinium, Gonyaulax, etc. Although Noctiluca actually belongs in this class also, it is a large and aberrant member. The tiny sparkles of light of the sea, whose origin is so hard to identify, are all due to such microscopic dino-

${ }^{30} \mathrm{~F}$. J. Cole in his History of protozoology (1926) attributes the delay in knowledge of unicellular animals to poor microscope objectives, which were not achromatic until 1824. Although Leeuwenhoek discovered bacteria, Vorticella and Volvox in 1677, and Paramoecium was anonymously described in some letters sent to Sir C. H. and published in the Phil. Trans. (No. 284, 23: 1368, for 1703), the protozoa were only established as unicellular forms by C. T. E. von Siebold (1804-1885) in his Lehrbuch der vergleichende Anatomie der wirbellosen Thiere in 1845. The word "infusoria" appears to have been used by M. F. Ledermüller (1719-1769) in 1763 and by H. A. Wrisberg (1739-1808) in 1765 but this designation included diatoms, worms, planaria, rotifers, and other minute multicellular forms. It is no wonder that luminescence of the smaller dinoflagellates was not definitely recognized until the work of G. A. Michaelis in 1830. 
flagellates which have been known as " animalcules" since the time of Otto Frederick Müller (1730-1784) without a suspicion of their ability to luminesce. Müller was the first to attempt a classification of animalcules and figured many forms in Vermium Terrestrium et Fluviatilium seu Animalium Infusorium, etc., published in 17731774. His great work, published after his death, Animacula Infusoria Fluviatella et Marina (1786) contains a Ceratium, under the name of Cercaria tripos, well figured in plate XIX. Franz von Paula Shrank in 1793 introduced the genus Ceratium and described Ceratium tetraceras from fresh water.

Luminous marine dinoflagellates were probably observed by John MacCulloch (1773-1835) who described in 1821 luminous Cercaria, Vibrio, Vorticella, and Volvox, as well as many larger forms, from the Western Islands of Scotland. Cercaria was the old name for Ceratium, Vorticella was a rotifer, and Volvox a ctenophore.

Quoy and Gaimard (1825), doctors of the royal marine and naturalists on a cruise around the world in the "Uranie" attributed sea light to various "animalcules et les mollusques" but could not refrain from adding that the luminous forms had a smell of electricity.

Christian Heinrich Pfaff (1773-1852), professor of medicine at Kiel, probably saw dinoflagellates in 1823 , and also in 1828 , when he declared that the sea light at Kiel was due to small organisms, especially "infusoria," which would luminesce on adding ammonia, acid alcohol, and ether. He carried out the interesting experiment of passing an electric current from a voltaic cell through sea water in a glass vessel and noted many moving light points when the current was closed. This was probably the first use of ammonia and of electricity to stimulate dinoflagellates to luminescence. F. Tiedemann (1830) also recognized luminous "infusoria," in addition to medusae and ctenophores, as contributing to the light of the Adriatic.

It is thus apparent that the tiny sparkles of the sea, due to microscopic dinoflagellates, were recognized as the cause of diffuse phosphorescence early in the nineteenth century. MacCulloch and Pfaff were certainly pioneers, but it is difficult to associate such a discovery with any one name.

\section{MICHAELIS AND EHRENBERG}

Hans Molisch (1912: 14) has attributed the first clear indication that dinoflagellates are luminous to G. A. Michaelis in 1830. Ehrenberg also, writing in 1834, described Michaelis' paper as containing " die wichtigsten Beobachtungen der neueren Zeit." Michaelis described in the luminous sea water of Kiel harbor a Volvox, Cercaria 
tripos, and two other Cercariae, and a Vorticella (the rotifer, Synchaeta baltica) which were always present and which he believed to be the source of the light. However Michaelis could see no "infusoria" on the surface of luminous fish. Pfaff, in an introduction to the Michaelis paper, pointed out that putrefaction, infusoria, and luminescence went together and should be further studied.

C. G. Ehrenberg (1795-1876), the foremost protozoologist of the time, immediately became interested and asked Michaelis to send to him in Berlin some sea water from Kiel. The water arrived after a ten-day journey and only a small worm was found to be luminous, described by Ehrenberg (1831) as Polynoë fulgurans. In a later sample of sea water, sent from Kiel in 1832, Ehrenberg completely confirmed Michaelis' observations and described such forms as Peridinium tripos, fusus and furca and Prorocentrum micans, all of which luminesced when acid was added to the sea water. In Ehrenberg's great work (1834), a plate reproduced as figure 40 depicts the above forms and in addition the new species, Peridinium michaelis and P. acuminatum. Peridinium tripos is the same as Cercaria tripos Müller, ${ }^{31}$ a form whose present name is Ceratium tripos. A second plate of Ehrenberg's (1834) paper depicts Nereis fulgurans and Synchaeta baltica, the rotifer. Although Michaelis had described this form, probably also seen by Baster (1757), as a Vorticella and said it was luminescent, Ehrenberg (1834: 536 and 538) never saw it luminesce. He suggested that luminescence might be connected with the breeding season, although some of his specimens carried eggs and yet were non-luminous. In 1859 Ehrenberg again determined that the minute sparkling lights in the harbors of Naples and Trieste came from dinoflagellates.

Although the work of Michaelis and Ehrenberg was confirmed by F. Dujardin, ${ }^{32}$ E. Claparède and J. Lachmann (1858-1859) and P. Gourret (1883) were unable to identify luminous dinoflagellates. However, the positive results of F. von Stein (1883), J. Reinke (1898), and many others indicate that these organisms give rise to the great displays of light, which evoked the enthusiastic descriptions quoted at the beginning of this chapter.

An interesting parallel can be drawn between discovery of the biological origin of diffuse sea light and that of wood and flesh, as recorded in Chapter XV. The dates of MacCulloch's (1821), Pfaff's (1823, 1828), Michaelis' (1830), and Ehrenberg's (1832, 1834) studies on flagellates may be compared with the date of Derschau, Nees von Esenbech, Bishof and Nöggerath (1823) on luminous

${ }^{31}$ Müller, O. F., Zoologiae danicae prodromus, Hauniae, 1777.

${ }^{32}$ According to Molisch (1904: 16). 
wood and of Heller $(1843,1853)$ on both wood and flesh. Recognition of luminous marine dinoflagellates was a little ahead of knowledge of luminous fungal mycelia and bacteria. Both discoveries came at a time when fermentation and putrefaction were proved to be of biological origin and helped to remove these words as "explanations" of the light of the sea, of wood, and of flesh.

Thus, the studies of many naturalists finally resulted in the general acceptance of the organismal theory for all types of phosphorescence of the sea. At the present time only a person familiar with the history of the subject can understand how perplexing the phenomenon was in the early nineteenth century. Some of the greatest names in biology have expressed opinions on the light of the ocean. Charles Darwin (1809-1882) during the Voyage of the Beagle in 1831-1835, whose description of phosphorescence of the sea off South America near the La Plata River has been quoted, noticed that as he proceeded farther south, sea light became less prominent and "this circumstance probably has a close connection with the scarcity of organic beings in that part of the ocean."

A little later, Joseph Dalton Hooker (1817-1911), the great botanist, and Himalayan explorer, a friend and confidant of Darwin, was also experiencing his first expedition, a voyage to Antartica on the "Erebus," commanded by Sir James C. Ross in 1838-1839. With no plants to study, Hooker busied himself with the many marine animals found at its surface. In a letter to his father, written after leaving St. Helena, March 17, 1840, he wrote: ${ }^{33}$

The causes of the luminescences of the sea I refer entirely to animals (living). I never yet saw the water flash without finding sufficient cause without electricity, phosphoric water, dead animal matter, or anything further than living animals (generally Entomostraca Crustacea if anybody asks you).

With this informal but definite statement of Hooker, we may leave a subject which has intrigued the curious of every nation, and pass on to discoveries concerning the manner in which living organisms produce their light-bioluminescence.

${ }^{23}$ Life and letters of Sir Joseph Dalton Hooker, by Leonard Huxley, 1: 57-58, 1918. 


\section{ANIMAL LUMINESCENCE}

\section{Luminous Terrestrial and Freshwater forms}

\section{Fireflies and Glowworms}

\section{EARLY SEVENTEENTH-CENTURY VIEWS}

7 HE Impetus which entomology received from the studies of Aldro1 vandi and Muffet carried into the seventeenth century. Even before Muffet's Insectorum sive Minimorum Animalium Theatrum (1634) was published posthumously, most writers described the glowworm and firefly in natural histories, or in connection with other matters. After Aldrovandi and Muffet came the Neapolitan physician and naturalist, Fabio Colonna or Columna (1567-1647), best known for his beautifully illustrated books on botany. He included "Noctiluca terrestris" in his Aquatilium et Terrestrium Aliquot Animalium, etc. (Romae, 1616). The account described the animal minutely, and included a woodcut, reproduced in figure 4 , an easily recognized glowworm. ${ }^{1}$ The skill of the illustrator had advanced, in comparison with the figures of Aldrovandi's book (see fig. 4) but was still far from the superb hand-colored insect drawings of the eighteenth century.

As an Italian familiar with fireflies, Colonna took pains to point out that, although " it shines like fire at night," as do the cicindelae (Greek lampyres), the common winged kind, "it does not glitter by the spread of its wings ... nor does it become obscure when pressing them together, the way the older writers describe the lampyris." Hence he applied the name, "Nyctilampes aptera " in Greek or "Noctiluca terrestris" in Latin, because they live on the ground rather than in the air, and, "walking at night like cockroaches, in their sideways motion the fiery radiance of their buttocks shines forth . . . with such light that a page with very small type can be

\footnotetext{
${ }^{1}$ Johann Amos Comenius or Komensky (1592-1670), in his book, The gate of languages unlocked, or a seedplot of all arts and sciences, containing a ready way to learn the Latin and English tongues (London, 1652), made a distinction between the Latin terms for fireflies and glowworms. In Chapter 19, "De Insectis," it was pointed out that cicadas, cockroaches, etc., were "small creatures divided almost asunder by partitions, and having life in one part, when it is parted from the other." He then defined hepioli (pyraustae) and cicindelae (lampyrides) as fireflies or candleflies, while nitedulae (noctilucae) were glowworms.
} 


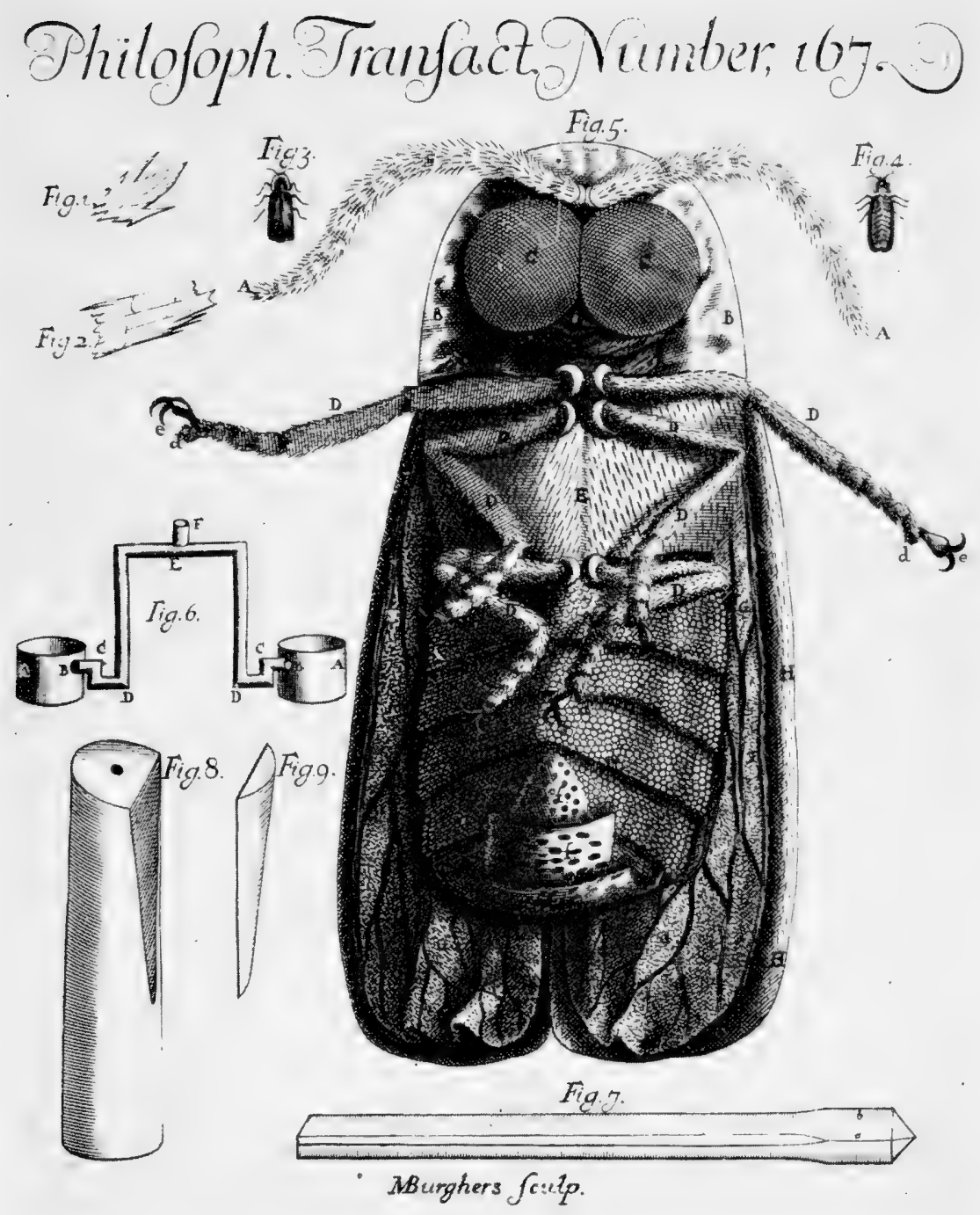

Fic. 41. A handsome drawing of a flying glowworm, reproduced as a plate to the paper of Richard Waller, "Observations on the Cicindela volans" in the Phil. Trans. for 1685 . 


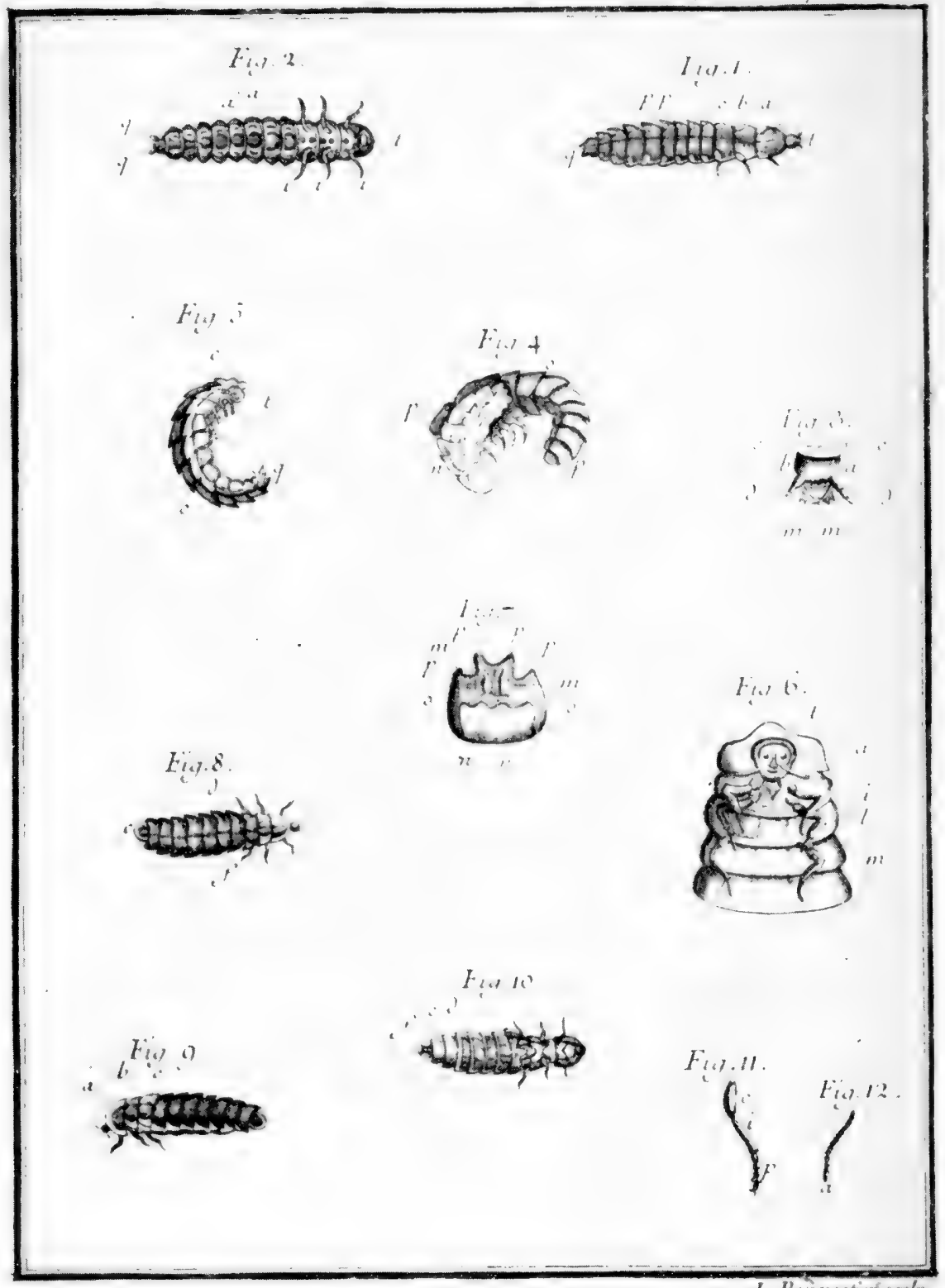

Fic. 42. The famous plate of C. De Geer, in his paper " Mémoire sur un Ver Luisant Femelle et sur sa Transformation" (1755) in which the change from larva to adult is first accurately illustrated. Fig. I and 2, larval glowworms, dorsal and ventral view. Fig. 1, the pupa coming out of the shin of the larra. Fig. 5, the pupa from the side. Figs, 8, 9, 10, the aduht, dorsal, lateral and ventral view. The other figures show parts of the inscet. 


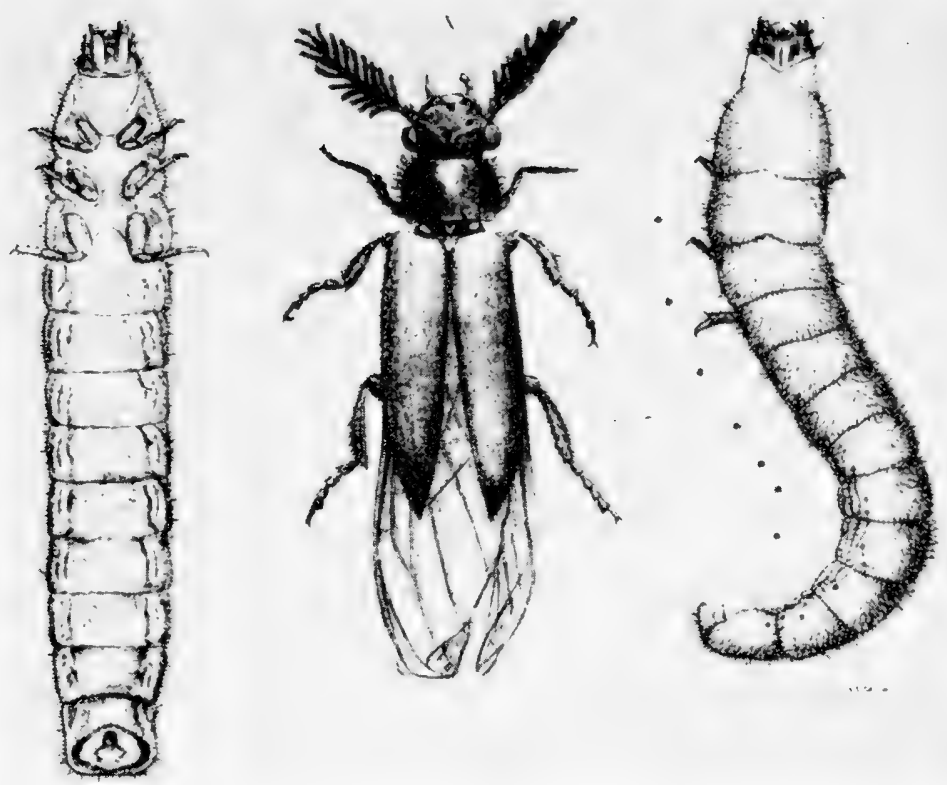

Fig. 43. The railroad worm (Phrixothrix) of South America. The female (left and right) has a red light on the head and a row of yellowish green lights on each side of its bods. It was first described by Oviedo in his Historia General y Natural de las Indias (1535). The male in center is only slightly luminous with no red light. From E. Haase Zur Kenntniss von Phengodes (1888).
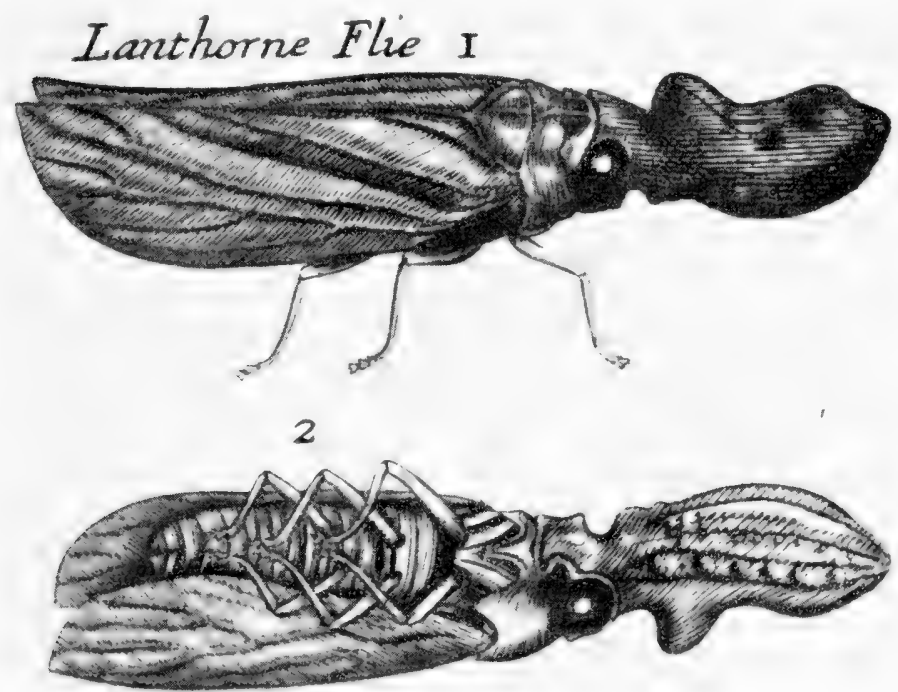

Fir. 44. The lantern fly (Fulgora), from a drawing of Neremiah Grew in Museum Regalis Societatis (London. 1681). A vivid description of its light was given by Maria Sibille Meriam in her book on the insects of Surinam (1705), but there has been much controversy concerning its true luminosity. 


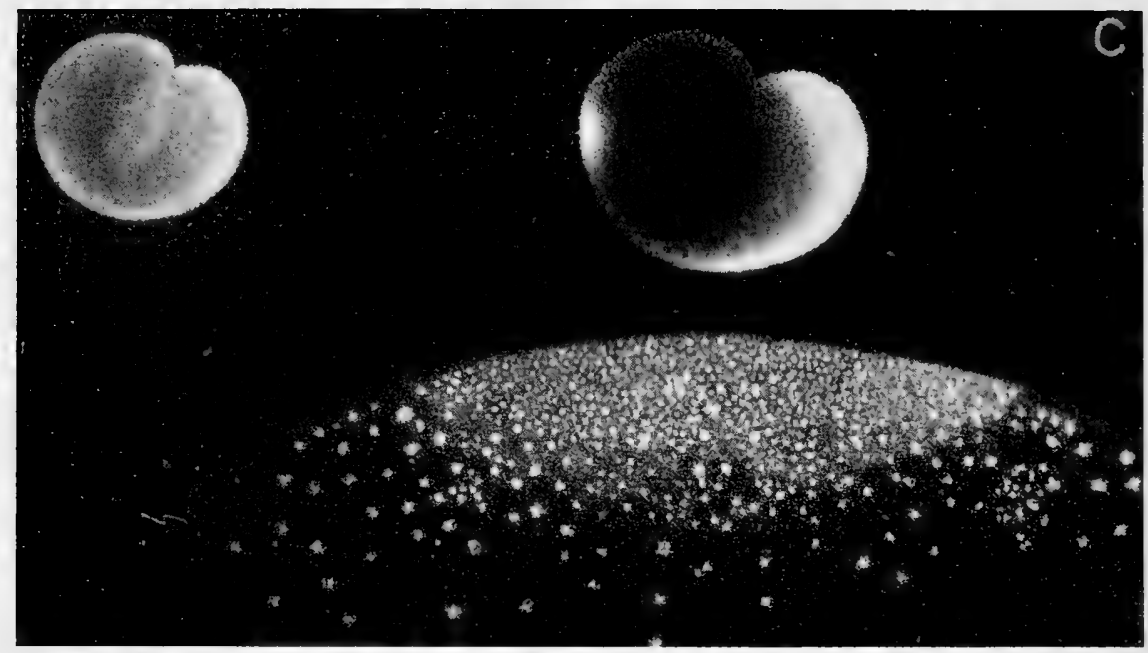

FiG. 45. Quatrefages' (1850) figure of Noctiluca seen through the microscope at night, showing that the light comes from granules in the protoplasm. Quatrefages was elected a foreign member of the American Philosophical Society in 1891.

$$
\text { Fis. } 2
$$
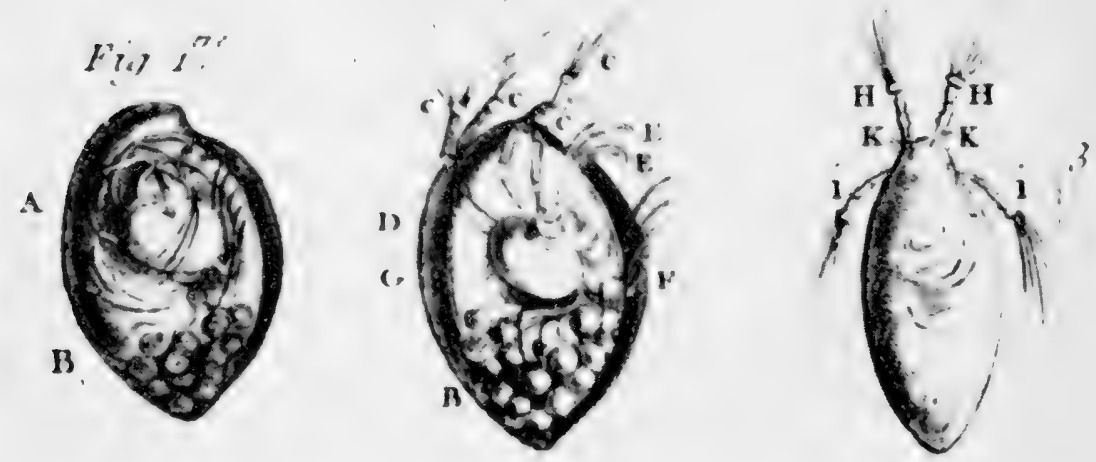

FIc. 46. The luminous ostracod crustacean, Cipridina, about one-cighth inch long. from the paper by Godeheu de Riville, "Mémoire sur la Mer Lumineuse," in the Mémoires of the French Academy for 1760. Whenever disturbed the animal squirts a luminous secretion into the sea from glands near the mouth. Its swimming legs can be withdrawn under a transparent shell when at rest, as shown in fig. 1. Fig. 3 is a dorsal view. This form has been most valuable for the chemical studies on light production carried out by E. N. Harvey and his students and colleagues over many years. 
read at night in a dark place without a torch, provided one moves the animal over it and conducts it slowly along the lines." Thus the brightness of a luminous animal was measured by the ability to read print in its presence at the beginning of the seventeenth century, a comparison followed by observers of luminescence ever since. Colonna also pointed out that "even after death, as long as there is still moisture, the buttocks of the dead body shine in the dark, but once they have become dry, the light goes out."

Another book of the same period was the Historia Animalium. Sacra, etc., started by Wolfgang Franz (1564-1628), a German protestant theologian. It first appeared in 1612, with many subsequent editions. In 1712 there were five parts, the last entitled "De Insectis," by Joannes Cyprian, containing a section " Quidam ignito modo iucent," which deals with fireflies and is especially valuable because of the large number of writers on these insects referred to.

In the 1659 edition, a section under Scarabaeus describes the "Lampyrides seu Cicindelae shining in a strange manner with something like a lucid moisture on their belly ... they say that if this fluid is mixed with others and used for writing it can be read at night and not in the daytime." Franz then went on to point out that "They resemble those [persons] who shine only as long as they are in the dark, that is among uneducated people, for among the educated they would be inconspicuous."

At the beginning of the seventeenth century, accurate knowledge of these insects was fairly well expressed by the statement of Francis Bacon in his Sylva Sylvarum (1627, sec. 712).

The nature of the glow-worm is hitherto not well observed. Thus much we see; that they breed chiefly in the hottest months of summer; and that they breed not in champain [fields], but in bushes and hedges. Whereby it may be conceived, that the spirit of them is very fine, and not to be refined but by summer heats: and again, that by reason of the fineness, it doth easily exhale. In Italy, and the hotter countries, there is a fly they call Lucciole, that shineth as the glowworm doth; and it may be is the flying glow-worm. But that fly is chiefly upon fens and marshes. But yet the two former observations hold; for they are not seen but in the heat of summer; and sedge, or other green of the fens, give as good shade as bushes. It may be the glow-worms of the cold countries ripen not so far as to be winged.

It is probable that Bacon did not have many glowworms for experimentation, as his treatment lacks the inquiring approach of his remarks on luminous wood (see Chapter XIV). The last sentence is a definite suggestion that glowworms might develop into fireflies, as indeed some species do, although the European glowworm, with 
which Bacon was acquainted, is an adult female of a particular species of the firefly family, whose male is winged. In other species both male and females can fly, whereas in all species the larvae are wingless. The relation between the creeping and the flying glowworm (or firefly) was to perplex and to confuse naturalists for some years to come. Another question for philosophic discussion had to do with the use of the light and a third was whether the animal could shine after death.

It will be recalled that an early pronouncement on the last question had been made by Fabio Columna. J. C. Scaliger ${ }^{2}$ also, had previously stated (in 1557) that "with the breath of life this light departs from the cicindela," although he was relating the opinion of others rather than personal observation. The Scaliger quotation is taken from Thomas Bartholin, who devoted considerable space in his book to the glowworm. Bartholin wrote: " "I tried to check on the truthfulness of this experiment [on light after death] and set aside a wingless noctiluca. But while I was waiting for the result it cleverly escaped and with itself took away its light." Thus was a laudable impulse foiled by capriciousness of experimental material.

Bartholin discussed ${ }^{3}$ particularly the relation of winged to wingless glowworms, giving the credit for correct interpretation to:

Carolus Vintimillia of Palermo, Sicily, who guided by his extraordinary genius, confined both kinds of lampyrides to the same glass and diagnosed the distinction in sex very well from their mating behaviour. He has written about this experiment faithfully in a letter to Fabius Columna and said that the winged cicindelae in his region were not different from the noctilucae, but the former ones were males, the latter females, as he had found out twice. He had obtained quite a few, which he caught at random, kept in his glass container, and taken pleasure in watching at night, feeding them with moist bread. One night at dinner a winged one flew around his light. He caught it and put it in the glass with the others. While he continuously watched, it overcame another one and hung on to it, as is the custom of the silk-worm. ${ }^{4}$ Finally, wrested from the first, he paired with one after the other, and, as he found out later, with all of them. On the following day they produced seeds of the shape and color of the millet, but smaller than those of the silkworm, and after a few days died. He saved the seeds or eggs, but found them damaged and cracked in the middle, perhaps because they required a moist place. A striking feature of the eggs was that they were distin-

\footnotetext{
${ }^{2}$ In Exotericarum exercitationum, etc., 194, n. 3, Paris, 1557.

${ }^{3}$ De luce animalium (1647, Book II, Chap. II), translated by Mrs. Annemarie Holborn.

${ }^{4}$ Both Muffet (1634) and Jonston (1653) credit J. C. Scaliger (1557) with having first observed copulation of cicindelae, while John Ray in Travels through the low countries, etc. (1673) again referred to the letter of Vintimillia to F. Columna.
} 
guished by the same splendor as the lampyrides, as Stephanus Spleisius, the authority on stars, suggested to me in Basel. Vintimillia discovered from this a miracle of nature, which denied the females wings, but endowed them with a more vigorous light in order that they could call the males at night with their shine. The males shone only with a small light, and the size of their body was much smaller.

No statement could be plainer than the above. In the case of the European firefly the male is winged, the female wingless. Moreover, Vintimillia appears to have been the first to realize that the eggs of the firefly are luminous and that the purpose of the light is sex attraction.

When Jonston's Historia Naturalis. De Insectis libri III appeared from Frankfort a M. in 1653, the same stories of perpetual light were included in the section, "De Cicindela." However, little can be said for Jonston's originality, as much of the description is directly copied from Aldrovandi and Muffet. Although a physician and professor of medicine at Frankfurt, Jonston traveled extensively in Poland, Germany, Holland, England, and Scotland, and should have known better than to repeat the fable of a "liquor lucidus" at so late a date.

Sir Thomas Browne in Pseudodoxia Epidemica (1646) and Athanasius Kircher both labeled the story a myth (see Chapter IV). Kircher devoted considerable space to a discussion of glowworms, both in his Ars Magna Lucis et Umbrae (1646, 1671) and again in Mundus Subterraneus (1664). He actually collected and observed fireflies (at Malta), refuting Pliny's statement that the light only shows when the wings were spread, but he was more interested in the insect as a spectacle and a marvel than in the chemical nature of the light. He was content to " say that the noctilucent Nitedula has this intrinsic and innate light . . . by the providence of nature for definite ends."

The use of fireflies and glowworms in medicine was highly recommended during the seventeenth century. Most of the remedies mentioned by Muffet (chapter III) were repeated by such writers as Stephano Rodriguez de Castro (1559-1637), professor of medicine at the University of Pisa, in De Meteoris Microcosmi, Venice, 1621 (book 4, chap. 16) ; also by Johann Rudolph Camerarius in Sylloges Memorabilium Medecinae, 1624, Tubingae, 1683 (cent. 4, part 30 and cent. 19, part 37) and Johannes Schroeder (1600-1664), who wrote a book on animals in relation to medicine, which was translated by T. Bateson as Zoologica, or the History of Animals as they are Useful in Physick and Chirugery (London, 1659). Johannes 
Jühling has recorded many of the folk-remedies in his Die Tiere in deutsches Volksmedezin alter und neuer Zeit (1900).

Later in the seventeenth century accounts of travelers appeared, recording observation of fireflies in different parts of the world, but little was added to scientific knowledge of light production. Among those men, whose quaint description of "the sparks of fire" make interesting reading, John Evelyn (1645), de Flacourt (1658), John Josselyn (1673), Thomas Ash (1682), and Lionel Wafer (1699) should be mentioned.

THE GLOWWORM OF ENGLAND

In England the glowworm was described in some detail by a number of writers-Henry Power (1664), John Templar (1671), and Richard Waller (1685). Waller published a very fine drawing in the Phil. Trans. reproduced as figure 41. Robert Plot (1684) discussed ${ }^{5}$ the question of light after death and John Ray ${ }^{6}$ in correspondence of 1692 took up the relation between "ye flying and creeping Glowworms," citing the experience of a neighbor who had seen "a flying Glow-worm, though it does not shine" couple with a creeping glowworm, and quoting Vintimillia's observation. Ray wrote: "I know no other way [to explain the winged and wingless varieties] but by supposing that there are two sorts of flying Glowworms, the one whereof hath both sexes flying, and the other is the male of the creeping Glow-worm." Ray was quite correct. Sir T. P. Blount, in his Natural History (London, 1693) also discussed the flying and creeping variety, disagreeing with Ray, and held that the light was " a Lantern to the Insect in catching its Prey, and to direct its Course by in the Night. ..."

However, the most important observation on glowworms was made by Robert Boyle. At the time (1667) he studied the behavior of shining wood and fish in a vacuum, Boyle also wished to test the glowworm, but none were then available. A few years later the experiment was carried out and the results appeared in Tracts touching the Relation betwixt Flame and Air, published in 1671. Boyle's motive was to learn more about the "Flamma Vitalis" of animals in relation to air, for he introduced his experiment with the explanation: ${ }^{7}$

\footnotetext{
${ }^{5}$ In the Philosophical Society of Oxford, formed in 1651. The minutes have been published by R. W. T. Gunther. Early science in Oxford 4, 1925.

${ }^{6}$ Correspondence of John Ray, edited by R .W. T. Gunther, 209, 228, London, Ray Society, 1928. The glowworm is also treated in Ray's Historia insectorum (1710) and in J. Swammerdam's Biblia naturae seu historia insectorum (1747).

${ }^{7} \mathrm{~T}$. Birch, Works of Boyle 3: 587-588, 1772.
} 
For the sake of those learned men, that have thought the light of glowworms and other shining insects to be a kind of effulsion of the biolychnium, or vital flame, that nature has made more luminous in these little animals than in others ... we took two glow-worms ... these we laid upon a little plate, which we included in a small receiver of finer glass than ordinary ... and as we expected, upon the very first exsuction there began to be a very manifest diminution of the light, which grew dimmer and dimmer, as the air was more and more withdrawn, until at length it quite disappeared, though there were young eyes among the assistants. This darkness having been suffered to continue a long while in the receiver, we let in the air again, whose presence as we looked for, restored at least as much light as its absence had deprived us of.

Thinking that the disappearance of the light might be due to some reaction of the whole animal, in the next experiment Boyle repeated the effect of the vacuum on a glowing excised light organ and found that its luminescence also disappeared. These experiments served to establish the similarity of the light of shining wood, fish and insects. They supplemented his observations that flames cannot exist in a vacuum, that the light of burning sulphur, camphor, or alcohol quickly disappears. He found in fact that an alcohol flame went out before a small bird (a green finch) showed signs of being affected by the lack of air. The experiments were an early demonstration of the necessity of something in the air for living things and burning bodies and clearly placed the luminescence of organisms in the same category.

\section{MARCELLO MALPIGHI AND THE ITALIAN FIREFLY}

Of all the seventeenth-century writers, Marcello Malpighi (16281694) was the most painstaking in his study of fireflies. ${ }^{8}$ His account is given by F. S. Bodenheimer (1928: 1: 337), who has quoted from unopened note-books ${ }^{9}$ of Malpighi in the University Library at Bologna. Malpighi wrote (30 Maggio, 1688) concerning "De Cicindela" as follows:

The end of the body cavity, the last two segments, contains a fluid which is the source of the light. In daylight it appears yellowish and contains a milky substance. In the dark it lights sulphur yellow. The fluid contains a mass of small yellow globules in a similar slimy substance, which is half fluid. The beetle lights at night and in the dark from both hind-

\footnotetext{
${ }^{8}$ Although F. Redi (1626-1697) studied the metamorphosis of many insects, he did not investigate the lucciole, nor is its development considered in J. Godart's Metamorphosis et historia naturalis insectorum, etc., 3 v., 1662-1667; in English, 1682.

- These notes have been published by G. Atti as Notizie edite ed inedite della vita $e$ della ópera di Marcello Malpighi, Bologna, 1847.
} 
most segments. Sometimes the light appears continuous but is often rhythmic like the heartbeat, but the rhythmic light ceases and becomes continuous when one cuts off the last segment ... there arises in the previously mentioned fluid rounded vesicles, which luminesce from the deeper layers and at times disappear.... During the lighting, the quiver of these small vesicles can be easily observed. The fluid lights outside the body but without rhythmic lighting ... and lights as long as it remains fluid. In water, vinegar and alcohol the sap retains its light, indeed luminesces longer and with more intensity than in the air.

Another Italian interested in fireflies as bearing on fire and light was Domenico Bottoni (1641-1731) in whose Pyrologia Typographica (Naples, I692) some eight pages are devoted to the insect. An accompanying plate (reproduced as fig. 13) shows a large male firefly in a flask on a table, near pens and an open book, to imply that enough light is emitted for reading and for writing. Bottoni's views have already been discussed in Chapter IV.

\section{SYNCHRONOUS FLASHING}

One of the extraordinary sights in the tropics of the Far East is synchronous flashing of fireflies, in which great numbers of these insects turn their light on and off at the same moment. This phenomenon appears to have been first recorded ${ }^{10}$ by Englebrecht Kaempfer (1651-1716), a German botanist and traveler, who visited southeast Asia between 1683 and 1693. In his book on Japan and Siam, translated and published by Sir Hans Sloane in 1727, Kaempfer wrote of the fireflies in the Meinam River near Bangkok, Siam:

The glow-worms (Cicindelae) represent another shew, which settle on some Trees, like a fiery cloud, with this surprising circumstance, that a whole swarm of these Insects, having taken possession of one Tree, and spread themselves over its branches, sometimes hide their Light all at once, and a moment after make it appear again with the utmost regularity and exactness, as if they were in perpetual Systole and Diastole.

Somewhat later, in 1771, the Civil and Natural History of the Kingdom of Siam, was published by François René Turpin, who gave the following description: "Nothing can afford a finer sight in the night time than to see a tree entirely covered with fire flies: It seems decked with bright sparks, which expire and rekindle almost at the same instant. These flies are not hurtful. It is easily per-

${ }^{10}$ The Jesuit, Père Guy Tachard, visited Siam in 1685 and wrote of the "mouches luisantes" on "trees along the river near Bancok" with their "infinitée de lumières" reflected in the water, but did not mention synchronous flashing (Voyages de Siam, etc., 150, 1689). 
ceptible that they give this light when they swell a little, and inhale the air."

The display of synchronous flashing is not confined to Siam but is particularly striking there, and has been observed by many later travelers, such as Bishop Pallegoix (1854); also Sir John Bowring (1857), who wrote:

They have their favorite trees, round which they sport in countless multitudes, and produce a magnificent and living illumination: their light blazes and is extinguished by a common sympathy. At one moment every leaf and branch appears decorated with diamond-like fire; and soon there is darkness, to be again succeeded by flashes from innumerable lamps which whirl about in rapid agitation.

The mechanism of flashing and particularly the cause and meaning of the remarkable synchronism is a problem still awaiting solution today.

\section{EIGHTEENTH-CENTURY RESEARCH}

During the eighteenth century glowworms and fireflies were included in all the natural histories and attempts were made to clear up the development, habits, method of flashing and the nature of the light. Many of the earlier beliefs were collected in the Sammlung von Natur und Medezin. sowie auch hierzu Gehöringen Kunst und Literaturegeschichte so sich in Schlesien (1718 and 1724) by Johann Günther (1695-1723), a poet and naturalist of Silesia, eulogized by Goethe.

Several pages are devoted to "De Cucujo" and "De Cicindela" in the fifth part of Theatrum Universale Omnium Animalium (Amsterdam, 1718), by Heinrich Ruysch (died 1727), and a very small figure (plate 15) of a glowworm accompanies the text, but there is little new to be found in the account. The treatment of cicindela by Antonio Vallisnieri (1661-1730) in the third volume of Opera Fisico-Mediche (Venice, 1733) also contains nothing new. Vallisnieri did remark that further research was necessary to find out " if they [a winged and wingless pair] copulate from mere desire for a sexual act, whether by their very nature they try to fecundate the wingless, or if the wingless ones alone are females and the winged are males, but I have not the leisure to make further research."

John Hill (1716-1775) included the glowworm (without a figure) under the name "Cantharis" in his History of Animals (London, 1752), describing the male as a small black beetle and the female as the glowworm with no wings, but " the last three joints of the body are of a yellowish colour on the under surface and these appear ignited or flaming in the dark." The glowworm is not mentioned as 
a remedy in Hill's Compleat History of Drugs (1737) or in the History of Materia Medica (1751).

The Abbé Nollet (1750) was fascinated by the sight of the winged Italian firefly in the countryside, observed on the same trip to Italy during which he studied luminous worms in the canals of Venice. Nollet observed that the lucciole always showed light when flying and thought the flashing might result from alternate hiding and exposing the light either by movement of the wings or owing to the position of the body. However, close examination soon showed him that the flashing "depended on an interior movement which I perceived through the skin with a lens." The flashing was much more marked when the animal was stirred up or about to fly; at other times a weak steady light appeared in the light organ.

Early in the eighteenth century, the life history of many insects was worked out. In 1755 a fairly detailed paper on structure and development of the glowworm was published by Baron Carl DeGeer (1720-1778), the great Swedish entomologist and pupil of Linné. His account only considered females, as these were common, whereas the winged males of beetle form were hard to find. His plate, reproduced as figure 42, gives an excellent idea of the larval stage (l'état véritable de ver), the pupal stage (nymphe) and the adult female (l'état de perfection) with one figure showing the process of moulting.

Fougeroux de Bondaroy (1766), in connection with his paper on the Pyrophorus beetle which escaped in Paris, also explained the relation between the male and female of the glowworm and the winged Italian lucciole. He published good drawings of all these forms (see figure 4 for the lucciole).

By far the most complete account has been given by P. Gueneau de Montbeillard, in 1782, as he started with the egg. The observation that the eggs of lampyrids are luminous, made by Vintimillia and recorded by Bartholin (1643), remained unconfirmed for over a century. Apparently Bartholin's book was unknown to Gueneau de Montbeillard, as he was rather astonished to find not only luminous eggs but luminosity throughout the life cycle, from egg to adult. He determined that unfertilized as well as fertilized eggs were luminous. Usually the light of eggs lasted eight to ten days but one batch of eggs were luminous after forty days. Only a single sickly female laid non-luminous eggs. It took about a year from egg to maturity. Although the female is wingless and remains on the ground, her brilliant lights were evidently designed to attract the male for "nature is always attentive to perpetuation of the species." 
Gueneau de Montbeillard pondered the question as to why wingless females of other insects are not also luminous and why the eggs of the glowworm should be luminous, without giving too logical an answer. He decided that luminescence of the eggs explains why the female is most brilliant before the eggs are laid and loses its brilliancy afterwards, "as if the principle of the light in them was the same as the principle of life."

Another memoir on the glowworm came from Lausanne; Switzerland, written in 1786, by the mineralogist, Count Gregor de Razoumowsky (died 1837). It added practically nothing new to knowledge of the animal. Count Razoumowsky merely described the "ver luisant" as "an insect of ways extremely gentle and peaceful, which lives alone and occurs in numbers only by accident. . .."

\section{RELATION TO OXYGEN}

Boyle's discovery that the light of the glowworm disappears in a vacuum and returns in air has already been mentioned. Apparently the second person to try the vacuum experiment was C. P. D. Beckerhinn, pharmacist of Strassburg, who obtained similar results in 1789 .

One of the earliest studies on respiration of the glowworm was that of Professor G. Forster of the University of Göttingen, who was impressed with "the unbelievable power of dephlogisticated air (oxygen) to ignite bodies and to facilitate respiration." He was the first to submit a theory of the control of luminescence by admission of air to the light organ. Forster determined in 1782 that the male glowworm (Lampyris splendidula) ceased to flash and its light became steady and very bright in oxygen. The flashing began again when the insects were removed to ordinary air. This behavior, together with the fact that spiracles were present in the rear segments of the insect where the light was produced led him to believe that respiration was concerned. He considered the flash to be controlled by a sudden inspiration, and " that the light decreased as the air in the tracheae became saturated with phlogiston, after they are shut off by the will [of the insect]." The luminous material was regarded as an animal humor comparable to phosphorus dissolved in oil, which lights but does not burn in free air. Although Forster could not imagine how the luminous substance was formed, he considered it no more unusual than the production of an electric fluid by electric fish, such as the torpedo.

Like many others he clung to the phlogiston theory, but his ideas were perfectly clear and his observations accurate. Forster also noted 
that luminous wood became no brighter in oxygen than in air, a correct observation, but he did not elaborate on the discovery.

In 1789 the experiments on oxygen (reiner Luft) were repeated by Beckerhinn, whose results did not agree. The wingless female glowworm obtained near Strassburg luminesced no brighter in oxygen than in "gemeiner Luft," a difference attributed to the use of the female rather than the male glowworm. Beckerhinn also tested other gases and found that the glowworms lived a long time in non-respirable gases, except for "salpeter-, salz-und vitriolsauren Luft" where they died in ten minutes. It is certain that Beckerhinn's gases were not very pure.

A much more careful research was carried out by Lazaro Spallanzani (1796). He had found the light of luminous wood and a dead squid to become weak in nitrogen and return in the air, while in oxygen the light was brighter. The light of the lucciole actually disappeared in nitrogen, hydrogen and $\mathrm{CO}_{2}$, and Spallanzani was impressed with the similarity in behavior of all these luminescences and that of phosphorus in different gases. He took the similarity to mean that they were all due to a slow burning.

The next student of firefly chemistry was G. Carradori (17581818), a professor at Pisa, whose paper on the luciole, Lampyris italica, appeared in the Annales de Chimie (1797), and was translated for the Philosophical Magazine (1798), as well as in the Annalen der Physik (1799). Carradori ${ }^{11}$ criticized Spallanzani's idea that the light was due to a slow burning, since he had found the phosphoric matter to shine under oil "without a single air bubble," and in a barometric vacuum. He thought that the bright light in oxygen observed by Forster did not

depend upon a combustion more animated by the inspiration of this gas, but on the animals feeling themselves, while in that gas, in a better condition ."Whence then arises," says the author, "the phosphoric light of the luciole? I am of opinion," adds he, "that the light is peculiar and innate in these insects, as several other productions are peculiar to other animals. As some animals have the faculty of accumulating the electric fluid, and of keeping it condensed in particular organs, to diffuse it afterwards at pleasure, there may be other animals endowed with the faculty of keeping in a condensed state the fluid which constitutes light. It is possible that by a peculiar organization they may have the power of extracting the light which enters into the composition of their food, and of transmitting it to the reservoir destined for that purpose, which they have in their abdomen. It is not even impossible that they may have the power to extract from the atmospheric air the luminous fluid;

${ }^{11}$ Quotations are from the Phil. Mag. 2: 77-80, 1798. 
as other animals have the power of extracting from the same air, by a chemical process, the fluid of heat."

Like other workers of his time, Carradori did not realize how small an amount of oxygen is necessary to cause the emission of visible light from luminous organisms. In the later work of $T$. von Grotthuss (1807, 1821), J. Macaire (1821), J. Murray (1826), and C. Matteucci (1847), it was correctly found that the light would disappear in hydrogen, nitrogen, $\mathrm{CO}_{2}$, or a good vacuum, and return in the air. In pure oxygen, Macaire, Murray, and Matteucci observed a brighter light while Hermbstadt ${ }^{12}$ (1808) and H. Davy ${ }^{13}$ did not. Actually the effect of oxygen depends on the species of firefly and time of exposure to the pure gas.

\section{EARLY NINETEENTH-CENTURY PHYSIOLOGICAL WORK}

The studies on lampyrids initiated by Forster, Beckerhinn, Spallanzani, and Carradori were continued during the early part of the nineteenth century by J. Macartney (1810), M. Faraday (1814), Macaire (1821), Murray (1826), Carrara (1836), and Matteucci $(1843,1844,1847)$. These men concerned themselves not only with the effect of various gases and other substances on the luminous material but also with habits, the "will " to flash, the effects of temperature, and of electricity and galvanism. Macartney thought he detected one or two degrees rise of temperature when a delicate thermometer was brought near a glowworm, but was not sure and his observations not well planned.

John Murray said: "Light as connected with the glow-worm, is a subtile evanescent material principle, perhaps connected with a peculiar organized structure."

At Geneva (July 10-12, 1814), Faraday ${ }^{14}$ determined that light from crushed organs of the glowworm would last for several days and concluded that this power "appears to depend more upon the chemical nature of the substance than upon the vital powers of the animal." The luminous matter

is yellowish-white, soft and glutinous. It is insoluble apparently in water or in alcohol. It does not immediately lose its power of shining

\footnotetext{
${ }^{12}$ Hermbstadt (1808) collected 200 "Leüchtkafer" and put them in a flask. In oxygen prepared from Braunstein $\left(\mathrm{MnO}_{2}\right)$, the luminescence was not much brighter than in air but lasted longer. In hydrogen and nitrogen there was a very faint luminescence but none in carbon dioxide.

${ }^{13}$ According to Macartney (1810:287), Humphry Davy found that a glowworm light " is not rendered more brilliant in oxygene... and that it is not sensibly diminished in hydrogene gas."

${ }^{14}$ Life and letters of Faraday, Dr. Bence Jones, pp. 144-146, 1870.
} 
in them, but it is sooner extinct in alcohol than in water. Heat forces out a bright glow, and then it becomes extinct; but if not carried too far, the addition of moisture after a time revives its power. No motion or mixture seems to destroy its power whilst it remains fresh and moist, but yet a portion thus rubbed, sooner lost its light than a portion left untouched.

It is to be regretted that in the long period following this early work Faraday did not further pursue luminescence studies.

The most complete paper on fireflies was that of Issac François (J.) Macaire (1796-1869), a professor of the Academy at Geneva, much of it reviewed by Tweedy John Todd, M. D., in 1824 and 1826, whose own conclusions ascribed the light to "vital action." Macaire's study of electricity and galvanism was the first to be made with glowworms (Lampyris noctiluca and L. splendidula). Under the heading "l'électricité," Macaire reported no effect from an electrical machine or Leyden jar. Even when a spark struck the insect it did not glow but under the heading "du galvanisme" he found that the voltaic stream from a pile did have an effect.

Although other workers had noticed that the light disappeared at a high temperature, Macaire made a special study and concluded that a certain temperature range was necessary for the voluntary lighting of the glowworms and that too great heat prevents even the luminous matter to shine. The light intensity increased to a temperature of $33^{\circ} \mathrm{R}$, then decreased in intensity and went out with a definite red color at $42^{\circ} \mathrm{R}$. Apparently Macaire was the first to note the reddish tinge of firefly light just before it is extinguished at high temperatures. He also noticed that all agents (acids, alcohol, heary metals, etc.) which coagulate albumen put out the light, and concluded that the luminous matter was principally albumen in a transparent state which becomes opaque on coagulation. The luminous material was not soluble in oils, either hot or cold, or in alcohol, as is phosphorus. Macaire's experiments led him away from the older idea that the luminous material was either phosphorus or a derivative of phosphorus, a very important concept.

Somewhat similar conclusions to those of Macaire were obtained in 1843 from a study of the Italian lucciole (Lampyris Italica) by Carlo Matteucci (1811-1868), professor in the University of Pisa. His final conclusions were collected in a chapter of his book, translated into English as Lectures on the Physical Phenomena of Living Beings, London, 1847. In addition to studying behavior in various gases which indicated that an oxidation was involved in light production, Matteucci claimed to have established the fact that when oxygen is used by the phosphorescent matter, a corresponding 
amount of carbon dioxide is produced. Although the $\mathrm{CO}_{2}$ produced by the respiring tissue could not be separated from $\mathrm{CO}_{2}$ produced by the chemical reaction actually producing light, and the conclusion may not be correct, the idea that light came from the oxidation of an organic carbon compound was definitely modern. To quote Matteucci's own words (1847: 182): "In the luminous segments of these animals, enveloped by transparent membranes, and by means of the numerous tracheae discovered here and there in these animals, atmospheric oxygen is brought in contact with a substance, sui generis, principally composed of carbon, hydrogen, oxygen, and azote." Thereby the light is produced. Knowledge that a number of additional compounds are necessary for light production in the firefly was to come in the twentieth century. Matteucci's work by no means concludes the nineteenth-century phrsiological and chemical investigations of the Lampyridae, but will serve as a convenient stopping place in anticipation of the modern period. The many papers which filled in the details of lamprrid phrsiolog: during the last half of the nineteenth century added little of importance for our history.

\section{PHYSICAL NATURE OF THE LIGHT}

Firefly and glowworm light is particularly well suited for phvisical investigations, although perhaps not as bright or as easy to study as that of the cucujo, Pyrophorus, discussed in a later section. The early attempts to detect heat from glowtiorms all failed, and even modern measurements, like those of $\mathrm{W}$. W. Coblentz (1912) in A Physical Study of the Fire-fly, have led to results difficult to interpret.

John Murray (1826) was probably the first to report on examination of the glowworm light with a prism, and to find that it " seems monochromatic and incapable of further decomposition." This result was due to faulty conditions. Dr. Lehman (1862, and J. Schnauss (1862) both observed the presence of red, yellow, and green components, and Schnauss noted that the light would affect a photographic plate, making it similar to ordinary light, with no unusual qualities, as some workers had supposed. Since 1862, C. A. Young (1870), P. Secci (1872), H. A. Severn (1881), J. Conrov (1882), and J. Spiller (1882, have all found the spectra of lampyrids to be short bands, entirely in the visible region but made up of several colors. Spectral energy curves were first plotted in the twentieth century, as a result of the work of $\mathrm{H}$. E. Ires and $\mathrm{W}$. $\mathrm{W}$. Coblentz (1910). 
The claim of penetrating radiation emitted by fireflies, made by C. Henry (1896) and by H. Muraoka (1896), was later traced by H. Muraoka and M. Kashya (1898) to chemical effects on a photographic plate, coming from material in the cardboard protecting the plate from the light of the insects.

\section{HISTOLOGY}

The fine structure of the light organ of the firefly, which has played such a prominent part in various theories of flashing, was studied by Franz Leydig (1821-1908) and Albert von Kölliker (18171905) about the same time. In Leydig's Lehrbuch der vergleichende Histologie des Menschen und der Tiere (1857), the fat body and the light organ of Lampyris splendidula are described and figured. Leydig regarded the organ as a modified fat body but recognized that the light substance was different from fat globules. Kölliker (1857, 1858) made one of the best early histological studies. He pointed out that the organ was quite distinct from the fat body and made up of two layers. There was an albuminous substance in the lower layer and ammonium urate crystals in the upper layer. As all tests for the element phosphorus were negative, Kölliker regarded the light as resulting from oxidation of albumin by the nervous system. Since the work of Leydig and Kölliker, the histology of glowworm and firefly lanterns has been a favorite material for study. At least six more authors published on the subject during the nineteenth, and sixteen during the first half of the twentieth century.

\section{THE RAILROAD WORM}

Several other striking luminous beetles, which have excited the admiration of naturalists, are closely allied to the lampyrid fireflies. One of the most famous is the railroad worm of South America, so called because of its double row of yellow lights, a pair on each segment of the wingless body, with a red light on the head, thus resembling a train illuminated at night. The animal is an adult larviform female of the genus Phrixothrix, whose male is winged and non-luminous. It was undoubtedly observed by Oviedo (see Chap. II), but then completely lost to science until Don Felix de Azara (1809) again spoke of the insect during his travels in South America, 1781 to 1801 . He wrote $(1: 214)$ : "I have seen in Paraguay a great worm of about two inches length, in which the head appears at night red and burning, and which has on each side along its body a row of round spots resembling eyes from which comes out a weak yellowish light." 
The next observation ${ }^{15}$ was by J. Reinhardt (1854), who gave a careful description in Danish of a specimen from Lagoa Santa found in April, 1853. In $1868 \mathrm{~A}$. Murray named the animal Astraptor illuminator, deriving the generic name from the Greek astrapton, meaning a flash of lightning. Murray thought the light was due to chemical action, i. e., a combustion throughout the body which was visible through the spiracles. Actually the light does not come from the spiracles but from small organs posterior to them.

H. Burmeister (1872) observed a similar insect, caught in 1858 in rotten wood near Paraná, the former capital of the Argentine Republic. It was 2 inches long and $\frac{1}{4}$ inch wide and ejected

from the anus a clear reddish brown fluid which had a corrosive effect upon the skin. During all this time it was emitting light. ... This light, which the animal can intensify or diminish at will is of two different colors. At the head end it emitted an entirely red light like a burning coal; but on the body the light was greenish white, like that of the glowworm, or of phosphorus.

Several additional records and descriptions of "Astraptor" by F. Smith (1869), R. Trimen (1870), H. Weyenbergh (1876), H. von Jhering (1887) are to be found in the nineteenth-century literature. Most of the early observers thought that the insect was the larva of the elaterid, Pyrophorus, but in 1886 E. Haase described "Ein neuer Phengodes," and in 1888 published a long paper giving the history of previous observations and a detailed description of a pair of the insects caught in copula by Dr. Hieronymus at Cordoba on October 10, 1881. This lucky find established the true identity of the larva as a Phengodes-like insect, named $\mathrm{P}$. hieronymi by Haase (1886). His drawing is reproduced as figure 43. In all species of this genus the adult females, pupae, and larvae are hardly distinguished from each other while the males are normal winged beetles. Dr. Hieronymus kept the living fertilized female, which laid eggs that later hatched to larvae during the last part of December. The eggs were not luminous, but the larvae (11 mm. long) had red and greenish lights like the mother. The adult male showed a greenish light from the underside of the abdomen.

${ }^{15} \mathrm{~J}$. Goudot described in 1843 luminous Phengodes pulchella and P. Roulini from the plateaus and hot valleys of the high mountains of Colombia (Nouvelles-Grenade), with a constant light of long duration but no mention of a red light (Rev. Zoologique, $12-22,1843)$. 


\section{PHENGODES AND STARWORMS}

A closely related form of the genus, Phengodes, which lacks the red light, is found in North America and appears to have been first recorded in a note of C. R. von Osten-Sacken in 1862 on unknown larvae which he thought might be lampyrids, telephorids, or elaterids, probably the latter, of the genus Melanactes. C. J. S. Bethune (1863), B. P. Mann (1875), and C. V. Riley (1880) also thought them elaterid larvae but Riley (1887), after finding the "larvae" in coitus with males of Phengodes laticollis, correctly established their identity as larviform females of the Phengodini. J. J. Rivers (1886) described the luminous female of Zarhipis riversi from California, and C. F. Atkinson (1887) found that his female, $60 \mathrm{~mm}$. long, burrowed in the ground by day and came out at night, attracting small males (15-20 $\mathrm{mm}$. long) with plumose antennae.

Allied insects, called starworms, but of different genera, with three rows of lights along their body, were caught in South China and Malaya during the latter part of the nineteenth century, by $\mathrm{A}$. $\mathrm{H}$. Swinton (1880), H. Lucas (1887), and C. O. Waterhouse (1889). ${ }+$ arworms obtained near Singapore belong to the genus Diplocladon.

\section{The Cucujo or Pyrophorus}

The Spanish historians of the sixteenth century who observed and described the cucujo, presented a fascinating if somewhat exaggerated picture of this brilliant tropical "firefly," a click beetle of the genus Pyrophorus. The stories of Oviedo and Peter Martyr (see Chap. III) have formed the basis for statements of the sixteenthcentury naturalists, especially Aldrovandi and Muffet, and have been repeated in accounts of many travelers to the Caribbean region since then. Such seventeenth-century writers on natural history as Bacon (1620), Jonston (1653), Swan (1635), Nieremberg (1635), Bartholin (1647), and Marcgrave (1648), all of whom mentioned the cucujo, mostly obtained their knowledge from books rather than personal acquaintance. The first published drawing of Pyrophorus, reproduced in figure 5 in Chapter III, appears to be that in Muffet's Insectorum Theatrum (1634), an adaptation of John White's watercolor (see Chapter III).

The story of the insect was often distorted in telling, for example, the frequently repeated statement that " each Cucuius carries around four lamps," made by J. E. Nieremberg in Historia Naturae (1635) and by John Swan in Speculum Mundi (1635). Actually there are two lights on the prothorax (not the eyes, as stated by Robert 
Burton in Miracles of Art Nature, 1678), and a single bifurcate ventral luminous organ, only visible when the insect flies.

Among those writers who actually visited America, such as Jean Baptiste du Tertre (1610-1687), in Histoire Générale des Isles (Paris, 1654), M. de Rochefort in Histoire Naturelle et Morale des Iles Antilles de l'Amérique (Rotterdam, 1681), and Jean Baptiste Labat (1663-1738) in Noveau Voyage aux Isles de l'Amérique (La Haye, 1724), accounts of the cucujos tell little more than can be found in the statements of Oviedo and Martyr, quoted in Chapter III.

The early English writers were all concerned with Pyrophori from the island of Jamaica. There are papers in the Phil. Trans. for 1668 by Dr. Stubbs (No. 36) and by Mr. Norwood the younger (No. 41), and a rather extensive account by Sir Hans Sloane (1660-1753), who visited the island in 1687 as a young physician in the suite of the Duke of Albemarle. He collected plants and curios, but relied on the books of Ovideo, Martyr, and Purchas for most of his statements on Pyrophorus, published in the second volume of $A$ Voyage to Jamaica (1725). Sloane described the insect as a "Scarabaeus" and said it had four lights. Although his collections were bought to start the British Museum, specimens of Pyrophorus collected by him appear to have been lost. His drawing is reproduced in figure 5 .

Somewhat later, Patrick Browne, M. D. (1720-1790), again described the insect as Elater phosphoricus in his Civil and Natural History of Jamaica (1756), without adding any new facts, and $T$. Jeffries, Geographer to H. R. H. the Prince of Wales, reported on a luminous "beetle half as big as a sparrow," from the island of Santo Domingo, in his book, The Natural and Civil History of the French Dominions in North and South America (London, 1760).

It was not until after the middle of the eighteenth century that a living cucujo, in French le maréchal, was seen in Europe. On a mild and calm evening in September, 1766, two women observed one of these insects descend and rest on the window sash of a house in the suburb of St. Antoine, near Paris. They reported that its light was so intense their eyes could hardly stand the brightness, and they compared it to a falling star.

A. D. Fougeroux de Bondaroy (1732-1789), member of the French Academy, was called in to identify the animal and he presented a short paper (1769) describing the two luminous organs with their emerald green light on the prothorax, and the median ventral light organ on the abdomen. He published a good drawing of the insect. Although nothing was known of the life history, de Bondaroy surmised that this click beetle (taupin) probably had a larval life similar to other click beetles and was probably introduced from Cayenne in a shipment of lumber. 
During the nineteenth century, Pyrophorus continued to be described by many travelers to the West Indies and South America and by scientists interested in luminescence. Karl Iliger's monograph on luminous elaterid beetles appeared in 1807, with descriptions of sixteenth luminous species of the genus, Elater. Macartney (1810) told of finding a yellow substance composed of globules in the light organs. His drawing of the insect is reproduced in figure 5 .

The first study of the spectrum of the light of Pyrophorus was made by the great Louis Pasteur (1864), who noted that it was continuous, without dark or light bands. However, it was not until the monographs of C. Heinemann $(1872,1886)$ and R. Dubois (1886) that the morphology, histology, ${ }^{16}$ physiology, and chemistry of Pyrophorus became well known, while the physical studies of Dubois and of Langley and Very (1890) hailed the animal as producing "the cheapest form of light." Possibly the insects's greatest claim to fame stems from the biochemical experiment of Dubois in 1885 , by which he established the existence of a thermostabile substance and a thermolabile enzyme, luciferin and luciferase, both necessary for light production.

\section{Myriapoda}

Probably the first record of luminous centipedes or scolopendrae is that of Oviedo (1520), already described in Chapter III. He found them on the island of Santo Domingo in the West Indies. In addition, early naturalists of the sixteenth century, like Muffet (1634, 1638), named several persons who saw them in Europe. At that time they were called Julus, a name now reserved for nonluminous species with two pairs of legs on each segment of the body, of the order Diplopoda.

During the seventeenth century, luminous centipedes were recorded by Christian Frederick Garman and by John Ray (16281705). In his posthumous work, Historia Insectorum (1710:45), Ray stated that " one evening after rain I found a small Scolopendra of this Sort [with 48 pairs of legs] shining like a glow-worm; 'twas covered with a slimy Matter, which being wiped away it ceased not to shine."

Garman (1670) wrote that his Scolopendra, commonly known as "Nassel," "shines so in the dark that one is reminded of particles of glowing coal " but "after death not the smallest spark remains." Garman went on to quote Kircher and Bartholin as evidence of the

${ }^{10}$ In a short note, Kölliker (1859), after dissecting dried and moistened specimens of "Elater," called attention to the essential similarily in structure of its light organ with that of the glowworm, which he had studied in 1857. 
existence of innate light among many creatures and spoke of producing a future light sufficient to read by and " glorified by the separation of light from fire." Francis Willoughby (1635-1672), the associate of Ray, had also seen them. When S. Reisel (1688) described luminescence on a stone drain where he had urinated, it is very likely that the light came from a luminous centipede disturbed by the urine.

Luminous centipedes were well known to zoologists of the eighteenth century also, observed and mentioned by Réaumur (1723: 204) in his work on Pholas as "d'especes assés communes qui brilloient au moins autant que le Vers luisants," and by Thomas Shaw (1738) during his travels to Barbary and the Levant. In the tenth edition of Systema Naturae (1758), the edition which inaugurated the consistent use of the binomial system, two species are described-Scolopendra electrica "lucet in tenebris manifeste" and S. phosphorea of Asia " noctu instar Lampyridis ignita ex alto coelo decidua in novam." The latter, which glows at night like a lampyrid, was found by the Swedish sea captain, Eckeberg, in a voyage to India and apparently "fell from the heavens." The captain informed Linnaeus of the event and the animal was described. Macartney (1810) referred to the luminous secretion of centipedes, as have many others since then.

Chemical studies of myriapod luminescence were first undertaken by $R$. Dubois $(1886,1893)$, who described fine granules (vacuolides) in the secretion which he observed to change into crystals.

Another group of myriapods, the millipedes, can also produce a light not due to luminous bacteria, but their discovery is very recent, a species of Spirobolellus by Y. Haneda (1939) and a Luminodesmus by D. Davenport et al. (Biol. Bull. 102: 100, 1952).

\section{Earthworms}

Discovery of luminous terrestrial earthworms is usually attributed to Herman Nicholas Grimm (1641-1711), a Swedish physician who traveled in Sumatra. In a short note "Vermes Rari Lucentes" in the Miscellanea Curiosa for 1682, Grimm described what he had once 1670 ) seen in Coromandel, ${ }^{17}$ southwest India. He wrote: ${ }^{18}$ "Having often stayed in forests to investigate rarities. .. . I [once] noticed something luminous in the dark night and delighted in the sight of so remarkable a thing. ..." At daybreak, Grimm

${ }^{17}$ Professor G. E. Gates, an authority on Oligochaetes of India, informs me that scarlet earthworms are found in Coromandel but luminous species have not been recorded from that region.

${ }^{18}$ Kindly translated by B. Luyet. A figure, worthless for reproduction, accompanied the article. 
found that it was worms which gave that light; they were rolled up in round forms, "conglobulated," of the color of scarlet; no eyes, no wings, no feet could be distinguished in them. I carried home a few of these worms with a little of the earth on which they were, in order to enjoy the light. I put them in a glass vial and obtained so much light from them that I could use it to read and write for the period of a month. But after that time light ceased in them together with life. One may rightly enquire from what [source] they can produce such light. The light would, I believe, arise from the very tenuous and extremely volatile sulfurous and nitrous particles of air which the worms attracted and concentrated in them. I observed a similar luminosity in the island of Ceylon on scorpions ${ }^{19}$ subjected to a slight compression until some liquid flew from them; this liquid then shows a sulfurous luminosity, an indication of its sulfureous, burning venom, so that if someone is struck by these (animals) he feels as if he were really wounded with aqua fortis, oil of sulfur or vitriol or by a cauterization.

Another probable record of luminous earthworms is to be found in the account of luminous peat given by Robert Plot (1640-1696) . In his Natural History of Staffordshire (1686: 115), Plot wrote that on Archer moor near Berefford, " if one ride in a dark night in so wet a season that a Horse breaks through the turf, and throws up this black, moist spungy sort of earth, He seems to fling up so much fire, which lyes shining upon the ground like so many embers." On another occasion a Capt. Lane helped a friend of his, "who casually fell into a ditch in Bescot grounds in the night time, and having stirred the mud and dirt pretty much in performing that good office; they presently found their gloves, bridles and horses, as far as the water or dirt had touched them, all in a kind of faint flame, much like that (as He described it) of burnt brandy, which continued upon them for a miles rideing."

The account is usually considered to be an observation of luminous fungus mycelium which often makes dead leaves and damp mould of forests luminous. However, the recent observation of A. Harker (1888) suggests a different explanation. He noted that footmarks on a peaty moor in Northumberland shone brilliantly while horse's hoofs threw showers of white glowing fire. Harker traced the luminescence to hundreds of small earthworms of the genus Enchytreaeus. The descriptions of Plot and Harker sound so much alike that the earthworm explanation seems highly plausible. ${ }^{20}$

\footnotetext{
${ }^{10}$ Scorpions are not self-luminous.

${ }^{20}$ According to a personal communication from Y. Haneda (1955), a small species of earthworm (Microscolex phosphoreus) was so abundant on a paved road near Fukuoka, Kyushu, one cold rainy night that the soles of shoes of pedestrians and the tires of bicycles and cars became brilliant in luminosity.
} 
Linnaeus did not mention Lumbricus as luminous in the tenth edition of Systema Naturae (1758) and no additional records of earthworm luminescence appear for nearly one hundred years after the note by Grimm. In $1780 \mathrm{M}$. de Flaugergues wrote a "Lettre sur le phosphorisme des vers de terre" to M. le Baron de Servières to be transmitted to M. l'Abbé Rozier, editor of the Journal de Physique. In this letter Flaugergues stated that during a beautiful evening in October, 1771, while walking along the Rhone he noted earthworms which luminesced like rotten wood. The bluish light appeared over the whole body, particularly on the "bourrelet" (clitellum). In a box with moist earth they presented "un trés joli spectacle." No light appeared from dead worms. Flangergues searched assiduously at other times and in other years but found only a single luminous worm in October, 1775, and asked the Abbé Rozier whether the light could be " an effect of some amorous efferverscence such as is produced in the rear part of the glowworm."

The idea that the light of earthworms is for attracting the sexes has not been substantiated by later work. Luminous species have been found in all parts of the world, although they are especially common in Europe. J. G. Brugière (1792) observed them at Avignon, and there are many records from 1837 to the present day. Most writers express astonishment that earthworms should luminesce and the use of the light is still uncertain, although many observers hold it to be a means of scaring predacious animals away. The luminous material actually comes from the coelomic fluid, a discovery of W. B. Benham (1899), overlooked by previous workers such as P. Panceri (1875) and A. Giard (1887).

\section{The Lantern Fly, Fulgora}

The luminosity of few animals has excited as much controversy as that of the lantern fly or lantern bearer. A large lantern-like protuberance on the head suggests that light should be emitted, although the structure of the lantern, which is said to contain an extension of the alimentary canal, speaks against luminosity. The earliest illustration of the insect, reproduced as figure 44, was made from a dried specimen from Peru in the museum of the Royal Society and appeared in Nathaniel Grew's Museum Regalis Societatis . . whereunto is subjoyned the Comparative Anatomy of Stomachs and Guts, published in London in 1681. The insect was named Cucujus peruvianus and said to be luminous. ${ }^{21}$ There are

\footnotetext{
${ }^{21}$ Grew described (p. 158) the insect as follows: "The Lanthorn-fly of Peru. Cucujus Peruvianus. Quite a different Species from that described by Moufet. And, with respect to its Wings, is in no way of kin to the Beetle or Scarabeus-kind but
} 
several species, the best known being Fulgora lanternaria from tropical South America and Fulgora (or Pyrops) candelaria from southern China.

One of the earliest observers of the living South American species was Maria Sibylla Meriam (1647-1717), the daughter of a designer and engraver, who married the painter, J. Andreas Graff of Nürnberg. After twenty years of marriage she divorced her husband and went first to Holland and then to Surinam where she studied new world insects from 1699 to 1701. An artist in her own right, she published two books on insects, beautifully illustrated, one of which Metamorphosis Insectorum Surinamensium (Amsterdam, 1705; ${ }^{22}$ French edition at Haye, 1726), described the lantern bearer. Meriam wrote:

The Indians brought a number of these insects which I put in a great wooden box. At night they made such a noise that I awoke with fear, not knowing what could have caused such a scuffle in the house, but soon realized that it was in the box. To my astonishment, on opening the box flames came out. Indeed the insects all lighted as if they were on fire and I was amazed by the splendor of these animals.

Many early entomologists like Réaumur and August Johann Rosel von Rosenhof (1705-1759) accepted her statement, which is certainly definite. Linnaeus, in the tenth edition of Systema Naturae (p. 435) recognized five species, described under the name of Cicada and grouped together as "Noctilucae." No advantage would be gained by recording the many reports for and against luminosity of Fulgora. About two-thirds deny and one-third affirm that light can be produced. The latest information ${ }^{23}$ is definitely favorable and includes the discovery that the light is apparently the basis of mating reac-

rather the Locust, I find it no where described. 'Tis above three inches long and thick as a Ring-finger. His head, in bigness and figure, admirable; near an inch and a half long, in the thickest part of it above half an inch over. . . .

"That which, beside the figure of the Head, is most wonderful in this Insect is the shining property of the same Part, whereby it looks in the Night like a little Lanthorne (Lamphorne). So, that two or three of these fastened to a stick or otherwise conveniently disposed off, will give sufficient light to those that travail or walk in the Night." There is no uncertainty in Grew's statement regarding luminosity of the insect, although he could not have seen it light.

${ }^{22}$ Subscriptions for the book were advertised in the Phil. Trans. of the Royal Society for 1703 (p. 1418). The statement described her as "that curious person . . lately returned from Surinam in the West Indies doth now propose to publish a Curious History of all those Insects, and their transmutations that she hath there observed, which are many and very rare with their Descriptions and Figures . . . curiously performed from her own Designs and Paintings." This famous book was to cost 30 shillings a volume.

${ }^{23}$ See E. N. Harvey, Bioluminescence, 373-376, 1952. 
tions. It only appears when several insects, males and females, are together, such as no doubt occurred in Madam Meriam's box.

Luminosity of the Asian species, Fulgora candelaria, the candle fly, has also been subject of controversy. Edward Donovan (17681837) in his Epitome of the Natural History of the Insects of China (1798: 30) implied that F. candelaria is luminous but did not state that he actually saw the light. In $1864 \mathrm{E}$. Newman published a statement of Mr. James Smith that Fulgora (Pyrops) candelaria is luminous between May and August but not in winter, when it is only occasionally seen. "In summer it has a pale blue or green light at the end of the snout, which may be considerably augmented by a gentle pressure of the insect; it is brightest in the female." It is common throughout all China and called the "Star of Eve," "Eye of Confucious," or "Spark fly." Smith stated that the same insect is called in winter the flying elephant, perhaps in reference to its long proboscis and "when the insect is settled the light is more luminous than when it is flying, and when the male and female have mated it is wholly extinguished." Others have called it non-luminous. So much sentiment and mystery have become associated with the candle fly in the minds of the Chinese that the facts concerning luminosity are still obscure.

\section{Miscellaneous Insects}

One of the most definite descriptions and yet a completely unconfirmed report of a luminous insect is due to Adam Afzelius (17501837) a Swedish naturalist and demonstrator of Botany at Upsala; later a scientific explorer of Sierra Leone, in 1792. He described a beetle of the genus Paussus, which fell from the ceiling of his room in Freetown, Sierra Leone, at dusk and was placed in a box. Afzelius wrote in 1798:

One evening going to look at it, and happening by chance to stand between the light and the box, so that my shadow fell upon the insect, I observed, to my great astonishment, the globes of the antennae, like two lanterns, spreading a dim phosphoric light. This singular phenomenon roused my curiosity, and after having examined it several times that night, I resolved to repeat my researches the following day. But the animal, being exhausted, died in the morning and the light disappeared.

The observation has never been confirmed. A luminous bacterial infection is possible.

A large number of insects other than beetles have been described as luminous. The oldest recognizable case appears to be that of a 
luminous mole-cricket caught by a farmer in 1780 and brought to a Dr. Sutton at Iskelton, Cambridgeshire, England. The find was described in Kirby and Spence's Introduction to Entomology, published in 1817. Another luminous mole-cricket, found by a pupil of F. Ludwig of Greiz, in 1891, established very definitely that this mole-cricket was infected with luminous bacteria.

Another early record of light from insects concerns luminous midges, observed at Astrabad, Persia by Carl Hablitzl (1789). He wrote a letter to Peter Pallas (1741-1811) in July 7, 1782, in which he said:

Besides this luminous insect (Lampyris), which is of very frequent occurrence on the shores of the Bay of Astrabad, I have likewise had the occasion to observe that in the dark a light also emanates from the gnats (Culex pipiens, L.). In fact I noticed this last autumn and in the spring of the present year, since these insects had established themselves in multitudes on board our ships.

It has now been established that midges from middle Europe and Asia, like the ones observed by Hablitzl, frequently become infected with luminous bacteria and, after lighting for some time, die of the infection.

The larvae of other flies, fungus gnats of the genus, Ceroplatus, which live on webs under mushrooms are self-luminous. They were first discovered by Peter Frederik Wahlberg (1800-1877) in Sweden in 1849. A closely allied form is the famous New Zealand glowworm, Arachnocampa or Boletophila, whose larvae live in great numbers in caves and dark places in New Zealand and Australia. The first descriptions were by E. Meyrick in 1886 and by G. V. Hudson in 1886 and later years.

Luminous caterpillars, whose light is now known to come from luminous bacteria were described as early as 1829 by B. A. Gimmerthal of Riga and by Jean Alphonse Boisduval (1799-1879) in 1832, while luminous bacterial infections of the antennae of a noctuid moth was observed in 1899 by Oskar Schultz.

Luminous May flies, presumably bacterial infections, were observed by Hermann August Hagen (1817-1893) in 1873 and A. E. Eaton in 1880, while luminous ants have been reported by $\mathrm{F}$. Ludwig in 1902 and W. M. Wheeler in 1916.

In the meantime, observation of light production in the simplest wingless insects, the Collembola, was noted by G. J. Allman on a hill near Dublin in Ireland in 1851. The animals are self-luminous and have been studied by Dubois (1886) and by numerous workers since then. 


\section{Land and Fresh-water Snails}

The only terrestrial mollusc known to produce light is of very recent discovery. ${ }^{24}$ It is a land snail, Dyakia striata, of the Malay peninsula, discovered and studied by Yata Haneda in 1946. The light organ is situated near the head and emits a flashing, bluish light when the animal is disturbed. Luminous bacteria could not be demonstrated.

Discovery of a fresh-water snail or limpet in New Zealand is of special interest as the first observed case of a self-luminous freshwater animal. ${ }^{25}$ The observation was made in 1890 by Henry Suter (1841-1918), the eminent conchologist of New Zealand. The limpet belongs in the genus Latia and lives in swift-running streams of the North Island. A luminescent mucous free of bacteria is secreted into the water.

\section{Luminous Marine Animals}

\section{Protozoa}

\section{FLAGELLATES}

Discovery of the various microscopic organisms of sea water and the final realization, around 1834, that all phosporescence of the sea comes from organisms, even the "diffuse" light, has been traced in Chapter XV on "Phosphorescence of the Sea." In particular, the history of knowledge concerning Noctiluca miliaris, the largest of the marine flagellates, has been recorded up to its systematic designation by M. Suriray in 1816, in a manuscript published by J. B. Lamarck in 1836. Within fifteen years the morphology and physi-

${ }^{24}$ An old record of a luminous slug (Limax noctilucus), discovered by M. d'Orbigny living under stones and dead leaves in the mountains of Teneriffe, is included in Baron de Férussac's Tableaux systématiques des animaux mollusques, part I: 24, Paris, 18211822. No more recent records have appeared.

${ }^{25}$ The only other fresh-water luminous animals which have been described, owe their light to bacterial infection, such as the "crevette" observed in 1786 by Thulis and Bernard from a stream near Trans in southern France, and the fresh-water shrimp of Lake Suwa, Japan, first seen by a Mr. Ushiyama in 1914 and described by Y. Yasaki in 1927.

Perhaps aquatic firefly larvae should also be classed as fresh-water luminous animals. Most glowworms are terrestrial, but a species described by Nelson Annandale in 1900 breathed by diffusion of oxygen through the cuticle. Another species described by him in 1906 possessed a tracheal funnel at the posterior extremity which could be extruded like a Snorkel of a submarine, pushed into an air bubble on a plant under water and then withdrawn. K. G. Blair in 1927 described a third type of aquatic lampyrid larva, which breathed by tracheal gills. 
ology of Noctiluca was studied in great detail. Some of the smaller flagellates are reproduced in figure 40.

The fine structure of Noctiluca was first described by P. Van Beneden (1846), using observations of Verhaege, who published in 1848 , and by L. Doyère (1846). As early as 1850 , J. L. A. de Quatrefages (1810-1892) made a classic study of both morphology and physiology of Noctiluca, and was followed by a host of workers on structure and relationships, including T. H. Huxley in 1855. Quatrefages' famous figure of Noctiluca shows very clearly that the light comes from minute granules scattered in the protoplasm (see fig. 45). He distinguished between "the flash" resulting from stimulation, and the "steady glow" which appeared under unfavorable conditions. Quatrefages paid particular attention to the steady glow, observing that it might occur locally in one region and then shift its position, and could be observed even in fragments of the animal as many bright spots of light, each spot made up of a "cluster of minute instantaneous scintillations, dense at the center and more scattered toward the circumference of the spot."

It is the response of a luminous form to stimulation, which intrigued the earlier workers. This response is characteristic of the animal kingdom, since bacteria and fungi emit a steady light. Many remarked how sea water seemed on fire when struck by oars, but the modern concept of stimulation of a cell by mechanical, electrical, chemical, or thermal stimuli developed during the first part of the nineteenth century, largely as a result of the Galvani experiments with frog's legs (1791). As indicated in the next section, Spallanzani studied the relation between contraction and luminescence in medusae in 1793, and von Humboldt stimulated a medusa electrically in 1799 .

James Macartney (1810) had called special attention to the flash of Noctiluca on mechanical agitation (as well as to the stimulation of medusae mechanically, electrically, on heating, or when plunged into "spirits") but the first electrical stimulation of minute marine forms, probably dinoflagellates, was made by C. H. Pfaff (1823) at Kiel. The first electrical stimulation of Noctiluca was attempted by J. H. Pring (1849), who, curiously enough, observed no effect from two "Smee batteries" until the current had been passed for some time, when the Noctiluca gave a constant glow, an effect possibly due to electrolysis products. Pring studied the luminescence of Noctiluca in some detail, speculating on the nature of the phosphorescent matter and demonstrating that luminescence was independent of previous exposure to sunlight. He spoke of animal light as "vital phosphorescence" and found that the light of Noctilucae 
went out when acids, ether, chloroform or hydrogen sulphide were added to the sea water, but that nitrogen, hydrogen, and nitrous oxid had no effect. In carbon dioxide, the Noctilucae gave a steady glow which disappeared after a short time.

Quatrefages (1850) also studied the effects of electricity. He came to the conclusion that the light was not a secretion, as in Pholas and Medusae, but was connected with contraction, since all agents which cause contraction of the sarcode would cause luminescence. This view was no doubt influenced by his previous study (1843) of luminous marine worms. More specifically Quatrefages thought the scintillations of Noctiluca came from rupture of protoplasmic filaments and the permanent glow from contraction of filaments adhering to the surface envelope of the Noctiluca. Light emission was considered a vital act connected with muscle action, a concept which has persisted in bioluminescence literature for over fifty years.

Later workers of the nineteenth century were mostly concerned with morphology, but some physiological experiments were undertaken. C. Robin and C. Legros (1866) were astonished at the slight mechanical disturbance necessary to produce light. Observing Noctilucae under a microscope, they noted that a local touch of the surface with a needle would result in luminescence only in the touched spot; it did not spread to the rest of the animal. In this way all regions of Noctiluca were found to be capable of luminescence. Later Robin (1878) took exception to Quatrefages' statement that light production was always connected with contractility, since he had observed that slight vibrations which did not cause tentacle movement or shortening of protoplasmic strands would, nevertheless, excite luminescence.

W. Vignal (1878) and J. Massart (1893) carried out the most comprehensive and extensive studies. Vignal distinguished between the effect of the current in causing retraction of the protoplasmic strands, in stimulating the tentacle and in causing luminescence, while Massart (1893) emphasized that the light emission was a response to stimulation, comparable to muscle contraction or gland secretion, rather than a result of muscle contraction, as Quatrefages had implied. He found that not only would chemical and electrical stimuli cause light emission but also changes in the salt content of the medium, as when fresh water or concentrated salt came in contact with the animals. The fatiguing effect of continued stimulation was particularly noted and the physiology of Noctiluca given a modern interpretation. The reversible narcotic action on luminescence of various compounds was clearly established by Massart. 


\section{RADIOLARIA}

Although dinoflagellates are the most abundant microscopic organisms responsible for sea light, another group of protozoa is also luminous. These forms, the Radiolaria, are few in number and their light is weak. Their luminescence appears to have been discovered by Tilesius, recorded in the account of the Russian voyage of discovery around the world in 1803-1806, under the command of von Krusenstern. A résumé of the results appeared, arranged by L. W. Gilbert, in the Annalen der Physik for 1819 with special attention to light-emitting organisms. It is probable that figure 23 of plate II in this article is a radiolarian. W. Baird (1831) has likewise been credited with observing the light of radiolarians but K. Brandt (1885) considered his drawing questionable.

A little later, F. J. F. Meyen (1834) studied the luminous forms collected on a trip to Canton in a trading vessel. He gave more recognizable figures of the Radiolaria, Sphairazoon fuscum, and what he called Physaematium atlanticum and vermiculare, all new species. Radiolarians are never responsible for the brilliant displays of phosphorescence described by so many mariners but they may be considered to add their mite to the light from other microscopic protozoa.

Knowledge of the morphology and physiology of these luminous protozoa, which may be solitary or colonial, is almost entirely due to Karl Brandt (1885), whose great monograph on the Radiolaria of the Gulf of Naples is beautifully illustrated with drawings of many species. He noted that it was the central capsule of the radiolarian which responded by luminescence after various kinds of stimulation, recorded the onset of fatigue and recovery from fatigue, and in general proved that these organisms behave like Noctiluca in most respects, although their light is very much less intense.

\section{Jellyfish or Medusae}

Like the dactylus, the jellyfish or pulmo marinus of the Romans is a well-known luminous animal. Pliny's story of the luminous slime which adheres to the fingers and that "a walking stick rubbed with the pulmo marinus will light the way like a torch," directed the attention of the scientific world to luminous medusae. The large scyphomedusan, Pelagia noctiluca of the Mediterranean, was undoubtedly the species seen by Pliny and described by such later naturalists as Rondelet, Boussuet, Aldrovandi, Belon, and Gesner. In the seventeenth century Kircher (1640) and Bartholin (1647) also listed the pulmo marinus as a luminous animal. 
In addition to the large medusae, many marine naturalists observed the smaller transparent hydromedusae but in most cases it is almost impossible to identify the luminous species. Linné included a "medusa noctu vagatur" in the tenth edition of Systema Naturae (1758) and Thomas Pennant described luminous Medusa simplex in his British Zoology in 1777. Additional eighteenth-century records of luminescence are due to. P. Forskål ${ }^{26}$ (1775) on a trip to Egypt in 1762; to J. Banks ${ }^{26}$ and D. C. Solander on Captain Cook's voyage of the "Endeavor" in 1768-1771; to the Dutch naturalist, M. Slabber (1771), and to Andrew Sparmann ${ }^{26}$ (1772), a Swedish physician who thought large luminous spots in the surface of the sea near the Cape of Good Hope were luminous medusae, although he had no real proof. Olaf Schwarz ${ }^{26}(1789,1792)$ and Adolph Modeer (1792), both on sea voyages, also saw luminous medusae. Modeer noticed that when the jellyfish was broken up in sea water, the light came from "little sparks" that spread from the medusa like stars. This is characteristic of luminous jellyfish slime, which contains granules whose dissolution is accompanied with a burst of light.

The scientific study of luminous medusae begins with experiments of the Abbé Lazaro Spallanzani, made at Messina during a journey to Sicily in 1788. Spallanzani (1794) published a special article on "Medusae fosforische" and included the work in his Viaggi alle due Sicilie (1793). ${ }^{27}$

After a detailed description of the anatomy and a study of the pulsation, Spallanzani directed his attention to the relation between luminescence and movement. He had noticed that the light was much brighter during systole than diastole and had previously observed luminescence in the worm, Nereis marina, when it moved, and lighting of the glowworm with each oscillation of the body. He, therefore, concluded that it was probable the increase in brightness on systole resulted from a stimulation of some kind which set off pulsation and luminescence simultaneously. Many observers since then, for example Quatrefages in 1843 and 1850, and S. Watasé as late as 1898 , have called attention to the relation between movement and luminescence. However, this relationship is not fundamental, for an undisturbed Pelagia, swimming quietly through calm water does not spontaneously luminesce with every pulsation.

Taking medusae to his house where they were kept in large glass vessels, Spallanzani noted that the light continued after death, when

${ }^{26}$ Banks observed Medusa pellucens on November 29, 1768. Journal, ed. by J. D. Hooker, 21, 1896. The Forskål (Descript. anim. itin. orient, 109, 1775), Medusa has been identified as Pelagia noctiluca. Sparmann $(1772)$ and Schwarz $(1789,1792)$ are quoted from Ehrenberg (1834, 435 and 438-439).

${ }^{27}$ English translation, Travels in the two Sicilies, London, 1798. 
decomposition had set in, although it was weaker. To his astonishment, a medusae that had remained on a sheet of paper for twentytwo hours and which had mostly liquefied and was completely dark, became very bright on adding fresh water (but not sea water), bright enough to read print. Spallanzani referred to these liquefied medusae as dried medusae and has been credited with observing that luminous animals could be dried and would again luminesce on moistening, but it is a question as to how dry they really were, especially since he found that movement, as by rubbing the "dried " dark medusae with his finger would revive the light again. He wrote:

Another medusa which was dead, and had not been luminous for some time, was lying, out of the water, in the window of my chamber during the night. A slight rain chanced to fall, and every drop which fell on the dead medusa was changed into a brilliant spangle, till in a short time the medusa was studded all over with such shining points. I could produce no such effect by sprinkling it with sea-water in imitation of rain.

By crushing two large medusae in thirteen ounces of water until no more light appeared, an " artificial phosphor" could be made which gave light when heated to $30^{\circ}$ Réaumur $\left(100^{\circ} \mathrm{F}\right.$.).

Spallanzani found that the luminous material was a mucous formed on the edge of the umbrella and especially abundant on the arms. The mucous luminesced on mixing with water, urine, or milk. The rest of the animal, devoid of this mucous, or the "sap" of body tissue, could not be made to light in any way. The luminescence in milk was so great " that I could read the writing of a letter at three feet distance."

It was early recognized that the light of medusae only appeared as a result of mechanical stimulation. Alexander von Humboldt (1769-1859) was apparently the first to discover that luminescence could be elicited by electrical stimulation. In his Travels to the Equinoctial Regions of the New Continent during the years 17991804, medusae were described as abundant between Madeira and Teneriffe in the Canaries. He wrote, ${ }^{28}$

If we place a very irritable medusa on a pewter plate, and strike against the plate with any sort of metal, the small vibrations of the plate are sufficient to make this animal emit light. Sometimes in galvanizing the medusa, the phosphorescence appeared at the moment the chain closes, though the exciters are not in immediate contact with the organs of the animal.

There is no detail regarding the electrical apparatus, but it was no

${ }^{28}$ From the English edition, 1853. 
doubt similar to that used for his previous nerve and muscle studies, which were made in 1797, soon after Galvani's famous frog nerve discoveries were published in 1791.

During the nineteenth century there were innumerable records of luminous jellyfish, both the large more or less opaque scyphomedusae and the smaller transparent hydromedusae, whose asexual polypoid forms are hydroids. Further studies of stimulation-mechanical, electrical, thermal and chemical-were made by J. Macartney in 1810 on a small species, Medusa hemispherica. His experiment 11 reads as follows:

Some hemispherical medusae were placed in contact with the two ends of an interrupted chain, and slight electric shocks passed through them. During the very moment of their receiving the shock no light was visible, but immediately afterwards the medusae shone like illuminated wheels, which appearance remained for some seconds. Upon the closest inspection with a magnifying glass, no contractile motion could be perceived to accompany the exhibition of the light. The application of electricity in this instance seems to have acted merely as a strong mechanic shock.

Macartney also found that when heated or when plunged into "spirits," the luminescent spots again appeared "like illuminated wheels."

He placed some medusae in a vacuum and could not discover that the light was any less brilliant, in fact it was more easily excited by shaking and continued longer in a vacuum. This experiment is of considerable interest, for the author discovered in 1926 that medusae, (Pelagia) at Naples, will luminesce under conditions of complete anoxia, in this respect differing from most luminous animals in which the light production only occurs if dissolved oxygen is present.

Macartney continued:

It seems proved by the foregoing experiments, that so far from the luminous substance being of a phosphorescent nature, it sometimes shews the strongest and most constant light, when excluded from oxygene gas; that it in no circumstances undergoes any process like combustion, but is actually incapable of being inflamed; that the increase of heat, during the shining of glow-worms, is an accompaniment, and not an effect of the phenomenon, and depends upon the excited state of the insect; and lastly, that heat and electricity increase the exhibition of light, merely by operating like other stimuli upon the vital properties of the animal.

Nevertheless, Macartney did believe that "the power of shewing light resides in a peculiar substance or fluid, which is sometimes situated in a particular organ, and at others diffused throughout the 
animal's body." One of Macartney's medusae, M. pellucens, also found by Sir Joseph Banks, is shown in figure 47.

Among later workers interested in histology, physiology, and chemistry of the light production, the names of Edward Forbes (1848), G. Busk (1852), and P. Panceri (1872) must be mentioned as pioneers.

\section{Ctenophores or Comb jellies}

These transparent jelly-like organisms have often been mistaken for medusae and in early descriptions it is somewhat difficult to tell what organism was referred to. According to Carl Chun (1880), Friedrich Martens, a ship's surgeon, saw ctenophores in the neighborhood of Spitzbergen in 1671, and Patrick Brown near Jamaica in 1756, but neither mentioned luminescence. Linnaeus included two species in the tenth edition of Systema Naturae, Volvox beroë and Volvox bicaudatus. Again there is no mention of luminescence. The discovery of luminescence is undoubtedly connected with early explorers and the general study of sea phosphorescence.

The Abbé Dicquemare (1733-1789) in 1775 placed a drawing of a ctenophore on the same plate on which he figured Noctiluca miliaris for his article on sea phosphorescence. He called it a "porteiris" but made no definite statement that the animal was luminous. P. Forskål described Medusa beroë in 1775 and it is quite certain that luminous ctenophores were observed in 1800 by Louis Bosc (1759-1828), and in 1801 by S. L. Mitchill (1764-1831), professor of chemistry, natural history, and philosophy at Columbia University, and a member of the American Philosophical Society. Many other students of marine forms since that time have described luminous comb jellies.

The most important contribution of ctenophores to bioluminescence knowledge comes from the discovery in 1862 of G. J. Allman (1812-1898) that daylight inhibits the luminescence, but if the animals are placed in the dark for twenty minutes or so, they can again emit light on stimulation. Allman (1862) also noted that the developing eggs and embryoes of ctenophores are luminescent. The histology was first studied by P. Panceri (1872) and A. Agassiz (1874). Finally it should be mentioned that the ctenophores belong among the relatively few luminous forms which do not need dissolved oxygen for light production, a discovery of the author in 1926. 


\section{Sea Pens}

Although sea pens were known to the ancients, and were called by the Romans Penna marina (sea feather) or Mentula alata (winged penis), no special attention was paid to their luminescence until the time of Rondelet (1554) and Gesner (1555). Gesner mentioned the light both in De Lunariis and in the Historia Animalium, while Boussuet (1558) sang of their glitter. The Rondelet-Aldrovandi (1613) wood cut of the Penna marina is reproduced in figure 2.

Later the sea pen was seen and mentioned, among others, by such naturalists as Johannes Jonstonus (1603-1675) in Historia Naturalis, de Exsanguibus Aquatis, libri IV (1650). He published a beautiful woodcut of Penna marina with the description, "Noctu maxime splendit, stellae modo, ob candorum et laevorum."

In the eighteenth century many books refer to the light of the sea pen. Thomas Shaw (1692-1751), the divine who became Regius Professor of Greek at Oxford, published his Travels or Observations Relating to Several Parts of the Barbary and the Levant in 1738. He wrote: ${ }^{29}$

The fishermen find, sometimes, in drawing and clearing their nets, the penna marina or sea feather; which in the night time particularly is so remarkably glowing and luminous, as to afford light enough to discover the quantity and size of the fish that are enclosed along with it in the same net.

Probably the first indication of deep-sea life came with the discovery of a pennatulid, Umbellularia groenlandica, caught on a sounding line at 300 fathoms by M. Christlob Mylius in 1754, off the coast of Greenland. This form, which is luminous, was described by John Ellis (1763) and later rediscovered by M. Lindahl in the Northern Ocean. ${ }^{30}$

Linnaeus said of Pennatula phosphorea: "Habitat in Oceano, fundum illuminans," while writers on zoophytes such as J. B. Bohadsch (1761), John Ellis (1763), P. S. Pallas (1766), L. Spallanzani (1784), and J. Ellis and D. C. Solander (1786) all devote considerable space to the light of sea pens. Ellis (1763) described the " kidney shaped purple sea pen from South Carolina," a Renilla, but did not mention its luminescence. The Ellis drawings are reproduced as figure 48. In 1850 Louis Agassiz was impressed with its "golden green light of a wonderful softness."

As in so many other fields of science, Spallanzani's observations

29 2nd ed. 1757, p. 191.

${ }^{30}$ See Voyage of the Challenger, by C. W. Thomson 1: 151, 1877. 
on sea pens involved experimentation. They were presented in the same paper, Sopra Diverse Produzioni Marine (1784), in which he reported luminous worms at Portovenere near Genoa. He determined that only the feather part, not the stem of the sea pen luminesced, and found that when the feather part was pressed with the hand a luminous liquid gushed out of a hole in the stem, appearing like a bright fountain in the dark. He appears to have been the first to observe the waves of light which pass from polyp to polyp on stimulation, and are caused by nerve transmission of impulses. After indicating that the light came from the polyps whose shining was so bright at night that candlelight had little effect on it, Spallanzani wrote: ${ }^{31}$ "If one touches the borders of the feather part, the light flows rapidly from the polyps toward the middle of it. In my book I shall spend some time in describing this phenomenon. . .." This future study never appeared. The "waves of light" were also seen by $\mathrm{H}$. D. de Blainville (1834), and others, but a comprehensive physiological analysis of their transmission in sea pens had to await the experiments of Paolo Panceri in 1873. He also investigated the histology.

An early study of stimulation of luminescence of sea pens was made by Edward Forbes (1815-1854), and published as a letter by G. Johnson in A History of British Zoophytes (1st ed., 1838; 2nd ed., 1847, pp. 150-155). Forbes drew the following conclusions from his study of Pennatula phosphorea:

1 st, The polype is phosphorescent only when irritated by touch; $2 \mathrm{~d}$, The phosphorescence appears at the place touched, whether it be the stalk or the polypiferous part, and proceeds from thence in an undulating wave to the extremity of the polypiferous portion, and never in the other direction; 3d, If the centre of the polypiferous portion be touched, only those polyps above the touched part give out light; and if the extreme polypiferous pinna be touched, it alone of the whole animal exhibits the phenomenon of phosphorescence; 4 th, The light is emitted for a longer time from the point of injury or pressure than from the other luminous parts; 5th, Sparks of light are sometimes sent out by the animals when pressed-these are found to arise from luminous matter investing ejected spicula.

Forbes even persuaded his friend, George Wilson (1818-1859), the distinguished chemist, to determine whether Pennatula evolved electricity like an influence machine or a voltaic battery. By insulat. ing the Pennatula in the air or in turpentine and bringing it near a gold leaf electroscope or connecting it to a sensitive galvanometer, no indications of electric charge or current were obtained. Wilson

${ }^{31}$ Translated by Dr. Luigi Crocco of the Forrestal Laboratories, Princeton University. 
finally concluded: "On the whole I believe it most probable that the animal secretes a spontaneously inflammable substance. It may be a compound of phosphorus but it is not necessary to assume that it is."

Panceri (1872) paid particular attention to the waves of light. He pointed out that the colonies, living at depths of 40 to 100 meters, must be freshly collected for good results since, owing to poor conditions in an aquarium, pennatulids absorb water and swell, sometimes to double their bulk. An English account states:

With colonies in good condition a stimulus at one point will result in what he called "luminous currents," as if the little polyps took fire one after another, those on one branch before those of the following one, ... If we operate on the basal extremity of the stalk, we shall have on the stem an ascending luminous current. If the stimulant is on the contrary, applied to the top of the polypidom, there will be a descending current. Lastly, if the stimulus is applied to the feathered part of the rachis, one will then obtain two divergent currents. If the two extremities of the polypidom are simultaneously excited, one will have two currents convergent, which usually cease after a period of great vivacity at the point where they meet. I have only once seen in a very sensitive Pennatula the two converging currents continue after thus meeting, each one their own way, as if the other did not exist.

Panceri's results thus differ from Forbes.

Panceri observed a latent period of $4 / 5$ second before " application of the excitement and the commencement of the (luminous) current." He then measured the velocity of propagation in both Pennatula phosphora and P. rubra, finding an average value of $5 \mathrm{~cm}$. per second (temperature not specified) which he took pains to point out is 600 times slower than the Helmholtz figure for the velocity of nerve conduction in the sciatic nerve of the frog. Another rather rare pennatulid, Cavernularia pusilla, behaved in the same way.

Panceri regarded the transmission of a luminous wave as most remarkable. He suspected that nerve fibers were involved but decided that further work would be necessary to determine whether the luminous current is actually transmitted along nerves. Since then the nerve net of coelenterates has become well known, and all later writers have been equally intrigued by the propagation of the luminous wave.

\section{Siphonophores}

Although a Physalia was reported (1819) as luminous by W. G. Tiselius (1767-1857), who noticed so many luminous animals in his cruise around the world, the identification is questionable. The 
present genus, Physalia, the Portuguese man-of-war is not luminous. Only the delicate transparent forms produce light. They have been known for a long time but apparently the first recognition of luminosity came from F. J. F. Meyen (1804-1840) in 1834. C. W. Peach (1850) also found that siphonophores were responsible for some of the light along the English coast and E. H. Giglioni (1870) named four species as luminous on the high seas, while Panceri (1871) studied luminescence of the varieties at Naples in some detail. The light is relatively weak and has not attracted the attention lavished on the more striking organisms.

\section{Hydroids}

The light of sea growths described by Aelian under the name of "Aglaophotis marina" was most probably due to hydroids. Since that time many naturalists must have noted the sparkling when the hand is rubbed over hydroids growing on rocks or piles in the sea at night. It is difficult to name the actual time of identification of the animals, but one of the first to recognize luminous hydroids appears to have been Charles Stewart. In 1802 he published Elements of the Natural History of the Animal Kingdom. Speaking of Serularia pumila growing on Fucus, he wrote:

This species and probably many others, in some particular states of the atmosphere, give out a phosphoric light in the dark. If a leaf of the above Fucus, with the Sertularia upon it, receive a smart stroke with a stick in the dark, the whole Coralline is most beautifully illuminated, every denticle seeming to be on fire.

Later François Péron (1804) described luminous Sertularia, and Charles Darwin, during the voyage of the "Beagle" in 1831-1836, noticed a luminescent Clytia-like growth while collecting at Tierra del Fuego. By 1841, the year that M. Sars (and in 1842 J. J. Steenstrup) worked out the alternation of generations for hydroid and medusa, A. H. Hassal was able to state: "All the most transparent Zoophytes possess highly luminous properties. This fact I discovered in a specimen of Laomedia gelatinosa..." The statement is not entirely true, as many transparent hydroids are now known to be non-luminous.

Further observations were made by D. Landsborough (1842), by E. Forbes (reported by George Johnson in 1847), and particularly by P. Panceri (1878), who identified the luminous cells and studied stimulation of the hydroids. 


\section{Marine Worms (and Oysters)}

Oysters are not self-luminous organisms. When Kircher ${ }^{32}$ (1640, 1643) mentioned the light of " rotten oysters," luminous bacteria are suspect, but such an explanation cannot be applied to the observation reported by Philipp Jacob Sachs von Lewenhaimb (16271672), a physician at Breslau, in his Gammarologia (1665: Cap. XI. sec. 6, p. 210). A friend, Johann Daniel Major (1634-1693), another physician in Hamburg, had sent him a letter, dated December 6, 1664, with the following statement: ${ }^{33}$

I have several times noticed with respect to oysters that, if still living, juicy and in good condition, they are placed in the darkness, especially when the moon is waxing, then in either shell a droplet of pearl [perla] of rather small size shines about its denser part, radiating with a small but very clear light. The color of the light is the same as that in the belly of glow-worms. ...

The explanation of this light was soon given by M. de la Voie, who communicated his observations to M. Adrien Auzout (died 1692), the French mathematician and astronomer and one of the founders of the French Academy, who published in the Journal de Sçavons for April 12, 1666. Auzout did not at first believe that worms which "twinkled like a great star" could occur in oysters so he had more than two dozen opened by candlelight and actually observed four kinds of worms in them, some of which were luminous. An account of his paper is given in the first volume of the Philosophical Transactions for May 7, 1666, as follows:

That the two first sorts [of worms] are made of a matter easily resoluble, the least shaking or touch turning them into a viscous and aqueous matter; which falling from the shell, stuck to the Observers fingers, and shone there for the space of 20 seconds: and if any little part of this matter, by strongly shaking the shell, did fall to the ground, it appear'd like a little piece of a flaming Brimstone, and when shaken off nimbly, it became like a small shining Line, which was dissipated before it came to the ground. ...

The form observed was possibly a species of Polycirrus. The author has seen Polycirrus living in oysters from the Jersey coast, just as described above.

\footnotetext{
${ }^{32}$ Kircher's rotten oysters must be different from the ostracea described as living in clay on the ocean floor by N. Zucchi, who mentioned them in Philosophia Optica, 48, 1652. According to Ehrenberg (1834: 418) the word "ostracea" was used for any shellfish and could have been applied to the rock-boring mollusc, Pholas, a selfluminous organism.

${ }^{33}$ Quoted from the Rivinus and Boehme thesis (1673), Sec. 19, translated by R. A. Applegate.
} 
No further observations on free swimming marine worms occur until the middle of the eighteenth century when Vianelli, professor of medicine in Chioggia, Griselini, a physician in Venice and the Abbé Nollet (1700-1770), during the year 1749 and 1750, discovered luminous specks in the canals of Venice. The Italians published drawings of the animals, called Scolopendra marina, which were undoubtedly annelids, and which Panceri later (1878) identified as belonging to the family Syllidae or Nereidae. The Abbé actually went into the water and saw the worms dart from the bottom covered with weeds in a manner that greatly resembled the motions of insects. On catching them only luminous specks appeared on his handkerchief.

These accounts aroused great interest since they came at a time when many were beginning to attribute phosphorescence of the sea to small animals or "insects." ${ }^{34}$ The Vianelli paper was translated and appeared in the Universal Magazine for December, 1751. V. Donati mentioned these scolopendres in his Histoire Naturelles de la Mer Adriatic (1750) and A. D. Fougeroux de Bondaroy saw them at Venice in 1767. He noted the bluish light, and that the "insect" would luminesce until it dried. However, Fougeroux de Bondaroy was not convinced that all phosphorescence of the sea was due to living organisms but inclined to believe that several causes, electric fire and particularly phosphoric material from decomposition of animal and plant substance, might be involved.

New descriptions of marine annelids from other regions soon appeared. C. F. Adler, a Swedish physician who journeyed to China, figured a luminous worm (see figure 38 ) in his dissertation, $D e$ Noctiluca Marina (1752), carried out under the direction of Linnaeus, and Henry Baker in Employment for the Microscope (1753) devoted one chapter to "Luminous Water Insects." He received a description of sparks of light found in oyster shells and a drawing from "a Friend whom I can depend on," who " after many Examinations became perfectly convinced, that these shining Sparks are lucid Emanations from a minute Insect, differing in its general Form but little from the common Scolopendra." The figure shows a worm, probably a syllid, about $1 / 8$ inch long and $1 / 100$ inch wide. "This little Insect can emit or conceal its Light: and sometimes its Lustre

\footnotetext{
34 Father Torrubia made observations about the same time as those of Vianelli, Griselini, and the Abbé Nollet but in another part of the world. In his Asparato para la historia natural española (1754) there is an account of "phosphoros marinos" observed near Jucatan. The sea was greenish by day and very luminous at night, owing to a small marine Scolopendra with ten feet on each side. Father Torrubia attributed the luminescence on sea turtles (Xicoteas), which the Spaniards ate, and also the light of rotten wood to these "insects."
} 
is so bright as to be discoverable even in open Daylight, especially on being touched or disturbed."

According to Panceri (1875), luminous worms were seen by Pehr Osbeck (1757) on a trip to China in 1750-1753 and Job Baster in 1757 published a careful drawing of several varieties. In the tenth edition of Linnaeus' Systema Naturae (1758), Nereis noctiluca (the Noctiluca marina of Adler) is mentioned, as well as the "Scolopendre marine luisante" of Grisellini and the "Lucioletta dell'aqua marina " of Vianelli. The discoveries continued, with Peter Forskal (1736-1768) in 1775 describing luminous worms called Nereis coerulea, N. pelagica, and N. viridis from the Kategat, Otto Fabricius (1744-1822) in 1780 with a luminous Nereis noctiluca from Greenland and Lazaro Spallanzani (1729-1799) with luminous marine worms at Portovenere near Genoa in 1784, which he described in a letter to Charles Bonnet (1720-1793). Domenico Viviani (1805) in Phosphorescentia Maris again described and figured a number of annelids from the seacoast near Genoa.

It is obvious that luminous annelids are widely distributed in various seas. Some eight families of polychaetes are now known to produce light. Of great interest are the transparent, pelagic forms of the genus Tomopteris, not known to be luminous until R. Greeff's observations in 1882. The lighting ability of terebellid worms was recognized by Adolf Grube (1812-1880) in 1861.

Luminescence of the genus Chaetopeterus, living throughout life in an opaque parchment tube, buried in the mud, yet brightly luminescent from a slime secreted over most of the external surface, appears to have been first seen by F. Will at Trieste in 1844. Chaetopterus is also of note as the first luminous marine form, whose spectrum was observed, by E. Ray Lankester in 1868 .

The physiology and histology of a number of marine annelids has been studied by A. de Quatrefages (1843), by P. Panceri (1878), by W. A. Haswell (1882), and Et. Jourdan (1885), pioneers in the investigation of luminescence in this group. Quatrefages, of Noctiluca fame, began his luminescence work with polynoid worms and ophiurians in 1843, and it was these animals which led him to announce the connection between luminescence and contractility. In fact, he thought that the light of the polynoid worm actually came from the muscles, while Panceri (1878) regarded nerves as the source of the light. Both mistakes were rectified by Jourdan in 1885 .

\section{The Piddock or Dail (Pholas dactylus)}

The publicity which Pliny gave to the ungues or finger nails, the shellfish which "shine as if with fire in dark places, even in the 
mouths of persons eating them " and the mention of their luminescence by naturalists of the sixteenth century, Wotton, Belon, Rondelet, Boussuet, Aldrovandi, Gesner, and Olaus Magnus, early served to direct attention to these remarkable boring molluscs. They were called dactyli (fingers), solenes ${ }^{35}$ (pipes), balani (dates) or pholades (lurking in holes) in Latin. ${ }^{36}$ Despite a life within a shell in a hole in the rock or hard mud, the animal nevertheless produces an abundant luminous secretion whenever disturbed (see fig. 2).

During the seventeenth century the luminescence of Pholas was mentioned by Jonston, ${ }^{37}$ Zucchi, ${ }^{38}$ Kircher, ${ }^{39}$ Schott, ${ }^{40}$ Bounanni, ${ }^{41}$ and other writers. The light-emitting ability was doubted by Bartholin, as he never happened to have seen the animal alive; and considered Pliny's account a phantasy. Nevertheless, Bartholin referred to Olaus Magnus and Kircher's statements and quoted a poem of Lippius ${ }^{42}$ speaking of the luminescence.

The dactylus illuminates with beaming light the sea

When he is put on the table, the table glitters with light.

For some reason pholads never came to the attention of Boyle and his companions in the Royal Society, despite the abundance of the piddock along the English coast, and Martin Lister (ca. 1638-1711), the great English conchologist, did not stress the luminescence. ${ }^{43}$

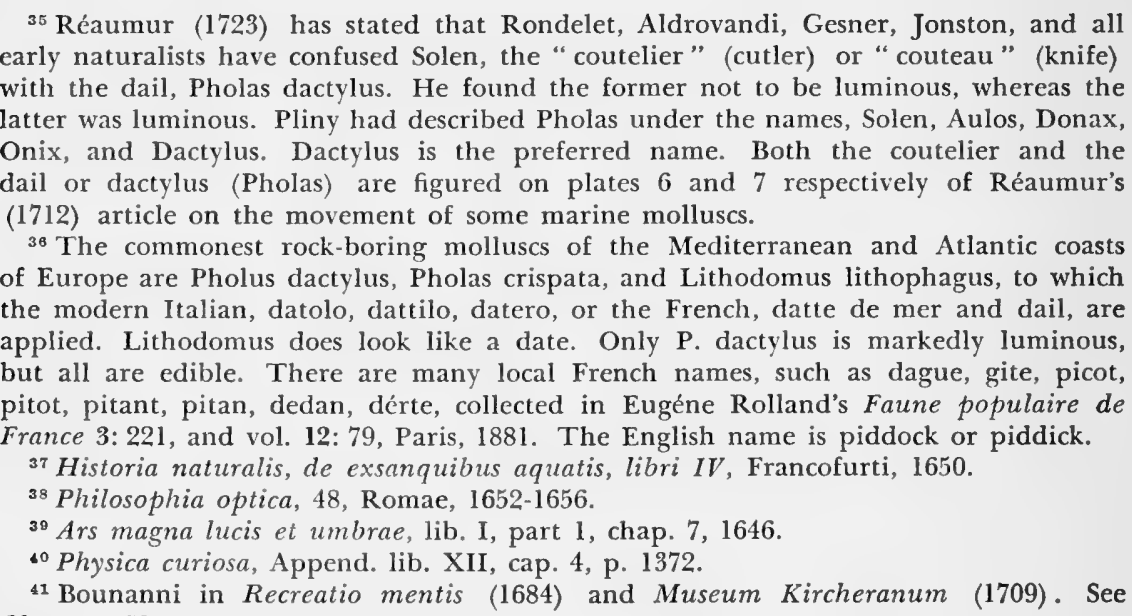
Chapter IV.

42 Translated by Mrs. Annemarie Holborn. The author is probably Lorenzo Lippi (1606-1664), artist and poet.

${ }^{43}$ Sir Robert Sibbald (died 1712) published an excellent figure of Pholas in his Scotia illustrata (1684), on the natural history of Scotland, without mentioning the luminescence of the animal. 
One of the earliest attempts to preserve the light of Pholas was made by Balthasar de Monconnys, the physician of Lyons, who traveled widely through southern Europe. In his Journal des Voyages (Part II: 434), published at Lyon in 1665, he described how a transparent liquid from the "ballari " or " dattes de mer," which he obtained near Ancona in May 1664, would remain luminous the next day, having been prepared the night before, but when the liquid was distilled, the light disappeared. No doubt the experi. ment reflected the goal of many philosophers-a persistent luminous material. This goal seemed to have been realized by the discovery in 1669 of the element phosphorus, the "phosphorus mirabilis" of Krafft.

With the new interest in experimental science in the early eighteenth century, it is not surprising that attention should again be directed to methods of preserving the luminous secretion of Pholas. The mollusc was the subject of a monograph in the Mémoires of the French Academy by Réaumur (1683-1757) in 1723, "Des Merveilles des Dails ou de la Lumière qui ils Repandent," and several communications appeared as a result of work in 1724 from an Italian group of investigators, Beccari, Monti, and Galeati (1747) working at the Bologna Academy of Science.

Réaumur's title is a translation of Pliny's De Dactylis, Eorumque Miraculis. He noticed that the fresher the Pholas, the more light it produced, whereas other "fish" became more luminous the longer they were kept, a reflection of the growth of luminous bacteria on the dead animal. He was the first to observe that by drying the luminous parts of an animal, in this case Pholas, and then moistening with fresh water or sea water, the light would be restored. If dried six days, light still appeared on moistening but was much weaker. Brandy (eau de vie) immediately extinguished the light of Pholas. Salt preserved it for some time, but his attempts to prepare a permanent lighting liquid, a durable phosphor, failed.

Nevertheless, Réaumur called Pholas a true natural phosphor. He reasoned that the light was connected with a kind of fermentation, which might vary from time to time since even fresh caught specimens of Pholas did not always luminesce, and he compared the light of Pholas to that of the glowworm. When this animal mates it is characterized by a particular kind of fermentation and " it is probable that the light which spreads from the vers luisant owes part of its vivacity to this fermentation." Réaumur's (1712) plate of Pholas (dail) is reproduced as figure 49.

The work of Beccari, Monti, and Galeati started when Count Marsigli brought some specimens of living Pholas in the rock where 
they lived to Bologna in 1724. Unlike Réaumur, they had better luck in preserving the light. Priestley (1772: 567-569) has given the account: ${ }^{\mathbf{4 4}}$

Beccarius observed that, though this fish ceased to shine when it became putrid, yet that, in its most putrid state, it would shine, and make the water in which it was immersed luminous, when they were agitated. Galeatius and Montius found that wine or vinegar extinguished this light, that in common oil it continued some days, but in rectified spirit of wine, or urine, hardly a minute. . . .

Of all the liquors to which he put the pholades, milk was rendered the most luminous. A single pholas made seven ounces of milk so luminous, that the faces of persons might be distinguished by it, and it looked as if it was transparent.

Air appeared to be necessary to this light; for when Beccarius put the luminous milk into glass tubes, no agitation would make it shine, unless bubbles of air were mixed with it. Also Montius and Galeatius found that, in an exhausted receiver, the pholas lost its light, but the water was sometimes made more luminous; which they ascribed to the rising of bubbles of air through it.

Beccarius, as well as Réaumur, had many schemes to render the light of these pholades permanent. For this purpose he kneaded the juice into a kind of paste, with flour, and found that it would give light when it was immersed in warm water; but it answered best to preserve the fish in honey. In any other method of preservation the property of becoming luminous would not continue longer than six months, but in honey it had lasted above a year; and then it would, when plunged in warm water, give as much light as ever it had done.

The Italians and the French have always been most impressed by Pholas and its light. Fougeroux de Bondaroy published a memoir on the "datte" in 1768, with a fine drawing of the appearance in rock. J. Barbut (1783) also mentioned the light in his Genera Vermiorum (1783). An excellent dissection of the animal itself, showing for the first time all five luminous regions was published by Josepho Xaverio Poli in 1791.

Modern study of the luminescence began in 1872 with Paolo Panceri, whose work on histology led him to discover the granules connected with light emission. Pholas bears a special claim to fame as the animal used by Raphael Dubois in many biochemical expertments. In 1887 he introduced the terms "luciférine" and "luciférase" for the substances involved in light production and pub-

${ }^{44}$ The article in the Commen. Acad. Bonon., "De luce dactylorum," 2 (1): 248-273, 1745 , was not signed. It was a joint work of a number of the Academicians, chiefly Beccari, Monti, and Galeati. It has been fully described in French in Follection Académique Etranger 10: 127-150, 1773. 
lished a large monograph dealing with all aspects of light production in Pholas dactylus in 1892. In the same year a histological study of Pholas also appeared in German by B. Rawitz (1892), from the University of Berlin.

It is interesting to note that Dubois was quite up to date in his use of the word "luciferase." Although W. Kuhne had suggested that unorganized ferments like ptyalin and pepsin be called "enzymes" in 1878, it was not until 1883 that Emile Duclaux introduced the termination "ase" added to the substrate on which the enzyme acted to designate the enzyme itself. Four years later Dubois was using luciferase in connection with luciferin.

\section{Nudibranchs}

According to Ehrenberg (1834: 498), F. S. Leuckart (1794-1843) in 1827 saw both Aplysia and Doris luminesce, but the animals were dead and the light probably due to luminous bacteria. A second statement may refer to nudibranchs but the reference is uncertain. The Reverend Wm. Kirby, co-author with Wm. Spence of the famous Introduction to Entomology (1817), wrote another book in 1835, The Creation of Animals and Their History, Habits and Instincts. In this book Kirby mentioned violet snails (Ianthina ${ }^{45}$ of Bosc) which float at the surface of the sea and color the water with a blue fluid when disturbed and "are vividly phosphoric at night."

R. T. Lowe (1842) found a nudibranch called Peplidia (now Plocamopherus) at Madeira, and studied the method of movement and the luminescence for some days. He wrote, "At night, especially when thus in motion, it appeared most brilliantly phosphorescent; the light flashing progressively but very rapidly along the body, especially from all the branchial tufts and the edges of the veil and crest." Another record is of a luminous Tethys fimbria, seen by A. E. Grube (1812-1880) along the Dalmation coast in 1861.

The most famous luminous nudibranch, Phillirhoë bucephala, has been known since 1807. It was named by François Péron, but no one noticed the luminescence until 1873 when Paolo Panceri's monograph appeared. He wrote:

... if the water in which they are found be agitated, or if they are touched, flashes of light will be seen to come from their body; and if, for the purpose of provoking the complete illumination of the phosphorescent elements of the Phyllirrhoë, one stimulates it with a drop of

\footnotetext{
${ }^{45}$ The Ianthinidae float at the surface of tropic seas and expel a violet secretion when disturbed, which might appear like a phosphorescence.
} 
ammonia, the surface of the body and of the gigantic tentacles shine immediately with a brilliant azure light. The upper and lower edge of the body are the parts where the light is most bright and abundant, so much so that the outline of the animal can be perfectly seen. The light is not communicated to liquids or solids put in contact with it, as happens in many other luminous animals.

With a microscope Panceri noted that "the light escapes from myriads of shining points which are more or less large and brilliant and more abundant at the upper and lower edges of the animal."

\section{Squid and Octopi}

With the exception of Aristotle's mention of luminous squid (see Chapter I), one of the oldest records of a luminous cephalopod is that of a polypus or octopus described by Oliger Jacobaeus or Jacobi (1650-1701), the distinguished physician and philosopher, professor of medicine and natural philosophy in the University of Copenhagen. He wrote in the Acta Medica et Philosophia Hafnensia for 1696 that on opening the animal " it was so luminous as to startle several persons who saw it; and he says that the more putrid the fish was, the more luminous it grew. The nails also, and the fingers of the person who touched it became luminous; and the black liquor which issued from the animal, and which is its bile shown also; but with a very faint light." ${ }^{46}$ From the description, a growth of saprophytic luminous bacteria on the dead octopus may safely be designated as the source of the light.

Many living squid are now known to have parasitic or symbiotic bacteria associated with them. The light of these forms must have been seen by many but descriptions are quite recent. Linnaeus does not mention light from Sepia. W. T. Meyer (1906) investigated the light in Sepiola, an allied species at Naples, but it was not until 1918 that U. Pierantoni pointed out the bacterial origin and held that the bacteria of squid must be regarded as symbiotic.

Many deep sea squid have lantern-like luminous organs on various regions of the body. These peculiar skin structures had been observed at the beginning of the nineteenth century but the first knowledge of their luminosity appears to have come from observations of Jean Baptiste Verany on a large specimen of Histioteuthis Bonelliana (see fig. 50) caught at Nice, France, in 1834. The account of the animal is given in his Mollusques Méditerranéens (1851). He stated that the squid did not live long although placed in a great bucket of sea water. Nevertheless, "during the night the 
opaline spots projected a phosphorescent splendor, making this mollusc one of the most brilliant products of nature. . . . It probably lives at great depths."

Knowledge of the large number of deep-sea luminous squid came as a result of the great exploring expeditions, pioneered by that of the Challenger in 1873-1876, and followed by others of every nationality.

The first histological studies of squid were made on Histioteuthis Ruppeli by L. Joubin in 1893-1894, to be followed by many others in the next century.

\section{Crustacea}

\section{OSTRACODS}

Allied to the Copepods but considerably larger and a striking sight to the unaided eye at night, ostracod luminescence was noticed as early as 1754 by Godeheu de Riville (1760) off the Malabar coast of India and the Maldives. At nine o'clock in the evening on the fourteenth of July, 1754 (the fall of the Bastille did not take place until 1789), he saw to his great surprise that the sea "was covered over with small stars; every wave which broke about us dispersed a most vivid light, in complexion like that of a silver tissue electrified in the dark. ..." 47

Riville noticed that the light specks stuck to the rudder, and on collecting sea water and filtering it through a handkerchief, the brilliant points stuck to the handkerchief. With the magnifying glass a sensible motion was perceived, and Riville observed,

notwithstanding the light of two candles, we saw issuing from its body a blueish and luminous liquor, the glare of which extended to the distance of two or three lines into the water. I took it upon the point of the tongs, and it was no sooner placed under the microscope than it yielded again a considerable quantity of the same azure liquor; notwithstanding I had the satisfaction of seeing it still full of life, and moving with much vivacity.

Riville's drawing, reproduced as figure 46 , leaves no doubt of the fact that his luminous speck was an ostracod, one of the marine forms characterized by the abundant luminous secretion poured from large gland cells near the mouth, whenever they are irritated.

Such a striking behavior was noticed by many other explorers of the sea during the nineteenth century. Histological studies were

${ }^{47}$ From the translation in the Gentleman's Magazine 38:408, 1768. The Riville account appeared in the Mémoirs of the French Academy of Sciences for 1760. 
made by G. W. Müller (1891) and H. Watanabe (1897), but the extensive biochemical investigation of these forms did not begin until 1916, when the author pointed out the value of these organisms for such research (see E. N. Harvey, 1952).

\section{COPEPODS}

The discovery of luminescence in copepods begins with a misconception. One of the most striking of the group, Sapphirina, is a transparent floating form whose chitinous surface structure is such as to give colored interference patterns in daylight, an irridescence which was mistaken for luminosity by the earlier observers. Such is the interpretation by Meyen (1834) of a luminous animal called Oniscus fulgens by Johann Anderson (1674-1743) in 1746, although others believe that Anderson saw luminous shrimp. J. V. Thompson, in 1829, also called Sapphirina luminous but the opal-like play of colors disappears completely in total darkness.

W. Giesbrecht, to whom so much of copepod knowledge is due, believed that $O$. Fabricius in 1780 probably saw the modern genus, Metridia, common in Davis Straight, although the record is questionable. Fabricius described a Cyclops brevicornis, also figured by O. F. Müller. One of D. Viviani's (1805) figures looks like a copepod, and there can be no doubt but that W. Baird $(1830,1831$, 1843 ) in his articles on the "Luminousness of the Sea" saw luminous copepods called Cyclops. Many others have observed the light, although the animals are so small that they would be easily overlooked without a microscope. Important information on histology, and some chemical studies are to be found in Giesbrecht's (1895) great monograph on the pelagic copepods in the vicinity of Naples.

\section{AMPHIPODS}

In recent years some species of deep-sea amphipods have been reported as possessing luminous organs but the light has not been observed, and the luminosity awaits confirmation. Amphipods are chiefly famous for infection by parasitic luminous bacteria which multiply in the living animal, making it luminous for a short time, but eventually killing the host. The first record of such an infection was by Thulis and Bernard (1786) for the "Crevette," identified by Etienne Louis Geoffroy (1800: 2: 667) as Cancer macrurus rufescens and by Ehrenberg (1834) as Cancer pulex. The common freshwater amphipod of Europe is Gammarus pulex.

The report of Thulis and Bernard was published in the Journal de Physique, again indicating the interest of contemporary physicists, 
as well as biologists, in anything luminous. The animals were observed one night in June at the border of a "ruiffeau " of the river passing through Trans in Southern France. They saw little luminous bodies which they thought were glowworms and only on catching them did their true nature as crevettes appear. Although some were completely luminous, others were not. In an attempt to rationalize these isolated cases of luminescence Thulis and Bernard recalled that the glowworm is brighter at the time of mating and that sea light is believed to be due to eggs and emanations of living things. They wrote: "far from indicating a feeble state, the light [of the crevettes] manifests that vigor necessary to fulfill sexual desire [vou de la nature], the more evident because nature has given them a double organ to reproduce themselves."

The first case of luminous marine amphipods appears to have been observed by D. Viviani (1772-1840). In his "Phosphorescentia maris" (1805), six species of Genoese crustaceans called Gammarus, undoubtedly amphipods, are figured. Tilesius (1819) also lists amphipods as luminous. However, the first indication that the light of these forms, particularly the sand fleas or beach fleas of the genera Orchestia and Talitrus, is bacterial in origin, comes from the observations of Alfred Giard $(1889,1890)$ and A. Giard and A. Billet (1890). These men isolated the luminous bacteria in pure culture and thus introduced the idea of bacterial infection as a cause of light, now recognized for a number of animal forms-marine, freshwater and terrestrial.

\section{SHRIMP}

The assessment of early records of luminescence among shrimp, prawns, lobsters, and crabs is difficult, because in so many cases the light undoubtedly came from luminous bacteria, as in the case of Boyle's (1681) statement that "of all fishy substances the eggs of lobsters which have been boiled shown the brightest." A similar explanation must be given for the light of the river lobsters of Leo Allatius (1586-1669) previously described, which looked like burning sulphur. They were discussed by the great student of crustacea, Philipp Jacob Sachs von Lewenhaimb (1627-1672), in his Gammarologia, ${ }^{48}$ with the conclusion that the light would be more likely to appear brighter in seacrabs than in river crabs.

Crabs and lobsters are not known to be self-luminous. The first observations of true shrimp luminescence is hard to place. These animals, shrimp or prawns, may belong to either of three orders

\footnotetext{
${ }^{48}$ Sachs, Gammarorum, vulgo cancrorum, Cap. XI, sec. 6, p. 212, Frankoforti et Lipsiae, 1665.
} 
of crustacea, the decapods, the schizopods or euphausids, and the mysids. The animals usually occur in great schools at medium depths and frequently migrate to the surface at night. The old names, Cancer, Gammarus, and Oniscus were applied to these shrimp-like crustacea and it is possible that the Oniscus fulgens of $\mathrm{J}$. Anderson (1746), observed during his trip to Iceland and Greenland, was a schizopod rather than the copepod, Sapphirina, as Meyen (1834) believed. Before Macartney's paper on luminous animals appeared in 1810, he was given permission to inspect the journal of Sir Joseph Banks, kept during his trip with Captain Cook in 1768-1771, and to copy some of the original drawings of luminous animals. One of these is the Cancer fulgens, apparently a schizopod, reproduced in figure 47 .

Tilesius (1819) also figured shrimp-like luminous animals. It is quite certain that the luminous crustaceans mentioned by $\mathrm{J}$. V. Thompson (1829) as Cynthia, Noctiluca, Lucifer, and Podopsis, and the one figured by W. Baird (1831, were mysids or euphausids. Later, many marine collecting expeditions saw luminous shrimp, and during the U. S. Exploring Expedition of 1838-1842, J. D. Dana (1852) described both luminous schizopods (Euphausia splendens) and luminous decapods (Regulus lucidus).

Many of the luminous shrimp possess definite light organs, first called "luminous globules" by G. O. Sars (1837-1927) in 1885 . They contain a lens and structures somewhat similar to the eye, hence were called accessory eyes by Carl Claus (1835-1899) in 1863. The first important histological study was by R. Vallentin and J. T. Cunningham in 1888, followed by a number of other papers by various writers.

In contrast to shrimp possessing luminous dots or photophores, the most interesting of the decapods are the species living in the deep sea and having the ability to produce great masses of luminous secretion with which they surround themselves whenever disturbed. These forms were first caught by A. W. Alcock and described in his book A Naturalist in Indian Seas (1902).

Sometimes shrimp become infected with luminous bacteria. The most remarkable case of this kind, because living infected animals can be regularly obtained, has been described by Y. Yasaki (1927), who demonstrated the presence of the bacterial organisms and grew them in pure culture. Knowledge of the shrimp, a species of Xiphocarida, living in Lake Suwa, Japan, comes from a Mr. Ushiyama who first noticed them in 1914. 

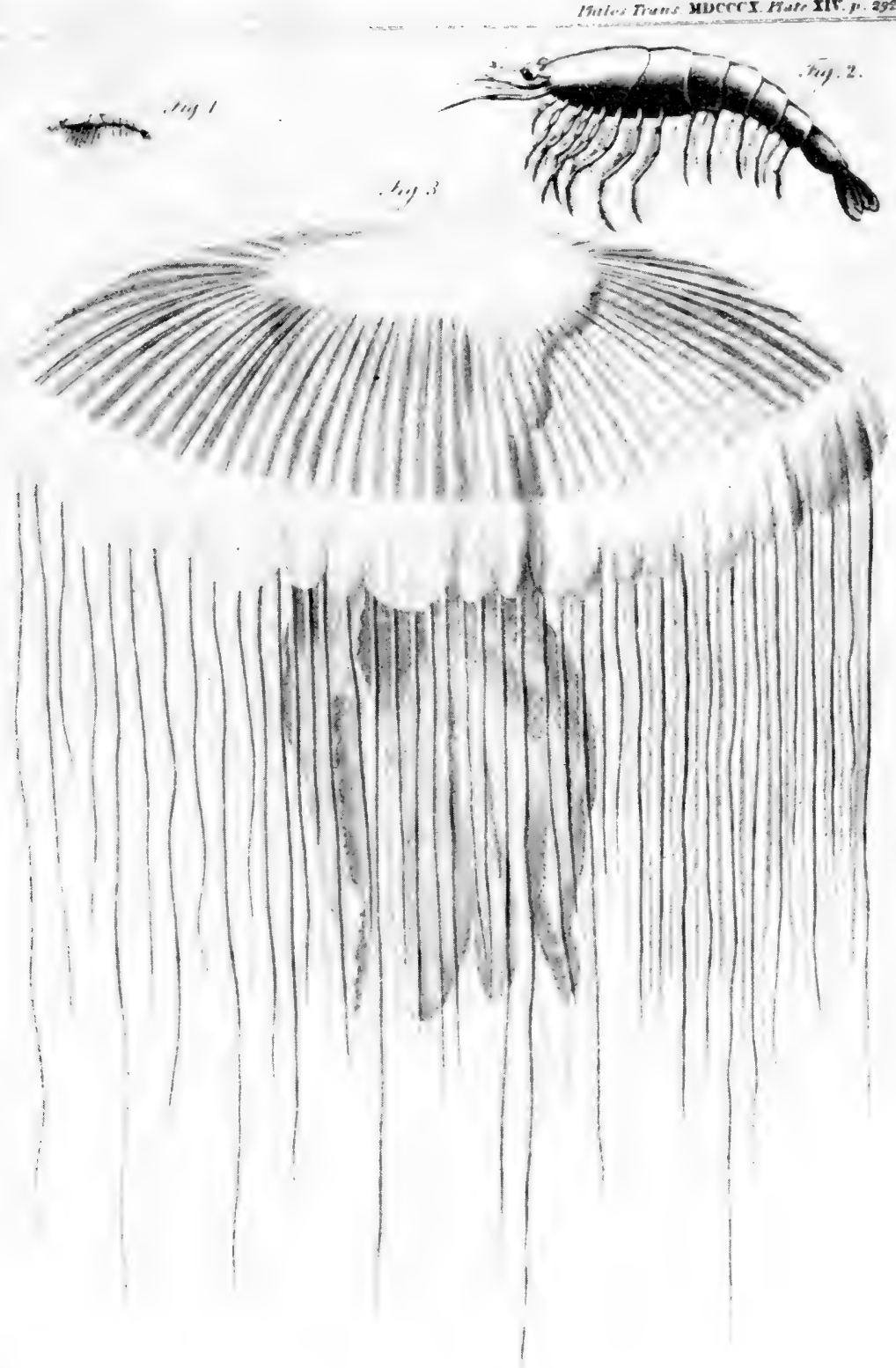

Fig. 47. The figure of a luminous jellyfish (Medusa pellucens) and two luminous shrimp (Cancer fulgens) described by James Macartney in his paper. "Observations on Luminous Animals" in the Phil. Trans. for 1810. Macarmey had the advantage of Sir Joseph Banks notes on sea light in preparing his paper. Sir Joseph was elected a member of the American Philosophical society in 1787. 


\section{皮}

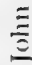

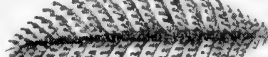

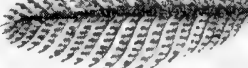

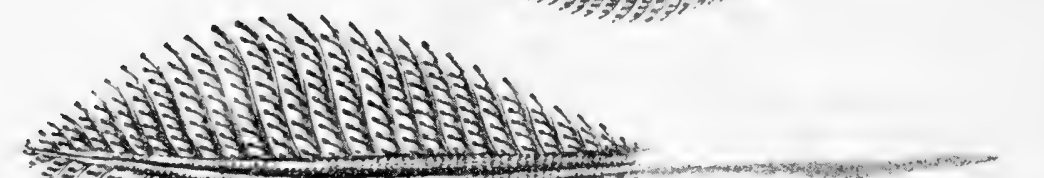

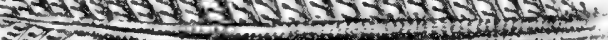

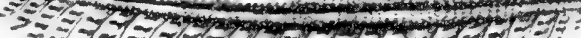

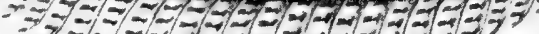

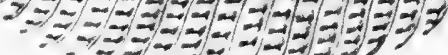

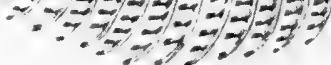

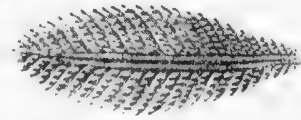

플

三

$\Xi$

ह

ఏ

$\tilde{\Xi} \cong$

$\stackrel{\Xi}{\Xi}$

$\Xi$
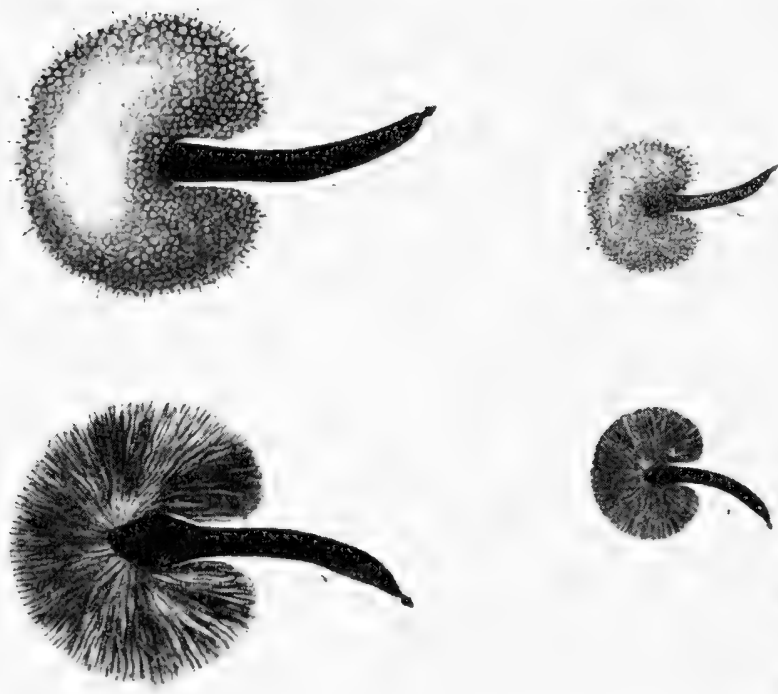

$\Xi$

$\therefore \equiv$

$\cong$ 


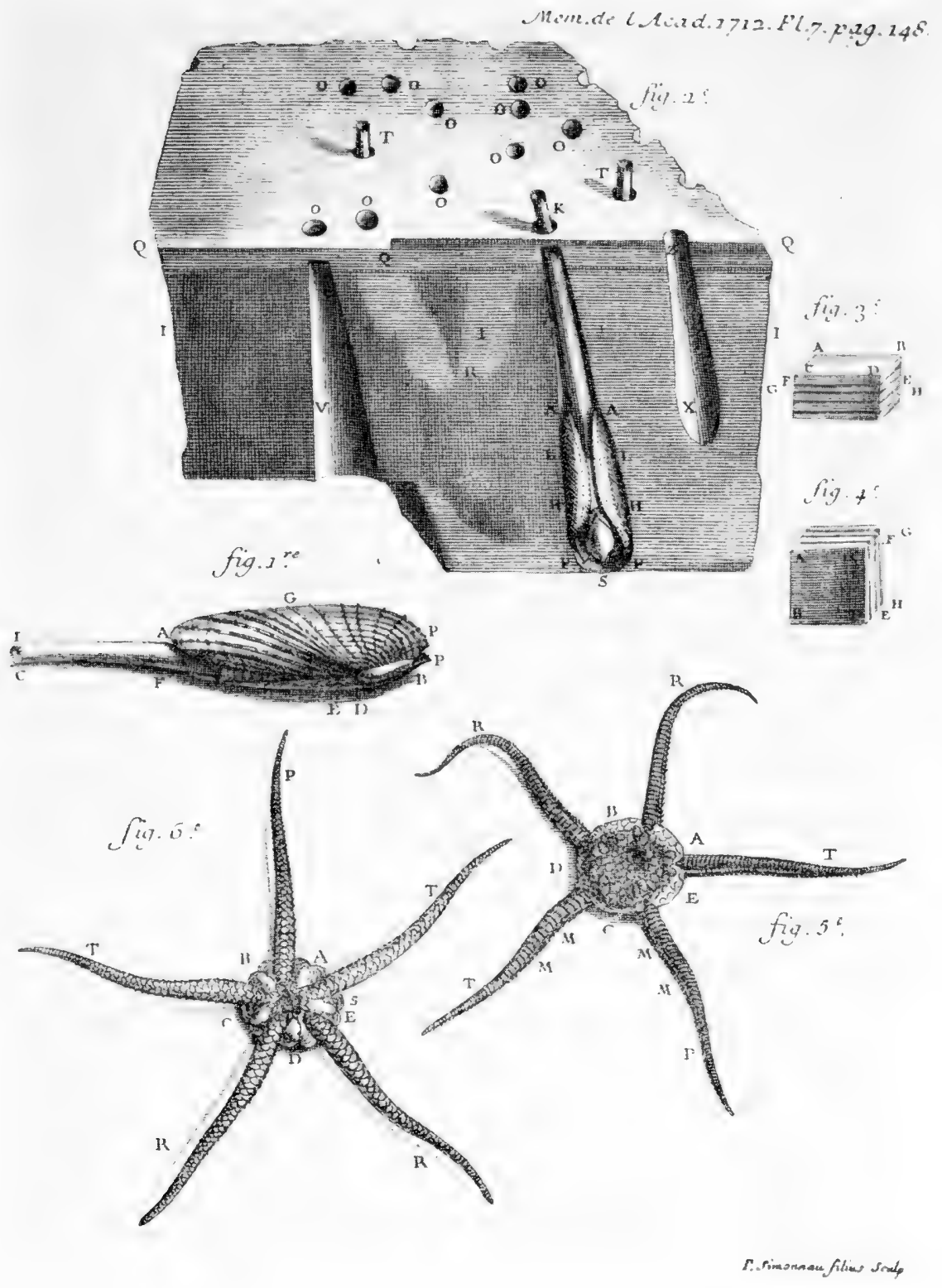

Fig, 49. The plate of Réamur (1712) showing the "dail," the luminous mollusc (Pholas dactylus), which lises in holes in the rock (aborc), and two liews of a brittle star or snake star, many of which are luminous (below). Réamm s classic paper, "Des Merreilles des Dails ou de la Lumiere quils Repandent," was published in 1723, also in the Mcmoires of the French Academs. In the late nineteenth centurs luminescence in this form was intensively studied by Raphacl Dubois. 


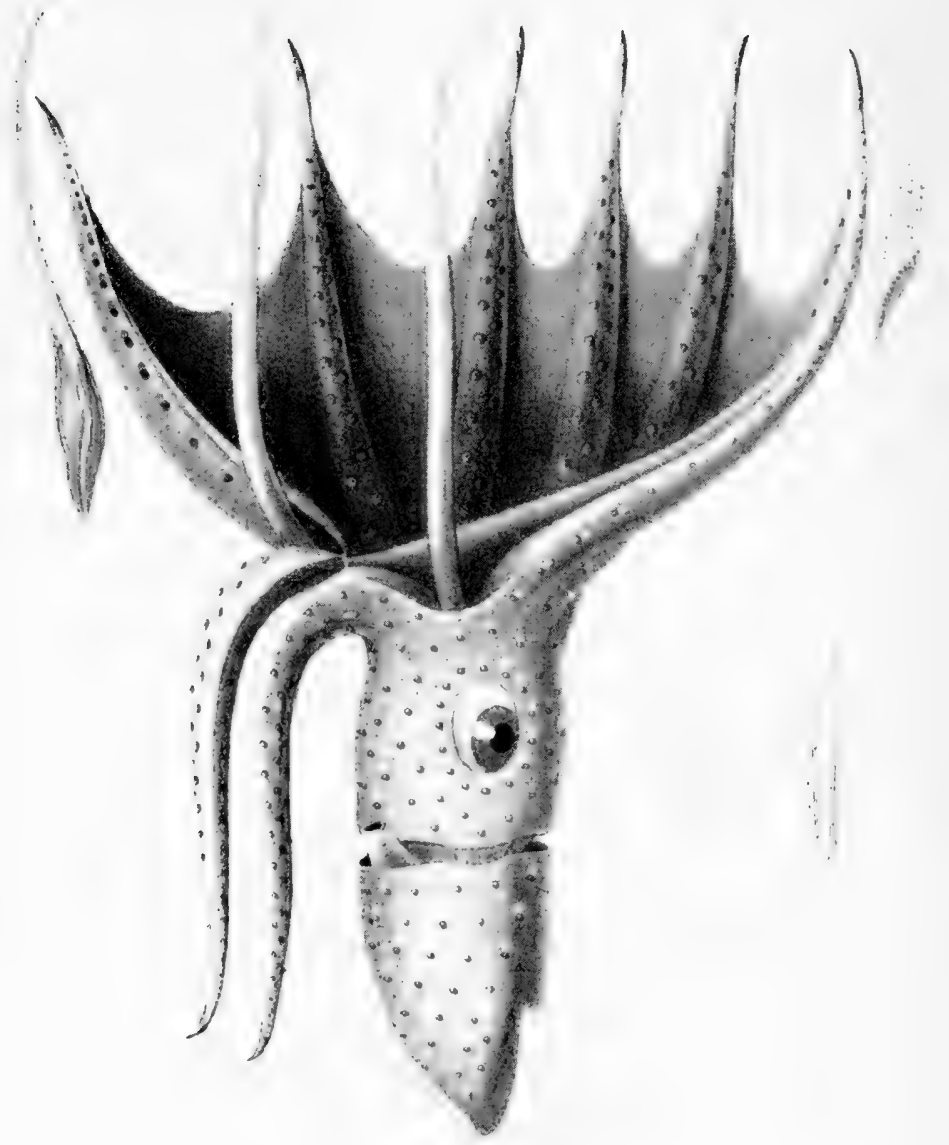

Fig. 50. The first drawing of a deep sea Juminous squid. Histioteuthis Bonelliana, from J. B. Verany's book, Mollusques Méditeraméns (Gènes, 185i). Note the large lantern-like luminous spots on body and arms. 


\section{Brittle Stars or Snake Stars}

It is possible that Michael Adanson, during $A$ Voyage to Senegal, the Isle of Goree and the River Gambia ${ }^{49}$ in 1749-1753, saw luminous brittle stars. He kept fish alive in pails of sea water and saw a pilchard, mole-bat, purple-fish, periwinkle, polypus, crab and starfish " by rays of light which darted from every part of their bodies." This description sounds as if the light might have been due to micro-organisms in the water, providing the "star-fish" were actually alive and not infected with luminous bacteria. The common forms of true starfish are not luminescent, but one species, Brisingia endecacnemos, dredged by P. C. Asbjörnsen in 1856, has been reported as luminous, an observation not yet verified.

In $1805 \mathrm{D}$. Viviani published a figure of luminous Asterias noctiluca, which Panceri (1875) identified as a well known brittle-star, Amphiura squamata, and since that time the light of brittle stars has been observed by many naturalists, Péron (1807) Tilesius (1818) and others. Two excellent views (at left, lower; at right, upper side) of a brittle star are shown in Réaumur's plate, figure 49.

In $1843 \mathrm{~A}$. de Quatrefages published his memoir on luminous annelids and ophiurians, in which he came to the conclusion that the " motor muscles of the feet are the exclusive source of the light," which he said appeared in a completely closed cavity in a liquid and that luminescence coincided with contraction and disappeared when contraction has ceased. The luminous strips above mentioned ran parallel to muscle fibers and the light process was quite "independent of all secretion properly so called."

Panceri (1878) described the luminescence of Amphiura squamata, common in the Gulf of Naples, in a one-page appendix to his monograph, La Luce e Gli Organi Luminosi di Alcuni Annelidi. His figures indicate that only the arms are luminous, the light coming from two oval luminous dots on each segment, near the points where the tube feet arise. When stimulated, the ophiurans gave repeated flashes of light and then scurried quickly away without lighting. Consequently Panceri was inclined to doubt the validity of Quatrefages' alleged parallelism between muscle contraction and luminescence, especially as Péron had described an Ophiura phosphorea from the island of Bernier, which luminesced not only on the arms but also on the disc where there were no muscles. Panceri hoped to observe young ophiurians, whose tissues would not be so opaque, but his untimely death in 1877 put an end to his

${ }^{40}$ The English translation, London, 1759, p. 183, of Histoire naturelle du Sénégal, Paris, 1757. 
luminescence work. Later histological and physiological studies came in the next century.

\section{Pyrosoma and Salpa}

Pyrosoma, the fire cylinder or fire body, a colony of small tunicate animals, was named by Francis Péron (1775-1810), one of the naturalists on the Baudin expedition to Australia and New Zealand in 1800-1804. His memoir (1804) particularly stressed the brilliance of the various luminescent colors exhibited, "le rouge, l'aurore, l'orange, le verdatre, et le blue d'azur." Jean Bory de St. Vincent (1780-1846), describing his finds on a trip to the four islands of the African sea, called the fire cylinder Monophora noctiluca in 1804, and all explorers and observers (H. Kuhl, 1822; F. D. Bennett, 1833; F. J. F. Meyen, 1834) since that time have exclaimed at the beauty of the light at night. Thomas Huxley (1825-1895) during the voyage of the "Rattlesnake" in the Atlantic on June 15, 1850, wrote,

[The ship] drifted, hour after hour through this shoal of miniature pillars of fire gleaming out of a dark sea, with an ever-waning everbrightening, soft bluish light, as far as the eye could reach on every side... . The light commenced in one spot, apparently on the body of one of the "zooid's," and gradually spread from this as a center in all directions; then the whole was lighted up; it remained brilliant for a few seconds, and then gradually faded and died away until the whole mass was dark again.

H. N. Moseley, speaking of the light of the sea in his book, Notes of a Naturalist on the Challenger (1879) wrote:

A giant Pyrosoma was caught by us in the deep-sea trawl. It was like a great sac, with its walls of jelly about an inch in thickness. It was four feet in length, and ten inches in diameter. When a Pyrosoma is stimulated by having its surface touched, the phosphorescent light breaks out at first at the spot stimulated, and then spreads over the surface of the colony as the stimulus is transmitted to the surrounding animals. I wrote my name with my finger on the surface of the giant Pyrosoma, as it lay on deck in a tub at night, and my name came out in a few seconds in letters of fire.

It is possible that observation of luminous Salpae goes back to Aelian (A. D. 3), who mentioned a flickering light coming from a sea growth, which A. Steuer ${ }^{50}$ believed might be the luminescence of Salpa africana maxima which he observed as great chains in the

${ }^{50}$ A. Steuer, Leitfaden der Planktonkunde (1911: 1). 
Mediterranean. In more modern times the luminous organs of Salpa were certainly seen by Peter Forskål, friend of Linnaeus, who first accurately described Salpae in 1775 and proposed the generic name. Forskål did not know that certain clumps of cells in the animal were luminous, and their function has given rise to much speculation, being regarded as ovaries or renal organs. According to Ehrenberg (1834), A. Chamisso (1781-1839) saw luminous Salpae in 1819, while S. Delle Chiaje (1828) declared them non-luminous. However, W. Baird (1831), in his article " On the Luminousness of the Sea," recorded a Salpa as emitting light and his figures depict what were evidently Salpae. All animals retained their "luminous property for upwards of 12 hours after they were placed in a tumbler of clear salt water."

F. D. Bennett (1837) and many naturalists since then have spoken of the luminescence of Salpa while E. H. Giglioni (1870) saw the light of Doliolium and Appendicularia, on a voyage around the world in 1865-1868. As with so many other luminous animals, P. Panceri $(1872,1873)$ gave the first detailed account of the light organs, with a number of physiological and biochemical observations, while P. Secchi (1872) reported on the spectrum of the light. Elucidation of the complicated life history of the luminous cells during embryonic development, with the possibility that they might contain symbiotic luminous bacteria was an accomplishment of the next century.

\section{Miscellaneous Marine Organisms}

Among several additional groups of the animal kingdom, reports of luminous forms have appeared from time to time. Some of these may be due to ingestion of luminous food, for example the rotifer seen by G. A. Michaelis (1830) and called a Vorticella. It was later described by Ehrenberg (1834) as Synchaeta baltica, but Ehrenberg was unable to observe the luminescence.

A luminous flatworm, Planaria retusa, was described and figured by Viviani (1805), but the identification is questionable and the luminosity of this form and other luminous flatworms has not been verified.

Among arrowworms or Sagittae, two reports of luminosity exist, one by E. H. Giglioni (1870) and one by C. Khvorostansky (1892), but nothing is known of the light organ.

Sponges have for many years been regarded as in the doubtful category, as far as luminescence is concerned. Most of the reports have turned out to be luminescence of organisms living on the sponge. However, the author in 1921, found a Grantia-like sponge 
at Friday Harbor, Washington, which presented all the characteristics of self-luminosity.

Pteropod molluscs were called luminous by W. Baird (1831), F. D. Bennett (1837), and Giglioni (1870), and heteropod molluscs by $W$. Keferstein, ${ }^{51}$ but the observations have not been confirmed.

Two additional phyla of marine animals contain undoubted luminous species, the Enteropneusta and the Nemertea. Although the phyla have been recognized for many years, discovery of luminosity is recent. The luminescence of Balanoglossus minutus, one of the Enteropneusta was first noted by Panceri (1875) at Naples and the light of the nemertean, Emplectonema Kandai, by S. Kanda (1939) in Aomori Bay, Japan, in 1936.

A luminous bryozoan, Acanthodesia serrata, has been described in 1950 by K. Kato, but several earlier reports (e. g., Landsborough, 1842) of luminosity are dubious.

\section{Living Fish}

Early records of fish luminescence suffer from the doubt that the light may have come from the dead animal and be due to luminous bacteria or, if the fish was living, result from small luminous organisms in the sea water, stimulated by the moving fish and outlining its body in fire. Although the ancients spoke of a "Lucerna piscis " or lantern fish, and many records of luminous dead fish exist, true fish luminescence reports are mostly from the nineteenth century. The question is still unsettled as to whether Marcgrave's (1642) luminous fish, "jurucapeba" contained symbiotic luminous bacteria or not (see Chapter XIV).

A. Risso's (1810: 53) statement concerning the "Chimère arctique," the Chimaera monstrosus of Linnaeus, whose " snout is filled with a soft viscous substance which oozes from numerous pores and emits a quantity of luminous rays during the night" probably refers to luminous bacteria. However, his paper of 1820 on "Scopèles observées dans la mer de Nice" showed the prominent skin structures which are the photophores of these fish. These skin structures were also known to A. Valenciennes (1794-1865), and in the Histoire Naturelles des Poissons (Paris, 1828-1849), a considerable number of deep sea fish are described (22, 1849), including "Le scopèle lumineux" which had a luminous organ near the eye.

In 1833 Anastasio Cocco (1799-1854) described deep sea fish from

${ }^{51}$ In Bronn's Klassen und Ordnung des Tierreichs (III-2), on Malacozoa (18621866), W. Keferstein wrote (p. 839) that "Heteropoda contribute to sea phosphorescence, and in Pterotracheates I have myself admired the beautiful bluish light which streams out at the slightest stimulation, especially from Nucleus." 
Messina and in 1838 used the expression "punti luminosi" or "lucidi" and "apparecchio lucido" for the skin structures. His figures show the photophores clearly and he worked in a region where the light of the living fish could have been observed. Nevertheless, the great histologist, Rudolf Albert Kölliker (1817-1905), thought the skin spots of deep sea fish were sense organs in 1853, while Rudolph Leuckart (1822-1898) in 1865 regarded them as accessory eyes (Nebenaugen). They were called modified eyes in a long paper by M. Ussow as late as 1879 .

In the meantime, F. D. Bennett (1840), during a whaling voyage around the world in 1833-1836, had described the glow from a living shark, kept in an aquarium for three hours, and Franchesco Orioli wrote De Pesci e del Mare che Rilucono Nella Oscurita in 1850. It is quite certain that J. T. Reinhardt (1854) saw the greenish luminescence of fish photophores of the genus, Astronestes, during a voyage to Brazil.

However, it was not until the deep sea expedition of the "Challenger" (1873-1876) that scientists generally realized how large the deep sea fish population is and how many of them are luminous. Discussion of the skin spots continued, and in 1879 Franz Leydig (1821-1905) designated the "Nebenaugen" of Chauliodus as probable luminous organs. In his book Die Augenahnlichen Organe der Fische (Bonn, 1881), he became convinced that their function is photogenic.

Since then the various deep sea expeditions have added enormously to the number of luminous species known to science and many observations of light from the "pearly spots" have confirmed their function as light emitting, not light detecting. C. Emery (1884) and $\mathbf{R}$. von Lendenfeld (1887) were pioneers in study of the histology of the light organs, followed by a host of workers at the turn of the century.

In recent times it has been discovered that a number of fishes are not self-luminous, but possess special organs in which symbiotic luminous bacteria are cultivated. These bacteria are always present and the light organ a permanent structure, often of complicated make-up, with reflectors and devices for shutting off the light. The first inkling of the presence of bacteria was contained in a short note of B. Osorio (1912) regarding the macrurid fish, Malacocephalus laevis, which when disturbed, secretes the luminous bacterial mass through a duct. The second observation was made by the author (Harvey, 1921) for the fishes, Anomalops and Photoblepharon of the Banda Islands, Indonesia. These forms possess a large permanent light organ containing luminous bacteria under the eye. The 
bacteria are not extruded but remain in place in elongate cells richly supplied with blood vessels. Although the fish have been known since the observations of Peter Boddaert in 1781, the first suggestion that the peculiar eye structure was luminous was made by A. Günther (1887), and the light was later observed by A. G. Vordermann in 1900, without knowing that bacteria were present.

\section{Summary}

It is apparent that the study of light production by animals and plants has been approached from many different points of view. The chemistry of light production, the physical nature of the light and more biological aspects, such as physiology, the structure and development of the luminous organ, the habits of the animal, and the purpose of luminescence have all received their share of attention. It would be satisfying if a clear-cut statement could be made that a certain worker first discovered this or that important fact concerning bioluminescence. Apart from the hazard confronting an historian, who may overlook some important paper, it is not always certain that one man alone made the discovery. A few firsts do stand out, and in this summary the attempt will be made to list some of the important steps in knowledge of light production by living things. Reference to twentieth-century papers will be found in E. N. Harvey (1952).

There is little doubt that Boyle (1668) in 1667, using his air pump, was the first to show the necessity of air for luminescence of wood (fungi) and dead fish (bacteria), although oxygen was not recognized at that time. A second demonstration is due to Beccari, Galeati, and Monti (1724) who observed that the light of a luminous liquid from the mollusc, Pholas, would disappear when evacuated with an air pump and also if kept in a stoppered bottle, unless bubbles of air were present. Spallanzani (1796) likewise demonstrated that the glowworm only lighted in air or oxygen, not in non-respirable gases. Bioluminescences which can appear in absence of dissolved oxygen, for example the jellyfish, Pelagia, were demonstrated by E. N. Harvey (1926), while the first use of a luminous organism (bacteria) to detect small amounts of oxygen was made by M. W. Beijerinck (1889), who was responsible for initiating (1889-1891) the many metabolic studies which have been made on luminous bacteria. He also studied their mutation (1889, 1900, 1912).

The discovery that luminous tissue can be dried and will give light on moistening must be attributed to Réaumur (1723) and to 
Beccari and collaborators (1724), using Pholas, perhaps confirmed by Spallanzani in 1788 with medusae, although it is doubtful if Spallanzani's jellyfish were thoroughly dried. Spallanzani (1796), Carradori (1798), and Macaire (1821) demonstrated that after the glowworm lantern is dried, light will again appear on moistening.

Although many had supposed that animal light might be due to the element phosphorus, or a compound of phosphorus, the first indication that some organic compound might emit the light came from Macaire (1821), who suggested an albumin-like material responsible for the glowworm light. He did not give it a name, an oversight remedied by later workers. Phipson (1872) thought in terms of a fat, called noctilucine, as responsible for the light of dead fish (luminous bacteria), and Dubois (1885, 1887) of a protein, luciferin, present in the beetle Pyrophorus and in the mollusc, Pholas. Luciferin was next discovered both in the firefly and in the ostracod crustacean, Cypridina, by E. N. Harvey (1916), who also demonstrated the reduction of the oxidized luciferin by any procedure which adds hydrogen to the compound (1918).

Although seventeenth-century scientists attributed the cause of many bioluminescences to "fermentation," this word had no specific meaning at that time. The first demonstration that an enzyme in the modern sense is involved in luminescence is due to R. Dubois $(1885,1887)$, who named the enzyme luciferase. The part played by adenosinetriphosphate and magnesium ions in firefly luminescence was discovered by W. D. McElroy (1947). That light-emitting materials are associated with granules while in the cell, appears to have been first recognized by Malpighi (1688) for the firefly and by Quatrefages (1850) for Noctiluca.

Physical study of a bioluminescence involving observation of its spectrum was made by Achard (1783), using luminous wood and a glass prism. Achard was rather surprised to find no colors and regarded the light as irrefrangible. Murray (1826) also examined the glowworm light and reported "that it seems monochromatic and incapable of further decomposition." These results were due to experimental difficulties, as both Lehmann (1862) and Schnauss (1862) observed red, yellow, and green components in glowworm light. Louis Pasteur (1864) appears to be the next observer, on the beetle, Pyrophorus, and E. Ray Lancaster next (1870), using the worm, Chaetopterus. All these men found a short continuous spectrum not crossed by bright or dark lines, in the visible region. The spectral energy curve was first measured by Ives and Coblentz (1909) .

Both Dubois (1886) and Langley and Very (1890) attempted to 
detect radiant heat from Pyrophorus without success, thus establishing animal light as of high luminous efficiency. Quantitative efficiency studies on a luminous bacterium, regarded as a power house for producing light, were first made by E. N. Harvey (1925), who found an "overall " efficiency about equal to that of an incandescent electric lamp. A single bacterium emitted about $2 \times 10^{-14}$ candle.

Older workers referred to light intensity of luminous organisms in terms of the ability to read fine print. The first actual measurement appears to have been made by Dubois (1886), who found 1/150 of a "Phoenix" candle of 8 to the pound, while Langley and Very (1890) observed $1 / 1600$ candle, both observers using the beetle Pyrophorus. The first measurements on colonies of luminous bacteria were made by A. Lode (1904), whose figure was $7 \times 10^{-10}$ international candle per square millimeter.

That luminous animals require mechanical agitation or some kind of stimulation in order to light must have been apparent to any who observed marine forms. Von Humboldt, during his journey to the equinoctial regions of the new continent in 1799-1804 observed that a jellyfish on a pewter plate would luminesce by electrical stimulation. Macartney (1810) also noticed the luminescence of jellyfish on electrical stimulation, on heating, and on plunging into " spirits." The first electrical stimulation of minute dinoflagellates responsible for the light of the sea appears to have been made by Pfaff (1823) at Kiel, and the first electrical stimulation of Noctiluca by Pring (1849) or by Quatrefages (1850).

In 1843 Quatrefages had observed that the light of small worms and ophiuroids appeared when their muscles contracted, and he is mostly responsible for a rather general idea in the late nineteenth century that luminescence and contractility are related. Actually there is no relation except that both luminescence and muscular contraction appear as a result of stimulation.

It is difficult to ascribe the recognition that nerves can carry impulses to a luminous organ to any one person. Spallanzani (1783) and others noticed the waves of light which pass over a pennatulid after stimulation by touching one part of the colony, although it is doubtful whether it was recognized at that time that nerves were involved in the transmission, and even Panceri (1870-1872) was not sure the impulse was a nervous one.

Many observers spoke of the will to flash on the part of a firefly and Macaire (1821) showed that when the head was cut off and the body connected to wires from a galvanic pile, light appeared on making the current, but he did not speak of nerve control. A. W. 
Peters (1841) showed that firefly flashing stops when the nerve cord is cut, and Kölliker (1857) said nerves controlled the organ, while M. Verworn (1892) spoke of an automatic nerve center in the oesophagial ganglia of the Italian lucciole.

The second method of controlling activity in animals, by hormones, is also effective in luminescence control. Light production in the photophores of a fish, Porichthys notatus, was found to be set off by injection of a small amount of adrenalin by Greene and Greene in 1924.

The fact that low temperatures reduce or extinguish bioluminescences without permanent harm seems to have been first observed by Bacon (1627) who reported that shining wood was not hurt by "laying it abroad in frosty weather." A similar experiment was tried by N. Hulme (1800), using luminous wood and fish (bacteria) in a freezing mixture, and by Spallanzani (1796), using the glowworm. These men found that on rewarming, the light would reappear. Extreme low temperatures (liquid hydrogen at $-252^{\circ} \mathrm{C}$ ) were tested on luminous bacteria by A. Macfayden and S. Rowland (1900) and found to be harmless. Luminescence reappeared and growth began on warming to room temperatures and G. Zirpolo (1932) found that no injurious effect resulted from exposure to temperatures of liquid helium $\left(-271^{\circ} \mathrm{C}\right)$.

At high temperatures the light of a luminous liquid from the mollusc, Pholas, was observed to disappear by Réaumur (1723) and by Beccari, Monti and Galeati (1724). A. R. Martin (1761, 1764) saw the light of fishes (bacteria) go out at high temperature, but the first to observe reversibility of luminescence after extinction at high temperature was Canton (1769), also using shining fish. After the light had disappeared on heating, it returned on cooling, a general finding for bioluminescence reactions, now attributed to reversible denaturation of luciferase.

The first studies of high hydrostatic pressures (600 atmospheres) were made on the glowworm by Dubois and P. Regnard (1884). Slight injury was observed but no permanent impairment of the lighting ability. Luminous bacteria were tested under pressure by E. Suchland (1898) but no further work appeared until that of Brown, Johnson, and Marsland (1942), again using luminous bacteria. These men developed an important theory to explain the action of pressure, temperature, and drugs or chemicals on the luminescence of these organisms and on biological processes in general.

So many observers have noticed the effect of chemicals or alcohol on luminescence that it is almost impossible to say who was the first 
to study a particular action. Perhaps Boyle (1667) should receive the honor from his observation that "spirits of wine" and "salts" extinguish the light of shining wood. Réaumur (1723) and Beccari, Galeati, and Monti (1724) also noted the quenching effect of brandy (eau de vie) on the luminous liquid from the mollusc, Pholas. Probably the first study of cell narcosis in which a clearly reversible effect of the narcotic was noted was that of Achard (1783) on luminescence of wood and Massart (1893) on Noctiluca.

That sunlight will affect the ability to luminesce was discovered by G. J. Allman (1862). Ctenophores which he caught in daylight never luminesced until kept in a dark room for some twenty minutes. Other luminous organisms actually exhibit a day-night rhythm of the ability to emit light, observed for Noctiluca by L. F. Henneguy (1888) and by Massart (1888), but not always confirmed by later observers. The rhythm was definitely established for Ceratium by O. Zacharias (1905) and undoubtedly applies to other dinoflagellates.

The first histological study of luminous tissue depends largely on the use of the word " histological." Malpighi (1688) dissected the lantern of a firefly and described tiny globules in the tissue. Since then microscopical studies gave a somewhat inadequate account of the light organs until after the middle of the nineteenth century. Probably modern investigation should be ascribed to Leydig (1857) and Kölliker (1857) for their accurate descriptions of the minute structure of the lantern of lampyrids.

Embryological studies began with the realization that the egg of the firefly is luminous (Vintimillia, as quoted by Bartholin, 1647) and that segmentation stages of ctenophore eggs will also luminesce (Allman, 1862). Gueneau de Montbeillard (1782) raised glowworms from the egg through the many larval stages to pupa and adult, describing the changes which occurred. The development of light organs within the egg from fat body cells was first studied by R. Vogel (1913) in the European glowworm, and by F. X. Williams (1916) in the American firefly.

The development of a complicated luminous organ in fish appears to have been first studied by C. W. Greene (1899) for the California toad-fish, Porichthys notatus.

The habits of luminous animals, especially the firefly or glowworm were observed by many. Perhaps Pliny was the first to record the habitat of the cicindela. J. C. Scaliger (1557) first saw the male and female copulate. Early recognition of a purpose for the light must be again attributed to Vintimillia in a letter to $\mathrm{F}$. Columna (quoted by Bartholin, 1647), who realized that the light of the 
female glowworm was to attract the male. Since Darwin's theory of natural selection, a host of reasons have been advanced to account for the value of light emission.

The inter-relationship of luminous organisms to other animals is of special interest in connection with luminous bacteria, which not only live saprophytically on dead meat but are also parasites and symbionts. The first record of living animals infected with luminous bacterial parasites, giving them a luminous disease which proved fatal, is that of Hablitzl (1782), for the midges of Russia. Other recorded instances are the luminous river shrimp of Thulis and Bernard (1786), the beach fleas of Viviani (1805), and the caterpillars of Gimmerthal (1829). Realization that luminous bacteria caused the infection came from the work of Giard and Billet (1889) on beach fleas.

The actual living together of luminous bacteria and other organisms appears to have been suggested without foundation by $\mathrm{P}$. Kuhnt (1907), who thought glowworm light might be due to luminous bacteria. Actual discovery of luminous symbiosis was made by B. Osorio (1912) for the macrourid fish, Malacocephalus. This animal possesses a special gland filled with luminous bacteria, which are poured into the sea water when the fish is squeezed. That other fish whose lights result from symbiotic luminous bacteria do exist was established by the work of Harvey (1921) on Photoblepharon and Anomalops of the Banda Islands in the East Indies. The claims of symbiotic luminous bacteria in other organisms by Pierantoni (1914) and P. Buchner (1914) have not been accepted by all students. 

Bibliography 



\section{SELECTED BIBLIOGRAPHY}

This bibliography contains only titles of articles or of books in which sections are devoted to knowledge of luminescences of various kinds. It is not intended to be complete, but includes most of the important contributions * of the period 1555 (Gesner's book on luminescence) to 1900. A few earlier and a few twentieth-century papers on special discoveries are included. Sources of historical comment, and publications with only casual reference to luminescence will usually be found in footnotes. The page for a bibliographic footnote can be obtained from the author index.

ABNey, W. DE W. 1881, 1882. On lines in the infra-red region of the solar spectrum. Phil. Mag. (5), 11: 300-301; see also 13: 212-214.

1882. On the violet phosphorescence in calcium sulphide. Proc. Physic. Soc. 5: 35-38; Phil. Mag. (5) 12: 212-214.

Accum, F. 1799. On the light emitted by supersaturated borate of soda, or common borax. Nicholson's Jour. Nat. Philos. Chem. and Arts 2: 28.

ACHARD, F. 1785. Experiences sur le bois pourri luisant. Nouv. Mém. d. l'Acad. Roy. d. Sci. et Belles Lettres, Berlin, 1783: 98-106.

ADAms, G. 1794. Lectures on natural and experimental philosophy, considered in its present state of improvement, Lec. XXI, Of phosphoric bodies, 428-453. London.

Adanson, M. 1757. Histoire naturelle du Sénégal. Paris. Translated in 1759 as A voyage to Senegal during the years 1749-53, p. 176, 183.

Ad-Damiri. 1906, 1908. Hayât Al-Hayawân (A zoological collection), trans. from Arabic by Lt. Col. A. S. G. Jayakar. 2 v. Bombay. 1: 504 on firefly.

Adler, C. F. 1752, 1756, 1757. Noctiluca marina. Quam sub Presidio D: N. Doct. Caroli Linnaei, Upsallae. In Caroli Linnaei. Amoenitates Academicae, 3: 202-210, Holmiae, 1756. Abstracted in Gentleman's Magazine 27: 208-209.

Aeliani, C. 1556. Opera. Tiguri (Gesneros fratres). De animalium natura liborum XVII. $365 \mathrm{pp}$. Also 1616, Coloniae Allobrogum.

Afzelius, A. 1798. Observations on the Genus Pausus and description of a new species. Trans. Linnean Soc., London, 4: 243-261.

Agassiz, A. 1874. Embryology of the Ctenophorae. Mem. Amer. Acad. Arts \& Sci. 10, pt. 2, supp: 357-398.

Agassiz, L. 1850. On the structure of the halcyonoid polypi. Proc. Amer. Assoc, Adv. Sci, 3: 207-213.

AkIN, C. K. 1865, 1867. On calcescence. Phil. Mag. (4) 29: 28-40; 136-151. See Ann. der Physik 130: 162-165; 131: 554-564.

Albertus Magnus. 1478. De animalibus libri XXVI. From the Cölner Urschrift by Hermann Stadler. Beiträge zur Geschichte der Philosophie des Mittelalters 15, 892 pp., 1916-1921.

Albrecht, J. S. 1740. De ligno non putrido in tenebris lucente. Acta Physica Medica. Acad. Caesar-Leopol.-Car. Nat. Curios. Norimbergae, 5: 482-488.

* A rather complete bibliography of bioluminescence, 1800-1950, will be found in E. N. Harvey, Bioluminescence, New York, Academic Press, 1952. 
Alcock, A. 1902. A naturalist in Indian seas. 238 pp. London.

Aldrovandi, U. 1602. De animalibus insectis. Luminis Natura, 492-499. Bononiae. 1606. De reliquis animalibus exsanguibus. De mollibus, crustaceis, testaceis et zoophytis. Bononiae.

Alenitzyn, W. D. 1875. Uber das Leuchten von Diptera. Dtsch. Ent. Ztschr. 19: 432.

Allman, G. J. 1851. On the emission of light by Anurophorus (Leptura) fimentarius, Nicolet. Proc. Roy. Irish Acad. 5: 125.

1862. Note on the phosphorescence of Beroë. Proc. Roy. Soc. Edinb. 4: 518-519.

Alter, D. 1855. On certain physical properties of the light of the electric spark within certain gases, as seen by a prism. Amer. Jour. Sci. (ser. 2) 19: 213-214. See also 18: $55-57,1854$.

Alvergniat. 1871. Sur les tubes lumineux electrodes exterieures. Com. Rend. Ac. Sci. 73: 561 .

Ames, J. S. 1890. On some gaseous spectra. Hydrogen, Nitrogen. Phil. Mag. (5) 30: 48-58.

Anderson, J. 1750. Histoire naturelle de l'Islande, du Groenland et du Detroit de Davis. Traduite de l'Allemand of 1746. 2 v. Paris.

ANDRAde, E. N. DAC. 1913. Lenard's researches on phosphorescence. Sci. Prog. 8: 54-71. ANDREOCCI, A. 1895. Sui quattro acidi santonosi. Gazz. Chim. Ital. 25 (1) : 462-568.

1899. Sopra alcune relazioni riscontrate fra l'isomeria ottica e la triboluminescenza. Gazz. Chim. Ital. 29 (1): 516-519.

Angot, A. 1896. The aurora borealis. $264 \mathrm{pp}$. London.

Ångström, А. J. 1855. Optische Untersuchungen. Handl. Svensk. Vetensk. Akad. 1853: 333-360, in Swedish. See Phil. Mag. (4) 9: 327-342, trans. from Ann. der Physik 94: 141-164.

1869. Spectrum des Nordlichts. Ann. der Physik 137: 161-163, and Phil. Mag. 38: 246-247.

1871. Ueber die Spectren der einfachen Gase. Ann. der Physik 144: 300-307; Phil. Mag. (4) 42: 395-399.

ÅNGSTRÖM, K. 1803. Bolometrische Untersuchungen über die Stärke der Strahlung verdünnter Gase unter dem Einflusse der electrischen Entladung. Ann. der Physik 48: 493-530. From Acta Reg. Soc. Upsaliensis, 1892.

Annandale, Nelson. 1900. Observations on the habits and natural surroundings of insects made on the "Skeat Expedition" to the Malay Peninsula, 1899-1900. VI Insect luminosity (an aquatic lampyrid larva). Proc. Zool. Soc. Lond. 862-865.

- 1906. Notes on the freshwater fauna of India. III. An Indian aquatic cockroach and beetle larva. Jour. Asiat. Soc. Bengal (N.S.) 2: 106-107.

Anon. 1784. Observation sur le phenomène des lueurs phosphoriques de la mer baltique. Jour. de Physique 24: 56-60.

1832. On the luminous appearance of the roots of the garden lettuce. Graves' Naturalist's Jour. 1: 18-20.

1871. Luminous plants. Science Gossip, 121-125.

Arago, D. F. J. 1840. Phosphorescence de la mer; Rapport sur les travaux scientifique executés pendent le voyage de la frégate la Venus commandée par M. le capitaine de vaisseau Du-Petit-Thonars. Com. Rend. Ac. Sci. 11: 327-328.

Aristotle. 1908, 1923. Works. Oxford ed. De anima, De sensu, Historia animalium, Metereologia.

Armstrong, H. E. 1888, 1892, 1893. The origin of colour and the constitution of coloring matters. Chem. News 57: 106-108; Jour. Chem. Soc. 61: 789-790; Proc. Chem. Soc. 8: 191; 9: 54 . 
Arnaud, E. R. 1897. Etudes sur le phosphore et phosphorisme professionel. Paris.

ARnold, W. 1897. Ueber Luminescenz. Disert. Erlangen 1896. Ann. der Physik 61: 313-329.

AsBjörnsen, P. C. 1856. Brisinga endecacnemos. Fauna litoralis Norvegiae 2. Bergen.

Ash, T. 1682. Carolina; or a description of the present state of that country, etc. Published by T. A. Gent, London, p. 24-25.

Atrinson, G. F. 1887. Observations on the female form of Phengodes laticollis, Horn. Amer. Nat. 21: 853-856.

Auzout and De La Voye. 1666. Sur les vers luisant dans les huitres. Mém. de l'Acad. Paris 10: 453-455.

Azara, F. DE. 1809. De voyages dans l'Amerique Méridional par Don Felix de Azara, depuis 1781 jus qu'en 1801 1: 114-221. Paris.

BABo, von, and J. Müller. 1856. Die Fluorescenz erregende Eigenschaff der Flamme der Schwefelkohlenstoff. Ann. der Physik 97: 508-510.

Bacon, F. 1605. The advancement of learning. Book IV, Chap. 3, and Novum organum. London, 1620.

- 1612? Topics of inquiry concerning light and the nature of light. in Basil Montagu, Esq. The works of Francis Bacon, 15: 82-87. London, 1834.

- 1627. Sylva Sylvarum or a natural history in ten centuries. Sec. 209 on shining wood; sec. 278 on the glowworm.

BAIrD, W. 1830-1831. On the luminousness of the sea. Mag. Nat. Hist., London, 3: 308-321 and 4: 500-511.

1843. Note on the luminous appearance of the sea, with descriptions of some of the entomostracous insects by which it is occasioned. Zoologist 1: 55-61.

Bajon. 1778. Mémoires pour servir à l'histoire de Cayenne et de la Guiane Fran'çoise 2. Mémoire XII. Observations sur les corps lumineux qui brillent dans l'obscurité sur la mer, 402-414. Also in Jour. de Phy'sique 3: 106-109, 1774.

BAKER, H. 1742. The microscope made easy. ... 311 pp. London.

- 1753. Employment for the microscope. 3rd ed. 1785. On some luminous water insects, 399-403. London.

BAKER, H. B. 1885. Combustion in dried gases. Jour. Chem. Soc. 47: 349-352.

— 1888. Combustion in dried oxygen. Phil. Trans. 179 A: 571-591.

Balduin (Baldewein), C. A. 1673-1674. Phosphorus hermeticus sive Magnes luminaris. Misc. Acad. Nat. Cur. Dec. I. (5th year) : 105-172.

- 1676. Aurum superius et inferius aurae superioris et inferioris Hermeticum. Amstelodami.

Balmer, J. J. 1885. Notiz über die Spectrallinien des Wasserstoffs. Verhand d. Naturf. Ges. in Basel 7: 548-560, and Ann. der Physik 25: 80-87.

BALY, E. C. C. 1893. Separation and striation of rarefied gases under the influence of the electric discharge. Phil. Mag. (5) 35: 200-204.

BANDRowSKI, E. 1894, 1895. Uber Lichterscheinungen während der Krystallisation. Ztschr. Phys. Chem. 15: 323-326; 17: 234-244.

BANKS, J. 1796-1799. Catalogus bibliothecae historico-naturalis 1-4. London. Luminiscences classified.

Banks, J., and D. C. Solander. 1768. An account of a voyage around the world in the Endeavor in 1768-71. Hawkesworth Account II, 15.

Bardetscher, G. A. 1889. Ueber den Einfluss der Temperatur auf Phosphorenzerscheinungen. Dissert. Bern 1889; Mitth. d. Naturf. Ges. Bern 1888, 75-108; Beiblätter 16: $742-744$. 
Bartholin, T. 1647. De luce animalium, libri III. Ludguni Batavorum. 2nd ed. De Luce hominum et brutorum, libri III. Hafniae.

1667. De flammula cordis epistola, cum Jacobi Holsti . . . eiusdam argumenti dissertatione. Accessit de carnibus lucentibus Danielis Puerarii responsio. 136 pp. Hafniae.

Baster, J. 1757. Observationes de Corallinis, isque insidentibus Polypis, aliisque Animaculis Marinis. Phil. Trans. 50: 258-280.

1760. Opuscula subseciva. 1: 31. Haarlem.

Bateman, S. 1581. The doom warning all men to the judgements, etc. London.

- 1582. Bateman uppon Bartholome his Booke De Proprietatibus Rerum, newly corrected enlarged and amended: etc. Lond. De Noctiluca in book 18, chap. 77.

Battarra, G. A. 1755. Fungarum agri Ariminesis historia. 80 pp. Faventiae.

Baumhauer, H. 1867. Über Lichtentwicklung bei der langsamen oder vollständigen Oxydation verscheidener Stoffe. Jour. f. Pract. Chem. 102: 123, 361-362.

BEAL, J. 1665-1666. An experiment to examine, what figure and celerity of motion begetteth, or encreaseth light and flame. Phil. Trans. 1: 226-228 (No. 13).

- 1676. Two instances of something remarkable in shining flesh. Phil. Trans. 11: 599-603 (No. 125).

BECCARI, J. B. 1745. De adamante aliisque rebus in phosphorium numerum referendis. Comm. Accad. Bonon. 2 (1): 274-303.

1746. De quam plurinis phosphoris nunc primum detectis. Commen. Accad. Bonon. 2 (2): 136-179.

- 1747, 1773. De luce dactylorum fossilium de qualitatibus quibusdam quae phosphorum luci obstat. Com. Accad. Bon. 2 (1): 248-273. Translation in Collec. Acad. Etranger 10: 127-150.

Beccaria, G. B. 1753. Dell' Elettricismo Artificale e Naturale. Turin.

— 1758. Lettere dell'Elettriscismo. Bologna.

1771. Letter to Mr. John Canton F. R.S. on his new phosphorus receiving several colours and only emitting the same. Phil. Trans. 61: 212.

- 1776. A treatise upon artificial electricity, etc. London.

Beckerhinn, C. P. D. 1789. Versuche und Beobachtungen über das Leuchten der Zündwürmer, und hir Verhalten in Verschiedenen Luftgattungen. Crell's Chemische Ann. fur die Freunde der Naturlehre. 1st pt.: 309-314. Also in Annales de Chemie 4: 19.

Becquerel, A. C. 1826. Luminous stones. Phil. Mag. 68: 389 (an abstract) .

1834-1840. Traité expérimental de l'électricité et du magnetisme. 7 v. Paris.

Vol. 4, book 8, 1836, p. 23-77, de la phosphorescence.

1839. Sur la propriété qu'a la lumière de rendre des corps phosphorescents. Com. Rend. Ac. Sci. 8: 183.

1839. De quelques propriétés nouvelles relatives au pouvoir phosphorescent de la lumière électrique. Com. Rend. Ac. Sci. 8: 216-223.

- 1842-1844. Traité de physique considérée dans ses rapports avec la chimie et les sciences naturelles. 2 v. Paris. 2: 129-182, De la phosphorescence.

Becquerel, A. C., and E. Becquerel. 1855-1856. Traité d'électricité et magnétisme. 3 v. Paris. 1: 335-365, Effects lumineux.

Becquerel, A. C., J. B. Biot, et E. Becquerel. 1839. Mémoire sur la phosphorescence produite par la lumière électrique. Arch. du Museum d'Hist. Natur. 1: 215-241.

Becquerfi, E. 1839. Recherches sur le rayonnement calorifique de l'étincelle électrique. Com. Rend. Ac. Sci. 8: 334-337; also 493-497.

1843. Des effets produits sur les corps par les rayons solaires. Ann. de Chim. et Phys. (3) 9: 257-322. Phosphorescence, 314-322. 
1848. Note sur la phosphorescence produit par isolation. Ann. de Chim. et Phys. (3) 22: 244-255.

1858. Recherches sur divers effets lumineux. Com. Rend. Ac. Sci. 45: 815-819; 46: 969-975. Abstracts of material in 3 memoirs in Ann. de Chim. et Phys. (ser. 3) 55: 5 -119; 57: 40-128.

1859. Recherches sur Divers Effets Lumineux qui resultent de l'action de la lumière sur les corps. (1st, 2nd and 3rd mémoires.) $115+86 \mathrm{pp}$. Paris. From Ann. de Chim. et Phys. 55: 5-119; 57: 40-124.

1860, 1861. Recherches sur divers effets lumineux, etc. IV Mémoire. Intensité de la lumière émise. Com. Rend. Ac. Sci. 51: 921-925; Ann. Chim. et Phys. (3) 62: 5-100.

1866. Note sur phosphorescence de la blende hexagonal Com. Rend. Ac. Sci. 63: $142-146$.

- 1867. La lumière, sa cause et ses effets. 2 v. Paris. Vol. 1 on Sources de lumière.

1869. Recherches sur les effets lumineux qui résultent de l'action de la lumière sur les corps. Réfrangibilité des rayons actifs. Com. Rend. Ac. Sci. 69: 994-1004.

1872. Mémoire sur l'analyse de la lumière émise par les composés d'uranium phosphorescents. Ann. Chim. et Phys. (4) 27: 539-579.

1877. Sur l'observation de la partie infra-rouge due spectre solaire au moyen des effets de phosphorescence. Ann. Chim. et Phys. (5) 10: 5-13. Also Jour. de Phys. 6: 137-144.

1879. Observation relative a une note de M. Lamansky. Com. Rend. Ac. Sci. 88: 1237-1239, 1352.

1881. Remarks after W. Crookes's paper, Sur les spectres phosphorescents discontinue observés dans le vide parfait. Com. Rend. Ac. Sci. 92: 1283.

— 1882. Sur les phosphorographies du spectre solaire. Jour. de Phys. (2) 1: 139-140. 1885. Etude spectrale des corps rendus phosphorescents par l'action de la lumière ou par les descharges électriques. Com. Rend. Ac. Sci. 101: 205-210.

1886. Action du manganèse sur le pouvoir de phosphorescence du carbonate de chaux. Com. Rend. Ac. Sci. 103: 1098-1101.

1886. Sur la phosphorescence de l'alumine. Com. Rend. Ac. Sci. 103: 1224-1227.

1888. Sur la préparation des sulfures de calcium et de strontium phosphorescents. Com. Rend. Ac. Sci. 107: 892-895.

Becquerel, H. 1883, 1884. Mémoire sur l'étude des radiations infra-rouges au moyen des phénomènes de phosphorescence. Ann. Chim. et Phys. (ser. 5) 30: 5-68. Com. Rend. Ac. Sci. 96: 121-124, 1215-1218, 1853-1856; 97: 71-74; 99: 374-376, 417420.

1885, 1886. Relations entre l'absorption de la lumière et l'émission de la phosphorescence dans les composés d'uranium. Com. Rend. Ac. Sci. 101: 1252-1256; 102: 106-110; 103: 198-202.

1891. Sur les différentes manifestations de la phosphorescence des minéraux sous l'influence de la lumière ou de la chaleur. Com. Rend. Ac. Sci. 112: 557-563. 1891, 1892. Sur les lois de l'intensité de la lumière émise par les corps phosphorescents. Com. Rend. Ac. Sci. 113: 618-623, 672; Jour. de Phys. (3) 1: 137-144.

- 1896-1897. Sur les radiations émises par phosphorescence, etc. Com. Rend. Ac. Sci. 122: $420-421,501-503,689-694,762-767,1086-1088$; 123: 855-858; 124: 438-444, 800-803.

- 1899. Recherches sur les phénomènes de phosphorescence produits par le rayonnement du radium. Com. Rend. Ac. Sci. 129: 912-917, 996-1001, 1205-1207. See also 128: $771-777$.

1901. Sur quelque observations faites avec uranium à de très basses temperatures. Com. Rend. Ac. Sci. 133: 199-202. 
1903. Sur la phosphorescence scintillante que présentent certains substances sous l'action des rayons du radium. Com. Rend. Ac .Sci. 137: 629-634.

Beijerinck, M. W. 1889. Les bactéries lumineuses dans leur rapports avec l'oxygène. Arch. Néerl. Sci. 23: 416-427.

— 1889. Le photobacterium luminosum, bactérie lumineuse de la mer du nord. Arch. Néerl. Sci. 23: 401-415.

- 1889. L'auxanographie ou la méthode de l'hydrodiffusion dans la gélatine appliquée aux researches microbiologique. Arch. Néerl. Sci. 23: 367-372.

- 1890. Over lichtvoedseeln plastisch voedsel van Lichtbacterien. Proc. Acad. Sci. Amst. Natuurk. 2 de Reeks, Deel 7: 239.

1891. Sur l'aliment photogène el l'aliment plastique des bactéries lumineuses. Arch. Néerl. Sci. 24: 369-442.

- 1900. On different forms of hereditary variation of microbes. Proc. K. Akad. van Wet. Amsterdam. 3: 352-365.

1912. Mutation bei Microben. Folia Microbiol. 1: 1-97, esp. 49-54.

— 1915. Die Leuchtbacterien der Nordsee im August und September. Folia Microbiol. 4: 15-40.

Bellani de Monza, A. 1813. Recherches physico-chimiques sur le phosphore. Bull. de Pharm. (Jour. de Pharm. et de Chim.) 5: 489-505.

Benham, W. B. 1899. Phosphorescent earthworms. Nature 60: 591:

Bennet, F. D. 1833. On the light emitted by a species of Pyrosoma. Proc. Zool. Soc. Lond. (Part 1): 79-80.

- 1837, 1838. On marine Noctilucae. Proc. Zool. Soc. Lond. 5: 1-3, 51-52. Also in Phil. Mag. 12 (Ser. 3) : 212-213.

- 1840. Narrative of a whaling voyage around the world from the year 1833 to '1836. 2 v., 401 and $395 \mathrm{pp}$. London.

Bergsma, P. A. 1854. De phosphorescentia per irradiationem. Dissertatio historica physica. $139 \mathrm{pp}$. Utrecht.

Bernoulli, C. 1803. Uber das Leuchten des Meeres u.s.w. 6 pts. Göttingen.

Bernoulli, J. I. 1700, 1701, 1707. Sur le phosphore du baromètre. Mem. de l'Acad. Roy. de Paris 178-190, 1700; 1-8, 1707. Histoire de l'Acad. Roy. de Paris 5-6, 1700; $1-9,1701$.

Berthelot, M. 1887-1888. Collection des anciens alchemists grecs. 3 v. I Introduction, II Greek text, III Translation. Paris.

—_ 1888. Sur un procédé antique pour rendre les pierres précieuses et les vitrifications phosphorescents. Ann. de Chem. et Physique (6) 14: 429-432.

1893. La Chemie au moyen âge. 3 v. Paris.

1897. Nouvel appareil pour l'application de l'analyse spectrale a la reconnaisance des gaz. Com. Rend. Ac. Sci. 124: 525-528.

Berthold, A. A. 1837. Lehrbuch der Physiologie, Göttingen. 2nd ed. In vol. 1, sec. 69, 129-132, Phosphorescenz.

Berthold, G. 1876. Zur Geschichte der Fluorescenz. Ann. der Physik 158: 620-625.

Berthollet, C. L. 1795. Sur les propriétés eudiométriques du phosphore. Jour. Ecole Polyt. Paris 1 (3 cahier): 274-278.

Bertholon de Saint Nazaire, Abbé P. 1793. Aurore boreale, Dictionnaire de physique in Encyclopédie méthodique.

Berzelius, J. J. 1843-1848. Lehrbuch der Chemie 5th ed. 5 v. 1: 195.

BEst, T. W. 1887. On the delicacy of spectroscopic reaction in gases. Manchester Proc. 26: 102-108.

Bethune, C. J. S. 1863. Luminous larvae. Canad. Ent. 1: 38-39. 
BettendorfF, A. 1891, 1892. Studien über die Erden der Cerium- und Yttrium-Gruppe. Liebig's Ann. der Chem. 263: 164-174; 270: 376-383.

Bezold, M. von, and G. EnGlehardt. 1877. On the fluorescence of the living retina. Phil. Mag. (5) 4: 397-400.

Bıт, J. B. 1839. Sur de nouveaux procédés pour étudier la radiation solaire, tant directe que diffuse. Com. Rend. Ac. Sci. 8: 259-272, 315-327.

Biot, J. B., and A. C. BecQuerel. 1839. Sur la nature de la radiation émanée de l'étincelle électrique, qui excite la phosphorescence à distance. Com. Rend. Ac. Sci. 8: 223-229.

Bischof, G. 1823. Ueber die Phosphoreszenz der unterirdischen Rhizomorphen Schweigger's Jour. für Chem. u. Phys. 39: 259-305.

BLACK, J. 1803. Lectures on chemistry, pub. by John Robison from his manuscript. 2 v. Edinburgh. Appendix-Pyrophori, 2: 296-305.

Blainville, H. D. DE. 1833. Cours de physiologie general et comparée. Paris. 3 v. 3: 81-89, De la phosphorine.

1834. Manuel d'actinologie, 82.

Blair, K. G. 1927. An aquatic glowworm. Nat. Hist. Mag. 1: 59; Trans. Roy. Ent. Soc. London 75: $43-45$.

Blondlot, N. 1868. Sur l'ozone et l'acide phosphorique produits dans la combustion lente du phosphore. Com. Rend. Ac. Sci. 66: 351-352.

Blumhoff, J. G. L. 1800. A short view of observations which have been made at different times of the luminous appearance of the sea. Phil. Mag. 8: 97-107. From Mag. f. den Neuesten Zustand der Naturkunde 1, 1797.

Boccone, P. 1674. Recherches et observations naturelles, etc. Amsterdam. Also Bologna, 1684, in Italian.

- 1697. Museo di fisica e di esperienze variato e decorato di osservazione naturali, note medicinali, etc. (J. B. Zuccato) $319 \mathrm{pp}$. Venetia.

BodDaERT, P. 1787. Beschreibung zweier merkwürdiger Fische (Sparus palpebratus und Murena colubrina). Neue Nord. Beitr. (Pallas) 2: 55-57. See also Schrift, Ges. Naturf. Fr. Berlin 3: 458-460, 1782.

Bodenheimer, F. S. 1928-1929. Materialen zur Geschichte der Entomologie bis zum Linné. 2v. Berlin. See 1: 337, for Malpighi and glowworm.

BöckmanN, C. W. 1800. Versuche über das Verhalten des Phosphorus in verschiedenen Gasarten. 342 pp. Erlangen.

- 1803. Observations and experiments on the light emitted by rotten wood in different kinds of gases and in fluids. Scherer's Alleg. Jour. der Chemie 5: 3-35; Phil. Mag. 16: 18-26.

BoerhaAve, H. 1735. Elements of chemistry, being the annual lectures trans. from Latin by T. Dallowe, M.D. 2 v. $528+376$ pp.

— 1727, 1741. A new method of chemistry, trans. from Elementa chemiae (1724), by P. Shaw, M.D. 2 v., $393+410$ pp. 1: $353-357$ on phosphors. 1727 ed. by P. Shaw and E. Chambers.

BötTGER, R. 1840. Über Phosphorescenz der alkaloide und sonstiger Pflanzenbildungstheile. Liebig's Ann. der Chem. 33: 342-343.

— 1855, 1856. Über die Fluorescence des Kaliumplatincyanürs und die Benutzung des Lichtes von in Sauerstoff verbrennenden Schwefel odor Phosphor zur Erzeugung von Photographien. Ann. der Physik 95: 173; 96: 333-334.

Bohadsch, J. B. 1761. De quibusdam animalibus marinis. Dresdae. De penna, 98-128.

BohlendorfF, W. 1891. Bemerkung zur Abhandlung des Herrn B. Walter (1889). Ann. der Physik 43: 784-489.

Boнn, C. 1867, 1868. Ueber negative Fluorescence. Ann. der Physik 130: 367-393; 133: 165-177; Phil. Mag. (4) 34: 109. 
Boie, F. (and Rolander). 1827. Uber das Leuchten eiriger Batrachier. Isis von Oken, Jena 20: 726-728.

Boisduval, J. A. 1833. De la phosphorescence de certaines chenilles de Mamestra oleracea, L. Gen. Rev. Ent. 1: 226. Also Ann. Soc. Ent. Fr., 424, 1832.

Boot, A. B. DE. 1647. Gemmarum et lapidum historia. 428 pp. Ludguni Batavorum.

Borch, Conti DI. 1781. Memoria sopra il fosforo marino. Atti dell' Accad. delle Scienze di Siena 6: 317-324.

Borel, P. 1657, 1678. Historiarum et observationum medico-physicarum centuriae IV. Paris. Francoforti et Lipsiae.

BORY DE ST. Vincent, J. B. 1804. Voyages dans les quatres principales isles des mers Afrique 1: 112. Paris.

Bosc, L. A. G. 1800. Histoire des vers. Suite de Buffon.

Boscovich, R. G. 1738. De aurora boreali dissertatio. Romae.

Bose, G. M. 1744. Tentamina electrica etc. 50 pp. Wittembergae.

- 1745. Letter on electricity to M. de Mairan, communicated and translated out of the Latin by Mr. Baker. Phil. Trans. 43: 419-421.

Botroni, D. 1692. Pyrologia topographica, id est de igne dissertatio juxta loca, cum eorum descriptionibus. $245 \mathrm{pp}$. Naples.

Bouḱ, A. 1869. Ưber das gefärbte See-wasser und dessen Phosphorescenz im Allgemein. Sitzungsber. d. Math-Naturwiss. Classe, Ac. d. Wiss. Wien. 59 (II Abt.) : 251-262.

Bourguet, L. 1724. Sur une pierre de Berne qui est une epèce de Phosphore. Hist. de l'Acad. Roy. des Sci., 58-61.

Bourzes. 1713. A letter from Father Bourzes to Father Estienne Souciet concerning the luminous appearance observable in the wake of ships in the Indian Seas etc. Taken from the ninth volume of letters of the Missionary Jesuits. Phil. Trans. 28: $230-235$.

Boussuet, F. 1558. De natura aquitalium carmen etc. 2 books, $240+135$ pp. Ludguni.

Bouttatz, F. 1800. Über den Phosphor als Arzneimittel. Göttingen.

Bowring, J. 1857. The kingdom and people of Siam: with a narrative of the mission to that country in $1855,1: 233-234.2 \mathrm{v}$. London.

Boyle, R. 1661. The sceptical chymist: or chymico-physical doubts and paradoxes, touching the experiments whereby vulgar spagirists are wont to endeavour to evince their salt, sulphur and mercury to be the true principles of things. $440 \mathrm{pp}$. Oxford. Glowworms, p. 344, 1680 ed.

1664. Experiments and considerations touching colours. Contains observations on Lignum nephriticum (pp. 199-203) and luminous diamonds (pp. 413-423). London. Latin ed., 1680.

1668. Experiments concerning the relation between light and air in shining wood and fish. Phil. Trans. 2: 581-600 (No. 31).

1668. Observations and trials about the resemblances and differences between a burning coal and shining wood. Phil. Trans. 2: 605-612 (No. 32).

1672. Some observations about shining fesh, both of veal and of pullet. Phil. Trans. 7: 5108 (No. 89).

- 1675. Experiments, notes etc. about the mechanical origine or production of divers particular qualities. Oxford. Contains the tracts on Magnetism and Electricity reprinted in Old Ashmolean Reprints by R. T. Gunther, Oxford, 1927.

1680. The aerial noctiluca or some new phoenomena and a process of a factitious self-shining substance. Imparted in a letter to a friend living in the country. London.

1681-1682. New experiments and observations made upon the icy noctiluca imparted in a letter to a friend living in the country. To which is annexed a chymical paradox. London. 
1682. A continuation of new experiments physico-mechanical touching the spring and weight of the air. London. Triboluminescence, exp. XLII.

- 1692-1693. Account of making phosphorus. Phil. Trans. 17: 583-584 (No. 196).

BRANDT, K. 1885. Die Koloniebildenden Radiolarien (Sphaerozen) des Golfes von Neapel. Fauna u. Flora Neapel 13: 1-276. Phosphorescenz, pp. 136-139.

Braun, F. 1897, 1898. Uber ein Verfahren zur Demonstration und zum Studium des Verlaufes variabler Ströme. Ann. der Physik 60: 552-559.

- 1898. Uber Lichtemission an einigen Electroden in Electrolyten. Ann. der Phys. 65: 361-364.

Brauner, J. 1877. Versuche über Fluorescenz. Anzeiger der Wien Akad. Math. Nat. Cl. 14: 178-180.

BRAYLEY, E. W. 1835. Notice of a memoir on the natural laws which appear to regulate the distribution of the powers of producing heat and light amongst the different groups of the animal kingdom. Phil. Mag. (3) 6: 241-247.

Brembridge, R. H. 1889. Combustion in moist and dry oxygen. Pharm. Jour. (3) 19: $958-960$.

Bressy, J. 1800. Essai sur l'électricité de l'eau, 178. Paris. Also in Ann. der Physik 1: $377-378,1799$.

BREwSTER, D. 1819-1821. On the phosphorescence of minerals. Edinburgh Philos. Jour. 1: $383-388 ; 2$ : $171-172 ; 4$ : 180-185.

1823. Phosphorescence and structure of the Chara vulgaris and hispida. Edinburgh Philos. Jour. 9: 194.

1831. Letters on natural magic addressed to Sir Walter Scott, Bart. London.

1832. Edinburgh encyclopedia (American edition) 18 v. 15: 531-551, Phosphorescence.

1833. On the colours of natural bodies. Trans. Roy. Soc. Edinburgh 12: 538-545.

Also Rep. Brit. Assoc. Adv. Sci. 1832: 547-548.

1838. On a new phenomenon of colour in certain specimens of fluorspar. Rep. Brit. Assoc, Adv. Sci. Newcastle.

1842. On the luminous bands in the spectra of various flames. Brit. Assoc. Adv. Sci. Notes, 15.

1846, 1848. On the decomposition and dispersion of light within solid and fluid bodies. Trans. Roy. Soc. Edinburgh 16 (part II) : 111-123; Phil. Mag. (3rd ser.) 32: 401-412. Also in Ann. der Physik 73: 531-548.

Brooks, E. E. 1890, 1891. On the phosphorescence of lithium compounds in vacuo, and the spectra of coated terminals. Chem. News 62: 239; 64: 30-31.

Brown, D. E. S., F. H. Johnson and D. A. Marsland. 1942. The pressure, temperature, relations of bacterial luminescence. Jour. Cell. Comp. Physiol. 20: 151-168.

Browne, P. 1756. The civil and natural history of Jamaica. 503 pp. Part I, Civil history, 1-34. Part II, Natural history, 35-503. London.

BRÜCKE, E. 1845, 1846. Über das Verhalten der optischen Medien des Auges gegen Lichtung Wärmestrahlen. Arch. f. Anat. u. Physiol. u. Wiss. Med., 1845: 262-276 and 1846: $379-382$.

Brugnatelli, L. 1897. Ueber Santonin und einige seiner Derivate. Ztschr. f. Krystallogr. 27: $78-90$.

Brugnatelli, L. G. 1797. Observations sur le phosphore. Ann. de Chim. 24: 57-77, and Nicholson's Jour. Nat. Philos. Chem. and Arts 1: 444-450.

1800. Ueber die verschiedenen Zustände in welchen der Lichtstoff vorkommt. Ann. d. Physik 4: 438-442, trans. from Annali di Chimica 13, No. 13, Pavia, 1797. Also in Phil. Mag. 7: 285-286.

1814. Nota sul fosforismo di varj corpi e segnatamente degli animali vivi. Gior. d. Chim. Phys. e Storia. Nat. 7: 238-240. 
Bruguière, J. G. 1792. Sur la qualité phosphorique du ver de terre dans certains circomstances. Mém. d'Hist. Nat. 2: 267-268.

Buch, L. von. 1800. Scipio Breislak's physikalische Topographie von Campanien. Ann. der Physik 5: 396-407; Jour. de Physique 6: 325-331.

Buchner, P. 1914. Sind die Leuchtorgane Pilzorgane? Zool. Anz. 45: 17-21.

BÜCHNER and S. W. DöBEREINER. 1824, 1825. Über Lichterscheinungen bei Krystallisationen (a letter from Döbereiner) Schweigger's Jour. für Chem. u. Phys. 41: 221-228; with a Nachtrag by Schweigger, 228-232. Also Quart. Jour. Sci. 19: 341.

Buckingham, E. 1894. Über einige Fluorescenzerscheinungen. Ztschr. Physik. Chemie. 14: $129-148$.

Buonanni, F. 1684. Recreatio mentis et oculi in observatione animalium testaceorum curiosis naturae inspectoribus. 269 pp. Ex Typographia Varesij. Romae. 1st ed., 1681, in Italian.

1709. Museum Kircherianum sive Museum A. P. Athanasio Kirchero in Collegio Romano Societatis Jesu jam pridem incoeptum, nuper restitutum, auctum, descriptum et inconibus illustratum. 522 pp. Romae. Lapis bononiensis, p. 205.

Burbank, J. E. 1898. X-rays and mineral phosphorescence. Amer. Jour. Sci. (4) 5: 53-54.

Burke, J. 1895. Luminescence of glass due to cathode rays. Phil. Mag. (5) 39: 115-122.

- 1897, 1898. On the change of absorption produced by fluorescence. Proc. Roy. Soc. 61: 485-487; Phil. Trans. 191A: 87-105.

Burmeister, H. C. C. 1832. Handbuch der Entomologie 1: 535. Berlin.

— 1872, 1875. Observations on a light giving coleopterous larva. Jour. Linn. Soc. (Zool.) 11: 416-421. Also Stettin. Ent. Ztg. 26: 344.

Busk, G. 1852. Observations on certain points in the anatomy of a species of Thaumantias. Jour. Roy. Micr. Soc. 3: 22-25.

Cabanis, P. J. G. 1802. Rapports du physique et du moral de l'homme. 6th Mem. De l'influence des témperaments sur la formation des idees et des affections morales (Sec. III). CEuvres 3: 379-381, 1824.

Camerarius, E. 1700. De naturalis phosphori phaenomenonis. Misc. curiosa, Dec. III, An. 5, 86-89.

Camerarius, R. J. 1690. De linteis noctu lucentibus. Misc. curiosa, Dec. II, An. 8, $428-430$.

- 1691. Lintea lucida. Obs. CXXI. Misc. curiosa, Dec. II, An. 1, 211-212.

CAnton, J. 1753. Electrical experiments with an attempt to account for their phenomena; together with some observations on thunder-clouds. Phil. Trans. 48: $350-358$.

— 1754. A letter to the Right Honorable, the Earl of Macclesfield, Pres. R. S. concerning some new electrical experiments. Phil. Trans. 48: 780-785.

- 1759. An attempt to account for the regular diurnal variation of the horizontal magnetic ncedle; and also for its irregular variation at the time of an aurora borealis. Phil. Trans. 51: 398-445.

- 1768. An easy method of making a phosphorus that will imbibe and emit light like the Bolognian stone; with experiments and observations. Phil. Trans. 58: 337-344.

- 1769. Experiments to prove that the Iuminousness of the sea arises from purification of its animal substances. Phil. Trans. 59: 446-453.

CAntor, M. 1900. Versuch über die Absorption des Lichtes in electrisch leuchtenden gasen. Ann. der Physik 1: 462-465.

Capron, J. R. 1880. Relative intensity of the spectral lines of gases. Phil. Mag. (5) 9: $329-330$. 
Cardan, H. 1557. De rerum varietate. 2nd ed. in 1558. Avinione.

Cario, G., and J. Franck. 1923. Úber sensibilisierte Fluorescenz von Gasen. Ztschr. für Physik 17: 202-212. See 9: 259-266, 1922, by J. Frank, and 10: 185-199, 1922, by G. Cario.

Carpenter, W. B. 1843. The popular cyclopedia of natural science. 579 pp. London. Animal physiology, 394-402

- 1854. Principles of comparative physiology. $770 \mathrm{pp}$. London. Evolution of light, pp. 441-449. 1st ed., 1839.

Carpenter, W. B., J. G. Jeffries, and W. Thomson. 1869. Preliminary report . . . of the Porcupine, etc. Proc. Roy. Soc. 18: 397-429, especially 431-432.

Carradori, B. 1798. Experiments and observations on the phosphorescence of the Luciole, Lampyris Italica. Phil. Mag. 2: 77-80. Trans. from Ann. de Chemie 26: 96-101, 1797.

Carradori, J. 1797. Contre l'opinion du Prof. Spallanzani sur la cause du luisant des phosphores naturels. Ann. de Chimie 24: 216-225. Also in Nicholson's Jour. 2: 132.

- 1799. Beobachtungen und Bemerkungen über das leuchten der fliegenden Johanniswürmchen; über das Leuchten des faulen Holzes. Ann. d. Physik 1: 205-213.

Carrara, M. 1836. Sulla fosforescenza della Lucciola commune. Biblioteca Italiana, ossia Giornale di Letter., Scienze, etc. 82: 357-370.

Cartheuser, J. F. 1749. Fundamenta materiae medicae tam generalis quam specialis. 2 v. Francofurti ad Viadrum (I. C. Kleyb). 1: 166 for Lapis bononiensis and Phosphorus balduinus.

— 1755. Matiere médicale traduite du latin. 4 v. Paris. Vol. 1, Sec. 2, Chap. 9, part 5, De la chaux vive et de l'infusion aqueuse qu'on en prépare.

Casati, P. 1688. Dissertationes physicae de igne. Francofurti et Lipsiae. See pp. 348-355.

Cassini, G. D. 1683. Nouveau phenomene rare et singulier d'une lumière celeste, qui paru au commencement du printemps de cette année 1683. Jour. des Sçwvons (May 10), 131-144.

CAstro, E. DI. 1642. Ignis lambens, historia medica, prolusio physica. Rarum pulchrescentis naturae specimen. $198 \mathrm{pp}$. Veronae.

Cavallo, T. 1782. Complete treatise on electricity in theory and practice. 2nd ed. Chap. VI, pp. 214-239, Exps. on electric light. 1st ed., 1777. London.

Cellio, M. A. 1680. Il fosforo o vero la pietra Bolognese praeparata per far rilucere fra l'ombre. $102 \mathrm{pp} .18^{\circ}$ : Roma. Review in Phil. Trans. abr. by Hutton 2: 515.

Centnerszwer, M. 1898. Über den katalytischen Einfluss vercheidener Gase und Dämpfe auf die Oxydation des Phosphors. Ztschr. f. Phys. Chem. 26: 1-16.

Chambers, E. 1728. Cyclopedia, or an universal dictionary of art and sciences. $2 \mathrm{v}$. 2nd ed., 1738. Supplement 2 v., 1751.

Chappuis, J. 1881. Quelques faits pour servir à l'histoire de la phosphorescence. Bull. Soc. Chim. de France (2) 35: 419-420.

Chautard, J. 1864. Phénomènes observés dans les spectres produits par la lumière des courants d'induction traversant le gaz rarefiés. Com. Rend. Ac. Sci. 59: 383-384.

— 1874-1876. Action exercée par un électroaimant sur les spectres des gaz raréfies, traversés par des déscharges électriques. Com. Rend. Ac. Sci. 79: 1123-1124; 80: 1161-1164; 81: 75-77; 82: 272-274.

Chiaje, S. Delle. 1828. Memorie sulla storia e notomia degli animali senza vertebre del regno di Napoli 3: 58.

Chree, C. 1891. Some experiments on liquid electrodes in vacuum tubes. Proc. Cambridge Phil. Soc. 7: 22-246. 
Chun, C. 1880. Die Ctenophoren des Golfes von Neapel. Fauna u. Flora Neapel. 313 pp. 1: 194-195.

Ciamician, G. 1878. Úber die Einfluss der Dichte und der Temperatur auf die Spectren von Dämpfen und Gasen. Sitzber. d. K. Akad. Wiss. Wien 78 (II): 867-890.

Claparìde, E., and J. Lachmann. 1858-1859. Etudes sur les infusories et les rhizopodes. Mem. Inst. Nat. Genev. 5 (mem. 3) : 1-260; 6 (mem. 1) : 261-482.

Claus, C. 1863. Uber einige Schizopoden und niedere Malacostraken Messina's. Ztschr. Wiss. Zool. 13: 422-454.

Clausius, R. 1858. Über die Natur des Ozon. Ann. der Physik 103: 644-652.

Clémendot, L. 1881. Action de la lumière sur les corps phosphorescents. Com. Rend. Ac. Sci. 92: 1107.

CoAtes, R. 1720. A description of the great meteor which was on the 6 th of March 1715-6. Phil. Trans. 31: 66-70.

Coblentz, W. W. 1912. A physical study of the firefly. Publ. Carneg. Inst. Wash., No. 164: 3-47.

Cocco, A. 1833. Su di alcuni pesci de' mari de Messina. Giorn. Sci. Lett. Arti Sicilia 42: 9-21; Maurolico 2: 236-244.

— 1838. Su di alcuni Salmonidi del Mare di Messina, lettera al C. L. Bonaparte. Nuovi Ann. Soc. Nat. Bologna 2: 161-194.

Coetlogen, D. DE. 1745. An universal history of arts and sciences. 2 v. London. Phosphorus 2: 654-664.

Conausen, J. H. 1717. Lumen novum phosphoris accensum, sive exercitatio physicochymica, de causa lucis in phosphoris tam naturalibus quam artificialibus. $306 \mathrm{pp}$. Amstelodami.

СонN, F. 1878. Vezameling van stukken betreffende het geneeskundig staatsoetzicht in Neederland, 126.

Coldstream, Dr. 1847. Luminousness, Animal. R. B. Todd's Cycloped. Anat. Physiol. 3: 197-205. London.

Collie, J. N., and W. Ramsay. 1896. On the behavior of argon and helium when submitted to the electric discharge. Proc. Roy. Soc. 59: 257-270.

Collier, G. F. 1842-1843. Case of psoriasis palmaria in which the entire body becomes luminous from a phosphorescent secretion. Lancet 2: 374.

Columna or Colonna, F. 1616. Aquatilium et terrestrium aliquot animalium, etc. 73 pp. Romae.

Conring, H. 1647. De calido innato sive igne animali liber unus, disputatio publice habita 10 novembri 1627, Lugduni Batavorum. Helmstadii.

Conroy, J. 1882. The spectrum of the light emitted by the glowworm. Nature 26: 319.

Cooper, D., and R. Cooper. 1838. On the luminosity of the human subject after death, etc. Phil. Mag. (3) 12: 420-426.

Corne, I. 1882. Sur la phosphorescence et l'oxydation du phosphore. Jour. Pharm. Chim. (5) 6: 17-20.

Cornu, A. 1886. Sur le spectre ultra-violet de l'hydrogene. Jour. de Physique (2) 5: 100-143, 341-354.

CossA, A. 1877. (Thermoluminescence of magnesium fluoride) in Italian. Gazzetta Chimica Italiana 7: 212-219. Also in Chem. Soc. Jour. 2: 707, and Ztschr. für Krystall. u. Miner. 1: 207-211.

Cotte, J. 1944. Poissons et animaux aquatique au temp de Pline. 266 pp. Paris.

Coudréniere, M. DE LA. 1775. Observations sur la lumière de l'eau de la mer. Jour. de Physique 5: 451-452. 
Crawshay, L. R. 1935. Possible bearing of a luminous syllid on the question of the landfall of Columbus. Nature 136: 559-560.

Crell, L. von. 1778. Versuch aus menschlichen Knocken einen Phosphorus zu bereichten. Crell's Chemische Jour. 1: 23-39.

- 1795. Nachricht von einen neuen Flusspath (Pyrosmaragd) nebst einigen Versuchen mit mehreren Flusspatharten. Crell's Chem. Ann. I: 534-536.

Crequy, Compte DE. 1752. Explication de la nature du feu et de sa propagation. Recueil des pièces qui ont remparté les prix de l'Acad. 4: 55-217. Paris.

Crookes, W. 1879. On the illumination of lines of molecular pressure and the trajectory of molecules. Phil. Trans. 170: 135-164.

1879. Contributions to molecular physics in high vacuo. Phil. Trans. 170: 641-662.

1879. De la lumière verte et phosphorescente du choc moléculaire. Com. Rend. Ac. Sci. 88: 283-284.

1883, 1884. On radiant matter spectroscopy (Bakerian Lecture). Proc. Roy. Soc. 35: 262-271; Chem. News 47: 261-264; Phil. Trans., 891-918; Ann. Chim. et Phys. (6) 3: 145-187.

1885. On radiant matter spectroscopy. Part II. Samarium. Proc. Roy. Soc. 38: 414-422; Com. Rend. Ac. Sci. 100: 1380-1382, 1495-1497; Chem. News 51: 301-303; Phil. Trans., 691-723.

1886. Opening address to the chemical section of the Brit. Assoc. Adv. Sci.; Chem. News 54: 115-126, 155-158.

1886. On radiant matter spectroscopy: Note on the spectra of erbia. Proc. Roy. Soc. 40: 77-79; Chem. News 53: 75-76; Com. Rend. Ac. Sci. 102: 506-507.

1886. On radiant matter spectroscopy: Note on the earth Ya. Proc. Roy. Soc. 40: 236-237; Chem. News 53: 133; Com. Rend. Acad. Sci. 102: 646-647.

1886. On some new elements in gadolinite and samarskite, detected spectroscopically. Proc. Roy. Soc. 40: 502-509; Chem. News 54: 13-15; Com. Rend. Ac. Sci. 102: 1464-1466.

1887. On the crimson line of phosphorescent alumina. Proc. Roy. Soc. 42: 25-31. 1887. Genesis of the elements. Chem. News 55: 83-89, 95-99; 56: $39-40$.

1887. On radiant matter spectroscopy: Examination of the residual glow. Proc. Roy. Soc. 42: 111-131; Nature 35: 425-428, 447-451.

- 1888. On elements and meta-elements. Chem. News 57: 206-209, 216-217, 226-228. 1899. Photographic researches on phosphorescent spectra: on victorium, a new element associated with yttrium. Proc. Roy. Soc. 65: 237-243; Nature 60: 317-319; Chem. News 79: 212.

1903. Certain properties of the emanations of radium. Chem. News 87: 241.

CubA, J. DE. 1536. Hortus sanitatis quatuor libris, etc. De animalibus et reptilibus; De avibus et volatilibus; De piscibus et natatilibus; De gemmis et in ueuis terrae nascentibus, etc. Argentorati.

Curie, S. 1898. Rayons emis par les composes de l'uranium et du thorium. Com. Rend. Ac. Sci. 126: 1101-1103.

Cusack, R. 1897. Effect of change in temperature on phosphorescent substances. Nature 56: 102.

Cuvier, G., et A. Valenciennes. 1829-1849. Histoire naturelle des poissons. Paris. 22 v. Vol. 22 on deep sea fish.

Daguerre, L. J. M. 1839. Phosphorescence du sulfate de baryte calciné; communication de M. Arago sur quelques experiences de M. Daguerre. Com. Rend. Ac. Sci. 8: $243-246$. 
Dalton, J. 1793, 1823. Meteorological observations and essays. London. pp. 153-194, On the aurora borealis.

Dammer, O. 1862. Fluorescence der Wärme. Ann. der Physik 115: 658-659.

DanA, J. D. 1852. Crustacea of the U.S. Exploring Exped. 1838-1842 13 (pt. 1) : 598, 644 ; (pt. 2) : 1295.

Daniel, L. 1870. Action du magnétisme sur les gaz raréfiés. Com. Rend. Ac. Sci. 70: 183-185.

Daniell, J. F. 1839. An introduction to the study of chemical philosophy. London. Pp. 402-404.

Darwin, C. 1839. The zoology of the voyage of the Beagle. (Journal of Researches) London.

1872. The origin of species. London, 6th ed. Chap. VI, Difficulties of the theory. 1874. The descent of man and selection in relation to sex. London. 1st ed. 1871.

Darwin, E. 1798. The Botanic Garden. New York. Part I, The economy of vegetation; Part II, The loves of the plants.

1800. Phytologia, or the Philosophy of agriculture and gardening. London. Sec. X, 2.1 and 5.1, on rotten wood.

DARwin, L. 1881. Rate of decrease of light given off by a phosphorescent surface. Phil. Mag. (5) 11: 209-212.

Daubuisson, J. F. 1802. Lettre: extrait du cours verbal d'orictognosie de M. Werner. Jour. de Phys. 54: 414-420.

Davis, C. A. 1822. On the natural history of the ocean. Luminousness of the sea. Amer. Jour. Sci. 5: 133-134.

DAvis, T. L. 1927. Kunkel and the early history of phosphorus. Jour. Chem. Ed. 4: $1105-1113$.

Davy, H. 1799. Experimental essays on heat, light and the combinations of light, with a new theory of respiration and observations on the chemistry of life. Contributions to physical and medical knowledge collected by Th. Beddoes, 1-147. Bristol.

1800. Experiments and observations on the silex composing the epidermis or external bark and contained in other parts of certain vegetables. Nicholson's Jour. Nat. Philos. Chem. \& Arts. Also in Jour. de Physique 49: 202-206, 1799, and Ann. der Phys. 6: 105-115, 1800.

1800. Letter on the nitrous oxide, or gaseous oxide, of azote, on certain facts relating to heat and light, and on the discovery of the decomposition of the carbonate and sulfate of ammonia. Nicholson's Jour. of Nat. Philos. Chem. \& Arts 3: 515-518; also in Ann. der Physik 6: 105-115.

1803. Theorie des Lichts und der Verbindungen und Wirkung des Lichts. Ann. der Physik 12: 574-596. Phosphorescence, pp. 581-583.

1811. On a combination of oxymuriatic gas and oxygen gas. Phil. Trans., 1-35, 155-162. Also 231-257, 1810.

1812. Elements of chemical philosophy, a historical review. $296 \mathrm{pp}$. Philadelphia.

1822. On the electrical phenomena exhibited in vacuo. Phil. Trans. 112: 64-75.

Davy, J. 1833. Some observations on phosphorus. Edinb. New Philos. Jour. 15: 48-52.

Decharme, C. 1869. De la phosphorescence de la mer prognostique du temps et specialement comme signe précurseur des orages. Com. Rend. Ac. Sci. 69: 832-835.

De Dietrich. 1783. Sur differens phénomènes de fusion operes par l'air dephlogistique. Jour. de Phys. 23: 17-27.

DE Flacourt. 1658. Histoire de la grande isle Madagascar. Paris. p. 158 describes the "Herecherche" like the "ver-coquins" of France. 
DE GeER, C. 1755. Mémoire sur un ver luisant femelle et sur sa transformation. Mém. Acad. Sci. Paris Savant Etrang. 2: 261-275.

1774. Mémoires pour servir à l'histoire des insectes. $7 \mathrm{v}$. 4: 160-162.

De Grosser, see Grosser.

De Lamanon. 1785. Sur la combustion du quartz, du crystal de roche et des pierres qui leur sont analogues. (Rozier) Jour. de Phys. 27: 66-69.

Delamétherie, L. P. à J. C. 1802. La phosphorescence du diamant. Jour. de Physique 55: $60-61$.

DE LA Rive, A. 1849. Extrait d'une lettre a M. Regnault (regarding effect of magnet on electric discharge in gas and the aurora borealis). Com. Rend. Ac. Sci. 29: 412-415.

1858. Note sur l'influence du magnetisme sur les déscharges électriques. Ann. de Chim. et Phys. 54: 238-242, extracted from Bib. Univ. (Arch. de Sci. Phys. et Nat.) Geneva (2) 2: 34-37.

1859, 1862. Recherchés sur la propagation de l'électricité dans les fluides elastiques très-rarefiés. Com. Rend. Ac. Sci. 48: 1011-1016; 56: 669-677, 1862. See also 54: 1171-1175.

1862. Further researches on the aurorae boreales and the phenomena which attend them. Phil. Mag. (4) 23: 546-553.

1866, 1867, 1870. Recherches sur l'action qu' exerce le magnetisme sur les jets électrique qui se propagent dans les milieux gazeux tres raréfies. Arch. Sci. Phys. \& Nat. (2) 27: 289-316; Phil. Mag. (4) 33: 512-530. See also Ann. de Chimie 20: 103-120, and Com. Rend. Ac. Sci. 70: 286-287.

1866, 1867. Recherches sur la propagation de l'électricité dans les fluides élastiques tres raréfies et particulièrement sur les stratifications de la lumière électrique qui accompagnent cette propagation. Arch. Sci. Phys. Nat. (2) 26: 177-208; Phil. Mag. (4) 33: 512-530.

1870. Observation sur la notice de M. Sarasin relative a la phosphorescence des gaz raréfies. Ann. Chim. et Phys. (4) 19: 191-192.

— 1872. Théorie de aurores polaires. Ann. de Chim. (4) 26: $355-361$ and Com. Rend. Ac. Sci. 74: 893-898.

DE la Rive, A. and E. Sarasin. 1871-1872. De l'action du magnetisme sur les gaz traverses par des décharges éléctrique. Arch. Sci. Phys. Nat. (2) 41: 5-26; 45: 387-407; Com. Rend. Ac. Sci. 74: 1141-1154; Phil. Mag. (4) 42: 211-223; 44: 149-153.

De la Rue, W. and H. W. Müller. 1878, 1880, 1883. Experimental researches on the electric discharge with the chloride of silver battery. II. The discharge in exhausted tubes. Phil. Trans. 169: 155-233; 171: 65-114; 174: 477-515, 1883. For discharge in air, see 169: 55-118, 1878.

De-LA-voye ET Auzout. 1666. Lettres sur les vers luisauts dans les ouitres. Mém. de l'Acad. d. Sci. 10: 455. Also in Jour. de Scavans, 1666 (March).

De Lens. 1820. Dictionnaire de science medical. 41: 526-541, Phosphorescence.

Delius, H. F. von. 1748, 1785. Phosphorescentia lapidum et gemmarum. Acta Physicomedica Naturae Curiosum 8, and Vom Leuchten der Steine und Edelsteine in Crell's Neues Chem. Arch. 3: 265-267.

1784. Vermischte chemische Bemerkungen. Crell's Chem. Ann. (1st part), 524-525.

Delle Chiaje, S., see Chiaje.

Della Valle, A. 1875. La luce negli animali. 69 pp. Thesis. Napoli.

Deluc, J. A. 1787. Nouvelles idées sur la métérologie. Paris. 2 v. 1: 97-100, on phosphors.

De Magellan, see Magellan. 
de Mairan, see Mairan, J. J. D. DE.

Demarcay, E. 1896-1901. Rare earth phosphorescence (in French). Com. Rend. Ac. Sci. 122: 728-730; 130: 1019-1022, 1185-1188, 1496-1472; 131: 387-389, 995-998; 132: $1484-1486$.

De Parcieux. 1797. Zersprengen der Blase (a letter from de Mons). Gren's Jour. der Physik 8: 20.

Derham, W. 1726. Philosophical experiments and observations of the late eminent Dr. Robert Hooke, S. R.S. and other eminent virtuosos in his time. 391 pp. London. See p. 174-183 on phosphori.

- 1729. Of a meteor called the ignis fatuus from observations made in England, by the Rev. W. Derham and others made in Italy by Sir Tho. Derham. Phil. Trans. 36: 204-214.

Derschau, see Nees von Esenbeck.

De Saussure, see Saussure.

Descartes, R. 1637. Les Méteores, in CEuvres, pub. by C. Adam and P. Tannery. Paris, 1902,12 v. 6: 255-256, on sea phosphorescence.

— 1644. Principia philosophiae. Amstelodami. 4 parts, $331 \mathrm{pp}$. French translation, 1647.

Deschamps, M. H. 1861. Sur l'action que le principe aromatique du goudron exerce sur le phosphore. Jour. de Pharm. et de Chim. (3) 39: 412-415.

Deslandes. 1759. Anmerkungen ueber das Seewasser und ueber das susse Wasser, das man auf den Schiffen mitnimmt. Aus "recueil des differens traites de physique." etc. par M. Deslandes, Commissaire de la Marine, 1713. Allgemeines Magazin der Natur, Kunst u. Wiss., Leipzig 10: 225-235.

DeslandREs, H. 1888. Spectres des bandes ultra-violets avec une faible dispersion. Thèse, Paris, 1888; Ann. Chim. et Phys. (6) 15 5-86.

Deslongchamps, J. A. 1838. Note concernant des pêches phosphorescentes. Mem. Soc. Linn. Normandie 6: 307-308.

Dessaignes, J. P. 1809-1812. Mémoire sur les phosphorescences. Jour. de Physique 68: 444-467; 69: 5-35, 169-200; 70: 109-128; 71: 67-70, 353-361; 73: 41-53; 74: 101-120, 173-193. Also, Jour. des Mines, Paris 27: 213-230.

1811. On phosphorescence. Phil. Mag. 38: 3-13. From Jour. des Mines 27: 213$230,1809$.

1814. On the phosphorescence of compressed gases. Phil. Mag. 44: 313-314.

Deville, H. St. C. et H. Tkoost. 1861. De la reproduction des sulfres métallique; de la nature. Com. Rend. Ac. Sci. 52: 920-923.

Dewar, J. 1880. Studies in chinoline series. Proc. Roy. Soc. 36: 164-169.

— 1888. Phosphorescence and ozone. Proc. Roy. Inst. G. B. 12: 557-560; Proc. Roy. Soc. 43: 1078 ,

1894. Phosphorescence and photographic action at the temperature of boiling liquid air. Chem. News 70: 252-253.

- 1901. The nadir of temperature and allied problems. Proc. Roy. Soc. 68: 360-366.

Dezallier, A. J. (Anon, par M . . . de la Soc. Roy. des Sc. de Montpellier) 1742. L'histoire naturelle éclaircie dans deux de ses parties principales la lithologie et la conchyliologie dont l'une traité des pierres et l'autre des coquillages. $492 \mathrm{pp}$. Paris.

Dibbits, H. C. 1864. Über die Spectra der Flammen einiger Gase. Ann. der Physik 122: $497-545$.

Dicquemare, J. F. 1775. Observation sur la lumière dont la mer brille souvent pendant la nuit. Jour. de Phys. 6: 319-321.

1775. Description d'un insecte marin remarquable par les iris que l'environnent. Jour. de Phys. 6: 321-322. 
1778. Sur l'usage qu'on pourroit faire du phénomène de la mer lumineuse, relativement à la navigation. Jour. de Phys. 12: 137-141.

Diderot, D. et J. LE R. D'Alembert. 1751-1780. Encyclopédie ou dictionnaire raisonné des sciences, des arts et des métiers par un société de gens de letters. 35 v. Paris.

Dieberne, A. 1899. Sur une nouvelle matière radio-active. Com. Rend. Ac. Sci. 129: 593-595.

Digby, K. 1645. Two treatises, in the one of which, The nature of bodies, etc. $429 \mathrm{pp}$. London. Chap. VI, Of light, what it is.

Dittrich, R. 1888. Über das Leuchten der Tiere. Wissenschaftliche Beilage zum Programm des Realgymnasiums am Zwinger zu Breslau. Breslau. Progr. Nr. 200, 70 pp. Bibliog. of 250 titles.

Dixon, H. B., and E. J. Russel. 1899. On the combustion of carbon disulphide. Chem. News 79: 234.

Dızé. 1799. Sur la matière de la chaleur, considérée, d'après des expériences chimiques, comme la cause de l'effet lumineux. Jour. de Phys. 49: 177-202.

Dolbear, A. 1890. Die Fluorescenz- und Phosphorescenzerscheinungen. Electrot. Ztschr. 11: 478 .

Dolomieu, D. DE. 179I. Sur un genre de pierres très-peu effervescentes avec les acides, et phosphorescentes par la collision. (Rozier) Jour. de Phys. 39: 3-10.

Dombey. 1780. Extrait d'une lettre datée de Lima, a M. l'Abbé Rozier sur la lumière phosphorique de la mer. Jour. de Phys, 15: 212-214.

Donovan, D. 1840. Case of emanation of light from the human body? Dublin Med. Press 3: 52-54.

DorN, E. 1900. Versuche über Secondärstrahlen und Radiumstrahlen. Abh. d. Naturfor. Ges. für Halle-a-S. 22: 37-51.

Dove, H. W. 1861. Ueber Phosphorescenz durch Bestrahlung von polarisirtem Licht. Monatsber. d. K. Akad. d. Wis. Berlin, 272.

DowneY, W. E. 1924. The relation between the glow of phosphorus and the formation of ozone. Jour. Chem. Soc. 125: 347-357.

Doyère, M. P. L. N. 1846. Sur la noctiluque miliarie. Inst. (Soc. Math. Phys. Nat.) Paris 14: No. 677, 428.

Draper, J. W. 1841. On some analogies between the phenomena of chemical rays and those of radiant heat. Phil. Mag. (3) 19: 195-210.

1842. A new imponderable substance and on a class of chemical rays analogous to the rays of dark heat. Phil. Mag. (3) 21: 453-461.

1843, 1844. Description of the tithonometer, an instrument for measuring the chemical force of the indigotithonic rays. Phil. Mag. (3) 23: 401-415. Also in Amer. Jour. Sci, 46: 217-232.

1845. Account of a remarcable difference between the rays of incandescent lime and those emitted by an electric spark. Phil. Mag. (3) 27: 435-457.

1847. On the production of light by heat. Amer. Jour. Sci. (2) 4: 388-402; Phil. Mag. (3) 30: 345-360.

1848. On the production of light by chemical action. Phil. Mag. (3) 32: 100-114.

1851. On the phosphorescence of bodies. Phil. Mag. (4) 1: 81-100.

1881. On the phosphorograph of a solar spectrum and on the lines of its infra-red region. Amer. Jour. Sci. 21: 171-182, or Phil. Mag. (5) 11: 157-169.

Driessen, J. C. 1818. Beobachtung von Ausleerungen leuchtenden Urins. Ann. der Physik 59: 262-267.

- 1819. Dissertation de phosphuria et diabete mellito, 28. Göttingen.

Dubors, R. 1884, 1885. Note sur la physiologie des Pyrophores. Com. Rend. Soc. Biol.

(Ser. 8) 1: 661-664; 2: 559-562. 
1886, 1887. De la fonction photogénique chez les myriapodes. Com. Rend. Soc. Biol. (ser 8) 3: 518-522, 523-525; 4: 6-8. Also in Rev. Sci. Paris (ser. 3) 13: 509.

1886. Les Elaterides Lumineux. Bull. Soc. Zool. France 11: 1-275.

1886. De la fonction photogénique chez les Podures. Com. Rend. Soc. Biol. (ser. 8) 3: 600-603.

1887, 1888. Fonction photogenique chez le Pholas dactylus. Com. Rend. Ac. Sci.

105: 690-692; and Com. Rend. Soc. Biol (ser. 8) 3: 564-565; 5: 451-453.

1888. Sur la role de la symbiose chez certains animaux marine lumineux. Com. Rend. Ac. Sci. 107: 502-504.

1889. Sur la production de la lumière chez le Pholas dactylus. Com. Rend. Soc. Biol. 40: 451-453; 41: 611-614.

1889. Les microbes lumineux. Extrait de Echo. Socs. Veterinaires, Lyon, 1-24.

1892. Anatomie et physiologie comparées de la Pholade dactyle. Ann. Univ. Lyon 2 (fasicle 2): $167 \mathrm{pp}$.

- 1893. Sur le mechanisme de production de la lumière chez Orya barbarica d'Algerie. Com. Rend. Acad. Sci. 117: 184-186.

1896. Physiological light. Smithson. Inst. Ann. Rep. for 1895: 413-431, transl. from Rev. Gen. Sci. Pur. Appl. 5: 415-422, 429-534.

— 1898. Leçons de physiologie générale et comparée. Paris. $530 \mathrm{pp}$. Production de la lumière et des radiations chemique par les êtres vivants. Deuxieme part, 301528.

— 1901. Luminescence obtenue par certains procédes organiques. Com. Rend. Ac. Sci. 132: 431.

1914. La vie et la lumière. 338 pp. Paris.

Dubois, R., et P. Regnard. 1884. Note sur l'action des hautes pressions sur la fonction photogenique du Lampyre. Com. Rend. Soc. Biol. (ser. 8) 1: 675-676.

Dufay, C. F. 1723. Mémoir sur les barometres lumineux. Mém. de l'Acad. Paris, 295306.

1726. Sur un pierre de Berne qui est une espèce de phosphore. Hist. de l'Acad. Roy. de Sci. Paris, 1724, 58-61.

1732. Mémoire sur un grand nombre de phosphores nouveaux. Hist. de l'Acad. Roy. de Sci. Paris, 1730, Mem., 524-535.

- 1733. Concerning electricity (a letter to his grace Charles, Duke of Richmond and Lennox). Phil. Trans. (No. 431) 38: 258-266.

- 1738. Recherches sur la lumière des diamants et de plusieurs autres matières. Hist. de l'Acad. Roy. de Sci. Paris, 1735, Mem., 347-372.

Duges, A. 1838. Traité de physiologie comparée de l'homme et des animaux. Montpellier et Paris. 3 v. 2: 9-21, De la phosphorescence dans les animaux vivants.

Dumas, M. 1826. Sur la lumière qui se développe au moment on l'acide borique fondu se séparé en fragments. Ann. de Chim. 32: 335.

DuTaL, M. 1716. Pièce justificative pour M. Bernoulli contra Messieurs de l'Académie Royal des Sciences en faveur du Phosphore. Nouvelles de la République des Lettres 40 (Sept. 1706) : 243-255.

Du Tertre, J. B. 1654. Histoire générale des isles des Christophe, de la Guadeloupe, de la Martinque et autres dans Amérique, 481. Paris. See p. 323 for Pyrophorus.

EAMES, J. 1734. A philosophical and historical treatise concerning the aurora borealis, being a supplement to the Memoires of the Academy of Sciences for the year 1731. Review of De aurore boreale, by de Mairan, Phil. Trans. 38: 243-257.

EAton, A. E. 1880, 1882. Sur la phosphorescence du Caenis dimidiata. Trans. Ent. Soc. Lond. Proc., p. VIII, and Proc. XIII. 
EberT, H. 1888. Uber den Einfluss der Dicke und Helligkeit der Strahlenden Schicht auf das Aussehen des Spectrums. Ann. der Physik 33: 155-158. From Sitzb. $d$. Phys. Med. Soc. Erlangen 19: 22-25.

- 1894. Über langandauernde electrische Swingungen und ihre Wirkungen. $A n n$. der Physik 53: 144-161. See also 43: 790-807, 1891.

— 1899. Das Entwickelungsgesetz der Hittorf'schen Kathodendunkelraumes. Ann. der Physik 69: 200-219.

— 1899. Glimmlichterscheinungen bei hochfrequentem Wechelströme. Ann. der Physik 69: 372-397.

Ebert, H. and E. Wiedemann. 1893. Electrodynamische Schirmwirkung leuchtender Gase. Ann. der Physik 49: 32-49, especially 43-49. See also 48: 548-592; 49: 1-31.

EbERT, H. and E. WIEDEMANN. 1893. Leuchterscheinungen in electrodenlosen gasverdunnten Räumen unter dem Einflusse rasch wechselnder electrischer Felder. $A n n$. der Physik 50: 1-46, 221-254.

EDER, J. M. 1887. Phosphorescenzerscheinungen beim Hervorrufen von Gelatineplatten. Photog. Mitth. 24: 74 .

- 1913. Quellenschriften zu den frühesten Anfängen der Photographie. pp. 83-88. Wien. Translation of Baldewein's phosphor paper.

Eder, J. M., and E. Valenta. 1897. Spectalanalytische Untersuchung des Argons. Wiener Ak. Denkschr. 64: 1-39.

EhrenberG, C. G. 1834. Das Leuchten des Meeres. Abh. Preuss. Akad. Wiss. 411-572. References to 436 papers. For review, see Ann. Mag. Nat. Hist. 1: 409-412, 1837. See also Ann. der Physik 23: 147-151, 1931.

- 1859. Über das Leuchten und über neue microskopische Leuchthiere des Mittlemeeres. Monatsber. d. Preuss. Akad. Wiss. 1859: 727-738, 791-793.

Ehrenberger, B. H. 1745. De amatrice lumen et scintillas spargente. Coburgi.

Eisenlohr, W. 1854. Über die Wirkung des violetten und ultravioletten unsichtbaren Lichtes. Ann. der Physik 93: 623-626.

- 1856. Die brechbarsten or unsichbaren Lichtstrahlen in Beugungspectrum and ihre wellenlängen. Ann. d. Phys. 98: 353-370.

Ellis, J. 1754. Concerning a cluster-polyp, found in the sea near the coast of Greenland. (Letter from J. E. to Peter Collinson F. R. S.) Phil. Trans. 48: 305-307.

- 1763. An account of the sea pen or Pennatula phosphorea of Linnaeus; likewise a description of a new species of sea pen found on the coast of South Carolina with observations on sea pens in general. Phil. Trans. 53: 419-435.

Ellis, J., and D. Solander. 1786. The natural history of many curious and uncommon zoophytes. 208 pp. London.

Elsholtz, J. S. 1676. De phosphoris quatuor observationes, Berolini. On thermoluminescence of fluorspor.

- 1681. De phosphoris observationes quarum priores binae antes jam editae, tertia vero primo nunc vice prodit, $15 \mathrm{pp}$. Berolini.

Elster, J., and H. GeItel. 1889. Notiz über die Zerstreuung der negativen Electricität durch das Sonnen-und Tageslicht. Ann. der Physik 38: 40-41, 497-514. 1890. Ubber Ozonbildung an glühenden Platin fläschen und das electrische Leitvermögen der durch Phosphor ozonisirten Luft. Ann. der Physik 39: 321-331. 1891. Uber die durch sonnenlichte bewirkte electrische Zerstreuung von mineralischen Oberfläschen. Ann. der Physik 44: 722-736.

1903. Uber die durch radioaktiv Emanation erregte scintillierende Phosphorescenz der Sidot-Blende. Physik. Ztschr. 4: 439-440.

Emelaeus, H. J. 1926. The inhibition of the glow of phosphorus. Jour. Chem. Soc. 129: 1336-1344. 
EMERY, C. 1884. Intorno alle macchie splendenti della pelle nei pesci del genere Scopelus. Mitteil. Zool. Sta. Neapel 5: 471-482. Also in Arch. Ital. Biol. 5: 316-325. - 1884. Untersuchungen über Luciola italica I. Ztschr. Wiss. Zool. 40: 338-355.

Emmert, A. G. F., and Hochstetter. 1811. Untersuchung über die Entwickelung der Eidechsen in ihren Eiern. Archiv. für die Physiol. 10: 84-122.

Emsmann, H. 1861. Positive and negative fluorescence. Ann. der Physik 114: 651-657. — 1868. Zur Geschichte der Fluorescenz. Ann. der Physik 133: 175-176.

Encyclopedia Britannica. 1768-1771, 1777-1784. Ist ed., 3 v. 2nd ed., 10 v. Light, pp. 4214-4223, 1780. Many later editions with articles on phosphorescence.

ENGLEFIELD, H. C. 1802, 1803. Experiments on the separation of light and heat by refraction. Jour. Roy. Inst. 1: 202-208. Also in Ann. der Physik 12: 299-408.

Esselbach, E. 1863. On the duration of fluorescence. Rep. Brit. Assoc. Adv. Sci. for 1862 32: 22.

Esser, C. L. 1826. Über das Leuchten des Augen bei Tieren und Menschen, nebst einer Beobachtung über phosphorescirenden Harn. Kastner's Arch. f. die gesammte Naturlehre, Nürnberg 8: 394-415. Also trans. in Edinb. New Phil. Jour. 2: 164172,1827 , but with the urine account omitted.

Eugenianus, I. 1733. De rariore ignis lambentis specie. Acta Physico-Med. Acad. Caes. Leop. Nat. Cur. Ephemerides 3 (Obs. III) : 11-13.

Euler, L. 1746. Recherches physiques sur la cause de la queüe des cométes, de la lumière boreale, et de la lumière Zodiacle. Mem. Berlin Acad. 2: 117-140.

- 1752. Dissertatio de igne, etc. in latin. Recueil des Pièces qui ont Remparté les Prix de le Acad. Royal des Sciences 4: 1-19.

- 1777. Reflexions sur quelques nouvelles experiences optiques, communiquées a l'Académie des Sciences par Mr. Wilson. Acta Acad. Sci. Imp. Petropolis 1: 71-77.

- 1802. Letters of Euler on different subjects in physics and philosophy, addressed to a German princess, translated from the French by Henry Hunter, D. D., 2nd ed. 2 v. London. 1st ed., 1795. Ist German ed., 1769.

Evelyn, J. 1819. Diary and correspondence (1641-1706), ed. by Wm. Bray, 1: 129, 446, 620. 2nd ed. London.

Ewan, T. 1894, 1895. On the rate of oxidation of phosphorus, sulphur and aldehyde. Phil. Mag. 38: 505-536; also Ztschr. für Physik. Chem. 16: 315-343.

Fabre, J. H. 1855. Recherches sur la cause de la phosphorescence d'Agaric de l'Olivier. Ann. Sci. Nat. (ser. 4) 4: 179-197.

Fabricius ab Aquapendente, G. 1592. Tractatus de oculo visusque organo. Padua. Chap. 4, p. 45 for luminous meat.

FAbricius, O. 1780. Fauna groenlandica systematice sistens etc., 291. 452 pp. Hafniae et Lipsiae.

FAHRIG, E. 1890. The phosphorescence produced upon the first contact of ozone with certain fluids. Chem. News 62: 39-40.

FAILle, J. BAART DE LA. 1821. De animalibus phosphorescentibus. Groeningae.

Fallot. 1847-1848. Observation de photurie ou miction lumineuse. Bull. Acad. Roy. de Med. de Belg., Brussels 7: 239-246.

Faraday, M. 1814. Journal of 1814. In Bence Jones, Life and letters of Faraday, 1: 1870 .

1838. Experimental researches on electricity, 11th-13th series. Phil. Trans., $79-168$.

1839. Experimental researches in electricity. 3 v. London. Vol. 1, sec. 1359 to 1616 on electroluminescence.

_ 1857. On the persistent appearance of lightning flash. Phil. Mag. (4) 13:506. 
- 1859. On phosphorescence, fluorescence, etc. (A review of E. Becquerel). Proc. Roy. Inst. 3: 159-163.

Favt, M. 1878. Les vibrations de la matière et les ondes de l'ether dans la phosphorescence et la fluorescence. Com. Rend. Ac. Sci. 86: 289-294.

FERRY, E. S. 1898. On the relation between pressure, current and luminosity of the spectra of pure gases in vacuum tubes. Phys. Rev. 7: 1-9, 296-306.

FiEbig, O. 1861. Uber den Einfluss der Wärme auf Phosphorescenz. Ann. der Physik 114: $292-296$.

FIEsC, L. DE. 1752. Discourse sur la propagation du Feu. Recueil des Pièces qui ont Remparté les Prix de l'Acad. Paris 4: 23-54.

Finlayson, G. 1826. The mission to Siam and Hué, the capital of Cochin China, in the years 1821-1822, with a memoir of the author by Sir Thomas Stamford Raftles FRS. 427 pp. London, J. Murray. P. 37-38, Luminous appearance of the sea.

Fischer, B. 1887. Bacteriologische Untersuchungen auf einer Reise nach West Indien. II. Uber einen lichtentwickelnden, in Meerswasser gefunden Spaltpilz. Ztschr. Hyg. Infektkr. 2: 54-95.

_- 1888. Ueber einen neuen lichtentwickelnden Bacillus. Zbl. Bakt. 3: 105-108, 137-141.

— 1888. Bacterien Wachstum bei $0^{\circ}$ so wie über das Photographieren von Kulturen leuchtender Bakterien in ihren eigenen Lichte. Zbl. Bakt. 4: 89-92.

- 1894. Die Bakterien des Meeres. Ergebn. Plank. Exped. Humboldt Stiftung 4: 1 -83.

Fischer, N. W. 1845, 1846. Über das Leuchten des Phosphors. Jour. Prak. Chem. 35: 342-356; 39: 48-54.

Flaugergues, M. DE. 1780. Lettre sur le phosphorisme des vers de Terre, adressé par M. de Flaugergues fils, à M. le Baron de Servières. Jour. de Phys. 16: 311-313.

Forbes, E. 1848. A monograph of the naked-eyed Medusae with figures of all the species. 104 pp. (London, Ray. Soc.) Phosphorescence on pp. 11-14.

ForsKÅL, P. 1775. Descriptiones animalium etc. quae in itinere Orientali observavit, $100,109-111$.

Forster, A. 1868. Uber Darstellung künstlicher Leuchtsteine. Ann. der Physik 133: 94-121, 228-258.

- 1871. Notiz zur Kenntniss der Phosphorescenz durch Temperaturerhöhung. Ann. der Physik 143: 658-660.

Forster, G. 1783, 1784. Ein Versuch mit Dephlogistisirter Luft ueber das Leuchten von Lampyris splendidula L. Lichtenberg's Gotting. Mag. de Wissensch. u. Litt. 3: 281-288; also in Jour. de Physique 23: 24; and Neues Mag. f. d. Liebh. d. Entom. 2: 103.

Forster, J. R. 1778. Observations made during a voyage around the world, on physical geography, natural history and ethic philosophy. London. The phosphoreal light of sea-water, pp. 61-68.

Fougeroux DE Bondaroy, A. D. 1766. Mémoire sur un insect de cayenne apellé Marechal; et sur la lumière qu'il donne. Mem. d. Ac. Paris, 340-345.

— 1767. Mémoir sur la lumière que donne l'eau de la mer principalement dans les lagunes de Venise. Mem. de l'Acad. Roy. de Paris, 120-126.

- 1768. Mémoire sur le coquillage appelé datte en Provence. Mem. Math. et Phys. de l'Acad. Roy. du Sci. Sçavans Etranges 5: 467-478.

Fourcroy, A. F. DE. 1788. Sur la combustion de pleusieurs de corps dans le gaz acide muriatique oxigène. Mem. de l'Acad. de Sci.363-375.

1801. System des connaissances chimiques. 11 v. Paris. On bois pourri 8: 222-223. 
Frankland, E., and J. N. Lock Yer. 1869. Researches on gaseous spectra in relation to the physical constitution of the sun, stars and nebulae. Proc. Roy. Soc. 17: 453-454.

FrankLin, B. 1769. Experiments and observations on electricity to which are added letters and papers on philosophical subjects. London. Pp. 111 and 274 on phosphorescence of the sea. First ed. 1751; last ed. 1774.

Franz, W. 1712. Historia animalium sacra, etc. 5 parts. 3624 pp. Francofurti \& Lipsiae. Part 5, De insectis by Cyprian, J. Cap. III. sec. 65. Quidam ignito modo lucent. Ist ed., 1612.

Frenzel, J. and H. Schultes. 1934. Luminescenz im ultraschallbeschickten Wasser. Ztschr. Physik. Chemie 27: 421-424.

FREYesLeben. 1825. Lichterscheinungen. Neuere Beobachtungen. Uber das Leuchten der Rhizomorphen. Jour. für Chem. Physik 44: 65-78.

Frezier, A. F. 1714. Relation du voyage de la mer du sud aux côtes du Chilly et du Perou in 1712-1714. Paris. English translation, 335 pp. London, 1717.

Friedlaner, S. 1896. Uber Argon. Ztschr. Physik. Chem. 19: 657-667.

FrITz, H. 1873. Verzeichniss beobachteter Polarlichter. Vienna.

— 1881. Das Polaricht. Leipzig. 348 pp.

Frobesius, F. 1739. Nova et Antiqua Aurorae Boreales Spectacula. Helmstädt.

Frytschius (Fritsche), M. 1555. Meteorum, hoc est impressionum, aerearum, mirabilium naturae operum. . . Item catalogus prodigiorum atque ostentatorum. Narimbergae.

Fulke, W. 1560. A goodly gallerye with a most pleasaunt prospect, into the garden of naturall contemplation, to behold the naturall causes of all kynde of meteors, as well fyery and ayery, as watry and earthly, etc. London. Later eds. entitled Meteors, by W. F., in 1640 and 1655 .

FUretière, A. 1690. Dictionaire universal contenant generalement tous le mots françois tant vieux que modernes et les termes de toutes les Sciences et des Arts. 3 v. Haye et Rotterdam.

Gadeau de Kerville, H. 1881, 1887. Les insects phosphorescents. Notes complementaire et bibliographie generale. 133 pp. (Anatomie, Physiologie et Biologie.) 133 pp. Rouen.

1890. Les vegetaux et les animaux lumineux. $327 \mathrm{pp}$. Rouen. In German, Leipzig, 1893.

Gaertner, C. F. 1799. Bemerkungen und Versuche uber das leuchtende faule Holz. Allg. Jour. der Chem. 3: 3-29.

Galilei, Galileo, see Olschki, L., and Liceti, F.

Galitzin, B. 1895. Zur Theorie der Verbreiterung der Spectrallinien. Ann. der Physik 56: 78-99. From Bull. Acad. St. Petersburg (5) 2: 397-415.

Galvani, C. 1780. Della pietra fosforica Bolognese. 91 pp. Bologna.

Garman. 1670. Scolopendra lux innata. Misc. Acad. Nov. Curios., Dec. I, Ann I, 307.

Garnier, P. 1874. Apparitions lumineuses ou feux follets. La Santé Publique (of P. Garnier), Paris. N.S. 6 and 7th years, No. 49: 11-12.

Gassend, P. 1658. Opera omnia, 6 v. (Ludguni.) Vol. II. Chap. 7, pp. 107-117, De aurora borea.

Gassiot, J. P. 1858, 1859. On the stratifications and dark bands in electrical discharges in Torricellian vacua (Bakerian Lecture). Phil. Trans. 148: 1-16; Proc. Roy. Soc. 9: 146-150; Phil. Trans. 149: 137-160.

- 1860. On the application of electrical discharges from the induction coil to the purposes of illumination. Proc. Roy. Soc. 10: 432. 
- 1860. On the luminous discharge of voltaic batteries, when examined in carbonic acid vacua. Proc. Roy. Soc. 10: 393-404.

1862. Experimental investigations on the stratified appearance in electrical discharges. Effect obtained by varying the resistance. Proc, Roy. Soc. 12: 329 340. See also 11: 329-335, 1861 .

GeIssLeR, H. 1868. Neue Erfahrungen in Gebiete der elektrischen Lichterscheinungen. Ann. der Physik 135: 332-335.

Geoffroy, E. L. 1762, 1800. Histoire abrégée des insectes. 556 pp. Paris. Pp. 165-168 on lampyridae.

Gernez, D. 1905, 1908. Triboluminescence des composes métalliques. Com. Rend. Ac. Sci. 140: 1134, 1234, 1337; 147: 11.

GeSNER, C. 1555, 1669. De raris et admirandis herbis quae sive quod noctu luceant, sive alias ob causas, LunARIAE nominantur et obiter de alias etiam rebus, quae in tenebris lucent, Commentariolus. Tiguri, 1555. Editione hac secunda emendatior. 82 pp. Hafniae.

1558. Historiae animalium. Lib. IV, Tiguri. De piscium et aquatilium animantium natura.

1563. Tierbuch, including Fishbuch. Meerfaederen, p. 156; Pholades conchae, p. 149; Dactylus mas and foemina, p. 150.

Ghaye, M. 1856. Note sur la phosphorescence de la neige, observée le 5 decembre, 1855. Bull. Roy. Ac. Sci. de Belge (part 1) 23: 256-257.

GIARD, A. 1887. Sur un nouveau genre de lombriciens phosphorescents et sur l'espèce type de ce genre, Photodrillus phosphoreus Dugès. Com. Rend. Ac. Sci. 105: 872-874.

1889. On the phosphorescent infection of the Talitri and other crustaceans. Ann. Mag. Nat. Hist. (6) 4: 476-478.

1890. Les animaux et les vegetaux lumineux. Rev. Sci., Paris 45: 29-30.

Giard, A., and A. Billet, 1889. Observations sur la maladie phosphorescente des Talitres et autres cructaces. Com. Rend. Soc. Biol. 41: 593-597 and Com. Rend. Ac. Sci. 109: 503.

Giard, A. and A. Billet. 1890. Novelles recherches sur les bacteries lumineuses pathogènes. Com. Rend. Soc. Biol. (ser. 9) 2: 188-191.

GiEsbrecht, W. 1895. Ueber das Leuchten der pelagischen Copepoden und das tierische Leuchten im allgemeinen. Mitt. Zool. St. Neapel 11: 631-694. Ueber das Leuchten, 648-694.

GIESE, W. 1882. Experimentelle Beiträge zur Kenntniss vom electrischen Leitungsvermögen der Flammengase. Ann, der Physik 17: 1-41, 236-257, 519-550.

Giesel, F. 1899. Einiges über das Verhalten des radioactiven Baryts und über Polonium. Ann. der Physik 69: 91-94.

— 1903, 1904. Über den Emanationskörper aus Pechblende und über Radium. Ber. d. d. Chem. Ges. 36: 342-347; 37: 1696-1699.

Giglioni, E. H. 1870. La fosforescenza del mare. Note pelagiche ed osservazioni fatte durante un viaggio circumnavigazione 1865-68. Colla descriptione di du nuove noctiluche. Atti Accad. Torino 5: 485-505.

Gilchrist, E. 1923. The slow oxidation of phosphorus. Proc. Roy. Soc. Edinb. 43: 197-215.

Gillet-Laumont. 1791. Sur quelques propriétés des pierres calcaries, relativement à leur effervescence et leur phosphorescence. Jour. de Phys. 40: 97-101.

Gimmerthal, B. A. 1829. Observations sur la metamorphosis de quelques Dipteres de la famille des Muscides, et sur la phosphorescence d'une chenille de Noctuelle (Noctua occulta, L.). Bull. Soc. Imp. Nat. Moscow 1: 136-141. Also in Bull. Sci. Nat. 26: 101; and Ann. Soc. Ent. France 1832: 424. 
Gioanetri. 1780. Observations sur la source phosphorique de Fontane-more. Jour. de Phys. 15: 495-496.

Giobert, G. A. 1790. Sur le phosphorisme du Tartre vitriolé. (Rozier) Jour. de Phys. 36: 256-262.

Gmelin, L. 1848, 1849. Handbook of chemistry, translated by $\mathrm{H}$. Watts. London. 1: 181-208, on luminescence; 2: 116-117, on luminescence of phosphorus. First German ed., 1817-1819.

Godeheu DE Riville. 1760. Mémoire sur la mer lumineuse. Mém. de Math. et Phys. Acad. Roy. Sci, Paris 3: 269-276.

- 1768. Observations on a luminous appearance of the sea, with a curious description of the minute animals, which occasion it; with the description of two other very similar sea animals. Gentleman's Mag. 38: 408.

GöвEL, F. 1824. Leuchtende Entwickelung der Kohlensäure. Schweigger's Jour. für Chem. u. Phys. 40: 257-258.

GöPPELSRöDER, F. 1868. Über die fluoreszierende Substanz aus dem Kubaholz und über Fluoreszenzanalyse. Jour. f. Prakt. Chem. 104: 10-27; see also 101: 408-414, 1867.

GoEthe, J. W. von. 1810. Zur Farbenlehre, Historischer Teil II, Weimar. Phosphors with T. J. Seebeck.

Göttling, J. F. A. 1795. Etwas über den Stickstoff und das Leuchten des Phosphors in der Stickluft. (Gren) Neues Jour. der Physik 1: 1-15.

Goldsmith, O. 1774. An history of the earth and animated nature. 8 v. London. 2nd ed., 1805.

Goldstern, E. 1874, 1875. Über Beobachtung an Gasspestris. Monatsber. d. Berlin Akad., 593-610. Also in Phil. Mag. 49: 333-345; Ann. der Physik 154: 128-149.

1876. Vorläufige Mittheilungen über electrische Entladungen in verdünnten Gasen. Stizber. d. k. Ac. Wiss. Berlin, 279-295.

1877. Uber einige Erscheinungen in Geissler'schen Rohren. Sitzber d. k. Akad. d. Wiss. Wien 74 (Abt. 2) : 463-470.

1879. Uber die durch electrische Entladungen erregte Phosphorescenz. Sitzber. d. Ac. d. Wiss. Wien 80 (Abt. 2) : 151-156.

1880. Uber die Entladung der Electricität in verunnten Gasen. Ann. der Physik 11: 832-856; 12: 90-109. From Monatsber d. K. K. Acad. Sc. Berlin 1880: 82-106, 106-124. See Phil. Mag. (5) 10: 173-190, 234-247.

1880. Untersuchungen über die electrische Entladung in Gasen. I. Eine neue Art electrische Abstossung. 197 pp. Berlin.

1881. Uber den Einfluss der Kathodenform auf die Vertheilung des Phosphorescenzlicht. Wien Anzeiger 18: 12-14.

1881. Uber electrische Lichterscheinungen in Gasen. Ann. der Physik 12: 90-109, 249-279. From Monatsber. Berlin Akad., 1880.

1881. Uber Bandenspectrum der Luft. Ann. der Physik 15: 280-288. From Sitzber. d. Akad. d. Wiss. Wien 84 (Abt. 2) : 693-701, 1882.

1882. Uber den Einfluss der Kathodenform auf die Vertheilung des Phosphorescenzlichtes Geisslersche Röhren. Ann. der Physik 15: 254-277, 277-288. From Ber. Monatsber. Berlin Acad., 781-802, 1881. See also Phil. Mag. 14: 455-472.

1882. Uber den Zusammenhang zwischen Gasdichte und Schichtinterwal in Geissler'schen Röhren. Ann. der Physik 15: 277-288. From Monatsber. Ber. Akad. 876-878, 1881.

1885. Uber electrische Leitung im Vacuum. Ann. der Physik 24: 79.92. From Sitzber d. Berlin Acad. Wiss., 63-73, 1884.

1886. Uber eine noch nicht untersuchte Strahlungform an der Kathode inducierter Entladungen. Stizber. der K. K. Akad. d. Wiss zu Berlin 1886 (2): 691-699; reprinted in Ann. der Physik 64: 38-48. 
1892. Uber die sogenannte Schichtung des Kathodenlichts inducirter Entladungen. Sitzber. d. K. Akad. Berlin, 827-839.

1894, 1895. Über die Einwirkung von Kathodenstrahlen auf einige Salze. Sitzber. d. K. Acad. Berlin, 937-945; reprinted in Ann. der Physik 54: 371-380.

1895. Über die durch Kathodenstrahlen hervorgerufenen Färbungen einige Salze, Sitzber. d. K. Akad. Berlin, 1017-1024.

1897, 1899. Über die Structur des Kathodenlichts und die Natur der Lenard'schen Strahlen, Sitzber. d. K. Akad. Berlin 1897: 905-914. Ann. der Physik 67: 84-94.

1900. Uber die Phosphorescenz anorganischer Chemischer Preparate. Sitzber. d. k. Akad. der Wiss. Berlin, 818-828.

1902. Uber den Einfluss der Lichtbrechung auf Beobachtungen an Geissler'schen Röhren. Ann. der Physik 8: 94-102. From Verh. d. d. Phys. Ges. Jan. 24, 1902.

Gordon, J. E. H. 1880. A physical treatise on electricity and magnetism. London. 2 v. 2: $64-130$.

GoRE, G. 1861. On the origin and progress of the phosphorus and match industry. Chem. News and Jour. Phys. Sci. 4: 16-18, 31-32, 45-47, 77-79, 89-90.

Goudot, J. 1843. Insects nouveaux, observés sur le plateaux des Cordillères et dans les vallées chaudes de Nouvelles-Grenade, decrits par M. Guerin-Meneville, etc. Revue Zoologique (Paris), 12-22.

Gourret, P. 1883. Sur les Peridiniens du Golfe de Marseille. Ann. Mus. Hist. Nai. Marseille, Zool. 1: 1-144.

Graham, T. 1829, 1876. Observations on the oxidation of phosphorus. Quart. Jour. Science 2, 83-88; also Pogg Ann. der Physik 17: 375-380, and Chem. o Phys. Researches, 36-39.

Graham, W. P. 1898. Úber den Verlauf des Potential-gradienten in Geissler'schen Röhren. Ann. der Physik 64: 49-77.

Grailich, W. J. 1858. Krystallographisch-optische Untersuchungen. 226 pp. Wien und Almütz.

Granqvist, G. 1898. Quantitative Bestimmung über die Zerstäubung der Kathode in verdünnter Luft, Äfvers. Svensk. Vetensk. Ak. Förh. 55: 709:734.

Grant, R. E. 1827. Notice respecting the structure and mode of growth of the Virgularia and Pennatula. Edinb. Phil. Jour. 7: 330.

Graves, R. J. 1834-1835. Lectures on phosphorescence. Lond. Med. Surg. Jour. 6: 705-710.

1863. Phosphorescence. In Studies in Physiology and Medicine. London, pp. 47-54.

Gravesande, W. J. van's. 1731. Mathematical elements of natural philosophy. 6th ed., 2 v., 1747, trans. into English by J. T. Desaguliers. London.

GraY, S. 1720. An account of some new electrical experiments. Phil. Trans. 31: 104-107.

1735. Experiments and observations upon the light that is produced by communicating electrical attraction to animal and inanimate bodies together with some of its most surprising effect. Phil. Trans. 39: 16-24, 166-170.

GREEFF, R. 1882. Ueber die rosettenförmigen Leuchtorgane der Tomopteriden und zwei neue Arten von Tomopteris. Zool. Anz. 5: 384-387; Abs. in Jour. Roy. Micr. Soc. 2 (ser. 2): 780.

GREen, R. 1712. The principles of natural philosophy. $391 \mathrm{pp}$. Cambridge.

Greene, C. W. 1899. The phosphorescent organs in the toad fish. Porichthys notatus Girard. Jour. Morph. 15: 667-696.

Grecory, G. 1796. Economy of nature. 3 v. London. Chap. XXXVI, Phosphorus 2: $277-288$. 
Greiss, C. B. 1861, 1864. Über Fluorescenz der Auszüge aus den verscheidenen Theilen der Pflanzen. Ann. der Physik 114: 327-333; 123: 171-175.

GREw, 1681. Museum Regalis Societatis ... whereunto is subjoyned the comparative anatomy of stomachs and guts, 158. London.

Grimaldi, F. M. 1665. Physico-mathesis de lumine, coloribus et iride. Opus posthum. Bononiae, lib. I, prop. 42 , No. 19, p. 327.

Grimm, H. N. 1682. Vermes rari lucentes. Miscell. Curiosa, Decurae II, Ann. I, 406-407.

Griselini. 1750. Observations sur la scolopendre marine luisant. 14. Venise.

Grosser, M. DE. 1777. Phosphorescentia adamantum novis experimentis. Viennae.

— 1782. La phosphorescence du diamant. Jour. de Phys. 20: 270-283.

Grotthuss, T. von. 1807. Sur la combinaisons du phosphore avec les metaux et leurs oxides par la voie humide etc. Ann. de Chim. 64: 19-41. Pp. 38-41 on Lampyris light in gases.

- 1815. Über einen neuen Lichtsauger nebst einigen allegemeinen Betrachtungen über die Phosphorescence und die Farben. Schweigger's Jour. für Chemie u. Physik 14: 133-192. Also in Ostwald's Klassiker, No. 152.

- 1815. Beweis, dass bei der Phosphorescenz der Körper vermittelst Insolation ein wahres Lichteinsaugen im wörtlichen Sinne statt hat. Schweigger Jour. für Chemie und Physik 15: 172-199.

- 1821. Observations sur la phosphorescence du Lampyris italica, L. Ann. Gen. des Sci. Physiques, Bruxelles 8: 31-32.

Grube, A. E. 1861. Ausflug nach Triest und dem Quarnero, 79. 175 pp. Berlin.

Gruendler, G. A. 1774. Vom dem Leuchten der Eidechsen-Eier im Finstern. Der Naturforscher, Halle. Stück 3: 218-221.

Grummert, G. H. 1745. Danzig Memoirs 1: 417.

Gucci, P., and G. Grassi-Cristaldi. 1892. Sopra alcuni derivati della santonina. Gazz. Chim. Ital. 22 (1): 1-55.

GuÉneau De Montbeillard, P. 1782. Mémoire sur la lampyre ou ver luisant. Nouvelles memoires de Dijon (sem. 2), 80-98.

GUERICKE, O. voN. 1672. Experimenta nova (ut vocantur) madgeburgica, de vacuo spatio, etc. Amstelodami. Review in Phil. Trans. 7 (No. 88): 5103-5105. German translation in Ostwald Klassiker, No. 59.

Guillemin, A. V. 1873. The force of nature, trans. by Mrs. N. Lockyer from the French, Le Phénomènes de la physique, 1868, Paris. Phosphorescence, pp. 386-393.

Guinchant. 1905. Sur la triboluminescence de l'acide arsenieux. Com. Rend. Ac. Sci. 140: 1170 .

Günther, A. 1880. An introduction to the study of fishes. Chap. XXI on the fishes of the deep sea, 296-311. 720 pp. Edinburgh.

- 1887. Report on the deep-sea fishes collected by H. M. S. Challenger during the years 1873-76. Challenger Reports, Zoology 22. $335 \mathrm{pp}$.

GüNTHER, S. 1904. Das Polarlicht im Alterum. Beiträg. zur Geophysik, Ztschr. f. physik. u. Erdkunde 6: 98-107.

Guyton-Morveau. 1814. Sur quelque cas d'ejection d'urine phosphorescente. Ann. de Chimie 89: 182-190. Trans. in Ann. der Physik 49: 291-297.

HAASE, E. 1888. Zur Kenntniss von Phengodes. Dtsch. Ent. Ztschr. 32: 145-167.

HABER, F., and W. Zisch. 1922. Anregung von Gasspektren durch chemische Reaktionen. Ztschr. für Physik 9: 302-326.

HablizL. 1789. Leuchtende Tiere im und um den Kaspischen. See Lichtenberg's Mag. f. d. neuste d. Physik u. Naturges, Neue Aufl. 2: 159.

Hagen, H. A. 1873. Notes on the ephemeridae. Trans. Roy. Ent. Soc. Lond., 399. 
Hagenbach, E. 1869. Untersuchung der optischen Eizenschaften des Blattgrüns. Ann. der Physik 141: 245-275.

1872. Versuche über Fluorescenz. Ann. der Physik 146: 65-89, 232-257, 375-405, 508-538.

1874. Ferner Versuche über Fluorescenz. Ann. der Physik (Jubelb.), 303-314.

1877. Ueber das Aufleuchten, die Phosphorescenz und Fluorescenz des Fluss. pathes. Ber.d.d. chem. Ges. 10: 2232.

1879, 1883. Das Stokes'sche Gesetz. Ann. der Physik 8: 376-400; 18: 45-56.

Hahn, D. 1874. Die Phosphorescenze der Mineralien. Dissertation. Halle.

Hales, S. 1748. Concerning some electrical experiments. Phil. Trans. 45: 409-412.

HaLle, J. S. 1788-1801. Fortgesetzte Magic, oder die Zauberkräfte der Natur. 12 v. Berlin (Pauli).

Halley, E. 1716. An account of the late surprising appearance of the lights seen in the air, on the sixth of March last; with an attempt to explain the principle phenomena thereof. Phil. Trans. 29: 406-428 (No. 347) ; 159-164 (No. 341).

Hamberger, G. E. 1727. Elementa physices. 433 pp. Ienae.

Hamlion, Wm. 1795, 1800. An account of the late eruption of Mount Vesuvius. Phil. Trans. 85: 73-116; also in Ann. der Physik 5: 408-455; 6: 21-52.

HAMmer, W. J. 1903. Radium and other radioactive substances . . phosphorescent and fluorescent substances, etc. $72 \mathrm{pp}$. New York.

Hanckewitz, A. G. 1733. An account of some experiments upon the phosphorus urinae, which may serve as an explanation of those shewn to the Royal Society by Dr. Frobenius in Nov. 18, 1731, together with several observations tending to explain the nature of that wonderful chemical production. Phil. Trans. 38: 58-70.

Hankel, W. G. 1862. Notiz über phosphorische Leuchten des Fleisches. Ann. der Physik (ser. 4) 25: 62-70. Also Dtsch. Chem. Ges. 13: 5-12, 1861; and Jour. Prakt. Chem. 83: 153-161, 1861 .

Hannemann, J. L. 1697. Sur le phosphore d'urine. Translation in Collec. Acad Etranger 6: 336 from Ephemerides, Dec. III, An. IV.

Harker, A. 1888. On a luminous oligochaete (Enchytraeus). Rep. Brit. Assoc. Adv Sci., Manchester, 1887, 767.

HarRis, J. 1704. Lexicon technicum or a universal English dictionary of arts and sciences, explaining not only the terms of art but the arts themselves. $1220 \mathrm{pp}$. London.

Hartig, G. 1861. The sea and its living wonders (trans. from 4th German ed. by the author). 427 pp. The phosphorescence of the sea, pp. 326-334.

HArtig, R. 1873. Vorläufige Mittheilung über den Parasitismus von Agaricus melleus und dessen Rhizomorphen. Bot. Zeitung 31: 295-297; 353-357.

Hartig, T. 1855. Ueber das Leuchten des weissfaulen Holzes. Bot. Ztg. 13: 148-149.

Harting, P. 1852. Het Lichten van Dieren. In Album der Natur (Te Haarlem). 225-250, translated as Das Leuchten der Thiere, by J. E. A. Martin in Skizzen aus der Natur, 1854.

HaRtLey, W. N. 1892. Observations on the origin of colour and on fluorescence. Jour. Chem. Soc. 63: 243-256.

Hartmann. 1760. Recueil de pieces sur l'usage interne du phosphòre. Dissertation. Halle.

Hartsoeker, N. 1706, 1708. Conjectures physiques. $371 \mathrm{pp}$. Amsterdam. Suites des conjectures, 1708.

- 1710, 1712. Eclaircissements sur les conjectures physique. Paris.

Harvey, E. N. 1916. The mechanism of light production in animals. Science 44: 208-209. 
1916. On the production of light by certain substances in the presence of oxidases. Amer. Jour. Physiol. 41: 454-464.

1920. The nature of animal light. Philadelphia. For bibliography.

1940. Living light. Princeton. For bibliography.

1940. Benjamin Franklin's views on the phosphorescence of the sea. Proc. Amer.

Philos. Soc. 83: 341-348.

1951. Phosphorescence of the sea. Answer No. 2 to Query 117. Isis 42: 142-143. 1952. Bioluminescence. $646 \mathrm{pp}$., with bibliography of 1800 titles (1800-1950). New York.

Hassal, A. H. 1841. Supplement to a catalog of Irish zoophytes. Ann. Mag. Nat. Hist. (1) 7: 276-287.

Hasselberg, B. 1879. Über das durch electrische Erregung erzeugte Leuchten der Gase bei niedriger Temperatur. Mém. de l'Acad. Imp. de Sci. St. Petersbourg (7) 27, No. 1: 1-17. Also as book, St. Petersbourg, 1878.

1880. Uber die Spectra der Cometen und ihre Beziehung zur denjenigen gewisser Kohleverbindungen. Mém. de l'Acad. Imp. de Sci. St. Petersbourg (7) 28, No. 2, $94 \mathrm{pp}$.

1881, 1882. Zur Spectroscopie des Wasserstoffs. Bull. de l'Acad. Imp. de St. Petersbourg 27: 97-110 and Mémoires (7) 30, No. 7.

1881. Beitrage zur Spectroscopie der Metalloide. Bull. de l'Acad. Imp. de Sci. St. Petersbourg 27: 405-417.

1882. Bemerkung zu Hrn. Wüllner's Aufsatz: Ǔber die Spectra des Wasserstoff und des Acetylens. Ann. der Physik 15: 45-49.

— 1885. Zur Spectroscopie des Stickstoffs. Mém. de l'Acad. Imp. de Sci. St. Petersbourg (7) 32, No. 15, 50 pp.

Haswell, W. A. 1882. On the structure and functions of the elytra of the Aphroditean Annelids. Ann. Mag. Nat. Hist. (ser. 5) 10: 238-242; and Jour. Roy. Micr. Soc. (ser. 2) 2: 779-780.

Hauch, A. W. von. 1795. Beschreibung einiger mit Phosphor angestellten Versuche, etc. (Gren) Neues Jour. der Physik 1: 20-35.

Hauksbee, F. 1705. Experiments on the production and propagation of light from the phosphorus in vacuo. Phil. Trans. 24: 1865-1866.

- 1705. Several experiments on the mercurial phosphorus. Phil. Trans. 24: 21292135.

1706, 1707. An experiment touching the production of a considerable light upon a slight attrition of the hands on a glass globe exhausted of its air; with other remarcable occurances. Phil. Trans. 25: 2277-2282. See also 2372-2377.

1709. Physico-mechanical experiments on various subjects containing an account of several surprising phenomena touching light and electricity, producible on the attrition of bodies. 194 pp. London. 2nd ed. 336 pp., London, 1719.

Hausen, C. A. 1743. Novi profectus in historia electricitatis. Lipsiae.

HaÜY, R. J. 1787. Exposition raisonnée de la theorie de l'électricité et du magnétisme, d'apres les principles de M. Aepinus. 122 pp. Paris.

— 1801. Traité de minéralogie, 5 v. Paris. 1: 235, 273, 512-521.

— 1817. Traité des charactères physiques des pierres précieuses. $253 \mathrm{pp}$. Paris.

HАYЕK, G. von. 1869. Über phosphorescirende Naturkörper. Schriften des Vereins zur Verbreitung naturwiss. Kenntnisse, Wien 8: 313-336.

Heinemann, C. 1872. Untersuchungen über die Leuchtorgane der bei Vera-Cruz vorkommenden Leuchtkäfer. Arch. Mikr. Anat. 8: 461-471.

- 1886. Zur Anatomie und Physiologie der Leuchtorgane mexikanischer Cucujos. Arch. Mikr, Anat. 27: 296-382. 
Heinrich, P. 1808. Von der Natur und den Eigenschaften des Lichtes, 1-287. St. Petersburg. Prize essay.

1811-1820. Die Phosphorescenz der Körper nach alle Umständen untersucht und erläutert. Nürmberg (bei Schrag) $595 \mathrm{pp}$. 1st Abhandlung 1811 Phosphorescenz durch Licht, 1-132. 2nd Abhand. 1812, Phosphorescenz durch Temperaturerhohlung, 133-312. 3rd Abhand. 1815 Daz Leuchten des Pflauzen und Thieren, 313-424. 4th Abhand. 1820, Phosphorescenz durch mechanische Erregung 425-570. 5th Abhand. 1820, Leuchten bei chemischer Mischung, 573-596. Also Jour. für Chem. u. Physik 30: 218-239, 1820.

1812. Traité de la phosphorescence des corps. Jour. de Physique 74: 307-315.

1815. Uber Phosphorescenz im Pflanzen und Tierreich (a letter to Schweigger). Schweigger's Jour. für Chem. u. Physik 13: 266-273.

1820, 1821. Ueber Phosphorescenz durch Bestrahlung. Schweigger's Jour. für Chem. u. Physik 29: 101-135 and Quart. Jour. Sci. 11: 399-401.

1820. Ueber die durch äussere Temperaturerhöhung der Körper bewickte Phosphorescenz. Schweigger's Jour. für Chem. u. Physik 29: 450-474.

- 1820. Von dem Leuchten vegetabilischer und animalischer Substanzen. Schweigger's Jour. für Chem. u. Physik 30: 218-239.

HelBiG, R. 1805. Merkwürdige Beobachtungen am Johanniswürmchem Lampyris noctiluca. Mag. für den Neuste Zustand d. Naturkunde, Weimar 9: 166-168.

Heller, J. F. 1843. Leuchten gefaulter Hölzer. Deutsch. Naturf. Versamml. Berlin. 1853. Ueber das Leuchten im Pflanzen- und Tierreiche. Arch. physiol. Pathol. Chem. Mikr. 6: 44-54, 81-90, 121-137, 161-166, 201-216, 241-251.

Hellot, J. 1740. Le phosphore de Kunckel. Mém. Acad. Sci. Paris, 342-378, 1737.

Helmheim, A. 1896. Leuchtende Entwickler. Photogr. Archiv. 37: 203-205; also Fortschr. d. Phys. 52, 2: 76.

Helmholtz, H. von. 1855. Über die Empfindlichkeit der Menschlichen Netzhaut für die breckbarsten Strahlen des Sonnenlichts. Ann. der Physik 94: 205-211.

Helmholtz, R. von and F. Richarz. 1890. Über die Einwirkung chemische und electrischer Processe auf den Dampfstrahl und über die Dissociation der Gase, inbesondere des Sauerstoffs. Ann. der Physik 40: 161-202.

Helmont, J. B. van. 1707. Opera omnia. Magnum oportet, pp. 143-155.

Helvig. 1815. Einige Gedanken über das Leuchten des Meerwassers. Ann. der Physik 50: $126-128$.

- 1815. Einige Versuche mit gläsernen sogenannten Knallbomben. Ann. der Physik 51: 112-115.

Henckel, J. F. 1740. Sudor phosphorescens, materiae phosphori argumentum. Acta physico-medica. Acad. Caesar. Leopoldini-Car. Nat. Curios. 5: 332-336. Norimbergae. Also in Minerologische und Chemische Schriften, 601.

- 1744. Kleine mineralogische Schriften, p. 99. St. 7, p. 605 (1756). Dresden und Leipzig.

— 1784. Von einem phosphorescirenden Schweiss. Crell's Neues Chemisches Archiv. 1: 291-292.

— 1794-1795. Minerologische, Chymische and Alchymistische Briefe, etc. 3 v. Dresden.

Henderson, J. 1828. On the luminous appearance of the ocean. Edinb. Jour. Sci. 8: $167-169$.

Henneberg, W. 1846. Notiz über das Zircon. Jour. Pract. Chem. 38: 508-510.

1899. Leuchtbakterien als Krankheitserreger bei Schwammücken. Zbl. Bakt. (Abt. I) 25: 649-650. 
HeNNEguy, L. F. 1888. Influence de la lumière sur la phosphorescence des noctiluques. Com. Rend. Soc. Biol. 5 (ser. 8) : 707-708.

Henning. 1724. Von einigen Insectis oder Ungeziefer; II. Von den Cincindelis oder Johanniswürmlein. Breslau Natur- $u$. Kunstgeschichte, Vers. 30, 514-517.

Hennings, P. 1904. Úber leuchtende Hutpilze. Naturwiss. Wochsch. 3: 570-571.

Henry, C. 1892, 1893. Preparation nouvelle et photometrie du sulfure du zinc phosphorescent. Com. Rend. Ac. Sci. 115: 505-507, 811-814; 116: 98-99.

1896. Utilité en radiographie d'ecrans au sulfure de zinc phosphorescent, emission par les vers luisants, de rayons traversant le papier aiguille. Com. Rend. Acad. Sci. 123: 400-401.

— 1896. Augumentation du rendement photographique des rayons Röntgen par le sulfure de zinc phosphorescent. Com. Rend. Ac. Sci. 122: 312-314.

Henry, J. 1843. On phosphorogenic emanation. Proc. Amer. Philos. Soc. 3: 38-44.

Herbert, J. E. von. 1773. Dissertatio de igne, etc. 178 pp. Viennae.

Hermann, K. S. L. 1824. Uber den Kaligehalt meherer Salinen, und die Umbildung des Salzgehaltes derselben; über Gewinnung des Nickels im Grossen und über Lichterscheinungen bei Krystallisationem. Schweigger's Jour. für Chem. u. Phys. 40: $70-75$.

HERмBSTÄDT, S. F. 1808. Bemerkungen über das Leuchten organischer Körper im Leben und nach dem Tode derselben. Magazin (d. Naturf. Freunde) f. d. neuesten Entdeckungen i.d. Naturkunde 2: 248-256.

Herschel, A. S. 1899. Triboluminescence. Nature 60: 29.

Herschel, J. F. W. 1823. On the absorption of light by colored media and on the colours of the prismatic spectrum exhibited by certain flames; with an account of a ready mode of determining the absolute dispersive power of any medium, by direct experiment. Trans. Roy. Soc. Edinb. 9: 445-460.

1828. On the theory of light. London.

1845. On a case of superficial colour presented by a homogeneous liquid, internally colourless. Phil. Trans., 143-145.

1845. On the epipolic dispersion of light. Phil. Trans., 147-153.

Hertz, H. 1883. Versuche über die Glimmentladung. Ann. der Physik 19: 782-816.

— 1892. Uber den Durchgang der Kathodenstrahlen durch rünne Metalschichten. Ann. der Physik 45: 28-32.

Herz, A. 1895. Zur Kenntniss des Potentialgradienten im positiven Theil der Glimmentladung. Ann. der Physik 54: 244-264.

Heumann, K. 1882. Verbrennung der Schwefel mit weisser Phosphorescenzflamme. Ber. d. d. Chem. Ges. 16: 139-144.

Heusinger, J. M. 1716. De noctiluca mercuriali sive de luce quam argentum vivun in tenebris fundit. Gissae.

Higgins, B. 1776. A philosophical essay concerning light. 2 v., 256 pp. London.

Hildegard, Saint. 1150-1160. Physica. Der Aebtissin St. Hildegardis Myst. Tier-u. Artzneyen-Buch. trans. into German by Alfons Huber, 1927. P. 91, Kapitel LXX, De Glimo.

HiLl, J. 1774. Theophrastus' History of Stones. Greek, with English translation and copious footnotes. 2nd ed. London. 1st ed., 1746.

Hittorf, W. 1869-1884. Über die Elektricitätsleitung der Gase. Pogg. Ann. der Physik 136: 1-30, 197-234; Jubeland, 430-444; Wied Ann. der Physik 7: 553-630; 20: 705755; 21: 90-139.

Hoffmann, F. 1675. Clavis Pharmaceutica Schröderiana. Hale Saxonum. Lapis Bononiensis, 191-192. 
- 1700. Demonstrations physicae curiosae experimentis et observationibus mechanicis ac chymicis illustratae. $59 \mathrm{pp}$. Magdeburgicae.

1736. Observationum Physico-Chymicorum selectorum, libri III. Halle Lib. III, Obs. XIV. Experimenta circa Phosphorum Anglicanum.

Hoffmann, M. W. 1897. Über Entladungsstrahlen und einige Beziehungen derselben zu den Kathodenstrahlen und Röntgenstrahlen. Ann. der Physik 60: 269-299.

HofmanN, C. G. 1750. Erfahrungen vom Leuchten der Scharfenbergen Blende in einen Briefe an Prof Kastern, mitgetheilt. Hamburgisches Mag. 5: 288-306, 441-443; oder Gesammlete Schriften.

HoH, T. 1868. Zur Geschichte der Fluorescenz. Ann. der Physik 131: 658-659.

Holder, C. F. 1887, 1892. Living lights. 179 pp. London. Also in Marvels of animal life series, $127 \mathrm{pp}$. New York.

Holstius (Holst), J. 1667. De flammula cordis epistola, Hafniae. See T. Bartholin.

Homberg, W. 1693. Nouveau phosphore. Mém. de l'Acad. Roy. des Sci. 10: 445-448, 1730.

Hооке, R. 1678. Lectiones Cutlerianae. Reprinted in facsimile as Vol. VIII of Early science in Oxford by R. T. Gunther, 270. Oxford, 1931.

1705. The posthumous works of Robert Hooke, M. D., S. R.S. London. See also W. Derham (1726) .

HoRne, C. 1869. Note on the phosphorescence of the lobster after death. Zoologist (ser. 2) 4: 1725-1726.

Hort, W. P. 1848-1849. An application of the philosophy of various terms of matter, and the laws of motion, to the explanation of the phosphorescence or luminosity of animals, plants and gems. N. Orl. Med. Surg. Jour. 5: 728-743.

Hoyle, W. E. 1885. Phosphorescence. Encyclop. Brit., 9th and 10th ed., 18: 813-814. Also, Trans. Manch. Micr. Soc. 1890: 1-18.

Hudson, G. V. 1886. A luminous insect-larva in New Zealand. Ent. Mon. Mag. 23: 99-100.

Hulme, N. 1800. Experiments and observations on the light which is spontaneously emitted, with some degree of permanency, from various bodies. Phil. Trans. Roy. Soc. 90: 161-187.

1801. A continuation of the experiments and observations on the light which is spontaneously emitted from various bodies with some experiments and observations on solar light, when imbibed by Canton's phosphorus. Phil. Trans. Roy. Soc. 91: 403-326.

Humboldt, A. von. 1799. Versuche über die chemische Zerlegung des Luftkreises und über einige andere Gegenstände der Naturlehre. IX Über die Entbindung des Lichtes, 193-235. Braunschweig.

1849. Views of nature. Translated from the first German edition 1849 by F. C. Otté and H. G. Bohn, London, 1875. Pp. 245-250 on phosphorescence of the sea.

1853. Personal narrative of travels to the equinoctial regions of America during the years 1799-1804. Trans. by Thomasina Ross, London. 3 v. Light of sea, 1: $27-28 ; 3: 113,147,151$.

Huxley, T. H. 1855. On the structure of Noctiluca miliaris. Quart. Jour. Micr. Sci. 3: $49-54$.

Hyndman, H. H. F. 1898. Radiation. 307 pp. New York. See pp. 152-287.

IdELER, J. L. 1822. Über den Ursprung des Feuerkugeln und des Nordlicht. 98 pp. Berlin.

IlLiger. 1807. Monographie der Elateren mit leuchtenden Flecken auf dem Halsschilde. Ges. Nat. Freunde Mag. Berlin 1: 141-152. 
INCE, J. 1853, 1858. On the discovery of phosphorus. Pharm. Jour. (1) 13: 280-282. See also 18: 126-130, 157-162, 215-222.

Isidore of Seville. 1911. Isidori Hispalensis episcopi Etymologiarum sive Originum, libri XX. 2 v. W. M. Lindsay ed. Oxford.

Ives, H. E., and W. W. Coblentz. 1910. Luminous efficiency of the fire-fly. Bull. U.S. Bur. Stand. 6: 321-336. Also in Proc. 3d Ann. Convent. Illum. Engr. Soc., Sept. 30, 1909 , N.Y.

Jablonski, J. T. 1721. Allgemeines Lexicon der Künste u. Wissenschaften. Leipzig. 2nd ed., 1748, 1568 pp., 1 v. 3rd ed., 1767, 1852 pp., 2 v.

JACKSON, H. 1894. Observations on the nature of phosphorescence. Jour. Chem. Soc. 65: $734-744$.

1898. On phosphorescence. Phil. Mag. (5) 46: 402-414.

Jacobaeus, O. 1677-1679. De phosphoro hermetico et sepiae luce. Acta Medica et Philosophica Hafniensia 5: 282-283.

Jallabert, J. 1748. Experiences sur l'électricité. 303 pp. Geneve. See pp. 26-64, 215247.

Jamin, J. C., and E. M. L. Bouty. 1878-1883. Cour de Physique, 3rd ed. 4 v. Paris. 3: 150-179. De la transformation des radiations, 1881.

Jaumann, G. 1894, 1895. Zur Kenntniss des Ablaufs der Lichtemission. Ann. der Physik 53: 832-840; 54: 178-180.

JHERING, H. von. 1887. Uber eine merkwürdige leuchtende Käferlarvae. Berlin Entom. Zeit. 31: 11-16.

Joнn, I. F. 1817. Bemerkungen über die Lichtmagnete. Ann. der Physik 55: 453-460.

Johnson, G. 1847. A history of the British zoophytes. 2nd ed. 2 v. 1: 150-155, on phosphorescence. 1st ed., 1838.

Jonston, J. 1633. Thaumatographia naturalis in classes decem divisa in quibus admiranda, etc. 2nd ed. Amstelodami. Ist ed., 1632. 1653. Historia naturalis. De insectis. Lib. III Frankfort a.m., 200 pp. Lib. I Cap. VIII: De cucujo, pp. 107-108; Cap. IX: De cicendula, pp. 108-110.

1657. An history of the wonderful things of nature set forth in ten severall classes, rendered into English by a person of quality. London.

JORRISSEN, W. P. 1948. The use of phosphorescent calcium sulfide by the baccantes. Jour, Chem. Educ. 25: 685-686.

Josselyn, J. 1673. New England rarities discovered in birds, beasts, fishes, serpents and plants of that country, etc. London. Reprinted in Trans. and Collec. of Amer. Antiquarian Soc. 4: 134-238, 1860.

Joubert, J. 1874. Sur la phosphorescence du phosphore du soufre et de l'arsenic. Com. Rend. Ac. Sci. 78: 1853-1855.

1874. Thèses sur la phosphorescence du phosphor, published in Ann. Science de l'Ecole Normal, Supp. 3.

Joubin, L. 1893. Recherches sur l'appariel lumineux d'un cephalopode; Histioteuthis Ruppellii, Verany. 32 pp. Rennes. Bull. Soc. Sci. Méd. Ouest Rennes 2: 49-78. Also Com. Rend. Soc. Biol. 44: 142-146.

1894. Nouvelle recherches sur l'appareil lumineuse des cephalopodes du genre Histioteuthis. Bull. Soc. Sci. Med. Ouest Rennes 3, July 6.

Jourdan, Et. 1885. Structure des élytres de quelques Polynoës. Zool. Anz. 8: 128-134. Juch, Dr. 1799. Luminous appearance produced by sugar. Phil. Mag. 5: 207-208.

Juhling, J. 1900. Die Tiere in deutsches Volksmedezin alter und neuer Zeit. Mittweida.

Jurine. 1813. Lettre de M le Dr Jurine sur un cas d'ejection d'urine phosphorescente. Jour. Gen. de Med. Chir. et Pharm., Paris 48: 48-51. 
KAEMPFER, E. 1727. The history of Japan etc. together with a description of the Kingdom of Siam, etc. by Sir Hans Sloane. French translation, 1729. German transiation, 1779.

KALÄHNE, A. 1898. Über die Spectra einiger Elemente bei der stetigen Glimmladung in Geisslerschen Röhren und die Abhängigkeit der Lichtstrahlung von Stromstärke und Druck. Ann. der Physik 65: 815-848.

Kanda, S. 1939. The luminescence of a Nemertean, Emplectonema Kandai, Kato. Biol. Bull. 77: 166-173.

KanN, L. 1899. Radiation phenomena of the Balmain luminous paint. Phys. Rev. 8: $250-251$.

KAstner, K. W. G. 1826. (Luminous urine) a foot-note to the C. L. Esser paper. Kastner's Arch. f. die gesamte Naturlehre 8: 406.

KATZ, O. 1887. Preliminary remarks on phosphorescent bacteria from sea water. Proc. Linn. Soc. N. S. W. (ser. 2) 2: 331-336.

1891. Zur Kenntniss der Leuchtbakterien. Zbl. Bakt. 9: 157-163; 199-204; 229234; 258-264; 311-316; 343-350.

Kauffmann, H. 1906. Die Beziehung zwischen Fluorescenz und chemische Konstitution. 102 pp. Stuttgart.

Kayser, H. 1896. Ueber die Spectren des Argon. Sitzungsber. d. k. Akad. d. Wiss., Berlin, 451-464.

- 1900. Geschichte der Spectroscopie, in Handbuch der Spectroscopie 1: 3-130 (Chap. I).

1900. Die Erzeugung leuchtender Dämpfe. in Handbuch der Spectroscopie Vol. 1, Chap. 2, Sect. 3. Electrische Entladungen. Untersuchungen von Gasen, pp. 230-252.

- 1902. Flammen. Handbuch der Spectroskopie. Vol. 2, Chap. 3, Sec. 113-115. Strahlung der Gase. Electrisch erregte Gase, Sec. 113-128, pp. 164-184.

- 1908. Handbuch der Spectroskopie, Leipzig. Phosphorescence, 4: Chap. 5, pp. 599-838. Fluorescence by $\mathrm{H}$. Konen 4: Chap. 6, pp. 841-1214.

Kester, F. E. 1899. A method for the study of phosphorescent sulphides. Phys. Rev. 9: $164-175$.

Ketteler, E. 1882. Eine Bemerkungen zu Arbeiten der Herren Lommel, Glasebrook, und Mathieu. Ann. der Physik 15: 613-623.

Khvorostansky, C. 1892. Sur la lumination des animaux de la mer Blanche. Congr. Intern. Zool., Moscou, 1892, 2 sess., pt. 4: 185-186.

Kikinger, F. J. 1759. De phosphoro anglicano, chymice et medice considerato, etc. 14 pp. Ingolstadt.

KindT, G. C. 1867. Phosphorescenzlicht. Ann. der Physik 131: 160.

Kirby, W., and W. SPEnce. 1817. An introduction to entomology. On luminous insects 2: Letter XXV, pp. 408-429.

Kircher, A. 1641. Magnes, sive de arte magnetica tripartitum, 481. Rome. 2nd ed. Coloniae Agrippinae, 798 pp., 1643.

1646, 1671. Ars magna lucis et umbrae in X libros digcsta, etc. 935 pp. Rome. In liber 1, pars 1 , caput 8 , De photismo lapidum. De lapide Phenggite, seu phosphoro minerali. Amstelodami in 1671.

— 1678. Mundus subterraneus in XII libros digestus, etc. 507 pp. Amstelodami. 1st ed., 1664.

Kirchioff, G., and R. Bunsen. 1860, 1861. Chemische Analyse durch Spectralbeobachtung. Ann. der Physik (4) 20, 110: 161-189; (4) 23, 113: 338-381.

Kirchmaier, G. K. 1676. Noctiluca constans et per vices fulgurans diutissime quaesita, nunc reperta; dissertatione brevi praevia de luce, igne ac perennibus lucernis, Wittebergae. 
1680. De phosphoris et natura lucis nec non de igne. $72 \mathrm{pp}$. (Dissertation.) Wittenberg.

KIRN, C. 1894. Uber die Aehnlichkeit der Lichtemission einer Nachleuchtenden Geissler'schen Röhre mit dem Beginn des Glühen fester Körper. Ann. der Physik 52: 381-384.

KIRWAN, R. 1788. An essay on the variations of the barometer. Trans. Royal Irish Ac. Sci., 68 and 72.

Klatt, V., and P. Lenard. 1889. Ueber die Phosphorescenzen des Kupfers, Wismuths und Mangans in den Erdalcalien. Ann. der Physik 38: 90-107.

KLETwich, J. C. 1688. Dissertatio de phosphoro liquido et solido. 56 pp. Frankfurt a.O.

KNECHT, C. 1882. Beziehung zwischen Fluorescenz und chemischer Constitution der organischen Verbindungen. Dissert. Zurich. See Ber. d. d. Chem. Ges. I5: 348$362,1068-1072,1377-1378$.

KNight, T., 1749. Reflections upon Catholicons ... and the luminous emanations from human bodies. London, $116 \mathrm{pp}$.

Knoblauch, O. 1895. Über die Fluorescenz von Lösungen. Ann. der Physik 54: 193-220.

Kobert. 1881. Das Leuchten der lebenden und todten Substanzen. Deutsche med. Wochensch. 7: 428-430.

Koch, K. R. 1889. Über das Spectrum der Gase bei tiefen Temperaturen. Ann. der Physik 38: 213-216.

Koch, W. E. 1882. Notes on the luminosity of sea water taken on the west coast of Norway from Sept. 1881 to April 1882. Ann. Mag. Nat. Hist. (ser. 5) 10: 176-178.

Kölliker, A. von. 1853. Eigenthumliche Hautorgane u. Wirbel von Chauliodus. Ztschr. Wiss. Zool. 4: 366-367.

—_ 1858-1859. Ueber die Leuchtorgane von Lampyris; Eine vorläufige Mittheilung. Mber. Preuss. Akad. Wiss., 392; also in Verh. Würzburg Phys. Med. Ges. 8: 217224; 9: 28-29; Quart. Jour. Micr. Sci. 6: 166-173.

Konen, H. 1908. Fluorescence, in H. Kayser, Handbuch der Spectroscopie 4: 843-1214.

Kortum, K. von. 1794. Resultate einer Reihe electrische phosphorische Eigneschaft verscheidener Körper zu beobachten. Lichtenberg-Voigt's Mag. f. d. Neuste an der Physik u. Naturgesch. 9: 1-44.

— 1800. Ueber die Phosphorescenz vegetabilischer, in Fäulniss gehender, Körper. Voigt's Mag. Neuest Zust. Naturk. 2: 67-70.

KRAFFT, F. 1888. Úber einige hochmoleculare Benzolderivate II. Ber, d. d. Chem. Ges. 21: $2265-2271$.

KrafFT, W. L. 1777. Expérience sur le phosphore sulphuréocalcaire de Mr. Canton. Acta Acad. Scient. Imp. Petropol. 1: 77-79.

Kratzenstein, C. G. 1754. Om adskillige legemers phosphorescentz samt aarsagen til Samme etc. Skrift. Kiöblh. Selsk. 6.

Kreutz, F. 1895. Steinsalz und Fluorit, ihre Farbe, Fluorescenz und Phosphorescenz. Anz. d. Acad. d. Wiss. Krakau, 118-127. Abs. in Fortschr. d. Phys. 51 (2) : 99, and 55 (2) : 106.

Krukenberg, C. F. W. 1887. Neue Tatsachen für eine vergleichende Physiologie der Phosphorescenzerscheinungen bei Thieren und bei Pflanzen. Vergl. Physiol. Studien, Experimentelle Unterschungen II Reihe, 4 Abt., Heidelberg, pp. 77-141.

Kunl, H. 1822. Reizbarkeit und Phosphorescenz der Pyrosomen. Schweigger's Jour. für Chem. u. Physik 34: 363-364.

Kunnt, P. 1907. Das Leuchten der Lampyriden. Ent. Wochenschrift 24: 3-4.

Kunckel (Kunkel) von Löwenstern, J. 1678. Oeffentliche Zuschrift von dem Phosphor mirabili, etc. 67 pp. Leipzig. 
- 1716. Collegium Physico-Chymicum Experimentale, odor Laboratorium Chymicum etc. 737 pp. Hamburg \& Leipzig.

Kunz, G. F. 1894, 1895. On phosphorescent diamonds. Trans. New York Acad. Sci. 14: 260; Fortschr. d. Phys. 51 (2): 100.

1913. The curious lore of precious stones. $406 \mathrm{pp}$. Philadelphia and London. Chap. V, pp. 143-175, On ominous and luminous stones.

KusNezoFf, I. D. 1890. On the luminescence of diptera. (In Russian.) Westn. Estestwasnanijo St. Petersburg No. 4: 167-171.

LABAT, J. B. 1724. Nouveau voyage aux isles de l'Amérique, contenant l'histoire naturelle de ces pays. . . La Haye. See pp. 117-118 for Pyrophorus.

Labillardière, J. J. H. DE. 1791. Relation du voyage à la recherche de la Pérouse, etc. 2 v. Paris. 1: $44,63,431$.

Laborde, M. 1869. Phosphoroscope electrique. Com. Rend. Ac. Sci. 68: 1576.

LACHowIEZ, B. 1882. Über die Einwirkung von phosphorchloriden auf phenanthrenchinon. Ber, d. d. Chem. Ges. 16: 330-333.

LACORDAire, J. 1834, 1838. Introduction à l'entomologie. (Suites a Buffon.) 2 v. Paris. Matière phosphorique, pp. 140-150.

LAET, J. DE. 1647. De gemmis et lapidibus libri duo, quibus praemittitur Theophrasti liber de lapidibus. Lugduni Batavorum. 210 pp. Book II, Chap. 31, De lapide Bononiensi.

Lagalla, G. C. 1612. De phenomenis in orbe lunae Novi telescopii usu a Galilaeo nunc iterum suscitatis, physica disputatio. Nec non de luce et lumine altera disputatio. $72 \mathrm{pp}$. Ventiis.

LAGARDE, H. 1885. Recherches photométrique sur les spectre de l'hydrogène. Ann. de Chim. (6) 4: 248-370. Also Com. Rend. Ac. Sci. 95: 1350-1352, 1882.

Lallemand, A. 1869, 1870. Recherches sur l'illumination des liquids par un faisceau de lumière neutre ou polarisée. Com. Rend. Ac. Sci. 69: 189-193, 282-284, 917-920, 1294-1296; Ann. de Chim. (4) 22: 200-234.

Lamansky, S. 1879. Sur la loi de Stokes. Com. Rend. Ac. Sci. 88: 1192-1194, 1351-1352. Jour. de Phys. 8: 367-371, 396; also in Phil. Mag. (5) 8: 179-180.

Lampadius, W. A. 1795. Sammlung praktisch-chemischer Abhandlungen und vermischter Bemerkungen. Dresden.

Landsborough, D. 1842. On the phosphorescence of zoophytes. Ann. Mag. Nat. Hist. (ser. 1) 8: 257-260.

Langley, S. P., and F. W. Very. 1890, 1901. On the cheapest form of light, from studies at the Allegheny Observatory. Amer. Jour. Sci. (ser. 4) 40: 97-113; Smith. Misc. Coll. 41.

LANkester, E. R. 1868. Preliminary notice of some observations with the spectroscope on animal substances. Jour. Anat. and Physiol. 2: 114-116.

Lassar, O. 1880. Die Mikrokokken der Phosphorescenz. Arch. für d. ges. Physiol. 21: 104-108.

LAssone, J. M. F. DE. 1775. Analogie ou similitude du zinc \& du phosphore etc. Mem. Ac. Sci. Paris, Année 1772 (Part I) : 380-397.

LAtreille, P. A. 1804. Hist. Nat. des Insects (Suites de Buffon) Paris. On luminous beetles, 10: 262 .

LAufer, B. 1915. The diamond, a study in Chinese and Hellenistic folk-lore. Pub. 184, Field Museum Nat. Hist. Chicago, Anthropological Series 15: 1-74. Pp. 55-71 on luminous stones.

Lavoisier, A. L. 1793. Elements of chemistry, 201. Trans. by Robert Kerr. Edinburgh. 1864. Euvres. 6 v. Published by Minister of Instruction and Culture. Paris. La combustion du phosphore de Kunckel. 2: 139-152, 1777. 
LeBon, G. 1899. La luminescence invisible. Rev. Scientifique (ser. 4) 11: 106-109.

- 1899. De la transparance des corps opaques pour les radiations luminescences de grand longueur d'onde. Revue Scientifique (4) 11: 161-167.

— 1900. Les formes diverses de phosphorescence. Rev. Scientifique (4) 14: 289-305.

LeCoQ de Boisbaudran. 1869-1873. Sur la constitution des spectres lumineux. Com. Rend. Ac. Sci. 69: 445-451, 606-615, 657-664, 694-700; 1189-1191; 70: 144-146, 974977, 1090-1091; 73: 658-660; 74: 1050-1052; 77: 937-940.

1885. Sur la fluorescence des terres rares. Com. Rend. Ac. Sci. 101: 552-555, 588592; Chem. News 52: 290-291, 299-300.

1886. Sur un spectre électrique particulier aux terres rares du groupe terbique. Com. Rend. Ac. Sci. 102: 153-156; Chem. News 53: 63.

1886-1888. Fluorescence, etc. Com. Rend. Ac. Sci. 102: 647-648, 899-902, 1003-1006; 103: 113-117, 468-471, 627-631, 1064-1068; 104: 1584-1585, 1680-1685; 105: 45-48, 206-208, 258-262, 301-304, 343-348, 784-788, 1228-1233; 106: 452-455, 1386-1387, 17081710, 1781-1784; 107: 311-314, 468-471, 490-494.

1886, 1887. Sur la fluorescence rouge de l'alumine. Com. Rend. Ac. Sci. 103: 1107; 104: 330-335, 478-482, 554-556, 824-826.

1889-1893. Rare earth phosphorescence (in French). Com. Rend. Ac. Sci. 108: 165-168; 110: 24-28, 67-71; 111: 393-395, 409-411, 472-475; 114: 575-577; 116: 611-613, 674-677; 117: 199-201.

1890. Remarques sur un discours de M. W. Crookes relatif à l'histoire des terres rare. Bull. Soc. Chim. de Paris (3) 3: 53-67.

— 1895. Sur un élément probablement nouveau existant dans les terbines. Com. Rend. Ac. Sci. 121: 709.

LEDENFELD, R. von. 1887. Report on the structure of the phosphorescent organs of fishes. Challenger Rep. 22, Appendix B, 277-329 and Biol. Zbl. 7: 609-621.

LE Duc, J. A. 1787. Nouvelles idées sur la météorologie. 2 v. Paris.

Lefort, J. 1874-1875. Apparitions lumineuses ou feux follets. Santé Pub. Paris 6: 11-13.

Legati, L. 1677. Museo Cospiano annesso a quello de famoso Ulisse Aldrovandi e donato all sua Pairia dall' Illustrissimo Signor Fernando Cospi, etc. Bologna. P. 278, Pietra luminare.

Le Gentil de la Galaisiere, G. H. J. J. B. 1779. Voyage dans les mers de l'Inde. 2 v. 1: 685-698. Paris.

LE Grand, A. 1675. Institutio philosophiae. London.

1694. An entire body of philosophy according to the principles of the famous Renate des Cartes, etc. In three books. I. The institution; II. The history of nature; III. Dissertation on the want of sense and knowledge in brute animals. Translated from Latin (1680) of the learned A. LeGrand by Richard Blome, London.

Lehmann, Dr. 1862. Zur Lampyrispreisfrage. Nova Acta Leop. Carol. 30: 113-114.

Lehmann, J. G. 1749. Abhandlung von Phosphorus, deren verschiedener Bereitung, Nutzen, usw. 36 pp. Dresden u. Leipzig.

Lemmann, O. 1888-1889. Molekularphysik, etc., 2 v., 852 \& 697 pp. 2: 220-235, Elektrische Entladungen.

— 1892. Uber das Entladungspotentialgefalle. Ann. der Physik 47: 427-439. 1895. Uber Aureole und Schichtung beim electrischen Lightbogen und bei Entladungen in verdunnte Gasen. Ann. der Physik 55: 361-388.

- 1898. Elektrische Lichterscheinungen oder Entladungen bezeichnet Glimmen, Büschel, Funken, und Lichtbogen, in freier Luft und in Vacuumröhren, etc. 569 pp. Halle a S. 
Leibnitz, G. B. von. 1710. Historia inventionis phosphori. Berlin. Also in Miscellanea Berolinensia 1: 91-98. Partly trans. in Crell's Neues Chem. Archiv. 1: 213-218, 1784.

LÉMERY, N. 1685. Modern curiosities of art and nature. Extracted out of the cabinets of the most eminent personages of the French court ... made English, from the original French, 1684. 355 pp. London.

1686. A course of chemistry, trans. from Cours de Chymie, Paris, 5th ed., by Walter Harris, London. On phosphors, pp. 523-541.

1698. A course of chemistry. 3rd English ed., edited by J. Keill, from Cours de Chymie. On phosphors, pp. 684-732.

1699. Traité universal des drogues, etc. $441 \mathrm{pp}$. Paris.

LÉMERy LE FILS. 1709. Conjectures et reflexions sur la matière du feu ou de la lumière. Mem. de l'Acad. Roy. des. Sci. 1711: 400-418.

Lempe und Lampadius. 1795. Uber das Leuchten des Phosphors. (Gren) Neues Jour. der Physik 1: 16-19.

Lenard, P. 1892. Notiz über ein Phosphoroscop mit Funkenlicht. Ann. der Physik 46: 637-641.

1893, 1894. Über Kathodenstrahlen in Gasen von atmosphäreschem Druck und im aüssersten vacuum. Ann. der Physik 51: 225-267. From Sitzber. d. K. prus. Akad. der Wiss. Berlin, 1893: 3-7.

— 1895. Uber die Absorption der Kathodenstrahlen. Ann. der Physik 56: 255-275. 1899, 1900. Erzeugung von Kathodenstrahlen durch ultraviolettes Licht. Sitzber. d. d. Acad. Wiss. Wien 108: 1649-1666; Ann. der Physik 2: 359-375.

1903. Ueber die Beobachtung langsamer Kathodenstrahlen mit Hülfe der Phosphorescenz und uber Secundärentstehung von Kathodenstrahlen. Drude's Ann. der Physik 12: 449-490.

Lenard, P. und F. Klatt. 1904. Ueber die Erdalcaliphosphore. Ann. der Physik 15: 225-282, 425-484, 633-672.

Lenard, P. and M. Wolf. 1888. Luminescenz der Pyrogallussäure. Ann. der Physik 34: $918-925$.

LENDENFELD, R. voN. 1887. Report on the structure of the phosphorescent organs of fishes. Challenger Rep. Zool. 22: Appendix B 277-329. Also Biol. Centralb. 7: 609-621.

LENGYeL, B. 1878. Ueber das Spectrum der Gasgemenge. Litter. Ber. aus Ungarn 3: $177-179$.

Lentilius, R. 1685, 1761. Preparation du phosphore hermétique. Translation in Collec. Acad. Etranger 6: 293-294, from Ephemerides, Dec. 2, An. 4. 1685.

LeroI, A. 1798. Extract of experiments and observations on the use of phosphorus administered internally. From Bull. d. la Soc. Philomatique. Phil. Mag. 2: 290-293.

LE Roy, J. B. 1760. Observations sur une lumière produite par l'eau de la mer. Mem. Sav. Etrange d. l'Acad. d. Sci. Math \& Physik 3: 143-154.

Leslie, P. D. 1778. Philosophical inquiry into the cause of animal heat, London. Pp. 225-229 on explanation of phosphorus.

LeUCKart, R. 1865. Ueber mutmasslich Nebenangen bei einem Fische, Chauliodus sloani. Ber, deutsch. Naturf. Aerz. 39: 153-155.

Levison, W. G. 1898. A simple and convenient phosphoroscope. Ann. New York Acad. Sci. (3) 11: 401-403.

LEWIS, F. P. 1899, 1900. The effect of certain impurities on the spectra of some gases. Astrophys. Jour. 10: 137-163; 12: 17-23; also in Ann. der Physik 69: 398. 425; 2: 442-458.

1900. Some new fluorescence and afterglow phenomena in vacuum tubes containing nitrogen. Astrophysical Jour. 12: 8-15. 
Lewis, H. C. 1884. Phosphorescent limestone. Science 3: 267.

LEYDig, F. 1857. Lehrbuch der vergleichende Histologie der Menschen und der Tiere, 342-344. Frankfurt a. M.

1879. Ueber die Nebenaugen von Chauliodus Sloanii. Arch. Anat. Physiol. (Anat. Abt.), 365-382.

- 1881. Die augenähnlichen Organe der Fische. 100 pp. Bonn.

Libes, A. 1790, 1791. Sur les aurores boréales. Jour. de Physique 36: 416; 38: 191-199.

LiCETI, F. 1640. Litheosphorus sive de lapide Bononiensi lucem in se conceptam ab ambiente claro mox in tenebris mire conservante. Utini.

- 1642. De lunae subobscura luce proper conjuctiones et in eclipsibus observata libros tres, serenissimo principi Leopoldo Tusciae dedicat. $468 \mathrm{pp}$. Utini.

1653. De lucernis antiquorum reconditis, lib. sex. Utini. Ist ed., Venice, 1621.

Liebermann, C. 1880. Über die Fluorescenz in der Anthracenreihe. Ber. d. d. Chem. Ges. 13: 913-916.

Lindahl, J. 1874. Om Pennatulid-slägtet Umbellula Handl. K. Svensk, Vetensk-Akad. (ser. 4) 13 (No. 3), 22 pp.

Lindhardt, E. 1822. Uber Fluorescenz erster Art. Dissert. 22 pp. Erlangen. Also Sitzber. der Phys.-Med. Soc. Erlangen 14: 128.

Link, H. F. 1808. Ueber die Chemischen Eigentschaften des Licht. 92 pp. St. Petersburg.

Linnemann, E. 1858. Uber die electrolytische Abscheidung des Kalium. Jour. Prak. Chem. 73: 128, 415-418.

Liveing, G. D. 1878. Note on the spectra of calcium fluoride. Proc. Cambr. Phil. Soc. 3 (3) : 96-98.

LIvius, T. Historiarum Romanarum. Book XXIX, Chap. 13 and XXIII, Chap. 31.

Lobstein, J. F. D. 1825. Researches and observations in the use of phosphorus in the treatment of various diseases. $107 \mathrm{pp}$. Philadelphia. Trans. from the French, 1815.

Loche, F. M. DE. 1801. Observations diverses sur les insects Lampyris italicus. Mem. de l'Acad. de Turin 11: 127-128.

LoDE, A. 1904. Versuche, die optische Lichtintensität bei Leuchtbakterien zu bestimmen. Zbl. Bakt. (Abt. 1) 35: 524-527.

Lommel, E. 1862. Versuch einer Theorie der Fluorescenz. Ann. der Physik 117: 642-645.

1871-1880. Uber Fluorescenz. Pogg. Ann. de Physik 143: 26-51; 159: 514-535; 160: 75-76; Wied. Ann. der Physik 3: 113-125, 251-283; 6: 115-119; 8: 244-253; 10: $449-472$ and 631-654.

1875, 1876. Das Wesen des Lichtes, 329 pp. 80 Leipzig. Trans. as The nature of light, with a general account of physical optics, New York.

— 1878. Theorie der Absorption und Fluorescenz. Ann. der Physik, 3: 251-283.

- 1879. Uber die dichroitische Fluorescenz des Magnesiumplatincyanurs. Ann. der Physik 8: 634-640.

- 1879. Úber zwei neue fluorescirende substanzen (1. Anthracenblau. 2. Bisulfochloranthracenige Saure), Ann. der Physik 6: 115-118.

— 1879. Uber das Stokes'sche Gesetz. Ann. der Physik 8: 244-253.

1883. Spectroscop mit phosphorescirendem Ocular, Beobachtungen uber Phosphorescenze. Sitzber. d. Acad. Wiss. München 13: 408-422; Ann. der Physik 20: 847-860.

1883. Zur Theorie des Lichtes. Ann. der Physik 16: 427-441.

1883. Die Fluorescenz des Ioddampfes. Ann. der Physik 19: 355-358. 
1884. Die Fluorescenz des Kalkspat. Sitzb. d. Phys. Med. Soc. Erlangen 16: 13-17. 1885. Zur Theorie der Fluorescenz. Ann. der Physik 25: 643-655.

1885, 1887. Beobachtung über Fluorescenz. Sitzber. d. Acad. Wiss. München 14: 605-610; 16: 283-298. In Ann. der Physik 24: 288-292.

1886, 1887. Beobachtungen uber Phosphorescenz. Sitzber. d. Acad. Wiss. München, 283-298 and Ann. der Physik 30: 473-487.

1889, 1891. Phospho-Photographie des ultrarothen Spectrum. Sitzber. d. Ac. Wiss. München 18: 397-403; 20: 83-87; Ann. der Physik 40: 681-690.

1895. Verbreiterung der Spectrallinien continuerliches Spectrum, Dampfungsconstante. Ann. der Physik 56: 741-745.

Loomis, E. 1872. The aurora borealis or polar light. Ann. Report Smithsonian Inst. for $1865,208-248$.

Lovell, R. 1661. Panzoologicominerologia, or a compleat history of animals and minerals, etc. 519 pp. Oxford.

LowE, R. T. 1842. Description of a new dorsibranchiate gasteropod, discovered at Madeira. Proc. Zool. Soc. Lond., 51-53.

Lubarsch, O. 1874, 1879. Uber Fluorescenz. Ann. der Physik 153: 420-440; 6: 248-267. 1880, 1881. Das Stokes'sche Gesetz. Ann. der Physik 9: 665-671; 14: 575-580.

Lucas, H. 1887. Description d'une larve de Lampyridae considerée comme devant appartenir au sexe femelle, dont l'insecte parfait est encore inconnu. Ann. Soc. Ent. Fr. (ser. 6) 7: Bull. xxxv-xxxvi.

LucE. 1794. Description d'un insecte phosphorique qu'on recontre dans une partie du district de Grasse, département du Var. (Scarabaeus phosphoricus) Nouv. Jour. de Physique 44: 300-302.

Ludolff, C. F. 1745. Sur l'électricité des baromètres. Mém. de l'Acad. Roy. des Sciences et des Belles Lettres de Berlin (Classe physique), 3-13.

Ludwig, F. 1874. Uber die Phosphorescence der Pilze und des Holzes. 30 pp. Inaug. Dissert. Göttingen.

- 1884. Micrococcus Pflugeri, ein neuer photoger Pilz. Hedwigia, 23: 33-37.

1884. Uber die spektroskopische Untersuchung photogener Pilze. Ztschr. Wiss. Mikr. 1: 181-190.

1891. Über die Phosphorescence von Gryllotalpa vulgaris. Zbl. Bakt. 9: 561-562. 1902. Leuchtende Ameisen. Ill. Ztg. No. 3088.

Lumière, A. et L. 1899. Influence des températures très basses sur la phosphorescence. Com. Rend. Ac. Sci. 128: 549-552.

Lupton, T. 1586. A thousand notable things of sundry sorts whereof some are wonderfull, some straunge, some pleasant, divers necessary, a great sort profitable and many very precious. London. See p. 84 on liquor lucidus.

Lycosthenes, C. (Wolffhart, C.). 1557. Prodigiorum ac ostentorum chronicon. Basileae.

M. L. P. 1802. Sur la phosphorescence du diamant. Jour. de Phys. 55: 60-61

Macaire, J. 1821. Mémoire sur la phosphorescence des Lampyres. Ann. de Chimie 17: 151-167; Ann. der Physik 70: 265-280.

Macartney, J. 1810. Observations upon luminous animals. Phil. Trans. 100: 258-293.

MCAtee, W. L. 1947. Luminosity in birds. Amer. Midland Naturalist 38: 207-213.

M'Cormac, H. 1846. Case of phosphorescence of the human body. Med \& Surg. Jour., Edinb. 66: 285-286.

MacCulloch, J. 1821. Remarks on marine luminous animals. Quart. Jour. Sci. Lit. Arts 11: 248-260. Also in Edinb. Philos. Jour. 5: 388-389. 
MCELroy, W. D. 1947. The energy source for bioluminescence in an isolated system. Proc. Nat. Acad. Sci. 33: 342-345.

Macfadyen, A., and S. Roland. 1900. Influence of the temperature of liquid hydrogen on bacteria. Proc. Roy. Soc. 66: 488-489.

McIntosh, W. C. 1872. On the abyssal theory of light, the protozoic-absorption theory, and the azoic-mud theory, propounded in the reports of H. M. S. Porcupine 1869 and 1870. Ann. Mag. Nat. Hist. (ser. 4) 9: 1-13.

1885 , 1886. Phosphorescence of marine animals, a presidential address. Rev. Sci., Paris 36 (ser. 3) 10: 545-552; Nature 32: 476-481; Report Brit. Assoc. Adv. Sci. held at Aberdeen 1885, 55: 1043-1053.

Macquer, P. J. 1764. Elements of the theory and practice of chemistry, 2nd ed. trans. by Andrew Reid from Elemens de chymie théorique, Paris, 1749. 2nd ed., 1756. 2 v. London.

- 1778. Dictionnaire de chymie 2: 237-245. 2nd ed. 2: 223-231. Ist ed. 1766.

MAGellan, M. DE. 1777. Sur une experience faite avec le phosphore. (Rozier) Jour. de Physique 9: 153-155.

Maier, C. 1726. De luce boreali. Akademia Nauk. Commentarii Ac. Sc. Imp. Petropolitanae 1: 351-367.

MAIN, J. 1837. Remarks on the possible origin of ignis fatuus. Mag. Nat. Hist. (n. s.) 1: $548-554$.

Mairan, J. J. Dortous DE. 1717. Sur la cause de la lumière des phosphores et des noctiluques. 54 pp. Bordeaux.

- 1733-1754. Traité physique et historique de l'aurore boréale. 2nd ed., 1754. From articles in Mém. Ac. Sc. Paris for 1731, 1732, 1747, 1751.

Majolus, S. 1600. Dies caniculares etc. Tomi VII Moguntiae. Colloq. V for Cicindela.

Mangold, E. 1910. Die Produktion von Licht. Hand. Vergl. Physiol. 3 (2d half): 225-392. Jena. Bibliography of 649 titles.

ManN, B. P. 1875. Notes on the luminous larvae of Elateridae. Psyche 1: 89-93.

Marat, J. P. 1780. Recherches physique sur le feu. 202 pp. Paris.

Marcgrave, J. 1648. Historia rerum naturalium Brasiliae. Leyden and Amsterdam. Portuguese translation by I. Procopio de Megahhàes, Sao Paulo, 1942.

Marchand, R. F. 1850. Über das Leuchten des Phosphors. Jour. für Prakt. Chem. 50: $1-10$.

Marchetti, G. 1791. De phosphoris quibisdam ac praesertim de Bononiensi. Comment. Acad. Bonon. 7: 25-27; 289-300.

Margcraff, A. S. 1743. Einige neue Methoden, den Phosphor im festen Zustande sowohl leichter als bisher aus dem Urin darzustellen als auch denselben bequem und rein aus brennbarer Materie (Phlogiston) und einem eigentümlichen, aus dem Urin abzuscheidenden Salze zu gewinnen. Miscel. Berolinensia 7: 324-344. In Ostwald's Klassiker, no. 187.

1749, 1750. Mémoire concernant certaines pierres, etc. Hist. d. l'Acad. d. Sci. et Belles Lettres de Berlin 5: 56-70; 6: 144-162.

— 1761,1767. Chymische Schriften, Berlin, 2nd part, 113-115 and 135-163.

1785. Verschiedene nene Arten, den Harnphosphorus leichter zu verfertigen, und ihm geschwind aus Phlogiston und einem besondern Harnsalze zusammenzusetzen. Crell's Neues Chem. Archiv. 3: 300-303.

Marignac, J. C. G. DE. 1845. Sur la production et la natur de l'ozone. Com. Rend. Ac. Sci. 20: 808-811.

1887. Quelques réflexions sur le groupe des terres rares à propos de la théorie de M. Crookes sur la genèse des éléments. Arch. Sci. Phys. et Nat. (3) 17: 373-389,

Mariotte, E. 1688. Traité de la nature des couleurs. Paris. 
Markheinecken, N. L. 1744. De phosphoris. 40 pp. Jena.

Marsh, H. 1842. On the evolution of light from the living human subject. Prov. Med. and Surg. Jour. 4: 163-172.

Marshall, J. 1868. Outlines of physiology, human and comparative with additions by F. G. Smith. Phila. Pp. $889-891$ devoted to evolution of light, p. 888 to spontaneous combustion.

Marsigli, L. F. 1698, 1702. Dissertatione epistolare del fosforo minerale ò sia della pietra illuminabile bolognese. 44 pp. Lipsiae. 2nd ed., 1702. See also Phil. Trans. 20: 308 , for review.

MARTENS, F. 1675. Spitzbergische oder Groenlandische Reise Beschreibung, gethan im Jahr 1671, etc. 132 pp. Hamburg. See Voyage into Spitzbergen and Greenland. A translation by Sir John Narborough, edited by Adam White. Hakluyt Soc. No. $18,1855$.

Martin, A. R. 1761. Naturlig Phosphorus, eller Ren om Fisk och Kett, som lyser i merkret. Kongl. Vetenskaps Academiens Handlinger 22: 225-230.

Martin, B. 1735, 1762. The philosophical grammar, being a view of the present state of experimental physiology or natural philosophy. 6th ed. London.

- 1742, 1747, 1771. Philosophia Britannica, or a new and comprehensive system of the Newtonian philosophy, astronomy and geography, etc. 2 v. 3 editions. London.

Martin, T. H. 1866. La foudre. L'électricité et le magnétisme chez les anciens. Paris.

Martyn, J. E., and E. Chambers. 1742. The philosophical history and memoirs of the Royal Academy of Science at Paris from 1699-1720. $5 \mathrm{v}$.

Martyr de Anghierra, P. 1516, 1536. De rebus Oceanis et Orbe Novo-Decades Tres. Basel. Decades VIII, Paris.

Mascart, E. 1869. Sur les spectres ultra-violets. Com. Rend. Ac. Sci. 69: 337-338.

Massart, J. 1893. Sur l'irritabilité des noctiluques. Bull. Sci. Fr, Belg. 25: 59-76.

Masson, A. 1851. Études de photométrie électrique. IV-V De la nature de l'étincelle électrique et de sa cause. Ann. de Chim. (3) 31: 295-325.

Matteucci, C. 1842. Sur la phosphorescence excitée par la lumière solaire, par l'étincelle électrique et par les flammes du phosphore, du potassium et du sodium. Bibl. Univers. (Arch. de Sc. Phys. et Nat.) Geneva 40: 159-172; 42: 373-375.

1843. Sur la phosphorescence du lampyre d'Italie (L. italica). Ann. Chim. et Phys. (3) 9: 71-89; Com. Rend. Ac. Sci. 17: 309-312. Also Ann. \& Mag. Nat. Hist. 12: $373-374$.

1844. Lezioni sui fenomeni fisico-chimici dei corpi viventi. Pisa. 2nd ed., 1846. English translation, 1847.

1847. Lectures on the physical phenomena of living beings. $435 \mathrm{pp}$. London. Trans. by J. Pereira. Sect. VIII. 161-185, Phosphorescence of organized beings.

1849. Sur la matière phosphorescente des poissons et sur la phosphorescence de la mer. Ann. Chim. et Phys. (3) 24: 358-360.

1850. Mémoire sur la propagation de l'électricité dans les corps isolants, solides et gazeux. Ann. de Chim. (3) 28: 385-429.

Maurer, F. 1713. Observationes curioso-physicae, etc. 1039 pp. Franckfurt und Leipzig. See chap. 8 for luminescences.

MAYer, J. 1786. Beobachtung über das Leuchten des Adriatichen Meeres. Abhand. d. Gesellsch. fur Wiss. (Ceska Akademie Ved.) for 1785 (2 abt.) : 3-12.

Mayow, J. 1790. Chemical experiments and opinions, extracted from a work in the last century; with a slate, by T. Beddoes. XLI $+81 \mathrm{pp}$. Oxford.

Mazzotta, B. 1653. De triplici philosophia, naturali astrologica et minerali. P. 148. Bononiae. 
Mebius, C. A. 1896. Über Polarizationserscheinungen in Vacuumröhren. Ann. der Physik 59: 695-714.

Meidinger, von, 1777. Gedanken über das Leuchten welches man an einigen Gattungen des faulen Holzes im Dunkeln wahrnimmt. Beschaftigungen der Gesellschaft der Naturfor. Fremde von Berlin 3: 149-156.

Melchior, J. A. 1742. De noctilucis. Dissertatio philosophica manguralis. Franequere, 62 pp. Sec. I, De noctilucis artificialibus; II De noctilucis naturalibus.

Melvill, T. 1756. Essays and observations, physical and literary. Edinburgh. 2: 33, on Sodium Spectrum.

Mentzel (Menzel), C. 1675. De lapide bononiensi in obscuro lucens collatus cum phosphoro hermetico claris. $77 \mathrm{pp}$. Bilefeldiae.

Menzius (Mentz). 1751. De la virtu medicinal du Phosphore pris interieurement. Dissertation, Wirtemberg.

Merian, M. S. 1726. Dissertation sur la generation et les metamorphases des insectes de Surinam, 49. From the 1705 edition in Dutch.

MEyen, F. J. F. 1834. Uber das Leuchten des Meeres und Beschreibung einiger Polypen und anderer niederer Tiere. Nova Acta Leop. Carol. supp. 16: 125-218.

Meyer, H. A. 1866. Leuchten des Meerwassers unter Eis. (vorgetragen von Ehrenberg Feb. 21, 1865, from Hamburg). Sitzber. der Gesell. Naturforschende Freunde zu Berlin, 1865: 6.

MEYER, R. 1897. Uber einige Beziehung zwischen Fluorescenz und chemischer Constitution. Ztschr. Physik. Chem. 24: 468-508.

Meyer, W. T. 1906. Ueber das Leuchtorgan der Sepiolini. Zool. Anz. 30: 388-392.

Meyrick, E. 1886. A luminous insect larva in New Zealand. Ent. Month. Mag. 22: 266-267.

Michaelis, G. A. 1830. Über das Leuchten der Ostsee nach eigener Beobachtungen. 52 pp. Hamburg.

Miles, H. 1745. Observations of luminous emanations from human bodies and from brutes with some remarks on electricity. Phil. Trans. 43: 441-446.

Millikan, R. A. 1895. A study of the polarization of light emitted by incandescent and liquid surfaces. Phys. Rev. 3: 81-99, 177-192.

Milne-Edwards, H. 1841. Observations sur la structure et les fonctions de quelques Zoophytes. Sur les Acalèphes. Ann. de Sc. Nat. 16 (ser. 2). P. 216 on luminescence of Béroés.

1863. Leçons sur la physiologie et l'anatomie comparée de l'homme et des animaux. Paris. 8 (68 leçon): 93-120; Production de lumière par les animaux.

Misson, F. M. 1714. A new voyage to Italy. London. 2 (1): 320-321 on phosphors.

Mrtchill, S. L. 1801. Luminous appearance of ocean-water caused by animals. Letter to Professor Barton of Phila. Phil. Mag. 10: 20-27.

Modeer, A. 1792. Om Slagtet Siokolf, Medusa. (in Swedish). Nya Handlingar Kongl. Acad. Stockholm 12: 81-112.

MofFAT, W. 1863. On the luminosity of phosphorus in connection with atmospheric conditions; and on the magnetic condition of phosphorus vapor. Proc. Royal Brit. Meteorolog. Soc. 1: 197-201.

Molisch, H. 1904. Leuchtende Pflanzen. Eine physiologische Studie, 198 pp. Jena. Second ed., 1912.

MolnaR, F. 1883. Über den Einfluss einiger Gase und Dämpfe auf die Entzundungstemperatur des Phosphors, und auf die langsame Verbrennung desselben. Budapest.

Monardes, N. 1577. Joyfull Newes out of the New Founde Worlde. English by J. Frampton, 2 v. London, 1925. Lignum nephriticium on pp. 46-47 of Vol. 1. 
Monconys, B. DE. 1665. Journal de voyages. 3 parts. Lyon. Pholas, part 2, p. 434.

Montalbani, O. 1634. De illuminabili lapide bononiensi epistola. Bologna.

Moray, R. 1667. Observations made by a curious and learned person sailing from England to the Caribbean islands, as they were obtained from him by Sir Robert Moray. Phil. Trans. 2: 496 (No. 27).

MOREAU, L. 1897. On the Indian porcupine (phosphorescence of blood). Jour. Bombay Nat. Hist. Soc. 11: 166.

Morgan, Rev. Mr. 1785. Observations and experiments on the light of bodies in a state of combustion. Phil. Trans. 75: 190-212.

MORGAN, W. 1785. Electrical experiments made in order to ascertain the conducting power of a perfect vacuum. Phil. Trans 75: 272-278; also 198-208.

Morozzo, C. L. DI. 1786. Sopra alcuni fenomenoni de fosfori bolognesi ne differenti fluidi aeriformi. Memorie di Mathematica e Fisica della Societa Italiana, Verona 3: $420-439$.

— 1798. Lumière phosphorique que quelques pierres donnent en se frottant avec une plume, ou avec une épingle de laiton, et particulièrement sur la phosphorescence de la tremolite, et de la cyanite, suivie de quelques observations sur l'électricité positive, ou négative de différentes pierres." Mem. Ac. Sc. Torino 6: $140-149$.

Morren, A. 1865, 1866. Sur les phénomènes lumineux, dits de phosphorescence, qui présentent quelques gaz très-raréfiés pendant et après le passage de l'étincelle électrique. Ann. de Chim. (4) 4: 293-305; Ann. der Physik 115: 350-352; and 126: $643-654$.

1869. Nouvelles observationes sur la phosphorescence des gaz raréfiés. Com. Rend. Ac. Sci. 68: 1033-1035, 1060-1062. See also 53: 794-795, 1861.

Mortimer, C. 1733. An account of the experiments shewn by Sigismund August Frobenius, M.D., F. R.S. at a meeting of the Royal Society on Nov. 18, 1731, with his spiritus vini aetherus, and the phosphorus urinae, from the minutes of that day. Phil. Trans. 38: 55-58.

- 1745. Concerning the natural heat of animals. Phil. Trans. 43: 473-480.

MoRton, H. 1872, 1875. Fluorescent relations of anthracene and chrysogene. Chem. News 26: 199-201; 31: 35-36, 45-46, on pyrene. See also Phil. Mag. (4) 44: 345-349. 1872.

Morton, H., and H. C. Bolton. 1878. Investigation of fluorescent and absorption spectra of uranium salts. Chem. News 28: 47-50, 113-116, 164-167, 233-234, 244-246, 257-259, 268-270.

Moscardo, L. 1672. Memorie del Musco del Conte Moscardo 488 pp. Verona. 1st ed., Padua, 1656.

Moseley, H. N. 1879. Notes by a naturalist on the Challenger. $620 \mathrm{pp}$. London. P. 574 and 590 for phosphorescent animals.

Mourelo, J. R. 1897-1899. La phosphorescence du sulphure de strontium. Com. Rend. Ac. Sci. 124: 1237-1238, 1521-1523; 126: 420-423, 904-906, 1508-1510; 127: 229-231, 372-374; 128: 427-429, 557-559, 1239-1241; 129: 1236-1238.

MülleR, G. W. 1891. Neue Cypridiniden. Zool. Jahrbuch (Abt. 1) 5: 211-252.

Müller, J. 1844. Handbuch der Physiologie des Menschen fur Verlesungen. 2 v. Coblenz. 1: 85-91, Lichtentwickelung. 1st ed., 1834.

Müller, O. F. 1786. Animalcula, infusoria fluviatilia et marina, etc., opus posthumum cura O. Fabricii. Hafniae.

Müller, W. 1870. Über das Leuchten des Phosphors. Ber. d. d. Chem. Ges. 3: 84-90. Also Ann. der Physik 141: 95-109.

MUfFET, T. 1634. Insectorum sive minimorum animalium theatrum. $326 \mathrm{pp}$. Londini. 
1658. The theatre of insects; or lesser living creatures as bees, flies, caterpillers, spiders, worms, etc., a most elaborate work. Trans. by John Rowland, M.D. London. Chap. XV, Of the glow-worm, p. 975-981. Chap. XXV, Of the fire-fly, p. 1019-1021.

Mulder, E. 1860, 1861. Natürliches und künstliches Phosphorescence von Fischen. Arch. Holland Beitr. Natur. u. Heilik., Utrecht 2: 398-407 and Nederl. Gast. Ooglijd. Versl. (Donders) 2: 398-407. Also Jour. de Physiol. 4: 234-241.

Munk, P., and E. Leyden. 1865. Die acute Phosphor-Vergiftung, etc. 188 pp. Berlin.

Muraoka, H. 1896, 1897. Das Johanniskäferlicht. Ann. der Physik 59: 773-781; also Jour. Coll. Sci. Tokyo 9: 129-139.

MURAOKA, H., and M. Kashya. 1898. Das Johanniskäferlicht und die Wirkung der Dämpfe von festen und flüssigen Körpern auf photographische Platten. Ann. der Physik 64: 186-192.

MurRay, A. 1870. On an undescribed light giving Coleopterous larva (provisionally named Astraptor illuminator). Jour. Linn. Soc. 10: 74-82.

Murray, J. 1819. A system of chemistry. Edinburgh, 4 v. Phosphorescence, 1: 536-548. 1821. Luminosity produced by compression, fraction and animal bodies. Edinburgh Philos. Jour. 4: 217-218.

- 1821, 1826. On the luminosity of the sea. Mem. Nat. Hist. Soc. 3: 446-471; also Fror. Nat. 16 (No. 338) : 122; and Experimental Researches, Glasgow, 70-85.

NAIRNE, E. 1777. Experiments made with an air pump on Mr. Smeaton's principle. Phil. Trans. 67: 614-648.

Napier, J. 1851. Phosphorescence of chalk lines. Phil. Mag. (4) 1: 260-261, 432.

Naudin. 1846. Phosphorescence des feuilles sèches. Rev. Hort., Paris (ser. II), 254.

NeBEL, B. 1885. Über die in einer Plücker'schen Wasserstoffrohre frei werdende Energie und deren Einfluss auf die Intensität des Lichtes. Rep. f. Phys. Techn. 21: $671-682$.

Nebel, W. B. 1719. Dissertatio physica de mercurio lucente in vacuo. $73 \mathrm{pp}$. Basel.

Nees von Esenbeck, T. F. L. 1823. Uber das Leuchten der Rhizomorpha subterranea (letter of Derschau). Flora 6 (1st part) : 115-123.

Nees von Esenbeck, C. G., and T. F. L., J. J. Noggerath and G. W. Bishoff. 1823. Die unterirdischen Rhizomorphen, ein leuchtender Lebensprozess. Nova Acta Leop. Carol. 11 (Part 2) : 603-712 and 12: 2, 875. Abstract in Flora 2: 419, 1924.

Negotius, T. 1715. Schediasma physicum quo novum consilium barometra phosphorescentia sive in vacuo suo ad agitationem noctu fulgurantia conficiendi, primum in lucem editur. Vitembergae.

Neumann, C. 1759. The chemical works of Caspar Neuman, M.D. Trans. by Wm. Lewis. 586 pp. London. A German text in 1740.

Neush, J. 1879. Bactéries lumineuses sur la viande fraîche. Jour. Pharm. Chim. Paris 29: 20-22; also Bull. Sci. Dept. Nord et Rev. Internat. Sci., Oct., 1878.

Newall, H. F. 1895. Note on the spectrum of argon. Proc. Roy. Soc. 57: 346-350, and Astrophys. Jour. 1: 372-376.

1896. On luminosity attending the compression of certain rarified gases. Proc. Cambridge Philos. Soc. 9: 295-302.

NEwLAND, C. 1772. Observations on the milky appearance of some spots of water in the sea. Phil. Trans. 62: 93-94.

Newman, E. 1864. Luminosity of the lantern-fly. Entomologist 2: 22-26.

Newton, I. 1672. New theory about light and colours. Phil. Trans. 6: 3075-3087. Lignum nephriticum, p. 3084.

- 1718. Opticks. 2nd ed. London. P. 190 on Lignum nephriticum, and Queries, pp. 316-318. 1st ed., 1704. 
Nicolas, M. 1784. Mémoire sur le spath phosphorique calcaire d'Apremont. Jour. de Phys. 25: 28-31.

Nichols, E. L., \& M. L. Crehore. 1894. Studies of the lime light. Phys. Rev. 2: 161-169.

Nichols, E. L., and H. L. Howes. 1916. A new form of phosphoroscope. Science 43: $937-939$.

Nichols, E. L., and B. W. SNow. 1892. On the character of the light emitted by incandescent zinc oxide. Phil. Mag. (5) 33: 19-28.

Nicholson, W. 1788. An introduction to natural philosophy. 3rd ed. 570 pp. Philadelphia. See p. $508 \mathrm{ff}$. for phosphors.

Nicolson, Pere. 1776. Essai sur l'histoire naturelle de l'isle de Saint-Domingue. 374 pp. Paris. Pp. 353-358, Mouches luisantes, nominées mouches de feu.

Nieremberg, J. E. 1635. Historia naturae, maxime peregrinae libris XVI distincta. 104 pp. Antverpiae. In Book XIII, Cap. 3, De cucuijs.

Nieuwentyt, B. 1718-1719. The religious philosopher: or The right use of contemplating the works of the Creator, etc. Trans. by John Chamberlayne. $3 \mathrm{v}$. London. Vol. 2, pp. 621-627 for phosphorus.

NoAck, K. 1887. Verzeichniss fluorescirender Substanzen nach der Farbe ihres Fluorescenzlichtes geordnet, mit Literaturnachweisen. $155 \mathrm{pp}$. Marburg.

Nocetı, C. 1747. De iride et aurora boreali carmina, cum notis R. J. Boscovich. 127 pp. Romae.

NöGgerath, J. J. 1823. Ausgezeichnete Lichtenwickelungen beim Schleifen harter Steinarten. Ann. der Physik 150: 325-331.

Nöggerath, J. J., and C. G. NeEs von Esenbeck. 1825. Lichterscheinungen. Rhizomorphan in den zartesten Klüften des Gesteins und der Stein-Kohle wachsend (letter of Fryesleben). Schweigger's Jour. für Chem. u. Physik 44: 65-74.

Nollet, Abbé J. A. 1745. Leçons de physique expérimentale. 4 v. Paris. 2nd ed., 6 v. Paris. 1753-1764. See vol. 5, pp. 28-46 for phosphors.

- 1747. Essai sur l'électricité des corps. 227 pp. Paris.

- 1749. Recherches sur les causes particulières des phénomènes électriques. Paris. 1750. Suite des experiences et observations faites en differents endroits de l'Italie. Article 6. Insectes lumineux. Mém. Acad. Sc. Paris 4: 54-62.

- 1755. Lettere intorno all'eletricita. $180 \mathrm{pp}$. Venezia. From Recueil des lettres sur l'électricité des corps, 3 v., Paris, 1753.

- 1754. Letters concerning electricity, etc. translated from the French by Wm. Watson. Phil. Trans. 48: 201-216.

NORWOOD, MR., THE YOUNGER. 1668. An account of some particulars, referring to those of Jamaica. Phil. Trans. 3 (No. 41): 824-825.

Nose, K. W. 1780. Etwas über die Doppelfarbe einiger Holztinkturen. Crell's Chemische Jour. 5: 5-9.

Nuguet, L. 1705. Systeme sur les couleurs. Mém. pour l'Hist. des Sc, et des Beaux-arts. Trevoux 17: 675-686.

Nutring, C. C. 1898. The color of deep-sea animals. Proc. Iowa Acad. Sci. 5: 27-36. 1899. The utility of phosphorescence in deep-sea animals. Amer. Nat. 33: 792-799.

Obermann, J. J. 1871. Bemerkung die Fluorescenz betreffend. Ann. der Physik 143: 660 .

Obsequens, J. 1679. De prodigiis liber cum annotationibus J. Schefferi. Amstelodami. Oldenburg, H. 1676. Four sorts of facticious shining substances. Phil. Trans. 11: 867. Olschki, L. 1927. Galilei und seine Zeit. 479 pp. Halle. See pp. 453 ff. for Bolognian stone. 
Orioli, F. 1850. De' pesci e del mare che rilucono nella oscurità. Ann. Sci. Mat. Fis. (Tortolini) 1: 242-247.

OsanN, G. W. 1825, 1828, 1829. Ueber einige neue Lichtsauger von vorzüglicher Stärke. Arch. f. d. ges. Naturlehre 5: 88-107; Quart. Jour. Sc. 2: 204-205; Archives des Sc. Phys. et Nat. 40: 118-122.

1834. Versuche über Phosphorescenz durch Insolation und Beschreibung eines neuen Photometers. Ann. der Physik 33: 405-416.

1854. Ueber die Erscheinungen der Fluorescenz mit Hinblick auf die der Phosphorescenz und des electrischen Lichtes. Verhandl. physik.-med. Ges. Würzburg 5: 394-406. Einige Bemerkungen uber Fluorescenz. Ann. der Physik 94: 640-642; Jour. für Prak. Chem. 66: 87-103.

1857. Beitrage zur Lehre von der Fluorescenz. Ann. der Physik 97: 329-331.

Osвеск, P. 1757. Dagbok öfver en Ostindisk Resa Åren 1750-1752 etc. Translated as Reise nach Ostindien und China, etc., 1765, and A Voyage to China and the East Indies. 2 v., London, 1771.

Osorio, B. 1912. Une propriété singulière d'une bactérie phosphorescente. Com. Rend. Soc. Biol. 72: 432-433.

Osten-Sacken, C. R. von. 1862, 1865. Description of some North American Coleoptera. Proc. Entomol. Soc. Phila 1: 125-130; 4: 8.

Oтто, M. 1896, 1898. Recherches sur l'ozone. Com. Rend. Ac. Sci. 123: 1005-1007; Ann. Chim. et Phys. (ser. 7) 13: 77-144.

Oviedo y Valdis, G. F. DE. 1535. Historia natural y general des las Indias. Seville. Liv. XV, chap. 2, 13. Madrid, 1851. From De Sommario, etc., Toledo, 1526. See English trans. by F. A. MacNutt, 2 v., New York, 1912.

Owens, R. B. 1899. Thorium radiation. Phil. Mag. (5) 48: 360-387.

Ozanam, J. 1735, 1791. Recréations mathématiques et physiques. 4 v., Paris. 1st ed., 1694, 2 v. 2nd ed., 1724, 4 v. 4, Des phosphores et des lampes perpetuelles, 392 pp. English translation, London, 1803.

Paalzow, A., and F. Neesen. 1895. Über den Durchgang der Electricität durch Gase. Ann. der Physik 56: 276-303, 700-716.

PaAlzow, A., and H. W. Vogel. 1881. Ueber das Sauerstoff spectrum. Ann. der Physik 13: $336-338$.

Pallas, P. S. 1766. Eleuchus Zoophytorum ... 451 pp. with index. Haag.

- 1781. Kurze Nachrichten und Auszuge aus Briefen. Neue Nord. Beitr. zur physik. u. geogr. Erd. und Volkerscheibung 4: 393-397, 1783.

- 1787. Sur le spath de Catherinenbourg. Nova Acta Acad. Sc. Imp. Petropolis 1: $157-158$.

Pallegoix, J. B. 1854. Description du Royaume Thai ou Siam, etc. 2 v. Paris. 1: 186, for synchronous flashing of fireflies.

PAnceri, P. 1871. Intorno ad un caso di sudore luminoso. Rendiconto d. Accad. Sci. Fis, e Mat. Napoli 10: 188-190.

— 1871, 1872. Intorno alla luce emanata dal grasso. Rendiconti Accad. Sci. Napoli 10: 79-81; Ann. Chim. Appl. Roma.

1871. Intorno alla sede del movimento luminoso nelle meduse. Rendiconti Accad.

Sci. Napoli 10: 140-146.

- 1872. The luminous organs and light of the pennatulae. Quart. Jour. Micr. Sci. 12: $248-254$.

1872. The light organs and the light of the Pholades. Quart. Jour. Micr. Sci. 12: 254-259.

1872. Etudes sur la phosphorescence des animaux marines. Ann. Sci. Nat. (Zool.) 16 (ser. 5), No. 8: 68. 
1872. Intorno a due casi di fosfuria. Rendiconti Accad. Sci. Fis. e Mat. Napoli 11: 232-234.

1873. The luminous organs and light of Pyrosoma. Quart. Jour. Micr. Sci. 13: 45-51.

1873. La luce e gli organi luminosi dei Beroidei. Atti Accad. Sci. Fis. Mat. Napoli 5: (No. 20) 1-15.

1873. Intorno alla luce che emana delle cellule nervosi della Phyllirrhoe bucephala. Atti. Accad. Sci. Fis. Mat. Napoli 5 (No. 14): 1-12; Quart. Jour. Micr. Sci. 13, n.s.: 109-116.

1873. Gli organi luminosi e la luce dei Pirosomi e della Foladi. Atti. Accad. Sci. Fis. Mat. Napoli 5 (No. 13): 1-51.

1873. Gli organi luminosi e la luce della pennatule. Atti. Accad. Sci. Fis. e Mat. Napoli 5 (No. 10): 1-38.

1877, 1878. Intorno alla sede del movimento luminoso nelle Campanularie. Nature 16: 70; Atti. Accad. Sci. Fis. e Mat. Napoli 7 (No. 9) : 1-6.

1878. La luce e gli Organi luminosi di alcuni annelidi. Atti Accad. Sci. Fis. e Mat. Napoli 7 (No. 1) : 1-20.

Panciroli, G. 1715. The history of many memorable things lost, which were in use among the Ancients: etc. 2 v. 542 pp. Done into English. London.

Panckoucke, C. J. 1781-1782. Encyclopédie méthodique. 166 v. 3: 707-729, Lumière. 4: 288-289, Phosphorescence. Contains the Dictionnaire de physique with article on l'aurore boreali.

Papin, N. 1647. Traicté de la lumière de la mer. Appendix to Raisonnements philosophiques touchant la salûre, flux et reflux de la mer, etc. $156 \mathrm{pp}$. Blois.

Paracelsus. 1894. The hermetic and alchemical writings of Aureolus Phillipus Theophrastus Bombast of Hohenheim, called Paracelsus the Great, now for the first time faithfully translated into English by A. E. Waite. 2 v. London, 2: 316.

Pasteur, L. 1864. Sur la lumière phosphorescente des Cucujos. Com. Rend. Ac. Sci. 59: 509-510. See also M. Blanchard's remarks, pp. 510-511.

Paullinus, C. F. 1687. Sur des œufs lumineux. In Collection Académique Étrangère tome IV, p. 174. Dijon, 1757 from Epheimer. Nat. Curio. Dec. II, An. 6, Append. Obs. 26.

PEACH, C. W. 1850. Observations on the luminosity of the sea, with descriptions of several of the objects which cause it, some new to the British coast. Ann. Mag. Nat. Hist. 6 (ser. 2): 425-434.

Pearsall, T. J. 1830. On the effects of electricity on minerals which are phosphorescent by heat. Jour. Roy. Inst. 1: 77-83; 267-281. Also Ann. de Physik 20: 252-260, 1830; 22: $566-584,1831$.

Pelletier, P. J. 1821. Sur la phosphorescence du sulphate de quinine. Jour. de Pharm. 7: 579.

Pennant, T. 1777. British zoology, London. 4th ed. 4 v. 4: 46, 59. Ist ed. London, $1 \mathrm{v}$.

Penny, F. 1855. On the composition and phosphorescence of plate-sulfate of potash. Phil. Mag. (4) 10: 401-406.

Percy, P. F., and Laurent. 1820, 1822. Phosphorescence des plaies, in Dict. de Se. Medical, 41: 530-541. Translated in Schweigger's Jour. für Chem. et Physik 35: 228, and Quart. Jour. Sci. Lit. and the Arts 12: 180.

PERKIN, W. H. 1882. Some observations on the luminous incomplete combustion of ether and other organic bodies. Jour. Chem. Soc. 41: 363-367.

Péron, F. 1804, 1805. Mémoire sur le nouveau genre Pyrosoma. Ann. Mus. Hist. Nat. Paris 4: 437-446. Also in Jour..Med. 10: 88-89; Jour. Phys. 59: 207-213; Voigt, Magazin f. den neuesten Zustand der Naturkunde 9: 3-12. 
1804, 1805. Sur la température des eaux de la mer, soit à sa surface, soit à diverses profondeurs, le long des rivages et en pleine mer. Ann. Mus. Hist. Nat. Paris 5: 123-148. Also in Phil. Mag. 21: 129-133.

- 1807. Voyage de decouvertes aux terres australes 1. 496 pp.

Peters, A. W. 1841. Uber das Leuchten der Lampyris italica. Arch. Anat. Physiol., Lpz., 229-233; and Ann. Sci. Nat. 17 (ser. 2): 254, a translation.

Peters, H. 1902, 1912, 1916. Geschichte des Phosphors nach Leibniz und dessen Briefwechsel. Chem. Ztg. 26: 1190-1198. See also Arch. Geschichte Naturwissen. 4: 206; 7: 92.

Petrie, W. 1850. The phosphorescence of potassium. Amer. Jour. Sci. (2) 10: 413.

PfafF, C. H. 1815. Vermischte Bemerkungen. Schweigger's Jour. für Chem. u. Phys. 15: $273-276$.

1823. Ueber das Kicler Seebad. Kiel.

1828. Bemerkungen über das Leuchten des Meeres. Schweigger's Journ. f. Chem. u. Physik 22: 311-318.

Pfeffer, W. 1906. The physiology of plants. 2nd German (1897) ed. revised, edited and translated by A. J. Ewart. The production of light, 3: 382-388.

PFlüger, E. 1875. Die Phosphorescence lebendiger Organismen und ihre Bedeutung für die Principien der Respiration. Arch. f. die Ges. Physiol. 10: 275-300.

— 1875. Ueber die Phosphorescenz verwesender Organismen. Arch. für die Ges. Physiol. 11: 222-263.

Phipson, T. L. 1859. On some new cases of phosphorescence by heat. Rep. Brit. Assoc. Adv. Sci. Notes, 76-77.

- 1860. Sur la matière phosphorescente de la raie. Com. Rend. Ac. Sci. Paris 51: 541-542.

1860. Sur quelques cas nouveaux de phosphorescence. Com. Rend. Ac. Sci. 50: 316-317.

1862, 1869. Phosphorescence; or, the emission of light by minerals, plants and animals. $210 \mathrm{pp}$. London, and New York.

1872. Sur la noctilucine. Com. Rend. Ac. Sci. 75: 547; also Chem. News 25: 130.

- 1875, 1876. On noctilucine, the phosphorescent principle of luminous animals. Jour. Franklin Inst. 101: (ser. 3) 71: 68-72. Also Chem. News 32: 221-230.

PicArd, J. 1675, 1730. Sur la lumière du baromètre. Hist. dé l'Acad. Roy. des Sci. 2: 202-203. See also Mém. Acad. des Sci. 10: 566.

PICKel, J. G. 1787. Taschenbuch für Scheidekünstler aus das Jahr 1786, 55.

PICTET, R. 1894. Recherches expérimentales sur l'influence des basses températures sur les phénomènes de phosphorescence. Com. Rend. Ac. Sci. 119: 527-529.

Pictet, R., and M. Altschul. 1894. Ueber das Verhalten der Phosphorescenzerscheinungen bei sehr tiefen Temperaturen. Ztschr. f. Physik. Chem. 15: 386-388.

Pierantoni, U. 1914. La luce degli insetti luminosi e la simbiosi ereditaria. Rendiconti Accad. Napoli 20: 15-21.

- 1918. I microrganismi fisiologica e la luminescenza digli animali. Scientia, Bologna 23: 102-110.

Pierre, V. 1862, 1866. Uber die Anwendung der Fluorescenz zur Erkennung von fluorescirenden Stoffe. Sitzber. böhm. Ges. Wiss. Prag. 2: 66-82, 82-85; also Sitzber. Ac. Math-Nat. Kl. Wien 53 (III): 704-727.

Pincinelli, P. 1687. Mundus symbolicus. Lib. 8, Cap. 7. Cicindela. Coloniae agrippinae. Ist ed., 1635.

Prsco, F. J. 1861. Die Fluorescenz des Lichts. 115 pp. Wien.

Piso, W. 1648. De medicina Brasiliensi libri quatuor. Sec. I of Historia naturalis 
Brisiliae, ed. by Johann de Laet. 122 pp. Ludguni Batavorum et Amstelodami. Also in De Indiae utriusque de naturali et medecina libri quatuordecim. Amstelodami, 1658.

Pleischel, A. M. 1835. Ueber Lichterscheinungen bei dem Abdampfen einer Lösung des sauren schwefelsauren Kali (Bisulfas lixiviae). Baumgartner, Ztschr. Phys. f. verwandte Wiss. 3: 210-222.

Pliny, C. 1601. The historie of the world. Commonly called the naturall historie of C. Plinius Secundus. Translation into English by P. Holland. $2 \mathrm{v}$. in one. London.

PLot, R. 1686. Natural history of Staffordshire. P. 115 on luminous turf.

PlüCKER, J. 1858, 1859, 1860. Über die Einwirkungen des Magneten auf die electrischen Entladungen in verdünnten Gasen. Ann. der Physik 103: 88-106, 151-157. Translated in Phil. Mag. (4) 16: 119-135, $408-418$ and in Proc. Roy. Soc. 10: 256-259. 1859-60.

— 1858. Fortgesetzte Beobachtung Uber die Elektrische Entladiung durch gasverdünnte Räume. Ann. der Physik 104: 113-128, 622-630; 105: 67-84; 107: 77-113.

— 1859. Über die Constitution der electrischen Spectra der verschiedenen Gase und Dämpfe. Ann. der Physik 107: 497-538, 638-643.

1861. Uber die Einwirkung des Magnets auf die elektrische Entladung. Ann. der Physik 113: 249-280.

1862. Uber recurrente Ströme und ihre Anwendung zur Darstellung von gas Spectren. Ann. der Physik 116: 27-54.

- 1863. Uber die Spectra der Gase and Dämpfe. Sitzb. des Naturhist. Vereins d. Pruss. Rheinl. u. Westphal. 20: 39-42, 89-92.

Plücker, J., and J. W. Hittorf. 1865. On the spectra of ignited gases and vapors, etc. Phil. Trans. 155: 1-30.

Pocgiale, A. B. 1859. Rapport sur l'empoisonnement par le phosphore. Paris.

Poli, I. X. 1791. Testacea utriusque Siciliae, etc. See figs. of Pholas, Vol. 1, Plate 8.

Ромeт. 1737. A compleat history of drugs written in French by Monsieur Pomet chief druggist to the late French King Lewis XIV to which is added what is further observable from Mess. Lémery and Tournefort, etc. by John Hill. 3rd ed. London.

Pontoppidan, E. 1755. The natural history of Norway. Trans. from the Norwegian. London (A. Linde), Pt. 1, sec. VIII, pp. 73-75.

Pontus. 1833. Sur la congelation de l'eau par l'ether. Jour. de Soc. des Sc. Phys. et Chim. et Arts Ind. et Agric. de France 1: 131-132.

Pope, W. J. 1899. On triboluminescence. Nature 59: 618-619.

Porta, J. B. Della. 1558, 1589, 1658. Magia naturalis sive de miraculis rerum naturalium libri IIII. 163 pp. Neapoli. Libri XX, Neapoli. See translation Natural Magick in Twenty Books. 409 pp., London.

Poterius (Potier), P. 1625. Pharmacopoea spagirica. Liber II Cap. 27 De Lapide quondam incognito, admirabilis virtutis, a paucis annis in agro Bononiensi reperto, 533-539. 1st ed. Bononiae, 1622.

Porr, J. H. 1746, 1757. Chymische Untersuchungen welche für nehmlich von der Litheogeognosia usw handeln. Potsdam. 2nd ed., p. 39, Berlin. 1st ed. 1746.

Power, H. 1664. Experimental philosophy, in three books, containing new experiments, microscopical, mercurial, magnetical. 193 pp. London. Glow-worm, pp. 23-24.

Prandtl, W. 1948. Some early publications on phosphorus. Trans. by R. E. Oesper. Jour. Chem. Ed. 25: 414-419.

Precht, J. 1895. Das Phosphoresciren der Gelatineplatten und die Luminescenz der Pyrogallussäure. Photogr. Rundschau. 9: 321-324; Fortschr. d. Phys. 51 (2): 100. 
1897. Untersuchungen über Kathoden- und Röntgen-strahlen. Ann. der Physik 61: $330-362$.

Prevost, B. 1810, 1827. Considérations sur le brillant des yeux du chat et de quelques autres animaux. Biblioth. Universelle Britannique 45: 196-212. Also in Edinb. New Philos. Jour. 2: 297-304.

Priestley, J. 1767, 1769, 1775. History and present state of electricity. 2 v. 3 editions. London.

- 1772. The history and present state of discoveries relating to vision, light and colours. 812 pp. London. Luminescence on pp. 360-383.

- 1774. Experiments and observations on different kinds of air. 3 v. London. Light from animals 1: 279.

Pring, J. H. 1849. Observations and experiments on the Noctiluca miliaris, the animalcular source of the phosphorescence of the British seas; together with a few general remarks on the phenomena of vital phosphorescence. Phil. Mag. 34 (ser. 3) : 401-421. Also in Rep. Brit. Ass. 19th meeting, 81.

Pringsheim, E. 1892, 1893. Das Kirchoffsche Gesetz und die Strahlung der Gase. Ann. der Physik 45: 428-459; 49: 347-365.

Puerarius, D. 1667. De carnibus lucentibus. 19 pp Hafniae.

PuluJ, J. 1880-1882. Strahlende Elektrodenmaterie. 'itzber. Akad. Wiss. Wien. 81 (II) : 864-923; 83: 402-420, 676-708; 85: 871-881.

Pütrer, A. 1905. Leuchtende Organismen. Ztschr. f. Allg. Physiol., Sammelref. 5: 17-53.

Quatrefages, A. DE. 1843. Note sur un nouveau mode de phosphorescence observé chez quelques annelides et ophiures. Ann. Sci. Nat. Zool. (sér. 2) 19: 183-192.

— 1850, 1853. Mémoire sur la phosphorescence de quelques invertébrés marins. Ann. de Sci. Nat. Zool. 14: 226-235. Trans. in Amer. Jour. Science 15: 193-204; 16: $69-77$.

— 1850. Observations sur les noctiluques. Ann. Sci. Nat. Zool. (ser. 3) 14: 236-281.

Quellmalz, S. T. 1735. De cadmia fornacum phosphorescente. Commercium literarium Norimbergae, anno 1735, hebd. 46: 361-362.

QUET, M. 1852-1853. Sur quelque faits relatifs au courant et à la lumière électrique. Com. Rend. Ac. Sci. 35: 949-952; 36: 1012-1015.

QUeT ET SEQuin. 1862. Mémoire sur la théorie de la lumière électrique stratifiée. Ann. de Chim. 65: 317-330. See also Com. Rend. Ac. Sci. 47: 964-967, 1858, and 48: 338-341, 1859; Phil. Mag. 7: 109-112, 1859.

Quoy, J. R. C., and J. P. GAImARD. 1825. Observations sur quelques mollusques et zoophytes, envisagés comme causes de la phosphorescence de la mer. Ann. Sci. Nat. Zool. (ser. 1) 4: 5-13.

RAAB, O. 1900. Uber die Wirkung fluorescirender Stoffe auf Infusorien. Ztschr. für Biologie 39: 524-546.

Rabanus Maurus. 1617. De universo. Coloniae Agrippinae. Also 1852, Paris.

RAdZIsZEwsKI, B. 1877. Untersuchungen uber Hydrobenzamid, Amarin und Lophin. Ber. d. d. Chem. Ges. 10: 70-75, 321-322.

1880. Ueber die Phosphorescenz der organischen und organisierten Körper. Ann. der Chem. 203: 305-336.

1883. Zur Theorie der Phosphorescenzerscheinungen. Ber. d. d. Chem. Ges. 16: $597-601$.

Raffenau-Delile, A. 1833. Description de l'agaric de l'olivier (Agaracus olearius), et examen de sa phosphorescence. Guillemin Arch. Bot. 2: 519-527. 
RATHKE, H. 1836. Uber das Leuchten des Meeres, verursacht durch Oceania Blumenbachii. Wiegmann's Arch. f. Naturges., Jahrg. II, 1: 117-119.

Rawitz, B. 1892. Der Mantelrand der Acephalen. Jena. Ztschr. Naturw. (N. S.) 20: 1-232.

RAY, J. 1673, 1738. Observations topographical, moral, \& physiological made in a journey through part of the Low-Countries, Germany, Italy, and France, etc. 499 pp. London. See p. 115.

1710. Historia insectorum. Opus posthumum. 400 pp. Londini. P. 45, myriapod and pp. 79-81, Cicindela impennis seu foemina. The Gloe-worm.

1928. Further correspondence of John Ray, ed. by R. W. T. Gunther. London (Ray. Soc.).

Razoumowski, G. DE. 1786. Mémoire sur le ver-luisant. Mém. Soc. Sci. Phys. de Lausanne 2 (1789): 240-260.

1787. Sur le phosphorisme des corps du règne minéral par le frottement. Mém. Soc. Sci. Phys. de Lausanne. Part 2, 2 (1789): 39.

RÉAmuR, R. A. F. DE. 1712. Observations sur le mouvement progressif de quelques coquillages de mer, sur celuy des hérissons de mer, et sur celuy d'une espèce d'étoile. Mém. de l'Acad. Roy. des Sci. 1712 (1731): 115-145.

- 1723. Des merveilles des dails ou de la lumière qu'ils repandent. Mém. de l'Acad. Roy. de Sci. Paris, 198-204.

REDI, F. 1687. Osservazioni di Napoli. 216 pp. Naples. Luminous snake, pp. 10-11.

Reichenbach von. 1861. Zur Intensität der Lichterscheinungen. Ann. der Physik 112: 459-468.

ReinhardT, J. T. 1854. Note on a luminous fish (Astronesthes fieldii). Zoologist 12: $4299-4300$.

1854, 1855. Tvende Jagttagelser of phosphorisk Lysning hos en Fisk og en Insectlarve. Videnskabeliger Medeleser 60-65; Trans. R. Ent. Soc. Lond. (ser 2a) 3: Proc. 5-8; also in Ztschr. Naturwiss. 5: 208-213. (1855).

REINkE, J. 1898. Ueber das Leuchten von Ceratium tripos. Wiss. Meeresunters., herausgeg. v.d. Kommis. z. wiss. Unters. Deutsch. Meers in Kiel u.d. Biol. Sta. Helgoland, N.F. 3: Abt. Kiel, 37-41

Reinlein, J. 1768. Dissertatio physico-chemico-medica de phosphoris. $62 \mathrm{pp}$.

Reisch, G. 1517. Margarita philosophica. Basel. 1st ed., Heidelberg, 1496.

Reisel, S. 1688, 1759. De urina noctu lucente. Misc. Acad. Nat. Curios. Francof et Lips. 6-7: 277-282. Trans. in Abh. d. Röm. Kais. Akad. d. Naturf. Nurnb. 6: 330-335.

Reitlinger, E. 1862, 1863. Uber die Schichtung des electrischen Lichts. Sitzber. d. Acad. de Wiss. Wien, Abt. II 43: 15-25; in Ann. de Chim. 67: 114-116.

Remington, E. C. 1893. Luminous discharges in electrodeless vacuum tubes. Phil. Mag. (5) 35: 506-525.

Renaudot, E. 1655-1656. Recueil général des questions traictées ès Conférences du Bureau d'Addresse. Paris (L. Chamhoudry). Ed. by E. Renaudot, Lyons, 1666.

1664. A general collection of discourses of the virtuosi of France, upon questions of all sorts of philosophy, and other natural knowledge. Render'd into English by G. Havers, Gent. 580 pp. London. Another Collection, etc. trans. by G. Havers and J. Davies, 496 pp. 1666.

Reuland, J. 1889. Ueber Abkömmlinge des Diphenylins. Ber. d. d. chem. Ges. 22: 3011-3019.

Richarz, F. 1899, 1900. Ueber eine Erscheinung am Salophen. Ber. d. naturw. Ver. zu. Griefswald; Neu-Vorpommern Mitth. 31: xv.

Richarz, F., and R. Schenck. 1903, 1904. Analogien zwischen Radioktivitat und dem Verhalten des Ozons. Sitzber. d. k. pr. Akad. Wiss. Berlin. 1903: 1002-1006; also 37-45; 1904: 490-493. Abstract in Chem. Zentralb. 1904 (I) : 342, 494, 1053. 
Richter, G. F. 1832. Ueber eine neue Art Farbenverwandlung am pyramidalen Zircon (Varietät Hyacinth). Ann. der Physik 24: 386-388.

Riess, P. T. 1845. Zur Phosphorescenz des Diamants. Ann. der Physik 64: 334-335.

— 1853. Die Lehre von der Reibunselektricität. 2 v. Berlin.

— 1860. Geissler's nachleuchtende Röhren. Ann. der Physik 110: 523-124.

Rigaut, M. 1765, 1770. Observations sur les lumières scintillantes qui paroissent de temps en temps dans l'eau de la mer, produites par des insectes et sur l'effet de l'acide nitreux sur ces insectes. Mém. de l'Acad. de Paris, Hist., 26. Also in Jour. de Scavans (ser. 3) 43: 554-561.

RILEY, C. V. 1880. Large phosphorescent larva. "Answers to correspondents." Amer. Entom. 3: 201-202.

1887. Luminous organs of Phengodes laticollis and Zarhipis riversii. Entom. Mo. Mag. 24: 148-149.

1887. Notes on Phengodes and Zarhipis. Proc. Ent. Soc. Wash. 1: 62-63, 86-88; Ent. Mon. Mag. 24: 148-149; Nature 36: 592.

Rinman, S. 1747. On Lysspat ifrån Garpenberg. Vetensk. Acad. Handling, 168-173.

Risso, A. 1810. Icthyologie de Nice ou histoire naturelle de poissons du deportment des alpes maritimes. 388 pp. Paris. See p. 55.

1820. Sur deux nouvelles espèces de poissons du genre scopeles, observées dans la mer de Nice. Mem. R. Accad. Torino 25: 262-272.

Rirsert, E. 1890. Phosphorescenz durch Ozonewasser. Pharm. Ztg. 35: 372-373. See Chemische Zentralb. 1890 (II): 199.

Rirter, J. W. 1803. Bemerkungen zu vorstehender Abhandlung der Herrn Wünsh. Gehlen Jour. d. d. Chem. u. Physik 6: 633-719.

Rivers, J. J. 1886. Descriptions of the form of the female in a Lampyrid (Zarhipis Riversi, Horn). Amer. Nat. 20: 648-650.

Rivinus, F., and Boенмe, J. G. 1673. De noctu lucentibus. Dissertation. Lipsiae.

Rовві, J. H. 1818. Merkwürdige Beobachtungen über den innern und aussern Gebrauch des Phosphors, sowohl bei chronisch als auch einig acuten Krankheiten grundlich zu heilen. Wien.

Robertson, H. 1819. On the tides of the Mediterranean, and the occasional luminous appearance of its waters. Edinburgh Philos. Jour, 1: 236-238.

Rosin, C. 1878. Recherches sur la reproduction gemmipare et fissipare des Noctiluques. (Noctiluca miliaris.) Jour. Anat. 14: 563-629, and Com. Rend. Ac. Sci. Paris 86: 1482-1486.

Robin, C. et C. Lecros. 1866. De l'action exercé par l'électricité sur les Noctiluces miliaires. Jour. Anat. 3: 558-559.

Robinson, T. R. 1858. On fluorescence produced by the aurora. Phil. Mag. (4) 15: 326-327.

Rochefort, M. DE. 1681. Histoire naturelle et moralle des iles Antilles de l'Amérique. Dernière edition reveuè et augmentée. $583 \mathrm{pp}$. Rotterdam. See pp. 154-157 for Pyrophorus.

Roentgen, W. C. 1896. Eine neue Art von Strahlen. Trans., On a new kind of rays. by Arthur Stanton from Sitzber. Würzberger Phys.-Med. Gesellsch. 1895. Nature 53: 274-276, Jan. 30, 1896.

Rohaul, J. 1735. Rohault's system of natural philosophy, illustrated with Dr. Samuel Clarke's notes, taken mostly out of Sir Isaac Newton's philosophy, with additions. 2 v. London. Part I, Chap. 27, on luminescences. In French, 1671.

Rolland, E. 1877-1915. Faune populaire de la France. Noms vulgaires, dictons, proverbes, légendes, contes et superstitions. 13 v. Paris. Vols. 3, 12, 13 on Invertebrates. 
Roloff, M. 1898. Ueber Lichtwirkungen. Ztschr. f. physik. Chem. 26: 337-361.

RoNDELET, G. 1554. Libri de piscibus marinis in quibus verae piscium effigies expressae sunt. 583 pp. Lugduni.

1555. Universae aquatilium historiae pars altera, cum veris ipsorum imaginibus. 242 pp. Lugduni.

1558. L'histoire entière des poissons. Lyon.

Rose, H. 1835, 1836, 1841. Uber die Lichterscheinungen bei der Krystallbildung. Ann. d. Physik 35: 481-485; 52: 443-464, 585-600. Ann. de Chim. et Phys. 61: 288-293.

- 1858. Uber die Lichterscheinungen welche gewisse Substanzen beim Erhitzen Zeigen. Ann. der Physik 103: 311-330.

Rouelle, G. F. 1752. Sur l'inflammation de l'huile de terebinthe par l'acide nitreux pur, etc. Men. Ac. Sci. Paris 1747: 34-56.

Rowning, J. 1735-1742. A compendious system of natural philosophy with notes, in 4 parts. 2nd ed. Cambridge. See pp. 147-169 for aurora borealis.

RudolphI, K. A. 1821. Grundrisse der Physiologie. 2 v. Berlin. I: 196-198 (Sec. 192).

Rumph, G. E. 1683. De mari indico noctiluco, in a letter from Amboina, 1682. Acad. Nat. Curios. Dec. II, Ann. I, p. 56.

1750. Herbarium Amboinense (in 12 v.). Amsterdam. 6: 130 on Agaricus igneus.

Runge, C., and F. Paschen. 1897, 1898. Ueber die Serienspectra der Elemente Sauerstoff, Schwefel und Selen. Ann. der Physik 61: 641-686. Astrophysical Jour. 8: $70-101$.

Russell, H. L. 1892. Impfungsversuche mit Giard's pathogenen Leuchtbacillus. Cent. f. Bakt. 11: 557-559.

RUtheRFord, E. 1900. A radio-active substance emitted from thorium compounds. Phil. Mag. (5) 49: 1-14; see also 161-192.

RuYsch, H. 1718. Theatrum universale omnium animalium, Amsterdam. Pars 5, De Insectis, Lib. II, Caput VIII De Cucujo and X De Cicindela.

RyE, E. C. 1878. Luminous lepidopterous larvae. Ent. Mon. Mag. 14: 257-260.

Sachs von Lewenhaimb, P. J. 1665. Gammarologorum, vulgo Cancrorum consideratio physico-historico-medico-chymica, etc. 962 pp. Francofurti and Lipsiae.

SAFFORD, W. E. 1916. Lignum nephriticum, its history and an account of the remarcable fluorescence of its infusion. Ann. Rep. Smith. Inst. 272-298, Washington.

SAGE, M. 1780. Observations sur l'altération des pilotis en bois de chêne retirés des démolitions du pont de Chatov et sur la phosphorescence de ce bois pourri dans l'eau. Académie gemeinnutziger Wissensch. Erfurt. Acta Acad. Elect. Mog. Scien. 1778-1779: 300-302.

Salet, G. 1871, 1872. Sur les spectres du soufre. Com. Rend. Ac. Sci. 73: 559-561, 742-745. See also 74: 865-866; 75: 76-77.

1873. Sur les spectres des metalloides. Ann. Chim. et Phys. (4) 28: 5-71. See Com. Rend. Ac. Sci. 74: 1249, 1872.

1876. Sur le spectre de l'azote et sur celui des metaux alcalins dans les tubes de Geissler. Com. Rend. Ac. Sci. 82: 223-226, 274-275; Phil. Mag. (5) 1: 331-333.

- 1892. Sur la loi de Stokes, sa verification et son interpretation. Com. Rend. Ac. Sci. 115: 283-284.

Salm-Horstmar, F. 1861. Über Fluorescenz der Wärme. Ann. der Physik 113: 54.

SARASIN, E. 1869, 1870. De la phosphorescence de gaz rarifies apres le passage de la décharge électrique. Arch. des Sc. Phys. et Nat. (2) 34: 243-254 and Ann. de Chim. et Phys. (4) 19: 180-190.

1870. Von der Phosphorescenz verdünnter gase nach dem Durchgang einer elektrischen Entladung. Ann. der Physik 140: 425-434. 
SARS, G. O. 1885. Report on the Schizopoda. Voyage of H. M. S. Challenger, 13, 225 pp. Pp. 70-72 on luminous globules.

SARTON, G. 1948. Early observations of aurora borealis. Introduction to the History of Science 3: 709-711.

- 1948, 1950. Is Burzurg's description of the phosphorescent sea c. 953 the first of its kind? Isis 39: 235; 41: 198.

SAussure, H. B. DE. 1792. Analysis de la dolomie. (Rozier) Jour. de Physique 40: 161-173.

Scaliger, J. C. 1557. Excercitationum exotericarum liber XV de Subtilitate ad. Hier. Cardanum. Paris.

ScharfF, E. 1907. Über das Leuchten des Phosphors und einige seiner Verbindemgen. Marburg.

SCheEle, C. W. 1771. Experiments upon the spatum phosphorescens, called by Dr. Linneus, Muria chrysolampis, and of Cronstedt Sparry. Fluor. Dissert. 4 pp.

- 1779. Untersuchung des Flusspathes und dessen Saure. Crell's Chem. Jour. 2: 192-203; from Ber. d. Schwed. Acad. 33: 122, 1771.

- C. W. 1780. Chemical observations and experiments on air and fire. Trans. by J. R. Forester. 259 pp. London. From Chemische Abhandlung von der Luft und der Feuer, 101-103, 1777.

— 1786. The chemical essays. Translated by Thomas Beddoes. Fluor, pp. 1-67.

Scheerer, T. 1840. Untersuchungen des Allanit, Orthit, Cerin und Gadolinit. Ann. d. Physik 51: 465-505.

Scheiner, J. 1898. On the spectrum of hydrogen in the nebulae. Astrophys. Jour. 7: $231-238$.

Schenk, O. 1873. Ubber Veranderlichkeit der Spectra glühender Gase. Ztschr. f. Anal. Chem. 12: 386-390.

Scherer, A. N. 1795. Ueber das Leuchten des Phosphors und der kalkerdigen Schwefelleber, uber die Krystallisirung des ätzenden feuerbestandigen Alkalis, und andere physikalischchemische Gegenstande. Gren's Neues Jour. d. Phys. 1: 319-330.

Scherer, A. N. von, and C. C. F. JÄGER. 1795. Über das Leuchten des Phosphors im atmosphärischen Stickgas.... Weimar.

Schertel, S. 1902. Leuchtpilze, unsere gegenwärtige Kenntnis von ihnen, ihr vorkommen in Literatur und Mythe. Deutsch. bot. Monatsch. 22: 39-42, 56-60, 76-77, 139-152.

Schiller, J. M. 1791. Taschenbuch für Scheidekünstler auf das Jähr 1791. P. 45 on crystalloluminescence.

Schmid, W. 1866. Über die Phosphornebel. Jour. für Prak. Chem. 98: 414-418.

Schmidr, G. C. 1896. Beiträge zur Kenntniss der Fluorescenz. Ann. der Physik 58: 103-130.

1897. Polarisirte Fluorescenz. Ann. der Physik 60: 740-754.

1897. Uber das lichtelectrische Verhalten des Flusspaths und des Selens. Ann. der Physik 62: 407-414.

- 1898. Uber die Beziehung zwischen Fluorescenz und Actinoelectricität. Ann. der Physik 64: 708-724; also in Sitzb. d. Phys. Med. Soc. Erlangen 29: 10-16.

— 1898. Über die von den Thorverbindungen und einigen anderen Substanzen ausgesende Strahlung. Ann. der Physik 65: 141-151.

1899. Nachtrag zu meiner Arbeit über "Polarisirte Fluorescenz." Ann. der Physik 68: 779-782.

1900. Uber die Fluorescenz des Chinins. Physik. Ztschr. 1: 466-467.

1900. Uber den Einfluss der Temperatur auf das Potentialgefälle in verdünnten

Gasen. Ann. der Physik 1: 625-647 and Physik. Ztschr. 1: 251-254. 
- 1902, 1904. Uber die chemischen Wirkungen der Kanalstrahlen. Ann. der Physik 9: 703-711; 11: 613-618, and 13: 622-633.

Scнмidr, G. G. 1795. Chemische Untersuchung über den phosphorescirenden Bestandtheil des Quarzes, nebst Versuchen uber die Verwandlung des Wassers in Stickluft beim Durchgang durch gluhenden Thon und Quarz. Gren's Neues Jour. d. Phys. 1: 297-318.

Schmidr, P. 1894. Über das Leuchten der Zuckmücken (Chironomidae). Zool. Jb. Abt. 1, 8: 58-66. Transl. Ann. Mag. Nat. Hist. (6) 15: 133-141.

Schmitz, J. von. 1843. Über den Bau, das Wachtum und einige besonderen Lebenserscheinungen der Rhizomorpha fragilis. Linnaea 1: 487-535.

Schnauss, J. 1862. Bericht über meine Versuche, die chemische Wirkung des Lichtes von Lampyris nachzuweisen. Nova Acta Leop.-Carol. 30: 114-116.

Schneider, J. 1855. Ueber Phosphorescenz durch mechanische Mittel. Ann. der Physik 96: 282-287.

Schönbein, C. F. 1840. Recherches sur la natur de l'odeur qui se manifeste dans certaines actions chimiques. Com. Rend. Ac. Sci. 10: 706-710.

— 1845. Uber das Leuchten des Phosphors in atmosphärische Luft. Jour. f. Prak. Chem. 36: 246-249, 379-381.

- 1845. Uber die Natur des Ozons. Ann. der Physik 65: 69-80.

— 1848. Uber die Erzeugung des Ozons durch Phosphor in reinen Sauerstoffgase. Ann. d. Physik 75: 367-377, 377-386.

1853. Uber einen wesentlichen Unterschied zwischen gewöhnlich und amorphan Phosphor. Jour. Prak. Chem. 60: 154-158.

Schönwald. 1786. On crystalloluminescence. Crell's Chemische Ann. f. d. Freunde d. Naturlehre 2: 48-50.

Schoтт, K. 1657. Magia universalis naturae et artis, etc. Pars IV, Herbipoli.

-1662. Physica curiosa, etc. libris XII. Herbipoli.

Schove, D. J. 1948, 1950, 1951. Sunspots and aurorae. Jour. Brit. Astron. Assoc. 58: 178-190, 202-294; 61: 22-25, 1950. See also Isis 42: 133-138.

Schrank, F. von P. 1788. Anmerkungen zu den ersten zwanzig Stücken des Naturforschers. Der Naturforscher (Halle) stuck 23, p. 137.

Schroetter, A. 1852, 1853. Über die Ursachen des Leuchtens mancher Körper beim Erwärmen. Deutsche Naturf. Versamml. Bericht, 102-105; Wiener Sitz. Ber. 9414 419; Jour. Prak. Chem. 58: 150-155.

Schuller, A. 1881. Über das Leuchten des Ozon während seiner Zersetzung. Mittheilungen der Ungar. Naturwiss. Gesellsch. 13: 277. Abs. in Beibl. zu dem Ann. der Phys. u. Chem. 5: 419, 666.

Schultz, O. 1899. Phosphorescierende Lichterscheinung an den antennen von Asteroscopus sphinx Hufn. (cassinia F.) Berlin Ent. Ztschr. 44: 319-320.

Schultze, M. 1864, 1865. Über den Bau der Leuchtorgane der Mannchen von Lampyris splendidula. Sitzber. Wiederheim Ges. Natur. u. Heilk. zu Bonn, 61; also in Arch. Naturgesch. 30: 363-365, and Arch. Mikr. Anat. 1: 124-137.

Schuster, A. 1877. On the passage of electricity through gases. Proc. Cambridge Philos. Soc. 3: 57-61.

- 1879. On the spectra of metalloids. Spectrum of oxygen. Phil. Trans. 170: 37-54. 1880. On our knowledge of spectrum analysis. A report. Rep. Brit. Assoc. Adv. Sci., 258-298.

1881. On harmonic ratios in the spectra of gases. Proc. Roy. Soc. 31: 337-347. See Nature 20: 533, 1879.

- 1884. Experiments on the discharge of electricity through gases. Sketch of a theory. Bakerian Lecture. Proc. Roy. Soc. 37: 317-339. 
1890. The discharge of electricity through gases. Proc. Roy. Soc. 47: 526-561.

Schwarz, G. 1903. Luminescenz bei Lösung. Oesterr. Chem. Ztg. Also in Fortschr. d. Phys. 59 (2): 452. Firefly, p. 551.

Schweigger, J. S. C. 1823. Uber Dobereiner's neues Feuerprincip Anhang I. Uber allgemeine Körperanziehung mit Hinsicht auf die Theorie der Krystallelectricität als allgemeinen Naturprincip. Schweigger's Jour. für Chem. u. Phys. 39: 231-250.

- 1824, 1825. Uber Lichterscheinungen bei Krystallisationen. Schweigger's Jour. für Chem. u. Phys. 40: 271-279; see also 10-24, and 44: 74-78.

SchwenkfELd, C. 1603. Theriotropheum Silesiae, in quo animalium, hoc est quadrupedum, reptilium, avium, piscium, insectorum natura, sex libris. $563 \mathrm{pp}$. Ligniciae.

SchytтEs, E. 1765. Miscellan-Observationen auf die Jahre 1758 and 1759. Drontheimische Gesellsch. Schriften 1: 245.

SEcCHI, P. 1872. Nouvelles observations sur les lumières phosphorescentes animales. Ann. Sci. Nat. Zool. (ser. 5) 16, article 9.

SECCI, A. 1870. Sur les modifications apportées par le magnétisme dans la lumière émise par les gaz raréfiés. Com. Rend. Ac. Sci. 70: 431-433.

Seelhorst, G. 1869. Uber fluorescirende Flussigkeiten in Geissler'schen Röhren. Ann. der Physik 137: 167-171.

1873. Ueber Phosphore. Abh. der Naturhist. Ges. Nürnberg 5: 119; Dingler's Polytechn. Jour. 207: 220-224.

SeguY, G. 1895. Sur un phenomenon de phosphorescence obtenu dans des tubes contenants de l'azote raréfiés àpres le passage de la décharge électrique. Com. Rend. Ac. Sci. 121: 198-199.

1898. Modification des pressions intérieures exercées dans les récipients clos et vidés et soumis aux influences des courants électriques. Com. Rend. Ac. Sci. 127: 385-387.

SenecA, L. A., 63 A. D. Questiones Naturalis. Trans. by J. Clarke as Physical Science in the time of Nero. $368 \mathrm{pp}$. London, 1910. Also translated by T. Lodge, 1614.

Sennert, D., N. Culpeper, and A. Cole. 1661. Thirteen books of natural history. London. Book IV, Chap. 2, pp. 105-111, Of fiery meteors.

Severn, H. A. 1881. Notes on the Indian glow-fly. Nature 24: 165.

SGuario, E. 1738. Dissertazione sopra le aurore boreali, etc. Venezia. $119 \mathrm{pp}$.

SHARKEY, E. 1840. Emanation of light from the human body. Dublin Medical Press 3: $129-131$.

SHAw, T. 1757. Travels, or observations relating to several parts of the Barbary and the Levant. 2nd ed. London. 1st ed., 1738.

Sibbald, R. 1684. Scotia-Illustrata sive prodromus historiae naturalis, etc. Edinburgh. Cicindela, part 2, p. 31.

Sidor, T. 1866. Recherches sur la crystallisation de quelque sulphures métalliques et sur les propriétés de la blende hexagonale. Com. Rend. Ac. Sci. 62: 999-1001; 63: $188-189$.

Silliman, B. 1830. Elements of chemistry. New Haven.

Simpson, W. 1675. Zymologia physica, or a brief philosophical discourse of fermentation from a new hypothesis of acidum and sulphur. $149 \mathrm{pp}$. London. Review in Phil. Trans. 9: 410-416.

Simson, A. 1622-1624. Hieroglyphica animalium, terrestrium, volatilium, natatilium, reptilium, insectorium, vegetivorium, metallorium, lapidium ... quae in Scripturis Sacris inveniuntur, etc. Edinburgh.

Skinner, C. A. 1899. Uber das Anodengefälle bei der Glimmentladung. Ann. der Physik 68: 752-768. 
- 1900. On the potential gradient in the so-called Faraday dark space of vacuum tubes as related to conditions prevalent at the cathode. Phil. Mag. (5) 50: 563-574.

SLABber, M. 1771-1778. Natuurkundige Verlustigingen. Haarlem. Physikalische Belustigungen (trans. from Dutch), Nürnberg, 1775-1781. Plate VIII for Noctiluca.

Slare, F. 1683. An account of some experiments made at several meetings of the Royal Society by the ingenious Fred. Slare M.D. etc. Phil. Trans. 12 (No. 150): 289-290. Exp. I, A parallel betwixt lightning and a phosphorus.

SloAne, H. 1707, 1725. A voyage to the Islands ... and Jamaica, 2 v. London. 2: 206-207, on Pyrophorus.

Smith, F. 1869. The larva of the Pyrophorus of Uruguay. Proc. Roy. Ent. Soc. Lond. 15.

SMYTH, C. P. 1882. On the constitution of the lines forming the low temperature spectrum of oxygen. Trans. Roy. Soc. Edinb. 30: 419-425.

1887. Micrometrical measurements of gaseous spectra under high dispersion. Trans. Roy. Soc. Edinb. 32: 416-460. See also 80 (1): 93-160, 1883, and Nature 31: $314-315,1885$.

- 1889. Reexamination of the spectra of twenty-three gas-vacuum end-on tubes, after six to ten years of existence and use. Chem. News 60: 223-224.

Smyth, C. P., \& A. S. Herschel. 1883. Gaseous spectra in vacuum tubes, under small dispersion and at low electric temperature, with appendix by $A$. S. Herschel. Trans. Roy. Soc. Edinb. 31: 93-160; Roy. Scotch. Soc. of Arts 10: 226-265.

SoHncke, L. 1896. Polarisirte Fluorescenz ein Beitrag zur kinetischen Theorie der festen Korper. Sitzber. d. K. Bay. Ak. Wiss. München. 26; Ann. der Physik 58: 416-454.

SORBY, H. C. 1875. On the connection between fluorescence and absorption. Monthly Micr. Jour. 13: 161-164.

Soret, J. L. 1869. Sur l'illumination des corps transparents. Com. Rend. Ac. Sci. 69: $1192-1196$.

- 1871. On harmonic ratios in spectra. Phil. Mag. (4), 464-465, from Arch. de Sci. Phys. et Nat. Geneva (2) 42: 82-84.

- 1874, 1877. Spectroscope a oculaire fluorescent. Arch. de Sci. Phys. et Nat. (ser. 2) 49: 338-343; 57: 319-333. Ann. Chim. et Phys. (ser. 5) 11: 72-86.

Southwell, R. 1698. Some philosophical experiments. Phosphorus metallorum. Phil. Trans, 20: 365 .

SowERby, J. 1797. Colored figures of English fungi 1. London. See plate 100 for luminous Rhizomorpha.

Spallanzani, L. 1784. Lettera prima relativa a diverse produzioni marine. Memoria de Mat. e Fis. della Soc. Ital., Verona 2: 603-661.

- 1794. Memoria sopra le Meduse fosforiche. Mem. d. Mat. e Fis. d. Soc. Ital. d. Sci. Modena e Verona 7: 271-290. Also in Jour. de Phys. 28: 67.

— 1796, 1797, 1799. Chimico esame degli esperimenti del Sig. Göttling, sopra la luce del fosforo di Kunkel osservata nell' aria comune. Modena. Also in Ann. de Chim. 22: 246-254; Ann. der Physik 1: 33-63.

- 1798. Travels in the two Sicilies and some parts of the Apennines. Translated from orig. Italian (1793) . $4 \mathrm{v}$. London. Chap. XXVII on Phosphorescent medusae.

Specia, G. 1876. Sul colore del zircone. Atti Acc, di Torino 12: 37-43.

SpidberG, J. K. 1724. De causa et origine ventorum, etc. Eigenschaften und Ursachen des sogenannten Nordlichts. ... Halle.

Spiflman, J. R. 1763. Institutiones Chemiae, Argentorati. 2nd ed., 1766.

SPILler, J. 1882. Spectrum of the light of the glow-worm. Nature 26: 343.

Splittgerber, D. 1839. Beobachtungen über mehrere Glasfarben. Ann. der Physik 47: $466-470$. 
Spottiswoode, W. 1876. On stratified discharges. II Observations with a revolving mirror. Proc. Roy. Soc. 25: 73-82; III, 547-550. See also I, 23: 455-462, 1875.

Spotriswoode, W., and J. F. Moulton. 1879. On the sensitive state of electrical discharges through rarefied gases. Phil. Trans. 170: 165-229.

Spottiswoode, W., and J. F. Moulton. 1880. On the sensitive state of vacuum discharges. Part II. Phil. Trans. 171: 561-652.

Spotriswoode, W., and J. F. Moulton. 1882. On the movement of gas in vacuum discharges. Proc. Roy. Soc. 33: 453-455.

Stark, J. 1902. Die Elektrizität in Gasen. 509 pp. Leipzig.

Stebing, T. R. R. 1888. Report on the Amphipoda. Challenger Rep. XXIX. Pp. 1-600, on history.

STEEL, T. 1899. Luminosity of sugar. Nature 59: 295-296.

Stein, F. L. 1883. Der Organismus der Infusionstiere. Leipzig, III Abt., 2nd half, Abs. in Jour. Roy. Micr. Soc. (2) 4: 403-404.

STEnGer, F. 1885. Beiträge zur Electricitätsleitung der Gase. Ann. der Physik 25: 31-48. 1886. Zur Kenntniss der Fluorescenzerscheinungen. Ann. der Physik 28: 201 . 230. See also 33: 577-586, 1888, on absorption.

Stewart, C. 1802. Elements of the natural history of the animal kingdom 2: 441. 2nd ed., 1817.

Stier, J. 1641. Praecepta doctrinae, logicae, ethicae, physicae, metaphysicae, etc. London. Aurora borealis, p. $24 \mathrm{ff}$.

Stokes, G. G. 1852, 1853. On the change of refrangibility of light. Phil. Trans., 1st paper, 142: 463-562; 2nd paper, 143: 385-396.

- 1855. On the alleged fluorescence of a solution of platinocyanide of potassium. Phil. Mag. (4) 10: 95.

— 1862. On the long spectrum of the electric light. Phil. Trans. 152: 599-619.

1864. On the application of the optical properties to detection and discrimination of organic substances. Chem. Soc. Jour. 2: 303-318. See also Phil. Mag. (ser. 4) 47: 385-395.

- 1882. On the cause of the light border frequently noted in photographs, just outside the outline of a dark body seen against the sky; with some introductory remarks on phosphorescence. Proc, Roy. Soc. 34: 63-68.

Stoney, G. J. 1870, 1871. On the cause of the interrupted spectra of gases. Phil. Mag. (4) 41: 291-296. See Rep. Brit. Assoc. Adv. Sci. 1870. Notes, p. 41-43, 1871.

1880. A new harmonic relation between the lines of hydrogen. Nature 21: 508.

1891, 1892. On the cause of double lines and of equidistant sattelites in the spectra of gases. Sci. Trans. Dublin Soc. (2) 4: 563-608. See also Phil. Mag. (5) 33: 503-516; Nature 46: 29, 126, 222, 268-269.

- 1894. Of the electron or atom of electricity. Phil. Mag. (5) 38: 418-420.

Stubrs. 1668. A continuation of the voyage to Jamaica. Phil. Trans. 3 (No. 36): 699-709.

Sturm, J. 1799. "Die Amphibien" Deutschlands Fauna Abt. 3. Heft. 2, Nürnberg. Sturmius, J. C. 1681. Letter re phosphores of Dr. Kunckel. Philos. Collec. No. 2: 8-9.

Suchsland, E. 1898. Physikalische Studien über Leuchtbakterien. Festschr. d. 200jähr. Jubelfeier der Franckeschen Stiftungen. $16 \mathrm{pp}$. Halle. In Zbl. Bakt. (Abt. 2), 4: 713-715.

Suriray, M. 1836. Recherches sur la cause ordinaire de la phosphorescence marine et description du Noctiluca miliaris. Magazin Zool. Guerin 6: 1-16.

SUTER, H. 1890. Miscellaneous communications on New Zealand land and fresh water molluscs. Trans. N. Z. Inst. 23: 93-96. 
SviAtskir, D. O. 1934, 1936. Aurora borealis in Russian literature from the 10th to the 18th century (in Russian. Arch. of the Hist. of Sci. 4: 47-67. See Isis 24: 282.

Swammerdam, J. 1737. Biblia naturae sive Historia Insectorum. 2 v. In Latin and Dutch. Leyden. Cicindula, p. 283.

Swan, J. 1635. Speculum mundi, etc., Cambridge. Pp. 93-94, Ignis fatuus; pp. 97-98, Licking light; p. 271, Nyctilops an herb that shines.

Swinton, A. H. 1880. Insect variety; its propagation and distribution, 87-89. London, Paris, and N.Y.

Swinton, C. 1897. Some experiments with cathode rays. Proc. Roy. Soc. 61: 79-95.

- 1899. On the luminosity of the rare earths when heated in vacuo by means of cathode rays. Proc, Roy. Soc. 65: 115-119.

Symmer, R. 1759. New experiments and observations concerning electricity. Phil. Trans. 51: 340-347.

SzÜTZ, C. von. 1800. Verschiedene pharmaceutisch-chemische und physikalische Erfah. rungen. Trommsdorffs Jour. der Pharm. für Artze und Apotheker, Leipzig 8 (Pt. 2) : 49-64.

TAchard, G. 1689. Voyages de Siam des Pères Jésuites, envoyés par le roy aux Indes et à la Chine, avec leurs observations astronomiques et leurs remarques de physiques, de géographie, d'hydrographie et d'histoire. Paris. Sea light, p. 39; fireflies, p. 150.

TAFEL, J. 1903. Úber die Wirkung von Kanalstrahlen auf Zinkoxyd. Ann. der Physik 11: $613-618$.

Talbot, H. F. 1826. Some experiments on colored flames. Edinburgh Jour. of Sci. 5: $77-81$.

— 1835. On the nature of light. Phil. Mag. (3) 7: 113-118.

TAPPeiner, H. von, and A. Jodlbauer. 1907. Die sensibilisierende Wirkung fluores. zierender Substanzen. Leipzig.

Terchmeyer, H. F. 1733. Elementa philosophia naturalis experimentalis. $259 \mathrm{pp}$. Jena. 1st ed., 1717. Part I, chap. 28 on phosphors.

- 1737. Institutiones materiae medicinae. $235 \mathrm{pp}$. Jenae.

Templar, J. 1671. Some observations about the shining of glow worms. Phil. Trans. 6: $2177-2178$ and 3035-3036.

Thenard, L. J. 1812, 1813, 1814. Résultats d'expériences sur la phorphore. Ann. Chim. et Physiq. 81: 109-112 and 85: 326-328. Also in Ann. der Physik 44: 341-345, and 46: 270-227.

Theodosius, J. B. 1553. Medicinales epistolae LXVII. L. De Lampyride. Basileae.

Thompson, E. P. 1896. Roentgen rays and phenomena of the anode and cathode. 190 pp. New York.

Tномpson, J. V. 1829. Zoological researches III. On the luminosity of the ocean, with descriptions of some remarkable species of luminous animals, and particularly of the four new genera, Noctiluca, Cynthia, Lucifer and Podopsis of the Schizopodae, 37-67.

Tномpson, S. P. 1897. Light, visible and invisible. 294 pp. New York.

Thomson, J. 1798. Über den weissen Marmor des Vesuvs. Crell's Chem. Annal. f. d. Freunde d. Naturl. 1: 267-273.

Thomson, J. J. 1886. Some experiments on the electric discharge in a uniform electric field with some theoretical considerations about the passage of electricity through gases. Proc. Camb. Philos. Soc. 5: 391-409. See Phil. Mag. 15: 427-434, 1883 , for theory.

- 1890. Some experiments on the velocity of transmission of electric disturbances, 
and their application to the theory of striated discharge through gases. Phil. Mag. (5) 30: 129.140.

1891. On the rate of propagation of a luminous discharge of electricity through a rarefied gas. Proc. Roy. Soc. 49: 84-100.

- 1891. On the discharge of electricity through exhausted tubes without electrodes. Phil. Mag. (5) 32: 321-336, 445-464.

- 1893. Notes on recent researches in electricity and magnetism, intended as a sequel to Clerk Maxwell's treatise on electricity and magnetism. Chap. 2, pp. 53207, Passage of electricity through gases.

- 1895. On the electrolysis of gases. Proc. Roy. Soc. 58: 244-257.

- 1897. Cathode rays. Proc. Roy. Inst. 15: 419-432 and Phil. Mag. (5) 44: 293-316.

- 1899, 1900. On the theory of the conduction of electricity through gases by charged ions. Phil. Mag. (5) 47: 253-268, 494-416; see also the Genesis of ions 50: $378-382$.

- 1899. On the masses of the ions in gases at low pressures. Phil. Mag. 48: 547-567. 1903. The conduction of electricity through gases. $678 \mathrm{pp}$. Cambridge. 2nd. ed. 1906.

Thorpe, T. E. 1890. The glow of phosphorus. Chem. News and Jour. Physical Sci. 61: $140-141$.

Thorpe, T. E., and A. E. Tutton. 1890, 1891. Phosphorus Oxide, I and II. Jour. Chem. Soc. (Trans.) 57: 545-573; 59: 1019-1029.

Thudichum, L. W. 1868. On chemical identification of diseases. Tenth Report (for 1867) of the Medical Officer of the Privy Council, London. 10 (Appendix): 152-294. Hematoporphyrin fluorescence, p. 228.

Thulis and Bernard. 1786. Observations sur les crevettes de rivière phosphoriques. Jour. de Physique 28: 67-68.

Tiede, E., and P. Wulf. 1920, 1922. Bortrioxyd-Hydrate als Bestandteil hochphosphorescenz-fähiger organische Verbindungen enthaltender System. Ber. d. d. Chem. Ges. 55: 588-597. See also 53: 2206-2216, 1920.

Tiedemann, F. 1830. Physiologie des Menschen. 3 v. Darmstadt. 1: 480-510, Von der Licht-Entwickelung der organischen Körper. English trans., 1834.

Tilesius von Tilenau, W. G. 1803-1806. Atlas zum Krusensterns Reise um die Welt ausgefuhrt in den Jahren 1803 bis 1806. 21. Also in Ann. d. Wetterauische Ges. für die Gesam. Naturkunde zu Hanau 3: 567.

- 1813. Naturhistorische Früchte der ersten Kaiserlich-Russischen, unter dem Kommando des Herrn v. Krusenstern glücklich vollbrachten Erdumseeglung [sic] gesammelt. 130 pp. St. Petersburg.

- 1819. Resultate seiner, während der drei Jahren der Krusensteruschen Entdeckungsreise, etc. Ann. d. Physik 61: 36-44, 161-176, 317-336.

Tingry. 1798. De la phosphorescence des corps, et particuliarement sur celles des eaux de la mer. Jour. de Physique 4: 287-295.

Tod, T. J. 1824-1826. An inquiry into the nature of the Iuminous power of some of the Lampyrides. Quart. Jour. Sci. Lit. Arts 17: 269-270; 21: 241-251, 1926; also in Zool. Jour. 1: 274 (1925).

Tollhausen, P. 1889. Untersuchungen über Bacterium phosphorescens Fischer. Diss. Würzburg.

Torrubla, J. 1754. Asparato para la historia natural española. Translated as Vorbereitung zur Naturgeschichte von Spanien by C. G. von Murr. Halle (Gebauer), 1773. Pp. 101-102 on sea phosphorescence.

Trabaud, M. 1753. Le mouvement de la lumière ou premiers principes d'optique. 344 pp. Paris. See Les phosphores et les noctiluques, pp. 319-323 and L'aurore boreale, pp. 323-339. 
Trautz, M. 1904. Uber neue Lumineszenzerscheinungen. Ztschr. Wiss. Photog. 2: 217-223, and Ztschr. für Elektrochem. 10: 593-597.

1905. Studien uber Chemilumineszenz. Ztschr. Physik. Chem. 53: 1-111.

Trautz, M., and P. Schorigin. 1905. Kristallolumineszenz und Tribolumineszenz. Ztschr. Wiss Photog. 3: 80-90.

TrEmbly, A. 1745. Concerning the light caused by quicksilver shaken in a glass tube, proceeding from electricity. Phil. Trans. 44 (No. 478): 58-60.

Trève, A. 1870. Action du magnétisme sur les gaz. Com. Rend. Ac. Sci. 70: 36-39.

Treverinus, L. C. 1829. Entwickelt sich Licht und Wärme beim Leben der Gewächse. Tiedemann's Ztschr. f. Physiol. 3: 257-268.

Treviranus, G. R. 1802-22. Biologie oder Philosophie der lebenden Natur für Naturforscher und Aerzte, Gottingen. 6 v. 5: 81-140, Zweiter Abschnitt. Phosphorische Erscheinungen der organischen Natur.

1831-1833. Die Erscheinungen und Gesetze des Organischen Leben. 2 v. Bremen. 1: 432-447, on Phosphorescenz der Organischen Wesen.

TRIMEN, R. 1870. On the occurrence of Astraptor illuminator, Murray, or a closely allied insect, near Buenos Ayres. Jour. Linn. Soc. Lond. 10: 503-504.

Trowbridge, C. C. 1899. Phosphorescent substances at liquid-air temperatures. Science (2) 10: 245-249.

Trowbridge, J., and J. E. Burbank. 1898. Phosphorescence produced by electrification. Amer. Jour. Sci. (4) 5: 55-56; Phil. Mag. (5) 45: 100-102.

Trowbridge, J., and T. W. Richards. 1897. The temperature and ohmic resistance of gases during the oscillatory electric discharge. Amer. Jour. Sci. (4) 3: 15-20, $117-120,327-342$.

Tukey. 1818-1819. Leuchten des Meeres auf seiner Entdeckungsreise nach dem Kongostome beobachtet. Ann. der Physik 61: 317-320, with Anmerkungen des Hofrath Tilesius, 320-330. Also in Edinburgh Philos. Jour. 1: 217.

Tulasne, L. R. 1848. Sur la phosphorescence spontanée de l'Agaricus olearius DC., du Rhizomorpha subterranea Pers et de feuilles mortes du chêne. Ann. de Sci. Nat. ser. 3, Bot. 9: 338-362.

Turpin, F. R. 1771. Histoire civil et naturelle du Royaum de Siam, etc. Paris. See trans. in Pinkerton Travels 9: 631, 1811.

TYChSEN. 1797. Versuche mit verfaulten leuchtenden Holze in Wasser und verschiednen Luft- oder Gas-Arten eingeschlossen. Chem. Annal. fur die Freunde der Naturlehre, 1st part: 17-27.

Tyndall, J. 1865. On the history of negative fluorescence. Phil. Mag. (4) 29: 44-55, 164, 241-244. See also 29: 136-151.

- 1877. Lessons in electricity at the Royal Institute (1875-76). New York, D. Appleton and Co.

Urbain, G. 1904-1907. Rare earth phosphorescence (in French). Com. Rend. Ac. Sci. 139: 736-738; 140: 1233-1234; 141: 521-523, 954-958; 142, 205-207, 785-788, 1518 1520; 143: 229-231.

Ussow, M. 1879. Ueber den Bau der sogenannten augenähnlichen Flecken einiger Knochenfische. Bull. Soc. Nat. Moscou 54: 79-115.

Valentini, M. B. 1704, 1714. Museum museorum oder vollständige Schau-Bühne. Francoforto a M. Lapis bononiensis, p. 42. 2nd ed., Lapis bononiensis, pp. 55-58.

Vallentin, R., and J. T. Cunningham. 1888. The photospheria of Nyctiphanes Norvegica. Quart. Jour. Micr. Sci. N.S. 28: 318-341.

VAllerius, H. 1708. Exercitium philosophicum de chasmatibus. Upsala.

VAllisnieri, A. 1733. Opera physico-medicale. 3 v. Venezia. 3: 419, on Cicindela. 
Valmont-Bomare, J. C. 1790. Lettre à Strasbourg 11 Janvier 1790 de M D'H. . . Officier d'Alsace, sur un phénomène phosphorique (read by de Bomare 28 Jan. 1790). Jour. de Physique 36: 225-226.

1791. Dictionnaire raissonné universal d'histoire naturelle. Mer lumineuse ou Noctilucum Mare, 8: 396-407. Mouche luisante, 9: 28-32. Phosphor ou portelumière 10: 407-408.

Van Aubel, E. 1898. Action du magnétisme sur les spectres des gaz. Jour. de Phys. (2) 7: 408-409.

Van Bemmelen, A. 1818. Untersuchungen über das Entflammen des Phosphors im Leeren Raum der Luftpumpe. Ann. der Physik 59: 268-278.

VAN BENEDEN, P. 1846. Rapport sur le mémoire du docteur Verhaeghe, ayant pour titre: Recherches sur la cause de la phosphorescence de la mer dans les parages d'Ostende. Bull. Acad. Belg. 13 (2nd part) : 3-17.

VAN DeR Willigen, V. S. M. 1858, 1859. Over het electrish spectrum. Vers. en. Med. d. Akad. Wetens. Amsterdam 7: 209-256, 267-273, 274-315, 362-367; 8: 32-64, 189224, 308-315. Also in Ann. der Physik 106: 610-631.

Van Marum, M. 1782. Neue Wahrnehmungen uber das Leuchten der fetten Oele und ähnlicher Substanzen. Crell, Die neuesten Entdeckunger in der Chemie. 7: 186-191. Extracted from the Verhandl. Maatsch. Haarlem. 16, 271, 1776.

1797. The combustion of phosphorus in the vacuum of the air-pump. Nicholson's Jour. of Nat. Philos. Chem. and Arts 1: 236-237, 279-283.

- 1800. A short view of the new electric experiments performed by Dr. Van Marum (translated from the Dutch, 1795). Phil. Mag. 8: 193-202, 313-322.

VAN Monckhoven, D. 1877. Sur les moyens propres a la reproduction photographique des spectres ultraviolets des gaz. Bull. de Belg. (2) 43: 187-192.

1882. De l'élargissement des raies spectrales de l'hydrogène. Com. Rend. Ac. Sci. 95: 378-381.

Van Mons, J. B. 1797. Nouvelles sur la propriété d'entrentenir la combustion que Göttling, professor à Jena prétend trouver dans le gaz azote (letter to Brugnatelli) . Ann. de Chem. 22: 221-231.

Van Musschenbroek, P. 1724. Introductio ad philosophiam naturalem. 2nd ed. Ludguni Batavorum, 2: 739, 1762.

1737. Tentaminta experimentorum naturalium captorum in Accademia del Cimento .. ex Italico in Latinum sermonem conversa. Lugduni Batavorum (2 pts.) 4 .

- 1744. Elements of natural philosophy, trans. by J. Colson. London (J. Nourse). 2 v. Luminescence in vol. 2.

— 1751. Essai de physique, 2 v. Translated from Dutch by P. Massnet. Leyden. Aurora borealis, 2: 813-828.

- 1769. Cours de physique experimentale et mathématique. Translated by S. de la Fond. 3 v. Paris. Phosphors, 2: 446-451.

VAN Rensselaer, J. 1822. On the natural history of the ocean. Luminousness of the sea. Amer. Jour. Sci. 5: 133-134

VAN't Hoff, J. H. 1895. Uber die Menge und die Natur des sogen. Ozons, das sich bei langsamer Oxydation des Phosphors bildet. Ztschr. Phys. Chem. 16: 411-416.

VARLEY, C. F. 1871. Some experiments on the discharge of electricity through rarefied media and the atmosphere. Proc. Roy. Soc. 19: 236-242.

Venturi, C. G. 1821. Memorie e lettere inedite finora o disperse di Galileo Galilei. 2 parts. Modena. In part II Articolo VI (p. 293), Quistione del Galileo col Liceti.

Verany, J. B. 1851. Mollusques méditerranéens. I. Cephalopods de la Méditerranée, Genes, 116. 
Verdries, J. M. 1728. Physica, sive naturae scientiam introductio. 560 pp. Gissae. See chap. 10.

Verhaeghe. 1848. Recherches sur la cause de la phosphorescence de la mer, dans les parages d'Ostende. Mém. Sav. Etr. Acad. Sci. Belg. 22, 31 pp.

Verneuil, A. 1886. Sur la préparation du sulfure de calcium à phosphorescence violette. Com. Rend. Ac. Sci. 103: 600-603.

- 1887. Sur les causes déterminantes de la phosphorescence du sulfure de calcium. Com. Rend. Ac. Sci. 104: 501-504.

- 1888. Recherches sur la blende hexagonale phosphorescente. Com. Rend. Ac. Sci. 106: 1104-1107. Also 107: 101-104.

Verslingius (Wesling or VesLing), J. 1664. Observations anatomiae et epistolae medicae ex schedis posthumis selectae et editae a T. Bartholino. Hafniae.

VERWORN, M. 1892. Ein automatisches Centrum fur die Lichtproduction bei Luciola italica, L. Zbl. Physiol. 6: 69-74.

—_ 1894. Allegemeine Physiologie. Trans. by F. S. Lee, 1899. Pp. 253-256 on animal light.

ViANELLI, J. 1749, 1753. Nuove scoperte intorno alle luce notturne dell'aqua marina. Venezia. Reviewed in Gentleman's Mag. 24: 513-514.

Viano, J. DE. 1788. Mémoire sur les aurores boreales. Jour. de Phys. 2nd part, 33: 151-152.

Vignal, W. 1878. Researches histologiques et physiologiques sur les noctiluques (Noctiluca miliaris, Suriray). Arch. Physiol. Norm. Pathol. (ser. 2) 5: 415-454.

Vil.LARD, P. 1899. Sur les rayons cathodiques. Jour. de Phys. Theor. et App. (3) 8: 5-16, 148-161.

Ville, J., and E. DerRien. 1913. Catalyse biochemique d'une oxydation luminescente. Com. Rend. Ac. Sci. 156: 2021.

Vincent de Beauvis. 1473. Speculum naturale. Argentorati. Sec. III, par. CXXVI, De cicendela.

VIREY, J. J. 1819. Revue général des substances naturellement phosphorescentes, et de leurs causes principales, chez les minerauz, les végétaux et les animaux. Jour. de Pharm. 5: 26-42. Also Tromsdorff's Neues Jour. d. Pharm. III, 1819 (2) : 3-30.

Visser, L. E. O. DE. 1901. Essai d'une théorie sur la phosphorescence de longue durée, specialement celle des sulphures alkalino-terraux. Rec. des Trav. Chim. de PaysBas 20: 435-456.

Viviani, D. 1805. Phosphorescentia maris. quatuordecim animaliculorum novis speciebus illustrata, $17 \mathrm{pp}$. Genua.

Vogel, C. 1669. Schediasma de avibus noctu lucentibus, sub praesidio J. Felleri. 12 pp. Dissertation. Leipzig.

Vogel, H. A. von. 1840. Über die mannigfachen Hinternisse, welche bein Anvendung des Phosphors als eudiometrisches Mittel zu beachtess sind. Jour. Prakt. Chem. 19: $394-401$.

Vogel, H. W. 1879. Über die Spectra des Wasserstoffs, Quecksilbers und Stickstoffs. Sitzber. d. k. Akad. Wiss. Berlin, 586-604.

Vogel, R. 1913. Zur Topographie und Entwicklungsgeschichte der Leuchtorgane von Lampyris noctiluca. Zool. Anz. 41: 325-332.

Volta, A. 1777. Lettere sull' Aria infammabile nativa della paludi. Milano. Lettera quinta, pp. 61-78.

Vorderman, A. G. 1900. Twee lichtgewende visschen van Banda. Ikan lewéri batoe (Heterophthalmus palpcbratus Lac) en Ikan lewéri ajer (Heterophthalmus katoptron Blkr.?). Natuurk. Tijdschr. Ned.-Ind. 59: 72-77.

Vulpius, J. C. 1686. De ignibus lambentibus. Jena. 
WACH, G. F. 1833. Zum Lehre vom Lichte. Uber Leuchtsteine. Schweigger's Jour. für Chemie u. Physik 47: 283-290.

Wadsworrh, F. L. O. 1896. Note on the preparation of phosphorescent barium sulphide. Astrophys. Jour. 4: 308-309.

WAFER, L. 1704. A new voyage and description of the isthmus of America, 95. 2nd ed. London. Ist ed., 1699.

WAHLBERG, P. 1849. Merkwürdiger Instinkt und Lichtentwicklung bei einer schwedischen Mückenart (Ceroplatus sesiodes). From Oversigt Vetenskaps Akad. Förh. Stockholm 5: 128-131, 1848, and Stettin. Ent. Ztg. 10: 120-123.

WALL, DR. 1708. Experiments of the luminous qualities of amber, diamonds and gum lac. Phil. Trans. 26 (No. 314) : 69-76.

WALlER, R. 1684. Essayes of natural experiments made in the Academie del Cimento, written in 1667 . $160 \mathrm{pp}$. London.

- 1685. Observations on the Cicindela Volans or flying glowworm, with the figure thereof made and designed by Richard Waller. Phil. Trans. 15 (No. 167): 841-845.

Wallerius, J. G. 1750. Minerologie. Trans. by Denso (Berlin) from 1747. Minerologia eller mineral-Riket, Stockholm. 2nd ed. under title Systema minerologicum 1772.

Wallis, J. 1676. Sept. 20, 1676 an unusual Meteor seen in Oxford, London, Kent, etc. Phil. Trans. 12: 863-866.

Waltenhofen, A. von. 1865. Einige Beobachtung über das electrische Licht in höchst verdünnten Gasen. Sitzb. d. K. Akad. Wiss. Wien 51 (II) : 535-545; Ann. der Physik 126: 527-539.

WALTER, B. 1888. Die Anderung des Fluorescenz-vermögens mit der Concentration. Ann. der Physik 34: 316-326.

— 1889. Uber den Nachweiss der Zerfalles der Moleculargruppen durch Fluorescenz und Absorptionsercheinungen. Ann. der Physik 36: 512-532. See also 45: 189190, 1902, and 46: 160-62, 1892 by E. Wiedermann.

Warburg, E. 1884. Phosphorescence des tubes de Geissler. Arch. des Sci. Phys. et Nat. Geneva (3) 12: 504-505.

- 1887. Uber des Kathodengefälle bei der Glimmentladung. Ann. der Physik 31: 545-594.

1890. Uber eine methode Natriummetall in Geissler'sche Rohren einzuführen und über das Kathodengefälle bei der Glimmentladung. Ann. der Physik 40: 1-17.

- 1892. Uber die elektrische Kraft an den Electroden und die Electrisirung des Gases bei der Glimmentladung. Ann. der Physik 45: 1-27.

— 1895. Uber Wärmeleitung und Temperatur der in Geissler'schen Röhren leuchtenden Gase. Ann. der Physik 54: 265-275; see also 396-433.

Wargentin, P. 1752. Variation of the magnetic needle. (A letter in Latin.) Phil. Trans. 47: 126-131.

Wasstrom, O. 1799. Uber einen besondern Schein im Wasser der Ost-see oder das in den Scheren von Wermdoe sogennanten Schwachfeuer (marelden). Ann. der Physik 2: 352-358; Crell's Chem. Ann. 392.

Watanabe, H. 1897. The phosphorescence of Cypridina hilgendorfi. Annot. Zool. Jap. 1: $69-70$.

WatasÉ, S. 1895. On the physical basis of animal phosphorescence. Biol. Lect. Marine Biol. Lab., Wood's Hole, 101-119.

1898. Protoplasmic contractability and phosphorescence. Biol. Lect. Marine Biol. Lab. Wood's Hole, 177-192.

Waterhouse, C. O. 1889. (Larva (?) of Phengodes.) Trans. Roy. Ent. Soc. Lond. Proc., 30. 
WATson, G. C. 1845. Luminous breath. Lancet 1: 11.

Watson, W. 1746. Experiments and observations tending to illustrate the nature and properties of electricity. $59 \mathrm{pp}$. 3rd ed. London.

1747. A sequel to experiments and observations tending to illustrate the nature and properties of electricity. Phil. Trans. 44: 704-749. See also pp. $41-50$ and 695-704, and a book of the same title, 80 pp., London, 1746.

1747. Some further inquiries into the nature and properties of electricity. Phil. Trans. 45: 93-120.

1750. A letter from W. Watson to the Royal Society declaring that he, as well as many others have not been able to make odours pass thro glass by means of electricity; and giving a particular account of Prof. Bose at Wittemberg his experiment on beatification or causing a glory to appear round a man's head by electricity. Phil. Trans. 46: 348-356.

1751. An account of Prof. Winkler's experiments relating to odours passing through electrified globes and tubes, being the extract and translation from the Latin of two letters sent by that gentleman to Cromwell Mortimer, M. D. . . . with an account of some experiments made herewith globes \& tubes transmitted from Leipzig by Mr. Winkler to the Royal Society. . . Phil. Trans, 47: 231-241.

1752. An account of the phenomena of electricity in vacuo with some observations thereupon. Phil. Trans. 47: 362-376.

Weber, J. 1802. Feuerstrahlen im Donaueise. Ann. der Physik 11: 351-353.

WeDGwood, T. 1792. Experiments and observations on the production of light from different bodies, by heat and by attrition. Phil. Trans. 82: 28-47, 270-282.

Wehnelt, A. 1898. Dunkler Kathodenraum. Ann. der Physik 65: 510-542. 1899. Zur Kenntniss der Canalstrahlen. Ann. der Physik 67: 421-426.

WeIDler, J. F. 1715. Excercitatio de phosphoro mercuriali, praecipue eo, qui in barometris lucet et ejus rationibus, una cum schediasmate in quo Apollonia Pergaeo promotae doctrinae gloria vindicatur. $2 \mathrm{pt}$. Vitembergae.

Wesendonck, K. 1884, 1885. Uber die Diathermansie von Aesculinlösungen. Ann. der Physik 23: 548-553; 26: 525-527.

_ 1897. Zur Thermodynamik der Luminescenz. Ann. der Physik 62: 706-708.

WEstwood, J. O. 1831. Additional remarks on the luminousness of the sea. Mag. Nat. Hist., London 4: 505-511.

Weyenbergh, H, 1876-1877. Eine leuchtende Käfer-larve. Horae Soc. Ent. Ross 12: 177-180.

Wheatstone, C. 1836. On the prismatic decomposition of the electrical light. Rep. Brit. Assoc. Adv. Sci. (Dublin, 1835), 11-12; also in Phil. Mag. (3) 7: 299.

WheEler, W. M. 1916. A phosphorescent ant. Psyche, a Jour. of Entomology 23: 173-174.

Whiston, W. 1716. An account of a surprising meteor seen in the air, etc. 78 pp. London.

WiedemanN, E. 1878, 1879. Untersuchungen über die Natur der Spectra (1) Theorie. (2) Spectra gemischer Gase. Ann. der Physik 5: 500-524. Phil. Mag. 7: 77-95.

1879. Über das Leuchten der Gase durch electrische Entlandungen. Nachtrag zu der arbeit über die Natur der Spectra. Ann. der Physik 6: 298-302; Phil. Mag. 7: 248-251.

1880. Ueber das durch electrische Entladungen erzeugte Phosphorescenzlicht. Ann. der Physik 9: 157-160.

1880. Uber das themische und optische Verhalten von Gasen unter dem Einflusse electrische Entladungen. Ann. der Physik 10: 202-257; Phil. Mag. 10: 357-380, 407-427. 
1883. Uber die Dissociationswärme des Wasserstoffmolecüls und das electrische Leuchtens der gase. Ann. der Physik 18: 509-510.

- 1883, 1884. Uber electrische Entladungen in Gasen. Ann. der Physik 20: 756798; Phil. Mag. (5) 18: 35-54, 85-97.

1887. Optische Notizen. Sitzungsber. d. Physikal.-Medic. Soc. Erlangen.

1888. Uber Fluorescenz und Phosphorescenz. Ann. der Physik 34: 446-449.

1889, 1899. Zur Mechanik des Leuchtens. Ann. der Physik 37: 177-248; Phil. Mag.

(5) 28: 149-163, 248-267, 367-399.

1889. Über Cathodo- und Photoluminescenz von Gläsern. Ann. der Physik 38: $488-489$.

1890. Optische Notizen. (1) Über die Farbe des Jodes. (2) Fluorescirende Dämpfe. Ann. der Physik 41: 299-301.

1892. Beitrage zur Kenntniss der Luminescenzerscheinungen. Eder's Jahrbuch der Photog. 6: 206-209.

1895. Uber chemische und Leuchtwirkung der Kathodenstrahlen. Entladungsstrahlen. Ztschr. f. Elektrochem. 1895-1896: 155-159.

1895. Uber eine neue in Funken und elektrischen Entladungen erhaltene Art von Strahlen (Entladungsstrahlen). Zischr. f. Electrochem. 2: 159-162.

1896. Luminescenz und astrophysikalische Probleme. Vrtljschr. Astr. Ges. Leipzig 31: 258-261.

1897. Gegenseitige Beinflussung verscheidener Theile einer Kathode. Ann. der Physik 63: 246-252.

1897. Beziehung der positivem Lichtes zum dunkeln Kathodenraum. Ann. der Physik 63: 242-245.

— 1898. Umwaldlung der Energie von Kathodenstrahlen in diejenige von Lichtstrahlen. Ann. der Physik 66: 61-64.

1898. Zur Thermodynamic der Luminescenz. Ann. der Physik 66: 1180-1187.

1901. Uber Luminescence. Festschrift der Universität Prinzregent Luitpold von Bayern. 28 pp. Erlangen und Leipzig.

1909. Zur Kenntnis der Phosphorescenz bei den Muslimen. Arch. f. Gesch.d. Math. d. Naturw. u. Technic 1: 156-157.

Wiedemann, E. and H. Ebert. 1888, 1889. Uber electrische Entladungen in Gasen und Flammen. Ann. der Physik 35: 209-264; 36: 643-655.

Wiedemann, E., and J. B. Messerschmitt. 1888. Uber Fluorescenz und Phosphorescenz. I. Abhandlung, II. Gültigkeit des Talbot'schen Gesetzes. Ann. der Physik 34: 446-463, 463-469.

Wiedemann, E., and G. C. Schmidt. 1895a. Über Luminescenz. Ann. der Physik 54: 604-625.

WiedemanN, E., and G. C. Schmidt. 1895 $b$. Ueber Luminescenz von festen Körpern und festen Lösungen. Ann. der Physik 56: 18-26.

Wiedemann, E., and G. C. Sснмidt. 1895c. Ueber Lichtemission organischer Substanzen im gasförmigen, flüssigen und festen Zustand. Ann. der Physik 56: 201-254.

Wiedemann, E., and G. C. Schmidt. 1896. Fluorescenz des Natrium und Kaliumdampfes und Bedeutung diese Thatsache fur die Astrophysik. Ann. der Physik 57: 447. 453, see also 454-458. From Sitzber. d. Phys. Med. Soc. Erlangen 27: 104-109, 127-144.

Wiedemann, E., and G. C. Schmidt. 1897. Einfluss der Canalstrahlen auf die electrischer Eigenschaften von Entladungsröhren. Ann. der Physik 62: 468-473.

Wiedemann, E., and G. C. SснмidT. 1897. Über das Fluorescenzspectrum des Natriums. Verhand. Berlin Phys. Gesell., 37-40.

WiedemanN, E., and G. C. Schmidt. 1897. Uber die Absorption electrische Swingungen 
durch electroluminescierende Gase und die durch letzte ausgeübten Schirm. wirkungen. Ann. der Physik 62: 460-467. From Sitzber. der Soc. Phys.-Med. Erlangen, Mar. 8, 1897.

Wiedemann, E., and G. C. Schmidt. 1898. Electrische und thermische Messungen an Entladungsröhren. Ann. der Physik 66: 314-340.

WiedemanN, E., and G. C. Schmidt. 1898. Ueber die gefärbten Alcalihalogenide. Eder Jahrb. d. Phot., 247-250; Ann. der Physik 64: 78-91.

Wiedemann, G. H. 1876, 1877. Uber die Gesetze des Durchgangs der Elektrizität durch Gas. Ann. der Physik 158: 35-71, 252-286; Phil. Mag. 3: 161-188.

Wiedemann, G., and R. Ruhlmann. 1872. Úber den Durchgang der Elektrizität durch gase. Ann. der Physik 145: 235-259, 364-399.

Wiegleb, J. C. 1789. A general system of chemistry, theoretical and practical. Trans. lated from Handbuch der allgemeneinen Chemie. Ist ed., 1787, by C. R. Hopson, M.D. 670 pp. London. Phosphori, p. $608 \mathrm{ff}$.

WIEN, W. 1898, 1902. Untersuchungen über die electrische Entladung in verdünnten Gasen. Ann. der Physik 65: 440-452. See also 8: 244-266.

—_ 1901. Uber Fluorescenzerregung der Kanalstrahlen. Physik. Ztschr. 3: 440-441.

WIER, J. 1579. Histoires disputes et discours des illusions et impostures des diables, des magiciens infames, sorcières et empoisonneurs, des ensorcelez et demoniaques et de la guerison d'iceus; etc. Reprinted for the Bureau du Progrès Medical, 1855. Paris.

WiLDE, E. 1838, 1843. Geschichte der Optik vom Ursprunge dieser Wissenschaft bis auf die gegenwörtige Zeit. Part I Von Aristoteles bis Newton. 352 pp. Part II Vom Newton bis Euler. 407 pp. In Part II, pp. 384-407 on Von der phosphorescirenden Körpern.

Will, F. 1844. Über das Leuchten einige Seethiere. Arch. Naturgesch. 10: 328-337. Also in Horae tergestinae, 57-58.

Williams, C. B. J. 1835. On the phenomena and products of a low form of combustion. Report, 4th meeting Brit. Assoc. Adv. Sci. 1835, 588-591.

Williams, F, X. 1916. Photogenic organs and embryology of Lampyrids. Jour. Morph. 28: $145-186$.

Willows, R. S. 1901. The effect of a magnetic field on the discharge through a gas. Phil. Mag. (6) 1: 250-260.

Wilisford, T. 1658. Nature's secrets; or, the admirable and wonderful history of the generation of meteors; particularly describing the temperatures and qualities of the four elements, etc. London.

Wilson, B. 1752. A treatise on electricity. 224 pp. 2nd ed. London.

- 1759. Experiments on the tourmalin, with some experiments on electricity. Phil. Trans. 51: 308-339.

- 1775. A series of experiments relating to phosphori and the prismatic colors they are found to exhibit in the dark. $92 \mathrm{pp}$. London. Bound with an account of the great number of Phosphori discovered by J. B. Beccari, Prof. of Philosophy in Bolonia, pub. in the Bolonia Acts, 1744.

- 1778. An account of experiments made at the Pantheon on the nature and use of conductors. $100 \mathrm{pp}$. London.

Wirson, H. A. 1900. On the variation of the electric intensity and conductivity along the electric discharge in rarefied gases. Phil. Mag. (5) 49: 505-516.

Winderlich, R. 1936. Goethe und die Leuchsteine. Chemikerztg. 60: 188 (No. 18). Winkelmann, A. and R. Straubel. 1896. Ueber einige Eigenschafter der Röntgen'schen X-Strahlen. Ann. der Physik 59: 324-345.

WinN, J. S. 1774. Remarks on the aurora borealis in a letter to Dr. Franklin. Phil. Trans. 64: 128-131. 
Wolf, C. von. 1716. Gedancken über das ungewöhnliche Phenomenon, etc. 38 pp. Halle.

1721-1723. Experimenta physica oder allerhand nützliche Versuche. Part 2, p. 520. 2nd ed., Halle, 1745.

WolfF, J. L. 1733. Excercitatio physica, perpendens praejudicium an ignes fatui sint spectra? Gedani.

Wolffhart, C. See C. Lycosthenes.

Wood, A. 1844. Notice of a case of alleged luminous appearance on the hand and other parts of the body before death. Northern Jour. Med., Edinb. 1: 368-370.

Wood, R. W. 1896. Experimentelle Bestimmung der Temperatur in Geissler'schen Rohren. Ann. der Physik 59: 238-251.

1905. The scintillations produced by radium. Phil. Mag. (ser. 6) 10: 427-430.

1905. The fluorescence of sodium vapour and the resonance radiation of electrons. Phil. Mag. (6) 10: 513-525.

1905. Physical optics, New York. Pp. 433-451.

Woodward, S. 1831. Luminosity of the sea. Mag. Nat. Hist. 4: 284-285, 505-511; 5: $302-303$.

WoRM, O. 1655. Museum Wormianum seu historia rerum rariorum, tam naturalium, quam artificialium, tam domesticarum, quam exoticarium, quae Hafniae danorum in aedibus authoris servantur. Lugduni Batavorum. Lib. I, Sec. II, Cap. 5, p. 46, De Lapide Bononiensi.

Woyt, J. J. 1709. Gazophylacium medico-physicum oder Schatz-Kammer medecinish und Natürlicher Dinge. 1032 pp. Leipzig.

WülLnER, A. 1868, 1871, 1872. Ueber die Spectren einiger Gase in Geissler'schen Röhren. Ann. der Physik 135: 497-527; 144: 481-525; 147: 321-353.

1869. Ueber die Spectren einiger Gase bei hohem Drucke. Ann. der Physik 137: $337-361$.

1874. Studien über die Entladungen des Inductionsstromes in mit verdünnten Gasen gefüllten Räumen. Ann. der Physik, Jubelband, 32-60.

1875. Uber die Spectra der Gase. Ann. der Physik 154: 149-156.

1878, 1883, 1899. Berichtigung zu einen Notiz des Herrn Lommel, betreffend die Fluorescenz. Ann. der Physik 8: 474-478, and Lehrb. der Experimtal physik 4th ed. 4: 530-534; 5th ed. 5: 437-445.

1879-1882. Über allmähliche Überfuhrung des Bandenspectrums des Stickstoffs in ein Linienspectrum. Ann. der Physik 8: 590-623, 253-266. See also 14: 355-366; 17: $587-592$.

1881. Über den Einfluss der Dicke und Helligkeit der strahlenden Schicht auf das Aussehen Spectrums. Ann. der Physik 34: 647-661.

1882. Uber die Spectra des Wasserstoffs und des Acetylein. Ann. der Physik 14: $355-366$.

1883, 1899. Lehrbuch der Experimental Physik. 4th ed. 4 v. 5th ed., 4 on electroluminescence, pp. 391-406; fluorescence, pp. 421-445; phosphorescence, pp. 445-456.

1889. Über den allmählichen Übergang der Gasspectra in ihre verschiedenen Formen. Sitzber. d. Akad. d. Wiss. Berlin, 793-812, 1113-1119; Ann. der Physik 38: $619-640$.

Wünsch, C. E. 1792. Versuche und Beobachtung über die Farben des Lichtes. Leipzig.

— 1807. Versuche über vermeinte Sonderung der Sonnenstrahlen von der Wärme derselben. Mag. der Ges. d. naturforsch Freunde zu Berlin 1: 185-207. Also Gehlen Jour. d. Chem. u. Physik 6: 597-632, 1803.

Wyenbergh. 1876-1877. Eine leuchtende Kefer-larvae. Horae Soc. Rossicae 12: 177. 
Wyrouboff, G. 1867. Die Farbstoffe der Flusspathe. Jour. f. Pract. Chem. 100: 58-62.

YASAKI, Y. 1927. Bacteriologic studies on bioluminescence. 1. On the cause of luminescence in the fresh water shrimp, Xiphocaridina compressa (De Haan). Jour. Infect. Dis. 40: 404-407.

Younc, C. A. 1870. The spectrum of the fire-fly. Amer. Nat. 3: 615; also in Jour. Roy. Soc. Arts and Trans. Roy. Ent. Soc. Lond. Proc., 17.

Younc, T. 1807. A course of lectures on natural philosophy and the mechanical arts. 2 v. London. Bibliography in vol. 2.

ZACHARIAS, O. 1905. Beobachtungen über das Leuchtvermögen von Ceratium tripos (Müll.). Biol. Zbl. 25: 20-30. Forsch. Ber. Biol. Sta. Plön 12: 316-330.

Zanotti, F. M. 1748. De lapide bononiensi. Commen. Accad. Bonon. 1: 181-205.

ZEDLER, J. H. 1732-1750. Grosses vollständiges Universal Lexicon aller Wissenschaften und Künste welche bisher durch menschlichen Verstand und Witz erfunden worden. $64 \mathrm{v}$. Halle u. Leipzig.

ZEEMAN, P. 1897. On the influence of magnetism on the nature of the light emitted by a substance. Phil. Mag. (5) 43: 226-239; 44: 55-60, also Astrophys. Jour. 5: 332-347. From Zittingsber. Akad. Amsterdam 5: 181-184, 242-248, 1896.

ZeHnder, L. 1894. Ueber Natriumstickstoff. Ann. der Physik 42: 56-66.

Zirpolo, G. 1932. Studi sulla bioluminescenza batterica. XII Azione dell idrogeno $\left(-253^{\circ}\right.$ C.) e dell elio liquido $\left(-269^{\circ}\right.$ C. $)$. Boll. Soc. Nat. Napoli 44: 229-235.

Zöllner, F. 1871. Uber der Einfluss der Dichtigkeit und Temperatur auf die Spectra glühende Gase. Ann. der Physik 142: 88-111. From Sitzber. Säch. Gesell.d. Wiss. 22: $233-254,1870$.

Zucchr, N. 1652. Optica philosophica experimentis et ratione a fundamentis constituta. Lugduni. De lapide bononiensi, p. 30-39. 



\section{Indices}

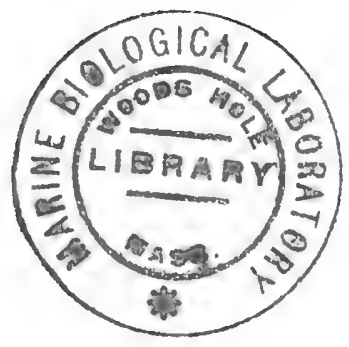





\section{SUBJECT INDEX}

Important references only to the various types of luminescence and reportedly luminous animals and objects, together with a few other categories, are included. Class rather than specific names (jewels instead of diamond and carbuncle) have been indexed.

Afterglow in gases $301-302,449-451$

Aglaophotis terrestris and marina 32

Air gun 292

Alchemy 63

Alpha rays, see radium rays and Anode rays

Amber 271, 280

Amphipods 584-585

Anodoluminescence 4, 415-416

Ants 562

Arab writers 47-49

Arrow-worm 589

Arum spadix 459

Aurora borealis 3, 11, 19, 37-40, 44-45, 56, $68,83-84,86,252,253,255-263,399$

Baaras 32,110

Bacteria, parasitic 506-507, 561-562, 584585, 586, 597

Bacteria, saprophytic (see also flesh and dead fish) 227, 503-506, 590

Bacteria, symbiotic 507, 582, 591-592, 597

Balanoglossus 590

Balanus, see Pholas

Baldewinian phosphor 120, 321-323

Barometer light, see mercury phosphor

Beta rays, see cathode rays or electrons

Bible 12, 13, 14, 15, 111, 115, 264

Bibliographies 108, 198-199

Bioluminescence 4, 5, 222-246, 459-597

Bioluminescence chemistry 593

Bioluminescence and drying 568, 579, 593

Bioluminescence, inhibition by light 596

Bioluminescence, physical nature 551-552

Birds, Hercynian 29, 47, 52, 67, 111

Bolognian Institute 99, 156-158, 324-327

Bolognian phosphor 94-95, 306-320

Breath 478

Brittle-stars 587-588

Bryozoa 590

Burning bush 15

Cadaver, see corpse

Calcium sulphide phosphor 323. See also Canton's phosphor

Candoluminescence 6, 377

Canton's phosphor 180, 329-331, 369
Caterpillars 58, 562

Cathode rays $410-414$

Cathodoluminescence 4, 251, 353-354, 410414

Centipedes 52, 58-59, 76, 78, 129, 556-557

Cephalopoda, see squid

Chara 373

Cheese 486

Chemiluminescence 4, 5, 207, 211-212, 228, $251,423-456$

Chemiluminescence of organic compounds $453-456$

Chenomyce 29

China 16-20

Chromophyton 3, 460

Cicindela, see glowworm

Classics of China 16-17

Clouds 15, 262

Cobra stone 22

Cold flames 423, 448, 449-452

Collembola 562

Comb-jellies, see ctenophores

Copepods 584

Corposants, see ignis fatuus

Corpse 111, 478, 493-494, 501-503

Cow, luminous 18-19

Crustacea 116, 117, 470, 519, 583-586

Crystalloluminescence $4,5,189,379,387$ 389

Ctenophores 159, 570

Cucujo 60-63, 125, 554-556

Cuttlefish, see squid

Dactylus or dattes, see Pholas

Dail, see Pholas

Deep-sea exploration 239-241

Deep-sea luminescence 239-241, 582-583, $584,586,590-592$

Dictionaries and lexicons 159-161, 179, 242

Dilyxnos of Strabo 26

Dinoflagellates 534-539, 563-565

Diplocladon 554

Dittany 459-460

Earthworms 52, 557.559

Effluvia, see virtues

Eggs 119, 476-478 
Electric light and aurora 259-261

Electric light and fire 269-304, 334-337

Electricity, rise of 281-296

Electrodeless discharges 302-303

Electroluminescence 3, 5, 35-40, 56, 120, $142,149-151,176,181,251-304,378,381$ $382,388,524,529$

Electrolytic flames 251

Electrons 411-414

Embryology 596

Encyclopedias 49-53, 161-166, 206, 232-233

Epipolic and internal, dispersion 395-396

Evolution and bioluminescence 233-237

Explorers 56-63, 239-241

Eyes, glow 3, 24, 28, 112, 113

False luminescence 3, 459-460

Fermentation 131-134, 498-499, 593

Feux follets, see ignis fatuus

Fire of Baccantes 23, 35

Fire-cylinder, see Pyrosoma

Fire, theories of, see Light

Fire-flies, see glowworm

Fire-fly light, physical nature 551, 593-594

Fire-fly physiology 549-551

Fish, dead 23, 24, 28, 51, 73, 86-88, 104, $129,139,180,217,218,231,469-472$, $475-476,480-481,491,495,496,498$

Fish, living 73, 112, 469-470, 590-592

Flagellates 521-524, 534-537, 563-565

Flame, theories of, see light

Flashing of flowers 459

Flat-worm 589

Flesh 17, 24, 86-88, 110, 127, 145-146, 214, $217,218,227,231,462-469,471-472,495$, 496, 501-503

Flint 27, 120, 306

Fluorescence 4; 107, 207, 210-211, 220, 390 . $409,410-422$

Fluorescence analysis 400-401

Fluorescence and absorption 404

Fluorescence and chemical constitution 401-402

Fluorescence, methods of excitation 398399

Fluorescence and phosphorescence, difference 4-5, 390-391

Fluorescence, theories of 363-365

Fluorspar 120, 366-376, 394-397

Fox-Fire 60

Fruit 486

Fulgora, see lantern-fly

Fungus 24, 136, 227, 231-232, 499-501

Galvanoluminescence 5, 251

Gamma rays, see radium rays

Gas luminescence 278-279, 287-290, 291,
294-304, 423, 448-451, see also electroluminescence

Gases, effect of 276-304, 448-451, 487-493

Gems, see jewels

Glimus 46

Glowworms and fireflies $3,11,14,16,17$, 20-22, 25-26, 27, 30-31, 44, 45-47, 47-48, $50,51,53,54,57,60-63,65,72,74,75-77$, $78-80,85,92,103-104,113,129,138,189$, $190,191,232,235-236,239,538-552$

Greek fire 53

Greek views 22-42

Heat, theories of, see light

Histology 228, 552, 596

Homberg's phosphor 381

Hormones and bioluminescence 595

Human luminescence $3,110,111$

Hydrogen peroxide 453

Hydroids 574

Hydrostatic pressure 595

Ice 388,525

Ignis lambens and electricity $268-269$

Ignis lambens and ignis fatuus 3, 13, 35$39,56,67-68,84-85,253,254,263-269$

Indian reed 110

Infrared quenching 341-342

Ionoluminescence 4

Japan 17-18

Jelly-fish 31, 69, 73, 74, 88, 105, 111, 158, $529,566-570$

Jewels, luminous 3, 15, 19, 23, 33-34, 44, $45,49,52,67,70-72,89,110,140,155$. $156,306,325,327-328,331,368,380,413$ Journals 99-100, 194, 219

Knallbomben 292

Koran 14

Lampyrides, see glowworm

Lantern-fly 158, 559-651

Latex 459

Leaves 486

Light and heat, fire and flame, theories of $95-98,104,108-109,130,151,154-$ $155,167,169,172-173,174,177,180,183$, 195-198

Lignum nephriticum 98, 107, 391-395

Lime 35, 452-453

Liquor liquidus $51,53,54,64,76,80-82$, 104-105

Lucerna piscis 31,67

Luminescences, list of 3-6, 23-24, 27, 43, $65,87,91-92,101-103,106,116,119,122-$ $124,126,128-129,132,133,135,136,137$, 
$139-140,141,142,147-148,151-152,157$, $159-160,161,162-163,164,165-166,168-$ $169,170,171,172-173,174,175,176,177-$ $178,192,196,197,200,202,203,204$, 205-206, 213, 214, 215, 216, 223, 224, 241, $245,326-327,331,371,372,374$

Lyoluminescence 389

Magnet and aurora borealis 257, 261

Mahabharata 20

Marmoritis 29

May-flies 562

Meat, see flesh

Medusae, see jelly-fish

Men, see human luminescence

Mera (Meira), goddess of luminescence 13

Mercury phosphor 120, 271-277, 291

Meteors 83-84, 252-255

Mica 252, 293

Midges 562

Millipedes 557

Minerals, see stones, jewels or phosphors

Mole-cricket 562

Museums and Luminescence 100-103

Mushroom 28, 484

Myriapoda, see centipedes

Mythology 11-13

Natural histories, early 72-80, 116-119

Near East 13-15

Negative fluorescence 399-400

Nemertean worms 590

Noctiluca 521-524, 563-565

Noctiluca, icy, gummous and aerial 64, 427-432

Northern lights, see aurora borealis

Nudibranchs 581

Nyctygreton or Nyctalops 29, 110

Octopus, see squid

Oils, luminescent $371,448,459$

Ostracods $159,583-584$

Oxygen and luminescence 125, 184-189, $432,436-440,471-473,487-493,547-549$, 592

Oyster shell phosphor, see Canton's phosphor

Oysters 111, 116-117, 575, 577-581

Ozone and luminescence 442-444, 450-451

Paussus (a beetle) 561

Penetrating radiation 416-419, 444, 522

Perpetual lamps 82.83

Phengodes 554

Phlogiston 182-183, 186-189, 340

Pholas 69, 73, 74, 104, 105, 111, 116, 117$118,156,158$
Phosphene 3, 24

Phosphorescence duration 324-327, 354-357

Phosphorescence and electric sparks 334 337

Phosphorescence, law of decay 356-357

Phosphorescence of the sea, see sea phosphorescence or sea light

Phosphorescence and phosphors 4, 5, 19, $53,94-95,106,109,119-121,143,145$, $152,153,157,158,179,180,215,218$, $220,292,294,305-365,418,525-526$

Phosphorescence and photoelectric effect 360-361, 414

Phosphorescence and spectral colors 314, 333-334

Phosphorescence and temperature 358359

Phosphorescence, theories of 307, 310, 311, $313,314,318-320,322,323-324,328,329$, 332 , 337-340, 343-345, 361-365

Phosphorescence and ultraviolet or infrared light $340-342,352-354$

Phosphoroscope 354-356, 386

Phosphors and combustion 337-340

Phosphors and metal traces $317,331,345$ 349

Phosphors, medical use 309

Phosphorus, commercial use 445-446

Phosphorus, discovery 424-435

Phosphorus, element 6, 63-64, 120, 127 , $130,144,152,153,179,181-182,188$, $424-488,526-527,593$

Phosphorus, medical use 446-448

Phosphorus of urine, see phosphorus element

Phosphorus, periodic phenomena 432, 442

Phosphorus and water vapor 440-441

Photographic plate 454

Photoluminescence, see phosphorescence

Photons, see quanta

Phrixothrix, see railroad worm

Piddock, see Pholas

Piezoluminescence, see triboluminescence

Pigeon dung 118

Plants or herbs $29,32,66,85,110,459$. 460 , see also fungus

Poetry and luminescence 63, 73, 189-192, 508-509, 578

Polarized luminescence $359-360,402-403$, 413

Popular science books 237-239

Porcupine 478

Potassium, 449

Potatoes 485-486

Prince Rupert drops 291-292

Prize essays 151-155, 199-206

Pteropod molluscs 590

Pulmo marinus, see jelly-fish 
Putrefaction 114, 118, 139, 214, 481, 491, 498-499, 527-528, 529

Pyralis or pyrusta 29

Pyrophore 448

Pyrophorus, see cucujo

Pyrosoma 588

Quanta 246-247

Quenching of luminescence 405-406, 441

Quinine and quinidine and heat 374

Radioactive substances $418-420$

Radiolaria 566

Radioluminescence 4, 207, 211, 303-304, $376-377,410-422$

Radium rays $417-420$

Railroad worm 58, 113, 552-553

Rare earths 299, 347, 357, 413

Rays, new types 303-304, 410-422

Resonance radiation $406-407$

Rhizomorphs 484-485, 499-501

Roentgenoluminescence 4, 416-417

Roman views 27-42

Roots 486

Rotifers 536, 589

Sagitta 589

St. Elmo's Fire 15, 36, 41, 138, 152, 253

Salpae 588.589

Sapphirina 460, 584

Schistostega 3, 460

Scintillation counter 7, 420-421

Sea light and weather 533-534

Sea light, theories 510-518, 520, 521, 524$529,530,531.533$

Sea pen or sea feather $69,73,74,105,111$, $571-573$

Sea phosphorescence or light or burning $13,17,27,40-42,48,50,56,57,95,97$, $112,114,127,136,138,140,158,189$, $194,200,206,224,241,508-537$

Sensitization $406-407$

Serpent 111, 145, 476

Shrimp 585-586

Siphonophores 573-574

Snails, land and fresh water 563

Snakes, see serpent

Snake-stars, see brittle-stars

Societies and luminescence 98-99

Sodium 449

Solen, see Pholas

Sonoluminescence 5, 252

Spectroscopy 207-210, 219, 221, 228, 263, $299-300,340-342,357,414,452,455,593$

Spinthariscope, see scintillation counter

Sponges $589-590$
Squid 25, 470, 488, 582-583

Starfish 587

Star-worms 554

Stella figura 52

Stimulation to luminescence $564-565,569$, $572.573,595$

Stones $366-377,379-386$, see also jewels or phosphors

Sugar 91, 379, 381

Sweat 478

Synchronous flashing 544-545

Talmud 14

Tape 252

Temperature and bioluminescence 595

Text-books of biology 229-233, 242

Text-books of chemistry and physics 121$122,138-139,141-142,143-146,166-178$, $184,185,197,198,199,212-215,216,217$. 218

Text-books of entomology 74-80, 232, 239

Text-books of physiology 229-231

Theories of aurora borealis 256, 257, 258, 259, 260, 261-263

Thermal phosphor 120, $267 \mathrm{ff}$.

Thermoluminescence $4,53,210,366-377$

Thermoluminescence, theories 369, 371$373,375,376$

Theses and Tracts 122-124, 178-181

Torches of the Bacchae 35

Triboluminescence 4, 5, 121, 252, 292-293, $370-371,378-386,525$

Triboluminescence in organic compounds $379,381,386-387$

Turf $134,476,558$

Ultraviolet excitation $340-341,349,352$ 353,398

Urine 478

Vapor fluorescence 406-407

Vedas 20, 21

Viper, see serpent

Virtues 269-271

Weather and sea light 533

Wood, luminous (see also fungus) 11, 24, $28,56,59,93-94,104,110,127,139,227$. $461-462,472-474,479,482-483,487,488$, $489,490,490-491,492-493,494,495,496$, 499-501

Worms, marine $56,58,59,67,76,99,111$, $158,159,480,519,575-577$

Wounds 478

Zodiacal light 258 


\section{AUTHOR INDEX}

Every author or translator (not editor) mentioned in an important connection in text or footnotes has been indexed. Numbers in italics indicate that a reference to the publication of the author will be found on the page. By this means the bibliography has been supplemented by addition of publications (such as science histories, not chiefly concerned with luminescence) which it does not include.

Abney, W. de W. 353

Accum, F. C. 213, 384

Achard, F. 188, 448, 593

Adams, G. 177, 188

Adams, W. G. 360

Adanson, M. 587

Addison, J. 190

Adelard of Bath 49

Adler, C. F. 484, 519, 576

Aelian, C. 29, 32-34, 69, 70, 588

Aepinus, F. U. T. 260

Afzelius, A. 561

Agassiz, A. 234, 237, 570

Agassiz, L. 108, 237, 511

Aiken, P. 51

Ajasson de Grandsage 67

Akin, C. K. 399, 400

Alacci (Allatius) L. 72, 116, 123, 470, 585

Albertus Magnus 30, 49.52, 53, 76, 80, 91, 102

Albrecht, H. O. 455

Albrecht, J. S. 482

Alcock, A. 586

Al-Damiri 47

Aldrovandi, U. 72-75, 76, 77, 78, 101, 538, 566,578

Alenitzyn, W. D. 507

Alexander of Aphrodisias 23

Al-Jāhiz 48

Allamand, J. N. S. 284

Allatius 72, 116, 123, 470, 585

Allman, G. J. 245, 562, 596

Al-Ramhurmuzi 48

Al-Razi (Rasis) 80

Alter, D. 209

Altschul, M. 292, 359

Alvergniat 302

Ames, J. S. 299

Ammonius 24

Anaximander 22, 40

Anaximenes 40

Anderson, J. 519, 584, 586

Anderson, S. 251

Andrade, E. N. da C. 349

Angot, A. 37

Ángström, A. J. 209, 263, 297, 299, 396
Ångström, K. 299

Annandale, N. 563

Anonymous 80, 486

Applegate, R. A. 32, 66, 103, 312, 575

Arago, F. J. 261, 285, 347

Arber, E. 59

Aristophanes 26

Aristotle 3, 23-26, 24, 37, 40, 49, 52, 59, $68,76,86,91,96,104,113,114,118,131$, 223, 224, 483

Armstrong, H. E. 402

Arnaud, E. R. 448

Arnold, W. 386, 413, 417

Artemidor of Ephesus 26

Asbjörnsen, P. C. 587

Aschner, B. 63

Ash, T. 542

Athenaeus of Naucratis $30,42,110$

Atkinson, E. 215

Atkinson, G. F. 554

Atti, G. 543

Augustine, Saint 44

Auzout 99, 117, 119, 123, 575

Azara, F. de 552

Baart de la Faille, J. M. 222

Babo, C. H. von 398

Bacon, F. 90, 91-94, 95, 147, 152, 255, 289 $379,462,510,539-540,554,595$

Bacon, R. 50

Baeyer, A. von 401

Baird, W. 566, 584, 586, 589, 590

Bajon, M. 524

Baker, H. 159, 479, 480, 483, 501, 516, 521 522,576

Baker, H. B. 441

Balduin (Baldewein), C. A. 101, 120, 130, $321 \cdot 322,367$

Ballard, H. H. 36

Balmer, J. J. 300

Baly, E. C. C. 300

Bancroft, W. D. 251

Bandrowski, E. 389

Banks, J. 159, 199, 222, 567, 570, 586

Barbut, J. 580

Bardetscher, G. A. 359 
Bartholin, E. 107, 123

Bartholin, T. 15, 32, 66, 69, 107-115, 116, 233, 239, 313, 463-465, 466, 540-541, 546, $554,566,578,596$

Bartholomaeus Anglicus 49, 64

Baster, J. 519, 522, 523, 536, 577

Bateman (Batman) 49, 64, 65, 85

Bates, H. W. 236

Bateson, T. 541

Battarra, G. A. 484

Bauhin, J. 392

Baumé, A. 168

Bayle, F. 97

Beal, J. 100, 474-475, 480, 506

Beare, J. I. 24, 25

Beccari, J. B. 156-158, 163, 177, 324-327, $331,333,354,356,390,579-580,592,593$, 595,596

Beccaria, G. B. 260, 290-292, 306, 330, 333, 382

Becher, J. J. 168, 186

Bechil, A. 424

Beckerhinn, C. P. D. 189, 547-548

Beckmann, J. 379

Beclard, J. 230

Becquerel, A. C. 208, 216-218, 349, 350, 388, 398

Becquerel, E. 53, 207, 209, 210, 216, $218-$ $219,220,221,297,301,302,305,336$, $341,342,344,348,350,351-359,363,375$, $386,390,405,408,410,412,413,449$

Becquerel, H. 211, 216, 353, 356, 386, 388, $417-419,420,421$

Beddoes, T. 369

Beijerinck, M. W. 502, 592

Bellani de Monza, A. 437

Belon, P. 72, 578

Belt, T. 235

Benham, W. B. 559

Bennett, C. 77

Bennett, F. D. 245, 589, 590, 591

Bergmann, T. O. 187, 383, 440

Bergsma, P. A. 220

Bernard, see Thulis and Bernard

Bernard, C. 230

Bernoulli, C. 194, 199-201, 495, 527, 530531

Bernoulli, J. Ist. 120, 149, 163, 272-274, 381

Berthelot, M. 53, 54, 299

Berthold, A. A. 230

Berthollet, C. L. 187, 437, 438, 441

Bertholon de St. Lazaire 260

Berzelius, J. J. 388, 498

Best, T. W. 299

Bethune, C. J. S. 554

Bezold, M. von 400

Billet, A. 506, 577, 585
Biononius, P. 514

Biot, J. B. 349

Birch, T. 127, 128

Biringuccio, V. 423

Bisaccioni, M. 309

Bischoff, K. C. G. 500

Black, J. 183, 184, 187

Blainville, H. D. de 572

Blair, K. G. 563

Blefken, D. 112

Blome, R. 143

Blondlot, N. 443

Blount, T. P. 542

Blumhoff, J. G. L. 529

Boccone, P. 119, 316, 476

Boddaert, P. 592

Bodenheimer, F. S. 47, 75, 543

Boeckmann, C. W. 437, 438-439

Boehme, J. G. 111, 123-124, 575

Boerhaave, H. 167, 289, 435

Boetius, see De Boot

Böttger, R. 374, 399

Bohadsch, J. B. 571

Bohlendorff, W. 404

Bohn, C. 375,400

Bohr, N. 246

Boisbaudran, see Lecoq de Boisbaudran

Boisduval, J. A. 507, 562

Bolton, H. C. 199

Bonanni, see Buonanni

Bonardo, G. M. 88

Borch, Conti di 527

Borel, P. 313, 463

Bory de St. Vincent, J. 530, 588

Bosc, L. 159, 245, 285, 296

Boscovich, R. G. 259

Bose, G. M. 259

Bostock, J. and H. T. Riley 28, 34, 41

Bottoni, D. 137-138, 316, 543

Boué, A. 518

Boulenger, G. A. 26

Bourguet, L. 368

Bourzes, Father 516-517, 528

Boussuet, F. 72, 73, 566, 571, 578

Bouttatz, F. 447

Bouty, E. M. L. 215

Bouvier 477

Bowdoin, J. 520

Bowring, J. 545

Boyd, C. A. 376

Boyle, R. 34, 64, 70, 124-127, 129, 150 , $160,173,268,270,271,289,306,314$, $366,380-381,382,392-393,406,426,427$ $432,436,442,445,470-473,493,513$, $542-543,592,596$

Brand (Brandt), K. 102, 120, 127, 424, 426,566 
Braun, F. 251, 414

Brauner, J. 404

Brembridge, R. H. 441

Bressy, J. 525

Breuning, E. 444

Brewer, E. C. 13

Brewster, D. 24, 118, 203, 206, 208, 209, $210,292,373,395-398,400,423$

Brockhaus, F. A. 161

Bronn, H. 590

Brown, D. E. S. 595

Browne, P. 555, 570

Browne, T. 71, 269, 314, 541

Brücke, E. 400

Brugière, J. G. 523, 559

Brugnatelli, L. G. 195-196, 212, 371, 437, $448,489,525$

Buch, L. von 385

Buchner, E. 499

Buchner, P. 507, 597

Bucholz, C. F. 213

Buckingham, E. 404, 405

Büchner and Döbereiner 388

Bunsen, R. W. 208

Buonanni, F. 106, 117, 118, 578

Burbank, J. E. 376, 417

Burdach, K. A. 230

Burke, J. 291, 404

Burlingame, E. W. 21

Burmeister, H. C. C. 232,553

Burton, R. 554, 555

Busk, G. 570

Butler, S. 265

Butschli, O. 523

Byron, Lord 508

Cabanis, P. J. G. 493, 494

Cagniard-Latour, C. 498

Cailletet, L. 359

Calceolari, F. 100

Callaud, M. 374

Camerarius, E. 267

Camerarius, R. J. 76, 267, 541

Camoens 508

Canton, J. 19, 35, 180, 184, 260, 261, 289 $290,293,329-330,333,358,481,490$, 527-528, 595

Capron, J. R. 299

Cardan, H. 28, 79, 80, 86, 87, 91, 112

Cario, G. 407

Carleton, W. 269

Caro, H. 401

Carpenter, W. B. 230, 231, 232, 233

Carradori, G. 488-489, 548, 593

Carrara, M. 549

Carrington, B. H. 82

Cartheuser, J. F. 168, 309
Carus, J. V. 199

Casati, P. 118, 122, 135-136, 316, 486

Cascariolo 94, 103, 110

Cassini, G. D. 258, 261, 272, 387

Cassiodorus 49

Cassius, Dion 38

Castro, E. di 122, 266

Caub, see Cuba

Cavallo, T. 215

Cavendish, C. 288, 289, 290, 291

Cavendish, H. 183, 184, 187, 189, 339

Caxton, Wm. 65

Celeste, M. 311

Cellini, B. 34, 70, 366

Cellio, M. A. 317

Centnerszwer, M. 440, 441, 444

Ceriziers, R. de 462

Chalmers, Lord 21

Chambers, E. 161, 162-163, 165, 167, 518

Chambers, W. and R. 161

Chamisso, A. 589

Chappuis, J. 441, 443

Chaptal de Conteloup, J. A. C. 187

Chaucer, G. 131

Chautard, J. 297, 299

Chiaje, S. Delle 589

Chinard, G. 510

Chiocco (Chioccus) A. 72

Chree, C. 300

Chun, C. $240,241,570$

Ciamician, G. 299

Cicero 37

Claparède, E. 536

Clark, S. 139, 511

Clarke, J. 38, 139, 511

Claude, G. 304

Claus, C. 586

Clausius, R. 444

Cleidemus 40

Coblentz, W. W. 551, 593

Cocco, A. 245, 590

Coetlogen, C. D. de 161

Cohausen, J. H. 154-155, 164, 323, 362

Cohen, I. B. 519

Cohn, F. 505

Coldstream, Dr. 226, 232, 233

Cole, A. 253

Cole, F. J. 534

Coleridge, S. T. 190

Collie, J. N. 299

Colonna, F. 72, 538, 540, 596

Colson, J. 172, 283

Columbus 56, 57

Columna, see Colonna

Comenius (Komensky) 538

Conrad von Megenberg 52

Conring, H. 109, 465 
Conroy, J. 551

Cooper, D. and R. 478, 502-503

Cordus, V. 283

Corne, I. 442, 443

Cornu, A. 299

Cossa, A. 375

Cotte, J. 31

Coudréniere, M. de la 525

Cowell, E. B. 21

Crabbe, G. 190

Crawshay, L. R. 56

Crehore, M. L. 377

Crell, L. von 369,435

Croasdale, H. 155, 463

Crocco, L. 572

Croll, O. 121

Crookes, W. 7, 207, 219, 298, 299, 303, 347, $348,350,354,356,360,403,404,410$ 414,420

Cross, M. F. Jr. 446

Cuba or Caub, J. de 65, 67, 112

Culpepper, N. 253

Cunningham, J. T. 236, 586

Curie, M. and P. 211, 419, 421

Cusack, R. 359

Cuvier, G. 31, 67, 211

Cyprian, J. 539

Daguerre, L. J. M. 347

Daguin, P. A. 215

D'Alembert, J. B. le R. 165

Dalibard, T. F. 281

Dallowe, T. 167

Dalton, J. 261

Dalton, J. C. 231

Dammer, O. 399

Dampier, W. 510

Dana, J. D. 586

Daniel, J. F. 213

Daniel, L. 297

Daniels, F. 376

Dante 46,189

D'Argenville, A.-J. D. 158

Darwin, C. 191, 233, 234, 236, 237, 509. 537, 574, 597

Darwin, E. 191, 447, 494

Darwin, L. 356

Davenport, D. 557

Davis, J. 57

Davis, T. L. 424

Davy, H. 196-198, 212, 295-296, 340, 384, $449,451,452,492$

Davy, J. 437, 441

Day, R. E. 360

De, see also under name.

De Blainville, D. 230

De Boot (Boëtius) A. 71, 306
De Bournon, Count 385

De Castro, João 56

De Castro, S. R. 541

Decembrus, P. C. 65

Decharme, C. 533

De Férussac, Baron 563

De Flacourt 542

Defolin, Marquis 241

De Fourcroy, A. F., see Fourcroy

De Greer, C. 156, 546

De Groot, J. J. M. 18

De Kowalski 361

De la Coudréniere, M. 525

De Laet, J. 306

De Lamanon 383, 384

Delamétherie, L. P. et J. C. 342

De la Perriere, C. F. 524

De la Rive, A. 262, 297, 302, 410

De la Rue, W. 298

De-la-voye $99,117,119,575$

De Lens 232, 447

Delepine, W. L. 455

Delius, H. F. von $328,369,382,481$

Della Valle, A. 242

Delor 281

Deluc, J. A. 183

de Magellan 334

De Mairan, see Mairan

De Marignac, J. C. G. 443

De Milt, C. 143

Democritus 23, 29, 95

De Mons, see van Mons

De Monza, A. B. (Bellani de Monza) 437

Denise, L. 67

De Parcieux 292

Derham, W. 264, 479

Derrien, E. 454

Derschau 485, 494, 499

Desaguliers, J. T. 170, 281, 283

Descartes, R. 95-97, 139, 143, 171, 176, 255, $273,319,462,510-511$

Deschamps, M. H. 441

Deslandes, M. 517-518

Deslandres, H. 299

Deslongchamps, J. A. 486, 500

Desmazieres 498

Dessaignes, J. P. 195, 205-206, 208, 336, $341,342-345,363,371,372,385,412$, 495-496, 531

De Viano, J. 254

Devic, L. M. 48

De Visser, L. E. O. 361

Dewar, J. 355, 359, 377, 386, 388, 402, 450, 451

Diaconus, P. 30

Dibbits, H. C. 452

Dickens, C. 475 
Dicquemare, Abbe 523, 570

Diderot, D. 165

Dieberne, A. 420

Digges, W. 268

Dioscorides 29, 31

Dittrich, R. 199, 239, 244

Dixon, H. B. 452

Dizé 452

Dodoens, R. 65

Döbereiner, J. W. 388

Dolomieu, D. de 370, 374

Dombey 523

Donati, V. 119

Donovan, E. 561

Doppelmayr, J. G. 282

D'Orbingny, M. 563

Dorn, E. 420

Dove, H. W. 359

Downey, W. E. 444

Doyère, L. 564

Drake, F. 57

Draper, J. W. 213, 219, 337, 341, 345, 350, $352-353,375,449$

Driessen, J. C. 478

Dryden, J. 90

Du Bartas, G. de S. 63, 189

Du Bary 503

Dubois, R. 24, 87, 158, 228, 231 242-243, $387,454,507,556,557,562,593-595$

Du Cange, D. 60

Duclaux, E. 581

Ducluzeau 223

Dufay, C. F. 52, 155-156, 271, 275, 281$283,327-328,362,368,370,381-382$

Duges, A. 230

Duhamel, J. B. 179

Duhamel de Monceau, S. F. G. 187

Dujardin, F. 536

Dumas, C. L. 230

Dumas, J. B. 213

Dumas, M. 293

Du Puget 83

Du Tal, M. 174, 273

Du Tertre, J. B. 555

Eames, J. 258

Eaton, A. E. 507, 562

Ebert, H. 220, 299, 300, 301, 302, 305

Eden, R. 59

Eder, J. M. 299, 454

Edison, T. A. 304,417

Ehrenberg, C. G. 26, 50, 151, 199, 224$225,226,230,239,501,515,518,523$, $526,535-536,575,581,589$

Ehrenberger, B. H. 269

Einstein, A. 199, 246

Eisenlohr, W. 352, 363

Ellis, J. 239, 571
Elsholtz, J. S. 95, 120, 160, 322, 366, 425

Elster, J. 360, 414, 420, 444

Emelaeus, H. J. 443

Emery, C. 591

Emmert, A. G. F. and Hochstetter 477

Empedocles 95

Emsmann, H. 399, 400

Encyclopaedia Britannica 166, 233

Englefield, H. C. 334, 340

Englehardt, G. 400

Englemann, W. 199

Epicurus 95

Esenbeck, see Nees von Esenbeck

Esselbach, E. 354

Esser, C. L. 224, 478

Etzel, H. W. 422

Eugenianus I 266

Euler, L. 98, 177, 195, 332, 362

Euripides 23, 35

Evelyn, J. 313, 433, 542

Ewan, T. 440, 441

Ewart, A. J. 231

Fabre, J. H. 501

Fabricius, J. 261

Fabricius, O. 577, 584

Fabrizia (Fabricius ab Aquapendente), G. 87,88

Fahrig, E. 451

Falconer, W. 190, 509

Falcucci, N. 80

Fallot 478

Faraday, M. 296, 301, 303, 549

Fenton, E. 71

Ferry, E. S. 300

Festus, P. 30

Ficino, M. 96

Figuier, E. 241

Filhol, H. 241

Finlayson, G. 523

Fischer, B. 505

Fischer, N. W. 437

Flaccus, V. 30

Flaugergues, M. de 233, 559

Florentinus, N. 80

Fludd (Fluctibus), R. 90, 264

Fonrobert, F, 450

Fontanelle, B. de B. de 154

Forbes, E. 239, 570, 572, 574

Forskål, P. 522, 567, 577, 589

Forster, A. 347, 375

Forster, G. 188, 487, 547

Forster, J. R. 337, 509, 523, 527, 528

Fougeroux de Bondaroy, A. D. 102, 519, $546,555,576$

Fourcroy, A. F. de 187, 213, 437, 439, 484, 439

Fovargue, S. 445 
Frampton, J. 391

Franck, J. 407

Frankland, E. 299

Franklin, B. 176, 259, 262, 280, 286-287, 519-520

Franz, W. 539

Fraunhofer, J. von 207, 208, 209, 219

Frazer, J. G. 12

Freigius, J. T. 77

Frenzel, J. 252

Fresnel, A. 195, 199

Freyesleben 485,499

Frézier, A. F. 517

Friedlaner, S. 299

Fritz, H. 255

Frobenius, S. A. 283, 434

Fuchs, L. 65

Fulke, W. 84, 254, 255

Funke, O. 230

Furetière, A. 159-160

Gadeau de Kerville, H. 232, 239

Gaertner, C. F. 490

Gahn, J. C. 435

Gaimard 535

Galeati, D. M. G. 157, 158, 324, 579-580, $592,595,596$

Galen 118

Galilei, G. 94, 306, 307, 311

Galitzin, B. 364, 404

Galvani, C. 180,333

Ganot, A. 215

Garman, C. F. 556

Gassendi, P. 255

Gassiot, J. P. 297, 298, 302, 304, 410, 411

Geber 186

Geissler, H. 298, 302

Geitel, H. $360,414,420,444$

Gemma, C. 86

Geoffroy, E. L. 584

Gerland, G. 37

Gernez, D. 389

Gesner, C. 13, 24, 26, 32, 33, 34, 64-70, 74, $78,85,105,108,112,566,571,578$

Geyer, H. 477

Ghaye, M. 336

Giard, A. 506, 507, 559, 585, 597

Giesbrecht, W. 584

Giese, W. 444

Giesel, F. 420

Giglioni, E. H. 241, 245, 574, 589, 590

Gilbert, L. W. 566

Gilbert, O. 37

Gilbert, W. $80,150,269,270,271$

Gilchrist, E. 443

Gillet-Laumont 384

Gimmerthal, B. A. $507,562,597$
Gioanetti, M. 483

Giobert, J. A. 387

Glaser, C. 121,143

Glauber, J. R. 119

Glen, K. 455

Gmelin, J. G. 435

Gmelin, L. 213-214, 441

Gmelin-Kraut 213

Gnudi, M. T. 423

Godart, J. 543

Godeheu de Riville 159, 519, 528, 583

Godfry, see Hanckewitz

Goebel, F. 486

Göppelsröder, F. 401

Goethe, J. W. von 190, 307, 334, 341, 342, 459

Göttling, J. F. A. 184, 437, 438, 448, 488

Goldstein, E. 298, 299, 411, 412-415

Gollancz, H. 49

Goodyear, J. 29, 31

Gorbasso, A. 460

Gordon, J. E. H. 300

Gore, G. 424

Goudot, J. 553

Gough, A. E. 21

Gourret, P. 536

Graham, T. 437, 441

Graham, W. P. 300

Grailich, W. J. 360, 402-403

Granqvist, G. 300

Grassi-Christaldi, G. 386

Graves, R. J. 232

Gravesande, W. J. van's 170, 172, 289

Gray, S. 268, 271, 281, 282, 283, 292

Greef, R. 577

Greene, C. W. 596

Gregory of Tours 44

Gregory, W. 229

Greiss, C. B. 400

Gren, F. A. C. 168,213

Grew, N. 101, 137, 515, 559-560

Grimaldi, F. M. 98

Grimm, H. N. 119, 137, 557

Griselini 519, 528, 576, 577

Groot, J. J. M. de 18

Grosser, M. de 180, 334, 336

Grotthus, T. von 203, 334, 341, 342-345, $358,363,371-373,386,549$

Grube, A. 577, 581

Gruendler, G. A. 476

Grummert, G. H. 286, 290

Gucci P. 386

Gudden, B. 361

Guéneau de Montbeillard 156, 546-547, 596

Günther, A. 241, 592

Günther, J. 545 
Guericke, O. von 106, 150, 270, 271, 276, 289, 304

Guillemin, A. V. 237

Guinchant, J. 389, 455

Gunther, A. P. 230

Gunther, R. W. T. 125, 129, 130, 542

Gunther, S. 37

Guyton de Morveau, L. B. $168,187,478$

Haase, E. 553

Haba, G. de la 58

Haber, F. 247, 449

Hablizl 159, 223, 507, 562, 597

Haeckel, E. 31, 524

Hagen, H. A. 507,562

Hagenbach, E. 375, 400, 404, 405

Hales, S. 183, 294

Haller, A. von 229

Halley, E. 257, 261

Hallwachs, W. 305, 360

Hamberger, G. E. 171, 274

Hamilton, W. 385

Hammer, W. J. 417

Hanckewitz, A. G. 433-434, 446

Haneda, Y. 17, 484, 557, 558, 563

Hankel, W. G. 504, 505

Hannemann, J. L. 445

Harker, A. 476, 558

Harris, J. 160

Harris, W. 121, 143

Hartig, G. 40

Hartig, R. 485,500

Hartig, T. 500, 503

Harting, P. 225

Hartley, W. N. 402

Hartmann 446

Hartsoeker, N. 170, 274

Hartung, J. H. 161

Harvey, E. N. 158, 199, 251, 252, 293, 454, $455,490,519,560,570,584,591,592$, $593,594,597$

Harvey, W. 87, 88

Haslewood, J. 71

Hassal, A. H. 574

Hasselberg, C. B. 298, 299

Haswell, W. A. 577

Hatfield, H. S. 411

Hauch, A. W. von 438

Haüy, R. J. 371, 394

Hauksbee, F. 3, 120, 149-150, 163, 171, $259,274,275,276-280,281,282,284,291$, $302,335,381,382,437,442$

Hausen, C. A. 285

Havers, G. 96

Hayek, G. von 232

Heinemann, C. 556

Heinrich, P. 24, 52, 151, 195, 200, 201,
202-205, 220, 292, 306, 336, 341, 342-345, $363,371,372,374,378,386,448,452$, $486,496-497,499,525,531$

Helberger, J. H. 455

Heller, J. F. 227, 229, 477, 503-504

Hellot, J. 435

Helmholtz, H. von 400

Helmholtz, R. von 444

Helsham, R. 172

Helvig, K. G. von 292, 526

Henkel (Henckel), J. F. 267, 383, 433, 478

Henneberg, W. 375, 507

Henneguy, L. F. 595, 596

Hennings, P. 28

Henry, C. $356,416,552$

Henry, J. 219, 350-351

Henry, W. 212

Hensoldt, H. 22

Herbert, J. E. von 180, 333-334

Hermann, K. S. L. 231, 388

Hermbstädt, S. F. 268, 486, 495, 549

Hermes 54

Hernandez, F. 107, 391

Heroditus 33

Herrtage, S. J. H. 60

Herschel, A. S. 299, 376

Herschel, F. W. 184, 341

Herschel, J. F. W. 208, 210, 394-397, 399

Hertz, H. 301, 303, 360, 411

Herz, A. 301

Hesychius 26, 79, 114, 118

Heumann, K. 452

Heusinger, J. M. 274

Hicks, R. D. 23

Hickson, S. J. 237, 241

Hierne, V. 525

Higgins, B. 188, 329

Hildebrand, F. 230

Hildegard, Saint 45-46

Hill, J. 33, 306, 309, 545, 546

Hirth, F. 19

Hittorf, J. W. 209, 297, 299, 301, 411

Hjörter, O. P. 261

Hjort, J. 239

Hochstetter 477

Hoefer, F. 424

Hoffmann, C. G. 347,383

Hoffmann, F. 323, 435

Hoffmann, M. W. 301

Hofmeister, W. 503

Holborn, A. 75, 87, 108, 116, 137, 269, 308, $314,392,463,540,578$

Holder, C. F. 238, 239

Holland, P. 28, 29, 36

Holst (Holstius), J. 109, 115, 465

Homberg, W. 121, 144, 167, 289, 317-318, $381,427,435,436$ 
Homer 23, 24, 508

Hooke, R. 98, 127-131, 134, 150, 160, 195, $292,392,426,479,498,515$

Hooker, J. D. 537

Hopson, C. R. 168

Hora, S. L. 20

Hornberger, T. 174

Horne, C. 476, 505

Horner, W. E. 448

Hort, W. P. 232

Howes, H. L. 356

Hoyle, W. E. 233

Huber, A. 46

Hudson, G. V. 562

Hübner, J. 161

Hulme, N. 329, 330, 358, 491-492, 495, 595

Humboldt, A. von, 13, 223, 485, 490, 523, $531-532,568,594$

Hume, R. E. 20

Hunt, R. 237

Hu Shih 14, 19

Hutton, C. 174

Huxley, T. H. 564, 588

Huygens, C. 98, 195

Hyndman, H. H. F. 417

Ibn-al-Baithar 47

Ideler, J. L. 262

Illiger, K. 556

Imhoof-Blumer, F. 27

Imperato, F. 72

Ince, J. 424, 433

Isidore of Seville 44, 45, 50

Ives, H. E. 551, 593

Jablonski, J. T. 161

Jacobaeus, O. 321, 425, 470, 581

Jäger, C. C. F. 437

Jallabert, J. 287

Jamin, J. E. 215

Jâqût 49

Jaumann, G. 364, 404

Jayakar, A. S. G. 47

Jeffries, J. G. 233

Jhering, $H$. von 553

Jodlbauer, A. 407

John of Arderne 81

John of Trevisa 49

John, J. F. 323, 346

Johnson, F. H. 595

Johnson, G. 572, 574

Jones, B. 549

Jones, H. C. 26

Jones, J. 42

Jonston, J. 26, 36, 51, 70, 112, 116, 263, $540,541,554,571,578$

Jorrissen, W. P. 23, 35
Josephus, F. 32, 110

Josselyn, J. 542

Joubert, J. 440, 441, 443, 452

Joubin, L. 583

Jourdan, E. 577

Juch, Dr. 385

Jühling, J. 542

Julia-Fontenelle, J. S. E. 388

Juncker, J. 186

Jurine 478

Kaempfer, E. 544

Kalähne, A. 299, 374

Kallmann, H. 421

Kanda, S. 590

Kann, L. 444

Karlgren, B. 16

Kashya, M. 552

Kato, K. 590

Katz, O. 505

Kauffmann, H. 402

Kautsky, H. 455

Kayser, H. 154, 199, 207, 221, 299, 306, $340,389,391,408$

Keats, J. 190

Keenan, G. L. 221

Keferstein, W. 590

Keill, J. 143, 144, 172

Keller, O. 26, 27

Ken, T. 190

Kennedy, R. 413

Ker, W. C. A. 42

Kerr, R. 185

Kerville, see Gadeau de Kerville

Kester, F. E. 356, 357

Ketteler, E. 364, 404

Khvorostansky, C. 589

Kikinger, F. J. 446

Killerman, S. 52, 65

Kindt, G. C. 357,375

King, C. W. 70

Kiranides 79

Kirby, W. 223, 232, 507, 562, 581

Kircher, A. 103-107, 312-313, 392, 393, 541, $566,575,578$

Kirchhoff, G. R. 208, 299

Kirchmaier, G. K. 367, 368, 425-426

Kirn, C. 301, 302

Kirwan, R. 261, 262

Klaproth, M. H. 419

Klatt, V. 348, 350, 357, 361, 362

Kleist, G. von 286

Kletwich, J. C. 124

Knecht, C. 402

Knight, T. 267

Knoblauch, O. 364, 404

Koch, K. R. 299 
Koch, R. 499

Koch, W. E. 534

Kölliker, A von 228, 552, 556, 591, 595, 596

Kofoid, C. A. 524

Kolbert, Dr. 453

Komensky (Comenius), J. A. 538

Konen, H. 221, 391, 408

Kortum, K. von 336, 486

Krafft, F. 386

Krafft, J. D. 130, 167, 425-426, 431, 435

Krafft, W. L. 334

Krebs, A. T. 421

Krukenberg, C. F. W. 56, 244

Krumbiegel, I. 14

Kuhl, H. 588

Kuhne, W. 581

Kuhnt, P. 507

Kunckel (Kunkel) von Löwenstern, J. $130,152,153,160,191,322,425.426,435$

Kunz, G. F. 70

Kusnezoff, I. D. 507

Labanius, M. F. 68

Labarde 356

Labat, J. B. 555

Labillardière 523

Lachmann, J. 536

Lachowiez, B. 454

Lacordaire, J. T. 232

Laet, J. de 306

Lagalla, G. C. 94, 306, 307

Lagarde, H. 299

Lallemand, A. 396

Lamansky, S. 404

Lamark, J. B. de 523, 563

Lampadius, W. A. 440

Lancaster, E. R. 577, 593

Landsberger, B. 14

Landsborough, D. 534, 574, 590

Lane, E. W. 48

Lane, Mr. 336

Langley, S. P. 556, 593, 594

Lapellitier, De la S. 230

Lassar, O. 505

Lassone, J. M. F. 383

Latreille, P. A. 223

Laufer, B. 19

Laurent 478

Lavoisier, A. L. 128, 183, 184, 185, 187, 188,189435

LeBon, G. 352, 418

Lecoq de Boisbaudran 219, 299, 347, 348, 357,413

Le Duc, J. A. 302

Lee, F. S. 231

Le Fèbure, N. 121
Legati, L. 101, 316

Le Gentil, J. J. B. 524

Legge, J. 16

LeGrand, A. 97, 98, 141-143, 319-320, 512

Legros, C. 565

Lehman, Dr. 228, 551, 593

Lehmann, J. G. 179-180, 347, 383

Lehmann, O. 298, 301, 302

Leibnitz, G. B. von $367,425-426$

Lémery, N. 98, 111, 121, 122, 143-146, 153, $155,167,170,317-319,346,352,436,439$, $441,468,506$

Lémery le fils 289

Lemnius, L. 80

Lempe und Lampadius 438

Lenard, P. 348, 350, 356, 357, 360, 361, $365,411,414,421,454$

Lendenfeld, $R$. von 591

Lengyel, B. 299

Lentilius, R. 321, 425, 427

Leroi, A. 447

Le Roy, J. B. 522

Leuckart, F. S. 581, 591

Levinson, W. G. 356

Lewis, E. P. 299, 302, 450

Lewis, H. C. 384

Lewysohn, L. 14

Leyden, E. 448

Leydig, F. 228, 552, 591

Libavius, A. 64

Libes, A. 262

Liceti, F. 72, 82, 94, 95, 106, 116, 311-312, 322

Liebermann, C. 401,402

Liebig, J. 131, 229, 497, 498, 499

Lien-sheng Yang 16, 18

Ligon, R. 513

Lindahl, M. 239, 571

Lindhardt, E. 364, 404

Link, H. F. 201-202, 495, 531

Linné, C. von (Linnaeus) 459, 557, 560, 567

Linnemann, E. 449

Lippi, L. 578

Lister, M. 116, 578

Liveing, G. D. 375

Livy $35,36,38,41$

Lobstein, J. F. D. 447

Lockyer, J. N. 299

Lockyer, N. Mrs. 237

Lode, A. 594

Lodge, O. 418

Lodge, T. 38

Lommel, E. 210, 219, 221, 350, 352, 357, $363,403-404,406,408$

Lonicer, A. 77

Lopez de Gomara, L. 63 
Lowe, R. T. 581

Lubarsch, O. 404

Lucan 28, 39

Lucas, H. 554

Luce 223

Lucretius 110

Ludolff, C. F. 283, 284

Ludwig, F. 501, 505, 507, 562

Ludwig, K. 230, 505

Lumière, A. et L. 359

Luyet, B. 557

Lycosthenes, C. (Wolffhart, C.) 40, 85

Lyonet 174

Macaire, J. 549, 550-551, 593, 594

Macartney, J. 194, 222-223, 227, 523, 531, $532-533,556,568,586,594$

McAtee, W. L. 67

MacCulloch, J. 11, 233, 535

McDermott, F. A. 455

McElroy, W. D. 593

Macfayden, A. 595

MacGowen 18

McIntosh 233, 244

MacNutt, F. A. 61

Macquer, P. J. 168, 338

Magendie, F. 230

Magnus, O. 59, 72, 112, 578

Mairan, J. J. d'O. 40, 44, 45, 86, 151-154, $164,258-259,274,323,479,518$

Majolus, S. 77

Major, J. D. 116, 575

Malebranche, N. 97

Malpighi, M. 321, 515, 543, 593

Mandeville, J. 70

Mangold, E. 274

Mann, B. P. 554

Maplet, J. 67, 71

Marcelle, M. 480

Marcgrave, G. 469, 554

Marchand, R. F. 438

Marchetti, G. 338

Marggraf, A. S. $168,169,187,208,328-329$, 435

Marheinecken, N. L. 179, 318, 328

Marignac, J. C. G. de, see de Marignac

Mariotte, E. 142, 394, 423

Mark the Greek 53, 54

Marshall, J. 230

Marsigli, L. F. 99, 119, 156, 158, 315-317, 324,476

Marsland, D. A. 595

Martens, F. 514, 570

Martialis 42,110

Martin, A. R. $480,527,528,595$

Martin, B. 174

Martin (Martyn), J. E. A. 225, 272
Martin, J. and E. Chambers 518

Martin, T. H. 36

Martius, von 459

Martyr de Anghierra, P. 57, 60, 61-63

Mascart, E. 300

Maskelyne, Prof. 360, 403, 412

Massart, J. 565, 595

Mathiolus 65

Matteucci, C. 226, 349, 350, 444, 497-498, $549,550-551$

Mayer, J. 526

Mayow, J. 184

Mazzotta, B. 315

Mebius, C. A. 301

Meidinger, K. von 483

Melchior, J. A. 179, 328

Mellor, J. W. 424, 440

Melvill, T. 207, 423

Mentz (Menzius) 446

Mentzel (Menzel), C. 309, 321-322, 381, 514

Merian, M. S. $119,158,223,560$

Merret, C. 116, 264

Merritt, E. 219, 365

Merula, G. 78, 80

Meyen, F. J. F. 222, 230, 245, 566, 574, 584, 586,588

Meyer, H. A. 534

Meyer, J. F. 452

Meyer, R. 402

Meyer, W. T. 581

Meyrick, E. 562

Michaelis, G. A. 501, 534, 535-536, 589

Miles, H. 268

Millson, H. E. 72

Milne-Edwards, H. 230, 231, 239

Mitchill, S. L. 570

Mizaldus 76

Modeer, A. 567

Moffatt, W. 443

Moldenke, H. N. and A. J. 15

Molisch, H. 232, 244, 459, 460, 477, 506, $507,535,536$

Molnar, F. 441

Monaco, Prince of 240

Monardes, N. 107, 391

Monconnys, B. de 271,579

Monnier, M. le 165

Montague, B. 92

Montalbani, O. 309-310, 314, 322

Montbeillard, see Gunéau de Montbeillard

Montgomery, J. 508

Monti, G. 157, 158, 368, 579-580, 592, 595, 596

Montucla, M. 174

Moore, D. M. 304 
Moore, F. G. 41

Moore, G. F. 11

Moray, R. 514

Moreau, L. 478

Morgan, Rev. Mr. 338-339, 370

Morgan, W. 295

Mornay, A. F. 459

Morozzo, C. L. di 339, 384

Morren, A. 298, 302

Mortimer, C. 286,434

Morton, H. 405

Moscardo, L. 101, 316

Moseley, H. N. 588

Moufet, T., see Muffet, T.

Moule, L. 23

Moulton, J. F. 301

Müller, G. W. 584

Müller, J. 229.230, 398

Müller, O. F. 223, 535, 536, 584

Müller, W. 440

Muffet (Moufet), T. 26, 30, 52, 63, 75, 77 $81,114,538,540,556$

Mulder, E. 504

Munk, P. 448

Muraoka, H. 418, 552

Murray, A. 553

Murray, D. 100

Murray, J. 213, 239, 240, 241, 501, 533, 549, 551,593

Mylius, M. C. 571

Nairne, E. 294

Napier, J. 375

Naudin 486

Nebel, B. 301

Nebel, W. B. 274

Neckam, A. 49

Needham, J. 17, 18, 19

Nees von Esenbeck, C. G. and T. F. L. 494, 499-500

Neesen, F. 301

Negotius, T. 274

Neucrantz, P. 112

Neumann, C. $168,187,318$

Newall, H. F. 292, 299, 302

Newland, C. 523

Newman, E. 561

Newton, I. 139, 147-148, 170, 173, 176, 205 . 289, 338, 393, 399

Nicephorus Callistus 44

Nichols, E. L. 5, 219, 356, 365, 377

Nicholson, W. 168

Nicolas, M. 369

Niepce de St. Victor, A. 220-221

Niepce, J. N. 347

Nieremberg, J. E. 554

Noack, K. 402, 408
Noceti, C. 259

Nöggerath, J. J. 500

Nollet, Abbe J. A. 175-176, 282, 286, 287 . $290,435,519,546,576$

Norwood the younger 555

Nose, K. W. 394

Nuesh, J. 505

Nuguet, L. 393

Nutting, C. C. 234

Obermann, J. J. 364, 404

Obsequens, J. 40, 68, 86, 467

Oken, L. 523

Oldenburg, H. 120, 321, 367

Olivier, E. 14

Olschki, L. 307

Oppian 42, 112

Orioli, F. 591

Ornstein, M. 98

Osann, G. W. 334, 346-347, 358, 398

Osbeck, P. 577

Osorio, B. 507, 591

Osten-Sacken, C. R. von 554

Otto, M. 451

Ovid 36, 42

Oviedo y Valdis, G. F. de 57, 58-61, 113, 556

Owens, R. B. 419

Ozanam, J. 174

Paalzow, A. 299, 301

Packard, A. S. 232

Packe, C. 119

Pallas, P. S. 369, 571

Pallegoix, Bishop 545

Panceri, P. 241-242, 245, 453, 478, 505, $570,573,574,576,577,581,582,587$, 590, 594

Panciroli, G. 53

Panckoucke, C. J. 165

Papin, N. 116, 512-513

Paracelsus 63, 64, 65, 80, 186

Paschen, F. 299

Pasteur, L. 498, 499, 556, 593

Paton, J. 15

Paulin (Paullinus), C. F. 463, 477, 493

Peach, C. W. 574

Pearsall, T. J. 336, 341, 374

Pelletier, P. J. 374

Pennant, T. 102, 567

Penny, F. 388

Penny, T. 74, 77, 78

Pepys, S. 291, 514

Percy et Laurent 478

Perkin, W. H. 451

Péron, F. 222, 245, 529-530, 574, 581, 587. 588 
Perrin, J. 411

Perscrutator (Robert of York) 54

Peters, A. W. 595

Peters, H. 425, 435

Petrie, W. 212, 449

Petrikaln, A. 444

Petrus Candidus 52

Petsch, W. 455

Pfaff, C. H. $388,535,564,594$

Pfeffer, W. 231

Pfeiffer, F. 52

Pflüger, E. 228, 504, 505

Philalethes, E. 90

Phillips, E. 265

Phipson, T. L. 220, 238, 285, 386 449, 453 504, 593

Picard, J. 120, 149, 271

Pickel, J. G. 189, 387

Pictet, R. P. 292, 359

Pierantoni, U. 582, 597

Pierre, V. 401, 404, 405

Pisco, F. J. 220, 407

Planck, M. 6, 246

Planta, M. 281

Plato 23, 95

Pleischl, A. M. 388

Pliny, C. 23, 27-31, 34, 36, 41, 45, 49, 67, $74,79,87,91,103,110,111,136,153$, $253,483,566,577,596$

Plot, R. 82, 116, 134-135, 476, 542, 558

Plücker, J. 207, 209, 211, 219, 296-297, 301, $302,353,410,411$

Poggiale, A. B. 448

Pohl, R. 361

Poiret, J. L. M. 83

Poli, I. X. 580

Pomet, M. 309

Pontoppidan, E. 525

Pontus, M. 388

Pope, W. J. 387

Porta, J. B. della 54, 76, 79, 87, 99, 104, 105

Potier (Poterius), P. 308-309

Pott, J. H. 187, 369, 383

Poulton, E. B. 236

Power, H. 128, 542

Prandtl, W. 424

Precht, J. 417, 525

Prevost, B. 224

Priestley, J. 87, 94, 103, 149, 166, 181-183, $184,187,205,208,260,264-266,284,285$, $289,292,293,306,335,339,340,382$, $426,480,582$

Pring, J. H. 564-565, 594

Pringle, J. 528

Pringsheim, E. 452

Pringsheim, P. 365
Privati, G. 161, 287

Ptolemy 54

Puerarius, D. 109, 465-468, 493

Pulteney, R. 459

Puluj, J. 301

Pupin, M. 416

Purchas, S. 57,58

Pythagoras 95, 195

Pytheas of Massilia 37

Quatrefages, J. L. A. de 226-227, 564, 565, $567,577,593,594$

Quellmalz, S. T. 383

Quet et Sequin 298

Quoy et Gaimard 535

Raab, O. 407

Radziszewski, B. 207, 212, 228, 231, 448, 453-454, 455

Raffenau-Delile, A. 501

Raimondo di Sangro 424

Ramsdem, J. 281

Ramsey, W. 299, 411, 412

Ranke, H. 14

Raven, C. E. 78

Rawitz, B. $58 \mathrm{I}$

Ray, J. 116, 264, 314, 540, 542, 556

Rayleigh, Lord 302, 450

Razoumowski, G. de 547

Réaumur, R. A. F. de $69,156,158,557$, $560,579,580,587,592,595$

Redi, F. 116, 470, 476, 543

Rees, A. 163

Regnard, P. 595

Reichenbach, K. J. von 453

Reid, A. 435

Reinhardt, J. T. 553, 591

Reinke, J. 536

Reisch, G. 75, 76, 86, 115

Reisel, S. 478, 557

Reitlinger, E. 298

Remington, E. C. 302

Renaudot, E. 96

Reuland, J. 386

Richards, T. W. 301

Richarz, F. 387, 444, 451

Richerand, L. C. 230

Riddell, W. H. 19

Ridley, E. 39

Riess, P. T. 171, 281, 301

Rigaut, M. 522, 523

Riley, C. V. 554

Riley, H. T. 28, 34, 41

Rinman, S. 369, 383

Ripley, G. 131

Risso, A. 590

Ritsert, E. 451 
Ritter, J. W. 340-341, 363, 399

Rivers, J. J. 554

Riville, see Godeheu de Riville

Rivinus, F., 111, 123-124, 575

Robbi, J. H. 448

Robert of York 54

Robin, C. 565

Robinson, J. 184

Robinson, T. R. 399

Rochefort, M. de 555

Roemer, O. 97

Roentgen, W. C. 211, 304, 410, 416-417, 421

Rohault, J. 98, 122, 138-140, 143, 170, 319, 510-512

Roland, S. 595

Rolland, E. 78, 578

Rolli, P. 286

Rondelet, G. 69, 72, 73-74, 112, 566, 571, 578

Rose, H. 377, 388, 389

Rosel von Rosenhof, A. J. 560

Ross, J. 239

Ross, W. D. 25

Rouelle, G. F. 435,448

Rousseau, J. B. 154

Rowland, J. 78

Rowland, S. 595

Rowning, J. 172, 257

Roy, P. C. 20

Rudolphi, K. A. 230

Ruhlmann, R. 301

Rumford, Count 167, 189

Rumph, G. E. 484, 514

Runge, C., 299

Rupp, H. 18

Russel, E. J. 452

Russel, W. J. 221

Russell, H. L. 506

Rutherford, E. 419

Ruysch, H. 545

Rye, E. C. 507

Sachs von Lewenhaimb, P. J. 104, 116, $117,470,575,585$

Saeland 361

Safford, W. E. 391

Sage, E. T. 35

Sage, M. 483

Salet, G. 299, 404

Salm-Horstmar, F. 399

Salverte, E. 35

Salviani, H. 72, 73

Sarasin, E. 297, 302

Sars, G. O. 240,586

Sars, M. 240, 574

Sarton, G. 45, 46, 48, 53, 138, 170
Saunders, D. F. 376

Saussure, H. B. de 338, 346, 370, 375, 384

Sauvaget, J. 48

Sawaya, P. 469

Scaliger, J. C. $28,30,72,75,79,81,102$, 540,596

Schäfer, E. A. 231

Schaffer, J. 40

Scharff, E. 444

Scheele, C. W. 183-185, 187, 329, 340, 369, 435,440

Scheerer, T. 377

Scheiner, J. 299

Schenck, O. 299

Schenk, R. 444, 451

Scherer, A. N. von, 334, 437

Schertel, S. 13

Schiller, J. M. 387

Schmid, W. 441

Schmidt, G. C. $301,303,348,350,359,360$, $363-365,376,383,389,403-405,414,415$, 419

Schmidt, P. 507

Schmitz, J. von 500

Schnauss, J. 551, 593

Schneider, J. 386

Schönbein, C. F. 440, 441, 443, 450

Schönwald, 189387

Schoppe, C. 30

Schoringen $379,389,454$

Schott, K. 106-107, 271, 313, 578

Schove, D. J. 20

Schrank, F. von P. 477, 535

Schroeder, J. 541

Schroetter, A. 437

Schuckard, W. E. 232

Schuller, A. 450

Schulman, J. H. 422

Schultes, H. 252

Schultz, O. 562

Schultze, J. H. 340

Schultze, M. 228

Schulz, J. H. 52

Schumann, V. 337

Schuster, A. 299, 301

Schwann, F. T. 498

Schwarz, G. 389

Schwarz, O. 567

Schweigger, J. S. C. 388

Schwenkfeld, C. 77

Schyttes, E. 525

Scott, W. 508

Seager, H. W. 50

Secci, A. 270

Secchi, P. 297, 551, 589

Seebeck, T. J. 334, 341, 342

Seelhorst, G. 399 
Seguey, G. 301, 302

Seidel 450

Semper, K. 234

Senebier, J. 459

Seneca 36, 38-39, 253

Sennert, D. 253

Sepi, G. 106

Sequin 298

Severn, H. A. 22, 551

s'Gravesande, W. J. van $170,172,289$

Sguario, E. 259

Shakespeare, W. 46, 189

Shaw, P. 167,186

Shaw, T. 557, 571

Sibbald, R. 578

Sidot, T. 347

Siebold, C. T. E. von 534

Silberschlag 526

Silliman, B. 212-213

Silvester, B. 30

Simpson, W. 132-133

Skinner, C. A. 301

Slabber, M. J. 523, 567

Slare, F. 82, 130, 432-433, 436, 442, 445

Sloane, H. 101, 267, 280, 555

Sluginov, N. P. 251

Smeaton, J. 289

Smith, C. S. 423

Smith, F. 553

Smith, J. A. 24, 25

Smith, W. 305, 360

Smyth, A. H. 520

Smythe, C. P. 299

Snow, B. W. 5, 377

Sohncke, L. 360, 403

Solander, D. C. $159,567,571$

Solinus 29,49

Sorby, H. C. 404

Soret, J. L. 300, 352, 396, 403

Sosigenes 23

Southwell, R. 367

Sowerby, J. 484, 485

Spallanzani, L. 158, 180, 181, 437, 438-439, $488-489,491,528,548,564,567-568,571$, $577,592,593,595$

Sparmann, A. 567

Sparshall, J. 521, 522

Specia, G. 375

Spence, W. 232, 507, 562

Speter, M. 425

Spidberg, J. K. 256

Spielmann, J. R. 168

Spiller, J. 551

Spottiswood, W. 298, 301

Stadler, H. 51

Stahl, G. E. 133, 186

Stark, J. 246, 301, 361, 365
Steenstrup, J. J. 574

Stein, F. von 536

Stenger, F. 301, 364, 404, 405

Steuer, A. 588

Stewart, C. 574

Stierio, J. 253

Stokes, G. G. 207, 210, 211, 350, 352-355, $357,363,390,391,394-398,399,405,406$, $413,441,452$

Stoney, G. J. 300, 412

Störmer, C. 15

Strabo $26,27,37$

Straubel, R. 417

Strömberg, R. 26

Strutt, R. J. 302, 450

Stubbs, Dr. 555

Sturm, J. C. 446,477

Suchland, E. 595

Suidas of Byzantium 26

Suriray, M. 523, 563

Suter, H. 245, 563

Sviatskii, D. O. 45

Swammerdam, J. 515, 542

Swann, J. 254, 255, 267, 554

Swezy, O. 524

Swinton, A. H. 554

Swinton, C. 377

Symmer, R. 267

Szütz, C. von 486

Tachard, G. 514-515, 525, 544

Tacitus 38

Tafel, J. 415

Talbot, W. H. F. 208, 353

Tappeiner, H. von 407

Taylor, B. 190

Teichmeyer, H. F. 171, 446

Telang, K. T. 20

Templar, J. 542

Terajima, R. 17

Testi, G. 424

Thales of Miletus 22

Thenard, L. J. 441

Theodosius, J. B. 80

Theophrastus 28, 24, 33, 65

Thevet, F. A. 112

Thibant, P. 121

Thomas of Cantimpre 50, 51, 52

Thompson, D'A. 25, 27

Thompson, E. P. 417

Thompson, J. V. 584

Thompson, S. P. 417

Thomson, A. T. 35

Thomson, C. W. 233, 234, 239, 240, 241, 571

Thomson, J. 370

Thomson, J. A. 237 
Thomson, J. J. 246, 291, 301, 302, 303, 361, $411,414,421,451$

Thomson, T. 213

Thorndike, L. 53, 54

Thorpe, T. E. 424, 443

Thou, J. A. de (Thuanus) 70, 72

Thucydides 110

Thudichum, J. L. W. 401

Thulis and Bernard 159, 223, 506, 563, 584,597

Tiede, E. 349

Tiedemann, F. 213, 230, 535

Tilesius von Tilenau, W. G. 194, 222, $245,531,533,573,586,587$

Todd, R. B. 232

Todd, T. J. 550

Tollhausen, P. 506

Topsell, E. 78

Toricelli, E. 271

Torrubia, J. 519, 576

Traube, M. 499

Trautz, M. $221,379,387,389,450,454$, 455

Trembly, A. 284

Trève, A. 297

Treverinus, L. C. 223

Treviranus, G. R. 195, 222, 223-224, 229, 479

Trimen, R. 553

Troost, J 213

Trowbridge, C. C. 359,417

Trowbridge, J. 301, 376

Tuckermann, A. 199

Tulasne, L. R. 486,500

Turnebus, A. 30

Turner, E. 213

Turpin, F. R. 544

Tutton, A. E. 443

Tychsen, N. 437, 489-490

Tyndall, J. 356, 399, 400, 499

Ussow, M. 591

Valenciennes, A. 590

Valenta, E. 299

Valentin, G. 230

Valentini, M. B. 102

Valle, A. della 242

Vallentin, R. 586

Vallerius, H. 256

Vallisnieri, A. 545

Valmont-Bomare, J. C. 179, 485, 529

Van Aubel, E. 297

Van Bemmelen, A. 437

Van Beneden, P. 564

Van Buren, E. D. 14

Van der Lith, P. A. 48
Van der Willigen, V. S. M. 209, 297

Van Doren, C. 520

Van Heerden, P. J. 421

Van Helmont, J. B. 12, 95, 119, 306

Van Leeuwenhoek, A. 498, 515

Van Marum, M. 371, 437, 448

Van Monckhoven, D. 299

Van Mons, J. B. 437, 438

Van Musschenbroek, P. 99, 172-173, 283, 286, 394

Van s'Gravesande, W. J. 170, 172, 289

Van't Hoff, J. H. 440, 444

Vanino, L. 308

Varley, C. F. 411

Varro, T. T. 30

Varthema (Vartomanus), L. 71

Vaughan, T. 90

Venturi, C. G. 311

Verany, J. B. 245, 582

Verdries, J. M. 171

Verhaege 564

Verneuil, A. 347

Verworn, M. 231, 595

Very, F. W. 556, 593, 594

Veslingius (Wesling or Vesling), J. 468

Vianelli, J. 519, 528, 576, 577

Viano, J. de 254

Vierard, K. 230

Vignal, W. 565

Villard, P. 414

Ville, J. 454

Vincent de Beauvais 45, 50

Vintimillia, C. 233, 540, 542, 596

Virey, J. J. 206

Virgil 27, 36, 508

Vital du Four (Vitalis), 53

Viviani, D. 222, 271, 506, 530, 531, 577, $584,585,587,597$

Vogel, C. 122, 299

Vogel, H. W. 340

Vogel, H. A. von 441

Vogel, R. 596

Volta, A. 265, 295, 339, 340, 459

Voltaire, F. M. 154

Von, see under name

Vordermann, A. G. 592

Vulpius, J. C. 266

Wach, G. F. 346-347

Wafer, L. 542

Wagner, W. 230

Wahlberg, P. F. 245, 562

Waite, A. E. 6364

Walchner 229

Wall, W. 271, 280, 282

Wallace, A. R. 236

Waller, R. 99, 129, 379, 542 
Wallerius, J. G. 328, 329

Walsh, Mr. 183, 295

Waltenhoften, A. von 299

Walter, B. 404,405

Wang, L. 17

Warburg, E. 302

Wargentin, P. 261

Warren, H. C. 21

Wasstrom, O. 388, 525

Watanabe, H. 584

Watasé, S. 567

Waterhouse, C. O. 554

Watson, G. C. 478

Watson, W. 260, 283, 285, 287-289

Watts, H. 213

Watts, T. 150

Weber, J. 336, 525

Weber, V. F. 17

Webster, E. W. 37, 40

Weckers (Wecxerus), H. J. J. 76

Wedgwood, T. 292, 370-371, 383-384, 448. 450

Weeks, M. E. 424

Wehnelt, A. 415

Weidler, J. F. 274

Weiser, H. B. 251

Weismann, A. 236

Weitlaner, F. 455

Wesendonck, K. 364, 404

Wesley, J. 283

Wesling, J. 468

Weyenbergh, H. 553

Wheatstone, C. 208, 209

Wheeler, W. M. 562

Whiston, W. 32, 256

White, J. H. 186

White, T. H. 47

Wick, F. G. 378

Wiedemann, E. 4, 49, 219, 299, 300, 301, $302,303,305,348,350,355,356,359$, $363-365,376,386,389,390,403,405,406$, 413,414

Wiedemann, G. H. 219, 299, 301

Wiegleb, J. C. 168, 169

Wien, W. 415

Wier, J. 84, 85, 264

Wilcke, J. C. $284,292,382$
Wilcocks, J. C. 534

Will, F. 577

Williams, C. B. J. 371

Williams, F. X. 596

Willis, T. 98, 131, 132

Willoughby, F. 116, 264, 557

Willsford, T. 253

Wilson, B. $157,180,184,187,289-290,294$, $306,324,325,329,332,338,340,346,370$

Wilson, G. 168, 572

Winckler, J. H. 283, 285

Winderlich, R. 307, 341

Winkelmann A. 417

Winn, J. S. 260

Wöhler, F. 200, 388

Wolf, C. von 256, 394

Wolf, M. 454

Wolff, J. L. 264, 265

Wolffhart, C. 40,85

Wollaston, W. H. 207, 357

Wood, R. W. 219, 301, 407, 408, 450

Worm, O. and W. 100, 313

Worms 515

Worster, B. 150, 172

Wotton, E. $65,66,74,-77,78,578$

Woyt, J. J. 161

Wüllner, A. 205, 298, 299, 364, 404, 408

Wünsch, C. E. $334,341,394$

Wulf, P. 349

Wundt, W. 230

Wyrouboff, G. 375

Yasaki, Y. 563, 586

Yonge, C. D. 30

Young, C. A. 551

Young, T. 40, 98, 167, 195, 198-199, 214, 262

Zacharias, O. 596

Zanotti, F. M. 208, 315, 324, 325, 333, 357

Zedler, J. H. 164

Zirpolo, G. 595

Zisch, W. 247, 449

Zocher, H. 455

Zöllner, F. 299

Zucchi, N. 313-314, 325, 333, 575, 578 





